\title{
Bernd Herrmann
}

\section{„... mein Acker ist die Zeit“}

Aufsätze zur Umweltgeschichte

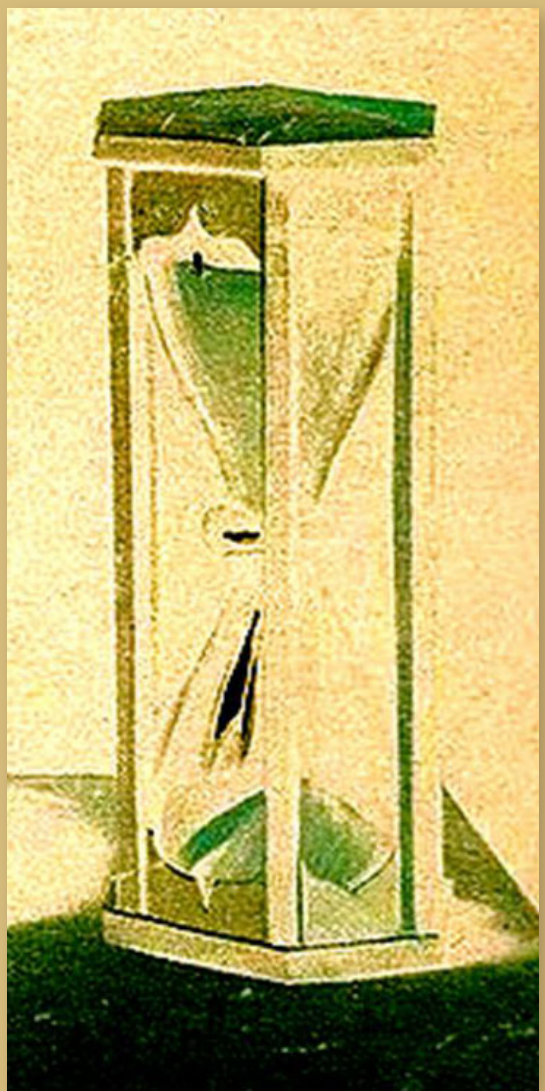



Bernd Herrmann „... mein Acker ist die Zeit“

This work is licensed under the Creative Commons License 3.0 "by-nd", allowing you to download, distribute and print the document in a few copies for private or educational use, given that the document stays unchanged and the creator is mentioned. You are not allowed to sell copies of the free version. 
erschienen im Universitätsverlag Göttingen 2011 
Bernd Herrmann

„... mein Acker ist die Zeit“

Aufsätze zur Umweltgeschichte

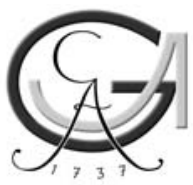

Universitätsverlag Göttingen 2011 


\section{Bibliographische Information der Deutschen Nationalbibliothek}

Die Deutsche Nationalbibliothek verzeichnet diese Publikation in der Deutschen Nationalbibliographie; detaillierte bibliographische Daten sind im Internet über $<$ http://dnb.ddb.de $>$ abrufbar.

Adresse des Autors:

Prof Dr. Bernd Herrmann

Georg-August-Universität Göttingen

Biologische Fakultät

Johann-Friedrich-Blumenbach-Institut für Zoologie und Anthropologie

Abteilung Historische Anthropologie und Humanökologie

Bürgerstr. 50

37073 Göttingen

E-Mail: bherrma@gwdg.de

Dieses Buch ist auch als freie Onlineversion über die Homepage des Verlags sowie über den OPAC der Niedersächsischen Staats- und Universitätsbibliothek

(http://www.sub.uni-goettingen.de) erreichbar und darf gelesen, heruntergeladen sowie als Privatkopie ausgedruckt werden. Es gelten die Lizenzbestimmungen der

Onlineversion. Es ist nicht gestattet, Kopien oder gedruckte Fassungen der freien

Onlineversion zu veräußern.

Satz: Franziska Lorenz, Jutta Pabst

Umschlaggestaltung: Margo Bargheer

(C) 2011 Universitätsverlag Göttingen

http:/ / univerlag.uni-goettingen.de

ISBN: 978-3-941875-99-9 


\section{Vorwort}

Äußerer Anlass für die Vorlage dieser Aufsatzsammlung ist mein weitgehender Rückzug aus der aktiven Forschungstätigkeit mit dem Eintritt in den so genannten Ruhestand am Ende des Wintersemesters 2010/11.

Das Datum markiert damit auch eine Art persönliches „Epochenende“. Von meinen Historiker-Kollegen habe ich gelernt, wie sehr die Diagnose solcher Zäsuren das praktische wissenschaftliche Leben erleichtern kann und dass deren Benennung das Gerüst der Erinnerungskultur ausmacht. Die persönliche Epoche, deren Ende mit diesem Sammelband eingeleitet ist, war eine Dekade intensiver umwelthistorisch ausgerichteter Arbeit, deren größter sichtbarer Ertrag zweifellos die Einrichtung des Graduiertenkollegs „Interdisziplinäre Umweltgeschichte“ an der Universität Göttingen ab 2004 war und das bis 2013 seine Tätigkeit fortsetzen kann.

Die Aufsatzsammlung ist als ein Rechenschaftsbericht zu lesen. Der Band versammelt Aufsätze ausschließlich aus den letzten Jahren, frühere Arbeiten sind nicht aufgenommen. Von ihnen seien aber doch noch das Begleitbuch zur Göttinger Sommerakademie „Natur und Geschichte“ erwähnt, das als graue Literatur ziemlich erfolgreich war. ${ }^{1}$ Die Sommerakademie hätte nicht so umstandslos und erfolgreich über mehrere Jahre durchgeführt werden können, wenn es nicht die publizistische Vorbereitung durch die Beiträge aus den Anfängen des Umwelthistorischen Kolloquiums gegeben hätte, die in erster Auflage 1986 erschien. ${ }^{2}$ Dieser Band ist mittlerweile mehrfach und auch von anderen Verlagen nachgedruckt worden. Nachfolgebände im Taschenbuchformat konnten mit ihrer Verbreitung an der Erfolg des Vorbildes nicht anschließen, ${ }^{3}$ auch deswegen, weil Verlage mittler-

\footnotetext{
${ }^{1}$ Herrmann B, Budde A (Hrsg.) Naturwissenschaftliche und historische Beiträge zu einer ökologischen Grundbildung. Hannover, 1989 (Schriftenreihe Expert, Nieders. Umweltministerium)

2 Herrmann B (Hrsg.) Mensch und Umwelt im Mittelalter. DVA Stuttgart,1986

3 Herrmann B (Hrsg.) Umwelt in der Geschichte. Vandenhoeck, Göttingen; 1989
} 
weile Beitragsbücher ungern verlegen. Sie werden zumeist nicht gekauft, sondern aus einem Ausleihexemplar werden zwei, drei Aufsätze von Interesse herauskopiert. Diese wirtschaftlichen Überlegungen der Verlage haben die Entwicklung des wissenschaftlichen Diskurses der Umweltgeschichte früh und hart getroffen und sind letztlich auch ein Grund dafür, dass es Umweltgeschichte nicht leicht hatte, sich in der Breite zu etablieren. Seit einigen Jahren können die Beiträge des Umwelthistorischen Kolloquiums vom Universitätsverlag Göttingen verlegt werden und sind auch als Online-Versionen einsehbar unter http://www.anthro.unigoettingen.de/gk/, dank finanzieller Unterstützung durch die Deutsche Forschungsgemeinschaft.

Aus der hier weiter nicht berücksichtigten Zeit soll zumindest noch der Aufsatz „Umweltgeschichte als Integration von Natur- und Kulturwissenschaft" ${ }^{“ 4}$ erwähnt werden, der vor 15 Jahren mein „Ceterum censeo“ der interdisziplinär ausgerichteten Umweltgeschichte erstmals ausführlicher skizzierte. Leider kann ich nicht sehen, dass die Entwicklung diesem Ideal zwischenzeitlich wirklich näher gekommen wäre. Nach wie vor behindern strukturelle wie menschliche Begrenzungen, dass die Herausbildung eines Lehr- und Forschungsgebietes „Umweltgeschichte“ dem inhaltlichen Gebot folgte und dass der thematischen Kompetenz der Vorzug gegenüber einer bestimmten grundständigen Ausbildung des Dozenten gegeben würde. Unabhängig und vor jeder Einzelmotivation der Beteiligten ist die Bedeutung der Umweltgeschichte für eine allgemeine ökologische Grundbildung intuitiv einsichtig und ihr allein deshalb überall Raum zu gewähren, wo Umweltfragen ernsthaft erörtert werden. Ein Beispiel hierfür ist der Aufsatz: „Naturerfahrungsgebiete - Humanökologische Prolegomena zur Sicherung der Landschaft und zur Förderung einer natur- und landschaftsverträglichen Erholung“" 5 der nicht aufgenommen wurde, weil er sich an eine anders orientierte Leserschaft wendet. Auf zwei weitere Arbeiten wurden wegen ihrer leichten Erreichbarkeit verzichtet. ${ }^{6}$

Die hier abgedruckten Versionen entsprechen im Wortlaut nahezu völlig den ursprünglichen Manuskriptversionen. Die bisherigen Druckversionen mussten sich mitunter redaktionelle Verfeinerungen von Herausgebern gefallen lassen, mit und ohne Rückfragen an den Autor. Insofern ergeben sich kleine Abweichungen. Sie führen zwar in keinem Falle zu einer substanziellen Aussageverschiebung. Es erüb-

Schubert E, Herrmann B (Hrsg.) Von der Angst zur Ausbeutung. Umwelterfahrung zwischen Mittelalter und Neuzeit. Fischer. Frankfurt, 1994

${ }^{4}$ In: Bayerl G, Fuchsloch N, Meyer T (Hrsg.) Umweltgeschichte - Methoden, Themen, Potentiale. Tagung des Hamburger Arbeitskreises für Umweltgeschichte, Hamburg 1994. Cottbuser Studien zur Geschichte von Technik, Arbeit und Umwelt. Bd. 1 (1996), S. 21-30

5 zusammen mit H Schutkowski. In: Schemel H-J u.a. (1998) Naturerfahrungsräume. Angewandte Landschaftsökologie 19, Bundesamt für Naturschutz, Bonn-Bad Godesberg. S. 13 - 30

${ }^{6}$ Jakupi A, Steinsiek P, Herrmann B (2003) Early maps as stepping stones for the reconstruction of historic ecological conditions and biota.Naturwissenschaften 90:360-365

Herrmann B, Woods W (2010) Neither biblical plague nor pristine myth: a lesson from central European sparrows. The Geographical Review 100(2):176-186 
rigt sich also das Kollationieren; aber ich fühle mich mit meinen eigenen Formulierungen doch wohler. Für diese Sammlung wurden die Aufsätze einheitlicher formatiert, „Zusammenfassungen“" und „Abstracts“ entfernt und die Orthographie meist in die Nähe der Rechtschreibreform gebracht. Bloße formale Einheitlichkeit der Zitate und Referenzen schien mir um den Preis des zeitlichen Aufwandes, der auf einen Punkt o.ä. verwendet wird, den der Leser ohnehin intuitiv setzt bzw. ersetzt, nicht anstrebenswert. Es reichte mir, wenn innerhalb der Beiträge hinreichende Einheitlichkeit herrscht.

In dem bezeichneten Zeitraum sind mehr thematisch zugehörig erscheinende Arbeiten entstanden als hier aufgenommen wurden. Zum Teil hängt dies auch damit zusammen, dass sich leichte Redundanzen ergeben, dass einige Arbeiten sich am Ende doch stärker auf andere Bereiche beziehen und umwelthistorische Belange eher randständig thematisieren. Umgekehrt sind Aufsätze aufgenommen, die sich scheinbar hauptsächlich mit meiner Heimatdisziplin, der Biologischen Anthropologie, befassen. Tatsächlich behandeln sie das Verhältnis der Anthropologie zur Umweltgeschichte ausführlich. Sie tragen dazu bei, meine Auffassung von interdisziplinärer Umweltgeschichte deutlich zu machen

Die Aufsätze stehen zumeist unter dem Vorbehalt des Verwendungszusammenhangs einer bestimmten Tagung. Die Zufälligkeit solcher Anlässe verhindern am Ende, dass eine Aufsatzsammlung entstehen könnte, die ein geschlossenes Kompendium bildete, das auch als Fernziel nie beabsichtigt war. Es erscheint mir erforderlich, hieran besonders zu erinnern.

Während der Zusammenstellung der Aufsätze und ihrer Vorbereitung für die Drucklegung hat mich überrascht, wie früh mancher Gedanke sichtbar wurde, den ich aus heutiger Perspektive erst für eine spätere Einsicht gehalten hätte. Weniger überraschend ist wahrscheinlich, dass die in den Arbeiten behandelten Beispiele fast ausschließlich aus dem Reich der belebten Natur stammen. Hierfür bitte ich mit dem Hinweis auf meine wissenschaftliche Erstsozialisation in der Biologie um Verständnis. Erstaunlicher ist dann schon, dass eine vergleichsweise geringe Zahl konkreter Beispiele wiederholt zum Ausgangspunkt von Überlegungen gewählt wurde, um an ihnen doch unterschiedliche allgemeine Fragen der Umweltgeschichte zu erörtern. Einerseits war die Umweltgeschichte für mich zwar früh ein Anliegen. Andererseits hatte ich hauptamtlich eine andere Aufgabe zu versorgen. Schließlich hängt das thematische Beharren auch mit meiner Unfähigkeit zusammen, mir vorstellen zu wollen, man könne sich ständig und gleich bleibend kompetent grundsätzlich neuen Fragestellungen zuwenden.

In der Zusammenstellung wird deutlich, so hoffe ich, dass sich alle Aufsätze bemühen, auch ihren jeweiligen wissenschaftstheoretischen Beitrag zur Schärfung der Umweltgeschichte zu liefern. Insofern ist die Aufsatzsammlung nicht nur eine Dokumentation meiner kontinuierlichen Bemühung, nicht nur Rechenschaftsbericht, sondern auch mit der Hoffnung verbunden, jenseits der behandelten Beispie- 
le Argumente zur Entwicklung der umwelthistorischen Forschungen und ihrer strukturellen Verstetigungen gesammelt und bewahrt zu haben.

Der Aufsatzsammlung ist als Titel eine Zeile aus Goethes West-Östlichem Divan gegeben (Buch der Sprüche): „...mein Acker ist die Zeit.“ Seit Jahren war mir diese Metapher wertvoll für einen epistemologischen Zentralbegriff der Umweltgeschichte. Es hat sich leider nie ergeben, dass ich diese Zeile in einem meiner Beiträge verwendet habe. So beschließt ihr Erscheinen auf dem Buchdeckel ein biographisches Kapitel, auch dies der Zeit geschuldet.

Mein Kollege Rainer Willmann sei für seine Unterstützung als Vertrauensdozent der Biologischen Fakultät bei der verlegerischen Umsetzung vieler umwelthistorischer Projekte bedankt. Mein besonderer Dank gilt Frau Margo Bargheer und Frau Jutta Pabst und den Mitarbeitern vom Universitätsverlag Göttingen für die vielfältige Hilfe und jahrelange wunderbare Zusammenarbeit, die mit diesem Band nun ein voraussichtliches Ende findet.

Göttingen, den 31.März 2011

Bernd Herrmann 


\section{Inhaltsverzeichnis}

Vorwort 1

Inhaltsverzeichnis $\quad 5$

$\begin{array}{ll}\text { Rekonstruktion historischer Biodiversität } & 7\end{array}$

Zur Historisierung der Schädlingsbekämpfung 25

„Auf keinen Fall mehr als dreimal wöchentlich Krebse, Lachs oder Hasenbraten essen müssen!“

Holz - Umwelt - Mensch $\quad 77$

Natur und Mensch in Mitteleuropa im letzten Jahrtausend: Eine interdisziplinäre Umweltgeschichte

Die „Suppenfrage“ in der Anthropologie Sortiertes und Unsortiertes zum Tagungsthema 105

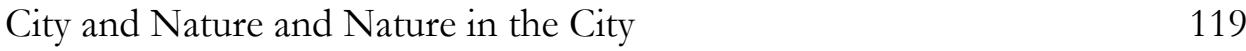

Ein Beitrag zur Kenntnis von Schädlingsbekämpfungen und ihren Konzepten im 18. und frühen 19. Jahrhundert an Beispielen aus Brandenburg-Preußen

Man is made of mud. "Soil", bio-logical facts and fiction, and environmental history 
Empirische Zugänge zu historischen Biodiversitätsverdrängungen und Biodiversitätslenkungen: Die Beispiele Melioration und Schädlingsbekämpfung

Umweltgeschichte wozu? Zur gesellschaftlichen Relevanz einer jungen Disziplin

Kartoffel, Tod und Teufel Wie Kartoffel, Kartoffelfäule und Kartoffelkäfer Umweltgeschichte machten

Das landesverderbliche Übel der Sprengsel in den brandenburgischen Gemarkungen - Heuschreckenkalamitäten im 18. Jahrhundert

Comments on contributions to "Health versus Wealth - the biological and economic standards of living" - Fondatione Istituto Internazionale die Storia Economica "F. Datini", Prato (I), 26-30 April 2010

100 Meisterwerke umwelthistorischer Bilder

Ein Plädoyer für eine Galerie von Bildern mit umwelthistorischen Objekten, Vorbildern, Metaphern, Deutungsebenen und Dokumentationen

Innerfachliches und Fächerübergreifendes aus einer anthropologischen Sicht und historische Mensch-Umwelt-Beziehungen

Natura morte im Delikatessenladen oder Wie viele Divisionen hat die Natur? 


\title{
Rekonstruktion historischer Biodiversität
}

\author{
Bernd Herrmann ${ }^{7}$
}

\section{1 Über Maßstäbe und woher sie kommen können}

Wer etwas über die Pflanzen und Tierwelt in der Geschichte wissen will hat, so meint man, reichlich Auswahl unter den coffee table books dieser Welt. Da findet sich vom „Mythos Baum“ (LAUDERT, 1998) über die „Wahre Geschichte der Tiere“ (DELORT, 1987) bis zur „Naturgeschichte Pompejis“ (JASHEMSKI, 2002) alles was das Herz begehrt. Und wer es noch genauer wissen will, greift dann eben zu den Lehrbüchern der Zoogeographie oder Vegetationsgeschichte.

Woher wissen wir aber eigentlich wann der Dodo ausstarb (z. B. BALOUET \& AliBERT, 1990), die Tulpe nach Amsterdam kam (PAVORD, 1999), die Türkentaube nach Mitteleuropa (z. B. GEBHARDT, KINZELBACH, SCHMIDT-FISCHER, 1996), die Wasserpest nach England (J̈̈GER, 2001) usw.? Wir wissen es aus historischen Quellen, die in den seltensten Fällen genuin naturhistorische Aufzeichnungen darstellen. Man käme nicht einmal auf die Idee, MATTIOLUS’ Kräuterbuch, Konrad GESSNERS „Naturgeschichte“ oder vergleichbaren Büchern uneingeschränkt zu vertrauen.

Wie immer in der Geschichte wissen wir nicht, was passiert ist, wir kennen bloß die Erzählungen darüber. Und allzu häufig erliegen die auf positives Wissen konditionierten Naturwissenschaftler beim Konsultieren solcher Erzählungen, die als Texte überliefert wurden, der Illusion, dass das, was dort zu lesen ist, den

\footnotetext{
7 Zuerst erschienen in: Leibniz-Institut für Gewässerökologie und Binnenfischerei (Hrsg.): Biodiversität: Was kennen und verstehen wir von der Artenvielfalt?. 3. Stechlin Forum 2002. S 53 - 62
} 
„wirklichen“ Sachverhalt wiedergibt. Warum und zu welchem Zweck ein solcher Text verfasst wurde, ist eine in der Naturwissenschaft praktisch nicht gestellt Frage. Zumeist sind solche Texte Erzählungen über historische Ereignisse oder historische Strukturen, die sich bestimmter Interessenlage verdanken und eben nur begrenzt dem Ziel der primären Unterrichtung über naturhistorische Ereignisse oder Sachverhalte entsprangen.

Unter solchen historischen Erzählungen ist der Mythos vom Paradies mit einer ganzen Erzählungsgattung vertreten. Voltair setzt ihm im „Candid“ ein ironisches Denkmal. Die europäischen Siedler erzählen diese Fabelgeschichten über NordAmerika, die Konquistadoren erzählen sie über Süd-Amerika, die Israeliten erzählen sie über Kanaan, die Missionare über die Donauländer. Hier gibt es die Behauptung, dass einer seinen Hut ins Wasser der Donau halten solle und er würde voll mit Fischen sein. Doch wie trügerisch solche Bilder sein können, sollte spätestens mit der Ausreise ins Gelobte Land und der Chiffre von Milch und Honig erkennbar geworden sein. Es ist eben nicht die Rede von einem Überflussland, sondern von einem, in dem keine Ackerkultur möglich ist, weil nach vieljähriger Vernachlässigung des Feldbaus nur noch die Haltung von Schafen und Ziegen und die Bienenweide Ertrag liefern. Vor den Siedlern liegen vielmehr Jahre voller Mühe und Arbeit, in denen das Land erst wieder mühsam kultiviert werden muss (HÜTTERMANN, 2002). Milch und Honig - eine missverstandene Botschaft.

Andere Erzählungsmythen zielen auf Gesindeverträge. Bei den Rheinanliegern soll sich das Gesinde ausbedungen haben, nicht mehr als dreimal die Woche Lachs serviert zu bekommen. Fontane schreibt über den Tierreichtum des Oderbruchs, dieser sei so gewaltig gewesen, dass sich das Gesinde verbeten habe, mehr als 3 Tage in der Woche Krebse oder Hasenbraten vorgesetzt zu bekommen.

Wir verstehen die Didaxe dieser Erzählungsgattung:

früher gab es mehr und vor allem

früher gab es von den uns heute wertvollen Dingen mehr

Analysiert man die vorgeblichen Inhalte dieser Verträge, zeigt sich eine besondere Eigentümlichkeit. Das Gesinde verbittet sich nämlich ausdrücklich immer nur die übermäßige Behelligung mit Herrenspeise. Die Berichte erwähnen in keinem Fall, dass sich Gesinde etwa 5-mal Kohlsuppe in der Woche verbeten habe. Versucht man gar, solche „Verträge“ ausfindig zu machen, hat man kein Glück. Uns ist kein einziger Fall bekannt geworden, mit der eine solche Angabe bestätigt werden könnte. Alles verflüchtigt sich ins anonyme Hörensagen.

Interessanterweise werden auch in historischen Quellen von den Zeitgenossen häufig Zunahmen von Individuenzahlen bei solchen Arten, die nicht strikten Naturschutzmaßnahmen bzw. entsprechenden Vorläufermaßnahmen unterliegen, entweder überhaupt nicht registriert oder eine Zunahme wird in doppelt negativer Weise als übles Prodigium gewertet, als Beleg für eine Störung der sogenannt na- 
türlichen Verhältnisse konnotiert. Etwa, wenn seltene Vögel in Massen einfallen (vgl. die zahlreichen Einzelbelege bei KINZELBACH \& HÖLZINGER, 2000). Umgekehrt wird der Verlust von Lästlingen oder Schädlingen nicht weiter thematisiert. Alle diese Berichte gehören damit in jene erwähnte Kategorie des Mythos vom verlorenen Paradies bzw. zu seinen vielfältigen Verwandten. Oder sie gehören in die Kategorie von Wandersagen, in der etwa auch die „urban legends“(nach Art der „Spinne in der Yucca Palme“) angesiedelt sind.

Sicherlich kann es „mehr“ gegeben haben, bevor die Landschaft zu einer tiefgreifend umgestalteten Kulturlandschaft wurde, aber was und wovon kann keineswegs als grundsätzlich ausgemacht gelten. Die Frage ist überhaupt so zu stellen: „Wovon gab es mehr“? und wenn, gab es „mehr Arten und/oder mehr Individuen"? Wobei wir selbst wieder dem Mythos aufsitzen, wenn wir die Frage auf das „Mehr" ausrichten, statt auf „gab es andere Häufigkeiten“? Wer immer auf diese Fragen zu antworten sich berufen fühlt, wird Zeugen beibringen müssen.

Im 18. Jh. beispielsweise, aus dem Abschusslisten erhalten sind, wurden allein in Alt-Preußen, und ähnlich im Herzogtum Celle-Lauenburg, über Jahrzehnte jährlich ca. 60.000 Greifvögel geschossen. Die Preußen entnahmen über eine Kopfsteuer im 18. Jh. jährlich ca 350.000 Sperlinge allein in Brandenburg (HERRMANN, im Druck). Solche oder andere Zahlen spielen, meiner Kenntnis nach in der Diskussion z. B. bei Festsetzung der Vögel des Jahres keine Rolle. Dort existiert lediglich eine diffuse Ahnung, dass es heute weniger als damals gibt (wann immer das war).

Niemand hat bisher offenbar die Frage ernsthaft verfolgt, ob die vermutlich größere Verbreitung und Anzahl einzelner Arten, wie z.B. des Waldrapp, sich im späten Mittelalter und der frühen Neuzeit, wie die spätere Verbreitung und Anzahl des Sperlings, einer anthropogenen Lizenz verdanke (ein Gedanke, den INEICHEN 1997 für den Waldrapp anstößt, ohne ihn weiter auszuformulieren). Kaum jemand erinnert sich z.B. daran, dass der Kranich und die Trappe noch bis ins frühe 20. Jh. als Saatschädlinge schwer verfolgt wurden. Die Trappe verursachte im 18. und 19. Jahrhundert in Brandenburg solchen Schaden, dass sie sogar aus der Hohen Jagd in die Niederwildjagd umgesetzt wurde und damit, wie der Kranich, von jedermann geschossen werden durfte (KLOSE, in vorber.). Beim Sperling wird es noch interessanter, weil er Teile Deutschlands offenbar noch in der Mitte des 19.Jh. nicht erreicht hatte (MARSHALL, 1887), sofern den ornithologischen Beobachtungen dieser Zeit die gleiche Zuverlässigkeit wie heutigen Daten zukommt. Die Pferdefuhrwerke in den Städten des fin du siecle sind ihm die letzte große sichere Subsistenzgrundlage. Sie verschwand mit dem Siegeszug des Automobils. Die gewaltige anthropogene Lizenz verschwindet mit den Pferdefuhrwerken aus den Städten. Und nun wird es knapper für die Sperlinge.

Damit sind wir bei der spannenden Frage der Individuenzahlen angelangt. Fällt der Sperling nach seinem bekundeten Massenauftreten im 18. und 19. Jahrhundert, das nachweislich auf anthropogene Einflüsse zurückgeht, heute auf Bestandszahlen zurück, die seiner ursprünglichen Häufigkeit in unsere Region entsprechen? Wenn 
wir den Sperling vermissen, beziehen wir uns dann (heimlich) auf Abundanzen des 18. und des 19. Jh.? Ist uns dabei die damalige Ursache seiner relativen Häufigkeit bewusst? Und wie viele Sperlinge hätten wir denn heute gern? Denn die Angabe dieser Zahl wäre nichts anderes als die Angabe dessen, was wir als vorwissenschaftliche Setzung der nach unserer Auffassung „natürlichen“ Häufigkeit des Sperlings unterstellen.

Solche Fragen werden in der Biodiversitätsdebatte nicht gestellt. Wilsons Buch (1992) „Ende der biologischen Vielfalt?“ ist ein Musterbeispiel für ahistorische Abhandlungen des Problems. Trotz aller Forderungen z. B. des WBGU (1999) und des Sachverständigenrates für Umweltfragen nach Historisierung von Umweltproblemen, fallen solche Arbeiten wie die, aus der ich unten berichte, dem Verdikt der sozioökonomischen Ausrichtung zum Opfer, wenn sie denn überhaupt zur Durchführung gelangen. Der Förderschwerpunkt BIOLOG konnte sich z. B. trotz positiver Evaluation 2002 nicht entschließen, von sich aus eine Fortsetzung unseres Projektes in einer zweiten Förderphase zu empfehlen. Die „sozialökologische“ Fokussierung des Schwerpunktes stünde dem entgegen. Da helfen dann auch keine positiven Einschätzungen etwa von UNEP oder etwa die Einzigartigkeit des Forschungsansatzes, der international auf großes Interesse stößt. Die in der Biodiversitätsforschung fehlende Prämierung von Vorhaben, die sich mit Wertefragen anstatt mit der Zahlenproduktion befassen, ist ein Beispiel für die Fehleinschätzung, nach der nur Maß und Zahl die Lebenswelt beschrieben und nach der eine Ökonomie ohne Wertevorstellungen auskäme. Auch Voraussetzungswissen hat ökonomische Bedeutung, wenn auch vielleicht mehr indirekte.

Woher die Maßstäbe kommen, die sich am angeblich „Früheren“ orientieren, bleibt offen. Es ist einzuräumen, dass Naturschutzmaßnahmen aus pragmatischen Gründen schon auf kurzzeitige Schwankungen, etwa der Größenordnung von 10, 20, vielleicht 30 Jahren, reagieren können oder müssen. Für solche kurzen Zeiträume scheint es schon eher Bestandszählungen zu geben. Aber das Reagieren auf kurzfristige Schwankungen ersetzt nicht die Notwendigkeit der Kenntnis von langzeitlichen Bestandsschwankungen (longue durée Phänomene), es macht ihre Kenntnis geradezu notwendig, um mit Kurzzeitreaktionen nicht die Tendenzen der Langzeitphänomene zu stören bzw. zu zerstören.

Die Begründungen für Naturschutzmaßnahmen können allein deswegen keine größere zeitliche Tiefe haben, weil die historischen Daten, auf die man sich angeblich bezieht, in der Regel nicht vorhanden, oder: nicht zugänglich, nicht erschlossen, nicht systematisiert, nicht aufgearbeitet und nicht ausgewertet sind. Dass sich jemand an die Erzählung seiner Großeltern erinnert, wonach es früher viel mehr Rotkehlchen gegeben habe, erfüllt nicht wirklich die Anforderungen an die Qualität eines historischen Faktums. Wir wissen recht wenig und was wir zu wissen glauben, ist mehr der Kategorie vom paradiesischen Mythos als der Kategorie der gesicherten Zahl zuzurechnen. 


\section{Das Oderbruch als Fallstudie:}

\subsection{Die kultur-archivalische Rekonstruktion}

Seit längerem arbeitet unsere Abteilung über die Historische Humanökologie des Niederen Oderbruchs. Dabei interessiert uns der Wandel von einer nachhaltig und moderat genutzten Flußauenlandschaft hin zu einer extensiven landwirtschaftlichen Exklusivnutzung seit 1747 (Herrmann \& Kaup, 1997). Im Zentrum unseres Interesses stehen dabei diejenigen Fragen, die Aufschluss über den angeblichen Überfluss, über den Artenreichtum, über die natürliche Biomasseproduktivität vor der Melioration geben können. Dabei betreten wir insofern Neuland, als es weder Vorbildarbeiten in der Naturwissenschaft als auch in der Geschichtswissenschaft gibt. Daraus resultiert als besondere Erschwernis, dass die Suche nach geeigneten Quellen und ihre Anpassung an die Fragestellungen mit langwierigen Systematisierungsleistungen verbunden sind, die es späteren Projekten erlauben wird, sich ihren Fragezielen schneller zu nähern. Unter welchen Voraussetzungen und in welchem Umfang sich die historische Biodiversität in einer bestimmten Region (hier Oderbruch) mit archivalischen Mitteln der Umweltgeschichtsforschung rekonstruieren lässt, untersuchen wir in einem Vorhaben des BIOLOG Schwerpunktprogramms des BMBF. Archivbestände, das kulturelle Gedächtnis der Menschheit, sind bisher für die Biodiversitäts-Bemessung nicht herangezogen worden. Sie bilden jedoch gegenüber ausschließlich aktualistisch orientierten Datensammlungen zur Biodiversität ein unersetzliches Quellenmaterial für die Rekonstruktion früherer Naturzustände, weil sie die Nachzeichnung von anthropogenen Funktionalitätswandlungen aus dem historischen Zustandsbild und die Herleitung von Parametern für die Abschätzung der Biodiversitätsverschiebungen ermöglichen. Unsere Fallstudie wird an der zwischen 1747 und 1753 meliorierten Oderflussaue durchgeführt, in dem Abschnitt etwa zwischen Letschin und Bad Freienwalde, dem so genannten Niederen Oderbruch. Friedrich II ordnete hier die Gewinnung fruchtbaren Ackerlandes durch Trockenlegung der Flussaue und Kanalisierung der Oder bei ihrer gleichzeitigen Verkürzung um über 25 Flusskilometer an. Der Vorgang ist archivalisch recht gut rekonstruierbar (Herrmann \& Kaup, 1997).

Mit der Trockenlegungsmaßnahme verfolgte Friedrich II vor allem das Ziel, die Agrarproduktion zu steigern und Siedlungsraum für ausländische Arbeitskräfte zu schaffen (sogen. Peuplierung). Ein viele Jahrzehnte währender Umformungsprozess hat unsere Beispielregion in ertragreiches Wiesen- und Ackerland überführt. Tiefgreifende Veränderungen der betroffenen Ensembles der Flußauenlandschaft waren die Folge. Rund zweihundertfünfzig Jahre danach ist unklar, welche Faunen- und Florenelemente verdrängt wurden bzw. verloren gingen, welche hinzu kamen, welche Auswirkungen die Landgewinnungsmaßnahme auf das Vorkommen von Tieren und Pflanzen im 18. Jahrhundert und in der Folgezeit nahm. Artenlisten, die eine unmittelbare Vorstellung von der Tier- und Pflanzenwelt des Oderbruchs vor seiner Melioration vermitteln, existieren nicht. Die Untersuchun- 
gen stützen sich daher hauptsächlich auf die Aktenbestände der ehemaligen preuBischen Staatsarchive in Potsdam und Berlin-Dahlem. Archivquellen müssen für solche Fragestellungen erschlossen werden, da sie im Hinblick auf andere Unterrichtung verfasst wurden. Für sie wird ein Merkmalskatalog entwickelt, der es ermöglichen soll, Quellengattungen, die für diesen Ansatz einen hohen Informationsgehalt besitzen, von geringwertigen zu unterscheiden. Konzepte wie das der Indikator- und Schlüsselarten gestatten es schließlich, die Suche gezielt auf solche Arten zu konzentrieren, deren Existenz auf das Vorhandensein weiterer Arten hindeutet oder auf die Strukturen und Funktionen einer Lebensgemeinschaft schließen lässt.

Aus erreichbaren historischen Quellen ist eine Übersicht über die im historischen Wandel vorhandenen Fischarten erstellt worden (Abb. 1), die hier als Beispiel für die Erhebung und -Bewertung von Daten über Faunenelemente aufgeführt ist. Die Rekonstruktion für den betreffenden Oderabschnitts vergleicht die ältesten Daten des Fischbestandes von 1571 mit denen von 1700, 1788 und jüngeren Quellen. Auffällig scheint eine numerische Abnahme der Arten nach der Landschaftsumgestaltung, die auffälligerweise die kleinen Fische betrifft. Tatsächlich handelt es sich um Beobachtungsartefakte, weil die Verwertung kleiner Fischarten als Naturdünger wie auch in der Schweine- und Entenmast nach 1830 keine wirtschaftliche Rolle mehr spielt und allgemein nur noch die wirtschaftlich verwertbaren Arten aufgeführt werden. Betroffen sind darüber hinaus auch Arten mit einer geringen Individuendichte. Wir vermuten, dass die zunehmende Verschmutzung der Oder durch die einsetzende Industrialisierung ist, auch durch das Schlesische Revier als einer Ursache mit Fernwirkung. Unlängst haben wir in den Archivbeständen die Fischarten für den hier untersuchten Oderabschnitt in der Originalaufstellung vom Februar 1782 gefunden, die als Grundlage für das weltberühmte Fischbuch von Marcus Elieser BLOCH (1782 - 1784) dienen sollte. Mit 31 Arten, von denen fünf als selten eingestuft werden, fällt der Bestand 1782 annähernd wie vor der Melioration aus. Die Schwankungen können noch nicht als signifikant gelten, weil sie - entsprechend der Intention des Blochschen Werkes - wieder die wirtschaftlich uninteressanten Arten betreffen. Zudem unterscheidet man zu dieser Zeit zwei Arten, die heute als vier gelten. Auffallend ist u.a., dass die ehedem typische Barbe heute nicht mehr anzutreffen ist. Bemerkenswert waren auch Änderungen bei der Fischernte, also bei der Individuendichte. Hierfür liegen vereinzelt Ertragsangaben vor. Wir suchen z.Zt. noch spezifizierte Steuerlisten, die Hinweise auf Ertragsmengen einzelner Arten geben könnten. Am deutlichsten macht sich ein Rückgang bei den Hechten bemerkbar, die ausschließlich von einer privilegierten „Hechtreißer“-Innung in Wriezen vermarktet werden durften. Die Fänge schwanken auch vor der Melioration in der ersten Hälfte des 18. Jh. beträchtlich, sie erreichen merkwürdigerweise wenige Jahre nach der Melioration ihren historischen Höchststand. Dies könnte zusammenhängen einmal mit den Störungen durch Eingriffe in die Landschaft, die vorübergehend zusätzliche opportunistische Nutzung für Hechte ermöglichten, zum anderen mit der zunehmenden Drainage, 


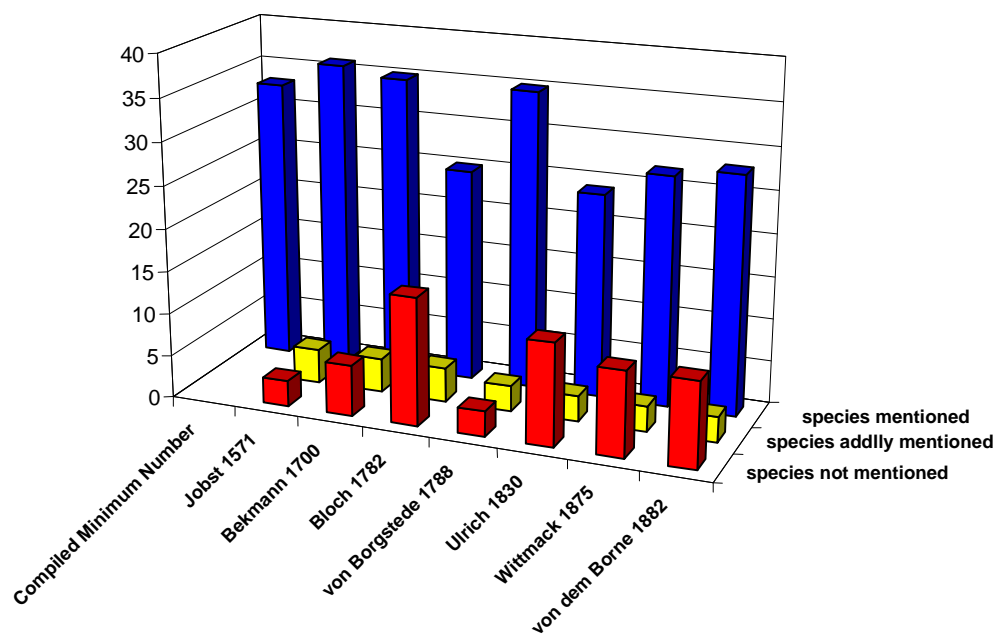

Abb. 1 Aus historischen Quellen rekonstruierte Artenzahlen für Süßwasserfische im Bereich Niederes Oderbruch. Dargestellt sind hier die Artenzahlen, die sich nach der Auswertung historischer Quellen ergeben, d.h. nach Bewertung der biologischen Plausibilität unter Berücksichtigung der Quellenintention. Der Vergleich mit der Mindestartenzahl, wie sie sich u.a. auch aus einem Vergleich mit den Artennachweisen für den Nationalpark Unteres Odertal, ergibt, muss daher außerordentlich quellenkritisch erfolgen. Dabei sind moderne enzyklopädische Arbeiten besonders hilfreich (wie von Wolter et al. 1999)

wodurch die Hechte allmählich aus den trockenfallenden, entlegeneren Wasserflächen in die Fanggründe der Hechtreißer hineingezwungen wurden und so zu einem einmaligen Erntehochstand führen. Anschließend geht der Bestand zurück, der Hecht wird bereits 1782 als „selten“ bezeichnet. Die Hechtreißer beklagen besonders 1793 die Verschmutzung des Wassers durch ortsansässiges Gewerbe. Schließlich wird die Innung Mitte des 19.Jh. aufgelöst. Waren 1733 noch 37 Hechtreißer tätig, sind es bei Auflösung der Innung 1866 nur noch sieben, die das Gewerbe auch nicht mehr ausschließlich betreiben.

Ungleich komplexer noch als bei den Faunenbeständen gestalten sich Rekonstruktionen der Florenbestände. Mitteilungen über den Pflanzenbesatz einer Region lassen sich nur aufwendig aus sehr unterschiedlichen Quellengattungen ermitteln. Wie bei den Faunenbeständen ist auch hier die ergänzende Auswertung biologischer Archive (naturkundliche Sammlungen, Pollendiagramme, archäobotanische Angaben, Herbare) selbstverständlich. Die Kriegsverluste der größten Herbarbestände sind dabei besonders nachteilig. Als sehr informativ erweisen sich vor allem Planungskarten (Abb. 2) mit differenzierten Legenden sowie zeitgenössische Beschreibungen lokaler Landschaftsprospekte als Hinweisgeber (JAKUPI et al., in review). 
Das Vorhaben wird Auskunft darüber geben, welche Belastbarkeit historische Daten für die Rekonstruktion von Faunen- und Florenbeständen haben. Dabei kann das Projekt nur erfolgreich sein, wenn es den Transformationsprozess des Landschaftswandels und der Sozio-Ökonomie der Bewohner des Oderbruchs ebenso wie die politischen und gesellschaftlichen Determinanten so weit wie nur möglich zu überblicken und zu bewerten in der Lage ist.

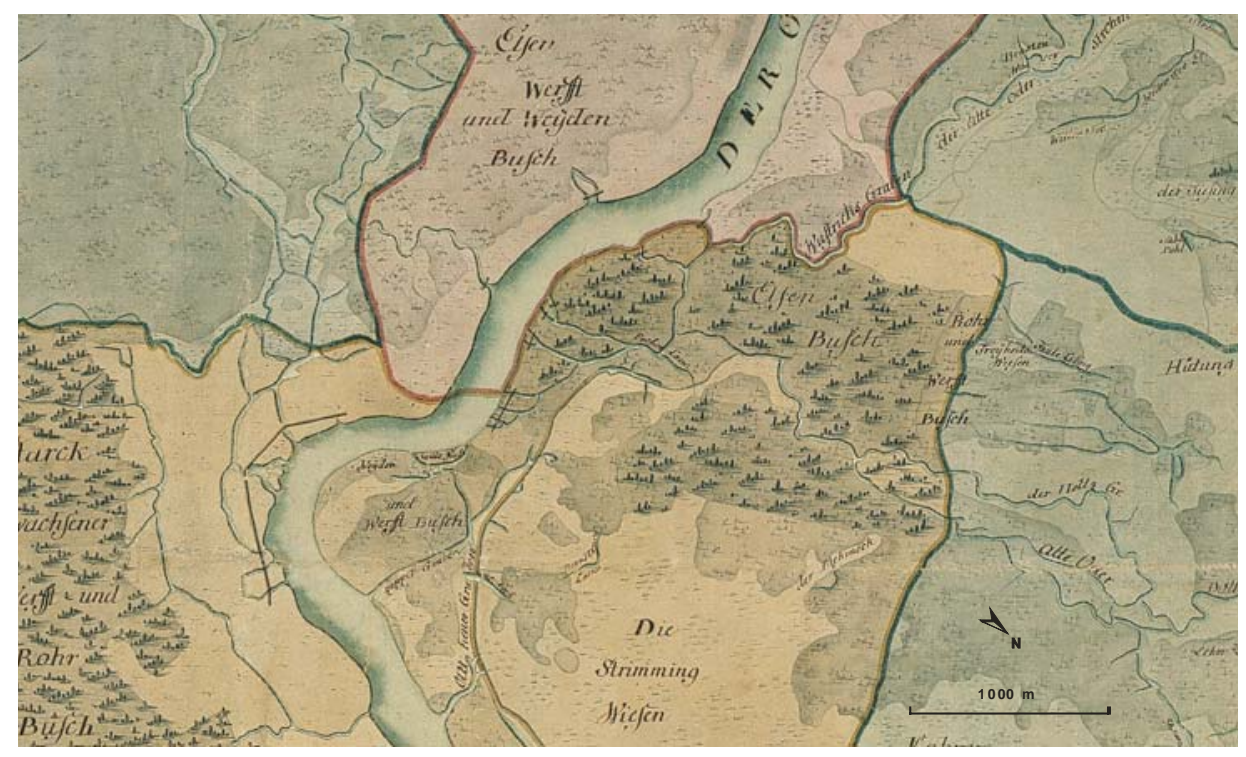

Abb. 2 Ausriss aus einer Planungskarte der Oderbruchregion, die den Zustand vor der Melioration (ca. 1746) zeigt. Ähnliche Regionalaufnahmen reichen bis ins frühe 18. Jh. zurück. Die Eintragungen über Nutzung und Vegetationszustände sind so detailliert, dass eine Rekonstruktion der Pflanzengesellschaften bis hinunter auf ein etwa 10.000 Quadratmeter-Raster möglich wird. Wiedergabe mit freundlicher Genehmigung des Geheimen Preußischen Staatsarchivs, Berlin-Dahlem.

Schließlich soll das Vorhaben in die Erarbeitung eines Monitoring-Systems für Biodiversitätsveränderungen aus archivalischen Beständen münden. Derartige Angaben wären nicht nur nutzbringend für den rekonstruierenden Naturschutz oder für die Pflege von Kultur-Altlandschaften einzusetzen. Archivalisch rekonstruierte Kenntnisse ließen sich auch für jene Entwicklungsländer, die früh unter europäischen Einfluss kamen, nutzbar machen. Sofern eine der hiesigen Tradition verpflichtete Aktenüberlieferung besteht, können Versuche zur Rekonstruktion zerstörter oder veränderter Ökosysteme in den ehemaligen europäischen Kolonien auf den Erfahrungen unserer Pilotstudie aufbauen.

Die Ergebnisse des Projektes lassen darüber hinaus Einblicke in Mentalitätsverschiebungen zu, die auf grundsätzliche und nicht ausdiskutierte Fragen des 
Biodiversitätsdiskurses führen. So wird im 18. Jh. in unserem Fallstudiengebiet z. B. der ehedem geschützte Biber planmäßig ausgerottet, weil er die neuen Deiche der Oder untergräbt. Verliert die betroffene Bevölkerung mit dem Biber Lebensqualität oder gewinnt sie solche durch Hochwasserschutz? Lassen sich mögliche Meliorationsverluste im Artenbestand numerische Gewinne jener Arten gegenrechnen, die der Mensch mit seinem Vieh oder seinen Ackerfluren importiert? Wer entscheidet nach welchen Kriterien, ob etwas gewonnen oder verloren wurde? Sind Klagen über vermeintliche Verluste begründet, oder verdanken sie sich etwa irriger Wahrnehmung und stellen am Ende wieder nur jene Varianten von Klagen über den Paradiesverlust dar? Dann wären sie Ausdruck jener „Angst im Abendland“, die dem Wandel gilt (DELUMEAU 1989). Die Biodiversitätsdebatte ist, bei aller Wissenschaftlichkeit, auch eine Angstdiskussion. Die historisch-anthropologische Analyse von Fallstudien, wie der hier vorgestellten, führt damit auch in die gesellschaftlichen Grundfragen dieses hochaktuellen Themas, das eben keinesfalls der Biologie allein gehört.

\section{Was heißt und zu welchem Ende studiert man Biodiversität? Oder: Wissenschaftlich - enzyklopädischer Anspruch vs. Nutzungsinteresse}

Das Biodiversitätskonzept ist, in letzter Konsequenz, ein Konzept, in dem sich allen Beteuerungen zum Trotz - die Vollendung der menschlichen Machtübernahme über die Natur realisiert: Nachdem er sich anfänglich mit dem Benennen und Zählen begnügte, stellt sich der Mensch schließlich selbst auf den Platz des verantwortlichen Bewahrers. Was als Überwindung des naturtheologischen Weltbildes durch Aufklärung und Rationalismus begann, hinterlässt offenbar eine schreckliche Lücke im Weltbild. Ein sich selbst organisierender Vorgang, wie ihn die Biologie mit dem Prozess des Lebens gefunden hat, liegt in niemandes Verantwortung, auch dann nicht, wenn dieser Prozess Elemente hervorbringt, die ihn selbst gefährden. Unbestritten hat dieser Prozess mit Homo sapiens eine Art hervorgebracht, die in der Lage ist, den Prozess der Evolution zu beenden.

Aber, selbst diese Bewertung erweist sich am Ende als anthropozentrisch. „Realistisch“ gesehen könnte der Mensch sicher „dem Leben“ auf unserm Planeten schweren Schaden zufügen, aber den Prozess der Evolution nicht wirklich quantitativ beenden. Die Bedrohungseigenschaft ist außerdem keineswegs singulär und nur beim Menschen zu finden. Sie existiert grundsätzlich auch z. B. bei pandemischen Pathogenen. Interessanter Weise wurde aber Seuchenhygiene nie als Kampf um die Erhaltung der Evolution gesehen, sondern als Abwehr und Aufrechterhaltung eigener (menschlicher) Lebensansprüche. So geht es also beim „Erhalt der Evolution“, der im Gewande des „Erhaltes der Biodiversität“ steckt, am Ende immer um die Aufrechterhaltung menschlicher Eigeninteressen. Für dieses Ziel würde der „Erhalt der Biodiversität“ ohne Zögern sogar den Schalter umlegen, der 
die Evolution in Gang hält, weil „Naturschutz“ von seiner Idee her auf Evolutionsvermeidung abzielt.

Das wäre alles akzeptabel, wenn es entsprechend deklariert wird, nicht aber in einer moralischen Verbrämung von der angeblichen Verpflichtung zur Schöpfungsbewahrung (denn auch diese Idee verdankt sich wiederum einem bestimmten - z. B. jüdisch-christlichen Konstrukt - dessen Zweck selbst seinerseits in der Bedürfnisbefriedigung und Stabilisierung einer bestimmten Kultur liegt. Es gibt hingegen auch Überzeugungssysteme, die in gesellschaftliche Großalternativen gemündet haben, die ohne kreationistischen Mythos auskommen).Es ist ausschließlich menschliches Eigeninteresse, das den Menschen sich selbst an die Stelle des Verantwortlichen setzen lässt. Damit ist die Biodiversitätsdebatte zugleich eine Debatte über gesellschaftliche Großalternativen (ein Ausdruck, den Niklas LUHMANN für die nebeneinander existierenden Überzeugungssysteme und ihre gesellschaftlichen Organisationsformen gefunden hat).

War es ehedem ein numinoses Täterwesen, dann der benennbare Gott, schließlich nur noch die sogenannte „Naturgewalt", welche die kleinen und großen Ereignisse, Störungen und Katastrophen verursachte, ist heute akzeptiert, dass menschliche Handlungsfolgen weiterreichend sein können als das unberechenbare Naturgeschick (hierzu BORST, 1981). Dieser Gedanke forderte bereits mit der Sichtweise BACONS $(1561$ - 1626) auf die Natur erstmals selbstbewusst seinen Tribut. Anders als SPINOZA (1632 - 1672), der in der Natur nichts sah, was ihr als Fehler vorgehalten werden könne, hatte Bacon durchaus eine Vorstellung von Schöpfungsmängeln, und damit implizit von der Verbesserungsfähigkeit der Natur, wenn er von „Misszeugungen“ spricht:

„Die Einteilung der natürlichen Historie wollen wir nach dem Zustand und der Beschaffenheit der Natur selbst unternehmen, als die in dreifachen Zustand gesetzt erfunden wird und gleichsam eine dreifache Regierung eingeht. Denn entweder ist die Natur frei und erklärt sich durch ibren gewöhnlichen Lauf, wie an den bimmlischen Körpern, den Tieren, den Pflanzen und dem ganzen Vorrat der Natur; oder sie wird durch bösartige Ungewöbnlichkeiten eines unbändigen Stoffes und durch die Gewalt der Hindernisse außer ibrem Zustand gestoßen, wie in Missgeburten. Also teilt sich die natürliche Historie in die Historie der Zeugungen, der Misszengungen und der Künste, welche let2tere man auch die Mechanik und die erfahrende Naturlehre zu nennen gewohnt ist. Die erste derselben behandelt die Freibeit der Natur, die zweite die Febler, die dritte die Bande." (Bacon, 1783, S.173).

Bacons Enkel in den heutigen molekularen Disziplinen schicken sich an, die Melioration der Natur direkt in Angriff zu nehmen. Denn es handelt sich ja bei den großangelegten Projekten wie HUGO und anderen in Wahrheit nicht um die bloße Aufdeckung des Natürlichen und seiner Diversität, sondern um den Aufbau zweckrationaler Legitimationsfiguren zur Erzeugung einer Hoffnung, in der sich die Überwindung der Natur durch sozial festgelegte genetische Künste einstellen soll. Nicht nur, dass diese Kunst auf Eindämmung von Diversität gerichtet ist, sie wird am Ende auch jedem Individuum das Recht auf seine unteilbare Einmaligkeit 
bestreiten, indem sie ihm zunächst einredet, Leben sei ohne das Risiko der Rekombination möglich. Aber die gesellschaftlichen Konsequenzen der totalen Naturaneignung, die sich durch die molekularen Techniken in den nächsten Jahrzehnten ergeben, werden dazu führen, dass sich niemand mehr seiner selbst als akzeptierter Bedingung in der Gesellschaft sicher sein kann. Nach dem Verlust einer religiösen Weltsicht werden wir damit auch die profane Sicherheit verlieren, dass jeder einzelne von uns seinen Ort in „der Natur“" hätte, einen um unserer selbst willen zugewiesenen Platz. Die Biologie schickt sich an, die Menschenrechte zu überwinden, die eine Überwindung der konkreten Natur darstellten (die Überwindung des durch Geburt zugewiesenen gesellschaftlichen Platzes durch die Vorstellung von der Verwirklichung der angelegten Möglichkeiten), Nach der Überwindung der Menschenrechte durch die molekulare Biologie wird die konkrete Natur wieder zum Maß gesellschaftlichen Handelns gemacht (indem die Möglichkeit eines krankheitsbergenden Genoms nach gesellschaftlichen Vorstellungen vom richtigen Menschen therapiert wird). Wenn die Gesellschaft auch an dieser Stelle nicht die erforderlichen Wachstumsverweigerungen festschreiben wird, erscheint mir ein Diktat oder gar eine Diktatur von Medizintechnik und Molekularbiologie unvermeidlich. Welche Fragen werden dann an die Biodiversität (des Menschen) gestellt werden?

Die biophile Verantwortungshaltung gegenüber der Artenfülle verdankt sich also nicht demütiger Grundhaltung, sondern der aufgeregten Angst, der Mensch (stillschweigend gehen wir vom euro-amerikanischen Kulturmenschen aus) könne auf eine fatale Weise seines bisher Erreichten verlustig gehen. Die vermeintlich demütige Anerkennung des Existenzrechtes aller bestehenden Arten ist keine aus dem Prozess der Naturabläufe selbst ableitbare Einsicht, sondern ein konservierter naturtheologischer Gedanke, wie er in der Idee der Kette der Wesen, die LOVEJOY (1933 [1993]) so eindrucksvoll nachzeichnete, angelegt war. Soweit mir bekannt, gilt nämlich die Frage, wie viele Arten ein Ökosystem bzw. wie viele Arten ein bestimmtes Ökosystem ausmachen bzw. wie viele oder welche Arten in einem Ökosystem fehlen könnten, ohne dass seine grundsätzliche Qualität geändert würde, unter Ökologen als offen. Auch die Annahme, eine hohe Diversität bedeute hohe ökologische Stabilität, gilt zumindest nicht als gesichert, wenn nicht sogar als falsch. Wenn nun Ökosystemwissenschaftler die Diversität grundsätzlich als scheinbar paradoxes Ergebnis von Nahrungsknappheit erkennen, läuft dies in der gedanklichen Konsequenz sogar auf grundsätzliche Verträglichkeit von Diversitätsverlust hinaus, weil Wettbewerbsabnahme die Ressourcenlage verbessert.

Die grundsätzliche Anerkennung eines alle Arten umfassenden Existenzrechtes setzt den Menschen in einen offenkundigen Gegensatz zu allen anderen Lebewesen, denen bei ihrer Lebensausübung das Existenzrecht anderer Arten nicht vorgehalten wird. Ein solcher Vorwurf ist für die innerhalb eines sich selbst organisierenden Prozesses stehenden Organismen auch absurd. Erst durch das menschliche Interesse und die Konstruktion einer „Verantwortung“ wird Biodiversität überhaupt wahrnehmbar, wissenschaftlich wie gesellschaftlich vermittelbar und damit 
politisch nutzbar. Zugleich enthält diese Wahrnehmung die Formulierung eines Machtanspruchs und die faktische Machtausrufung. Allerdings werden der absolute Verfügungswille und das dazu gehörige Instrumentar unlauter hinter einem moralischen Appell verborgen und für seine Zwecke in Gesellschaft wie Wissenschaft instrumentalisiert. Nicht der Gedanke der Aufzählung, Kenntnis und Bewahrung aller Arten, die zusammen denn die Biodiversität ausmachten, um ibrer selbst Willen ist das Ziel, sonder vielmehr deren Bewahrung um der Nutzung willen. Nicht von ungefähr ist mit der Idee der Kette der Wesen untrennbar die Entwicklung des Gedankens von der Nutzbarkeit der Lebewesen wie auch der oeconomia naturae verbunden, der Gedanke, der sowohl die Wirtschaftstheorie der Moderne nachhaltig beeinflusste (hierzu vor allem MEYER 1999) als auch die Biologie, deren darwinsches Paradigma eine ökonomische Theorie der Natur ist.

Die bis hier vorgetragenen Überlegungen diskutieren nicht die thematisch subsumierbare, unverdächtige Wissensproduktion auf der Ebene des positiven Wissens und sie diskutieren auch nicht die zweifelsohne existierenden pragmatischen Aspekte der Idee der Biodiversität. Sie diskutieren vielmehr ihre Verwertungszusammenhänge. Für die Humanökologie sind die kulturell bzw. gesellschaftlich moderierten Prozesse auch jenseits der unmittelbaren Verwertungszusammenhänge als Teil der Mentalitätsgeschichte, als Rezeptionsgeschichte, bedeutsam. Erst die Aneignung der Biodiversität im Verlauf der Geschichte wird den Menschen zu dem machen, was er ist, weil der Mensch das einzige Lebewesen ist, das als Appropriateur auftritt und die Biodiversität exzessiv ausbeuten kann. Das Grundproblem der biologischen Wissenschaften, welchem Kalkül denn das balancierte Miteinander so vieler Spezies folge, ist zumindest auf unsere Spezies hin ausschließlich utilitaristisch beantwortet. Dabei ist es gleichgültig, ob hier vom Nutzen in wirtschaftlicher Hinsicht oder vom Nutzen aus interesselosem Wohlgefallen, worunter nach Kant auch der Genuss des Naturschönen zu verstehen ist, ausgegangen wird. Insofern ist die Entdeckung der Biodiversität und ihre immer raffiniertere Nutzung die eigentliche Geschichte des Menschen und der menschlichen Herrschaft über die Natur. Die Herrschaft über die Natur drückt sich überraschenderweise aber nicht in der Aufdeckung des Evolutionsgeschehens durch die biologische Wissenschaft aus, sondern schon viel früher in den scheinbar harmlosen Formeln von Schöpfungsreichtum und Artenfülle aus. Wer den Dingen einen Namen gibt, hat die Verfügungsmacht. Das ist so seit jenen Tagen im Garten Eden.

Die Agrargesellschaften verdrängten mit ihrer Flächennutzung kontinuierlich für den Menschen uninteressante Arten. Entstehende Verluste werden vielleicht registriert, aber eben nur in Zusammenhang mit ihrem Nutzwert, etwa, wenn die Brandenburgischen Churfürsten schon Ende des $16 \mathrm{Jh}$. Braunbären aussetzen lassen, um sie zu jagen, oder Ende des 17. Jh. ein Patent erlassen, wonach man Nachtigallen nicht mehr fangen dürfe, weil ihr Gesang kaum noch zu hören sei, ein seltenes Beispiel für Berücksichtigung von Symbol- bzw. Optionswert, dem man auch Rechnung trug, als man den seit 1720 in Preußen als Ernteschädling verfolg- 
ten Kranich 1936 unter Naturschutz stellte. Ähnliches war auch nicht zu vernehmen, als die WHO die Welt vor einigen Jahren für pockenfrei erklärte. Niemand (außer vielleicht einigen bioethischen Puristen) thematisierte den impliziten Verlust für die Biodiversität.

\section{Die ,gelenkte" Vielfalt}

Die Ausrichtung der Stoffströme auf die Zentren menschlicher Aktivität hin wird, seit man diese Zentren („Städte“ und ihr Umfeld) etabliert, also seit rd. 10.000 Jahren, zu einem Problem. Paradoxerweise haben sich Städte heute längst zu Zentren höchster Biodiversitätsdichte entwickelt (wenn auch nicht funktional). Gleichzeitig setzt aber eine Entwicklung ein, die Nutzung auf immer weniger Arten zu konzentrieren. Heute werden 90\% der energetischen Primärproduktion durch nur 20 Pflanzenarten gedeckt (für die allerdings große ex situ Genbanken bestehen). Bekannt ist aber, dass mit der Gesamt-Biodiversität eines Landes die NPP im volkswirtschaftlichen Maßstab steigt (Haberl, 1995). Damit wird hier deutlicher als in anderen Zusammenhängen, dass es in der Betrachtung nicht auf die numerische Biodiversität sondern auf eine funktionale ankommt. Die sich zwingend anschlieBende Frage des Grenzertragsnutzens durch Artenzahlerhöhung ist nicht nur bei landwirtschaftlichen „Ökosystemen“ besonders interessant. Aber die Frage, was wie mit wem und ob überhaupt alles mit allem zusammenhängt, ist keine taugliche Frage, weil sie nur zu der Aussage führt, dass die Welt ist wie sie ist und alles Geschehen entweder als kontingentes oder determiniertes Ereignis begreift. Mindestens eine dieser resultierenden Sichtweisen gehört in den Bereich der BioReligionen.

Die biowissenschaftliche Sichtweise auf die biologische Vielfalt ist tatsächlich eine ausschließlich anthropologische Perspektive, weil sie keine anderen Bereiche abbildet, als jene, die im unmittelbar menschlichen Nutzungsinteresse liegen und nicht begründet, warum andere Betrachtungsebenen nicht vorkommen. Unter einer solchen Betrachtung kommt der menschlichen Moderation der kleinräumigen Diversität zur Steuerung der großräumigen sicher die größte Bedeutung zu. Mit seiner kulturellen Innovationskraft kann der Mensch seine kosmopolitsche Verbreitung erreichen, einzig, weil er Diversität aktiv zu seinem Vorteil lenken und nutzen kann. Hierzu gehört auch die Idee der Vermehrung der genetischen Diversität durch Züchtung und Manipulation, die seit der Neolithischen Revolution in der Welt ist und heute durch die molekularen Technologien atemberaubende Perspektiven erhält.

Neben der selbstverständlichen und pragmatischen Arbeit, die sich als ,biodiversitätsorientiert" versteht, gibt es anhaltenden Anlass, nach den Grundlagen des Begriffs „Biodiversität“ bzw. nach der darin verborgenen Vorstellungswelt zu fragen, soweit er über ein bloßes Synonym für „zahlreiche biologische Arten“ bzw. „biologische Verschiedenheit" hinausgeht. Es besteht Anlass, auch über seine allgemei- 
neren Implikationen nachzudenken, über Aneignung der Naturgüter und den Umgang mit ihnen auch im Hinblick auf die Rezeptionshaltung der Menschen innerhalb des Prozesses der Geschichte. Eine solche Forderung ist keinesfalls akademisch, sondern reflektiert die ungeheure Verbreitung des Diversitätsdenkens auch in der Alltagserfahrung. Dort finden wir es in vielerlei Formen wie Verkleidungen wieder, z. T. in unglaublich trivialisierter Weise, was aber eben nur auf seine Wirkmächtigkeit hinweist. Die „Pokémon“-Darstellungen oder die Phantasy-Figuren aus „Star Wars“ bis zum „Herrn der Ringe“ sind Beispiele für Verlängerungen des Biodiversitätsdenkens. Die weiter bestehende Vertrautheit mit der Idee der Kette der Wesen ohne, dass diese noch zum explizierten allgemeinen Bildungsgut gehören würde, lässt sich u. a. für pädagogische Konditionierungen nutzen. Solche Konzepte verhelfen letztlich den genetischen Utopien unserer Tage zu gesellschaftlicher Akzeptanz. Sie finden in Cyberspace-Schöpfungen wie Lara Croft ihre gleichsam ,natürliche“ Fortsetzung. Nun wird erkennbar, wie kümmerlich Natur doch eigentlich im Vergleich zu den überoptimalen Proportionen solcher Geschöpfe beschaffen ist. Und am Ende könnten Entwicklungsbiologen die Herausforderung sehen, nicht nur genetische Meliorationen durchzuführen, sondern Bauplanchimären zu konstruieren (HALDANES berühmte Visionen von 1963 sind gegen die sich hier abzeichnenden realen Möglichkeiten geradezu läppisch). Eine Welt dann nicht mehr in der ehedem einfältig gedachten Vorstellung vom horror vacui der Natur, deswegen in der scala naturae alle denkbaren Positionen besetzt sein sollten, sondern eine Welt nur noch im horror.

\section{Danksagung}

Die Darstellungen über das Oderbruch verdanken sich den Arbeitsergebnissen unserer Oderbruchstudie. Ich danke Antje Jakupi, Johannes Klose und Peter Michael Steinsiek für die Zusammenarbeit. Die Arbeit wird materiell durch den BIOLOG Förderschwerpunkt des BMBF und das DFG-Graduiertenkolleg „Wertschätzung und Erhaltung der Biodiversität" unterstützt.

\section{Literatur}

Bacon, F. (1783) Über die Würde und den Fortgang der Wissenschaften. Pest

Balouet, J-Chr., Alibert, E. (1990) Extinct Species of the World. Lessons for our Future. Ch. Letts, London

Borst, A. (1981) Das Erdbeben von 1348. Historische Zeitschrift 233: 529 - 569

Delort, R. (1987) Der Elefant, die Biene und der heilige Wolf. Die wahre Geschichte der Tiere. Hanser, München Wien 
Delumeau, J. (989) Angst im Abendland. Die Geschichte kollektiver Ängste im Europa des 14. Bis 18. Jahrhunderts. Rowohlt, Reinbeck

Fittkau, E.J. (1984) Tropischer Regenwald. Die Zusammenhänge. Spixiana Suppl. 10, $47-54$

Gebhardt, H., Kinzelbach, R., Schmidt-Fischer, S. (Hrsg.) (1996) Gebietsfremde Tierarten. Auswirkungen auf einheimische Arten, Lebensgemeinschaften und Biotope. Situationsanalyse. EcoMed, Landsberg

Haberl, H. (1995) Menschliche Eingriffe in den natürlichen Energiefluss von Ökosystemen. Wien. Schriftenreihe Soziale Ökologie des IFF, Wien

Haldane, J.B.S. (1963) Biological possibilities for the human species in the next ten thousand years. In: G. Wolstenholm, Man and his Future , 337 - 361. [ zit. nach der Paperbackausgabe Churchill, London, 1967]

Herrmann,B. (im Druck) Die Entvölkerung der Landschaft. Der Kampf gegen „culturschädliche“ Tiere in Brandenburg im 18. Jahrhundert. Cottbuser Studien zur Geschichte von Technik, Arbeit und Umwelt [in diesem Band]

Herrmann, B., Kaup, M. (1997) „Nun blüht es von End' zu End' all überall. Die Eindeichung des Nieder-Oderbruchs 1747 -1753“ Münster, New York (Waxmann) (Cottbuser Studien zur Geschichte von Technik, Arbeit und Umwelt 4)

Hüttermann, A.P. (2002) Am Anfang war die Ökologie: Naturverständnis im Alten Testament. Kunstmann, München

Ineichen, St. (1997) Die wilden Tiere in der Stadt. Zur Naturgeschichte der Stadt. Die Entwicklung städtischer Lebensräume in Mitteleuropa verfolgt am Beispiel von Zürich. Im Waldgut, Frauenfeld $(\mathrm{CH})$

Jashemski, W.F. (2002) The Natural History of Pompeji. Cambridge Univ. Press, Cambridge

Jäger, E.J. (2001) Auswertungsmöglichkeiten von Pflanzenverbreitungsmustern. Jahrbuch Leopoldina (R.3) 46, $287-299$

Jakupi; A., Steinsiek,P.M., Herrmann,B. (in review) Early Maps as Stepping Stones for the Reconstruction of Historic Ecological Conditions and Biota. Naturwissenschaften 90(2003):360-365

Laudert, D. (1998) Mythos Baum. BLV, München Wien Zürich

Lovejoy, A.O.(1993 [1933]) Die große Kette der Wesen. Frankfurt/M (Suhrkamp)

Kinzelbach, R., Hölzinger, J. (2000) Marcus zum Lamm (1544 - 1606). Die Vogelbücher aus dem Thesaurus Pictuarum. Ulmer, Stuttgart 
Klose, J.(in vorber.) Zur sozioökonomischen Bedeutung von Vögeln in Brandenburg: Zur Wertschätzung von Biodiversität vom 17.bis zum 20. Jahrhundert. Diss. Biolo. Fakultät Univ. Göttingen

Marshall, W. (1887) Deutschlands Vogelwelt im Wechsel der Zeiten. Richter, Hamburg

Meyer, T. (1999) Natur, Technik und Wirtschaftswachstum im 18. Jahrhundert. Risikoperzeption und Sicherheitsversprechen. Münster, New York (Waxmann) (Cottbuser Studien zur Geschichte von Technik, Arbeit und Umwelt 12)

Pavord, A (1999) Die Tulpe. Eine Kulturgeschichte. Insel, Frankfurt Leipzig

Wilson, E.O. (Hrsg.) (1992) Ende der biologischen Vielfalt?: Der Verlust an Arten, Genen und Lebensräumen und die Chancen für eine Umkehr. Spektrum Akademischer Verlag, Heidelberg

WBGU (1999) Jahresgutachten. Welt im Wandel. Erhaltung und nachhaltige Nutzung der Biosphäre. Springer, Heidelberg

Wolter, C., Bischoff, A., Tautenhahn, M., Vilcinskas, A. (1999) Die Fischfauna des Unteren Odertales: Arteninventar, Abundanzen, Bestandsentwicklung und fischökologische Bedeutung der Polderflächen. In: Dohle, W., Bornkam,R., Weigmann,G. (Hrsg.) Das Untere Odertal Auswirkungen der periodischen Überschwemmungen auf Biozönosen und Arten. Limnologie Aktuell 9, 369 - 386 

Prolog

[Wilhelm Busch, Dideldum!, Der Maulwurf]

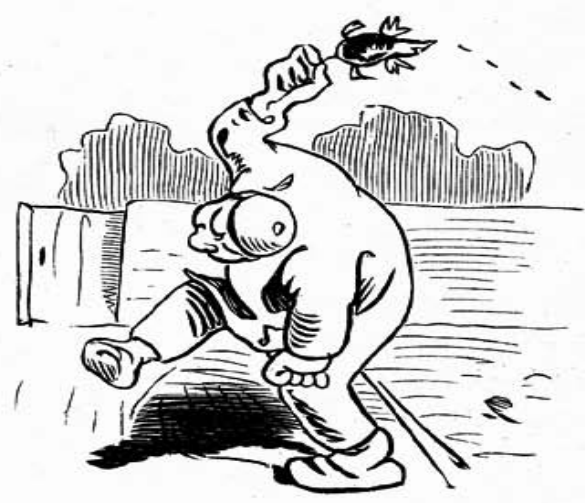

Dod Zinoll, bex fid emporgexafft, Beraubt ibn feiner Lebenstraft.

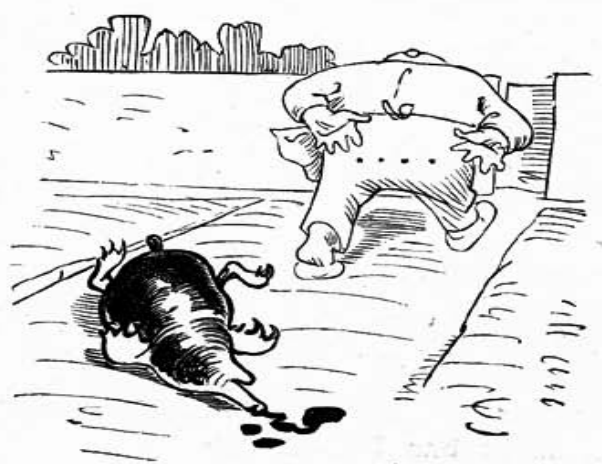

Da liegt bex fowarze Bofewidht.

Und wiblte gern und Eann bod nidht; Denn binderlid, wie ỉberall, Ift bier ber eigne Codesfall. 


\title{
Zur Historisierung der Schädlingsbekämpfung*
}

\author{
Bernd Hermann
}

Es überrascht, dass zeiten- und kulturenvergleichende Betrachtungen zur Umweltgeschichte der Schädlinge und der Schädlingsbekämpfung bisher zu fehlen scheinen. ${ }^{8}$ Das Thema berührt zwei Kategorien der Umweltgeschichte, diejenige der pragmatisch-technischen Handlungsweise und jene der Wertvorstellungen. In beiden konkretisiert sich der „Umgang mit Natur" innerhalb von Gesellschaften auf eine sehr unmittelbare Weise. Hier scheint nicht nur eine wenig reflektierte Seite des bomo necans auf, sondern es werden auch Lebensansprüche sehr direkt angemeldet. Weil das Thema vielfältig Elementares berührt, das keinen einfachen Dichotomien folgt, können hier nur ausschnitthafte Überlegungen und Systematisierungsansätze vorgestellt werden. Systematisch-handlungspraktisch betrifft „Schädlingsbekämpfung“ nicht nur heute überwiegend den Bereich des Pflanzenschutzes einschließlich des ihm zugeordneten Vorratsschutzes.

\footnotetext{
* Günter Bayerl zum 60. Geburtstag in freundschaftlicher Verbundenheit gewidmet. Torsten Meyer und Marcus Popplow danke ich für ihre Initiative und für die redaktionelle Betreuung der Festschrift. - Zuerst erschienen in: Meyer T, Popplow M (Hrsg.) (2006) Technik, Arbeit und Umwelt in der Geschichte. Günther Bayerl zum 60. Geburtstag. Münster u.a. S 317-338

8 Selbst die kenntnisreichen und gewinnbringenden Beiträge von Heinz Meyer [in: Peter Dinzelbacher (Hg.): Mensch und Tier in der Geschichte Europas, Stuttgart 2000] blenden „Plagen“, „Ungeziefer" und "Schädlinge“ als selbstverständliche Kategorien des Alltagslebens und konstitutiven Teil der Mensch-Natur-Beziehung in historischer Tiefe aus und beschränken sich nur auf sehr kurze Erwähnungen vereinzelter einschlägiger Arten
} 


\section{Schädlinge, Shoah und Naturalistischer Fehlschluß}

Das 1485 geschaffene „Landplagenbild“ (Abb.1) an der südlichen Außenwand des Grazer Doms bezieht die beschwörende Abwehrformel des Gebets („A peste, fame, bello libera nos, Domine!") ganz konkret auf die Situation der Stadt im Jahre 1480. In diesem Jahr erschienen drei der apokalyptischen Reiter vor den Stadttoren: die Krankheit kam als Seuchenzug der Pest, den Krieg trugen die Türken vor und in die Stadt, den Hunger schließlich verursachten Heuschreckenschwärme. Zusammen sorgten die drei Plagen dafür, dass der vierte Reiter, der Tod, reichliche Ernte halten konnte.
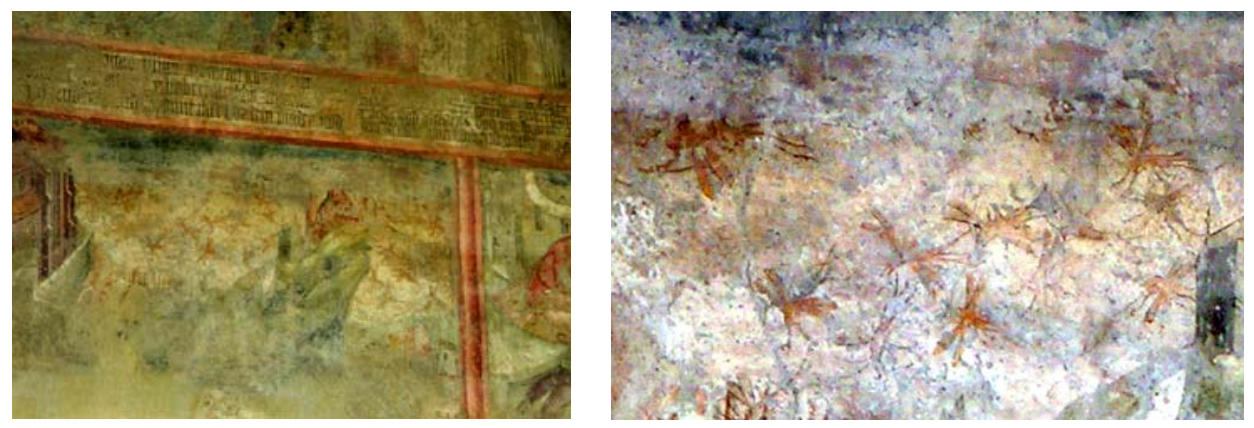

Abb.1 Landplagenbild am Grazer Dom, links: Bildausschnitt mit Heuschreckeninvasion. rechts: Heuschreckenschwarm, Ausschnitt, Farbfilter (Aufnahme Frühjahr 2004)

Die Heuschrecken zogen in diesem Jahr nicht das erste Mal durch ihre klassische geographische Einfallspforte, und sie zogen diesen Weg auch später aus Südostnach Mitteleuropa, regelmäßig noch bis ins 19. Jahrhundert. Das Landplagenbild repräsentiert die Bedeutungsmacht dieser Heimsuchung und verweist zugleich auf die überzeitliche Bedrohung, die der Mensch durch Schädlinge erfuhr und bis heute erfährt. Und aus der Sicht des Holzwurms liest sich nicht nur die Geschichte der Arche Noah ganz anders. ${ }^{9}$ Hätten die Heuschrecken, die Läuse oder die Ratten eine Geschichte von der Art, wie die Menschen sie erleben, dann hätten sie, denen er ein Ende macht, längst mit ihm fertig werden können. ${ }^{10}$

Doch so läuft die Geschichte der Schädlingsbekämpfung ziemlich asymmetrisch und hat eigentlich nur prosaische Seiten, in denen empirische, über Versuch und Irrtum gesteuerte, von Unwissen und Aberglauben beeinflusste Verfahren oder Handlungen in die allmähliche Verbesserung der Schädlingsbekämpfung führten. Diese Fortschrittsgeschichte sollte mit der Erfindung chemischer Be-

\footnotetext{
${ }^{9}$ Julian Barnes: A History of the World in 10 1/2 Chapters. New York 1990; Hans Zinsser: Ratten, Läuse und die Weltgeschichte. Stuttgart/Calw 1949

${ }^{10}$ Eine respektvolle Abwandlung des Einleitungssatzes von Arno Borsts „Drei mittelalterliche Sterbefälle“
} 
kämpfungsmethoden ein historisches Optimum an Effizienz und Wirksamkeit bereitstellen. ${ }^{11}$ Wiederholt wurde der epistemologische Zusammenhang zwischen der Bekämpfung tierlicher Schädlinge und der Massenvernichtung von Menschen in der Shoah abgeleitet. ${ }^{12}$ Für die Herstellung dieses Zusammenhangs wurden auch jene Konstruktionen entscheidend, die sich um 1880 in dem neuen Wort „Schädling“" verdinglichen. ${ }^{13}$ Nach Auffassung der Hauptprotagonistin dieser Sicht, Sarah Jansen, ist zudem die betonte Einbeziehung von ökonomischem Denken in die Schädlingsbekämpfung eine zentrale Bedingung, aus der sich die Begünstigung des Absturzes in die moralische Katastrophe folgerichtig ergeben habe. Möglich, dass sich alle jene Faktoren in einem bestimmten historischen Moment unter furchtbaren Folgen miteinander verbanden. Aber sämtliche äußere Faktoren, die für die Zusammenführung von „Schädlingsdenken“ und der Shoah als bedeutend herangezogen werden, durchziehen auch die Menschheitsgeschichte seit der Erfindung des Ackerbaus und der Vorratshaltung. ${ }^{14}$ Die Bewertung Jansens ergibt sich allein aus der Wahl ihrer Perspektive. Die Wortschöpfung „Schädling“ ist letztlich der zeitgenössische Ausdruck einer stetig gewachsenen Natureinsicht und einer Beherrschungsphantasie, vermittelt durch das Potential der damals aufstrebenden dynamischen Teerchemie. Das neu geschaffene Nomen bediente sich bei dem

\footnotetext{
${ }^{11}$ Hier bleibt außen vor, dass dieser „Fortschritt“ z.B. Anlass für Carsons „Stummer Frühling“ war und die Belastung der Umwelt mit Pestiziden ein in seinen Konsequenzen bis heute ein nicht überschaubares Problem darstellt. - Eine „Geschichte der Schädlingsbekämpfung“ steht aus. Aus umweltgeschichtlicher Sicht liegen vor allem Beiträge über historische Kalamitäten, etwa Heuschreckenzüge oder Forstschädlinge, vor. Es fehlt eine umfassendere Zusammenführung.

${ }^{12}$ Karl-Heinz Leven: Die Geschichte der Infektionskrankheiten. Von der Antike bis ins 20. Jahrhundert. Bd. 6 Fortschritte der Präventiv- und Arbeitsmedizin. Landsberg/Lech 1997.

Vor allem: Sarah Jansen: „Schädlinge“ Geschichte eines wissenschaftlichen und politischen Konstrukts 1840 - 1920. Frankfurt 2003. - In gedanklicher und inhaltlicher Verbindung hierzu: Sarah Jansen: Der ,kranke deutsche Wald': Krankheit und Körperlichkeit in der Bekämpfung von Insekten in Deutschland, 1840 - 1925. In: Christoph Gradmann/Thomas Schlich (Hg.): Strategien der Kausalität. Konzepte der Krankheitsverursachung im 19. und 20. Jahrhundert. Pfaffenweiler 1999, S.151 184.

${ }^{13}$ So Jansen, Schädlinge, jedoch mit einer unbefriedigenden etymologischen Retrospektive, in der die Vielschichtigkeit der Vorläuferbegriffe (z.B. „Ungeziefer“, „Geschmeiß“) praktisch unerwähnt bleibt. Warum sollte der Begriff des „Schädlings“ soviel unheilträchtiger als der schon vorher und seit vielen Jahrzehnten sehr gebräuchliche Ausdruck von den „kleinen Feinden der Landwirtschaft“ sein, in dem „klein“ eine Bezeichnung für die Größe der Lebewesen ist und nicht etwa für die Dimension der Bedrohung, im Gegenteil. Ich halte das Wort „Feind“ für nicht minder ideologieanfällig und hermeneutisch ausbeutbar als das Wort „Schädling“"

Außerdem ist der Mensch-Ungeziefer-Vergleich historisch keine Erfindung der lingua tertii imperii bzw. seiner unmittelbaren Vorläufer. Als stellvertretendes Beispiel möge hier genügen: „Eine volle Million Juden zum allerwenigsten, wonen dermalen mitten unter den Europäischen Christen zerstreut [...]; und incommodieren letztere, wie Zigeuner, Hamster, Tarkanen [d.i. Küchenschaben, B.H.] und Pest.“" (aus: „Bürgerliche Verbesserung der Juden. Extract aus einer Menge von Druckschriften, die hierüber seit 12 Jahren im Publico erschienen sind“. In: August Ludwig Schlözer: Stats-Anzeigen 18, Heft 72 (Dezember 1793), S. 482- 503, S. 483. Das Zitat verdanke ich dem freundlichen Hinweis von Herrn Dr.Wiard Hinrichs, Göttingen)

${ }^{14}$ Selbstverständlich ohne die chemischen Insektenvertilgungsmittel. Auch die Idee, zahlreiche Menschen gleichzeitig mit Gift (oder Krankheitserregern) umzubringen, ist kein originärer Gedanke des 20. Jahrhunderts.
} 
jahrhundertealten Adjektiv „schädlich“. Nicht die ökonomische Qualität sucht ihren Ausdruck, sondern die notwendig gewordene Benennung des naturalen Akteurs, des Gegenspielers menschlicher Interessen. „Der Schädling“ ist die metonymische Transformation eines vordem als „Natur" anonym agierenden Täterwesens, dessen vielfältige Stellvertreter in diesem neu geschaffenen Gattungsbegriff systematisiert werden. ${ }^{15}$ Das seinerzeit technisch modernste Instrument der Bekämpfung benötigte den Begriff als logischen Ort für den Gegner, weil die rationalen Prinzipien der Naturwissenschaften im 19.Jh. diesen aus einer ehedem unverstandenen Plage endgültig in einen kalkulierbaren Akteur überführt haben. ${ }^{16}$ Aber anders als Jansen hervorhebt, führte nicht die Idee des „Schädlings“, für den es bedeutungsnahe Vorläuferbegriffe gibt, in die Katastrophe. Es war auch nicht der vermeintlich neue Betonung des wirtschaftlichen Denkens in der Schädlingsbekämpfung, ${ }^{17}$ denn die Idee der Schädlingsbekämpfung ist grundsätzlich ohne Kosten-Nutzen-Überlegungen nicht denkbar. Es war die moralische Enthemmung, mit der ein pervertiertes Denken einer falschen Rationalität zur politischen und technischen Durchsetzung verhalf.

Die zweite Facette der Geschichte der Schädlingsbekämpfung berührt ebenfalls eine Wertefrage. Sie betrifft elementar den wertekategorialen Umgang des Menschen mit „Natur“, in dem sich entweder eine teleologische Auffassung oder ihr scheinbar wertneutrales ontologisches Äquivalent abbildet. Es ist entweder die Vorstellung einer auf den Menschen hin konstruierten Natur, die es möglich macht, Rechtfertigungsgründe für die Tötung von Organismen zu finden, die nach

15 Noch um die Mitte des 19.Jh. ist die Zeugungsweise vieler niederer Tiere, zu denen die meisten Schädlinge gehören, nicht allgemeines Wissensgut. Das modernste Lehrbuch seiner Zeit weist immer wieder darauf hin: H.Nördlinger: Die kleinen Feinde der Landwirthschaft oder Abhandlung der in Feld, Garten und Haus schädlichen oder lästigen Schnecken, Würmer, Gliederthierchen, insbesondere Kerfe, mit Berücksichtigung ihrer natürlichen Feinde und gegen sie anwendbaren Schutzmittel. Stuttgart 1869 (2.Auflage)

16 Der Gegenbegriff „Nützling“ wird etwa zeitgleich zum „Schädling“ gefunden (Moritz Heyne: Deutsches Wörterbuch, Leipzig 1892). Dabei existierte auch zu diesem Nomen ein viel älteres Adjektiv. Der dritte Begriff dieser Reihe, der „Lästling“ ist eine relativ junge Wortschöpfung, die sich dem nachlassenden ökonomischen Druck auf die Nahrungsproduktion verdankt. Die Uberflussgesellschaft kann es sich leisten, den Schädlingsstatus in einer Grauzone der Lästlinge enden zu lassen, deren Bekämpfung keine ökonomische oder ästhetische Notwendigkeit darstellt. Die emphatische Aufladung ist hingegen lange bekannt: Die Erfurter Dominikaner ärgerten sich 1493 sehr über die Elstern, die in ihrem Kirchturm nisteten, denn die Bürger verspotteten sie, deren Ordenstracht an die Elstern erinnerten. Die Mönche dingen schließlich einen Vaganten, die Elstern zu vertreiben. Aus: Ernst Schubert: Das Interesse an Vaganten und Spielleuten. In: Hans-Werner Götz/Jörg Jarnut (Hg.): Mediävistik im 21. Jahrhundert. Stand und Perspektiven der internationalen und interdisziplinären Mittelalterforschung. München 2003 (= Mittelalterstudien, hrsg. von Ernst Bremer/Jörg Jarnut/Matthias Wemhof, Bd. 1), S. 409 - 426, S. 411. - Oder konkreter: man vertreibt z.B. in den Siedlungen des Oderbruchs im 18.Jh. die lästigen Insekten durch Räucherwerk aus den Wohnungen (vgl: Bernd Herrmann/Martina Kaup: „Nun blüht es von End zu End all überall“ Die Eindeichung des Nieder-Oderbruchs 1747 - 1753, Münster u.a. 1997 (= Cottbuser Studien zur Geschichte von Technik, Arbeit und Umwelt 4)

17 Die hierzu gehörige Fußnote 2 bei Jansen bemüht die Encyclopädien des 18. Jh. und übersieht u.a., dass diese, wie etwa der Krünitz, sich z. T. bereits im Titel „oeconomisch“(!) nennen und damit selbstverständlich die Wirtschaft im Auge haben. 
jeweils herrschender Auffassung gegen menschliche Interessen agieren. Von keinem Tier als dem Menschen ist bekannt, dass es andere Tiere um ihrer selbst willen tötet ${ }^{18}$. Oder die Rechtfertigung ergibt sich aus dem „naturalistischen Fehlschluss", wonach es ein logischer Fehler wäre, aus der bloßen Feststellung biologischer Tatsachen ( z. B. der Existenz eines Organismus) darauf zu schließen, dass diese Tatsachen im ethischen Sinne richtig wären. Aus dem Sein folge unmittelbar weder das Sollen noch das Nicht-Dürfen. Daher können auch Unwerturteile hinreichend darauf gegründet werden, dass das Existenzrecht eines Organismus ethisch nicht zwingend aus der Existenz selbst abzuleiten wäre. David Humes (1711-1776) Diktum (There is no Ought from an Is) ist zwar nicht im konkreten Hinblick auf die Schädlingsbekämpfung formuliert worden, liefert aber bis heute ein wichtiges, wenn auch implizites Rechtfertigungstheorem. Aus den heutigen Diskursen über „Biodiversität“ führen zahlreiche Argumentationslinien hingegen wieder zurück in religiöse Grundauffassungen. ${ }^{19}$

\section{Karriere der Begriffe}

Es ist intuitiv erkennbar, dass nicht die einzelne Heuschrecke das Problem macht, sondern der Heuschreckenschwarm. Aber auch dem reflexhaften Erschlagen einer einzigen Laus, einer einzelnen Mücke oder einer einsamen Maus kommt der Charakter der Schädlingsabwehr zu. Dieser Reflex bedürfte an sich keiner Reflexion, bedarf aber weiterer Erörterung, weil er zwar ebenso einfach wie instinktiv ausgeführt, aber vordem kulturell fundiert und als instinktgleiche Handlung institutionalisiert wurde. Denn wer oder was ${ }^{20}$ und wann und von wem ${ }^{21}$ erschlagen werden darf, ist keine ein für allemal ausgemachte Sache. Entsprechend ist auch der moderne Ausdruck „Schädling““ als Kollektivbezeichnung für eine Tierart, die gegen-

\footnotetext{
${ }^{18}$ Gemeint ist hier selbstverständlich nicht der Beutegreifer, der sich vorzugsweise von zwei oder drei Arten Beutetieren ernährt, sondern der Mensch, der den Floh, den Wolf usw. erschlägt, wann immer er ibn trifft.

$19 \mathrm{Zu}$ dieser Verknüpfung siehe Bernd Herrmann: „Auf keinen Fall mehr als dreimal wöchentlich Krebse, Lachs oder Hasenbraten essen müssen“. Einige vernachlässigte Probleme der „historischen Biodiversität“. In: Hans-Peter Baum u.a. (Hg.): Wirtschaft - Gesellschaft - Mentalitäten im Mittelalter. Festschrift zum 75. Geburtstag von Rolf Sprandel, 2006

${ }^{20} \mathrm{Ob}$ ein lästiges Insekt auf meiner Haut eine potentielle Bedrohung durch Stich oder als Übertragungsvektor besitzt, wird mir kulturell mit dem Einüben der Nützlich-Schädlich-Opposition ebenso vermittelt, wie das Erkennen von und Vorgehen gegen Nahrungsschädlinge. Unterschiedliche gesellschaftliche bzw. religiöse Großalternativen haben zudem unterschiedliches Verständnis vom Lebensrecht der Tiere, das sich in Kulturen, die Wiedergeburtsvorstellungen pflegen, steigert.

${ }^{21}$ Vgl. James George Frazer, The Golden Bough, New York 1922, zum Keyword “vermin” auch als online Version unter www.bartleby.com
} 
über dem Menschen Schaden bewirkt, ${ }^{22}$ abhängig von Wertvorstellungen der Gesellschaft. ${ }^{23}$

Auf den Heuschreckenschwarm kann nicht mit dem Reflex reagiert werden ${ }^{24}$. Was beim einzeln auftretenden Tier als Voraussetzung wie als Konsequenz völlig gleichgültig ist, ob es nun eben wahrgenommen, gefressen, erschlagen wird oder am Leben bleibt, erreicht durch die bloße Zahl der Individuen eines Schwarmes seine Bedeutung, seine Bedrohung, schließlich seine geschichtsbildende Kraft. Heuschreckenschwärme lassen sich vom Standpunkt des agrarwirtschaftenden Menschen ohne jede ideologische Mühe als Unglück, als Extremereignis, als Katastrophe ${ }^{25}$ begreifen. Die In-Dienst-Stellung der Natur in Form der Landwirtschaft ist zwangsläufig mit der Attraktion von Nahrungskonkurrenten auf das anthropogene Ökosystem verbunden. Ihren Katastrophenstatus erhalten die Heuschrecken aus dem einfachen Sachverhalt, dass der Schwarm die vom Menschen im Agrarsystem erzeugte Biomasse nicht von anderer Biomasse unterscheidet und daher ausnahmslos alle sich darbietenden Pflanzen vertilgt. Das Verhalten der Tiere richtet sich selbstverständlich nicht intentional gegen das Interesse des agrarwirtschaftenden Menschen ${ }^{26}$, wird aber vom ihm so erfahren. Für die Durchsetzung der menschlichen Interessen gegenüber denen des Heuschreckenschwarmes und hierzu analoger Verhaltensmuster gegenüber anderen schädlichen Organismen praktiziert der Mensch mindestens seit Einführung der Landwirtschaft „Schädlingsbekämpfung“.

In der Karriere der einschlägigen Begriffe drückt sich eine zunehmende Säkularisierung des Deutungsmusters und Auffassungswandels aus, wenn der zunächst biblisch festgelegte Begriff der „Plage“ seit dem 15.Jh. differenziert wird und u.a. das „landverderbliche Übel“ [z.B. der Heuschrecken] als Synonym erscheint. Re-

\footnotetext{
22 Als Überträger von Infektionen, als Nahrungskonkurrent oder als Zerstörer der vom Menschen genutzten Biomasse

${ }^{23}$ Korrekter spräche man von den ,unterschiedlichen Wertvorstellungen innerbalb der Gesellschaft", denn die sozialen Klassen bzw. Schichten diskriminieren offenbar durchaus unterschiedlich. Ein Beleg hierfür stammt z.B. aus dem Interview des ehemaligen „Pink-Floyd“-Vormanns, Roger Waters, im SPIEGEL 38 (2005), S.175, in dem er die Britische Fuchsjagd verteidigt :"Füchse sind Ungeziefer, sie müssen gejagt werden. Man kann sie nicht einfach sich selbst überlassen, da sie keine natürlichen Feinde haben..... Füchse sind Ungeziefer wie Moskitos und Ratten." Das ist die bekannte Apologese einer Klasse, die die Hetzjagd auf Füchse als „humane“ (sic!) Hegearbeit und „Ungezieferbekämpfung" reklamiert. Gegen diese Bewertung hat die Britische Regierung 2004 ein gesetzliches Verbot der Hetzjagd auf Füchse gestellt.

${ }^{24}$ Die Überlegung bedient sich hier des „Schwarms“, weil er wegen seiner offenkundigen Bedrohungsmacht das didaktisch geeignete Bild abgibt. Die Überlegung gilt auch in gleicher Weise für alle Organismen, die als Einzeltiere einen unbedeutenden Schaden verursachen, deren Bedeutung vielmehr aus ihrer Zahl erwächst, wie z.B. bei Mäusen. - Anders bei solitären, vaganten (vagilen) Schädlingen, etwa dem Wolf, die vor dem Hintergrund zeitlich variabler Schädlingskonzepte sehr differenziert zu betrachten sind.

${ }^{25}$ Hier vordergründig ohne jede etymologische Subtextdeutung als „Schadensfall großen Ausmaßes“ verwendet

${ }^{26}$ Sondern folgt, wenn man überhaupt in diesen Kategorien argumentieren möchte, ausschließlich dem Eigeninteresse der Heuschrecken
} 
gelhaft tritt dann im 18.Jh „Ungeziefer“ an die Stelle dieser Begriffe27. Diesem werden, ganz nach der Idee der Leibniz-Wolffschen Philosophie, neben seinen schädlichen Eigenschaften durchaus auch nützliche Eigenschaften zugeschrieben, so dass Zedlers „Universal-Lexicon“ von „nützlichem Ungeziefer“ sprechen kann. 28 Am Ende des 19. Jh. tritt dann der Begriff des „Schädlings“ auf, nachdem mindestens seit dem 16.Jh. - nur das Adjektiv „,schädlich“ bekannt war. ${ }^{29}$ Das als Element der Nahrungskette noch nützliche Ungeziefer wird seiner Ambivalenz entkleidet und allein im Hinblick auf das Schädlichkeitspotential bewertet. Selbstverständlich wurden bereits früher bestimmte Tiere als schädlich und auch als entbehrlich eingestuft. Johann Beckmann etwa preist die Naturkunde (1767), da sie alles lehre, was der Mensch zur Erhaltung und Bequemlichkeit seines Lebens brauchen und brauchen könnte, kennen, aufzusuchen, erhalten und verbessern. Schließlich: „Sie lehret uns kennen, zu vermeiden und ausrotten was nicht nur unser Leben und unserer Gesundheit, sondern auch unserer Bequemlichkeit schaden kann. Zum Exempel

a) Schädliche und reißende Thiere auf die leichteste Art auszurotten; ein Thier wider das andere zu brauchen.

b) Die gesunden und eßbaren Pflanzen von denen oft sehr ähnlichen giftigen zu unterscheiden; Unkraut auszurotten. $[\mathrm{c}), \mathrm{d}) \ldots]^{\text {‘3 } 30}$

Die Vorstellung von der „Verbesserung“ der Natur ist eine logische Folge ihrer Aneignung. Nach Bacon wird die Natur durch menschliche Kunst, und Arbeit gebunden, gestaltet und gleichsam erneuert. ${ }^{31}$ Verbesserung heißt hier: die Natur durch „Kunst und Arbeit“, durch „Gestaltung und Erneuerung“ näher an den menschlichen Bedürfnissen auszurichten. „Ausrotten“ ist in diesem Sinne eine Verbesserungsweise. $\mathrm{Ob}$ es dabei um lokale, überregionale oder globale Ausrot-

\footnotetext{
27 Verblüffend ist die etymologische Ableitung des Wortes „Ungeziefer“ (DWB), mit dem zunächst das für das Opfer nicht Geeignete (Pflanze wie Tier) bezeichnet wird, wobei sich die Bedeutung später auf das nicht opferbare Tier beschränkt. Hier liegt also praktisch der gleiche Unterscheidungskatalog zugrunde, wie er für die ungleiche Proportion bei der Auswahl von reinen und unreinen Tieren für die Arche Noahs zur Anwendung kam.

Der Ausdruck „Geschmeiß“ findet seinen Weg aus der Jägersprache nach und nach in den gewöhnlichen Umgang, als er von einer ursprünglichen Bezeichnung für den Vogelkot später für die unverdaulichen Bestandteile der Beutetiere im Kot verwendet wird, dann allmählich zur Bezeichnungskategorie für die Beutetiere selbst und schließlich in alltagssprachlichen, gleichwohl aber pejorativen Zusammenhängen verwendet wird.

${ }^{28}$ Zedlers Universal-Lexicon, Lemma „Ungeziefer“ (www.zedler-lexikon.de)

${ }^{29}$ Auch in Zusammensetzungen, z.B. ,landschädliche Leute“. Der Begriff bezieht sich zu dieser Zeit auf den vaganten Bevölkerungsteil. Die Parallelität zur vaganten Lebensweise der meisten „Schädlinge" ist unübersehbar.

30 Zitiert nach Günter Bayerl: Die Natur als Warenhaus. In: Sylvia Hahn/Reinhold Reith (Hg) Umwelt-Geschichte. Arbeitsfelder, Forschungsansätze, Perspektiven, Wien/München 2001, S.33-52, S.39

${ }^{31}$ Christof Dipper: Deutsche Geschichte 1648 -1789. Frankfurt a.M. 1991, S.10
} 
tung geht, ist zwar ein heute relevanter Aspekt, ${ }^{32}$ kann aber hier vernachlässigt werden, weil einem Autor der Mitte des 18. Jh. die Endlichkeit der Naturdinge noch kaum geläufig war. Dennoch: der Anspruch der Aufklärer zielte durchaus mit heiligem Ernst auf die ganze Welt. Ob aber in dieses Verständnis die ultimative Billigung oder gar Absicht eines endgültigen, globalen Verlustes aus der Artendiversität eingeschlossen war, ist bislang offen.

Bei den Einschätzungen der Schädlinge ist der von ihnen angerichtete Schaden oft nicht sicher bezeichnet, ${ }^{33}$ und er kann unrealistisch wahrgenommen werden. Die Angewandte Biologie des 20. Jahrhunderts schließt zwar in ihrem Biodiversitätsdiskurs vielfältig an die „oeconomia naturalis“-Vorstellungen des 18. Jhs. an. ${ }^{34}$ Sie lockerte aber den Schädlingsbegriff sowohl aus Einsicht wie aus derzeit herrschendem Überfluss. Jedoch gelten nach wie vor die Interessenlagen im Wirtschaftsbereich des Menschen als prioritär, etwa in der heutigen Agrarwirtschaft und bei den Rechtfertigungen für gentechnische Veränderungen von Organismen gerade in ihrem Hinblick auf Schädlingsresistenz. Konzessionen- z. B. in Form biologischer Schädlingsbekämpfung - verdanken sich nicht etwa einem fürsorglichen Konzept, sondern einer Vermeidungsstrategie, welche die direkten wie indirekten Nachteile für den Menschen selbst so gering wie möglich halten will. Das ökonomische Kalkül bestimmt auch nicht erst im 19. Jh. das Raisonnement der Schädlingsbekämpfung, Sichtbar wird dies in der Bekämpfung der Forstschädlinge, ${ }^{35}$ wo es schwerlich verwundern kann. Wie sonst wäre Nachhaltigkeit z. B. als forstliches Leitmotiv zu denken, wenn sie nicht Kosten-Nutzen-Erwägungen auch im Hinblick auf Kalamitäten in einer Balance hielte? Deshalb redet auch das 18. Jh. längst explizit von der Ökonomie. Und zwar sowohl unverhohlen wie umfassend

32 Die damals für unerschöpflich gehaltene Natur schließt die Möglichkeit, dass hier zugleich der globalen Dimension gedacht wird, zum diesem Zeitpunkt praktisch aus. Die ersten definitiven globalen Ausrottungen, die allmählich das Bewußtsein der gebildeten Welt erreichen, datieren erst ans Ende des 18. und den Beginn des 19.Jh. Gleichwohl hatte bereits Voltaire eine gewisse Vorstellung davon, dass der Mensch im Verlauf der Geschichte Einfluss auf die Artenzahlen gehabt haben müsse (Gerhard Wagenitz: Die ,Scala naturae' in der Naturgeschichte des 18.Jahrhunderts und ihre Kritiker. In: Jahrbuch Gesch. Theorie Biol. 4 (1997), S 179 - 195)

33 Wenn z.B. der nach heutiger und objektiver Auffassung nützliche Regenwurm im 18.Jh. als schwerer Schädling der Gartenkultur gilt

${ }^{34}$ Herrmann, Krebse, Lachs und Hasenbraten

35 Deren Bekämpfung im 18.Jh. ganz klar ökonomisch begründet ist und vermutlich bereits früher mit gleicher Begründung durchgeführt wurde. -- Die ökonomischen Grundlagen der Schädlingsbekämpfung ist z.B. der obersten Überwachungsinstanz Deutschlands, der Biologischen Bundesanstalt, in ihrer einzigen veröffentlichten ,Liste der repräsentativen tierischen Schadorganismen und der Einzelschädlinge (ohne Wirbeltiere) im Allgemeinen Pflanzenschutz" (Merkblatt 60, Braunschweig 1984) so selbstverständlich, dass sie sich nicht einmal mit einer abstrakten Schädlingsdiskussion aufhält und entsprechend ausschließlich Schädlinge der Nutżpflanzen aufführt.

Das zitierte Merkblatt 60 ist die einzige in der Bundesrepublik veröffentlichte „offizielle“ Liste von Schädlingen. Sie wird heute (Auskunft der BBA am 23.5.2005) als in vielen Punkten nicht stimmig angesehen. Eine EU-Liste unter der Federführung Portugals befindet sich in Vorbereitung. Ihr Entwurf wird für Ende 2005 erwartet. Eine Liste der schädlichen Wirbeltiere ist in der Bundesrepublik nie erschienen. 
auch im Konzept jener „oeconomia naturae“,36 ohne das die Hausväterliteratur und die wissenschaftliche Agrarliteratur der Zeit nicht denkbar sind. Andererseits ist die Integration des „Glückseligkeitsversprechens“ bis in die Schädlingsbekämpfung des 18. Jh. nicht zu übersehen. Die Bemühung um Verstetigung der Nahrungsversorgung der Untertanen verlangt bei Kalamitäten nach interventionistischem Handeln der Obrigkeit. Die angestrebte Abwendung des Notstandes der Bevölkerung birgt eine grundsätzliche Aporie: steht das Fürsorgemotiv im Vordergrund oder die Abwendung des wirtschaftlichen Schadens? Tatsächlich fallen beide ununterscheidbar zusammen.

Es gibt einen, gleichsam apriorischen ökonomischen Druck auf den nahrungsproduzierenden wie für den unter der beständigen Gefahr parasitischer Bedrohung stehenden Menschen, sich der Nahrungskonkurrenten, der Nahrungsverderber, der Krankheitsüberträger und der Parasiten zu erwehren. Dieser Druck kann in direkten Rohstoff- und Nahrungsverlusten gemessen werden bzw. in Dimensionen des reproduktiven Verlustes ${ }^{37}$. Die Kosten-Nutzen-Rechnung gilt damit sowohl für den Bereich der Rohstoff- und Nahrungsproduktion und am Ende schließlich auch für den Bereich der menschlichen Reproduktion. Das entsprechend präventive oder akute Verhalten ist Schädlingsabwehr bzw. Schädlingsbekämpfung, und man darf es für eine anthropologische Konstante halten, da auch der vorökonomische Mensch überall auf der Welt die Mücke erschlagen haben und seine Nahrung vor unwillkommenen Mitessern in Sicherheit gebracht haben wird. Diesem Verhalten können zu bestimmten Zeiten bestimmte Facetten und weiterreichende Bedeutungen zuwachsen. Aber die aufkommende chemische Keule des späten 19. Jh. in ihrer praxeologischen Bedeutung im Kern als etwas grundlegend anderes aufzufassen als die in der Wirkung wie hilflos erscheinenden Bemühungen des 18. oder 17. Jh., ist meiner Einsicht nach falsch, weil sie für mich aus derselben handlungsleitenden Wurzel kommen.

Ausgemacht werden in der Regel drei verschiedene Organismengruppen, deren Lebensansprüche zeitlich und örtlich als gegen menschliches Interesse gerichtet empfunden werden: Tiere, Pflanzen und Mikroorganismen. Obwohl das funktionale Bekämpfungsinteresse gleich gelagert ist, existieren erheblich differenzierende Begriffe zu dessen Beschreibung. Die Pflanze ist kein „Schädling“ i.e.S., offenbar, weil sie nicht als direkter Nahrungskonkurrent des Menschen auftritt. Als „Unkraut“ entzieht sie der Kulturpflanze auf derselben Fläche Nährstoffe und Sonnenenergie und trifft daher menschliches Interesse indirekt. Selbst die Belästigung des Menschen etwa durch Nesselwirkung, führt bei der Brennessel nicht zur Schädlingsdiagnose, wohl aber die physiologisch gleiche Erfahrung durch die

\footnotetext{
36 Die Ökonomisierung des eigentlich naturwissenschaftlich - creationistisch abgeleiteten Konzeptes am deutlichsten dargestellt von Torsten Meyer: Natur, Technik und Wirtschaftswachstum im 18. Jahrhundert: Risikoperzeption und Sicherheitsversprechen. Münster u.a. 1999 (= Cottbuser Studien zur Geschichte von Technik, Arbeit und Umwelt 12)

${ }^{37}$ Beim unmittelbar betroffenen Menschen wie bei der Primärproduktion von Rohstoffen und Nahrung
} 
Stechmücke. Die Euphemismen einer ökologisch bewegten Sprache versuchen seit längerem, „Unkraut" gegen „Wildkraut“ oder „Pflanzen am falschen Standort“ zu ersetzen. Sonderbarerweise wird ein ähnliches Angebot für tierliche Schädlinge (etwa „Tiere am falschen Ort") nicht gemacht. Wie das „Unkraut" ist auch der Mikroorganismus kein „Schädling“. Schädliche Mikroorganismen sind „Pathogene" oder „Erreger“.

„Schädlinge“ sind offenbar nur höhere Tiere, mit dem Schwerpunkt im wirtschaftlichen Kontext. ${ }^{38}$ Das Konfliktpotential der kategorialen Einordnung wird offenkundig, wenn betriebswirtschaftliche und volkswirtschaftliche Interessenlagen, die der Schädling berührt, nicht gleichgelagert sind. Wenn beispielsweise Kormorane gegenwärtig wegen volkswirtschaftlicher Unerheblichkeit sogar als schutzwürdige Vögel eingestuft werden, obwohl sie betriebswirtschaftliche Probleme verursachen. Aber, die Schutzwürdigkeit auf Grundlage der gesamtgesellschaftlichen Norm schließt sie politisch korrekt aus der Gruppe der Schädlinge aus, weil sich gesellschaftliches Bewußtsein und Handeln zumindest heute auf die volkswirtschaftliche Dimension bezieht. Deswegen verbleiben z.B. auch die symbolgeladenen Elefanten grundsätzlich in der Gruppe der globalwirtschaftlich schutzwürdigen Tiere, obwohl sie aus in manchen Ländern aus volkswirtschaftlichen und betriebswirtschaftlichen Gründen zum kontrollierten Abschuss freigegeben werden können. Sie erlangen aus offensichtlichen Gründen keinen nominellen „Schädlingsstatus". 39

Ohne bestreiten zu wollen, dass Verdinglichungen oder Repräsentationen aus dem Schädlingsdiskurs in Deutschland in einer sich selbst beschleunigenden Spirale in abgründiges normatives Handeln geführt haben, rate ich zu einer zurückhaltenden Analyse. „Das Reden über ,schädliche’ Insekten bedeutet eine Ökonomisierung, ein buchhalterisches Denken in den Kategorien von Schaden und Nutzen, das dem früheren „Ungeziefer“ nicht eingeschrieben ist.“40 Anders als behauptet, war der ökonomische Gedanke auch in der Handlung gegen „Ungeziefer“ immer eingeschlossen. Die Differenz, auf die man sich richtigerweise beziehen sollte, betrifft nicht allererst jene abstrakte ökonomische Ebene, sondern vielmehr die Ebene des konkreten Flächenbezuges. In den agrar-solaren Regimes vor der Industrialisierung wird selbstverständlich die „Ausrottung“ von Schädlingen thematisiert. ${ }^{41}$ Soweit sich zurückverfolgen lässt, bezieht sich „Ausrottung“" auf die Ent-

\footnotetext{
38 Die körperaffinen Schädlinge des Menschen, in der Regel „Parasiten“, lassen sich mühelos unter die wirtschaftlichen Sachverhalte subsumieren.

39 Eine Beispiel für eine relativierende umwelthistorische Behandlung des Elefanten-Themas bei Mark Elvin: The Retreat of the Elephants. An Environmental History of China. New Haven 2004

${ }^{40}$ Jansen, Schädlinge, S.1

${ }^{41}$ Beispiele in Bernd Herrmann: Die Entvölkerung der Landschaft. Der Kampf gegen „culturschädliche Thiere" in Brandenburg im 18.Jh. In: Günter Bayerl/Torsten Meyer (Hg.) Die Veränderung der Kulturlandschaft. Nutzungen - Sichtweisen - Planungen. Münster u.a. 2003 (= Cottbuser Studien zur Geschichte von Technik, Arbeit und Umwelt 22), S. 33 - 59
} 
fernung von einer konkreten Fläche. ${ }^{42}$ In einem anderen Zusammenhang hat Marquardt unlängst darauf hingewiesen, dass im mitteleuropäischen Agrarregime die geltenden Nutzungsrechte an den Landflächen vor 1800 eine andere Bewirtschaftungspraxis zur Folge hatten, als sie nach der Einführung des Privateigentums an Grundbesitz seit Beginn des 19.Jh. realisiert wurden. ${ }^{43}$ Die Handlungszuständigkeiten endeten ehedem an den Arealgrenzen der lokalen Herrschaften. Daher bezieht sich praxeologisch die zeitgenössische Schädlingsbekämpfung auf solche begrenzten Flächen. ${ }^{44}$ Erst durch Aufgabe der Brachenwirtschaft, die Auflösung der lokalen Herrschaften und die Schaffung einer überlokalen, nationalstaatlichen Zuständigkeit auf rational-naturwissenschaftlicher Basis wird das lokale Ungeziefer zum allgemeinen und überregionalen Prinzip des „Schädlings“. ${ }^{45}$ Erst mit der ,gesamtstaatlichen“ Zuständigkeit ergibt sich jene Diffusion allgemeingültiger Einstellungen zum Schädling, die dann auch Transformationen in andere gesellschaftliche Zusammenhänge des 20.Jh. hinein ermöglichen und erfahren.

\section{Tierprozesse und Schädlingsbekämpfung}

Entfällt mit dem Blick auf die gewandelten lokalen Nutzungsrechte im frühen 19. Jh. ein gewichtiges Argument für die Fundierung eines impliziten Schädlingsdiskurses, ${ }^{46}$ empfiehlt sich auch für eine zweite Anknüpfung Zurückhaltung. Danach würde früheren Maßnahmen gegen Schädlinge der universalistische Ansatz fehlen. Beleg lieferten angeblich die mittelalterlichen Tierprozesse, und ganze Tierarten gerieten erst im 17. Jh. als kollektiv schädlich ins Visier. ${ }^{47}$ Das historiographische

\footnotetext{
42 Ähnlich auch das Lemma „Ungeziefer“ im LMA; so auch der regelmäßige Bedeutungsinhalt des Wortes bei Luther

43 Bernd Marquardt: Umwelt und Recht in Mitteleuropa. Von den großen Rodungen des Hochmittelalters bis ins 21. Jahrhundert. Zürich u.a. 2003 (= Zürcher Studien zur Rechtsgeschichte 51)

${ }^{44}$ Das bildet sich selbst in den Verordnungen etwa Preußens im 18.Jh. ab, wenn Edicte zur Schädlingsbekämpfung eben nicht für das ganze Königreich sondern konkret auf bestimmte Verwaltungsbezirke beschränkt sind. Erst die Gesetzgebung gegen Ende des 19.Jh. macht die reichsweite Verpflichtung zur Schädlingsbekämpfung zum Prinzip, Ich vermute, einerseits wegen des Wegfalls der lokalen genossenschaftlichen Nutzungsrechte, andererseits naheliegender Weise wegen des neuen staatlichen Selbstverständnisses. Vgl. Albert Otte: Die Unterlassung des obrigkeitlich gebotenen Raupens - erste Pflanzenschutzbestimmung für das deutsche Reich. Mitteilungen der Biologischen Bundesanstalt für Land- und Forstwirtschaft, Berlin 1998, Heft 348, S. 7 - 8

45 Ich kann diese These hier aus Platzgründen nicht weiter verfolgen. Eine Ergänzung hierzu weiter unten. Soviel zumindest: Ein neues Staatsverständnis mit neu verteilten staatlichen Zuständigkeiten verlangt nach einheitlichen Wertkategorien und Handlungsmustern. Die Erfindung des „Schädlings“ entspricht diesen Erfordernissen.

${ }^{46}$ Ich lese Jansen, Schädling, als impliziten Schädlingsdiskurs, jedenfalls bezüglich der ereignishistorischen Mitteilungen. Ich habe keinen expliziten, detailreichen Abriß der Schädlingsbekämpfungen im Abendland und ihrer ideengeschichtlichen Analyse gesehen. Ihrem Diskurs fehlt in der Ableitung der Voraussetzungen eine historische Tiefe jenseits des späten 19.Jh., so dass er m.E. auf implizite Verständnisse des Lesers rekurriert, ohne die Vielschichtigkeit des Themas autoptisch aufzudecken und diesem gerecht zu werden.

${ }^{47}$ Trotz aller Trivialität sei an die allmählich fortschreitenden Naturerkenntnisse erinnert.
} 
Erstaunen entdeckt in diesem Moment schlicht die alltagsweltliche Lebenspraxis. ${ }^{48}$ Am einfachsten ist eine kontextuelle Definition des Schädlings, und die richtet sich zunächst immer lokal gegen konkrete Individuen einer Tierart. Bei näherer Prüfung stellt sich dann nämlich auch noch heraus, dass systematisch den Rechtsakten gegen Tierindividuen allermeist strafrechtlich abgeleitete Vorgehensweisen zugrunde liegen. Gegen das Tier wird also wie gegen einen Straftäter verhandelt, und daher ist das immer ein individueller Akt.

Es werden aber durchaus auch gegen das Kollektiv gerichtete Konzepte entworfen, wenn z. B. der Bischof von Lausanne $1479{ }^{49}$ die Maikäfer bannt. ${ }^{50}$ Solche „Tierbannungen“ beruhen aber auf dem „auf kirchlichem Boden erwachsenen Justifizieren" 51

Der alltagspraktische Impuls einer Schädlingsbekämpfung mag ja durch die Thesen von Descartes und Kant sehr erleichtert worden sein. Wenn Tiere seelenlose mechanische Apparate sind, ergeben sich kaum noch ethische Rechtfertigungsnotwendigkeiten wegen ihrer Tötung. Aber auch die ökonomische Werttheorie Thomas von Aquins stünde einer solchen Sichtweise überhaupt nicht im Wege. ${ }^{52}$ Doch ist mit der Tötung von Lästlingen/Schädlingen der theologische Konflikt durchaus nicht entschieden, der sich aus diesem Eingriff in die Schöpfung

${ }^{48}$ Es macht keinen Sinn, gleichzeitig gegen alle Mäuse der Welt anzutreten, wenn man Probleme mit den Nagern in einem bestimmten Weinberg hat.

${ }^{49}$ Hans Albert Berkenhoff: Tierstrafe, Tierbannung und rechtsrituelle Tiertötung im Mittelalter. Bühl/Bd. 1937. S.93 - weitere Beispiele in der immer noch grundlegenden Sammlung von Karl von Amira: Thierstrafen und Thierprozesse. Mitteilungen des Instituts für österreichische Geschichtsforschung 12, Heft 4 (1891), S. 545 - 601. Speziell zu Insektenprozessen und Insektenbeschwörungen siehe Fritz Bodenheimer: Materialien zur Geschichte der Entomologie bis Linné. Berlin 1928, Bd. I, S. 233 passim

${ }^{50}$ Zumindest von der Konzeption her ist eine Bannung die umfassendste denkbare normative Leitlinie. Natürlich kann die schon nach $10 \mathrm{~km}$ im Umkreis ihre Wirkung verlieren, weil sich möglicherweise weder Maikäfer noch Menschen an den Bannspruch halten.

51 Zur Rechtssystematik, die bereits v. Amira herausgearbeitet, aber durch nomenklatorischen Unübersichtlichkeit verstellt hat, vorzugsweise Berkenhoff, Tierstrafe, S.7, S. 84 ff.

${ }^{52}$ Herrn Kollegen Marggraf, Agrarökonom in Göttingen, danke ich für den Hinweis auf das Aquinsche Wertmodell. Der ökonomische Wert von Naturdingen wird darin, sofern die Dinge käuflich sind, durch die Nützlichkeit für den Menschen bestimmt. Hierfür greift Thomas auf eine Setzung aus dem „Gottesstaat“ von Augustinus zurück, die sehr aufschlussreich ist: „Die Art der Schätzung eines jeden Dinges ist je nach seinem Gebrauch verschieden, derart, dass wir sinnlose Wesen den Sinnenwesen vorziehen, und zwar so weitgehend, dass, wenn wir es könnten, wir sie völlig aus der Naturordnung beseitigen würden, sei es aus Unkenntnis ihres Standortes in ihr [in der Naturordnung] sei es trotz klarer Erkenntnis, weil wir sie hinter unsere Annehmlichkeiten stellen. Wer hätte zu Hause nicht lieber Brot als Mäuse oder Silbermünzen an Stelle von Flöhen? Was ist denn Verwunderliches daran, wenn bei der Einschätzung von Menschen, deren Natur doch wahrhaftig eine so große Würde besitzt, ein Pferd höher gewertet wird als ein Sklave, ein Schmuckstück mehr als eine Magd? So weicht die Schauweise des nur Betrachtenden in der freien Urteilsgestaltung weit ab von der Not des Bedürftigen oder der Lust des Begierigen." Zit. übernommen aus dem Kommentar von A.Utz (S. 540) zu Thomas von Aquin: Summa Theologica II-II, Heidelberg u.a. 1953. [Hervorhebung durch BH] Die hervorgehobene Passage impliziert m.E. auch das Unwerturteil und Verhalten gegenüber den Schädlingen. 
Gottes ergibt. ${ }^{53}$ Da die „Ausrottung“ der Schädlinge nicht alternativlos ist, wird es verständlich, wenn die spätmittelalterliche oder frühneuzeitliche Kirche zum Mittel des Tierbanns (der Malediction oder Excommunication) greift. Das Verfahren ist ein exorzistisches, ${ }^{54}$ das sich gegen die allgemeine Vertretung des Schädlings, also gegen die (anonyme) Art richtet. ${ }^{55}$ Von Amira hat in seiner grundlegenden Untersuchung zu den Tierprozessen erstaunliche Details über die meisten exorzierten Tierarten zusammengetragen. Sie galten danach bereits in heidnischer Zeit als vorzugsweise Wohnstätten von Seelen und finden von hier ihren Weg in die christliche Variante des Teufelsglaubens. Die Tierbannung ist in v.Amiras Bewertung ein Gespensterprozess. Verhandelt wird gegen Mäuse, Ratten, Maulwürfe, Kröten, Schlangen, Schnecken, Insekten. Selbst die „Haupttiere der Fabel“, der Wolf, der Fuchs und der Bär, sind alle drei ,gespenstig“, auch sie werden zauberisch gebannt und vertrieben. Unübersehbar steht hier eine Schädlingsliste.

Neben den kirchlichen Tierbannungen stehen nun allerdings auch solche weltlichen Urteile wie die vielzitierte Ausweisung der Lutmäuse ${ }^{56}$ bei freiem Geleit aus der Gemeinde Stilfs (Tirol), wobei schwangeren und jungen Mäusen eine 14tägige Frist gewährt wurde. ${ }^{57}$ Solche Urteile schließen m.E. demonstrativ an die kirchenrechtlichen Vorbilder an, weil damit nicht nur ein formalrechtlich einwandfreier Weg beschritten, sondern gleichzeitig auch den in der Volkskultur umlaufenden zauberischen Bannungen Schädlingen gegenüber Rechnung getragen wird. Nicht, ob das im geschichtstheoretischen Sinne ein klassischer Fall von „Zirkularität“ (Bachtin/Ginzburg) wäre, erscheint mir interessant, sondern, ob hier eine kluge obrigkeitliche Regie die Fäden zieht. Denn an sich ist bis heute nicht verstanden, warum man ernsthaft Mäuse vor ein Gericht zitiert. ${ }^{58}$ Selbst der Hinweis auf den Wandel in der Bewertung des Tieres von seiner bedingten Rechtsfähigkeit im Mittelalter zur heutigen Rechtsunfähigkeit scheint mir als Erklärung nicht endgültig überzeugend. ${ }^{59}$ Verknüpft man aber die Stränge Abwehrzauber und Schädlingsna-

\footnotetext{
${ }^{53}$ Peter Dinzelbacher: Mittelalter, In: Peter Dinzelbacher (Hg.): Mensch und Tier in der Geschichte Europas. Stuttgart 2000, S. 181 - 292, S. 287, verweist auf die Beispiele des Walthenus von Melrose $(† 1159)$ und des Wulfric von Haselburg († 1154), deren Gewissensbisse wg. Tötung einer Bremse bzw. einer Maus in ihrer frommen Umgebung Unverständnis und Gelächter auslösten.

${ }^{54}$ Das ist umso überraschender, als Thomas von Aquin die Benediction oder Malediction eines Tieres aus sehr rationalen Gründen für unmöglich erklärte. Da aber Gott oder der Teufel hinter den Handlungen der Tiere stünde, sei es sinnvoll an Gott Bitten zu richten und an den Teufel Beschwörungen. (Dinzelbacher, Mittelalter, S. 282)

55 Auch hier ist noch nicht entschieden, ob denn „die Maikäfer“ die abstrakte Menge der Individuen der gesamten Art einschließt, oder einen bestimmten geographischen Ausschnitt. In jedem Fall richtet sich der Bann gegen ein Kollektiv.

${ }^{56}$ Lutmäuse: Zusammensetzung aus Lut $=$ Bande, Rotte und Maus. Zoologisch geht es hier offenbar um Wühlmäuse

${ }^{57}$ Berkenhoff, Tierstrafe, gibt den Prozeßbericht ausführlich wieder. S. $98 \mathrm{ff}$

${ }^{58}$ So auch Dinzelbacher, Mitelalter, S. 283

59 Zumal Dinzelbacher, Mittelalter, S. 288 passim, eine Fülle von Belegen zusammengetragen hat, nach denen ein Urteil über die angebliche Tierliebe bzw das Tierverständnis im MA sehr differenziert abzugeben wäre (wenn nicht sogar eine Legendenbildung durch das heutige Mittelalterbild vorliegt). Auch in den dort genannten Fällen tierlicher Rechtspersonen handelt es sich um strafrechtliche Fälle. Der
} 
tur mit demjenigen der Tierbannung auf der Grundlage theologischer Wertenormen, fügt sich m.E. alles zu einem geschlossenen Bild. Den vom Schädling betroffenen Menschen wird mit Prozeß und Urteil ein rechtlich und ethisch einwandfreier öffentlicher Raum geboten. Der Abwehrzauber wird als Gerichtsverfahren öffentlich und gemeinschaftlich geübt und befreit die Menschen aus der moralischen Not, im Verborgenen Falsches zu tun. ${ }^{60}$ Die Handlung nimmt ihren Ausgang vom konkreten Fall, schließt aber das Kollektiv mit ein, weil sonst keine Erlösung denkbar wäre.

\section{Strategien}

Schwarmbildungen im Tierreich verdanken sich immer zweier Grundbedingungen. Es sind die Reproduktion und der bessere Schutz gegenüber Raubfeinden. Der Schwarm selbst reduziert für die Raubfeinde z. B. der Heuschrecke die Chance, ein Beutetier zu ergreifen. Indem der Schwarm die Handlungsorientierung des Räubers bis zum Misserfolg stört, sichert er dem einzelnen Schwarmmitglied eine verbesserte Überlebens- und damit Fortpflanzungsmöglichkeit.

In der Umkehrung ergibt sich der einfache Schluss, dass eine planvolle, koordinierte und mit einer konkreten Zielvorgabe ${ }^{61}$ versehene Vorgehensweise das adäquate Handlungsmuster für Feinde der Heuschreckenschwärme darstellen sollte. Diese koordinierte Vorgehensweise kann dann eben auch bereits bei den Voraussetzungen für die Schwarmbildung einsetzen, bei den Gelegen oder den Larven. Aufsammlung von Gelegen oder Eintreiben der Larven in dafür vorbereitete Gräben ist dann auch eine Bekämpfungsstrategie des 18./19.Jh. Über das Beispiel hinaus sind koordiniertes und zielorientiertes Handeln unabdingbar für die Schädlingsabwehr. Sie setzen ein technisches Mittel voraus, aber auch ein Konzept, in dem sich Wertvorstellungen einer Gesellschaft abbilden. Die Interessenlage orientiert sich an letztlich betriebs- und volkswirtschaftlichen Dimensionen. Ich verwende diese Begriffe hier ohne jeden Bezug zu einer historischen oder herrschenden Ökonomietheorie, sondern

o deskriptiv zur Beschreibung der betroffenen ökonomischen Ebene der Akteure und

alltagsweltlichen Einstellung des Mittelalters scheint der emphatische Blick auf die Tiere als leidensfähige Mitgeschöpfe danach nicht bekannt gewesen sein, zumindest habe er ihr nicht am Herzen gelegen.

${ }^{60}$ Ginzburg wirft in Zusammenhang mit Feldkulten des 16. und 17.Jh. eine ähnliche Frage auf, inwieweit nämlich Elemente des Fruchtbarkeitskultes der Verchristlichung unterlägen. In diesen Feldkulten tauchen interessanterweise auch Tiere bzw. Tiergestalten für Reisen ins Jenseits auf (im Friaul sind das Schmetterlinge und Mäuse). Damit könnte direkt an von Amira angeschlossen werden. Leider wird den Schädlingen bei Ginzburg keine explizite Betrachtung zuteil. Siehe: Carlo Ginzburg: Die Benandanti. Feldkulte und Hexenwesen im 16. und 17. Jahrhundert. Frankfurt a.M. 1980, S. 46 und 53.

61 Alles oder in Teilen koordiniert vertreiben bzw. vernichten, mit bestimmten Mitteln, usw. 
o analytisch zur Aufdeckung von Wissensständen und Interessenlagen, die sich hinter den normativen oder sonstigen handlungsleitenden Konzepten gegen Schädlinge verbergen.

Dabei lassen sich ausnahmslos auch alle individuellen Motive der betriebswirtschaftlichen Dimension zurechnen, ebenso die Motive der Aufrechterhaltung und ggfl. der Verbesserung der kleinsten betriebswirtschaftlichen Einheit, des im System existierenden Menschen. ${ }^{62}$

Es ist im 18. Jh. offenbar die Bestimmungsschwierigkeit, die Grenze zwischen der betriebswirtschaftlichen und der volkswirtschaftlichen Bedeutung eines „Schädlings“ zu fassen, welche die strategischen Bekämpfungsmuster des Absolutismus bestimmen. Die Erfahrung des betriebswirtschaftlichen Schadens ${ }^{63}$ führt den fürsorgepflichtigen Landesvater zur grundsätzlichen Annahme der Bekämpfungsnotwendigkeit. Hierfür werden zwei Modelle entwickelt: ein prämiengestütztes Anreizsystem und ein steuergestütztes Abgabensystem. Während das Anreizsystem augenscheinlich eher für schwächere betriebswirtschaftliche Schädlinge umgesetzt wird, werden aber die vermeintlich oder tatsächlich erheblicheren Schädlinge, wo immer möglich, durch direkte Steuern (Zwangsabgaben von Köpfen, Ohren, Schwänzen, Klauen etc.) oder durch allgemeine Verhaltensregeln (wie Hygienestandards; freie, bedenkenlose Verfügbarkeit für jedermann) bekämpft. Die Verhaltensregeln können ihrerseits gesetzlichem Regelwerk unterliegen, wenn eine aktive Schädlingsbekämpfung wegen der „Ortlosigkeit“ des Schädlings nur punktuell möglich ist. An ihre Stelle tritt ggfl. eine ständige Prophylaxe (regelmäßige Wolfsjagden, Sperlings- und Hamstersteuer). Deren volkswirtschaftliche Dimension kann ihrerseits derart unproduktive Dimensionen annehmen, dass es zu einer allmählichen Nicht-Befolgung oder zur Aufhebung des Verhaltensmusters kommt (Sperlingsedikte geraten in Vergessenheit; nachlässige Durchführung der Wolfsjagden, Entlassung eines Tieres aus dem Schädlingsstatus). ${ }^{64}$

Die heuristische Systematik einer Einordnung von Schädlingsbekämpfungen nach Anreizsystem (betriebswirtschaftlich orientiert) und Steuersystem (volkswirtschaftlich orientiert) hat leider Brüche, da z.B. die Heuschreckenbekämpfung trotz volkswirtschaftlicher Schädlingsdimension in Preußen prämiengestützt durchgeführt wird. ${ }^{65}$ Die Schädlingsbekämpfungen gegen die Sumpffieber-Mücke werden erst im 19. Jh. im Hinblick auf den Anschlussnutzen der meliorierten Flusstäler durchgeführt und parallel mit Argumenten zur Beförderung der Volksgesundheit

\footnotetext{
${ }^{62}$ Dabei werden von mir auch Motive des interesselosen Wohlgefallens oder der Befindlichkeit als letztlich betriebswirtschaftlich relevante Merkmale eingestuft.

${ }^{63}$ Aus dem betriebswirtschaftlich auftretenden Schaden folgt über die Entlastungsgesuche der steuerpflichtigen Untertanen die volkswirtschaftliche Dimension

${ }^{64}$ Gilt z. B. heute für die Aufhebung des Impfzwanges gegen Pocken. Andererseits wird das Impfmuster bei Tierseuchen (Schweinepest) irrationaler weise nicht verfolgt. Hier laufen also unterschiedliche Wertemodelle nebeneinander her.

${ }^{65}$ Herrmann: Entvölkerung der Landschaft
} 
flankiert. ${ }^{66}$ Sie werden (gemäß der vorgeschlagenen Systematik) in staatlichen Programmen organisiert und bezahlt. Frühere Meliorationen wurden offenbar ausschließlich mit der Gewinnung von Ackerland begründet, das seuchenhygienische Argument hat jedenfalls keine herausgehobene Bedeutung. ${ }^{67}$ Entsprechend gibt es Refinanzierungen der Maßnahmen durch Grundeigentümer. ${ }^{68}$, also die Verlagerung auf die betriebswirtschaftliche Ebene.

\section{Muster}

Die historische Reihenfolge, in der die einzelnen Arten für den Menschen kulturgeschichtlich Bedeutung erlangten, vermutet Kemper ${ }^{69}$ mit intuitiv einsichtigen Argumenten und systematisiert Schädlinge nach ihrer Schadwirkung:

1. durch ihre Abwehrgifte

2. durch ihre ektoparasitische Lebensweise, meistens verbunden mit Stichbelästigung

3. als Endoparasiten

4. durch Ruhestörung und Ekelerregung

5. durch Weiterverbreitung und direkte Übertragung pathogener Keime oder als Reservoir für Krankheitserreger des Menschen

6. durch Zerstörung von Materialien und Vorräten

7. durch Befall von Nutzpflanzen (oft mit Übertragung phytopathogener Keime verbunden)

8. durch Parasitismus, Stichbelästigung und Krankheitsübertragung bei Nutztieren

9. durch Betriebsstörungen bei sanitären Einrichtungen sowie durch Reise- und Transportgefährdung ${ }^{70}$

Diese Systematik liefert das aktuelle Begründungsrepertoir für Schädlingsbekämpfungen. Es ist nicht wirklich verschieden von demjenigen, das 200 Jahre älter ist, wenn auch bei Beckmann (1751) ${ }^{71}$ nicht die vorgeblich kulturgeschichtliche Tie-

\footnotetext{
${ }^{66}$ Rita Gudermann: Miasmen und Meliorationen. Die Debatte über die Not der Spinner in der Senne. In: Manfred Jakubowski_Tiessen /Klaus-J:Lorenzen-Schmidt: Dünger und Dynamit. Beiträge zur Umweltgeschichte Schleswig-Holsteins und Dänemarks. Neumünster 1999 (= Studien zur Wirtschafts- und Sozialgeschichte Schleswig-Holsteins 31) S. 137 - 154

${ }^{67}$ Mir ist kein historisches Beispiel für eine seuchenhygienische Melioration obne (agrar)wirtschaftlichen Anschlussnutzen bekannt

${ }^{68}$ Z.B. Herrmann/Kaup, Oderbruch

${ }^{69}$ Heinrich Kemper: Kurzgefaßte Geschichte der tierischen Schädlinge, der Schädlingskunde und der Schädlingsbekämpfung. Berlin 1968, S. 15

${ }^{70}$ Die unter 6 - 9 genannten Schadwirkungen sind anthropogen begründet und daher nicht universalistisch anzunehmen

${ }^{71}$ Johann Christopf Beckmann/Bernhard Ludwig Beckmann: Historische Beschreibung der Chur und Mark Brandenburg, Berlin 1751, Teil 1, Kap III, XXX, Sp. 828 ff
} 
fendimension wie bei Kemper, sondern unverblümt die Rangskala der wirtschaftlichen Bedeutung und die ästhetische Distanz ${ }^{72}$ den äußeren Hintergrund für die Liste der Ungeziefer in Brandenburg liefert:

o Ratten und Mäuse

o die zu den Feldmäusen gehörenden Hamster

o Schlangen (mit besonderem Bezug zum Odertal)

o mit besonderem Gewicht, das „entsetzliche Heer Gottes, die Heuschrecken“"

o die Raupen, „die so gar das Laub von den Fichten und Eichen...abgezehrte“

o Maikäfer, zum ,schädlichen Geschmeiß“ gehörig

o Mücken (u.a. auch Motten, Gelbe Fliegen, Hemerobius, Bremsen)

Allgemein sind nicht alle Tiere, die nach heutigem Verständnis Schädlinge sind, seit dem 18. Jh. in dieser Kategorie verortet. ${ }^{73}$ Wir wären wohl etwas nachsichtiger mit Schlangen, nicht zuletzt, weil ihre biblische Metaphorik heute bedeutungslos geworden ist. Es sind gerade jene Beispiele, die einen Kategorienwechsel erfahren haben, welche die besondere Aufmerksamkeit auf sich ziehen. Krünitz führt beispielsweise Regenwürmer oder Maulwürfe als ernst zu nehmendes Ungeziefer auf. Die Trappe macht in Brandenburg-Preußen eine rasante Schädlingskarriere: Ist sie im 18. Jh. noch in der Hohen Jagd, wird sie langsam zurückgestuft und als Saatschädling schließlich zu Beginn des 20. Jh. in öffentlichen Treibjagden niedergestreckt. Erste Schutzvorschriften werden in den 30er Jahren formuliert, umfassen-

\footnotetext{
${ }^{72} \mathrm{Da}$ es in Mitteleuropa außer der Kreuzotter keine Giftschlange gibt, deren Biss lebensbedrohlich sein kann, sollte es sich bei den weiter unten als Ungeziefer aufgeführten „Schlangen“ um eine Einordnung aus ästhetischen Gründen oder religiösem Vorurteil handeln. Dabei wurden ehedem einheimische Schlangen (als nützliches Ungeziefer) durchaus zur Bekämpfung von häuslichen Schädlingen in der Küche gehalten: Stefan Ineichen: Die wilden Tiere in der Stadt: zur Naturgeschichte der Stadt. Die Entwicklung städtischer Lebensräume in Mitteleuropa, verfolgt am Beispiel von Zürich. Frauenfeld 1997

${ }^{73}$ Hier werden also nur Schädlinge aufgeführt, die mit dem Menschen nicht Tisch, Bett und Kleider teilen. Überhaupt bleibt das häusliche Ungeziefer in der Literatur wie in den Quellen merkwürdig unterrepräsentiert. Dabei gehört „Ungeziefer in den Häusern“ schon ins alttestametarische Repertoir (Exodus 8, 20). Läusekamm, Flohfalle, Pomander, Wurmfarn und Fliegenpilzbröckchen in der Milch sind auch in der frühen Neuzeit Hinweise auf die ständigen Begleiter des Menschen. Ihre Ausblendung aus den jeweils einschlägigen Diskursen verweist darauf, dass sie als Parasiten des Menschen in der alltäglichen Lebenswirklichkeit in einer anderen Kategorie eingeordnet wurden als die Schädlinge in Garten, Scheune, Feld und Forst. Sie bleiben selbst in den emblematisch nun wahrlich aufgeladenen Stillleben des Barock thematisch merkwürdig abwesend [zum Stillleben: „Sinn und Sinnlichkeit. Das Flämische Stillleben 1550 - 1680.“ Katalog zur Ausstellung der Kulturstiftung Ruhr Essen und des Kunsthistorischen Museums Wien. 1.9.-8-12.2002 Villa Hügel, Essen. Lingen 2002. Zur disproportionierten Respräsentanz selbst in der Emblematik vgl. Arthur Henkel \& Albrecht Schöne: Emblematik. Handbuch der Sinnbildkunst des xvi. und xvii. Jahrhunderts. Stuttgart, Weimar 1996. Auch im „Prozeß der Zivilisation“ (Norbert Elias, 2 Bde., Frankfurt 1981) scheinen Parasiten und ihre Abwehr (z.B. kratzen, knacken, lausen) nicht vorzukommen.

Das als lästig wahrgenommene Ungeziefer ist in jenen Zeiten zudem noch nicht als Überträger gefährlicher Krankheiten (z.B. Pest, Typhus, Sumpffieber, Enzephalitis, Borreliosen) ausgemacht.
} 
de Bestimmungen ergehen nach dem Zweiten Weltkrieg.74. Für den Schutz eines knappen Dutzends Brutpaare in der Priegnitz hat die Bundesbahn nach der Wiedervereinigung viele Millionen DM aufgewendet. ${ }^{75}$

Ein paradoxes Schicksal erlitt der Medizinischen Blutegel (Hirudo medicinalis). Eigentlich ein Ektoparasit der Wirbeltiere (und damit auch ein Schädling der Haustiere und des Menschen), hatte der Blutegel bis gegen Ende des 19.Jh. in Mitteleuropa nach dem Muster des „nützlichen Ungeziefers“ einen festen Platz in der Schulmedizin. Nicht etwa durch seine Bekämpfung, sondern durch seinen Massenverbrauch zu medizinischen Zwecken (und verstärkt sicher auch durch die parallelen Einschränkungen seines Lebensraumes), galt er um 1900 als „,vollkommen ausgerottet". In Deutschland war er 1909 an nur drei Standorten nachweisbar. ${ }^{76}$ Herter konnte 1937 bereits wieder immerhin 130 Fundorte benennen. Zur Zt. wird der Medizinische Blutegel nicht in der Liste der Gefährdeten Tiere Deutschlands geführt. ${ }^{77}$

Führen radikale Bekämpfung (Trappe) und überproportionale Wertschätzung (Blutegel) für den Schädling in den Status des beschützten Tieres, gilt für den Schädling Sperling (Passer domesticus), dass ihm in letzter Zeit die für sein Überleben in unseren Breiten erforderliche ganzjährige Zufütterung, wie sie zur Zeit der vorindustrialisierten Landwirtschaft allenthalben gegeben war, abhanden gekommen ist. Was der Bekämpfungswahn des 18.Jh. nicht erreichte, besorgt eine vollmechanisierte Landwirtschaft, die - als Kollateralschaden - dem Sperling die Körner vorenthält. Jetzt werden die letzten seines Stammes zum „Vogel des Jahres“ (2002) und mutieren zum gehätschelten Symbol einer städtischen Biophilie.

Man ist versucht zu glauben, dass die schließlichen Schutzbemühungen um ehemalige Schädlinge Ausdruck eines Skrupels angesichts einer drohenden Ausrottung darstellten. ${ }^{78}$ Hier ergibt sich, gleichsam aus einem „Feldversuch“, eine Quan-

\footnotetext{
${ }^{74}$ vgl. Johannes Klose: Aspekte der Wertschätzung von Vögeln in Brandenburg: Zur Bedeutung der Artenvielfalt vom 16. bis zum 20. Jahrhundert. Math.-Nat. Diss., Göttingen 2004, S. 126 - 136

${ }^{75}$ Leider „gibt es im Bahnkonzern offenbar keine Dokumentation mehr zu diesem Thema" (Auskunft der DB per Mail am 26.5.2005) Nach zeitnahen Presseberichten könnten für bis zu 50 Großtrappen bis zu 70 Mio. DM aufgewendet worden sein. Es wäre eine interessante Frage, ab wieviel Millionen Arbeitslosen die volkswirtschaftlichen Aufwendungen für den Unterhalt der Trappenpopulation von der Allgemeinheit als unvertretbar empfunden werden. Im Gegensatz hierzu fehlt ein Beispiel, in dem ein Schädling mit einem ähnlichen Aufwand in einer ähnlich kleinen Region systematisch bekämpft worden wäre.

${ }^{76}$ Konrad Herter: Der medizinische Blutegel und seine Verwandten. Wittenberg 1998. S. 68-69. Roy Sawyer: Leech Biology and Behaviour. Oxford 1986, Vol. II, S. 571 passim.

77 Margret Binot, Rüdiger Bless, Peter Boye, Horst Gruttke, Peter Pretscher: Rote Liste gefährdeter Tiere Deutschlands. Bundesamt für Naturschutz 1998 (Schriftenreihe für Landespflege und Naturschutz H. 55). Nach FFH-RL, Anlage V, kann seine Entnahme aus der Natur aber geregelt sein [www.bfn.de/03/030306_egel.pdf, zuletzt besucht am 18.8.2005].

${ }^{78}$ Eine solche Annahme unterstellt, dass Schädlingsbekämpfung im Einzelfall nicht auf die Entfernung aus der Artendiversität zielt, sondern auf eine kontrollierte Minimalpopulation auf einer musealisierten Parzelle bzw. auf biologisch-numerisch unfunktionale Bestände in der Fläche.
} 
tifizierungsmöglichkeit für gesellschaftlichen Wertewandel. ${ }^{79}$ Eine vertiefte umwelthistorische Analyse müsste diesem Aspekt besondere Aufmerksamkeit widmen und die Beispiele systematisch sammeln. Dabei müsste auch nach Belegen dafür gesucht werden, dass Schädlinge dauerhaft aus dem Artenspektrum entfernt wurden, ohne dass sie je einen Schutzstatus erreicht hätten. Das scheint gegenwärtig nur für den Erreger der Pocken zuzutreffen.

\section{Risiken und Schäden}

Vor der Erfindung von Pestiziden bestand die Abwehr praktisch nur in Strategien zur Reduktion der Abundanzen durch Wegfangen und mechanischem Töten einzelner Individuen. ${ }^{80}$. An diesem Muster der physischen Entnahme orientieren sich auch im alten Agrarregime die Steuern bzw. Anreizsysteme zur Kollektivbekämpfung bzw. -prävention. Das konnte zeitaufwendig sein und zu negativen KostenNutzen-Bilanzen führen. Bekannt sind einschlägige Klagen bekämpfungspflichtiger Bauern (s. u.). ${ }^{81}$

Dass Risikokalkulationen in Zusammenhang mit Schädlingen eine Voraussetzung für wirtschaftliche Überlegungen sind, belegt ein weiteres Mal Krünitz. Er zitiert einen Ökonomen Peter Kretschmar, der 1744 vorgerechnet habe, dass 3 Mio. Sperlinge 4.4 Mio. Taler Schaden anrichten und führt Überlegungen vor, nach denen sich Spatzen wie die sprichwörtlichen Kaninchen vermehrten. ${ }^{82}$ Für eine gedachte Dorf-Gemarkung mit 800 Sperlingspärchen ergeben sich rechnerisch im Jahr insgesamt 20.000 Sperlinge. „Hat ein Amt nur zehn Dörfer und ein Land etwa 30 Ämter, so finden sich in einem solchen Lande etwa 6 Millionen Sperlinge in

\footnotetext{
${ }^{79}$ Die hierin angelegte Problematik kann für puristische Argumentationslinien dann besonders verzwickt werden, wenn dem kollektiven Gedächtnis entfällt, dass ein Schädling nicht zum autochthonen Artenspektrum gehört, sondern als Kulturfolger eingewandert ist, wie z.B. der Sperling oder der Feldhamster. In solchen Fällen steht Burians Esel vor der Klage über den Verlust des Schädlings einerseits und der Freude über die Wiederherstellung eines konservativen Artenspektrums andererseits. Der Kern des Problems liegt also in den normativen Grundlagen der Biodiversitätsdiskussion, eines weiteren vernachlässigten Problems der Umweltgeschichte.

${ }^{80}$ Insgesamt keine sehr effizienten Strategien. Heuschreckenlarven wurden u.a. in Gräben getrieben und zertreten, die Eiere aufwendig gesammelt und z.T. mit kochendem Wasser überschüttet

${ }^{81}$ Herrmann, Entvölkerung der Landschaft

82 Krünitz, Lemma Sperling, S. 205 - Derartige Berechnungen nehmen m.E. ihren Anfang in zahlentheoretischen Erwägungen, wie jenen von Leonardo Pisano gen. Fibonacci, der 1202 am Beispiel der potentiellen Nachkommenschaft eines Kaninchenpaares die Regel für die nach ihm benannte Zahlenfolge formuliert. Wenngleich Fibonacci von biologisch zweifelhaften Setzungen ausging (Kaninchen haben immer paarweisen Nachwuchs, sie werden einen Monat nach ihrer Geburt geschlechtsreif und sie sind innerhalb des Betrachtungszeitraumes weder unfruchtbar noch sterblich), ermöglicht das von ihm gefundene Rechenprinzip letztlich eine Überschlagskalkulation für mögliche Schadensausmaße. Der Nachwuchs eines Kaninchenpaares beträgt danach innerhalb zweier Jahre 59.084 Paare. Mir scheint es naheliegend, Fibonaccis Ableitung auch aus dem Blickwinkel möglicher Schadenskalkulationen zu betrachten und in ihr das praktische Hilfsmittel zu erkennen, zumal Kaninchenplagen schon aus römischer Zeit bekannt waren (vgl. Robert Delort: Der Elefant, die Biene und der heilige Wolf. München 1987). Jedenfalls liegt seit Fibonaccis Kalkül die mögliche ökonomische Dimension einer ungehinderten Schädlingsvermehrung offen zutage.
} 
einem einzigen Jahr.“83 Das Schadenspotential beliefe sich auf 8.8 Mio. Taler. Dass diese Summe (die wegen ihrer angenommenen Rahmenbedingungen natürlich unsinnig ist, aber dennoch argumentativ eingesetzt wird) niemanden ruhig schlafen lassen kann, ist sicher. Zumal die Ertragssituation beim Getreide zu jener Zeit grundsätzlich prekär ist.

Ähnliche Argumentationsstränge gelten für den Hamster. Wenigstens seit der Mitte des 17. Jahrhunderts ist die Hamsterbekämpfung auf preußischem Gebiet durch Verordnung zur Pflicht der Landbevölkerung geworden. Preußen unterscheidet sich hierbei - wie auch bei der Sperlingsbekämpfung - nicht grundsätzlich von anderen mitteleuropäischen Ländern. Hamster waren einst gefürchtete Feldschädlinge. ${ }^{84}$ Beispielsweise werden in einem Fall die hamsterbedingten Schäden um Quedlinburg für eine Vegetationsperiode im 18. Jh. auf 10.000 - 12.000 Taler geschätzt. ${ }^{85}$ Andererseits wehren sich 1728 die Halberstädter Bauern in einer Eingabe an den preußischen König gegen den Zwang zur Hamster- und Sperlingsbekämpfung, denn: ,„.. der Schaden fällt auf uns, und da wir denselben lieber ertragen alls mit schweren Kosten Hamster und Sperlingsfänger, die mehr kosten alls der Schade imponieret... " 86 Der König ist dem rationalen Argument nicht zugänglich und setzt die Befolgung des Edicts durch. Aber gerade diese Verordnung liefert einen Beleg für Ahnungslosigkeit und Dysfunktionalität der administrativen Bemühungen. Denn Füchse, Marder, Wiesel, Iltisse und Greifvögel, alles natürliche Feinde des Hamsters, werden zur selben Zeit ebenfalls, und zwar prämiengestützt, bekämpft.

Die zeitgenössisch geschätzten Schadensdimensionen durch Schädlinge für das 18. Jh. sind erstaunlich groß. Man ist eher verwundert, dass die Kopfsteuern angesichts dieser Größenordnung verhältnismäßig gering ausfielen. Vermutlich gab es aber auch noch zusätzlich eine funktional spürbare Entlastung durch parallele Verfolgung der Sperlinge als kostenlose Nahrungsergänzung. ${ }^{87}$ Auch der Feldhamster ist schließlich essbar. ${ }^{88}$

\footnotetext{
${ }^{83}$ Krünitz, Sperling, a.a.O.

${ }^{84}$ Reuss C F : Mittel zur Vertilgung schädlicher Thiere, zum allgemeinen Besten jeder Haushaltung in der Stadt und auf dem Lande. Leipzig, Zweite Aufl. (1796), S. 60

85 Reuss, a.a.O.

86 Aus Herrmann, Entvölkerung der Landschaft, S. 41

${ }^{87}$ Krünitz, Sperling, lobt Vorrichtungen für den nahrungsergänzenden Sperlingsfang und tüchtige Hausfrauen wegen ihrer findigen Kochrezepte

${ }^{88}$ Noch zu DDR-Zeiten wurden auf der Magdeburger Börde die jährlichen Erntekampagnen mit einem Gulaschessen mit Hamster - Einlage begangen. Mir berichtete ein Mitarbeiter des Magdebuger Umweltamtes, dass zu dieser Zeit aus den Hamster-Innereien ein schmackhaftes Shashlyk bereitet wurde. Wegen der Pestizid-Akkumulation in der Hamster-Leber war dies eine zweifelhafte Leckerei, sie weist aber auf die vielseitige Verwendungsmöglichkeit des Fleischlieferanten in der Volkskultur hin. Auch Maikäfer fanden bis ins 20.Jh. ihren Weg in den Suppentopf. Nur für Heuschrecken fehlt bislang für Preußen eine verbürgte Verwendung als Nahrungsergänzung.
} 


\section{Agenda}

Betrachtet man die Schädlingsbekämpfungsideen als Inversen von Wertschätzungsideen, gewinnt man zugleich Anhalt über die historischen Verschiebungen von Wertvorstellungen innerhalb der Gesellschaft. Dabei soll das Zeitalter der Aufklärung und die Einsichten in den Haushalt der Natur besonders einflussreich gewesen sein. Wirklich? Immerhin wird schon 1335 in Zürich ein Singvogelschutz erlassen, weil die Vögel „muggen und ander gewurme tilggent und vertribent.“89 Größer sollte die Einsicht in das antagonistische Verhältnis zwischen Vögeln und Insekten aus der Sicht des schädlingsgeplagten Menschen bis auf den heutigen Tag nicht werden. ${ }^{90}$

Unter den historischen Erzählungen ist der Mythos vom Paradies mit einer ganzen Gattung vertreten: Sagenhafter Tierreichtum zu früheren Zeiten ist darin ein bekanntes topisches Element. Andere Erzählungsmythen zielen auf Gesindeverträge, worin sich Bediensteten verbeten hätten, mehr als 3 Tage in der Woche Krebse. Lachs oder Hasenbraten vorgesetzt zu bekommen. ${ }^{91}$ Solche Erzählungen haben bei Theoretikern der Umwelt-Depravation Konjunktur. Das Prinzip der Erzählungsgattung zielt darauf, dass es „früher“" von den uns beute wertvollen Dingen „mehr“ gab. ${ }^{92}$ In historischen Quellen werden von den Zeitgenossen häufig Zunahmen von Individuenzahlen selbst bei solchen Arten, die nicht Bekämpfungsoder Schutzmaßnahmen unterliegen, entweder überhaupt nicht registriert oder eine Zunahme wird in doppelt negativer Weise als übles Prodigium gewertet, als Beleg für eine Störung der sogenannt natürlichen Verhältnisse konnotiert. Etwa, wenn seltene Vögel in Massen einfallen ${ }^{93}$. Selbst Erzählungen über Massensterben von Ratten in Zeiten der Pest dürften topischen Charakter haben. Der Verlust von Lästlingen oder Schädlingen wird nicht weiter thematisiert, so dass nicht einmal Angaben zu ihrer (relativen) Häufigkeit möglich sind. Andererseits fehlt den historischen Zahlen die Vergleichsbasis: Im 18. Jh. beispielsweise, aus dem Abschusslisten erhalten sind, wurden allein in Alt-Preußen, und ähnlich im Herzogtum CelleLauenburg, über Jahrzehnte jährlich ca 60.000 Greifvögel als Schädlinge geschossen. Die Preußen entnahmen über eine Kopfsteuer im 18. Jh. jährlich ca. 350.000

\footnotetext{
${ }^{89}$ Günter Heine: Ökologie und Recht in historischer Sicht. In: Hermann Lübbe/Elisabeth Ströker (Hg.): Ökologische Probleme im kulturellen Wandel. Paderborn 1986. S. 116 - 134. S. 126

${ }^{90}$ Gedenkt man der 1685/1686 erlassenen Schutzvorschriften für Nachtigallen (Halle, Brandenburg) aus ästhetischen Gründen (Wertschätzung des Gesangs), wendet sich der Mensch den Tieren auch aus interesselosem Wohlgefallen zu. Das ist nun freilich doch nicht ganz ,interesselos“, denn es nützt der Verbesserung der Selbstbefindlichkeit.

${ }^{11}$ Herrmann, Krebse, Lachs und Hasenbraten

92 Sympathiekundgebungen für Schädlinge sind historisch im kulturellen mainstream nicht belegt, selbst heute haben sie Fürsprecher lediglich unter Systembiologen. Immerhin hat es der Maikäfer bis in ein bekanntes deutsches Chanson geschafft („Es gibt keine Maikäfer mehr"). Das schließt aber keineswegs an seine Rolle als historischer Forstschädling an. Dagegen ist „La Cucaracha“ trotz des Titels kein Lied auf die Küchenschabe (Blatta orientalis).

${ }^{3}$ Siehe die zahlreichen Einzelbelege bei Ragnar Kinzelbach/Jochen Hölzinger (Hg.): Marcus zum Lamm (1544 - 1606). Die Vogelbücher aus dem Thesaurus Picturarum. Stuttgart 2000
} 
Sperlinge allein in Brandenburg. Heuschreckengelege und -larven wurden im 18. Jh. in Brandenburg in riesigen Mengen gesammelt, ${ }^{44}$ für Maikäfer war hingegen das 19. Jh. offenbar der historische Höhepunkt. Nur bleiben alle diese Zahlen zunächst ohne Einschätzungsmöglichkeit, weil sie ohne Referenzangaben oder Angaben über die Metapopulationen sind, aus denen die gesammelten Individuen entnommen wurden. Gelänge es, über biologische Proxidaten oder andere Hilfskonstruktionen diese Zahlen zu Schätzungsgrundlagen zu machen, würden sie außerordentlich wertvoll, weil damit endlich eine Grundlage für die Rekonstruktion historischer Abundanzen von Arten und Individuen gefunden wäre.

Das Zeitalter der Aufklärung sortierte, nicht immer mit glücklicher Hand, die Tiere mit alttestamentarischer Schärfe nach „schädlich“ (unrein) und „nützlich“ (rein). Als Folge nehmen auch die gedruckten Ratschläge zur „Vertilgung schädlicher Thiere und Ungeziefer" zu. ${ }^{95}$ Die Landesherren erlassen erste Verordnungen zu ihrer Bekämpfung. Neben detaillierten Erfahrungsberichten von Waidmännern, Forstwirten und Kammerjägern über erfolgreiche Maßnahmen gegen Raub- und Singvögel und viele als schädlich erachtete ,vierfüßige Thiere“ wie Hamster, Mäuse, Ratten, Fischotter, Dachs und Maulwürfen, ${ }^{96}$ stehen theoretische Schriften über die Naturgeschichte der Tiere und die Stellung der Schädlinge in der vollendeten göttlichen Schöpfung. ${ }^{97}$ Die Auflistungen „culturschädlicher Thiere“ des 18. Jahrhunderts lesen sich heute zum Teil wie Auszüge aus den Roten Listen gefährdeter Tierarten. ${ }^{98}$ Mit steigender Erkenntnis des ökonomischen Nutzens biologischer Schädlingsbekämpfung ${ }^{99}$ setzte allmählich aber eine Umwertung ein. Aus manchen vormals als schädlich erachteten Tieren, wie Maulwürfen und Spitzmäusen, wurden langsam „Nützlinge“. ${ }^{100}$ Die gelegentliche Relativierung seit der Mitte des 19.Jh. ist aber auch abhängig von der allgemeinen Verbesserung der Nahrungsversorgung. Zusätzlich treten neben Bekämpfungsmaßnahmen auch „Beliebtheitsleitbilder“, die den Übergang in den Naturschutz vorbereiteten (z.B. von der Verfolgung von

\footnotetext{
94 als Beispiel: 1753 wurden allein im Kreis Lebus (Brandenburg) insgesamt 449 Wispel Heuscheckenlarven gesammelt, im darauf folgenden Jahr 1754 waren es 273 Wispel. Ein Wispel enthielt 1319 Liter, also 1,3 Kubikmeter [Zahlen-Angaben aus Akten: Geheimes Staatsarchiv Preußischer Kulturbesitz Berlin. HA II, Kurmark, Materien. Tit. CCLVIII, 2, Vol I ]

95 Z.B. Christian Friedrich von Reuss: Mittel zur Vertilgung schädlicher Thiere, zum allgemeinen Besten jeder Haushaltung in der Stadt und auf dem Lande, Leipzig 1796

${ }^{96}$ Etwa Robert Smith: [Des] Rattenfängers im Dienste der weyland Königlich Großbritannischen Prinzessin Amalia Handbuch zur Vertreibung der schädlich vierfüßigen und geflügelten Thiere. Hannover, 1800

${ }_{97}$ Z.B.: Die besten Mittel gegen die den Menschen und Hausthieren, der Oekonomie und Gärtnerey schädlichen Thiere, gesammelt und herausgegeben zum Nutzen für Jedermann, Quedlinburg bey Friedrich Joseph Ernst 1795; weitere Details in Herrmann: Entvölkerung der Landschaft.

$98 \mathrm{Vgl}$. Smith, Rattenfänger, Inhaltsverzeichnis

${ }_{99}$ Beckmann, Naturgeschichte (s.o.) ,...ein Thier wider das andere zu brauchen..“

${ }^{100}$ Hierzu die damals verbreitete Schrift: C.W.L. Gloger: Kleine Ermahnung zum Schutze nützlicher Thiere als naturgemäße Abwehr von Ungezieferschaden und Mäusefraß . 7. Auflage, Berlin 1862 [Erstausgabe 1858].
} 
Schädlingen des 18. Jh., wie der Singvögel oder dem Biber, bis zu deren Schutz im ausgehenden 19. Jh.). Insofern vollzieht sich im 19. Jh., vor allem in dessen zweiter Hälfte, ein Paradigmenwechsel. Mit dem zunehmenden naturwissenschaftlichen Verständnis von der Entstehung und Wirkung der Schädlinge, werden die objektiven und rationalen Kriterien zu Grundlagen der Schädlingsbekämpfung. Gegenwärtig führt die „Biophilie“101 westlicher Standards zu einer weiteren Einschränkung der Bedenkenlosigkeit, da sie behauptet, dass grundsätzlich die Verantwortung für Konvivialität in der Hand des Menschen läge.

Hier hätte eine vertiefende umwelthistorische Analyse der Schädlingsbekämpfung anzusetzen. Sie müsste sich nicht nur auf die Unterschiede und Übergange ökonomischer, ökologischer und ästhetischer Begründungmuster konzentrieren. Selbstverständlich müsste sie auch den allgemeinen mentalitätsgeschichtlichen Hintergrund mit Blick auf die Schädlinge herausarbeiten, darunter vor allem die Bedeutung harmonistischer Natur- und Schöpfungsvorstellungen, welche die Forschungskonzepte des 18. Jh. und die Frühzeit des 19. Jh. bestimmen. ${ }^{102}$ Dass dabei auch der Blick auf die besonders abgründigen Seiten der Schädlingsbekämpfung angezeigt sein kann, lehrt nicht nur die genannte Ableitung von Jansen, sondern auch die skrupellose Verwendung schädlicher Organismen in der biologischen Kriegführung. ${ }^{103}$ Schließlich müsste der je rechtliche Rahmen der Schädlingsbekämpfungen und seine territorialen Bezüge verfolgt werden. ${ }^{104}$ Eine solche Erörterung bezieht zweckmäßig den politischen Rahmen, in dem die Agrarwirtschaft zwischen dem 17. und 19. Jh. stattfand, mit ein und hätte den Einfluß der Agrarkrisen des 18. und des späten 19. Jh. aufzuzeigen. ${ }^{105}$

\footnotetext{
101 Stephen Kellert/Edward Wilson (Hg.): The Biophilia hypothesis. Washington 1993

102 Arthur O. Lovejoy: Die große Kette der Wesen, Frankfurt 1993 [Erstausgabe 1933].

103 Vgl. Erhard Geißler: Schwarzer Tod und Amikäfer. Biologische Waffen und ihre Geschichte. Berlin-Buch 2001

104 Die erste übernationale Konvention im Pflanzenschutz (Reblauskonvention von 1881 mit ihrem Vorgänger von 1878) ist einerseits Ergebnis der jetzt reichsweit einheitlich geregelten Vorgehensweisen, andererseits stellt sie die gebotene funktionale Erweiterung in den kontinentalen Raum her. Begünstigt wurden diese Regelwerke durch die bereits seit Beginn des 19.Jh. einsetzende Rezeption des „Code Napoleon“ in deutschen Territorien.

105 Dieter Redlhammer: Ein Blick in das 19.Jahrhundert und seine Agrargeschichte. Mitteilungen der Biologischen Bundesanstalt für Land- und Forstwirtschaft, Berlin 1998. Heft 348, S. 115-131 sowie das Einleitungskapitel in Ulrich Sucker: Anfänge der Phytomedizin. Mitteilungen der Biologischen Bundesanstalt für Land- und Forstwirtschaft, Berlin 1998. Heft 334
} 



\title{
„Auf keinen Fall mehr als dreimal wöchentlich Krebse, Lachs oder Hasenbraten essen müssen!“‘ Einige vernachlässigte Probleme der „historischen Biodiversität ${ }^{\text {‘ }}{ }^{106}$
}

\author{
Bernd Herrmann
}

Die akademischen wie die öffentlichen und laienhaften Umwelt- und Naturdiskurse bedienen sich gern des Schlagwortes „Biodiversität“, wenn es gilt, damit einem Argument zu souveräner Kompetenz, fachlichem Nachdruck sowie dem letzten terminologischen Schliff zu verhelfen. Mühelos und gelehrig ist der Begriff von

\footnotetext{
106 Zuerst veröffentlicht in: Hans-Peter Baum, Rainer Leng, Joachim Schneider (Hg.) Wirtschaft Gesellschaft - Mentalitäten im Mittelalter. Festschrift zum 75. Geburtstag von Rolf Sprandel. Stuttgart 2006 (= Beiträge zur Wirtschafts- und Sozialgeschichte 107), S. 175-203.

Herrn Kollegen Rolf Sprandel zum 75. Geburtstag zugeeignet. Unsere wissenschaftlichen Wege haben sich vor Jahren mit der Behandlung von Themen erstmals berührt, bei denen die geschichtsbildende Kraft der Biologie im Vordergrund stand. Das schien bei den behandelten demographischen Themen eigentlich unproblematisch. Doch wurden die damals formulierten ersten deutlicheren Ansprüche der Biologie, wonach die anthropologischen Fundierungen der Geschichtsdisziplinen stärker an modernen evolutionsbiologischen Gesichtspunkten menschlicher Motivationssteuerung zu orientieren wären, nicht unbedingt enthusiastisch aufgenommen. Seitdem scheint mir doch eine zunehmende Integration biologischen Wissens in die Geschichtsdisziplinen stattgefunden zu haben. Nicht nur evolutionsbiologische Einsichten haben ihre Beachtung gefunden. Ökosystemisches Wissen ist in umwelthistorischen Zusammenhängen essentiell geworden.

Mein Beitrag berührt Probleme aus dem Grenzbereich zwischen Geschichtswissenschaft und Biologie, dessen Nähe der Jubilar nie gemieden und zu dem er Gewichtiges beigetragen hat.

Für redaktionelle Mithilfe danke ich meiner Studentischen Hilfskraft, Frau cand. phil. Magdalena Krokowski.
} 
den biologisch bewegten Diskursen in andere Zusammenhänge adaptiert worden. Seit einiger Zeit trifft man in Erörterungen irgendwie historisch daherkommender Sachverhalte auf einen begrifflichen Abkömmling, die "historische Biodiversität". Wie bei den meisten Mutationen, ist auch hier die Befürchtung naheliegend, dass sich hinter dieser Sprachwelt-Komposite nicht nur positive genetische Eigenschaften verbergen.

Der folgende Beitrag behandelt vordergründig Fragwürdigkeiten des Begriffs und seiner Ableitung. Mehr noch sind es allerdings die impliziten Episteme des Begriffs und die Begrenztheiten seiner analytischen Kraft, die mich beschäftigen, ebenso, wie die mit ihnen verbundenen Krisen des Denkens. Sie sind Gegenstand der folgenden Ausführung.

\section{Biodiversität}

\subsection{BioDiversität?}

Die Frage, wofür der Biodiversitätsbegriff denn eigentlich erfunden wurde bzw. welche Forschungsprogrammatik er abdecken soll, findet sich selten gestellt und seltener noch erörtert. Man scheint darauf zu vertrauen, dass sich das Verständnis irgendwie von selbst einstelle. Das mag für eine pragmatische Vorgehensweise oder praktische Belange, etwa die Frage nach der Diversität tierlicher Schädlinge in einer Vorratskammer, ausreichen, weil in diesem Beispiel die Frage voraussetzungslos gestellt wird und auf der Ebene der ingenieurtechnischen Lösungen beantwortet werden kann. Im Beispiel geht es, mit Max Weber gesprochen, ${ }^{107}$ um eine „Wie-Frage“. Doch wies Weber bekanntlich auch auf die „Ob-Frage“ hin. Für ihn zielte diese Frage auf die gesellschaftliche Akzeptanz eines wissenschaftlichen Tuns. Für den agierenden Wissenschaftler zielt die Frage gleichzeitig auf die mindestens ebenso gewichtige Bedeutung des möglichen epistemologischen Gewinns, wenn ein konkret erkanntes Problem noch seiner ersten oder seiner weiteren Analyse harrt.

Die Gegenstände unserer Neugierde sind nicht immer schon und einfach so da, sondern treten ins Bewußtsein erst dadurch, dass sie zum Erkenntnisobjekt gemacht werden. ${ }^{108}$ Besser müsste es wohl heißen: Das Problem ist noch nicht

\footnotetext{
${ }_{107}$ Max Weber, Wissenschaft als Beruf, in: Gesammelte Aufsätze zur Wissenschaftslehre, hg. von Max Weber und Johannes Friedrich Winckelmann, Tübingen ${ }^{7}$ 1988, UTB 1492, Seiten 582-613.

108 bzw. (im Sinne Webers) unter den gegebenen gesellschaftlichen Entscheidungen gemacht werden können, weil die gesellschaftlichen Rahmenbedingungen das zulassen, sei es durch ein geistigmaterielles Klima der Förderung, sei es durch eine laissez-faire - Grundhaltung. Wie berechtigt Webers Unterscheidung der Dichotomie von ,wissenschaftlich' versus gesellschaftlich akzeptiert' ist, lehrt nicht erst der Blick speziell in deutsche Geschichtsbücher, sondern allein schon der Blick ins Feuilleton während der zweiten Jahreshälfte 2004, nachdem in Großbritannien im August das therapeutische Klonen unter bestimmten Randbedingungen zugelassen wurde. In der Bundesrepublik fehlt hierfür zu diesem Zeitpunkt eine gesellschaftliche (d.i. eine kodifizierte) Akzeptanz. Obwohl die deutschen
} 
gefunden, weil die Frage, die zu ihm führt, noch nicht gestellt wurde. Es ist dabei unmöglich, eine Frage zu einem Problem zu stellen, das sich erst in der Zukunft erkennen lassen wird, denn mit der Frage nach ihm ist zugleich auch immer das Problem bezeichnet, also gleichsam in die Welt gesetzt. ${ }^{109}$ Und ob etwas dann ein wissenschaftliches Problem ist oder zu einem gemacht wird, steht nicht von vornherein fest. Ein solches Problem erscheint dann auch nicht erst beim Erreichen z.B. einer methodischen Grenze innerhalb analytischer Arbeit, vielmehr ist es unter anderem bereits in der Semantik der Ausgangsfrage eingeschlossen.

Da uns die Dinge der Natur nicht als solche entgegentreten, sondern in der uns eigenen Form der symbolischen Weltaneignung ${ }^{110}$ und unter der erkenntnisproduzierenden Kraft der Sprache ${ }^{111}$ erst konstruiert werden, scheint es mir folgerichtig, den Biodiversitäts-Begriff nicht einfach hinnehmen zu sollen, sondern nach seinen Bedeutungsmöglichkeiten zu fragen. Mit der Hervorbringung des Biodiversitäts-Begriffs ist - mit oder ohne Absicht - eine unbekannte Menge vorher so nicht bestehender Annahmen und Bedeutungen in die Welt gesetzt worden. Welcher Bedeutungen diese sind, ob der Begriff von deskriptiver Qualität oder ein Konzept im Sinne eines Forschungsprogramms ist und damit vielleicht sogar eine spezifische Natursicht abbildet und wer Interesse an seiner Verwendung hat, ${ }^{112}$ soll im Folgenden nachgegangen werden.

Meine Frage zielt nicht auf eine Revue lexikalischer Informationen, etwa der Art: Wann und von wem der Begriff erstmals benutzt wurde, sondern auf seine Konnotationen und Kontexte in den wissenschaftlichen Partikularsprachen. Haeupler hat in seinem Handbuchartikel ${ }^{113}$ zu recht darauf hingewiesen, dass der Begriff Diversität ohne adjektivische Bestimmung sinnlos ist: Diversität gibt es nicht als solche, das Epitheton „Bio-“ könnte demnach eine Erklärung liefern, zumal dasjenige Forum, welches die nachhaltigste Plazierung und Multiplizierung des Begriffs

\footnotetext{
Korporationen „der Wissenschaft“ nachdrücklich einschlägige Grundlagenforschung einfordern, spricht sich der Nationale Ethikrat gegen eine Freigabe des therapeutischen Klonens aus.

109 dieser Gedankengang führt u.a. auf die im Zusammenhang des Themas naheliegende Frage, ob denn die Organismen, die wir nicht kennen, Teil der Biodiversität sind oder Teil irgendeiner Biodiversität, also zu der Frage, ob und wenn ja, welche Teilbarkeit der Biodiversität besteht? Hierauf wird weiter unten zurück zu kommen sein.

${ }^{110}$ Ennst Cassirer, Versuch über den Menschen. Einführung in eine Philosophie der Kultur, Hamburg 1996.

111 es genügt hier der Hinweis auf das Problemfeld, linguistic turn'.

112 Sonderbarerweise taucht der Begriff „Biodiversität“ im Register des einflussreichen Werks von Ernst Mayr „Das ist Biologie“ (Spektrum, Heidelberg 1998) nicht auf. Ebenso wenig ist der von Edward Wilson herausgegebene Tagungsband „Ende der Biologischen Vielfalt“(deutsch bei Spektrum, Heidelberg 1992) im Literaturverzeichnis erwähnt. Dieses ursprünglich von der American Academy of Sciences 1988 publizierte Beitragswerk propagierte den Begriff mit beispielloser Wirkungsmacht. Ernst Mayr werden diese beiden auffälligen Auslassungen nicht aus Nachlässigkeit passiert sein.

${ }^{113}$ Hennig Haeupler, Lemma „Diversität“, in: Handbuch zur Ökologie, hg. von Wilhelm Kuttler, Berlin 1993, Seite 99-104.
} 
besorgte, ${ }^{114}$ das Wort dezidiert in einer bestimmten Schreibweise einsetzte: BioDiversity.

Überraschenderweise hat die Literatur, die fachliche wie die feuilletonistische, über diesen kleinen semiotischen Unterschied in der Folgezeit hinweggesehen. Inhaltlich scheint bei Verwendung des Begriffs im Sprachgebrauch überwiegend von „Verschiedenheit“ die Rede zu sein. Die Encyclopaedia Britannica gibt den mehrheitlichen Gebrauch im Sinne von „quantity of species“ an. ${ }^{115}$ Diese strikte Beschränkung wird im amerikanischen Wörterbuch nicht gemacht. Dessen weitergehende Bedeutungszuweisung eröffnet die Blickrichtung auf eine andere mögliche Lesart des Nomens, der sich letztlich auch die Schreibweise BioDiversität verdankt, weil sonst der Großbuchstabe in der Wortmitte sinnfrei wäre. So sind zwei Lesarten möglich: Es ist nämlich grundsätzlich nicht ausgemacht, ob von einer Diversität des Lebens oder im Leben gesprochen wird.

Nun sollte es in der Biologie keine Diversität des Lebens geben, denn Leben ist nur in einer Form und mit allen es konstituierenden Attributen möglich.

Möglich scheint noch, sich „Biodiversität“ als Kategorienbegriff zu denken, doch ergeben sich hieraus ebenfalls Probleme. Ähnlich den Zentralbegriffen der Biologie, wie etwa „Leben“ oder „Individuum“, wäre auch „Biodiversität“ nur von scheinbarer Eindeutigkeit. „Die Biodiversität" beschriebe dann einen abstrakten, idealtypischen Zustand. Weil es die Konstanz der Arten und die Festlegung von Individuenzahlen nicht gibt, repräsentiert der Ausdruck dann im günstigsten Fall eine Kategorie, deren Qualität zu jedem Zeitpunkt durch natürliche evolutive Abläufe selbst sowie die menschliche Sicht auf diese Abläufe bestimmt ist. Damit

\footnotetext{
114 „Grundlage dieses Buches ist das „National Forum on BioDiversity“, das vom 21.-24. September 1986 unter der Schirmherrschaft der National Academy of Sciences und der Smithsonian Institution in Washington in den Vereinigten Staaten stattfand [...]. Mehr als sechzig führende Biologen, Wirtschaftswissenschaftler, Landwirtschaftsexperten, Philosophen, Vertreter von Hilfsorganisationen und großen Banken und andere Fachleute nahmen daran teil...". Aus dem Vorwort des Herausgebers (zitiert nach der deutschsprachigen Ausgabe Spektrum Akademischer Verlag, Heidelberg usw., 1992, S. 14). - Der semiotische Gehalt der Schreibweise „BioDiversität“ wird nach meiner Einschätzung einfach übersehen, zumal die Änderung seiner Schreibweise in der nachfolgenden Literatur die Absicht der ersten Stunde verdeckt.

115 Die Encyclopaedia Britannica: "Quantity of plant and animal species found in a given environment. Sometimes habitat diversity (the variety of places where organisms live) and genetic diversity (the variety of traits expressed within a species) are also considered types of biodiversity.

http://www.britannica.com/ebc/article?eu=382600\&query=biodiversity\&ct

The American Heritage ${ }^{\circledR}$ Dictionary of the English Language: Fourth Edition. 2000 differenziert allerdings stärker: "The number and variety of organisms found within a specified geographic region. 2. The variability among living organisms on the earth, including the variability...".

[http://www.bartleby.com/coi-

in $/$ texis/webinator/ahdsearch?search_type $=$ defn\&query $=$ biodiversity $\& \mathrm{db}=$ ahd]
}

Gern danke ich an dieser Stelle meinem Göttinger Kollegen Gert Webelhuth, dem Fachmann für anglistische Linguistik, für seine Beratung bei der Frage, ob die Wortzusammensetzung „biodiversity“ mit denselben sprachtheoretischen Sektionsmitteln und bei grundsätzlich gleichem Ergebnis analysiert werden dürfe, wie der deutsche Begriff „Biodiversität“. Es gibt offenbar keinen Grund, die im Deutschen möglichen zwei Lesarten des Biodiversitäts-Begriffs nicht auch genau so auch für das Englische anzunehmen. 
wäre „Biodiversität“ auch als pragmatischer Begriff und im gelehrten Austausch zwischen den Wissenschaftlern ein Begriff für einen je verständigungsnotwendigen Inhalt. Selbstverständlich gilt dies aber auch für den gleichsinnigen Gebrauch von „Artenvielfalt“. Allerdings ist dieser Begriff nie in ähnlichem Maße für programmatische Aussagen verwendet worden.

\section{Biodiversität, Artenvielfalt, Schöpfungsreichtum}

Als ich 1965 mit dem Studium der Zoologie begann, war das Wort Biodiversität noch nicht erfunden und kam daher im universitären Alltagsgebrauch und in den Lehrbüchern nicht vor. Geläufig war damals der Ausdruck Artenvielfalt, dessen Stelle heute oft durch den Begriff Biodiversität ersetzt scheint. Die zeitliche Reihe semantischer Stellvertreter kann aber weiter zurückverfolgt werden. Dabei wundert es nicht, dass der Vorgänger der Artenvielfalt der Schöpfungsreichtum ist. Die chronologische Begriffsfolge Schöpfungsreichtum - Artenvielfalt - Biodiversität drückt als semantische Reihe auch einen wissenschaftsgeschichtlichen Wandel aus.

Abkürzend verweise ich auf Lovejoys „Große Kette der Wesen“116. Seine Darstellung, die sich u.a. auf das biologische Forschungsprogramm des 18. Jahrhunderts konzentriert, zeigt die untrennbare Verbindung des „Schöpfungsreichtums“ mit der Idee einer Schöpfung der Fülle auf. Dabei bestimmen drei Setzungen der Leibniz-/Wolffschen Philosophie auch die Weltsicht der Naturwissenschaftler des 18., zum Teil noch des 19. Jahrhunderts:

1. Die Große Kette der Wesen nimmt an, dass kein denkbarer Platz in der Natur unbesetzt blieb, weil das grundgütigste aller Wesen keiner denkbaren Kreatur seine Existenz vorenthalten könne: Alles was möglich ist, wird auch Wirklichkeit (Es gibt nichts Neues unter der Sonne).

2. Die unendliche Fülle der Arten wird in sich zu einer Art des Gottesbeweises. Dabei „macht die Natur keine Sprünge“ (Das Prinzip der lückenlosen Kontinuität in der unendlichen Kette der Wesen).

3. Das Prinzip der Gradation, welches die Naturdinge nach ihrem Vollkommenheitsgrad in einer hierarchisch abgestuften Ordnung (scala naturae) sieht. ${ }^{117}$

\footnotetext{
116 Arthur O. Lovejoy, Die große Kette der Wesen, Frankfurt 1993 (stw 1104).

117 verkürzt nach Ilse Jahn, Rolf Löther, Konrad Senglaub, Geschichte der Biologie, Jena 1985, S. 263. Eine substanzreiche Studie zur Scala naturae bei Gerhard Wagenitz, Die „Scala naturae“ in der Naturgeschichte des 18. Jahrhunderts und ihre Kritiker, in: Jahrbuch für Geschichte und Theorie der Biologie 4 (1997), S. 179-195.

Die Idee der ,scala naturae“ beinhaltet auch, dass bestimmte Grundeigenschaften des Lebens isoliert bereits in unbelebten Naturdingen vorkommen, die damit auf einer gleichsam vor-belebten Stufe verharren, aber zwischen den unbelebten und belebten Objekten vermitteln. Nach meiner Überzeugung ist der Begriff „quantity“ ideengeschichtlich an die deutschen Begriffe „Fülle“ (Arten-Fülle, engl. plethora) bzw. „Reichtum“ (Schöpfungs-Reichtum) anzuschließen, also in der Kontinuität des Ketteder-Wesen-Gedankens zu verstehen. Damit wird der Biodiversitätsbegriff zu einer heimlichen Fortsetzung von Ideen des 18. Jh.s: Eine Diversität des Lebens kann nur derjenige denken, der bestimmten Biologie-Konzepten anhängt, in denen Leben als additive Qualität auftritt. Dies gilt insbesondere für naturtheologische bzw. animistische Varianten des scala naturae-Gedankens.
} 
Die enzyklopädische Kartierung dieser Kette der Wesen, die Erfassung der gesamten Schöpfung, ist das Forschungsprogramm von der Mitte des 18. Jahrhunderts bis mindestens in die Zeit Darwins. ${ }^{118}$ Selbst heute ziehen Forscher immer noch aus, um neue Arten zu entdecken.

Hatte der „Schöpfungsreichtum“ seine Wurzeln in einer theologischen Natursicht, aus der sich letztlich Wissenschaft durch das Studium der Natur, die nach der Bibel das zweite Buch der Offenbarung darstellte, als Gotteslob, ja Gottesdienst, entwickelte, ist die Anschlussvokabel „Artenvielfalt" in der wissenschaftshistorischen Begriffsreihe geradezu der atheistische Gegenentwurf. Arten verdanken sich in der Zeit nach Darwin „der Natur“ selbst, sie entstehen in teleonomischen Reihen, ${ }^{119}$ und ihr Auftreten ist positivistisch erklärbar, also ohne jedes Hinzutun theologischer bzw. metaphysischer Erklärungselemente. ${ }^{120}$

Im Konzept des „Schöpfungsreichtums“ ist im 18. Jahrhundert die Konsequenz auffällig und bemerkenswert, mit der Kalküle zur Nutzung der Natur abgeleitet und umgesetzt werden. Wegen des göttlichen Auftrages, die Erde untertan zu machen und sie zu mehrender Fruchtbarkeit zu nutzen, sind Utilitaritätserwägungen der Zeitgenossen gegenüber der belebten Natur völlig unproblematisch, weil der Mensch als der von Gott bestimmte Nutznießer der Schöpfung gilt (Genesis 1, 26ff). ${ }^{121}$ Nützlichkeitserwägungen bestätigen in ihrer Funktionalität zirkulär geradezu das Vorliegen der besten aller Welten. Der ambivalente Begriff der „oeconomia naturae", der im Wesentlichen auf Linné zurückgeht, ist in seiner ökonomischen Lesart wohl die wichtigste Fundierung für die uneingeschränkte Nutzung der Natur mit einem völlig reinen Gewissen. Alles in der Schöpfung ist nicht nur sinnvoll einge-

\footnotetext{
118 Lovejoy (wie Anm. 11).

119 ich verwende hier absichtsvoll eine ältere Präzisierung Ernst Mayrs (Teleologisch und teleonomisch: eine neue Analyse, in: Evolution und die Vielfalt des Lebens, Berlin 1979, S. 198-227), mit der er zielgerichtete, programmgesteuerte (,teleonomische') Abläufe von zielsuchenden, auf ,Endursachen' ausgerichtete finalistische (,teleologische) Prozesse unterschied. Es gibt - scheinbare - Sprünge in der Natur, solange einzelne taxonomische Gruppen des Tierreiches sich noch nicht ohne weiteres in relationale Systematisierungsentwürfe einfügen lassen. Solche rezent ohne unmittelbare taxonomische „Verwandte“ vorkommenden Gruppen nehmen relativ isolierte Positionen im Stammbaum ein und sind das Ergebnis einer Radiation über bislang nicht bekannte Zwischenglieder bzw. eines ungewöhnlich schnellen Evolutionsprozesses. Diese Sprünge sind also anderer Ursache, als jene, deren Existenz die Kette der Wesen bestreitet.

Artenbildung als radiative Differenzierung der Organismen in der Zeit kann danach als teleonomischer Prozess beschrieben werden, der auf mit der Zeit immer stärker veränderten genetischen Programmen zwischen Stammart und Tochterarten beruht.

${ }^{120}$ Es gibt - scheinbare - Sprünge in der Natur, solange einzelne taxonomische Gruppen des Tierreiches sich noch nicht ohne weiteres in relationale Systematisierungsentwürfe einfügen lassen. Solche rezent ohne unmittelbare taxonomische „Verwandte“ vorkommenden Gruppen nehmen relativ isolierte Positionen im Stammbaum ein und sind das Ergebnis einer Radiation über bislang nicht bekannte Zwischenglieder bzw. eines ungewöhnlich schnellen Evolutionsprozesses. Diese Sprünge sind also anderer Ursache, als jene, deren Existenz die Kette der Wesen bestreitet.

121 hierzu liegt eine umfangreiche Literatur vor. Torsten Meyer hat diesem Aspekt in seiner Darstellung „Natur, Technik und Wirtschaftswachstum im 18. Jahrhundert“, Münster/New York 1999 (Cottbuser Studien zur Geschichte von Technik, Arbeit und Umwelt 12) das besonders aufschlussreiche Kapitel 4 gewidmet und auch auf die Bedeutung Linnés hingewiesen.
} 
richtet, sondern eben auch nützlich für den Menschen. Das ist für die genutzten Tiere und Pflanzen unmittelbar einleuchtend. Aber selbst die nicht genutzten Tiere und Pflanzen erfüllen ihre Zweckbestimmung als nützlich für den Menschen. Entweder sind sie letztlich doch wirtschaftlich nutzbar oder sie haben eine andere, dienende, womöglich auch erzieherische Aufgabe: So halten uns die wilden Tieren z.B. davon ab, in klimatisch unwirtliche Gegenden vorzudringen; alle Pflanzen der Welt sollen auf pharmakologische Wirkstoffe getestet werden, ${ }^{122}$ die kleinen Feinde der Landwirtschaft sichern dem Landmann den Preis, indem sie die halbe Ernte auffressen und damit ein preisschädliches Überangebot abschöpfen; selbst die Läuse sind sinnvoll, weil uns das Ungeziefer lehrt, gelegentlich Räume und Kleider zu lüften. ${ }^{123}$

Dieses ausgeprägte Nutzungs- und Nützlichkeitsdenken, das eigentlich seit Beginn der Entdeckungsreisen zu einem der Rechtfertigungsmotoren wurde und ins Gebäude der Wissenschaften durch das oeconomia-naturae-Konstrukt integriert werden konnte, tritt in der akademischen Lehre besonders der Nach-Darwin-Zeit in den Hintergrund. Die Wissenschaft emanzipiert sich im 19. Jahrhundert zunehmend von der Aufgabe, das Wohlstands- und Glückseligkeitsversprechen des Staates durch Forschungsarbeit einzulösen. ${ }^{124}$ Hierfür werden stattdessen verstärkt die Akademien mit ihren auf die Praxis zielenden Preisaufgaben sorgen. Außerdem werden spezielle Ausbildungseinrichtungen erfunden und aufgebaut, in denen praktisches (im weitesten Sinne ingenieurtechnisches) und ökonomisches Wissen vermittelt wird. Die Wissenschaft von den Organismen selbst hat viel damit zu tun, sich mit den Mitteln der exakten Naturwissenschaften zu konsolidieren. Fragen der praktischen Nutzung wurden weniger erörtert, zumal die Biologie plötzlich feststellte, dass sie mit ihren Forschungsresultaten Fundamentalbegriffe der abendländischen Philosophie erschütterte. Beispielsweise führten Hans Drieschs Schnürund Schüttelversuche am Seeigelei ihn zu bestimmten Einsichten und zu Beginn des 20. Jahrhunderts konsequenterweise zu seiner Berufung auf PhilosophieLehrstühle in Aberdeen, Heidelberg, Köln und Leipzig. D’Arcy Thompsons „On Growth and Form" beeinflusste ganze Generationen. In Deutschland gelingt es führenden Biologen, eine biologische Theorie als bedeutsam für das fundamentale Selbstverständnis des Staates darzustellen. ${ }^{125}$ Die Biologie hatte die philosophischen Implikationen ihrer Disziplin nicht nur erkannt, sondern sie zu diesem Zeit-

\footnotetext{
122 ein damals absolut gängiges Argument. Es findet sich wortgleich an vielen Stellen des heutigen Biodversitätsdiskurses wieder.

123 die genanten Beispiele sind keineswegs fiktiv, sie stammen aus zeitgenössischen Ratgebern, der Hausväter-Literatur, und deren Umfeld zur Ungezieferbekämpfung (hierzu Bernd Herrmann, Umweltgeschichtliche Perspektiven früher landwirtschaftlicher Schädlingsbekämpfung, in Vorbereitung).

${ }^{124}$ Meyer (wie Anm. 16).

125 Die Biologen Haeckel und Fraas konnten zusammen mit dem Nationalökonomen Conrad 1900 eine Preisaufgabe ausloben, für deren Prämierung Friedrich Krupp immerhin 30000 Mark bereitstellte. Das Thema lautete „W Wa lernen wir aus den Prinzipien der Deszenden rtheorie in Beziebung auf die innenpolitische Entwicklung und Gesetzgebung der Staaten?" Preisträger war Schallmayer, ein Hauptvertreter des deutschen Sozialdarwinismus.
} 
punkt auch angenommen. Die Auffassung, dass Biologie eine spezifische Form der philosophischen Weltbewältigung und Weltbildformierung sei, war noch in der Generation meiner akademischen Lehrer selbstverständlich: Portmann, Rensch, Remane, Büning, wer aus dieser Generation hätte nicht seinen Beitrag zu einer Philosophie der Natur geleistet? ${ }^{126}$

Die Distanz zum praktisch-pragmatischen Wissen, das die Bereitstellung von Antworten auf Webersche „Wie-?“-Fragen außerhalb von Weltbildentwürfen betrieb, war beträchtlich. Noch bei meinem Studienbeginn wurde in der Einführungsvorlesung des SoSe 1965 von Werner Ullrich (FU Berlin) allen Ernstes bestritten, dass Zoologen wissen müssten, was Tiere äßen oder welche Krankheiten sie hätten. Dies, so lernten wir, wobei der abschätzige Unterton unüberhörbar war, sei Sache von Zoo-Leuten und Veterinären, die als ,angewandte Wissenschaftler“ zur eigentlichen Wissenschaft wenig beitrügen. ${ }^{127}$ Die Biologie begriff sich letztlich als der faszinierende Hort der Philosophie, die untersuchte, was die Welt bzw. die Organismen im Innersten zusammenhält und welche die Naturvorfindlichkeiten mehr als mit jedem apparativen Hilfsmittel allein mit der Kraft der Gedanken durchdringt. Das war die ungebrochene Tradition eines Biologie-Verständnisses von Lamarck über Darwin und Haeckel bis in die Mitte des 20. Jahrhunderts. In dem Maße aber, in dem die ehemals scheel betrachteten Ancilla-Disziplinen der Biologie, allen voran die Mikrobiologie mit ihrer wirtschaftlichen Bedeutung, institutionellen und damit wissenschaftspolitischen wie wissenschaftstheoretischen Einfluss gewannen, in dem Maße wollten oder mussten die klassischen Biologien sich nach der Decke strecken und dem neu definierten Relevanzkriterium folgen. Anders gesagt, sie hatten die Definitionsmacht für die „Relevanz der Biologie“ um die 60er/70er Jahre des 20. Jahrhunderts verloren und haben sie bis heute nicht wieder gewonnen. An ihre Stelle sind längst die Vertreter der molekularen Disziplinen getreten, deren Heilsbotschaften die Gesellschaft in Erwartung ewiger Jugend und Gesundheit bei geistiger Frische und immerwährendem Wohlstand begierig aufsaugt. Die organismischen Biologen, die sich mit den Tieren und Pflanzen als sichtbaren Elementen der Natur befassen, spielten eine zunehmend untergeordnete Rolle, weil sie verdächtigt wurden, altmodischen bzw. obsoleten Fragestellungen mit unspektakulärem Instrumentar nachzugehen. In dieser Situation bildeten Fortschrittskritik und Umweltskeptizismus der westlichen Zivilisationen einen idealen gesellschaftlichen Humus, um mit der Sorge über die Zukunft des Artenbestandes

\footnotetext{
126 hierbei handelt es sich keineswegs um ein „deutsches“ Phänomen. In vielen anderen Ländern hatten Biologen zu dieser Zeit ebenfalls eine herausgehobene Bedeutung im allgemeinen philosophischen Diskurs. Beispielsweise werden für die Durchsetzung der „synthetischen Evolutionslehre“ im 20. Jahrhundert neben Rensch die Namen von Mayr, Simpson, Huxley, Stebbins und Dobshansky genannt [Ulrich Kutschera, Karl J Niklas (2004) The modern theory of biological evolution: an expanded synthesis. Naturwissenschaften 91: 255-276], die, wie z.B. Solly Zuckerman, Medawar und Haldane, auch als Meinungsführer gesellschaftliches Gehör fanden.

127 Daher ist es wenig verwunderlich, dass in den 60er Jahren, als die ersten Lehrstühle für „Angewandte Zoologie“ (sic!) eingerichtet wurden, deren Inhaber folgerichtig erst einmal am „Katzentisch“ der Biologen saßen. Aus diesen Anfängen entwickelten sich dann später ökologische Einrichtungen.
} 
von Tieren und Pflanzen den organismischen Biologen Bedeutung und Selbstbewusstsein zurück zu geben. Auf der Fahne dieses Kreuzzuges stand groß „BioDiversität", wobei es bis heute letztlich unklar ist, ob es ein Tauf- und Missionsgebot, ein Schlachtruf oder ein Börsenbegriff ist. ${ }^{128}$

In Anlage und Idee ist der Biodiversitäts-Begriff, wie er von seinen Hauptprotagonisten ${ }^{129}$ vertreten wird, meiner Einsicht nach dem Prinzip der Fülle sehr angenähert und sehr viel stärker auf die Idee der Kette der Wesen und seine Nützlichkeitstheoreme ausgerichtet, als auf die säkularisierte, naturwissenschaftlich positivistische „Artenvielfalt“ der Nach-Darwin-Zeit. ${ }^{130}$ „Schöpfungsreichtum“ war der Begriff, der eine bestimmte, nämlich die göttliche Ursache des Lebens und seiner Formen voraussetzte. Das Konzept hinter der „Artenvielfalt“ beruht hingegen auf der Tatsache eines materialistischen Prozesses, der sich selbst organisiert und damit in niemandes Verantwortung steht. Das Biodiversitätskonzept mit seiner politischen Konvention, mit der der Mensch sich selbst auf die Stelle des Verantwortlichen für das Biodiversitäts-Geschehen setzt, ist ebenfalls nichts als eine Rückkehr zu den Verantwortungskonzepten in den Naturprozessen, wie sie das 18. Jahrhundert kennzeichnen. Was ehedem der Schöpfer besorgte, steht bereits im 18. Jahrhundert in der Verantwortung des Menschen. Vor diesem Hintergrund gewinnt der Biodiversitätsbegriff - wie oben bereits angedeutet - die erweiterte Dimension, die in ihm angelegt ist, aber nicht expliziert wird. Die Diversität des Lebens ist für die Denker der Kette der Wesen eine ganz logische Kategorie, weil auch den anderen Naturvorfindlichkeiten psychische Eigenschaften, Beseeltheiten, Aufenthaltsorte von animistischer Kraft zugeschrieben werden. Der Übergang von unbeseelter Materie zum Lebewesen ist nach diesem Konzept in der Natur über viele Stufen verbunden. Einzelne Naturdinge erhalten teilweise Eigenschaften, die als Vorstufen des Lebendigen erkennbar sind. Die Naturdinge stehen damit wieder in

\footnotetext{
128 die ökonomischen Hauptprofiteure des „Biodiversitätswissens“ sind internationale Pharmagesellschaften, die z.T. ihre Profitinteressen mit Programmen zur Regenwaldkonservierung euphemisieren.

129 Otto Solbrig, Biodiversität. Wissenschaftliche Fragen und Vorschläge für die internationale Forschung. Deutsches Nationalkomitee für das UNESCO-Programm „Der Mensch und die Biosphäre“ (MAB), Bonn 1994.

Weiterhin verweise ich auf die Einleitung Edward O. Wilsons zum Sammelband „Ende der biologischen Vielfalt?" und auf seine beiden Bücher „The Diversity of Life“, New York 1992, und Edward O. Wilson, Biophilia, Cambridge, 1984.

130 E.O. Wilson stammt aus einer Baptistenfamilie in Alabama. Seiner religiös geprägten Kindheit folgte seit dem Studium ein religiös-,,missionarischer“" Eifer für die Sache der Biologie, die Wilson mit dem Instrumentar und den Konzepten baptistischer Religionsvermittlung betrieb. Er beruft sich dabei auf die Wissenschaften als einzig akzeptabler Aufklärungsform, mit dem Nachdruck und Anspruch, den religiöse Konzepte einfordern. Hierzu: Mark Stoll, EO Wilson, The Science of Religion, the Religion of Science and Wilson's „Inner Baptist“, (manuscript to appear in Eminent Lives in Science and Religion series at Johns Hopkins Press, ed. by Nicolaas Rupke)

Meiner Auffassung nach beruht Wilsons Biodiversitätspropaganda letztlich auf dem theistischen Konzept der Kette der Wesen.

Mehr noch ist ein Konzept des „Schöpfungsreichtums“ mit objektiven ökonomischen Theorien über den Wert der Natur verbunden, wie sie mit Thomas von Aquin aufkamen. Vgl. Fußnote 50.
} 
einer Reihe, einer scala naturae, die dem alläglichen Animismus zu voraufklärerischer Stärke verhilft. So kann sich der plötzlich verantwortliche Mensch auch leichter zu einem scheinbaren Verständnis des Prozesses verhelfen, dessen Verantwortung er übernommen hat, obwohl er ihn nicht im Detail überblickt. Wer mit den Steinen sprechen kann, wer die Seele in der Ruhe über den Wipfeln oder in der über die Hügel ausgestreuten Natur erkennt, bewegt sich in Wahrheit in den gradualistischen Kategorien der scala naturae. Der sorglose Umgang mit „Biodiversität“ leistet am Ende auch der Rückkehr in die vorwissenschaftliche Zeit Vorschub, in der das Alltäglich-Profane dann Zeichenhaftigkeit erlangt. Das ungebremste, unkontrollierte Schlagwort von der Biodiversität hat damit letztlich den New Age Philosophien und Heilslehren zugearbeitet.

\section{Etwas Neues unter der Sonne?}

Linné kannte gerade so um die 4000 Tierarten. ${ }^{131}$ Konservative Schätzungen gehen heute von 30 Mio. Tierarten aus, progressive von 100 Mio. und mehr. Beschrieben ist davon ein Bruchteil.

Mit diesem Beispiel lässt sich eine weitere Krise des Diversitätsdenkens beleuchten: Nicht alle Tiere können in absehbarer Zeit gleich gut bekannt sein, manche würden nur mit einem solchen Aufwand gefunden und untersucht werden können, dass man nicht systematisch nach ihnen suchen wird. Das Problem liegt nun offen: Gehören Tiere, die wir weder kennen noch von denen wir nicht einmal ahnen, in die Biodiversität hinein? Angenommen, solche Tiere würden leben und aus der Evolution verschwinden, ohne jemals vom Menschen wahrgenommen worden zu sein, so könnten wir über sie nur so reden wie über alles andere, was wir nicht kennen: Nämlich gar nicht, weil wir von ihnen nichts wissen. Tiere, die wir nicht kennen, gehören (mindestens in pragmatischer Hinsicht) auch nicht zur „Biodiversität“. Wer dies bestreitet, kehrt augenblicklich zum Konzept der Kette der Wesen zurück, weil für ihn nicht die wirklichen Plätze sondern die denkbaren entscheidend sind. Deshalb ist mindestens ein theoretischer Anspruch des Biodiversitätskonzepts unerfüllbar: Wer die Biodiversität im Sinne des Totalbegriffs schützen will ${ }^{132}$, begibt sich auf einen ähnlich mystischen Weg, wie derjenige, der das Übel der Welt auf sich nehmen will.

Thomas Kuhn hat für Regeln und Annahmen, die den kleinen wie den großen wissenschaftlichen Revolutionen vorgeordnet seien, den Begriff des Paradigmas

\footnotetext{
131 Alfred Schilder, Wie viele Tierarten gibt es?, in: Forschungen und Fortschritte 24 (1948) S. 42-45. 132 spätestens mit dem „Übereinkommen über die biologische Vielfalt“ (Biodiversitätskonvention) als Ergebnis der UN-Konferenz von Rio de Janeiro 1992 hat die Biodiversität auch eine institutionalisierte Naturschutzseite. Auf der Konferenz für Umwelt und Entwicklung wurde das Konzept der nachhaltigen Entwicklung als internationales Leitbild anerkannt und die Agenda 21 als zentrales Ergebnis verabschiedet.

Siehe auch: UNEP ( V.E. Heywood, R.T. Watson, Eds), Global Biodiversity Assessment. Cambridge 1995.
} 
gefunden. Nicht der Beweis stehe im Vordergrund, sondern eher „Bekehrungserlebnisse" 133 bei aufnahmebereiten Wissenschaftlern. Und in der Tat waren es diese externen Einflussfaktoren philosophischer, weltanschaulicher oder gesellschaftlicher Art, die bei der Akzeptanz und Verbreitung des Biodiversitätsbegriffs die entscheidende Rolle spielten. Inhaltliche Aspekte wird man vergeblich suchen. Den Verwendern des „Biodiversitätsbegriffs“ ist offenbar nur die Verwendung des Begriffs selbst gemeinsam und von gemeinsamem Interesse. Es gibt keine Annahmen innerhalb des „Biodiveritätsdiskurses“, die nicht schon vor seinem Gebrauch existierten oder die durch ihn etwa in einen neuartigen Sinnzusammenhang gebracht worden wären. Der Begriff selbst führt zu keiner Neuinterpretation oder zu Wissenszuwachs. Er hat keine inhaltliche sondern lediglich eine AufmerksamkeitsQualität. Seine medial gelungene Plazierung verhalf den nicht-medizinischen BioWissenschaften $\mathrm{zu}$ einem politisch instrumentalisierbaren Terminus. In seiner anthropomorphen Übersetzung wird „BioDiversität“ als „Reichtum“ in wörtlichmateriellem Sinne zur politisch-ökonomischen Aussage. ${ }^{134}$ Diese Verknüpfung ist deshalb von Bedeutung, weil in der ökonomischen Theorie des Wertes der Natur in der Nachfolge der objektiven Werttheorie von Thomas von Aquin den Naturdingen ein unwandelbarer Wert innewohne. Diese Sicht bildete ja auch den Hintergrund, in den die scala naturae eingebettet gedacht werden muss. Die Stellung im Schöpfungsprozess bestimme den Wert des Naturdings. Die heutige Variante dieser objektiven Werttheorie muss dann den objektiven Wert aller Genome als gleich (und damit gleich schutzwürdig) bestimmen, wodurch wiederum eine Position zur Bewahrung aller Elemente der Natur theoretisch fundiert wird. ${ }^{135}$ Dass dieses Konstrukt an scholastische Vorläufer anschließt, ist ebenso verblüffend wie weitgehend unbekannt.

Der politische Gebrauch führt allerdings auch zu weiteren begrifflichen Erschwerungen, wenn „Biodiversität“ - wie häufig geschieht - vereinfachend als Artenvielfalt übersetzt wird: im BNaschG \$1 wird neben Schönheit und Eigenart explizit „Vielfalt“ als schützenswertes Gut genannt. Diese Setzung tritt als postulate-ethische Grundhaltung auf. Im Falle des BNaschG ist der Verwendungszweck wegen des gesellschaftlichen Zusammenhangs wenigstens noch klar: Hier regelt der Mensch seine Angelegenheiten. Eine gewissermaßen „naturethische“ Ableitung der Schutzwürdigkeit der Biodiversität ist ohnehin nicht möglich. Dies wäre ein klassischer naturalistischer Fehlschluss. Als Hilfskonstruktion bleibt lediglich der Rückgriff auf handlungsethische Setzungen Kants, mit denen er etwa das Verbot der Instrumentalisierung und Nutzung von Mitmenschen und ihren Freiheitsan-

133 so die Formulierung von Wolfgang Büchel, in Seiffert/Radnitzky, Handlexikon zur Wissenschaftstheorie, Ehrenwirth, München 1989, Lemma Naturwissenschaften, S. 229.

134 z.B.: „Biodiversität ist der einzige wirkliche Reichtum des Planeten Erde“ (Wilhelm Bartlott, Globale Biodiversität. Ursachen und Konsequenzen der ungleichen Verteilung von Artenvielfalt, in: Biodiversität im Wandel, Mainz 1997:36, S. 27-41).

135 die Einsicht verdanke ich einer Diskussion mit meinem Kollegen Rainer Marggraf, Agrarökonom an der Göttinger Universität, der aber selbstverständlich nicht die Verantwortung für meine Ableitungen trägt. 
spruch begründete. Nur über solche Analogiebildungen wird man das Verbot des ungehemmten Umgangs mit „Natur“ moralisch-ethisch halbwegs vertretbar begründen können. So, wie man rational-logisch die Idee des Naturschutzes als gegen das Evolutionsgeschehen gerichtet bezeichnen muss, gehört es mit zu den merkwürdigen Paradoxien der Verwendungspraxis des Biodiversitätsbegriffs, dass die in ihm eingeschriebene Schutzformel gerade keine liberalistische evolutionstheoretische Position sondern eben den reinen Anti-Evolutionismus vertritt. 136

Eine wissenschaftstheoretische Analyse des Begriffs „Biodiversität“ hat Schurig 1999 vorgelegt, ${ }^{137}$ dem es gelang, ihn als synonym der „Mannigfaltigkeit“" (nicht als der enger zu fassenden „Vielfalt") freizulegen. Sein Bedeutungsinhalt wäre die Aussage, „die Mannigfaltigkeit [...] evolutionstheoretisch [... als] das Resultat irreversibler Anpassungen biologischer Systeme im Laufe der Phylogenese“ zu begreifen. Bei einem solchen geringen Bedeutungsinhalt wird es verständlich, dass Kinzelbach schon vor Schurig lapidar feststellte: „Biodiversitätsforschung ist - unter anderem Namen - so alt wie die biologische Forschung überhaupt." ${ }^{138}$ Man darf nur nicht übersehen, dass die genannte Bedeutungszuschreibung sich der Bemühung Schurigs verdankt und nicht etwa auf die Erfinder oder Protagonisten des Begriffs selbst zurückgeht. Schurigs Bedeutungsfindung ist deshalb nicht hilfreich, weil sie keine programmatische oder analytische Qualität aufweist, sondern einfach den Begriff retrospektiv in herrschende Ideen der Biologie einfügt. Auf die nämliche Weise würde heute auch ein Begriff wie „Schöpfungsreichtum“ im gelehrten Diskurs verwendbar werden können, weil niemand ernsthaft annehmen möchte, dass sein Gesprächspartner ein Kreationist ist, obwohl dieser Begriff sich der kreationistischen Auffassung verdankt und nur in kreationistischen Debatten sinngemäß verwendbar wäre. Gerade solche impliziten Verständnisunterstellungen oder gar ontologischen Zuweisungen machten es dem Biodiversitätsbegriff einfach. Jeder schien zu verstehen, wovon die Rede war: Man brauchte einfach eine Chiffre. Dass sich diese zu einem epistemologischen Joker emanzipierte, war angesichts der Lage der organismischen Biologen eigentlich folgerichtig. Es wäre hilfreich und präventiv gewesen, wenn in der Biologie ein Verständnis von der kritischen Wirkung des linguistic turns und der dekonstruierenden Methode existiert hätte, um sich der Chamäleonnatur des Begriffs entgegenzustellen.

Weitere semantische Bedeutungsfelder hat der Begriff, wie Schurig herausgearbeitet hat, durch Erweiterungen in einer „Breitendimension“: da gibt es Diversitäten von Arten, Strukturen, Ressourcen, Standorten. Durch die Übersetzungsmöglichkeiten „Reichtum, Vielfalt, Mannigfaltigkeit“ entstehe eine Tiefendimension 2. Ordnung, aber auch 3. Ordnung (z.B. als Bestand, Spektrum, Artenzahl) bis hin zu

\footnotetext{
136 Der Lebensanspruch der Gattung Homo hat Folgen für die Mitbewohner der Erde. Einem konsequenten Evolutionismus müssten die Folgen gleichgültig sein.

137 Volker Schurig, Kritische Anmerkungen zur Diversität des Begriffs „Biodiversität“, in: Jahrbuch für Geschichte und Theorie der Biologie 6 (1999), 195-204, Zitat S. 196. Trotz gewisser Mängel ist dieser Aufsatz verdienstvoll.

138 Biologie Heute, Heft 6 (1998) S. 1-5.
} 
einem unüberschaubaren Netz spezieller Diversitätsbegriffe. Außerdem existieren zusätzlich Nebenbegriffe gleicher hierarischer Qualität: Biodiversität mit Auto- und Allodiversität. Der Biodiversitätsbegriff entwirft also und schließt ein Begriffsnetz unklarer hierarchisch-encaptischer Qualität.

Der damit beschriebene Zustand gleicht einem sehr bekannten unsicheren Systematisierungsangebot, nämlich dem der „gewissen chinesischen Enzyklopädie“, in der es heißt, dass: „die Tiere sich wie folgt gruppieren:

a) Tiere, die dem Kaiser gebören,
b) einbalsamierte Tiere
c) gezähmte
d) Milchschweine
e) Sirenen
f) Fabeltiere
g) herrenlose Hunde
b) in diese Gruppierung gebörige
i) die sich wie Tolle gebärden
j) die mit einem gan feinen Pinsel aus Kamelhaar gezeichnet sind
k) und so weiter
l) die den Wasserkrug zerbrochen haben
m) die von weitem wie Fliegen aussehen"

Foucault ${ }^{139}$ sagt, dass man mit dem Erstaunen über diese Taxonomie mit einem Sprung die Grenze unseres Denkens erreiche, die schiere Unmöglichkeit, das zu denken. Was die Vorstellungskraft überschreite, sei einfach die alphabetische Serie ( $\mathrm{a}, \mathrm{b}, \mathrm{c}, \mathrm{d})$, die jede dieser Kategorien miteinander verbinde. Und es ist die plötzliche Nachbarschaft beziehungsloser Dinge, aus denen mannigfaltige Verwirrungsmöglichkeiten resultieren. Der Versuch, beziehungslose Dinge in eine Nachbarschaft zu stellen, trifft auf viele Bemühungen biologischer Systematiker des 18. Jahrhunderts zu. Auch dies war eine Folge des Denkens in den Kategorien der Großen Kette der Wesen. Entsprechend sehen graphische Darstellungen der lebensweltlichen Vielfalt im 18. Jahrhundert wie komplizierte, vielsträngige Netze aus. Ein eindrucksvolles Beispiel für die imaginierte Repräsentation gemäß der scala naturae hat Johann Hermann (1783) seinem Werk beigegeben, das auf den damaligen Ansichten über die vermittelnden Vernetzungen zwischen den Gruppen des Tierreiches beruht. ${ }^{140}$

139 das Zitat stammt aus Michel Foucault, Die Ordnung der Dinge, Frankfurt a.M. ${ }^{3}$ 1980, S. 17. Eine ähnliche Aufzählung findet sich auch bei Rabelais, Gargantua und Pantagruel, Kap 64.

${ }^{140}$ Johann Hermann (1783) Tabula affinitatum animalium, Argentorati (Straßburg), Georg Treuttel. Hermanns etwa $100 \mathrm{mal} 40 \mathrm{~cm}$ große Darstellung des Tierreichs mischt Ideen von Stufenleiter und Stammbaum, und mündet graphisch in einer asymmetrischen Netz-Darstellung. Besonders im ersten Kapitel (Seiten 4 - 37) seines Textes konzentriert sich Hermann auf die theoretischen Fundierungen der scala naturae. Im Hinblick auf „die Stufenleiter der Natur" bündelt er die wichtigsten naturphilosophischen Positionen und Autoren seiner Zeit sowie vorausgegangene Entwürfe exemplarisch. Hermanns Netzwerk der „Verwandtschaft der Tiere“ kann als herausragendes Beispiel der zeitgenössischen Vorstellungen gelten. 
Die Idee der monophyletischen Verbindung der Organismen, die sich graphisch im Stammbaummodell ausrückt, ist eben für die Lebenswelt zu diesem Zeitpunkt noch nicht verbindlich gedacht.

So produziert der Begriff „Biodiversität“, wenn er im wissenschaftlichen Zusammenhang daher kommt, mehr Verwirrung als er ordnet. Es müsste daher eine lohnende Aufgabe für alle jene Forschungseinrichtungen sein, die das Wortelement im Namen führen, zur theoretischen Fundierung des Begriffs durch seine Analyse beizutragen.

\section{Wie aus der Biodiversität eine „historische Biodiversität“ wird}

\subsection{Was bedeutet in diesem Zusammenhang, ,historisch“?}

In Debatten unserer Zivilisation werden häufig zwei Vokabeln zum ultimativen legitimatorischen Rückgriff benutzt. Die erste Vokabel ist „Natur“, die im rhetorischen Gebrauch das Konstante, das Gegebene, das Wesen einer Sache, das wirkliche Wahre bezeichnet. Dass es allerdings kaum etwas Kulturelleres als die sogenannte „Natur“ gibt, ist hinreichend belegt. ${ }^{141}$ Es besteht also Veranlassung, sich vor dem „Natur“"-Begriff zu hüten.

Aber wer immer eine Bekräftigungsformel für sein Argument sucht, scheint gut beraten, auf die „Naturbedingtheit“ zu rekurrieren. Dabei kann man allerdings auf die Nase fallen. Doch das Geschäft mit den naturalistischen Fehlschlüssen floriert, obwohl David Hume - weder als Erster noch als Letzter, aber als Prägnantester - warnte: „There is no ought from an is“. Damit ist völlig klar: so wie es ist, ist es nicht, weil es so richtig wäre, sondern lediglich, weil es so ist. Die Dinge sind eben wie sie sind, sie werden erst ein anderes durch die Meinungen der Menschen über sie. Darüber ist man sich seit Epiktet ziemlich sicher.

Die zweite Vokabel lautet ,historisch“,142 und ist in ihrer positiven Konnotation ein Synonym für das Sichere, das Bewährte und Verlässliche in einer zeitlichgenetischen Dimension. Außerdem beschreibt sie den einzig möglichen Bezugspunkt, der unserer Erfahrung zugänglich ist. Nicht das Künftige ist sicher, sondern das Vergangene. Deshalb kann das historische Faktum zu einem unwiderlegbaren Bestandteil eines Arguments werden.

\footnotetext{
141 es genügt hier der pauschale Hinweis auf einschlägige Erörterungen in der nationalen wie internationalen umweltgeschichtlichen Literatur.

142 ich schließe hier sinnverwandte und synonym benutzte Vokabeln mit ein, ohne sie aufzuzählen. Zur Vermeidung von Verständnisproblemen weise ich jedoch darauf hin, dass das hier benutzte Adjektiv „historisch“ nicht mit jenem aus der Opposition „historisch/systematisch“ der Hermeneutik gleichgesetzt werden soll.
} 
Kombiniert man einen naturalistischen Fehlschluss mit dem historischen Rückgriff, hat man eine praktisch unbesiegbare Waffe der politischen Biologie. Im Balkankrieg hieß es in geschichtsfälschender Weise über das Kosovarer Amselfeld: „Wo Serbische Knochen begraben sind, ist serbisches Land."143 Andere Kombinationen sind u.a. leider aus der deutschen Geschichte bekannt; Beispiele lassen sich aber auch aus anderen Regionen der Welt beibringen. Neben solchen entsetzlichen Vorfällen nimmt sich eine Episode fast lächerlich aus, die dennoch die Wirkungsmächtigkeit politisch-biologischer Fehlschlüsse illustriert. Rudolf Virchow wehrte sich gegen die unwissenschaftlich-chauvinistische Schmähung des französischen Anthropologen Armand de Quatrefage, der nach dem Deutsch-Französischen Krieg 1871 behauptete, dass die Preußen in Wahrheit Abkömmlinge der Finnen seien. Quatrefages Behauptung muss nun in unmittelbarer Nachbarschaft zu seiner eigenen These begriffen werden, wonach die heutigen dolichocephalen Europäer als physisch und geistig überlegene höhere Entwicklungsstufe des Menschen aus einer den Lappen verwandten brachycephalen Urbevölkerung hervorgegangen wäre. ${ }^{144}$ Quatrefages polemisches Diktum war, von Mitteleuropa her betrachtet, u.a. deshalb so pikant, weil sich die gebildete Welt seit Lavater nicht vorstellen konnte, dass die Theodizee im damals für hässlich gehaltenen Schädel eines Lappen gedacht werden könnte. ${ }^{145}$

Die Vokabel „historisch“ hat in bestimmten Bereichen die Funktion, nicht nur Legitimationsgründe beizubringen sondern auch als Richtgröße für „das von der Natur Vorgesehene“ zu dienen. „Von Natur aus“ heißt hier: zu dem Zeitpunkt, zu dem der Mensch noch nicht spürbar eingriffen hatte. Dieser Zeitpunkt liegt immer und eindeutig in der Vergangenheit, und diese ist die Ära der ,historischen Biodiversität '. Offenbar soll man sich historische Diversität als eine Artendiversität bei a-, oligo-, meso-hemerobem Einfluss vorstellen. ${ }^{146}$ Die Idee ist eindeutig: Der historische Rückgriff geschieht in der Hoffnung auf das von Natur aus gemeinte, selbstverständlich a-hemerobe Datum, das den archimedischen Bezugspunkt liefern und damit handlungsleitende Qualität für die Gegenwart, z.B. den Naturschutz, haben soll. Auch hierbei wird letztlich auf ein Element der Idee der Kette der Wesen zurückgegriffen, nach deren Vorstellung das Aussterben von Arten unmöglich

143 Olaf Rader, Grab und Herrschaft. Politischer Totenkult von Alexander dem Großen bis Lenin, München 2003, S. $17 \mathrm{ff}$.

144 vgl. Christian Andree, Rudolf Virchow. Leben und Ethos eines großen Arztes, München 2002, S. $122 \mathrm{ff}$.

145 die Vorstellung vom Zusammengehen körperlicher und moralischer Schönheit ist ebenfalls ein Produkt der Leibniz/Wolffschen Vorstellung von der besten aller Welten und damit in der Vorstellung der Kette der Wesen eingeschlossen. Eine hervorragende Analyse des Themenkomplexes bei Hans R. Brittnacher, Der böse Blick des Physiognomen, in: Der falsche Körper. Beiträge zu einer Geschichte der Monstrositäten, hg. von Michael Hagner, Göttingen 1995, Seiten 127-146. Dort auch das Lavater-Zitat zum Lappen-Schädel [S. 134].

${ }^{146}$ Hemerobie: Gesamtheit der durch den Menschen bedingten Einflüsse in einem Ökosystem. Nach dem Grad des Kultureinflusses auf die Lebensräume lassen sich diese einteilen in: a-, oligo-, meso-, eu-, poly-, metahemerob. [Matthias Schaefer, Wörterbuch der Ökologie, Heidelberg-Berlin, 2003]. 
schien. Dem kritischen Voltaire dämmerte bereits 1764 und 1769147, wohl als einem der ersten, dass zumindest der Mensch zwischenzeitlich längst an den Rädern der Artenzahlen gedreht hatte, weil er den Begriff des „Historischen“ richtig mit der Vorstellung des aus menschlicher Interessenlage Gemachten, Gewordenen und Bedingten in Verbindung brachte. Das begriffliche Missgeschick wäre auch nicht geringer ausgefallen, hätten die ersten Nutzer statt von der „historischen“ von der „naturgeschichtlichen Biodiversität" gesprochen, denn die Naturgeschichte wurde für die menschlichen Angelegenheiten erst zu dem Zeitpunkt bedeutsam, als der Mensch der Natur selbst als Naturmacht gegenübertrat. ${ }^{148}$

Wer aber hatte wann über die Zahlen des „,vormenschlichen Naturpotentiales“ entschieden, z.B. über die Zahl der Störche am Niederrhein, bevor die Gegend in eine Parklandschaft umgewandelt wurde? Wo ist diese Zahl hinterlegt? Leider wird immer nur präzise mitgeteilt, wie es heute ist. Seriöse Angaben bzw. Schätzungen von Artenzahlen oder Bestandsdichten in der Geschichte sind selten, sie fehlen zumeist und die wenigen verfügbaren sind von vager Qualität. Zeitzeugen, deren Augenzeugenschaft in solchen Zusammenhängen häufiger bemüht wird, erliegen der Rückvergoldung, und sind bereit, selbst für solche Tiere eine frühere größere Häufigkeit anzunehmen, die nachweislich erst vor einigen Jahrzehnten nach Mitteleuropa eingewandert sind. ${ }^{149}$ Das Verständnis von Geschichte reicht selbst bei offiziellen Stellen selten über wenige Jahrzehnte hinaus. Eine solche Zahl wird auch nur in Einzelfällen berichtet, z.B. wenn zufällig die Zahl der KormoranBrutpaare in Niedersachsen gezählt worden ist. ${ }^{150}$

Wer über historische Diversität sprechen will, spricht über ein Stück Geschichte. Wie immer in der Geschichte, gibt es keine Möglichkeit der direkten Beobachtung. Die historischen Zustände sind nur aus den Erzählungen über sie bekannt. Eine ziemlich ernst zu nehmende Geschichtskritik weist darauf hin, dass es bei solchen Erzählungen nicht nur um die Mitteilung von Fakten geht. Ernst Mayr konzentriert sich im 4. Kapitel von „Das ist Biologie“ auf die „historische Erzählung“ als wissensproduzierendes Instrument. ${ }^{151} \mathrm{Er}$ ist meines Wissens damit einer der wenigen Biologen, welcher die Bedeutung der Erzählung für die historischen Arbeitsrichtungen der Biologie anerkennt. Den geschichtstheoretisch zwingenden nächsten Schritt, die Kritik der sprachlichen Darstellung und die Ausdehnung der hermeneutischen Methode auch auf die immateriellen Befunde, vollzieht er allerdings nicht. Es gibt aber Bereiche, in denen die erkenntnistheoretischen Probleme der Biologie mit denen der Geschichtswissenschaft zusammenfallen. Mit dem In-

\footnotetext{
147 Wagenitz (wie Anm. 12), S. 187.

148 „Die Arbeit ist zunächst ein Prozess zwischen Mensch und Natur, ein Prozess, worin der Mensch seinen Stoffwechsel mit der Natur durch seine eigne Tat vermittelt, regelt und kontrolliert. Er tritt dem Naturstoff selbst als eine Naturmacht gegenüber." Karl Marx, Das Kapital, Bd.1, Berlin 1968, Dritter Abschnitt, S. 192.

149 das gilt z.B. für einige leicht wahrnehmbare Vogelarten.

150 zitiert von der website des Niedersächsischen Landesamtes für Ökologie, Mai 2004.

151 Mayr (wie Anm. 7), S. 99 ff.
} 
strument der historischen Erzählung steht die Biologie ebenfalls vor den Problemen, die sich aus der erkenntnisproduzierenden Kraft der Erzählung ergeben. Die Dinge sind damit nicht mehr so einfach, wie sie dem angeblich voraussetzungslos arbeitenden Naturwissenschaftler erscheinen wollen, weil er noch nicht gelernt hat, seiner Sprache und deren Implikationen zu misstrauen. Eine Entkleidung wissenschaftlicher Sprache der Biologie im Sinne des linguistic turns ist noch zu leisten.

\subsection{Wo kommen die historischen Daten her?}

Der Titel meines Beitrages verdankt sich leicht erkennbar Theodor Fontanes „Frau Jenny Treibel“ [„,Die Krebse waren wie eine Plage, natürlich ganz entwertet, und bei der dienenden Bevölkerung, die damit geatzt werden sollte, so verhasst und dem Magen der Leute so widerwärtig, dass es verboten war, dem Gesinde mehr als dreimal wöchentlich Krebse vorzusetzen "] und seinen „Wanderungen durch die Mark Brandenburg, Kapitel Oderland“ [„Hasen gab es so viel, dass die Knechte, wenn sie gemietet wurden, sich ausmachten, nicht öfter als zweimal wöchentlich Hasenbraten zu kriegen." ${ }^{152}$ Es sind vor allem die realistischen Erzählgattungen seit dem Ende des 18. Jahrhunderts, die mit derartigen Formulierungen im allgemeinen Bewußtsein für die Verfestigung des Bildes einer früheren, überreichen Individuenfülle, einer Superabundanz gesorgt haben. Die Grundlagen hierfür sind viel früher gelegt und z. B. bereits als mehr oder weniger anonymes Wissen in den Enzyklopädien des 18. Jahrhunderts zu finden, ${ }^{153}$ von dort finden sie ihren Weg in die Literatur des 19. Jahrhunderts. Zumindest Fontane hat ausgiebig auf derartige Nachschlagewerke zurückgegriffen. Aber auch das 18. Jahrhundert greift mit solchen Formulierungen bereits auf einen Topos aus der Hochzeit der europäischen Entdeckungs- und Eroberungsreisen zurück, der seinerseits Vorläufer hat: In anderen Weltgegenden halte die Natur überreich Geschenke für diejenigen bereit, die sie sich abholen wollten. ${ }^{154}$ Hierbei handelt es sich letztlich um Varianten der Geschichte vom paradiesischen Mythos. ${ }^{155}$

152 „Frau Jenny Treibel“, 7. Kapitel, und „Wanderungen ...“, Oderbruch, 4. Kapitel.

153 „In Hamburg wurden Lachse [...] ehedem in so großer Menge gefangen, dass sie kein Mensch mehr essen wollte; daher die Klagen der Dienstboten, über diese tägliche Kost Veranlassung zu dem Stadt-Gesetz gab, dass kein Herr seinen Domestiken in der Woche mehr als zwei Mal Lachs zu essen geben sollte" Johann Georg Krünitz, Oekonomisch-technologische Encyklopaedie, Bd 58, Berlin 1792, S. 228ff. Dort auch weitere angebliche Beispiele für Gesindeverträge.

Tatsächlich ist dieses angebliche Gesetz für Hamburg nach Auskunft des Staatsarchivs der Hansestadt (2004) nicht nachzuweisen. Darauf wird noch weiter unten zurück zu kommen sein.

Einen ähnlichen Topos verwendet übrigens bereits Zedlers Universal-Lexicon unter dem Lemma Lachs (1737, Spalte 117), vgl. Fußnote 68.

154 hier ist daran zu erinnern, dass auch die satirische Parabel über Candides Reise nach Eldorado, die als Element der Kritik Voltaires am Leibniz-Wolffschen Weltentwurf gesehen werden muss, sich letztlich diesem Topos verdankt. Dieser Weltentwurf liefert für die Kette der Wesen den größten Teil ihrer theoretischen Fundierung. Damit schließt sich also eine Betrachtungskette, die sich selbstreferentiell immer wieder auf dieselben Episteme bezieht. - Zu Candide: Voltaire, Candid oder die Beste aller Welten, Stuttgart 1998.

155 zum paradiesischen Mythos siehe Bernd Herrmann, Rekonstruktion historischer Biodiversität, in: Biodiversität: Was kennen und verstehen wir von der Artenvielfalt?, hg. von Leibniz-Institut für 
Hinweise auf Artenzahlen und Individuenhäufigkeiten können aus zahlreichen Quellengattungen der historischen Naturwissenschaften und jeder sonstigen Quelle, die über historische Geschehnisse berichtet, rekonstruiert werden. Nach unseren Erfahrungen ${ }^{156}$ lässt sich kein historischer Quellentyp ausschließen, wenngleich bestimmte Quellengattungen schwerpunktmäßig in Frage kommen. Dabei ist einsichtig, dass alle Quellengattungen hinsichtlich Aussagefähigkeit über Artenzahlen und Individuenhäufigkeiten methodische und inhaltliche Begrenzungen aufweisen müssen.

Die Mehrzahl der in gegenwärtigen gesellschaftlichen Diskussionen bemühten Zahlenvorstellungen bezieht sich hingegen auf eine anonyme und scheinbare Gewissheit, nach der es „früher" (wann immer das auch war) von allem , in der Natur" (was immer das auch war) ",mehr" (wieviel auch immer) gegeben habe. In aller Regel fehlen aber einfach die erforderlichen historischen Bestandszählungen, oder ihre Quellen sind bislang unerschlossen, auf die sich solche Behauptungen gründen müssten. Ein deutscher Liedermacher (Reinhard May) weiß z. B. ganz genau, dass „es keine Maikäfer mehr" gibt. Möglicherweise ist sein Wohnort Berlin nicht das Vorzugsrevier von Melolontha, denn man darf daran zweifeln, dass seine politischökologische Botschaft in den hessischen Forsten südlich Frankfurts oder etwa in bestimmten Gebieten Polens, in denen das Insekt ein aktuell gefürchteter Schädling ist, geteilt würde. Vielmehr verhilft ein solches Chanson einem allgemeinen Unbehagen über „Naturbedrohung“ und der scheinbar von allen gleichermaßen geteilten Erfahrung zum Ausdruck, wonach es auch ,in der Natur immer schlechter" werde. Nur wenige Arten verschwinden jedoch wirklich, andere werden räumlich-numerisch umverteilt. Dass selbst bei a-hemerobem Zustand der Gesamtbestand der Arten und ihrer Individuen dem zeitlichen Wandel unterliegt, entgeht der zumeist aufgeregt geführten Diskussion allzu leicht. ${ }^{157}$

Quellen, die zum historischen Artenbestand befragt werden könnten, sind vor allem die herrschaftlichen Erlasse und archivierten Verwaltungsakten seit dem 17. Jahrhundert, unter denen z.B. Fang- und Abschusslisten Aufschluss gebend sein können. Im Folgenden beschränke ich mich auf lediglich drei Beispiele einer ansonsten ausufernden Belegliste:

Gewässerökologie und Binnenfischerei, Berlin 2003, (3. Stechlin Forum 2002), S. 53-62. hier ist daran zu erinnern, dass auch die satirische Parabel über Candides Reise nach Eldorado, die als Element der Kritik Voltaires am Leibniz-Wolffschen Weltentwurf gesehen werden muss, sich letztlich diesem Topos verdankt. Dieser Weltentwurf liefert für die Kette der Wesen den größten Teil ihrer theoretischen Fundierung. Damit schließt sich also eine Betrachtungskette, die sich selbstreferentiell immer wieder auf dieselben Episteme bezieht. - Zu Candide: Voltaire, Candid oder die Beste aller Welten, Stuttgart 1998.

156 diese Erfahrung gründet sich auf unser Forschungsprojekt „Rekonstruktion historischer Biodiversität aus archivalischen Quellen“ Forschungsvorhaben im BMBF-BIOLOG - Schwerpunkt von 2000-2003. Beteiligt an dem Vorhaben waren neben dem Verfasser noch Peter Steinsiek und Antje Jakupi; Veröffentlichung in Vorbereitung.

157 keinesfalls soll der Eindruck entstehen, dass ich gegen Naturschutzbemühungen polemisiere. Diese sind weder Gegenstand noch Adressat dieses Aufsatzes. 
Für Rekonstruktionen auf der Grundlage ökosystemarer Verbundkonzepte sind detaillierte Planungs- und Verwaltungskarten mit „Biotopkartierungen“ die wohl wertvollste Quellengruppe. Wir haben Beispiele solcher Karten des 18. Jahrhunderts und ihrer Auswertung vorgelegt. ${ }^{158}$ Tatsächlich gibt es mindestens ins 17. Jahrhundert zurückreichende Karten deutscher Regionen, die für ganze Landstriche historisch-ökologische Grundaussagen liefern können, wie z.B. die bekannten, parzellen-genauen Matrikeln für Schwedisch-Pommern.

Das zweite Beispiel betrifft eine erhaltene Fischartenliste des Magistrats der Stadt Küstrin, die als Zuarbeit für das epochale Werk von Marcus Elieser Bloch über die ökonomische Bedeutung von Fischen 1782 für die Flüsse Oder und Warthe erstellt wurde, und ist ein seltenes Beispiel einer authentischen Artenliste (Abb. 1). Würde man die Fangquoten (deren Aufzeichnungen leider Kriegsverluste darstellen) zugrunde legen, ergäben sich gute Daten zu den Populationsgrößen. So muss man sich mit Proxydaten aus Steuerlisten behelfen, ein übliches, aber bedenkliches Schätzverfahren. Hierzu zählen auch Proxydaten, die sich aus Akten über „Brunftregister“159 oder Schädlingsbekämpfungsmaßnahmen ergeben, u.a. etwa gegen Heuschrecken oder Sperlinge. ${ }^{160}$

Schließlich bilden enzyklopädische und wirtschaftsstatistische Werke eine weitere wichtige Informationsquelle, aus deren aggregierten Datensammlungen Entwicklungstrends abschätzbar werden (können). Hierfür wird z.B. der Bestand einer Leitart verfolgt und nach bestimmten Parametern auf den gesamten Artenbestand geschlossen, der zur Leitart in funktionaler Beziehung steht. Das dritte Beispiel gibt eine solche Ableitung von Artenbeständen aus den Daten einer Leitart wird in Tab. 1 wieder. Die historischen Fangquoten für den Hecht, der an der Spitze der Nahrungskette steht, ermöglichen eine retrospektive Abschätzung der biologischen Produktivität eines Areals.

\footnotetext{
158 Antje Jakupi, Peter Steinsiek, Bernd Herrmann, Early maps as stepping stones for the reconstruction of historic ecological conditions and biota, in: Naturwissenschaften 90, (2003) S. 360-365.

159 Zählungen des Wildbestandes an spezifischen Aufenthaltsorten der Tiere durch Forstbedienstete.

${ }^{160}$ Bernd Herrmann, Die Entvölkerung der Landschaft. Der Kampf gegen „,culthurschädliche Thiere“ in Brandenburg im 18. Jahrhundert, in: Die Veränderung der Kulturlandschaft, hg. von Günter Bayerl und Torsten Meyer, Münster, New York, München, Berlin, 2003 (Cottbuser Studien zur Geschichte von Technik, Arbeit und Umwelt 22), S. 33-59.
} 


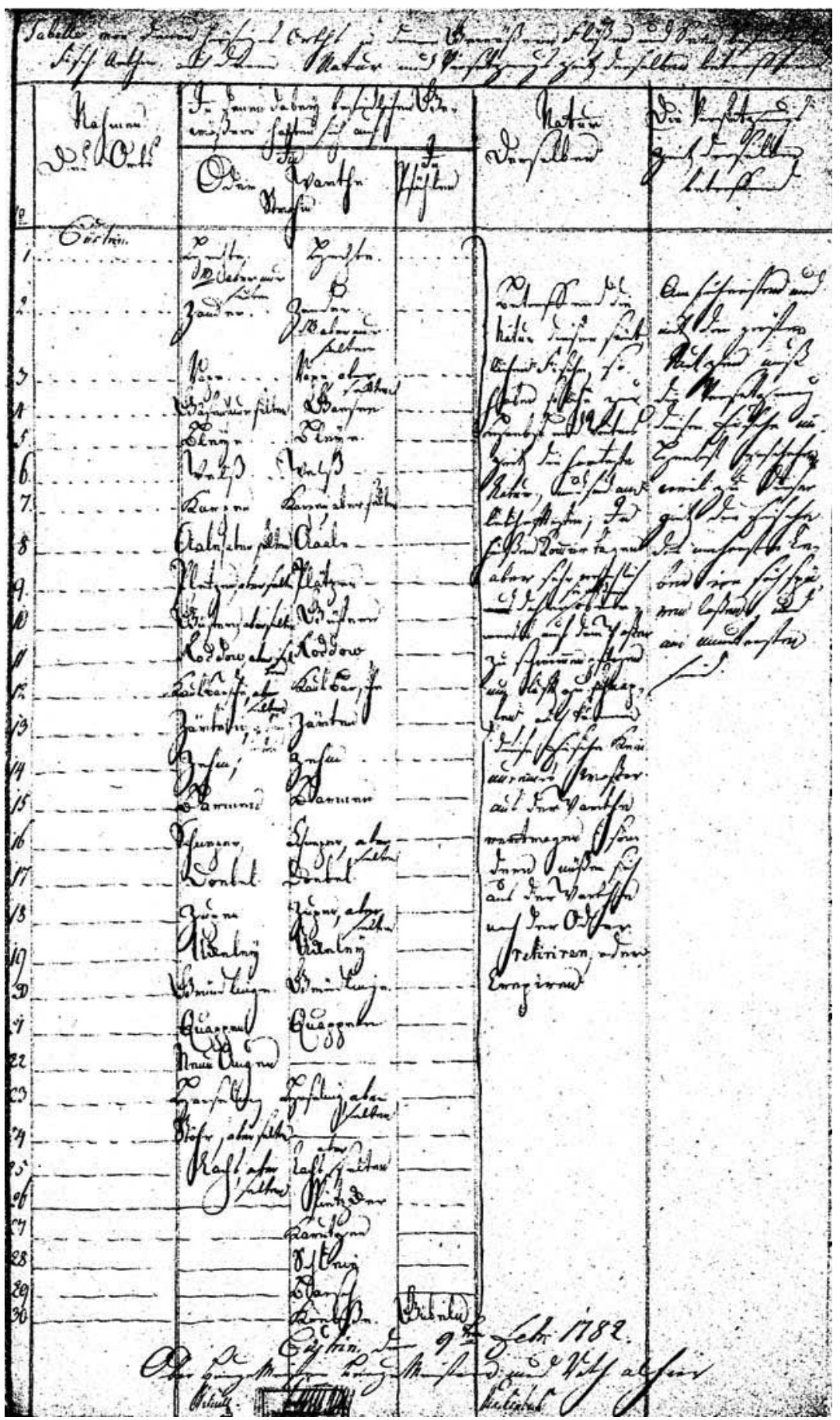


Abb. 1 (links nebenstehend) „Tabelle von denen hiesigen Orths in denen Gewässern und Flüssen und Seen befindlichen Fisch-Arthen, auch deren Natur und Versetzungszeit derselben betreffend" Liste des Magistrats der Stadt Küstrin über das Vorkommen von Fischarten in Oder und Warthe vom Februar 1782, die als Zuarbeit für die Enzyklopädie des Fischspezialisten Markus Elieser Bloch entstand, der mit der Unterstützung der königlichen Administration eine „Naturgeschichte der Fische Deutschlands“, Berlin, Hesse 1782 und Hesse und Buchh. der Realschule 1782-1784, veröffentlichte. Quelle: Brandenburgisches Landeshauptarchiv, Potsdam, Rep.8 Küstrin Nr. 20.(Wiedergabe mit freundlicher Genehmigung des Brandenburgischen Landeshauptarchivs). Solche Listen sind Rara und Glücksfälle für die Erforschung historischer Artenbestände. Ich verdanke das Beispiel dem archivalischen Spürsinn von Peter Steinsiek. Auffällig ist, dass in dieser Liste nicht nur Lachs und Stör als für die Oder selten geführt werden, sondern durchaus auch gewöhnlichere Arten wie Aal, Plötze, Güster, Kaulbarsch.

Tab. 1 Geschätzte historische Tragfähigkeit der Gewässer des Oderbruchs an Hechten und der gesamten Fischartengemeinschaft.

Die Erträge sind auf die Gewässerfläche der Bruchdörfer zwischen Letschin und Hohensaaten sowie die Fläche der Stromoder bis Kostrzyn (Küstrin) bezogen (insgesamt 5148,7 ha). Die Tabelle beruht auf Ausarbeitungen von Antje Jakupi.

In den Jahren ab 1753 machen sich die Biotopverluste durch die Meliorationsmaßnahmen im Zusammenhang mit der Oderkanalisation seit 1747 bemerkbar. ${ }^{161}$

\begin{tabular}{|l|l|l|l|c|}
\hline Jahr & $\begin{array}{l}\text { In Wriezen } \\
\text { verkaufte Hech- } \\
\text { te } \\
{[\text { Tonnen }} \\
\text { à 154,34 kg] }\end{array}$ & $\begin{array}{l}\text { Hechter- } \\
\text { trag } \\
{[\mathrm{kg} / \mathrm{h} / \mathrm{Jah}} \\
\mathrm{r}]\end{array}$ & $\begin{array}{l}\text { Gesch. } \\
\text { Biomasse der } \\
\text { fischbaren } \\
\text { Hechte* } \\
{[\mathrm{kg} / \mathrm{ha}]}\end{array}$ & $\begin{array}{l}\text { Gesch. Bio- } \\
\text { masse } \\
\text { der ges. } \\
\text { Fischgemein- } \\
\text { schaft** } \\
{[\mathrm{kg} / \mathrm{ha}]}\end{array}$ \\
\hline 1705 & 674,0 & 20,3 & 40,6 & 203,0 \\
\hline 1706 & 911,0 & 27,4 & 54,9 & 274,5 \\
\hline 1707 & 549,0 & 16,5 & 33,0 & 165,0 \\
\hline 1735 & 1658,5 & 50,0 & 100,0 & 500,0 \\
\hline $1753^{* * *}$ & 914,0 & 27,5 & 55,0 & 275,0 \\
\hline $1754^{* * *}$ & 914,0 & 27,5 & 55,0 & 275,0 \\
\hline $1755^{* * *}$ & 914,0 & 27,5 & 55,0 & 275,0 \\
\hline Mittelwert & & 28,1 & 56,2 & 281,1 \\
\hline
\end{tabular}

* Die Biomasse der fischbaren Hechte (älter als 1 Jahr) wird auf das Doppelte des Hechtertrages geschätzt (= gesch.).

** Die Gesamtbiomasse der Fischgemeinschaft basiert auf der Annahme eines Anteils der Hechtbiomasse von $20 \%$.

*** Diese Daten entsprechen den Durchschnittswerten der in einer Drei-Jahres-Periode verkauften Hechte (1753-1755: insgesamt $2742 \mathrm{~kg})$.

Abschätzungen sind allerdings auch durch deduktive Ableitungen nach allgemeinen aktualistischen Prinzipien möglich. Die Änderung der Landschaft seit dem

161 Bernd Herrmann und Martina Kaup, „Nun blüht es von End' zu End' all überall.“ Die Eindeichung des Nieder-Oderbruches 1747-1753. Umweltgeschichtliche Materialien zum Wandel eines Naturraums, Münster, New York, München, Berlin, 1997. 
hohen Mittelalter muss in Mitteleuropa zu einem Anstieg der Arten- und Individuenzahlen in Lebensgemeinschaften der geöffneten Landschaft geführt haben: hier wird es heute sicher mehr Spinnen- und Ameisenarten geben als vor Tausend Jahren. Andererseits sind die Lebensraumangebote für Amphibien und Reptilien kontinuierlich dezimiert worden, am meisten wohl durch die großflächigen Meliorationsmaßnahmen des 18. und 19. Jahrhunderts. Durch anthropogene Lizenzen bzw. Nischen wird sich auch zumindest eine höhere Besatzdichte bei kulturfolgenden Arten eingestellt haben, aber auch bei allgemein opportunistischen Folgearten, z.B. dem grünlandgebundenen Weißstorch, dessen Verbreitung ganz sicher eine Folge menschlicher Wirtschaftsweise war. ${ }^{162}$ Ein sehr eindruckvolles Beispiel deduktiver Rekonstruktion hat der Entomologe Ordish für das langsame Aussterben des Schwarzgefleckten Bläulings (Maculinea arion) in Kent durch die Konzentration des wilden Thymians in den Kräutergärten seit dem 16. Jahrhundert erarbeitet. ${ }^{163}$ Durch umfangreiche Bemühungen existieren neuerdings wieder einzelne Vorkommen des Schmetterlings in Großbritannien. ${ }^{164}$

Obwohl es sich bei den genannten Beispielen um besonders eindrucksvoll quantifizierbare Angaben handelt, gilt unserer Einsicht nach durchaus allgemein, dass sich aus archivalischen Quellen recht gute, wenn auch nur auf einzelne Tiergruppen begrenzte Angaben zu Arten- und Individuenzahlen ableiten lassen. Allerdings ist die Beibringung solcher Zahlen mit einem hohen Aufwand an Archivarbeiten verbunden. Aber das eigentliche Problem mit historischen Beständen liegt bislang nicht in ihrer relativen Unsicherheit, sondern vielmehr in der vorgeblichen Sicherheit, mit der Vertreter bestimmter Interessen oder Gruppen oder auch gelehrte Autoren behaupten, relative oder absolute Zahlen zu besitzen. Die meisten dieser Zahlenangaben verdanken sich aber keiner systematischer Sammelarbeit, sondern stellen unzulässige Verallgemeinerungen großzügigster Plausibilitätserwägungen dar, um nicht ,gelehrtem Raten“ zu sagen.

In der Tat kennt man zwar Abschusslisten für Seeottern, Gemsen und Paradiesvögel oder das Datum, an dem z.B. die letzte Stellersche Seekuh oder die Dronte (Dodo) oder der Riesenalk erlegt wurden, aber Angaben über deren ehemalige Populationen bzw. Metapopulationen über längere Zeiträume liegen nicht oder bestenfalls als nicht überprüfte Phantasiezahlen vor.

Eine weitere Schwierigkeit besteht darin, dass alle Welt fest an den Mythos zu glauben und unkritisch an ihm festzuhalten scheint, wonach es früher von allem mehr gegeben habe. Wobei man dem Mythos selbst aufsitzt, wenn die Frage auf das „mebr" ausgerichtet wird, statt auf die Frage, ,ob es andere Häufigkeiten" gab?

\footnotetext{
162 ich danke Herrn Kollegen Matthias Schaefer, Leiter der Abtlg. Ökologie im gemeinsamen Institut, für seine Geduld und die längeren Gespräche über diese Sachverhalte, in denen meine Vorstellungen reifen konnten.

163 George Ordish, Geschichte eines Gartens: vom 16. Jahrhundert bis zur Gegenwart, Frankfurt, 1989, S. $29 \mathrm{ff}$.

164 Jeremy Thomas, The return of the large blue butterfly, British Wildlife 1(1989), S. $2-13$.
} 
Hierzu hält die Geschichte ein vielleicht überraschendes Beispiel bereit, das zur Nachdenklichkeit auffordert. Die Nordamerikanische Wandertaube (Ectopistes migratorius) ist im 19. Jahrhundert mit unvorstellbar großen Indivuenzahlen belegt, bis der Vogel mit dem Tod der letzten Taube 1913 im Zoo von Cincinnati (USA) ausstarb. ${ }^{165}$ Das allgemeine Bewußtsein orientiert sich an seiner erwiesenen Häufigkeit zur Zeit des Western Trails. Dabei wird die Frage nach der Häufigkeit der Taube im vorkolumbischen Amerika nicht gestellt, obwohl archäologische Belege des Vogels aus indianischen Kulturschichten vor 1500 praktisch nicht vorliegen. Darüber hinaus existieren zwingende Hinweise, wonach sich das Massenauftreten der Vögel, vor allem dann im 19. Jahrhundert, letztlich der vorausgegangenen Verdrängung der Indianer von ihren Siedlungsparzellen durch die vordringenden europäischen Siedler verdankte, wodurch sich eine enorme Vermehrung der Brutgelegenheiten für die Wandertauben ergaben. ${ }^{166}$ Deren Superabundanz im 19. Jahrhundert ist damit ein anthropogenes Ergebnis, und jede Ableitung in Richtung auf ein historisch zeitlich längeres und häufigeres Vorkommen des Tieres ist ein mehr als gewagtes Unterfangen. Nicht der europäische Invasor ist der erste Störer eines unterstellten einstigen paradiesischen Zustandes ${ }^{167}$, sondern es war der Amerikaner, der in grauer Vorzeit mit seiner Siedlungstätigkeit der Taube den Brutplatz genommen hatte, wobei deren damalige Häufigkeit völlig unbekannt ist. Dem kollektiven Gedächtnis hingegen prägte sich der Zustand der Superabundanz des 19. Jahrhunderts ein und suggeriert heute als plakatives Beispiel einen Raum und ein Zeitalter der Fülle, die beide in dieser Verkürzung niemals bestanden. ${ }^{168}$

\subsection{Zwischen paradiesischem Mythos und Apokalypse}

Die veröffentlichte Diskussion um die ,historische Biodiversität“ bewegt sich zwischen zwei Extrempositionen, einmal derjenigen eines vermeintlichen historischen Paradieseszustands, zu dem alle Arten überall in großer Individuenzahl, zumindest einer deutlich größeren als „heute“, vorkamen. Die andere Position beschwört eine künftige Apokalypse des Artenrückgangs. Zur Bezugsgröße werden dabei unreflektierte Erzählungen über die Vergangenheit und interessengefärbte Szenarien einer Zukunft produziert, in denen der volkspädagogische Impetus des „Stummen Frühlings“ einer populistischen Darstellungsweise gewichen ist und die geschickt die Zukunftsangst instrumentalisieren.

165 Arlie William Schorger, The Passenger Pigeon. Its Natural History and Extinction, Caldwell, New Jersey [Reprint of first edition 1955].

166 diese Argumentationskette wurde erstmals vorgetragen auf der Jahrestagung der American Society for Environmental History, Providence, March 26-30, 2003: Bernd Herrmann \& William Woods, Between Pristine Myth and Biblical Plague: Passenger Pigeons, Sparrows, and the Construction of Abundances. Die Veröffentlichung (Georgia University Press) befindet sich in Vorbereitung.

167 allerdings rottet er die Wandertaube durch Überjagung aus, wobei menschliche Ignoranz und komplizierte Brutbiologie der Taube einander ergänzten.

168 aufschlussreich hierzu William Denevan, The Pristine Myth: The Landscape of the Americas in 1492, Annals of the Association of American Geographers 82 (1992), S. 369-385. 
Offenbar fällt es allgemein grundsätzlich schwer, die Einsicht zu akzeptieren, dass die Umwelt allererst prozessual organisiert ist. Die Prozesse der Natur sind keine Dauerzustände, werden aber zumeist vom Menschen so wahrgenommen, weil die Rhythmik naturaler Großsysteme einer Zeitskala folgt, die jenseits der menschlichen Generationendauer liegt und damit jenseits der individuellen Erfahrbarkeit. Die Zahlen im Naturbestand können sich verändern, ohne dass es „gefährlich" für das Ökosystem ist. Dass Abnahme mit Verlust gleichgesetzt wird, ist möglicherweise eine menschliche Verhaltenskonstante. Das wäre verständlich, weil der wirtschaftende Mensch auf sichere Ertragsaussicht angewiesen ist und deshalb die Deutung von Vorboten eines möglichen Mangels in seinem kulturellen Vorsorge-Verhalten institutionalisiert hat.

Die Liste der Tiere und Pflanzen, die in den vergangenen Jahrhunderten bei uns einen Rückgang der Individuenzahlen erlebt haben, scheint vergleichsweise beträchtlich. ${ }^{169}$ Dabei scheint von vornherein festzustehen, dass es immer derselbe Mechanismus sei: der Mensch verdränge oder dezimiere den Bestand. Listen für Artenzuwächse (Neophyten und Neozoen) nehmen sich dagegen offenbar bescheidener aus ${ }^{170}$ und werden auch als Elemente einer „falschen Fauna“ gewöhnlich nicht als Zugewinn gerechnet. Unter evolutionsbiologischen Gesichtspunkten ist das ein falscher Purismus.

Die Feststellung eines Verlustes wäre aber nur durch den Einsatz von Verrechnungskalkülen möglich. Deren Einheit könnte eigentlich nur das Genom eines Organismus sein, wobei dann den Genomen vermutlich je gleiches Gewicht zukommen müsste. ${ }^{171} \mathrm{Am}$ Ende würden dann vielleicht dem verlorenen Braunbärengenom 5000 neue Mikrobenarten gegenüberstehen. Wie wäre dann eine Entscheidung über die Verlustklage zu führen?

Eine Verlustklage müsste den Verlust auch hinsichtlich etwaiger Rückgänge bei den Bestandszahlen der Individuen führen. Eine solche Überlegung führt direkt zu Vorstellungen über eine ,potentielle natürliche Häufigkeit". Ein solcher Gedanke ist bis heute zumindest nicht ernsthaft konkretisiert worden. Weder in der Ökologie noch im Naturschutz existieren z.B. Karten oder andere Informationsmedien, aus denen die Abundanz von Tier- oder Pflanzenarten nach einer ,potentiellen natürlichen Häufigkeit" abzulesen wäre, äußerstenfalls als regionale Einzelstudien für die eine oder andere Art. Dabei läge es doch nahe, auf die Aussage „Es gibt keine Maikäfer mehr“ mit der Frage „wo?“" zu reagieren. Und erst der Abgleich mit einer (noch zu

169 einschlägige Angaben in den verschiedenen „Roten Listen“. Allerdings fehlen jegliche Maßstäbe. Selbstverständlich lässt sich argumentieren, dass jeder Artenrückgang ein Verlust ist. Bedenklich ist jedoch nicht ein Artenrückgang als solcher, sondern der gegenwärtige Umfang und die Geschwindigkeit des heutigen Rückgangs, die offenbar ohne historische, vielleicht aber mit erdgeschichtlichen Parallelen sind.

170 Ingo Kowarik, Biologische Invasionen. Neophyten und Neozoen in Mitteleuropa, Stuttgart, 2003.

$171 \mathrm{zu}$ dieser Frage vgl. Bernd Herrmann, Historische Humanökologie und Biodiversitätsforschung, in: Biodiversitätsforschung - Die Entschlüsselung der Artenvielfalt in Raum und Zeit, hg. von Stephan Robert Gradstein, Rainer Willmann, Georg Zizka, Stuttgart 2003, (Kleine Senckenberg-Reihe 45), S. 225-235, bes. S. 230. 
findenden) „potentiellen natürlichen Häufigkeit“ führte dann zu der Aussage, dass es an einem bestimmten Ort „zu wenige Maikäfer“ gäbe. Erwägungen zur potentiellen natürlichen Häufigkeit kämen ohne umfassende, historisch seriös gewonnene Arten- und Individuenzahlen nicht aus. Über die Rekonstruktion historischer Arten- und Individuenhäufigkeiten liegen bisher nur wenige Untersuchungen vor, so dass sich eine allgemein akzeptierte methodische Vorgehensweise noch herausbilden muss. Von den besonderen Problemen, die sich dabei für Quantifizierungen aus Proxydaten historischer Arten- und Individuenhäufigkeiten ergeben, zeugt schließlich das angebliche Paradebeispiel eines sprichwörtlich gewordenen Bestandsverlustes: Der Lachs in Mitteleuropa.

Zedlers Lexikon ${ }^{172}$ gibt über die Häufigkeit des Lachses in unkritischgeneralistischer Übersicht u.a. an: „Weichsel, Oder, Elbe bis über Saale und Mulde, unter welchen die Elb-Lächse vor die besten und schmackhaftesten gehalten werden“ sind Flüsse mit hohem Lachsaufkommen, „ingleichen [...] Weser, Rhein und Mosel, welche Ströme insonderheit dem Lachs einen angenehmen und gedeihlichen Aufenthalt geben," denn sie übertreffen die Lachse aus Schelde, Themse, Loire und Garonne an Güte bei weitem. ${ }^{173}$ „Bei Antwerpen sollen so schlechte Lachse gefangen werden, dass auch die Knechte in Holland mit ihren Herren accordiren, wie viel Lachse sie alle Wochen bei ihnen verspeisen sollen“. ${ }^{174}$

Als einzigen Hinweis auf ein außergewöhnliches Lachsaufkommen berichtet Zedler aber nicht etwa von einem jüngeren Ereignis, sondern bezieht sich aus dritter Hand auf das Jahr 1432, in dem ,ein so großes Heer an Lachsen angekommen, dass sie beinahe die Elbe nicht beherbergen, und ein Fisch dem anderen nicht ausweichen können, daher die Leute haufenweise mit Äxten herbeigelaufen, und die Fische erschlagen. “" ${ }^{175}$ Und bereits Zedler stellt den Rückgang des Lachsfangs fest: „Den Vorteil des Lachs Fangs genießt auch Schlesien von der Oder, und es sind von langen Jahren her ansehnliche Fängereien längs der Oder, z.B. bei Beuthen, Glogau, Steinau und so weiter gehalten worden. Man bat bisweilen auch noch in denen ersten Jabren dieses Jahrbunderts 3,4 bis 500 Lachse gefangen. Deswegen sind auch von dem Stadt Magistrat zu Breslau besondere Verordnungen gemacbt worden, insonderbeit, das alle Fischer und Müller, so unter der Stadtjurisdiktion gebörig, bei Vermeidung großer Strafe, alle Lachse an den Herm Rats-Präsidenten lieferm müssen [...]“..176

Noch präziser lesen sich am Ende des 18. Jahrhunderts in Krünitz’ „Oeconomisch-technologischer Encyclopaedie“ die Berichte über den Rückgang der Häufigkeit des Lachses und den angeblichen Widerwillen selbst der so genannt kleinen

\footnotetext{
172 Johann Heinrich Zedler, Universal - Lexicon [...]. Zedler, Halle.Leipzig, ab 1732.

173 Zedler (wie Anm. 66), Lemma „Lachs,“ Spalte 115/116.

174 Zedler (wie Anm. 66), Spalte 117.

175 Zedler (wie Anm. 66), Spalte 117. Zedler zitiert Bohuslav Balbin, Miscellanea Historia Regni Bohemiae, Prag, 1679, decadis I, lib.I, caput LII, p 120.

176 Zedler, a.a.O, Hervorhebung von BH.
} 
Leute, die inflationär heruntergekommene Herrenspeise zu essen. ${ }^{177}$ Das Hamburgische Staatsarchiv, das die Verordnungstexte auch aus der Zeit kennen sollte, über die Krünitz berichtet, ist nicht in der Lage, eine einschlägige Quelle zu benennen und hat bislang auch keinen Anhalt für ihre ehemalige Existenz. Klaus Schwarz ${ }^{178}$ hat mit viel Mühe und Sorgfalt die Dienstbotengeschichte verfolgt und kommt zu dem verblüffenden Urteil: urban legends. Historisch richtig ist vielmehr, dass Lachs vom Mittelalter bis ins 20. Jahrhundert eine (durchgehend) teure Herrenspeise ist. Zwischen 1620/30 und 1670/80 stieg aus bislang unbekannten Gründen in Deutschland die Zahl der gefangenen Lachse. Entsprechend sank der Preis. In der Folgezeit entstand die Legende, der Edelfisch sei ehedem selbst von Dienstboten verabscheut worden. Der angebliche Überdruss der Dienstboten ist in keiner zeitgenössischen Quelle (gilt z. Zt. für Deutschland) belegt, wird aber immer wieder behauptet. ${ }^{179}$

Dass solche Schwankungen im Fischbestand vorkommen, möglicherweise in Abhängigkeiten von großen Zyklen der Meeresströmungen, Salinität und Wassertemperatur, ist historisch belegt. Die Fischer aus Bristol folgen den Fischschwärmen, die vor der Ausbreitung des polaren Wassers ausweichen, bereits 1470/80 bis in den Bereich der Neufundlandbank. Der Kabeljaufang kommt Ende des 17. Jahrhunderts zwischen Island und den Faröer völlig zum Erliegen (1685 bis 1704). Ursächlich sollen Meeresströmungen und Klimaverschiebungen sein. ${ }^{180}$ Welche Auswirkungen solche Schwankungen auf den Lachs hatten, ist meines Wissens bisher nicht untersucht, aber im 18. Jahrhundert scheint die Diskrepanz zwischen Lachsfang und allgemeiner Erwartung aufgefallen zu sein. Schwarz zitiert eine Quelle über das Lachsvorkommen in der Saale „Lachs ist in der Saale in so großen Mengen gefangen worden, dass die Dienstboten sich zuletzt geweigert haben, ihn zu essen..." und stellt dieser Angabe die Fangquoten bei Bad Kösen gegenüber, wo zwischen 1567 und 1600 in 17 Jahren überhaupt keine und nur in 9 Jahren drei oder mehr Lachse gefangen wurden. Die durchschnittliche Fangquote errechnet sich also über die 33 Jahre am Ende des 17. Jahrhunderts mit ganzen 3 Exemplaren pro Jahr. Tatsächlich sagt selbst eine solche Quote noch wenig über die Lachshäufigkeit aus, weil der Lachs zumeist an Wehren gefangen wurde. Damit ergibt sich eine höhere Fangwahrscheinlichkeit bei niedrigem Wasserstand und eine geringere Wahrscheinlichkeit bei höherem. Die Fangquote ist also mindestens ebenso ein Indikator für den mittleren Wasserstand wie für die Lachshäufigkeit, wenn nicht eher sogar einer für das erstere. Man müsste daher die Fangquoten von am

\footnotetext{
177 siehe Fußnote 47.

178 Klaus Schwarz, Der Weserlachs und die bremischen Dienstboten, Bremisches Jahrbuch Bd. 74/75, (1995/96), S. 134-173 und Klaus Schwarz, Nochmals: der Lachs und die Dienstboten, Bremisches Jahrbuch 77, (1998), S. 277-283.

${ }^{179}$ sonderbarerweise beklagen sich in all diesen Geschichten, ob es nun um Lachs, Krebs oder Hasen geht, die Dienstboten immer nur über eine Belästigung mit „Herrenspeise“. Nirgends wird auch nur ein Gesindevertrag erwähnt, nachdem es nicht öfter als 3 mal in der Woche Kohlsuppe geben dürfe. War Kohl etwa vor 200 Jahren viel seltener als heute, zumindest seltener als Lachs?

180 Hubert Horace Lamb, Klima und Kulturgeschichte, Reinbek 1989, Seiten 208, 239, 241, 249.
} 
Flusslauf aufeinander folgenden Fangstationen kennen, um aus der Quote auf die Lachshäufigkeit schließen zu können. ${ }^{181}$

Die Ableitung historischer Individuenzahlen muss zuerst die Populationsschwankungen innerhalb des betrachteten Ökosystems kennen. Bestandsschwankungen sind innerhalb der Prozessabläufe in einem Ökosystem normal und natürlich. Liegt nun das Betrachtungsfenster zur Ermittlung einer historischen Bestandshäufigkeit in einem Abschnitt geringer Abundanz, kann leicht der Eindruck einer Bestandsabnahme entstehen, im umgekehrten Fall derjenige einer Bestandszunahme. Tatsächlich wären beide Bewertungen inadäquat, weil die „,natürliche Bestandszahl“ keine konstante Größe ist. In aller Regel existieren keine Kenntnisse über die ökologischen Prozessabläufe in historischer Zeit. Vergleicht man hilfsweise jedoch mit den heutigen Bestandszahlen, ergeben sich lediglich absolute Beträge ohne Vorzeichen. In der Tat ist es ein Faktum, dass kaum Lachse gefangen werden. Ob daraus aber abzuleiten ist, dass der Lachs hinsichtlich seiner Häufigkeit wirklich einen historischen Absturz erlebt hat, erscheint mir diskussionswürdig.

\section{Ausblick}

Wird der Begriff „Biodiversität“ verwendet, ist grundsätzlich unklar, ob er als Konzeptbegriff für ein Forschungsprogramm oder deskriptiv als modernistischer Ersatz für „Artenvielfalt“ bzw. deren Ableitungen verwendet wird. Als Konzeptbegriff ist er meiner Einsicht nach ideengeschichtlichen mit dem Konzept der „Kette der Wesen“ verbunden. Dieses Konzept gilt der modernen Biologie als obsolet. Daher plädiere ich dafür, den Begriff „Biodiversität“ in wissenschaftlichen Zusammenhängen nicht zu verwenden, bzw. ihn nur dann zu verwenden, wenn der Verwendungszusammenhang eine sub- oder metatextliche Deutung in dieser epistemologischen Richtung ausschließt. Bei Institutionen, die den Begriff aus programmatischen Gründen in ihrem Namen führen, ist die Gefahr der Fehlinterpretation besonders groß. Die unkritische Verwendung des Begriffs befördert nach meiner Einsicht naturphilosophische Positionen zweifelhafter Reife.

Historische Daten über Arten- und Individuenzahlen lassen sich bei ausreichender Datendichte zu Prozesskurven verbinden. Für die meisten Prozesskurven zu Arten- und Individuenzahlen in der Geschichte sind nur Einzelwerte bekannt, nicht aber die Graphencharakteristika. Wer über historische Abundanzen spricht, müsste aber über solche Graphen sprechen. Über solche Prozesskurven wissen wir allgemein wenig. Wer weiß dann aber, was „historisch richtig“ ist und was „,von Natur aus" so sein soll? Solange die Voraussetzungen für die Beantwortung dieser

\footnotetext{
181 Ich danke Herrn Dr. Christian Wolter, Leibniz Institut für Binnenfischerei und Gewässerökologie, Berlin, für diesen Gedanken und hilfreiche Gespräche. Herr Wolter hat mit Kollegen ein Schätzverfahren zur Ermittlung von Fischbeständen aus historischen Daten entwickelt: Christian Wolter, Antje Bischoff \& Klaus Wysujack, The use of historical data to characterize fish-faunistic reference conditions for large lowland rivers in northern Germany, in: Archiv für Hydrobiologie, (2005) in press.
} 
Fragen nicht sorgfältiger und auf breiterer Basis bereitgestellt werden können, kann von „historischer Biodiversität" nur im Sinne eines Forschungsprojektes zur Ermittlung historischer Artenvielfalt und Individuenzahlen gesprochen werden. Keinesfalls aber deckt der Begriff heute mehr als eine im besten Falle punktuelle Plausibilitätserwägung ab. Er steht nicht für zuverlässiges, positives Wissen und nicht für ein gesichertes methodisches Instrumentarium, sondern er kann nur Chiffre für eine retrospektive Betrachtung sein, der die Maßstäbe bislang fehlen. Damit ist „,historische Biodiversität“ ein klassischer black box-Begriff ohne analytische Qualität. Er redet lediglich über historische Arten- und Individuenzahlen, ohne sie zu beschreiben oder zu kennen. Daher ist er eigentlich entbehrlich, denn mit den Begriffen „historische Abundanz“ bzw. „historische Arten- und Individuenhäufigkeit" stehen Begriffe zur Verfügung, die eindeutig, klar und ohne epistemologische Subtexte sind. Diese Begriffe sollten in der wissenschaftlichen Arbeit verwendet werden. Aber als Schlagwort des wissenschaftspolitischen Diskurses ist der Begriff wohl nicht mehr von den Tischen der Podiumsdiskussionen zu vertreiben. 


\title{
Holz - Umwelt - Mensch
}

\author{
Bernd Herrmann 182
}

Natürlich hätte die Kulturgeschichte ohne Holz nicht den Weg gemacht, den sie gehen konnte. Die Feststellung ist so trivial wie in ihrer Perspektive reizlos, weil schließlich ohne Salz, ohne Leder, ohne Steine, ohne Metalle auch keine Kulturen der uns bekannten Arten hätten entstehen können.

Dennoch: nachwachsend wie fossil lieferte Holz die Energie für die Etablierung und den Unterhalt der menschlichen Kulturen.

Es lieferte den Baustoff für Behausungen, ohne die eine Siedlung außerhalb der Tropen nicht denkbar gewesen wäre.

Ohne Speer, ohne Speerschleuder, Pfeil und Bogen keine Jägerkulturen.

Der Grabstock markiert den Beginn des Ackerbaus.

Aus Holz war das erste Rad. Holz ermöglichte Bergbau und Verhüttung, ohne Holz kein Glas und damit unter anderem kein Blick in den Mikrokosmos und den Makrokosmos. Und ohne hölzernes Hörrohr und Beißholz kein Fortschritt der Medizin. Holz ist Werkstoff für Transportmittel, für Behälter, für Werkzeuge, Möbel, Waffen. Die Kontinente wären nicht zueinander gekommen, hätten nicht Holz, Holzkohle und Holzasche die erforderliche materielle Basis geliefert und die Umsetzung technischer Prozesse ermöglicht.

Man müsste einschränken und sagen: vielleicht. Aber die kontrafaktische Erwägung erübrigt sich.

182 Zuerst erschienen in: Fansa M, Vorlauf D (Hersg.) (2007) Holz-Kultur. Von der Urzeit bis in die Zukunft. Ökologie und Ökonomie eines Naturrohstoffs im Spiegel der Experimentellen Archaeologie, Ethnologie, Technikgeschichte und modernen Holzforschung. Wissenshcaftlicher Begleitband zur Ausstellung. 4.2.-28.5.2007, Landesmuseum für Mensch und Natur, Oldenburg. S.52-57 


\section{Holzwege oder Wege zum, „Holz"}

Dem Thema „Holz“ müsste, angesichts seiner kulturhistorischen Bedeutung, mehr als nur die realienkundliche Seite, mehr als nur die ökonomie- und ökologiegeschichtliche Seite abgewonnen werden. Deshalb plädiere ich für den Mut zur ,aristotelischen Wendung“" in der Ausstellung. Zur Veranschaulichung dient mir eine bekannte Geschichte, mit der ich nach anderen „Möglichkeiten des Holzes“ frage:

Ehedem hauste bei Theben die Sphinx auf einem Felsen und stellte jedem Vorbeikommenden ein Rätsel. Konnte er es nicht lösen, erwürgte und verschlang sie ihn. Das Rätsel lautete: „Was läuft am Morgen auf vier, am Mittag auf zwei und am Abend auf drei Beinen und ist am schwächsten, wenn es auf den meisten läuft?" Der Held Ödipus löste das Rätsel, woraufhin sich die Sphinx in die Tiefe stürzte. Gesucht war nach dem „Menschen“, der als Säugling auf allen Vieren kriecht, in seiner Jugend fest auf seinen Füßen steht und sich im hohen Alter auf einen Stock stützt.

Mich fasziniert dieser Stock, von dem die Rede ist. Die barocke Biologie rüstet nämlich die Menschenaffen regelmäßig mit einem Stock aus, möglicherweise aus einem diffusen Gefühl, weil ihre Natur noch unsicher schien: waren es nun Tiere oder doch Menschen, vielleicht Zwischenstufen zwischen Tier und Mensch? Ist das hölzerne Attribut ein Indikator für den heimlichen Platz in der Schöpfung, jenseits des taxonomischen Urteils der Zeit?

Mir ist nicht bekannt, ob jemand bisher darüber nachgedacht hätte, wie viel Stock denn eigentlich einen Menschen ausmacht. Denn das Rätsel der Sphinx sieht zwar, dass der aufrechte Gang am Lebensabend des Stockes bedarf, übersieht aber, dass auch zu Beginn die Aufrichtung nicht ohne Hilfe möglich ist und dass es reichlich Kulturen gibt, die den Stock auch für die Abschnitte dazwischen benutzen, entweder zur Beseitigung des aufrechten Ganges oder zu seiner je kulturspezifischen Begeleitung. Ist der Stock des Troglodyten ein ikonographischer Trick, mit dem die Abbildung eine qualitative Teilhabe andeutet? Dann wäre die Botschaft klar: der Mensch verdankt sich dem Holz, ob als Krückstock, als Grabstock, als Hirtenstab oder als Keule.

Der Grat ist schmal zwischen der philosophischen Perspektive aus der metonymischen Transformation des Stockes einerseits, zwischen der Zuchtrute und am deprimierenden Ende dann der Holzstange in den grausigen Abarten der Tortur andererseits. Seine Thematisierung könnte auch ein Desiderat in der Ausstellung sein, unter anderem weil die älteren Ausstellungsbesucher noch die häusliche oder schulische Strafe mit dem Holzlineal oder der Weidengerte aus eigener Erfahrung kennen. Und Goyas Pfählungsbild aus den „Desastres“ ist ein Holzthema allemal wie auch die europäischen Scheiterhaufen der Hexenverfolgung oder der Gegenreformation. Keiner entkommt dem Holz, nicht im Sarg und nicht am Galgen. Und schon gar nicht in der Zeit davor, wo mancher etwas auf dem „Kerbholz“ hat oder sein Leben in der Tretmühle verbringt. 


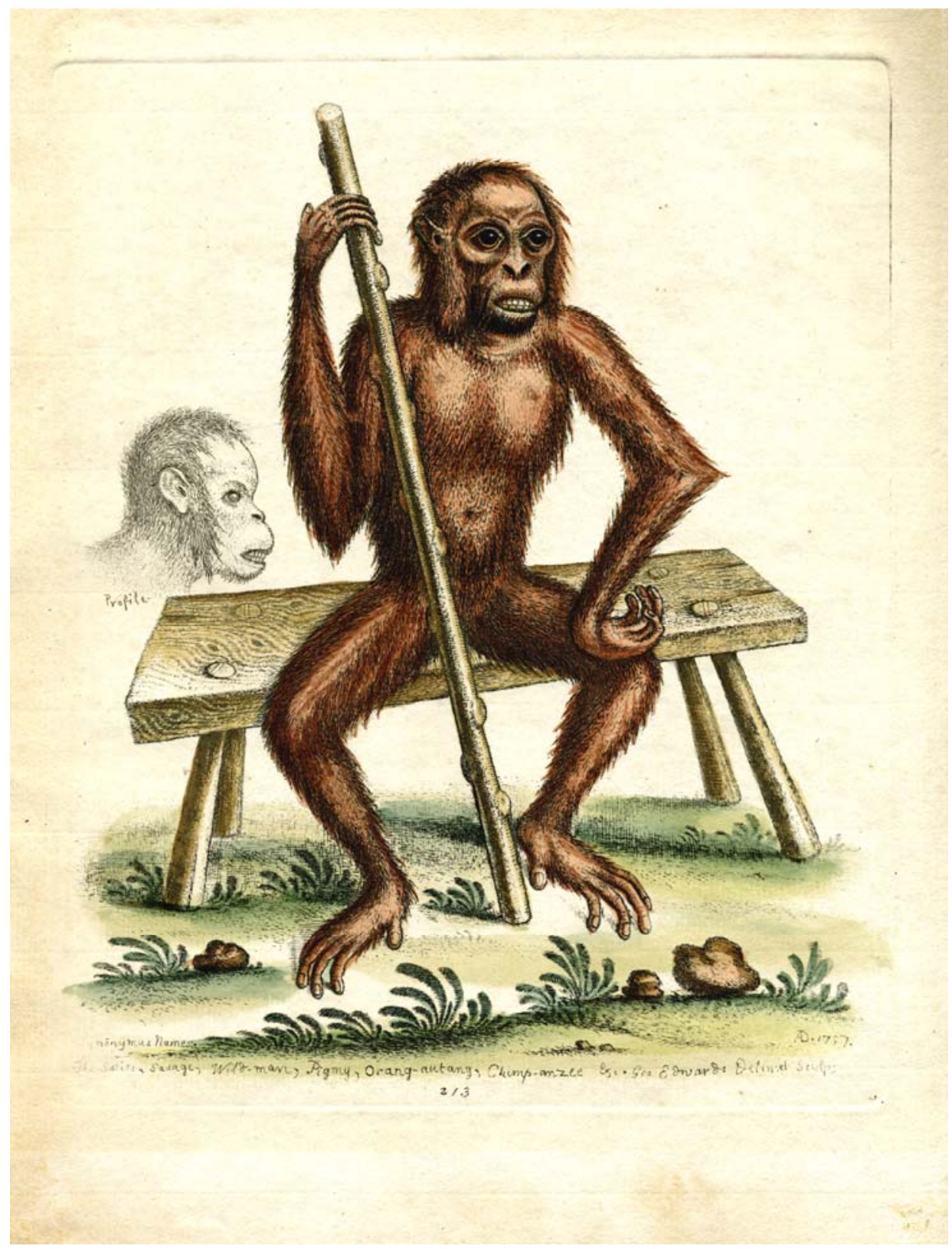

Abb.1. Barockzeitliche Abbildung eines Menschenaffen (in der Legende des Stichs wird sowohl von Schimpanse als auch Orang-Utan gesprochen), in zeittypischer Weise mit Requisiten menschlicher Kultur. Kolorierter Kupferstich nach Edward Tyson; nach 1749, Sammlung des Verf. 
Wer die Kulturgeschichte des Menschen nur als realiengeschichtliche Fortschrittsmöglichkeit der „Holz-Kultur“ entfaltet, dem wird die Geschichte gelegentlich den Knüppel zwischen die Beine stecken und ihn in Albträumen mit Holzmasken der Fassnacht heimsuchen oder ihn mit den schlesischen Webern zur Fronarbeit am Webstuhl vergattern.

Es ist merkwürdig. Wir alle schätzen ein gemütliches Kaminfeuer, dessen Wärme und Stimmung wir dem Holz verdanken, so, wie wir das Holz selbstverständlich als Energieträger, Werk- und Baustoff schätzen und aus seinen Bestandteilen chemische Verbindungen mit erstaunlichen Eigenschaften destillieren. Unser kollektives Gedächtnis ist weitgehend auf Holz gedruckt, die tägliche Zeitung sowieso. Die Liste geschätzter hölzerner Produkte bzw. holzgeschuldeter Annehmlichkeiten ist schier endlos, und enthält unter anderem so eminent wichtige Beiträge zur Menschenwürde wie Papiertaschentücher und Toilettenpapier.

Doch sonderbar quer hierzu dankt unsere Sprache dem Holz seine universelle Nützlichkeit keineswegs. Mit Bezug auf den Menschen existiert offenbar kaum ein positiv besetztes Lexem der „Holz“-Familie resp. seine Abwandlungen, fast ausschließlich findet es sich in pejorativen Zusammenhängen:

ein Mensch ist „hölzern“, er hat ein „Brett vor dem Kopf“, womöglich einen „Ast“ und den „Balken im Auge“. Suspekt erscheint uns ein „,stocksteifes, vierschrötiges“ Gegenüber, eine „lange Latte“ mit einem „Holzkopf“.

Der Spott kennt den Unterschied zwischen einem Stück Holz und einem Beamten genau, der darin bestehe, dass „Holz arbeitet“". Am Ende erweist sich überraschend selbst ein so schwachsinniger Witz als mit dem Thema eng verbunden, weil der Begriff „Kalauer“ eine mögliche Ableitung von jenen Holzpantinen zweifelhafter Qualität darstellt, die in Calau (Brandenburg) gefertigt wurden.

Aus Holz sind Altarbilder oder andere Schnitzwerke kontemplativer Zweckbestimmung, ist das Hauptsymbol der christlichen Weltreligion, sind heidnische Totempfähle gemacht. Den Vampir im Grab erledigt ein Holzpflock. Ist der Sündenfall in der Bibel noch eine Art misslungener Obstklau, verbindet ihn Rousseau thematisch richtig mit jenen Holzpflöcken, mit denen einer die erste Landparzelle als Eigentum absteckte und die anderen dumm genug waren, ihm das zu glauben. Seitdem ist das ein Thema für Menschen, die dicke Bretter bohren wollen, wie Karl Marx in den Debatten über das Holzdiebstahlsgesetz.

Aus Holz werden Musikinstrumente und auch der Abakus gefertigt. Schließlich das Zündholz, ein wichtiges Fortschrittssymbol. Auch wenn die Dampfmaschine am Ende nur mit Holz - wenn auch fossilem - in Gang kam, nicht jeder Fortschritt verdankt sich xylophilen Ideen. Aber die Eigenschaften des Werkstoffs haben die ingeniöse Phantasie des Menschen unglaublich beflügelt. 


\section{Umwelt}

Erst der irgendwo erwirtschaftete energetische Überschuss ermöglichte in grauer Vorzeit die Freistellung von Individuen von der unentwegten Beschäftigung mit der Idee der Nahrung und der Deckung der animalischen Grundbedürfnisse. Ohne die konsequente Nutzung und Lenkung der Biodiversität waren die einsetzende Spirale der Kulturentwicklung und ihre Selbstbeschleunigung nicht möglich. Hierbei spielte Holz die entscheidende Rolle, wenn darunter die Begriffsgemeinschaft aus dem Rohstoff und den bereitstellenden Bäumen und Sträuchern verstanden wird.

Wer Ackerbau betreibt, ist gut beraten, ihn dort zu betreiben, wo die ,potentielle natürliche Vegetation“ Wälder oder zumindest geschlossenere Gehölzbestände vorsieht. Das hat nicht nur bestimmte naturräumliche Vorteile, sondern auch den, dass bei der Öffnung der Landschaft zugleich das Holz anfällt, das zur kulturellen Konkretisierung erforderlich ist, es sei denn, man betreibt den kaum wachstumsproduzierenden Wanderfeldbau. Die Gestaltung der Landschaft verdankt sich also einmal der Entfernung des Holzes, dann seiner Nutzung und schließlich seinem Fehlen in der Landschaft, wenn an die Öffnung der Landschaft und die Erosion als Folge gedacht wird.

Die holzbedingte Gestaltung der Umwelt war darüber hinaus vielfältig, wirkmächtig und bedarf keiner weiteren Erläuterung. Einfluss nahmen durch Holzverbrauch, durch landschaftsformende Konsequenzen und weit verzweigte Nebenfolgen $z$. B.:

Stauwehre, Archen (Schleusen), Wasser- und Windmühlen, Bergbau (Stollen, Wasserkünste), Land- und Wasserfahrzeuge, Pflüge, Brunnenfassungen, Wasserleitungen, Latrinen, Ufer- und Küstenschutz (Buhnen, Faschinen), Brückenbau, Pumpen, Fortifikationen (Palisaden), Fässer (Wein, Salz, Hering), Städtebau, Kanalbau für Brennholz, Holzschwellen für den Eisenbahnbau, Hang- und Uferzerstörungen durch Flößerei, Holzmärkte überregionaler Bedeutung.

So, wie die ackerbauenden Holzkulturen einfacher Art bis hin zu denen des ancien régime das Holz suchen, müssen sie es paradoxerweise gleichzeitig bekämpfen. Man braucht das Holz, kann aber den Wald nicht überall gebrauchen, weil er oft jenem ökonomisch erforderlichen Wachstum im Wege ist, das sich nur durch Ausdehnung der bewirtschafteten Fläche einstellte. Prekär wird die Situation, wenn die instabile Balance zwischen nachhaltiger Holzwirtschaft und kulturellem Bedarf gestört wird. Am mangelnden Holz-Nachschub sind nachweislich etliche Kulturen gescheitert.

Der Holzhunger der Städte war sprichwörtlich. Bevor die Stadt jene „Oase aus Stein" (Mumford) wurde, war sie eine aus Holz. Neben dem Bauholz steht ein kontinuierlicher Bedarf für den Hausbrand und das Werkholz. Als die Häuser dann aus Backstein errichtet und mit gebrannten Ziegeln gedeckt wurden, entstand ein ungeheurer Brennstoffbedarf, der erst im 19. Jahrhundert durch Kohle gedeckt wurde. 
Die technischen Errungenschaften in der oben aufgeführten Liste wirken gleichzeitig auf verschiedenen Ebenen landschaftsbildend. Einmal stellen sie selbst Elemente einer Landschaft dar bzw. verändern durch ihre Existenz bzw. ihre Folgen und Nebenfolgen die Landschaft. Allen voran vielleicht die bis auf den heutigen Tag auf hölzernen Schwellen fahrende Eisenbahn.

Aber beispielsweise eine Sägemühle sägte auch nicht nur Holz, sie „produzierte" vielmehr einen Holžbedarf. Ihrem Mühlenstau verdankte sich oft eine schleichende Veränderung des Landschaftsbildes. Als klassische Folge eines ungeregelten Holzverbrauchs wird immer auf die Verkarstung von Teilen der Mittelmeerregion hingewiesen.

Die Vermarktung des Holzes durch Flößerei ist bis ins 20. Jahrhundert auf den großen deutschen Strömen betrieben worden. Sie verband Produktionsstandorte mit entlegenen Märkten, eine Entwicklung, die seinerzeit schon Gilgamesch in den Libanon führte, im 12. Jahrhundert die Erbauer der Kathedrale von Norwich nach Hamburg (wo sie womöglich schon baltisches Holz kauften) und später die Niederländer in den Schwarzwald. Englische Möbel und Schiffe sind Särge kolonialer Wälder.

Schließlich hat selbst die Produktion des Rohstoffs landschaftsprägende und ökologische Konsequenzen ${ }^{183}$. Das beginnt mit den Wäldern, die von den Städten vorgehalten werden, und als Rückhaltesysteme bedeutsam sind. Ihre Verteilung im Raum ist das wichtigste wahrnehmbare Strukturelement der damaligen Landschaft. Köhlerei und Glashütten bilden Gliederungselemente im Wald. Die Waldareale sind der Schlüssel zum Verständnis der früheren landschaftlichen Infrastruktur und prägten wirkmächtig das Lebensgefühl. Die Rohstoffproduktion mündet in der Förderung bestimmter Holzarten für den Bedarf, was in Deutschland zum Siegeszug der Fichte führt. Vergleichbare Monokulturen bilden die Haine der salztoleranten Dattelpalmen.

Ein großer Vorteil bei der Nutzung von Holz als Energieträger ist die günstige $\mathrm{CO}_{2}-$ Bilanz. Das heißt nicht, dass Holzrauch nicht auch eine ziemliche Immisssionsbelastung bilden konnte. Ein Beispiel liefert die Dresdner Kreuzkirche. Canaletto hatte sie gemalt, bevor sie 1760 von den Preußen zusammengeschossen wurde, so dass eine Vorstellung über die zeitgenössische Fassadenfarbe existiert. Sie zeigte nicht mehr das sanften Gelb des Elbsandsteins, sondern die grau-schwarze Patina durch den steten Holzascheregen.

Dass Holzasche zum Waschen wie zur Glasherstellung benötigt wird, führt in das weite Feld der Veredlungsprodukte. Zu denken ist an Baumharze (Weihrauch, Myrrhe, Terpentin), Schwelprodukte (Holzteere) und Wirkstoffe (Aspirin, Chinin, Zimt, Gerbstoffe aus Baumrinden, Baumsäfte wie Ahornsirup). Spätestens bei den Veredlungsprodukten wird das umweltfreundliche Holz zum Problem, weil Zellulose- und Papierfabriken zu den immissionsstärksten Betrieben zählen.

${ }^{183}$ Hier nicht erwähnt werden die vielfältigen Nutzungen des Waldes jenseits der bloßen Holzproduktion. Dass diese Nutzungen ebenfalls eine außerordentliche wirtschaftliche und ökologische und emotionale Bedeutung haben, ist offenkundig. 
Glaubt man den Forstmeistern, verdankt die heutige politische Umweltsensibilität den Bemühungen um die Verstetigung der Holzproduktion zu Beginn des 18. Jahrhunderts einen ihrer Zentralbegriffe, dessen Grundidee sowohl der ökologische Imperativ (Jonas) als auch die Konferenz von Rio übernommen haben: Nachbaltigkeit.

Man wird also nicht nur Realien- und Landschaftsgeschichte, sondern auch die Geschichte der Innovationen bis hin zu mentalitätsgeschichtlichen Grundfragen mit dem Thema „Holz“ verbinden müssen. Damit ist auf den Dritten Teil dieser Überlegungen verwiesen:

\section{Mensch}

Dass der Produktionsort des Holzes, der Wald, seinerseits selbstverständlich ein Thema der besonderen Art ist, sei hier nur erwähnt: Der Wald als Wildnis, als Gegenentwurf der Zivilisation ebenso wie als Wirtschaftsraum bis hin zum Sinnbild der Betrachtung des Naturschönen, aber auch als Grenzregion usw. Das Thema „Holz“ reduziert die Mensch-Wald-Beziehungen kulturgeschichtlich einseitig, in dem es nur noch um eine Fläche bestimmter Biomasseproduktion geht. Tatsächlich kann eine solche monofaktorielle Betrachtung den zahlreichen und unterschiedlichsten politischen, sozial- und mentalitätsgeschichtlichen Verflechtungen, welche die Trias „Wald-Holz-Mensch“ miteinander verbinden, nicht gerecht werden.

Die technischen Errungenschaften des Werkstoffs aber wirken auch vielfältig auf die Menschen zurück. Am 26. August 1346 haben die englischen „long-bow“Schützen mit ihren Eibenholzbögen im Krieg gegen die Franzosen europäische Geschichte geschrieben. Die Möglichkeit des Holzes führt zu einer neuen Kriegstaktik, die ein neues Denken darstellt. So gesehen, stehen die folgenden Beispiele auch und vor allem für jeweils neues Denken durch die Möglichkeiten, die sie in der Menschheitsgeschichte und für sie eröffnet haben:

Für die Nahrungssicherung eigenen sich Holzgefäße und Verschwelungsdestillate des Holzes, die bei der Räucherung und als erste Kleb- und Dichtmittel genutzt werden.

Holzreusen fangen Fische, wenn man sie nicht mit dem Stock angeln will.

Holz liefert Energie und damit Keramik.

Holz führt zu Metall.

Holz führt zu weiterer Energie (Wasserkraft, Windkraft, Kohle) und damit zu energieabhängigem ökonomischen Wachstum.

Holz ermöglicht durch Fahrzeuge überregionale Bezüge.

Auch die wichtigste Beschleunigung der Menschheit, die Eisenbahn, war ohne Holz nicht denkbar. 
Gibt es Beispiele dafür, dass Kriegführung zur Sicherung der Ressource Holz geführt wurde? Dass hölzerne Kriegsmaschinen geschichtsbestimmend waren, weiß man nicht erst seit Troja, seit den römischen Schleudern oder den mittelalterlichen Bliden, mit denen Pesttote ins belagerte Kaffa geschleudert wurden. Leonardo da Vinci hat eine phantastische Kollektion skizziert, darunter den ersten Panzer - aus Holz.

Die vielseitigen physikalischen Eigenschaften des Holzes begründen seine Nutzung durch den Menschen. Der Bedarf an diesem Rohstoff hat nicht nur bei uns zu einer alle Bereiche der Lebenswelt beherrschenden Biodiversitäts- und Landschaftsbeeinflussung geführt. Der Holzhunger der Menschheit verschlingt weltweit jährlich rund $125.000 \mathrm{~km}^{2}$ Regenwald.

Aus der Perspektive des Holzes wie aus der menschlichen Perspektive kann getrost von einer Ko-Evolution der kulturellen Systeme und der Ressource Holz gesprochen werden. Die globale Holz-Biomasse ist seit der Zeit menschlicher Aktivitäten sicher absolut verringert worden; dafür versucht der Mensch zunehmend, den Holzbedarf durch gezielte Biomasseproduktion zu decken. Er muss aufpassen, dass er dabei nicht den Ast absägt, auf dem er sitzt. 


\title{
Natur und Mensch in Mitteleuropa im letzten Jahrtausend: Eine Interdisziplinäre Umweltgeschichte
}

\author{
Bernd Herrmann ${ }^{184}$
}

\section{Zusammenfassung}

Der Aufsatz skizziert einige Entwicklungen und Auswirkungen des naturalen Einflusses auf die Menschen in Mitteleuropa während der letzten eintausend Jahre, wie auch den Einfluß der Menschen auf Natur und Umwelt. „Mensch und Natur“ werden in dieser Zeit zu einem engen Bedingungsgefüge, in dem die „Naturmacht" Mensch alle Bereiche der Umwelt beeinflusst bzw. dominiert. Angesprochen werden u.a. Bevölkerungsgeschichte, Urbanisierung. Aufklärung und Umwelt, Schädlingsdiskurs und Hygienemaßnahmen, Hunger und Krankheiten und Der Europäische Sonderweg.

\section{Einleitung}

Der Titel des Beitrags greift den Titel unseres Göttinger Graduiertenkollegs auf (DFG GK 1024; http://www.anthro.uni-goettingen.de/gk/). Er ist eigentlich eine Tautologie, denn „Umweltgeschichte“ ist monodisziplinär nicht denkbar. Sie be-

\footnotetext{
184 Zuerst erschienen in: Natur und Mensch in Mitteleuropa im letzten Jahrtausend: Eine interdisziplinäre Umweltgeschichte. In Bayerische Akademie der Wissenschaften (Hrsg.) Rundgespräche der Kommission für Ökologie, Bd. 32 „Natur und Mensch in Mitteleuropa im letzten Jahrtausend“, S. 125 $-136$
} 
fasst sich „,mit der Mensch-Natur-Beziehung im historischen Wandel“ und geht von der Selbstverständlichkeit aus, dass menschliches Handeln einerseits auf die Elemente der Natur wirkt, und dass andererseits die Elemente der Natur auf das menschliche Handeln zurückwirken. In dieser Betrachtung erlangt auch bereits die bloße Wahrnehmung von Natur durch Bedeutungszuschreibung Einfluss auf menschliche Handlungsweise. Aus umwelthistorischer Perspektive wird „Natur“ durch menschliche Rezeption und Handlung zu „Umwelt“ transformiert. Umwelt wird damit zum geschichtsbildenden Faktor. Dass diese Beziehung vielschichtig ist, ist eine ebenso triviale wie richtige Aussage. Sie führt indes in eine geschichtstheoretische Grundsatzdebatte, ob denn Geschichte am Ende überhaupt anders als Umweltgeschichte gedacht werden könne. Natürlich ist das möglich, aber ich werde dieser Frage hier nicht weiter nachgehen, sondern durch ein pointierendes Zitat auf eine m.E. für das Rundgesprächsthema zentrale Frage aufmerksam machen: „Die Arbeit ist zunächst ein Prozess zwischen Mensch und Natur, ein Prozess, worin der Mensch seinen Stoffwechsel mit der Natur durch seine eigne Tat vermittelt, regelt und kontrolliert. Er tritt dem Naturstoff selbst als eine Naturmacht gegenüber." (Marx, S. 192)

Unter diesem Blickwinkel geht es also um unbeabsichtigte und absichtsvolle Beeinflussung von Umwelt, vermittelt durch Arbeit. ${ }^{185}$ Genauer: es geht um die jeweilige Voraussetzung wie Folge der Organisation von Arbeitsprozessen, die die Umwelt beeinflussen und zur Ablösung der Subsistenzwirtschaft durch Marktbezug, zum Ausbau der Kulturlandschaft, zum Manufakturwesen und zur Industrialisierung führen. Gleichzeitig wird diese Umwelt aus einer nach autonomen Gesetzen ablaufenden Natur mitbestimmt. Eine solche Betrachtung konzentriert sich offenkundig auf den homo faber. Sie übersieht dabei aber keineswegs, dass emotionengeschichtliche und mentalitätengeschichtliche Qualitäten für die Rezeption von Natur und damit Umwelt besonders wichtig sind. Nachweislich haben kollektive emotionale Erschütterungen die europäische Sicht auf die Umwelt beeinflusst und dadurch handlungsleitende Qualität erreicht. ${ }^{186}$ In andren Beiträgen des Rundgesprächs erörterte Einflussfaktoren, z.B. klimatischer Art, werden in diesem Beitrag nicht behandelt.

\footnotetext{
185 Schließlich liegt der Focus des Rundgespräches der Kommission für Ökologie auf dem „letzten Jahrtausend“, dem mit Martin Luther, Karl Marx und Werner Sombart drei Denker angehörten, die sich mit „Arbeit“ befassten. Wie kaum ein zweiter Begriff steht das soziale und produktive Phänomen „Arbeit“ als besonders prägend für die Zeitläufte dieses Jahrtausends.

186 Man könnte den Beginn einer Umweltgeschichte geradezu an bestimmte emotionale Erschütterungen knüpfen, etwa diejenige Petrarcas nach dem Aufstieg auf den Mont Ventoux (1336; siehe Groh \& Groh 1996) oder diejenige der Europäer nach dem Erdbeben von Villach (1348; siehe Borst) knüpfen.
} 


\section{Bevölkerungsgeschichte bis 1500, „Natur66 als Akteur}

Zweckmäßig sollte der Betrachtungszeitraum zwischen 1000 - 2000 AD geteilt werden. Der Abschnitt bis 1500 ließe sich unter der hier verfolgten Thematik hinsichtlich lange nachwirkender Ereignisse oder struktureller Faktoren auf nur wenige herausgehobene Daten bzw. Ereignisse begrenzen, zum Beispiel auf:

- Ostkolonisation und Landnahme im Hohen Mittelalter (1)

- Das Erdbeben von Villach 1348 (2)

- Zweite Marcellusflut [,Grote Manndränke“] 1362 (3)

- Der schwarze Tod ab 1347 (4)

- Die Urbanisierung ab 13.Jh. (5)

Drei der genannten Ereignisse $(1,3,5)$ betreffen direkt Veränderungen der Umwelt, indem sie die Kulturlandschaft in die Fläche bringen bzw. das Landschaftsbild nachhaltig verändern. Die beiden anderen $(2,4)$ wirken, wie auch die katastrophale Sturmflut (3), auch oder mehr indirekt, über die Erschütterung der Menschen und deren nachfolgende Einstellungen.

Mit der Ostkolonisation war endgültig die großflächige Öffnung der Landschaft für Siedlung und Landwirtschaft verbunden und damit eine nachhaltige Biodiversitätsverschiebung eingeleitet.

Das Erdbeben von Villach war zwar in erster Linie eine Naturkatastrophe, brachte in seiner Konsequenz aber einen Modernisierungsschub für die Gesellschaft (Borst 1981/1990), dem auch eine verstärkte Naturbeobachtung zum Zwecke ihrer Beherrschbarkeit zugerechnet wird.

Die schwere Sturmflut von 1362 verändert die deutsche Nordseeküste erheblich. Sie gilt, wie der Schwarze Tod, als Prüfung oder Strafe Gottes, vielleicht als Hinweis auf das bevorstehende Ende der Welt.

Die Langzeitwirkung des Schwarzen Todes ist tiefergreifend. Nicht nur muss sich Gesamteuropa von einem bedeutenden Bevölkerungsverlust erholen. Das Ereignis hatte möglicherweise auch Konsequenzen für die Einstellung im Umgang mit der Umwelt. Betrachtet man die Charakteristik der rekonstruierbaren Bevölkerungskurve bis zum Ende des 14.Jh. (Abb.1), ist das Sättigungsplateau in der ersten Jahrhunderthälfte offenkundig. Nimmt man mit einigen Mittelalterhistorikern an, dass sich in dieser Zeit, die überlagert war von klimatischer Verschlechterung, die europäische Bevölkerung an ihrer Kapazitätsgrenze befunden habe, dann wären Erwartungen kontinentweiter Hungersituationen mit Bevölkerungszusammenbruch die logische Folge. Das Agrarsystem wäre zu diesem Zeitpunkt über seine Leistungskapazität hinaus gefordert gewesen und hätte vor einem klimatisch bedingten Kollaps gestanden. Aus dieser Vorstellung hat Bowlus (1980) die reizvolle Überlegung abgeleitet, dass der schwarze Tod aus „,volkserzieherischer“ Sicht zum falschen Zeitpunkt kam. So blieb Gott der Urheber des pestbedingten Bevölkerungsrückganges und es entfiel die Chance, mit dem nicht eingetretenen alternati- 


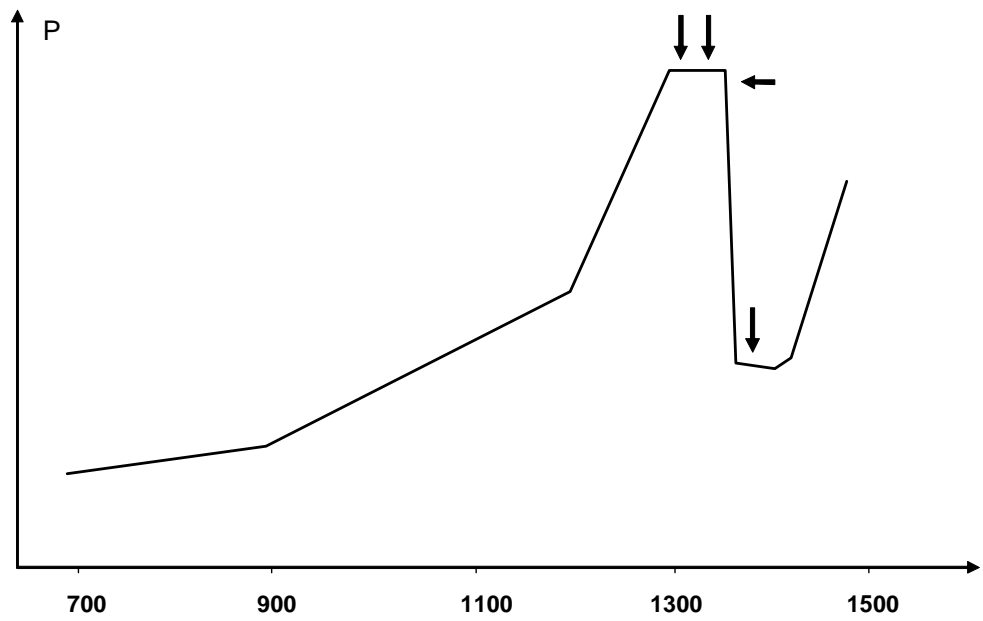

Abb. 1 Modellkurve der Bevölkerungsentwicklung (P) in Europa vom frühen zum späten Mittelalter (nach Grupe 1986, S.27). Während die absolute Einwohnerzahl nach wie vor unsicher ist, gilt die Kurvencharakteristik weiterhin als zutreffend.

Deutlich ist das „Sättigungsplateau“ der Kurve in der ersten Hälfte des 14. Jh.s (Weiteres im Text). Die hier eingefügten Pfeile repräsentieren Elementarereignisse in Mitteleuropa von hoher überregionaler Bedeutung und emotionengeschichtlicher Konsequenz, offenbar auch für das generative Verhalten: 1315 - 1317: Hungersnöte; 1342 Jahrtausendhochwasser; 1347: Beginn der Pestwelle; 1348: Erdbeben von Villach; 1362: Marcellusflut.

ven Szenarium das ausbeuterische menschliche Wirtschaften im energetisch begrenzten, solarbasierten Agrarsystem als Grund des Bevölkerungsrückgangs zu begreifen. Europa hätte so seine Lektion nicht lernen können, die ihm und seinen späteren Filiationsbetrieben in der Dritten Welt möglicherweise eine Hilfe und die Grundlage für eine ökosensible Gesellschaft hätte sein können. So verlockend diese These sein mag, es gibt Anzeichen, dass diese Lektion auch unter anderen Vorzeichen zu keiner historischen ökologischen Wende geführt hätte.

\section{Urbanisierung}

Der Prozess der Urbanisierung beginnt im 13. Jh. und wird mit dem Wüstfallen vieler Siedlungen durch die Bevölkerungsverluste des 14. Jhs. beschleunigt. Er ist in seinen wesentlichen Zügen um 1500 abgeschlossen (Abb 2). Der Wüstungsprozess hat vermutlich Auswirkungen im Floren- und Faunenbestand auf opportunistische Nutzer dieser Brachflächen, die kurz- und mittelfristig stark veränderte Indi- 


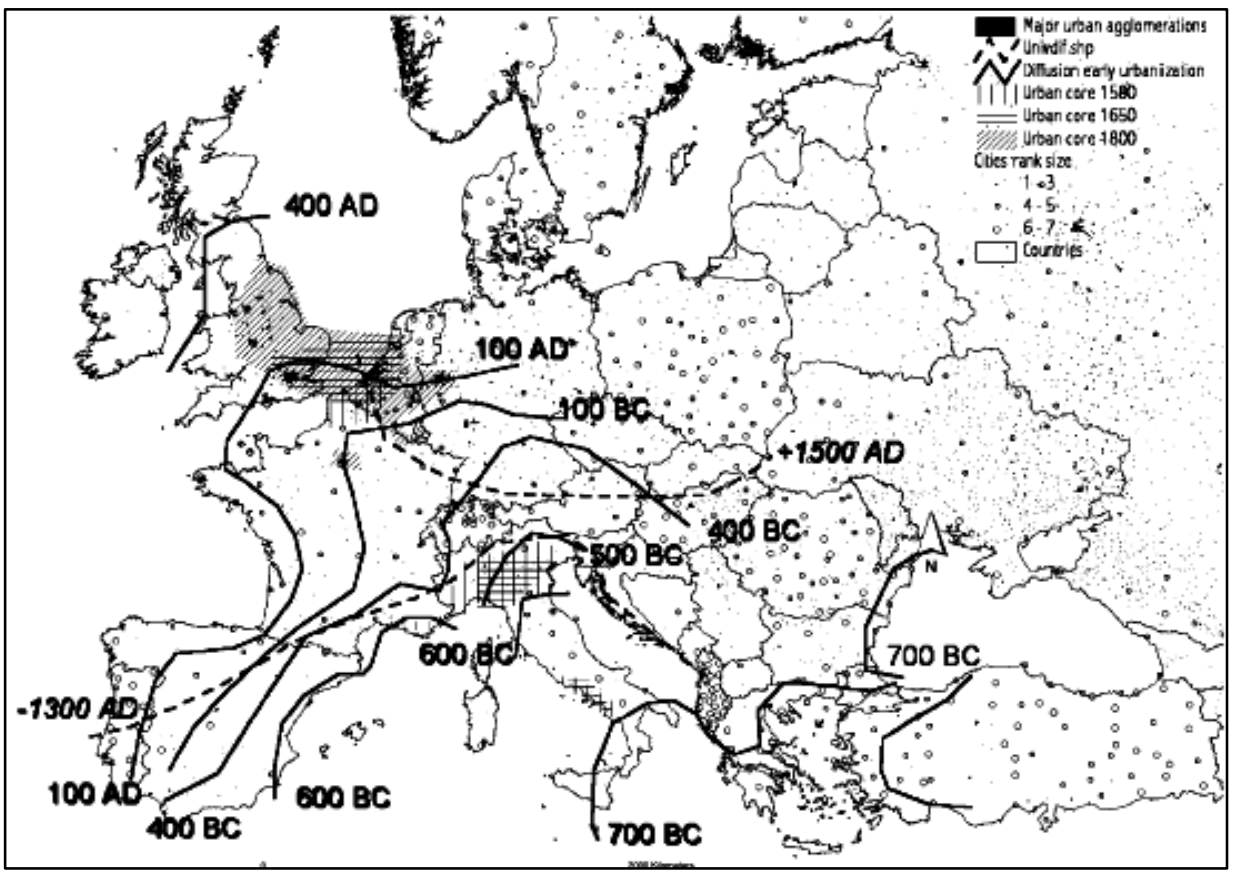

Abb. 2. "Diffusion of urbanization through Europe. The early urbanization in Greek and Roman times expands from the Southeast from 700 B.C. to the border of Scotland in 400 A.D. Universities are created in the cities and indicate an expanding urbanization from the south before 1300 A.D. to the Northeast after 1500 A.D. The urban clusters from Northern Italy and Flanders in the 16th century shifts and expands around the North Sea in the 19th century." [Fig.1 und dazugehörige Legende; aus Antrop 2004, S. 11]

viduen-Abundanzen zeigen. ${ }^{187}$ Diese Abundanz-Änderungen beeinflussen langfristig die kollektiven Gedächtnisse der Menschen und ihre Meinungen von einer angeblichen früheren Häufigkeit vor allem bestimmter Tierarten und deren Individuenzahlen. Anders als in den früheren Lokalwirtschaften kommt es nun auch zum ersten spürbaren Stofftransport und zur Ausrichtung von Energieflüssen auf die Stadt hin, in der sich auch allmählich die Bevölkerung konzentriert. Nach der Eigengesetzlichkeit der Transportgeschichte können sich größere Städte nur an den transporttechnisch günstig gelegenen Orten in der mitteleuropäischen Fläche an schiffbaren Flussläufen herausbilden. Der Bedarf der Bewohner schafft Kulturlandschaften um die Städte, schafft einen bewirtschafteten Wald, verändert die Determinanten der Biodiversität (Lebensraum für domestizierte und nicht-

187 Als beliebiges Beispiel könnte auf den Waldrapp verwiesen werden, dessen größere Individuenund Verbreitungsdichte im Spätmittelalter sich sehr wahrscheinlich auch dem hohen Angebot an Nistplätzen in den Siedlungsruinen verdankte. 
domestizierte Tiere und Pflanzen), verstärkt durch innerstädtische Hygieneverhältnisse die bevölkerungsbiologische Binnenkonkurrenz, beschleunigt die menschliche Gesellschaft durch Transport- und Informationswege. Es ist letztlich auch innerstädtischen Prozessen zu verdanken, dass es nach $1500 \mathrm{zu}$ dem historisch größten Freisetzungsexperiment kommt, indem Europa nun, nach dem Kontakt mit den neu entdeckten überseeischen Gebieten, überschwemmt wird von Neophyten (Abb. 3) und - mit einiger zeitlicher Verzögerung - z.T. auch mit Neozoen. Über neue Mikroorganismen ist, mit Ausnahme einiger von ihnen verursachter neuen Krankheiten, nichts bekannt.

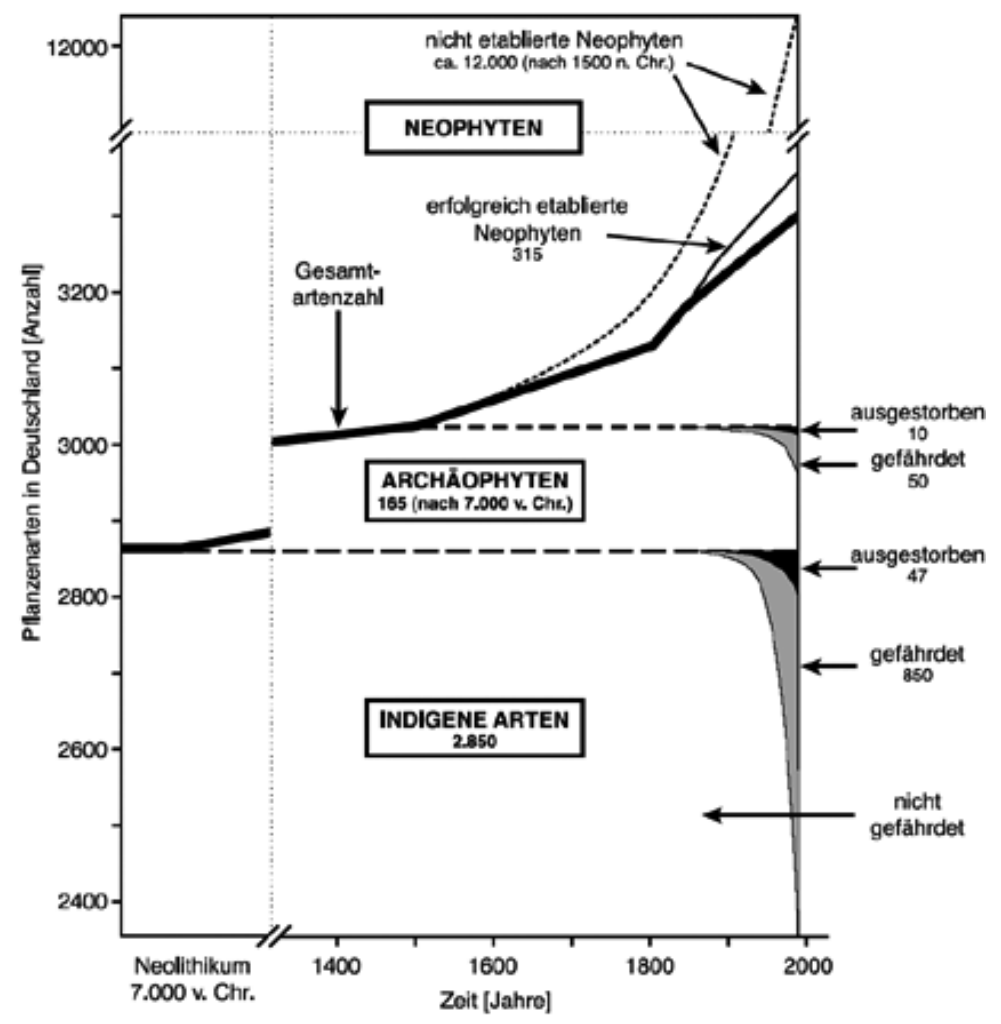

Abb. 3. Änderung der Pflanzenvielfalt in Deutschland. Der Zuwachs etablierter Neophyten nach 1500 beträgt rund 10\% der ursprünglichen, indigenen Artenzahl. Nicht diese Zahl ist jedoch bemerkenswert, sondern die bis auf 9.000 geschätzte Artenzahl von Neophyten, die sich heute in Europa in menschlicher Obhut befinden. [aus: WBGU (2000), Jahresgutachten 1999, Abb. E 2.1-3, S. 108] 


\section{Entwicklung seit 1500}

Umweltwirksame Ereignisse und handlungsleitende Konzepte, welche die letzten eintausend Jahre nachhaltig prägten, sind sonst erst im Zeitraum nach $1500 \mathrm{zu}$ verorten, weil die Intensität von „,longue-durée-Effekten“ erst nach 1500 jenes Ausmaß erreicht, dem Gegenwartswirksamkeit zugesprochen werden kann. ${ }^{188}$ Und auch in diesem Zeitraum der zweiten Jahrtausendhälfte bestehen Asymmetrien, da die meisten anhaltend wirksamen Umwelteingriffe und umweltwirksamen Konzepte vor allem dem 18. und 19. Jh. und dann der zweiten Hälfte des 20. Jh. zu verdanken sind. ${ }^{189}$ Dieser letzte Abschnitt wird hier nicht behandelt. Er hat durch den Umfang des Einsatzes technischer Hilfsmittel und fossiler Energieträger zur beispiellosen Verstärkung und Beschleunigung von Entwicklungen geführt, die uns Zeitgenossen sehr bewusst sind. Ebenfalls nicht weiter erörtert werden die Aspekte des klimatischen Wandels während des Betrachtungszeitraumes, weil sie in mehreren Beiträgen thematisiert werden. Selbstverständlich sind in dem Klimaoptimum des Hochmittelalters, der daran anschließenden „Kleinen Eiszeit“ und der nachfolgenden allmählichen Erwärmung bis hinein in den jetzt erkennbar werdenden Klimawandel die zentralen geschichtswirksamen Charakteristika des Klimagraphen zu sehen.

Ich wurde gebeten, auch „Lebensbedingungen der Bevölkerung“, u.a. Nahrungsversorgung, Hunger, Kriege und Auswanderung in den Blick nehmen. Aus der Sicht der Umweltgeschichte sind dies relevante Probleme, aus einzelfachlicher Perspektive muss jedoch eingeräumt werden, daß sich die Datenlage für belastbare Übersichten nur bedingt hergibt. Zunächst ist festzuhalten, dass in einem erweiterten Verständnis von „Lebensbedingungen“ den umweltwirksamen Faktoren ein allgemein erheblicher Einfluss auf eine Bevölkerung und ihre Individuen eingeräumt werden muss.

Das 18. und 19. Jh. markieren in bestimmten umweltrelevanten Bereichen einen Epochenwechsel.

\section{Aufklärung und „Umwelt"6}

Die Geistesströmung der Aufklärung ersetzt den Blick auf die Natur als ein zweites Buch der Offenbarung, ersetzt den Blick auf eine fürsorglich für die menschlichen Bedürfnisse eingerichtete Welt, aus der die Menschen entnehmen, was Gott zu gewähren bereit ist, durch den Blick auf eine Umwelt, die der Mensch durch

\footnotetext{
188 Das ist erkennbar ein Argument, dessen Richtigkeit sich nicht prüfen, sondern nur plausibel annehmen lässt.

189 Gewichtige Vorläufererscheinungen des 17. Jh.s sind einzuräumen, werden aber wegen der hier verwendeten groben Betrachtungsskala nicht weiter erörtert.
} 
„Kunst und Arbeit“190 gestaltet, zu höherer Produktivität verändert und bis an die Grenzen seiner eigenen Fähigkeiten abschöpft und ausbeutet. Die Naturwissenschaften sollen nach dem Willen der deutschen Staatstheoretiker des 18. Jh. explizit zum Glückseligkeitsversprechen beitragen bzw. es durch Nutzungskonzepte von Natur sichern helfen (Meier 1999). Zwar wird Europa philosophisch durch das Erdbeben von Lissabon (1755) erschüttert, die optimistische Haltung der Naturwissenschaften wird davon aber kaum berührt. Sie machen sich seit der Mitte des 18. Jh.s mit ungeheurem Elan daran, das „Warenhaus Natur“ (Bayerl 2001) nutzbar zu machen.

Empirisch war einschlägiges Vorwissen für intensive bzw. ausbeuterische Naturnutzung bereits verfügbar, z.B. durch das Montanwesen, dessen negative Seiten in Form des Landschaftsverbrauchs aber offenbar trotz mahnender Stimmen (von Agricola selbst wie auch anderen, z.B. Paul Schneevogel. Hierzu Böhme 1988) nicht weiter beachtet worden sind.

Die Gliederung der Umwelt, die als kleinräumige Kulturlandschaft immer ein selbstverständliches Nebenprodukt der ackerbauenden Subsistenzwirtschaft der Menschen war, ergibt sich nun auch nicht mehr ohne weiteres beiläufig. Sie ergibt sich jetzt vielmehr zwangsläufig und systematisch in bestimmter Weise zur Ressourcensicherung als Folge der Urbanisierung und des Landesausbaus, u.a. mit der Gliederung nach dem von-Thünenschen-Prinzip und mit der damit verbundenen Einführung von Strukturelementen (Straßen, Deiche, Erdwerke). Allein die Einführung von Straßenbäumen, die seit dem 16./17.Jh. die Fernstraßen säumen, verändert die Landschaft.

Landschaftsveränderung wird auch in großen Meliorationsprojekten des 18. Jh. s und 19. Jh. s nach staatspolitischen Vorgaben durchgeführt (Preußen, ÖsterreichUngarn, Württemberg, Frankreich, Schweiz, England, Bayern: z.B. durch von Hazzi, siehe Beck 2003). Modell hierfür stehen zunächst die europaweiten Aktivitäten der Niederländer zur Trockenlegung von Feuchtgebieten, ${ }^{191}$ für die Flussbegradigungen später vor allem Preußen und Österreich. Diese Meliorationen richten sich auf

1) die Gewinnung von Ackerland

2) den Hochwasserschutz

${ }^{190}$ Francis Bacon (zit. nach Dipper 1991, S. 1) Unter „Kunst“ ist hier das ingenieurtechnische Vorgehen zu verstehen.

191 Mit der Drainage der Flußauen entsteht eine spezifische Kulturlandschaft, zumeist Polderwirtschaften. Es darf nicht übersehen werden, dass mit dieser Kulturlandschaft ein bestimmtes Arbeitsethos vermittelt wird, ohne das diese Kulturlandschaft nicht aufrechterhalten werden kann. Die Niederländer „exportieren“ damit eine dritte Disziplinierungsmaßnahme mit Bedeutung für den menschlichen Körper, die europaweite Auswirkungen hatte. Die beiden anderen waren die Einführung des Kirchengestühls (Sitzen in Reihe und Glied) und die koordinierte Fortbewegung der Heerestruppen (Marschieren in Reihe und Glied). 
3) die Steigerung des Commerzes (auf dem Fluss)

4) die Peuplierung (Volksvermehrung)

5) und im 19. Jh. zusätzlich, teilweise ausschließlich, die Malariabekämpfung.

Diese Ziele stehen in Zusammenhang mit der Bestrebung nach Verstetigung der Agrarproduktion, der Produktionssteigerung, letztlich auch der Produktivitätssteigerung, aber auch einer produktionsorientierten Ästhetisierung der Landschaft.

\section{Schädlingsdiskurs, Malaria und Hygienemaßnahmen}

Meliorationen beruhen auf Landschaftsleitbildern und Wertvorstellungen. Es ist kein Zufall, dass zeitgleich mit ihnen die Differenzierung des Schädlingsdiskurses einsetzt, also die Diskussion der Frage, welche Pflanzen und Tiere situativ oder um ihrer Selbst willen ,ausgerottet“ werden können, durchaus bis an die Frage heran, ob ein Tier aus der Evolution entfernt werden dürfe (Herrmann 2007a). Die Wirkung des Schädlingsdiskurses auf die allmähliche Herausbildung von „Naturbildern“, allgemeiner: auf die „Wertung“" von Natur, ist bis heute wenig beachtet, obwohl er von erheblicher, wenn auch mehr indirekter, Wirkung war. Sehr früh sind die großen Gipfelräuber dem Menschen ausgewichen bzw. von ihm systematisch bejagt worden, d.h., sie fehlen jetzt einfach in der Landschaft. Spätestens um 1800 hat daher die „gefühlte Gefährdung“ beim Aufenthalt in der Natur kaum noch eine praktische Bedeutung. Hier liegt eine Wurzel des heutigen „Bruno Syndroms“, 192 nachdem von „Natur" keinerlei Bedrohungspotential ausgehen dürfe.

Die Verfolgung der Forst-, Ernte- und Nahrungsschädlinge auf rationaler Grundlage setzt im 18.Jh. ein, wird aber erst mit der vollständigen Aufklärung der Generationswege und Metamorphosen der Insektenschädlinge und den Errungenschaften der organischen Chemie am Ende des 19. Jh.s zu breiter Wirksamkeit gelangen. Dabei ist die Quellenlage über die objektiven Schäden nicht gerade übersichtlich aufgearbeitet (z.B. Beck 1909). Ebenfalls erst in der zweiten Hälfte des 19. Jh. s gewinnen Hygienevorstellungen hinreichenden Einfluss, so dass auch eine systematische Bekämpfung der Hygiene-Schädlinge einsetzt. Dies setzte kausale ätiologische Konzepte voraus, die vor der Mikrobentheorie Pasteurs weitgehend im Unwirksamen verharren mussten. Interessanter Weise treten im 19. Jh. ätiologische Konzepte von Prävention und Therapie als Gestaltungsargumente für Malaria-Zonen in Mitteleuropa auf (in Frankreich bereits z.Zt. der Franz. Revolution), und zwar zu einem vortheoretischen Zeitpunkt, an dem bereits der empirische Zusammenhang zwischen Feucht-/Sumpfgebiet und Malaria unübersehbar wird, noch bevor der kausale Zusammenhag zwischen Anopheles-Mücken und Plasmo-

192 In Anlehnung an den Abschuss des Braunbären „Bruno“, der im Frühsommer 2006 einem vom bayerischen Umweltminister gefühlten Gefährdungsrisiko beim Aufenthalt in der Natur zum Opfer fiel. 
dien naturwissenschaftlich erkannt und gesichert ist (Mannaberg 1899). Die volkswirtschaftliche Bedeutung der erfolgreichen Malariabekämpfung durch Landschaftsgestaltung kann nicht überschätzt werden, zumal sie einhergeht mit der Einbeziehung des bisherigen Unlands in den agrarwirtschaftlichen Sektor.

Die Schädlingsproblematik führt übrigens auch direkt in die Städte (Ernte- und Lagerschädlinge; Infektionskrankheiten, zunächst noch ohne funktionale ätiologische Konzepte). Die Hygienesituation wird im 19. Jh. für die Städte endgültig prekär. Mit enormen Anstrengungen werden aber die dichteabhängigen Entsorgungsfragen einer grundsätzlichen Lösung zugeführt (Schwemmkanalisation, Wassergütekontrolle). Hygienemaßnahmen und damit verbundene zunehmende Eindämmung der Infektionskrankheiten führen zusammen mit Volksbildungsmaßnahmen dazu, daß Ende des 19. Jhs. die Lebenserwartung der Stadtbewohner erstmals über diejenige der Landbewohner steigt. Bis dahin galten Städte als „bevölkerungsverbrauchend“", das heißt, Städte konnten den Bestand ihrer Bevölkerung bis zu diesem Zeitpunkt nur durch kontinuierlichen Zuzug aus dem Hinterland, nicht aus sich selbst aufrechterhalten.

\section{Auswirkungen der Verstådterung}

Städte werden mit ihren strukturellen Folgen in der zweiten Hälfte des Jahrtausends zu den größten „Naturverbrauchern“. Sie öffnen die eigentlich geschlossenen Kreisläufe der Ökosysteme, was in den Zeiten der Lokalwirtschaften durch die absolut noch geringe Eingriffstiefe praktisch unbedeutend war, und Städte entwickeln sich zu Ökosystemen eigener Art (Herrmann 2007b). In Zusammenhang mit der Urbanisierung ist humanökologisch auf drei bedeutsame Umstände hinzuweisen:

Auf die zunehmende Entkoppelung der Stadtbewohner von naturalen Zyklen, auf die Städte als energetische Senken und die Erfindung eines stadtspezifischen Zeitregimes.

Kunsträume, Kunstlicht und verstetigte Versorgungsleistungen puffern saisonale naturale Faktoren für die Stadtbewohner zunehmend ab. Das alte Agrarregime war im Jahreszyklus von einem Zusammenhang zwischen menschlicher Reproduktion und agrartechnischer Produktion geprägt (agro-liturgischer Zyklus; Imhof 1983, S. 30ff). Eheschließungen und Geburten folgten Rhythmen, die einerseits vom Vegetationszyklus und der Tageslichtmenge vorgegeben waren, andererseits von den Fastentagen des Kirchenjahres, für die sexuelle Enthaltsamkeit galt. An die Stelle dieses agro-liturgischen Zyklus tritt, auch begünstigt durch die Reformation, eine neue Synchronisation. Die Stadtbewohner werden einem säkularisierten urban-manufaktoriellen Zeitregime unterworfen.

Das Problem der energetischen Senke, die Städte und ihnen zuzurechnende Infrastrukturen in den ökosystemaren Energieflüssen darstellen, führte immer wieder 
und vor allem in der Neuzeit zu Versorgungsengpässen. Mit dem aufkommenden Manufakturwesen, der Bevölkerungszunahme und der Industrialisierung ist das Agrarsystem absolut überfordert, weiterhin allein den energetischen Bedarf bereit zustellen. Im 18. Jh. beginnt die fossilenergetische Substitution und erreicht schnell ein solches Ausmaß, dass für seine Deckung allein durch Forstwirtschaft z.B. bereits 1850 für Großbritannien eine zusätzliche Fläche von 100\% des Vereinigten Königreichs erforderlich gewesen wäre, um 1910 wird das Dreieinhalbfache erreicht (Sieferle et al. 2006). Für andere Länder gelten ähnliche Zahlen, je nach Industrialisierungsgrad. Ohne fossilenergetische Substituierung wäre das mitteleuropäische Agrarsystem nicht zu den Anstrengungen der Modernisierung in der Lage gewesen.

Der dritte Sachverhalt betrifft ein sonderbares Dichte-Phänomen (Tabelle 1). Städte scheinen bereits früh auf humanökologische Dichte-Faktoren zu reagieren, ein etwas überraschendes Ergebnis. Lediglich ein einziges Mal (Paris 1637) wird ein im Vergleich erheblicher Quotient $\left(4,3 \mathrm{~kg} / \mathrm{m}^{2}\right)$ ) erreicht. Unmittelbar danach erweitert Paris sein Stadt-Territorium. Die übrigen Quotienten bewegen sich zumeist deutlich unter $2 \mathrm{~kg} / \mathrm{m}^{2}$. Offenbar regulieren sich die Städte hinsichtlich der humanen Biomasse-Dichte selbst (autopoetisch?). In Umkehrung wäre zu folgern, dass höhere Dichtequotienten für die in den Städten und durch sie ihre Bedürfnisse abdeckenden Stadtbewohner ökologisch als dysfunktional anzusehen sind. Dies wäre eine parsimonitäre Erklärung für den anhaltenden Flächenbedarf von Städten bei anhaltendem Zuzug von Bewohnern. Der Befund ist insofern kontraintuitiv, weil sich der Flächenbedarf nicht aus den gewerblichen, manufaktoriellen bzw. industriellen Funktionsdifferenzierungen innerhalb des Stadtgebietes ergibt, sondern allein als Funktion der menschlichen Dichte erklärbar wird.

Tab.1 (nächste Seite) Beziehungen zwischen Stadtfläche und menschlicher Biomasse. Die hier eingesetzten aktuellen demographischen Daten stammen von den Internetseiten der bezeichneten Landes- und Stadtregierungen und statistischen Handbüchern (zuletzt besucht Nov. 2006). Widersprüche wurden nach Plausibilitäten geglättet. Die Bevölkerungszahlen für Buenos Aires, Delhi, Kolkata und Mexico City scheinen zu niedrig angesetzt, obwohl sie von örtlichen Behörden stammen.

Das Gewicht heutiger Einwohner ist mit durchschnittlich $50 \mathrm{~kg}$, das Gewicht der Einwohner deutscher Städte bis 1800 mit durchschnittlich $45 \mathrm{~kg}$ angenommen. Für das heutige Kolkata, Delhi, Mexiko City und Los Angeles, für London bis 1901 und Paris bis $1856=$ $45 \mathrm{~kg}$, Florenz $1250=40 \mathrm{~kg}$. Über- oder Unterschätzungen des angenommenen Gewichtes haben für das Massen-Flächen-Verhältnis nur geringere Auswirkungen, die Verhältniswerte bleiben innerhalb der hier angegebenen Größenordnung. 


\begin{tabular}{|c|c|c|c|c|}
\hline Stadt & Jahr & $\begin{array}{c}\text { StadtgröBe } \\
\text { [ha] }\end{array}$ & Einwohnerzahl & $\begin{array}{c}\text { Human } \\
\text { Biom ass Ratio } \\
{\left[\mathrm{kg} / \mathrm{m}^{2}\right]}\end{array}$ \\
\hline Florenz & 1250 & $480^{1}$ & $100.000^{1}$ & 08 \\
\hline Bamberg & 1861 & $2.204^{2}$ & $7.000-17.000^{\circ}$ & $0.01-0.06$ \\
\hline Braunschweig & 1500 & $130-190^{2}$ & $16000-27.000^{6}$ & $0.5-0.6$ \\
\hline Köln & $1180-1870$ & $199^{2}$ & $30000-45.000^{6}$ & $0.6-1.0$ \\
\hline Leipzig & $1165-1885$ & $81^{2}$ & $10.000-35.000^{6}$ & $0.5-1.9$ \\
\hline München & 1722 & $1.593^{2}$ & $10.000-34.000^{6}$ & $0.02-0.08$ \\
\hline Nümberg & $1500-1800$ & $159^{2}$ & $25.000-40.000^{6}$ & $0.7-1.1$ \\
\hline Soest & $1500-1850$ & $102^{2}$ & $5.000-15.000^{6}$ & $0.2-0.6$ \\
\hline Würzb urg & $1500-1856$ & $131^{2}$ & $9.000-16.000^{\circ}$ & $0.3-0.5$ \\
\hline Paris ${ }^{3}$ & 1365 & 430 & 275.000 & 29 \\
\hline $\operatorname{Paris}^{3}$ & 1637 & 430 & 415000 & 43 \\
\hline Paris ${ }^{3}$ & 1700 & 1.340 & 600000 & 20 \\
\hline Par is ${ }^{3}$ & 1784 & 3.450 & 660000 & 0.8 \\
\hline Par is ${ }^{3}$ & 1796 & 3.450 & 556304 & 0.7 \\
\hline Par is ${ }^{3}$ & 1856 & 3.450 & 174.346 & 15 \\
\hline Paris ${ }^{3}$ & 1921 & 10.500 & 906.472 & 1.4 \\
\hline Par is ${ }^{3}$ & 1999 & 10.500 & 2.125 .246 & 10 \\
\hline London( $(\text { Inner })^{3}$ & 1801 & $8.137^{3^{*}}$ & & 0.14 \\
\hline $\begin{array}{l}\text { London } \\
\text { (Inner) }^{3}\end{array}$ & 1901 & $38.476^{3 *}$ & & 0.7 \\
\hline $\begin{array}{l}\text { London } \\
(\text { Inner })^{3}\end{array}$ & 2001 & $23.460^{3 *}$ & & 0.5 \\
\hline $\begin{array}{l}\text { London } \\
\text { (Tnn. and } \\
\text { Outer) }\end{array}$ & 2005 & 157.900 & 7.421 .209 & 0.2 \\
\hline Berlin ${ }^{5}$ & 2006 & 89.192 & 3.398 .205 & 0.2 \\
\hline $\begin{array}{c}\text { Buenos Aires } \\
\text { Delhis }\end{array}$ & $\begin{array}{l}1991 \\
2006\end{array}$ & $\begin{array}{r}20.000 \\
4.270\end{array}$ & $\begin{array}{r}2.965 .403 \\
321883\end{array}$ & $\begin{array}{l}0.7 \\
03\end{array}$ \\
\hline Kolkata & 2006 & 18.733 & 4.638 .350 & 10 \\
\hline Los Angeles" & 2005 & 129.000 & 3.877 .129 & 015 \\
\hline Mexico City' & 2006 & 312.900 & 16.000 .000 & 0.2 \\
\hline New York ${ }^{4}$ & 2005 & 121.400 & 18.700 .000 & 0.8 \\
\hline Tokyo & 2003 & 218.700 & 12.360 .000 & 0.3 \\
\hline
\end{tabular}

${ }^{1}$ Daten von Benevolo 1999 (S. 67 ff);

${ }^{2}$ Stadtfläche nach Auskunft des Stadtarchivs, eigene Erhebung

${ }^{3}$ Basierend auf Daten von www.demographia.com und eigenen Berechungen

$3^{3 *}$ Einwohner je Quadratmeile

${ }^{4}$ Basierend auf Daten vom US Government Census (www.census.gov) und eigenen Berechnungen

${ }^{5}$ Basierend auf statistischen Angaben der kommunalen Behörden und eigenen Berechnungen

${ }^{6}$ nach deVries 1984 (S. 272 ff) 


\section{Hunger und Krankheiten}

$\mathrm{Zu}$ den Lebensbedingungen der Bevölkerung zählen schließlich Nahrungsversorgung (Angebote wie Engpässe; Montanari 1993), die Bevölkerungsentwicklung selbst (Geburten- und Sterberaten, Migration) und Kriege.

Kriege bleiben hier als nicht-naturale Katastrophen ausgeblendet. Es ist nicht $\mathrm{zu}$ übersehen, dass sie in Bevölkerungskrisen, Hunger und in opportunistische Epidemien führen und insoweit auch naturale Auswirkungen haben. Sie sind damit jedoch eine Folge von primär nicht auf die Natur zielender menschlicher Aktivität.

Die Diskussion um Ernteverluste und Heuschreckenverheerungen lässt etwas in den Hintergrund treten, dass auch Viehseuchen ihren Beitrag zur temporären Verelendung der Bevölkerung leisten. So wird Mitteleuropa im 18. und 19. Jh. wiederholt von der Rinderpest heimgesucht, deren unmittelbare Folge der wirtschaftliche Niedergang bäuerlicher Betriebe in den Niederlanden, Deutschland und Dänemark war, zu deren mittelbaren Folgen aber auch die wirtschaftliche Bedrohung des transkontinentalen Ochsenhandels und die Einschränkungen der Fleischversorgung gehörten.

Sieht man von der objektiven Bestimmungsunsicherheit ab, weil es sich in erster Linie um subjektive Kategorien handelt, sind Nahrungsknappheit und Hunger bis ans Ende des 18. Jh. s letztlich Folgen eines ungelösten Transportproblems, Hungerkatastrophen von gesamt-mitteleuropäischem Ausmaß sind daher Ausnahmen: 1315 - 17, $1571-74,1771-72$ und 1813 - 15. ${ }^{193}$ Große Hungersnöte sind auch deswegen selten, weil Mitteleuropa naturräumlich ein agrarischer Gunstraum von struktureller agrarwirtschaftlicher Portfolioeigenschaft ist. Die häufigeren lokalen Hungersnöte haben bevölkerungsbiologische Konsequenzen, weil ihnen Geburtenrückgänge folgen, die von lokaler und vergleichsweise kurzer Dauer und Auswirkung sind. Die Veränderung des generativen Verhaltens seit der Mitte des 18. Jhs. (der „demographische Übergang“) folgt hingegen keinen naturalen Determinanten sondern allgemeinen gesellschaftlichen Veränderungen. ${ }^{194}$

Diejenige Quellengruppe, die als erste und am authentischsten über den erlittenen Hunger berichten könnte, die in Ausgrabungen gewonnenen Skelette der Menschen, verweigert sich hier. Zwar sehen wir in der Knochenstruktur Hinweise auf mögliche Nahrungsengpässe, der Tod aus akutem Hunger ist nicht nachweisbar. Tod durch Unterernährung ist letztlich auch ein soziales Geschehen, kein primär phy-

193 Die mitteleuropäischen Hungerereignisse sind nur bis 1317 in Übersicht erreichbar (Curschmann), für die Folgezeiten liegen ähnliche Kompilationen nicht vor. Für die vorindustrielle Zeit ist Abel (1972) nach wie vor die zentrale Referenz.

194 Auffällig ist übrigens, dass in gängigen historischen Betrachtungen von einem heimlichen Konzept einer bestimmten Bevölkerungszahl ausgegangen wird. Thematisiert wird nämlich „Verlust“ und anschließender „Ausgleich“, statt von der biologieüblichen, bewertungsfreien „Änderung der Bevölkerungszahl“" zu sprechen. 
siologisches (ein eindrucksvolles Dokument zu diesem Bedingungsgefüge bei Virchow, 1849). Und die Ernährungslage ganzer Bevölkerungsschichten ist am Skelett bisher nicht untersucht. Aber es gibt Hinweise aus der neueren Wirtschaftsgeschichte, die Rekrutendaten des 18. und 19. Jh. untersucht und dabei zu erstaunlichen Befunden kommt. Es zeigt sich, wobei Verallgemeinerungen zu vermeiden sind, dass selbst ausreichende Nahrungsproduktion nicht gleichbedeutend mit ihrer lokalen Verfügbarkeit ist. Das ist zwar seit den Zeiten, seit denen Abgabenpflicht für landwirtschaftliche Produkte eingeführt wurde, bekannt, erreicht aber mit den schnellen Transportmitteln des 19. Jh. eine überraschende Steigerung des Problems für die produzierende Bevölkerung. Der Markt schöpft ab, so daß sich die produzierende Bevölkerung nicht im Ernährungsoptimum befindet (Baten 1999;

Schuster 2005). ${ }^{195} \mathrm{Ob}$ die Körperhöhen insgesamt nicht nur konjunkturellen Faktoren folgen sondern auch klimatischen longue-durée-Effekten, kann man bisher nur vermuten (Abb.4).

Die Allianz von Hunger und opportunistischen Krankheiten ist offensichtlich. Aber für Nahrungsknappheit gilt nicht notwendig, dass alle Bevölkerungsschichten gleichermaßen davon betroffen sind. Auch hier ist die Quellenlage schwierig (für das Spätmittelalter Dirlmeier 1988; Wollasch 1988). Erste Erfolge bei der Eindämmung der großen Volksseuchen setzen mit Impfungsmaßnahmen gegen Pocken am Ende des 18. Jh.s ein. Hygienisierungs- und Antiseptizierungskampagnen, vor allem des fortgeschrittenen 19. Jh.s, zeitigen ihrerseits einige Erfolge, der Durchbruch wird allerdings erst mit den Fortschritten der pharmazeutischen Chemie, den Antibiotika und konsequenter Impfpolitik im 20. Jh. erreicht. Allgemein galt eine soziale Ungleichheit vor dem krankheitsbedingten Tod. Wer arm war (als Chiffre für schlechte Ernährungs- und Hygienelage, unwürdige Wohnverhältnisse, mangelhafte Lebensperspektive), hatte eine geringere Lebenserwartung. Zwar trafen Infektionskrankheiten gleichermaßen Arm wie Reich, aber ihre Folgen konnten doch in den sozialen Umfeldern ganz unterschiedlich gemildert werden.

Man könnte vor allem im Hunger einen push-Faktor für Migration und Auswanderungen sehen. Die individuelle Binnenmobilität war in Europa, mindestens dort, wo sie herrschaftlich möglich war, immer hoch. Dass größere Bevölkerungsgruppen innerhalb Europas migrieren, hat seine Ursache nicht im Ausweichen vor Elementarschäden, sondern vor sozialen Bedingungen. Die Zahlen dieser Migrantengruppen werden allgemein überschätzt, sie haben aber sozialgeschichtlich usw. außerordentlich nachhaltige Wirkungen. Das gilt auch bevölkerungsbiologisch, z.B. für die preußischen Hugenotten. Sie liegen in ihrer Gesamtfruchtbarkeit unter dem preußischen Durchschnitt, übertreffen diesen aber in der Überlebenszahl ihrer Kinder.

${ }^{195}$ Man denke z.B. an die ewigen Hungerkrisen in Irland, trotz der dortigen hohen landwirtschaftlichen Produktivität. Ursächlich war hier der koloniale Export nach England. 

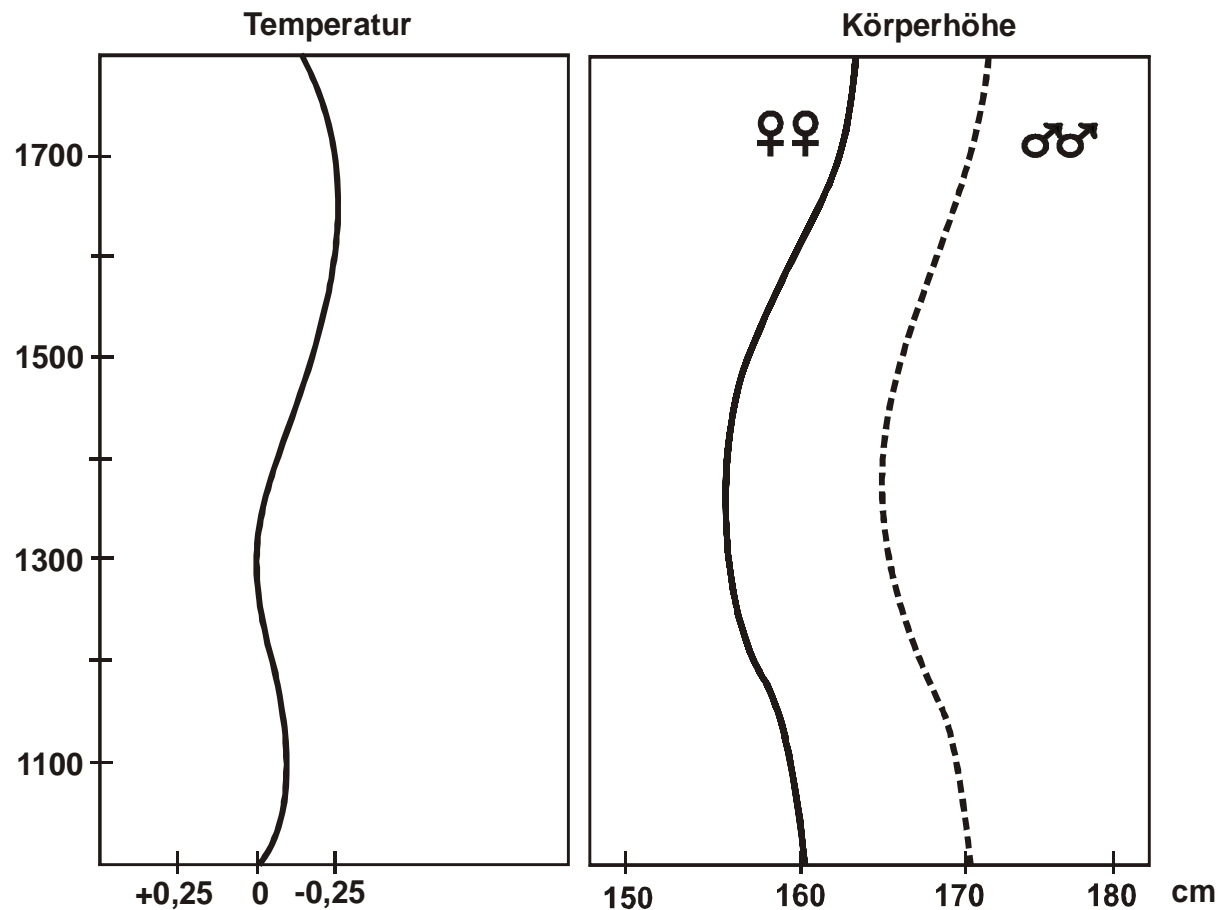

Abb. 4 Heuristische Abduktion eines Zusammenhanges zwischen mittlerer Körperhöhe und Temperaturentwicklung in Mitteleuropa zwischen den Jahren 1000 und 1800. Links: relative Temperaturschwankungen um einen Bezugswert im Jahre 1000; rechts: diachrone Änderungen der Körperhöhen in Mitteleuropa. Die Körperhöhenzunahme bei Temperaturabnahme scheint zumindest als Trend augenfällig. Der geringfügige Versatz der Körperhöhenkurven gegenüber der Temperaturkurve würde mit der Resilienzlogik des biologischen Systems erklärbar sein.

Übliche ökotypologische Erklärungen beziehen sich auf Temperaturgradienten zwischen Lebensräumen von Populationen polytypischer Spezies. Hier wird vorgeschlagen, einen Intraspezies-Gradienten als kausal zu diskutieren. Auffällig ist die Übereinstimmung der Körperhöhenkurven und der Kurve der Temperaturentwicklung. Eine abgesicherte kausale Verknüpfung von Temperatur- und Körperhöhenkurve ist bisher nicht bestätigt.

Kurven nach Daten aus Herrmann (1987, S. 61) und Glaser (2001, S. 181, Abb 56)

Einig ist sich die Forschung, dass Deutschland bis 1500 ein klassisches Land der Einzelauswanderung ist. Die „Massenauswanderungen“ nach 1500 bewegen sich jedoch in der Größenordnung von $<1 \%$ des Gesamtbestandes und schöpft nur zeitweilig und lokal bis zu 20\% des Geburtenüberschusses vor dem demographi- 
schen Übergang ab.196 Pfister (1994) schätzt die Individuenzahlen für Auswanderungen aus Deutschland bis 1800 auf 600.000 bis 1.2 Mio. (Amerika: 200.000 500.000; Südosteuropa 100.000 - 350.000; Polen/Russland 50.000; andere Zielländer, wie: Spanien, Dänemark, Franz.-Guyana 250.000 - <1.000.000). Livi Bacci (1999) geht für die Zeit bis 1800 von deutlich geringeren Zahlen aus. Zwischen 1820 und 1914 verließen ca 5 Mio. Individuen Deutschland, davon allein bis zu 1.8 Mio. zwischen 1880 und 1893 (Ehmer 2004).

\section{Der europåische Sonderweg}

Eine Betrachtung von „Mensch und Natur in Mitteleuropa“ wird nicht umhin können, die zentrale Frage der Universalgeschichte aufzugreifen, wie sich der Vorgang erklären lässt, der als "Industrialisierung", "Modernisierung" oder "Entstehung des Kapitalismus" bezeichnet wird, als Europäischer Sonderweg. Wie kam es, dass eine bestimmte Kultur, nämlich das neuzeitliche Europa, aus dem gemeinsamen Muster der agrarischen Zivilisationen ausbrechen konnte und dabei einen Weg einschlug, der die übrigen agrarischen Zivilisationen (islamischer Raum, Indien, China, Japan) gezwungen hat, sich früher oder später diesem Muster anzuschließen (Mitterauer 2003; Sieferle 2000)?

Obwohl hierfür vor allem gesellschaftliche, z.T. auch technisch-innovative Gründe gelten, kann nicht darüber hinweg gesehen werden, dass daran auch naturale Gründe beteiligt waren.

Unter den naturalen Faktoren, die Sieferle (2000) als besonders wichtig hervorhebt, wäre zu nennen die annähernd ubiquitäre Verfügbarkeit von Metallen und fossilenergetischen Substitutionsmitteln. Die naturräumliche Situation Mitteleuropas begünstigt das engräumige Nebeneinander intensiver wie extensiver Landwirtschaft (naturräumliche Portfolio-Eigenschaft, also weniger strukturelle Hungerkrisen). Das Muster der kognatischen Kern- und Kleinfamilie verhinderte über lange Zeit malthusianische Sackgassen, weil eine Koppelung von Ressourcenverfügung und Bevölkerungsbewegung bestand. Erst mit Einleitung der Transformationszeit (1750-1850) gerät Europa in die malthusianische Krise. Diamond (1999) hat auf die Verfügbarkeit von Biokonvertern (Kühen, Pferden, Ziegen, Schafen) für Produkte, Arbeitskraft und Transportmittel sowie auf die Ausstattung der Europäer mit einem avancierteren Immunsystem hingewiesen.

Hinzuzufügen wäre das kulturhistorische Moment des Betrachtungswandels seit der Aufklärung, seit der die Natur als ein unerschöpfliches und ausbeutungsfähiges Reservoir von Ressourcen galt (Bayerl 2001). Dass dies nicht zutrifft, ist eine erst nach der Mitte des 20. Jh.s verbreitete Einsicht. Ob diese Einsicht zu einem wirklich qualitativ neuen Denken hinsichtlich der ökologischen Randbedingungen

196 Erreichbar war mir nur die Zahl für Württemberg, die Pfister (1994) angibt. Sie dient hier als Größenordnung zur Orientierung. - Eine Migrationsgeschichte für das neuzeitliche Europa bei Bade (2000). 
der künftigen Lebensgrundlagen führt und wer die Definitionsmacht hierfür besitzt oder an sich zieht, ist offen.

\section{Danksagung}

Für umfangreiche Hilfe danke ich Daniel Herrmann. Der Deutschen Forschungsgemeinschaft ist für die Förderung des GK 1024 „Interdisziplinäre Umweltgeschichte“, Göttingen, zu danken.

\section{Literatur}

Abel, Wilhelm: Massenarmut und Hungerkrisen im vorindustriellen Deutschland. Vandenhoeck \& Ruprecht, Göttingen 1972

Antrop, Marc: Landscape change and the urbanization process in Europe. Landscape and Urban planning 67 (2004) 9-26

Bade, Klaus: Europa in Bewegung: Migration vom späten 18.Jahrhundert bis zur Gegenwart. C.H.Beck, München 2000

Baten, Jörg: Ernährung und wirtschaftliche Entwicklung in Bayern (1730 - 1880). Beiträge zur Wirtschafts- und Sozialgeschichte 82. Franz Steiner, Stuttgart 1999

Benevolo, Leonardo: Die Stadt in der europäischen Geschichte. C.H. Beck, München 1999

Bayerl, Günter: Die Natur als Warenhaus. In: Sylvia Hahn/Reinhold Reith (Hrsg.) Umwelt-Geschichte. Arbeitsfelder, Forschungsansätze, Perspektiven. Verlag für Geschichte und Politik, Wien und Oldenbourg Wissenschaftsverlag, München 2001, S.33-52, S.39

Beck, R: Die Insekten- und Pilzkalamitäten im Walde. Historische, wirtschaftliche und forstpolitische Betrachtungen. Tharander Forstliches Jahrbuch. Leipzig, 60. Band (1909) $1-65$

Beck, Rainer: Ebersberg oder das Ende der Wildnis. Eine Landschaftsgeschichte. Beck, München 2003

Böhme, Hartmut: Geheime Macht im Schoß der Erde. Das Symbolfeld des Bergbaus zwischen Sozialgeschichte und Psychohistorie. In: Böhme Hartmut, Natur und Subjekt. Suhrkamp, Frankfurt 1988

Borst, Arno: Das Erdbeben von 1348. Historische Zeitschrift 233 (1981): 529 - 569. Erweiterte Fassung in: Borst, Arno: Barbaren, Ketzer und Artisten. Welten des Mittelalters. Piper. München, Zürich, 1990, S. 528 - 563

Bowlus, Charles: Ecological crises in fourteenth century Europe. In: Lester Bilsky (ed) Historical Ecology. Essays on Environment and Social Change. National University Publications, Kennikat Press 1980, Port Washington, London, S. 86 99 
Curschmann, Fritz: Hungersnöte im Mittelalter. Ein Beitrag zur deutschen

Wirtschaftsgeschichte des 8. bis 13. Jahrhunderts. Leipziger Studien aus dem Gebiet der Geschichte 6 (1). B.G.Teubner, Leipzig 1900

Diamond, Jared: Guns, Germs, and Steel. The fates of human societies. Norton \& Co, New York 1999

Dipper, Christof: Deutsche Geschichte 1648 - 1789. Suhrkamp (Neue Historische Bibliothek), Frankfurt 1991

Dirlmeier, Ulf: Lebensmittel- und Versorgungspolitik mittelalterlicher Städte als demographisch relevanter Faktor. (Die Bevölkerungsentwicklung des europäischen Mittelalters. Das wirtschaftsgeographische und kulturelle Umfeld. Bernd Herrmann und Rolf Sprandel (Hrsg.): Saeculum 39 (1988) S. 149 - 153

Ehmer, Josef: Bevölkerungsgeschichte und Historische Demographie 1800 - 2000. (Enzyklopädie Deutscher Geschichte Band 71). R.Oldenbourg, München 2004

Glaser, Rüdiger: Klimageschichte Mitteleuropas. 1000 Jahre Wetter, Klima, Katastrophen. Wissenschaftliche Buchgesellschaft, Darmstadt 2001

Groh, Ruth; Groh, Dieter: Die Außenwelt der Innenwelt. Zur Kulturgeschichte der Natur 2. Suhrkamp, Frankfurt 1996

Grupe, Gisela: Umwelt und Bevölkerungsentwicklung im Mittelalter. In: Bernd Herrmann (Hrsg.): Mensch und Umwelt im Mittelalter. Deutsche Verlagsanstalt, Stuttgart 1986, S. $24-34$

Herrmann, Bernd: Anthropologische Zugänge zu Bevölkerung und Bevölkerungsentwicklung im Mittelalter. In: Bernd Herrmann, Rolf Sprandel (Hrsg.) Determinanten der Bevölkerungsentwicklung im Mittelalter. Acta Humaniora, Weinheim 1987. S. $55-72$

Herrmann, Bernd: Ein Beitrag zur Kenntnis von Schädlingsbekämpfungen... (2007a; in diesem Bande)

Herrmann, Bernd: City and Nature and Nature in the City. In: Ursula Lehmkuhl, Hermann Wellenreuther (ed) Historians and Nature: Comparative Approaches to Environmental History. Berg Publishers, Oxford (2007b, in diesem Bande)

Imhof, Arthur E.: Leib und Leben unserer Vorfahren: Eine rhythmisierte Welt. In: Arthur E. Imhof (Hrsg.): Leib und Leben in der Geschichte der Neuzeit. Berliner Historische Studien 9. Duncker \& Humblot, Berlin 1983. S. 21 -38

Livi Bacci, Massimo: Europa und seine Menschen. Eine Bevölkerungsgeschichte. C.H.Beck, München 1999

Mannaberg, Julius: Die Malaria Krankheiten. In: Hermann Nothnagel, Specielle Pathologie und Therapie. II. Band, II. Theil. Alfred Hölder, Wien 1899

Marx, Karl: Das Kapital. Dietz Verlag, Berlin/DDR 1968. Bd. I, Dritter Abschnitt, S. $192-213$ 
Meier, Torsten: Natur, Technik und Wirtschaftswachstum im 18. Jahrhundert. Risikoperzeption und Sicherheitsversprechen. (Cottbuser Studien zur Geschichte von Technik, Arbeit und Umwelt 12) Waxmann; Münster, New York, München, Berlin 1999

Mitterauer, Michael: Warum Europa? Mittelalterliche Grundlagen eines Sonderwegs. C.H.Beck, München 2003

Montanari, Massimo: Der Hunger und der Überfluß. Kulturgeschichte der Ernährung in Europa. C.H.Beck, München 1993

Pfister, Christian: Bevölkerungsgeschichte und Historische Demographie 1500 - 1800. (Enzyklopädie Deutscher Geschichte Band 28) R.Oldenbourg Verlag, München 1994

Schuster, Klaus: Wirtschaftliche Entwicklung, Sozialstruktur und biologischer Lebensstandard in München und dem südlichen Bayern im 19. Jahrhundert. (Studien zur Wirtschafts- und Sozialgeschichte 25) Scripta Mercaturae Verlag, St. Katharinen 2005

Sieferle, Rolf Peter: Der Europäische Sonderweg: Ursachen und Faktoren. Rolf Peter Sieferle, Helga Breuninger (Hrsg.) Der Europäische Sonderweg Band 1, Breuninger Stiftung, Stuttgart 2000

Sieferle, Rolf Peter: Transport und wirtschaftliche Entwicklung. In: Rolf Peter Sieferle, Helga Breuninger (Hrsg.) Transportgeschichte im internationalen Vergleich: Europa-China-Naher Osten. Der Europäische Sonderweg Band 12, Breuninger Stiftung, Stuttgart 2004

Sieferle, Peter; Krausmann, Fridolin; Schandl, Heinz; Winiwarter, Verena: Das Ende der Fläche. Zum gesellschaftlichen Stoffwechsel der Industrialisierung. Böhlau, Köln, Weimar, Wien 2006

Virchow, Rudolf: Mittheilungen über die in Oberschlesien herrschende TyphusEpidemie (1949) In: Rudolf Virchow, Sämtliche Werke, hrsg. v. Christian Andree, Bd. 4, Abteilung I, Medizin. Peter Lang, Bern usw. 1992. S. 357 - 492

De Vries, Jan: European Urbanization 1500 - 1800. Methuen \& Co, London 1984

WBGU (Wissenschaftlicher Beirat der Bundesregierung Globale

Umweltveränderungen): Erhaltung und nachhaltige Nutzung der Biosphäre. Jahresgutachten 1999. Springer, Berlin usw. 2000

Wollasch, Joachim: Konventsstärke und Armensorge in mittelalterlichen Klöstern. Zeugnisse und Fragen. (Die Bevölkerungsentwicklung des europäischen Mittelalters. Das wirtschaftsgeographische und kulturelle Umfeld. Bernd Herrmann und Rolf Sprandel (Hrsg.) Saeculum 39 (1988) S. 184 - 206 



\title{
Die „Suppenfrage“ in der Anthropologie Sortiertes und Unsortiertes zum Tagungsthema ${ }^{197}$
}

\author{
Bernd Hermann
}

\section{Sozial-metabolische (humanökologische) Prolegomena}

Warum die Tagungsmacher nicht den Mut zur dritten Alitteration im Thema aufbrachten (Küche, Kochen, Kauen) weiß ich nicht. Ich vermute, dass noch Nachwirkungen jener Forschungstradition wirksam sind, die eine kulturwissenschaftliche Beschäftigung mit dem Essen sowohl als Materie wie als Vorgang als profan denunzierte und ausschloß. Es bedurfte immerhin erheblicher Anstrengungen, bis weit nach den 60er Jahren des letzten Jahrhunderts endlich solche Untersuchungen möglich wurden. Die Schrittmacherfunktion der Kulturanthropologie (Norbert Elias, Claude Levi-Strauss und Marvin Harris) ist dabei unübersehbar. Die Historiker und Kunsthistoriker nahmen sich zeitlich noch später einschlägiger Themen an, von vereinzelten Ausnahmen abgesehen. Die jüngeren Tagungsteilnehmer werden dies nicht glauben wollen, doch ist der gegenwärtig in unserer Gesellschaft enthemmt praktizierte Hedonismus des Gaumens erst ein Produkt der toskanischen Wende der Nach-68er-Zeit. Zur Zeit des Wirtschaftswunders ersetzte noch Quantität die Qualität, eine immerhin stammesgeschichtlich als existenzsichernd erprobte Strategie. Der niedergangstheoretischen Parallelisierung einer Pflege heu-

\footnotetext{
197 Zuerst erschienen in: Klein U, Jansen M, Untermann M (Hrsg.) (2007) Küchen - Kochen - Ernährung. Archäologie, Bauforschung, Naturwissenschaften. Tagung Schwäbisch Hall, 6.-8. April 2006 (Mitteilungen der Deutschen Gesellschaft für Archäologie des Mittelalters und der Neuzeit). Paderborn. S. 35-42. Schriftliche Fassung meines Vortrags vom 6.4.2006 in Schwäbisch-Hall. Sie behält Struktur und Rhetorik des Vortrags weitestgehend bei.
} 
tiger Gaumenfreuden mit solchen früherer Epochen wird hier nun allerdings nicht nachgegeben.

Wie auch immer, die drei Bereiche der Tagung reden in Wahrheit über die Nahrungsbereitstellung

die Nahrungszubereitung

die Nahrungsaufnahme

Der Betrachtungsfokus der Tagung blendet dabei Bereiche aus, die zwingend einzubeziehen wären und die ich deshalb mit aufgenommen habe.

Zunächst erscheinen die drei Bereiche logisch aufeinander folgend. Stellen wir sie jedoch in einen größeren Zusammenhang, wird erkennbar, dass sie einander nicht wie in einem Stufenmodell sequentiell folgen, sondern dass sie sich polyvalent aufeinander beziehen, zumeist in der geometrischen Grundform eines Dreiecks, dessen Hierarchie aber nicht durch einen der Eckpunkte vorgegeben ist. Das Tagungsthema nimmt zwar seinen Anfang bei der einfachen Wahrheit, dass Menschen Nahrung zu sich nehmen müssen. Aber, so wie es einen individuellen Stoffwechsel gibt, so gibt es einen gesellschaftlichen, und es ist gerechtfertigt, beide in Beziehung zu setzen. Diese Beziehung beschreibt das Sozial-Metabolische Regime (Fischer-Kowalski \& Weisz, 1999). Wenn von den Eckpunkten des Dreiecks geredet wird, ist über gesellschaftliche Parameter zu reden. Ich will dies mit Hilfe dreier bekannter ontologischer Setzungen illustrieren:

Der Titel meines Beitrags ist eine leicht erkennbare Anspielung, die im Heine-Jahr erlaubt sei:

Ob man es so ausdrückt
A: „Die Suppenfrage regiert die Welt" (Heine) oder anders
B: „Erst kommt das Fressen, dann die Moral (Brecht), man landet bei der Einsicht:
C: „Der Mensch ist, was er ißst“

Die Aussagen markieren Endpunkte jener Ebene, deren geometrisches Äquivalent das besagte Dreieck ist. Sie ist eine Metaebene gesellschaftlicher Konstruktionen, auf die sich jede Handlung des Alltagslebens direkt oder indirekt bezieht, bzw. von der individuelles Handeln vorgesteuert wird. Damit bezeichnen die drei Eckpunkte letztlich zentrale Begriffe der conditio humana (vgl. Abb. 1).

In den Ebenen der Alltagskultur werden die Begriffsfelder als Wirkkräfte sichtbar bzw. erfahrbar. Sie sind Ausdruck sehr elementarer Bereiche menschlichen Seins, denen essentialistische Qualität nachgesagt wird (vergleichbar den abstrakten Ideen Platons, den Kategorien Kants, den Verhaltensmustern von Lorenz). Sie gehören zu den (angeborenen) „Strukturen“. 


\section{Die Suppenfrage regiert die Welt. $\rightarrow$ „Macht"}

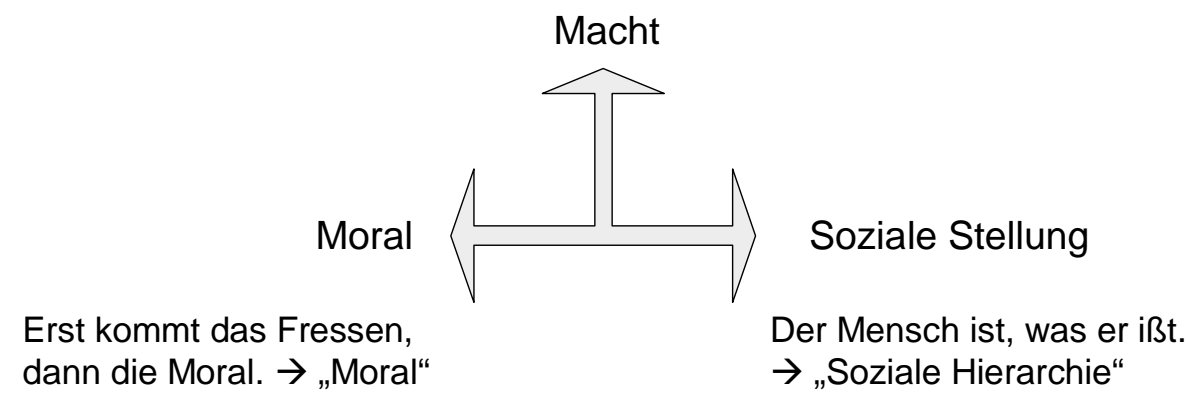

Abb. 1 Wie die „Suppenfrage“ mit der sozialen Organisation der Menschen verbunden gedacht werden kann.

In den Ebenen der Alltagskultur werden die Begriffsfelder als Wirkkräfte sichtbar bzw. erfahrbar. Sie sind Ausdruck sehr elementarer Bereiche menschlichen Seins, denen essentialistische Qualität nachgesagt wird (vergleichbar den abstrakten Ideen Platons, den Kategorien Kants, den Verhaltensmustern von Lorenz). Sie gehören zu den (angeborenen), Strukturen“.

Das Dreieck ist übertragbar in das „kulinarische Dreieck“ von Levi-Strauss und daraus abzuleitende Grundphänomene, die in symbolischen Oppositionen der Welterfahrung niedergelegt sind. Die Bezüge zwischen den Eckpunkten werden durch Achsen gebildet, die parallel zu den Seiten des Dreiecks laufen und dabei Gruppen sehr elementarer Oppositionen bilden.

Meine Darstellung folgt in den nächsten drei Absätzen bis in die Formulierungen hinein der m.E. nach besten Darstellung des Kulinarischen Dreiecks in deutscher Sprache von Böhmer-Bauer (1990, S. 19 ff). Hilfreich ist auch eine neuere Ausführung von Hauer (2000).

Die Küche stellt nach Levi-Strauss die Verbindung zwischen Natur und Kultur dar. Sie gehört beiden Bereichen an und spiegelt diese Dualität in jeder ihrer Erscheinungsformen wider.

Nahrung stellt sich für den Menschen in drei wesentlichen Zuständen dar: roh, gekocht und verfault. Im Gekochten sieht Levi-Strauss die kulturelle Verwandlung des Rohen, während das Verfaulte die natürliche Verwandlung des Rohen darstellt. Diese drei Begriffe stellt er im "kulinarischen Dreieck" einander gegenüber. Der 


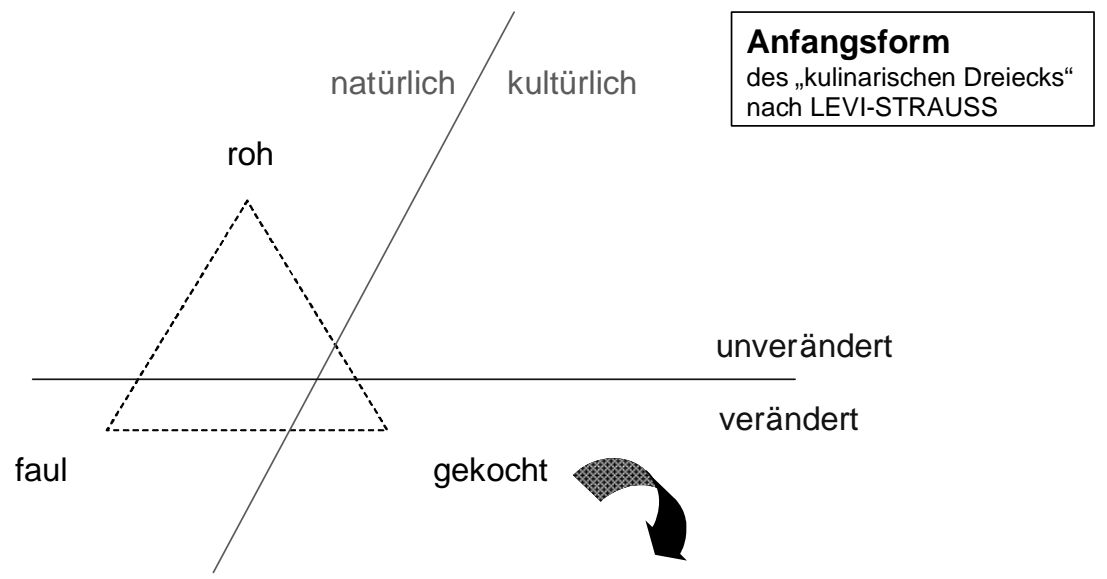

in der „Entwickelten Form “ unterscheiden die Achsen gekochtes, geräuchertes und gebratenes Essen.

In Bezug auf die Mittel sind Braten und Räuchern natürliche Prozesse, Kochen ein kultureller.

In Bezug auf die Endprodukte sind gebratenes und gekochtes Essen Natur, geräuchertes Essen aber Kultur.

Abb. 2 Das Kulinarische Dreieck nach Levi-Strauss. Ableitungen nach Levi-Strauss; Böhmer-Bauer (1990) und Hauer (2000)

rohe Zustand bildet keinen ausgeprägten Pol, während die beiden anderen Zustände in entgegen gesetzten Richtungen ausgeprägt sind. Diesem Grunddreieck liegt der doppelte Gegensatz verarbeitet/unverarbeitet und Kultur/Natur zugrunde. Das Dreieck kann jeder Kultur als formaler Rahmen dienen, um andere Gegensätze, z. B. kosmologischer oder soziologischer Art, zum Ausdruck zu bringen.

Da für keine Küche etwas nur gekocht, sondern immer auf eine bestimmte Weise zubereitet ist, wird das kulinarische Dreieck um die Begriffe „Gebraten“, „Gesotten“" und „Geräuchert" erweitert. Gebratenes und Gesottenes verkörpern für viele Kulturen die Grundzubereitungsarten der Nahrung. Der Gegensatz zwischen beiden Zubereitungsarten besteht in der unterschiedlichen Einwirkung des Feuers. Die gebratene Nahrung steht mit dem Feuer in direkter Verbindung, während die gesottene Nahrung aus einem doppelten Vermittlungsprozess entsteht: Durch das Wasser, in das sie gelegt ist und den Behälter, der beides enthält. In doppelter Hinsicht ist demnach das Gebratene auf die Seite der Natur und das Gesottene auf die der Kultur gestellt: Real, weil das Gesottene einen Behälter erfordert, also einen Kulturgegenstand, und symbolisch, da die Kultur eine Vermittlung zwischen dem 
Menschen und der Welt bewirkt, ebenso wie das Kochen eine Vermittlung durch das Wasser bewirkt. Der Gegensatz, der das Gebratene auf die Seite der Natur stellt und das Gesottene auf die der Kultur, umfasst gleichzeitig den Gegensatz zwischen unbearbeiteter und bearbeiteter Nahrung. Bei vielen Gesellschaften wird das Gebratene dem Rohen zugerechnet, d.h. dem Unverarbeiteten, und das Gesottene dem Verfaulten. Weiterhin kann bei der Zubereitungsart unterschieden werden, dass das Gebratene von außen zubereitet wird, das Gesottene von innen (in einem Behälter). Das Gesottene untersteht häufig der „Endo-Küche“, ist also zum Gebrauch für eine kleinere geschlossene Gruppe bestimmt. Das Gebratene gehört dagegen oft der „Exo-Küche“ an, die auch die Versorgung von Fremden übernimmt. So steht das Gesottene möglicherweise für die Festigung, das Gebratene für die Lockerung der familiären oder gesellschaftlichen Bindungen.

Als dritten Begriff der Zubereitungsarten unterscheidet Levi-Strauss das Räuchern, das der abstrakten Kategorie des Gekochten am nächsten kommt. Kochen verzögert ebenso wie das Räuchern das Verrotten, geräucherte Nahrung widersteht der Fäulnis aber viel länger als eine auf andere Art zubereitete Nahrung. Wie bei der Technik des Bratens befindet sich während des Räuchervorgangs nichts außer Luft zwischen Feuer und Fleisch. Der Unterschied besteht darin, dass beim Braten die dazwischen liegende Luftschicht minimal ist, beim Räuchern aber maximal. Das schließt die Gegensatzpaare nah/fern (zum Feuer) und schnell/langsam (bei der Beseitigung des Rohen) ein. Braten geht ohne Kulturgegenstand vor sich, zum Räuchern ist ein Rost o. ä. nötig.

Die Bedeutung des Kulinarischen Dreiecks ist, ich vermute seiner Komplexität wegen, nicht besonders intensiv erprobt worden. Nicht um hier eine besondere anwaltliche Position für das Kulinarische Dreieck zu übernehmen, ist mir diese ausführlichere Darstellung wichtig. Sondern um darauf hinweisen, dass die theoriegeleitete Wissenschaft hier ein Epistem vorfindet, dessen analytische Kraft noch seiner breiteren Bewährungsprobe harrt, besonders, wenn das Thema Küche und Kochen in einen größeren Zusammenhang menschlicher Handlungsweisen eingebettet wird. Dabei wird entscheidend, dass nach der Einsicht von Levi-Strauss „die Küche“ den Übergang von Natur zu Kultur markiert.

Mir genügt dieser Hinweis, die grundlegende Bedeutung der strukturellen Oppositionen ins Gedächtnis zu rufen, bevor ich am folgenden Überblick einschlägige sozial-metabolische Bezüge demonstriere. Zuvor ist das mit den drei Substantiven der Tagung heimlich zugrunde gelegte Menschenbild zu korrigieren: Sie suggerieren einen Prozess, an dessen Ende der Mensch steht, den man sich (polemisch gesprochen) offenbar als Hafergrützemann aus Maler Kleksel (Wilhelm Busch) denkt. Der Hafergrützemann repräsentiert drei Sachverhalte, die den Nahrungsdiskurs beherrschen. Zum einen versteht er den Menschen als Endpunkt der Nahrungspyramide im Sinne einer Teleologie der Nahrung. Danach wäre es die Bestimmung eines Nahrungsmittels, in einer menschlichen Mahlzeit zu enden. Diese 
Facette wird besonders sichtbar in zeremoniellen Mahlzeiten. Der zweite Sachverhalt missversteht die menschliche Mahlzeit als Endstufe naturaler Zyklen, als Endstufe der Verwertung. Spätestens seit Eintritt in die städtische Lebensweise sollten Menschen wissen, dass dies so nicht ist. Der dritte Sachverhalt schließlich bezieht sich auf die Nahrung als Identitätssymbol, ich esse (dieses oder jenes), also bin ich. Ökologisch ist dieses Menschenbild nicht haltbar, sozialhistorisch ein anderes kaum denkbar.

Wie die Zusammenhänge im Sinne des sozial-metabolischen Regimes gedacht werden könnten (die auf ihre Erarbeitung in eigenen Forschungsprogrammen warten), versuche ich in der Tabelle (Abb. 3) zu skizzieren.

\begin{tabular}{|c|c|c|c|c|}
\hline & Strategie & $\begin{array}{l}\text { Entscheidungs- } \\
\text { grundlage }\end{array}$ & $\begin{array}{c}\text { Zirkuläre } \\
\text { Abhängigkeit } \\
\text { (führt zu/ } \\
\text { hängt ab von) }\end{array}$ & $\begin{array}{c}\text { soziale } \\
\text { Grundstruktur }\end{array}$ \\
\hline Nahrungsproduktion & $\begin{array}{l}\text { sammeln } \\
\text { anbauen }\end{array}$ & $\begin{array}{l}\text { Kosten } \\
\text { Nutzen }\end{array}$ & Landnutzung & $\begin{array}{l}\text { Territorialität } \\
\text { Herrschaft }\end{array}$ \\
\hline Nahrungsbereitstellung & $\begin{array}{l}\text { Pflanze } \\
\text { Tier }\end{array}$ & $\begin{array}{l}\text { auswählen } \\
\text { ausrotten }\end{array}$ & $\begin{array}{l}\text { Funktionelle } \\
\text { (d.i. kulturelle } \\
\text { Biodiversität }\end{array}$ & $\begin{array}{l}\text { Verteilungs- } \\
\text { systeme }\end{array}$ \\
\hline Nahrungszubereitung & $\begin{array}{l}\text { roh } \\
\text { gekocht }\end{array}$ & $\begin{array}{l}\text { einfach } \\
\text { komplex }\end{array}$ & $\begin{array}{l}\text { gesund } \\
\text { krank }\end{array}$ & $\begin{array}{l}\text { Soziale } \\
\text { Stratifizierung }\end{array}$ \\
\hline Nahrungsaufnahme & $\begin{array}{l}\text { einfach } \\
\text { komplex }\end{array}$ & $\begin{array}{l}\text { gourmand } \\
\text { gourmet }\end{array}$ & Körperkultur & Menschenbild \\
\hline Entsorgungssysteme & \multicolumn{3}{|c|}{$\begin{array}{l}\text { Vorstellungen von: Verunreinigung und Tabu; } \\
\text { Ästhetik; Prozess der Zivilisation }\end{array}$} & $\begin{array}{l}\text { ntsorgungs- } \\
\text { rsteme }\end{array}$ \\
\hline
\end{tabular}

Abb. 3 Heuristische Darstellung der Zusammenhänge, die zumeist auf Oppositionen gegründet sind. Der Komplexitätsgrad nimmt in der Tabelle von links nach rechts zu, er nimmt zugleich tendenziell nach oben zu. Nahrungsproduktion und Nahrungsbereitstellung bilden zwar eine funktionelle Einheit, sind jedoch aus Gründen der inneren Systematik hier voneinander getrennt worden.

Natürlich fehlen in dieser Zusammenstellung wichtige Dinge, von denen ich nur die anthropologischen Dimensionen des Tötens um des Essens willen nenne (Baranzke et al., 2000). „Für die Tiere ist jeden Tag Treblinka“ hat in unserer Zeit Isaac Bashevis Singer gesagt, und sich dabei vielleicht im Vergleich vergriffen. Richtig aber ist, dass Kulturgeschichte und Archäologie zwar wissen, dass ehedem im November/Dezember die Sau geschlachtet und wie sie zerlegt wurde. Aber 
richtig ist auch, dass wir fast nichts über die Kultur des Schlachtens wissen. Die Arbeit von Doll (2003) leistet hier hervorragende Pionierdienste, kann aber wegen von ihr verfolgter anderer Aspekte nicht zu den von mir angemahnten Themen vordringen.

\section{Thematisches aus der Skelettquelle}

Die klassische Quelle der physischen Historischen Anthropologie ist die Skelettquelle. Umfang und Qualität thematisch einschlägiger Informationen aus der Skelettquelle sind weder kontinuierlich noch folgen sie einem hierarchisch einsichtigen Schema. Häufig besteht die anthropologische Literatur dem Titel nach aus Generalthemen, obwohl es nur um Punktuelles oder Ausschnitthaftes geht, um dann im Einzelfall zu bedauern, dass die Quelle konkret nichts oder nur Vages hergibt.

Das Missverhältnis zwischen Anspruch und Aufklärungsleistung resultiert in der Hauptsache daraus, dass Knochen oder Zähne auf die Fülle von Umwelteinflüssen im Prinzip nur mit der Veränderung von vier Reaktionsparametern reagieren können (Anbau - Abbau; Auflockerung - Verdichtung). Entsprechend sind Veränderungen an Knochen und Zähnen in den meisten Fällen lediglich Symptome einer Krankheit bzw. eines physischen Zustands, nicht aber diagnostisch spezifische Zeichen für den konkreten Sachverhalt. So kommt es dann häufiger zu zirkulären Argumentationen: Die Annahme des Bearbeiters stützt sich auf den Befund, der sich auf die Annahme des Bearbeiters stützt.

Entsprechend sieht meine Übersicht über küchen- und nahrungs- bzw. ernährungsrelevante Befunde an Skeletten auch etwas mager aus

Besonders aufschlussreich ist das Beispiel der Harris-Linien, für die es nach der beeindruckenden Plausibilitäts-Erwägung McHenrys (1968) keinen ähnlich fundierten Versuch einer kausalen Rückführung für diese Strukturen gegeben hat. Zumeist ohne Rückgriff auf diese Quelle, hat sich in Aufsätzen und Lehrbüchern seine Verdachtsdiagnose (und die seiner Vorläufer) längst zu einer sicheren Gewissheit verdichtet. Dabei steht ein kausaler Beweis der adäquaten Ursache für eine (historische) menschliche Population bis auf den heutigen Tag aus. Dennoch ist die Jagd auf die Harris Linie im Skelettmaterial bis heute ungebrochen, wobei ihr Auffinden verwechselt zu werden scheint mit ihrer Erklärung.

Solche Beispiele ließen sich vermehren. Bei aller berechtigten Kritik sollte nun nicht der Eindruck entstehen, als sei vieles nur intelligent erfunden. Allerdings warten die Aussagen aus morphologischer Diagnostik oftmals immer noch auf ihre fundierte Absicherung. Vielleicht reicht „Plausibilität“ als erkenntnistheoretische Fundierung ja aus. Es spricht nur eben nicht für die Dynamik einer Disziplin, wenn seit 30 oder 40 Jahren kein einschlägiger Fortschritt gegenüber dem zu 


\begin{tabular}{|c|c|c|}
\hline am äußeren Aspekt & $\begin{array}{l}\text { nach analytischer } \\
\text { Transformation }\end{array}$ & Aussageebene \\
\hline \multirow[t]{4}{*}{$\begin{array}{l}\text { Abriebmuster an Zähnen; } \\
\text { Veränderungen am } \\
\text { Knochen, z. B. an Zehen } \\
\text { gliedern; } \\
\text { Verfärbungen }\end{array}$} & & $\begin{array}{l}\text { Nahrungskomponenten; } \\
\text { ernährungsbedingte Habituation; } \\
\text { Nahrungszubereitung }\end{array}$ \\
\hline & Isotopien & $\begin{array}{l}\text { Trophiestufen } \\
\text { (Nahrungshauptkomponenten, } \\
\text { Intergeburtenabstände); } \\
\text { Wanderungen }\end{array}$ \\
\hline & Spurenelemente & z.B. (Pb-)Intoxikationen \\
\hline & DNA & $\begin{array}{l}\text { genetisch bedingte Nahrungsver- } \\
\text { träglichkeit }\end{array}$ \\
\hline \multirow[t]{2}{*}{$\begin{array}{l}\text { Eisenmangel; } \\
\text { Nieren-/Blasensteine; } \\
\text { Skorbut; } \\
\text { Rachitis; } \\
\text { Zahnkaries; Zahnbildungs- } \\
\text { störungen; } \\
\text { Harris’ Linien }\end{array}$} & & ernährungsbedingte Krankheiten \\
\hline & Eingeweideparasiten & $\begin{array}{l}\text { Gartenwirtschaft; } \\
\text { Küchen- und persönliche } \\
\text { Hygiene }\end{array}$ \\
\hline
\end{tabular}

Abb. 4 Einige nahrungs- und ernährungsrelevante Indikatoren, die aus dem Skelett ermittelt werden können.

sehen ist, was die Urheber solcher diagnostischer Vorschläge in die Literatur einbrachten. Manches hat sich eben durch die endlose Wiederholung zur vermeintlichen Gewissheit verdichtet, ist deswegen aber nicht wirklich sicherer geworden.

Der Fortschritt durch die analytischen Techniken ist unbestreitbar und großartig, aber er bezieht sich doch auf Ebenen, die nicht die Alltagsgeschichte i.S. der histoire evenementiell wiedergeben, sondern sie erfassen die Nahrungshauptkomponenten über ein großes Zeitfenster. Das wäre anders, wenn aus dem Knochen Strukturen isoliert und analysiert werden könnten, für die sich konkrete Bildungsdaten angeben liessen. Solche Strukturen liegen bisher nicht vor, bzw. sind, wo sie vermutet werden, bisher nicht chronobiologisch interpretierbar (z. B. Herrmann \& Danielmeyer, 1994). Die Erfassung genetisch bedingter Individualeigenschaften, die ernährungs- 
relevant sein können, wie etwa die Laktoseintoleranz, befindet sich noch im Anfangsstadium (Herrmann et al., 2006).

\section{Thematisches, über das die Skelettquelle nichts sagt, andere Quellen aber schon}

Dass die Körperhöhe ein Indikator für Lebensqualität auch in historischen Bevölkerungen ist, ist eine Einsicht, deren Fundierung überraschender Weise den Wirtschaftshistorikern zu danken ist. In der Bundesrepublik sind hier die Münchner Wirtschaftshistoriker um John Komlos hervorzuheben. Hierzu braucht man nicht nur große Datensätze, sondern auch ausreichende und vernetzungsfähige Daten zur Nahrungsmittelproduktion, zum Einkommen und zur Wirtschaftsstruktur. Erst unter diesen Voraussetzungen werden die Daten belastbar und zeigen dann auch eindrucksvolle Effekte (z.B. Baten, 1999, oder Schuster 2005)

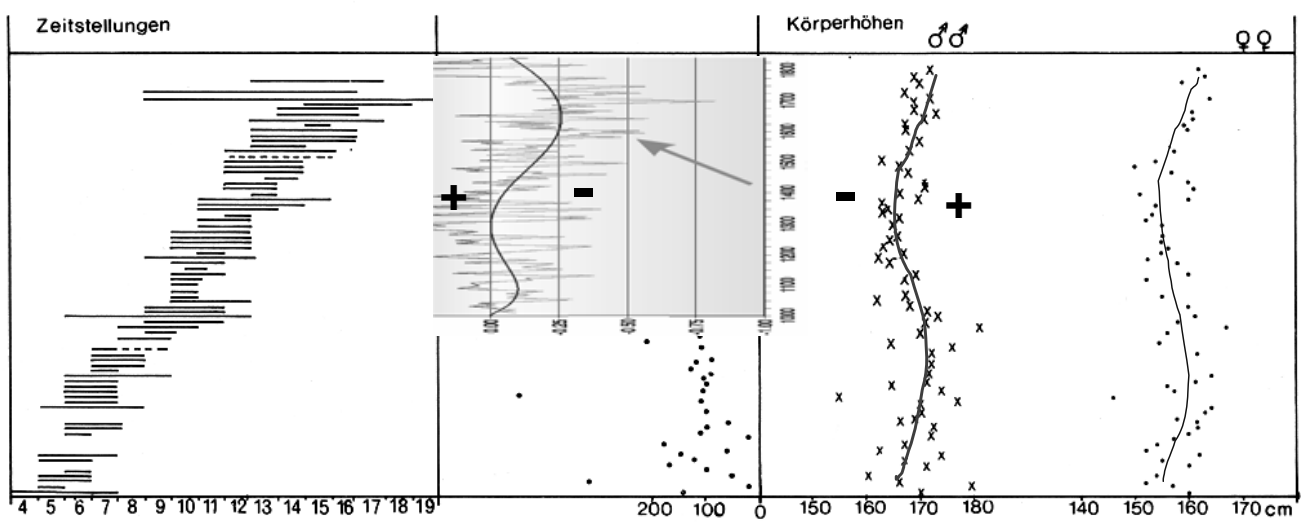

Abb. 5 Skizzierter Zusammenhang zwischen mittleren Körperhöhenschätzungen aus Skelettserien des Mittelalters und der Frühen Neuzeit (rechts, aus Herrmann, 1987) und Jahresmitteltemperatur. Zeitstellungen der Skelettserien links. In der Mitte eingeblendet die Kurve der mittleren Temperatur (aus Glaser, 2001). Der synchrone Zusammenhang zwischen größerer Körperhöhe und niedrigerer Temperatur (und mit ihr assoziierter biologischer Determinanten) ist augenfällig und wäre theoriekonform, wenn der Zusammenhang einer Nachprüfung standhalten sollte.

Die Rekonstruktion der Körperhöhe aus dem Skelett ist dagegen von anderer Qualität als direkt ermittelte Rekrutendaten historischer Populationen. Sie zeigen selbst unter massenstatistischen Gesichtspunkten viel größere Fehler der Mittelwerte. Außerdem fehlen diffizile Schichtenmodelle für Skelettserien. Dennoch lohnt sich 
der Blick auf eine Langzeitentwicklung, wenn es gelingt, aus ihnen auf die Indikatoren von Nahrungsverfügbarkeit zu schließen (Abb. 5).

Dass sich „,biologischer Lebensstandard“ (im Sinne der Wirtschaftsgeschichte) in der Knochenstruktur niederschlägt, lässt sich im histologischen Bild am Beispiel von Kindern und Jugendlichen aus dem mittelalterlichen Thüringen zeigen (Abb. 6).

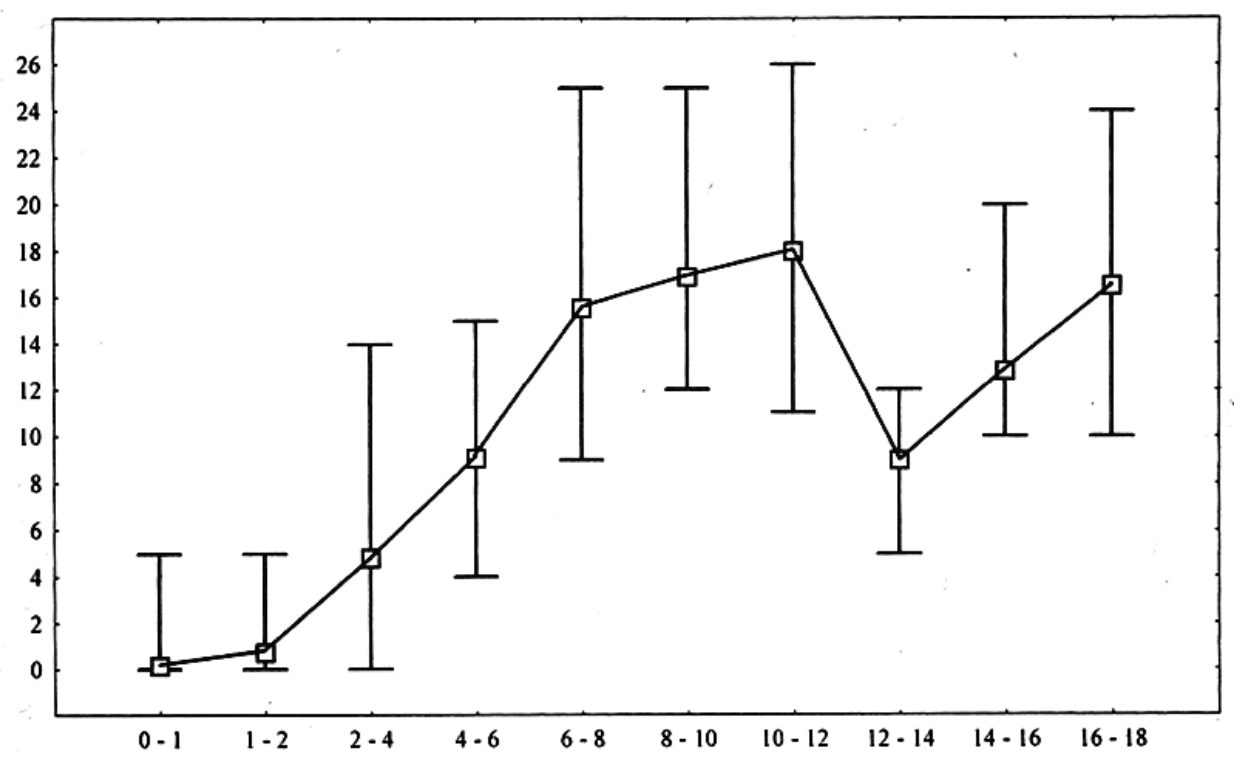

Abb. 6 Anzahl von Linien sistierenden Wachstums im Querschnittsbild des Oberschenkelbeins bei mittelalterlichen Kindern und Jugendlichen aus Thüringen. Gepoolte Daten von 300 Individuen (Herrmann \& Danielmeyer 1994). Auffällig ist die geringe Zahl von Wachstumsstillständen in der Altersgruppe der 12-14Jährigen. Zu bedenken ist das Nachlaufen des biologischen Phänomens, so dass es sich hier um ein Ergebnis eines Prozesses handeln muss, der bereits in der davor liegenden Altersgruppe eingesetzt haben muss. Insgesamt ist damit der klassische Altersbereich von Initianten bezeichnet.

Im Moment gibt es keine andere belastbare Deutung für die absolut geringe Zahl spezifischer Bildungen in der Altersgruppe der 12 - 14 Jährigen, als durch den Rückgriff auf eine gesellschaftliche (vielleicht institutionelle?) Ursache. Diese wird in der optimalen Versorgung der Kinder dieser und der davor liegenden Altersgruppe gesehen. Dann wäre eine optimale und verstetigte Nahrungsversorgung eine Voraussetzung dafür, dass auch opportunistische Infektionskrankheiten in signifikant geringerem Maße wirksam wurden (Herrmann \& Danielmeyer, 1994). So gut wie nichts wissen wir über einzelne Zutaten zur Nahrung, und bislang sind auch keine erfolgreichen Versuche bekannt, spezifische Nahrungsinhaltsstoffe aus 
dem Skelett nachzuweisen. Matossian (1989) hat in ihrem bei uns wenig rezipierten Buch überzeugend auf die Möglichkeit aufmerksam gemacht, dass die nicht immer intendierte Aufnahme von Nahrungszusatzstoffen mit pharmakologischer Wirkung (Gewürze, Halluzinogene) zu kollektiven psychotischen Zuständen geführt habe.

Fraglos wäre dies ein interessanter Aspekt, den ich an einem grundsätzlichen Beispiel illustrieren möchte, der uns zunächst in völlig anderen Bereiche führt. Etwa zeitgleich mit der flächendeckenden Einführung der Kartoffel kommt es im 18. Jh. zu einem sprunghaften Anstieg der Bevölkerung. Von Gundlach (1986) hatte - unabhängig von Matossian - darauf verwiesen, dass in den Samen vieler Ackerunkräuter des Getreides pharmakologisch wirksame Substanzen enthalten sind, denen eine fertilitätshemmende Wirkung unterstellt werden kann. Gewiss hängt deren Wirksamkeit von den Verarbeitungsformen des Getreides ab, aber grundsätzlich ist nicht auszuschließen, dass die Getreidegrundnahrung eine gewisse pharmakologische Last enthielt. Die Kartoffel und ihr Vorläufer, die Topinambure, sind dagegen frei von solchen Belastungen. Es ist plausibel, in beiden Früchten eine indirekte Ursache des Bevölkerungsanstiegs zu sehen. Nur: Der empirische Beweis wäre erst dann erbracht, wenn nachgewiesen wäre, dass es zu einer Verstoffwechselung der besagten Substanzen gekommen ist. Dieser Beweis steht aus.

Er wäre direkt verknüpft mit einem Thema, das die Skelettanalyse bislang auch nicht in den Griff bekam: Den Hunger.

Definitive Beweise von chronischer Nahrungsunterversorgung am Skelett sind mehr als diffizil und praktisch nicht erforscht. Man muss vor Verwechselungen warnen. Es werden in der Regel am Skelett die Folgen opportunistischer Infektionskrankheiten als ernährungsbedingt vorgestellt. Das trifft nur insofern zu, als die reduzierte Nahrungsaufnahme Folge eines anderen pathologischen Geschehens sein kann, etwa um ein einfaches Beispiel zu nennen, der Diarrhöe. Das führt, zu mitunter moralisch absurden Konstruktionen, wie die Sozialhistoriker es für das Frankreich des Ancien Regime und bis ins 19.Jh. wissen, wenn Kinder trotz ausreichender Nahrungsversorgung in einen strategischen Infantizid zum Sterben gebracht wurden, indem die Amme sie regelmäßig mit roher Ziegenmilch fütterte.

Gesicherte Gräberfelder oder Skelettdepots nach Hungerkatastrophen sind meines Wissens in der Literatur Mangelware. Und wer jetzt an die Grönländischen Normannen von Herjolfsnes denkt, wäre gut beraten, die Originalpublikationen aus den 20er Jahren des 20. Jh. und die wenigen Folgeuntersuchungen sorgfältig nach wirklichen Beweisen des Hungers abzuklopfen, die sich aus den Skeletten zweifelsfrei und ohne Beweiskonkurrenz ergäben. Natürlich sind diese Menschen verhungert, es lässt sich nur nicht aus dem Skelett belegen. Bedenkenswert scheint mir auch nach wie vor das Argument, dass man Meuvret (1946) entgegenhielt, als er in seinem berühmt gewordenen Aufsatz auf den Zusammenhang zwischen Getreidepreisentwicklung und demographischen Schwankungen hinwies: Man sterbe nicht so ohne weiteres Hungers mit dem Ozean vor der Tür, dem Fluss durchs Dorf und dem Wald und dem Feld hinter dem Haus. Dass demographische Ent- 
wicklungen auch und vor allem an soziale Parameter geknüpft sind, sollte wohl in der heutigen Bundesrepublik kein halbwegs Informierter bestreiten wollen. Noch nie lebte eine Bevölkerung in Deutschland auf so hohem materiellem Niveau, und noch nie war die Kinderzahl so gering. Auch ist die Differenzierung zwischen chronischem und akutem Hunger m.W. in der anthropologischen Literatur bisher nicht akzeptabel erfolgt. Das Thema Hunger wäre sicher ein eigenes Tagungsthema und daher hier nicht weiter zu strapazieren.

Schließen möchte ich mit dem Hinweis, dass das Tagungsthema auch in den umwelthistorischen Bereich hinein verlängert werden könnte. Zur allgemeinen Überraschung wird man dabei ebenfalls auf erhebliche Informationsdefizite stoßen. Ich meine hier nicht nur Aspekte der Nahrungsproduktion, obwohl z.B. der transkontinentale Ochsenhandel in Europa, der ja erst Mitte des 19. Jh. zum Erliegen kam, kaum noch bekannt ist.

Es sind vor allem Themen der Nahrungssicherung, wie die Schädlingsbekämpfung (Herrmann 2006) und der Qualitätskontrolle, die der Bearbeitung harren. Dass es Reinheitsgebote für Bier und Wein gab und auch Qualitätskontrollen für Mehl und Backwaren ist zwar bekannt, aber nicht gut untersucht. Noch geringer sind die Kenntnisse über Fleischbeschau und Frischeprüfung. Immerhin weiß man, dass den Rebhühnern in Erfurt, wenn sie nicht sofort verkauft werden konnten, am nächsten Tag ein Bein abgeschnitten werden musste. Und dass in Basel der Rheinfisch nur am Fangtag verkauft werden durfte, an Ortsfremde hingegen noch am zweiten Tag. Solche Beispiele der Alltagsgeschichte harren ihrer systematischen Erfassung. Dann können auch Historiker sich ein besseres Bild von Ernährung und Küche der Menschen machen, die keine Geschichte schreiben, aber ohne die Geschichte nicht denkbar ist.

\section{Literatur}

Baranzke, Heike; Gottwald, Franz-Theo; Ingensiep, Hans-Werner (Hg.) (2000) Leben, Töten, Essen: anthropologische Dimensionen. Stuttgart

Baten, Jörg (1999) Ernährung und wirtschaftliche Entwicklung in Bayern 1730 1880. Stuttgart

Böhmer-Bauer, Kunigunde (1990) Nahrung, Weltbild und Gesellschaft. Ernährung und Nahrungsregeln der Massai als Spiegel der gesellschaftlichen Ordnung. Saarbrücken, Fort Lauderdale

Doll, Monika (2003) Haustierhaltung und Schlachtsitten des Mittelalters und der Neuzeit. Rahden, Westf. 
Fischer-Kowalski, Marina; Weisz, Helga (1999) Society as a hybrid between material and symbolic realms: Towards a theoretical framework of societynature interaction. Advances in Human Ecology 8:215-251

Glaser, Rüdiger (2001) Klimageschichte Mitteleuropas: 1000 Jahre Wetter, Klima, Katastrophen. Darmstadt

Gundlach, Christoph von (1986) Agrarinnovationen und Bevölkerungsdynamik aufgezeigt am Wandel der Dreifelderwirtschaft zur Fruchtwechselwirtschaft unter dem Einfluß der Kartoffeleinführung im 18. Jh.

Geowiss.Diss. Universität Freiburg

Hauer, Thomas (2000) Carl Friedrich von Rumohr und Der Geist der bürgerlichen Küche. Phil.Diss. Universität Karlsruhe

Herrmann, Bernd (1987) Anthropologische Zugänge zu Bevölkerung und Bevölkerungsentwicklung im Mittelalter. In B. Herrmann \& R. Sprandel: (eds) Determinanten der Bevölkerungsentwicklung im Mittelalter. Weinheim S. 5572

Herrmann, Bernd : Zur Historisierung der Schädlingsbekämpfung. In: Torsten Meyer, Marcus Popplow (Hg.): Technik, Arbeit und Umwelt in der Geschichte. Günter Bayerl zum 60. Geburtstag. Münster u.a. 2006. S. 317 338

Herrmann, Bernd, Danielmeyer, Anja (1994) Bone structures reflecting rhythm, seasonality, and life-style of past human populations.

Naturwissenschaften 81: 399 - 401

Herrmann, Bernd; Schilz, Felix; Fehren-Schmitz, Lars; Schütt, Rebecca; Pollmann, Jutta; Hummel Susanne (2006) Der Knochen als molekulares Archiv Nova Acta Leopoldina (im Druck)

Matossian, Mary (1989)Poisons of the Past. Molds, epidemics and history. 3. Aufl. New Heaven u.a.

McHenry, Henry (1968) Transverse lines in long bones of prehistoric California Indians. American Journal of Physical Anthropology 29: 1-17

Meuvret, Jean (1946) Les crises de subsistances et la démographique de la France d'Ancien Régimes. Population 1: 643-650

Schuster, Klaus (2005) Wirtschaftliche Entwicklung, Sozialstruktur und biologischer Lebensstandard in München und dem südlichden Bayern im 19. Jahrhundert. St.Katharinen 



\title{
City and Nature and Nature in the City
}

\author{
Bernd Hermann ${ }^{198}$
}

The title of this contribution came as part of the invitation to the conference. ${ }^{199}$ In my understanding "City and Nature" does not imply an enumeration, but an opposition. In terms of environmental history, cities are specific environments of a specific species, comparable to large-scale beaver lodges or termite mounds. Therefore the paper consists of two parts. The first one aims to demonstrate the "nature of cities" in terms of biology and is built up as textbook chapters.

As "Nature in the City" stands in line with the opposition included in "City and Nature", the expression suggests:

- a sort of subversive recapture of lost territory by "nature" and

- the unintended or deliberate introduction of nature into cities, or

- a displaced "nature".

All three points lead to meditations on "biodiversity" in cities. Thus the second part of the paper is dedicated mainly to three related aspects of interest to me: "The human population", "Displaced Nature", and "Cities and Biodiversity".

\footnotetext{
198 Zuerst erschienen in: Lehmkuhl U, Wellenreuther H. (eds.) Historians and Nature: Comparative Approaches to Environmental History. S. 226 - 256. Berg Publishers, Oxford 2007 - Abdruck mit freundlicher Genehmigung des Verlages.

${ }^{199}$ I thank the conference organisers for the invitation and the set up of the conference at Krefeld. I appreciated the spirit of the meeting as much as the opportunity to share thoughts with a number of highly respected scholars also attending the conferences, who helped to develop my own thoughts. The help of Daniel Herrmann with gathering, checking, and compiling of the data used is also thankfully acknowledged.
} 


\section{Introduction}

The term "city" will be used here in the common dictionary meaning of a town of significant size and importance, serving as a center of population, commerce, and culture that is erected and maintained on legal powers, within definite boundaries. However, I will not strictly follow this definition but will also refer to smaller settlements for the sake of functional reasoning. Surprisingly enough, cities are not really much studied in environmental history. Of course, there are many articles and monographs on various aspects of urban life and the consequences of urbanization. But the structure itself, which has changed the face of the earth like no other structure made by man, and which has produced most of the ecological conditions of the planet, is not really much dealt with. Examples which I am relying on are mostly from the Western, namely European, hemisphere.

Every town, city, metropolis, is different, as is its societal atmosphere, its "spirit", its "vibration". These differences are among the major reasons why people like to visit cities or are attracted by different cities in different ways. However, in terms of structural features all cities share basic properties, since all have to cope with basically similar demands and expectations of their residents. Residents may increase in numbers faster, and may be replaced faster for biological reasons, than the cities can change. Cities do not respond by themselves; they are unable to remodel in terms of autopoetic systems. Any change has to be initiated and performed by the residents. This relationship between "city" and "society", including the societal frictions resulting from it, is usually addressed by "urban ecology" as defined by Robert E. Park and his followers, and is a branch of sociology. I will not go into this realm.

Instead of referring to specific statements by specific authors, I would like to mention three important and influential books for my topic, although they do not at all or not really discuss "cities" or related subjects. ${ }^{200}$ They mention "urbanisms" in context of environmental history, but they mostly do not address the fields and problems in the way I intend to. Instead, I found inspiring Mumford's contribution to the pioneering work in environmental history "Man's Role in Changing the Face of the Earth", ${ }^{201}$ which offered an excellent systematic view of the problem. Unfortunately, what later became "environmental history" started by dissecting the problem and atomized the complexity of the structure. Influenced by Mumford's

\footnotetext{
200 The three books are: B.L.Turner, William Clark, Robert Kates, John Richards, Jessica Mathews and Wiliam Meyer, The Earth as Transformed by Human Action (Cambridge: University Press with Clark University, 1990);

Andrew Goudie, The buman impact on the natural environment 5th ed.( Oxford: Blackwell, 2000);

Shepard Krech, John McNeill and Carolyn Merchant, Encyclopedia of World Environmental History, 3 vols. (New York, London: Routledge, 2004)

${ }^{201}$ Lewis Mumford, "The natural history of urbanisation", in: William Thomas, Carl Sauer, Marston Bates, and Lewis Mumford (eds.) Man's Role in Changing the Face of the Earth. (Chicago: University of Chicago Press, 1956), pp 382 - 398
} 
approach was the dissertation by Britta Padberg ${ }^{202}$. Although limited by a narrow empirical basis, mostly in the German medieval sources available at that time, this book is still useful because of its ecosystemic approach. Recently, Joel Tarr ${ }^{203}$ has provided an overview, which is highly recommended for comparative reading.

There are various subjects I will not go into, or at least not deeply, notably the fresh water and wastewater issue, a subject extremely closely related to the wellbeing of people and to epidemics. The quality of water is usually measured by acceptable taste (disregarding the microbial burden, which is without taste). But the "good taste" of water is defined almost without, or only minimally by, cultural opinions or predispositions. So standards for drinking water are less culturally influenced than quality standards for other environmental media, for example "good air". Furthermore, there are many distinguished papers and monographs available on the water supply of cities, as on two other subjects which I will therefore not deal:

the disposal of human fecal remains and manure of animals within towns, issues that are related to sewage, and the issue garbage and waste in cities.

These subjects are related to decreasing tolerance to smells, refuse, and filth. Conceptualizations about "cleanliness" and "contagious" effects of bad-smelling air and undrinkable water are among the driving forces that led to hygienization, the development of antiseptics, and the "ultimate sink". Natural sciences and their positivistic knowledge overruled any alternative cultural concept of smell and refuse. Ignoring forerunners, advanced sewage systems owe their existence mainly to the pressure put on cities by nineteenth-century epidemics, starting in the $1830 \mathrm{~s}$ with the newly arrived disease of Cholera in Europe. The waste disposal system was overtaken by rational and enlightened engineering knowledge during that century.

A further aspect not being dealt with is "soil" in cities, about which many ecologists and environmentalists feel very concerned about. Unfortunately, this subject is also missing from the book Soils and Societies. ${ }^{204}$ Finally, I won't be discussing emissions. Since the times of the Roman lawyer Aristo, and likely even earlier than that, this mostly trade-related feature became important for neighbourly coexistence in cities as well for the polluted hinterland. All these aspects and related ones are traditionally covered by environmentalists' and ecolo-

\footnotetext{
202 Britta Padberg, Die Oase aus Stein. Humanökologische Aspekte des Lebens in mittelalterlichen Städten, (Berlin: Akademie Verlag, 1994)

${ }^{203}$ Joel Tarr, "Urban History and Environmental History in the United States: Complementary and Overlapping Fields", in: Christoph Bernardt (ed), Environmental problems in European Cities in the 19th and 20th Century: Umweltprobleme in europäischen Städten des 19. und 20. Jabrbunderts, (München, Berlin: Waxmann, 2001), pp. 25 - 39

${ }^{204}$ John R. Mc Neill und Verena Winiwarter, Soils and Societies: Perspectives from Environmental History, Isle of Harris: White Horse Press, 2006.
} 
gists' understanding of "urban ecology". I mention here only the remarkable stateof-the-art conference "Urban Ecology" held in 1997.205

In terms of historic theories, it remains unclear to me what a description and analysis of the "city" phenomenon would look like according to standards of environmental history written from a microhistoric perspective. Would a strict theoryoriented treatise be a narrative of the life of a municipal gardener? Or a report on the last street tree in downtown Siena? Or a thick description of zoo visitors in Philadelphia? A meticulous observation of pigeons in St. Mark's Square? A video clip of pest exterminators in one metropolis of each continent? A copy of the diary of a microbiologist working in the waterworks of Kolkata? Chekhov's Cherry Orchard? Kafka's "Metamorphosis"? Would it be simply a copy of the cadastral register of a city? Or the history of Purrysburgh, SC (USA), founded in 1731 by and named after Jean Pierre Purry?

As I see it, the microhistoric perspective is a widely but only implicitly used approach in environmental history. This obviously also holds true for papers that deal with aspects of towns, cities, and urbanization. But it appears to me that such a complex structure as a city with its related phenomena and their side effects and epi-phenomena can hardly be handled adequately by following monolinear analyses that lead to a tiered model of causality or simply sweep around in a twodimensional microcosmos instead. Thus, in my opinion, a microhistoric approach to the "city" would resemble a biological analysis of an ecosystem, say a pond, by following the life history of a single carp. This would be a difficult bottom-up perspective. And the analogy is certainly short of explanatory power, since many cities are connected in various ways and exchange materials, people, and information, which is definitely not true for most of the ponds in the world. Moreover, it is also certainly easier to argue top down. When it comes to cities and therefore human societies, the actors do not necessarily follow the concepts of behaviouristic automata, which is the standard consideration of a biological interpretation with respect to ecosystems. Due to human will and decision-making, superimposing upon and conditioning specifically the "city"-ecosystem, which is only one subsystem within a multiple-city ecosystem, cities are by far the most complex ecosystems on earth. If this is doubted, at least the multiple-city ecosystems that are tied together in the worldwide city web must surely be considered of higher complexity than "the tropical rain forest" or "the ocean". Be that as it may, we are talking about a very complex structure in the world, and one that is completely man-made.

Today approximately half of the world's population lives in cities; by 2015 this figure expected to reach 75 percent. In 1800 only 3 percent of the total population

205 Conference papers edited by J.Breuste, H.Feldmann, O.Uhlmann (Heidelberg: Springer, 1998). Important future-oriented contributions are available form the Bundesamt für Bauwesen und Raumordnung, FRG, which collected preparatory expert opinions for the "World Report on the Urban Future for the Global Conference on the Urban Future URBAN 21" held in Berlin July 4-6, 2000 (URL: http://www.bbr.bund.de/english/index.htm, last accessed October 14, 2005) 
lived in cities; by 1900 this percentage had increased to 14 percent, and by 1975 to 30 percent.

In 2015 it is likely that 21 percent of the world's human population will be concentrated in metropolitan cities. It is remarkable that already today more than 70 percent of all cities with more than one million inhabitants (i.e. metropolitan cities) are located in developing and threshold countries. Thus, urbanism has displaced and outnumbered all other forms of human ecological conditions. Cities appeared late in human history and started as relatively small communities. But it took only 10,000 years for this specific human invention to turn into by far most altering impact of humans on the face of the earth (see Figure 1).

\section{City and Nature}

\subsection{Baselines}

The main feature of the biosphere is that processes are organized in cycles. ${ }^{206}$ Those cycles are interrupted or greatly changed in the urban organization of human life. Cities require a set of prerequisites or determinants that need to be achieved by human societies building them up. Disregarding societal features, the most important among these prerequisites are a constant supply of fresh water and a nutritional and energy supply for a high concentration of people, and therefore a need for waste and sewage disposal. In terms of biology, a city is a very limited area of space, permanently inhabited by a large number of people that use and/or exploit the adjacent and surrounding areas, mostly beyond the carrying capacity level compared with human population densities of hunter-gatherer or other nonagricultural societies in comparable places. Cities require people more or less constantly.

As a constant flow of energy is required to supply and maintain the city, cities cannot emerge prior to agricultural production. But once agriculture was achieved in human ecology on whatever continent, cities were invented and implemented by necessity. They are by no means comparable with any example or archetype in nature; even agriculture can be considered an optimization and enhancement of what can be found under a-bemerobic natural conditions. In terms of biology, life in cities must be beneficial to their human inhabitants despite clear disadvantages, such as exposure to high-risk infectious diseases and the intermittent shortage of nutrients. The main benefits are: 1) access to informational processes that accelerate themselves and produce advantages in terms of cultural achievements that allow the intensified use and exploitation of natural goods, including other humans; 2) easier access to sexual partners.

206 These are best outlined and systematized in Lance H. Gunderson and C.S. Holling (eds.), Panarchy: Understanding Transformations and Human and Natural Systems. (Washington, Covelo, London: Island Press, 2002). 

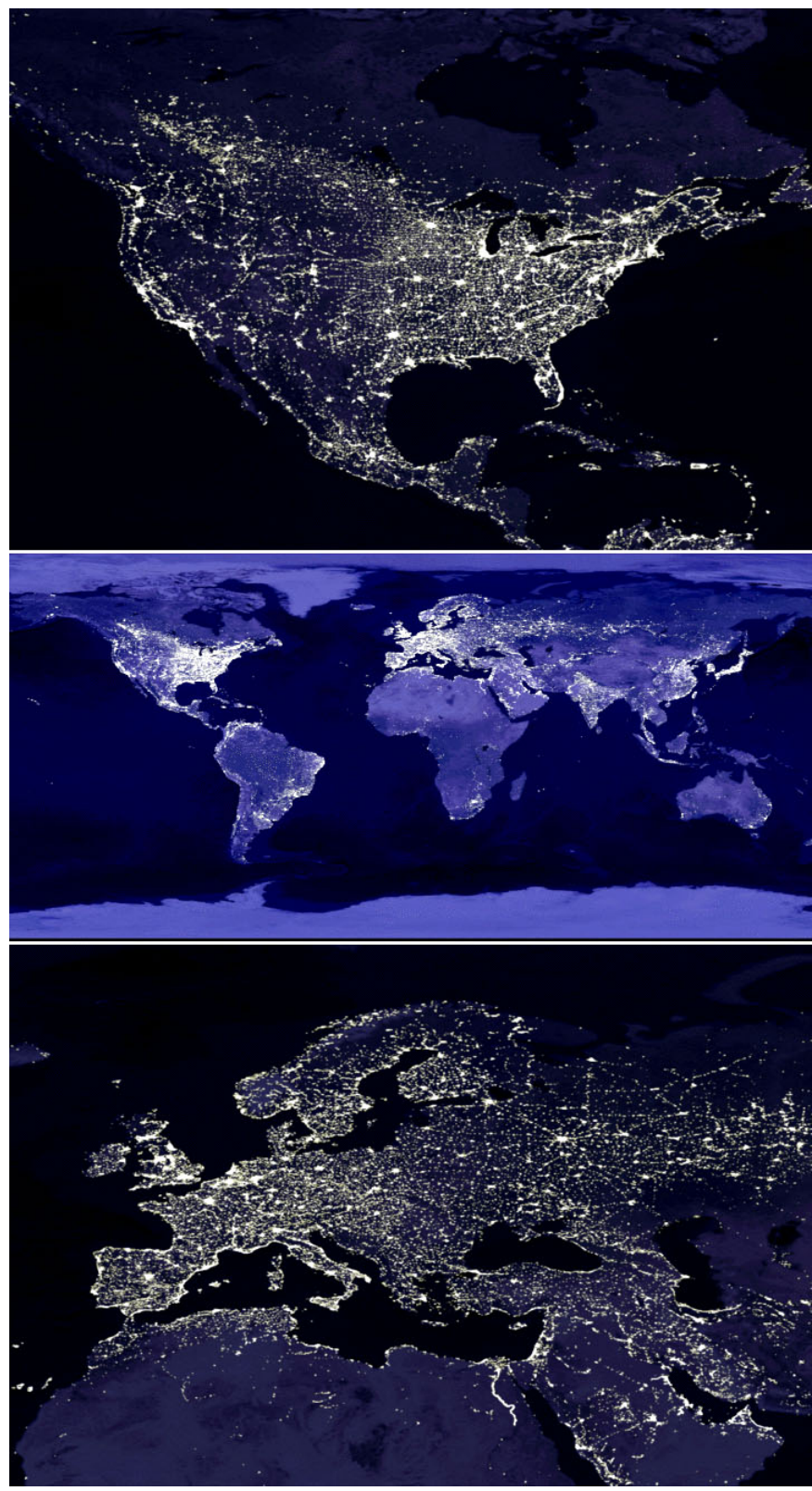

Figure 1 Night lights around the world. Note the hot spots, which resemble the "central places", and which are cities and metropolitan cities. The production and use of light are proxidata for population concentration, energy and matter concentrations and flows, and land use and governance. Source: NASA 2001, http://epod.usra.edu/archive/images/ nightlights/jpg; last accessed October 11, 2005. 
The essentials of the ecosystem (space, matter, energy, information, time) are all fundamentally and specifically altered in cities, compared with other ecological situations where humans may live.

Space is cut off from the surrounding area and made accessible for the purpose of the corporative interests of town inhabitants.

Matter is accumulated for houses, buildings, and connecting streets, to an extent that has today exceeded natural erosion on the global level.

Energy is concentrated in terms of nutrition and technical energy to maintain, support, and increase growth, even on the global level.

Information in ecosystems usually refers to genetic programs of the organisms. This holds true for humans in cities with respect to easier access to sexual partners or mates. In towns "tradigenetic information" (experience and various kinds of information in the form of knowledge passed from generation to generation by oral tradition or written sources as well as in agreements on societal principles and organizations) became the most important ecosystem essential for humans. "Information" and its exchange are the basic and most important features for the development of cities and for the self-acceleration of their development.

Time is the guideline for processes in nature. Since cities are decoupled from natural processes (in many ways), the development of a specific clock cycle was crucial in order to supervise and manage both people and manufacturing processes.

\subsection{Space}

The set up of cities should follow the topographical features of areas, such as altitude, incline, exposure to main wind directions, prevention from flooding, isothermal lines, etc. But in general human efforts may overcome any disadvantage of place (e.g. digging wells or building cisterns in the absence of rivers). Efforts were more laborious in times of strict agrarian regimes and more limited in extent, compared to the efforts made possible by fossil fuels.

Cities should also rely on natural features in terms of improved usage or exploitation of resources in their respective hinterland. Thus with technological progress allowing better processing of natural goods, cities should also be sited at places of accessibility to natural goods (see Table 1), which leads generally into questions and problems of geographic determinism. 
Table 1 Arbitrary List of Cities Founded to Exploit Natural Resources

\begin{tabular}{|c|c|c|c|}
\hline Name & Country & Resource & Founded/ Mentioned \\
\hline $\begin{array}{l}\text { Aachen } \\
\text { (Aquis villa) }\end{array}$ & Germany & $\begin{array}{l}\text { Curative } \\
\text { Water }\end{array}$ & $\begin{array}{l}765 \text { AD first diplomatic mention by King Pipin. } \\
\text { Former stone-age settlement } \\
(3000-2500 \text { BC) }\end{array}$ \\
\hline $\begin{array}{l}\text { Ute City } \\
\text { /Aspen }\end{array}$ & USA / Col. & Silver & 1879 first settlers, named Aspen in 1880 \\
\hline Beatty & USA / Nev. & Mining & $\begin{array}{l}1904 \text { founded as a railroad service centre for } \\
\text { Bullfrog Mine }\end{array}$ \\
\hline $\begin{array}{l}\text { Christiansdorf } \\
\text { (Freiberg, } \\
\text { Saxony) }\end{array}$ & Germany & Silver & silver found in 1168 \\
\hline Coober Pedy & Australia & Opal & $\begin{array}{l}1915 \text { opal was found (kupa piti= white man in a } \\
\text { hole) }\end{array}$ \\
\hline Cripple Creek & USA / Col. & Gold & $\begin{array}{l}1890 \text { gold was found, today abandoned "Ameri- } \\
\text { cas greatest gold camp" }\end{array}$ \\
\hline Denver & USA / Col. & Gold & founded 1859 as gold mining camp \\
\hline Glen Lyon & USA / Pen. & Coal & $\begin{array}{l}1710 \text { coal found. Mining started by the Susque- } \\
\text { hanna coal company } 1869 / 1870 \text {. }\end{array}$ \\
\hline Goldkronach & Germany & Gold & $\begin{array}{l}\text { first settlement about } 1000 \text { AD; mining of gold } \\
\text { since } 1300\end{array}$ \\
\hline Hallstatt & Austria & Salt & $\begin{array}{l}\text { "industrial mining" of salt, proven since } 2000 \text { BC; } \\
\text { world's oldest saltmining }\end{array}$ \\
\hline Johannesburg & $\begin{array}{l}\text { South } \\
\text { Africa }\end{array}$ & Gold & $\begin{array}{l}1886 \text { gold was found in Witwatersrand, mining } \\
\text { settlement }\end{array}$ \\
\hline Karratha & Australia & Iron Ore & $\begin{array}{l}\text { founded } 1968 \text { as a joint State Government - } \\
\text { Hamersley Iron project to meet the expanding } \\
\text { accommodation needs of the mining company }\end{array}$ \\
\hline Kimberley & $\begin{array}{l}\text { South } \\
\text { Africa }\end{array}$ & Diamonds & $\begin{array}{l}1871 \text { diamonds were found. Soon after newspa- } \\
\text { per report nearly } 30.000 \text { inhabitants, today } \\
\text { world's diamond capital }\end{array}$ \\
\hline Mable Bar & Australia & Gold/ Tinn & $\begin{array}{l}\text { named by environment, founded in } 1893 \text {, Austra- } \\
\text { lia's hottest town }\end{array}$ \\
\hline Marienberg & Germany & Silver ore & since 1311 "Marktfreiheit" \\
\hline $\begin{array}{l}\text { Schwaebisch- } \\
\text { Hall }\end{array}$ & Germany & Salt & approx. by end of $11^{\text {th }}$ cent. \\
\hline Sudbury & Canada & $\begin{array}{l}\text { Nickel, } \\
\text { Copper, } \\
\text { Platinum }\end{array}$ & 1880ies \\
\hline Summitville & USA/ Col. & Gold & $\begin{array}{l}\text { founded } 1870 \text {. In } 1883 \text { abandoned after fire, } 1935 \\
\text { mines partly reopened, later supplies for WW II }\end{array}$ \\
\hline
\end{tabular}


The cities listed in Table 1 were new foundations dedicated to the exploitation and processing of natural minerals. It is obvious that they are mostly located in the New World, while most Old World cities had precursor settlements. Nevertheless, quite a few Old World cities developed through the general processing of a vast variety of natural goods, without specializing on niche products, for example for Aquileia (amber) or Krefeld (silk). In the case of severe and unfavorable changes in the natural environment, cities may loose their relevance or even be abandoned (e.g. Maya cities, Ephesus, Mesopotamia, Mohenjo Daro).

The uneven geographic distribution of natural goods leads directly to the space-linked ecosystem essentials of materials (see section 1.3.) and energy (especially fossil fuels, section 1.4.). The increase in the number of cities through history (urbanization) expands the spatial use and exploitation of the hinterland (see Figure 2.). The hinterland is formed by the various needs and demands of the cities that depend on it. Therefore in urbanized areas the vast majority of cultivated landscapes can be considered as byproducts (normally without a master plan) of urbanization.

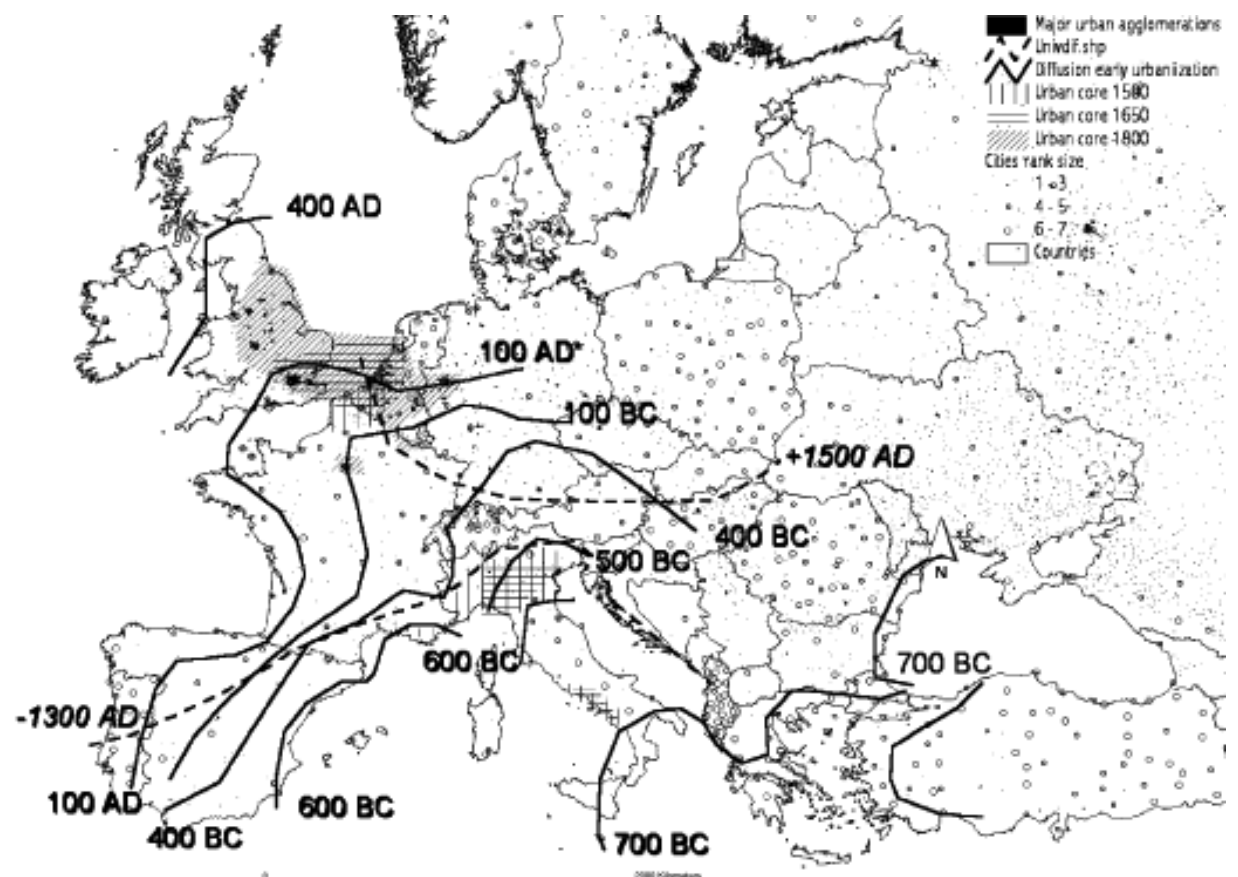

Figure 2. Diffusion of urbanization throughout Europe. Source: From M. Antrop, "Landscape Change and the Urbanization Process in Europe," Landscape and Urban Planning 67 (2004), pp. 9-27, Fig.1. (The original caption reads: "The early urbanization in Greek and Roman times expands from the Southeast from $700 \mathrm{BC}$ to the border of Scotland in AD 400. Universities are created in the cities and indicate an expanding urbanization from the south before AD 1300 to the Northeast after AD 1500. The urban clusters from Northern Italy and Flanders in the sixteenth century shift and expand around the North Sea in the nineteenth century.") Reproduced with permission from Elsevier. 


\subsection{Matter}

The erection of cities depends on the availability of materials for building within reach of the settlement (see also section 1.4.). However, timber and/or stone seem to be available in most areas suitable for human existence. If availability of crucial building materials becomes problematic, cities (settlements) may be abandoned (e.g. pueblos and canyons of the American Southwest) or have to rely on materials from further away, which requires the use of energy supplies, such as wind, water (shipping), or, later, fossil fuels (railway systemsand the internal combustion engine). Energy equivalents produced by the market economy and capital may exceptionally be used to subsidize land transport by muscle power (oxen and horses). The major use of human muscular strength in historic China (carrying and wheelbarrow), even for long-distance transport, appears to be quite unique and has to be considered a large-scale exploitation of a cheap energy source.

In section 1.2. (Space) the foundation of cities is related to the geographic distribution of inorganic matters used by human being. Uneven distribution of biomaterials, which should also be taken into account, is due to the geographic gradients (clines) of various parameters that trigger the occurrence of species. This leads to macro-ecosystems (biomes). Interestingly, the most ancient and important areas of high genetic and species diversity are related to the areas of the earliest cities: the Fertile Crescent, Central America and Indochina. This demonstrates the dependence of the emerging urbanism on agricultural production, since almost all plant or animal species convenient for domestication were taken from such genetic hot spots (see Figure 3.).

There are more cities that process or trade biomaterials from plants (timber, fibres, grain, wine, oil, spices, dyes, amber) than cities that process and trade animal products (furs, bone, hides, shells, fish, cattle). Later in time cities existed that specialized in the exploitation and processing of specific, even singular, biomaterials (Purple, Tyrus; Silphion, ancient North Africa), although a few very peripheral settlements (not really cities) were dedicated solely to biomaterials. This is true, for example, of whaling stations and fur-producing cities; some of the latter started as fortresses during colonization times (e.g. Tumen in Siberia).

In terms of materials, water is the most brought-in and the most used resource in cities. It is essential for any organism, and it is used as a solvent for many technical processes. Rivers through cities not only provide fresh water, but also have the capacity to provide hydraulic power. An important advantage is the selfdisposing of wastewater. As for matter that is no longer wanted in towns (emissions, waste) or that has been transformed into unusable compounds (faeces, manure, sewage), cities depend on effective waste management due to their limited space and the unfavorable consequences for living conditions arising from garbage dumps. Rivers that run through cities have been used for general disposal, while some of the waste was brought to surrounding fields. Increasing numbers of in- 
habitants and intensified technical processes required sophisticated disposal systems, which were sometimes introduced very early in cities, but which only became standard in the nineteenth century after severe global cholera epidemics. The category of emissions also covers the noise caused by human activity. This feature is specifically part of the problem of the increased population density in cities.

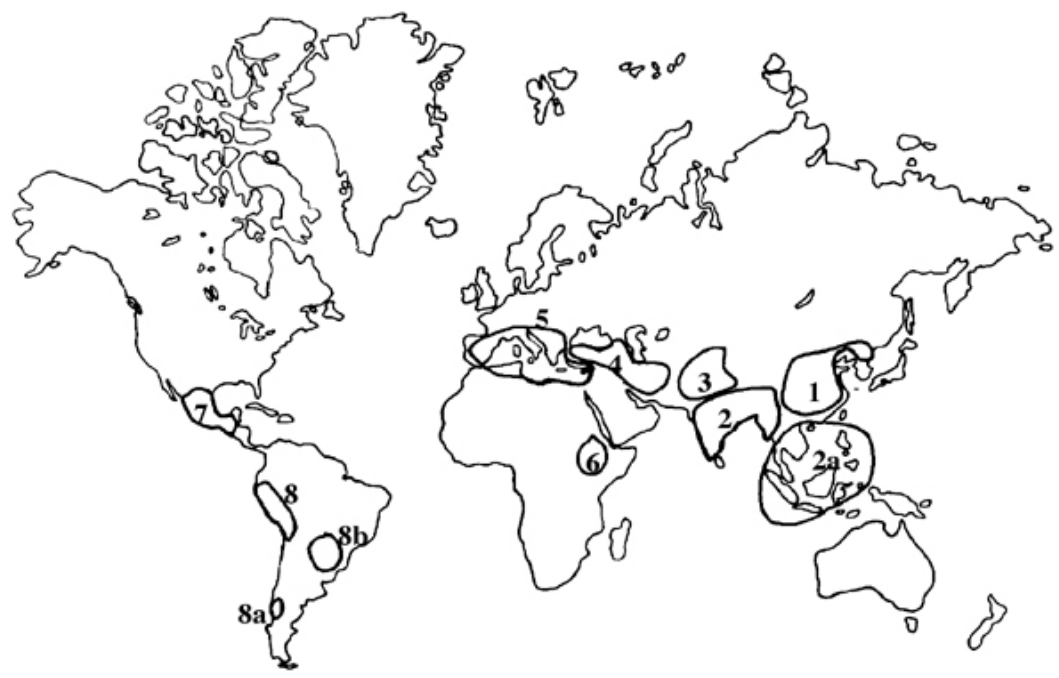

Figure 3. Vavilov Centers of origin of cultivated plants that after domestication led to newly developing areas of diversity of cultivated plants (Harlan Centres) by introgression, i.e. the in- and backflow of genetic material from and to other populations. Both types of centers are highly connected with human activities, but the latter can only exist through human impact. The centres of genetic diversity provide likewise roughly the main animal resources for domestication. Source: From: http://cuke.hort.ncsu.edu/cucurbit/international/vavilov.jpg; last accessed October 12, 2005).

\subsection{Energy}

Cities are mostly differentiated from other eco-structures by changes to what are called "natural cycles". One of these is the energy flow that starts with primary production in ecosystems, i.e. the transformation of solar energy into plant materials. Cities do not provide the energy basis for their maintenance by primary production but depend on energy supplies from outside their area. Again, in contrast to self-organizing ecosystem structures, which are characterized by circular flows, for cities the discharge of matter and energy is symptomatic, which means a constant input of energy is required. As a consequence, a splitting up of "primary structures" leads to the implementation of "secondary structures" of energyconsuming formations. These structures combine artificially what has been split 
before, e.g. maintenance and disposal by (energy-consuming) transportation of waste to garbage dumps outside of towns. Thus cities are consumer exclaves.

Urbanism developed on the energy basis of nutrients for humans (and dependent animals) and of fuel for domestic and manufacturing processes. For almost 9,000 years the only energy basis was provided by crops and wood. Wind and water power have added not much directly, but a little indirectly since antiquity. Fossil fuels came into towns only in the last 500 years, with a culmination around the 1950s. To sustain the inhabitants of a city, the use and exploitation of the area surrounding towns is decisive. An interrelation between land use patterns and energy benefits is predictable. Prosperous cities should not violate cost-benefit principles with respect to the energy required for transportation. Thus, the hinterlands of cities generally follow a similar pattern (von-Thünen circles). Irsigler ${ }^{207}$ has adapted von Thünen's ideas to match up the conditions and situations of medieval towns, which is a useful model for the general coverage of the area around cities in agricultural regimes. He suggested an exploitation model of the town hinterland according to the following spatial divisions:

\section{Close by area}

1) horticulture

2) a- specialised crop for technical usage (dyes, fibre)

b- municipal forest

c- logging

d- hydraulic power

e- fatten pasture

3) improved crop rotation

\section{Distant area}

4) three-field crop rotation

5) two-field crop rotation

6) a- pasture

b- forestry

If the costs of transportation exceed the specific benefit of the natural product or of the commodity, the operational balance for a city becomes negative and the continued existence of the city is endangered. (Southwest American pueblos; decline of the Netherlands in the seventeenth century; peripheral cities in the former USSR).

But maintenance can still be provided by higher subsidization inputs. This is achieved by increased scales for matter/energy flows, usually provided by longdistance trade using ships (energy subsidization by wind energy). However, this

207 Franz Irsigler, "Bündelung von Energie in der mittelalterlichen Stadt,“ Saeculum 42, (1991), pp. 308-18. 
type of subsidization is possible only by using the market as an exchange place to transform matter or money into energy or energy equivalents respectively ( e.g. medieval Florence, since Tuscany could not produce sufficient grain for the subsistence of the town population for the whole year). For transportation, cities rely on traction power provided by domesticated animals (donkeys, oxen, horses, camels). If such animals are not available, the development of cities is strongly hampered (Precolumbian North America, Africa).

\subsection{Information}

Information (in any form, be it encoded in oral tradition or written sources or in technical and manufacturing processes) is the clue to understanding the "nature" and the "success" of cities as structures for organizing human issues. Cities should meet those expectations first by their localization in the landscape, second by their integration into city networks (the central place theory of Christaller ${ }^{208}$ ), and third by their interior organization. Cities should be accessible (with the exception of defensive fortifications) for the purpose of informational exchange, which is provided by connecting streets. (The improvement of arterial road constructions occurs with strongly centralized kingdoms/empires (informational exchange) and an increase in city populations (matter and energy flows).)

The female figures in Lorenzetti's famous fresco in the town hall of Sienna, an allegory for "life in the city," represent peace, fortitude, prudence, magnanimity, temperance, and justice, all being positive characters describing favorable living conditions in a well-governed city. As an effect of the good government inside and outside of the town, his fresco also allegorizes prosperity, happiness, security, and orderly commerce. All these qualities result from informational processes between city inhabitants and the principles of how they regulate living together.

Because of the high informational exchange and throughput (education) per capita and per life history, cities are centers of research, innovation, and excellence. The development of notation systems is linked to the emergence of cities. The attraction of cities is based on the variety of and access to these information processes. Obviously, cities are constantly remodeled in their infrastructure in order to fit the required informational demands. Since early modern times cities have built up archives of nature (e.g. the colonial archives of Seville and natural history museums) and thus offered another possibility for decoupling cities from nature by handling and processing information about natural entities by studying them off site and - with the rise of sciences - increasingly "in vitro".

Life in cities may benefit from informational processes (including judicial privileges) but it might be endangered at the same time by the adaptability of the biological information (i.e. genetic variation) of other organisms, since high popula-

208 Walter Christaller, a German geographer, outlined the influential "Theory of Central Places" in 1933. 
tion densities open up possibilities for epidemic pathogens (some of which in fact emerged only in urban times) as well as for opportunistic pathogens.

\subsection{Time}

Ecosystems are related to time by their stages of maturity. Imagine the initial stage of a future forest, an ecosystem that has an average "life expectancy" of around 300 to 600 years, if it remains untouched. During the initial 10 percent of the time span the floral diversity increases dramatically, but it declines soon after. Some species will be replaced by others. Therefore the maximal and final plant diversity is only reached slowly and does not take place before the final 20 percent of the life span of the system. Similarly, in the case of the fauna there is initially a moderate diversity of species; this then decreases and later increases faster than the plant diversity. The maximal and final diversity likewise reached roughly during the last 20 percent of the life expectancy of the ecosystem.

The example aims to show that there are three different scales of time. One timescale affects the shape of continents, mountains, and rivers and is almost without influence (despite some mythical narratives) for humans. This is the geological time. For humans, cycles as described in the forest example are, however, important; this is called "ecological time". But humans likely do not notice the changes in the forest, since these changes are too small and take place too tacitly for human perception. However, it is necessary to synchronize human activities with the natural cycles within the forest ecosystem, otherwise the community might run out of resources. The third timescale directly regulates the synchronization of human activities. Equivalents of these timescales can be found in historical theories and may be addressed as longue durée, durée structurelle, or histoire evenementielle respectively.

In cities, humans became more and more decoupled from ecological time and seasonal variations, as variations in climate and nutrient flows are diminished and access to energy and matter is stabilized. The necessity of coordinating peoples in towns generates and favors systems of time measurement to synchronize human activities effectively. However, the consequences of human activities (e.g. the economy, management of natural sources, warfare) certainly affect the material basis for the long-term persistence of cities, which is nothing but the influence on the ecological time of the ecosystem "city" by its own inhabitants.

\subsection{Comparative summary}

Cities are ecosystems, but in contrast to other ecosystems, they do not emerge by themselves and they are unable to maintain themselves, they are therefore not autopoietic systems in terms of self-reproduction. The ecosystemic character of a city applies to abiotic features (soil, water, climate) and biotic features (humans, plants, animals). These factors are linked by energy and material flows and build a 
dynamic structure. Urban ecosystems are superimposed by "cultural" (informational) structures (see Table 2). Urban systems depend on the hinterland (sometimes for specific materials or energy equivalents by extreme extension of the hinterland, i.e. extending the hinterland even into other continents).

Table 2. Ecological Character of "Natural" and "Urban" Ecosystems. Source: Adapted from Padberg, Die Oase aus Stein (1994)

\begin{tabular}{|c|c|c|}
\hline & $\begin{array}{l}\text { „NATURAL“ ECO- } \\
\text { SYSTEMS }\end{array}$ & $\begin{array}{c}\text { „URBAN“ } \\
\text { ECOSYSTEMS }\end{array}$ \\
\hline system factors & $\begin{array}{l}\text { abiotic, biotic } \\
\text { self-organization of } \\
\text { regulation processes }\end{array}$ & $\begin{array}{l}\text { abiotic, biotic, cultural } \\
\text { no self regulation }\end{array}$ \\
\hline $\begin{array}{l}\text { interrelation of producers, consum- } \\
\text { ers, and reducers }\end{array}$ & spatial entity & spatial segregation \\
\hline $\begin{array}{l}\text { state of equilibrium between produc- } \\
\text { ers, consumers, and reducers }\end{array}$ & balanced & $\begin{array}{l}\text { overbalance of consumers } \\
\text { outsourcing of producers and } \\
\text { reducers }\end{array}$ \\
\hline material cycling & closed ("recycling") & no, discharge \\
\hline energy flow & natural & $\begin{array}{l}\text { natural, but moderated; } \\
\text { also artificial, subsidised by } \\
\text { fossil energy }\end{array}$ \\
\hline $\begin{array}{l}\text { processes to regulate material cycles } \\
\text { and energy flows }\end{array}$ & natural & $\begin{array}{l}\text { partly natural, but moderated } \\
\text { by humans } \\
\text { partly anthropogenic }\end{array}$ \\
\hline abiotic spatial features & natural & anthropogenic modified \\
\hline organismic community & natural successions & anthropogenic modified \\
\hline change & slow & fast \\
\hline
\end{tabular}

This ecosystemic comparative approach seems to suggest an opposition between "natural" and "urban". But in reality this comparison is not between "natural" and "artificial" or "cultural", but merely describes the differences between systems by discrimination. Since the vast majority of humans tend to live in a specific (urban) environment that maintains and enhances the reproductive success of the human species, overall urban environments are not "artificial" in terms of being unfavorable to or even against human biology or human ecological principles. On the contrary, they support and improve human interests. Thus "cities" should be considered a specific invention to benefit and serve human ecological demands. In this respect, it is not decisive that urban life depends on a number of technical inventions (cultural protheses) that help to accelerate all informational (cultural) processes in cities. But it is decisive that the human species has been able so far to provide such inventions to fend off many unfavorable conditions from human life - 
Table 3. (left) Differences between non-urban and urban ecosystems with respect to the biosphere. Source: From WBGU (Wissenschaftlicher Beirat der Bundesregierung Globale Umweltveränderungen), Welt im Wandel: Erbaltung und nachbaltige Nutzung der Biosphäre (Heidelberg, New York, Barcelona: Springer, 2000). For the English version, see German Advisory Council on Global Change (WBGU), Conservation and Sustainable Use of the Biosphere (London: Earthscan, 2000). An internet version is available at: http://www.wbgu.de/wbgu_jg1999_engl.html, last accessed October 14, 2005.

\begin{tabular}{|c|c|c|}
\hline & $\begin{array}{l}\text { NON-URBAN } \\
\text { ECOSYSTEM }\end{array}$ & $\begin{array}{c}\text { URBAN } \\
\text { ECOSYSTEM }\end{array}$ \\
\hline System limitation & $\begin{array}{l}\text { functionally limited by the } \\
\text { weakest intrasystemic } \\
\text { relations; } \\
\text { but also geographically limited } \\
\text { (forest periphery, } \\
\text { bank of a lake) }\end{array}$ & $\begin{array}{l}\text { geographically limited, e.g. town limit, } \\
\text { settlement boundary }\end{array}$ \\
\hline $\begin{array}{l}\text { Biogeochemical and } \\
\text { energy flows }\end{array}$ & $\begin{array}{l}\text { energy received mainly form } \\
\text { the sun; } \\
\text { self-contained biogeochemical } \\
\text { cycles }\end{array}$ & $\begin{array}{l}\text { import of fossil fuels, inorganic and organic } \\
\text { resources; } \\
\text { high biogeochemical turnover and genera- } \\
\text { tion of large quantities of wastes and emis- } \\
\text { sions; } \\
\text { exports of wastes and emissions and import } \\
\text { into the environmental media }\end{array}$ \\
\hline $\begin{array}{l}\text { Degree of integration } \\
\text { (system intercon- } \\
\text { nection, whereby } \\
\text { each system is } \\
\text { functionally linked } \\
\text { with the sphere of } \\
\text { influence of an- } \\
\text { other) }\end{array}$ & $\begin{array}{l}\text { causal and functional; } \\
\text { heavily integrated ecosystem; } \\
\text { corresponds to functional } \\
\text { ecosystem }\end{array}$ & $\begin{array}{l}\text { living creature in the area not necessarily } \\
\text { linked by causal and functional relation- } \\
\text { ships; } \\
\text { in an extreme case completely disintegrated } \\
\text { ecosystem feasible; } \\
\text { system elements do not maintain any 'eco- } \\
\text { logical' relationships; } \\
\text { corresponds to geographic ecosystem }\end{array}$ \\
\hline $\begin{array}{l}\text { Succession } \\
\text { (sequence of vari- } \\
\text { ous stages of } \\
\text { development, } \\
\text { succession of plant } \\
\text { communities in } \\
\text { certain ecosystems } \\
\text { over a period of } \\
\text { time) }\end{array}$ & $\begin{array}{l}\text { succession of ecosystems } \\
\text { mainly caused internally or } \\
\text { controlled; } \\
\text { succession deterministic, i.e. } \\
\text { targeted, repeatable and pre- } \\
\text { dictable to a certain extent; } \\
\text { final community often predict- } \\
\text { able }\end{array}$ & $\begin{array}{l}\text { succession of urban biocoenoses have a } \\
\text { historical character and are subject to an- } \\
\text { thropogenic influences; } \\
\text { succession not deterministic, not repeat- } \\
\text { able, not predictable, most on the basis of } \\
\text { social science studies; } \\
\text { final community not predictable }\end{array}$ \\
\hline $\begin{array}{l}\text { Invasion } \\
\text { (invasion of living } \\
\text { creatures into } \\
\text { habitats that they } \\
\text { otherwise do not } \\
\text { inhabit) }\end{array}$ & $\begin{array}{l}\text { generally relatively resistant to } \\
\text { the invasion of alien species; } \\
\text { number of species is generally } \\
\text { limited to a certain level }\end{array}$ & $\begin{array}{l}\text { particularly large number of alien species } \\
\text { because of favourable distribution and } \\
\text { naturalisation conditions }\end{array}$ \\
\hline
\end{tabular}




\begin{tabular}{||l|l|l||}
\hline \hline $\begin{array}{l}\text { Sustainability and } \\
\text { equilibrium }\end{array}$ & $\begin{array}{l}\text { establishment of a dynamic } \\
\text { equilibrium under natural con- } \\
\text { ditions and over a long period } \\
\text { (decades or centuries) }\end{array}$ & $\begin{array}{l}\text { states of equilibrium in urban biotic com- } \\
\text { munities more or less ruled out because the } \\
\text { system will probably be destroyed before } \\
\text { the state of equilibrium can be attained }\end{array}$ \\
\hline Biodiversity & $\begin{array}{l}\text { species abundance } \\
\text { 'normal' }\end{array}$ & $\begin{array}{l}\text { high diversity of sites, organisms, and biotic } \\
\text { communities }\end{array}$ \\
\hline
\end{tabular}

precisely in cities. Despite the fundamental differences between urban and nonurban ecosystems, there are other differences that have to be stressed. They bring into focus the functional characters and links between system elements and biological entities (see Table 3).

Cities can be described and analysed in terms of ecological approaches, and once they have achieved a certain stage, they even show cyclic phases of developmental stages as other ecosystems do (see Figure 4.).

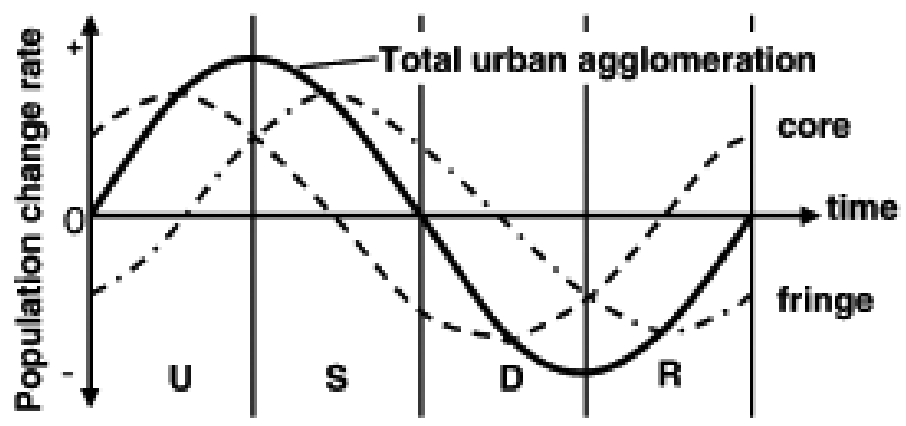

Figure 4. Cyclic model of stages of urbanization based upon population change in core and fringe zones of urban agglomerations. Compare Table 6. Notes: $\mathrm{U}=$ urbanization; $\mathrm{S}=$ suburbanization; $\mathrm{D}=$ disurbanization or counterurbanization; $\mathrm{R}=$ reurbanization phase. Source: From Antrop, "Landscape Change", Fig. 2; reproduced with permission from Elsevier.

As city ecosystems are created and maintained only by human decisions, they do not emerge by themselves. This is why I consider this cyclic behaviour as a mere analogy (instead of a homology), especially as it is described only for contemporary cities. Therefore one should be wary of biological analogies which are willingly absorbed by decadence or depravation theories that address cities as if they were organisms and subjects of organismic evolution or selection. Those approaches are fallacies. 


\section{Nature in the City}

\subsection{Human Population, Population Density, and Epidemics}

In this section, humans in cities are looked at as being part of the natural components with respect to the population, its density, and density-related deviations of human biology. Since Malthus' times and perhaps according to earlier deprivation theories, cities have been considered to need a constant input of humans to maintain their size, since urban mortality constantly worked against a stable or even increasing population number. Generally speaking there are not many reliable population data prior to the seventeenth century. Available information concentrates almost exclusively on urban settlements, i.e. there are no data for the countryside.

Although precise numbers do not exist for pre-modern times, historic demographers agree on the "notorious higher urban mortality", at least after 1500. It is assumed that London in the seventeenth and eighteenth centuries already absorbed the birth surplus of the whole of England to compensate for the death rate. At this time the urbanization process in England was exclusively concentrated on London. Already at the beginning of the sixteenth century in the Netherlands more than 30 percent of the inhabitants lived in towns, and from the middle of the seventeenth century the population expansion of cities was possible only by reducing the population in the countryside or by massive immigration from other countries. In both examples, London and the Netherlands, urbanization is clearly a populationreducing feature. But these are exceptional cases, differing from other countries. ${ }^{209}$

While this "model of natural decrease" may hold true for the overall total of a city population, it is evident that the general mortality pattern does not apply to all residents in cities. A tendency for a correlation between mortality rates and town size was found for pre-industrial cities, but there are clear differences in the mortality patterns of different social groups. Lower-class residents (mostly highly mobile and unmarried migrants who give rise to the "model of urban migration") exhibit a high mortality rate. This resulted in a high "turnover" of lower-class residents and a constant flow of underprivileged people into cities. In contrast, upperclass residents were able to manage the reproduction of their class without nonurban inputs by matching or even exceeding the number of deaths through reproductive success. Reliable figures since the seventeenth century reveal death rates for urban children (up to age 6) of around 40-50 percent, while smaller towns and

\footnotetext{
209 The demographic data used here are basically taken from the survey in Padberg,Die Oase aus Stein; for Halle see Arthur Imhof, "Mortalität in Berlin vom 18. bis 20. Jahrhundert." Berliner Statistik 31(8) (1977), pp. 138 - 45, here p. 142; for Tuscany, see David Herlihy, "Outline of population developments in the Middle Ages," in: Bernd Herrmann and Rolf Sprandel (eds.), Determinanten der Bevölkerungsentwicklung im Mittelalter. (Weinheim: Acta Humaniora, VCH, 1987, pp. 1 - 23.
} 
the countryside showed death rates of about 25- 30 percent. But the lower-classes contributed much more to the total mortality in infants, as for example in nineteenth-century Halle (Germany), were 55 percent of all deaths were of lower-class children who died before the age of 10 , whereas only 27 percent of all deaths in that age group were of upper-class children. Among other things, this points to different parental investment strategies, as well as to specific fertility behaviour. As dying is generally unpredictable, influencing fertility is the recommended strategy for manipulating the numbers of the living. For Renaissance Tuscany, for example, the fertility of upper-class urban people was increased by reducing the age of marriage for females.

All this leads into attitudes toward sexual behavior birth control, as well as into public and tacit moral mentalities. There should not be many differences between social rules in towns and in the countryside with respect to sexual regulations and moral settings, whereas everyday life and common practices may have differed enormously. Differences in the numbers of males and females of urban populations are important though not well investigated. Due to traditional gender roles in Western societies, females mostly outnumbered males in cities from medieval to recent times, because of warfare loss among males.

No doubt there is a higher density and therefore probably a higher number of people in cities than outside, at least in the urban hinterlands. But what are the measures for population density in cities? Throughout the eighteenth century Prussia (core area) was a genuine farming state. Therefore I use it here as a model for calculating the average numbers for a reasonably advanced agrarian regime in preindustrial times. The population density by 1725 is around 10 residents per square kilometer (approx. 25 residents per square mile), and the numbers for 1801 are about 20 residents per square kilometer (50 residents per square mile). 210

The increase in residents is due to the beginning of the demographic transition after the 1750s, active population policy, and some minor progress in farming methods. Therefore a number between 25 and 50 residents per square mile might be taken as a benchmark for the carrying capacity of a reasonably advanced agricultural regime in low fertility areas. The number of residents in more fertile farming areas is unlikely to have exceeded this figure by more than four times. This gives for non-urbanised areas, given advanced agriculture and one harvest per year, an estimate of at most 200 residents per square mile for prime soil regions. These numbers give a vague idea of the carrying capacities of thinly urbanized areas dedicated to agriculture, where human life is essentially triggered by primary production (plant growth and harvest by humans or domesticated animals). By comparison cities carry immense numbers of people, especially as they are totally dependent on primary and secondary production of non-urban places. Table 4 shows selected data on population densities in various cities.

210 The population data taken from Friedrich W.A.Bratring, Statistisch - topographische Beschreibung der gesamten Mark Brandenburg (1809, reprinted Berlin: de Gruyter 1968) 
Table 4. Population densities per square kilometer in selected cities by years. Source: Data taken from www.demographia.com As any demographic data, also those provided by demographia.com are criticized for various reasons, mostly for occasionally inclusion of peri-urban areas of unknown size. However, the advantage is that those data are easily accessible, they are correct at least within an order of magnitude, and they are arranged in a suitable way. Since they are also used by government and academic bodies, they are considered to be reliable by and large.

\begin{tabular}{||l|l|rr|rl||}
\hline \hline City & 1600 & 1800 & \multicolumn{1}{|c||}{ Current } & \\
\hline Berlin & & & 3,800 & $(2003)$ \\
\hline Buenos Aires & & $904 \quad(1869)$ & 13,883 & $(2001)$ \\
\hline Kolkata (Calcutta) & & & & 33,000 & $(1991)$ \\
\hline London & $20,0000^{*}$ & $34,749(1821)$ & 5,901 & $(2001)$ \\
\hline New York & & $101 \quad(1800)$ & 10,238 & $(2000)$ \\
\hline Paris & $96,512 \quad(1637)$ & $15,851 \quad(1801)$ & 20,240 & $(1999)$ \\
\hline Tokyo & & & & 5,517 & $(2000)$ \\
\hline
\end{tabular}

Note: $*$ number of residents only, as area is unknown

These numbers considerably exceed the carrying capacity for humans of the surrounding areas of towns, as estimated above. Already by the high Middle Ages cities in Europe greatly exceeded the carrying capacity of non-urbanized areas. Benevolo 211 , for example, counted 100,000 residents in Florence in the middle of the thirteenth century, living on not more than two square miles. The computed surface area value per resident is 48 square meters ( 57 square yards), but this would include the total area of the city surface, even the Arno River. Such a high biomass concentration is surprising given infrastructure and transport facilities of that time, but these obviously coped successfully with the necessary and extended flows of matter and energy.

I try a different approach by taking biomass as a standard. The tropical rain forest, which is the ecosystem of highest biomass concentration on earth, contains around $800,000 \mathrm{~kg}$ of biomass per ha (2.47 acres), including all organisms except those in the soil. I take this as the maximum "natural" biomass ratio. The biomass concentration in temperate forests is of course lower at around $150,000 \mathrm{~kg} / \mathrm{ha}$ [i.e. $15 \mathrm{~kg} / \mathrm{m}^{2}$, but this may be considered the maximum "natural biomass ratio" in temperate European regions. Industrialized contemporary agriculture produces biomasses of up to $14 \mathrm{~kg} / \mathrm{m}^{2}$ (grain and straw) and $25 \mathrm{~kg} / \mathrm{m}^{2}$ (energy maize), which is a man-managed and hence "artificial" primary production.

Assuming an average biomass for a mediaeval resident of $40 \mathrm{~kg}$, Florence carried almost $0.8 \mathrm{~kg}$ of human biomass $/ \mathrm{m}^{2}$. Despite the apparently high number of residents in thirteenth-century Florence, the biomass ratio (with respect to humans

211 Quoted from the German edition. English edition: Leonardo Benevolo, The European City (Oxford, Cambridge: Blackwell, 1993) 
only) was considerably below that of an average temperate European forest (15 $\mathrm{kg} / \mathrm{m}^{2}$ ), as are all values calculated for cities in history (see Table 5). We must not forget that within this estimation humans are at the summit of the food pyramid. A basic principle of general biology teaches that biomass is reduced from one stage in the food pyramid to the next by roughly a factor of 10 . Thus our estimate ends within an order of magnitude of less than two pyramid stages with respect to the human population in medieval Florence, if it is compared with the productivity of the temperate European forest. Such values for cities seem indeed still comparatively high given the fact that city ecosystems are not primary producers, although they do concentrate the biomass production of huge hinterland areas.

Table 5. Human Biomass Ratios per Square Meter of City Area for Selected Cities.

\begin{tabular}{||l|c|c||}
\hline \hline CITY & YEAR & $\begin{array}{c}\text { HUMAN } \\
\text { BIOMASS } \\
\text { RATIO [KG/M }]\end{array}$ \\
\hline Florence* & 1250 & 0.8 \\
\hline Paris & 1365 & 2.9 \\
\hline Paris & 1637 & 4.3 \\
\hline Paris & 1700 & 2.0 \\
\hline Paris & 1784 & 0.8 \\
\hline Paris & 1796 & 0.7 \\
\hline Paris & 1856 & 1.5 \\
\hline Paris & 1921 & 1.2 \\
\hline Paris & 2000 & 1.0 \\
\hline London & 1901 & 0.6 \\
\hline Buenos Aires & 1991 & 5.2 \\
\hline Kolkata (by Indian Gov.) & 1991 & $1.3[?]$ \\
\hline Los Angeles & 2000 & 0.16 \\
\hline Berlin & 2000 & 0.2 \\
\hline London & 2000 & 0.2 \\
\hline Mexico City & 2000 & $0.2[?]$ \\
\hline New York & 2000 & 0.5 \\
\hline Tokyo & 2000 & 0.6 \\
\hline Delhi & 2001 & $0.4[?]$ \\
\hline \hline
\end{tabular}

Note: The calculations are based on density data provided by Demographia; average resident weight assumed with $50 \mathrm{~kg}$ for contemporary cities; $45 \mathrm{~kg}$ for London in 1901 and Paris until 1856; $40 \mathrm{~kg}$ for Florence 1250; $40 \mathrm{~kg}$ for Buenos Aires, Delhi, Kolkata, Mexico City. The numbers for Kolkata, Mexico City, and Delhi likely to be underestimates, although originally taken from government sources. $-*$ data from Benevolo

Our approach offers a surprise. The numbers for human biomass per area appear counterintuitive, as one would expect higher human biomass concentrations in towns correlated to increased world, continent, country populations and an increased degree of urbanization. But it seems that times of prime densities are al- 
ready gone (early modern Paris), with the exception of contemporary Buenos Aires, where the high biomass values are attributable to overpopulated slums.

Overall, we may consider that the human biomass ratios of the vast majority of contemporary cities are considerably below 1.0 (or within an order of magnitude of that value). This would imply that cities adjust to a capacity level which balances the physical needs of residents as well as social demands and options. The numbers given in Table 5 suggest a capacity optimum below and around 1.0 for cities. ${ }^{212}$ The computed values for Paris represent an average surface area per resident of 15 square meters in 1365 and of 10 square meters in 1637. Even, if these numbers are incorrect or educated guessing, since many determinants cannot be taken into account or simply remain unknown, I assume they are reliable within an order of magnitude.

Increasing density leads to enlarged city areas, in order to give relief to the residents for functional as well as for anthropological demands. This holds true, for example, for the reduction of densities in Paris as given in Table 5. Enlarged areas allow residents to move to suburbs. In some cases, suburbs today are more densely populated than the centers of the respective cities (see Table 6).

Table 6. Density of Residents in Suburbs of Selected Contemporary Cities.

\begin{tabular}{||l|c|l|c|l||}
\hline $\begin{array}{l}\text { CITY } \\
(1997)\end{array}$ & $\mathrm{KM}^{2}$ & $\begin{array}{l}\text { CITY- } \\
\text { RESIDENTS } \\
/ \mathrm{KM}^{2}\end{array}$ & SUBURB-KM & $\begin{array}{l}\text { SUBURB- } \\
\text { RESIDENTS } \\
/ \mathrm{KM}^{2}\end{array}$ \\
\hline Amsterdam & 220 & 4.283 & 1.253 & 1.002 \\
\hline Berlin & 892 & 3.900 & 4.476 & 178 \\
\hline Hamburg & 755 & 2.300 & 18.116 & 130 \\
\hline London & 1.578 & 7.074 & 8.807 & 4.883 \\
\hline Vienna & 414 & 3.934 & 4.664 & 128 \\
\hline Zurich & 92 & 3.900 & 847 & 700 \\
\hline
\end{tabular}

Source: Data from http://www.wien.gv.at/vtx/vtx-rk-xlink?SEITE=019990111009; last accessed October 14, 2005. One might question these values, as they were computed by the city authorities to prove that Vienna was the best metropolitan area in Europe with respect to suburban density.

Density raises the question of "privacy" for people living in highly populated areas. Unfortunately, there seems to be no analysis available on the "processes of civilization" in cities, as Norbert Elias did for a variety of other features, and "cities" are also not a category dealt with in analyses of the Burckhardt and Huizinga type. This again is remarkable, since cities were the most visible and the most influential structures of the

212 Of course, this value is somewhat arbitrary, as it depends on a number of assumptions that might be questionable and on numbers that might be doubted. However, it is not the respective value that is important for my argument, but the similarity of the way in which this value is found for different cities. Changing the numbers in the calculations would certainly lead to different values, but the message would be similar. 
Old World in Europe already by 1500 . At a very rough estimate the daily nutritional intake of an average adult person in pre-industrial times was $1 \mathrm{~kg}$ of food per day (dry weight), which can serve as a basic value for the minimum daily food flow into noncontemporary cities, not forgetting the fodder for animals kept in towns.

The history of epidemic diseases is mostly a history related to urbanism. I assume that these developments are well known and thus will not go into details. It is mentioned here because it is probably the most important determinant in population history and because it is clearly density dependent. One important difference between cities and the countryside emerges not earlier than by the end of the nineteenth century. By that time the mortality in cities (at least in Germany ${ }^{213}$ ) had fallen below the mortality in the countryside. Similar developments took place in other (Western) European countries, though in different decades. The reasons lay mainly in the improved accessibility to health care, a better sanitary infrastructure, and health education in cities.

This achievement is a milestone in the ecohistory of cities, as previously residents had been prone to dangerous infectious diseases for thousands of years, as most epidemic diseases depend on population density. After the discovery of the pathogens that caused these dangerous diseases, major developments to combat them were possible by the invention of the autoclave, improved hygienic behaviour, and vaccination. Since hospitals are located in cities, residents now benefited from them. However, the support of accompanying measures was necessary, such as improved sewerage systems, waste disposal, and fresh water supply.

\subsection{Displaced Nature, Resettled Nature, Cited Nature}

Mumford coined the expression that a city is an "inverted oasis of stones or clay", which points to the most notable property of cities. They are areas where "nature" is primarily removed and replaced by buildings. Cities are surrounded by walls to protect residents against predators (animals and, more importantly humans), which also mark the distinct difference between the "nature containing" outer environment (agriculture, wilderness) and the "nature-free" inner environment of cities. "Nature-free" means the absence of natural elements that would exist on that area without a city. Of course, this does not include the natural media, although water flow, soil, and air are sometimes influenced, and perhaps even managed by city arrangements.

There are two main elements of "nature" which are moderated by humans in cities, one being plants and the other animals. With respect to these organisms, city communities seem to discriminate between "good nature", which means tolerable organisms at tolerable places, and "bad nature", which is fought off. "Good nature" is deliberately given space of its own in cities. Public parks were likely first introduced in medieval Italian cities, and certainly started as private establishments. The idea of public parks as unsealed city areas, places for recreation and watching small animals leads

213 Alfons Labisch and Jörg Vögele, „Stadt und Gesundheit“, Archiv für Sozialgeschichte 37 (1997), pp. $396-424$ 
directly into the almost regular establishment of public greens in nineteenth-century Western urban design, for example Central Park, New York.

Sealing the city surface prevents plants from growing. However, horticulture of various kinds on city plots is a common practice. But streets and public places were without greenery for a long times. Because of their fire-resisting capacity, oak trees were sometimes introduced in medieval towns, but not regularly. Possibly this is one of the origins of street trees.

It would be interesting to do comparative work on city maps with respect to public and private green areas, an idea that is briefly sketched here for the city of Berlin. ${ }^{214}$

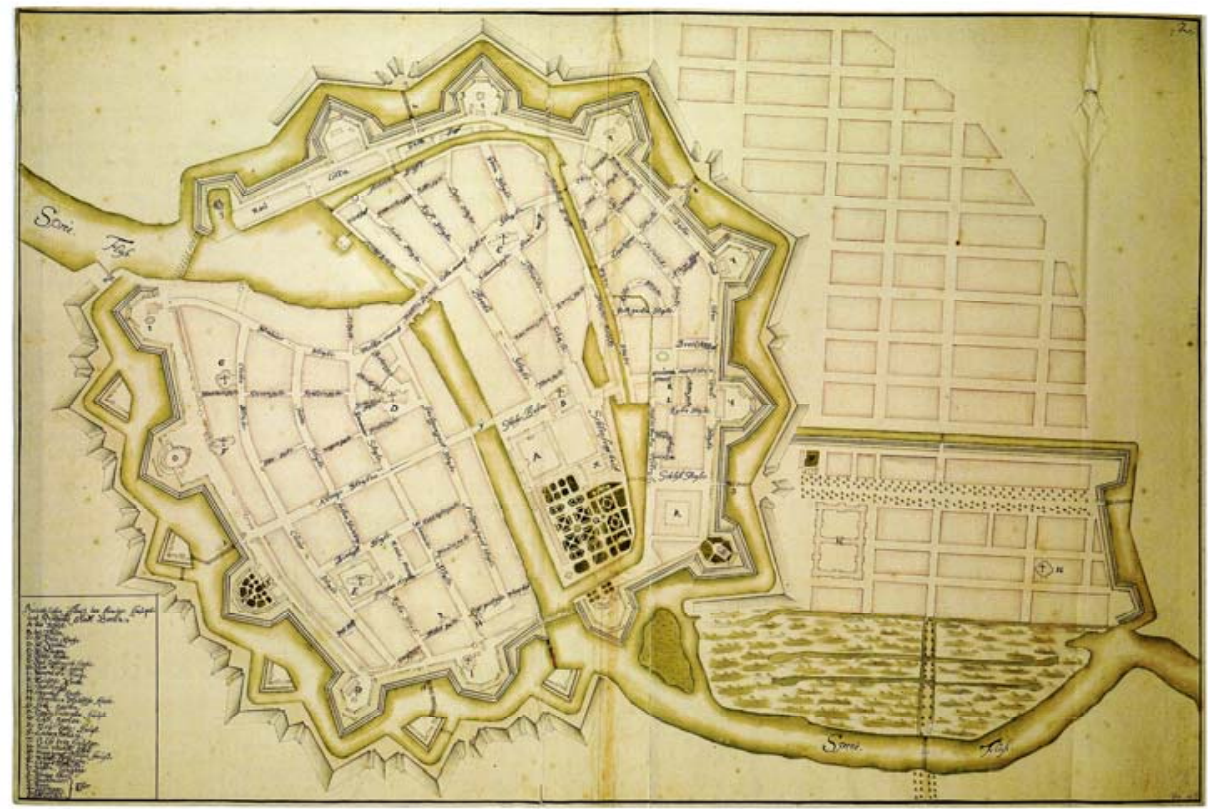

Figure 5. Berlin 1712. - The map shows a huge castle park, but no green areas in public places except for non-canalized river banks, graveyards, and a small baroque garden in front of the theatre. There are no trees in the streets, except those planted for decoration in front yards (if any) or in street areas closely attached to private property. But the first decree on public protection of private trees, grapevines, and bushes on street verges already published in 1660. Penalty: cutting off a hand. [Source: Brunnen- und Gassen-Ordnung beyder Residentz- und Haupt-Städte Berlin und Cölln an der Spree. Vom 14ten August $1660, \$ 13$. (available as digitalized source by courtesy of the Staatsbibliothek Berlin, http: // altedrucke.staatsbibliothek-berlin.de/Rechtsquellen/CCMT51/start.html,Bild 03346)]

${ }^{214}$ Figures 5. to 9. are taken from Günter Schulz, Stadtpläne von Berlin 1652 bis 1920, Schriftenreihe des Landesarchivs Berlin, vol. 3 (Berlin: Gebr. Mann, 1998) and Günter Schulz und Andreas Matschenz, Stadtpläne von Berlin 1652 bis 1920, Schriftenreihe des Landesarchivs Berlin, vol. 4 (Berlin: Gebr. Mann, 2002) Unfortunately, these publications focus on maps as a printing and cartographical medium rather than on the qualities of changes in interior city organization. Thus my approach is tentative; a proper analysis needs to look at the original maps. 


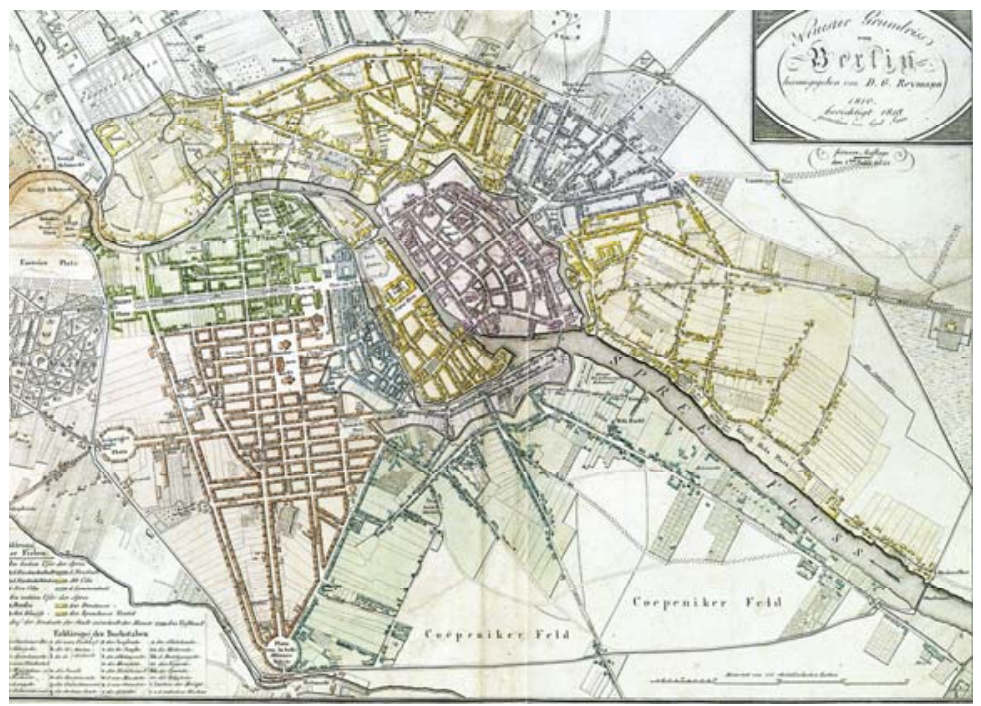

Figure 6. Berlin 1821 Various public green areas con be seen, including the tree-shaded "Lustgarten" developed from the former castle park. The boulevard "Unter den Linden", with rows of lime trees, is integrated into the city and connects the king's palace and the "Tiergarten" (the noble hunting ground). The planting emphasizes the ceremonial character of the street and echos elements of baroque palace gardens. "Unter den Linden" was first planted with 1,000 lime trees and 1,000 walnut trees in 1647, following the model of lime-tree parkways of Fürst Johann Moritz von Nassau-Siegen. After 1800 chestnut, plane, maple, and mountain ash trees were preferably planted.

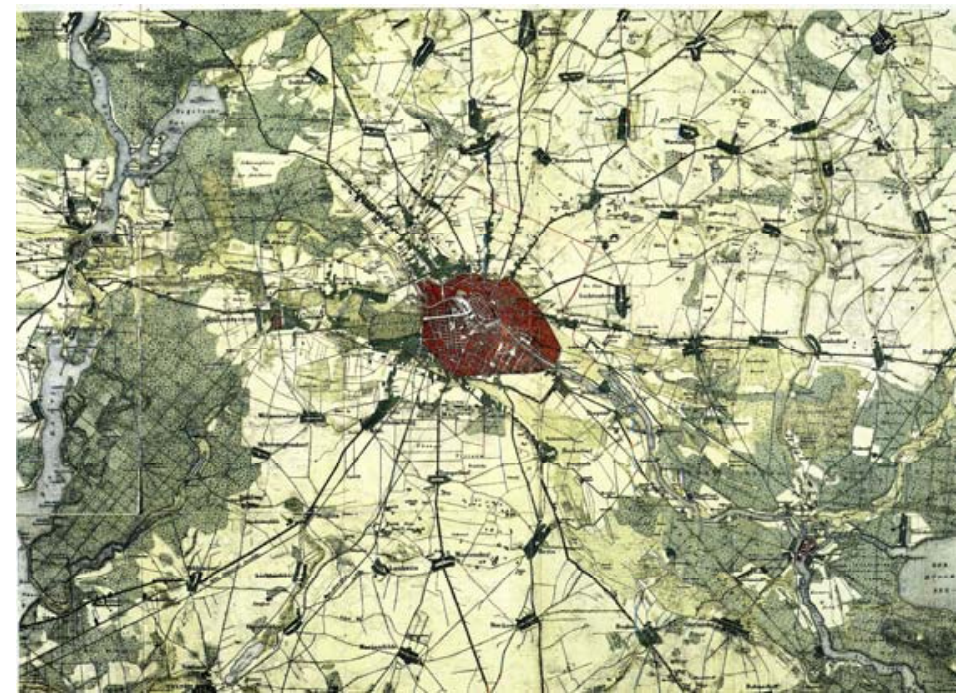

Figure 7. Berlin 1853. This map shows the whole metropolitan area of today. Huge areas of green, lakes, and the arable land surrounding the city became integrated gradually without displacing nature totally. 


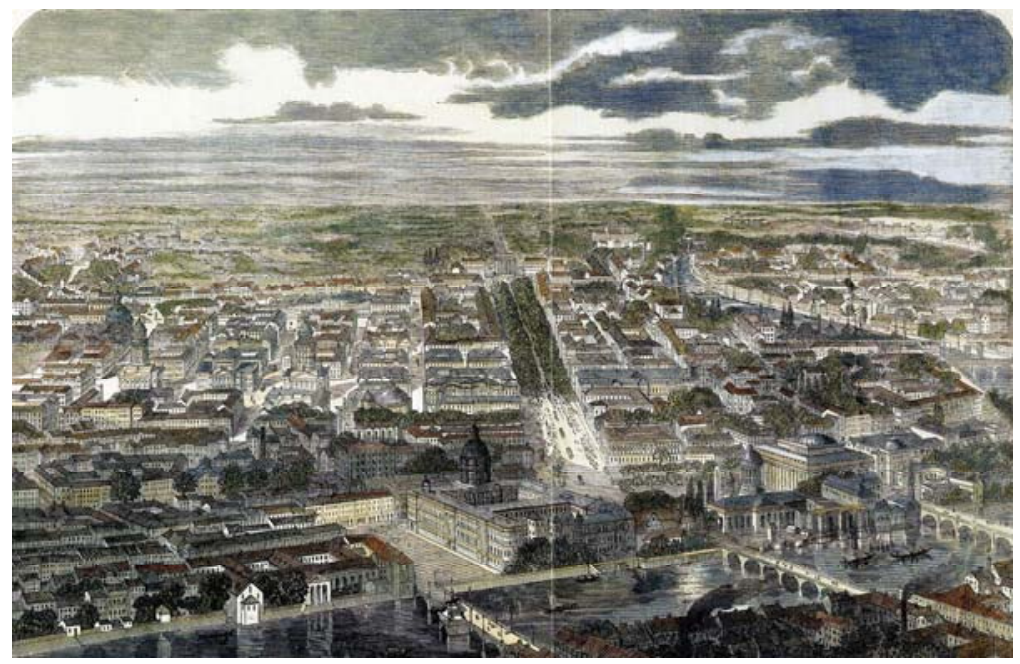

Figure 8. Berlin 1858. A birds's eye view along "Unter den Linden" looking toward the "Tiergarten". Other street trees are also visible. Contemporary genre paintings exhibit private plots with considerable greenery.

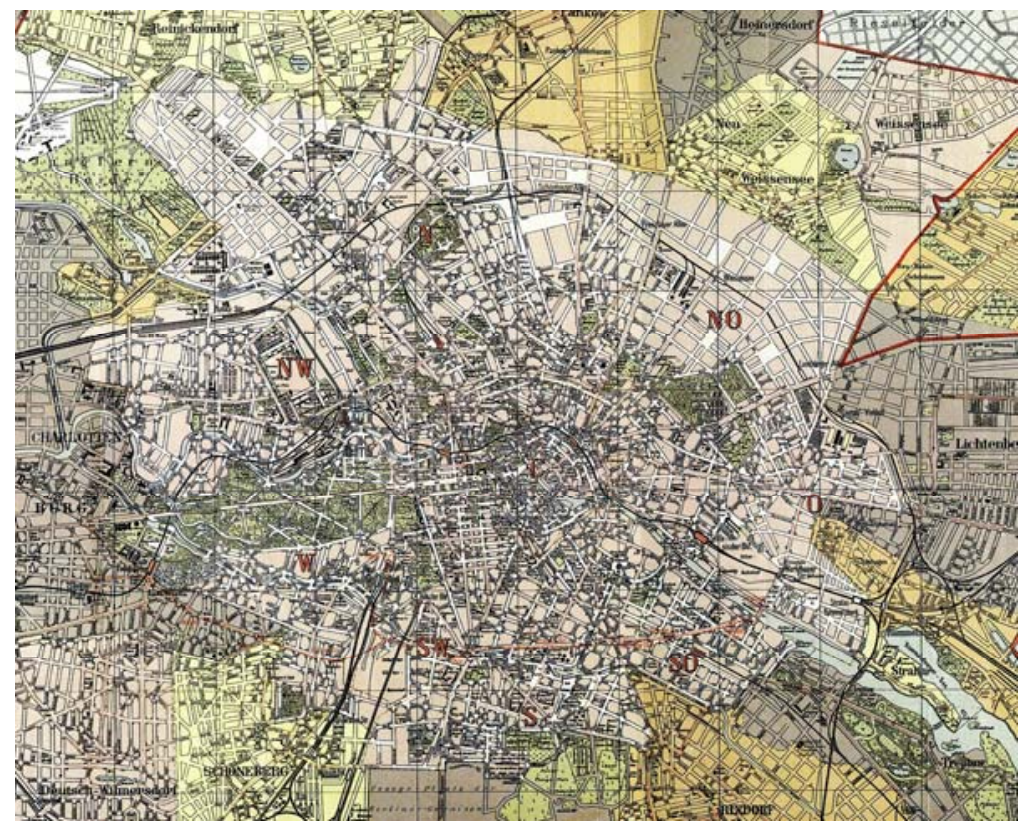

Figure 9. Berlin 1904. A metropolis with one of the world's largest public green areas and expanses of water is established. 
Evolutionary biologists claim that plants are introduced deliberately into human environments as they encourage humans to linger in a humane environment. ${ }^{215}$ If this opinion is correct, public parks represent a displaced piece of nature, an ensemble or tableau of arranged plants and pleasant scenes on a small surface. Thus a city park stands for a walkable diorama of "nature" that is available outside of cities.

Likewise, keeping pets can be taken as the desire for permanent contact with creature, as cities are not preferential natural places for animals that humans like for aesthetic reasons or as companions. As such animals are not available on demand in cities, zoological gardens were the logic consequence. But zoo animals are not to be stroked and they are limited in their activities. So keeping pets is a way simply to enjoy or compensate for haptic or psychological deficits in privacy.

There are only a few animals that have recolonized cities, mostly misunderstanding buildings as rock walls (pigeons, falcons) or whatever they mistake this anthropogenic niche for. Many of these animals have needs that are opposed to human interestsand are therefore considered as vermin or pests. Pest control is important for managing epidemic diseases (e.g. rats-fleas: bubonic plague) and for the protection of food. Pest control, which has become important in cities, is a displacement of nature. Only contemporary affluent societies have become more liberal and accepted, for example, foxes, wild boar, etc. in cities, even if they are a nuisance. Although these animals are regulated in number by city authorities, residents are amused by the subversive character of such animals and tend to tolerate them. ${ }^{216}$

Compensating for the displacement of nature, civil society developed strategies for the desideratum. Since the Romantic era, pictures of landscapes have conquered the walls of living rooms, intensified specifically in Germany by roaring deer. But this attitude may have started much earlier with the ambivalence of the Flemish still life. Subtexts like those of still lifes are missing in post-Romantic pictures, which simply stand for what they picture, namely a desire for a "locus amoenus". This has, however, been an attitude of city inhabitants since the ancient world. 217

But museum galleries (which are located in cities) may also compensate for feelings about "nature lost" by displaying pictures of nature. Here residents learn about how nature looks in terms of cultural and emotional settings. And they surely (tacitly) learn how "nature" has to be viewed. Thus galleries and art history conceive the educated perception of nature, which is stronger than enlightened and

${ }^{215}$ E. Oberzaucher and K. Grammer, "Phytophilie - Pflanzen steigern die Effizienz von kognitiven Vorgängen", Homo 51 (2000), suppl. p. 94

216 Intruding animals are reported from many central European cities, e.g. Zurich (Switzerland) and Berlin, serving as the background for many urban legends specifically told about exotic animals. The snakes and crocodiles in the sewerage systems of New York are the best known.

217 See a number of contributions on plants and animals evidenced from wall paintings in Pompeii presented in Wilhelmina F. Jashemski and Frederick G.Meyer (eds.), The natural history of Pompeii. (Cambridge: Cambridge University Press, 2002. 
rational education. Furthermore, the still lifes of market scenes, with their plethora of dead game, flowers, vegetables, and fruits, taught beholders about the inexhaustible world of nature "outside". 218

Although not yet studied, the flowerpot must be an invention of the city. It enables residents to grow plants (for whatever reason) on a minute piece of soil. Easily brought inside the house, the flowerpot requires architectural prerequisites, mainly bigger and more translucent windows. One aspect of the flowerpot is the winter garden built in civic houses, which echo the stately orangery. Thus the flower pot might be taken as a metaphor for the secularized and democratised share of ordinary people in the ornamental beauty of nature. Or it simply functions as the self-assurance of living in a humane place (in terms of the idea of "phytophilia").

From the beginning of the nineteenth century, there has been a tendency to transform former horticultural plots within cities into areas for recreation. However, recreation by resting and rejoicing in the colorfulness of flowers in the backyard can be traced back to medieval times. It is not by chance that the ideas of the "bortus conclusus" and the "locus amoenus" have a considerable overlap. From the beginning of the nineteenth century, the allotment garden movement ("SchreberGarten") started its triumphal procession through many European cities, and an allotment is still an object of desire for many city residents. Any suburb settlement follows basically this principle. It should not be overlooked that many of these small plots contributed considerably to the nourishment of city residents during periods of food shortage, a structural problem that cities have to face from time to time. A related aspect of "displaced nature" is the gradual but increasing reduction of seasonal differences in cities (as compared with the countryside) and the generation of a specific climate (the heat island phenomenon).

I end this section ex negativo by mentioning the importance of "nature" outside of the city. Social control and restrictions within cities may be so stressing that residents search for relief by "going into the nature". The entity "nature" stands as a synonym for a place without (or almost without) any human rules. Here the meaning of "nature" falls back on its antique understanding as: the "chaos", nature free of rules that man once had to arrange. After thousands of years of arrangements and regulations, this arranged and regulated caricature of "nature" is called on because it is misunderstood as being a curing wilderness. As one consequence, a provocative question arises: is "nature", at least in some respects, an invention of city residents?

\footnotetext{
${ }^{218}$ I am referring specifically to Dutch, Flemish and Upper German still-lifes of the sixteenth century which have been studied with respect to "biodiversity". From a broad variety of publications I mention specifically A.C.Zeven and W.A. Brandenburg, "Use of paintings from the $16^{\text {th }}$ to $19^{\text {th }}$ centuries to study the history of domesticated plants", Economic Botany 40(1986), pp. 397 - 408; Mirella Levi D'Ancona, Lo Zoo del Rinascimento. Il significato degli animali nella pittura italiana dal xiv al xvi secolo, (Lucca: Maria Pacini Pazzi,2000); Sam Segal, Flowers and Nature: Netherlandish Flower Painting of Four Centuries. (The Hague: SDU Publ. 1990)
} 


\section{Cities and Biodiversity}

in cities, but ex situ. Postglacial Central Europe housed 2,850 indigenous higher plants, to which 165 introduced species were added between 7000 BC and AD 1500. Some 300 species of neophytes arrived after 1500, most of them trees and "weeds" that now exist without human support. These are so-called "established" neophytes. The number of "nonestablished" neophytes today is approximately 8,500 , threefold the number of indigenous plants. Of course the nonestablished neophytes live in flowerpots and greenhouses. ${ }^{219}$ Hence plant biodiversity of cities exceeds that of non-urban areas by far, but the city biodiversity is not a functional one, since the living plants are not linked by ecosystem processes and usually do not build up lively populations. This diversity is "ex situ".

Indeed, this is the main character of the city biodiversity managed by humans, who plant, for example, exotic trees in parks and flowers in public greens. This biodiversity is one that may be represented by just one single specimen in certain cases, and it is not a diversity in terms of the abundance of individual plants. But a concentration of ex-situ biodiversity is a structural consequence of the informational demands of humans living in cities:

0 There are zoological gardens and aquariums, which not only keep many vertebrates but also conduct breeding programs to promote the survival of highly endangered species. Interestingly enough, lower vertebrates and the creepy crawlies are not usually kept and put on display.

o Museums of natural history became collections of "biodiversity", mostly of dead, stuffed, or dried specimens (e.g. Washington, London, St. Petersburg). Nowadays science provides access to genome information by analysing DNA of museum specimens. This opens up a way to concentrate genetic information other than by collecting whole specimens. A tissue sample is now sufficient without losing much of the information about a given species. With respect to this we expect increasing collecting activities.

o What applies to natural history museums also holds true for botanical museums and gardens that grow specimens and keep herbarium species. The most important institutions are located in cities (e.g. Kew, Vienna).

0 Libraries have collected and provided knowledge about descriptions of nature since historic times, and museum galleries exhibit pictures of nature's plethora and sometimes even of extinct species (e.g. the dodo, Steller's sea cow).

o Colonial archives (e.g. in Seville, London, and Dar es Salaam) hold huge numbers of samples from the colonies, samples of species, which were thought to be of economic value for the respective empire.

219 The numbers are taken from WBGU, Conservation and Sustainable Use of the Biosphere, ed. German Advisory Council on Global Change (WBGU), (London: Earthscan, 2000), p. 98 
o Museums of ethnology store materials which demonstrate the use of nature in other cultures. (e.g. London, Madrid, and Turin).

Biodiversity, or more precisely the diversity of natural products and processed natural products, is in fact one of the backbones of city economy (see Figure 10). Moreover, the behavior of consumers (in cities, simply because of their sheer number) was the driving force on the market to initiate the breeding of cash crop diversity, mainly fruit and vegetables but also numerous varieties of grain, rice, tomatoes, etc. The market is that of the cities, as can again already be seen in Flemish market scenes, for example those by the painter L.V.Valckenborch (15351597). Not a single one of the contemporary variety of fruits, vegetables, or staple fruits is older than 200 years (at the most), ${ }^{220}$ which demonstrates the marketrelated improvement of their features.

in cities, in situ. Cities are "anthropogenic licences" for a few organisms. These licences are ecological niches built, provided, and maintained by city residents, sometimes deliberately but mostly unintentionally. The first species to benefit from them was man himself, for intuitive reasons. City areas, for example the graveyards in European cities, presently support more bird species than the countryside and woods. But what holds true for birds does not hold true for terrestrial animals such as spiders, snails, amphibians, reptiles, and mammals, which that are not as diverse and, with respect to vertebrates, not as numerous as airborne organisms. (bats are more common in cities than outside them, and some bat species are known today only from cities.)

Since cities provide niches not known in "nature" (e.g. canalization/sewage water systems, houses), and those niches are occupied by animal cosmopolitans, such as rats. Sparrows, starlings, pigeons, and crows are among the birds that cope successfully with the urban environment. If their numbers exceed human tolerance levels, they are considered to be a nuisance or vermin, for example in wintertime Rome (starlings) or St. Mark's Square in Venice. But, in general, the city is not the preferential biotope for most organisms. Therefore they are simply absent. Some plants, however, manage to jump form the countryside to urban places without human support, for example on railway tracks or anthro-sols in a process called apophytization.

The microbial burden of cities is not usually associated with biodiversity, but quite a few microbes are pretty well off in urban environments, especially human pathogens. As a consequence, many activities in cities have to cope with problems caused by "bad nature", which is completely dedicated to the city itself. To end positively, cities were the birthplaces of the green movement.

\footnotetext{
220 Of course „cabbage“ or ,apples“ as such are much older. But the sorts, varieties, and species that are on the market today are breeds of short life expectancy intended to give the consumer a treat or delicacy.
} 


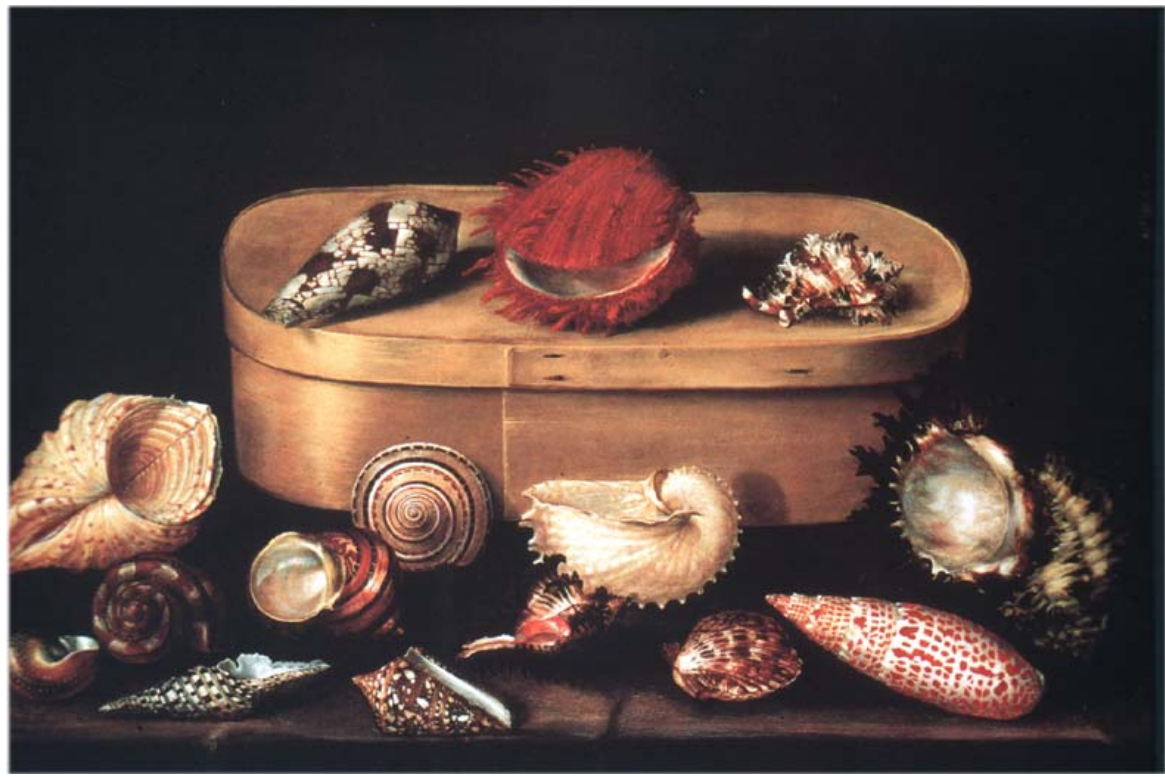

Figure 10. Jaques Linard, Still-life of shells and a collecting box (Paris 1621 or 24, panel, 38 x 51,7 cm, private collection, USA). Courtsey of Edward Speelman Ltd., London. Note: Except for one European species, all the pictured shells are from the Near and Far East. Thus, it seems a document of encyclopaedic interest, indicated by the shells' beauty and diversity and the box to file them. But in truth this stilllife is not a picture of mollusc hard tissues, it has to be understood as one of the earliest metaphors of modern time gambling on the stock exchange, a very specific institution in cities. Shells were traded like shares, as were tulip bulbs. We have to understand these items as being equivalent to gold bars. Most of the wealth of Old Europe (and of today's Western World) is due to the exploitation of natural goods and the management of biodiversity and humans abroad. 



\section{Ein Beitrag zur Kenntnis von Schädlings- bekämpfungen und ihren Konzepten im 18. und frühen 19. Jahrhundert an Beispielen aus Brandenburg-Preußen ${ }^{221}$}

\section{Bernd Herrmann}

\section{Einführung}

Eine Geschichte der Schädlingsbekämpfung, einschließlich ihrer technischen, ideengeschichtlichen und normativen Aspekte, ist noch nicht geschrieben. Dies ist umso erstaunlicher, als nächst der Witterung Fraß-, Ernte- und Vorratsschädlinge die Hauptbedrohung für den energetischen Ertrag des Agrarregimes stellen. In der

221 Zuerst erschienen in: Engelken K, Hünniger D, Windelen S (Hrsg.): Beten, Impfen, Sammeln. Zur Viehseuchen- und Schädlingsbekämpfung in der frühen Neuzeit. Universitätsverlag Göttingen 2007. S 135 - 189. - Der Beitrag ist die ergänzte Fassung, aus deren ursprünglicher Version ich am 22.6.06 im GK-Workshop vorgetragen habe. Er ist im Zusammenhang mit anderen Ausführungen von mir zu lesen, die hier nicht oder nur sehr verkürzt einbezogen sind. Im Einzelnen sind dies: Herrmann (2003), Herrmann (2006a), Herrmann (2006b). Die vorliegende Darstellung konzentriert sich auf deutschsprachige Quellen des 18. wie auch des 19. Jahrhunderts und praktische Schädlingsbekämpfungsmaßnahmen dieses Zeitabschnitts im Gebiet Brandenburg-Preußen. 
umwelthistorischen Periodisierung reichte das Agrarregime immerhin bis in die Mitte des 20. Jahrhunderts, und es konnte sich erst seit der Entwicklung chemischer Pestizide am Ende des 19. Jahrhunderts der Schädlinge wirksam erwehren. Für den Zeitraum davor sind Schädlinge als Alltagsbedrohung zwar seit biblischen Zeiten geläufig, gleichwohl in der Breite ihrer naturalen wie gesellschaftlichen Bedeutung nicht gut erforscht, was nur zum Teil an der schwierigen Quellenlage liegen kann. Im ,Göttinger Graduiertenkolleg' werden thematische Annäherungen erprobt; der vorliegende Aufsatz ist ein Beitrag hierzu.

Für die Historisierung ist die Kenntnis der aktuellen Situation hilfreich. Daher beginnt der Beitrag mit drei Hinführungen, in denen, von heutiger Einsicht ausgehend, thematisch Einschlägiges als historisches und erkenntnisgeschichtliches Problem skizziert wird. Im zweiten Teil werden jene, Naturtheorien', die in umwelthistorischen Diskursen geläufig sind, auf ihre Vereinbarkeit mit Schädlingsbekämpfungsmaßnahmen geprüft. Immerhin handelt es sich um gezielte Aktionen gegen Tiere (bzw. auch gegen Pflanzen), die um ihrer selbst willen getötet werden, so dass ein gedanklicher Aufwand für die Bereitstellung der Tötungslegitimation erwartet werden kann. Der dritte Teil verfolgt dann konkret Konzepte und ideengeschichtliche Hauptstränge des Schädlingsdiskurses für das 18. und frühe 19. Jahrhundert vor allem in Preußen und gibt Beispiele hierzu, mit denen sich auch eine überregionale, allgemeine Entwicklung nachzeichnen lässt. Dabei sind die Entwicklung einer eigenständigen Literaturgattung der Schädlingsbekämpfung, parallel zur sich herausbildenden wissenschaftlichen Entomologie, das staatliche Glückseligkeitsversprechen und die zunehmende Etablierung des positivistisch rational-logischen Weltbildes die Hauptmotoren des Fortschritts der Schädlingsbekämpfung. Dass die Durchsetzung der positivistisch rational-logischen Bewertungen erwartungsgemäß problembehaftet ablief, wird an den Kategorien des Schädlingsdiskurses und ihrer Fundierungen besonders deutlich. Der Beitrag zielt neben den konkret erörterten Sachverhalten und gedanklichen Entwicklungen auf eine Systematisierung des einschlägigen Wissens, die Komplexität des Beziehungsgeflechts, in das die Schädlingsbekämpfung eingebettet ist, und weist auf anschlussfähige Fragestellungen hin. 


\section{Eine kurze Orientierung von heute aus in drei Annäherungen}

\subsection{Erste Annäherung}

Das Statistische Jahrbuch der Bundesrepublik weist 2003 letztmalig ,Jagdstrecken aus.222 Als Jagdstrecke wird »die in Deutschland [Jagdfläche] entnommene Wildmenge, bei größeren Wildarten einschließlich der erfassten Verkehrsverluste« bezeichnet. Seit der Wiedervereinigung sind in Deutschland jährlich etwas mehr als eine Million Rehe erlegt worden. Unterstellt, die Rehpopulation wäre stabil, müsste der Gesamtbestand an Rehen auf wenigstens zwei bis drei Millionen Individuen geschätzt werden.

Obwohl Rehe Wald- und Flurschäden anrichten und Verkehrsunfälle verursachen, existiert kein zentrales Register für rehbedingte Schadensfälle.223 Wald- und Flurschäden wie auch Haftungen aus Verkehrsunfällen werden von den Jagdpächtern subsidiär beglichen. Es existieren keine verfügbaren Schätzungen über das gesamte Schadensausmaß. Das Beispiel ist ausbaufähig auch für Rot-, Dam- und Schwarzwild. ${ }^{224}$ Für eine gesamtstaatliche Schadenserfassung, und damit für die Erfassung der volkswirtschaftlichen Dimension, fehlt offenbar der Anlass. Rehe werden allgemein nicht als Schädlinge ${ }^{225}$ angesehen, vielmehr sind sie populäre

222 Statistisches Bundesamt (2003) S. 189. Aktuelle Zahlen in: Deutscher Jagdschutzverband (2005).

223 Der Deutsche Jagdschutzverband [Deutscher Jagdschutzverband (2005)] gibt für das Jahr 2004/05 den durch, Wild verursachten Verkehrsunfallschaden mit 464 Millionen Euro an. Davon entfallen rund $90 \%$ auf von Rehen verursachte Unfälle. Rechnerisch ergäbe sich damit allein ein Schadensbetrag von mindestens 410 Millionen. Euro.

224 Insbesondere Wildschweine erobern in den letzten Jahren Innenstadtbereiche von Großstädten (z.B. Berlin), verursachen Geländeschäden und bilden ein ernstes Gefährdungspotential für Stadtmenschen.

225 Die Biologische Bundesanstalt führt gegenwärtig eine Liste von Schadorganismen, deren ständige Beobachtung durch die Pflanzenschutzdienste der Bundesländer den Wirtschaftsbetrieben rechtzeitige Hinweise auf einen möglichen Schadensfall durch den Schadensorganismus geben, sofern dessen Dichte bestimmte Werte übersteigt. Interessanter Weise erfasst diese Liste nur solche Organismen, für die der Markt zugelassene Bekämpfungsmittel bereitstellt. Existieren solche Mittel nicht, wie etwa im Fall der Kirschfruchtfliege (Rhagoletis cerasi), gelangt dieser schwere Obstbaumschädling nicht auf die Liste der Schadorganismen. Es bestimmt also letztlich das Angebot an zugelassenen Bekämpfungsmitteln über die Karriere eines Schädlings. Anders gewendet ist es der ökonomische Anreiz für die Schädlingsmittelindustrie, der auf der Seite der Produktionsbetriebe anhaltenden wirtschaftlichen Schaden voraussetzt, der aus einem Organismus einen Schadorganismus macht. Wo nicht von Amts wegen interventionistisches Handeln erfolgt (Bekämpfung der Maikäfer 2006 im Südhessischen), prüft jeder Produktionsbetrieb in Eigenverantwortung und Abstimmung mit dem Pflanzenschutzdienst des Bundeslandes die Bekämpfungsmaßnahme. Normative Grundlage für die Schädlingsbekämpfung bildet heute vor allem das ,Gesetz zum Schutz der Kulturpflanzen' (Pflanzenschutzgesetz - PflSchG) in der Fassung vom 14.5.1998 (BGBl. I S.971). Dort heißt es (\$2,7): »Schadorganismen: Tiere, Pflanzen und Mikroorganismen 
Sympathieträger.226 Über die Hintergründe dieser widersprüchlichen Tatsache und über Interessenlagen der im Beispiel handelnden Gruppen zu spekulieren, ist verlockend. Doch vor allem lehrt das Beispiel, dass nicht der Schaden den Schädling macht, sondern die auf den Schaden gelenkte Aufmerksamkeit, vorzugsweise die öffentliche oder staatliche. Das Beispiel lehrt weiterhin, dass Schädlinge auch konstruiert werden können. 227

Wie ein lupus in fabula tauchte Mitte Mai 2006 erstmals wieder seit 170 Jahren im Südbayerischen ein Braunbär auf, der einige Schafe riss und in Hühner- und Kaninchenställe eindrang. Der bayerische Umweltminister Schnappauf gab daraufhin den ,Problembären' zum Abschuss frei, weil dieser sich in "artfremder Weise« in der Nähe menschlicher Siedlungen aufhielt und dort Schaden anrichtete. ${ }^{228} \mathrm{Da}$ bei wurde die Schädlingsdiagnose durch den Vorwurf seines angeblich nicht artgerechten Verhaltens gestellt und verstärkt und durch das behauptete Gefährdungspotential gegenüber Sachwerten und Menschen legitimiert. Das Beispiel macht in drastischer Weise deutlich, dass der Beutetrieb des Bären nur außerhalb menschlicher Interessen als ,naturgemäß gilt. Der Bär, in der Presse als ,Bruno vorgestellt, wurde am 26.6.2006 erschossen. Dem Vorgang unterliegt offenbar ein Naturkonzept, in dem naturale Risiken vorrangig oder ausschließlich für Menschen und ihre Interessen minimiert werden sollen. Das Muster fällt damit hinter die Bemühungen eines auf, gerechten Interessenausgleich ${ }^{c}$ ausgerichteten Naturschutzes zurück und argumentiert in gleicher Weise wie die Obrigkeit des 18. und frühen 19. Jahrhunderts. Außerdem ist in dieser Haltung eine Gewöhnung an einen Naturzustand erkennbar, in dem das Gefährdungspotential abhanden kam, das in einer unregulierten Natur besteht. Sarkastisch ließe sich dies als ,Bruno-Syndrom apostrophieren: ,Natur' ist dann ,richtige und ,schön', wenn sich der Mensch in ihr mit interesselosem Wohlgefallen und ohne gefühlte Gefährdung aufhalten kann. Es wird sich zeigen, dass in der Vergangenheit zwischen Bär, Maus und Mücke in der Schädlingsbekämpfung nur ein gradueller Unterschied gemacht worden ist und

in allen Entwicklungsstadien, die erhebliche Schäden an Pflanzen oder Pflanzenerzeugnissen verursachen können. Viren und ähnliche Krankheitserreger werden den Mikroorganismen, nicht durch Schadorganismen verursachte Krankheiten werden den Schadorganismen gleichgestellt« vgl. Formulierung im Biozidgesetz \3b,6, siehe unten. Die Durchführung ist durch »Grundsätze für die Durchführung der guten fachlichen Praxis« (Bundesanzeiger Nr. 58a vom 24.3.2005) geregelt. Ein privater Schädlingsbekämpfungsbetrieb führt auf seiner Internetseite ein ,Zoologisches System der Schädlinge auf, das Arthropoden und Nagetiere umfasst, die in Hygieneschädlinge, Materialschädlinge, Vorratsschädlinge und Lästlinge unterschieden werden. (http://dieschaedlingsbekaempfer.com - zuletzt besucht am 23.5.2006). Die Systematik entspricht gegenwärtigem Alltagsverständnis.

226 Nach PflSchG \& 2,7 ist allerdings ihre örtlich mögliche Schädlingsnatur zweifelsfrei.

$227 \mathrm{Da}$ ist es dann eigentlich erstaunlich, dass die so vielen Handlungen und Kulturäußerungen gegenüber wissenschaftlich aufgeschlossene Europäische Ethnologie (Kulturanthropologie) das Thema ,Schädling' heute nicht in ihrem Zentralkanon hat. Im Lehrbuch von Brednich (1994) fehlen die einschlägigen Stichwörter.

228 Überlegungen zum Fangen des Tieres und zu seiner Überführung in ein Gehege wurden verworfen. 
dass das heutige naturphilosophisch bewegte Gerede von der Konvivialität hier seine anthropozentrische Grenze findet.

\subsection{Zweite Annäherung}

An die Stelle einer irgendwie reflexhaften Schädlingsabwehr tritt irgendwann in der Geschichte das reflektierte und kulturell institutionalisierte Muster als Grundlage eines akuten wie prognostischen Verhaltens. Dies ist die Geburtsstunde der Schädlingsbekämpfung ${ }^{229}$, in der auch die Kategorien fundiert werden, die dann allmählicher Schärfung unterliegen: Ungeziefer, Schädlinge, Vorratschädlinge, Pflanzenschädlinge, Lästlinge, Parasiten, Krankheitserreger, Unkraut.

Im Rahmen der Zielsetzung dieser Arbeit ist es nicht erforderlich auf die terminologischen Karrieren einzugehen. ${ }^{230}$ Der Begriff ,Schädling ${ }^{c}$ kommt als Neologismus um 1880 auf, davor kennt die deutsche Sprache „schädliche“ , „culturschädliche“ oder „grausame Thiere“ und meint damit in der Regel die größeren Tiere, Säuger wie Vögel, während die Insekten (gr. entomos, aber auch andere Arthropoden), Reptilien und Amphibien das eigentliche „Ungeziefer“ stellen.

Sehr bedenkenswert erscheint mir, dass bereits einer der ersten wissenschaftlichen Entomologen, Johann Leonhard Frisch (1666 -1743), sich mit etymologischen Details befasst hat. ${ }^{231}$ Wegen seiner philologischen Bildung ist die von ihm gegebene Ableitung von einigem Gewicht, nicht nur in Bezug auf das ,Ungeziefer sondern auch auf die Tatsache, dass er sich in einer überraschend modern anmutenden Weise Gedanken über die mit dem Wort transportierten Denkfiguren und Fundierungen macht:

Der Übersetzer des Blankartischen Schau-Platzes der Raupen ${ }^{232}$ bedient sich des Wortes Schmetterling, welches in seinem Dialecto von allen Sommer-Vögeln gebräuchlich ist; aber im Hochteutschen da man schmeißen für schmeiten oder schmeeten schreibt, als wovon Schmetterling herkommt, ist es dennoch nicht aufgenommen. Da hat man eben in dieser Bedeutung das Wort Geschmeiß, wird aber von mehr Insecten, als von Schmetterlingen gebraucht. Indessen kan doch dieser Name denjenigen Sommer-Vögeln bleiben, welche mit ihren Eyern und daraus kriechenden Raupen die Pflantzen, sonderlich Bäume und Kohl, be-

229 Ergiebige Zeittafeln zur Geschichte des Pflanzenschutzes und der Schädlingsbekämpfung unter besonderer Berücksichtigung der Verhältnisse in Deutschland, jedoch ohne jede historische Reflexion, bei Mayer (1959) und bei Braun (1933). Erstaunlicherweise finden sich mehr historische Abhandlungen über die Schädlingsbekämpfungen der letzten einhundert Jahre als Abhandlungen zu denen der davor liegenden 10.000 Jahre. Auf Arbeiten dieser jüngeren Phase gehe ich nicht ein. Sie nehmen entweder ihren Ausgang um die Zeit der Reblauskalamität in Mitteleuropa oder sind Folgeprodukte der von Rachel Carson angestoßenen Diskussion. Eine Überblicksarbeit der letzten Kategorie bietet z. B. Winston (1997).

230 Hierzu Herrmann (2006a), Jansen (2003).

231 Frisch war studierter Theologe und Altphilologe, seit 1699 am Gymnasium zum Grauen Kloster in Berlin tätig, ab 1727 bis zu seinem Tod als Rektor. 1706 wurde er Mitglied der Preußischen Akademie der Wissenschaften, ab 1731 Direktor der historisch-philosophischen Klasse.

232 Gemeint ist Blankaart (1690). 
schmeißen und vor andern also ein Geschmeiß sind. Solche schlimme Bedeutung hat auch das Wort Ungeziefer, mit dem man die Insecta aus Verachtung nennet, indem man damit etwas beschreibt, das man wegwerfen, ausrotten und nicht nähren soll, im Gegensatz andrer nützlicher Thiere, die man nährt und aufziehet. Ungeziefer heißt so viel als Ungezüchte, das man nicht zur Zucht behält, wie man in der Vieh-Zucht redet, für welches Wort Zucht man ehemals gesagt, Gezüchte, davon übrig Schlangen- und Otter-Gezücht, das ch und f ist offt miteinander verwechselt worden, als in Gerüchten für Gerüffte, in achter für affter. Weil aber einige von solchen Thieren sind, als Bienen u. Seiden-Würmer, die man nicht Ungeziefer nennen kan, weil man sie nicht austilget, sondern zur Zucht hält, so habe ich indessen den Namen Insecta behalten, biss ein andrer in den Gang kommt, der bequemer ist. Oder wann ich es vor einigen aberglaubischen Sprach-Künstlern sagen darf, damit dieses lateinische Wort in den Gang komme. Welches so viel Mühe nicht kosten wird, als wann man ein neues teutsches Wort einführen wolte. ${ }^{233}$

Die Kategorien der Schadorganismen sind zunächst allgemein eher unsicher, ${ }^{234}$ sowohl hinsichtlich ihrer Grenzen als auch hinsichtlich des Schädlichkeitspotentials. Sie gewinnen indes zu keiner Zeit absoluten Status, weil ,Schaden ' letztlich eine ebenso subjektive Kategorie wie ,Not ${ }^{e}$ ist. Entsprechend unterliegen Schadensschwellen ebenso variabler Bewertungsabhängigkeit wie die Einstufung der Schadorganismen selbst: Wenn die Heuschrecke nach Beendigung der DreifelderWirtschaft und den Meliorationen des 19. Jahrhunderts keine mitteleuropäische Bedrohung mehr darstellt, kann sie hier auch als Schädling aus dem kollektiven Gedächtnis entlassen werden, ohne dass sie ihren objektiven Charakter geändert hätte. Das 19. Jahrhundert befreit Mitteleuropa auch von der durch die AnophelesMücke übertragenen Malaria, ohne dass irgendjemand über diesen Biodiversitätsverlust ausdrücklich trauern würde. Der Hamster hingegen verdankt seinen Wechsel vom verfolgten Schädling (Deutschland Ost) hin zur Roten Liste (Deutschland West) zweifellos einem historischen Zufall, nämlich dem Zusammenfallen von landwirtschaftlicher Überproduktivität, Bestandsrückgängen, erhöhter Umweltsensibili-

233 Frisch, Johann Leonhard: Insecten in Teutsch-Land, 3. Teil, 1721, dritte Seite der unpaginierten Vorrede. Die Erfindung eines deutschen Wortes (,Schädling) ließ noch bis ca. 1880 auf sich warten. Siehe Jansen (2003).

234 Eine völlig versachlichte Darstellung der Insekten findet sich im „Hausvater' Münchhausens [Zweiter Teil (1765), Seite 733], der in seinem Literaturteil überwiegend naturwissenschaftliche Autoren (im heutigen Verständnis) aufführt. Überraschend und in der gleichen Weise ausschlieBend sonst nicht zu finden, ist dagegen seine Definition des Ungeziefers: »Eine dritte Klasse machen bei ihm [gemeint ist Linné, BH] die Amphibia aus; oder was wir eigentlich Ungeziefer nennen, als Schlangen, Frösche, Kröten, und dergleichen.« So modern Münchhausen bezüglich der ,Insekten-Kategorie ist, so ,altmodisch' ist seine Bewertung der Amphibia noch in der Tradition der magischen Wissenschaft, die auch noch große Teile des Raisonnements bei Krafft (s.u.) ausmacht. Das hängt m.E. damit zusammen, dass die ,Ungeziefer-Natur' dieser Tiere nicht wirklich zu konkretisieren ist, wenn man von gelegentlicher Giftigkeit der Tiere und den ästhetischen Vorbehalten ihnen gegenüber absieht. Sicherlich spielte dabei die Ikonographie dieser Tiere für ihre Qualifizierung eine größere Rolle. 
tät und dem gesellschaftlichen Umbruch. Der Ost-Hamster wird zu einem Profiteur der deutschen Einheit. 235

Dass der Vorstellung vom Schädling kein elaboriertes ökologisches Konzept unterliegt, ist offensichtlich. Die Biologie kennt keine ,Schädlinge: Alle Organismen existieren gewissermaßen aus eigenem Recht (wobei diese Formulierung ihrerseits einen gewissen naturalistischen Fehlgriff darstellt). Ziel einer jeden Schädlingsbekämpfung ist, die Populationsdichte von Schadorganismen unter der ,Schadensschwelle zu halten. Die Opportunitätskosten einer Haltung, die keine Schädlingsbekämpfung vorsieht, sind im Agrarregime zu hoch. ${ }^{236}$ Diese wirtschaftliche Schadensschwelle ist die Befallsstärke (oder der Verunkrautungsgrad), die unter wirtschaftlichen Gesichtspunkten gerade noch geduldet werden kann. Daraus folgt, dass Bekämpfungsmaßnahmen erst dann wirtschaftlich sinnvoll sind, wenn die erwarteten Ertragsverluste größer sind als die Bekämpfungskosten. Für die einzelnen Schadorganismen existieren empirische Schadensschwellen, z.B. für den Kartoffelkäfer mit bis zwei Käfern oder zwanzig Larven je Pflanze. Diese Schadensschwellen werden jeweils an die Standorte angepasst.

Es ist offenkundig: Der Begriff ,Schädlinge (bzw. seine gedanklichen Vorläufer) ist ausschließlich ökonomisch fundiert. ${ }^{237}$ Die Übernahme des Begriffs in die Biologie und ihre Filiationen (etwa Forst- und Agrarbiologie) folgt allein den Gesichtspunkten angewandter Forschung im Dienste von Öffentlichkeit und Privatwirtschaft, ist also wissenschaftlich als ingenieurtechnische Problemforschung, als ,angewandte Forschung, einzuordnen. Daher ist deren Definition des Schadorganismus, die normativen Charakter hat, ausschließlich am menschlichen Eigeninteresse orientiert ${ }^{238}$ : „Organismen, die für den Menschen, seine Tätigkeiten oder für Produkte, die er verwendet oder herstellt oder für Tiere und die Umwelt unerwünscht oder schädlich sind." (Biozidgesetz \ 3b,6 - vom 20. Juni 2002 (BGBl. I S. 2076) Selbst dort wo die Definition vorgibt, Schadensabwendung im Interesse

235 Feldhamster wurden noch bis zur Wende 1989 in der Magdeburger Börde als Ernteschädlinge bekämpft und in großen Stückzahlen für die Pelzgewinnung (Westexport) gefangen.

236 Für die Bekämpfungsmaßnahme ist aus der Sicht der Akteure das Bewusstsein und die reale Durchführung einer Abwehrhandlung offenbar mindestens ebenso wichtig, wenn nicht wichtiger als deren objektive Wirksamkeit.

237 Das ist die gängige vordergründige Ableitung, die lediglich über Nahrungsverluste oder Beschädigungen menschlicher Produkte als wirtschaftlicher Gegenstände klagt. Da der Mensch nicht von Brot allein lebt, also auch nicht vom Brotgetreide allein, müsste sich zumindest der Gedanke finden, wonach Schädlinge auch einen Teil des menschlichen Selbstverständnisses (zumindest im Agrarregime) attackieren bzw. zerstören, weil sie die Ergebnisse der menschlichen Anstrengung zerstören. So expliziert habe ich diesen Gedanken in der Literatur bisher nicht gefunden. Schädlingsbekämpfung wäre also mühelos auch aus einer philosophischen Perspektive zu verstehen. Hierzu unten Kap. 2.1. Ein Anschluss an den existenziellen Bereich ergäbe sich, wenn die vielschichtige Deutungsmöglichkeit der göttlich gesandten Plage in dieser Richtung verfolgt würde.

238 Zur Vermeidung von Missverständnissen ist darauf zu verweisen, dass z.B. in der Biologie durchaus Bereiche existieren, die 'objektiv', d.h. frei von menschlichem Interesse sind. Das gilt z.B. für die Systematik der Organismen auf der Grundlage ihrer natürlichen Verwandtschaft; in der Physik wäre mit den Naturgesetzen und Naturkonstanten ähnliches gegeben, usw. 
von ,Tieren und der Umwelt in den Blick zu nehmen, geschieht dies aus menschlichem Eigeninteresse, zumindest aus menschlichem Maßstab.

Die ,Georgica curiosa ${ }^{e}$ von Wolfgang Helmhard von Hohberg, die ab 1682 in mehreren Auflagen erschien, wird gelegentlich als Höhepunkt der Hausväterliteratur eingestuft. ${ }^{239}$ Obwohl er selbst vorgibt, die antiken Vorläufer nicht weiter zu berücksichtigen, führt doch eine inhaltliche Linie von den namhaften antiken Ratgebern direkt zu Hohberg. Wie sein heimliches antikes Vorbild Columella 240 äußert Hohberg sich auch zu Schädlingsfragen, aber wie sein antiker Vorläufer verfasst Hohberg keine eigenen Kapitel hierzu, sondern seine Diagnosen und Empfehlungen sind eingebettet in Texte über Kulturpflanzen oder die Pflege der Nutztiere. Hohbergs Ratschläge zur Bekämpfung sind lapidar. Detaillierter werden von ihm Angaben über alternative Nutzungsformen der Schadorganismen in der Therapierung von Krankheiten bei Mensch und Vieh bis hin zum Abwehrzauber gemacht. ${ }^{241}$

Damit ist ein entscheidender Aspekt benannt, der das Raisonnement vom 17. bis ins 19. Jahrhundert hinein bestimmt: Es ist die Gleichzeitigkeit nützlicher wie schädlicher Eigenschaften eines Schädlings, welche die damalige Herausbildung und das heutige Erkennen eines klar definierten ,Schädlingsdiskurses e erschwert. ${ }^{242}$ Eine Fundierung jenes Denkens in ambivalenten Qualitäten aus den damals herrschenden harmonistischen Naturvorstellungen wäre mühelos herstellbar. Indes scheinen mir Zweifel angebracht, ob es sich hierbei um ein Absinken eines gelehrten Diskurses bis auf die Ebene der Volkskultur bzw. die praxeologische Ebene handelt. Viel eher vermute ich ein Überleben und anhaltendes Durchschlagen einer alltagspraktischen Ordnung, in der zweckrationales Handeln die selbstverständliche Basis für die Durchsetzung des menschlichen Eigeninteresses abgibt. ${ }^{243}$ Aber die

239 Ein willkürlicher Beginn kann bereits mit Johann Domnitzer gesetzt werden, dessen 32 Seiten umfassender Ratgeber (1529) mit Empfehlungen zur Schädlingsbekämpfung endet.

240 Columella, besonders Bücher 1,2,6 und 7. Hierzu vgl. Kreyser (1996).

241 Eine verdienstvolle Zusammenstellung der Schädlinge aus den wichtigsten Hausvätern hat Grau (1971) vorgelegt, ohne zu den epistemologischen Fragen vorzudringen.

242 Das wird besonders deutlich, wenn das ansonsten schädliche Tier bzw. Produkte aus ihm als Handelsware erhebliche wirtschaftliche Bedeutung bekommen. Paradebeispiel hierfür ist das Fell des Hamsters: Meusel (1817) S.43; Stein (1811) Bd.1, Fürstentum Gotha, S. 795; Courtin (1835) S. 356; Schiebe (1837) Bd 2, S. 9. Ähnlich ambivalent ist die Situation beim Maikäfer, für den sich früh eine wirtschaftliche Verwendung als Dünger ergibt wie im besonders maikäfergeplagten Kanton Bern: Say (1818) Bd. 1, S. 328.

243 Die Lage ist sicherlich noch komplexer als hier skizziert, aber im Hinblick auf unser Thema bislang nicht untersucht. Die Balance zwischen Aufklärungsanspruch und abergläubischen Reminiszenzen ist z.B. das Hauptproblem der, Volkskalender', die im 18. und 19.Jahrhundert eine wichtige Informationsquelle auch für den lesekundigen Bauern bzw. Landwirt darstellen. Die Kalender verschneiden um des Verkaufserfolges willen die aufgeklärte Einsicht mit dem verbreiteten ,abergläubischen' Standard bzw. Relikt, also der Kenntnis der voraufklärerischen magischen Wissenschaft und der volkskulturlichen Praxeologie. Damit avanciert die Kalendergeschichte einerseits zum wichtigen pädagogischen Aufklärungsvehikel, mit dem auch Einsichten zur Schädlingsthematik transportiert werden. (Das Paradebeispiel hierfür liefern Johann Peter Hebels Ka- 
Ratio folgt dabei eben nicht nur logisch-rationalen Prinzipien. In einem sehr unmittelbaren Sinne wird das gemacht, woran geglaubt wird, d.h. auch das scheinbar Irrationale, das ,Abergläubische ${ }^{e}$, hat seinen festen Platz. Die Handlungsweise erkennt zu dieser Zeit, zu der das Reden über Schädlinge in der wissenschaftlichen Literatur fassbar wird, auch das Zeichenhafte in der Natur als gleichberechtigtes Erfassungsinstrument der Wirklichkeit und leitendes praxeologisches Prinzip an. Die Wissenschaftsgeschichte hat für diese Art der Erklärung der Weltordnung den Begriff der ,magischen Wissenschaft ${ }^{e}$ gefunden. ${ }^{244}$ Diese wundergläubige Erklärung der Welt, die den magischen Volkspraktiken vielleicht näher ist als die heutige rationale Wissenschaft, leidet keineswegs Mangel an Differenzierungsmöglichkeiten, ${ }^{245}$ wie der Blick auf die nach wie vor grundlegende einschlägige Ableitung der vergleichenden Ethnographie lehrt. ${ }^{246}$ Die Überlegungen von Lévi-Strauss machen mehrere grundsätzliche Dinge deutlich, von denen der Schädlingsdiskurs im Hinblick auf den Übergang von der magischen zur experimentellen Wissenschaft profitieren könnte: Lévi-Strauss führt überzeugend vor, dass in einer Kultur, in deren Sprache ein bestimmtes Bezeichnungsäquivalent nicht vorkommt, sehr wohl dennoch ein Begriff, eine Vorstellung vom Nicht-Bezeichneten existiert und auch differenzierte Vorstellungen über damit verbundene komplexe Ableitungen. Das erkenntnistheoretische Hauptproblem der ,magischen Wissenschaft ${ }^{`}$ und des ,mythischen Denkens', deren Gemeinsamkeit im Zusammenfügen scheinbar beziehungsloser Gedanken oder Vorgehensweisen oder Bewertungen besteht, löst Lévi-

lendergeschichten aus dem ,Badischen Landkalender ${ }^{`}$ und dem ,Rheinischen Hausfreund'). Durch die belehrende Distanzierung von der abergläubischen Praktik wird andererseits diese aber zugleich bewahrt. Besonders auffällig ist die Aufnahme von Episoden nach dem Muster der Kalendergeschichte in der Enzyklopädie von Krünitz, wobei dort neben dem aufklärerischen Gestus das ältere abergläubische, das magische, das mythische Wissen bewahrt bleibt und gerade damit den heute wertvollen Blick auf diesen sonst nicht mehr so einfach zugänglichen volkskultürlichen und nicht-akademischen Bereich ermöglicht.

244 Thorndike (1958) Bd. 8, S. 629 ff.

245 Man denke z.B. an die komplexen Erklärungsmodelle in der subkulturellen Schöpfungslehre eines Menocchio (Ginzburg 1979) oder die Erörterung von Wunderdingen im Umfeld von Sterben und Tod, mit denen 1670 ein Garmann den Beginn der forensischen Forschung in Deutschland markiert (Benetello und Herrmann 2003).

246 Lévi-Strauss (1973). Der Einwand Levi-Strauss beziehe sich auf grundsätzlich anders verfasste Kulturen als die mitteleuropäische des 18. Jahrhunderts, trifft meines Erachtens nur den zeitlichörtlichen Aspekt, nicht hingegen eine methodische Differenz. Nach meiner Auffassung gleichen sich in der ,magischen Wissenschaft' und im ,mythischen Denken' die Erkenntnismittel wie die Erkenntnisprinzipien. Daher fasse ich sie erkenntnistheoretisch zusammen. Entscheidend sind für mich die strukturellen Übereinstimmungen des analytischen Instrumentariums der Akteure, nicht deren kulturelle Differenzen. 
Strauss in dem Begriff der bricolage auf. ${ }^{247}$ Er sieht im mythischen Denken »eine intellektuelle Form der Bastelei.«248

$\mathrm{Zu}$ ergänzen wäre diese Einsicht aus vielfach belegter Erfahrung, für die auch Mary Douglas ein Beispiel gibt:

Eine band von !Kung-Buschmännern hatte ihre Regenrituale gerade beendet, da erschien eine kleine Wolke am Horizont, wuchs an und verfinsterte sich. Dann setzte der Regen ein. Als die Ethnologen die Buschmänner daraufhin fragten, ob sie glaubten, daß der Ritus den Regen bewirkt habe, wurden sie jedoch schallend ausgelacht [...]. Die Naivität, mit der wir den Glaubensvorstellungen anderer Völker begegnen ist erstaunlich.... ${ }^{249}$

Bedenkt man einen Teil der Anweisungen, mit denen die magische Wissenschaft im 17. und 18. Jahrhundert den Schädlingen beikommen will, ist der Beschwörungscharakter, die zauberische Praktik, das rituelle Element offenkundig. ${ }^{250}$ Es wäre missverstanden, sie als bloßen Unfug, als falsche Rationalität abzutun, ${ }^{251}$ aber

247 Gemeint ist eine gedankliche Arbeit, die ihre Analogie in der Bastelei (fr : bricolage) findet. Die konzeptualisierte Wirklichkeit der magischen Wissenschaft der vormodernen Gesellschaften in Europa ist, von uns aus gesehen, ebenfalls eine intellektuelle Bastelei und verfügt durchaus über Vorstellungen vom Nicht-Bezeichneten, ohne bereits über den Begriff ,Schädling zu verfügen.

248 Lévi-Strauss (1973) S. 35: „Auch unter diesem Gesichtspunkt erscheint die mythische Reflexion als eine intellektuelle Form der Bastelei. Die Wissenschaft baut sich ganz und gar auf der Unterscheidung zwischen Zufälligem und Notwendigem auf, die gleichzeitig die zwischen Ereignis und Struktur ist. Die Qualitäten, die sie bei ihrer Entstehung für sich in Anspruch nahm, waren genau diejenigen, die, da sie nicht der gelebten Erfahrung angehörten, außerhalb der Ereignisse und ihnen gleichsam fremd blieben: das ist der Sinn des Begriffs der Ersten Qualitäten. Die Eigenart des mythischen Denkens besteht, wie die der Bastelei auf praktischem Gebiet, darin, strukturierte Gemeinsamkeiten zu erarbeiten, nicht unmittelbar mit Hilfe anderer strukturierter Gesamtheiten [hier Fussnote im Original: Das mythische Denken errichtet strukturierte Gesamtheiten mittels einer strukturierten Gesamtheit, nämlich der Sprache; aber es bemäcbtigt sich nicbt der Struktur der Sprache; es erricbtet seine ideologischen Gebäude auf dem Schutt eines vergangenen gesellschaftlichen Diskurses.], sondern durch Verwendung der Überreste von Ereignissen: ,odds and ends', würde das Englische sagen, Abfälle und Bruchstücke, fossile Zeugen der Geschichte eines Individuums oder einer Gesellschaft. In gewissem Sinn ist also das Verhältnis zwischen Diachronie und Synchronie umgekehrt: das mythische Denken, dieser Bastler, erarbeitet Strukturen, indem es Ereignisse oder vielmehr Überreste von Ereignissen ordnet [bier Fußnote im Original: Das Basteln arbeitet mit, zweiten Qualitäten'; cf. englisch , second hand', aus zweiter Hand, ,Gelegenheit'], während die Wissenschaft, ,unterwegs' allein deshalb, weil sie sich stets begründet, sich in Form von Ereignissen ihrer Mittel und Ergebnisse schafft, dank den Strukturen, die sie unermüdlich herstellt und die ihre Hypothesen und Theorien bilden...."

249 Douglas (1988), S. 79.

250 Nicht zu unterschätzen ist übrigens auch die Didaxe solcher Texte, für die das Ungezieferbuch von Acxtelmeier (1692) wegen seiner Metaphorik ein besonders eindrucksvolles Beispiel liefert. Sie setzt sich fort in den späteren Kalendergeschichten.

251 Thorndike (1958) Bd. 8, S. 558-559, verweist auf den Exorzisten Candido Brognolo (1651), der mit gewissem professionellen Neid auf die Männer der Wissenschaft schaute und ihnen krankhaftes Denken vorwarf, wenn sie Hexenkräfte leugneten. Er selbst gibt exorzistische Anweisungen zur Vernichtung von Vögeln, Würmern und Heuschrecken. Die Naturwissenschaftler machten sich nach Brognolos Auffassung des Atheismus schuldig, wenn sie Wirkkräfte der Natur und nicht der Handlung Gottes zuwiesen. 
eben auch ein Missverständnis, für sie eine Wirkungszuschreibung zu behaupten, die bei den Akteuren die Annahme einer Deckungsgleichheit mit der rituellen, magischen Applikation unterstellt, wie das Beispiel der !Kung lehrt.

Spätestens ab der Mitte des 17. Jahrhunderts werden die Konzepte der magischen Wissenschaft zunächst zaghaft, dann immer stärker werdend, flankiert von der aufkommenden rationalen Sichtweise, welche für die heutige Naturwissenschaft bestimmend ist. Diese Gleichzeitigkeit der letztlich inkompatiblen Natursichten läuft im Schädlingsdiskurs erst in der ersten Hälfte des 19. Jahrhunderts aus. Daher verfügt der Schädling des 18. Jahrhunderts als ,Ungeziefer durchaus noch alternativ über positive Eigenschaften bis hin zu pharmazeutischen Wirkungen gegen unerwünschte psychische wie somatische Molesten und Malaisen. Zugleich fehlt der Schädlingsdiagnose des 17., 18. und 19. Jahrhunderts entsprechend noch jene terminologische und ideologische Radikalität, die sich auf die naturwissenschaftliche Rationalität stützt, mit der dieser Unwertbegriff seit seiner Entstehung um 1880 zur Anwendung kommt. Dabei ist die inhaltliche Verschärfung der Vorläuferbegriffe für den Terminus, Schädlinge seit der Mitte des 18. Jahrhunderts spürbar. Aber die Einstimmung auf die künftig ausschließliche Thematisierung der negativen Eigenschaften der Schadorganismen hat bereits mit den Anfängen der Literaturgattung begonnen, den Krafft 1712/13252 markiert. Von nun an erscheinen, während des 18. Jahrhunderts zunehmend, monographische Darstellungen zur Schädlingsthematik. Dabei beseitigen die Texte die erwähnte Ambivalenz des

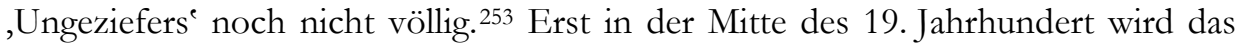
Ungeziefer ausschließlich ,schädlich ${ }^{`}$ wird zu »Feinden der Landwirtschaft«. ${ }^{254}$ Eine solche klare Zuweisung hatten die körperlich größeren Schadorganismen, Säugetiere wie Vögel, als »grausame Thiere« bereits im 18. Jahrhundert und früher erhalten.

Würde die Schädlingsgeschichte als eine einfache Fortschrittsgeschichte hin zum ,richtigen` Denken begriffen, übersähe man einen sehr großen Anteil allgemeinerer Einstellungen der historischen Akteure, der Zweifel an einer solchen Gradlinigkeitshypothese weckt. Die Bastelei der magisch-mythischen Welterklärung bringt mit Notwendigkeit nicht nur unwirksame Abwehrempfehlungen hervor: Ihr sind Abwehrzauber und ,abergläubisches ${ }^{\top}$ Handeln selbstverständlich. Weil Vorhersagemöglichkeiten und wirksame Abwehr fehlen, wird das Ohnmachtsge-

252 Krafft (1712 und 1713). Krafft bezieht sich ausdrücklich auf Aldrovandus, Britius, Camerarius, Clusius, Jonstonus, Moufetus, Pennius, Quickelbergius, Rogerius, Scaliger und Wottonius, sämtlich gut bekannte Autoren der ,magischen Wissenschaft ${ }^{\circ}$ und, zumindest was Aldrovandi und Moufet anbelangt, auch anerkannte Pioniere der naturwissenschaftlichen Entomologie.

253 Besonders auffällig sind die vielfältigen pharmakologischen Verwendungsmöglichkeiten für diese Tiere. Gewöhnlich wird auf die zeitgenössische Überzeugung hingewiesen, nach der die Applikation sympathetischer Mittel angezeigt war. Das mag vom Grundsatz zutreffen, für die konkrete Mehrzahl der aus den Tieren gewonnenen Mittel erschließt sich dieser Zusammenhang aber keinesfalls spontan.

254 Nördlinger (1869). 
fühl dem Schädling gegenüber in zauberischer Praxis kompensiert. ${ }^{255}$ Nachwirkungen dieser Praxis sind beispielhaft noch im 18. Jahrhundert an den Begleitumständen etwa der Heuschreckenbekämpfungen sichtbar. Sie ist, wie viele Bekämpfungsmaßnahmen um diese Zeit, bereits weitgehend rational, bezogen auf die zeitgenössischen Möglichkeiten. Aber u.a. schießt man durchaus noch Kanonen gegen die Heuschrecken ab und einige verstörte Zeitgenossen erinnerten sich immer noch, dass im Tracheenmuster der Zugheuschrecken Buchstaben standen, die zu einer Mahnung biblischer Art zusammengefügt werden konnten. ${ }^{256}$

\subsection{Dritte Annäherung}

Wollte man ernsthaft den Bedeutungsinhalt des Begriffs ,Schädling in die Biologie einführen, würde man ziemlich erschrecken. Schnell stellte sich heraus, dass Schädlinge einen Teil der organismischen Vielfalt darstellen, und zwar bei weitem den größten. Grundsätzlich verdankt die Mehrzahl der organismischen Vielfalt den Schädlingen überhaupt ihre Existenz. ${ }^{257}$ Und oberhalb der Ebene der Primärproduzenten lebt in der Natur jeder Organismus auf Kosten anderer. So ist beispielsweise aus der Sicht von Wiesengras die Kuh ein Schädling. Die Nahrungskette beruht auf dem Prinzip der Trophiestufen, sehr verkürzt beschrieben mit der Formel ,die Großen fressen die Kleinen'. Der dabei entstehende Schaden ist für die teilweise oder ganz gefressenen Organismen leicht zu beziffern: mittelfristig bis langfristig haben sie geringeren reproduktiven Erfolg, kurzfristig sind sie, wo sie überleben, kümmerlich, krank, haben Schmerzen oder müssen sich beeilen, ihre Blattmaße rechtzeitig vor dem Herbst zu erneuern. Wenn sie, Glück haben, kommen sie mit benachteiligenden Einschränkungen davon, wenn sie ,Pech haben, überleben sie den Tag nicht. Und zwar tagein tagaus.

Zwischen dem Schädling und dem Geschädigtem, zwischen Räuber und Beute, zwischen Primärproduzenten und Konsumenten stellt sich ein balanciertes Gleichgewicht ein. Wichtigste thematische Einsicht der Naturwissenschaft scheint mir aber zu sein, dass es innerhalb der natürlichen Gleichgewichtszustände auch solche Zustände gibt, denen mehrere Gleichgewichte zugrunde liegen und innerhalb derer auch der Wechsel zwischen zwei stabilen Populationsdichten und Massenauftreten möglich ist. Abundanzänderungen gehören also einerseits zur inneren Logik der Populationsdynamik nach dem Null-Isoklinen-Modell (und der durch es beschriebenen Wirklichkeit), sie können sich aber auch plötzlichen Veränderungen

255 Am deutlichsten wohl ausgedrückt in den Tierbannungen des Späten Mittelalter und der Frühen Neuzeit. Siehe z. B. Herrmann (2006a), sowie Rohr, in diesem Band. Allgemein, aber ohne historische Analyse: Secoy und Smith (1978).

256 Krünitz (1781), Lemma Heuschrecke: „Franz schreibt, dass auf den Flügeln der Heuschrecken, im Jahr 1542, die Worte lra Dei gestanden, und zwar soll diese Schrift in Apulien Griechisch, in Deutschland aber Hebräisch, Arabisch und Aethiopisch zu lesen gewesen seyn.“

257 Die Biologie führt das Phänomen der Sexualität, in deren Folge die Vielgestaltigkeit der Arten zu sehen ist, auf einen Anpassungsdruck an Parasiten zurück. So gesehen sind ,Schädlinge ${ }^{`}$ Hauptmotoren der Evolution. 
von Umweltbedingungen verdanken. ${ }^{258}$ Kenntnis beider Tatsachen sollten verhindern helfen, dass ein allzu schlichter Rückgriff auf die Biologie in der (irrigen) Hoffnung auf einen hier verorteten archimedischen Punkt erfolgt. Es gibt ihn nicht.

Man braucht nicht erst den ,naturalistischen Fehlschluss' zu bemühen, um die Fruchtlosigkeit wie Problematik der eingangs vorgeschlagenen Begriffsübertragung zu erkennen. Die wertende Übertragung der Begriffe, und damit der von ihnen beschriebenen Fakten, Abläufe und der in sie eingeschriebenen Werturteile, aus der menschlichen Gesellschaft in die Biologie hinein oder aus der Biologie heraus in die Gesellschaft bzw. die sie begleitenden Wissenschaften, kann nur zu Verwirrung und Missverständnis führen. ${ }^{259}$ Dennoch gilt, dass im ,Naturzustand ${ }^{e}$ zwischen vielen Organismen Beziehungen bestehen, die für andere Individuen oder Arten ,nachteilige ${ }^{\complement}$ Folgen haben. Der ,Nachteil' wird dabei festgelegt bzw. gemessen durch den verminderten Umfang der potentiellen oder tatsächlichen Beteiligung der Betroffenen am Prozess der Evolution (d. i. die Nachkommenzahl).

Schädlinge bilden eine Kategorie von Organismen, die in menschlicher Wahrnehmung mit menschlichen Ansprüchen an Lebensqualität und Naturnutzung über ein erträgliches Maß hinaus konkurrieren, also von nachteiliger Wirkung sind. In der Sprache des Gesetzes sind es Organismen, die für den Menschen, seine Tätigkeiten, die von ihm verwendeten bzw. hergestellten Produkte oder für Tiere oder die Umwelt unerwünscht oder schädlich sind. ${ }^{260}$ Die Schädlingsbekämpfung ist die daraus resultierende, ingenieurtechnische ${ }^{e}$ Seite, die praktische Umsetzungsebene. Ob aber eine Maus in der Klappfalle getötet, in der Lebendfalle gefangen oder mit dem Drudenfuss abgewehrt wird, steht nicht von vornherein fest.

258 Hier wird auf ökologisches Grundwissen zurückgegriffen. Vgl. z. B. Begon, Townsend und Harper (1998), vor allem Teil 2. Das massenhafte Auftreten von Schadensorganismen, das den Menschen so ärgert, ist also auch ohne menschliche Wirtschaftsweise grundsätzlich im Naturzustand möglich, damit keineswegs ausschließliche Folge menschlicher Wirtschaft. Der Mensch beeinflusst lediglich die komplexen naturalen Systeme so, dass auf den Wirtschaftsflächen die Determinanten für Gleichgewichtszustände so eingestellt werden, dass unvermeidbar auch die Schädlingszahlen ansteigen.

259 Diese Missverständnisse sind deshalb vorgezeichnet, weil in der Rede über die Dinge im Naturzustand offenbar auch immer metatextlich die Rede über menschliche Grundprobleme enthalten ist, wenn die archimedischen Punkte menschlicher Existenzbestimmung implizit oder offenkundig , in der Natur' vermutet werden (vgl. Fußnote 17).

260 Die Formulierung des Biozid-Gesetzes »oder für Tiere oder die Umwelt unerwünscht oder schädlich« dürfte, wenn sie nicht bloß dilatorisch oder kosmetisch ist, so zu verstehen sein, dass von ,Tieren ${ }^{e}$ und ,Umwelt auszugehen ist, die menschliches Interesse berühren. Immerhin wird hier eine Anpassung an EU-Recht vorgenommen, also die sinngemäße Gültigkeit der Klausel endet nicht an den Grenzen Deutschlands. Sofern keine rhetorische Floskel unterstellt wird: Woher käme denn das Wissen, was »für Tiere und die Umwelt unerwünscht oder schädlich« ist, wenn z.Zt. nicht einmal ein Modellierungskonzept besteht, mit der sich für ein bestimmtes Biotop die Artenzahl voraussagen ließe? Hier wird ein Naturleitbild suggeriert, tatsächlich aber beliebigen heimlichen Vorstellungen interessierter Gruppen die Tür geöffnet. 
Da die Schädlingsbekämpfung eine allererst auf das Alltagspraktische zielende Tätigkeit ist, steht ihre Berechtigung zunächst auch völlig außer Frage. Später muss sich der Mensch gegenüber der göttlichen Plage bewähren. Auch hierfür ist ihm von Gott der Verstand gegeben. Eine ethische Bewertung setzt im späten 18. Jahrhundert vereinzelt, im 19. Jahrhundert etwas verstärkt, regelhaft und vor allem im 20. Jahrhundert ein. ${ }^{261}$ Seit jedoch die Idee der besten aller Welten verstärkt den Blick auf die Natur bestimmt, wird die Erklärung der Existenz derjenigen Organismen schwierig, die dem Menschen Probleme bereiten. Die Schwierigkeiten werden aufgefangen mit der doppelten Funktion der Schädlinge, die sowohl nützliche wie auch schädliche Eigenschaften aufweisen: Nützlich in ihrer Stellung im Naturganzen, schädlich in ihrer Beeinträchtigung der Geschäfte der Menschen. Da die Welt auf den Menschen hinkonstruiert ist, darf der Mensch in seinem Interesse handeln. Die Herausbildung von Bedenken bzw. ihre Zurückweisung ist damit eng verknüpft mit den Vorstellungen von ,Nature.

\section{Schädlingsbekåmpfung und Naturtheorien}

Man kann Schädlingskalamitäten als wundersames Ereignis, ${ }^{262}$ im biblischen Sinn als Plage oder schließlich naturwissenschaftlich auffassen. Während sich die praktische Seite mit der Schädlingsbekämpfung und möglicherweise deren theoretisch bester ökologischer bzw. populationsbiologischer Fundierung befasst, existieren aber auch mentalitätsgeschichtliche, epistemologische, kulturgeschichtliche, strukturalistische Aspekte des Themas. Sie gehen ein in die umweltgeschichtliche Erörterung.

Schädlingsbekämpfung ist logisch wie historisch ableitbar. Als logische Hypothese ist sie eine Folge der Agrarproduktion. Historisch ist sie seit den Anfängen schriftlicher Berichte belegt. Ein grundsätzliches Problem besteht dabei allerdings in den handlungsleitenden Wahrnehmungen der praktischen Landwirtschaft einerseits, die nicht nur ohne jede metatheoretische Fundierung einer Schädlingsbekämpfung

261 An dieser Stelle offenbart sich eine Parallele zur Tötung von Tieren für die Nahrungsgewinnung. Es handelt sich um ein zutiefst unbequemes Thema, das am liebsten verdrängt wird. Der Vorwurf moralischer Abstumpfung oder moralischen Desinteresses an einer akzeptablen Lösung des Problems gipfelt in der Entgleisung von Isaak Bashevis Singer, wonach für Tiere jeden Tag Treblinka sei. Das Dilemma liegt in der Aporie zwischen physiologischen Grundbedürfnissen und der Annahme einer moralischen Verantwortung für die Nutzung der Natur durch den Menschen. Die Nutzung selbst dürfte doch wohl keine moralischen Bedenken provozieren, wohl aber der Nutzungsexzess. Wenn es ihn überhaupt geben kann, ab wann träte dieser Exzess ein? Ist Exzessfähigkeit der menschlichen Natur zuzurechnen? Dann erübrigt sich die hier anschließende Schuldfähigkeitsdebatte. Bis zu welchem Punkt ist dann analog die Schädlingsbekämpfung statthaft, ab wann geht sie in den Exzess über? Usw.

262 z. B. Fritz (Ende 17. Jahrhunderts), S. 238: „Anno 1638. wahren viel meise (Mäuse) in Thüringen und andern lendern/ die den Frichten grosen schaden thaten, und viel seindicke gewesen/ und haben junge im Leibe gehabt und wen man sie hat Todt geschlagen, haben/ die jungen inleibe schonwider junge gehabt“. Ich danke Matthias Deutsch, Göttingen/Erfurt, für diesen Hinweis. 
auskommt, sondern sich nur um die Theorie der praktischen Bekämpfung (wie beseitige ich den Schadorganismus?) und vielleicht um die betriebswirtschaftliche Sicht kümmert. Diesem Handlungsstrang läuft andererseits das handlungsleitende Konzept aus territorialhistorischer Sicht parallel (bis beide Stränge sich um den Zeitpunkt der Reichsgründung 1871 maximal annähern und so seitdem beieinander liegen). Die territoralhistorische Sicht greift auf eine naturrechtliche, politische Metaphysike als Metatheorie zurück, innerhalb derer der Schädlingsdiskurs Bedeutung für das staatliche Glückseligkeits- und Sicherheitsversprechen erhält (Meyer, 1999; s.u.).

\subsection{Theoretische Ableitungen}

Weil Schädlingsbekämpfung logisch mit der Agrarproduktion verknüpft ist, bestehen keine Schwierigkeiten, sie in unterschiedlichste Naturnutzungstheorien der umwelthistorischen Diskurse einzubetten. Eine provisorische Übersicht ist in Tabelle 1 zusammengestellt. Die theoretischen Konzepte überlappen teilweise, sie stehen in keinem hierarchischen oder besonderen zeitlichen Verhältnis zueinander. Die jeweiligen Legitimationshinweise für die Schädlingsbekämpfungen ergeben sich als Ableitungen aus den theoretischen Konstrukten. Sie sind in den Quellen und der Primärliteratur seltener explizit auszumachen, weil dort der Theoriebezug eine untergeordnete Rolle spielt. Keine Naturtheorie widerspricht der Schädlingsbekämpfung. Das scheint mir deswegen erklärlich, weil sie alle vor dem Hintergrund einer Agrarwirtschaft gedacht wurden.

Ein Gesichtspunkt grundsätzlicher Art verdient nach meinem Urteil dabei besondere Beachtung: In der Schädlingsbekämpfung tritt ein konkreter Akteur den menschlichen Interessen gegenüber. Nicht wie sonst wird hier ,Natur' als erzieherisches göttliches Werkzeug oder anonyme Kraft tätig, es gibt vielmehr in der organismischen Individualität des Schädlings den logischen Ort und den physischen Akteur, auf den der Mensch seine Aktion hin ausrichten kann. Diese psychologisch wichtige Entlastungsfunktion durch Handlung wird nur dann nicht gewährt, wenn die Schädlingszahl überwältigend groß wird, etwa im Falle von Heuschreckeneinfällen oder anderen Kalamitäten. Überwiegend in solchen Ohnmachtssituationen bemühen Menschen transzendentale Mittel, etwa Tierbannungen. 


\begin{tabular}{|c|c|}
\hline $\begin{array}{l}\text { Theoretisches Konzept } \\
\text { Sicht auf die Natur }\end{array}$ & \\
\hline $\begin{array}{l}\text { Scholastische Werttheo- } \\
\text { rie }\end{array}$ & Augustinus, Thomas von Aquin ${ }^{\mathbf{A}}$ \\
\hline Natura lapsa & $\begin{array}{l}\text { Niedergangstheoretische Auffassung von der Natur als Folge } \\
\text { des Sündenfalls, weil sich Gott aus der ursprünglich perfekten } \\
\text { Schöpfung zurückgezogen, es einen Abfall vom ursprünglichen Plan } \\
\text { gegeben habe }\end{array}$ \\
\hline Dominium terrae & $\begin{array}{l}\text { Auf Genesis 1, 26-28 gegründete Annahme, als Stellvertreter } \\
\text { des Schöpfers eine legitimierte Herrschaft über die Natur auszuüben; } \\
\text { Tiere sind seelenlose Automaten (Descartes und Kant) }\end{array}$ \\
\hline $\begin{array}{l}\text { Naturalistischer Fehl- } \\
\text { schluss }\end{array}$ & $\begin{array}{l}\text { Die Ableitung eines Sollens aus dem Sein. Diese Ableitung ist } \\
\text { nach Hume ein Fehlschluss und unzulässig. Also ist aus der Existenz } \\
\text { eines Organismus (Schädlings) nicht zu folgern, dass seine Existenz } \\
\text { richtig ist }\end{array}$ \\
\hline $\begin{array}{l}\text { Oeconomia / } \\
\text { harmonia naturae }\end{array}$ & $\begin{array}{l}\text { Die Schöpfung beruht auf einer grundsätzlich harmonischen } \\
\text { Ordnung. Das Übel ist ein für die Menschen nicht verstehbarer Teil } \\
\text { der größeren Ordnung. }\end{array}$ \\
\hline $\begin{array}{l}\text {,Naturzustand des Men- } \\
\text { schen und der Natur }\end{array}$ & $\begin{array}{l}\text { Projektion einer spezifischen anthropologischen Setzung in An- } \\
\text { lehnung an Hobbes und Nachfolger B; die Konkurrenz um knappe } \\
\text { Güter; staatsrechtstheoretische Fundierungen des ,Glückseligkeits- } \\
\text { versprechens }\end{array}$ \\
\hline $\begin{array}{l}\text { Artenvielfalt (nachdar- } \\
\text { winische Sicht) }\end{array}$ & $\begin{array}{l}\text { Die Evolution ist ein sich selbst organisierender Prozess, der in } \\
\text { niemandes Verantwortung steht }\end{array}$ \\
\hline Biodiversitätskonvention & $\begin{array}{l}\text { Schließt an Konzepte der oeconomia naturae des 18. Jahrhun- } \\
\text { derts an c }\end{array}$ \\
\hline $\begin{array}{l}\text { Sozialmetabolisches } \\
\text { Konzept, Kolonisierung } \\
\text { der Natur }\end{array}$ & $\begin{array}{l}\text { Gesellschaften ändern gezielt die Parameter natürlicher Systeme } \\
\text { (,Kolonisierung), damit diese für die Gesellschaft nützlicher sind als } \\
\text { ohne den Eingriff }\end{array}$ \\
\hline $\begin{array}{l}\text {,Erfahrungsraum }{ }^{e} \text { und } \\
\text { Erwartungshorizont }^{\mathrm{C}} \mathrm{D}\end{array}$ & $\begin{array}{l}\text { Das Auseinanderrücken von Erfahrung und Erwartung in der } \\
\text { Moderne auch in Bezug auf Beherrschbarkeit der Natur }\end{array}$ \\
\hline
\end{tabular}

Tabelle 1: Schädlingsbekämpfung und Naturtheorien.

A Pribram (1992), Bd. 1. S. $21 \mathrm{ff}$.

B Die analoge Übertragung der Idee des Krieges Aller gegen Alle, wie sie Thomas Hobbes im 13. Kapitel des Leviathans entwickelt, aus der menschlichen Gesellschaft in die außermenschlichen Bereiche hinein, die - wie die Landwirtschaft - für den Menschen wichtig sind, ist nur auf den ersten Blick gewagt, weil ungewohnt. Tatsächlich scheint mir diese Verknüpfung sehr nahe 


\begin{tabular}{|c|c|}
\hline $\begin{array}{l}\text { Theoretisches Kon- } \\
\text { zept }\end{array}$ & Implikation für den Schädlingsdiskurs \\
\hline $\begin{array}{l}\text { Scholastische Wert- } \\
\text { theorie }\end{array}$ & $\begin{array}{l}\text { Bemisst den ökonomischen Wert eines Naturdings an der Nützlichkeit für den } \\
\text { Menschen; im Schädling wird das Böse in der Welt bekämpft }\end{array}$ \\
\hline Natura lapsa & $\begin{array}{l}\text { Schädlinge als Folge des Paradiesverlustes, ,Plagen als Heimsuchung Gottes; } \\
\text { Schädlingsabwehr als logische Folge der notwendig gewordenen menschlichen } \\
\text { Kultivierungsleistung }\end{array}$ \\
\hline Dominium terrae & $\begin{array}{l}\text { Die Stellvertreterfunktion des Menschen gibt ihm das Recht auch zur Tötung } \\
\text { bzw. Bekämpfung des Schädlings. Gott hat dem Menschen hierfür die Mittel gege- } \\
\text { ben (teleologisch) }\end{array}$ \\
\hline $\begin{array}{l}\text { Naturalistischer Fehl- } \\
\text { schluss }\end{array}$ & $\begin{array}{l}\text { Schädlingsbekämpfung ist moralisch unbedenklich, zumal sie die Lebensinte- } \\
\text { ressen bzw. -ansprüche des Menschen vertritt }\end{array}$ \\
\hline $\begin{array}{l}\text { Oeconomia / harmonia } \\
\text { naturae }\end{array}$ & $\begin{array}{l}\text { Schädlinge haben ihren ,Sinn', sind nützliche Glieder im Naturhaushalt, beleh- } \\
\text { ren die MenschenE; Bekämpfung der Schädlinge zur Wiederherstellung des Gleich- } \\
\text { gewichts. }\end{array}$ \\
\hline $\begin{array}{ll}\text { Naturzustand }^{e} & \text { des } \\
\text { Menschen und der } \\
\text { Natur }\end{array}$ & $\begin{array}{l}\text { Übertragung der Idee der Anwendung von Gewalt und des präventiven Agie- } \\
\text { rens zur Durchsetzung des Eigeninteresses }\end{array}$ \\
\hline $\begin{array}{l}\text { Artenvielfalt } \\
\text { (nachdarwinische Sicht) }\end{array}$ & $\begin{array}{l}\text { Ausschließlich menschliche Interessenlagen bestimmen über den vom Men- } \\
\text { schen praktizierten Umgang mit Natur }\end{array}$ \\
\hline $\begin{array}{l}\text { Biodiversitätskonven- } \\
\text { tion }\end{array}$ & $\begin{array}{l}\text { Behauptet die Verantwortung des Menschen für die Biodiversität; profanisierte } \\
\text { Version des Dominus-Terrae-Prinzips }\end{array}$ \\
\hline $\begin{array}{l}\text { Sozialmetabolisches } \\
\text { Konzept }\end{array}$ & $\begin{array}{l}\text { Schädlingsbekämpfung ist Teil der Pflege und Arbeit, derer das kolonisierte } \\
\text { Natursystem bedarf } \mathbf{F}\end{array}$ \\
\hline $\begin{array}{l}\text {,Erfahrungsraum }{ }^{e} \text { und } \\
\text {,Erwartungshorizont }\end{array}$ & $\begin{array}{l}\text { Naturwissenschaftliches Wissen, zentralstaatliche Normen und chemische Be- } \\
\text { kämpfungsmittel werden das Problem ultimativ lösen }\end{array}$ \\
\hline
\end{tabular}

liegend und letztlich doch genuiner Bestandteil des ,naturhistorischen Sicherheitsversprechens', das Meyer, 1999, herausgearbeitet hat. Hobbes ist offenbar bisher als direkter Ideengeber im Schädlingsdiskurs nicht diskutiert, zumal die deutsche Staatstheorie des 18. Jahrhunderts auf Locke und Wolf und später dann auf Pufendorf und Justi rekurriert, deren anthropologischer Entwurf dem Hobbesischen diametral gegenüber steht. Hobbes geht von einer negativen, die deutschen Staatstheoretiker hingegen von einer positiven Anthropologie aus. Aus der Sicht des Schädlings ist es jedoch einerlei, ob er von einem Misanthropen oder einem Gutmenschen erschlagen wird, d.h. die Durchsetzung menschlichen Interesses gegenüber dem Schädling endet (ob im Naturzustand oder kulturell geleitet) immer in der Verdrängung oder physischen Vernichtung des Schädlings. Sie folgt damit demselben Grundmuster, das auch im menschenfreien Naturzustand realisiert ist. Damit ist - bezogen auf die Schädlingsfrage - Hobbes' Vorstellung vom Kampf Aller gegen Alle im positivistischen Sinne die richtige Beschreibung. Hobbes selbst hat übrigens das Recht auf Tötung von Tieren und die Verfolgung von Schädlingen schon vor dem Leviathan (1651) aus dem Naturrecht abgeleitet (Hobbes, 1977 [1642] S.165). Das positive göttliche Recht scheint ihm dabei Probleme zu bereiten, wird von Hobbes aber mit einem Hinweis ausgehebelt: Wenn Tiere den Menschen töten bzw. fressen könnten und dürften, dann müsste dies (und viel eher noch) auch umgekehrt gelten.

c Herrmann (2006b).

D Koselleck (1989), besonders S. $360 \mathrm{ff.}$ 
E So halten uns die wilden Tieren z.B. davon ab, in klimatisch unwirtliche Gegenden vorzudringen; die kleinen Feinde der Landwirtschaft sichern dem Landmann den Preis, indem sie die halbe Ernte auffressen und damit ein preisschädliches Überangebot abschöpfen; selbst die Läuse sind sinnvoll, weil uns das Ungeziefer lehrt, gelegentlich Räume und Kleider zu lüften. Zusammenfassung eines längeren Textzitats aus: Anonymus (1795). Anstatt einer Vorrede, ohne Seitenzählung.

F Schmid, M. (1998), S.91.

Die Tabelle bildet eine Zusammenstellung von verbreiteten ,Naturtheorien', die in umwelthistorischen Diskursen implizit wie explizit benutzt werden, ohne dass sich deren Ursprung oder Urheberschaft immer klar benennen ließe. Die linke Spalte führt die am häufigsten benutzte Bezeichnung der jeweiligen ,Naturtheorie an, die in der zweiten Spalte inhaltlich erläutert wird. In der dritten Spalte wird eine theoriekonforme Begründungs-Rhetorik für eine eingebettete Schädlingsbekämpfung aufgeführt. Es handelt sich um idealtypische Abgrenzungen, in Anlehnung an umwelthistorische Bemühungen um Kategorien oder Sortierungen oft miteinander verschränkter theoretischer wie praktischer Begründungselemente. Die Liste ist als heuristisch und (nahezu) beliebig erweiterbar zu verstehen, ohne dass logische Konflikte zwischen dem jeweiligen Naturkonzept und der praktizierten Schädlingsbekämpfung auftreten würden. Sie eignete sich auch für umwelthistorische Verwendungen außerhalb dieses konkreten Zusammenhangs.

Über die in Tabelle 1 aufgeführten Positionen hinaus vermute ich, dass Ideen der Schädlingsbekämpfung auch in den Kontext von ,Reinheit und Gefährdunge (Douglas 1988) gestellt und in diesem größeren Zusammenhang ebenfalls produktiv zu analysieren wären. Zweifel an diesem Vorschlag ließen sich allein schon mit dem Hinweis auf die Sprachwurzel des Wortes ,Ungeziefer ${ }^{`}$ begegnen, der den Bezug zum Heiligen im Sinne der Leitidee Mary Douglas' herstellt.263 Dabei ist unerheblich, ob für das Unwertkriterium die Anwesenheit am falschen Ort (wie Douglas betonen würde) oder die unterste Stufe des Konzeptrasters gilt (wie der Douglas-Kritiker Miller einwendet).264 Eine Diskussion von Gesichtspunkten, die sich aus den Naturdefinitionen von Holling, Gunderson und Ludwig (2002) für den Schädlingsdiskurs ergeben, erfolgt wegen ihrer problematischen historischen Übertragbarkeit an anderer Stelle.265

In seiner Darstellung von Risikoperzeption und Sicherheitsversprechen im 18. Jahrhundert führt Meyer in einsichtiger Weise aus, dass die Schädlingsfrage in das damals im betrachteten deutschen Raum gültige staatstheoretische Konzept des Glückseligkeitsversprechens integriert ist. ${ }^{266}$ Er begründet dies einmal mit der

263 Zum Ungeziefer-Begriff: DWB bzw. Herrmann (2006a). Wichtig ist in diesem Zusammenhang der Hinweis auf die biblische Unterscheidung von ,reinen' und ,unreinen' Tieren.

264 Miller (1998); hierzu auch Edelman (2002).

265 Herrmann (2007).

266 Ich verweise auf Meyer (2003) und das Kap. 4.3. bei Meyer (1999) und führe daher hier nicht weiter aus. Bei Meyer auch zahlreiche exemplarische Belegstellen für das Folgende, ebenso in Herrmann (2006b). 
Bedeutung des Epistems, sehen', das in der Naturwissenschaft über den reinen Deskriptionsakt ausgedehnt wäre. Tatsächlich befindet er sich mit dieser Diagnose in Übereinstimmung mit dem Urteil von Alpers ${ }^{267}$, die am Beispiel der niederländischen Naturmaler vor allem des 17. Jahrhundert zeigt, wie sich aus der Deskription „mit getreulicher Hand und ehrlichem Auge“268 allmählich die naturwissenschaftliche ,Sichtweise entwickelt. ${ }^{269}$ Mit dem ,Sehen ${ }^{e}$ ergibt sich auf der Grundlage des damals gültigen Naturkonzeptes der oeconomia naturae und der in ihr niedergelegten scala naturae ein je spezifisches Verständnis von der ,Natur', ein spezifisches Verständnis von den Eigenschaften der Organismen. Am weltlichen Ende dieser Stufenleiter steht der Mensch, dem die natürliche Verpflichtung zufällt, die Schöpfung nach seinen Bedürfnissen zu vollenden, das heißt in der Konsequenz auch, gegen alles mögliche Getier und Unkraut vorzugehen. ${ }^{270}$ Das ist insofern ohnehin bedenkenlos, weil der oeconomia naturae der Gedanke des Aussterbens von Arten absolut fremd ist. Der Nutzen einer ,Naturgeschichte der Schädlinge für die staatlichen Ziele bestand einmal in der Beibringung von Wissen über die Tiere selbst, durchaus im Sinne einer Optimierung der gegen sie gerichteten Kampagnen, und zum anderen in dem durch Schädlingsbekämpfung möglichen Beitrag an der Verstetigung der materiellen Versorgung der Untertanen und der Steigerung staatlichen Reichtums. Meyer hat die Zurückdrängung der physiko-theologischen Skrupel, wonach der Mensch letztlich nicht beurteilen könne, ob ,Schädlinge tatsächlich ,schädlich ${ }^{`}$ seien, durch die Naturgeschichte betont und die Naturgeschichte geradezu in der Verpflichtung zum Ignorieren dieses Erkenntnisproblems gesehen: »Die physiko-theologische Annahme einer Gleichheit aller Geschöpfe wurde angesichts des Ressourcenrisikos obsolet, denn dies anzuerkennen, hätte bedeutet, keine praktischen Sicherheiten anbieten zu können. Der ,Schädling' hätte nicht als ,Schädling' gebrandmarkt werden können, die Eingriffstiefe des Menschen in die Natur wäre beschränkt geblieben - eine unvorstellbare Konsequenz angesichts des verbindlichen Bezugspunktes der säkularen ,Glückseligkeit'.«271 In dieser Zeit

267 Alpers (1998).

268 Zunächst des Beobachters, der entweder Künstler ist oder Naturforscher wird. Vgl. Alpers (1998) Kap. 3.

269 Unter diesen Naturmalern des 17. Jahrhunderts finden die Tiere des ,Ungeziefers', die Insekten, eine besondere Aufmerksamkeit. Großartigste Beispiele liefern Maler wie Georg Flegel, Jan van der Kessel, Joris Hoefnagel, Roelant Savery, Jan Breughel und Ambrosius Bosschaert. Vgl. Das Flämische Stilleben (2002), S. 61 - 109, darin insbesondere Schütz (2002), S. 61 - 109.

270 Als beliebiges Beispiel, das alle einschlägigen Topoi enthält, ein Kommentar zur Sperlingsbekämpfung: „Es fällt mir gar nicht leicht, diese kleinen listigen Raubvögel [sic ! BH] in besondern Schutz zu nehmen [..]; allein sie gänzlich auszurotten hieße wohl, sich an der Schöpfung zu versündigen [..].Überdies möchte es doch wohl zu den Unmöglichkeiten gehören, weil ihre Aufenthaltsschlupfwinkel schwer auszuspähen sind.“ und etwas weiter: „[..] denn der Mensch, als das edelste Geschöpf Gottes, hält sich berechtigt, alles ihm Schädliche von sich zu entfernen, wozu ihm der Schöpfer den Verstand verliehen hat." Dies ist zugleich auch die Position des Autors ,W.' in seinem Beitrag in der Allgemeinen Landwirthschaftlichen Zeitung 1812, Halle, S. 343345, aus dem das Zitat stammt.

271 Meyer (1999), S. 72. 
kommt Bechstein zu einer ziemlich modern anmutenden Einsicht, ${ }^{272}$ als er sich Gedanken über den ,Naturzustand ${ }^{`}$ der Natur macht (er meint durchaus das gleiche, was die heutige Ökologie unter a- bis oligo-hemerobem Zustand versteht), in der er die Logik des Regulierungsanspruchs der Staatstheorie bruchlos auf das Problemfeld bezieht. Daher steht nicht die Bekämpfung als solche bei ihm in Frage, aber das Vorgehen könne mit Zurückhaltung erfolgen. Die Kenntnis der vollständigen Naturgeschichte sichere eben den vernünftigen und richtigen Umgang mit den unerwünschten naturalen Wettbewerbern, durchaus auch unter Anerkennung derer Lebensinteressen, aber vor allem und selbstverständlich bei Wahrung der menschlichen Interessen. Bechstein spricht bemerkenswerter Weise zunächst weder von Gott noch von der Schöpfung, sondern vom vernünftig handelnden Menschen (d.i.: das zeitgenössisch rationale, positive anthropologische Modell). Für die Modernität dieses Gedankens nimmt Bechstein am Ende dann aber doch noch den Schöpfer selbst in Anspruch, wenn er dessen Bedeutung auch geschickt relativiert ${ }^{273}$ : »Ich zähle es mit unter den Nutzen, den dieß schädliche Waldinsect, die Nonne, jetzt stiftet, daß durch sie die Menschen aus allen Ständen einmal auf die Natur, auf eine so erschütternde Art, aufmerksam gemacht werden. Es ist der weise Schöpfer gleichsam selbst, der uns hier durch sein gewöhnliches Erziehungsmittel, die Noth und das Unglück, wie wir es zu nennen pflegen, aufzuwecken sucht, auf das, was um uns her durch ihn lebt, wächst und wirkt zu merken, es zu untersuchen, durch unsern Verstand zu bereichern, unser Herz zu veredeln, und für unsere körperlichen Bedürfnisse zweckmäßiger als sonst zu sorgen.«

Von hier richtet sich der Blick folgerichtig auf die praktischen Maßnahmen.

272 Bechstein (1800), S. 4 ff: „Alle diese Thiere, die uns jetzt so großen Schaden zufügen, sind da, wo die Menschen noch als Naturmenschen mit wenig Bedürfnissen leben, nicht unnütz, sondern als Räder in der großen Weltuhr anzusehen, durch deren Mangel die ganze Maschine nicht stocken, doch unrichtig gehen würde; sie sind wie die Raubthiere dazu bestimmt, in der sich selbst überlassenen Natur Gleichgewicht zu erhalten ... In der sich selbst überlassenen Natur ist daher, wie Vernunft und Erfahrung lehren, immer Gleichgewicht. Allein der Mensch kultiviert sich, er schafft sich Bedürfnisse, die mit dem Interesse der Thiere streiten, er stellt und dreht also, so viel er weiß und kann, an dem natürlichen Gang jener Uhr, und glaubt er könne dies mit Recht, da er sich als unumschränkten, ungebundenen Beherrscher aller Erdengeschöpfe hält, zu dessen Gebrauch alles da sey. Hierbey sollte er sich nun aber, wenn er sich als vernünftigen Beherrscher, und wohlbestellten Haushalter in der sichtbaren Natur ansieht, fein besinnen, weil er in dieser Natur zu schalten und zu walten habe, und es ist in der That Pflicht für ihn, auf welche Vernunft und selbst sein eigenes Interesse ihn hinweisen, es zu einer Gewissensfrage zu machen: In wie fern habe ich, um am wenigsten und ohne Frevel, in den Naturgang zu Gunsten meines Interesses einzugreifen, an jener Uhr zu drehen und zu stellen Dann wird er auch zu einer weisen Mäßigung und zu Regeln gelangen, welche ihn bey seinen Operationen in der Natur leiten müssen; dann wird er richtiger entscheiden, welche Gegenstände der Natur mehr oder weniger mit seinem Interesse zusammen stimmen, welche schädlich oder nützlich seyn, welche er zu veredeln, zu begünstigen habe, und welche er zu vermindern, zu entfernen, zu verscheuchen sich erlauben dürfe."

273 Bechstein (1800), S. 7. Die rationale Modernität Bechsteins ist verblüffend, und der folgende Rückgriff auf den Schöpfer geschieht nach meinem Eindruck eher aus präventiv-apologetischer Ursache als aus innerer Überzeugung des Autors. 


\section{Historische Schädlingsbekämpfungen}

\subsection{Vorerwägungen oder Schädlinge als zwangsläufige Hervorbringung des Agrarregimes}

Gegenüber deduktiven, logischen Ableitungen stehen die primär abduktiven Empirien, mit denen man sich die Schädlinge vom Halse schaffen will.

In meiner Betrachtung habe ich zwei Mängel einzuräumen: Der erste Mangel betrifft meine Unkenntnis über die Entwicklung der Landwirtschaft und die Agrarkrisen des späten 18. und des 19. Jahrhunderts sowie die in diesem Aufsatz geübte Ausblendung der forstlichen Schädlingsbekämpfung. ${ }^{274}$ Es ist zwar beispielsweise völlig unstreitig, dass allein die Aufhebung der Dreifelderwirtschaft und Feldgemeinschaften sich mindestens teilweise nachteilig auf die Lebensbedingungen einzelner Schädlingsarten (z.B. Heuschrecken) auswirkte, gleichzeitig werden andere Organismen zum Ausweichen in die Kulturen gezwungen und damit gleichsam ,Nachrücker in der Schädlingsreihe gewesen sein. Aber eine Gesamtbetrachtung des Themas unter angemessener Berücksichtigung der Agrarentwicklung und der Forstschädlingskalamitäten übersteigt nicht zuletzt den Rahmen dieses Aufsatzes. Für die Behandlung der weiter unten behandelten Fragen ist diese Beschränkung jedoch unerheblich, weil die gefundenen Schlussfolgerungen und Bewertungen davon im Grundsatz unbeeinflusst bleiben.

Grundsätzlich spielt für die Geschichte der Schädlingsbekämpfung das in der Ökologie eminent wichtige Phänomen des ,Nachlaufense von Entwicklungen eine große Rolle. Wegen der Resilienz ökologischer Systeme führt jede Änderung innerhalb des Systems nur zu einer allmählichen Anpassung, und zwar mit zeitlicher Verzögerung, d.h., innerhalb des Systems laufen die Anpassungsänderungen noch längere Zeit weiter, obwohl die Stellgröße selbst schon lange nicht mehr geändert wird. Werden nun Änderungen im Agrarsystem umgesetzt, machen sich auf der Schädlingsebene diese Änderungen notwendiger Weise erst mit Verzögerungen bemerkbar. Der Gedanke kann mit einer Kurve illustriert werden, die den grundsätzlichen Zusammenhang zwischen Biodiversität (BD) und Eingriffsintensität qualifiziert. Danach führt landwirtschaftliche Nutzung zu Zeiten des alten Agrarregimes (das zunächst bis in die Mitte des 19. Jahrhunderts gedacht werden muss) wegen des Mosaikcharakters und der kleinräumigen Parzellierung der Landschaft zu einem Biodiversitätsanstieg, die Artenzahlen pro Fläche Kulturlandschaft nimmt zu, also auch die Diversität von Schadorganismen. Oberhalb einer gewissen Eingriffstiefe nimmt die BD dann ab (Abb.1).

274 Sie wird im Graduiertenkolleg 1024 von Katharina Engelken verfolgt. 
Nach der neueren Forschung im europäischen Verbund ${ }^{275}$ stellt sich der zeitliche Zusammenhang zwischen BD und Eingriffstiefe so dar, dass sich hochgerechnet der Kurvenscheitel für etwa die Mitte des 19. Jahrhunderts ergibt, d.h. zu diesem Zeitpunkt das Maximum der Artendiversität in der Kulturlandschaft Mitteleuropas anzunehmen ist. Der intensivierte Landesausbau und die Inkulturnahme zahlreicher vorher

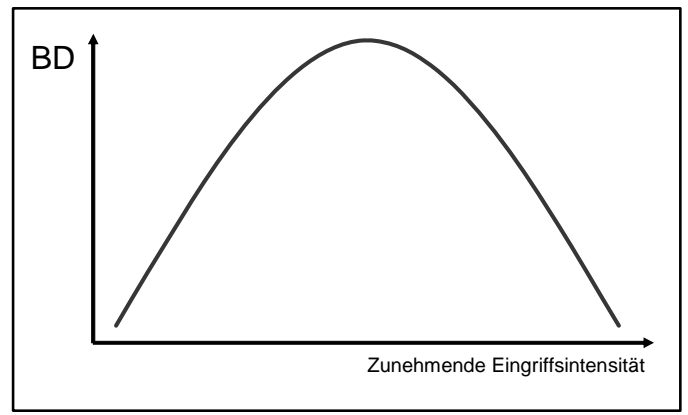

Abb. 1: Allgemeiner qualitativer Zusammenhang zwischen Biodiversität (Artendiversität; BD) und Eingriffstiefe in der Kulturlandschaft (Bredemeier, pers. Mittlg., in Anlehnung an Schmid, B., 2002, und Gasto/ Spicer, 1998, S. 33). Der darin enthaltene Anteil ,unerwünschter Arten` (Schadorganismen) muss einmal allgemein mit der Eingriffsintensität steigen und dann noch einmal auf der Seite rechts vom Kurvenscheitel (Näheres im Text).

nicht (zumindest nicht so intensiv) genutzter Flächen seit der Mitte des 18. Jahrhunderts (Stichwort Bevölkerungszunahme) führen trotz grundsätzlich ähnlichem Bewirtschaftungsmuster wegen des Nachlaufcharakters des Systems erst mit dieser Verzögerung zu dem (angenommenen) Biodiversitätsmaximum. Die seit der Mitte des 19. Jahrhunderts einsetzende Intensivierung und Mechanisierung der Landwirtschaft und der Übergang zu großflächiger Anbauweise hat dann die bekannte BDAbnahme zur Folge. Betont sei, dass es sich dabei um Artenabundanzen, nicht jedoch notwendig und gleichermaßen um Individuenabundanzen handelt, die für die Schädlingsfrage von erheblicher Bedeutung sind. Für die Schädlingsproblematik hat die eingriffsabhängige BD-Änderung eine überraschende Folge. Nach logischen Prinzipien muss die Zahl der Schadorganismenarten zunehmen, wenn die BD zunimmt. Da die BD in der Kulturlandschaft durch die Agrarkultur zunimmt, muss auch der absolute Anteil der Schädlingsarten auf den Kulturflächen zunehmen. Wenn durch weitere Eingriffsintensität die BD abnimmt, nimmt die relative Zahl der Schadorganismenarten weiterhin zu, es verbleibt z.B. neben der alleinigen Kulturart Mais nur noch der Maiszünsler. Grundsätzlich bedeutet dies die Zunahme der Schädlingsproblematik bei zu-

275 Nach aggregierten Daten aus dem Forschungsverbund ALTER-NET (http://www.alternet.info/). Ich danke Herrn Kollegen Michael Bredemeier, Forschungszentrum Waldökosysteme, Universität Göttingen, für diesen Hinweis. 
nehmender Eingriffstiefe und gleichzeitig abnehmender BD. Eine unangenehme Konsequenz, weil sie eine Verschärfung des Problems bedeutet.

Die interessante Frage, welcher Zusammenhang zwischen menschlicher Wirtschaftsweise und dem Massenauftreten von Schädlingen historisch besteht, ist bisher meines Wissens nur punktuell verfolgt worden. Dabei sind doch z.B. die Sperlingsplagen des 18. Jahrhunderts in ihrer anthropogenen Ursache unbezweifelbar. ${ }^{276}$ Überhaupt verdankt sich das vom Menschen beklagte Schädlingsproblem dem Faktum seiner eigenen Wirtschaftsweise. Doch ist der Zusammenhang konkreter, subtiler und wenigstens in Einzelfällen bekannt. Lang anhaltende Weidenutzung von Waldgebieten etwa führt zu einer Anfälligkeit des Baumbestandes gegenüber Schadinsekten. Die Zusammenhänge können sehr speziell werden. So ist durch Zwölfer ${ }^{277}$ nachgewiesen worden, dass Massenvermehrungen des Buchenspinners (Dasychira pudibunda) im Spessart und Reinhardswald fast ausschließlich auf Beständen auf Buntsandstein auftraten, die durch jahrhundertelange Streunutzung degradiert waren. ${ }^{278}$ Für die Regeneration der Waldböden nach Weidenutzung nennt Schimitschek (1964) Schätzzahlen von 300 - 500 Jahren. Er weist auch, geeignete Bodenbeschaffenheit und Klima vorausgesetzt, auf den Zusammenhang zwischen [in aller Regel anthropogener, BH] Absenkung des Grundwasserspiegels und ,Maikäferseuchen ‘ sowie dem Massenauftreten von »Blattwespen, Kleinschmetterlingen und Großschmetterlingen, Borken- und Bockkäfer sowie Holzwespen « hin: »Es entstehen somit neue Seuchenlagen und Seuchenherde « ${ }^{279}$ durch Langzeitfolgen menschlicher Wirtschafts- und Nutzungsweise.

An dieser Stelle greift der zweite Mangel meiner Ausführung. Es existieren aus der Biologie wie aus den historischen Archiven keine Daten zu historischen Populationsdynamiken von Schadorganismen und geschädigten Organismen.280 Dabei wären gerade solche Daten im Hinblick auf die Populationsdynamik von Schadorganismen dringend erwünscht. Immerhin lassen sich für einzelne Schädlingskalamitäten archivalisch Jahre ihres Auftretens benennen (mitunter sogar ,lange Reihen). Beispielsweise für Heuschrecken in Brandenburg des 18. Jahrhunderts sind dies 1730, 1731, 1748, $1750,1752,1753,1754,1760,1761,1763,1777,1782,1783,1784,1785.281$

Ein Rückschluss aus den (im Umfang nicht benannten) Schäden auf eine objektivere Abschätzung des Schadensfalls und damit des Umfangs des Schädlingsbefalls scheint bisher nicht möglich. Einzuräumen ist, dass für eine solche Frage der Bedarf in

276 Herrmann, Bernd und Woods, William (2003) Between biblical plague and pristine myth: Passenger pigeons, sparrows and the construction of abundances. Oral presentation at the ASEH Conference, Providence 2003. Veröffentlichung in Vorbereitung.

277 Zwölfer (1957); weitere Beispiele in Schimitschek (1969).

278 Ein eindrucksvolles Beispiel für die weiter oben erwähnte Nachlaufeigenschaft in Ökosystemen.

279 Schimitschek (1964), S. 23. Da Schimitschek Forstzoologe war, fokussiert seine Arbeit überwiegend forstliche Probleme.

280 Im Näherungsmodell könnte man von Ernteerträgen und Viehproduktionen auf entsprechende Populationsdynamiken schließen. Ob das ginge und mit welchem Kenntnisgewinn, vermag ich nicht zu beurteilen. Zumindest sind die historischen Daten, die sich ggfl. in Archivbeständen finden ließen, bisher nicht aufgearbeitet.

281 Herrmann (2003). Aber das objektive Ausmaß dieser Schadensereignisse ist bisher unbekannt. 
der heutigen praktischen Schädlingsbekämpfung nicht zu bestehen scheint und daher Modellierungen aktuell offenbar nicht beforscht werden. Damit fehlen auch für historische Sachverhalte die für Anleihen geeigneten Vorbilder. Immerhin lassen sich in Einzelfällen unabhängige Bestätigungen für das Vorliegen historischer Kalamitäten beibringen. Dendrochronologische Untersuchungen belegen historische Schädlingsgradationen z.B. für den Lärchenwickler, den Schwammspinner und den Maikäfer. ${ }^{282}$ Wirklich zufrieden stellend sind solche Proxydaten nicht, weil sie am Ende nur den Befall der dendrochronologisch konkret untersuchten Bäume belegen und das Ausmaß des Schadensfalles weiterhin unklar bleibt.

\subsection{Hauptstränge des Schädlingsdiskurses}

In Anlehnung an eine Systematik von Grau ${ }^{283}$, der Empfehlungen der deutschen Hausväterliteratur zwischen 1570 und 1786 zur Schädlingsbekämpfung gruppiert hat, lassen sich die Maßnahmen zur Bekämpfung zweckmäßig nach handlungspraktischen Gesichtspunkten ordnen:

- Mechanische Verfahren (d. i. alle Varianten des Tötens durch Anwendung physischer Gewalt)

- Gifte ( Räuchern giftiger Pflanzen, Atemgifte, Fraßköder)

- Abschreckungsmittel (Ausbringen von übel riechenden Substanzen)

- Vorbeugung (technische Mittel oder Einbringen abschreckender Substanzen)

- Lockmittel (Ausbringen von Ködern, ggf. Fangen, anschließende Tötung)

- Nutzung biologischer Antagonisten (Förderung bekannter Schädlingsräuber)

- Magische Verfahren (Einsatz von Abwehrmitteln mit besonderen, innewohnenden ,Kräften', Abwehrzauber)

Die Anfertigung einer Statistik nach Schädlingen und Maßnahmen erscheint nicht hilfreich: Die jeweiligen praktischen Anwendungen bleiben unsicher, weil die zeitgenössische Literatur nur Empfehlungscharakter hat, wobei immer mehrere Optionen genannt werden. Den damaligen Mitteilungen über eigene praktische Erfahrungen der Autoren in der Verwendung konkurrierender ,bester Mittel zur Vertilgung oder Vertreibung' ist immer eine gesunde Skepsis entgegenbringen, weil es z.B. nicht wirklich überzeugend sein kann, eine Fledermaus mit der aus einem entgegengestreckten Eschenzweig ausströmenden magischen Kraft zur Meidung eines Aufenthaltsraums zu bewegen. Die beständige Empfehlung von Vorgehensweisen auch aus unsicherer Quelle und von empirisch zweifelhafter Güte werte ich nicht nur als bloße Mitteilung nach dem bekannten Muster konventioneller magischer Wissenschaft gepaart mit en-

282 Weber (1997); Vogel und Keller (1998); Leuschner und Leuschner (2002); Leuschner (2005).

283 Grau (1971). Hingegen hatte Kemper (1968), S.15, seine Liste der Schädlingswirkungen deduktiv nach ,ihrem historischen Auftreten' entworfen. Sie eignet sich nicht zur Aufdeckung von Mustern oder Konzepten. 
zyklopädischem Ehrgeiz des Autors, sondern durchaus auch als Beleg für eine gängige Praxis des Magischen im Alltag.

Die Bekämpfungsmuster dieser Systematik reichen, wegen ihrer im Prinzip die gesamte Breite technisch möglicher Mittel abdeckenden Vorgehensweise, bis auf den heutigen Tag. ${ }^{284}$ Die Mittel und Hilfsmittel mögen sich dabei geändert haben. Offiziell aufgegeben sind die magischen Praktiken. Man darf indes daran zweifeln. Jedenfalls nehmen die magischen Verfahren zahlenmäßig am Ende des 18. Jahrhunderts einen immer noch erheblichen Anteil ein und werden erst im 19. Jahrhundert allmählich aus den gelehrten Darstellungen weichen.

Das Leitmotiv der Entwicklungslinie im hier betrachteten zeitlichen und räumlichen Fenster, wobei man die Anfänge sicher bis ins 17. Jahrhundert zurückverfolgen kann, ist grundsätzlich die Produktivitätssteigerung. Unsicherheit herrscht nur über die dabei eingesetzten Mittel. Die Verbindung des Schädlings-Themas mit der alltäglichen Praxis ist vielfältig und vielfältig greifbar, nicht nur in gelehrten Blättern, Magazinen, Zeitungen, Kalendern, und hausväterlichen Ratgebern ${ }^{285}$, sondern auch in den gelehrten Zusammenhängen, wie den wissenschaftlichen Monographien. Mit ihrem Vermittlungsauftrag zwischen der Mehrung des allgemeinen Fortschritts und den Bedürfnissen des praktischen Alltags, suchen auch die gelehrten Akademien des 18. Jahrhunderts praktisch europaweit nach Lösungen. ${ }^{286}$ Erstaunlicherweise sind es nicht die Schädlinge von europäischer Dimension, wie die immer wieder einfallenden Heuschrecken, welche die Akademien zu Preisschriften anregen, sondern, oder vielleicht sogar bezeichnender Weise, die Probleme vor jedermanns Haustür: Die Schädlinge im Obstund im Weingarten, die ,Käfer ${ }^{`}$ und die ,Würmer in den Speichern, kaum noch die Mäuse und völlig unterrepräsentiert, wenn überhaupt behandelt, Vertreter anderer zoologischer Schädlingskategorien. Was am Ende jeden betrifft, dient schließlich letztlich auch und ganz unmittelbar der Volkswirtschaft, der Wohlfahrt, der Glückseligkeit.

Ohne hier noch weiter auf die zahlreichen Empfehlungen in zeitgenössischen gelehrten Blättern, Magazinen, Zeitungen, Kalendern einzugehen, deren heutiges Äquivalent wohl am ehesten mit grauer Literatur ${ }^{\circledR}$ beschrieben ist, stellt sich für mich der

284 In der Diskussion wies Sarah Jansen darauf hin, dass es die Mittel ,der Küche und des Handwerks' waren, die zum Einsatz kamen. Das läßt sich komplikationslos in den Begriff der ,bricolage’ überführen. Im Übrigen beschreibt es überzeugend eine Differenz gegenüber der Einbringung von Pestiziden auf Baumwollfelder etwa mit dem Flugzeug. Indes werden in Haus und Garten und auf der kleineren Parzelle auch heute noch die Schädlingsbekämpfungsmittel in nämlicher Weise angewendet. Die Vielzahl der Schädlinge und ihre dadurch bedingte situative Definition greift notwendig auf die ,Bastelei’ als angemessenes Reaktionsmuster zurück, vor allem aus Praktikabilitätsgründen (d.i.: was ich gerade zu Hand habe, um den Schädling zu töten), aber auch aus ökonomischer Ursache.

285 Man setzt z.B. von privater Seite Belohnungen für Erfolg versprechende Rezepte aus, z.B. Aerenthal (1802), S. $582 \mathrm{ff}$ [Remedia, Mittel um allerley Ungeziefer abzuhalten und zu vertreiben], der 20 Dukaten für ein verlässliches Mittel zur Vertreibung von Mäusen auslobt.

286 Für eine entsprechende Überblicksrecherche danke ich Frau Cornelia Buschmann, Potsdam, DFG-Projekt ,Preisschriften als Institution der Wissenschaftsgeschichte im Europa der Aufklärung'. 
Diskurs der sachverständigen Autoren nach der gehobenen und gelehrten Literatur in der Hauptsache als aus fünf Diskussionssträngen gespeist dar, ${ }^{287}$ den ich nachfolgend in ganz groben Zügen skizziere. Sie bilden nach meinem Urteil die Fundierungen der Schädlingsdiskurse der jeweiligen Eliten und liefern, neben dem volkskultürlich Alltagspraktischen, das handlungstheoretische Unterfutter der Bekämpfungspraxis. ${ }^{288}$

Der erste Strang liegt zunächst noch ganz auf der Linie der magischen Wissenschaft und symbolischen Ausdeutung der Natur. Als ein einschlägiger zeitgenössischer Protagonist ist Acxtelmeier (1692) auszumachen, der behauptet, überhaupt das erste Buch über Ungeziefer (,Unzieffer) verfasst zu haben. ${ }^{289}$ Immerhin thematisiert er auch Tiere, die nach zeitgenössischem Urteil dem Ungezieferreich angehören. Indes sind ihm diese Tiere nicht (bzw. nicht vordringlich) Subjekte praktischer Erwägung der Schädlingsbekämpfung, vielmehr sieht er in ihnen vor allem moralisierende Belehrungen des natürlichen Buches der Offenbarung. In dem Maße, in dem sich die Wissenschaft von solchen magisch-symbolischen Naturdeutungen entfernt und sich rationallogischen, zunehmend positivistischen Erklärungen zuwendet, gerät auch diese Sichtweise allmählich ins Abseits und ist - zumindest aus den gelehrten Diskursen - nach der Mitte des 18. Jahrhunderts weitgehend verdrängt. Ein Refugialraum bot sich im abergläubischen Bereich und in volkskulturellen Zuschreibungen, von wo aus sie bis auf den heutigen Tag gelegentlich sichtbar wird. ${ }^{290}$

287 Natürlich ist dies eine retrospektive Diagnose, ein bei historischer Forschung grundsätzlich nicht hintergehbares Faktum. Es ist zu allen Zeiten die Durchsetzungsmöglichkeit eines Argumentes, die dessen Überleben im gelehrten Diskurs sichert (wohlgemerkt: das ist nicht notwendig gleichgesetzt mit der Richtigkeit eines Argumentes!). Ist ein Argument, aus welchen Gründen auch immer, nicht durchsetzungsfähig, wird es letztlich aus dem gelehrten Mainstream-Diskurs entfernt. Ich betrachte also die Hauptprotagonisten des Schädlingsdiskurses des 18. Jahrhunderts in ihrer Wirkung auf die Herausbildung und die Präzisierung des Schädlingsthemas im Laufe des 18. und zu Beginn des 19. Jahrhunderts und diagnostiziere die Durchsetzung fünf gedanklicher Hauptlieferanten.

288 Den Grenzfall zwischen Volks- und Elitenkulturen betrachtet Freytag (2003), S. 316 ff, mit einer für das vorliegende Thema nützlichen Fokussierung.

289 Den früheren Naturgeschichtsbüchern, wie etwa Conrad Gesners Tierbuch, ist diese bis auf den Physiologus zurückgehende Tradition der symbolischen Naturbehandlung durchaus geläufig. Durch Acxtelmeiers Konzentration auf diese Themen ist sein Werk letztlich wohl dem Umfeld der emblematischen Literatur zuzurechnen.

290 Die Verfolgung dieses Aspektes sprengt den Rahmen und die Intention dieses Aufsatzes. Ich verweise zum thematischen Einstieg pauschal auf die volkskundliche Literatur und auf neuere Forschungen der Arbeitsgruppe um Wolfram Siemann, München. Den Hinweis auf Karin Dosch-Muster (1996) verdanke ich Nils Freytag, München. Darin findet sich aus der ersten Hälfte des 19. Jahrhunderts das Beispiel einer magischen Praktik mit Bannspruch (Spruch 69) gegen Mäuse in der Scheune (Lagerschädlinge). Vgl. im übrigen Stichwort Ungeziefer im Handwörterbuch des Deutschen Aberglaubens $(1927$ - 1942). Eine einschlägige Fundgrube von ,Sonderbarkeiten', deren Praxis bis ins 19. Jahrhunderts verfolgt wird, stellt Cowan (1865) bereit, auf den mich dankenswerter Weise Karin Barton aufmerksam machte. Dass sich Bannungen gegen Insekten als magische Praxis bis ins 19. Jahrhundert hielten, weist auch Evans (1906) nach; darin beachtenswert das Vorwort von N. Humphrey mit weiterführender moderner historischer Literatur. Am Ende wird keine Überlegung zur damaligen, Wissensgesellschaft' um ein simples Faktum 
Einen zweiten Einflussstrang sehe ich mit Meyer (1999) in den handlungsleitenden staatswissenschaftlichen Konzepten. Ist die Untertanenfürsorge ohnehin eingeschrieben in das Konzept des guten aufgeklärten Herrschers, dann ermutigen die staatstheoretischen Erwägungen der Zeit, wie Meyer herausarbeitet, besonders auch die Naturgeschichtsforscher, durch Erklärungen der Naturdinge deren Beherrschbarkeit für das Staatsziel (die allgemeine Glückseligkeit) nutzbar zu machen. Diese territoralherrschaftliche Sicht greift Ende des 18. Jahrhunderts auf eine naturrechtliche ,politische Metaphysike als Metatheorie zurück, innerhalb derer der Schädlingsdiskurs Bedeutung für das staatliche Glückseligkeits- und Sicherheitsversprechen (Meyer, 1999) erhält. Mit dem Heuschreckenedikt von 1753 wird bereits eine Regelung für das gesamte Preußische Territorium formuliert, für das gleichzeitig die örtliche Umsetzung funktional festgelegt wird. ${ }^{291}$ Von hier lässt sich eine Entwicklungslinie ziehen, an deren Ende 1898 die Einrichtung der ,Biologischen Abteilung für Land- und Forstwirtschaft ${ }^{e}$ beim ,Kaiserlichen Gesundheitsamt ${ }^{`}$ steht, aus der letztlich die heutige ,Biologische Bundesanstalt ${ }^{e}$ hervorgegangen ist. Die Herausbildung dieses Professionalisierungsstranges ist u.a. bei Jansen (2003) dargelegt, eine ,Innensichtdarstellung ‘ bei Sucker (1998a, 1998b). Dabei scheint mir der Umstand besonders wichtig, dass mit der Änderung der Eigentumsrechte an Grund und Boden ${ }^{292}$ sich zu Beginn des 19. Jahrhunderts eine Entwicklung beschleunigt, die eine zentrale staatliche Regelung auch für Schädlingsfragen begünstigt. Dies findet sich entsprechend umgesetzt bereits mit ersten Gesetzesaktivitäten der Reichsregierung nach 1871, ${ }^{293}$ mit der Elemente der territorialstaatlichen Praxis in zentralstaatlicher Institutionalisierung münden. Ganz sicher ist hier auch die Philosophie einer ,In-Dienst-Stellung der Natur im 18. Jahrhundert (Bayerl 2001) angesiedelt, in deren konsequenter Logik ,Unnützliches ${ }^{e}$ aus der Natur zu beseitigen, zumindest zu verdrängen ist.

Die Nähe dieses zweiten Einflussstranges zu einem dritten, der Hausväterliteratur, ist für mich unbezweifelbar, wenn man das Selbstverständnis führender Hausväter wie Hohberg ${ }^{294}$ bedenkt, die sich nicht nur zu den bloßen ökonomischen Fragen der Führungspraxis eines Gutsbetriebs äußern, sondern sich letztlich auch als Äquivalente im Kleinen eines aufgeklärten absolutistischen Landesfürsten begreifen. Die Bemühung der Hausväter zur Anhebung der Produktivität, damit zur Ertragssteigerung und damit am Ende auch zur Beförderung von Wohlfahrt und Glückseligkeit im gesamten Herrschaftsbereich ist unübersehbar. So werden die Hausväter nach Hohberg, der allerdings nur sehr kursorische Angaben zur Schädlingsbekämpfung macht, dann doch auch zunehmend und zunehmend umfangreicher Hinweise und Rezepte zur Schädlingsbekämpfung aufnehmen.

herumkommen: um 1750 können in Deutschland rund 10\% lesen, um 1800 sind es $25 \%$. Hierzu Freytag (2003), S. 143-144.

291 Die Anweisungen zur Vorbereitung für und Durchführung von Bekämpfungsmaßnahmen werden im Edikt auf heuschreckengefährdete Gebiete beschränkt.

292 Marquardt (2003), S. 61 ff.

293 Otte (1998); auch Herrmann (2006a).

294 Hohberg (ab 1682). 
Aber die Zeit der spezialisierten ,Fachbücher ${ }^{`}$ der Schädlingsbekämpfung, wie Krafft (1713/14), ist bereits angebrochen, so dass die Hausväter diese Thematik letztlich nicht mehr in großer Breite ausführen müssen, wenngleich sie ihrem enzyklopädischen Selbstverständnis zumindest mit Aufnahme einschlägiger Stichwörter und Kurzanleitungen folgen. Entsprechend kommt es zwar noch nicht zu einem umfassenden Rückgang einschlägiger Anteile, aber zumindest zu einem Stagnieren in der Hausväterliteratur vor allem in der zweiten Hälfte des 18. Jahrhunderts, wobei diese, wie etwa das frühere Vorbild Hohberg, aus damaligem Mangel an deutschsprachigen Werken, zunächst noch überwiegend aus der englischen Literatur zitieren. Krafft (1713/14) markiert dann den Beginn eines vierten Einflussstranges, der sich in der Spezialliteratur zur Schädlingsbekämpfung herausbildet. Diese versammelt verständlicher Weise zwar noch kleine und große Raubtiere, auch Amphibien und Reptilien aus weit weniger einsichtiger Ursache, sowie alle Klassen der Arthropoden und noch solche Tiere, die entweder gar nicht existieren (z. B. den Basilisk noch bei Krafft) oder deren Schädlingsnatur falscher Vorstellung entspringt (z.B. Regenwurm, Maulwurf). Dabei wird der praktischen Bedeutung wegen allmählich auf die Insekten als Hauptschädlinge des agrarproduktiven Sektors und der Vorrats- und Lagerhaltung fokussiert.

Einen späten Vermittler zwischen der Hausväterliteratur und der Spezialliteratur der Schädlingsbekämpfer kann man in der Enzyklopädie von Krünitz sehen, die zwischen 1773 und 1858 das thematisch Einschlägige wahrlich enzyklopädisch zusammenfasst. Dabei verschmäht er die Rezepte der magischen Wissenschaft durchaus nicht, selbst nicht in den späten Bänden nach 1830. Zweifellos trägt gerade dieser Umstand zum Überleben der obsolet gewordenen Anschauungen im 19. Jahrhundert bei. ${ }^{295}$

In jenen vierten Einflussstrang entsendet die entstehende Naturwissenschaft von den Insekten (als fünfte Entwicklungslinie) Einsichten über die Naturgeschichte dieser Tiere, deren Kenntnis für die Schädlingsbekämpfung nützlich wird, weil sie damit die Möglichkeit zu einer kausalen Bekämpfungsstrategie erhält. In demselben Maße entledigt sich die naturwissenschaftliche Forschung dieser praktischen Fragen und gliedert sie in die Schädlingsbekämpfungsliteratur aus. ${ }^{296}$ Damit ist eine Trennung eingeleitet, als deren Ergebnis die Naturgeschichtsforschung über Insekten sich zu einer reinen akademischen Entomologie hin entwickeln wird, während die Aspekte der angewandten Schädlingskunde vorwiegend von den akademischen Lehrern der Agrarwissenschaft (bzw. der Forstwissenschaft) zusammengetragen und auf dem Stand der wissenschaftlichen Kenntnisse der entomologischen Forschung gebracht und gehalten werden. Ein wichtiges Beispiel dieser Gruppe wäre Nördlinger (1869), dessen Standardwerk in der zweiten Hälfte des 19. Jahrhunderts mehrere Auflagen erlebt.

295 Vgl. Fußnote 22.

296 Diese Entwicklung ist vorgezeichnet bei Frisch, wird am deutlichsten später bei Bouché, der neben seiner ,reinen' Naturgeschichte von Insekten zeitgleich eine Monographie zur praktischen Bekämpfung der Gartenschädlinge vorlegt. Das steht im Erscheinungsjahr 1833 /34 dann schon freilich fast am Ende dieser Entwicklung. 


\subsection{Das Praktische Feld: Steuern und Anreize}

Im Folgenden wähle ich Beispiele praktischer Schädlingsbekämpfung, um ihre allgemeinen Grundzüge zu illustrieren. Dabei werden eventuelle kleinere Inkonsistenzen der Kategorienbildung nicht weiter verfolgt, weil ich in ihnen keinen grundsätzlichen Einwand gegen meinen Systematisierungsvorschlag erkennen kann.

Zwei Modelle bestimmen die territorialherrschaftliche Schädlingsbekämpfungspraxis Brandenburg-Preußens: ${ }^{297}$ ein prämiengestütztes Anreizsystem und ein steuergestütztes Abgabensystem. Während das Anreizsystem augenscheinlich für betriebswirtschaftliche eher schwächere Schädlinge umgesetzt wird, werden die vermeintlich oder tatsächlich erheblicheren Schädlinge, wo immer möglich, durch direkte Steuern (Zwangsabgaben von Köpfen, Ohren, Schwänzen, Klauen etc.) oder durch allgemeine Verhaltensregeln (wie Hygienestandards; Verfolgung durch jedermann) bekämpft. Die Verhaltensregeln können ihrerseits normativem Regelwerk unterliegen, wenn eine aktive Schädlingsbekämpfung wegen der ,Ortslosigkeit ' des Schädlings nur punktuell möglich ist. An ihre Stelle tritt daher ggf. eine permanente Prophylaxe (regelmäßige Wolfsjagden, Sperlings- und Hamstersteuer). Deren betriebswirtschafliche/ volkswirtschaftliche Ausmaße können dysfunktional werden, so dass es zu einer allmählichen Nicht-Befolgung oder zur Aufhebung des Verhaltensmusters kommt (Sperlingsedikte geraten in Vergessenheit; nachlässige Durchführung der Wolfsjagden; Entlassung eines Tieres aus dem Schädlingsstatus). ${ }^{298}$ Die heuristische Systematik nach Anreizsystem (betriebswirtschaftlich orientiert) und Steuersystem (volkswirtschaftlich orientiert) wird bei der Heuschreckenbekämpfung durchbrochen. Trotz Schadensdimensionen im Amts- bzw. Kreismaßstab und darüber hinaus (also deutlich oberhalb der betriebswirtschaftlichen Ebene) wird diese zunächst prämiengestützt durchgeführt. ${ }^{299}$ Wegen der unerwartet hohen Kosten für die öffentlichen Kassen, reduziert die Obrigkeit mitunter willkürlich das zugesagte Sammelgeld. Das wegweisende Edikt vom November 1753300 erlässt klare Richtlinien über abzuliefernde Mengen von Heuschrecken, Heuschreckenlarven (,Bruth) und Heuschreckeneiern (,Samen). In ihm ist vollständig auf ein Steuersystem umgestellt, das den Umfang des persönlichen Eigentums an Boden und das Ausmaß regionaler Betroffenheit berücksichtigt, indem auch Dorf- und Stadtbewohner ohne Bodenbesitz in den Heuschreckengebieten zur Mithilfe bei der Bekämpfung verpflichtet werden. Allerdings soll besonderer Sammelfleiß [Übererfüllung des Solls mit 2 Gr. je Metze (=3,4 l)] belohnt werden. ${ }^{301}$ Als Beispiel für die Umsetzung einer solchen Kampagne dient hier eine Quelle über die Bekämpfungsmaßnahmen im Amt

297 Ich übernehme hier verkürzt Überlegungen aus Herrmann (2006a).

298 Gilt z.B. selbst heute für die Aufhebung des Impfzwanges gegen Pocken. Andererseits wird das Impfmuster bei Tierseuchen (Schweinepest) irrationaler Weise nicht verfolgt. Hier laufen also unterschiedliche Wertemodelle nebeneinander her.

299 Durchführung und Entgelte sind geregelt im ,Edict wegen Vertilgung der Heuschrecken oder Sprengsel, de dato Berlin, den 13.April 1731'.

300 Herrmann (2003).

301 Heuschreckenedikt vom November 1753, \ 2. 
Lebus des Sommers 1753 (Tab. 2).302 Im Jahre 1754 werden, in der annähernd gleichen Gegend, wiederum 273 Wispel 12 Scheffel $\left(=360 \mathrm{~m}^{3}\right)$ gesammelt, ${ }^{303}$ womit eine Dimension des Schädlingsbefalls umrissen ist.

\begin{tabular}{|c|c|c|c|}
\hline Ortschaft & Wispel & Scheffel & Liter \\
\hline Berckenbrügge & 0 & 0 & - \\
\hline Biegen & 0 & 0 & - \\
\hline Briesen & 0 & 0 & - \\
\hline Lietzen (Commandery Lieten) & 0 & 0 & - \\
\hline Dubberow Vorwerk & 0 & 0 & - \\
\hline Frankfurth & 0 & 0 & - \\
\hline Hohenwalde & 0 & 0 & - \\
\hline Hoppengarten & 0 & 0 & - \\
\hline Kayser Mühle & 0 & 0 & - \\
\hline Kersdorf & 0 & 0 & - \\
\hline Madlitz & 0 & 0 & - \\
\hline Mahlisch & 0 & 0 & - \\
\hline Müllrose & 0 & 0 & - \\
\hline Neubrück und Neuhaus & 0 & 0 & - \\
\hline Nuhnen & 0 & 0 & - \\
\hline Petersdorff & 0 & 0 & - \\
\hline Schlaubehammer & 0 & 0 & - \\
\hline Schönefeld & 0 & 0 & - \\
\hline Libbenichen (Lebbenichen) & 0 & 1 & 54,96 \\
\hline Manschnow & 0 & 1 & 54,96 \\
\hline
\end{tabular}

302 Geheimes Staatsarchiv Preußischer Kulturbesitz, Berlin Dahlem. II HA Kurmark, Materien. Tit. CCLXVIII No.2, Vol.2.

303 Ebd. Die Akten informieren leider nicht detailliert über den Befall anderer Kreise. Das Amt Lebus kann als Schwerpunkt des Heuschreckenbefalls westlich der Oder gelten. 


\begin{tabular}{|c|c|c|c|}
\hline Ortschaft & Wispel & Scheffel & Liter \\
\hline Behlendorf & 0 & 6 & 329,76 \\
\hline Friedersdorf & 0 & 6 & 329,76 \\
\hline Schlangenthien & 0 & 8 & 439,68 \\
\hline Zernickow & 0 & 8 & 439,68 \\
\hline Buckow & 0 & 10 & 549,60 \\
\hline Lindow Ober & 0 & 12 & 659,52 \\
\hline Neuentempel & 0 & 12 & 659,52 \\
\hline Reitwein (Reutwen) & 0 & 12 & 659,52 \\
\hline Rathstock & 0 & 12 & 659,52 \\
\hline Werbig & 0 & 12 & 659,52 \\
\hline Worin & 0 & 12 & 659,52 \\
\hline Kuhnersdorf (Wüste) & 0 & 19 & $1.044,24$ \\
\hline Podelzig (Bodeltig) & 0 & 21 & $1.154,16$ \\
\hline Karzig (Cartig) & 1 & 2 & $1.428,92$ \\
\hline Zeschdorf (Zesdorff) & 1 & 3 & $1.483,88$ \\
\hline Platkow & 1 & 4 & $1.538,84$ \\
\hline Bienenwerder Vorwerk & 1 & 8 & $1.758,68$ \\
\hline Niederjesahr & 1 & 8 & $1.758,68$ \\
\hline Helenen Ruh & 1 & 10 & $1.868,60$ \\
\hline Hathenow & 1 & 12 & $1.978,52$ \\
\hline Klessin (Clessin) & 1 & 13 & $2.033,48$ \\
\hline Heinersdorf & 1 & 18 & $2.308,28$ \\
\hline Wulkow bei Frankfurt & 1 & 18 & $2.308,28$ \\
\hline Rosengarthen & 1 & 20 & $2.418,20$ \\
\hline Markendorff & 2 & 0 & $2.638,00$ \\
\hline Pilgram & 2 & 5 & $2.912,80$ \\
\hline Hohenjesar & 2 & 6 & $2.967,76$ \\
\hline Malnow & 2 & 6 & $2.967,76$ \\
\hline
\end{tabular}




\begin{tabular}{|c|c|c|c|}
\hline Ortschaft & Wispel & Scheffel & Liter \\
\hline Arensdorf & 2 & 12 & $3.297,52$ \\
\hline Falckenberg & 2 & 12 & $3.297,52$ \\
\hline Jahnsfelde & 2 & 12 & $3.297,52$ \\
\hline Schöneflies & 2 & 14 & $3.407,44$ \\
\hline Marxdorff & 3 & 0 & $3.957,00$ \\
\hline Gusow & 3 & 6 & $4.286,76$ \\
\hline Trebus & 3 & 8 & $4.396,68$ \\
\hline Wuhden & 3 & 8 & $4.396,68$ \\
\hline Tzschetznow (Zetschnow) & 3 & 19 & $5.001,24$ \\
\hline Kienbaum & 4 & 0 & $5.276,00$ \\
\hline Seelow & 4 & 0 & $5.276,00$ \\
\hline Lichtenberg & 4 & 2 & $5.385,92$ \\
\hline Kliestow (Cliestow) & 4 & 8 & $5.715,68$ \\
\hline Brieskow & 4 & 16 & $6.155,36$ \\
\hline Unter Lindow & 4 & 16 & $6.155,36$ \\
\hline Booßen & 4 & 17 & $6.210,32$ \\
\hline Lieten & 4 & 20 & $6.375,20$ \\
\hline Trepplin & 5 & 0 & $6.595,00$ \\
\hline Neuendorff im Sande & 5 & 10 & $7.144,60$ \\
\hline Loßow & 5 & 14 & $7.364,44$ \\
\hline Rosenthal & 6 & 0 & $7.914,00$ \\
\hline Wüst Sieversdorff & 6 & 0 & $7.914,00$ \\
\hline Wüste Gählsdorff & 6 & 0 & $7.914,00$ \\
\hline Diedersdorff & 7 & 0 & $9.233,00$ \\
\hline Görlsdorff & 7 & 0 & $9.233,00$ \\
\hline Demnitz & 8 & 0 & $10.552,00$ \\
\hline Wilmersdorff & 8 & 0 & $10.552,00$ \\
\hline Falckenhagen & 9 & 0 & $11.871,00$ \\
\hline Eggersdorf & 9 & 16 & $12.750,36$ \\
\hline Dahmsdorf & 10 & 0 & $13.190,00$ \\
\hline
\end{tabular}




\begin{tabular}{lllr} 
Ortschaft & Wispel & Scheffel & Liter \\
Jacobsdorf & 10 & 2 & $13.299,92$ \\
Steinhöffel & 10 & 6 & $13.519,76$ \\
Sieversdorf & 10 & 8 & $13.629,68$ \\
Hasenfelde & 11 & 0 & $14.509,00$ \\
Döbberin & 12 & 0 & $15.828,00$ \\
Fürstenwalde + Vorwerk & 12 & 0 & $15.828,00$ \\
Hermersdorf & 12 & 0 & $15.828,00$ \\
Petershagen & 12 & 0 & $15.828,00$ \\
Tempelberg & 12 & 4 & $16.047,84$ \\
Obersdorf & 13 & 8 & $17.586,68$ \\
Beerfelde & 14 & 15 & $19.290,40$ \\
Lebus + Lebus Amt & 15 & 0 & $19.785,00$ \\
Trebnitz & 15 & 0 & $19.785,00$ \\
Buchholt & 18 & 6 & $24.071,76$ \\
Quilitz & 20 & 0 & $26.380,00$ \\
Wulckow bei Quilitz & 20 & 0 & $26.380,00$ \\
Müncheberg & 20 & 15 & $27.204,40$ \\
Insgesamt & & & \\
\hline
\end{tabular}

Tabelle 2: „Namen der Feldmarken [des Lebusischen Kreises], wo Heuschrecken befindlich, wie viel davon bereits vertilget", also durch Absammelmaßnahmen erfasst und abgetötet wurden, vom 29. Juni 1753.304 [Die Gesamtmenge betrug bis zu diesem Datum etwa 573 Kubikmeter. Es handelt sich mehrheitlich um flugunfähige Larven (,Sprengsel'), von denen ca. 500 Stück im toten Zustand das Volumen eines Liters einnehmen. ${ }^{305}$ Insgesamt wären also Tiere in der Größenordnung von 286 Mio. vernichtet worden. Reihenfolge der Ortsnamen nicht nach der alphabetischen Serie der Akte sondern nach Mengenangaben; Angaben in Liter nach Umrechnung von $\mathrm{BH}$ ]

304 Aus Akte Geheimes Staatsarchiv Preußischer Kulturbesitz, Berlin Dahlem. II HA Kurmark, Materien. Tit. CCLXVIII No.2, Vol.2.

305 Für die Möglichkeit zur experimentellen Volumenbestimmung von Wanderheuschrecken danke ich Herrn Kollegen Norbert Elsner. Hierfür wurden keine Tiere getötet. 
Im 1753er Edikt findet sich auch Anweisung, wie die präventive Bekämpfung und die Bekämpfungsmaßnahmen gegen lebende Tiere durchzuführen sind:

Genaue Observierung wahrscheinlicher Brutgebiete

Brutgebiete vor dem Winter flach pflügen und die Schweine hineintreiben

Forstbediente und Bauern haben, abhängig vom Grundbesitz, nach ,Proportion der Quantitaet, so sich an Bruth findet vorgegebene Mengen an Eiern einzusammeln.

Nach Schlüpfen der Larven im Frühjahr Verbrennen mit Stroh(wischen); Ausheben von Gräben mit darin befindlichen Fanggruben

Einkehren von Heuschrecken mit Strauchbesen aus den Gräben in die Fanggruben und anschließendes Zertreten und Zerstampfen und Verfüllen mit Aushub, Anlegen neuer Fanggruben

Bei trüber Witterung Eintreiben von Schweinen und Puten in Areale mit flugfähigen Heuschrecken

Umfängliches Berichtswesen an die Landräte, von dort an die ,Kriegs- und Domainen-Cammer

Das Edikt ordnet Berichterstattung nicht nur über die umgepflügten Ackerflächen, sondern auch über umgepflügte Brachflächen an. Das ist insofern von Belang, als nach heutigem Wissen die Brachen die ungestörten Brutflächen der Heuschrecken darstellten. Das Edikt überwindet mit seiner Präferenz für bestimmte Bekämpfungstechniken den Anteil unökonomischer Praktiken des Edikts von 1731, dessen Bekämpfungsspektrum bereits Frisch abbildet (Abb. 2) und das daher als zeitgenössisch gängig gelten darf.

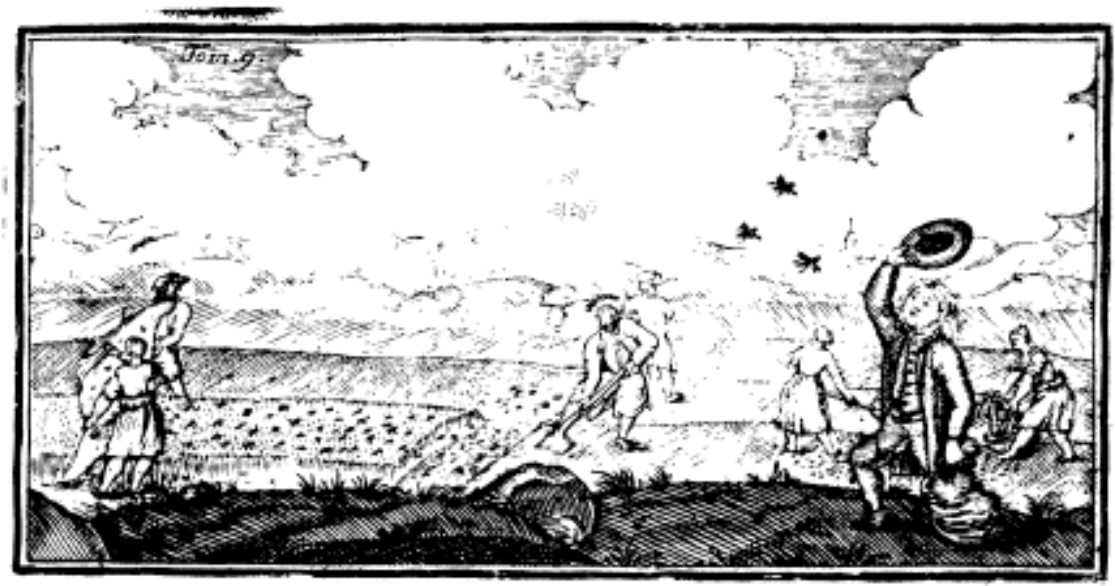

Abb. 2: Bekämpfungsmaßnahmen gegen Heuschrecken. Von links nach rechts: Eintreiben der Heuschrecken mit Tüchern (Laken) hinein in Fanggräben (Bildmitte); rechter Bildhin- 
tergrund: vermutlich Eintreiben auf Laken und Einwickeln der Heuschrecken, um sie anschließend mit kochendem Wasser oder mit Stampfen zu töten. Bildvordergrund rechts: kein allegorischer Hinweis auf die begrenzte Sinnhaftigkeit menschlichen Tuns, sondern zeitgenössische Fangtechnik mit Sieben, »oder anderen dazu bequemen Geräthschaften« (Edikt von 1731), bzw. »mit nach Art von Keschern an Stangen gebundenen Säcken.« Die Heuschrecken werden in Säcke gefüllt (in der Hand des Mannes sowie mittig im Bildvordergrund) und dann mechanisch getötet. (Aus: Frisch (1730), 9. Theil, S.1. Dort als Eingangskupfer ohne Erläuterung. Die spätere Aufzählung der Bekämpfungsmaßnahmen, S. 9 - 10, ohne Bezug zur Abbildung).

Die Bekämpfungstechniken (Abb. 2) entsprechen denen im Edikt von 1731. Davon übrig bleibt 1753 nur noch das Eintreiben in Gräben und das anschließende Töten. Hingegen sind die gezielten Maßnahmen gegen die Heuschreckengelege, wie sie das 1753er Edikt mit Pflügen und biologischer Schädlingsbekämpfung anordnet, ein Fortschritt gegenüber dem Text von 1731, der nur nebenbei das Eiersammeln erwähnt. Das naturwissenschaftliche Raisonnement führt Mitte des Jahrhunderts zu der Einsicht, das Übel am besten bei der Wurzel anzupacken, d.h. bei den Gelegen der Heuschecken. Um die Zeit der Formulierung des 1753er Edikts befasst sich Johann Gottlieb Gleditsch (1754), der damalige Direktor des Berliner Botanischen Gartens und Akademiemitglied, der die Arbeit Frischs gekannt hat, mit dem Problem und empfiehlt die Bekämpfung der Gelege. Sein Argument bedient sich wie Kretzschmer (s.u.) der Furcht vor dem potentiellen Schaden, indem er vorrechnet, dass in den 722 Litern an Heuschreckengelegen, welche die Ackersleute der Stadt Drossen (Neumark, Sternbergischer Kreis) im Frühjahr 1752 aufsammelten, insgesamt 16.690.905 Eier enthalten waren.

Ein Beispiel, in dem Schädlingsbekämpfung nach dem Steuerprinzip betrieben wurde, ist der Kampf gegen den Sperling im 18. Jahrhundert ${ }^{306}$ Preußen steht hier mit praktisch allen mitteleuropäischen Territorialherrschaften in einem gemeinsamen Abwehrkampf, der durch eigentumsabhängige Zwangsabgabe von Sperlingsköpfen durch die Einwohner gewonnen werden soll. Nichtbegleichen der Steuer konnte, eigentlich dysfunktional zur Intention dieser Steuer, durch Zahlung an die Armenkasse kompensiert werden. Die Steuer, die Herrmann (2003) in einer Massenstatistik für Brandenburg-Preußen zwischen 1733 und 1767 auswerten konnte, erfasst damit tatsächlich die Dynamik der menschlichen Population statt derjenigen der Sperlinge Rechnung zu tragen: Je mehr Menschen in Brandenburg Preußen wohnen, desto mehr Sperlingsköpfe werden eingeliefert. Im Durchschnitt liegt die Zahl zwischen 350.000 und 400.000 Köpfen, die in Brandenburg-Preußen jährlich abgeliefert werden. Sicher ist, da das jahraus-jahrein passierte, dass sich die Sperlingspopulation auf eine solche jährliche Entnahmemenge eingestellt hatte. Humanökologisch kann der Gewinn nicht im Verlust dieser Sperlinge gelegen haben, sondern muss in dem (zeitgenössisch nicht erkannten) Gewinn durch den Verzehr

306 Herrmann (2003). 
von Schadinsekten für die Aufzucht der jährlich um 350.000 Sperlingen bestanden haben. Ganz überwiegend dürfte es sich nämlich um Jungvögel gehandelt haben, die ihr Leben als Tribut lassen mussten.

Mentalitätengeschichtlich interessant ist der Umstand, dass bei der Erstellung der Massenstatistik der Sperlingssteuer für alle Kreise der Mark Brandenburg, für alle darin befindlichen Sperlingssammelstellen, zwischen 1733 und 1767 nicht ein einziger Fall gefunden wurde, in dem auch nur ein Sperlingskopf über dem berechneten Soll eingeliefert worden wäre, es kommt nicht einmal zu einem bloßen Additionsfehler in der Aktenführung. Kompensationszahlungen an die Armenkasse kommen vor, sind aber nicht häufig. Ganz anders hingegen das Bild, das sich später für die Preußische Besitzung Petershagen ergibt. Hier wurde das Soll praktisch überall übererfüllt (Abb. 3).

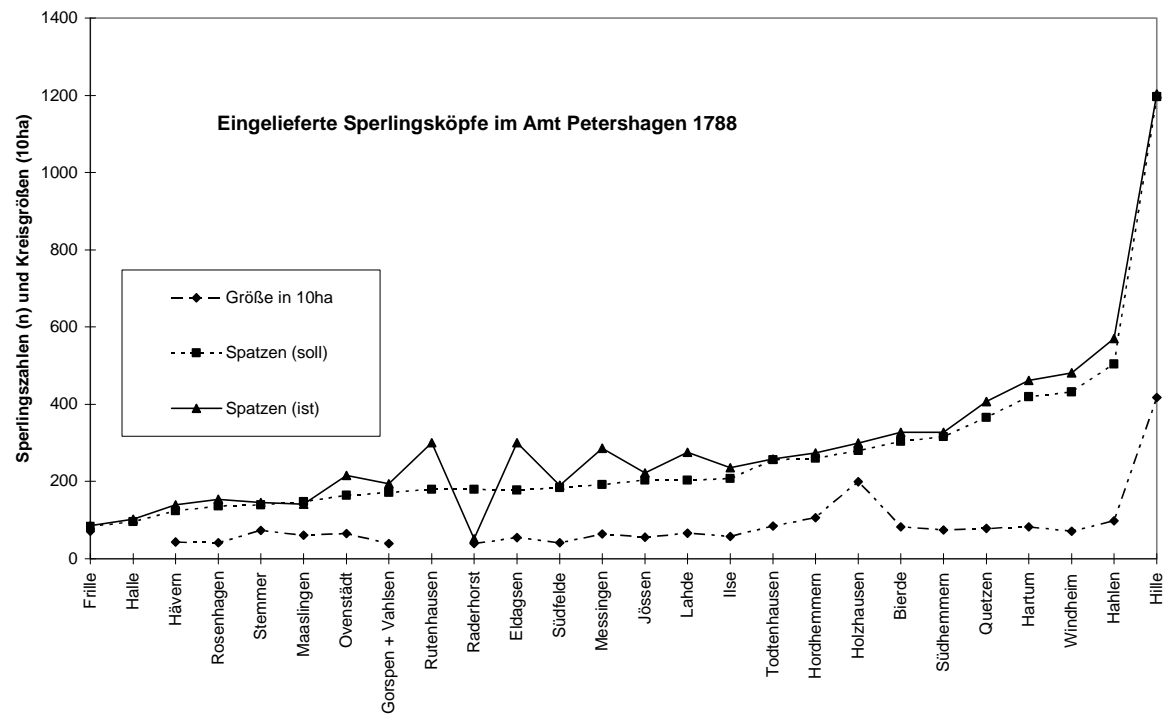

Abb. 3: Sperlingssteuer und abgelieferte Sperlingsköpfe 1788 im Preußischen Besitz Amt Petershagen (im heutigen Ost-Westfalen). Die Dorfgemarkungen sind nach Größe (x 10ha) angeordnet. Darüber finden sich die Kurven für die Sperlingssteuer (,Spatzen soll) und diejenige der tatsächlich geleisteten Abgaben (,Spatzen ist'). Die Ordinaten-Zahlen gelten sowohl für die Sperlinge als auch für die Hektarangaben (x 10). Mit Ausnahme des Dorfes Raderhorst wird das Sperlingssoll faktisch im gesamten Amt übererfüllt. Anreize hierzu wurden von Amts wegen nicht gewährt. (Auswertung von Akten des Geheimen Staatsarchiv Preußischer Kulturbesitz, Berlin-Dahlem, HA Kurmark Materien Tit. CCLXVIII) 
Gegen Ende des 18. Jahrhunderts scheint es hinreichende empirische Gründe zu geben, die Sperlingssteuer nicht weiter einzutreiben. Jedenfalls erlahmt das staatliche Interesse an der Sperlingsbekämpfung, die Akten ${ }^{307}$ enthalten am Ende des 18. Jahrhunderts nur noch sporadische und substanzlose Einträge. Die Schadensdimensionen scheinen abschätzbar geworden zu sein. Betroffen ist die betriebswirtschaftliche Ebene, die Bekämpfung geht ohne weiteres Regelwerk, aber folgerichtig, in den Privatbereich über. Das staatliche Interesse kann auch deswegen zurückgehen, weil nach der neuen Einsicht der Naturwissenschaft ein volkswirtschaftlicher Nutzen dieser Tiere besteht:

Den größten Nutzen leisten sie [die Sperlinge, BH] durch die Vertilgung unzähliger schädlicher Insecten, der Maikäfer, Erbsenwürmer, Raupen, besonders der grünen Wickelraupen und Heuschrecken, womit sie sich und ihre Jungen das ganze Jahr hindurch ernähren; sie sind gewiss nicht die schädlichen Thiere, wofür man sie ausschreyt; leisten im Ganzen gewiss mehr Nutzen als Schaden; ob es gleich gewiss ist, daß sie oft einzelnen Personen, deren Aecker nahe an den Dörfern und Städten liegen, große Verwüstungen in ihrem Getraide anrichten. Ich kenne Landgüter, die einzeln liegen und wo man sie ihrer Schädlichkeit halber gänzlich austilgte; was geschah? die Eigenthümer bekamen niemals Obst, und wenn die Bäume in ihrer Nachbarschaft noch so reichlich trugen. Die Ursache war, daß die Raupen nicht von den Sperlingen ausgerottet wurden. Durch Schaden wurde man klug, und setze sogar die Sperlinge wieder aus. ${ }^{308}$

So ähnlich war das 70 Jahre früher schon bei Frisch und sogar davor zu lesen, musste sich aber wohl erst seinen Weg mit der und durch die Aufklärung bahnen.

Auch der Hamster ist als Ernteschädling in den betroffenen Löß-Gebieten, was in Preußen vor allem die Gebiete um Magdeburg und Halberstadt waren, über eine Steuerabgabe bekämpft worden. Nach Verhältnissen an Bodenbesitz galten 10 - 30 Felle als Pflichtabgabe. Allerdings konnte man sich hiervon freikaufen. ${ }^{309}$ Auch hier geht das staatliche Interesse an der Schädlingsverfolgung gegen Ende des 18. Jahrhunderts auffallend zurück. Möglich ist, dass jetzt die Nutzung des Fells in den Vordergrund tritt und damit die Bestandsregulierung des Schädlings Kollateralfolge eines eigentlichen und zunehmenden Interesses am Rauchwerk ist. Immerhin gelten Hamsterfelle zu Beginn des 19. Jahrhunderts z.B. für die Herrschaft Gotha, aber auch andere Regionen Deutschlands als ein wichtiges Exportgut. ${ }^{310}$ Eine ähnliche wirtschaftliche Nutzung der bekämpften Schädlinge ist regional z.B. auch für Maikäfer gefunden worden, die als organischer Dünger vermarktet wurden. ${ }^{311}$

307 Geheimes Staatsarchiv Preußischer Kulturbesitz, Berlin-Dahlem, HA Kurmark Materien Tit. CCLXVIII.

308 Bechstein (Bd. II, 1791), S.391. Hervorhebung im Original.

309 Zu Details siehe Herrmann (2003).

310 z. B. Stein (1811), Bd 1, Sp. 795; Meusel (1817) S. 43.

311 z. B. Say (1818) Bd. 1, S. 328. 
Alle sonstigen zeitgenössisch als Schädlinge eingestuften Wirbeltiere, wie das kleine Raubzeug, der Wolf, Fuchs, Fischotter, Luchs, Biber und die Raubvögel, aber auch Krähen, werden im 18. Jahrhundert prämiengestützt bekämpft, d.h. für einen jeweils festgelegten Körperteil (Schwanz, Ohr, Nase, Klauen) zahlte die Obrigkeit einen bestimmten Betrag: ein Wolf brachte, je nach Alter, bis zu vier Taler Schießprämie, eine Krähe einen Groschen. Alle anderen Prämien sortieren sich dazwischen ein. ${ }^{312}$ Dass den Raubvögeln nachgestellt wird, hängt letztlich mit den jagdlichen Interessen der Herrschaften zusammen, die in diesen Vögeln traditionelle Feinde der Tiere der Niederen Jagd sahen. Der Otter gilt als Fischräuber und da die Fischerei letztlich ein Regal ist, mag hier, neben einem Missverständnis der biologischen Rolle des Otters, ein Grund für seine Verfolgung sein. Beim Biber gab es zu Beginn des 18. Jahrhunderts noch einen Schutz, freilich, weil der König an das Fell und seine Apotheke an das Geil wollten. Die Perspektive ändert sich drastisch wegen des Deichschutzes an der Oder nach 1753 und kurz nach dem Erlass vom 8. August $1765^{313}$ sind die Biber dort ausgerottet. Die Effizienzsteigerung solcher Abschussmaßnahmen, insbesondere die exorbitant hohen Abschusszahlen von Raubvögeln, ist ohne die zeitgenössischen Verbesserungen der Langwaffen nicht denkbar.

Vorratsschädlinge wie Mäuse und Ratten werden mit staatlichen Maßnahmen, zumindest im Preußen des 18. Jahrhunderts, nicht verfolgt, ihre Bekämpfung ist also bereits früh Privatsache, bis die Einrichtung der Schwemmkanalisation im 19. Jahrhundert das staatliche Handeln zumindest gegen Ratten erforderlich macht. Es gibt auch keine Verfolgungsanordnung z.B. gegen den Kranich, der als Zugvogel ein gefürchteter, aber nur saisonaler Saatschädling war. Allerdings ist er jedermann an jedem Ort zur Nachstellung freigegeben.

\subsection{Kategorien}

Der gesamten Entwicklung vom frühen 18. ins 19. Jahrhundert unterliegt eine grundsätzliche Wahrnehmungs- und Handlungsverschiebung, die sich aus der Verschiebung vom magisch-mythischen und empirisch-induktiven Konzept hin zum rational und empirisch-deduktiven Konzept ergibt. Es ist dies eben nur eine langsame Entwicklung, nicht eigentlich eine - wenn auch - stille und zögerliche Revolution, wie man mit Blick von Thomas Kuhn (1997) auf den erkenntnistheoretischen Paradigmenwechsel annehmen könnte. Hier, im Reich des Ungeziefers, fand ja kein Paradigmenwechsel statt. Hier gab es lediglich die Schärfung des Urteils, das Gewinnen von Bestimmungssicherheit und die Indienststellung der Wissenschaft, sei es für die notwendige Sicherung der Vorräte und Ernten, sei es am abstrakten Ende das Glückseligkeitsversprechen der Staatstheoretiker. Die ,Verall-

312 Herrmann (2003); die gedruckten Texte der einschlägigen Verordnungen, Edikte usw. in CCM und NCC.

313 GStA HA II, Generaldirektorium Kurmark, Forstdepartement, Generalia, Tit. XVII. No.10 Fol.188 (M). 
täglichunge314 nimmt entsprechend auch nicht von einer Kalamität oder einer initialen Publikation ihren Ausgang. Schädlingsbekämpfung zielt allererst ins Praktische und ist deshalb nach meinem Urteil immer, veralltäglicht, weil sie volkskultürlichpraktisches Wissen ggf. als wissenschaftlich-akademisch legitimiert bzw. umgekehrt eine Diffusion der akademischen Einsicht in den Raum des Praktischen hinein, ihre Überführung in das Alltägliche, stattfindet, wie sie am Beispiel der ,Kalender besonders deutlich wird. ${ }^{315}$

Überwiegen zu Beginn des betrachteten Zeitraums die akuten Interventionen aus ökonomischer oder privilegiengegründeter Ursache, verschieben sie sich innerhalb des Betrachtungszeitraums langsam hin zu ökonomischen, präventiven und hygienischen Motiven. Völlig abgelöst wird das theologisch-didaktische Modell von der naturwissenschaftlichen Hoffnung, dass immer mehr Wissen eine auch immer größere Beherrschbarkeit der Schädlinge nach sich zieht. Ordnungspolitisch erfüllt sich allerdings die Hoffnung der Staatstheorie des 18. Jahrhunderts erst in den ersten Reichsgesetzen zur Schädlingsbekämpfung nach 1871, eine amüsantironische Analogie zum Nachlauf-Phänomen biologischer Systeme.

Als Generaltrend wird auch die Betrachtungsebene geweitet. Zunächst stehen die kleinen Wirtschafts- oder Verwaltungseinheiten im Vordergrund. Dies bleibt wegen der Funktionalität der Schädlingsabwehr auch weiterhin bestehen. Das Regelwerk wird jedoch zunehmend flankiert von Ordnungsmaßnahmen für größere Areale bis hin zu gesamtstaatlichem Regelwerk.

Es ist nicht klar, inwieweit die auf Verwaltungseinheiten zielenden Anordnungen allmählich durch naturräumliches, also biotop-bezogenes Regelwerk präzisiert werden. Immerhin wird z. B. im Heuschreckenedikt von 1753 dem Faktum Rechnung getragen, dass es auf die heuschreckengefährdeten Gebiete zu beziehen ist, was als implizite Verwendung des Naturraumkonzepts verstanden werden kann. (Man könnte natürlich auch einfacher und näherliegend vom bloßen sinngemäßen Anwendungsbezug sprechen, was bei einem aufgeklärten Absolutismus wohl keine Unterstellung wäre.)

Bekannte Paradebeispiele für den Kategorienwechsel vom Schädling zum Nützling sind der Regenwurm und Maulwurf. Der Singvogelschutz ist für die meisten Naturforscher um 1800 längst ein Thema. Freilich hatten die Kleinvögel - bis auf den Sperling - nie ernsthaft einen Schädlingsstatus. Singvögel werden aber als Nahrungsbeitrag für weite Bevölkerungskreise noch bis ans Ende des 19. Jahrhunderts dezimiert. Nach 1800 scheint sich die Sperlingsproblematik zu entspannen. Der Kranich bleibt bis 1936 ungeschützt. Die Trappe wird vom sicheren Platz in der Hohen Jagd allmählich über die Niedere Jagd bis in die Schäd-

314 Burke (2002), S.64, weist auf diesen Begriff Max Webers hin, der sich mit Thomas Kuhns Begriff der ,normalen Wissenschaft' decke, die auf den Innovationszyklus folge.

315 Vgl. Fußnote 22. Eine systematische Auswertung der ,Kalender' im Hinblick auf das Thema scheint mir sehr lohnend. 
lingskategorie abgeschoben. ${ }^{316}$ Mit dem Fortschritt der Einsicht in die Zusammenhänge der Biosphäre lassen auch die Verfolgungen gegenüber zumindest einzelnen kleinen Raubtieren etwas nach.

$\mathrm{Ob}$ die Bemühung im Herzogtum Sachsen-Meiningen, zwischen 1840 und 1848 die Kreuzotter zu ,vertilgen ' noch der Schädlingsbekämpfung zuzurechnen ist, mag man bezweifeln. Sie ordnet sich meines Erachtens dem eher übergeordneten zunehmenden Bedürfnis nach Befriedung der Natur ein (siehe oben ,BrunoSyndrom $)$. Die Sachsen-Meininger prämierten jeden Otter-Balg und haben immerhin zwischen 1843 und 1848 für insgesamt 4165 Bälge jeweils 8 Groschen gezahlt. Sachsen-Meiningen konnte übrigens die benachbarten Herrschaften (wie Sachsen-Gotha) nicht bewegen, sich an dem Kreuzzug gegen Kreuzottern zu beteiligen. ${ }^{317}$ Die Verfolgung wird offenbar nicht zuletzt deswegen eingestellt, weil sich ein Schleichhandel mit Otternbälgen über die Landesgrenzen entwickelte.

Aus der Fülle wähle ich nur einige Beispiele aus. Wie allen historischen Beispielen haftet ihnen eine gewisse Willkür an, die hier durch das strukturalistische Prinzip der Bildung von Oppositionen begrenzt ist. Allerdings gibt es auch Transformationen. Zu ihnen gehört die Transformation der,Plage in den ,Schädlinge. Wenn man so will, ist es der einfachste aller Übergänge. Er folgt dem Prinzip der Entgöttlichung, der Profanisierung, der Säkularisierung der Natur, in dem die ehedem biblisch definierten Plagen allmählich in die Kategorie der Schädlinge überführt werden, die schließlich dem rational handelnden Staat zur Aufgabe werden.

Dabei ist auffällig, dass auch die seit dem 18. Jahrhundert spürbar zunehmende rational angegangene Schädlingsfrage das Problem des Schadensausmaßes nicht nach objektiven Kriterien bestimmt. Es bleibt nach den mir bekannten Akten unklar, ab wann ein Untertan oder eine regionale Verwaltung Klage beim König führt. Zumindest wird der Schaden allermeist nicht quantifiziert, und wo er quantifiziert wird, ${ }^{318}$ bleiben die Bezugsdaten unklar oder offen. Da der Schaden nicht objektiviert ist, ist auch die ,Schadensschwelle unklar und damit letztlich überhaupt deren Einschätzungsgrundlage. Selbstverständlich landen die Schädlinge zum einen aus Erfahrungswissen in der Schädlingskategorie, die eine ständige Handlungsaufforderung abgibt. Warum aber zum anderen Regenwürmer oder Maulwürfe überhaupt als Schädlinge qualifiziert werden, ist vermutlich aus der Übernahme vermeintlich sicheren Vorwissens erklärbar.

Wo keine Vorstellung vom Ausmaß des Schadens besteht, hat es der Präventionsgedanke nicht leicht. Jedenfalls findet er sich nicht explizit thematisiert. Zwar wird darauf verwiesen, wie man etwa zweckmäßig Nahrungsmittel lagert, um sie vor Schädlingsbefall zu schätzen, aber Prävention im eigentlichen Sinne, durch

316 Klose (2005).

317 Den Hinweis und die Zahlen verdanke ich Mathias Deutsch, Göttingen/Erfurt. Die Akten ,Vertilgung der Kreuzottern' befinden sich im Thüringischen Staatsarchiv Meiningen.

318 Eine Übersicht über Quantifizierungen angeblich durch Hamster erzeugter Schäden nach der Literatur des 18. Jahrhunderts bei Krünitz, Lemma ,Hamster'. 
systematische Unterweisung oder Aufklärung, erfolgt im 18. Jahrhundert eigentlich nicht. Den Grund hierfür sehe ich einerseits im Fehlen von Schädlingsbilanzierungen. Immerhin sind die »reißenden Thiere« und »Raubvögel« bereits so gut im Griff, dass sie (wenigstens in Brandenburg) keine wirkliche subjektive Bedrohung mehr darstellen, objektiv sind sie ohnehin vielfach Antagonisten anderer kleinerer Schädlinge. Andererseits sind die Insekten-Schädlinge noch der Vorstellung der biblischen Plage zu nahe, noch kommen sie einfach als Unglück über die Menschen. Der Präventionsgedanke ist vor dem Hintergrund einer Unglücksvorstellung oder einer schicksalhaften Erfüllung nur schwer zu denken.

Nur zweimal wird Prävention als leitende Überlegung deutlich: Zum ersten Mal bei der Biberausrottung an der Oder nach 1765. Es ist der befürchtete Schaden an den neu errichteten Deichen, der zur örtlichen Ausrottung der Biber führt. ${ }^{319}$ Zum zweiten Mal in der Praxis der Sperlingsbekämpfung, hierbei jedoch nicht in idealtypisch gleicher Weise mit dem völligen regionalen Bestandsverlust wie bei den Bibern. Immerhin weiß man von den Sperlingen, dass sie Erntebestände des Getreides vollständig unbrauchbar machen können und führt daher einsichtig eine Kopfsteuer ein. ${ }^{320}$ Doch eine Schadensstatistik sucht man vergeblich. Die Schadenskalkulation von Kretzschmer ${ }^{321}$ ist ziemlich singulär. Sie beruht auf angenommenen Häufigkeitszahlen für Sperlinge, die einfach multipliziert werden. Kretzschmer behauptet in einer ziemlich peniblen, aber willkürlichen Aufstellung, dass jeder Sperling „4 Thaler 2 Groschen und 3/7 Pfennige an jährlichen Unterhaltkosten“ verursache. „Man nehme nur 1) 100 Städte in jeder 1000 Sperlinge, thut 100000 Sperlinge 2) 4000 Dörfer in jedem 500 Sperlinge thut 1 Million Sperlinge. Summa 1.100.000 oder 1 Million hundert tausend Sperlinge. Man rechne nur die Thaler, die 2 Gr. und die 3/7 Pf. aber nicht, so bekomt man eine Summe von 4 Millionen und viermal hunderttausend Reichs-Thaler heraus." (S. 72-73). ${ }^{322}$ In der

319 Herrmann (2003).

320 In bestimmten Ämtern/Provinzen hatte jeder Untertan abhängig von seinem Landbesitz eine bestimmte Anzahl Sperlingsköpfe abzuliefern. Vgl. Herrmann (2003). Diese Kopfsteuer ist eine für die zeitgenössische Sperlingsbekämpfung des 18. Jahrhunderts in Mitteleuropa gängige Praxis. Die ökologische Sinnhaftigkeit dieser Bekämpfung lässt sich aus guten Gründen bezweifeln, weil Sperlinge eben nicht nur vom Getreide leben, sondern selbst anerkannte Schädlingsantagonisten sind. Die katastrophalen Folgen der Missachtung dieses ökologischen Hintergrundes sind an einem weiteren historischen Beispiel zu studieren, in dem die VR China während des ,Großen Sprungs' einen Feldzug u.a. auch gegen Sperlinge führte. Hierzu Shapiro (2001).

321 Kretzschmer (1744), S. 72.

322 Kretzschmer ist zunächst ein konventioneller Zeuge für die Rechtfertigung der Schädlingsbekämpfung; hinsichtlich der möglichen Entfernung des Sperlings aus der Kette der Wesen aber eine unerwartete und ganz seltene explizite Stimme (\$ 6, S. 69-70, seiner Arbeit): »Es gibt Difficultäten-Macher und windigte Critici, welche doch wol etwas einzuwenden haben möchten. Denn vielleicht kan ein solcher 1) überhaupt einwenden und sagen: Man handele wider des Schöpfers Willen, wo gedacht, dass ein solcher Sperling ohne des Vaters Wille nicht auf die Erde falle. Doch Antwort: Eben dieser HErr hat auch gesaget, dass man 2 [Sperlinge; siehe Matthäus 10,29; BH] um 1 Pf. kauffe, wodurch ihr Werth und Hochachtung ziemlich an den Tag geleget ist. Zudem sind wir ja, als Herren über die Creaturen gesetzet, und als Haußhalter in der Natur 
Tat käme es dabei kaum mehr auf die Pfennige an, die sich nur auf rd. 1637 Taler aufsummieren, damit aber immer noch dem Jahresdurchschnittslohn von 32 Tagelöhnern in Berlin um 1750 entsprochen hätten. ${ }^{323}$ Kretzschmer begeistert sich so sehr für seine Sache, dass er ohne jede objektive Grundlage behauptet, die Sperlinge und Maulwürfe würden in Preußen mehr Schaden anrichteten, als der jährliche Unterhalt der gesamten königlichen Kavallerie koste. ${ }^{324}$

Reicht diese Art des Alarmismus zunächst noch aus, die Sperlingssteuer bis weit in die zweite Hälfte des 18. Jahrhunderts in den Herrschaften Mitteleuropas einzutreiben, gelangen allmählich Stimmen zu Gehör, die Zweifel an solchen Berechnungen äußern:

Man will berechnet haben, daß ein Sperling im Durchschnitt des Jahres einen Gulden Getraide und Feldfrüchte verzehre, und daß in einem Lande von dreyhundert Dörfern sechs Millionen Sperlinge befindlich wären, also die Menge jährlich für sechs Millionen Gulden Schaden thäte. Daß diese Rechnung falsch sey, sieht jeder nur oberflächliche Beobachter ohne mein Erinnern, daß ich im Zimmer sechs Sperlinge, die das ganze Jahr nichts als Getraide fressen, für einen Gulden ernähren will. Und wie in aller Welt sollen in dreyhundert Dörfern sechs Millionen Sperlinge kommen? das müsste ja das Land der Sperlinge seyn. Es mag aber diese Beobachtung auch noch so unrichtig seyn, so ist es doch gewiss nöthig, daß man gar zu großer Vermehrung der Sperlinge Einhalt zu thun suchen muss. Es ist daher auch in vielen Ländern ein Landgesetz da, daß jeder Einwohner jährlich zwey Sperlingsköpfe liefern muss. ${ }^{325}$

Tatsächlich aber steht die Idee des potentiellen Schadens auch hinter Anordnungen bezüglich größerer ,Schädlinge, , die auf den staatlichen Abschusslisten stehen: Iltis, Ottern, Füchse, Wölfe, Raubvögel. Es mögen zwar die Motive zum Abschuss der jeweiligen Arten unterschiedlich sein und sich letztlich immer durch herrschaftlich-jagdliches Interesse begründet finden, immerhin wird ihnen aber kollektiv ein Schädlichkeitspotential unterstellt. Interessant ist an diesen Beispielen aber die Frage der Definitionsmacht für die Schädlingskategorie. Diese Frage führt in ihrer Perspektive zu Interessenlagen und damit zu den Gewinnern und den Verlierern.

Unklar ist mir die Situation bezüglich der, Gewinner ${ }^{e}$ des Schädlingsdiskurses. Tatsächlich wird aber die zeitgenössische Naturwissenschaft über die Schädlingsfrage eine Allianz mit der Staatslehre eingehen können und somit einen Gewinner stellen. ${ }^{326}$ Die Branche der Schädlingsbekämpfer resp. ihre Vorläufer gehört, was ihre Anteile aus der magischen Wissenschaft anbelangt, sicher zu den Verlierern. Sie wird erst gegen Ende des 19. Jahrhunderts unter anderen Namen wieder reüs-

bestellet, dass wir dasjenige, was uns schädlich, abschaffen, vertilgen und ausrotten, und hingegen das, was uns nützet, anschaffen und vermehren sollen. Und wer weiß denn, ob ibnen nicht eben nur solange die Zeit, sie in unsern Landen zu dulten, bestimet ist? « [Hervorhebung von $\mathrm{BH}]$.

323 Schultz (1992) S. 156.

324 Kretzschmer (1744), S. 64.

325 Bechstein (Bd. 2, 1791) S. 393.

326 Siehe oben Kap. 2.1. 
sieren, wobei dies dann mit dem Erfolg der chemischen Bekämpfungsmittel und der Herausbildung einflussreicher wissenschaftlicher Verbände einhergeht. Solche bürgerlichen Interessengemeinschaften sind doch wohl eindeutig auf die Entwicklungen des 19. Jahrhunderts zurückzuführen. $\mathrm{Ob}$ man in der Konzentration der Zuständigkeiten auf der Reichsebene im Staat selbst einen Gewinner sehen möchte, ist eher Geschmackssache. Sicher befördern die Reblausgesetze am Ende des 19. Jahrhunderts das gesamtstaatliche Handeln. Aber das hat letztlich seine Parallele, inhaltlich wie technisch, in den Bekämpfungsedikten der territorialstaatlichen Zuständigkeiten im 18. Jahrhundert, der Staat übernimmt Verantwortung gegenüber seinen Einwohnern zur Abwendung materieller Schäden und zur Beförderung der Nahrungsverstetigung: „zu unsrer Länder und getreuen Unterthanen Besten“327 (siehe auch weiter unten). Dass es kommerzielle Hamster- und Krähenfänger gegeben hat, kann nicht den Schädlingsbekämpfungsmaßnahmen zugerechnet werden, sondern muss als individuelle Versuche eines Broterwerbs aus der wirtschaftlichen Weiternutzung des Tierprodukts gesehen werden.

Interessant scheint mir die Frage, warum die Entwicklung nicht zu einer allmählichen Herausbildung eines Zentralregisters für Schädlinge geführt hat. Vermutlich sind letztlich biologische Gründe ausschlaggebend. Ob Biber, Maikäfer, Heuschrecken, Hamster oder Malaria, alles hat seinen Ort und seine Zeit. Die Schädlinge sind letztlich immer nur regionale oder parzellenbezogene Bedrohungen. Eine Umlage der Schäden als Gemeinkosten für das gesamte Territorium erfolgt nicht. Nach meiner Kenntnis enden die angeordneten Bekämpfungsmaßnahmen auf der Provinzebene. Sie können zwar gleichlautend für mehrere Provinzen (bzw. Cammern) angeordnet werden, werden aber nicht für den gesamten Herrschaftsbereich verbindlich. Selbst das in seiner Ausführlichkeit wie überregulierend erscheinende Edikt Friedrichs II. vom 30.11.1753 zur Heuschreckenplage, regelt detailliert die Vorgehensweise für die heuschreckengefährdeten Gebiete. Formal ist es allerdings »allen Unsern Land- und Steuer-Räthen, Gerichts-Obrigkeiten, Magisträten und Beamten« zur Beachtung befohlen. Damit wäre es wohl das erste Schädlingsedikt, das (mindestens implizit) für das gesamte Königreich gilt.

Für eine Annahme, wonach sich die unheilige Allianz von Schädlingsbekämpfern und falscher Politik, welche nach Jansen (2003) den Schädlingsdiskurs der ersten Hälfte des 20. Jahrhunderts in Deutschland beherrscht, bereits schon früher andeuten könnte, fehlen mir für die betrachtete Zeit und Region jegliche Hinweise. ${ }^{328}$ Sie müssten am ehesten in der Verbindung von Schädlingsbekämpfung und staatlichem Gewaltmonopol oder dem Einsatz eines speziellen, staatlich legitimierten Personenkreises resultieren. Der Staat regelt zwar im Einzelfall das Vorgehen gegen Schädlinge, greift dafür aber kei-

327 Seite 1 des ,Erneuerten Edicts wegen Vertilgung der Heuschrecken und Sprengsel' Berlin, 30.11.1753.

328 Der älteste greifbare Mensch-Ungeziefer-Vergleich in Deutschland stammt vielleicht vom Erzbischof Dietrich von Mainz, der Mitte des 15. Jahrhunderts Juden ,Ungeziefer' nennt. Zitiert nach Hüllmann (1827), S. 88. 
neswegs auf eine irgendwie besonders legitimierte Personengruppe zurück. ${ }^{329}$ Es wäre zu weit hergeholt, in den z. B. schießbefugten Jägern und Adeligen oder dem auf eigene Rechnung arbeitenden Hamsterfänger solche Personen erkennen zu wollen, statt sich am praktischen Grund (Besitz- und Gebrauchsrecht von Schusswaffen; ökonomische Gründe ${ }^{330}$ ) zu orientieren.

Im Mentalen verfestigt sich, wie die Verknüpfung der fünf Stränge erkennen lässt, während des betreffenden Zeitraumes die rational fundierte Einstellung, wonach es unbedenklich sei, für schädlich gehaltene Individuen oder Arten um ihrer selbst willen zu verfolgen bzw. auszurotten. Damit wird auch volkspädagogisch der Gedanke vorbereitet, schädliche Organismen, später ,Schädlinge systematisch zu bekämpfen, als die hierfür erforderlichen technischen Hilfsmittel durch die Naturwissenschaft des späten 19. Jahrhunderts bereitgestellt werden. Hier hat, wie Jansen (2003, Kap. 6) herausarbeitete, das mit der Entdeckung der Mikroorganismen neu formulierte Konzept der Ätiologie besonders großen Einfluss. Gleichzeitig bringen Schädlingsbekämpfungen des 18. und 19. Jahrhunderts naturwissenschaftliche Beobachtungen und Einsichten hervor, die den Weg zum Verständnis systemischer Zusammenhänge ebnen, also hin zum Verständnis ökologischer sowie antagonistischer Prinzipien in der Biologie. Die hier angeführten Beispiele aus dem Umfeld der Sperlingsbekämpfung sind dafür an dieser Stelle ausreichender Beleg.

Die Auflistung der Kategorien schließe ich mit dem Hinweis, dass schließlich auch die schon weiter oben behandelten Fragen von Prämien vs. Steuern hierunter zu rechnen sind. Sie werden an dieser Stelle lediglich zur Vermeidung von Wiederholungen nicht noch einmal aufgeführt.

Endlich sei noch auf zwei größere Oppositionen kurz eingegangen:

\section{Groß vs. Klein; Säuger/Vögel vs. Ungeziefer/Insekten}

Die literarisch fassbare Aufgeregtheit gegenüber den »reißenden, wütenden und rasenden Tieren« (z.B. Krafft) ebbt im 18. Jahrhundert deutlich ab. Sie findet in den Archivakten ohnehin weit geringere Erwähnung als in der Fachliteratur. Die Aufmerksamkeit verlagert sich auf kleine Tiere, vor allem Sperlinge, Hamster und die Insektenschädlinge in den Forsten (,Raupen') und auf den Feldern und im Garten (Heuschrecken, ,Würmer'). Dieser Umstand ist leicht erklärbar, da infolge der Kulturlandschaftsentwicklung sich die Lebensräume der großen Beutegreifer bereits früh mit menschlichen Wirtschaftsräumen überschneiden. Der Verlust einer Kuh oder eines Schafes durch Bär oder Wolf, und offenbar auch die von ihnen ausgehende gefühlte Bedrohung, führten früh zu derart konsequenten Verfolgungen dieser ohnehin relativ seltenen Tiere, dass im 18. Jahrhundert solche Raubtie-

329 Dankbar greife ich den Hinweis von Jutta Nowosadtko auf, wonach in den von ihr untersuchten Regionen/Zeiten Abdecker als bestellte Rattenfänger eingesetzt wurden. Vgl. auch Nowosadtko (2000).

330 Einen Hamsterfänger zu engagieren macht erst dann Sinn, wenn die Kosten seiner Anstellung unter denen einer selbstorganisierten Bekämpfungsmaßnahme liegen. 
ren keine Gefahr mehr darstellten. Es gab im 18. Jahrhundert in Preußen nur noch ein paar eingezäunte Bären im Hetzgarten von Königsberg. Wölfe sickerten dagegen immer wieder aus dem Russischen ein.

Systematische Kampagnen gegen die großen Raubtiere wie Bär oder Luchs waren durch die Umgestaltung der Landschaft nach 1500 im 18. Jahrhundert nicht mehr erforderlich. Lediglich gegen gelegentliche Wölfe wurden noch Wolfsjagden veranstaltet, kamen in Preußen jedoch westlich der Oder nur noch selten vor, wenn Abschüsse als Maß für die Häufigkeit herhalten können. Für das ,kleine Raubzeuge, deren Bekämpfung prämiert wurde, wie Iltis, Marder, Otter und Fuchs, bot die Mosaiklandschaft aber nach wie vor gute Lebensbedingungen. Die vorratsschädlichen Säuger, wie Ratten und Mäuse, profitierten vermutlich von der steigenden Siedlungsdichte.

Sorgte also allein der Landesausbau unbeabsichtigt für einen Rückgang bestimmter Schädlinge in Form ihrer Verdrängung, wurden Umgestaltungen der Landschaft erst im 19. Jahrhundert direkt mit Schädlingsbekämpfung in Verbindung gebracht, als die Meliorationsmaßnahmen der Flussauen auch mit der Malaria-Prophylaxe (Sumpf- bzw. Wechselfieber) begründet wurden. ${ }^{331}$ Nicht ausgeschlossen ist, dass die positiven Erfahrungen bezüglich des Malaria-Vorkommens, welche die Habsburger durch die Trockenlegungen im Ungarischen und Rumänischen beim Ausbau der Militärgrenze machten, implizit auch bereits frühere Meliorationsmaßnahmen begünstigten. ${ }^{332}$

Der als Schädling (Untertunnelung der Deiche) eingestufte Biber ist nach 1765 an der Oder ausgerottet, fällt damit dem neuen Landschaftskonzept zum Opfer. Er gilt zunächst als einziges einschlägiges Beispiel in Preußen, denn Bär oder Wolf usw. sind eigentlich Opfer eines Verdrängungswettbewerbs und keiner effizienten Ausrottungskampagne. Das Beispiel übersieht aber, dass mit der Melioration und der Landschaftsumgestaltung die Biomasseproduktion an Insekten drastisch zurückgeht und damit diese auch vom Verdrängungswettbewerb betroffen sind. Bekmann (1751, Sp. 845) berichtet noch Mitte des 18. Jahrhunderts von der massiven Belästigung durch Insekten, denen die Bewohner etwa Küstrins oder Freienwaldes ausgesetzt wären. Dieser Hinweis Bekmanns wird bereits 1863 von Fontane zitiert, um auf diese Differenz zwischen den Zuständen vor und nach der Melioration des Oderbruchs aufmerksam zu machen. ${ }^{333}$

331 Drainierende Maßnahmen gegen Schadinsekten sind seit dem 19. Jahrhundert eine explizite, erprobte und weit verbreitete Strategie. Ein hervorragendes Kompendium zur Malaria-Literatur des 18. und 19. Jahrhunderts bei Mannaberg (1899), ergänzende Literatur in einem Überblick geringerer Qualität bei Hirsch (1881); ein sehr präziser epidemiologischer Überblick bei Schuberg (1928), der auch die Malariagebiete Brandenburg-Preußens detailliert vorstellt. Landschaftsverändernde Eingriffe, die sich explizit gegen Schädlinge richten, sind mir sonst nur mit Bekämpfungsmaßnahmen gegen Elefanten in China bekannt (Elvin 2004, Kap. 2).

332 Schimitschek (1964).

333 Theodor Fontane, Das Oderbruch, Kap. 1, Wie es in alten Zeiten war. 
Wie immer die staatlichen Bekämpfungsmaßnahmen auch lauten, sie betreffen fast ausschließlich Wirbeltiere. Insekten, die nach heutiger Einsicht neben den Mikroorganismen die überwiegende Mehrzahl der Schädlinge stellen, werden, mit Ausnahme der Heuschrecken, im Agrarsektor nicht zum Gegenstand einer über Verordnungen fassbaren Maßnahme. ${ }^{334}$ Obwohl z. B. Halberstädter Bauern dem König 1728 vorrechnen, dass die Hamsterbekämpfung teurer sei als ihr Nutzen und neben dem Hamster mit mindestens ebensolchem Recht „die Schnecken und Erdt-Flöhe, alls welches Ungeziefer gleichfalls oft ganze Feldt-Fluren verzehret, wir denn wegfangen müssten. “335 Wie hätte deren effektive Bekämpfung vor Erfindung chemischer Schädlingsbekämpfungsmittel auch aussehen sollen?336 Die angestrebte ,Ausrottung heißt im 18. Jahrhundert Verdrängen von oder Töten auf einem bestimmten Areal, meint also letztlich eine parzellenspezifische Handlung. Solange die adäquate Bekämpfungsstrategie aber im Verfolgen und in der Tötung jedes einzelnen Tieres gesehen wird, und das sind die „Mittel der Küche und des Handwerks" bis auf den heutigen Tag, solange übersteigt die Macht des Schädlings die Kraft des Betroffenen. Natürlich helfen die Puten, Hühner oder Enten hier und da, die Insekten oder Schnecken einzudämmen. Hätte man Schmetterlingseier und -raupen z. B. vom Kohl absammeln lassen und das Gesammelte nach Volumen prämieren können? Als betriebswirtschaftlich relevantes Ereignis läge ein solcher Befall grundsätzlich außerhalb staatlicher Eingriffsüberlegungen. Bei Schädlingen hingegen, die sich in großen Maßen über größere Distanzen bewegen können (Heuschrecken, Sperlinge) sind große, organisierte Bekämpfungsmaßnahmen nicht nur Erfolg versprechender. Wegen der empfundenen allgemeinen Bedrohung sind sie auch aus psychologischen Gründen für eine Bekämpfung durch die Allgemeinheit prädestiniert.

Freilich sollten solche Überlegungen, wenn sie denn als Hintergrund herangezogen werden, die biologischen Grundlagen von Populationsdichten nicht vernachlässigen. Kleine Säuger erreichen beispielsweise in der Regel höhere Populationsdichten als größere Säuger. Hierfür lassen sich gute biologische Argumente beibringen, ${ }^{337}$ welche eine größere Häufigkeit von Mäusen gegenüber Bären begründen. Allein aus seiner populationsbiologisch relativen Seltenheit wird deshalb aus dem Schadbären ein psychologisch anders registriertes Ereignis als aus der täglichen Maus. Die numerische Seltenheit, die physische Kraft des Schadbären oder das unheimliche Heulen der Wölfe prädestinieren die Furcht vor ihnen eher

334 Forstschädlinge sind, wie bereits erläutert, nicht Gegenstand dieses Aufsatzes. Natürlich regelt der Staat massiv die Bekämpfung der Forstschädlinge, die sämtlich Insekten sind. Die normative und praktische Seite ihrer Bekämpfung wird ausführlich im Promotionsvorhaben von Katharina Engelken behandelt.

335 Ausgeführt bei Herrmann (2003) S.41.

336 Vor den Fortschritten der Organischen Chemie gegen Ende des 19. Jahrhunderts gab es schon lange das arsenikhaltige ,Mäusekorn' und natürlich das Milchschälchen mit Fliegenpilzen gegen die häuslichen Schädlinge und Lästlinge.

337 Purves et al. (2006) S.1301 ff. 
für eine mythenbeladene Kompensation als die lächerlich erscheinende Furcht vor dem Mäuslein.

Mitteleuropa ist, von den Zugvögeln abgesehen, frei von saisonalen Tierzügen. Dem Alltagsverständnis fehlt also in gewisser Hinsicht die Erfahrung im Umgang mit plötzlich auftretenden großen Tierzahlen. Treten hier Tiere in Massen auf, geschieht es allermeist zur Unzeit und am falschen Ort. Es lehrt die Erfahrung, dass es sich in solchen Fällen nahezu ausschließlich um gravierende ,Störungen ${ }^{`}$ von Gleichgewichtszuständen handelt, vor denen die Menschen Grund haben, sich zu fürchten. ${ }^{338}$ Das gilt auch für die größeren Zugvögel, die auf ihrer Durchreise in Deutschland rasteten und natürlich Nahrung aufnahmen. Das machte u.a. sowohl aus Kranichen wie Wildgänsen gefürchtete Saatschädlinge. Sie waren deshalb auch als Frühlingsboten nicht sonderlich willkommen. Noch komplexer wird es, wenn alte, regionale Vorstellungen über das unerklärliche Verschwinden der Kleinvögel während des Winters (Vogelzug) in ihrer Verknüpfung mit der Schädlingsfrage bedacht werden: Die Vögel verwandelten sich im Winter in Mäuse, weshalb sie in Scheunen so häufig wären. ${ }^{339}$

Lassen sich Begegnungen mit naturräumlich gebundenen Insektenschwärmen (Feuchtgebiete) durch Meidung solcher Areale umgehen, ist das massenhafte Auftreten von forstschädlichen oder landwirtschaftsschädlichen Insekten in der Zeit vor der chemischen Insektenbekämpfung praktisch ein schicksalhaftes Ereignis. Warum sollte nicht, was immer nur Hilfe gegen sie verspräche, auch versucht werden? Und wenn nichts hilft, kann wenigstens eine gemeinschaftliche Handlung das psychologische Moment der individuellen wie allgemeinen Ohnmacht mildern. Auch dies ist ein Blickwinkel, aus dem sich das Handeln vor 250 Jahren verstehen lässt.

Die Sperlingsbekämpfung wird in einzelnen preußischen Provinzen nachdrücklich umgesetzt (s.o.) und ist damit das einzige Beispiel für die Verfolgung eines kleinen Vogels als Schädling. 340 Unter den größeren Vögeln sind die Raubvögel durchgängig stark verfolgt worden. Ihre antagonistische Funktion tritt offenbar in der Wahrnehmung der Herrschaft hinter die (unterstellten, nicht belegten) Jagdschäden zurück. Negative Erfahrungen mit Rabenvögel, die zu mehreren in Kooperation z. B. einzelne Schafe zu töten vermögen, sowie Saatschäden sind wohl der Hintergrund für die Verfolgung von Krähen und Raben. Da Krähen auch als Pökelfleisch Verwendung fanden, ergänzten sich ein weiteres Mal unterschiedliche Interessen in der Verfolgung des vordergründig selben Zieles. Obwohl beliebte

338 Ein geeignetes Beispiel liefert der Masseneinfall etwa des Seidenschwanzes in das winterliche Mitteleuropa, der als Prodigium galt und dem Vogel bezeichnende Beinamen eintrug (siehe Kinzelbach 1995). Herrn Christian Rohr, Salzburg, verdanke ich den Hinweis auf Massenauftreten von Bergfinken als Prodigium (siehe Hilgers 2005).

339 Nach Kinzelbach (2005) S.21, der den Schlesischen Arzt Schwenckfeld (1603) zitiert, nach dessen Angabe diese Vorstellung damals in Schlesien und Sachsen verbreitet waren.

$340 \mathrm{Zu}$ den katastrophalen ökologischen Konsequenzen einer überregionalen Sperlings-(Singvogel)Bekämpfung vgl. Shapiro (2001). 
Objekte der herrschaftlichen Beizjagd, wurden Kraniche im 18. Jahrhundert als Saatschädlinge für jedermann zum Abschuss o.ä. frei gegeben. Dabei soll nicht übersehen werden, dass Schutzvorschriften für Zugvögel, wenn sie denn existierten, ohnehin locker waren.341

Im betrachteten Zeitraum treten die kleinen Säugetiere in den Hintergrund, ${ }^{342}$ die Amphibien und Reptilien steigen zwar nicht in der Wertschätzung, das Interesse an ihrer Verfolgung erlahmt jedoch spürbar. Über Schnecken oder Würmer (im zoologischen Verständnis) fand und findet sich ohnehin kaum etwas, sieht man von der unglücklichen Einschätzung des Regenwurms ab. Dass die Insekten zunehmendes Interesse erfahren, erklärt sich nicht nur aus ihrer tatsächlichen Schadwirkung, sondern auch aus dem zunehmenden Wissen über sie. Schließlich stellen sie die mit Abstand größte Artenzahl des Tierreichs und treten in mitunter unvorstellbaren Individuenzahlen auf. Seit Pasteur weiß man sicher, dass sie nicht nur Pflanzen, Ernten und Vorräte auffressen oder ungenießbar machen, sondern auch Krankheiten der Pflanzen, der Tiere und des Menschen übertragen. Folgerichtig kommt ihnen bis auf den heutigen Tag wachsende Aufmerksamkeit in der Schädlingsabwehr zu.

\section{Quellen und Literatur}

Acxtelmeier, Stanislaus Reinhard (Erscheinungsjahre 1692, 1715; zitiert nach

21715): Ebenbild der Natur/ in dem Entwurf dero Ge/ wächsen/ Unzieffern und einigen / Thieren von vermischter Arth/ mit lehr- und sinnreichen Sprüchen/ Gedichten/ Auss-/ legungen/ Sitten-Lehren/ schönen Geschichten/

Künsten und Artzneyen/ zur Lust und zum Nutzen allerhand/ Gattungen Menschen/ so wol in Schrifft/ verfasset/ als mit schönen Kupffern auf jede/ Materie/geziehret. Augsburg.

Aerenthal, Johann Lexa von (1802): Staatswirthschaftliche Aufsätze in strenger

Bezeichnung auf Zeitumstände und besonderer Rücksicht auf Böhmen. Bd. 3. Leipzig.

Alpers, Svetlana (1998): Kunst als Beschreibung. Holländische Malerei des 17. Jahrhunderts. Köln.

Anonymus (1795): Die besten Mittel gegen die dem Menschen und Haustieren der Ökonomie und Gärtnerey schädlichen Thiere: gesammelt und herausgegeben zum Nutzen für Jedermann. Quedlinburg. Auszug abgedruckt in: Herrmann (2003).

Bächtold-Stäubli, Hanns und Hoffmann-Krayer, Eduard (Hrsg.) (1927-1942):

Handwörterbuch des deutschen Aberglaubens. Berlin und Leipzig.

341 Klose (2005).

342 Eigentlich müsste man sarkastisch vom ,Untergrund sprechen, in den Mäuse und Ratten abgedrängt wurden und der im wahrsten Wortsinne deren Vorzugsrevier bildet. 
Bayerl, Günter (2001): Die Natur als Warenhaus. Der technisch-ökonomische Blick auf die Natur in der Frühen Neuzeit. In: Hahn, Sylvia und Reith, Reinhald (Hrsg.): Umwelt-Geschichte. Arbeitsfelder - Forschungsansätze - Perspektiven. Wien [u.a.] (=Querschnitte. Einführungstexte zur Sozial-, Wirtschafts- und Kulturgeschichte; 8), S. 33 - 52.

Bechstein, Johann Matthäus (1789 -1795): Gemeinnützige Naturgeschichte Deutschlands nach allen drey Reichen: ein Handbuch zur deutlichen und vollständigen Selbstbelehrung besonders für Forstmänner, Jugendlehrer und Oekonomen. 4 Bände. Leipzig.

Bechstein, Johann Matthäus (1800): Naturgeschichte der schädlichen Waldinsecten. Nürnberg.

Begon, Michael, Townsend, Colin und Harper, John (1998): Ökologie. Heidelberg und Berlin.

Bekmann [Beckmann], Johann (1751-1753): Historische Beschreibung der Chur und Mark Brandenburg nach ihrem Ursprung, Einwohnern, Natürlicher Beschaffenheit, Gewässer, Landschaften, Stäten, Geistlichen Stiften etc. Berlin.

Benetello, Silvio und Herrmann, Bernd (Hrsg.) (2003): Christian Friedrich Garmann, De Miraculis Mortuorum. Göttingen.

Blankaart, Steven (1690): Schau-Platz Der Raupen, Würmer, Maden Und fliegenden Thiergen Welche daraus erzeuget werden / Durch eigene Untersuchung zusammen gebracht. Leipzig.

Bouché, Peter Friedrich (1834): Naturgeschichte der Insekten. Berlin.

- (1833): Naturgeschichte der schädlichen und nützlichen Garten-Insekten und die bewährtesten Mittel zur Vertilgung der ersteren. Berlin.

Braun, Karl (1933): Überblick über die Geschichte der Pflanzenkrankheiten und Pflanzenschädlinge (bis 1880). In: Appel, O. (Hrsg): Handbuch der Pflanzenkrankheiten, Bd. 1, 1.Teil, 1 - 79. Berlin.

Brednich, Rolf Wilhelm (Hrsg.) (21994): Grundriss der Volkskunde. Eine Einführung in Forschungsfelder der Europäischen Ethnologie. Berlin.

Burke, Peter (2002): Papier und Marktgeschrei. Die Geburt der Wissensgesellschaft. Berlin.

CCM = Mylius, Christian Otto (1736): Corpus Constitutionem Marchicum. Berlin, Halle. digital erreichbar über: http:/ / altedrucke.staatsbibliothekberlin.de/Rechtsquellen/inhaltccm.html\#werk

Columella, Lucius Iunius Moderatus (1976): De re rustica libri x, [Über Landwirtschaft : ein Lehr- und Handbuch der gesamten Acker- und Viehwirtschaft aus dem 1. Jh u. Z. / Columella. Aus dem Lat. übers., eingef. und erl. von Karl Ahrens]. Berlin.

Courtin, Carl (1835): Allgemeiner Schlüssel zur Waaren- und Producten Wörterbuch aller wesentlichen, als Handelsartikel vorkommenden NaturErzeugnisse. Stuttgart. 
Cowan, Frank (1865): Curious facts in the history of insects, including spiders and scorpions. Philadelphia.

Das Flämische Stillleben 1550 - 1680 (2002): eine Ausstellung der Kulturstiftung Ruhr Essen und des Kunsthistorischen Museum Wien; Kulturstiftung Ruhr, Villa Hügel Essen, 1. September - 8. Dezember 2002. Lingen.

Deutscher Jagdschutzverband (2005): DJV-Handbuch 2005. Mainz.

Dosch-Muster, Karin (1996): Das Brauchbüchlein der Caroline Otte. Handschriftliche Aufzeichnungen aus dem Jahre 1842 von der Insel Rügen. Mainz (=Mainzer kleine Schriften zur Volkskultur; 11).

Douglas, Mary (1988): Reinheit und Gefährdung: eine Studie zu Vorstellungen von Verunreinigung und Tabu. Frankfurt a. M.

Domitzer, Johann (1529): Ein newes Pflantzbüchlein/ Von mancherley artiger Pfropffung und/ Beltzung/ der Bawm. Wittenberg.

Edelman, Brigitta (2002): 'Rats are people, too'. Rat-human relations re-rated. Anthropology Today (18, 3), S. 3-8.

Elvin, Mark (2004): The Retreat of the Elephants. An Environmental History of China. New Heaven und London.

Evans, Edward P (1906): The criminal prosecution and capital punishment of animals. London [zitiert nach reprint, London 1988].

Freytag, Nils (2003): Aberglauben im 19. Jahrhundert. Preußen und seine Rheinprovinzen zwischen Tradition und Moderne (1815 - 1918). Berlin (=Quellen und Forschungen zur Brandenburgischen und Preußischen Geschichte; 22).

Frisch, Johann Leonhard (1720-1730): Beschreibung von allerley Insecten in Teutsch-Land: Nebst nützlichen Anmerckungen und nöthigen Abbildungen von diesem kriechenden und fliegenden inländischen Gewürme...13 Teile. Berlin. [auch Sekundärausgaben ab 1730].

Fritz, Samuel (o.J.): Cosmographie, Stadtarchiv Erfurt 5/100-43 (Ende 17. Jh). Gaston, Kevin und Spicer, John (1998): Biodiversity: an Introduction. London.

Ginzburg, Carlo (1979): Der Käse und die Würmer: die Welt eines Müllers um 1600. Frankfurt a. M.

Gledtisch, Johann Gottlieb (1754): Abhandlung von Vertilgung der ZugHeuschrecken und den eigentlichen Hülfs-Mitteln, die sich aufeine richtige und Naturmässige Erkäntniss dieses Ungeziefers gründet. Berlin, Potsdam.

Grau, Wilfried (1971): Schädlinge der Landwirtschaft und Maßnahmen zur landwirtschaftlichen Schädlingsbekämpfung in der deutschen Hausväterliteratur. Agrarwiss. Diss. Hohenheim.

Hebel, Johann Peter (2001): Die Kalendergeschichten. Sämtliche Erzählungen aus dem Rheinländischen Hausfreund. Herausgegeben von Hannelore Schlaffer und Harald Zils. München. 
Herrmann, Bernd (2003): Die Entvölkerung der Landschaft. Der Kampf gegen ,culthurschädliche Thiere' in Brandenburg im 18. Jh. In: Bayerl, Günter und Meyer, Torsten (Hg.): Die Veränderung der Kulturlandschaft.. Münster u.a. (=Cottbuser Studien zur Geschichte von Technik, Arbeit und Umwelt; 22), S. $33-59$.

— (2006a) : Zur Historisierung der Schädlingsbekämpfung. In: Meyer, Torsten und Popplow, Marcus (Hg.): Technik, Arbeit und Umwelt in der Geschichte. Günter Bayerl zum 60. Geburtstag. Münster u.a., S. 317 - 338.

— (2006b): ,Auf keinen Fall mehr als dreimal wöchentlich Krebse, Lachs oder Hasenbraten essen müssen!' - Einige vernachlässigte Probleme der , historischen Biodiversität'. In: Baum, Hans-Peter [u.a.] (Hrsg.): Wirtschaft- Gesellschaft-Mentalitäten im Mittelalter. Festschrift zum 75. Geburtstag von Rolf Sprandel. Stuttgart (=Beiträge zur Wirtschafts- und Sozialgeschichte; 107), S. $175-203$.

— (2007): Empirische Zugänge zu historischen Biodiversitätsverdrängungen und Biodiversitätslenkungen: Die Beispiele Melioration und Schädlingsbekämpfung. In: Knopf; Thomas (Hrsg.): Umweltverhalten in Geschichte und Gegenwart. Vergleichende Ansätze aus Geistes- und Naturwissenschaften. [im Druck].

Hilgers, Wolfgang (2005): Das Stadtplagenbild im Heimatmuseum von Waidhofen an der Ybbs. In: 100 Jahre Musealverein Waidhofen/Ybbs. Waidhofen /Ybbs. S. $224-244$.

Hirsch, August (1881): Infectionskrankheiten vom historisch-geographischen Standpunkte und mit besonderer Berücksichtigung der Aetiologie. Stuttgart.

Hobbes, Thomas (1977): Der Bürger. Hamburg.

- (1996): Leviathan. Hamburg.

Hohberg, Wolf Helmhardt von (ab 1682): Georgica Curiosa Aucta : Das ist: Umständlicher Bericht und klarer Unterricht Von dem vermehrten und verbesserten Adelichen Land- und Feld-Leben, Auf alle in Teutschland übliche Landund Haus-Wirthschafften gerichtet . Nürnberg. [vergleichende Einsichtnahme in Ausgaben von 1682, 1687, 1701, 1715].

Holling, Crawford, Gunderson, Lance und Ludwig, D. (2002): In Quest of a Theory of Adaptive Change. In: Dies.: Panarchy. Understanding Transformations in Human and Natural Systems. Washington u. a. S. 3 - 22.

Hüllmann, Karl Dietrich (1827): Städtewesen des Mittelalters. Bonn.

Jansen, Sarah (2003): ,Schädlinge'. Geschichte eines wissenschaftlichen und politischen Konstrukts, 1840-1920. Frankfurt a. M. und New York (=Historische Studien; 25).

Kemper, Heinrich (1968): Kurzgefasste Geschichte der tierischen Schädlinge, der Schädlingskunde und der Schädlingsbekämpfung. Berlin. 
Kinzelbach, Ragnar (1995): Der Seidenschwanz, Bombycilla garrulus (Linnaeus 1758), in Mittel- und Südeuropa vor dem Jahr 1758. Kaupia (=Darmstädter Beiträge zur Naturgeschichte; 5). S. 1-62.

- (2005) Das Buch vom Pfeilstorch. Marburg.

Kersting, Wolfgang (Hrsg.) (1996): Hobbes, Thomas: Leviathan oder Stoff, Form und Gewalt eines bürgerlichen und kirchlichen Staates. Berlin.

Klose, Johannes (2005): Aspekte der Wertschätzung von Vögeln in Brandenburg: Zur Bedeutung von Artenvielfalt vom 16. bis zum 20. Jh. Göttingen.

Koselleck, Reinhart (1989): ,Erfahrungsraum' und ,Erwartungshorizont' - zwei historische Kategorien. In: Ders.: Vergangene Zukunft. Zur Semantik geschichtlicher Zeiten. Frankfurt a. M., S. 349 - 375.

Krafft, Abraham Friedrich (1712 und 1713): Der sowohl Menschen und Viehe grausamen Thiere/schädlichen Ungeziefers und verderblicher Gewürmer gäntzliche Ausrottung... Nürnberg. [1712 (anderer Theil), 1713 (erster Theil)].

Kreyser, Krystyna (1996): Zwierety Gospodarskie. W traktatach argarnych pisarzy rzymskich I wieku Cesarstwa. [Nutztiere in den Agrartraktaten römischer Schriftsteller des 1. Jh.s des Kaiser-Reiches.] Warschau.

Kretzschmer, Peter (1744): Peter Krezschmers Oeconomische Vorschläge wie das Holz zu vermehren, die Strassen mit schönen Alleen zu besetzen, in geraden Linien, wodurch selbige weit kürtzer und verbessert würden, von Ort zu Ort zu bringen, mehr Aecker dadurch fruchtbar zu machen/ und die MaulbeerBaum-Plantagen damit zu verknüpffen. Endlich auch die Obst-Bäume anzulegen, und die Sperlinge nebst denen Maulwürffen zu vertilgen sind : nebst einem Anhange ohnmaßgeblicher Vorschläge, wie mit großer Herren Küchen und Tafeln verbessert, und zur Gesundheit dienlicher eingerichtet werden können. Halle und Leipzig.

Krünitz, Johann Georg (ab 1733): Oekonomische Encyklopaedie, oder allgemeines System der Staats-, Stadt-, Haus- und Landwirthschaft, Berlin. [auch online verfügbar: unter http://www.kruenitz1.uni-trier.de/home.htm].

Kuhn, Thomas (1997): Die Struktur wissenschaftlicher Revolutionen. 14. Aufl. Frankfurt a. M.

Lepenies, Wolf (1986): Das Ende der Naturgeschichte. Wandel kultureller Selbstverständlichkeiten in den Wissenschaften des 18. und 19. Jahrhunderts. Frankfurt a. M.

Leuschner, Hanns Hubert und Leuschner, Barbara (2002): Lüneburg aus dendrochronologischer Sicht. In: Berichte zur Denkmalpflege in Niedersachsen (4), S. $215-218$.

Leuschner, Hanns Hubert (2005): Dendrochronologie - mehr als ein Datierungsverfahren. In: Fansa, Mamoun [u.a.] (Hrsg.): ArchäologieLandNiedersachsen. Archäologische Mitteilungen aus Nordwestdeutschland. Beiheft 42. S. 97-106.

Lovejoy, Arthur O. (1993): Die große Kette der Wesen. Frankfurt a. M. 
Lévi-Strauss, Claude (1973): Die Wissenschaft vom Konkreten. In: Claude LéviStrauss: Das wilde Denken. Frankfurt a. M., S. 11 - 48.

Mannaberg, Julius (1899): Die Malaria-Krankheiten. In: Nothnagel, Hermann (Hrsg.): Specielle Pathologie und Therapie, Bd. 2, II Teil. Wien.

Marquardt, Bernd (2003): Umwelt und Recht in Mitteleuropa. Von den großen Rodungen des Hochmittelalters bis ins 21. Jahrhundert. Zürich u.a. (=Zürcher Studien zur Rechtsgeschichte; 51).

Mayer, Karl (1959): 4500 Jahre Pflanzenschutz. Stuttgart.

Meusel, Johann ( $\left.{ }^{4} 1817\right)$ : Lehrbuch der Statistik. Leipzig.

Meyer, Torsten (1999): Natur, Technik und Wirtschaftswachstum im 18. Jahrhundert. Risikoperzeptionen und Sicherheitsversprechen. Münster u.a. (=Cottbuser Studien zur Geschichte von Technik, Arbeit und Umwelt; 12).

- (2003): Von der begrenzten zur unbegrenzten Ausrottung. ,Schädlinge' als ,natürliches Risiko' im 18. Jh. In: Bayerl, Günter und ders. (Hrsg.): Die Veränderung der Kulturlandschaft. Münster u.a. (Cottbuser Studien zur Geschichte von Technik, Arbeit und Umwelt 22). S. $61-73$.

Miller, William Ian (1998): The Anatomy of Disgust. Cambridge und London.

Münchhausen, Otto von (1765): Der Hausvater. Zweiter Teil. Hannover.

NCC $=$ Mylius, Christian Otto (1753 - 1810): Novum Corpus Constitutionum Prussico-Brandenburgensius praecipue Marchicum...Berlin. Digital erreichbar über: http:/ / altedrucke.staatsbibliothek-

berlin.de/Rechtsquellen/inhaltccm.html\#werk

Nördlinger, Hermann (1869): Die kleinen Feinde der Landwirtschaft oder Abhandlung der in Feld, Garten und Haus schädlichen oder lästigen Schnecken, Würmer, Gliedertierchen, insbesondere Kerfe, mit Berücksichtigung ihrer natürlichen Feinde und der gegen sie verwendbaren Schutzmittel. 2. Aufl. Stuttgart.

Nowosadtko, Jutta (2000): Die policierte Fauna in Theorie und Praxis. Frühneuzeitliche Tierhaltung, Seuchen- und Schädlingsbekämpfung im Spiegel der Policeyvorschriften. In: Härter, Karl (Hrsg.): Policey und frühneuzeitliche Gesellschaft. Frankfurt a. M. (=Ius Commune; Sh. 129), S. 297 - 340.

Otte, Albert (1998): Die Unterlassung des obrigkeitlich gebotenen Raupens - erste Pflanzenschutzbestimmung für das deutsche Reich. In: Mitteilungen der Biologischen Bundesanstalt für Land- und Forstwirtschaft (348), S. 7 - 8.

Pribram, Karl (1992): Geschichte des ökonomischen Denkens. Bd. 1. Frankfurt a. M.

Purves, William, Sadava, David, Orians, Gordon und Heller, H.Craig (2006): Biologie. 7. Aufl. Heidelberg. 
August Schiebe (Hrsg.) (1837): Universal-Lexicon der Handelswissenschaften: enthaltend die Münz-, Maß- und Gewichtskunde, das Wechsel-, Staatspapier-, Bank- und Börsenwesen ... Leipzig und Zwickau.

Say, Johann (1818): Darstellung des Nationalökonomie oder der Staatswirthschaft. Heidelberg.

Schimitschek, Erwin (1964): Einfluss von Siedlung, Wirtschaft und geistigen Strömungen auf Massenauftreten von Insekten. Göttingen. (=Göttinger Universitätsreden; 43).

- (1969): Grundzüge der Waldhygiene. Hamburg und Berlin.

Schmid, B. (2002): Reconceiling Experiment and Observation: The Species Richness - Productivity Controversy. In: Trends in Ecology and Evolution (17), S. 113-114.

Schmid, Martin (1998): Magie in der Kolonie. Vom Umgang mit Schädlingen und Unkraut um 1600. In: Dirlinger, Helga [u.a.] (Hrsg.): Bodenfruchtbarkeit und Schädlinge im Kontext von Agrargesellschaften. Social Ecology Working Paper 51. IFF Social Ecology. Wien. S. 89-112.

Schuberg, A. (1928): Das gegenwärtige und frühere Vorkommen der Malaria und die Verbreitung der Anophelesmücken im Gebiet des Deutschen Reiches. In: Arbeiten aus dem Reichsgesundheitsamte (59), S. 1 - 428.

Schütz, Karl (2002): Naturstudien und Kunstkammerstücke. In: Das Flämische Stillleben 1550 - 1680 (2002).

Schultz Helga (21992): Berlin 1650 - 1800. Sozialgeschichte einer Residenz. Berlin.

Secoy D. M. und Smith A. E. (1978): Superstition and Social Practices against Agricultural Pests. In: Environmental Review (5), S. 2-18.

Shapiro, Judith (2001): Mao's War against Nature. Politics and the Environment in Revolutionary China. Cambridge [u.a.].

Statistisches Bundesamt (Hrsg.) (2003): Statistisches Jahrbuch 2003. Wiesbaden.

Stein, Christian (1811): Geographisch-statistisches Zeitungs-Post und Comptoirlexicon. Leipzig.

Sucker, Ulrich (1998a): Anfänge der modernen Phytomedizin. Die Gründungsgeschichte der Biologischen Bundesanstalt für Land- und Forstwirtschaft (1998 bis 1919) - zugleich ein Beitrag zur Disziplingenese der Phytomedizin. In: Mitteilungen aus der Biologischen Bundesanstalt für Land- und Forstwirtschaft (334).

- (1998b): Die Biologische Reichsanstalt für Land- und Forstwirtschaft und die Entstehungsgeschichte eines reichseinheitlichen ,Pflanzenschutzgesetzes' (1914 bis 1937). In: Mitteilungen aus der Biologischen Bundesanstalt für Landund Forstwirtschaft (352).

Thorndike, Lynn (1923-1958): A History of Magic and Experimental Science. 8 Bde. New York. 
Vogel, Ralph und Keller, Siegfried (1998): Dendrochronologische Rekonstruktion der schweizerischen Fluggebiete des Maikäfers (Melolontha melolontha L.) für die vergangenen 800 Jahre. In: Mitteilungen der Schweizerischen Entomologischen Gesellschaft (71), S. $141-152$.

Weber, Urs (1997): Dendrochronological Reconstruction and Interpretation of Larch Budmoth (Zeiraphera diniana) Outbreaks in two Central Alpine Valleys of Switzerland from 1470 - 1990. In: Trees (11), S. 277 -290.

Winston, Mark (1997): Nature Wars. People vs. Pests. Cambridge und London.

Zwölfer, W. (1957): Ein Jahrzehnt forstentomologischer Forschung. In: Zeitschrift für angewandte Entomologie (40), S. 422 - 432. 



\title{
Man is made of mud. "Soil", bio-logical facts and fiction, and environmental history
}

\author{
Bernd Herrmann 343
}

Within the five essentials of an ecosystem (space, matter, energy, information, time) soil is not directly listed. However, it is one of three physical manifestations of "space", besides air and water, and an important purveyor of matter. All beings move through and are defined by either one or even more of these media of space. At least terrestrial and airborne organisms depend directly on soil, as the medium that support plants and carries animals, that builds the surface layer of the earth, and provides the basic matter for any organism.

So, any consideration about soil should start from the fact that it is a physical prerequisite, or even a determinant, for many organisms, including man. But before going into material aspects it seems necessary to understand that science and scientific approaches are nothing but tools of constructing nature. Thus the prerequisites of the scientific tools, the objects of their dedication, and the general aims of their epistemological interests have to be reflected first, not only to prevent

343 Zuerst erschienen in: Die Bodenkultur. Austrian Journal of Agricultural Research. 57 (2006): 215 - 230 (erschienen Dez. 2007) 
ourselves from circular results, but also to look for the underlying opinions. As, of course, there would be no progress from the factual alone, as only opinions about facts and matters produce progress in the long run, be it technological, scientific, or else. This is Epiktet, Ockham, and Popper more than roughly remembered. It is intuitively understood that Environmental History will have to deal not only with physical, pedological, ecological or else factors of soils but also and perhaps even more legitimately with reifications of human ideas, belief, and superstition about soil.

For humans, beings that reflect their environment, soil is not only sort of a simply given matter but has also a transformed quality, as for example being one of the magic four constituents, as there are soil, water, air, and fire. The meaning of them being ambiguous. It is as well as the physical matter of any of these constituents that make man think about these elements. But it is also the "principle," the concept behind all of those elements, as man sees it, that make people worship one or more of these elements.

Thus my essayistic contribution is divided into three parts: 1.) on mythical and metaphoric prerequisites of soil concepts, 2.) soil related features in biological issues, and finally 3.) problems of territoriality, that obviously merges ideas of the two previous. Since soil is a holistic matter, it is difficult to consider one property without taking the others into account. My contribution has neither a punch line nor a message, it simply aims at collecting some aspects and impacts of "soil" from a more general point of view, without which an "environmental history of soil" would be incomplete in my understanding. I do not intend a complete presentation rather than to briefly sketch an outline of the topic.

\section{Part I}

\section{Man: adam, and adamah. Soil and Creation}

In any agriculture the concept of soil is also an issue of myth, more precisely one of transformative philosophy. The metaphoric encompasses in our Old World culture of European-Near-Eastern origin the history of creation as well as deterministic concepts. Soil has an ambiguous meaning in Jewish-Christian religion. The Lord God banished Adam and Eve and assigned them to earn their living painstakingly by tilling the soil [Gen 3:14-19]. Thus, soil became related to humans in various facets of the conditio bumana, soil made man work. Work is an important part in the evolution from apes to man, according to one important philosophical forerunner of environmental history: Friedrich Engels argued that work created man (1962: 444-455).

Genesis claims also that a sort of soil, dust, mud, or clay was the matter man was made of. Although this in the first instance seems to be an expression of the inferiority, the worthless, and the ephemeral, as man describes himself before the Lord God, this expression instantly co-founds the metaphoric link between "soil" 
and unsophisticated earth-orientated and practical understandings of offspring. It is intuitively obvious that "soil" in this perspective is in a mythical way related to "inheritance," to "ancestry," and "genealogy."

The creationistic story is rather prosaic: [Gen 2:7, King James Bible] "Then the Lord God formed man of dust from the ground, and breathed into his nostrils the breath of life; and man became a living being." According to the revised [of 1984] German translation by Martin Luther, it reads: „Da machte Gott der HERR den Menschen aus Erde vom Acker und blies ihm den Odem des Lebens in seine Nase.“ [Then the Lord God made man of soil from the field..] However, the Latin bible, the "Vulgate," states: "Formanit igitur dominus deus de limo terre et inspiravit." An old translation into German used "clay" for "limo terre," which has the meaning of mud, or sludge, which again refers to aspects of fertility, given the Middle Eastern fertile river valley situations.

These minor but decisive differences in the translations of the phrase into different languages and throughout time sheds light on the change of concepts behind the translators expressions, even in one common cultural context, and even nowadays. The modern German phrase "soil from the field" is rather significant, as it includes the pictures of fertility and procreativity, whilst " $d u s t$ " transports concepts of infertility and inferiority.

However, this first glance hermeneutic approach lacks from deeper insight into the Hebrew text, as the Hebrew phrase (adamah) means "out of the soil from the field" (from the soil of arable land). The linguistic derivation of adam (man) from adamah is pointing to his intrinsic dedication for cultivating the soil. Somewhat later man was cursed by the Lord God and bound to die, as the Lord God said, to "return to the soil" [which becomes now the dusty and the dry, becomes "afar" (dust; dusty and dry soil; Gen 3,19)]. One has the impression that optimistic translators are closer to the "soil"-side whereas the more pessimistic ones emphasize the "dust"side. Interestingly enough "clay" points more towards the religious forerunners in the Middle East. In Mesopotamia man was created by the gods from "clay," to which the blood of a slaughtered god was added (cf. the Atramhasis epic of the time of Nebukadnezar I, Tablet I, lines 210 succ.; cf. also the Enuma Elish epic, which is only slightly younger, Tablet IV, lines 1-34). ${ }^{344}$

These are presumably the oldest sources we know that bring together blood and soil in the context of creation and ancestry, as well as the Atramhasis epic mentions also a plague in terms of soil erosion [Tablet II, line 14], which is nothing but the knowledge about the threat by a Mesopotamian "dust bowl" event.

\footnotetext{
344 I owe special thanks to my colleague Dr. Reinhard Kratz, Professor for the Old Testament at Göttingen University, for his advice and help. I refer here to the German edition of these two ancient Babylonic texts. Both quoted after: Kaiser O, Delsmann W (eds) Texte aus der Umwelt des Alten Testaments, for Enuma Elish see Vol III/3, ed. by W. Römer, p. 592. For the Atramhasis [Atrahasis] epic see Vol III/4, ed. by K. Hecker et al., p. 623. All volumes published by Gütersloher Verlagshaus Gerd Mohn, Gütersloh 1993, 1994. The English Lambert \& Millard- Edition is obsolete.
} 
The same general idea of creation is only slightly camouflaged in the Ashkenasim folklore tale about the golem, an artificially created human made of mud, supernaturally endowed with life and strength. Instead of blood the powerful and life giving sign of JHWH, the Lord God, is applied on the forehead of the golem. A contemporary interpretation of this tale would have to end up with genetically altered organisms, or creatures, and finally human clones, expressing that man has totally conquered the soil, being it physical or metaphysical.

The etymologic analysis of the linkage of adam and adamah meets with an obstacle from the fact, that the Lord God later did not well receipted the sacrifice of Cain, the agriculturalist, but that of Abel, the pastoralist. The resulting problems for the human race are well known. The difficulty of interpretation stems from the fact that the Lord God himself obviously is uneasy with the agricultural innovation although he himself put up this perspective development when he determined man to work in the field by the implications of his creation.

However, the Old World also provides an idea of autochthonous creation as an independent, as a non-theistic concept of linking decent with "soil," a general idea that is lively also in indigenous myths in other parts of the world. The most remarkable example from the Old World is the story about the emergence and formation of the city of Athens: Hephaistos tried to rape the goddess Athene, and his semen fell on her thigh. She removed it, and the semen fell on the soil. The soil conceived the semen and gave birth to Erichthonios (" vEricq"o,niog), the mythic king of Athens (Loraux 1990: 35-73). An important part of the story is, that and how the young child managed to survive a basket of snakes, the goddess hid him in. It can be taken as the moment of the emergence of a new word: autochthonous, a compound of awvto, -, self and cqüw, n, soil. The story is an earthly, a terrestrial statement in its purest sense (instead of a magic and religious background) and at the same time of highly metaphorical meaning with respect to ancient Greek mythology and history (see Loraux). With the "semen" another prerequisite is introduced to describe a feature of soil that everybody at least in the Old World is familiar with: the metaphor of "Mother Earth." This became a powerful and influential metaphor, even up to contemporary European philosophers (e.g. Serre 1985, especially the part on landscape). I assume that the worldwide used metaphor of Mother Earth was brought up independently in different places because of its selfevident meaning.

While knowledge on Old-World philosophy and religion is abundant and accessible for me, the same does not hold true about other important systems of belief that are widespread in the World. I am unfortunately unable to cope with the task of reviewing Chinese, Hindu, Buddhism, Islam, and other world religious ideas. But to my surprise, ethnologists, anthropologists, and environmental historians have obviously not yet focussed the soil problem in world religions, natural religions, and indigenous systems of belief with respect to questions outlined here briefly. Nothing useful in this context can be found e.g. in The Golden Bough (Frazer 
1907 -), as I did also not find any suitably related ethnographic literature of more recent origin, least of all a comparative study.

Certainly, the concept of Gaia, which became quite influential in non-scientific contexts of modern cultural criticisms in the Western hemisphere, has to be added in a way to Mother Earth related quasi religious views (Lovelook 2000). As such ideas might be sort of modish thinking and ephemeral, the Jewish-Christian religion had seriously to cope with alternative concepts in the past, especially in its subcultural expressions, in a long lasting struggle that culminated in the inquisition. One of the best documented cases is that of the poor Domenico Scandella, better known as Menocchio, who lived in the Italian Friaul of the $16^{\text {th }}$ century and who had his own ideas about the creation of the world (Ginzburg 2002). He is obviously just one tip of numerous icebergs of the subcultures of that time. Menocchio's model of the world is clearly influenced by very ancient thoughts about the four bodily humors and the four main elements that survived as tacit knowledge. His model contradicted that what was favoured by the Roman church. He beliefs that the ground/soil is dedicated from the beginning of times to walk on and is stomped upon all day long, and it is in the midst of the other elements, which are arranged and contracted as in an egg, where the yolk is the centre and the shell the periphery (Ginzburg 2002, chapter 34): "The yolk corresponds to the earth, the albumen to the air, the thin tissue that is between the albumen and the shell to the water, the shell to the fire: and they are joined together in this way, so cold and heat, dry and moist may work on each other. And our bodies are made out of and composed of these elements: by our flesh and bone we mean earth, by blood we mean water, by breathing air, and by heat fire. Our bodies are composed of these four elements." 345 To me the metaphor of the egg is, of course, not randomly used by Menocchio. His picture is just one in countless interpretations of elements of the environment as religious metaphors and messages to humans, to remember them the beauty and perfection of the creation.

A recent contribution by Patzel (2003) offers access to psychological interpretations in soil sciences, and emphasizes in one of its chapters the importance of the subconscious for the emergence of soil concepts, as e.g. is demonstrated by Freudian dream analysis of those dream episodes enclosed in interrogation reports of "Benedanti" 346 of the $16^{\text {th }}$ century by the officers of the inquisition.

Menocchio was sentenced to death and burnt on the pyre for heresy. But the important message from that example is, that there are many subcultural contexts in everyday life that deal with natural objects as are animals, plants, or soil in a metaphorical way, given the sheer superstitious knowledge. More examples of mediaeval superstition (or "folklore") with respect to soil may be found in Gur-

\footnotetext{
345 Quoted from Ginzburg C (1980) The cheese and the worms, The Johns Hopkins University Press, Baltimore \& London, p.69

346 Benedanti were kind of a sect in upper Italian Friaul (see Ginzburg,1980)
} 
jewitsch (1986, chapters on peasants and saints), to mention only one important contribution.

\section{Part II \\ Soil, space and their reflections in reproduction and production}

Soil features are reflected directly in the composition of organisms. Generally any food web starts with a plant eating organism. As plants grow by incorporating the minerals from the soil that is supporting them, plants from soils of different composition differ in their mineral composition too. Animals feeding on plants in their home range reveal that soil signature though it becomes altered for metabolic reasons. Finally the top predators in a given home range will also end up with mineral signatures that reflect the soil signature of the given range.

Within the set of soil related human activities, geophagia ${ }^{347}$ (earth-eating, dirteating) is known for all ethnic groups in all inhabited continents. Earlier anthropological scholars stressed cultural backgrounds for this habit, as they might be embedded in ritualised practices. Furthermore it appears intuitively that the habit was linked with the ideas of "Mother Earth", the "Good Earth," and that it can also to be seen as subtle expressions of territoriality. I mention it in this chapter, as it serves as a good example of a "nature-nurture" soil problem. Despite of being culturally embedded in what ever context, and considered of being an earth orientated magic practice, more recent studies on geophagia have emphasised the nutritional benefit soil eaters gain by the uptake of trace elements and nutrients (Reilly \& Henry 2000). Moreover the uptake of comestible earths can provide suitable absorptives and detoxicants for the consumption of phytotoxines, which are typical e.g. for Andean tubers (Browman \& Gundersen 1993). Since a phytotoxic burden of nutrition can be generally assumed before times of advanced plant breeding and the introduction of sophisticated meal preparation techniques, one would assume geophagia being a widespread and very common practice in agricultural societies. Not only anecdotic but even suitable in terms of prevention of malnutrition is the consumption of soup made of soil in times of dearth, as is described in "The Good Earth" by Han Suyin. Given the fact that soil is the biomass richest medium of the world (biomass provided mostly by microorganisms), one could certainly overcome food shortage by eating soil soup - if one manages to swallow it.

If "soil" is understood in a broader functional sense (see introductory remarks and more extensively Part III) it is related to features of "space". The aim of this

${ }^{347}$ I wish to thank Bill Woods for stimulating me to think about geophagia. 
chapter is to further briefly outline features of soil and space in relation to organisms and materials related to human culture. ${ }^{348}$

\subsection{The study of provenance of biomaterials: inorganic components}

"Der Mensch ist was er ißst" - this famous German pun ${ }^{349}$ reflects a trivial insight in general physiology. Humans, as well as other organisms, consist of that matter that is incorporated. In case of inorganic matter or organic matter that is physiologically degraded into inorganic components, this matter (elements and their isotopes, which are atoms of different atomic weight) may be stored in bodily tissues as well as in the human skeletal system, if they are not excreted. Thus the skeleton does not only serve as an internal supporting feature for the organism, and as site for the haematopoietic system, but also as the main storage organ for minerals. Mineral elements and their ions are most important for basic physiological processes within cells and the cell walls. Quite a few of them are under physiological control in terms of physiological uptake, metabolisation, and storage rate. There can be a physiological discrimination against or in favour of elements, as e.g. Strontium (Sr) can be discriminated in favour of Calcium (Ca). As in any mammal, the human physiology prefers $\mathrm{Ca}$ instead of $\mathrm{Sr}$ for the main mineral compound of the bone. Since humans are at the end of a food chain, their bone contain normally least $\mathrm{Sr}$ compared with non predating mammals of the same food web.

However, minerals, isotopes, and their ratios are not evenly distributed in soils of the world (Schmidt 2003). Specific local patterns in isotopic features consequently lead to reflections of those patterns in living organisms, as the isotopic ratios are reflected within every step of the food chain, but specifically altered in their proportion due to metabolic kinetics of the isotopes. In consequence their ratios in individuals will offer minor but significant differences in their composition in comparison to individuals from another part of the world, continent, region, or area. Even social control of nutritional components, that leads to such differences, can be traced back. Consequently these differences are observed for reconstructing food chains or food webs in archaeology or contemporary ecology (Ambrose 1993, Sandford 1993; Schutkowski et al. 2001; Zlateva \& Kuleff 2003).

If those patterns are known for regions, or countries, or areas of continents the isotopic patterns may serve as indicators for reconstructing the spatial origin of a human or other organism. These analytical tools are valid to reconstruct immigration in prehistory down to the individual's level (e.g. Grupe et al. 1999). Although this approach was elaborated for geological and archaeological purposes it is also

\footnotetext{
348 for a general overview in terms of archaeometry see Herrmann et al. 2002

349 the German words for "be/she is" and "be/she eats" are pronounced almost in the same way, which is the basis for this pun. However, "What you eat makes what you are" is an old European phrase, and supposedly also in other parts of the world.
} 
valid in forensic studies in tracing back unidentified corpses to their presumable country of origin, even in times of supermarkets and globalisation (Hölzl et al. 2004).

Moreover, with respect to land governance and soil use, those reconstructions reveal information about exploitation patterns of human communities by the study of skeletal series, in terms of main nutritional components. For instance, from the analysis of bone estimates can be made about the bulk plant nutrients. This allows to deduce the use of specific crops, if they are distinguished from each other by their principle photosynthesis carbohydrate compound (three- or four-carbon molecule near the start of the Calvin cycle, C3- vs. C4-plants). Maize, sugar cane, and millet for example are C4-plants, whilst many other cultivated plants, including cereals, are $\mathrm{C} 3$ plants. Evenly the stable isotopes of nitrogen are indicative, roughly for the proportion of animal products in the nutrition (see Fig.1). Using those signals enabled e.g. Hutchinson \& Norr (1993) to suggest the time for the introduction of maize into the North American South-East.

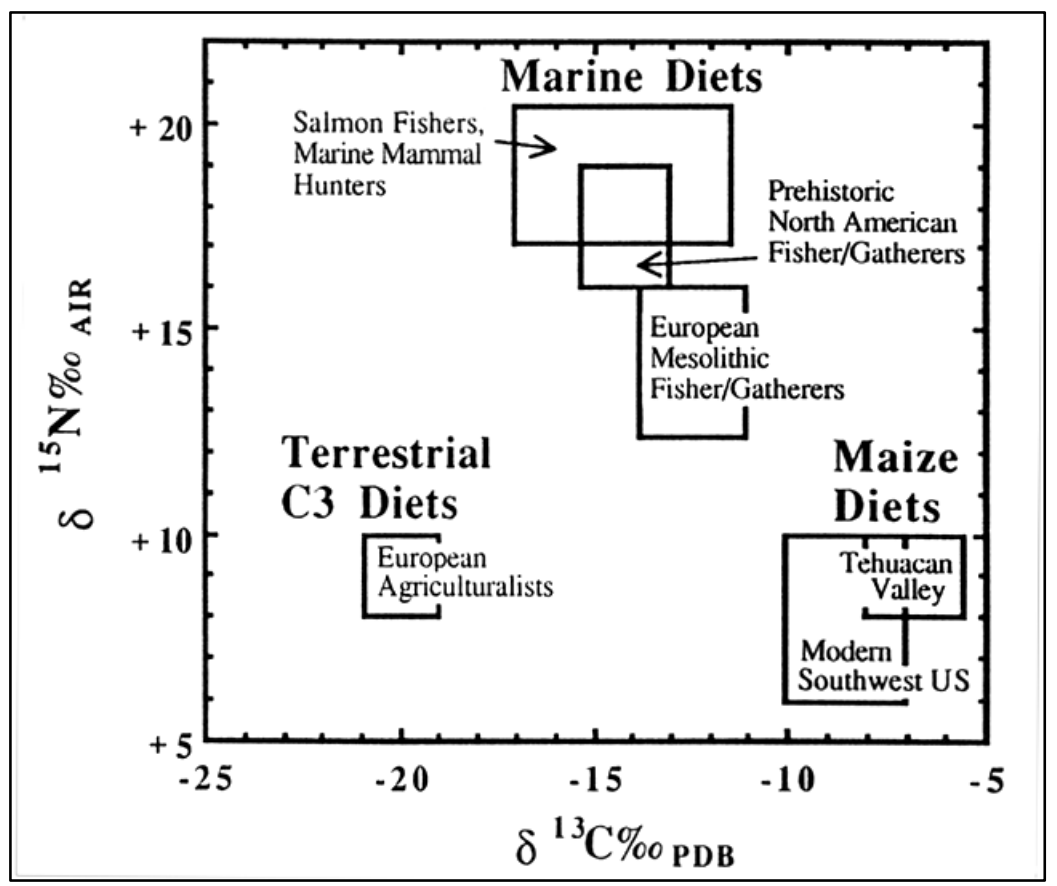

Fig. 1 Isotopic composition in terms of nitrogen $(\mathrm{N}) /$ carbon $(\mathrm{C})$ ratios of bone collagen from humans with isotopically distinct diets (adapted from Hutchinson \& Norr, constructed from data quoted after Schoeninger et al. 1983) 
Until recently bulk and trace element studies were also used to reconstruct food webs and land use systems in terms of prevailing crop or meat production (e.g. Schutkowski et al. 1999). The general principle of such approaches must be correct by reasons of theoretical deductions. However, so far published empirical data in case studies from which such conclusions were drawn upon, caused doubts for epistemological reasons, as was demonstrated by reanalysing the same sets of samples (Fabig \& Herrmann 2002). The problem is still under discussion. Undoubtedly this approach would be especially useful in studies on soil use in prehistoric times.

\subsection{The study of provenance of biomaterials: space related DNA features}

Within the first experiences in the discovery of the natural world is the constancy of distinct distributions of plant and animal species: ice bears in the Arctic, Tse-Tse flies in Africa, Osage Orange trees in America. The bio-geographic distribution of species depend on the trivial fact that the set of factors required for their existence and propagation usually occur only in limited areas. These factors derive from climatic and soil conditions, which are not evenly distributed over the world. The distinctness of bio-geographic patterns might be camouflaged by the interference of other species, mostly man, who provides unintended or deliberately ecological niches for the use of organisms that are not indigenous.

Well known examples for intended introductions are maize to Europe, wheat to the Americas and others of the set of the portmanteau biota. Of course they do not grow on any spot but only in those areas, where basic ecological requirements are fulfilled, be it by nature or by human activity. Examples for animals might be restricted here to cattle and sheep, which both require a specific land use regime for grazing.

However, those "anthropogenic niches" or "anthropogenic licences" are also used (in terms of spreading) by vermin, which essentials of life are by definition contrary to human interests. A nice example offers the Colorado beetle (Leptinotarsa decemlineata, "potato beetle"), which lived inconspicuously in remote hills of Colorado until the days of the Western trail. His feeding plant was Solanum rostratum, but as soon as European settlers brought in potatoes (Solanum tuberosum) in 1859 it became an opportunistic consumer of this plant. Now it had simply to jump literally from one potato plant to the next, it needed only a slight acceleration by the new railway transportation system to reach the North American East Coast already in 1874 (see Elton 1958). Europe became conquered after 1921 from a French harbour, and in 1980 the scrabbler had spread that far east as already behind the Caspian Sea. This remarkable example is not likewise shown by all intruding species, but it demonstrates how much the pattern of spreading can depend on human soil related activities.

As for the Colorado beetle the peopling of the earth is a process of opportunistic spreading in space and time into suitable environments. Since humans successfully cope with almost any environment by cultural innovations, they became 
cosmopolitans. This process took only 40.000 years for the anatomically modern Homo sapiens sapiens, what is almost a comparable speed to that of the Colorado beetle, since man had to rely on successful preparations and adjustments of soils and self invented implements of transportation.

All humans, as well as all other organisms, are the monophyletic product of a common male and female ancestor (this statement reads: from a minimum number of ancestors). Every living individual can be considered to be at the end of a branch of the genealogical tree. Due to modes of DNA-inheritance this ancestry can be rooted backwards in the female line by the use of mitochondrial DNA (mtDNA, so called Ancient-Eve-Theory, see Cann et al. 1987). In males phylogenetic lineages can be drawn back on Y-chromosomal features (Bowcock et al. 1994). Differences in the originally similar DNA features increase during time, since mutations are accumulated. As people in given geographic areas have more common offspring than people from two far distant areas, these differing features are not equally distributed but accumulate in given areas by time. Thus by time people in distinct geographic areas or regions are discriminated by sets of differences in their genetic features (coding and non-coding DNA polymorphisms) from people in other regions. These aspects hold true also for animal and plant species in a given region. Therefore the genetic composition in any territory is necessarily "unique."

Although the overall variability between groups of people is smaller than between the individuals of the groups, genetic profiles of groups are highly indicative with respect to geographical allocation of individuals. DNA profiling techniques nowadays analyse source materials for racial and regional origin of the causer (De Knijff et al. 1997). Those techniques are also available for historic or prehistoric source materials (Herrmann \& Hummel 1994, Hummel 2003), and have already provided suggestions for or confirmation of the ancestry of certain historical celebrities (e.g. the Evangelist Luke from Syria, Vernesi et al. 2001)

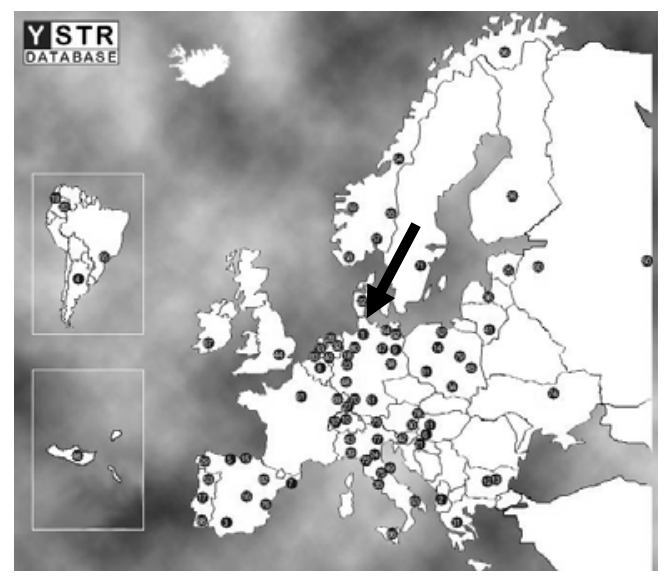


Fig. 2 Map of geographic distributions of human male groups analysed for their Y chromosomal haplotypes in contemporary Europeans as provided by the Y-STR database (http://ystr.charite.de/index_mkl.html). A haplotype found through the analysis of source material can be searched for its frequency and geographic distribution by a simply data retrieve. The arrow points to one single match for a questioned haplotype found previously only once in Northern Germany. The haplotype query in this example represents the skeleton EN462 from Enger, Northern Germany, which is likely the legendary Duke of Saxony, Widukind, an opponent of Charlemagne at the end of the $8^{\text {th }}$ centrury AD. The rarity and the geographic occurrence of the haplotype in question may be taken as further evidence for the authenticity of the skeleton (molecular data by courtesy of S Hummel \& D Schmidt, Dept of Historical Anthropology, University of Göttingen). In reverse, haplotype queries may indicate to geographic origin of individuals as shown in this example.

Genetic tools are equally capable of providing insight into plant and animal ancestry. The genetic relationship among European cattle breeds and the evidence of its Near-Eastern origin is a valuable information with respect to the neolithisation of Europe (Blott et al. 1998; Bradley et al. 1996; Troy et al. 2001). Currently suggestions have been made to focus trade routes and breeding patterns of cattle within Europe by means of mtDNA analyses (Herrmann et al. 2002).

Moreover sets of DNA-sequences of the Y-chromosome (so called haplotypes) that are inherited jointly through paternal lines have turned out to be also informative with respect to geographic origin of the bearer. Databases are built up currently by forensic scientists to locate ancestry of individuals (see: http://ystr.charite.de/ index_mkl.html; http://www.reliagene.com/ ) and Fig. 2. In conclusion DNA features indicate too the geographical origin or relation of organisms.

\subsection{The study of provenance of artefacts}

The fact of unequal distribution of chemical elements and isotopes in soils and ground is also the basis for archaeometric analyses to discover the provenance of artefacts. The types of analyses outlined above can be extended to isotopic and trace element profiles of metals, such as copper of Arad (Hauptmann et al. 1999), mediterranean pottery (Mommsen 2003) and even stones, as the marble stones of Didyma, Milet (Borg \& Borg 2003) that were brought in from the whole Aegean.

Moreover, as was mentioned above, artefacts made of biomaterials or biological remains can also be analysed by means of molecular biology (for examples see (2) above). Those approaches do not only provide insight into genetic features of the materials. Here again information on soil and space related features can be derived and transformed into insight into complex human action and interaction, such as trade routes and patterns of colonisation. 


\subsection{Soils and biological hazards}

Clinal $^{350}$ geographic distributions of "soil"-features bear not only the potential to foster human spreading but also for reducing quality of life or even to endanger the living. They hereby become one determinant for human colonisation, such as latitude and altitude, although it might be generally difficult to recognise and discriminate the direct influence of features of the soil s.str.

Natural scarcity or absence of trace elements is as well decisive for the health status of a population. I arbitrarily mention only two of them. Keshan disease is caused by selenium (Se) deficiency in Keshan and other Chinese soils (Fang et al. 2003), it causes severe disturbances in cardio-vascular systems and pregnancy. Endemic goiter is caused by the absence of iodine (I), that can ultimately lead into mental retardation. There are numerous diseases caused by element deficiency, which are widely discussed in medicine, nutrition science, and medical geology. However, sufficient bioavailability of these elements is depending primarily on their availability in soils on which cash crops and fodder plants are grown and animals are breed on.

Moreover, some inherited diseases show a clear geographical distribution. They might be concentrated geographically due to specific marital behavior (e.g. endogamy, first cousin marriages). But some are not. They can be related to vector transmitted disease, against which they may provide a certain resilience, for instance sickle cell anemia against malaria. As the ecology of the transmitting mosquito depend on environmental features, including suitable slops for the development of the larva, also soil conditions have impact. This impact might be more obvious, if the "natural factors" as mosquito and the inherited disease are combined with some "cultural factors." A certain resistance against malaria can be gained also by another inherited metabolic disease, glucose-6-phosphate dehydrogenase deficiency (G-6-PD). The resistance seems to be improved by simultaneous consumption of fava beans (vicia fava), but may lead to fatal results of affected persons as in cases of "favisms." Therefore a strict consuming regime for beans has to be kept, that is associated with climax activities and mating seasons of the mosquito. Fava beans are cash crops produced by horticulture, but also on larger plots. G-6-PD is mostly known for the Mediterranean and West Africa. Interestingly enough its Mediterranean occurrence corresponds roughly to the extension of the Roman Empire, from which time the use of fava beans is common in those parts of Europe and the Mediterranean until nowadays. It is important to know that variants of malaria existed even in river valleys and swampy areas north of the Alps. Therefore the consumption of fava beans was likely the suitable strategy here too, as fava beans were introduced during the Roman occupation. Although not well understood this is a remarkable example for the interconnectedness of "natural" and "cultural" features and their coevolution.

350 derivation from "clines" = gradients of features in space 
For important and selective infectious diseases in terms of population history that are related also to soil features or at least geographical variation in ground composition see numerous maps and provided information by the World Health Organisation (http://www.who.int/globalatlas/). It is evident that parasite eggs can survive in soils and infect people who work in orchards or consume uncleaned root vegetables. Also pathogens that cause severe infectious diseases can survive in soils and may infect people who touch the dirt, as e.g. holds true for poliomyelitis, anthrax, and tetanus. Finally, it is likely that pathogens of zoonoses from free ranging or breed animals are transmitted to humans by dirt contact or inhaled soil dust.

As these few examples of this chapter illustrate, soil is or can become a hazardous medium. Cultural practices may enhance unintentionally or reduce deliberately its dangerous potentials.

\section{Part III}

\section{Soil related concepts, determinisms, and reifications}

\subsection{Ancestry, genealogy, and kinship.}

My further consideration is based on the European and Jewish-Christian centred view, as outlined above. However, there can be no doubt that underlying initials of this perception of "inheritance" are and were independently present also in other cultures or cultural areas. I assume the intuitive understanding of the relation between soil and fertility in any horticulturalist or agrarian society, presumably even prior in gatherer societies.

The genetic concepts of the Old Testament ${ }^{351}$ are those of the stockbreeders and pastoralists who think in terms of blood relatives, and blood replacement, as blood is the essential quality and the seat of life. Therefore blood became the agent and substrate of inheritance, and any empirical based genetic theory before the scientific discovery of genetic materials depends (at least somehow) on the explanation value of "blood." 352 In addition, the belief in influence of environmentally mediated features on the physical appearance of offspring was usually also taken for granted. This is illustrated by Jacob's arrangement, but remained the prevailing "scientific" theory almost until the end of the $19^{\text {th }}$ century, even in natural science.

351 see applied genetic knowledge and superstition by which Jacob composed and enlarged his flocks (Gen 30, 25-43)

352 However, also semen and urine as bearer of soul features may be taken for magic practices with soil, e.g. the medieval idea of producing a homunculus. Here advice can be found that a successful sublimation of a homunculus is fostered by the use of soil from underneath gallows, because it contains the humoral effluents from the executed, which are the bearers of life features. 
For example it was generally accepted that a birthmark of a child developed because the mother had looked into an open fire during pregnancy.

Concepts that take distinct environmental factors of being very influential for bodily appearance of humans are widespread and favoured in societal discourses for their ostensible and suggestive power of persuasion. Such concepts shaped for example studies on immigrant families to the USA by the renowned ethnologist Franz Boas (1858 - 1942). He dismissed preponderance of genetic influence in immigrant families and claimed that environmental factors after immigration into the USA lead to bodily changes already in first generation descendants. Boas thus became a principle witness for a liberal immigration policy. This demonstrates the impact of opinions about apparently empirical data on societal and policy decisions. Recently a reassessment of Boas' data has proven that his conclusions are not really supported from his data, that he overestimated observed differences, and drew scientifically not justified conclusions (Sparks 2001).

It is obvious that such opinions are and were related to or perhaps did even co-found the concepts of physiognomists. Of course similarity of people within a given geographic area is higher than between such areas, due to that the former have more genes in common. This obvious empirical experience influences the uneducated consciousness and assumes bodily features as emergence of geographic or "soil" features. Physiognomic concepts are amongst the most important and influential constructs in human social discrimination, and might be considered an anthropological constant.

Moreover, in practical coexistence human groups realise the existence of language boundaries, which are often related to geographic boundaries, geographic barriers as rivers, mountains, woods, deserts, seas, etc. are effective physical borders of marriage systems, whereas languages are social borders, although both systems do superimpose quite well. In any case genetic differences between two populations separated by geographic and/or linguistic borders will increase. There are numerous examples in history that despite any knowledge of the scientific rationals claims are made on territories by using arguments of ancestry. Within those conflicts usually those, who use "genetic" reasoning are usually in a better position and considered to have better arguments than those who argue on a cultural basis. Even in non scientific societies genealogy (that is applied knowledge of a genetic concept) is an important argument. It legitimates claims of authority, power, ownership, and responsibility (see e.g. Gen 1,5 and Num $2 \& 3$ for examples of genealogy applied genealogical knowledge).

Therefore these reifications lead directly into advice for social interactions. It makes discrimination possible between two human groups or even populations by arguments that refer directly or indirectly to spatial -, soil -, or blood - features, which become synonymous at least to a certain extent. And by that they implicitly evoke the idea of property by this combination. Especially the latter idea was dis- 
puted by Rousseau [1755 (1994)] $]^{353}$, when he stated: "The true founder of civil society was the first man who, having enclosed a piece of land, thought saying, 'This is mine', and came across people simple enough to believe him. How many crimes, wars, murders and how much misery and horror the human race might have been spared if someone had pulled up the stakes or filled in the ditch, and cried out to his fellows: 'Beware of listening to this charlatan. You are lost if you forget that the fruits of the earth belong to all and that the earth itself belongs to no one!" " (p.55).

In his theory on early civilisations Steward stressed the importance of energetic aspects. It was in fact not only the idea of energy control that could lead Steward (1949) to his formulation of the tier model of early civilisations. He could have done this not without a fallback on concepts of genealogy and property. Conquest which becomes in his opinion a common feature of developing nations is based on ideological constructs of property and genealogy that aims to conceal the actual aspects of sheer power and source control. Consequently Steward (1955) is within the cultural anthropologists first mentioned to discuss the influence of property behavior in terms of territoriality (see below).

Property in land evidently became for example an important character of societal development throughout the European medieval centuries, and later reallocation of land property in terms of its secularisation improved state-forming during the late Medieval and in Early Modern centuries.

Consequently and summing up, if "soil", as both the material and mythical prerequisite of ancestry, becomes linked with space and human societies, the following problems will raise from merging these apprehensions:

o "Space" is a self-evident feature of "soil"

o soil is mythically tied to ancestry and kinship ${ }^{354}$

o genealogy and kinship is the basic rational in self recognition of human populations in different given spatial areas.

It seems that no creationistic myth exist that do not link rather directly ancestry (genes) and soils (space). However, there are different ideas on access and availability to space in different cultures and systems of belief.

\subsection{Territoriality}

Territoriality was defined by Sack (1986: 19) as the attempt by an individual or group to affect, influence, or control people, phenomena, and relationships, by delimiting and asserting control over a geographic area. This area is called territory.

\footnotetext{
${ }^{353}$ I do not misunderstand the principal direction of Rousseau's essay as a criticism of the absolutistic society and state. But he definitely brings in the idea that land should be classified as a common property.

354 an argument even recently used during ethnic clearance in the Balkan war: "Where the soil covers Serbian bones, there is Serbian land".
} 
The praxeologic and decisive motif is interest. Evolutionary biologists have adapted economic theories to describe the behavior of territorial animals, including territorial primates and man, in terms of costs and benefits. These impact on the individual's ability to survive and reproduce successfully. Considering abundance of sources in a given area their defence may be beneficial for the individual or the society and may lead to exclusion of others from using the source. Territorial behavior should be awarded by numbers of offspring. Although such sociobiological functionalisation almost always excludes the specific of cultural evolution, territorial behavior in man may be described according to cost-benefit analyses. Behavior should be adaptive, but for whom in complex human cultures? Territoriality for humans may be a powerful geographic strategy to control people - sometimes, but sometimes cost-benefit considerations may suggest alternative strategies. In terms of ecological behavior human societies are generally thought to be less territorial in areas of resource scarcity, while benefits in defending abundant source materials exceed their costs and thus may lead to territorial behavior. Cultural ecological explanations of spatial organization within anthropology have tended to ignore the possibilities of winners and losers, even when considering behavior such as warfare. Anthropologists and sociologists concerned with conflicts of interests, on the other hand, have tended to focus on conflicts between classes or other social units, assuming a homogeneity of interests within these units, as was criticised by Cashdan (1992: 266). Evolutionary biology at least contributes the insight that flexible and alternative strategies do not contradict the reachability of ultimate goals: for example to become and stay the owner of a territory for a very long time. Contrary to Rousseau's moralistic opinion freeholders may be considered being part of a natural behavior (territoriality). However, this should not to be mistaken for a moral verdict over this behavior, as this is judged only within every respective society.

Now we have achieved two essentials that merge often in human cultures: uneducated concepts of genetics, genealogy, and ancestry and concepts of territoriality.

\subsection{Geographic determinism, blood and soil}

Jean-Pierre Purry, born in 1675, a later employee of the Dutch East India Company, came up with the idea, that countries located between 30 and 36 degrees of latitude "far surpass the others in fertility, as one can see even in the land of Canaan, of whose provinces Galilee is one of the finest." Purry tried to convince the East India Company to send immigrants to those areas and get them supported by slave labour (Ginzburg 2003). He died 1735 in the city of Purysburg, South Carolina, that he had founded. His idea of latitude and fertility is remarkable in its basic rational, that claims that there are areas in the world that are more productive than others. Of course, this is part of the physiocratic view, as was emphasised by Adam Smith and others. But, Purry is a Calvinistic fundamentalist, whose economic Prot- 
estantism is even amplified by his Dutch adventure. His perception anticipates a conducting overall concept of "productivity" that turns into a decisive episteme, as it becomes a general perception on humans, the society and the world as a whole in those days (Burkhardt 1974). It is the 18th century that consolidates definitely ideas of inferiority and superiority in terms of "productivity" with respect to nature (great chain of beings) as well as to societal issues (emergence of the "third class") as to the European special course, 355 sometimes quoted as the "European miracle" (Jones 1987). Productivity (of what so ever) becomes a key issue, and it is just the "superior" outcome of "competition."

Within the second half of the $19^{\text {th }}$ century the Darwinian theory of organismic evolution became also appealing for attempts to explain differences in societal organisations of nations and cultures. Links were drawn between geographic features as climate, soil, and topography and human populations. It was assumed that biological (racial, genetic) differences were decisive for human societal achievements and that these "natural prerequisites" were responsible for the observable differences in civilisations. This view at least disregarded the importance of cultural concepts and praxeology within human societies, and Friedrich Ratzel (1846-1911) is usually referred to as being the founder of this "geographic determinism." The concept has been very influential in nationalistic discourses during the beginning of the $20^{\text {th }}$ century and were promoted amongst others by influential philosophers (e.g. Oswald Spengler) and geographers (e.g. Ellsworth Huntington). The natural fallacy of this concept lies in the misunderstanding of cultures, nations, and states as being equal to organisms, and thus being subjects to the principles of natural selection. Furthermore, as Braudel (1949/1994) emphasised, the geographic milieu can be considered a strong determinant, but more decisive are continued human efforts, the "human milieu," as Braudel says, to cope with those geographic limitations and perhaps to overcome them. His argument is about the design of a new and most successful ship in the Mediaeval, the cog, that cannot be explained in terms of determinism, as of course holds true for almost any invention.

It is interesting that although geographic determinism has been outdated, it survived to some extent (e.g. Wittfogel, 1957), getting recently a popular renaissance by the work of Jared Diamond (1997). One may speculate, if the societal determinants that bring about again these ideas today, are similar to mentalities at the end of the $19^{\text {th }}$ century. Sort of geographic determinism is still also lively in contexts of present day environmental psychology, and is directly derived from the nationalistic concepts of Ratzel and others at the end of the $19^{\text {th }}$ century to early adaptations in psychology, as by Hellpach [1911 "Die geopsychischen Erscheinungen," later to become "Geopsyche” $\left.(1935 / 1977){ }^{356}\right]$. Hellpach's work is equivocal,

\footnotetext{
355 Cf. the "Europe's Special Course" - Project of the Breuninger Foundation, headed by RP Sieferle 356 the fifth edition was not printed due to paper shortage in 1941, but released in 1949, without revision of text and references (sic!). Editions 6 to 8 are unchanged reprints of the $5^{\text {th }}$ edition, that was enlarged only by one single post war endnote (p.255)
} 
not only because he contributed to the sorry efforts of De Rudder \& Linke (1940) and that of Von Eickstedt (1941), but also because of ontologic assignments rather than scientific deductions. This is amidst the time of a climax for the metaphoric use of "soil" in terms of political constructs and reifications in Germany.

It has to be remembered that since the late European $18^{\text {th }}$ century and enhanced by (German) Romanticism, pessimistic views on urban life arose throughout the $19^{\text {th }}$ century. This anti-urbanism was promoted by influential philosophers (e.g. Spengler) but even more by nationalistic movements in Europe of the first decades in the 20th century. Hellpach (1939), De Rudder \& Linke, and Von Eickstedt were influential scientists and promoted the anti-urban attitude. In combination with anti-industrial distrust, the Nazis formed an anti-urban and antitechnological ideology. The "Aryan race" was believed of being endangered by migration into cities. As a consequence the ideology propagated the return to an agrarian society, which is one of the backgrounds for "Volk ohne Raum" (nation without space), as agrarian production is an economy of scale in terms of space. As early as 1930 the chief-ideologist for Nazi agrarian affairs, RW Darré, ${ }^{357}$ outlined this concept of anti-urbanisms and tied it to "soil." Already in this speech Jews became insulted as perfectly adapted to city-life, while Germanic people were considered to be peasants by eternal (divine?) appointment. The racist concept of the Nazis was thus added another aggressive facet.

The phrase "blood and soil" became programmatic in Nazi ideology. Bramwell (1985) translated it in the shortest possible way: the "unity of race and land." Darré's adaptation of "blood and soil" was originally a demagogic phrase to transport and promote crude ideas of inheritance of estate (1930/1940), as he wanted to change titles of inheritance only to the eldest son, to prevent constant division of plots. ${ }^{358}$ Blood was his synonym for kin (1930/1940: 21).

Now everything fits together: geographic determinism, soil, rules of genetic and cultural inheritance, and racism. Although Darré was marginalised within the Nazi hierarchy at the beginning of World War II, his initiatives developed further within the ideology of the regime. The unity of race and land became the master plan for designing conquered areas, mostly in Eastern Europe. Setting up the "General Arrangement Plan East" (Generalplan Ost) advice was included for land

\footnotetext{
357 in fact, Darré drew back on much earlier ideas such as those of Bartels (see Fuller 1996). Besides the monograph of Bramwell (1985) that of Eidenbenz (1993) is the most instructive political analysis of this subject.

358 „Wenn schon [.] die Frage gestellt wird nach der Beziehung des Volkes zu seinem Boden, so sind wir damit doch noch weit entfernt von dem Sinn der Einheit von „Blut und Boden,“ die den Kraftquell der nationalsozialistischen Bewegung und die Grundlage unseres Staates bildet. Denn Blut und Boden stehen nicht nur beide als Voraussetzungen unseres Staates in einem äußeren Zusammenhang, sondern bilden nach der germanischen Weltanschauung als Sippe und Hof sich gegenseitig erhaltende Glieder einer zeitlos dauernden rechtlichen Einheit.“ RW Darré (1936), Blut und Boden. In: Grundlagen, Aufbau und Wirtschaftsordnung des nationalsozialistischen Staates, Vol 1, Part 1, No 3, p 2. Industrieverlag Spaeth \& Linde, Berlin
} 
reclamation and governance (Meyer 1941), which defined "Aufbauelemente einer deutschen Heimatlandschaft" (elements of development of a German home-land;

See Fig.s $3 \& 4$. The specific modelling of the landscape was finally not realised because of the German surrender.

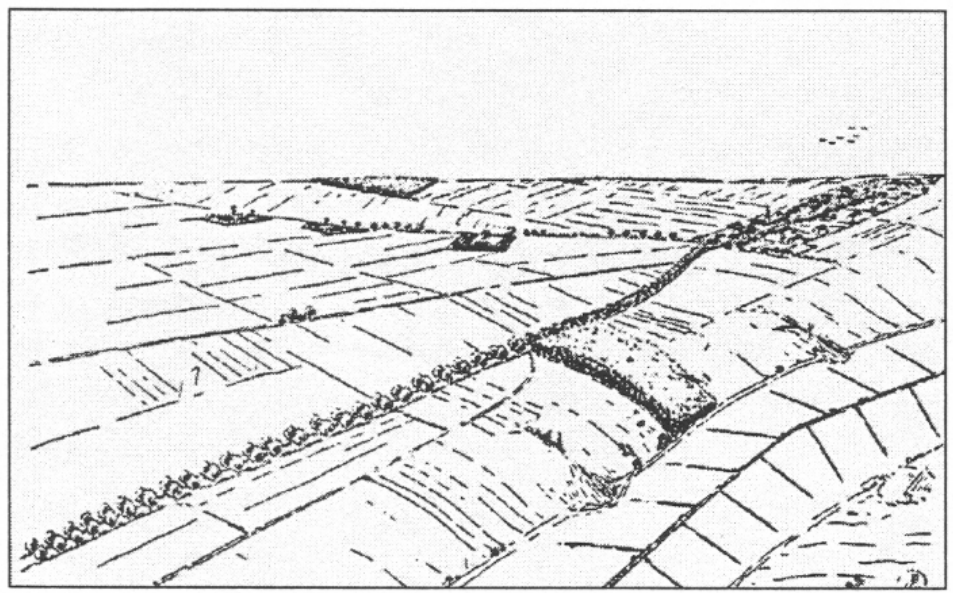

Fig. 3 From Junge (1941: 306).The caption states: unshaped "cultural steppe" (Kultursteppe), following only principles of agrarian use for the benefit of each single farm, as was purported for Eastern Europe landscapes by Nazi planners. Almost no woods and shrubs, relinquished to impacts of climatic disturbances (wind, frost etc.), ineffective use of soil productivity.

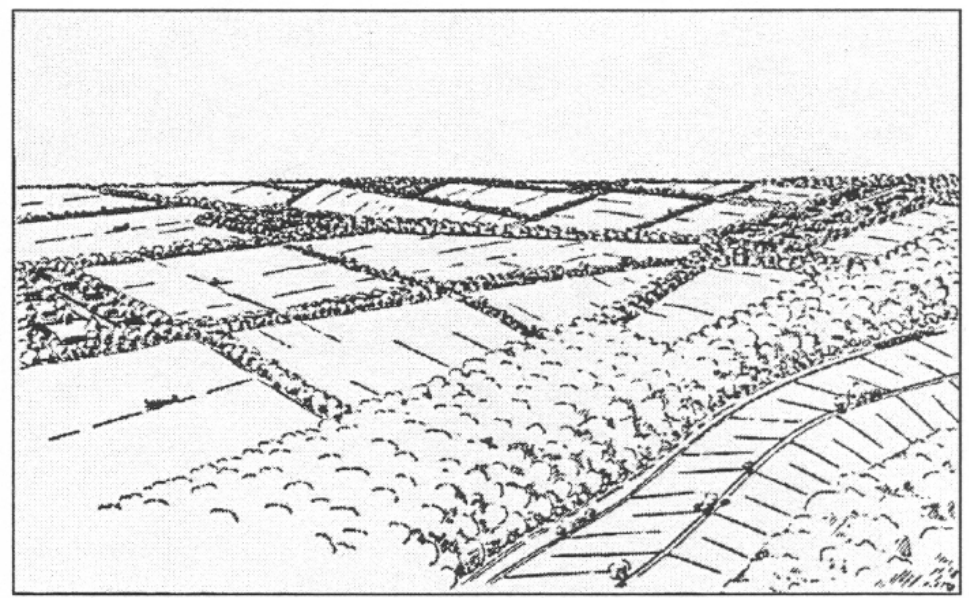

Fig. 4 From Junge (1941: 307). The caption states: designed German cultivated landscape of the future. Mistakes of the cultural steppe removed, diminished wind erosion by hedges, 
positive effects on microclimate and improvement of productivity. Increased cultural and economic success by sophisticated spatial patterning of villages, roads hidden by tree rows against birds view of enemy aircraft fighters.

\subsection{Landscapes}

Soil is transformed by human action into landscapes, primarily by driving forces of working the soil and by concepts of productivity. Cultivated landscapes may therefore be considered as being the most complex expression of the grand total of production and reproduction derived from human action. But landscapes exist not only through human action but also by human perception which transforms a scenery into a landscape. Both types of transformation rely on concepts of colonisation or exploitation of "nature."

The process of colonisation produces necessarily specific genetic entities: domesticated plants and animals, as well as "self-domesticated" humans. Processes underlying and governing the patterns of reproduction are cultural (in terms of breeding and marital concepts). Working the soil, tilling the field, protecting the woods, planting hedges, breeding the animals, moderating a hydraulic system: all agrarian societies end up with a specific landscape. Finally, landscapes exhibit a "physiognomy" as specific as that of humans. The natural fallacy is to mistake any genetic result associated with the specific landscape as for those of Darwinian selection. Landscapes, and everything in them are nothing short of cultural products.

Landscapes are the most complex non-technical environmental structures in the world produced by human impact. They are physically objectifications of long term experiments under natural conditions. Thus it seems impossible to me to consider landscapes as palimpsests. One may write a completely new text in a different language on a parchment, but alterations of soil from earlier activities will add to or take from the quality of soils. Mistakes may end up with problems for future generations (e.g. erosion, salinization; acidification). Therefore, long lasting effects in terms of longue durée, ${ }^{359}$ hold specifically true for soils and soil coined landscapes. However, as "constant" as a landscape might be, for example Tuscany has not much altered its physiognomy since the days of the Roman Empire, all what is in this landscape, regardless animate or inanimate, has changed through time. The genetic composition of humans, plants, and animals are continuously altered, even without reasonable input from other regions. Since cultural meanings are also altered during time, the apparent constancy of landscapes support human self recognition about and human pretension of "constancy." In this way landscapes keep the natural fallacies of constancy and determinism alive.

\footnotetext{
359 more in the meaning of long lasting effects instead of cyclic appearance of the structural phenomena, but turning soil into arable land that had been used by humans before may also be considered a phenomenon of longue durée, let alone slash-and-burn cultures, abandoning of fields after warfare and their re-cultivation etc.
} 
The phrase "places of moments" includes specifically emotional bonds to "soil." Many people, who went abroad or became displaced, express a deep desire to be buried in home soil. They express a desire for "return," for getting back "to the roots." Virtually the latter term ties people to the soil, and it should not be overlooked that the metaphoric background literally borrrows its semiotic cipher from plants rooted in the soil. As any of the countless examples in literature and poetry, Walt Whitman offered a formula for these emotional bondings in his "Song of Myself:"

I lean and loaf at my ease observing a spear of summer grass.

My tongue, every atom of my blood, form'd from this soil, this air,

Born here of parents born here from parents the same, and their

parents the same,

I, now thirty-seven years old in perfect health begin,

Hoping to cease not till death.

Of course, Whitman is not talking about "soil" in its physical meaning, but as being an essential element also of the world metaphysically experienced by humans and their kin. He is talking about the soils and the landscapes to be found in mental maps of human cultures.

\section{Acknowledgement}

This paper owes its beginning to the "World Environmental History Conference" on Wasan Island, CDN, in 2003. My thanks go to the Breuninger Foundation, Stuttgart (FRG), for making my participation in the conference possible. The efforts of the conference organisers, Verena Winiwarter and John McNeill, are also gratefully acknowledged, as well as discussions with the other participants, who all provided helpful advice in shaping my contribution. Final copy editing by V.W. and J.McN. is also gratefully acknowledged. I owe special thanks to an anonymous reviewer, whose remarks and objections stimulated my reflections and helped to clarify a few points. 


\section{References}

Ambrose SH (1993) Isotopic analysis of paleodiets: methodological and interpretive considerations. In: M Sandford (ed) Investigations of ancient human tissues. Gordon \& Breach, USA etc. pp 59- 130

Blott SC, Williams JL, Haley CS (1998) Genetic relationship among European cattle breeds. Anim Genet 29: 273 - 282

Borg, B.E. \& Borg, G. (2003) The history of Apollo's temple at Didyma, as told by isotopes, petrology, and historical sources. . In: L. Lazzarini (Ed.) Interdisciplinary Studies on Ancient Stone -ASMOSIA VI, 271-278, Bottega D'Erasmo, Padova.

Bowcock AM, Ruiz-Linares A, Tomfohrde J, Minch E, Kidd JR, Cavalli-Sforza LL (1994) High resolution of human evolutionary trees with polymorphic microsatellites. Nature 386: $455-457$

Bramwell A (1985) Blood and Soil. Richard Walther Darré and Hitler's green party. Kensal Press, Bourne End

Braudel F (1949) La méditerranée et le monde méditerranéen à l'époque de Philippe II. Armand Colin, Paris (quoted after the German translation of the last chapter: “Geohistoire und geographischer Determinismus" In: P Middell (ed) (1994) Alles Gewordene hat Geschichte. Die Schule der ANNALES in ihren Texten. Reclam Verlag, Leipzig. pp 233-246

Browman DL, Gundersen JN (1993) Altiplano comestible earths: prehistoric and historic geophagy of highland Peru and Bolivia. Geoarchaeology 8(5): 413-425

Bradley DG, MacHugh DE, Cunningham P, Loftus RT (1996) Mitochondrial diversity and the origins of African and European cattle. Proc Ntl Acad Sci USA 93: 5131-5135

Burkhardt J (1974) Das Verhaltensleitbild "Produktivität" und seine historischanthropologische Voraussetzung. Saeculum 25: 277-289

Cann RL, Stoneking M, Wilson AC (1987) Mitochondrial DNA and human evolution. Nature 325: 31-36

Cashdan E (1992) Spatial organization and habitat use. In: EA Smith \& B Winterhalder, Evolutionary ecology and human behavior. Aldine De Gruyter, New York. pp 237-266

Darré RW (1930/1940) Blut und Boden als Lebensgrundlage der nordischen Rasse (address to the Nordische Tagung, Berlin , 22.6.1930) In: RW Darré (1940) Um Blut und Boden. Reden und Aufsätze. Etd by H Deetjen \& W Clauß. Zentralverlag der NSDAP, Franz Eher Nachf., München. pp 17-29

De Knijff P, Kayser M, Caglia A, Corach D, Fretwell N, Gehring C, Graziosi G (1997) Chromosome y microsatellites: population genetic and evolutionary aspects. Int J Legal Med. 110(3): 134-149 
Diamond J (1997) Guns, germs, and steel: the fates of human societies. Norton, New York

Von Eickstedt E (ed)(1941) Bevölkerungsbiologie der Großstadt. Der Stadt Breslau zur Siebenhundertjahrfeier ihres Wiederaufbaus nach dem Mongolensturm gewidmet. Ferdinand Enke, Stuttgart

Eidenbenz M (1993) „Blut und Boden“ Zu Funktion und Genese der Metaphern des Agrarismus und Biologismus in der nationalsozialistischen Bauernpropaganda R.W. Darrés. Peter Lang Verlag, Bern etc.

Elton CS (1958) The ecology of invasions by animals and plants. Methuen, London

Engels F in: Marx K, Engels F (1962) Werke. Dietz Verlag, Berlin. vol.20: Engels F [1876] Anteil der Arbeit an der Menschwerdung des Affen. vol.20: 444-455

Fabig A, Herrmann B (2002) Trace elements buried in human bones: intra-population variability of $\mathrm{Sr} / \mathrm{Ca}$ and $\mathrm{Ba} / \mathrm{Ca}$ ratios - diet or diagenesis? Naturwissenschaften 89 : 115-119

Fang W, Wu P, Hu R, Huang Z (2003) Environmental Se-Mo-B deficiency and its possible effects on crops and Keshan-Beck disease (KBD) in the Chousang area, Yao County, Shaanxi Province, China. Environ Geochem Health 25: 267-80

Frazer J G (1907-)The golden bough: a study in magic and religion. London [etc.], Macmillan [etc.]

Fuller SN (1996) The Nazis` literary grandfather. Adolf Bartels and cultural extremism, 1871-1945. Peter Lang Verlag, New York etc.

Ginzburg C (1980) Die Benedanti: Feldkulte und Hexenwesen im 16. und 17.Jahrhundert. Frankfurt a.M., Syndikat.[I benandanti. Stregoneria e culti agrari tra Cinquecento e Seicento. G. Einaudi, Torino,1972.]

Ginzburg C (2002) Der Käse und die Würmer. [5 $5^{\text {th }}$ German edition of Ginzburg C (1976) Il formaggio e i vermi. Il cosmo di un mugnaio ‘500. Giulio Enaudi Edit.,Torino]

Ginzburg C (2003) Latitude, slaves and the Bible. Talk presented to the Tutkijakollegium, Finland, on April 10 ${ }^{\text {th }}$ 2003. (http://www.video.helsinki.fi/mediaarkisto/tutkijakollegium.htm; Finnish pages)

Grupe G, Price T D, Söllner F (1999) Mobility of Bell Beaker people revealed by Strontium isotope ratios of tooth and bone: a study of southern Bavarian skeletal remains. Applied Geochemistry 14: 271-275

Gurjewitsch A (1986) Mittelalterliche Volkskultur. Verlag der Kunst, Dresden [Проблемы срдиевековой народни културы, Москва 1981]

Hauptmann A, Begemann F, Schmitt-Strecker S (1999) Copper objects from Arad - Their composition and provenance. Bull American Schools of Oriental Research 314: 1-17

Hellpach W (1939) Mensch und Volk der Großstadt. Ferdinand Enke, Stuttgart

Hellpach W (1977) Geopsyche, die Menschenseele unter dem Einfluß von Wetter und Klima, Boden und Landschaft. Ferdinand Enke, Stuttgart ( $4^{\text {th }}$ German ed $1935,8^{\text {th }}$ and last German ed 1977) 
Herrmann B, Schmidt D, Hummel S (2002) Estimating provenance by biological tools. Atti del II Congresso Nazionale Di Archeometria, Bologna, 29 gennaio-1 febbraio 2002, a cura di C D’Amico, 307 - 311, Patron Editore, Bologna

Hölzl S, Horn P, Rossmann A, Rummel S (2004) Isotope-abundance ratios of light (bio) and heavy (geo) elements in biogenic tissues: methods and applications. Annal Bioanal Chem 378: 270-272

Hummel S (2003) Ancient DNA typing. Methods, strategies, and applications. Springer, Berlin etc.

Hutchinson DL \& Norr L (1993) Late prehistoric and early historic diet in Gulf Coast Florida. In: CS Larsen \& GR Milner (eds) In the wake of contact. Biological responses to conquest. Wiley-Liss, New York etc., pp 9-20

Jones EL (1987) The European miracle. Environments, economics, and geopolitics in the history of Europe and Asia. Cambridge Univ Press, Cambridge

Junge W (1941) Aufbauelemente einer deutschen Heimatlandschaft. In: K Meyer (ed)(1941) Landvolk im Werden. Material zum ländlichen Aufbau in den neuen Ostgebieten und zur Gestaltung des dörflichen Lebens. Deutsche Landbuchhandlung, Berlin. pp 303-310

Loraux N (1990) Les enfants d'Athéna, Paris [ Laroux N (1993) The Children of Athena: Athenian Ideas about Citizenship and the Division between the Sexes. Princeton, Princeton University Press]

Lovelock J (2000) Gaia: a new look at life on earth. Oxford University Press

Meyer K (ed)(1941) Landvolk im Werden. Material zum ländlichen Aufbau in den neuen Ostgebieten und zur Gestaltung des dörflichen Lebens. Deutsche Landbuchhandlung, Berlin

Mommsen H (2003) Attic pottery production, imports, and exports during the Mycenaean period by neutron activation analysis. Mediterranean Archaeology and Archaeometry 3: $13-30$

Patzel N (2003) Bodenwissenschaften und das Unbewußte. PhD Thesis No. 14870, ETH Zürich. Microfiche

Reilly C, Henry J (2000) Geophagia: why do humans consume soil? Nutrition Bulletin 25: 141-145

De Rudder D, Linke F (1940) Biologie der Großstadt. Theodor Steinkopff, Dresden and Leipzig

Rousseau JJ (1994)Discourse on the origin of inequality [Discours sur l'origine et les fondements de l'inégalité parmi les hommes, 1755], Translated by F Philip, Introduction by P Coleman. The World's Classics, Oxford Univ Press

Sack RD (1986) Human territoriality. Its theory and history. Cambridge Univ Press, Cambridge

Sandford M (ed)(1993) Investigations of ancient human tissue. Gordon \& Breach, USA etc. 
Schmidt H-L (2003) Fundamentals and systematics of the non-statistical distributions of isotopes in natural compounds. Naturwissenschaften 90: 537-552

Schoeninger MJ, DeNiro MJ, Tauber H (1983) Stable nitrogen isotope ratios of bone collagen reflect marine and terrestrial components of prehistoric human diet. Science 220: $1381-1383$

Schutowski H, Hansen B, Warmuth M, Herrmann B (2001) Signatures of stable strontium (Sr) isotopes in human hard tissue. Utilisation in osteological identification. In: Oehmichen M, Geserick G (eds.) Osteological identification and estimation of age. Research in Legal Medicine 26: 31-40

Schutkowski H, Herrmann B, Wiedemann F, Bocherens H, Grupe G (1999) Diet, status and decomposition at Weingarten: Trace element and isotope analyses on early mediaeval skeletal material. J Arch Sci 26: 675-685

Serres M (1985) Les cinq sens. Philosophie des corps mêlés. Edition Grasset et Fasquelle, Paris

Sparks CS (2001) Reassessment of cranial plasticity in man: a modern critique of changes in bodily form of descendants of immigrants. Masters Thesis (MA) University of Knoxville (http://etd.utk.edu/2001/SparksCorey.pdf)

Troy CS, MacHughes DE, Bailey JF, Magee DA, Loftus RT, Cunningham P, Chamberlain AT, Sykes BC, Bradley DG (2001) Genetic evidence for Near-Eastern origins of European cattle. Nature 410: 1088-1091

Steward J (1949) Cultural causality and law: a trial formulation of the development of early civilizations. American Anthropologist 51: 1-27

Steward J (1955) Theory of culture change. Univ of Illinois Press, Urbana

Wittfogel KA (1957) Oriental despotism; a comparative study of total power. Yale University Press, New Haven

Vernesi C, Di Benedetto G, Caramelli D, Secchieri E, Simoni L, Katti E, Malaspina P, Novelletto A, Terribile Wiel Marin V, Barbujani G (2001) Genetic characterization of the body attributed to the evangelist Luke. Proc Natl Acad Sci USA 98(23): 1346013463

Zlateva B, Kuleff I (2003) On the Possibilities for Determination of the Paleodiet by the Chemical Analysis of Archaeological Bones. Archaeologia Bulgarica 7,2: 1 - 23 



\title{
Empirische Zugänge zu historischen Biodiversitäts- verdrängungen und Biodiversitätslenkungen: Die Beispiele Melioration und Schädlingsbekämpfung
}

\author{
Bernd Hermann 360
}

Selbstbewusst hatte sich der Tübinger Workshop einem grundsätzlichen Thema zugewandt: „Umweltverhalten in Geschichte und Gegenwart: Vergleichende Ansätze aus Geistes- und Naturwissenschaften“. Das Problem steckt im „Umweltverhalten“, und natürlich ist von demjenigen „des Menschen“ die Rede. Dessen Umweltverhalten ist als ontologische Kategorie selbstverständlich zunächst von derselben Qualität wie das des Bibers, des Bären oder der Blindschleiche. Jede Art deckt erst einmal ihre Lebensansprüche. Sähen wir für den Menschen eine andere Qualität des Umweltverhaltens, wobei einzuräumen ist, dass dies häufig geschieht, dann wird damit eine „Umwelt“ konstruiert, die spezifisch für den Menschen zu sein scheint. Es ist eine Umwelt, aus der er auch bedarfsweise heraus- oder hineingedacht wird, um so zu tun, als sei die Welt ohne den Menschen oder bestenfalls mit Menschen mit Pfeil und Bogen und Grabstock eine irgendwie „eigentliche Welt und Natur“. In der spezifisch menschlich geprägten Umwelt ist die „Natur-

360 Zuerst erschienen in: Thomas Knopf (Hrsg.) Umweltverhalten in Geschichte und Gegenwart. Vergleichende Ansätze. Attempo Verlag, Tübingen 2008, S. 174 - 192 
macht Mensch“361 ihrer möglichen Folgen wegen gefürchtet. Nun ist es m.E. zwar unglücklich, einen weiteren cartesischen Dualismus zu behaupten, aber das Begriffspaar „Mensch und Umwelt" besteht nun einmal und muss auch als Ursache vieler tiefschürfender Erörterungen herhalten, obwohl sich viele Probleme in Wahrheit erst diesem Dualismus verdanken. ${ }^{362}$

Die Rückkoppelungen zwischen „Umwelt“ und „Mensch“ sind wechselseitig, und obwohl eine Unterscheidung von „Umwelt“ und „Mensch“ im Prinzip dysfunktional und erkenntnistheoretisch problematisch ist, lasse ich mich im Interesse des Tübinger Projektes auf diesen Kontrast ein ${ }^{363}$ (möglicherweise handelt es sich im oben angesprochenen Sinne sogar um eine Opposition). Darüber hinaus halte ich das bezeichnete „Umweltverhalten“, sei es in historischer oder aktualistischer Perspektive, für analytisch zugänglich nur in der Transdisziplinärität. Es wird damit zu einem Thema, das die Grenzziehung zwischen den Natur- und Geisteswissenschaften überwinden müsste und könnte, statt die Grenze zum Thema zu machen.

Nun bestehen die erwähnten Rückkoppelungen nicht nur diskursiv, konstruktivistisch oder als ontologische Zuweisung. Ihre Ergebnisse sind auch physisch real. Wer über das Reale redet, redet zu allererst über Dinge. Meine Betrachtung nimmt also ihren Ausgang von realen Dingen der Umwelt, denen ich mit den Mitteln der Umweltgeschichte nachgehen werde. Am Ende wird sich noch jede Annäherung an das Rahmenthema auch deshalb auf konkrete Sachverhalte beziehen müssen, um hinter der alltagsgeschichtlichen Handlung bzw. hinter dem mikrohistorischen Beispiel den Ausdruck des Strukturellen zu erkennen und freizulegen, um den es schließlich geht. Ihre Freilegung mit den Mitteln der umwelthistorischen Analyse veranschaulicht die transdisziplinäre Arbeitsweise, der sich auch die Tübinger Tagung verpflichtet fühlte. Mir dienen hierfür zwei Beispiele aus dem 18. Jh.: Den Meliorationen, also den planvollen Umgestaltungen von Landschaften, liegen, ebenso wie den Schädlingsbekämpfungen, Werturteile zugrunde. Sie bringen Naturleitbilder hervor und sind dabei selbst Produkte von Naturleitbildern. Auf jeden Fall sind sie Beispiele explizit fassbaren Umweltverhaltens. Dar-

\footnotetext{
361 „Die Arbeit ist zunächst ein Prozeß zwischen Mensch und Natur, ein Prozeß, worin der Mensch seinen Stoffwechsel mit der Natur durch seine eigne Tat vermittelt, regelt und kontrolliert. Er tritt dem Naturstoff selbst als eine Naturmacht gegenüber.“ Marx, Kapital, S. 192

362 Eine grundsätzliche Großalternative zur Deutung des „herausgehobenen Menschen“ ist seit langem von Catton \& Dunlop, 1980, formuliert.

363 „Umwelt“ ist, hier schließe ich in einem erweiterten Sinne an die Entdeckung der „Umwelt“ durch von Uexküll (1921) an, die vom Menschen durch Handeln und Wahrnehmen transformierte „Natur“. Also schließt „Umwelt“ den „Menschen“ mit ein, sie ist ohne ihn nicht denkbar, sondern ja erst durch ihn existent, und es gibt im Prinzip für den Menschen keine andere Umwelt als die menschliche. Die Formel „Mensch und Umwelt“ ist daher epistemologisch eigentlich ein Kategorienfehler im Sinne von Ryle (2002). Als rhetorischer Begriff und Mittel des „Marktgeschreis“ (Peter Burke) ist der Ausdruck „Mensch und Umwelt“ allerdings so etabliert, dass ein Feldzug gegen ihn lächerlich wäre. Deshalb genügt es, an dieser Stelle lediglich auf seinen zweifelhaften Bedeutungsinhalt hinzuweisen. Sein umgangssprachlicher, phrasenhafter Gebrauch bedroht schließlich nicht das Abendland, sondern nur viele kleine alltägliche Nachlässigkeiten der umwelthistorischen Diskurse.
} 
über hinaus sind sie miteinander in ihrer Wirkung auf die Biodiversität ${ }^{364}$ verbunden. Änderungen der Biodiversität stellen für die umwelthistorische Forschung insofern ein ziemliches Problem dar, weil hinreichende Angaben über Arten- und Individuenabundanzen und über Biotopänderungen zu den jeweils interessierenden historischen Zeitfenstern weitestgehend fehlen. Das Biodiversitätsspektrum ist quellenmäßig nur indirekt und in seiner zeitlichen Tiefe damit besonders schwer zugänglich. Analysen von Meliorationsvorhaben und von Schädlingsbekämpfungen können daher hilfreiche Einblicke in historische Biodiversitätszustände geben.

\section{1 „Biodiversitäts verdrängung und „Biodiversitätslenkung als historische Bedingungen und Folgen}

Mit „Biodiversitätsverdrängung“ ist eine Folge menschlicher Wirtschaftsweise bezeichnet, bei der es durch bloßen Aufenthalt von Menschen bzw. eine präferentielle Nutzung von Tieren oder Pflanzen in einem Lebensraum zu einer Bestandsverminderung bzw. zu einer Änderung des Landschaftsbildes kommt, ohne dass die Menschen diesen Zustand herbeizuführen beabsichtigt hätten. ${ }^{365}$ Wer Kühe in die Flussaue stellt, bringt z.B. zwangsläufig eine Parklandschaft hervor, ohne sie planen zu müssen. Die Veränderung der Landschaft führte in Mitteleuropa zu

\footnotetext{
364 Über den problematischen Inhalt des Biodiversitätsbegriffs habe ich mich an anderer Stelle geäuBert (Herrmann, 2006a) Ich verwende ihn aus dort ausgeführten Begründungen innerhalb des Aufsatzes hier ausschließlich in der Bedeutung von „Artenvielfalt und Vielfalt der Lebensräume“

365 Würde der Mensch ein Leben führen, wie es die anderen Tiere tun, so würde er nur abernten, was der Lebensraum zur Verfügung stellt. Es käme zu keiner (wirklich spürbaren) Änderung des Lebensraumes, weil letztlich kein Verbrauch vorläge. Erst die menschliche Maßlosigkeit, sein unstillbares ,desire for gain“ (Hume) führe in die heutige Umweltproblematik, die gekennzeichnet sei von einer Zerstörung der Umwelt.

Dies ist die häufig eingenommene Grundthese zur Ableitung von Einschränkungs- oder Bescheidungspostulaten, die selbst als pragmatische Setzungen ziemlich problematisch sind. Denn auch so unscheinbare Tierchen wie z.B. die Korallen oder Schwämme oder zarte Pflanzen wie die Gräser haben es am Ende geschafft, das Erdantlitz wirkmächtig zu prägen. Man kann auch sagen, vorherige Umwelten zu zerstören. Jede neue, numerisch erfolgreiche Organismengruppe hat bisher die Umwelt nachhaltig verändert, z.T. in erheblichem Maßstab, am tiefstgreifenden mit der Entstehung der Photosynthese und dadurch der Sauerstoffatmosphäre. Trotz dieser Beispiele vor Augen, wird mit dem Finger immer nur auf den Menschen gezeigt und ihm seine Umweltwirkung moralisch vorgehalten. Keinem Menschen, der bei Sinnen ist, würde es einfallen, den Korallen, den Schwämmen, den Gräsern oder den Chloroplasten eine Moralpredigt halten zu wollen. Aber, dieses Argument soll hier nicht weiter verfolgt werden. Es soll nur festgehalten sein, dass Menschen auch Lebensansprüche anmelden dürfen und selbst so etwas Künstliches wie Städte zum natürlichen Realisierungspotential menschlicher Lebensweise gehören, mithin seine Natur sind. Das offenbar spezifisch Menschliche, das Umweltzerstörungspotential, kann in einer biologischen Argumentationskette äußerstenfalls als Ausdruck einer teleonomisch untauglichen Spezies gewertet werden, und auch nur, wenn als Tauglichkeitskriterium Langlebigkeit einer Art gilt. Bisher sind aber noch immer alle Arten nach einer bestimmten Zeit „ausgestorben“ oder sie mussten sich „,anpassen“. Wenn „Natur[erhalt] als Kulturaufgabe“ (Markl) gesehen wird, wird zu diesem Zweck vom Menschen unnatürliches Verhalten verlangt, es sei denn, alle kulturellen Phänomene werden nicht als emergente Eigenschaften, sondern als natürliche begriffen. Dies führt zu Aporien im Nachdenken über biologische vs. kulturwissenschaftliche Setzungen.
} 
einem Rückgang der Sumpfschildkröte, ohne, dass dem ein Konzept der Schildkrötenbekämpfung zugrunde gelegen hätte. Die Schildkröte wich dem Menschen aus, sie wurde durch Einschränkungen ihres Lebensraums von ihm verdrängt. Die mittelalterliche Einführung der Wassermühlen bedingte die Anlage von Stauwehren. Damit stieg in einzelnen Regionen der Grundwasserspiegel, es kam zu Vernässungen als unbeabsichtigte Folge mit Konsequenzen für Pflanzengemeinschaften und Landschaft. Die Beispiele ließen sich entlang dieser oder ähnlicher Vorlagen beliebig vermehren.

Das Prinzip der Verdrängung wird deutlich: Die Verdrängung besitzt kein eigenständiges Handlungsmuster. Sie ist die unbeabsichtigte, vielleicht noch billigend in Kauf genommene Folge menschlicher Umwelteingriffe. Keinesfalls ist sie Folge einer auf sie hinzielender Handlungen und damit auch keine Folge eines gestalteten Naturkonzeptes. ${ }^{366}$ Sie ist das Ergebnis der Wirkung eines menschlichen Handelns und seiner Nebenfolgen, dem diese Folgen gleichgültig sind. Zweifellos ist Verdrängung die vorherrschende Nebenfolge aller Aktivitäten im Agrarregime. Entscheidend ist, daß Verdrängungen zu regionalen Bestandsverlusten einzelner Arten führen können, ohne den Bestand der Art als solcher zu gefährden. Möglich sind allerdings verdrängungsbedingte Aufsplitterungen der Individuen einer Art auf Metapopulationen an marginalen Standorten, zwischen denen die Ausbreitungskorridore verloren gehen. Eine solche Situation kann dann schließlich doch zur Bedrohung des Gesamtbestandes führen, vor allem bei endemischen Arten.

Eine gleichsam inverse Variante der Verdrängung besteht in der Zunabme von Arten- bzw. Individuenzahlen infolge menschlicher Aktivität, der aber ebenfalls noch keine Intentionalität zugrunde liegt. Ein klassisches Beispiel ist der Brandrodungsfeldbau, in dessen Folge bestimmte Arten des Regenwaldes durch menschliche Aktivität konzentriert werden, in dem diese Arten im Anschluss an die menschliche Nutzung die Freiflächen besetzen, ohne dass der Mensch an ihnen Interesse hätte. Selbstverständlich handelt es sich hierbei um eine anthropogene Begünstigung dieser Arten. Ein weiteres Beispiel betrifft die Kulturfolger-Arten, unter die auch die Schädlings- und Unkrautarten zu rechnen sind. Menschliche Lebens- und Wirtschaftsräume haben für diese Hemerobien einen hohen Attraktionswert, so daß sie zu Ballungsräumen dieser Arten werden, ohne dass der Mensch dies beabsichtigen würde. In einem weiten Sinne stellt diese opportunistische Mitnutzung von Lebensräumen zwar eine Form der (indirekten) Biodiversitätslenkung dar. Hauptsächlich aber soll unter Biodiversitätslenkung die Folge der Wirtschaftsweise im Agrarregime verstanden sein, die auf die Nutzung von domestizierten Tier- und Pflanzenarten zielt, indem sie diese Arten absichtsvoll auf den Wirtschafts- und Nutzungsflächen konzentriert bzw. fördert.

Die Bedeutung der Biodiversitätslenkung für die Weltgeschichte wird dann besonders deutlich, wenn man sich bewusst macht, dass von den ca. 300000 - 500000

366 Den Gleichgültigkeits- bzw. Unkenntnishaltungen sind konzeptionell die bewussten „laisser faire"-Haltungen gegenüberzustellen, obwohl sie sich hinsichtlich der Folgen nicht unterscheiden. 
Pflanzenarten, die auf der Erde existieren, etwa 30000 für essbar gehalten werden. Unter diesen gelten 7000 als Kulturpflanzenarten, davon haben nennenswerte lokale bzw. regionale Bedeutung nur 120 Arten. 90\% des weltweiten Kalorienverbrauchs hängen heute an insgesamt 30 Kulturpflanzenarten. ${ }^{367}$ Die Globalisierung bzw. ihre Vorstufen ist also das Ergebnis einer konsequenten Konzentration auf bestimmte Pflanzenarten.

Ein ganz ähnliches Resultat ergibt sich bei den Tieren. Von weltweit ca. 50000 Wirbeltierarten spielen in den Agrarsystemen nur ca. 40 domestizierte Arten eine Rolle. Weltweit verbreitet sind Rind, Schaf, Schwein, Huhn, der domestizierte Büffel und Ziegen. Domestizierte Tiere, die nicht den Wirbeltieren zuzurechnen sind, hatten historisch nur begrenzte Bedeutung (Bienen, Seidenraupen, Schnecken). Wie bei den domestizierten Pflanzen haben auch die domestizierten Tiere teilweise spezifische Lebensansprüche, auf die der mit ihnen wirtschaftende Mensch durch Produktionsformen bzw. Anpassungen der Landschaft Rücksicht nehmen muss.

Das Agrarregime ist eine Erfindung der Menschen, die unabhängig voneinander wenigsten an drei Regionen der Welt entstanden ist (Südostasien, Zentralamerika, Vorderasien). Eine Vorbedingung für die Entstehung von Agrarregimes war das naturräumliche Angebot von Pflanzen, die für die Kultivierung geeignet sind, also vom Menschen hierfür ausgewählt und an bestimmten Plätzen konzentriert werden. Seit der Neolithisierung hat es zumindest in der alten Welt eine kontinuierliche Zunahme der Biodiversitätslenkung und damit verbunden auch von Biodiversitätsverdrängungen gegeben. Grundsätzlich muss dies auch für andere Regionen mit Ackerbau zugetroffen haben. Mit dem Beginn des interkontinentalen Austausches und der Errichtung imperialer Großreiche des neueren Typs war die Globalisierung globaler Stoffströme aus den Agrarsystemen vorgezeichnet.

Die Herkunftsgebiete (sog. Vavilov-Zentren) wichtiger heutiger Kulturpflanzen sind weltweit regional sehr begrenzt. Interessanterweise und retrospektiv einsichtig sind diese Räume, wo sie mit anderen strukturellen Randbedingungen geomorphologischer Qualität und einem Interesse der dort lebenden Menschen zusammenfallen, verknüpft mit der Entstehung erster städtischer Anlagen. Zu diesem frühen Zeitpunkt richtet der Mensch die Konzentration seiner sozialen Strukturen zwar noch nach naturalen Determinanten aus. Das Prinzip der Sesshaftigkeit verlangt aber nach einer Moderation ökosystemarer Flüsse und Kreisläufe. In der Konsequenz kommt es zu einer Emanzipation von den primären naturalen Bedingungen. An die Stelle der ökosystemar vorgegebenen oder suggerierten Entscheidungsmuster treten politische Entscheidungen. Die Stoffströme und Energieflüsse bündeln und lenken die Biodiversität auf die sich herausbildenden Städte, richten

\footnotetext{
367 „Von den 7.000 Kulturpflanzenarten gelten lediglich 30 als ,crops that feed the world““ (WBGU Jahresgutachten 1999, S. 86). Der WBGU, aus dessen Gutachten die hier genannten Zahlen und Angaben zu den unten genannten Tieren entnommen wurden, zitiert seinerseits die FAO. Die Formulierung des WBGU ist leider nicht eindeutig. Die Rede ist hier vom Kalorienverbrauch aus Nahrungsmitteln für den Menschen und für die von ihm genutzten Tiere.
} 
ihre Produkte auf die Bedürfnisse der Städte und ihrer Gesellschaften aus, sie lenken die Biodiversität hin zur Optimierung des Agrarsystems. Ursächlich ist das Bedürfnis nach verstetigter Versorgung der Siedlung. Damit verbunden ist ihre weitestgehende Entkoppelung von naturalen Zyklen. Für die Verstetigungsbemühung war der Prozess der Domestikation entscheidend. Die Pflanzen und Tiere sind nach den Vorstellungen der menschlichen Nutzer gezüchtet worden, was in der Sprache der Biologie einer Lenkung der innerartlichen Vielfalt entspricht. Züchtungsziele sind Wertvorstellungen, die sich im Züchtungsprodukt verdinglichen. Die kontinuierliche Entwicklung domestizierter Tiere und Pflanzen stellt damit eine auf bestimmten Wertvorstellungen beruhende Nutzung bzw. Indienststellung der Natur dar. Die seit Jahrtausenden ablaufende Begegnung mit der „Natur" in Form der selektierenden Wahrnehmung der Kategorien „nützlich“ bzw. „,brauchbar“, 368 führt zwangsläufig zu einem impliziten Naturkonzept, das quer zu heutigen Naturmodellen der westlichen Industriestaaten verläuft: Einer früheren Naturvorstellung ist die Idee des Erhalts von „Natur“ um ihrer selbst willen fremd. Lübbe hatte schon 1986 darauf hingewiesen, dass sich ein naturschützerischer, gewissermaßen ,grüner“ Impuls historisch erst in den modernen Überflussgesellschaften herausbilden konnte. Vielleicht war seine Diagnose etwas handfest formuliert. Doch scheint es wirklich belastbare Beispiele für vormoderne Gesellschaften nicht zu geben, für die ein längerer nachhaltiger Umgang mit Natur belegt werden kann. Die „tragedy of the commons“ ist ein geflügelter Begriff geworden, und was im diachronen und interkulturellen Vergleich als nachhaltig wirken mag, entpuppt sich zumeist als Mangel an Möglichkeiten oder Desinteresse. Jedenfalls ist die Übernutzung von natürlichen Ressourcen auch für vormoderne Gesellschaften und weltweit nachweisbar, auch für solche, über die in der europäischen Rezeptionsgeschichte Nachhaltigkeitsmythen verbreitet wurden (z.B. Kaiser 1992).

Die interkontinentalen Folgen der Verdrängungen und Lenkungen werden u.a. dort idealtypisch sichtbar, wo die jeweiligen Neophyten oder Neozooen in ihrer Ausbreitungsgeschwindigkeit so schnell sind, dass sie den europäischen Siedlern in der Neuen Welt vorauseilen. Die Ausbreitung von Klee und Wiesenrispe (Kentucky Blue-Grass) erfolgte z.B. so schnell, dass die ersten Engländer, die nach Kentucky kamen, diese Neophyten bereits vorfanden. Pfirsichbäume breiteten sich mit einer Geschwindigkeit aus, dass die Farmer des 18. Jahrhunderts fürchteten, die beiden Carolinas würden eine „wilderness of peach trees“. In Südamerika entkamen Endivien und Spinat aus den Gärten und entwickelten sich zu unpassierbaren, bis sechs Fuß hohen Dickichten an der peruanischen Küste. Die Minze überwucherte ganze Täler in den Anden. Darwin fand die Pampas in Argentinien und

\footnotetext{
368 Nach der christlichen Meistererzählung steht die „Nutzlich-Schädlich-Kategorie“ sogar hinter der Auswahl der Tiere für die Arche Noah's. - Auch das historisch größte und riskanteste genetische Freisetzungsexperiment aller Zeiten, das mit dem nach 1500 stattgefundenen interkontinentalen Austausch von Pflanzen und Tieren vorliegt, verdankt sich allein dem Nutzungsdenken. Es gehört mit zu den Wundern dieser Welt, dass diese damaligen Freisetzungen offenbar keine erkennbar größeren Schäden angerichtet haben (von bestimmten Krankheiten des Menschen abgesehen).
} 
Uruguay über hunderte von Quadratkilometern mit wilden Artischocken besetzt. Und er berichtet, dass Pfirsichbaumholz das hauptsächliche Feuerholz in Buenos Aires sei (alle genannten Beispiele aus Mann, 2005). Besonders für Inselfaunen hat sich das Freisetzen von Neozooen europäischer Herkunft (wie Ratten, Kaninchen, Hunde, Ziegen, Schafe) fatal ausgewirkt. Abgesehen von diesen kleinen „ökologischen Imperialismen“ (Crosby 1986), als deren globaler Gewinner vermutlich der Löwenzahn zu gelten hat, besteht die Hauptlenkung der Biodiversität aber in der Übernahme des europäischen Agrarregimes in die überseeischen Kolonien. Das Land wurde für die mitgebrachten Pflanzen kultiviert, seltener und später kamen einheimische Pflanzen in den Flächenanbau. Aus Europa importierte domestizierte Tiere beeinflussten, wie die angebauten Pflanzen, den Landschaftstyp. Wo die aus Europa mitgebrachten Pflanzen hinter den Erwartungen zurückblieben, wurden Kulturpflanzen aus anderen Kolonien importiert. Auch bei den Tieren bildete sich eine Nutzungsflexibilität heraus, die intensiv allerdings immer nur in Richtung der Kolonien oder zwischen den Kolonien war. Die Übernahme von Tieren und Pflanzen nach Europa ist, von einzelnen frühen Erfolgsgeschichten wie die der Kartoffel abgesehen, wesentlich erst ein Phänomen des 20. Jh.s. Die Produktionsbetriebe konzentrieren sich allerdings heute aus naturräumlichen Gründen im südlichen Europa oder profitieren mehrfach von der heute üblichen fossilenergetischen Substitution des Agrarregimes (Gewächshauskulturen).

Intentionale Lenkung der Biodiversität und als Nebenfolge ihre Verdrängung bilden also eine Zwillingskonsequenz seit der Entwicklung des Agrarregimes. Die jeweils spezifischen Nutzungsformen von Pflanzen und Tieren haben zwangsläufig spezifische landschaftsbildende Konsequenzen. Dabei ist die Bedeutung von „Biodiversitätsverdrängungen“" weder historisch gut untersucht, noch scheint ihre Bedeutung aktuell angemessen eingeschätzt. Als „Verdrängung“ wurde weiter oben eine Bestandsverminderung bezeichnet, für die sich keine unmittelbare, auf sie zielende Ursache in der menschlichen Handlung finden lässt. Am sichtbarsten werden Bestandsverdrängungen in den Roten Listen, denn nur in Einzelfällen verdanken sich die Listenpositionen einer wirklichen Bekämpfung (intendierten Lenkung) der betroffenen Organismen. Die Unsicherheit, ob denn in den Roten Listen womöglich „natürliche Schwankungen der Arten- und Individuenhäufigkeiten" abgebildet werden, lässt sich mit dem Hinweis auf deren aktuelle Änderungsgeschwindigkeit relativieren. Seit der „Stumme Frühling“ (Carson 1962) die Aufmerksamkeit auf mittel- und langfristige Folgen umweltrelevanten Handelns richtete, ist mittlerweile deutlich geworden, dass die Ketten von Folgen und Nebenfolgen sehr lang sein können. ${ }^{369}$ Beispiele hierfür können auch jüngere mitteleuropäische Forstkalamitäten liefern, für deren Auftreten auch Bodendegradationen durch

\footnotetext{
${ }^{369}$ Es genügt der Hinweis auf mittlerweile weltweit in der Umwelt nachweisbare Chemikalien, die in den letzten einhundert Jahren synthetisiert wurden. Hierzu: Niedersächsisches Umweltministerium (Hrsg.), Schadstoffe mit hormoneller Wirkung - Wie sicher ist unsere Zukunft? Internationales Hearing zu endokrin wirksamen Stoffen in der Umwelt. 5.-6.Mai 1997 Hannover, Tagungsband.
} 
jahrhunderte lange spezifische Nutzungsmuster des Waldes verantwortlich gemacht werden (Herrmann 2007).

Dabei wäre es ein erkenntnistheoretischer Trugschluss, zu glauben, dass den Verdrängungsmechanismen keine Wertvorstellungen zugrunde lägen. Die Wertschätzungen sind dabei nur auf andere Bereiche als diejenigen der Biodiversität gerichtet, wodurch sich automatisch eine allgemeine Rangskala von Wertschätzungen ergibt. Wertschätzungsänderungen setzen in der Gesellschaft Prozesse der Bewusstwerdung, des Wissenszuwachses, der Veränderungen anderer Werte bzw. neu formulierte Konzepte voraus. Ohne Umsetzungsmöglichkeiten, die in geänderten Einflussstrukturen, in einer kulturellen Akzeptanz, einem sozialen Bedarf oder einer ökonomischen Struktur bestehen können, bleiben sie allerdings wirkungslos.

Phasen solcher Umsetzungsmöglichkeiten bestanden offenbar in den letzten zweihundert Jahren zweimal. In ihnen mag man auch Epochenwechsel der Umweltbetrachtung erkennen: Einmal von der Stellvertretereigenschaft des Menschen in seiner Stellung zur Schöpfung im 18. Jh. hin zum 19. Jh., in der das Konzept einer für den menschlichen Bedarf eingerichteten bzw. noch besser einzurichtenden physischen Natur radikalisiert wird. Die Erzählung vom Schöpfungsmythos wurde im 19. Jh. von derjenigen abgelöst, in der die physische Natur materialistisch dekonstruiert wurde. ${ }^{370}$ Am Ende des 20. Jh.s wechselt diese Sicht zu einer Vorstellung von physischer Natur, für die der Mensch der Wissensgesellschaften sich selbst die Verantwortung zuweist. Gegenwärtig beginnt eine Zeit, in der zwar weiter und intensiver denn je an der Beherrschbarkeit der Natur gearbeitet wird, in der aber zugleich eine vom Menschen ausgehende Heilsgeschichte für die Natur gefordert und inszeniert wird (Konferenz von Rio, Agenda 21).

\section{Leitbild Kulturlandschaft}

Meliorationen, im wesentlichen Ackerlandgewinnung durch Drainage von Feuchtgebieten und Hochwasserschutz vor allem in Flußauen, hatten in Europa eine lange Tradition. Sie nehmen an Intensität im 18. Jh. stark zu und erreichen im 19. Jh. ihren historischen Höhepunkt.

Als Beispiel dient hier die Melioration des Nieder-Oderbruchs unter Friedrich II. zwischen 1747 und 1753 (Herrmann und Kaup 1997). Die Anlage eines Kanals durch einen Mäanderschlingenhals verkürzte den Oderlauf um fast $30 \mathrm{~km}$ und das angrenzende Gebiet wurde durch Drainage einer landwirtschaftlichen Nutzung zugänglich. Unmittelbar waren $250 \mathrm{~km}^{2}$ betroffen, mit den Nebenflächen und den Wassereinzugsgebieten insgesamt aber eine Fläche von rund $4.000 \mathrm{~km}^{2}$. Die Ziele der Melioration wurden in einem vom König in Auftrag gegebenen Gutachten benannt:

\footnotetext{
370 Seit Darwin gilt, dass die organismische Evolution ein sich selbst organisierender Prozess ist, der in niemandes Verantwortung steht.
} 
o Gewinnung von Ackerland

o Peuplierung (Ansiedlung von Kolonisten mit dem Ziel der Bevölkerungsvermehrung)

o Hochwasserschutz

o Verbesserung der Schiffbarkeit der Oder

Zur Erlangung dieser Ziele waren tief greifende Veränderungen der Landschaft erforderlich. Mit dieser Drainage verbunden waren nicht nur Verluste aquatischer Lebensräume und der Bruchlandschaft. Auch die vieljährigen Erhöhungen des Schwebstoffanteils in den Vorflutern bzw. der Oder infolge der intensivierten landwirtschaftlichen Nutzung werden den Fischbestand beeinträchtigt haben. Die Drainage führte zum Verlust von Rastplätzen für Zugvögel, zu Bestandsänderungen der Vegetation und schließlich zur Anlage von Ackerflächen. Der Rückgang der ehemals „riesigen Mückenschwärme“, von den Menschen sicherlich sehr begrüßt, kann ebenfalls nicht ohne Folgen entlang der Nahrungskette und für die Parasitenepidemiologie geblieben sein (zu Details siehe Herrmann und Kaup 1997).

Bedenken gegen die Meliorationsmaßnahme existierten durchaus. Sie wurden von den Fischern der betroffenen Gemeinden vorgetragen, die gegen den drohenden Verlust ihrer Fischernte argumentierten, in dessen Folge sie in wirtschaftliche Not geraten und als Steuerzahler ausfallen würden. Das obrigkeitliche Augenmerk war dagegen auf die fruchtbaren Böden der Flussaue gerichtet. Tatsächlich findet sich hier, in dem ansonsten für Agrarproduktion nicht besonders begünstigten Raum der Mark Brandenburg, heute deren höchste Bodenfruchtbarkeit. Das Argument der Fischer scheint ein ökonomisches zu sein, nicht einmal entfernt berührt von naturkonservierenden Überlegungen. Der König bagatellisiert den Einwand mit dem Hinweis auf künftig höheren Gewinn aus Bodenbewirtschaftung.

Aber das Leitbild der Fischer ist nur vordergründig ökonomisch. Sie wirtschafteten in und mit einer naturräumlichen Gegebenheit, deren Übernutzung durch Innungswesen und Maschenweiten der Garnzüge vorzubeugen gesucht wurde. Sie wirtschafteten in einer bescheidenen Marktwirtschaft, in der im Wesentlichen Ökonomie und Ökologie zusammenfallen. Nicht zuletzt der Blick auf die zeitgenössischen Beschreibungen ihrer Lebensumstände zeigt, dass sie trotz gewisser technischer Hilfsmittel praktisch in der Wirtschaftsform von Jäger-Sammlern lebten. Wer sich unter diesem Blickwinkel gegen die Änderung der ökonomischen Basis ausspricht, bezieht gleichzeitig eine eindeutig konservative Position bezüglich der physischen Natur, weil er seine Existenz einer aneignenden Form der Subsistenzwirtschaft verdankt. Bei Lichte besehen konfligieren in diesem Beispiel zwei Naturkonzepte, die grundsätzlich darin übereinstimmen, dass die Beschaffenheit der physischen Natur durch das spezifische Nutzungsinteresse der Appropriateure bestimmt wird, die sich nur eben nicht über deren Nutzungsart verständigen können. Hüten muss man sich, an dieser Stelle die Gewinn-Verlust-Rechnung für eine Landschaft vor dem Hintergrund der seitdem verstrichenen 250 Jahre aufzuma- 
chen. Dieser Blick in die Zukunft war den historischen Akteuren unmöglich, als sie sich ihrer Leitbilder wegen stritten. Und auch heute ist diese Gewinn-VerlustRechnung nicht wirklich aufzumachen. Sie würde entweder an der gegenwärtig präferierten Zweckbestimmung des Oderbruchs gemessen, oder sie würde von der Annahme ausgehen, ein beliebiger hemerober Zustand sei der archimedische Bezugspunkt. Diese Überlegung führte dann u.a. direkt zu den Klagen vom Typus „Paradiesverlust“. Beide Sichtweisen wären unangemessen, weil sie jeweils von Leitbildern ausgingen, die nicht als absolut setzbar sind.

Das Beispiel der Oderbruchmelioration lässt sich leicht ins Allgemeine verlängern. Das autokratische Handeln Friedrich II und seiner Administration ist die Konsequenz aus der staatstheoretischen Position, die das Glückseligkeitsversprechen zur Maxime erhebt und die Glückseligkeit der Untertanen zum Staatsziel erklärt (mit Blick in die Umweltgeschichte vor allem: Meyer 1999). Vorarbeit hatte nicht zuletzt Friedrichs Vater mit seiner Anordnung zu einer oft übersehenen Wahrnehmungsänderung geleistet. Er hatte die „Große Wildnis“, wie die riesigen Wälder Ostpreußens seit den Tagen der Ordensritter genannt wurden, abgeschafft. Nicht etwa durch Fällen der Bäume, sondern per dekretiertem Wahrnehmungswandel. Er ließ 1728 kurzerhand die Verwendung des Begriffs verbieten, „weil seine Majestät keine Wildnis in ihren Landen erkenneten“. Ganz sicher stand dabei auch das protestantische Verhaltensleitbild „Produktivität“ Pate (Herrmann 2004).

Die auf die Landesverbesserung zielenden Aktivitäten der preußischen Hohenzollern sind keine Einzelfälle. Überall lebte, auf dem Kontinent wie den britischen Inseln, die Idee auf, die Natur zum Vorteil der Untertanen zu optimieren. Die Aufklärung setzt letztlich ökonomische Zweckmäßigkeit zum ästhetischen Leitbild. Aber erst das 19. Jh. wird über die Mittel und den allgemeinen politischen Willen verfügen, die Natur im großen Stil durch die menschliche Kunst zu verbessern, wie es bereits Bacon vorschwebte (zu Bacon das Einleitungskapitel bei Dipper 1991). Die Landesverschönerung des 19. Jh.s erweist sich so am Ende als eine direkte Folge der Aufklärung. Einer makelbehafteten Natur, in der sich die Flüsse unschön schlängeln oder krümmen, wird die Rektifikation nicht nur als ästhetisches Paradigma entgegensetzt (Tulla 1825). Die physisch vorgefundene Natur soll ökonomisch sinnvoll und zu ihrer wahren Bestimmung und Schönheit hin vollendet werden (Beiträge in Konold 1996, darin beispielhaft Beck), so dass das 19. Jh. in Deutschland geradezu zu einem Jahrhundert der Feuchtgebiet- und ÖdlandBekämpfung und der Landesverschönerung wird. Doch das Pendel beginnt schon gegen Ende des 19. Jh.s zurück zu schwingen, in Richtung einer neo-romantischen Naturauffassung und auf die z. T. naive Forderung hin nach einem restaurativen Landschaftsbild (beispielhaft Gradmann 1910).

Es ist selbstverständlich, dass mit allen Veränderungen der Landschaft, ob nun konzeptionell vorgesteuert oder beiläufig verursacht, erhebliche Verschiebungen 
und Lenkungen der Biodiversität verbunden waren, die sich aber ganz überwiegend nur durch Untersuchungen im kleinräumigen Maßstab erschließen und größtenteils noch auf ihre Untersuchung bzw. die Systematisierung verstreut vorliegender Informationen warten. Man muss einräumen, dass bisher bestenfalls punktuelle Kenntnisse über Artenspektren im historischen Wandel bestehen und dass diese Kenntnisse auch noch zu Ableitungen zweifelhafter Güte führen, wie etwa bei den sprichwörtlich gewordenen Gesindeverträgen, in denen man sich angeblich gegen das ständige Lachs-Essen-Müssen verwahrte. ${ }^{371}$ Das kollektive Gedächtnis registriert nicht nur selektiv, es argumentiert auch ebenso: Alle jammern über den Rückgang des Lachses, weil es dem populären Naturleitbild entspricht. Keiner beklagt den Rückgang der „Mückenschwärme“ im Oderbruch oder in den Rheinauen, obwohl dieser möglicherweise ein viel besserer Indikator für „den Zustand der Natur“ wäre. Der Betrachtungsgegenstand „Melioration“ führt also sehr unmittelbar in die Bereiche der Naturleitbilder, ihrer Voraussetzungen und Einflusslagen. Doch das Feld ist nicht einmal systematisch bestellt, geschweige denn ausdiskutiert.

\section{Fördern, dulden oder ausrotten?}

Neben Landschaftskonzepten existieren weitere erhebliche Einflussfaktoren auf die Biodiversität. Zu ihnen sind auch jene Wertvorstellungen über Tiere und Pflanzen zu rechnen, welche Begründungen für Förderungs-, Duldungs- oder Bekämpfungsmaßnahmen dieser Organismen liefern.

„Organismen, die für den Menschen, seine Tätigkeit oder für Produkte, die er verwendet oder herstellt oder für Tiere und die Umwelt unerwünscht oder schädlich sind“ werden vom Gesetz als „Schadorganismen“ bezeichnet (Biozidgesetz $\int 3 b$, Abs. 6). Diese heutige Definition kann in derselben Weise als handlungsleitend für das 18. Jahrhundert unterstellt werden. Wenn der Biber im Oderbruch ausgerottet wird, weil er die Deiche unterhöhlt und damit die Gefahr des Deichbruchs vergrößert, ist dies u.a. eine auf „die Umwelt“ zielende Maßnahme. Den Schutz vor Nahrungs-, Lager- und Fraßschädlingen auf der Ackerflur wird man nicht nur als selbstverständlich unterstellen, sondern auch belegen können. Ebenso, dass Menschen die von ihnen erzeugten Produkte vor dem Schädlingsbefall auch zur damaligen Zeit zu schützen versuchten.

Verglichen mit heutigen Verhältnissen muss die einer Schädlingsbekämpfung unterliegende Schadensschwelle, mit der die Wirtschaftlichkeit einer Bekämpfungsmaßnahme von der Populationsdichte des Schadorganismus abhängig gemacht wird, im 18. Jahrhundert niedriger angenommen werden als heute, nicht

\footnotetext{
371 Vgl. Herrmann 2006a. Bis heute ist kein einziger Gesindevertrag entsprechenden Inhalts nachgewiesen worden. Auffällig ist auch, dass die Literatur keine Parallelargumente kennt: Es werden nirgends Gesindeverträge erwähnt, in denen die Bediensteten sich gegen ein Zuviel an Kohl- oder anderen Alltagsgerichten wehrten.
} 
nur, weil die Schädlingsdichte höher gewesen sein dürfte. Die damaligen Erntemengen betrugen in der Größenordnung lediglich das Vier- bis Sechsfache der Getreideeinsaat. Unter solchen Umständen wird eine Schädlingsbekämpfung umso dringlicher. Man stand z.B. den zeitgenössischen Heuschreckeneinfällen, die zum Teil über das schlesische Revier bzw. aus Polen in das Oderbruch und die westliche Mark Brandenburg einwandern oder auch aus den Brachflächen vor Ort schlüpfen, weitgehend hilflos gegenüber. Die technischen Mittel der damaligen Zeit bestanden nur in der physischen Vernichtung der einzelnen Schadorganismen. Für die Heuschreckenbekämpfung bedeutet dies ein Aufsammeln der Gelege bzw. ein Einfangen der geschlüpften Tiere und ihre anschließende Tötung durch Zerstampfen oder Überbrühen bzw. Einfegen in Gruben und anschließende Abdeckung mit dem Aushub. Bei langsam ansteigender Gesamtbevölkerung erzwang die Grenzertragssituation der weitestgehend stagnierenden Agrarwirtschaft des 18. Jh.s, den Ressourcenschutz zu intensivieren. Im 18. Jh. entsteht daher der Typus der Schädlingsbekämpfungsliteratur, deren Anfang Abraham Friedrich Krafft $(1712 / 13)$ markiert. Die Obrigkeit setzt das systematisierte Wissen zunehmend in Regelwerke über die Durchführung von Schädlingsbekämpfungsmaßnahmen um. In ihrer Wirkung münden diese Maßnahmen eher in Verdrängungen, wie etwa bei den Maßnahmen gegen Großsäuger, gegen das kleine Raubzeug und gegen Raubvögel. Bekämpfungsmaßnahmen, die normativ geregelt werden, beziehen sich auf Vorratsschädlinge, Forstschädlinge und Enteschädlinge. Die oben erwähnte Biberbekämpfung würde man in diesem Zusammenhang als Vorgehen gegen einen Umwelt- oder Produktschädling einordnen. ${ }^{372}$

Gegenüber einem heutigen Verständnis werden im 18. Jh. manche Tiere als Schadorganismen eingestuft, die seitdem einen Kategorienwechsel erfahren. Das gilt nicht nur für den Biber, es gilt z.B. auch für Greifvögel, für den Regenwurm und den Maulwurf, denen im 18. Jh. nachgesagt wurde, dass sie schwere Schädlinge wären. Alleine der Maulwurf hätte, zusammen mit dem Sperling, nach Auffassung eines Autors des 18. Jh. in Preußen jährlich einen Schaden angerichtet, der weit über den Unterhaltskosten für die gesamte königliche Kavallerie gelegen hätte (Kretzschmer 1744). Schädlinge sind auch die Trappe, der Kranich, sind Amphibien und Reptilien und selbstverständlich der Hamster. Man muss sich dabei aber vergegenwärtigen, dass vor der Erfindung der chemischen Bekämpfungsmittel insgesamt eine relative Unwirksamkeit der Bekämpfungsmaßnahmen zumindest von Agrarschädlingen bestanden hat. Hingegen stehen heute zunächst einmal alle wild lebenden Tiere nach $\ 41$ des Bundesnaturschutzgesetzes (BNatSchG) unter Generalschutz.

Ist die Kulturlandschaftsgestaltung noch eine eher verdeckte Förderung oder Verdrängung des Artenbestandes, dann ist die Schädlingsbekämpfung die direkte Aufforderung zur Entfernung der Angehörigen einer Art. „Ausrotten“ bedeutet

\footnotetext{
372 Diese, wie die nachfolgenden historische Beispiele und Argumente zur Schädlingsbekämpfung,
} ausführlicher in Herrmann 2006b, 2007 
dem Wortsinn nach bei Martin Luther „die Entfernung von einer Fläche“. Ob daraus je eine Programmatik zur Entfernung einer Art aus dem gesamten Artenbestand geworden ist, muss man letztlich bezweifeln. 373 Die Hoffnung, mit einer Schädlingsbekämpfung seine Peiniger bzw. Schädiger von Hab und Gut zumindest im eigenen Umfeld los zu werden, scheint verständlich. Doch sollten etwaige Gewissensqualen der historischen Akteure nicht unterschätzt werden. Zweifel an der Rechtmäßigkeit der Schädlingsabwehr sind nicht erst aus dem 18. Jh. bekannt. Walthenus von Melrose († 1159) und Wulfric von Haselburg († 1154) gingen nach Tötung einer Bremse bzw. einer Maus wegen ihrer Gewissensbisse in die Geschichte der Mensch-Tier-Beziehungen ein. In ihrer frommen Umgebung ernteten sie nur Unverständnis und Gelächter für ihre inneren Konflikte. ${ }^{374}$ Das Problem, ob man durch Schädlingsbekämpfung dem Schöpfer möglicherweise ins Handwerk pfuscht, wird im 18. Jh. prekär. Doch es bietet sich angesichts der Notwendigkeit zur Bekämpfung nicht nur die aufklärerische Position zur Rechtfertigung an, wie sie etwa Beckmann ${ }^{375}$ in seinem Loblied auf die Naturgeschichte formuliert (bei Herrmann 2006b). Auch das eher sophistische Argument zur gänzlichen Entfernung des Schädlings aus dem Artenbestand (hier der Sperling) ist vernehmbar: „Es gibt Difficultäten-Macher und windigte Critici, welche doch wol etwas einzunvenden haben möchten Igegen die Bekämpfung der Sperlinge, BH]. Denn vielleicht kan ein solcher 1) überhaupt einwenden und sagen: Man handele wider des Schöpfers Willen, wo gedacht, dass ein solcher Sperling obne des V aters Wille nicht auf die Erde falle. Doch Antwort: Eben dieser HErr hat auch gesaget, dass man 2 [Sperlinge; siehe Matthäus 10,29; BH] um 1 Pf. kauffe, wodurch ibr Werth und Hochachtung ziemlich an den Tag geleget ist. Zudem sind wir ja, als Herren über die Creaturen gesetzet, und als Haußhalter in der Natur bestellet, dass wir dasjenige, was uns schädlich, abschaffen, vertilgen und ausrotten, und bingegen das, was uns nütret, anschaffen und vermehren sollen. Und wer weiß denn, ob ibnen nicht eben nur solange die Zeit, sie in unsern Landen zu dulten, bestimet ist?" (Hervorhebung von BH; Zitat aus Kretzschmer, 1744, \6, S. 69-70).376

Wenn Beckmann 1767 (a.a.O.) in seiner Aufstellung dessen, was von der „Naturgeschichte“ zu lernen sei, unter anderem aufführt „Schädliche und reißende Thiere auf die leichteste Art auszurotten; ein Thier wider das andere zu brauchen", dann ist darunter auch ein Bewusstsein dafür erkennbar, was heute unter biologischer Schädlingsbekämpfung verstanden wird. Nun hielt man etwa Hauskatzen

\footnotetext{
373 Ein Beispiel eigener Art bildet die Erklärung der WHO über die Pockenfreiheit der Welt. Hier wäre also ein Organismus durch systematische Bekämpfung ,auf der Fläche Erde“ ausgerottet worden. Davon zu unterscheiden sind Artenverluste durch Übernutzung und Ignoranz. Wenn das Wissen von der Endlichkeit der Dinge, also auch der Individuen einer Art, noch nicht besteht, laufen entsprechende Vorwürfe ins Leere. (siehe auch weiter unten)

374 Dinzelbacher, 2000, S. 287 --- Zu erinnern ist, dass es außereuropäische Überzeugungssysteme mit großer Anhängerschaft gibt, in denen die Tötung von Tieren peinlich vermieden wird.

375 Zit. nach Bayerl 2001

376 In der Nachbarschaft ähnlicher Argumentationslinien werden sich Ende des 19. und zu Beginn des 20. Jh.s Überlegungen entwickeln, die von der Schädlingsbekämpfung und mit ihren Mitteln in die Menschenvernichtung führen. Hierzu Leven 1997; Jansen 2003.
} 
gegen Mäuse usw. zwar schon seit Menschengedenken, doch die „Indienststellung der Natur" erfolgt seit dem 18. Jh. in der zunehmend systematischen Weise, die sie sich aus dem Glückseligkeitsversprechen des Staates ergab (s.o.). Mit dem Beginn der daraus folgenden systematischen Suche zur Instrumentalisierung einer Art von Organismen gegen eine andere Art ist nun doch eine neue Qualität des Naturverständnisses spürbar, das sich bereits andeutete in den Meliorationsmaßnahmen, wenn man den neuen Kanal für die Oder nur vorgestaltet und seine endgültige Ausformung den Kräften des Stroms in den Nachfolgejahren überlässt. Man könnte natürlich darauf verweisen, dass es die Ausnutzung der Schwerkraft schon immer gegeben habe, so, wie es seit Jahrtausenden die Idee der Hauskatze gab. Auch die Hausväter empfahlen bereits früher hier und da, in die Gartenkulturen nützliche Pflanzen zur Abwehr von Schädlingen einzusetzen. Das Neue besteht jetzt aber in der systematisch-intelligenten rationalen Nutzung dessen, was vorher so nicht, zumindest nicht programmatisch praktiziert wurde. Es kann jetzt mit den Umsetzungsmöglichkeiten des Glückseligkeitsversprechens in die Handlungsprogrammatiken mit aufgenommen werden.

Derjenige Organismus, der zum Schutz von Anbau, Eigentum, Produkten oder Vorräten belassen oder eingesetzt wird, verfestigt zugleich die Vorstellung von Nützlich-Schädlich-Oppositionen und hilft beim Sortieren von Entbehrlichem und Unentbehrlichem. Über diese Kategorien ist sich die magische Wissenschaft des 17. und frühen 18. Jh.s noch nicht sicher. Die rationale Wissenschaft verhilft hier zu klaren Kriterien und Entscheidungsgrundlagen, auch in der Einschätzung der Natur hinsichtlich ihrer Nützlichkeit und Nutzbarkeit für den Menschen.

Um 1800 ist z.B. die Waldameise nicht nur als absolut nützlich etabliert, sondern es ist auch ihre Rolle bei der Prävention und Bekämpfung von Forstkalamitäten geschätzt. Zur selben Zeit ist die Antagonistennatur der Singvögel, selbst des nach wie vor seiner Superabundanz wegen bekämpften Sperlings, in der Wissenschaft längst erkannt. Der geforderte Singvogelschutz scheitert in der Praxis zu diesem Zeitpunkt noch an der pauperistischen Alltagslage, die sich zur Deckung eines Mindestanteils an tierlichem Protein einfach bei den kostenlosen und verfügbaren Singvögeln bedienen muss.

Es gehört zu den überraschenden, gleichwohl verständlichen Einsichten einer historischen Betrachtung, dass sich unter den seit dem Mittelalter bekannten Naturtheorien bis ins 20. Jh. hierzulande keine befindet, für die Schädlingsbekämpfung ein Problem darstellt (ausführlichere und vergleichende Erörterung von Naturtheorien und Schädlingsbekämpfung bei Herrmann 2007). Wie sollte es auch, wenn man sich vergegenwärtigt, dass das Agrarregime eigentlich bis etwa 1950 dauerte und vor 1890 flächenwirksame Pestizide nicht bekannt waren.

Hingegen ist es überraschend, dass in der Generalkritik von Naturtheorien bei Holling et al. (2002; Tabelle 1), die als Plädoyer für eine nachhaltige Naturnutzung zu begreifen ist, das Problem der Schädlinge und ihre Bekämpfung kein Thema 
ist. ${ }^{377}$ Wie den übrigen Naturtheorien lässt sich die konzeptionelle Beseitigung von Organismen um ihrer selbst willen auch unter die von Holling et al. gefundenen fünf Grundmuster subsumieren. Wenn es, nach Auffassung der Autorengemeinschaft sowohl in den menschlichen Systemen als auch in den naturalen Systemen sowie in den Symbiosen von beiden allererst um „Stabilität“ geht, dann wäre Schädlingsbekämpfung mühelos als Bemühung zur Herstellung einer naturalen Stabilität zu klassifizieren. Verfahrensweisen (policies) außerhalb des ,nature evolving“-Modells wären dann wenig empfehlenswert, und die einzig richtigen Strategien lägen in jenen Maßnahmen, die zu den für dieses Modell angegebenen Konsequenzen führen. ${ }^{378}$ Eben diese Folgen (,active learning and new institutions“) gelten aber auch für das jenige Naturmodell, das im Glückseligkeitsversprechen eingeschrieben ist. Entscheidend sind eben immer die Setzungen, die einer Argumentationskette vorangestellt werden.

Holling et al. prüfen zwar ausschließlich zeitgenössisch veröffentlichte Konzepte, die sie als Naturtheorien klassifizieren. Ihr universalistischer Bewertungsanspruch fordert die Prüfung in der historischen Tiefe geradezu heraus. Dabei zeigt sich eine Schwäche ihres Ansatzes. Ihre Bewertung trifft nämlich nur für eine entgrenzt begriffene Natur zu, die erst in und nach der Aufklärung entworfen wird. Wer auf kleiner Parzelle oder im Provinzmaßstab für den Zeitraum eines Menschenlebens und im Bewusstsein einer unveränderlichen Schöpfernatur wirtschaftet, lebt mit der Naturtheorie der Genesis oder wird mit einer beliebigen Naturtheorie zufrieden sein, mit irgendeiner „Naturbastelei“, der im Zweifelsfall irgendeine Empirie (z.B. die Hausväter oder selbst die magischen Wissenschaften) den Weg weist (Herrmann 2007).

Das „,nature evolving“-Modell setzt aber die Verzeitlichung der Naturgeschichte voraus, setzt voraus die Entdeckung der historischen Tiefe der Natur, der Historizität der sie bestimmenden Prozesse und Prozessabläufe. Diese Einsicht wird gegen Ende des 18. Jh.s etabliert. ${ }^{379}$ Erst von jenem Moment an, von dem ,Zeit“ als eine entscheidende Größe der Natur erkannt ist, ${ }^{380}$ kann über Folgen, Nebenfolgen und Langzeitfolgen von naturbezogenen Handlungen nachgedacht werden. ${ }^{381}$

\footnotetext{
377 Jedenfalls fehlt im Register das Lemma „vermin“ bzw. seine Äquivalenzbegriffe

378 Die Einsichten von Holling et al. erleben gegenwärtig eine gewisse Konjunktur. In der historischen Perspektive bilden sie jedoch lediglich ein simples rationallogisches Fortschrittsmodell nach dem Stufenprinzip, dessen Pointe (nature evolving) vorhersehbar ist. Weil seine Aussage trivial ist, ist auch das Modell selbst von zweifelhafter analytischer Kraft, wenn seine Einsicht darin besteht, dass eine Vielzahl von Informationen, die Kenntnis vieler Einflußfaktoren und die rückkoppelndkorrigierende Beobachtung zum besten Ergebnis führen. Einen solchen Gemeinplatz wird niemand ernstlich bestreiten wollen.

379 Lepenies 1986

380 Der Gedanke ist gegen das Ende des 18. Jh. noch vage, mit dem Beginn des 19.Jh. deutlicher, bis er in der zweiten Hälfte des 19.Jh. seinen akzeptierten Platz gefunden hat

381 Folgerichtig beginnen z.B. Überlegungen über die Konstanz von Artenzahlen angesichts bzw. trotz menschlicher Tätigkeit erst in der Mitte des 18. Jh.
} 
Erst dann kann sich auch eine Verhaltensnorm entwickeln, die systematisch über Konsequenzen der Schädlingsbekämpfung nachdenkt, weil die bis dahin herrschende Natursicht der „Kette der Wesen“ von der Artenkonstanz ausging, womit Aussterben wie Hinzukommen von Arten ausgeschlossen war. ${ }^{382}$ Folglich war „ausrotten“ bis dahin immer gleichzusetzen mit Vertreiben bzw. Töten von auf einer bestimmten Fläche vorkommenden Organismen, ganz in dem von Luther im Vertrauen auf den Schöpfergott verwendeten Wortsinn. 383 Dass eine heutige Schädlingsbekämpfung zweckmäßig den Empfehlungen der ,nature evolving“ folgt, kann als intuitiv einsichtig gelten und damit als trivial. Die Naturtheorien von Holling et al. sind also für eine historische Betrachtung kaum produktiv verwendbar, zumindest verhelfen sie dem Schädlingsbekämpfungsdiskurs zu keiner neuen Einsicht.

Tabelle 1: Naturtheorien bzw. -mythen nach Holling et al. 2002, S.12. Die Naturmodelle werden dort in Bildern visualisiert, bei denen eine Kugel (Natur) auf einer jeweils unterschiedlich skulpturierten Fläche (Gesellschaft und naturale Determinanten) einen Platz sucht, auf dem die Kugel in Bewegungsruhe liegt. Im Weg der Kugel, dem Verlauf der Kugelbahn, sehen Holling et al. die geeignete Analogie mit Erklärungswert.

\begin{tabular}{||l|l|l|l|l||}
\hline \hline & STABILITY & PROCESSES & POLICIES & $\begin{array}{l}\text { CONSEQUEN- } \\
\text { CES }\end{array}$ \\
\hline $\begin{array}{l}\text { Nature } \\
\text { flat }\end{array}$ & none & stochastic & random & trial and error \\
\hline $\begin{array}{l}\text { Nature } \\
\text { balanced }\end{array}$ & $\begin{array}{l}\text { globally stab- } \\
\text { le }\end{array}$ & $\begin{array}{l}\text { negative } \\
\text { feedback }\end{array}$ & $\begin{array}{l}\text { optimize or } \\
\text { return to } \\
\text { equilibrium }\end{array}$ & $\begin{array}{l}\text { pathology of } \\
\text { surprise }\end{array}$ \\
\hline $\begin{array}{l}\text { Nature } \\
\text { anarchic }\end{array}$ & $\begin{array}{l}\text { globally } \\
\text { unstable }\end{array}$ & $\begin{array}{l}\text { positive } \\
\text { feedback }\end{array}$ & $\begin{array}{l}\text { precautionary } \\
\text { principle }\end{array}$ & status quo \\
\hline $\begin{array}{l}\text { Nature } \\
\text { resilient }\end{array}$ & $\begin{array}{l}\text { multiple } \\
\text { stable states }\end{array}$ & $\begin{array}{l}\text { exogenous input } \\
\text { and internal } \\
\text { feedback }\end{array}$ & $\begin{array}{l}\text { maintain } \\
\text { variability }\end{array}$ & $\begin{array}{l}\text { recovery at local } \\
\text { scales or adaptio } \\
\text { n; } \\
\text { surprise }\end{array}$ \\
\hline $\begin{array}{l}\text { Nature } \\
\text { evolving }\end{array}$ & $\begin{array}{l}\text { shifting } \\
\text { stability }\end{array}$ & $\begin{array}{l}\text { multiple scales } \\
\text { and discontinouus } \\
\text { structures }\end{array}$ & $\begin{array}{l}\text { flexible and } \\
\text { actively adaptive, } \\
\text { probing }\end{array}$ & $\begin{array}{l}\text { active learning } \\
\text { and new } \\
\text { institutions }\end{array}$ \\
\hline \hline
\end{tabular}

382 Lovejoy 1993; auch Herrmann 2006 a

383 So auch die Wortbedeutung nach DWB 


\section{Ein zurückhaltendes Resümee}

Meliorationen zielen auf ökonomische Landschaften. In ihnen treten Biodiversitätsänderungen als Nebenfolge auf. Meliorationen fördern zwangsläufig unerwünschten Artenbestand, weil sich auf den Nutzungsflächen mit Unkräutern und Schädlingen auch die unerwünschten Begleitarten konzentrieren. Bestandsänderungen werden gelegentlich auch schon zeitgenössisch im 18. Jh. registriert, bewirken aber noch keine explizite Leitbilddiskussion. Das implizite Leitbild einer Melioration ist die „Verbesserung der Natur“ durch menschliche Kunst und Arbeit. Darin eingeschlossen ist die Eindämmung des physikalischen Gefährdungspotentials, das von der Natur etwa durch Hochwasser ausgeht. Eine Leitbilddiskussion mit Konsequenzen für den Artenbestand erfolgt erst mit dem aufkommenden Naturschutz im Verlaufe des 19. Jahrhunderts. Doch werden im 19. Jahrhundert Meliorationen auch gezielt mit dem Zweck der Biodiversitätsänderung (Malariabekämpfung) durchgeführt. ${ }^{384}$ Die wichtigste Einsicht aus den Meliorationsmaßnahmen ist jedoch die Entstehung eines Leitbildes einer Natur, die durch menschliche Kunst und Arbeit in ihrer Gefährdung reduziert und ästhetisch erhöht werden kann. Dies ist eine Feststellung, die trotz der Erschütterung des aufkommenden Fortschrittsmodells durch das Erdbeben von Lissabon 1755 getroffen werden kann.

Demgegenüber problematisieren Anleitungen zu Schädlingsbekämpfungen relativ früh deren Berechtigung, aber sie entscheiden naturgemäß immer zugunsten menschlicher Interessen. Die Entscheidungsträger reagieren auf nachlassenden ökonomischen Druck überwiegend mit Gleichgültigkeit, im Einzelfall mit einem Kategorienwechsel, d.h., der Schädling kann bis in die Kategorie des geschützten Tieres wechseln (z.B. der Kranich oder die Trappe; Klose 2004). Dabei spielen selbstverständlich Wissenszuwachs der Naturwissenschaft und Beliebtheitsbilder für einzelne Tiere eine emotional wichtige Rolle. ${ }^{385}$ Auch im Falle der Schädlingsbekämpfung ist das implizite Leitbild die Verbesserung der Natur durch menschliche Kunst und Arbeit, hier als Ausgrenzung, als Vertreibung, als Tötung. Hinzu treten heimliche und offene ätiologische Konzepte. Das ist besonders dort spürbar, wo Schädlingsbekämpfung auf die bloße Beseitigung einer gefühlten Bedrohung durch wilde „reißende“ bzw. „giftige“ Tiere zielt. Der Schädlingsdiskurs ist besonders geeignet, um das Zusammenwirken mehrerer verschiedener mentaler Strömungen, aufklärerischer Ansätze und staatstheoretischer Fundierungen auf Naturleitbilder nachzuweisen (Herrmann 2007).

Das Grundproblem ist allgemein, aber nicht allgemein lösbar. Eine Leitbilddiskussion ist eine öffentliche Frage erst seit dem 19. Jahrhundert. Die Frage, wie soll, darf, kann, Natur aussehen, führt zwangsläufig zu normativen Naturkonzepten. Sie haben ihre besondere Schwierigkeit dann, wenn normative Konzepte von bestimmten konstanten Situationen ausgehen, was eine gängige Position in öffentli-

\footnotetext{
384 Zur Malariadiskussion, auch mit historischen Rückgriffen, Maier 2004

385 Hier wird auf den Zusammenhang zwischen dem Emotionalen und dem Ästhetischen in der Naturbetrachtung hingewiesen; s. u. und nächste Fußnote
} 
chen Leitbilddiskussionen ist. Konstante Zustände existieren in der Natur nicht. Weder im Naturzustand noch im Kulturzustand gibt es eine Artenkonstanz, eine Individuenkonstanz, eine Flächenkonstanz oder eine Prozesskonstanz. Daher geraten Naturleitbilder in Konflikt mit den realen Abläufen. Die Diskussion um den Problembär Bruno im Frühsommer 2006 führte das Dilemma in exemplarischer Weise vor. Populär gilt eine „Natur“ dann als „richtig“ und „schön“, wenn sich der Mensch in ihr mit interesselosem Wohlgefallen, ästhetisch befriedigt ${ }^{386}$ und ohne gefühlte Gefährdung aufhalten kann. Dies ist unverfälschtes Erbe der Aufklärung, in der die Natur vielfältig, bis in die Ästhetik hinein, ökonomisiert wurde, dem selbst in Bayern mit dem Nationalpark Bayerischer Wald längst eine alternative Sicht auf Natur entgegengestellt ist. Ein Nationalpark ist nun allerdings eine Art begehbares Museum, ${ }^{387}$ wobei im konkreten Beispiel selbst noch unentschieden ist, ob die Vergangenheit oder die Zukunft musealsiert wurde. Der Konflikt um die Vorsteuerung von Naturkonzepten wird erst dann gelöst sein, wenn Rhein, Elbe und Oder endlich wegen der Menschen, die in den Flußauen siedeln, ihr Flussbett nicht mehr verlassen.

\footnotetext{
386 Die eminent wichtige Frage nach dem „Naturschönen“ beschäftigt nicht erst seit Kants Setzung vom ästhetischen ,interesselosen Wohlgefallen“ die Gemüter. Tatsächlich ist sie zentral für das Problem der Naturkonzepte, lange schon vor Walther von der Vogelweide. Die Verfolgung des Themas ist einer anderen Darstellung vorzubehalten. Ich verweise hier lediglich auf den Satz von Adorno „Schön ist an der Natur, was mehr erscheint, denn was es buchstäblich an Ort und Stelle ist" (2003, S. 111). Der Satz und sein (langatmiges) Umfeld bedeutet in der Substanz nicht notwendigerweise die Rückkehr zum voraufklärerischen Naturverständnis. Er variiert meiner Einsicht nach vielmehr lediglich die alte Entdeckung von Epiktet ( $†$ um 140 n. Chr.), wonach es nicht die Dinge wären, welche die Menschen verstörten, sondern die Meinungen über die Dinge. Die Meinungen über die Dinge der Natur wandeln sich, aber Meinungen über Natur sind als solche untrennbar mit ihr verbunden. Deshalb ist die Natur selbst, d.i. die Meinung darüber, was denn „Natur“ sei und wie sie zu bewerten wäre, selbstverständlich ein zeit- und epochenabhängiges Kulturprodukt.

387 Die Diskussion wäre etwas anders zu führen, wenn es in Europa eine philosophische Tradition von ,wilderness“ gäbe, wie sie sich in Amerika in der Nachfolge Emersons und Thoreaus herausbildete. Eine ironische Facette ist dabei allerdings, dass Thoreaus zeitweiliger Ausstieg aus der Gesellschaft und sein Leben in Walden praktisch in Sichtweite zur Stadt Concord erfolgte und nach rund zweieinhalb Jahren im September 1847 mit einem Defizit von etwas mehr als \$ 25 endete (Thoreau 1979). Was für eine Pointe: wilderness als ökonomisch subventionierter geistiger Luxus.
} 


\section{Literatur}

Adorno, Theodor: Ästhetische Theorie. Suhrkamp, Frankfurt 2003

Günter Bayerl: Die Natur als Warenhaus. In: Sylvia Hahn, Reinhold Reith (Hrsg.) UmweltGeschichte. Arbeitsfelder, Forschungsansätze, Perspektiven. Verlag für Geschichte und Politik, Wien/München 2001, S.33-52, S.39

Beck, Rainer: Die Abschaffung der „Wildnis“. Landschaftsästhetik, bäuerliche Wirtschaft und Ökologie zu Beginn der Moderne. In: Werner Konold (Hrsg.) Naturlandschaft Kulturlandschaft. Die Veränderung der Landschaften nach der Nutzbarmachung durch den Menschen. Ecomed, Landsberg 1996. S. 27 - 44

Carson, Rachel: Silent Spring, 1962 (Hier zitiert nach der deutschen Ausgabe: Der Stumme Frühling. Beck, München 1987)

Catton, William; Dunlap, Riley: A new ecological paradigm for post-exuberant sociology. American Behavioral Scientist 24 (1980): S.15 - 47

Crosby, Alfred: Ecological Imperialism: the biological expansion of Europe $900-1900$. Cambridge University Press, Cambridge usw. 1986

Dinzelbacher, Peter: Mittelalter. In: Peter Dinzelbacher (Hrsg.): Mensch und Tier in der Geschichte Europas. Kröner, Stuttgart 2000, S. 181 - 292

Dipper, Christof: Deutsche Geschichte 1648 - 1789. Suhrkamp, Frankfurt 1991

Gradmann, Eugen, Heimatschutz und Heimatpflege. Strecker \& Schröder, Stuttgart 1910

Holling, C.S., Gunderson, Lance; Ludwig, Donald: In Quest of a Theory of Adaptive Change. In: Lance Gunderson, C.S. Holling, Panarchy. Understanding transformations in human and natural systems. Island Press, Washington 2002. S. 3 - 22

Herrmann, Bernd [unter Mitarbeit von Martina Kaup]: „Nun blüht es von End' zu End' all überall.“ Die Eindeichung des Nieder-Oderbruchs 1747 - 1753. (Cottbuser Studien zur Geschichte von Technik, Arbeit und Umwelt 4). Waxmann, Münster, New York, München, Berlin 1997

Herrmann, Bernd: Der Blick der Lebenden auf ,Die Drei Toten'. Soemmerings ,Tambour Flies', der Arm Herzogs Christian von Braunschweig-Wolfenbüttel und das Ende des ,Wilden Mannes'. In: Wolfgang Braungart, Klaus Ridder, Friedmar Apel (Hrsg.): Wahrnehmen und Handeln. Perspektiven einer Literaturanthropologie. (Bielefelder Schriften zu Linguistik und Literaturwissenschaft) Aisthesis Verlag, Bielefeld 2004. S. $154-173$

Herrmann, Bernd (2006a): „Auf keinen Fall mehr als dreimal wöchentlich Krebse, Lachs oder Hasenbraten essen müssen!“ - Einige vernachlässigte Probleme der „historischen Biodiversität“. In: Hans-Peter Baum, Rainer Leng, Joachim Schneider (Hrsg.): Wirtschaft - Gesellschaft - Mentalitäten im Mittelalter. Festschrift zum 75. Geburtstag von Rolf Sprandel. Stuttgart 2006 (= Beiträge zur Wirtschafts- und Sozialgeschichte 107), S. $175-203$ 
Herrmann, Bernd (2006b): Zur Historisierung der Schädlingsbekämpfung. In: Torsten Meyer, Marcus Popplow (Hrsg.): Technik, Arbeit und Umwelt in der Geschichte. Günter Bayerl zum 60. Geburtstag. Waxmann, Münster u.a. 2006. S. 317 - 338

Herrmann, Bernd (2007) Ein Beitrag zur Kenntnis von Schädlingsbekämpfungen und ihren Konzepten im 18. und frühen 19. Jahrhundert an Beispielen aus BrandenburgPreußen.. In:Engelken,K., Hünniger,D., Windelen,S (Hrsg): Beten, Impfen, Sammeln. Zur Viehseuchen- und Schädlingsbekämpfung in der frühen Neuzeit. Universitätsverlag Göttingen. S 135 - 189

Jansen, Sarah: „Schädlinge“ Geschichte eines wissenschaftlichen und politischen Konstrukts 1840 - 1920. Campus, Frankfurt 2003.

Kaiser, Rudolf, Die Erde ist uns heilig. Die Reden des Chief Seattle und anderer indianischer Häuptlinge. Herder; Freiburg, Basel, Wien 1992

Klose, Johannes: Aspekte der Wertschätzung von Vögeln in Brandenburg: Zur Bedeutung der Artenvielfalt vom 16. bis zum 20. Jahrhundert. Diss. Biol. Fak. Göttingen 2004

Konold, Werner (Hrsg.): Naturlandschaft - Kulturlandschaft. Die Veränderung der Landschaften nach der Nutzbarmachung durch den Menschen. Ecomed, Landsberg 1996

Krafft, Abraham Friedrich: Der sowohl Menschen und Viehe grausamen Thiere/schädlichen Ungeziefers und verderblicher Gewürmer gäntzliche Ausrottung... Buggel, Nürnberg 1712 (anderer Theil), 1713 (erster Theil)

Kretzschmer, Peter: Peter Krezschmers Oeconomische Vorschläge wie das Holz zu vermehren, die Strassen mit schönen Alleen zu besetzen, in geraden Linien, wodurch selbige weit kürtzer und verbessert würden, von Ort zu Ort zu bringen, mehr Aecker dadurch fruchtbar zu machen/ und die Maulbeer-Baum-Plantagen damit zu verknüpffen. Endlich auch die Obst-Bäume anzulegen, und die Sperlinge nebst denen Maulwürffen zu vertilgen sind : nebst einem Anhange ohnmaßgeblicher Vorschläge, wie mit großer Herren Küchen und Tafeln verbessert, und zur Gesundheit dienlicher eingerichtet werden können. Halle, Leipzig 1744

Leven, Karl-Heinz: Die Geschichte der Infektionskrankheiten. Von der Antike bis ins 20. Jahrhundert. Bd. 6 Fortschritte der Präventiv- und Arbeitsmedizin. Ecomed, Landsberg/Lech 1997

Lepenies, Wolf: Das Ende der Naturgeschichte. Wandel kultureller Selbstverständlichkeiten in den Wissenschaften des 18. und 19. Jahrhunderts. Suhrkamp, Frankfurt 1986

Lovejoy, Arthur O.: Die große Kette der Wesen. Frankfurt 1993

Lübbe, Hermann: Ökologische Probleme im kulturellen Wandel. In: Hermann Lübbe, Elisabeth Ströker, (Hrsg.): Ökologische Probleme im kulturellen Wandel. Wilhelm Fink, Ferdinand Schöningh, Paderborn 1986, S. 9 - 14

Maier, Walter: Das Verschwinden des Sumpffiebers in Europa: Zufall oder Notwendigkeit? Denisia 13, S. 515 - 527, 2004 
Mann, Charles: 1491: New revelations of the Americas before Columbus. Knopf, New York 2005

Marx, Karl, Das Kapital. In: Karl Marx, Friedrich Engels, Werke, Band 23, „Das Kapital“, Bd. I, Dritter Abschnitt Dietz Verlag, Berlin/DDR 1968

Meyer, Torsten: Natur, Technik und Wirtschaftswachstum im 18. Jahrhundert. Risikoperzeption und Sicherheitsversprechen. (Cottbuser Studien zur Geschichte von Technik, Arbeit und Umwelt 12). Waxmann, Münster, New York, München, Berlin 1999

Ryle, Gilbert: Der Begriff des Geistes. Reclam Stuttgart 2002

Thoreau, Henry David: Walden oder Leben in den Wäldern. Diogenes, Zürich 1979

Tulla, Johann Gottfried: Über die Rektifikation des Rheins, von seinem Austritt aus der Schweiz bis zu seinem Eintritt in das Großherzogthum Hessen. Müller, Karlsruhe 1825

von Uexküll, Jakob: Umwelt und Innenwelt der Tiere. Springer, Berlin 1921

WBGU (Wissenschaftlicher Beirat der Bundesregierung Globale Umweltveränderungen): Erhaltung und nachhaltige Nutzung der Biosphäre. Jahresgutachten 1999. Springer, Berlin usw. 2000 



\title{
Umweltgeschichte wozu? Zur gesellschaftlichen Relevanz einer jungen Disziplin
}

\author{
Bernd Herrmann 388
}

\section{Umweltgeschichte}

Das Organisationskomitee hatte mir die Aufgabe des Eröffnungsreferates übertragen. Als wäre allein die Rede über den Gegenstand der „Umweltgeschichte“ nicht Aufgabe genug, sollte sie auch noch mit der Relevanzfrage verknüpft werden.

Die folgende Zweiteilung meines Beitrags folgt der inneren Logik des Auftrags. Zunächst wird es um Inhaltliches und Disziplinäres der Umweltgeschichte gehen müssen, anschließend wird die Relevanzfrage samt ihres Umfeldes erörtert.

\subsection{Umwelt}

Dass die Umweltgeschichte als thematischer Rabmen älter ist als ihr Name, wird niemanden verwundern. Teile der Bibel, die als Parabel über die Neolithisierung gelesen werden können, der Mythos um die Gründung Athens, ${ }^{389}$ Guaman Poma de

\footnotetext{
388 Zuerst erschienen in: Masius P, Sparenberg O, Sprenger J (Hrsg.)(2009) Umweltgeschichte und Umweltzukunft. Zur gesellschaftlichen Relevanz einer jungen Disziplin. Universitätsverlag Göttingen, Göttingen. S. 13-50

389 Vor allem der Zeugungsmythos um den sagenhaften Athenischen König Erichthonios (Laroux 1993).
} 
Ayalas ${ }^{390}$ Geschichte seines südamerikanischen Volkes bis zur Ankunft der Europäer, die präzisen Beobachtungen, die uns Babur, 391 der Gründer der indischen Mogulnherrschaft, hinterlassen hat, Voltaires Candide, Kants Anthropologie 392 und Humboldts Kosmos sind nur einige namhafte Beispiele aus einer sehr langen Liste, die selbstverständlich bis in die vorschriftliche Tradition verlängert werden muss. Sie bezeugt, dass der reflektierende Geist dem Umgang des Menschen mit der „Natur“ und ihren Auswirkungen auf den Menschen zu allen Zeiten eine erhebliche Bedeutung beimaß. Sicherlich ist hierin auch eine Anerkennung der Bedeutung materieller Faktoren für den Lauf der Geschichte zu sehen. Die Zuschreibung von Sinn und Bedeutung eben auch der naturalen Elemente verleihen der sinnlosen Unendlichkeit des Weltgeschehens ihre je spezifische kulturelle Qualität. ${ }^{393}$ Insofern muss die Auseinandersetzung mit „Natur“, mit „Umwelt“ für jede Gesellschaft, für jede Kultur zentral sein. Sie ist es selbst dann, wenn sie die Überwindung der Leiblichkeit sucht und eine vergeistigte Lebensführung in asketischer Reduktion aller Ansprüche gegen eine wie immer aussehende „Umwelt“ als Leitidee einführt.

Niemand kann der Umwelt entkommen, ${ }^{394}$ weil sie konstitutiver Teil seiner selbst ist. Seit ihrer spezifischen Entdeckung durch Johannes von Uexküll (1864-1944) ${ }^{395}$ ist sie, gemeinsam mit der Genetik, das bestimmende Epistem der

390 Guaman Poma de Ayala (ca. 1550 - nach 1615), adeliger peruanischer Herkunft, zeitweilig in spanischen Diensten, beschrieb in „Nueva Crónica y Buen Gobierno“ eine Geschichte seines Volkes und seiner Kultur in vorspanischer Zeit. Eine umwelthistorische Aufarbeitung des Werks steht aus. Digital erreichbar unter: http://www.kb.dk/permalink/2006/poma/info/es/frontpage.htm

391 Das Baburnama, Das Tagebuch von Babur (1483 - 1530), enthält eine Fülle umwelthistorischer Details aus seinem Herrschaftsbereich (Stammer 1988). Aufgearbeitet sind bisher die zoologischen und botanischen Hinweise des Werks.

392 Als einer der Gründerväter der Anthropologie hatte sich auch Kant mit den Auswirkungen der naturalen Determinanten als Ursache der Variabilität des äußeren Erscheinungsbildes des Menschen intensiv auseinander gesetzt. Seine Betonung u.a. der Klimafaktoren ist im Grundsatz und auf einer sehr allgemeinen Ebene richtig, die von ihm angeführten konkreten Kausalitäten sind jedoch naturwissenschaftlich nicht zutreffend. Im Prinzip führen ihn diese behaupteten Kausalitäten, wie andere zeitgenössische Autoren auch, zu Idealtypologien. Solche werden Ende des 19. Jh.s in den entstehenden „geographischen Determinismus“ übernommen.

393 „, Kultur ${ }^{`}$ ist ein vom Standpunkt des Menschen aus mit Sinn und Bedeutung bedachter endlicher Ausschnitt aus der sinnlosen Unendlichkeit des Weltgeschehens. Sie ist es für den Menschen auch dann, wenn er einer konkreten Kultur als Todfeind sich entgegenstellt und ,Rückkehr zur Natur' verlangt. Denn auch zu dieser Stellungnahme kann er nur gelangen, indem er die konkrete Kultur auf seine Wertideen bezieht und ,zu leicht' befindet.“ Max Weber (1988a, S. 180).

394 Hier und im Folgenden wird ausschließlich auf den Umweltbegriff der Lebenswissenschaften bezogen. Ausschließlich aus diesem Bezug ergeben sich spezifische geschichtstheoretische Anschlüsse, weil die auch mögliche Lesart „Umgebung“ für „Umwelt“ sich für jede beliebige andere Geschichtsbetrachtung hergibt.

395 Umwelt und Innenwelt der Tiere 1909. Innerhalb dieses Aufsatzes beziehe ich mich auf die zweite, verbesserte Auflage von 1921.- In der Sekundärliteratur finden sich häufiger sinngemäße Hinweise, bei denen der Eindruck erweckt wird, sie griffen auf von Uexkülls „Umwelt und Innenwelt" zurück. Tatsächlich lesen sich in seiner „Theoretischen Biologie“ [1928] einige Passagen als gereifte Erläuterungen zu „Umwelt und Innenwelt“, auf die dann stellvertretend zurückgegriffen wird. Auch stammt das berühmt gewordene Zeckenbeispiel nicht aus „Umwelt und Innenwelt“, sondern ist erst 1934 veröffentlicht worden (von Uexküll \& Kriszat 1934). 
modernen Biologie geworden und hat darüber hinaus eigentlich alle Bereiche des gesellschaftlichen und kulturellen Lebens erreicht. Von Üxkuell hatte „Umgebung“ von „Umwelt“ geschieden und als entscheidende Differenz diejenige zwischen der bloßen Aufnahme von Objekten im Raum („Umgebung“准) und dem „Weltbild“ eines Lebewesens benannt, das durch bestimmten Beziehungen des Lebewesens zu seiner Außenwelt entsteht („Umwelt“, später auch synonym „Eigenwelt“). Umwelt ist bei von Uexküll als Relationsbegriff zu verstehen. ${ }^{396}$ Anders als „Natur“ ist „Umwelt" nicht er-lebbar, sondern nur lebbar. Sie lässt sich nicht verdinglichen.

Es handelt sich um einen Einflussbereich, der vom Individuum gestaltet wird, in den Dinge der Umgebung eintreten, der aber in jedem Falle ein ausschließlich individueller Bereich bleibt und sich zudem grundsätzlich der Erfabrbarkeit durch andere Lebewesen entzieht. Das je spezifische Lebewesen und der Raum „Umwelt“, in dem es sich bewegt, fallen zusammen. ${ }^{397}$

Anders als von Uexküll intendierte, operationalisierten die meisten Biowissenschaften „Umwelt“ hin zu einem Dingbegriff. Damit war Objektivierung und Verwendungsmöglichkeit für Gruppen von Lebewesen gewonnen. Die frühen Profiteure des Gedankens von Uexkülls haben außerdem seinen Umweltbegriff, der Anstoß gebend fruchtbar für die Entstehung der ökologischen Disziplinen und der Verhaltensforschung wurde, für ,eng “ gehalten, ${ }^{398}$ und ihn ziemlich über seine

${ }^{396}$ Das Wort „Umwelt“ ist ein Neologismus aus dem Jahre 1800, und beschreibt, vor dem späteren Gebrauch des Wortes „Milieu“, »die den Menschen umgebende Welt« (DWB). In diesem milieutheoretischen Sine scheint der Begriff auch heute von Historikern verstanden zu werden, selbst wenn sie sich auf von Uexküll beziehen, wie etwa Radkau (2002, S.14). Nur bei einem solchen Verständnis kann Umwelt ein „anthropozentrischer Begriff“ sein. Der Anschluss an von Uexküll trifft an dieser Stelle jedoch nicht zu, da von Uexküll seine Umweltdefinition allgemein als artbezogen verstanden wissen wollte. Erst in einem spezielleren Verständnis kann „Umwelt“ aus menschlicher Perspektive zu einem anthropozentrischen Epistem werden. Wenn man jedoch so verfährt, kann es keine „Umwelt des Seeigels" usw. geben, weil in jedem Falle eine anthropozentrische Zuschreibung vorläge. Damit müsste ein allgemeiner Bezug auf von Uexküll entfallen und dürfte nur als spezieller Bezug zugelassen werden.

397 „Es gibt also reine subjektive Wirklichkeiten in den Umwelten. Aber auch die objektiven Wirklichkeiten der Umgebung treten nie als solche in den Umwelten auf. Sie werden stets in Merkmale oder Merkbilder verwandelt und mit einem Wirkton versehen, der sie erst zu wirklichen Gegenständen macht, obgleich vom Wirkton in den Reizen nichts vorhanden ist. Und schließlich lehrt uns der einfache Funktionskreis, dass sowohl die Merkmale wie Wirkmale Äußerungen des Subjekts sind und die Eigenschaften der Objekte, die der Funktionskreis einschließt, nur als ihre Träger angesprochen werden können. So kommen wir dann zum Schluss, dass ein jedes Subjekt in einer Welt lebt, in der es nur subjektive Wirklichkeiten gibt und die Umwelten selbst nur subjektive Wirklichkeiten darstellen. Wer die Existenz subjektiver Wirklichkeiten leugnet, hat die Grundlagen seiner eigenen Existenz nicht erkannt.“" (von Uexküll \& Kriszat 1934, S.93).

398 So z.B. Thienemann (1958, S. 9). - Die unter den (deutschsprachigen) Biologen des 20. Jh.s gängige Verständnisformel für „Umwelt“ ist nach meiner Kenntnis von Friedrichs (1943), jenseits der ideologischen Einsprengsel (Friedrichs ist von 1940 -1945 Zoologe an der Reichsuniversität Posen), herausgearbeitet worden: Er definierte Umwelt „für den praktischen Gebrauch“ als „Komplex der direkten und der konkret greifbaren indirekten Beziebungen zur Außenwelt." Der Unterschied gegenüber der Definition von Uexkülls bestehe in der Aufnahme aller Beziehungen (Friedrichs 1943, S.157). Eine überdachte Begriffserläuterung durch Friedrichs (1950) kann als für die nachfolgenden Biologen leitend bezeichnet werden, ohne dass die Autoren sich jeweils explicit auf Friedrichs bezogen hätten. Friedrichs fasste die Leitlinien des biologischen Diskurses zusammen, wie er davor bestimmend war und es im Grunde bis heute ist. Von Uexkülls Einfluss auf die akademische Biologie blieb aus ver- 
Intentionen hinaus geändert. Die Biologen nehmen mit dem Umweltbegriff Bezug „auf dasjenige außerbalb des Subjekts, was dieses irgendwie angeht“. 399 Doch eigentlich handelt es sich nur darum, dass die Natur-Wissenschaft für ihre Aussagen über „Natur“ bzw. die „Umwelt“ messbare Größen, reproduzierbare analytische Kategorien und Zugangsmöglichkeit zum Forschungsgegenstand benötigt und das Subjektive aus der Naturwissenschaft entfernt. ${ }^{400}$ Eine Betrachtungsbeschränkung auf die Umwelt nur eines einzigen Lebewesens, eine subjektive Biologie, stünde zudem im Konflikt mit den Zielen der Naturwissenschaft, die Differenz zwischen Ereignis und Struktur, zwischen Zufall und Notwendigkeit aufzudecken, weshalb der Befund am Individuum stellvertretend als Regelverhalten der gesamten Art gilt. ${ }^{401}$ An diesem Missverständnis oder diesen Parallelpositionen hat sich bis heute wenig geändert. ${ }^{402}$ Nicht einmal, als Nagel (1974) in seinem berühmt gewordenen Aufsatz „What is it like to be a bat?" die Unmöglichkeit nachwies, sich in die Erlebniswelt der Fledermaus hinein zu versetzen. Während von Uexküll aber der Auffassung war, dass die Wissenschaft aus dem morphologisch-physiologischen Korrelat des Tiers hinreichend Aufschluss über dessen spezifische Erfahrungswelt gebe und das Verstehen des Korrelats gleichbedeutend mit dem Verständnis des Lebewesens wäre, 403 entwickelt Nagel den Gedanken erkenntnistheoretisch weiter und kommt zu dem Schluss, dass die Kenntnis des Korrelats keine Erkenntnis über die Erlebniswelt des (anderen) Organismus liefert. 404

schiedenen Gründen begrenzt, vor allem wohl, weil seine Ideen an vitalistische Vorstellungen anschließen, denen die moderne Biologie distanziert gegenüber steht.

${ }^{399}$ Friedrichs 1950, S.70.

400 Sowohl das Subjektive des Beobachters oder Experimentators als auch das Individuelle des Untersuchungsobjekts.

401 Überraschender Weise ist von Uexküll selbst dieser Perspektive seiner Gedanken nicht weiter nachgegangen. Als Biologe hatte er die Umwelt der Art im Blick. Seine Entdeckung der Umwelt hätte logisch in die Zuschreibung je individueller Umwelten führen müssen. Solche individuellen Umwelttönungen akzeptiert er für Menschen, die von ihm aufgeführten Beispiele sehr subjektiven (individualistischen) Verhaltens bei Tieren klassifiziert er überraschend als aberrantes bis subpathologisches Verhalten.

402 Tatsächlich ist es heute gängige biologische Praxis, einen weitgehend von komplexen Bedeutungsinhalten befreiten Umweltbegriff zu verwenden. Zumeist beschreibt dieser, jenseits seines erkenntnistheoretischen Ursprungs, nur noch Forschungsfelder. Er ist damit auch in der Biologie zu einer Black-Box-Vokabel geworden, vergleichbar etwa der umgangssprachlichen Verwendung des Begriffs „Gesellschaft“. Eine analytische, erklärende Qualität, wie sie sich von Uexküll vorstellte, wohnt ihm heute nicht inne. Spätestens seit die internationale (natur-)-wissenschaftliche Literatur anstelle von „Umwelt" das Wort „environment" verwendet, sind die sub- und metatextlichen Bedeutungen ausgeblendet.

403 Mit der Kenntnis des artspezifischen sensorischen Apparates wäre dann auch die Umwelt der Lebewesen einer Art erschlossen. Deshalb kann von Uexküll sagen, dass es „in der Welt der Mücke nur Mückendinge" gebe, in der der Zecke nur Zeckendinge, für die Seeigel nur Seeigeldinge usw.

${ }^{404}$ Der Anschluss Nagels an die bekannte „Ignoramus-ignorabimus“- Rede Emil Du Bois-Reymonds von 1872 ist unübersehbar, die Verbindung zu von Uexküll wird übersehen. Es handelt sich bei diesem Streit um erkenntnistheoretische Grundpositionen innerhalb der modernen Biologie, deren weitere Ausführung den Rahmen sprengen würde. Hier nur soviel: der Streit ist nicht entschieden und wird gegenwärtig zwischen Hirnforschern und Neurobiologen auf der einen, und Erkenntnisphilosophen auf der andern Seite geführt. Dabei geht es um die zentrale Frage, ob eine Willensfreiheit des Menschen existiere oder der menschliche Wille ein bloßes Produkt molekularer Konzentrationen 
Die inflationäre Verwendung des Begriffs „Umwelt“ und seine scheinbare Einfachheit haben in den letzten Jahrzehnten dazu geführt, dass kaum noch darüber nachgedacht wird, welches die Grundlagen des Begriffs waren, welches seine philosophischen Implikationen sind und welche Bedeutungen die Übernahme des Begriffs in außerbiologische Verwertungszusammenhänge hat. Dabei hatte doch spätestens Ernst Cassirer mit seinem „Versuch über den Menschen“ (1944) die Komplexität, aber auch die Produktivität, des Umweltbezugs demonstriert, in dem er die Aneignung der Welt durch Menschen als über eine Symbolwelt geleitet erkannte. Im direkten Anschluss an von Uexküll ist für Cassirer (beide hatten als Hamburger Kollegen Berührungen) der Mensch durch seine spezifischen Umweltbezüge als „animal symbolicum" definiert. Die geschichtstheoretisch nutzbare Konsequenz aus Cassirers Überlegung ist offensichtlich und zweifach:

Nichts auf der Welt ist dem Menschen einfach gegeben, alles muss von ihm symbolisch-kulturell dargestellt bzw. vermittelt werden und mit Sinnzuschreibung versehen werden. Damit wird selbstverständlich auch „Natur“ zu einem Kulturbegriff.

Fasst man weiterhin die alltagsweltlichen Bereiche oder die Institutionen zu je eigenen Symbolkomplexen zusammen, mündet dies in die bekannten Partikulargeschichten der Geschichtswissenschaften, wenn auch unter anderer Nomenklatur.

Es ist bemerkenswert, dass der umwelthistorischen Forschung das Wort „Umwelt“ im Wortgefüge „Umweltgeschichte“ bisher nicht Anlass zu einer theoriegerichteten Begriffsanalyse war. ${ }^{405}$ Nach meiner Einsicht scheint eine Umweltgeschichte mancher Autoren dem Umweltbegriff von Uexkülls unbewusst viel näher zu sein als dem umgangssprachlichen Verständnis von „Umwelt“, das dem der heutigen Bio-Disziplinen entspricht. Wer Umwelthandeln als subjektive Kategorie thematisiert, thematisiert zwar die Welt der „Menschendinge“. Nur redete er dann nicht mehr über eine objektivierbare Welt, nämlich diejenige Welt der Wissenschaft.

Eine objektivierbare Welt, also eine reproduzierbar vermittelbare Weltsicht, ist hingegen zum Teil sicherlich Folge subjektiven Umwelthandelns, sie ist aber ebenso Folge eines Prozessgeschehens außerhalb menschlicher Ursache oder Zuständigkeit. Daher ist die Aufnahme naturhistorischer Zustände in die Umweltge-

und neurophysiologischer Kaskaden sei. Wenn Nagels Überlegung richtig ist, könnten konsequenterweise bestimmte Forschungsbereiche aufgegeben werden. Diese Perspektive täte sich dann auch für „Umwelt“-Forschung auf. Sie stellt sich deshalb nicht, weil die oberflächliche Rezeption der Gedanken von Uexkülls bzw. die Abgrenzung ihnen gegenüber allmählich in die heute gängige Begriffspraxis mündete (siehe Friedrichs 1950).

405 Ich danke Verena Winiwarter für den Hinweis auf ihren Aufsatz von 1994, der mir bei Abfassung der Vorversion dieses Beitrags nicht gewärtig war. Mein Urteil ist also entsprechend zu relativieren. Bei dem Aufsatz von Winiwarter handelt es sich um eine Begriffsanalyse, die weiter als für den von mir verfolgten Zweck reicht, da sich nach meiner Einsicht der Umweltbegriff der „Umweltgeschichte" historisch und inhaltlich einem ausschließlichen Bezug auf die lebenswissenschaftliche Verwendungspraxis des Umweltbegriffs verdankt. Parallelverwendungen des Begriffs, die Winiwarter mit untersucht hat, liegen daher außerhalb meines Bezugsrahmens. 
schichte nach der Formel „Rezeption und Rekonstruktion“ des Göttinger Graduiertenkollegs zwangsläufig.

Neben den Vorbehalten, die von biologischer Seite gegenüber den Vorstellungen von Uexkülls geäußert wurden, steht zusätzlich jener ernste Einwand Adolf Portmanns, ${ }^{406}$ der von Uexküll ein Missverständnis seiner eigenen Theorie nachweist, wenn er beim Versuch der Übertragung seiner „Umwelt“-Idee einen entscheidenden Umstand vernachlässigt. Im Gegensatz zur arttypischen Umweltstruktur, die den Tieren zukomme, werden im Falle des Menschen diese arttypischen Differenzen gegenstandslos, weil ,alle diese verschiedenen Weltsichten ${ }^{407}$ an einer gemeinsamen Artwelt teilhaben, dass, Verstehen 'verschiedener derartiger Umwelten möglich ist - dass eine Aussprache über Gegensätze der Auffassung stattfinden kann.“

Das nach meinem Verständnis Neue in der Geschichtsbetrachtung umwelthistorischer Ausrichtung besteht in dem von ihr praktizierten Perspektivenwechsel, in dem ich eine Erweiterung historischer Fragestellungen und Bewertungen durch das Weglassen oder Ergänzen bisheriger Bezüge sehe, wofür folgendes Beispiel steht. André Malraux wird die Bemerkung über das Niederländische Stillleben zugesprochen: „Dass man einen Fisch auf einen Teller legen kann, bat Holland nicht erfunden, dafür aber, dass dieser Fisch nicht mehr die Speise des Apostels zu sein braucht." In nämlicher Weise hat Svetlana Alpers (1998) argumentiert, dass in der entsakralisierten dinghaften Darstellung der Stilllebenmaler "mit getreulicher Hand und ebrlichem Auge" eine der mächtigen Wurzeln der neuzeitlichen Naturwissenschaft zu sehen ist. Das Neue entsteht durch das Weglassen alter Bezüge, durch ihre Neuordnung und ihre Erweiterung.

Kopfläuse, Wasserstände, die Kleine Eiszeit und dergleichen haben Umwelthistoriker nicht erfunden, wohl aber, dass ihre Beachtung den Blick auf den Prozess der Geschichte um entscheidende Determinanten weitet. „Natur“, „Umwelt“ und ihre Begleiter werden in der Umweltgeschichte in einer anderen, eigenständigen Weise als bisher in die Geschichtsbetrachtung eingebracht. Dem Naturalen wird Geschichtsmacht zugebilligt, die Ausrichtung der Rezeption und des Handelns auf sie werden anerkannt. ${ }^{408}$ Nur hat das ideengeschichtlich mit von Uexküll praktisch nichts zu tun. Die gedankliche Verbindung zwischen „Umwelt“ und „Geschichte“ musste eigenständig konstruiert werden. Dass diese Verbindung sich ggfl. in von Uexkülls Gedankenwelt einfügen lässt und deshalb letztlich auch fälschlich für eine von seiner Einsicht mitgetragenen Idee gehalten wird, ist eine andere Sache.

\footnotetext{
406 Adolf Portmann (1997 - 1982), bedeutender Zoologe und Verfasser biologisch-philosophischer Abhandlungen, im Vorwort zu von Uexküll \& Kriszat (1956, S.11).

407 Portmann, a.a.O. Hier meint Portmann die Differenzen zwischen verschiedenen Überzeugungssystemen und Kulturen.

${ }^{408}$ Beispielhaft angelegt bei Borst (1981)
} 
Die unlängst geäußerten Überlegungen von Haidle (2008) können beispielhaft für ein heute verbreitetes, verkürztes Verständnis und fast reflexhaftes Zitieren der angeblichen Gedanken von Uexkülls benannt werden, der sich dagegen wehren würde, „Umwelt als ein Ausschnitt aus der Umgebung“409 zu verstehen. Heute, und so auch bei Haidle, wird philosophisch z.B. auf ein Urteil wie das von Sloterdijk

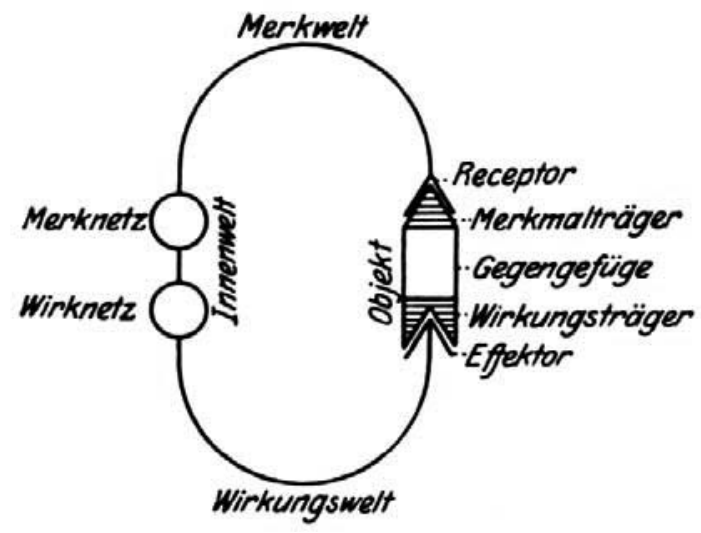

Abb1. Schema des Funktionskreises (aus von Uexküll 1921:45). Die Wirkungswelt (Wirkwelt) bezeichnet alles, was ein Tier in seiner Umgebung aktiv zu bewirken vermag: Bau eines Stauwehres durch Biber, das Radnetz der Spinne, die Grabungstätigkeit des Maulwurfs, der Nestbau der Vögel. Die Merkwelt (engl. perceptual field) ist derjenige Ausschnitt der Außenwelt eines Tieres, der von seinen Sinnesorganen erfasst und seinem Zentralnervensystem zugeleitet wird. Nach von Uexküll existieren in der Umwelt des Tieres nur jene Dinge oder Zustände, die wahrgenommen werden. Diese Wahrnehmung und seine neuronale Verarbeitung sind individuenspezifisch bzw. artspezifisch. ${ }^{410}$ Das Diagramm stellt der Innenwelt des Tieres die verdinglichte Form der Wechselwirkung zwischen Objekt und Tier gegenüber. Zu weiteren Erläuterungen wird auf die Originalpublikation verwiesen.

(2001) vertraut. Dieser hatte ein passives bzw. reaktives tierliches „UmweltHaben“ einem aktiven bzw. kreativen menschlichen „In-der-Welt-Sein“ gegenüber

\footnotetext{
409 Haidle 2008, S.30.

410 „Es ist zweifellos richtig, wenn wir sagen, in der Welt der Mücke gibt es nur Mückendinge. Wie aber die Mückendinge gestaltet sind, das verlangt eine genaue Untersuchung. Der wichtigste effektorische Apparat einer Mücke, nämlich ihr Stachel, ist für unser Blut gebaut. Von unserem Blut aber erfahren die Rezeptoren der Mücke keine Einwirkung; dafür ist es der Duft unserer Hautdrüsen, der auf sie einwirkt. Die Hautdrüsen und das Blut des Menschen sind durch das anatomische Gegengefüge der menschlichen Haut miteinander verknüpft, das wohl innerhalb des Funktionskreises der Mücke liegt, aber gänzlich außerhalb jeder Merkmöglichkeit für den Mückenorganismus gelegen ist.“ (von Uexküll 1921, S. 217).
} 
gestellt. ${ }^{411}$ Die inhaltliche Nähe dieser Definition zur cartesisch-kantischen Unterscheidung zwischen behavioristischen Automaten (Tieren) und willensfreien Wesen (Menschen) ist unübersehbar, war aber überhaupt nicht von Uexkülls Thema, als er seine Theorie formulierte. ${ }^{412}$ Außerdem ergibt sich, unter Vernachlässigung der von Nagel geäußerten Bedenken, nicht nur Anschluss an die weiter unten kritisierte Position von Maurice Godelier. Die hier erwähnte Meinung Haidles führt schließlich auch zu der kritisch zu bewertenden Opposition „Mensch und Umwelt", die ich als ein folgenschweres Kategorienproblem begreife, der sich ein Teil des heutigen Umweltdilemmas überhaupt verdankt. ${ }^{413}$

Wer sich auf von Uexkülls Umweltbegriff (auch engl. ,umwelt*) beruft, bezieht sich heute auf eine psychische Umwelt bzw. die „Eigenwelt“ eines Tieres, die aus Funktionskreisen besteht, welche sich aus der „Merkwelt“ und der „Wirkwelt“ des Tieres ergeben (Abb.1).

\subsection{Umweltgeschichte}

Erprobte man nun den Begriff der „Umweltgeschichte“ vor diesem vielschichtigen Hintergrund, der hier nur sehr kursorisch skizziert ist, müsste man die zunächst individualistisch zu denkenden Umwelten einzelner Menschen zu einer gemeinsamen Geschichte verbinden und würde schließlich, über jeweils zusammenführende Ebenen von Klassen, Gesellschaften, Kulturen, dem naturalen Tableau usw., bei einem die gesamte Menschheit und die physischen Zustände einschließenden Umweltgeschichtsbegriff enden. Es ist offensichtlich, dass dies ein Synonymbegriff für eine ,histoire totale“ wäre. Nur einmal, soweit ich das sehe, ist die Geschichtstheorie explizit ${ }^{414}$ in die Nähe dieser Auffassung gekommen, und zwar durch Bündelung

411 Diese Position entspricht der Setzung von F.L.Ward (1903) aus soziologischer Perspektive, auf die in Fußnote 27 näher eingegangen wird.

412 Die Übertragung auf menschliche Zusammenhänge erfolgt erst in „Streifzüge durch die Umwelten von Tieren und Menschen“ (1956 [1934], Kap. 13). - Nicht erst an dieser Stelle wird deutlich, dass die in Teilen der praktizierten Umweltgeschichte behauptete anthropologische Dimension bisher tatsächlich wenig von den Vorarbeiten der philosophischen Anthropologie profitiert hat.

413 Ansätze hierzu in Hermann 2008; sonst in Vorbereitung. Aus meiner Sicht sind „Mensch und Umwelt“ ebenso wenig äquivalente Kategorien wie „Körper und Geist“. Dieser „Descartsche Mythos" war durch Ryle [1969] dekonstruiert worden. Es scheint so, als würde der von Ryle identifizierte Fehler einer inkompatiblen ontologischen Kategorienbildung in den Umweltdiskursen mit dem Begriffspaar „Mensch und Umwelt“ wiederholt. Eine Position, die den Menschen neben der „Umwelt" oder ihr gegenüber sieht, spricht nicht von „Umwelt" sondern von „Umgebung“ und hat das Selbstverständnis von der menschlichen Sonderrolle auf der Erde noch nicht verlassen. „Umwelt“ (eigentlich „Umgebung“) und „Mensch“ sind dabei voneinander geschieden. Zahlreiche Missverständnisse resultieren aus der Tatsache, dass das Begriffspaar „Mensch und Umwelt“ häufiger nicht in einem ontologischen, sondern in einem analytischen Verständnis verwendet wird, ohne dass die Autoren dies besonders vermerken würden, allermeist scheint es ihnen sogar zu entgehen.

${ }^{414}$ Ich beziehe mich hier ausschließlich auf explizit geäußerte geschichtstheoretische Positionen. Ich übersehe nicht, dass in den großen Darstellungen zur Weltumweltgeschichte, etwa von Diamond, McNeill und Radkau, implizite theoretische Konzepte enthalten sind. Mir erscheint fraglich, ob die Autoren ihre Beiträge primär als dezidierte geschichtstheoretische Erweiterung oder Präzisierung aufgefasst wissen wollen. Deshalb werden sie hier in diesem Sinne auch nicht weiter diskutiert. 
von Überlegungen zum Umweltgeschichtsbegriff unterschiedlicher Provenienz, also durch induktives Schließen (Lehmkuhl 2002). Freilich ist bei diesem erkenntnistheoretischen Umweg nicht an von Uexküll angeknüpft worden:

„Als Synthesewissenschaft analysiert sie [d.i. die Umweltgeschichte, $B H]$ ₹.B. die Frage nach den Akteursqualitäten von Natur und Umwelt, und dies auf zwei Ebenen: zum einen, indem Einflüsse von Natur und Umwelt auf menschliches Handeln und Verhalten in den Blick genommen werden; zum anderen, indem Ideen über Natur als ökologische Akteure konzeptualisiert werden. Umweltgeschichte beschäftigt sich mit Phänomenen, die sich nicht in ein nationalhistorisches Korsett zwängen lassen, sondern transnationale Geschichtsschreibung oder sogar einen „globalen" Ansatz im Sinne der neuen global history verlangen. Dabei werden Konzepte von Ökonomie, Kultur und Ökologie in neue analytische Zusammenhänge gestellt und heuristisch fruchtbar gemacht, und auch dies auf unterschiedliche Weise: durch eine ökologisch perspektivierte Kulturanalyse, oder durch die Analyse des Dialogs zwischen Ökologie und Ökonomie oder [...] durch die Analyse der Interdependenz aller drei Faktoren, Ökologie, Ökonomie und Kultur. "415

Die Ablösung von „Umwelt“ vom Individuum und die ihr zugeschriebene eigenständige Akteursqualität, wie in diesem Beispiel, ist das am häufigsten anzutreffende gründliche Missverständnis des Umweltbegriffs von Uexkülls (s.o.).

Definitionen von „Umweltgeschichte“, die sich zudem nicht weiter mit Monita aufhalten, sind schnell zur Hand, wenn auch weniger zahlreich als man annehmen möchte. Das könnte zum einen daran liegen, dass in den Geschichtswissenschaften systematische Lehrbücher oder Review-Aufsätze nicht häufig sind. Gewiss liegt es aber auch daran, dass der Gegenstand der Umweltgeschichte vermeintlich ähnlich offensichtlich erscheint, wie z.B. derjenige der Botanik oder der Kirchengeschichte. Definitionen etwa der Botanik oder der Kirchengeschichte gehen für den Fachferneren kaum erkennbar über das intuitiv Selbstverständliche hinaus. In welche semantischen wie erkenntnistheoretischen Probleme man sich aber mit Definitionsversuchen hineinmanövrieren kann, sei an nur einem Beispiel skizziert:

Die Behauptung Maurice Godeliers, der Mensch habe deswegen Geschichte, weil er die Natur verändere, ist lediglich eine pointierte Spezialformulierung dafür, dass der Geschichtsbegriff an die aus menschlicher Ursache resultierenden Zustände in der Welt geknüpft ist. „... human beings have a bistory because they transform nature. It is indeed this capacity which defines them as humans. Of all forces which set them in movement and prompt them to invent new forms of society, the most profound is their ability to transform their relations with nature by transforming nature itself." (Godelier 1986, S. 2-3. Hervorhebungen im Original). ${ }^{416}$ Godelier schließt damit direkt an die bekannte

415 Lehmkuhl (2002, S.10). - Lehmkuhl wünscht sich in ihrem Abriss der umwelthistorischen Methoden (S.8) ein stärkeres Miteinander von natur- und geisteswissenschaftlichen Analyseinstrumenten, eine 2002 vielleicht immer noch nicht durchgängige, aber durchaus auch schon zu diesem Zeitpunkt verbreitete Praxis. Es kann hier aber vorweggenommen werden, dass die deutsche Umweltgeschichte viel stärkere Wahrnehmungsdefizite und -probleme gegenüber einschlägigen naturwissenschaftlichen Arbeiten hat als etwa die angelsächsische Umweltgeschichte.

416 Die Transformationsvorstellung findet sich neuerdings - unter dem Etikett „Metamorphose“ - in einer Geschichtsdefinition von Schatzki (2003) wieder. Sie bildet den Ausgang einer Überlegung, als 
Formulierung von Karl Marx an, nach dessen Einsicht es eine spezifisch menschliche Qualität ist, dass er der Natur selbst als Naturmacht gegenüber trete. ${ }^{417} \mathrm{Er}$ probte man Godeliers Setzung in einem evolutionsbiologischen Rahmen, müsste man den Kaninchen, den Bibern, den Radnetzspinnen und riffbauenden Korallen usw. auch Geschichtsmacht zuschreiben, wenn mit dem „Verhältnis zur Natur“" nicht zugleich ein reflektorisches Verbalten mit in Anspruch genommen wird. Zweifellos hat Godelier diesen Aspekt im Blick. Das Problem ist damit aber immer noch nicht befriedigend überwunden, weil die Reflexion von dem Ziel weggelenkt werden müsste, dass sich der Mensch setzt, hin auf das Ergebnis in der Natur. Nur wenn das sichtbare Ergebnis in der Natur eine Folge seines von ihm selbst veränderten Verhältnisses zur Natur ist, fiele es unter Godeliers Geschichtsdefinition. Illustrierendes Beispiel: Die Existenz der Zuckerrübe ist das Ergebnis menschlicher Geschichte, weil ihr ein Züchtungsvorgang zugrunde liegt. In ihm ist das Verhältnis zur Natur verändert. Kritisches Beispiel: Hingegen wäre die Auswahl von Pflanzen als essbar bzw. nicht essbar zunächst kein geschichtsbildender Akt, weil ein Hamster genau so verfährt. Während wir vom Menschen aber wissen, dass diese Auswahl durchaus von seinem reflektierten Verhältnis zur Natur bestimmt sein kann, ${ }^{418}$ haben wir vom Hamster keine solche Kenntnis. Also verdankt sich Godeliers Einsicht einer emischen Betrachtung und keiner etischen. Sein Kriterium erfasst damit keine objektive Eigenschaft, wie seine Setzung suggeriert. Es müsste

deren Ergebnis Winiwarter \& Schmid (2008, S.161) vorschlagen, ,sozionaturale Schauplätze“" als Untersuchungsgegenstände der Umweltgeschichte einzuführen. „Die Metamorphose sozionaturaler Schauplätze, der Prozess ihres Wandels, ist Umweltgeschichte.“ (Hervorhebung im Original)

417 Marx [1968 S.192]. Ein ähnlich populäres Schlagwort lautet „the environment transforms the animal, while man transforms the environment." Es handelt sich um eine Setzung von L.F.Ward (1903). Spätestens seit Steward (1955) ist ein solcher Ansatz, seiner scheinbaren Richtigkeit zum Trotz, überholt. Das Zitat lautet im Zusammenhang: "It is this fact of permanent human achievement that makes the broad distinction between animal and human societies. Just as there is a radical difference between cosmic and organic evolution, [...] so there is a radical difference between organic and social evolution. The formula that expresses this distinction the most clearly is that the environment transforms the animal, while man transforms the environment. Now it is exactly this transformation of the environment that constitutes achievement. The animal achieves nothing. The organic world is passive. It is acted upon by the environment and adapted to it. And although it is true that in the structural modifications that constitute such adaptation the efforts and activities of the organism play a prominent part, still even this is only a reflex response to the pressure from without, and really constitutes a part of the environment. Man, on the contrary, as a psychically developed being, and in increasing degrees in proportion to his psychic development, is active and assumes the initiative, molding nature to his own use." (Ward, S. 16-17, Hervorhebung im Original).

Diese Textpassage wird von Park u. Burgess aufgegriffen (1921, S. 718), deren Veröffentlichung den Beginn der sozialwissenschaftlich vermittelten Humanökologie begründet. Von hier fand Wards Diktum seinen Weg auch in die umwelthistorischen Diskurse. Da Park u. Burgess nur den bei Ward kursiv gesetzten Ausdruck übernahmen, entgeht den Zitierern aus zweiter Hand vor allem die Vorstellung Wards von einer „passiven organischen Welt“. Seine Zeugenschaft ist von zweifelhaftem Wert, weil sie dem Tier-Mensch-Vergleich unterstellt, dass „molding nature to his own use“ ein besonderes Alleinstellungsmerkmal wäre, ein evolutionshistorisch teleologisches Element. Dies trifft zumindest auf einige Tierarten nicht zu und ist, wegen des verfolgten teleologischen Prinzips, ohnehin abzulehnen. Eine sozialwissenschaftliche Gegenposition vertreten z.B. Catton \& Dunlap (1980). ${ }^{418} \mathrm{Zu}$ denken ist an Tabuisierungen; an komplexere Handlungsweise bei Coevolutionen (z.B. bei Glukose-6-Phosphat-Dehydrogenase-Mangel und gleichzeitigem Favabohnen-Konsum in MalariaGebieten), usw. 
vielmehr im Einzelfall geprüft werden, ob einer anthropogenen Veränderung in der Natur tatsächlich auch eine Veränderung des menschlichen Verhältnisses zur Natur zugrunde liegt. Dies ist zumindest dann nicht der Fall, wenn das Ergebnis unbeabsichtigte Nebenfolge eines im Grundsatz gleich gebliebenen Verhältnisses zur Natur ist. Der Niedergang z.B. der indianischen Kulturen des amerikanischen Südwestens ist nicht Ergebnis eines veränderten Naturverhältnisses, sondern eines anhaltend gleichbleibenden, obwohl es nicht unabänderbar in seinem Beginn enthalten war. Absurder Weise wäre dieser Niedergang mit der Godelierschen Definition aus der Geschichte ausgeblendet. - Wenn dagegen eingewendet würde, dass es nicht auf die konkrete Handlung oder Handlungsfolge oder eine historische Tatsache ankäme, sondern vielmehr die potentielle Eigenschaft „des Menschen“ gemeint sei, dann endete die Godeliersche Pointe lediglich in der Tautologie, dass der Mensch Geschichte habe, weil er Mensch ist. Aber „Geschichte“ wäre dann keine singulär menschliche Angelegenheit.

Ungeachtet der Probleme, in die sie uns führt, ist Godeliers Setzung bei Umwelthistorikern ziemlich beliebt, vermutlich wegen ihrer scheinbaren Griffigkeit. Godelier geht fraglos vom Menschen als dem Homo-sapiens-Tier und von einer dinghaften Natur aus. Es bleibt aber offen, welche menschlichen Aktivitäten beweisgebend für ein verändertes Verhältnis zur Natur sind, zumal sich Godelier eigentlich nur für die sozialen Strukturen interessiert. Für die meisten menschlichen Aktivitäten mit Bezug auf diese Natur finden sich Parallelen in der Tierwelt, die irgendein animalischer Spezialist zum Vorteil seiner Spezies umgesetzt hat und die für diese konstitutiv wurden. Aber erst mit dem Ackerbau und mit den technischen Transformationsprozessen, die zur Schaffung von Materialien führen, die als solche in der Natur nicht vorkommen, wird ein geändertes Verhältnis des Menschen zur Natur sicher beweisbar. Würde damit die menschliche Geschichte erst vor 10.000 Jahren beginnen? ${ }^{419}$ Eine Bestattung aber, die ganz sicher mit der Existenz von Überzeugungssystemen zusammen hängt, ist denkbar ohne die Godeliersche Verhältnisänderung, obwohl gerade die Einführung von Bestattungen Ausdruck eines Geschichtsbewusstseins ist. Möglich, dass die paläolithische Kunst bereits Hinweis auf ein geändertes Naturverhältnis gibt. Sie ist datierbar, hingegen nicht die ihr vorgeordnete Denkleistung, die auch an anderer Stelle ein Problem aufwirft, wenn man z.B. Fernwaffen als Ausgang eines geänderten Naturverhältnisses annimmt. Steine und Grasbüschel werden zwar auch von Schimpansen (ge-

\footnotetext{
419 Versuche, den Geschichtsbeginn früher anzusetzen, indem etwa über den Werkzeuggebrauch argumentiert wird, tragen nicht sehr weit, weil es hierfür viele Beispiele auch im Tierreich gibt. Hilfreicher wäre da schon der Feuergebrauch. Nur: wie will man Feuergebrauch als Beweis für ein verändertes Naturverhältnis verwenden, wenn er auch als opportunistische Indienststellung des Feuers verstanden werden kann, ähnlich der kulturell erworbenen Sitte bei Japan-Makaken, die Süßkartoffeln zu waschen oder im Winter in heißen Quellen zu baden. Wenn dieses Verhalten der Makaken nicht als opportunistische Nutzung eingeordnet würde: Hätten die Makaken damit im Godelierschen Verständnis für sich den Bereich einer Geschichte nach Art des Menschen erreicht? Schließlich: Die Beispiele paläolithischer Kunst sind unmittelbar auch nicht geeignet, ein neues Naturverhältnis zu beweisen.
} 
gen Feinde) geschleudert, doch für Homo erectus wird die zweckvolle Herstellung von Speeren als Jagdwaffe nachweisbar. ${ }^{420}$ Die ältesten bekannten Speere sind möglicherweise 400.000 Jahre alt. ${ }^{421}$ Sie stammen, wie auch Zeugnisse paläolithischer Kunst, die z.B. Jagdtiere thematisieren, von einem Menschentypus, der Vorläufer des anatomisch modernen Menschen ist, aber doch von diesem morphologisch unterscheidbar ist und hinsichtlich seiner kognitiven Fähigkeiten für verschieden gehalten wird. Damit entstünde ein neues und weiteres Problem, nämlich das eines arten-übergreifenden Geschichtsbegriffs.

Einerseits, so lehrt es das Beispiel, ist Definitionsarbeit mühselig. Andererseits erhebt sich die Frage nach ihrem zielführenden Nutzen. Dass andere etablierte Wissenschaften ihre Gegenstandsbereiche nicht mit letzter Präzision der Grenzziehung bestimmen, könnte an deren Einsicht liegen, dass noch schließlich alle Erkenntnisgegenstände nur in ihrem Bedeutungszentrum sicher sind, zu den Randzonen hin die Unsicherheiten gehäuft auftreten und die Gegenstände sich schließlich in den Überlappungszonen zu anderen Kompetenzbereichen verflüchtigen. Es ist die aus der neuzeitlichen Physik gewonnene und übertragbare Einsicht, wonach zunehmende Aussagepräzision abnehmende Aussagerelevanz zur Folge hat. Es könnte sich daher erübrigen, die definitorischen Spielarten des Grundkonsenses aller Definitionen für „Umweltgeschichte“ mit spitzer hermeneutischer Feder oder dem Ockhamschen Rasiermesser zu autopsieren. Letztlich stimmen alle Definitionen in jener trivialen Schnittmenge überein, dass es um „das Verhältnis des Menschen zur Umwelt in der Geschichte" gehe. Selbstverständlich liegt das Problem auch hier im Detail, nämlich in den Substantiva und ihren bestimmten Artikeln. Eine definitorische Entschärfung ist dadurch zu erreichen, dass die bestimmten Artikel ihrer grundsätzlichen ontologischen bzw. idealtypischen Zuweisungsqualität entkleidet werden und bei ihrer Verwendung lediglich eingeräumt wird, dass ein Präzisierungsbedarf bestehen kann. Ihm mag man aus pragmatischen Gründen nicht nachgehen wollen, weil ein allgemeiner Grundkonsens unterstellt werden kann. Definitorische Nachbesserung wird man erwarten dürfen, wenn einem Autor die pragmatische, unscharfe Definition nicht ausreicht. Es wäre dann die Aufgabe der scientific community, das von ihm gefundene Definitionsangebot kritisch zu prüfen und den Konsensbegriff ggfl. zu aktualisieren. Ein solches Selbstverständnis ist bisher von den wissenschaftlichen Gesellschaften, in denen sich Umwelthistoriker organisieren, nicht entwickelt worden.

Die genannten Substantiva fordern dann auch noch zu didaktisch-methodisch konzipierten geometrischen Figuren geradezu heraus. So sind in der Umweltge-

\footnotetext{
${ }^{420}$ Der nachgewiesene Gebrauch eines speziell angefertigten Gerätes als Fernwaffe für die Jagd setzt eine Reihe von Überlegungen bezüglich künftiger Erreichbarkeit von sonst nicht erreichbarer Jagdbeute voraus. Die Existenz eines solchen Speeres ist gleichzusetzen mit dem Nachweis einer bestimmten gedanklichen Leistung, die das Verhältnis des Jägers zu seiner Beute ändert, also das Verhältnis des Menschen zur Natur. Gegeben ist damit der Eintritt dieser speerschleudernden Menschen in eine Geschichte im Sinne Godeliers.

${ }^{421}$ Strömungswissenschaftliche Bewertungen stufen die berühmt gewordenen Schöninger Speere als aerodynamische Hochleistungsgeräte ein. (Thieme 2007).
} 
schichte graphische Visualisierungsversuche verbreitet, die das grundsätzliche Mensch-Umwelt-Verhältnis mit Varianten des Bedeutungsinhalts zu Mensch (auch „Gesellschaft“ bzw. „Kultur“) bzw. zu Umwelt (auch „Natur“, auch i.S. von „Umgebung") im Hinblick auf eine geschichtstheoretische Funktionalität darstellen. ${ }^{422}$ Die analytische Qualität solcher Diagramme bleibt jedoch oft unklar. Vielmehr scheint sich ihre Verwendung eher der Vorstellung zu verdanken, dass ein Diagramm als Ausweis gehobenen wissenschaftlichen Anspruchs gilt, als dass es einen Beitrag zur Erklärung eines konkreten Problems oder zur Systematisierung eines Forschungsfeldes leistet. Ich werde daher die diagrammatische Facette nicht weiter erörtern. ${ }^{423}$ Gleichfalls reizlos ist für mich die Demonstration einer fleißigen Belesenheit, die in die Präsentation einer Tabelle mit nuancenreichen Definitionsbemühungen mündete, wie sie aus der Literatur zutage gefördert werden könnten. Stattdessen genügen mir einige Beispiele:

Eine einflussreiche Schrift zur Frage „Was ist Umweltgeschichte?“ hat Radkau 1993 vorgelegt. Ihr folgten später Definitions-Varianten in Buchform. Donald Hughes definiert „Umweltgeschichte“ in einem Satz und hängt das erläuternde Buch dann an. ${ }^{424}$ Winiwarter u. Knoll (2007) definieren nicht explizit, sie machten ein Systematisierungsangebot, wie es eben die Aufgabe von Lehrbüchern ist. ${ }^{425}$ Lehmkuhls Aufsatz (2002) ist interessant, weil sie die Perspektive der histoire totale und das Zukunftspotential der Umweltgeschichte in den Blick nimmt. Der Aufsatz von Siemann \& Freytag (2003) erläutert die Bedeutung des Epistems Umwelt für die Geschichtswissenschaft und begründet seine gleichberechtigte Stellung neben den drei anderen Grundkategorien (Herrschaft, Wirtschaft, Kultur). ${ }^{426}$ Nach Auffassung der Autoren ist die Umweltgeschichte „letztlich Menschen- und Naturgeschichte in einem...“.427 Die Darstellung der „Umweltgeschichte im 19. und

422 Es genügt hier der Hinweis auf Winiwarter \& Knoll, Kap. 5.2., die einschlägige Graphiken (dort als „Modelle“ bezeichnet) zusammengestellt haben.

${ }^{423} \mathrm{Zu}$ den breiter rezipierten Naturdefinitionen von Holling \& Ludwig, die sehr einfache und damit einprägsame geometrische Darstellungen gefunden haben, vgl. Herrmann 2008. Sie sind aus den dort angegebenen Gründen m.E. für den umwelthistorischen Diskurs unbrauchbar.

${ }^{424}$ „It is a kind of history that seeks understanding of human beings as they have lived, worked and thought in relationship to the rest of nature through the changes brought by time." (Hughes 2006, S. 1). Ungeachtet dieses Zitats konzentriere mich innerhalb des hier vorliegenden Aufsatzes auf den deutschsprachigen Raum, muss jedoch mindestens auf den etwas entlegen publizierten Reviewaufsatz von McNeill (2003) verweisen.

425 Anstelle eines Definitionskapitels versammeln Winiwarter \& Knoll Definitionsangebote aus der Literatur in der Einleitung (S.14-15). Sie folgen damit der Praxis vieler Lehrbücher unterschiedlichster Disziplinen, die ihren Gegenstand nicht eigens definieren, sondern vermutlich dem didaktischen Mittel folgen, mit dem Lehrbuchtext den Leser zu einer intuitiven Definition verhelfen zu wollen. Tatsächlich wird mit der Systematisierung des Stoffs in einem Lehrbuch implizit ein eigenes Definitionsangebot gemacht, was für praktische Belange zumeist ausreichend erscheint. - Eine ältere Definitionszusammenstellung für „Umweltgeschichte“ findet sich bei Fuchsloch.

426 Siemann \& Freytag haben eine nach meinem Urteil überzeugende Darstellung zur geschichtstheoretischen Bedeutung der „Umweltgeschichte“ verfasst. Umweltgeschichte wird von ihnen nicht eigens definiert, sondern pragmatisch ein Konsens von der „Erforschung der Wechselwirkungen zwischen Mensch und Natur" unterstellt (S.8).

427 A.a.O., S. 10. 
20. Jhs." 428 von Uekötter (2007) enthält im ersten Kapitel eine kurze, kritische Revision theoretischer Positionen und forschungspraktischer Themen, die in der deutschen Fachliteratur der Umweltgeschichte zuzurechnen sind. Definitorische Probleme, die sich aus vergleichender Betrachtung von Naturaneignungen in der Organismenwelt ergeben, ${ }^{429}$ werden nicht allein von Uekötter abgelehnt, weil sie auf ein falsches Geschichtsverständnis gegründet wären. ${ }^{430}$ Greift man auf das Lehrbuch von Winiwarter \& Knoll zurück, dann gäbe es (wenigstens) zwei konsensfähige Definitionen:

„1) Umweltgeschichte befasst sich mit den Wechselbeziehungen zwischen Menschen und dem Rest der Natur in der Vergangenheit (nach Beinart \& Coates, 1995:1)

2) Umweltgeschichte beschäftigt sich mit der Rekonstruktion von Umweltbedingungen in der Vergangenheit sowie mit der Rekonstruktion von deren Wahrnehmung und Interpretation durch die damals lebenden Menschen (z.B. Herrmann, 1996:21, Sieferle, 1997:13f)" 431

Der Vorzug der zweiten Definition besteht darin, dass sie sich über die kulturell und subjektiv kontextualisierten Mensch-Natur-Beziehungen hinaus auch die Rekonstruktion objektiver Naturzustände zur Aufgabe macht. Insofern ist die scheinbar allgemeiner gefasste Definition 1 tatsächlich die weniger umfassende, weil sie sich ausschließlich auf die anthropologische Dimension beschränkt. Wie immer der Gegenstandsbereich von „Umweltgeschichte“ be- oder entgrenzt wird, ihr wohnt nach meinem Urteil ein größerer Anteil wissenschaftsgeschichtlicher Selbstreflexion inne als anderen Geschichtsdisziplinen. ${ }^{432}$ Für die „Umweltge-

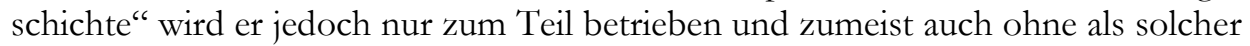
begriffen zu sein. An die historischen Bedingungen, unter denen sich „Umweltgeschichte" als Wissenskorpus etablieren konnte, wird zwar gelegentlich erinnert. Aber das Abarbeiten der Elementarbegriffe des Wissenszusammenhangs „Umweltgeschichte“ ist bislang in ihm selbst nur in geringem Umfang erfolgt, wie am Beispiel des „Natur“-Begriffs leicht erkennbar ist, der seit der Antike Dauerthema des philosophischen Diskurses ist, ohne von dort logisch in eine „Umweltgeschichte" geführt zu haben. Erschwert wird die wissenschaftshistorische Analyse allerdings durch methodischen Opportunismus (,anything goes“, Feyerabend

\footnotetext{
428 Uekötter 2007. Der Kürze seiner Gesamtdarstellung fallen einige gewichtige Aspekte und manches differenzierter zu denkendes Urteil zum Opfer. Uekötter scheint dem Raisonnement einer Umweltgeschichte nicht-historiographischer Provenienz skeptisch gegenüber zu stehen, obwohl er in Kap.10 die „Vereinigung von menschlicher und natürlicher Geschichte als einen alten Historikertraum" (S. 90) bezeichnet.

${ }^{429}$ Das ist letztlich bei „Umwelt“-Wortzusammensetzungen nicht zu umgehen und müsste ein selbstverständlich erweitertes Verständnis von „Umweltgeschichte“ nach sich ziehen.

${ }^{430}$ Eine solche Position führt nun ihrerseits u.a. zu Konflikten mit dem einflussreichen ,new ecological paradigm" von Catton \& Dunlap (1980) (siehe unten unter II).

431 Winiwarter \& Knoll 2007, S. 14 - 15.

432 Die Rede ist nicht von einer Wissenschaftsgeschichte, die eine Nacherzählung einer Entwicklung ist. Unübersehbar hat ein Teil der „Umweltgeschichte“ so begonnen, z.B. als Verschmutzungsgeschichte. Vielmehr ist das hier gemeinte Verständnis von Wissenschaftsgeschichte eines, das der Ideengeschichte und Wissenschaftstheorie verpflichtet ist und von rein nacherzählenden Ansätzen abgegrenzt.
} 
1986) und methodische Vielseitigkeit, über die „Umweltgeschichte“ im Zuschnitt von „Rekonstruktion und Rezeption“ verfügt. Wenn die Definition 2 ein wissenschaftsförderliches Potential beinhaltet, dann dasjenige, das aus ihr die Einsicht abzuleiten ist, wonach „Umweltgeschichte“ mit der „Wahrnehmung und Interpretation" zugleich über die Bedingung der Freilegung dieser Wahrnehmung und Interpretation zu reflektieren hat. Eigentlich ist „Umweltgeschichte“ damit eine Wissenschaftsgeschichte des Gegenstandsbereichs „Umwelt“. Als historische Epistemologie (i. S. von Rheinberger 2007) ist sie die Frage, wie und mit welchem Ziel die Facetten des Gegenstandsbereichs „Umwelt“ aus den Quellen zum Gegenstand des Erkennens gemacht werden. ${ }^{433}$

In der kursorischen Übersicht liest sich die Geschichte veröffentlichter umwelthistorischer Arbeiten eher als eine Geschichte der thematischen Selbstversicherung beteiligter Autoren als eine ausdrückliche Bemühung um die Inhaltsbestimmung und Wege der Erkenntnisgewinnung. Auch dies ist ein bekanntes Muster in der Wissenschaftsorganisation, wenn durch Gebrauch zirkulärer Techniken die Notwendigkeit von Begriffsbestimmungen und Reflexionen der Eingangsvoraussetzungen operational umgangen werden sollen, in dem simple Lösungen als zufrieden stellend gelten: „Umweltgeschichte ist das, was Umwelthistoriker erforschen. "Findet man mit dieser Einstellung zu einer Gruppe von Gleichgesinnten (z.B. in der ESEH, in einem Graduiertenkolleg oder auf einem Workshop) und kann mit ihnen eine Zeitlang den produktiven Gedankenaustausch pflegen, dann ist offenbar ausreichende Selbstbestätigung gewährt. Durch sie hat sich seit dem Ende der 80er Jahre bis gegen heute in einem „Selbstfindungsprozess“ (Toyka-Seid 2003) die Einschätzung zumindest der unmittelbar Beteiligten verdichtet, die Umweltgeschichte sei allmählich zu einer Disziplin aufgewachsen. Wenn das so wäre, hätten wir sicheres Terrain erreicht.

\subsection{Umweltgeschichte als Disziplin}

Ist „Umweltgeschichte“ eine wissenschaftliche Disziplin? Die Verwendung des Begriffs sagt nichts über die Etabliertheit des mit ihm umschriebenen Wissenszusammenhangs. Sie bezeichnet lediglich eine besondere Differenz zu den Inhalten

\footnotetext{
433 Rheinberger 2007, S. 11f: „Ich fasse unter dem Begriff der Epistemologie [...] die Reflexion auf die historischen Bedingungen, unter denen, und die Mittel, mit denen Dinge zu Objekten des Wissens gemacht werden, an denen der Prozess der wissenschaftlichen Erkenntnisgewinnung in Gang gesetzt sowie in Gang gehalten wird. An der Wende vom 19. zum 20. Jahrhundert [gibt es] einen Umschlag von der Erkenntnistheorie der klassischen philosophischen Tradition zur Epistemologie im genannten Sinne. Diese Verschiebung markiert zugleich eine Problemumkehr. Die Reflexion des Verhältnisses von Begriff und Objekt, die vom erkennenden Subjekt ihren Ausgang nahm, wird ersetzt durch die Reflexion des Verhältnisses von Objekt und Begriff, die am erkennenden Objekt ansetzt. Diese Problemverschiebung ist zugleich Kern der Epistemologie und Ausgangspunkt ihrer Historisierung. [...] Die Frage ist nicht mehr, wie das erkennende Subjekt seine Gegenstände unverstellt in den Blick bekommen kann, die Frage gilt jetzt vielmehr den Bedingungen, die geschaffen wurden oder geschaffen werden müssen, um Gegenstände unter jeweils zu bestimmenden Umständen zu Gegenständen empirischen Wissens zu machen.“ (Hervorhebung im Orig.).
} 
anderer Wortzusammensetzungen, etwa in Umweltpolitik, Umwelttechnik, Umweltproblem bzw. in Kirchengeschichte, Wirtschaftsgeschichte, Herrschaftsgeschichte.

Folgt man einer wissenssoziologischen Bewertung, dann gilt der „Disziplinen“Status als Ritterschlag und Ausweis für dynamische Entwicklung und Leistungsfähigkeit eines Wissensgebiets. Wissenschaftliche Disziplinen wären grundsätzlich durch bestimmte inhaltliche Merkmale gekennzeichnet (Fragestellungen, Methoden, Problemlösungen), ${ }^{434}$ woraus ein Korpus akzeptierter Wissenselemente und akzeptierter Forschungsmethoden resultiert. Danach könnte Umweltgeschichte Disziplinen-Qualität besitzen.

Die außerdem erhobene Forderung nach einem homogenen Kommunikationszusammenhang ist für inter- und transdisziplinäre Wissensbereiche schon schwieriger zu erfüllen. Und damit deutet sich an, dass die Umweltgeschichte diesem soziologischen Kriterium nicht genügen könnte. ${ }^{435}$

Ganz sicher nicht erfüllt ist gegenwärtig schließlich das Kriterium von spezifischer Karriere und beruflicher Sozialisation in eigenen Institutionen.

Ergänzend ist diesem Kanon die Frage der Alimentierung beizufügen (die nicht zwingend mit eigenen Institutionen verbunden sein muss). Auf sie wird im Zusammenhang mit der Relevanzfrage noch ausführlicher einzugehen sein. Man wird nicht fehlgehen, wenn man der umwelthistorischen Forschung eher eine Unterförderung als eine Überalimentierung attestiert und daraus auf ihren zumindest unsicheren Platz in der Wissenschaftssystematik schließt. In der Bundesrepublik gibt es z. Zt. keine selbstständige akademische Institution, die Umweltgeschichte als alleinigen Namen führte. Es gibt keinen Lehrstuhl mit umwelthistorischer Denomination. Die ersten (Junior-)Professuren für Umweltgeschichte sind gerade besetzt, weitere sind ausgeschrieben. ${ }^{436}$ Forschungsverbünde mit umwelthistorischer Ausrichtung haben Schwierigkeiten, sich im Wettbewerb bis zur Bewilligung zu behaupten. Immerhin gibt es einzelne Studienangebote zur Umweltgeschichte (z.B. TU Berlin, TU Darmstadt, Univ. Göttingen). Erstaunlich ist, dass die Rahmenrichtlinien der gymnasialen Lehrerausbildung die Behandlung von Umweltgeschichte ausdrücklich einfordern (z.B. in Niedersachsen), universitär dem aber kaum Angebote gegenüber stehen (hierzu auch Beitrag von Borries in diesem Band).

\footnotetext{
434 Zusammengefasst nach Stichweh 1994.

435 Unterstützung für meine Diagnose sehe ich u.a. auch in Kap.10 von Uekötter 2007.

436 Umweltgeschichte kann auch als historisierende Variante der Humanökologie verstanden werden. Für die humanökologische Umweltforschung insgesamt hatte der Wissenschaftsrat bereits vor vierzehn Jahre die Schaffung institutioneller Einrichtungen an den Universitäten - bislang folgenlos empfohlen (Wissenschaftsrat 1994, Bd.1, S. 104). Der Wissenschaftsrat hatte dabei die gesamte einschlägige Palette struktureller Maßnahmen vor Augen, die üblicherweise fachliche Gründungsinitiativen begleiten und vor allem darauf verwiesen, dass sich ohne institutionelle Strukturen der wissenschaftliche Nachwuchs nicht motivieren werden lasse, sich in diese Forschungsfelder hinein zu qualifizieren. Weiter heißt es (Bd.2, S.198): „Umweltgeschichte sollte hier [gemeint ist an der Biologischen Fakultät der Universität Göttingen, B.H.] zu einem weiteren Schwerpunkt entwickelt werden, der bis zu Aktivitäten im Rahmen von Global Change reichen kann." Eine Umsetzung erfolgte nicht.
} 
Was sich inhaltlich zu einer disziplinären Qualität zusammenfügen ließe, wird auf der strukturellen Ebene nicht erreicht: Umweltgeschichte ist nach den gängigen Regeln des Wissenschaftsbetriebes zurzeit keine etablierte Disziplin. ${ }^{437}$ Gilt dies schon für eine Betrachtung aus deutschsprachiger Perspektive mit Blick auf die deutschsprachige community, so sind die Wahrnehmungen dieser deutschen community durch die internationale Szene noch deprimierender. In ihrem Revisionsaufsatz über Inhalte und Ausrichtungen der Umweltgeschichte wird von Sörlin u. Warde (2007) auf den Text auch nicht eines deutschsprachigen Umwelthistorikers Bezug genommen. Dass hier wenigstens zum Teil die übliche angelsächsische Ignoranz ursächlich ist, wird man bei einiger Kenntnis des Metiers richtig vermuten. Es bleibt jedoch der Umstand der geringen internationalen Ausstrahlung, obwohl Deutsch traditionell eine lingua franca der Geschichtsdisziplinen zumindest war. Ein inhaltlicher Grund könnte allerdings auch sein, dass sich die deutsche umwelthistorische Gemeinde noch nicht als kohärente Gruppe gefestigt hat bzw. als solche nicht wahrnehmbar ist und dadurch ohne nennenswertes Gewicht wäre. 438

Der wissenssoziologischen Disziplinenbetrachtung ist eine wissenschaftssystematische an die Seite zu stellen. ${ }^{439}$ Sie hat den Vorzug, dass sie sich nahezu ausschließlich auf die Qualitäten der wissenschaftlichen Vorgehensweise bezieht und den soziologischen Aspekt der Institutionalisierungsebene mit Folgen und Nebenfolgen ausblendet. Vier Antworten gäbe es nach Lorenz Krüger auf die Frage, wonach Disziplinen zu unterscheiden wären: ${ }^{440}$

1) es sind die Gegenstände, doch nicht diese allein, weil interessierende Aspekte, Fragen oder Probleme notwendige erläuternde Beifügungen wären.

2) es sind die Methoden, wobei allerdings begrenzte innerdisziplinäre Kompetenz den Einsatz bestimmter Methoden zunächst ausschließt.

3) ist es das Erkenntnisinteresse, etwa auf allgemeine Gesetzmäßigkeiten oder auf das Erkennen einmaliger Individualitäten hin; oder auf ein technisches Erkenntnisinteresse hin; oder auf ein praktisches, d.h. ein auf Verständigung

\footnotetext{
${ }^{437}$ Die Diagnose wird verstärkt durch den Umstand, dass im weitverbreiteten „Bücherverzeichnis zur deutschen Geschichte" noch in der 16. Auflage weder im Register noch im Inhaltsverzeichnis „Umweltgeschichte“ vertreten ist (Baumgart 2006), ebenso fehlt „Umweltgeschichte“ in den Rezensionsrubriken von H-Soz-u-Kult bis auf den heutigen Tag (5.12.2008). Gegenüber diesem Ausdruck fachlichen Mainstream-Verständnisses ist das verlegerisch dominierte Konzept der „Enzyklopädie deutscher Geschichte" offener, das die Monographie von Uekötter (2007) aufgenommen hat.

${ }^{438}$ Dies ist u.a. ein Grund, warum m.E. von der deutschsprachigen Umweltgeschichte statt von einer Disziplin zumindest z.Zt. besser von einem Wissenszusammenhang zu sprechen wäre. Ausschlaggebend für diese begriffliche Bevorzugung ist allerdings anstelle des schwach entwickelten strukturellen Kriteriums eine Betonung des inter- bzw. transdisziplinären (und damit offenen) Kommunikationszusammenhangs.

439 Krüger 1987. Krüger stellt die Frage, was eine Disziplin sei, nicht direkt, sondern sucht nach den Merkmalen einer Disziplin, die sie von anderen abhebt.

${ }^{440}$ Krüger 1987, $115 f$.
} 
im Handeln zielendes; oder auf ein emanzipatorisches, d.h. auf den Abbau der Herrschaft von Menschen über Menschen gerichtetes Interesse. ${ }^{441}$

4) schließlich sind es ihre Theorien. Auch ohne die Formulierung elaborierter theoretischer Konstrukte wären allein schon in der Absicht der Wissenschaften, die Fülle der Tatsachen, Regeln, Tatbestände und Entscheidungen zu ordnen, zu deuten oder zu erklären der theoretische Gehalt erkennbar, „nämlich, dass die nächste durch das Leben herangetragene Einzelheit in vorgezeichneter Weise verarbeitbar wird.“

Folgte man diesen Überlegungen, ist der Wissenszusammenhang „Umweltgeschichte" disziplinär organisierbar und von sich selbst und von anderen als Disziplin wahrnehmbar. Doch ist die Kohärenz auch in dieser Betrachtung nach wie vor gering, weil „die Begriffe Natur und Umwelt sehr vage sind, das methodische Vorgehen wenig geklärt und zudem unsicher ist, wer das Subjekt und welches die Bezugsgrößen dieser neuen Richtung sein sollen." ${ }^{442}$ Auch acht Jahre nach diesem Verdikt sind „Natur“ und „Umwelt“ einer konsensualen innerdisziplinären Präzisierung nicht viel näher gekommen. Man mag darin das Symptom einer korporativen Kraftlosigkeit erkennen, die eine der Ursachen sein kann, warum sich keine selbstbewusste Gruppe formiert, um der Umweltgeschichte zu der entscheidenden Lobby zu verhelfen.

Letztlich könnte die Frage nach dem Disziplinencharakter als belanglos abge$\tan$ werden, wäre mit ihr andererseits nicht eine besondere, nämlich eine forschungspolitische Seite verbunden. Je nachdem, ob Umweltgeschichte als Disziplin oder als Subdisziplin begriffen wird, treten Vorbesitzer der Parzelle bzw. Besitzer benachbarter wissenschaftlicher Immobilien mit entsprechenden Ansprüchen auf. Wer von der Umweltgeschichte als von einer „historischen Subdisziplin“ spricht, ${ }^{443}$ und gleichzeitig die Definitionsmacht für den ihr zugrundeliegenden Geschichtsbegriff beansprucht, ${ }^{444}$ reklamiert Umweltgeschichte als Besitzstand bestimmter Fächer. Das blendet andere umwelthistorische Zugänge aus oder weist ihnen Ancilla-Funktionen zu. Die Diskussion ist älter ${ }^{45}$ und ich hatte sie für erledigt gehalten, weil die Wissenschaftspraxis und das Zusammenleben in der scientific community diese Differenzen überwunden zu haben schienen. Doch ein Blick in die Literaturlisten neuerer umwelthistorischer Arbeiten bzw. Sammelbände zeigt, dass Wahrnehmungsbeschränkungen immer noch bestehen. An manchen Stellen ist

\footnotetext{
${ }^{441}$ Krüger bezieht hier die Zweiteilung auf Wilhelm Windelband, die Dreiteilung auf Jürgen Habermas.

442 Brüggemeier 1996, S. 9. Fraglos trifft die Diagnose Brüggemeiers zu, aber nicht nur aus Gründen inhaltlicher Komplexität allein, welche die Gegenstandsbereichen und ihre Beziehungen zueinander so diffus erscheinen lassen. Gründergeneration wie Protagonisten der (deutschsprachigen) Umweltgeschichte scheuen das Abarbeiten des Theoriedefizits.

443 z. B. Siemann u. Freitag 2003, S. 7; Uekötter 2007, S.2

444 z. B. Uekötter a.a.O.

445 z. B. Herrmann 1996, S.28
} 
sogar ein erheblicher Entwicklungsrückstand bezüglich einer auf Inter- bzw. Transdisziplinarität ausgerichteten Umweltgeschichte mit entsprechender wissenschaftlicher Offenheit augenfällig.

Es ist immer zweischneidig, an professionelles Verhalten aller im Exempel agierenden Akteure zu appellieren. Gemeint ist sicher ein disziplinendienliches und gleichzeitig ein selbstdiszipliniertes Verhalten, das die Entwicklungsmöglichkeiten des Gebietes stärkt und fördert. Treffen wird man jedoch immer auch auf Machtund Interessenkonstellationen. Dennoch sei um der Sache willen für ein Miteinander geworben. Evolutionsbiologisch kann man zeigen, dass kooperatives Verhalten als Langfriststrategie für alle Beteiligten prämiert wird. Sollten allerdings die eben erwähnten Wahrnehmungsbeschränkungen Ergebnisse von stillschweigenden Kooperationsbünden sein, kann es einer beschränkten Umweltgeschichte nicht gelingen, sich gegen die Kompetenzen derjenigen anderen Disziplinen zu etablieren, die fruchtbar beizutragen hätten. Schlimmer noch, es würde die pointierte Unterscheidung zwischen den „Zwei Kulturen“ (C.P.Snow) der naturwissenschaftlichen und der geisteswissenschaftlichen Analyse weiter verfestigen. Damit wäre der interdisziplinäre Austausch, der für die Umweltgeschichte konstitutiv ist, durch eine neuerliche Diskriminierung zum Nachteil des Forschungsgegenstandes gefährdet, weil schon Erreichtes preisgegeben würde.

\section{Zur Relevanz der Umweltgeschichte}

\subsection{Unabhängiges Forschen und \\ Teilhabe an „aktuellen“ wissenschaftlichen Fragestellungen}

Verbreitet ist eine naive Ansicht, nach der wissenschaftliche Themengebiete sich allein aus dem Interesse der einzelnen Forscher ergäben. Tatsächlich sind es überwiegend die Interessensverbünde aus Wissenschaft und übriger Gesellschaft, die wissenschaftliche Themen akademisch überhaupt zulassen, integrieren und zu „hoch-aktuellen“, zu ,innovativen“, zu „,anschlussfähigen“, zu ,,zukunftsträchtigen" Themen machen, ihnen einen Aufmerksamkeitsstatus verleihen und als Attraktoren auf die Wissenschaftler zurückwirken. Damit wird eine sich selbst beschleunigende Spirale wissenschaftlicher Geschäftigkeit in Gang gesetzt, deren öffentliche Rezeption als Maßstab für die qualifizierteste, modernste und „hochaktuelle“ Forschung hergenommen wird. ${ }^{446}$ Solche wissenschaftlichen Konjunktu-

\footnotetext{
446 Es sei daran erinnert, dass nur extrem selten Nobelpreise verliehen werden, die zeitlich junge Arbeiten prämieren. Man kann darin einen Hinweis sehen, dass erst einmal die langfristige Tragfähigkeit „sensationeller, neuer Einsichten“ oder Befunde abgewartet wird, bevor man sich über deren wirklichen Wert sicher sein kann. Solche Beurteilungen zeigen sich unbeeindruckt vom wissenschaftlichen Tagesgeschäft, das sich an den Prinzipien des „Markgeschreis“ und der wissenschaftlichen wie der feuilletonistischen Seilschaftenpflege orientiert.
} 
ren, oder zumindest die Hoffnung auf diese, markierten auch Anfänge der deutschen wie der internationalen Umweltgeschichtsforschung.

Dennoch hält sich allgemein hartnäckig die Vorstellung einer allein aus dem persönlichen Interesse des Forschenden resultierenden Fokussierung auf sein Thema. So wurde auch Anlässlich der Übergabe seines Rektorats des Berliner Wissenschaftskollegs 2007 an Luca Giuliani von Dieter Grimm die Bedeutung dieser Institution mit folgenden Worten betont:

„...Die Forschung des Einzelnen ist wichtig, nicht nur sein Beitrag als Gruppenmitglied in Großprojekten. Die nicht von vornherein nutzenorientierte Forschung ist wichtig, nicht nur, weil sie manchmal ungeplanten Nutzen stiftet, sondern wegen des Selbstwertes von Erkenntnis. Die Forschung, die nicht von Drittmitteln abhängig ist, ist wichtig, weil hier das Erkenntnisinteresse nicht extern, sondern intern bestimmt wird und weil man besser Distanz. zu den beobachteten Systemen halten kann. Die Pflege der sogenannten kleinen Fächer ist wichtig, weil sie einen kulturellen Reichtum erhalten und Verständnishorizonte eröffnen, die unter Globalisierungsbedingungen nötiger denn je sind." 447 Einer solchen Bewertung wird man vermutlich vorbehaltlos zustimmen, denn Grimm trägt hier eben das bekannte und anerkannte Rechtfertigungsmantra für das individualistische, selbstbestimmte Forschen vor. Ein Institute for Advanced Studies anerkennt also die Bedeutung des Einzelnen, enthebt ihn der Drittmittelabhängigkeit und feiert den nur sich selbst verpflichteten Gelehrten. Im Kleinen, so deuten wir Grimms Beschreibung um, funktioniert ein Graduiertenkolleg letztlich wie ein Institute for Advanced Studies. Genauso sahen sich und es ja auch einige Kollegiaten des Göttinger Kollegs, wie im Vorwort geschildert. Mit dem Hinweis auf Grimm, auf die Idee der Institutes for Advanced Studies und dem Hinweis darauf, dass der Wissenschaftler allein entscheide, was relevant, was also im Wortsinne ,wichtig“ ist, könnte man die Sache als erledigt betrachten. Die „Relevanz“ wird damit kategorial zur „Relevation“ hin verschoben, mit der die „Befreiung von einer Verbindlichkeit“ gemeint ist. Der Wissenschaftler sei frei von Verbindlichkeiten gegenüber wem auch immer.

Sollte Dieter Grimm tatsächlich entgangen sein, dass sein Kolleg mit der Fernhaltung der Fellows von den Niederungen praktischer Wissenschaftsorganisation und -alimentierung die damit verbundenen Probleme lediglich auf andere Ebenen verlagert hat, nämlich die der Administration seines Kollegs selbst? Käme man ohne Auswahl ans Wissenschaftskolleg? Gibt es keinen jährlichen Rechenschaftsbericht, mit dem die Geldgeber beruhigt werden? Verdanken sich die gemeinschaftlichen Forschungsprojekte des Kollegs wie auch der Fellows selbst nicht etwa auch jeweiligem gesellschaftlichem Interesse? ${ }^{448}$ Eine ähnliches Beispiel kann man in dem geldschweren britische Forschungsprogramm erkennen, dem der programmatischen Name „Blue Skies Research“ gegeben wurde, und das sich beispielsweise überraschend konventionell der Mitwirkung von Gutachtern versi-

447 Aus: Ansprache des Rektors des Wissenschaftskollegs zu Berlin, Dieter Grimm, aus Anlass der Rektoratsübergabe am 1.April 2007. Wissenschaftskolleg zu Berlin. Seiten 9- 10.

448 Verf. glaubt, sich als ehem. Fellow-Sprecher (Class of 1995/96) diese Fragen erlauben zu dürfen. 
chert $^{449}$ - eine Rückversicherung, mit der das Entfernen der Projekte vom wissenschaftlichen Mainstream erschwert wird. Und warum veröffentlicht die Deutsche Forschungsgemeinschaft etwa mit den „Perspektiven der Forschung und ihrer Förderung" regelmäßig einen Fünfjahresplan, ${ }^{450}$ wenn von ihm nicht eine gewisse Selbstbindung an den dort skizzierten thematischen Rahmen ausgehen soll? Zweifel daran, dass die Bewegungsspielräume der Wissenschaft von gesellschaftlich gelenkten Vorstellungen und Geldmitteln abhängen, kann nur derjenige haben, der noch nie dem Zwang zur Formulierung von Antragsprosa, der Suche nach den passenden Schüsselbegriffen ausgesetzt war und sich noch nie dem Wohlwollen einer Gutachtergruppe zu stellen hatte. So, wie die geldabhängige Wissenschaft organisiert ist, wohnt ihr der Zwang zur Anbiederung an die Strukturen und an die Philosophien der Drittmittelgeber inne. Allerdings tun beide Seiten so, als ginge es immer nur um die Sachen, nie um Interessen. Selbstverständlich ist der Wissenschaftler frei und darf denken, was immer er will. Aber sein Denken, für das er um Subventionierung nachsucht, wird begrenzt durch den Fluss des Geldes. Es liegt außerdem in der Logik eines solchen Systems, dass der gesellschaftliche bzw. institutionelle Einfluss auf die Forschung umso höher sein wird, umso höher diese Forschung subventioniert ist.

Anlässlich dieser Feststellung müsste man nach den Geldmengen suchen, die in umwelthistorische Projekte fließen, um auf diesem Wege eine erste Vorstellung von der gesellschaftlichen Relevanz der Umweltgeschichte zu erhalten. Dass die Mittel auf der institutionellen Seite bescheiden sind, wurde bereits festgestellt. Immerhin sind die Drittmittelgeber aufgeschlossener, als es zunächst erscheint. Doch konzentriert sich die Förderung dabei in einem allgemeineren Sinne auf geistesund sozialwissenschaftliche Behandlung von Umweltthemen und praktisch nicht auf umwelthistorische. ${ }^{451}$ Immerhin enthielt die „Nachwuchsförderung in der fächerübergreifenden Umweltforschung“ der VW-Stiftung (Förderzeitraum bis 2006) zwei archäologische Projekte.

Insgesamt gesehen liegt mit dem Göttinger Graduiertenkolleg 1024 daher eine bemerkenswerte Fördermaßnahme vor, aber abgesehen von singulären und eher persönlichen als strukturellen Erfolgen, binden umwelthistorische Projekte in der Bundesrepublik keine erheblichen Geldmengen. Nach diesem Maßstab ist Umweltgeschichte eine wenig relevante Wissenschaftsrichtung. Wegen fehlender Möglichkeiten der Nachwuchsförderung durch Stellenabsicherung wird sich absehbar daran nichts ändern (können). Die Situation am Stellenmarkt ist aber ein starkes Motiv für Graduierte, ihre weitere Qualifikation thematisch auszurichten. Die Perspektive einer persönlichen wirtschaftlichen Unabhängigkeit wird zu einem Krite-

\footnotetext{
${ }^{449}$ Der Geldgeber, das Natural Environment Research Council, NERC, weicht Erklärungen oder Diskussionen über diesen sonderbaren Umstand aus, wie Verf. aus eigener Gutachtertätigkeit weiß.

450 Zuletzt: Deutsche Forschungsgemeinschaft, Perspektiven der Forschung und ihrer Förderung 2007 - 2011. Wiley-VCH, Weinheim 2008

${ }^{451}$ Eine Skizze der einschlägigen Förderlandschaft der letzten Jahre und der größeren Einzelprojekte bei Knopf 2008, S.12-14.
} 
rium der Qualifikations- und Zukunftsplanung und damit, neben dem Aspekt der reinen Wissenschaftlichkeit, zu einem offensichtlichen weiteren Relevanzkriterium. Für die Umweltgeschichte besteht auch hier ein strukturelles Defizit. „Forschen“, so stellt sich am Ende heraus, ist aus vielerlei Gründen nicht „unabhängig“, weil es sich auch an den Vorstellungen und Auswirkungen einer wie immer auch gearteten „Relevanz“ orientiert. Das gilt selbstverständlich auch für umwelthistorisches Forschen.

Der jeweils aktuelle Aufmerksamkeitsstatus lenkt Geldmengen zur gezielten Förderung wissenschaftlicher Arbeit um oder bewegt zusätzliche in die Forschung. Die Hoffnung auf eine solche Partizipation hat sich für die Umweltgeschichte bisher nur im bescheidenen Maße erfüllt, obwohl der Zeitpunkt ihrer Anfänge aus dem Katastrophendiskurs und den umweltbezogenen Alarmismus-Debatten in einem technischen Sinn „richtig“ lag. Obwohl die finanzielle und strukturelle Lage der Umweltgeschichte dies nahelegt und mit dem Hinweis auf die Relevation die Frage nach der Relevanz für möglicherweise erledigt erklärt wurde, ist sie selbstverständlich nicht erledigt, denn „Wichtigkeit“ bzw. „Erheblichkeit“ , die Wortinhalte von „Relevanz", sind keine objektiven Kategorien. Ist als ein Maßstab für „Relevanz" die in die Wissenschaft fließende Geldmenge ausgemacht, steht damit noch nicht fest, welche Relevanzerwartung der Geldgeber damit verbindet: wird Grundlagenforschung gefördert oder angewandte Forschung? Der gegenwärtige enorme Akquisitionserfolg beispielsweise biowissenschaftlicher Forschungsverbünde erklärt sich aus dem Besitz einer magischen Formel, die auf eine derartige Erwartung gründet. Was immer mit den Zauberworten „Stammzellen-Therapic“ oder „Besiegen des Krebses“ berührt wird, verwandelt sich augenblicklich in Geld. Heilsversprechen der Human- bzw. Biowissenschaften scheinen Garanten für die Steuerung der Geldströme. In der Gesundheitsforschung ist das deshalb einfach, weil die Erfindung der ultimativen Pille ein Wirtschaftsgut allerersten Ranges darstellt und "Gesundheit“ als allgemein schutzwürdiges und anzustrebendes materielles Gut und als mentaler Idealzustand akzeptiert ist. Könnte sich Umweltgeschichte - wenigstens in einem bescheidenen Umfange - an solchen strategischen Vorbildern orientieren und wenn, womit?

Tatsächlich sind Umweltthemen, jenseits eines marktgängigen Interesses an „öko“, durchaus prominent geförderte Forschungsfelder. Der Akquisitionserfolg der Klimaforschung verdankt sich gegenwärtig zweifellos der aufgeregt geführten Diskussion, die Anlass hat, die Welt dem Zustand des Hitzetodes mit allen ihren Vorboten nahe zu wähnen. Ein weiterer einschlägiger Geldgreifer sind die organismischen Biologen, denen es gelungen war, Mitte der 80er Jahre mit dem Schlagwort „Biodiversität“ einen Begriff zu etablieren, dessen Marketingwert auch den Begriffen der Molekulardisziplinen nicht sonderlich nachstand und neben dem Stichwort „Klimawandel“ heute ein bedeutendes Umweltthema besetzt. Drei Eigenschaften verbergen sich nach meiner Einsicht hinter dem Biodiversitäts- 
begriff:452 ein Tauf- und Missionsbefehl, ein Schlachtruf und ein Börsenbegriff. Der „Tauf- und Missionsbefehl“ bedient religiöse bzw. quasi-religiöse Bedürfnisse, auf die ich weiter unten noch eingehe. Der „Schlachtruf“ ist Instrument von NGOs und Körperschaften geworden und hat zu politischen Eckdaten geführt, die ihren Ausdruck u.a. im MEA 453 finden. Sehr interessant ist die börsenaffine Seite des Begriffs. Sie beklagt den Rückgang der Artendiversität vor dem Hintergrund entgehender menschlicher Verwertungsmöglichkeit und damit entgehender wirtschaftlicher Nutzung, vor allem aus pharmakologischem Interesse. Umwelthistoriker wissen, dass dieser Aspekt der Naturnutzung schon vor 250 Jahren den europäischen Blick in die Kolonien beflügelte: „Nutzung“ und „Verbesserung“ (der Natur) als Zentralbegriffe der Aufklärung. Allerdings bewegen sich heutige Ausbeutungsinteressen, die u.a. die Patentierung von Genombestandteilen anstreben, um dadurch wirtschaftliche Vormachtstellung zu erhalten, jenseits jeder Vorstellungsmöglichkeiten gutgläubiger Aufklärer. ${ }^{454}$

Fraglos sind „Biodiversität“ und sein mit der Rio-Konferenz etablierter Nachbarbegriff „Nachhaltigkeit“ sowie das Thema „Klimawandel“ gegenwärtige politikbestimmende Schlagwörter. ${ }^{455}$ Umweltthemen haben längst die Feuilletons erreicht, sind Gegenstand von unterhaltungsdienlichen Katastrophenszenarios. ${ }^{456}$ Die Werbung arbeitet mit umwelthistorischen Versatzstücken, wenn mit Chiffren des Paradiesverlustes die Lust auf einen Urlaub „im Südseeparadies“ geschürt oder ein beliebiger Konsumartikel als „Natur pur“ angepriesen wird. Alle sind Hinweis darauf, dass Umweltthemen breit rezipiert werden, mithin Relevanzcharakter haben. Ließe sich da der Umweltgeschichte nicht eine Teilhabe an Relevanzfragen zuweisen?

\footnotetext{
452 Herrmann 2006, S. 187

453 Millenium Ecosystem Assessment.
}

http://www.millenniumassessment.org - Wie man aus Biodiversitätsmodellen politische Kategorien macht, erzählen aufschlussreich Mann u. Plummer 1995.

454 Beispielsweise ist mit dem geplanten Zugriff der Firma Monsanto, mit einer für diesen Agrarkonzern (bzw. Tochterunternehmen) patentierten Sequenz des Schweinegenoms die weltweite Schweineproduktion zu monopolisieren, bereits heute die bedrückendste Folge von Naturausbeutung durch Kommerzialisierung erreicht, weil davon möglicherweise selbst alte Landrassen nicht mehr ausgenommen wären. Die fatale Perspektive solcher Gen-Monopole liegt auf der Hand.

$455 \mathrm{Zu}$ den Themen, die u.a. auf dem Workshop nicht erörtert wurden, gehört auch die Frage: „Was macht eigentlich....das Artensterben?" Nach Jahren des hochrangigen politischen Arguments, scheint es im Moment etwas stiller um diese Frage geworden zu sein. Es lohnt sich, neben der Lektüre von Mann \& Plummer (1995) auch jene Prognose von Global 2000 (1980, besonders S. 86) heranzuziehen, in der ein Aussterben von 15-20\% aller auf der Erde lebenden Arten bis zum Jahre 2000 für möglich gehalten wurde. Dies scheint nicht eingetroffen zu sein. - Für den ersten AlarmismusBericht des Club of Rome „Grenzen des Wachstums“ (Meadows et al. 1973) spielten mögliche Biodiversitätsverluste noch keine Rolle.

456 z. B. die Filme „,The Day after Tomorrow“ Regie: Roland Emmerich; „Deep Impact“ Regie: Mimi Leder; kriminalistische Bestseller: J.-C. Rufin, 100 Stunden, 2008 


\subsection{Aus der Geschichte lernen?}

Vielleicht sollte bei der Erwägung der vielbemühten Frage, „ob denn aus der Geschichte zu lernen sei“" und ihrer entsprechenden Abwandlung auf die Umweltgeschichte hin, zweckmäßig eine Unterscheidung zwischen geschichtstheoretischakademischem Purismus und praktischem Handeln gemacht werden. Die Theoretiker werden sich ad infinitum weiter streiten, weil sie den Kniff der ceterisparibus-Regel oder das Schließen aus normischen Gesetzen ${ }^{457}$ nicht einsehen oder adaptieren wollen und Unvorhersehbarkeit menschlicher Entscheidungsfreiheit und Unbegrenztheit der menschlichen Ingeniosität reklamieren. ${ }^{458}$ Nicht nur durch die Fortschritte der Wissenschaftstheorie ist diese Position überholt, sie ist es auch durch die alltägliche Lebenswirklichkeit. Ausdrücklich hat z.B. die Arbeitsgruppe der Berlin Brandenburgischen Akademie „Zukunftsorientierte Nutzung ländlicher Räume“, 459 die „Visionen für abgelegne Räume entwickelt“, an einen historischen Vorläufer angeschlossen. Vorbild ist ein Schlüsseltext der Aufklärung von Rudolph Zacharias Becker, ${ }^{460}$ dessen Anliegen „Wie man vergnügt leben, mit Ehren reich werden und sich und anderen helfen könne" ernsthaft zum Maßstab des Akademie-Projektes avancierte. ${ }^{461}$ Indes hatte bereits eine Klassikerin der Umweltgeschichte, Ester Boserup, ihre Analyse des Zusammenhangs zwischen Agrarwirtschaft und Bevölkerungswachstum ${ }^{462}$ vor dem Hintergrund ihrer profunden agrarbistorischen Kenntnisse entworfen. Historikern sei der Nutzen der Umweltgeschichte für die Geschichtsproduktion selbst wie auch für anschließende geschichtstheoretische Gedanken am Beispiel des Aufsatzes von Arno Borst über das Erdbeben von 1348 in Erinnerung gerufen. ${ }^{463} \mathrm{Er}$ ist ein außergewöhnliches historiographisches Zeugnis für die ebenso einfache wie wahre Tatsache, dass sich Vergangenheit durch Erinnerung in Erfahrung wandeln lässt und damit als Angebot für die Künftigen verfügbar wird. Hierauf gründet sich auch die Hoffnung, aus der Be-

457 Normische Gesetze gründen sich nicht auf eine monotone Logik, wie dies für streng monoton logische Gesetze, etwa die physikalischen, gilt. Vielmehr ermöglichen sie die Berücksichtung variabler Parameter mit variablen Ergebniskonstellationen. Sie erlauben das Schließen zur Erlangung von Hochwahrscheinlichkeitsaussagen nach dem Muster: „Das Licht geht normalerweise an, wenn der Lichtschalter betätigt wird.“ (Schurz 2006) - Ein solches alltagspraktisches Verständnis könnte ja auch dem Lernbedürfnis zugrunde gelegt werden, dass sich der Geschichte zuwendet. Das Schließen aus normischen Gesetzen ist die eigentliche Grundlage des größten Teils der Verabredungen, auf denen eine Gesellschaft gegründet ist, und nicht die akademische Abdeckung der letzten denktheoretisch möglichen Erwägung im Sinne monotoner Logik.

458 Wenn es in der Geschichte keine Strukturen gibt, dann bleibt unklar, warum überhaupt die Beschäftigung mit ihr lohnend sein sollte, wenn alles nur kontingent und anekdotisch ist. Unter solchen Randbedingungen kann sich kein Verständnis historischer Abläufe ergeben, weil die historischen Ereignisse sich weder inhaltlich noch kausal systematisieren ließen. Schließlich untersagt die Existenz der Geschichtsdisziplinen selbst die Behauptung, dass es problematisch sei, aus der Geschichte zu lernen, bzw. dass aus ihr nichts gelernt werden könne.

$459 \mathrm{http} / / /$ landinnovation.bbaw.de

460 Becker 1788

461 Das neue Hilfsbüchlein: Hüttl et al. 2008

462 Boserup 1970. Siehe auch: Boserup 1988

463 Borst 1981 
schäftigung mit Umweltgeschichte lernen zu können. Denn sie befasst sich mit dem, was ich wiederholt als „Langzeitversuche unter natürlichen Bedingungen“ bezeichnet und dabei bewusst den Jargon der experimentellen Naturwissenschaften verwendet habe. Das eindrucksvollste Argument stammt vom Wegbereiter der deutschen Umweltgeschichte, Arno Borst (1990, S. 563), der die Bedeutung des Erdbebenereignisses von 1348 für heutige gesellschaftliche Aufgaben (in diesem Falle der Katastrophenforschung) auf einen allgemeingültigen Nenner brachte: „Nur wer die Geschichte nicht kennt, ist dazu verdammt, sie zu wiederholen.“

Die Anfänge der Umweltgeschichte lassen sich in einem damals aktuellen Katastrophendiskurs und in der Fortschrittsmüdigkeit der 60er Jahre ausmachen. Verschmutzung der Umwelt allenthalben, depravationstheoretische Erwägungen und die Hoffnung auf die Erklärungsmacht der aufstrebenden Ökologie bündelten das Forschungsinteresse auch auf eine historische Perspektive. ${ }^{464}$ Niedergangsszenarien sollen nun für das europäische Selbstverständnis historisch geradezu konstitutiv sein. ${ }^{465}$ Solchen Erwartungshaltungen wäre eine Katastrophenfixiertheit dann auch in gewissem Maße selbstverständlich und damit erklärbar, warum die Anfänge der Umweltgeschichte übermäßig lange um einschlägige Themen kreisten.

Erkenntnis bzw. die ihr vorgeordneten Einsichten und Erfahrungen, hängen nun ab von den historischen Umständen ihrer Gewinnung. Man wird sich deshalb nicht wundern können, dass mit zunehmendem Verständnis für die Komplexität ökologischer Systeme sich die Einordnung umweltrelevanter Meinungen oder Beobachtungen mit den kulturellen Selbstverständnissen wandeln, somit auch der Blick darauf, was eigentlich eine Katastrophe sei oder in sie führe. So konnte noch zu Beginn des 19. Jh. die Idee von Charles Fourier (1772- 1837), durch spiegelgeführte Sonnenwärme die Polkappen abzuschmelzen, als bloße Phantasterei belächelt werden. ${ }^{466}$ Seine Vorstellung versetzte aber die Menschheit damals - anders als heute - keineswegs in „denkhemmende Angst" (Riechelmann). Das 19. Jahrhundert hatte seinen Blick auf die Schornsteine des Gewerbefleißes gerichtet, sich an ihren Rauchfahnen erfreut und sie als Fortschrittssymbole gefeiert, konnte sich im selben Atemzug aber durchaus auch am Pathos einer Landschaften delektieren, die u.a. von den englischen Kontinentreisenden am Rhein oder sonst wo entdeckt worden waren und seitdem das Gemüt erheben. Im Namen des Fortschritts und der Hygiene hat Deutschland im 19. Jh. Flüsse begradigt, ${ }^{467}$ Feuchtbiotope tro-

464 „Es gehört zum Historismus unserer Gegenwartskultur, dass jedes neu auftauchende Problem alsbald auch in historischer Beleuchtung vorgeführt wird. Philosophen zumal sind, in gewissen Schultraditionen, gewohnt, anstatt im Rabmen ibrer Möglichkeiten Antworten auf eine gestellte Frage zu geben, sich alsbald darüber zu verbreiten, in welchen evolutionären Variationen die einschlägige Frage früber auftrat und wie die einschlägigen Antworten früherer Philosophen lauteten. "Lübbe, S. 9

465 Das Geschichtsbild der europäischen Zivilisation ist nach der Einsicht Sieferles (2008) in hohem Maße von der Erfahrung von Zusammenbruch und Ruinerwartung geprägt.

466 Cord Riechelmann, Frankfurter Allgemeine Zeitung Nr. 286 (2007), S.Z5; vgl. auch Benjamin, S. 699

467 Es genügt hier der Hinweis auf die Rheinrektifikation durch Tulla (ab 1809) als eine der ersten Maßnahmen 
ckengelegt ${ }^{468}$ und begonnen, Abwässer auf Rieselfeldern zu klären. ${ }^{469}$ Es ist vermutlich das Jahrhundert mit den größten landschaftsverändernden Konsequenzen in Deutschland. ${ }^{470}$ Das Fortschrittsargument bringt nicht nur die Braunschweiger Müller vor dem Reichsgericht zum Verstummen, 471 es wird im Grunde bis in die 1960er Jahre das Zentralargument innerhalb der Gesellschaft bleiben. Fortschrittseuphorie brachte auch DDT in großen Mengen in die Nahrungskette ein. Vermutlich wäre aber die Rezeption der von Rachel Carson ${ }^{472}$ beschriebenen Umweltfolgen zumindest hierzulande erheblich gleichgültiger verlaufen, wenn sie nicht auf eine durch die Contergan-bedingten Missbildungen verstörte Öffentlichkeit gestoBen wäre. ${ }^{473}$ Der „Blaue Himmel über der Ruhr“"474 greift das Thema „Umwelt“ nicht mehr in der Tradition einer auf naturale Ausbeutung ausgerichteten Gesellschaft auf. Vielmehr geht er von der Setzung aus, wonach ein reduzierter Hemerobiegrad auch besser für die Menschen sei. Das Thema „Umwelt" hatte damit die staatspolitische Ebene erreicht. Es war aus den Bürgerinitiativen und lokalen Interessenverbänden in die Großstädte (oder auch umgekehrt) geschwappt und hatte begonnen, einen allgemeinen Bewusstseinswandel einzufordern. Aber dieser skizzierte Wandel des Urteiles setzt ein jeweils früheres Urteil voraus und ist nur fassbar durch Kenntnis der historischen Kontexte.

Anders aber als um die anderen staatspolitischen Themen wie Herrschaft und Wirtschaft und Kultur, um die sich breite Betätigungsfelder der Geschichtsdisziplin herausgebildet haben, hatte sich beim Thema „Umwelt“ zunächst eine professionelle Abstinenz bezüglich einer ähnlichen Breite des Themas ergeben. Fortschrittskritik bildet, einschließlich einer Selbstkritik ihrer gelegentlich schlichten Argumentation, seitdem ein häufiges Element umwelthistorischen Raisonnements. ${ }^{475}$ Seine Pointe ist vorhersehbar und läuft immer auf einen Aufruf zum Verzicht hinaus, als Einsicht in die Endlichkeit der Welt und ihrer Ressourcen. Der geringe Erfolg der Vermittlung einer solchen Postulatenethik, der die Umsetzung

\footnotetext{
468 In Zusammenhang mit der erfolgreichen Malaria-Bekämpfung siehe Schuberg 1927

${ }^{469}$ Anstoß gebend sind die Cholera-Epidemien, siehe z.B. Cordes 1861, 1868

470 Als Beispiel unter vielen: Der Landesplaner von Hazzi (1768 - 1845) hatte für Bayern entsprechende Ideen, die mindestens teilweise umgesetzt wurden (Beck 2003).

471 Zwei Braunschweiger Müller klagen 1881 bis 1883 erfolgreich gegen die Zuckerfabrik in Braunschweig-Rautheim, weil die Abwässer zur Eutrophierung ihrer Mühlenbäche führten und der überschießende Pflanzenwuchs die Mühlräder zum Stillstand brachte [(NLA-Staatsarchiv Wolfenbüttel) 37 A Neu Fb. 4 Nr. 30]. Die Geschichte ist Gegenstand des Romans „Pfisters Mühle“ von Wilhelm Raabe. Aber anders als bei Raabe, unterliegen die beiden Müller schließlich in der Revision 1884 vor dem Reichsgericht. Ihre Ansprüche werden dem Fortschrittsverständnis der wilhelminischen Gesellschaft untergeordnet.

472 Der Stumme Frühling, 1961, dtsch. 1962.

473 Thalidomid (Handelsname Contergan) wurde 1961 von Widukind Lenz als ursächlicher Wirkstoff für Missbildungen an Neugeborenen erkannt. Das Mittel wurde in der BRD unter Aufsehen erregenden Begleitumständen erst 1962 vom Markt genommen.

474 Willy Brandt in einer Rede am 28.4.1961; und wahlkampfpolitisches Ziel der SPD im Bundestagswahlkampf, dessen Themen vom Bau der Berliner Mauer 1961 überschattet werden.

475 Eine beispielhafte und kritische Übersicht über oft gelesene Positionen bei Brüggemeier 1996,S. $7 \mathrm{f}$
} 
in faktische Moral verwehrt bleiben wird, steht von vornherein fest, weil sie für den westlichen Kulturmenschen eine vierte negative existentielle Grunderfahrung zusätzlich zu jenen dreien bereit hält, die Siegmund Freud als narzisstische Kränkungen bestimmend für den Menschen der Moderne ausgemacht hatte. Sie betreffen sämtlich das Verhältnis von Menschen zur Natur:

o die erste Kränkung verdanke er Kopernikus, der nachwies, dass die Erde nicht der Mittelpunkt des Weltalls ist,

o die zweite Kränkung verdanke er Darwin, der nachwies, dass der Mensch nicht das Produkt einer kreationistischen Leistung ist,

o die dritte Kränkung verdanke er der Psychoanalyse, in deren Vermögen es liege, dem Bewußtsein erwachsener Menschen die unangenehme Einsicht vermitteln zu können, dass sein Anspruch auf Geborgenheit und Versorgung, auf Zuneigung durch einen anderen Menschen, auf Halt in Einrichtungen und Institutionen, infantil und illusorisch ist.

Alle drei Kränkungen lassen sich in umwelthistorische Erwägungen einbeziehen. ${ }^{476}$ $\mathrm{Zu}$ den Konsequenzen der dritten Kränkungen gehört nun ein allmähliches Erschrecken darüber, dass Folgen und Nebenfolgen menschlichen Handelns den in „prästabilierter Harmonie“ begriffenen Zustand der Welt zu destabilisieren in der Lage ist. Damit wird eine vierte Kränkung unausweichlich: der „Selbstbedienungsladen Natur" wird sich künftig einem größeren Teil der Menschheit verweigern. Eine weltweite Konsumgesellschaft auf der Basis desjenigen Naturverbrauchs, wie er der euroamerikanischen Zivilisation zugrunde liegt, wird es nicht geben können. Die narzistische Kränkung derjenigen, die von der Partizipation ausgeschlossen werden, weil sie ein entsprechendes Niveau noch nicht erreicht hatten, und jener, denen der Abbau erreichter Konsumhöhe abverlangt wird, hat im Bedrohungspotential der nuklearen Selbstauslöschung ein Äquivalent. Nur ist die Bedrohung durch den Falle der zurück genommenen, der verweigerten oder der unmöglichen Teilhabe an der Ressourcenausbeutung ungleich realistischer als jene durch die Atombombe. Am schlimmen Ende verbinden sich beide womöglich sogar.

Auf die zweite und dritte narzisstischen Kränkung bietet sich, wie weiter oben mit dem Biodiversitätsbegriff angedeutet, eine Antwort. Sie ist enthalten in jenem durch die Konferenz von Rio de Janeiro 1992 formulierten Anspruch, dass der Prozeß der natürlichen Evolution von nun an in der Verantwortung der Menschen stehe. Mag man hierin die Annahme einer Verantwortung sehen, die aus dem men-

\footnotetext{
476 Diese Behauptung kann selbstverständlich nur für jene Menschen gelten, die von den kopernikanischen, darwinschen und freudschen Erklärungsmodellen betroffen sind, also den westlichen Kulturmenschen. Vier Jahrhunderte nach Kopernikus wird aber kaum noch jemand an dem von ihm entworfenen Weltbild verzweifeln. Hundertfünfzig Jahr nach Darwin waren dagegen zu einer allgemeinen Beruhigung nicht ganz ausreichend, wie u.a. der Blick auf den amerikanischen bible belt und dort tätige Kreationisten zeigt. In den fünfzig Jahren nach Freud selbst sind seine Hypothesen und Theorien noch nicht einmal allgemein rezipiert. In summa gilt auch den narzisstischen Kränkungen gegenüber, die Freud ausgemacht hatte, die Gnade der späten Geburt. Dagegen ist die vierte Kränkung aktuell und bestimmend, bis hinein in Entscheidungen von weltpolitischer Bedeutung.
} 
schlichen Handeln Konsequenzen für alle Lebewesen altruistisch Konsequenzen ziehen will, so ist diese Position ideengeschichtlich ein Rückschritt. Man braucht dabei gar nicht das Paradox der altruistischen Handlung zu bemühen, die dem Menschen immer nur zu einer egoistischen gelingen wird. Vielmehr ist an die in den Sozialdisziplinen früh erreichte Einsicht zu erinnern, dass die umweltverträglichste Position des Menschen diejenige seiner Einsicht in die Einbettung in den naturalen Gesamtzusammenhang ist (Catton und Dunlap 1980). Mit der Rio-Agenda ist faktisch vor diese Einsicht zurückgekehrt worden. Die Annahme der Herausgehobenheit des Menschen (hier durch selbstzugewiesene Verantwortung für den Prozess der Evolution) provoziert immer ein Gegenüber anstatt eines förderlichen Miteinanders. Insofern knüpft die Philosophie der Rio-Agenda letztlich an die alte Opposition „Mensch und übrige Natur“ an, statt das Miteinander zu thematisieren, aus dem sich nachhaltige Verhaltensweisen und unverdächtige Rechtfertigungssätze für menschliches Umwelthandeln von selbst ergeben würden.

Hatte sich nach Darwin noch die Einsicht Bahn gebrochen, dass der Prozeß der Evolution selbstregulierend sei und in niemandes Verantwortung stände, ${ }^{477}$ wurde in Rio allgemein akzeptiert, dass Menschen Verantwortung für den Zustand der Naturräume der Welt trügen. Damit war endgültige bestätigt, dass der „biophile" Lebensstil, ${ }^{478}$ d.h. die Sorge um und das Eintreten für die Biodiversität, auch quasi-religiöse Bedürfnisse bedient bzw. bedienen kann. Die Almosenspende wird in eine Spende an den WWF gewandelt. An die Stelle der Sorge um das Seelenheil tritt die Sorge um die Jahresdurchschnittstemperatur. Die Postulatenethik der Zehn Gebote wird durch eine Globalisierungsethik nach Art des Ökologischen Imperativs ersetzt. ${ }^{479}$ Nächstenliebe wird durch eine Fernstenliebe erweitert. Der aufgeklärten nach-darwinschen Einsicht, wonach ,in der Natur" nichts so bleiben wird, wie es im Moment ist, entgegnen Menschen mit einem Beharren auf realitätsüberfordernden Konservativismus. Wenn schon die Blume welkt, Mutter und Vater sterben, dann soll wenigstens der Rest um uns herum so bleiben, wie er ist. Es ist die Furcht vor dem sicheren Ende des Vertrauten, das als Verlust erfahren und nur potentiell zur Chance wird. Aller Erfahrung nach besteht kaum je Grund, die Zukunft enthusiastisch zu erwarten. Nachdem die Sicherheit Gottes abhanden kam, die weltliche Sicherheit sich als unsicher herausstellte, müssen wir zur Kenntnis nehmen, dass auch „die Natur" keine Sicherheit bietet, weil sie keine Konstanz kennt. Im Moment ist diese Einsicht zugedeckt von den Problemen der Hyperhemerobie, die - paradoxer Weise - mit gesteigerter Zuwendung zur Natur überwunden werden soll. Sollten die dringendsten Probleme der Hyperhemerobie behoben worden sein, wird die Enttäuschung darüber erheblich ausfallen, dass eine Musealisierung der Natur durch ihr „Einfrieren“ auf dem status quo nicht gelingen

\footnotetext{
477 Herrmann 2006, S. 187

478 Wilson 1984

${ }^{479}$ Jonas 1984 „Handle so, dass die Wirkungen deiner Handlung verträglich sind mit der Permanenz echten menschlichen Lebens auf Erden.“
} 
kann. Wollte man einen aktiven „Rückbau“ naturaler Systeme betreiben, bereitet zudem deren Resilienzeigenschaft ein schwerwiegendes Problem. Denn resiliente Systeme haben durch ihre Nachlaufeigenschaften einen zum Zeitpunkt eines erkennbaren Systemumbruchs einen in seinem Umfang nicht bekannten Binnenwandel hinter sich. Wer resiliente Systeme zurückführen möchte, sollte zumindest wissen, bis vor welchen Zeitpunkt bzw. bis vor welche menschliche Verhaltensänderung. Wollte man beispielsweise den „Sauren Regen“ als Ursache des Waldsterbens beseitigen, müsste man den Autoverkehr abschaffen, die Kohlekraftwerke, die Hochschornsteine usw., bzw. die Technologien, die ursächlich für den Sauren Regen sind. Wenn es nicht möglich scheint, die Technologien in absehbaren Zeiträumen gänzlich zu ersetzen, bieten sich z.B. Biowissenschaften mit dem Konzept genetisch veränderter Organismen an. An Stelle einer Ursachenbeseitigung würde die Neutralisierung der Noxe durch entsprechend angepasste Individuen zu überwinden gesucht, was doch aber die Langfristfolgen des Sauren Regens für die Bodenqualität nicht berührte. Der Optimismus, mit dem molekulare Werkzeuge heute propagiert oder benutzt werden ist ungeheuer und mentalitätsgeschichtlich von Interesse. „Emanzipation“ war der zentrale Begriff der Aufklärung. Man kann sich von allem (Kulturellen) emanzipieren, nicht aber von seiner (der) Natur bzw. von den allgemeinen naturalen Voraussetzungen. In der Gentechnik ist der folgerichtige Versuch des Menschen angelegt, sich nun auch noch von der Natur zur emanzipieren. ${ }^{480}$ In diesem Zusammenhang wird allzu leicht übersehen, dass etwa eine gentechnisch hergestellte resistente Pflanze bei ihrer Schädlingsart sofort eine Coevolution in Gang setzt, die den erreichten Pflanzenschutz überwinden wird. Das Argument kann entsprechend auf andere Bereiche gentechnischer Bemühungen übertragen werden.

Jede ingenieurtechnische Beseitigung einer Kausalursache wird aber nur umsetzbar, wenn eine mentalitätengeschichtliche Begleitung die erforderliche Aufklärungsarbeit leistet, ohne die es kein zukunftsicherndes Umwelthandeln geben und sich die eingeforderte „neue Vorsorgekultur“ (Kofi Anan) nicht entwickeln kann. Manche ingenieurtechnische Lösung wäre entbehrlich, wenn die sozioökonomischen Bedingungen durch Bewusstseinswandel verändert würden. Auch in dieser Gewissheit steckt Umweltgeschichte.

\subsection{Was aus der Geschichte lernen?}

Man wird es drehen und wenden können wie man will, eines Tages, wann immer sich selbst oder Dritten Rechenschaft zu geben sein wird, steht man unausweichlich vor der Frage, ob dem hedonistischen Adam im Wissenschaftler auch noch ein „politischer" Adam ${ }^{481}$ zur Seite stand? Der sollte ohne größeren Aufwand in der

\footnotetext{
480 Herrmann 2003

${ }^{481}$ Gemeint ist mit „politisch“ hier die Fortschreibung der aristotelischen Etikettierung des Menschen als „zoon politikon“, also eines gesellschaftlich verantwortlich handelnden Menschen. - Vgl. Seite 4; http://www.wbgu.de/wbgu_jg1996.pdf
} 
Lage sein, die Sinnhaftigkeit seiner Arbeit nicht nur allgemeinverständlich zu erläutern, sondern auch Perspektiven eines Nutzens aus dieser Arbeit aufzuzeigen. Eingefordert wird hier nicht einmal ein direkter Nutzen, sondern lediglich der perspektivische. Das entspräche in wissenschaftstheoretischer Formulierung einer „Anschlussfähigkeit“ für das konkrete Ergebnis, also der kleinstmöglichen Zweckbestimmung des Forschungsertrags. Allerdings sollten dabei jene Argumente keine Berücksichtigung finden, die sich lediglich des ablenkenden Hinweises bedienen: wenn eine Gesellschaft für Dieses oder Jenes Geld ausgebe, könne sie auch dieses oder jenes Projekt der Wissenschaft fördern.

Als entscheidende Voraussetzung für die Förderung wissenschaftlicher Fragestellungen gelten der Wettbewerb der Argumente und der Einfluss der Interessenvertreter. Im Falle der Umweltgeschichte müsste das Förderkonzept umgedreht werden: Denn in einer Welt, die sich dem Wachstum des materiellen Wohlstandes aus naturalen Ressourcen verpflichtet hat, ist kaum zu erwarten, dass Argumente als mehrheits- bzw. wettbewerbsfähig gelten, die dem Individuum wie der Gesellschaft nahelegen, ein anderes Wertesystem zu entwickeln und die selbstzerstörerischen Eigenschaften des jetzigen Systems infrage zu stellen.

Damit wäre eine Relevanz der Umweltgeschichte benannt: Sie ist (erstens) zunächst einmal Anamnese. Sie betreibt die diachrone und diatopische Beobachtung und Analyse von naturalen, sozio-naturalen und sozio-ökonomisch-naturalen Systemen sowie an ihnen entwickelten Wertvorstellungen. Letztere beeinflussen die Entwicklung jener Wertesystemen, die nachfolgenden Generationen das (menschenwürdige) Leben in einer (intakten naturalen) Umwelt ermöglichen. Umweltgeschichte wird (zweitens) damit zu einem unveräußerlichen Bestandteil der ökologischen Grundbildung, die ihrerseits zu einem unveräußerlichen Bestandteil basaler Erziehung und Ausbildung werden muss.

Ein einfaches Beispiel von (drittens) der Verknüpfung historischer Umweltforschung mit zukunftsichernden Nachhaltigkeitsaspekten ist die Biodiversitätsforschung an Objekten naturkundlicher Sammlungen, die, z. T. über Jahrhunderte zusammengetragen, heute wertvollste diachrone Zeugnisse über genetische Vielfalt, über Arten, Lebensräume und Interaktionen sowie der Ökosysteme, ihrer Güter und Dienstleistungen geben (Leinfelder 2008). Aus ihnen sind Beiträge u.a. zur Beantwortung jener Probleme zu erwarten, die der WBGU-Jahresbericht bereits 1996 identifiziert: ${ }^{482}$ „Damit verbunden sind Forschungsfragen, deren Beantwortung in den kommenden Jabren weiter an Bedeutung zunehmen wird:

- Wie kommt es zu den Naturveränderungen, und wie sind sie mit der globalen Entwicklungsproblematik verknüpft?

- Wie kann man sie frühzeitig erkennen oder vorhersagen?

-Welche Risiken sind mit ibnen verbunden?

482 http://www.wbgu.de/wbgu_jg1996.pdf, Seite 4; 
-Wie muss der Mensch handeln, um negative Entwicklungen auf globaler Ebene zu verbindern, um drohenden Gefahren zu begegnen bzw. um die Folgen globaler Veränderungen zu minimieren?"

Solche Fragen sind ohne umwelthistorische Kenntnisse nicht beantwortbar, zumal in Wörtern wie "negative Entwicklungen“" kultureller Erklärungsbedarf steckt . Allein mit der historischen Perspektive kann ein sicheres Verständnis für die prozessualen Abläufe bereitgestellt werden. Unschwer ist daher in dieser Agenda auch eine Handlungsanleitung für Umweltgeschichte erkennbar.

In der Raumplanung etwa ist seit jeher dieser Rückgriff auf und der Vergleich von historischen Szenarien erfolgt, um die Nutzungs- und Wertewandel angemessen zu berücksichtigen. ${ }^{483}$ Die Dimensionen der Bedeutung umwelthistorischer Datensätze werden besonders deutlich, wo sie zu prognostischen Szenarien herangezogen werden. Tatsächlich greifen Modellierer aktuell als drängend betrachteter Globalprobleme bereits auf umwelthistorische Daten zurück, wenn etwa die Situation des Weltklimas als von historischer agrarwirtschaftlicher Entwicklung abhängig betrachtet wird (Pongratz et al. 2008). Dabei wäre eine Einbindung des kompetenten umwelthistorischen Sachverstandes erforderlich, weil den Nutzern bloßer Literaturangaben der Stand des umwelthistorischen Diskurses entgehen kann. ${ }^{484}$

Ganz folgerichtig ist damit ein vierter Aufgabenbereich erreicht worden: will man Umweltgeschichte nicht nur um ihrer selbst willen betreiben, ${ }^{485}$ dann führt Umweltgeschichte zwangsläufig in eine Beratungsposition (siehe hierzu auch den Beitrag Schlottau in diesem Band). Beraten wird „die Gesellschaft“ über Abläufe und Folgen von Umwelthandeln, soweit es sich um wissenschaftlich zugängliche Gegenstandsbereiche oder Sachverhalte handelt. Dabei müsste nach Max Weber (1988b) allerdings die Trennung von „Wie?“ und „Ob?“" gewahrt bleiben.

Die Frage „Umweltgeschichte wozu?“ ist gleichlautend vor einem Dutzend Jahren von Jost Hermand (1996) gestellt worden. Er hat ein vehementes Plädoyer dafür gehalten, der Umweltgeschichte eine weniger anthropozentrischen Ausrichtung zu geben und sie stärker auf Fragen der Zukunftssicherung auszurichten, eine „Mitweltgeschichte“ zu betreiben. Etwas nüchterner lässt sich feststellen, dass

483 Diese Aussage ist selbstverständlich nur von relativer Bedeutung und gilt vorderhand für mitteleuropäische Idealverhältnisse. Wie am Schadensausmaß des diesjährigen Erdbebens in China ersichtlich, hat die Raumplanung im betroffenen Gebiet historische Kenntnisse offenbar nicht hinreichend berücksichtigt.

484 Beispiel hierfür ist die Analyse von Pongratz et al. (2008), die in ihrer Darstellung die neueren Erkenntnisse über Vorkommen und Ausmaß fortgeschrittener Agrarkultur in Süd- und Nordamerika sowie Afrika nicht den Stand des heutigen Wissens abbilden, sondern sich auf Fortschreibungen älterer Arbeiten (im Anschluss an Whittlesley 1936) verlassen. Die sich ergebende Frage ist: Welche Aussagepräzision werden Modelle haben können, die sich auf unzulängliche Grundvoraussetzungen stützen? Ich danke William Woods, University of Kansas, dass er mich mit diesem Sachverhalt bekannt machte und für seine Zustimmung, darauf hinweisen zu dürfen, bevor er und Kollegen diesen Sachverhalt im Jahre 2009 auf dem 1st World Congress of Environmental History, Kopenhagen, genauer vorstellen werden.

${ }^{485}$ Ich halte das zwar für einen auch akzeptablen Grund, sich mit Umweltgeschichte zu befassen, plädiere jedoch dafür, einige Mühe auch auf „Relevanzfragen“ zu verwenden. 
umwelthistorisch interessierte Wissenschaftler seit längerem den Beratungsbereich anvisieren, ihn z.T. sogar als konstitutiv für die Weiterentwicklung der Umweltgeschichte ansehen. ${ }^{486}$ Einige haben ihren Weg unmittelbarer gewählt und sind über die sozialwissenschaftlich geprägte Humanökologie direkt in die Politikberatung gelangt. 487 Die aktuelle Hinwendung eines Teils der Umweltgeschichte zur Sozialgeschichte ist unübersehbar ${ }^{488}$ und nach meiner Einsicht diesem genannten Bewusstseinswandel von der bloß wissenschaftlichen zur gesellschaftlich einflussreichen Tätigkeit hin verdankt. Für die „Disziplinierung“ der Umweltgeschichte ist dies eine zwiespältige Entwicklung. Sie kann an Einfluss gewinnen und gleichzeitig an disziplinärer Kontur verlieren, wenn das umwelthistorische Profil zugunsten des sozialgeschichtlichen bzw. des soziologischen Profils aufgegeben wird. Ob über Politik-Beratung eine wirkliche Verbesserung der fachlichen umwelthistorischen Position und eine allgemeinere Verbreitung ihrer Einsichten erreichbar sind, erscheint offen. Unstreitig erscheint mir allerdings, dass die Umweltgeschichte ihre Szenarien nicht fiktional entwickeln muss, sondern sich auf einen Erfahrungsschatz stützen kann, von dem man weiß, dass seine Inhalte reale Möglichkeiten sind. „Die Science-Profession folgt einem Verständnis von ,guter Wissenschaft", nach der im Zweifel Sicherheit ihrer Aussagen der Vorzug zu geben ist. Der Gesellschaft geht es demgegenüber unter „Sicherheit" um die reale Sicherheit von Infrastruktur und Vermögen. “489 Die Umweltgeschichte ist hier in der komfortablen Situation, beide divergierenden Aspekte weitgehend verbinden zu können und die notwendige begleitende Moderation bereit zu stellen. Das Feld ist bereits ziemlich bestellt, doch sollte noch Platz für die spezifische Kompetenz der Umwelthistoriker sein.

\footnotetext{
486 Wie z.B. Sörlin \& Warde 2007

487 Für das sozialwissenschaftliche Feld der Humanökologie seien stellvertretend die Publikationen Glaeser \& Teherani-Krönner (1992), Glaeser (1996) und Serbser (2003) genannt. - Als Beispiel für einschlägige Politikberatung kann das Wissenschaftszentrum Berlin gelten. - Die Zeitschrift GAIA ist Beispiel eines Periodikums, das mit wissenschaftlicher Legitimation auf umweltpolitische Wirkung zielt.

488 z. B. die bevorstehende Tagung: „Terrains communs, Regards croisés. Intégrer le social et l'environmental en histoire." Centre de Recherches Historiques, UMR CNRS/EHSS, Paris 11-13 septembre 2008. - Ebenso ist die politische Motivation hinter dem Tagungsthema des ersten Weltkongresses für Umweltgeschichte in Kopenhagen unübersehbar: "Local Livelihoods and Global Changes: Understandig Human Interactions with the Environment", August 2009.

${ }^{489}$ Luhmann 2008, S. 30
} 


\section{Literatur}

Alpers S (1998) Kunst als Beschreibung. Holländische Malerei des 17. Jahrhunderts. DuMont, Köln

Baumgart W (2006) Bücherverzeichnis zur deutschen Geschichte. Hilfsmittel, Handbücher, Quellen. 16. Auflage. dtv, München

Beck R (2003) Ebersberg oder das Ende der Wildnis. Eine Landschaftsgeschichte. $\mathrm{CH}$ Beck, München

Becker RZ (1788) Noth- und Hülfsbüchlein für Bauersleuthe oder lehrreiche Freuden- und Trauergeschichte des Dorfs Mildheim. Gotha/Leipzig, Deutsche Zeitung/Göschen

Benjamin W [1974] Über den Begriff der Geschichte. In: W Benjamin, Gesammelte Schriften, Bd. 2, Teil 2. Hg. von R Tiedemann u. H Schweppenhäuser. Suhrkamp, Frankfurt. S. 698-699

Borst A (1981) Das Erdbeben von 1348. Historische Zeitschrift 233: 529-569 (hier zitiert nach der Fassung in: A Borst (1990) Barbaren, Ketzer und Artisten. Welten des Mittelalters. Serie Piper, München, Zürich. S. 528-563)

Boserup E (1970) The conditions of agricultural growth. Allen \& Unwin, London. (erste Auflage 1965)

Boserup E (1988) Environment, population, and technology in primitive societies. In: D Worster (Hg.) The ends of the earth. Cambridge University Press, Cambridge, New York. S. 23 - 38

Brüggemeier FJ (1996) Das unendliche Meer der Lüfte. Luftverschmutzung, Industrialisierung und Risikodebatten im 19. Jahrhundert. Klartext, Essen

Catton W, Dunlap R (1980) A new ecological paradigm for post-exuberant sociology. American Behavioral Scientist 24(1): 15-47.

Carson R (1987) [1962] Der Stumme Frühling. Beck’sche Reihe, München

Cassirer E (1996) Versuch über den Menschen [An Essay on Man, 1944]. Meiner, Hamburg

Cordes E (1861) Die Cholera in Lübeck: einige Worte an den Patriotismus und die Behörden, nebst einem Plan der Stadt, enthaltend die Todesfälle in den einzelnen Straßen. Aschenfeldt, Lübeck

Cordes E (1868) Die Cholera in Lübeck. Zeitschrift für Biologie 4(2) 
Feyerabend P (1986) Wider den Methodenzwang. Suhrkamp, Frankfurt [hier zitiert nach der 4. Auflage 1993]

Friedrichs K (1943) Über den Begriff der „Umwelt“ in der Biologie. Acta Biotheoretica 7: 147-162

Friedrichs K (1950) Umwelt als Stufenbegriff und als Wirklichkeit. Studium Generale 3: 70-74

Fuchsloch N (1996) Einführung in „Methodenfragen der Umweltgeschichte“. In: G Bayerl, N Fuchsloch, T Meyer (Hg.) Umweltgeschichte - Methoden, Themen, Potentiale. (= Cottbuser Studien zur Geschichte von Technik, Arbeit und Umwelt 1). Waxmann, Münster u.a. S. 1-12

Glaeser B (1996) Huamnökologie: Der sozialwissenschaftliche Ansatz. Naturwissenschaften 83:145-152

Glaeser B, Teherani-Krönner P (Hg.) (1992) Humanökologie und Kulturökologie. Westdeutscher Verlag. Opladen

Global 2000 (1980) Der Bericht an den Präsidenten. Hg. der deutschen Übersetzung Reinhard Kaiser. Zweitausendeins, Frankfurt/M.

Godelier M [1984] L'idéel et le matériel. Pensée, économies, societés, Fayard, Paris. (hier zitiert nach der engl. Ausgabe: The mental and the material: thought, economy and society. Verso, London 1986)

Haidle MN (2008) Verschiedene Welten: Umweltwahrnehmung und Umweltgestaltung im Laufe der menschlichen Evolution. In: T Knopf (Hg.) Umweltverhalten in Geschichte und Gegenwart. Vergleichende Ansätze. Attempo Verlag, Tübingen. S. 30 - 41

Hermand J (1996) Umweltgeschichte wozu? In: G Bayerl, N Fuchsloch, T Meyer (Hg.) Umweltgeschichte - Methoden, Themen, Potentiale. (= Cottbuser Studien zur Geschichte von Technik, Arbeit und Umwelt 1). Waxmann, Münster u.a. S. 303-308

Herrmann B 1996 Umweltgeschichte als Integration von Natur- und Kulturwissenschaften. In: G Bayerl, N Fuchsloch, T Meyer (Hg.) Umweltgeschichte - Methoden, Themen, Potentiale. (= Cottbuser Studien zur Geschichte von Technik, Arbeit und Umwelt 1). Waxmann, Münster u.a. S. 21-30

Herrmann B (2003) Historische Humanökologie und Biodiversitätsforschung. In: SR Gradstein, R Willmann, G Zizka (Hg.) Biodiversitätsforschung. Die Entschlüsselung der Artenvielfalt in Raum und Zeit. S. 225 - 236. Schweizerbarth, Stuttgart (Kleine Senckenberg Reihe 45) 
Herrmann B 2006 „Auf keinen Fall mehr als dreimal wöchentlich Krebse, Lachs oder Hasenbraten essen müssen!“"- Einige vernachlässigte Probleme der „historischen Biodiversität“،. In: H-P Baum, R Leng, J Schneider, (Hg.) Wirtschaft - Gesellschaft - Mentalitäten im Mittelalter. Festschrift zum 75. Geburtstag von Rolf Sprandel. (= Beiträge zur Wirtschafts- und Sozialgeschichte 107). Steiner, Stuttgart. S. $175-203$

Herrmann B (2008) Empirische Zugänge zu historischen Biodiversitätsverdrängungen und Biodiversitätslenkungen: Die Beispiele Melioration und Schädlingsbekämpfung. In: T Knopf (Hg.) Umweltverhalten in Geschichte und Gegenwart. Vergleichende Ansätze. Attempo Verlag, Tübingen. S. 174192

Holling CS, Gunderson L, Ludwig D (2002) In Quest of a Theory of Adaptive Change. In: L Gunderson, CS Holling (Hg.) Panarchy. Understanding transformations in human and natural systems. Island Press, Washington. S. 322

Hüttl RF, Bens O, Plieninger T (Hg.) (2008) Zur Zukunft ländlicher Räume: Perspektiven der Landnutzung in peripheren Regionen Nordostdeutschlands. Akademie-Verlag, Berlin

Hughes JD (2006) What is Environmental History? Polity Press, Cambridge, Malden

von Humboldt A [1847-62] Der Kosmos. Entwurf einer physischen Weltbeschreibung. Hg. v. O. Ette u. O. Lubbrich. Eichborn, Frankfurt/M. 2004

Jonas, H. 1984 Das Prinzip Verantwortung. Versuch einer Ethik für die technologische Zivilisation. Suhrkamp, Frankfurt/M.

Knopf T (2008) Umweltverhalten als Forschungsaufgabe. In: T Knopf (Hg.) Umweltverhalten in Geschichte und Gegenwart. Vergleichende Ansätze. Attempo Verlag, Tübingen. S. 9-15

Krüger L (1987) Einheit der Welt - Vielheit der Wissenschaft. In: J Kocka (Hg.) Interdisziplinarität. Praxis - Herausforderungen - Ideologie. Suhrkamp, Frankfurt/M. S. 106-125

Laroux N (1993) The Children of Athena: Athenian ideas about citizenship and the division between the sexes. Princeton University Press, Princeton

Lehmkuhl U (2002) Histoire totale oder Bindestrich-Geschichte? In: Erfurter Beiträge zur Nordamerikanischen Geschichte 4, S. 2-10 http://www.uni-erfurt.de/nordamerika/erfurterbeit/umweltgeschichte.html\#a

Leinfelder R (2008) Der größte Schatz ist noch nicht gehoben. Leibniz - Journal der Leibniz-Gemeinschaft 1/2008: 3 
Lübbe H (1986) Ökologische Probleme im kulturellen Wandel. In: H Lübbe u. E Ströker (Hg.) Ökologische Probleme im kulturellen Wandel. Finkh/Schöningh, Paderborn(= Ethik der Wissenschaften. Arbeiten aus einer Studiengruppe der Werner Reimers Stiftung V). S. 9-14

Lumann H-J (2008) Klimansensitivität, Leben und die Grenzen der ScienceKultur. Zum Vierten IPCC-Sachstandsbericht. Gaia 17(1): 25-30

Mann C, Plummer M (1995) Noah's choice. The future of endangered species. Alfred Knopf, New York

Marx K [1968] Die Produktion des absoluten Mehrwerts. 5. Kap. Arbeitsprozess und Verwertungsprozess. In: K Marx, F Engels, Werke, Band 23, "Das Kapital", Bd. I, Dritter Abschnitt, S. 192 - 213; Dietz Verlag, Berlin, DDR

McNeill J (2003) Observations on the nature and culture of environmental history. History and Theory, Theme Issue 42 (December 2003): 5-43

Meadows D, Meadows D, Zahn E, Milling P (1973) Die Grenzen des Wachstums. Bericht des Club of Rome zur Lage der Menschheit. Rowohlt, Reinbeck. [engl. u. dtsch. Erstveröffentlichung 1972]

Nagel T (1974) “What is it like to be a bat?” Philosophical Review 83: 435-450

Park RE, Burgess EW (1921) Introduction to the science of sociology. The University of Chicago Press, Chicago [hier zitiert aus der zweiten Auflage 1924]

Pongratz J, Reick C, Raddatz T, Claussen M (2008) A global land cover reconstruction AD 800 to 1992 - Technical Description.

Max-Planck-Institut für Meteorologie, Berichte zur Erdsystemerforschung 51. http://www.mpimet.mpg.de/fileadmin/publikationen/Reports/WEB_Bze_51 .pdf

Radkau J (1993) Was ist Umweltgeschichte? In: C Simon (Hg.) Umweltgeschichte heute. Environmental History Newsletter. Special Issue No1, S. 86-97

Radkau J (2002) Mensch und Natur in der Geschichte. Klett, Leipzig (= Historisch Politische Weltkunde, Kursmaterialien Geschichte Sekundarstufe II/ Kollegstufe)

Rheinberger H-J (2007) Historische Epistemologie - zur Einführung. Junius, Hamburg

Ryle G [2002] Der Begriff des Geistes. Reclam, Stuttgart

Schaefer M (2003) Wörterbuch der Ökologie. Spektrum Akademischer Verlag, Heidelberg 
Schatzki T (2003) Nature and technology in history. History and Theory, Theme Issue 42 (December 2003): 82-93

Schuberg A (1927) Das gegenwärtige und frühere Vorkommen der Malaria und der Anophelesmücke im Gebiet des Deutschen Reiches. Arbeiten aus dem Reichsgesundheitsamt 59: 1-424 (Springer, Berlin)

Schurz G (2006) Einführung in die Wissenschaftstheorie. Wiss. Buchgesellschaft, Darmstadt

Serbser W (Hg.) (2003) Humanökologie. Ursprünge - Trends - Zukünfte. LIT Verlag, Münster usw.

Sieferle RP (2008) Zusammenbruch von Zivilisationen. Eine konzeptuelle Analyse am Beispiel des Imperium Romanum. Gaia 17(2): 213-223

Siemann W, Freytag N (2003) Umwelt - geschichtswissenschaftliche Grundkategorie. In: W Siemann, N Freytag (Hg.) Umweltgeschichte. Themen und Perspektiven. Beck, München. S. 7-20

Sloterdijk P (2001) Domestikation des Seins. Für eine Verdeutlichung der Lichtung. In: P Sloterdijk (Hg.) Nicht gerettet. Versuche nach Heidegger Suhrkamp, Frankfurt. S. 142-234

Sörlin S, Warde P (2007) The problem of the problem of environmental history: a re-reading of the field. Environmental History 12: 107-130

Stammler, W. (Übers.) (1988) Die Erinnerungen des ersten Grossmoguls von Indien: d. Baburnama / Zahir-ad-Din Muhammad Babar. Manesse, Zürich

Steward JH (1955) Theory of cultural change. University of Illinois Press, Urbana

Stichweh R (Hg.) (1994) Wissenschaft, Universität, Professionen. Soziologische Analysen. Suhrkamp, Frankfurt/M.

Thieme H (Hg.) (2007) Die Schöninger Speere. Mensch und Jagd vor 400000 Jahren. Theiss, Stuttgart

Thienemann A (1958) Leben und Umwelt. Vom Gesamthaushalt der Natur. Deutsche Buchgemeinschaft, Berlin u. Darmstadt

Toyka-Seid M (2003) Mensch und Umwelt in der Geschichte. Neues aus dem produktiven Selbstfindungsprozess der Umweltgeschichte. Archiv für Sozialgeschichte 43: 423-447

Uekötter F (2007) Umweltgeschichte im 19. und 20 Jahrhundert. (Enzyklopädie Deutscher Geschichte Bd. 81). Oldenbourg, München

von Uexküll J (1921) Umwelt und Innenwelt der Tiere. Zweite Auflage, Springer, Berlin 
von Uexküll J [1928] Theoretische Biologie. Mit einem Vorwort von Rudolf Bilz. Suhrkamp, Frankfurt/M. 1973

von Uexküll J, Kriszat G (1934) Streifzüge durch die Umwelten von Tieren und

Menschen. Ein Bilderbuch unsichtbarer Welten. Springer, Berlin

von Uexküll J, Kriszat G [1934] Streifzüge durch die Umwelten von Tieren und

Menschen. Ein Bilderbuch unsichtbarer Welten. Rowohlt, Hamburg 1956

Voltaire [1971] Candid oder Die Beste der Welten. Reclam, Stuttgart

Ward LF (1903) Pure Sociology. A treatise on the origin and spontaneous development of society. Macmillan; New York, London

Weber M (1988a) [1904] Die „Objektivität“ sozialwissenschaftlicher und sozialpolitischer Erkenntnis. In: M Weber, Gesammelte Aufsätze zur Wissenschaftslehre. Hg. von J Winckelmann. (UTB) Mohr, Tübingen, S. 146214

Weber M (1988b) [1922] Wissenschaft als Beruf. In: M Weber, Gesammelte Aufsätze zur Wissenschaftslehre, Hg. von J Winckelmann, (UTB) Mohr, Tübingen, S. 582-613

Wilson EO (1984) Biophilia. Harvard Univ. Press, Cambridge/Mass.

Winiwarter V (1994) Umwelt-en. Begrifflichkeit und Problembewusstsein. In: G Jaritz, V Winiwarter (Hg.) Umweltbewältigung. Die historische Perspektive. Verlag f. Regionalgeschichte, Bielefeld. S. 130 - 159

Winiwarter V, Knoll M (2007) Umweltgeschichte. Eine Einführung. (UTB) Böhlau, Köln

Winiwarter V, Schmid M (2008) Umweltgeschichte als Untersuchung sozionaturaler Schauplätze?. Ein Versuch, Johann Colers »Oeconomia« umwelthistorisch zu interpretieren. In: T Knopf (Hg.) Umweltverhalten in Geschichte und Gegenwart. Vergleichende Ansätze. Attempo Verlag, Tübingen. S. 158-173

Wissenschaftsrat (1994) Stellungnahme zur Umweltforschung in Deutschland. 2 Bde. Wissenschaftsrat, Köln

Whittlesey D (1936) Major agriculture regions of the earth. Annals of Association of American Geographers 26(4): 199-240 


\section{Kartoffel, Tod und Teufel Wie Kartoffel, Kartoffelfäule und Kartoffelkäfer Umweltgeschichte machten}

\section{Bernd Herrmann 490}

Der hier beschriebene „Schauplatz der Umweltgeschichte“ ist es, wegen seiner eigentlichen Ortlosigkeit, nur im übertragenen Sinn. Tatsächlich behandelt er Beziehungen zwischen der seit dem 18. Jh. in Europa in der Fläche angebauten Kartoffel, zwei ihrer Hauptschadorganismen und den Auswirkungen ihres Auftretens. In ihrer Kombination bildet diese Trias ein umweltgeschichtliches Lehrbuchbeispiel, bei dem eine segensreiche Feldfrucht durch Pilz und Käfer bedroht und damit auch den Menschen im buchstäblichen Sinne Tod und Verderben gebracht wurde. ${ }^{491}$ Eigentlich stellen die Organismen selbst die Schauplätze, wobei zufällig jeder für eine der drei Hauptlinien des Organismenreiches steht. ${ }^{492}$

Historisch sicher sind sie nur manchmal mit konkreten Orten, selten mit Personen, für eine Veranschaulichung aber mit vielen Stätten zu verbinden. Wann immer möglich, werden Bezüge zum deutschsprachigen Raum hergestellt. Weil sich der Beitrag nur schwer für das Format der „Schauplätze“ hergibt, ist er als Essay konzipiert, dem folgende Struktur gegeben wurde:

490 Zuerst erschienen in: Herrmann B, Stobbe U (Hrsg.)(2009) Schauplätze und Themen der Umweltgeschichte. Umwelthistorische Miszellen aus dem Graduiertenkolleg. Werkstattbericht. Universitätsdrucke Göttingen. S. 71-126

491 Eine der beiden möglichen Titel-Anleihen bezieht sich auf die Ikonographie des Meisterstichs „Ritter, Tod und Teufel“" von Albrecht Dürer. Sie liefert die eigentliche Erklärung; die andere ergab sich als subtextliche Bedeutung, hat aber mit fortschreitender Ausarbeitung des Aufsatzes zunehmende Berechtigung erhalten: Es ist ein Merkmal des Umwelthistorischen, dass es den Zusammenhang zwischen vielen, scheinbar unverbundenen Sachverhalten sichtbar macht.

492 Gemeint sind die drei Bereiche, in welche die Biologie die organismische Vielfalt systematisiert: Pflanzen, Tiere und Pilze. 
$1 \quad$ Über die Kartoffel

1.1 Der lange Weg zum Erfolg

1.2 Marktbezug und Industrialisierung

1.3 Kartoffel und Bevölkerungswachstum

1.4 Von Europa in die Welt: Nicht nur Löwenzahn und Wiesenrispe

1.5 Zur Kartoffel drängt, an der Kartoffel hängt fast alles

2 Die Kraut-und Braunfäule der Kartoffel

$2.1 \quad$ Ein Pilz bringt Hunger und Tod

2.2 Sozio-Demographische Folgen

3 Der Kartoffelkäfer

3.1 Leptinotarsa decemlineata

3.2 Erstes Auftreten in Deutschland 1876/77

3.3 Ein Schädling etabliert sich.

3.4 Die Erfolglosigkeit der Abwehr

3.5 Schadensausmaße

3.6 Kartoffelkäfer, Biologische Kriegführung und politische Propaganda

$4 \quad$ Zusammenfübrung

\section{1 Über die Kartoffel}

\subsection{Der lange Weg zum Erfolg}

Die Spanischen Entdecker erreichten das Andenhochland, in dem die Kartoffel vermutlich seit über 7000 Jahren von den indigenen Amerikanern angebaut wurde, nach 1532. Die erste schriftlich überlieferte Erwähnung der Kartoffel erfolgt 1537, für das Gebiet des heutigen Kolumbien. In der gedruckten Literatur wird sie ab 1552 greifbar. Die Kanarischen Inseln, auf denen sie erstmalig „,in Europa“ angebaut wurden, verschifften Fässer mit Kartoffeln bereits im November 1567 nach Antwerpen und 1574 nach Rouen. Von den Kanarischen Inseln also, und nicht dem Spanischen Festland, tritt die Knollenfrucht ihren langsamen aber stetigen Erfolgsweg an. ${ }^{493}$ Der Vermehrungserfolg auf den Kanarischen Inseln ist mit der im südamerikanischen Ursprungsraum ähnlichen Taglänge erklärbar. Wie der weitere Weg von den Kanaren in die europäischen Länder verlief, ist bis heute nicht im Detail bekannt. ${ }^{494}$ Hatte man ehedem mit Blick auf den europäischen Langtag eine frühe Einführung auch chilenischer Kartoffeln (von der Insel Chiloè) diskutiert, kann eine ursprüngliche Doppelprovenienz oder alleinige Provenienz aus

\footnotetext{
493 Hawkes \& Francisco-Ortega

494 Hawkes hat 1985 den Nachdruck des klassischen Werkes über die Kartoffelgeschichte von Salaman (1949) herausgegeben und einige Ergänzungen vorgenommen, die schließlich zu einer eigenen Monographie führten (Hawkes). Einschließlich dieser Monographie von Hawkes ist der Forschungsfortschritt bezogen auf die allgemeine Ausbreitungsgeschichte der Kartoffel gegenüber Laufer und Salaman nicht sehr bemerkenswert, bezogen auf Deutschland jedoch durch Denecke entscheidend verbessert worden. Hingegen ist die Evolution der Kartoffel einschließlich von Resultaten nach bis zu diesem Zeitpunkt technisch möglicher molekularer Analysen von Hawkes erschöpfend erörtert.
} 
chilenischen Kultivaren nach DNA-Untersuchungen an Herbarmaterial ausgeschlossen werden. In europäischen Herbarexemplaren ist DNA chilenischen Ursprungs erst ab 1811 nachweisbar. ${ }^{495}$

Die Einführung der Kartoffel nach Deutschland erfolgte aus Italien, ${ }^{496}$ sie ist eng mit dem Namen des Botanikers Clusius (Jules Charles de l'Ècluse, 1526-1609) verbunden, dem 1588 die ersten Knollen nach Wien, und zwar aus Belgien, zugeschickt wurden (Abb. 1). ${ }^{497}$ Die Kartoffel war zu dieser Zeit als dekorative exotische Pflanze in Herrschaftsgärten einigermaßen populär, 498 aber ihre Knollen wurden noch nicht zur Nahrung genutzt. Clusius beschreibt die Taratouffli 1601, das seitdem als „offizielles Datum“ ihrer Einführung in den deutschsprachigen Raum gilt. 499

Ein früher Nachweis der Kartoffel als Zierpflanze betrifft den Berliner Lustgarten, ${ }^{500}$ der unter dem Großen Kurfürsten, Friedrich Wilhelm (1620-1688), nach niederländischem Vorbild zur barocken Gartenanlage umgestaltet wurde und seinen Namen seit 1647 trägt. Teile der Anlage dienten als Küchengarten und beherbergten exotische Pflanzen und Gewürze. Friedrich Wilhelm soll 1651 veranlasst haben, Kartoffeln in diesen Küchengarten zu setzen. ${ }^{501}$ Es ist eine der ältesten Erwähnungen der Kartoffel in Deutschland, die sich mit einem konkreten Ort verbinden lässt. Etwa zur selben Zeit werden erste Knollen auch nach Baden, Franken, Braunschweig, Westfalen und Sachsen eingeführt. Die Bedeutung als Grundnahrungsmittel erlangt die Kartoffel in Deutschland jedoch erst durch den Feldanbau ab der zweiten Hälfte des 18.Jahrunderts ( $\rightarrow$ Schauplatz Pilgamsreuth),502 im wesentlichen forciert durch administrative Maßnahmen unter dem Preußenkönig Friedrich II. Der Ausbreitungsgeschichte der Kartoffel in Deutschland ist ihr im Wesentlichen noch heute gültiger Bezugsrahmen durch Denecke (1976) gegeben worden.

\footnotetext{
495 Ames \& Spooner. Allerdings gibt es nur wenige erhaltene Herbare aus dem 18.Jh. bzw. noch ältere. Eine „Beweiskraft“ im Hinblick auf nicht untersuchte, weil nicht herbarisierte Exemplare, ist ohnehin nicht abzuleiten.

${ }^{496}$ Laufer, S. 66, von Gundlach S. 62

497 Salaman, S. 90. Für die Verbreitung innerhalb Deutschlands waren aber andere Orte, etwa Kassel (1588), viel bedeutsamer als Wien (siehe Denecke)

498 Unter den Bedingungen des europäischen Langtages entwickeln sich nicht an Tageslängen angepasste Kartoffelsorten zu großen Büschen, was einen Teil ihrer dekorativen Wirkung erklären mag, denn die Kartoffelblüten sind vergleichsweise klein und unspektakulär.

${ }^{499}$ Salaman, S. 88; Ames \& Spooner: Dabei hat Denecke bereits 1976 dieses Datum auf 1588 korrigiert. - Spooners Auffassung [http://www.ars.usda.gov/is/pr/2005/050318.htm (3.7.09)], dass auch Kartoffel-Kultivare aus dem Chilenischen Tiefland in den Europäischen Kartoffel-Genpool entsandt hätten, steht nicht im Widerspruch zum DNA-Befund.

500 Jager, S. 32

${ }^{501}$ Laufer, S.66. Elsholtz führt 1663 die Kartoffelpflanze im gedruckten Inventar der märkischen Flora auf, sein Inventar der Lustgartenpflanzen von 1657, das ebenfalls die Kartoffel erwähnt, liegt nur als Manuskript vor. Angaben über die erste Einführung der Kartoffel nach historischen Quellen gehen kaum über den Wissenstand von Salaman und Laufer hinaus. Zuckermann ist unpräzise und bringt keine neuen Erkenntnisse zur Einführungsgeschichte.
}

502 Barth 


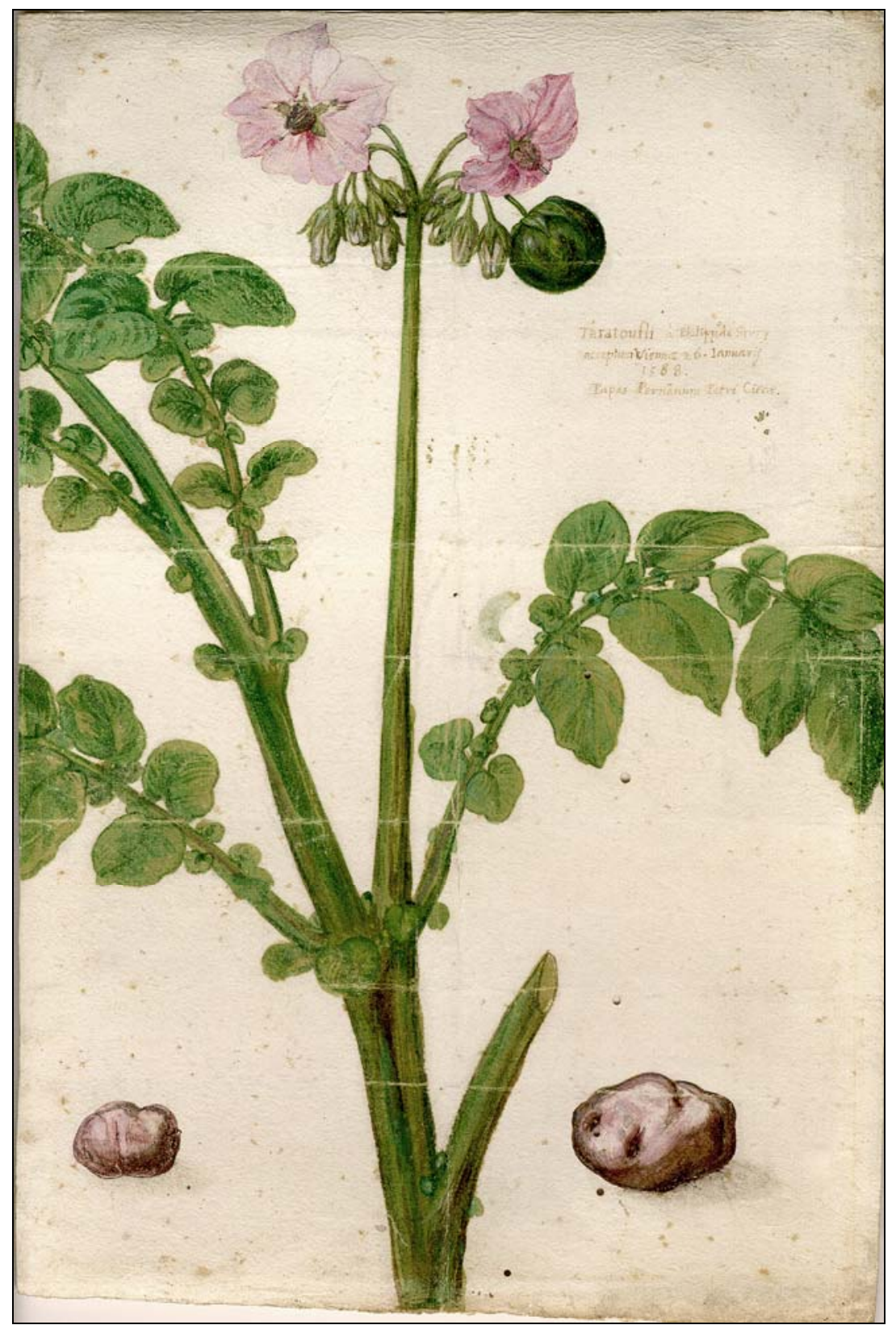

Abb. 1. Von Clusius in Auftrag gegebenes Aquarell der Kartoffelpflanze; Text rechts unter der Beerenfrucht: „Taratoufli à Philip de Sivry acceptum Viennae 26 Januarii 1588. Papas Peruanum Petri Ciecae“ - Vermutlich älteste Farbabbildung der Kartoffel. Für die freundliche Überlassung und Genehmigung zur Veröffentlichung danke ich dem „Museum Plantin-Moretus/Prentenkabinet, Antwerpen - UNESCO World Heritage“ 
Bei den Kartoffeln des 17. Jh.s handelt es sich jedoch noch nicht um langtagangepasste Formen. Der Anbau einer solchen Kartoffelsorte ist zunächst nur dort erfolgreich, wo die Temperatur des herbstlichen Kurztages nach Unterschreitung der kritischen Tageslänge von 13,5 Stunden für eine volle Vegetationsperiode ausreicht, damit die Knollen zur Ausreifung kommen. Man nimmt daher an, dass die Anpassung an europäische Langtagverhältnisse im mediterranen oder ausgeprägt atlantischen Klima erfolgte, die eine Knollenreife bis Dezember zulassen. ${ }^{503}$ Wobei noch an die ungünstigen klimatischen Gesamtverhältnisse des 16. und 17. Jh.s zu erinnern ist, die beide im Klimapessimum der Kleinen Eiszeit lagen. ${ }^{504}$ Nach verbreiteter Auffassung lief die erforderliche Präadaptationsphase an den Langtag über den Anbau in norditalienischen Gärten. Daran schloss sich die Ausbreitung über die Alpen nach Mitteleuropa und Deutschland während des 17. Jh. an.

Das Bild einer fieberhaften zeitgenössischen Suche nach einem Grundnahrungsmittel neben dem Getreide wäre sicherlich überzeichnet, aber die europäischen Administrationen des 18. Jh.s sorgten sich vor dem Hintergrund der immer wieder auftretenden Nahrungsengpässe doch erheblich um eine stetigere Verfügbarkeit von Nahrungsmitteln. Nach der Mitte des 18. Jh.s war in den europäischen Territorien eigentlich geklärt, dass die Kartoffel als Grundnahrungsmittel ideale Eigenschaften mit sich brachte. Die europäische Hungerkatastrophe von 1770-72 beschleunigte dann den flächenmäßigen Anbau der Kartoffel.505

Förderlich für die Akzeptanz der Kartoffel als Grundnahrungsmittel war u.a. auch die frühe anonyme Erfahrung, dass Kartoffeln als Diätetikum in der Krankenversorgung des 17. Jh.s zur beschleunigten Genesung der Patienten beitragen konnten. Zurückzuführen ist dies nicht nur auf ihren hohen Kohlenhydratgehalt, ihre „Reinheit" als gekochtes und damit keimarmes Gemüse; darüber hinaus ist sie auch ein wichtiger Vitaminspender. Aber ein im Maßstab des Kräutergartens angebautes Gemüse ist weit entfernt von einem Grundnahrungsmittel außerhalb einer reinen Subsistenzwirtschaft.

Das Verhältnis von Anbaufläche und energetischem Ertrag liegt bei Kartoffeln zwischen dem 1,6fachen und dem Doppelten über dem von Getreide, ${ }^{506}$ und räumt ihnen daher - zumindest in dieser Hinsicht - vor dem Getreide den Platz des besseren Grundnahrungsmittels ein. ${ }^{507}$ Es waren zunächst aber noch ganz andere

\footnotetext{
503 von Gundlach, S. 58

504 Glaser

505 Salaman, S. 100ff. - Siehe auch die sorgfältig recherchierte Internetseite : http://www.kartoffelgeschichte.de/index.html - (22.5.2009)

506 Scott, Rosegrant \& Ringler, S. 3.

507 Die gelegentliche Angabe, dass bei der Kartoffel in den gemäßigten Breiten „zwei Ernten“ möglich wären, beruht auf einer Ungenauigkeit bzw. einem Missverständnis. In den gemäßigten Breiten können auf derselben Fläche innerhalb einer Vegetationsperiode Kartoffeln nicht zweimal gesetzt und zur Reife gebracht werden. In Deutschland erstreckt sich die Kartoffelernte je nach Reifegruppe
} 
Hindernisse zu überwinden, die einer schnelleren Verbreitung der Knollen bis ins 19.Jh. entgegenstanden. ${ }^{508}$

\subsection{Marktbezug und Industrialisierung}

Getreidekörner sind ihrer botanischen Eigenschaft nach für Lagerfähigkeit und Transport optimierte Verbreitungskörper. Sie stellen geringe Ansprüche an das Umweltmilieu und die Massenlagerung. Durch Anlegen von zentralen Getreidelagern bei Überschusshaltung waren regionale Angebotsengpässe durch unaufwendige Transportausgleiche möglich.

Demgegenüber ist die Kartoffel nicht als Verbreitungskörper, sondern als vegetativer, clonaler Vermehrungskörper konzipiert. Der Knolle fehlt vor allem eine Toleranz gegenüber Milieuschwankungen, die bestimmte physiologische Reaktionsbereiche nicht verlassen dürfen. Lagerhaltung und Transport stellen daher Anforderungen, die einen verbrauchernahen Standort bei überregionaler Marktwirtschaft und einen stetigen Abtransport während der kalten Monate ausschließen. „Der Landtransport kann daher nur einen sehr kleinen Einzugsbereich für den Markt erschließen, während die Wasserstandorte des Anbaus zumindest den schubweisen Massentransport ermöglichen. Erst die Industrialisierung vermag die Probleme des Kartoffeltransportes zu lösen. Damit schließt sich der Kreis von Produktion, Angebot, Transport, Nachfrage und deren Rückwirkung auf die Produktion."509 Die Kartoffelproduktion kam erst in Gang, nachdem sich jenseits der Selbstversorgerwirtschaft Nachfrage entwickelte. Die Urbanisierung beschleunigt diesen Prozess. Dabei wird die Einführung der Kartoffel contraintuitiv nicht etwa von den sozial schwachen Gruppen „von unten“ her begünstigt, sondern von kapitalkräftigen Institutionen. Nur diese waren Ende des 18. und zu Beginn des 19. Jh.s in der Lage, die Angebotsschübe der Kartoffel zwischen Oktober und Dezember aufzukaufen und deren Verteilung über das Jahr hinweg zu übernehmen. ${ }^{510}$

Begünstigt wurde die allmähliche Verbreitung der Kartoffel in Deutschland nicht nur durch obrigkeitliche Anordnungen in der zweiten Hälfte des 18. Jh.s, vor allem durch Friedrich II., der besonders für Pommern und Schlesien Kartoffelkulturen propagierte. ${ }^{511}$ Immerhin sorgte er zunächst für eine kostenlose Verteilung von Saatkartoffeln. Offensichtlich überzeugten Erfahrungen während des Sieben-

von Juli bis Oktober. „Frühe“ bzw. „späte“ Kartoffelsorten sind der offensichtliche Verwechselungsgrund für die irrige Angabe „zweier Kartoffelernten.“ Träfe dies zu, läge der energetische KartoffelFlächenertrag um das Drei- bis Vierfache über dem von Getreide.

${ }^{508}$ Hier und im weiteren nach von Gundlach, S. $30 \mathrm{ff}$

${ }^{509}$ von Gundlach S. 30

510 Belege bei von Gundlach S. 34-35

511 Ein Beispiel hierzu abgedruckt im Anhang zum Schauplatz „Pilgramsreuth“ (Barth 2008): Circulare Friedrich II. von 1756 über den Anbau der Tartoffeln in Schlesien. - Laufer kommentierte die historische Entwicklung lakonisch „It was a truly militaristic procedure backed up by royale decrees and dragoons to enforce them." (S. 67). 
jährigen Krieges (1756-1763) und der Hungerkatastrophe 1770-72 vollends von den günstigen ernährungsphysiologischen Eigenschaften der Hackfrucht; und der Kartoffelanbau beginnt, sich in die Fläche auszubreiten.

Allerdings verlief die Erfolgsgeschichte noch im 19.Jh. keineswegs so geradlinig und unaufhaltsam, wie sie gern dargestellt wird. Denecke verdanken wir ein differenzierteres Bild der Abläufe, das sich skizzenhaft so darstellt: für die Subsistenz und dann für den lokalen Markt wird die Kartoffel zunächst auf den Ackerrandstreifen und auf Brachen der Mittelgebirgsregion angebaut. Hier konnte sie zuerst überzeugen, weil der Getreidebau in den Mittelgebirgsregionen wenig ertragreich war. Aus diesen Regionen wird die Kartoffel zu Beginn des 19.Jh.s allmählich ins Flachland vordringen, wo sie die heute geläufigen Hauptstandorte überhaupt erst zwischen 1840 und 1850 erreicht. Dort, in den Arealen des ,immerwährenden Roggenbaus“ waren Vorbehalte der Getreidebauern zu überwinden, die der neuen Feldfrucht keinesfalls aufgeschlossen gegenüber standen. Gewiss müsste eine Aktualisierung der Ausbreitungsgeschichte die Innovationen im Lagerungswesen, vor allem aber die im gewässerfernen Transportwesen berücksichtigen. Die Verbindungen zwischen dem Eisenbahnsystem und der Kartoffelproduktion sind unübersehbar.

Durch die Lösung des Transport- und Lagerproblems ${ }^{512}$ im Verlauf des 19. Jh.s war die Kartoffel auch auf den Tischen der Stadtbevölkerung gesichert. Die Industrielle Revolution transformierte die Agrargesellschaft, in England früher als auf dem Kontinent, und konzentrierte große Teile der Landbevölkerung nun in den Städten. In den städtischen Umwelten Englands wie auf dem Kontinent konnte sich die Kartoffel als erstes "Fertiggericht" etablieren: ${ }^{513}$ energiereich, nahrhaft, auch auf kleinen Parzellen leicht anzubauen, billig und ohne große Umstände zuzubereiten.

Der Pro-Kopf-Verbrauch an Kartoffeln liegt derzeit in der Bundesrepublik bei ca. $67 \mathrm{~kg}$, der von Getreide bei rd. $90 \mathrm{~kg}$. Vor Einführung der Kartoffel lag der Verzehr von Brot und Getreideprodukten je Person und Jahr in Europa bei 200 bis $250 \mathrm{~kg}$, er stieg bis ins 19. Jh. noch auf rund $300 \mathrm{~kg}$. Für Deutschland ist im Laufe des 19. Jh. eine Steigerung des Kartoffelkonsums von 40 auf $200 \mathrm{~kg}$ je Person und Jahr berechnet worden, in Preußen sogar auf $296 \mathrm{~kg}$ im Jahre 1900.514 Die Kartoffel war nach rund 100 Jahren als Grundnahrungsmittel, als Futtermittel und in der

\footnotetext{
512 Großmaßstäblich in Silos, zum persönlichen Bedarf im Kartoffelkeller, ländlich allerdings bereits sehr früh in der „Kartoffelmiete“. - Das Lagerproblem stellte sich im vergleichsweise milden Klima Irlands und Englands nicht in gleicher Weise, weil man in frostfreien Arealen die Kartoffel im Boden belassen konnte, sie zum Winter anhäufelte und nach Bedarf erntete (,lazy bed system“, Frazer. Der Begriff „lazy bed system“ ist irreführend, weil er vermutlich vom franz. „laissez faire“ abgeleitet wurde).

513 Die bis dahin obligatorischen Getreidebrei-Zubereitungen erforderten die Vorbereitung des Getreides (stampfen, walzen, schroten, mahlen) und benötigten zum Teil einen mehrtägigen Quell- und Fermentationsprozess.

${ }^{514}$ Saalfeld, 1982
} 
Rohstoffindustrie etabliert und hatte in diesen Bereichen mit dem Getreide gleich gezogen.

In der Bundesrepublik wurden 2005 auf rund 280.000 ha Kartoffeln erzeugt, im Mittel der Jahre 2000 - 2006 rund 110 Mio. Tonnen. Fast die Hälfte der deutschen Kartoffeln werden in Niedersachsen produziert, ${ }^{515}$ mit einem Schwerpunkt in den Heidegebieten. Vor allem hier sind die Kartoffelkulturen landschaftsbildend geworden, weil die Kartoffel eine ideale Frucht für die leichten Böden ist.

Große Anteile der Kartoffelerträge werden in der Tierproduktion eingesetzt. Rinder können täglich bis zu 20kg rohe Kartoffeln verzehren; Schweine mästet man mit einer Diät aus gekochten Kartoffeln. Dabei werden Kartoffelschnitzel ohne Energieaufwand in der Silage durch die Fermentationshitze gegart. Durch die Verwendbarkeit der Kartoffel in der Tierproduktion sind langfristig die Fleischpreise auf ein für viele Menschen erschwingliches Niveau gesunken.

\subsection{Kartoffel und Bevölkerungswachstum}

Der „Demographische Übergang“, also der Wechsel von hoher Reproduktion und Sterblichkeit zu niedriger Reproduktion und Sterblichkeit, der in den meisten Europäischen Ländern im 18. Jh. begann, war ab etwa 1740 zunächst mit einem Anstieg der Gesamtbevölkerung verbunden.516 Bevölkerungsanstieg bei gleichbleibender Agrarproduktivität bedeutet Nahrungsverknappung. ${ }^{517}$ Die Kartoffel bot sich in dieser Situation aus zwei Gründen für eine Überwindung des Engpasses an.

Einmal liegt der flächenbezogene energetische Ertrag bei der Kartoffel gegenüber Getreide in der Größenordnung fast doppelt so hoch, und die Kartoffel gilt insgesamt als ernährungsphysiologisch wertvoll durch ihren Gehalt an Proteinen, Vitaminen, Mineralien, Ballaststoffen und sekundären Pflanzenstoffen. Der höhere Flächenertrag ist, daran lässt das Beispiel des Bevölkerungszuwachses in Irland seit den Zählungen ab 1781 keinen Zweifel, ein Hauptgrund der Bevölkerungszunahme (Abb. 2). Nach Daten aus dem Jahre 1839 standen dem irischen Landarbeiter, der in die Zuständigkeit der Armengesetzgebung fiel, durchschnittlich täglich 5-6 kg Kartoffeln und 1,8 1 Buttermilch zur Verfügung, eine eintönige, aber ernährungsphysiologisch akzeptable Diät bei einem energetischen Äquivalent von $4.720 \mathrm{Kcal} .518$

\footnotetext{
515 Statistisches Jahrbuch für die Bundesrepublik 2005; Nieders. Ministerium für Ernährung, Landwirtschaft und Forsten: Landwirtschaft in Niedersachsen, 2002

516 Malthus(1766-1834) war der wohl bekannteste Bevölkerungstheoretiker des ausgehenden 18. Jh.s, der die ökonomischen und bevölkerungsbiologischen Folgen zu einer langfristigen Perspektive verknüpfte. Malthus und sein Zeitgenosse Ricardo haben bis heute erheblichen Einfluss auf die Theoriebildung. Siehe z.B. Richerson \& Boyd.

517 Saalfeld, 1983

518 Bittles,1988a
} 
Die andere Ursache ist diffiziler. Aus Gründen, die man allererst in institutionalisierten wie verdeckten Normen vermuten darf,519 lag die Gesamtfruchtbarkeit irischer Frauen deutlich über derjenigen im übrigen Europa. ${ }^{520}$ Dies kann vermutlich sogar hauptsächlich den Bevölkerungsanstieg erklären. In seiner Auswirkung bisher nicht abschätzbar ist ein überzeugendes zusätzliches Argument, auf das von Gundlach (1986) aufmerksam machte. Die Kartoffel ist ein von sonstigen Begleitstoffen freies Nahrungsmittel. Das gilt für Getreide bis ins 19.Jh. nicht in gleicher Weise. Getreide enthielt z.T. erhebliche Mengen an Diasporen von Ackerunkräutern. Gehaltsstoffe dieser Diasporen können pharmakologisch wirksame Substanzen sein, denen fertilitätssenkende Wirkung zukommt. Danach wäre also die europäische Gesamtfruchtbarkeit vor Einführung der Kartoffel durch Begleitstoffe des

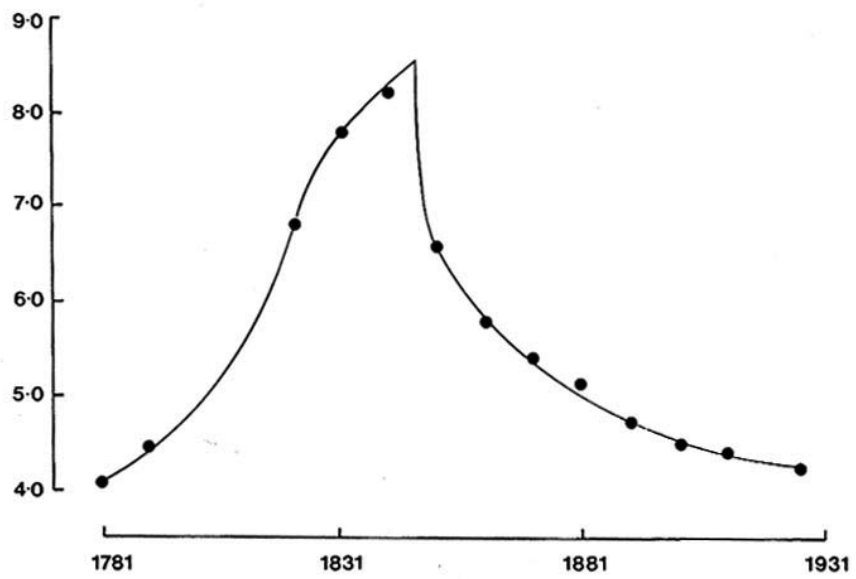

Abb. 2. Bevölkerungsentwicklung Irlands zwischen 1781 und 1931. Ordinate: Bevölkerung in Millionen; Abszisse: Jahreszahlen von Volkszählungen (aus Bittles, 1988a)

Getreidekonsums unter dem physiologisch möglichen Niveau gehalten worden. Die jährliche Wachstumsrate in Irland erreichte zwischen 1781 und 1846 trotz des optisch sich gewaltig ausnehmenden Anstiegs (Abb. 2) nur 1,2\%. ${ }^{521}$. Er entspricht einer Verdoppelungszeit für die Bevölkerung von 58,3 Jahren. Stellt man sich den Wegfall fertilitätssenkender Nahrungsbegleitstoffe in der Wirkung von Zehnteln

519 Das Bevölkerungswachstum Irlands bis 1845 beruht primär auf der irischen Neigung zu einem niedrigen Heiratsalter, dem aber zunächst die Schwierigkeit gegenüberstand, Haus und Ackerfläche für die Familiengründung zu erhalten. Mitte des 18. Jh.s fielen die Beschränkungen, und die Einführung der Kartoffel erlaubte die Deckung des Nahrungs-Grundbedarfs in einer Gegend Europas, in der Getreide nicht sonderlich gedeiht. Die steigende Rate der Eheschließungen und die hohe natürliche Fertilität bilden die Grundlagen des Bevölkerungswachstums ( hierzu Connell, 1950)

5201841 lag die Fruchtbarkeit irischer Frauen mit 360 - 377 Kindern auf 1000 Frauen z.B. deutlich über derjenigen in England und Wales 1851, die 307 betrug (Bittles, 1988b, S. 163)

${ }^{521}$ Dieser Betrag liegt deutlich unter den Wachstumsraten von Entwicklungsländern im 20.Jh. 
des Wachstumsfaktors vor, dann würden seine Erhöhung von 1,0 auf 1,1 die Absenkung der Verdoppelungszeit von 70 Jahren auf 63 Jahre bedeuten, bzw. eine Erhöhung von 0,8 auf 0,9 von 86 Jahren auf 77 Jahre, also eine Absenkung der Verdoppelungszeit um fast 10 Jahre. ${ }^{522}$ Aus dieser Perspektive erhält die Hypothese der fruchtbakeitssteigernden Wirkung der Kartoffel nachhaltige Unterstützung. Sie hätte darin bestanden, dass von der pharmakologisch unbedenklichen Kartoffel keine Wirksamkeit für die Fertilität ausging und diese daher auf ihren ,natürlichen“ Wert ansteigen konnte, nachdem sie durch Nahrungsbegleitstoffe der reinen Getreidekost in früheren Jahrzehnten und Jahrhunderten ,gedämpft" wurde. Zwar werden zumindest bei einigen Getreidezubereitungen (etwa beim Brotbacken) manche pharmakologisch wirksamen Substanzen thermisch zerstört. In Fallstudien an Dorfbevölkerungen des südwestdeutschen Raums in den 1770er Jahren konnte von Gundlach jedoch zeigen, dass eine Kartoffel- oder Maisdiät die Fertilität gegenüber einer auf Breistandard festgelegten Bevölkerung steigert. Die Fertilität sank infolge einer Kartoffelkrise 1780 in den auf Mais- und Kartoffeln ausgerichteten Dörfern auf das Niveau des Breistandards. ${ }^{523}$ Die Hypothese von Gundlachs erhält zusätzliche, wenn auch indirekte, Unterstützung durch Überlegungen, die Matossian (1989, und ohne Bezug auf von Gundlach) veröffentlichte.

\subsection{Von Europa in die Welt: Nicht nur Löwenzahn und Wiesenrispe}

Früh schon haben die Bewohner Europas davon profitiert, dass sie zu ihrem Nutzen Pflanzen einführten, die außerhalb ihres Kontinents heimisch waren. Erinnert sei an das Getreide im Neolithikum, später die Obstkultur, die ursprünglich aus der Kaukasus-Region stammt, an Gemüse- und Gewürzpflanzen während des Mittelalters aus Wildformen und Kultivaren des Mittelmeer-Raums.

Nach 1492 beginnt eine Prüfung ungeheuren Ausmaßes von Pflanzen (und Tieren) in den von den Europäern entdeckten Gebieten, um Nutzungsmöglichkeiten abzuschätzen. ${ }^{524}$ So kommen nicht nur Tabak, Tomate und Kartoffeln nach Europa, sondern auch zahlreiche Blumen in den Garten. Umgekehrt nehmen europäische Siedler vertraute Pflanzen mit in die neuen überseeischen Gebiete. Es sind aber die Unkräuter, die einen heimlichen Siegeszug um die Erde antreten, wie etwa der Löwenzahn. ${ }^{525}$ Er ist ein Modellorganismus für das Schlagwort vom „ökologischen Imperialismus“ (Crosby), mit dem Europäer die Welt überziehen.526

\footnotetext{
522 Als Faustformel gilt: 70 geteilt durch Prozentzahl des jährlichen Wachstums gleich Verdoppelungszeit für die Gesamtbevölkerung.

523 von Gundlach, S. 150

524 Diese Prüfung endet mit der opportunistischen Nutzung von Tieren und Pflanzen ferner Regionen in dem mehrhundertjährigen größten „Freisetzungsexperiment“ aller Zeiten seit 1492.

525 Ähnlich „erfolgreich“ wie Löwenzahn war, zumindest in Nordamerika, die Wiesenrispe („Kentucky Blue Grass"). Hierzu Herrmann 2008, S. 179.

526 Zur Frage des Zustandes der Biodiversität etwa in beiden Amerika vor der Zeit des europäischen Kontakts ist der Forschungsstand seit Crosby (1986) erheblich angewachsen. Neuere Übersichten bei Butzer und bei Mann, S. $312 \mathrm{ff}$
} 
Er ist ebenso ein Modellorganismus für den Hinweis auf die Verbreitungswege von Saatgut: die Unkrautsamen sind kein bewusstes europäisches Erbe, sondern gelangen als Beimengungen von Saatgut des Küchengartens, der Gemüsebeete oder des Getreides „mit der Schürzentasche“ in die neuen Gebiete (bzw. mit dem Handkoffer, als „Portmanteau-Biota“, wie Crosby es formulierte) ${ }^{527}$.

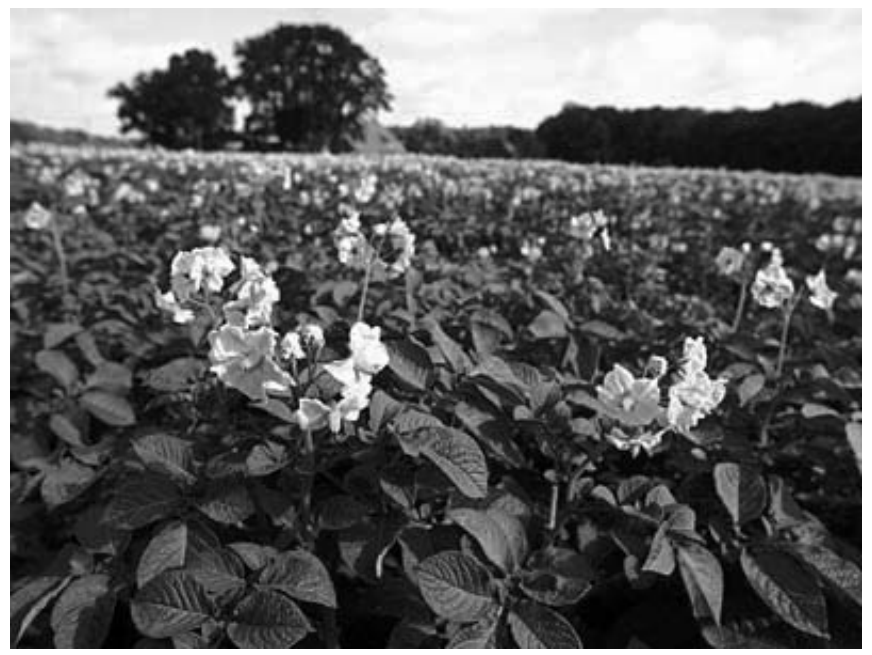

Abb. 3. Blühende Kartoffelpflanzen. Verbreitet sind weiß- und violett-blühende Sorten. Die Pflanzen wachsen heute bis etwas über Kniehöhe. Die großmaßstäbliche Produktionsweise in Monokulturen bietet Angriffsmöglichkeiten für Schadorganismen. (Foto: Bundesanstalt für Landwirtschaft und Ernährung)

Die Ausforschung der Welt verbindet die Kartoffel mit der expansiven Neugier der Europäer. Sehr früh wurden die Vorteile der Kartoffel als Schiffsproviant für lange Seereisen erkannt, die auf den Nährwerteigenschaften und Gehalt an Vitaminen und Spurenelementen beruhen. Sie ist aus diesen Gründen bereits um 1580 in allen europäischen Häfen bekannt. ${ }^{528}$ Vermutlich eher als Proviant und nicht als Direktimport erreichte die Kartoffel angeblich bereits im frühen 17. Jh. Indien, China und Japan. ${ }^{529}$ Möglicherweise brachten auch britische Missionare die Kartof-

\footnotetext{
527 Die deutsche Übersetzung verwendet den Begriff „, biologischer Musterkoffer“ (Crosby, S. 91). Es ist unklar, ob Crosby den Begriff "Portmanteau-Biota" in Anlehnung an den aus der Literaturwissenschaft geläufigen Begriff des „portmanteau (words)“ [,Kofferwort"] verwendete oder ihn als neues Synonym und wörtliche Anspielung auf den Ausbreitungsprozess benutzte, als dessen Ergebnis mit den Einwanderern mitgereiste Pflanzen und Tiere die Fauna und Flora der neu erschlossenen Gebiete beeinflussten.

528 von Gundlach, S. 51

${ }^{529}$ Laufer
} 
fel gegen Ende des 17. Jh.s nach Indien und China, zu gleicher Zeit wurde sie auch in Japan und Teilen Afrikas bekannt, Neuseeland erreicht sie 1769. 530

Durch die großen Trails in den amerikanischen Westen gelangt die Kartoffel schließlich mit europäischen Siedlern im frühen 19. Jh. auch an die Rocky Mountains. Von hier wird sich dann um die Mitte des 19. Jh.s ein Schadorganismus aufmachen, die Kartoffelbestände der Welt zu bedrohen: der Kartoffelkäfer (s.u.).

\subsection{Zur Kartoffel drängt, an der Kartoffel hängt fast alles}

Da die Kartoffel keine besondern Anforderungen an die Bodenqualität stellt, kann sie heute in über 100 Ländern angebaut werden. Viele Sorten sind mittlerweile taglängenneutral. Der Kartoffelanbau ist letztlich nur durch Temperaturgradienten limitiert. Unter $10^{\circ} \mathrm{C}$ und oberhalb $30^{\circ} \mathrm{C}$ erfolgt keine Knollenbildung, deren Optimum bei $18-20^{\circ} \mathrm{C}$ durchschnittlicher Tagestemperatur liegt. Daher werden Kartoffeln in den gemäßigten Breiten im Frühjahr gesetzt, in warmen Regionen aber gegen Winterende. Hier kommen die Knollen in nur 90 Tagen zur Ernte, während sie etwa in Mittel- und Nordeuropa bis zu 150 Tagen benötigen.
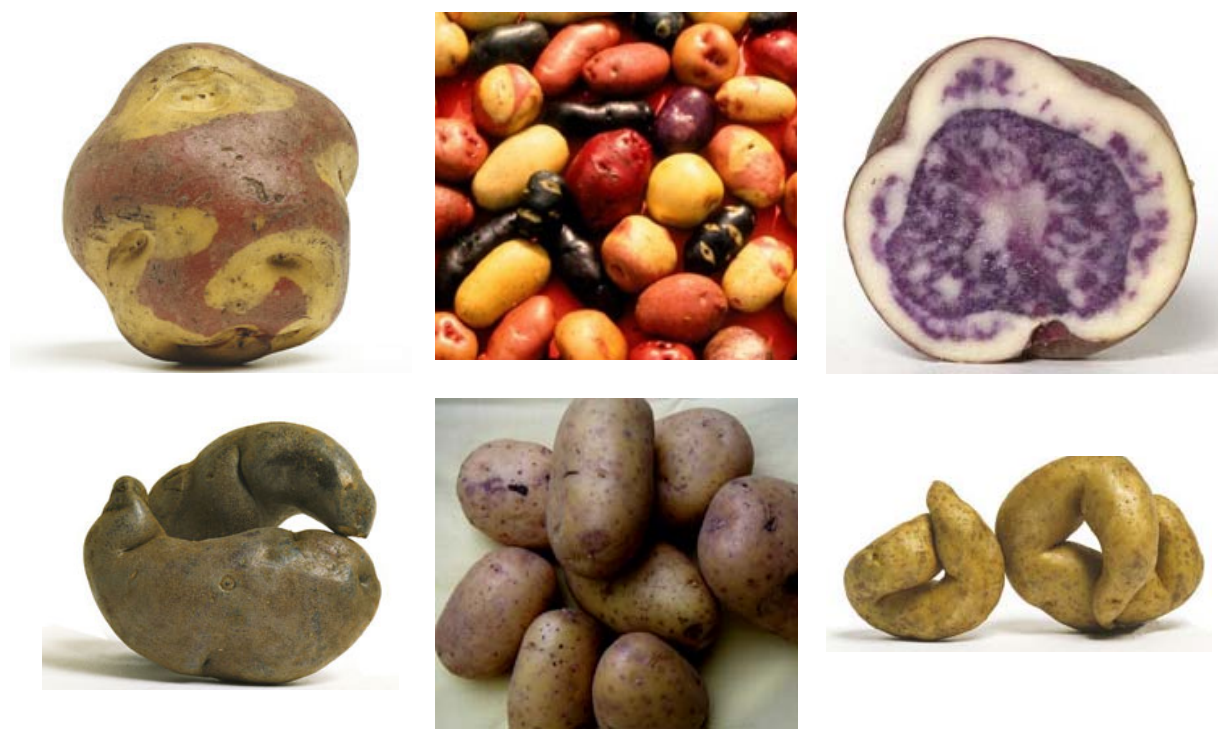

Abb. 4. Kartoffeln, insbesondere traditionelle Landrassen, zeigen eine hohe Variabilität an Formen, Farben und biologischen Eigenschaften verglichen mit den Hochleistungssorten der Agrarproduktion (unten Mitte; Fotos: CIP, B.H.)

${ }^{530}$ Hawkes, S. 39 
Die Welternährungsorganisation FAO schätzte die Weltkartoffelproduktion für 2007 auf 325 Milliarden Tonnen, wovon etwa zwei Drittel in den menschlichen Konsum gingen. 531

Das Internationale Kartoffel Zentrum in Peru (CIP) unterhält die weltgrößte genetische Sammlung für Kartoffelvarietäten, darunter mehr als 100 wilde Arten aus acht Lateinamerikanischen Ländern und 3.800 traditionelle Landrassen aus den Anden. ${ }^{532}$ Das CIP informiert mit einem „,Welt Kartoffel Atlas“ über den weltweiten Anbau. ${ }^{533}$

Als Rohstoff hat vor allem Kartoffelstärke wirtschaftliche Bedeutung. Sie wird als Klebstoff, Bindemittel, Füllstoff und Strukturmittel in der Pharmazeutischen Industrie sowie in der Textil-, Holz und Papierherstellung eingesetzt. In der Ölfördertechnik wird sie als Waschmittel für Bohrlöcher genutzt. Kartoffelstärke ist ein vollständig biologisch abbaubarer Zuschlag in der Herstellung von Polystyrolen und anderen Kunststoffen, u.a. für die Herstellung von Einweggeschirr und Bestecken.

Aus Kartoffelabfällen, die nicht weiter verarbeitet oder verwendet werden können, lassen sich erhebliche Mengen treibstofffähigen Ethanols gewinnen. Das Verfahren gilt jedoch gegenüber einer Ethanolgewinnung direkt aus Getreide, Mais u.a. gegenwärtig als teuer, wäre ökologisch aber der gebotene Weg.

\section{Die Kraut- und Braunfäule der Kartoffel}

\subsection{Ein Pilz bringt Hunger und Tod}

Erstaunlicher Weise blendet das kollektive Gedächtnis Europas aus, dass die groBen Kartoffel-Missernten von 1845 und danach nicht nur Irland betrafen. Die Folgen waren eine kontinentweite Erschütterung, regionale Hungersnot, Tod und Auswanderung: „Selten hat eine Pflanzenkrankheit so tief in das politische und soziale Leben eines Landes eingegriffen wie die Kraut- und Braunfäule der Kartoffel. “534 Eigentlich kennt die Geschichte keinen vergleichbaren Fall. Die Krise konnte in Irland eine besondere Intensität erreichen, weil die Kartoffelfäule dort nicht nur ungewöhnlich heftig auftrat, sondern $\mathrm{zu}$ einem andauernden Problem wurde, das erst mit den chemischen Bekämpfungsmitteln der 1920er Jahre reduziert werden konnte. ${ }^{535}$ Und die Krise traf Irland besonders hart, weil es gleichzeitig den größten Teil seiner Agrarprodukte an England abzugeben hatte.

\footnotetext{
531 http://www.potato2008.org/en/index.html - (16.4.2009)

$532 \mathrm{http}: / /$ www.cipotato.org/ - (18.4.2009)

533 http://research.cip.cgiar.org/confluence/display/wpa/Home - (18.4.2009)

534 Schöber-Butin, S. 6

535 Solar, S. 114
} 
Ab 1845 vernichtet diese Kartoffelkrankheit („Kartoffelfäule“, auch nur „Krautfäule“; engl. „,blight“" bzw. „late blight") auf Jahre die Kartoffelbestände in europäischen Anbaugebieten (Tab. 1). Verursacht wird die Krankheit durch einen Pilz, der sowohl oberirdische Pflanzenteile als auch die Knollen befallen kann. Seinen Namen Phytophthora infestans (der , angreifende' oder ,beunruhigende Pflanzenverderber') erhielt er vom Freiburger Botaniker de Bary. Zwischen 1845 und 1861 wird die Krankheit vollständig aufgeklärt. Der Pilz überwintert in Kartoffelknollen, wo er die „Braunfäule“ verursacht. Verfault die Knolle während der Überwinterung nicht, wächst der Pilz in der darauf folgenden Vegetationsperiode mit den Kartoffelsprossen aus und nekrotisiert Stengel und Blattgewebe. Die Vermehrungskörper des Pilzes werden an der Pflanzenoberfläche gebildet. Vor allem bei feuchter Witterung werden die Pilzsporen über Aerosole auf benachbarte Pflanzen übertragen oder sie infizieren aufliegende Blätter der Kartoffelpflanze direkt am Boden. ${ }^{536}$ Die Sporen werden auch ins Erdreich eingewaschen, erreichen so oder über Verletzungen bei der Ernte die Knollen, in denen sie überwintern. ${ }^{537}$

Tab. 1. Kartoffelproduktion und -konsum und Ernteeinbußen 1845 und 1846 im Vergleich zu „normalen“ Jahren (Daten von Vanhaute et al. ${ }^{538}$ )

\begin{tabular}{|l|c|l|c|c|}
\hline & $\begin{array}{l}\text { Prozentualer Anteil Kartof- } \\
\text { felanbau an Gesamtbewirt- } \\
\text { schaftungsfläche vor der } \\
\text { Krautfäule }\end{array}$ & $\begin{array}{l}\text { Kartoffelkonsum } \\
\text { pro Tag und } \\
\text { Kopf vor der } \\
\text { Krautfäule }[\mathrm{kg}]\end{array}$ & $\begin{array}{l}\text { Rückgang } \\
\text { des Kartof- } \\
\text { feler-trages } \\
\text { in } 1845\end{array}$ & $\begin{array}{l}\text { Rückgang } \\
\text { des Kar- } \\
\text { toffeler- } \\
\text { trages in } \\
1846\end{array}$ \\
\hline Belgien & $14 \%$ & $0,5-0,6$ & $-87 \%$ & $-43 \%$ \\
\hline $\begin{array}{l}\text { Frank- } \\
\text { reich }\end{array}$ & $6 \%$ & 0,5 & $-20 \%$ & $-19 \%$ \\
\hline Preußen & $11 \%$ & $1,0-1,1$ & n.b. & $-47 \%$ \\
\hline Irland & $32 \%$ & 2,1 & $-30 \%$ & $-88 \%$ \\
\hline
\end{tabular}

Entscheidend ist, dass der Pilz für die Ausbildung von Sporenbildungsorganen und reifen Sporen eine relative Luftfeuchtigkeit von 95-100\% benötigt. Eine Epidemie setzt also verbreitet anhaltend nasses Wetter voraus. Wie die Pflanzenkrankheit 1845 und danach die Qualität einer gesamteuropäischen Epidemie annehmen konnte, gehört zu den bisher nicht aufgeklärten Sachverhalten.

Der Pilz ist möglicherweise schon früh mit Kartoffelimporten aus Südamerika als Neomycet ${ }^{539}$ eingeschleppt worden, ohne dass es zum Zusammentreffen aller für

\footnotetext{
536 Schöber-Butin, S. 9

537 Schöber-Butin S. 19-20

538 Vanhaute, Paping, Ó Gráda, S. 22. - Der Kartoffelkonsum für Irland ist ein Durchschnittswert. Er lag für weite Teile der Bevölkerung deutlich über diesem Betrag.
} 
seine Massenvermehrung entscheidenden Faktoren gekommen wäre. Es scheint sicher, dass über die Kraut- und Braunfäule bereits 1765 von Gleditsch berichtet wurde. 540 Der südamerikanische Ursprung aller heute bekannten Linien von P. infestans und damit der Krautfäule ist nach molekularbiologischen Analysen wahrscheinlicher als eine Übernahme der Krankheit aus den USA oder Mexiko nach Irland zu Beginn der 1840er Jahre. ${ }^{541}$ Möglich ist allerdings auch, dass die Katastrophe von 1845 auf einen erneuten direkten Eintrag von P. infestans aus Südamerika nach Europa zu Beginn des 19. Jh.s zurückgeht.

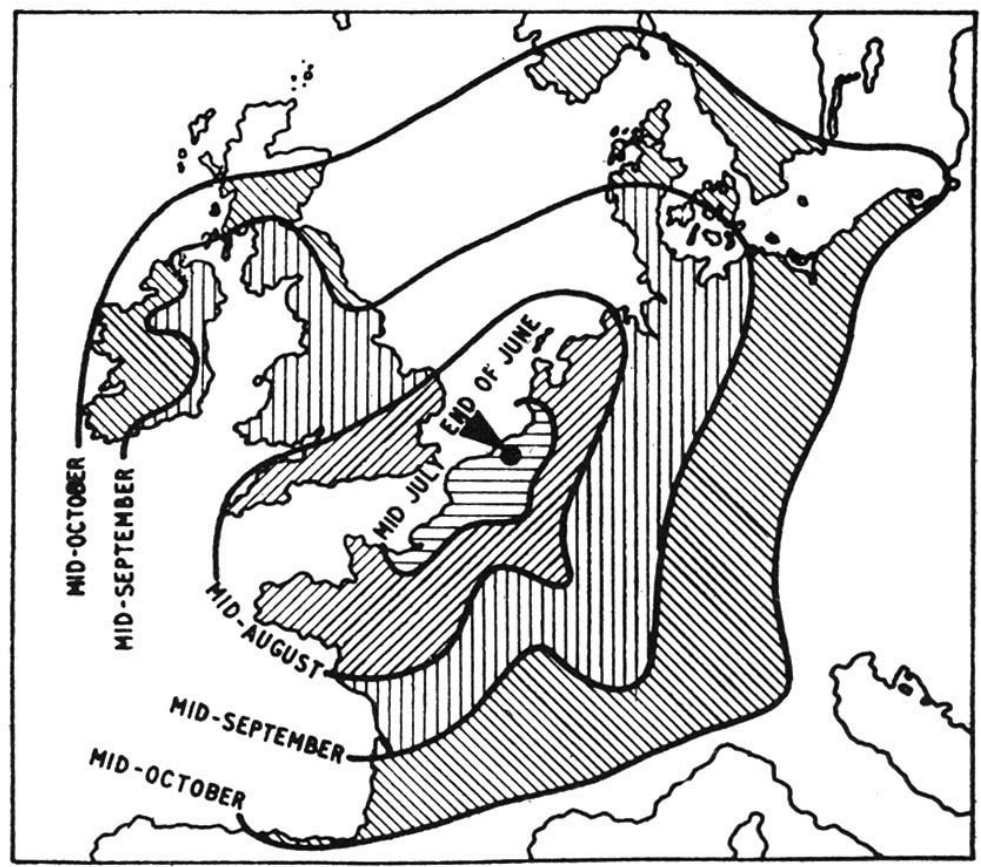

Abb. 5. Ungefähre Daten erster Berichte über das Auftreten von Kartoffelfäule in Europa 1845 (Bourke, S. 142)

1845 war in Mitteleuropa ein „Kälterekordjahr“, gefolgt vom „Wärmerekordjahr“ 1846; „sehr nass“ wiederum war 1843, hingegen 1842 ein trockenes Extremjahr. ${ }^{542}$

\footnotetext{
539 In Anlehnung an Neophyte und Neozoe; Neologismus, mit dem ein nach 1492 nach Europa eingeführter Pilz bezeichnet wird (Kowarik, S. 259)

540 Siehe kurzen Abriss zur Geschichte des Pilzes und seiner Bekämpfung bei Schöber-Butin

541 Ristaino

542 Glaser, S. 180. In Zusammenhang mit den Wetteranomalien danke ich Herrn Kollegen K.H. Pörtge für den Hinweis, dass am 31.3.1845 die Elbe das größte historisch bekannte Hochwasser führte und im Januar 1846 die Weser ein schlimmes Hochwasser führte.
} 
$\mathrm{Ob}$ diese klimatische Sequenz die Katastrophe begünstigte, ist völlig unbekannt. Dem europäischen Ereignis ging 1843 eine Krautfäuleepidemie in den USA voraus.

Sicher ist, dass die Krautfäule zuerst im Juni 1845 in Belgien beobachtet wurde, von wo aus sie sich in den nächsten Wochen in die Niederlande, nach Nordfrankreich und die benachbarte englische Küste ausbreitete (Abb. 5). Mitte August erreicht sie Westdeutschland, das südliche Dänemark, den Rest Englands und den östlichen Teil Irlands. Erst Mitte September sind das gesamte Irland, Ostdeutschland, Süd-Norwegen und Süd-Schweden erreicht. ${ }^{543}$

Das erste wirksame Fungizid, die Bordeauxbrühe,544 wurde ab 1888 auch erfolgreich gegen die Krautfäule eingesetzt. Es beruht auf der toxischen Wirkung anorganischen Kupfers. 1940 wurde das erste organische Fungizid entwickelt und seitdem die Gruppe wirksamer Fungizide gegen Krautfäule verbessert. Epidemien sind heute durch Sortenresistenz, Prognoseverfahen, Beobachtungen und Bedarfsspritzungen wirksam zu begegnen. ${ }^{545}$ Dennoch belaufen sich die jährlichen weltweiten Ernteverluste durch Krautfäule nach Angaben des Massachusetts Institute of Technology, das an der Aufklärung des Genoms von P. infestans arbeitet, ${ }^{546}$ auf fünf Milliarden US \$.

\subsection{Sozio-Demographische Folgen}

Ganz sicher hatte die Kartoffel ihren Anteil am Europäischen Bevölkerungsanstieg in der zweiten Hälfte des 18.Jh.s. Ihr Anbau auf der für persönliche Nutzung verfügbaren Parzellen oder auf Brachflächen war bei der nichtbesitzenden Landbevölkerung überlebensnotwendig und damit zugleich Ursache wie Wirkung.

In Irland wurden 1845 zunächst nur 30-40\% des Kartoffelbestandes zerstört (Tab. 1), aber man beließ die infizierten Knollen unter Verkennung der Ursachen einfach im Boden. Die offenbar idealen epidemiologischen Wetter-Bedingungen des Jahres 1846 führten zur sofortigen Infektion der Kartoffeln, so dass die Erträge in Irland auf unter $10 \%$ normaler Werte sanken. Große Teile der Bevölkerung waren ohne Nahrung, denn die Kartoffel war hier längst zum Hauptnahrungsmittel der Unterschichten geworden, wobei das Ausmaß der Kartoffelabhängigkeit großer irischer Bevölkerungsteile einzigartig bleibt. In Irland starb eine Million Menschen an den Hungerfolgen, eine weitere Million wanderte aus. ${ }^{547}$ Im übrigen

\footnotetext{
543 Vanhaute et al. S 23

544 „Bordeauxbrühe“ wurde 1885 gegen den Mehltau entwickelt, der durch amerikanische Weinrebenimporte eingeschleppt worden war.

545 Weitere Maßnahmen und detailliert Schöber-Butin S. 46ff

546 http://www.broad.mit.edu/annotation/genome/phytophthora_infestans/Info.html\#t5 (7.4.2009 )

547 Vanhaute et al. S. 26
} 
Europa war die Sterblichkeit nicht so exzessiv, sie wird insgesamt auf immerhin einige hunderttausend Individuen geschätzt. ${ }^{548}$ Für Preußen werden etwa 40.000 Tote angegeben, bei einer Bevölkerung, die doppelt so groß wie in Irland war. ${ }^{549}$ Dabei ist die Hungerkrise in den östlichen Landesteilen Preußens stärker als in den westlichen. In Preußen löste die Krise im gesamten Königreich örtlich Unruhen aus, nachdem sich die Kartoffelpreise zwischen Januar 1846 und April 1847 verdoppelt hatten und die Roggenpreise auf das Zweieinhalbfache gestiegen waren. ${ }^{550}$ Nach den Unruhen im April 1847 sanken die Preise bis zum Oktober wieder auf das Vorjahresniveau vom Januar.

Tabelle 2 zeigt die im Großen und Ganzen langsamen Erholungen für die Bevölkerungen nach dem Abklingen der Krise, wobei in einzelnen Ländern, vor allem Skandinavien, die Zuwächse wieder schnell einsetzten. ${ }^{551}$

Eine detailliertere Analyse belegt für Irland wie Preußen, dass die Sterblichkeit nur zu einem Teil dem Ausfall der Kartoffelernte zuzurechnen ist. Für Nahrungsknappheit gilt, dass nicht alle Bevölkerungsschichten gleichermaßen davon betrof-

Tab. 2. Schätzwerte jährlichen Bevölkerungswachstums [\%] in Europäischen

Ländern (aus Vanhauten et al., S. 25)

\begin{tabular}{llllllll} 
& $1840 / 45$ & $1845 / 6$ & $1846 / 7$ & $1847 / 8$ & $1848 / 9$ & $1849 / 50$ & $1850 / 6$ \\
\hline Belgien & +1.1 & +0.9 & +0.9 & +0.0 & +0.5 & +0.2 & +0.7 \\
Dänemark & +1.1 & +1.0 & +0.8 & +1.0 & +1.0 & +1.0 & +1.2 \\
Schweden & +1.1 & +0.8 & +0.6 & +1.0 & +1.3 & +1.2 & +1.0 \\
Frankreich & +0.5 & +0.7 & +0.4 & +0.1 & +0.3 & +0.0 & +0.5 \\
Deutschland (ges.) & +1.0 & +1.0 & +0.5 & +0.2 & +0.1 & +0.9 & +0.7 \\
Preußen & +1.3 & +1.4 & +0.8 & +0.5 & +0.4 & +0.9 & +1.0 \\
Niederlande & +1.1 & +1.1 & +0.3 & -0.2 & +0.1 & +0.3 & +0.7 \\
England & +1.2 & +1.2 & +0.7 & +0.7 & +0.7 & +0.7 & +1.3 \\
Irland & +0.4 & -0.2 & -4.0 & -4.0 & -4.0 & -4.0 & -1.7
\end{tabular}

Methodische Erläuterungen zur Tabelle siehe Originalpublikation

fen sind, was ebenso für die Allianz von Hunger und opportunistischen Krankheiten gilt. Übersterblichkeit hing in Irland wie in Preußen (und anderswo) ab vom durchschnittlichen Familieneinkommen und vom Lebensstandard in der Region. ${ }^{552}$ Es entsteht ein Faktorengefüge, das Vanhaute am Beispiel der Krise 1845-50 in

\footnotetext{
548 Ibid.

549 Bass

550 Ibid., S. 203. In der Wirtschaftsgeschichte gelten rasche Preissteigerungen eines Nahrungsmittels von mindestens $100 \%$ als Hinweis darauf, dass es sich um ein Grundnahrungsmittel handelt.

551 Die prozentualen Zuwächse müssen vor dem Hintergrund der absoluten Zahlen gesehen werden. Dann wird verständlicher, warum in vergleichsweise absolut gering bevölkerten Ländern der Anstieg relativ beachtlich sein konnte.

552 gemessen an Indikatoren wie Bildung (Lese- und Schreibfähigkeit) und Wohnqualität
} 
Flandern überzeugend freigelegt hat. Das Hungerrisiko hing danach ab von der Risikostreuung bei den Einkommensquellen, insbesondere protoindustriellen Nebenverdienstmöglichkeiten, einer Diversifikation des Feldfruchtanbaus als unbewusster Versicherung gegen Ernteausfälle, dem aktuellen Verlust der Kartoffelernte, und überregionalen Handelsbeziehungen in Abhängigkeit von der Wirtschaftskraft der einzelnen Regionen. Für Preußen wird ein zusätzlicher Faktor für die 1847er Hungerkrise in der geringen Transportkapazität und -leistungsfähigkeit gesehen. ${ }^{553}$ Zugleich müsste in Deutschland zwischen Mittelgebirgs- und Flachlandregionen differenziert werden, da die heute traditionellen Anbaugebiete der nord- und süddeutschen Ebenen erst vergleichsweise spät vom Kartoffelbau erreicht werden. Absolut gesehen war auch aus diesem Grund der Ernteausfall im Vergleich zu Irland geringer, entsprechend auch der akute Bevölkerungsverlust.

$\mathrm{Zu}$ den längerfristigen Folgen sind Bevölkerungsverluste durch Auswanderung zu rechnen. Die irischen Auswanderung erreichte dramatische Dimensionen: Zwischen 1847 und 1854 verließen jährlich 200.000 Menschen die Insel Richtung Amerika. 554

Tab. 3 Auswandererzahlen für Deutschland 1846 - 52

\begin{tabular}{cc} 
Gesamtzahl der Auswanderer aus Deutschland \\
Jahr & Anzahl \\
1846 & 94.581 \\
1847 & 109.531 \\
1848 & 81.895 \\
1849 & 89.102 \\
1850 & 82.404 \\
1851 & 112.547 \\
1852 & 162.301 \\
\hline
\end{tabular}

Hingegen waren die bevölkerungsbezogenen Auswirkungen in Preußen anderer Art. Immerhin war Preußen bis 1846 ein Einwanderungsland, gegründet vor allem auf die Frühindustrialisierung der westlichen Provinzen. Mit dem Krisenjahr 1847 setzt eine gegenläufige Entwicklung ein. In den ersten drei Jahren wird ein Wanderungsverlust von jeweils 29.000 Personen registriert. Bemerkenswert ist dabei, dass die höchsten Gesamtzahlen für Deutschland nicht im 1848er Jahr der politischen

\footnotetext{
553 Bass, S. 208

554 Livi-Bacci, S. 65
} 
Krise lagen, sondern im Jahr davor, also noch unmittelbar im Wirkungsbereich der Kartoffelkrise (Tab. 355); die Zahlen beginnen erst ab 1852 zu steigen, ab 1854 dann sehr deutlich (251.931 Personen). Zu diesem Zeitpunkt ist die Kartoffelkrise bereits überstanden.

In der Analyse der Auswanderungsmotive ${ }^{556}$ kommen die Nahrungsengpässe aus 1845 und Folgejahren überraschender Weise nicht explizit vor, was als Hinweis auf die insgesamt mäßige Bedeutung des Hungerphänomens verstanden werden könnte, wenn nicht 1848/49 zumindest die Hunger- und Sozialkrise in Schlesien darauf aufmerksam machte, dass eine angemessene Berücksichtigung des Hungers in der historischen Bewertung erforderlich ist. ${ }^{557}$

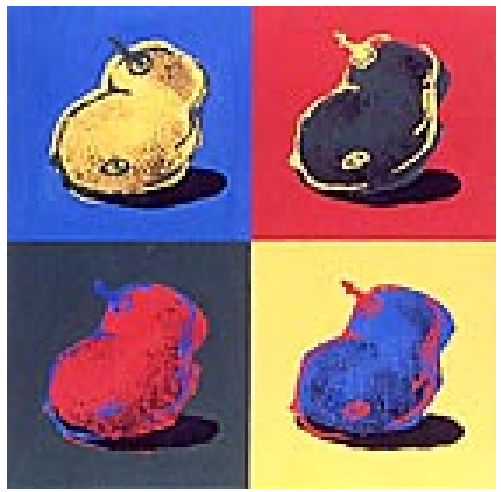

„Kartoffel für Andy“ Birgit Hofmann - 1998

Bild und Logo

Das Kartoffelmuseum

Grafinger Straße 2

81671 München

Öffnungszeiten:

Dienstag bis Donnerstag nach Vereinbarung

Freitag 9.00 Uhr bis $18.00 \mathrm{Uhr}$

Samstag 11.00 Uhr bis 17.00 Uhr

Eintritt kostenlos

\footnotetext{
555 Aus Obermann. - Selbstverständlich ist bei diesen Zahlen zu bedenken, dass man zu dieser Zeit zumindest legal nicht ohne Weiteres einfach „auswanderte“, sondern der Zustimmung der Obrigkeit bedurfte. In manchen Herrschaften war dies einfacher und fand im Krisenjahr 1845/46 sogar deren aktive Unterstützung (z. B. Königreich Hannover), in anderen Herrschaften wurden Auswanderungen gezielt erschwert.

556 Ibid.; desgl. Mieck

${ }^{557}$ Hierzu Virchow
} 


\section{Der Kartoffelkäfer}

\subsection{Leptinotarsa decemlineata}

Thomas Nuttal entdeckte 1811 in den Rocky Mountains auf der Büffelklette (Solanum rostratum, Nachtschattengewächse) einen Käfer, dem John Say 1824 in der wissenschaftlichen Erstbeschreibung den Namen Doryphora decemlineata gab (,der zehngestreifte Speerträger", Abb. 6). Die Verbindung zwischen Insekt und der Nachtschattenpflanze Kartoffel (Solanum tuberosum) war bis 1859 unbekannt, als dieser Käfer Kartoffelfelder westlich Omaha, Nebraska, durch Kahlfraß zerstörte. Erst 1865 wurde durch eine Zufallsbeobachtung in Colorado auf dieses Gebiet als ursprüngliches Heimatareal des Käfers geschlossen. Seitdem ist sein Trivialname „Colorado potato beetle“, Colorado- oder Kartoffelkäfer, geläufig. ${ }^{558}$ Heute trägt der Käfer den wissenschaftlichen Namen Leptinotarsa decemlineata (Say).

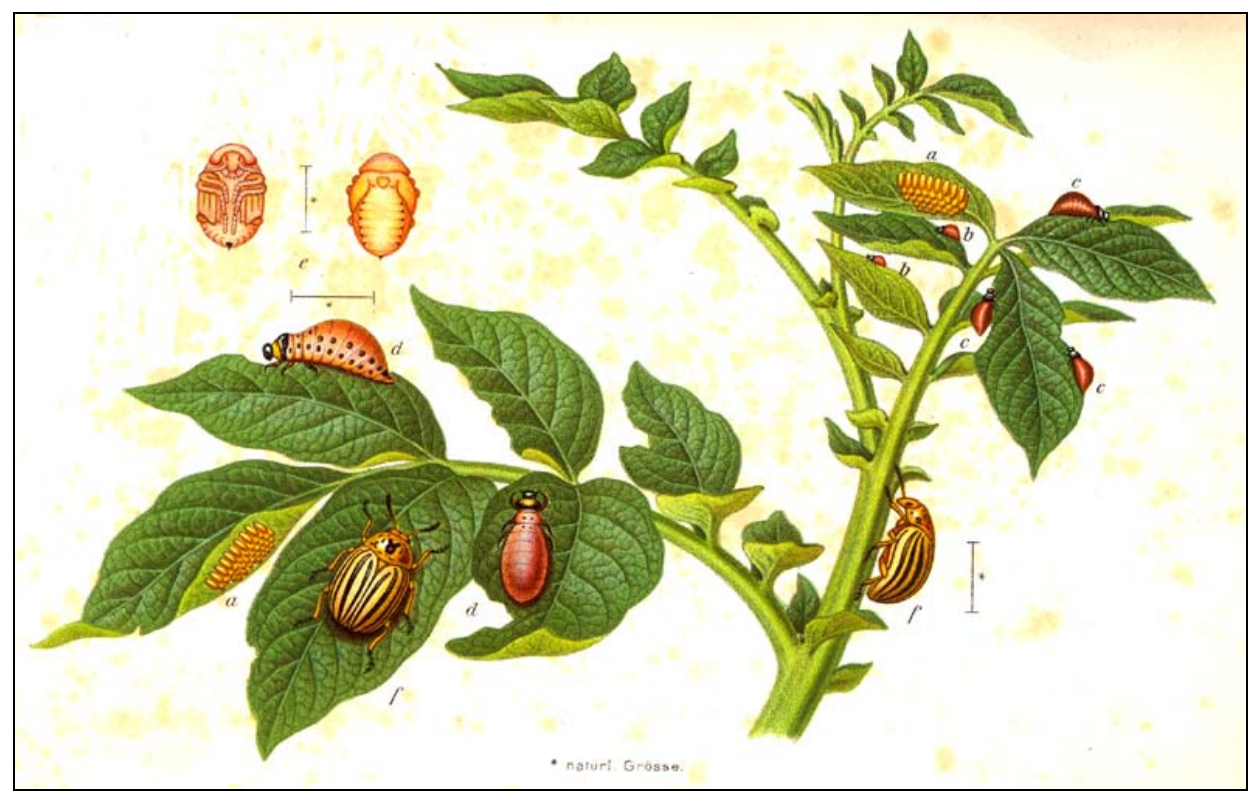

Abb. 6. Eigelege (a), Larvenstadien (b, c, d), Puppe (e) und Imago (f) des Kartoffelkäfers. Farbdrucktafel aus Gerstaecker, 1877, verkleinerte Wiedergabe.

${ }^{558}$ Jacques \& Fasulo 
Die Geburtsstunde dieses schweren Agrarschädlings liegt sicherlich vor 1859, weil die Entfernung vom vermuteten ursprünglichen Verbreitungsgebiet nach Nebraska überbrückt werden musste. Von Nebraska aus drang der Käfer dann nach Kansas vor, überflog in großen Scharen 1861 den Missouri und stand 1864 am Mississippi, den er noch im selben Jahr auf einer Strecke von insgesamt $1000 \mathrm{~km}$ in fünf „Brückenköpfen" überschritt. Der Käfer erreichte 1874 die Ostküste und war an ihr 1875-1876 zwischen den 35. und 43. Breitengrad vertreten. In 18 Jahren hatte er eine Strecke von annähernd $3.200 \mathrm{~km}$ zurückgelegt. Leptinotarsa decemlineata kommt heute nahezu in den gesamten USA vor. 559

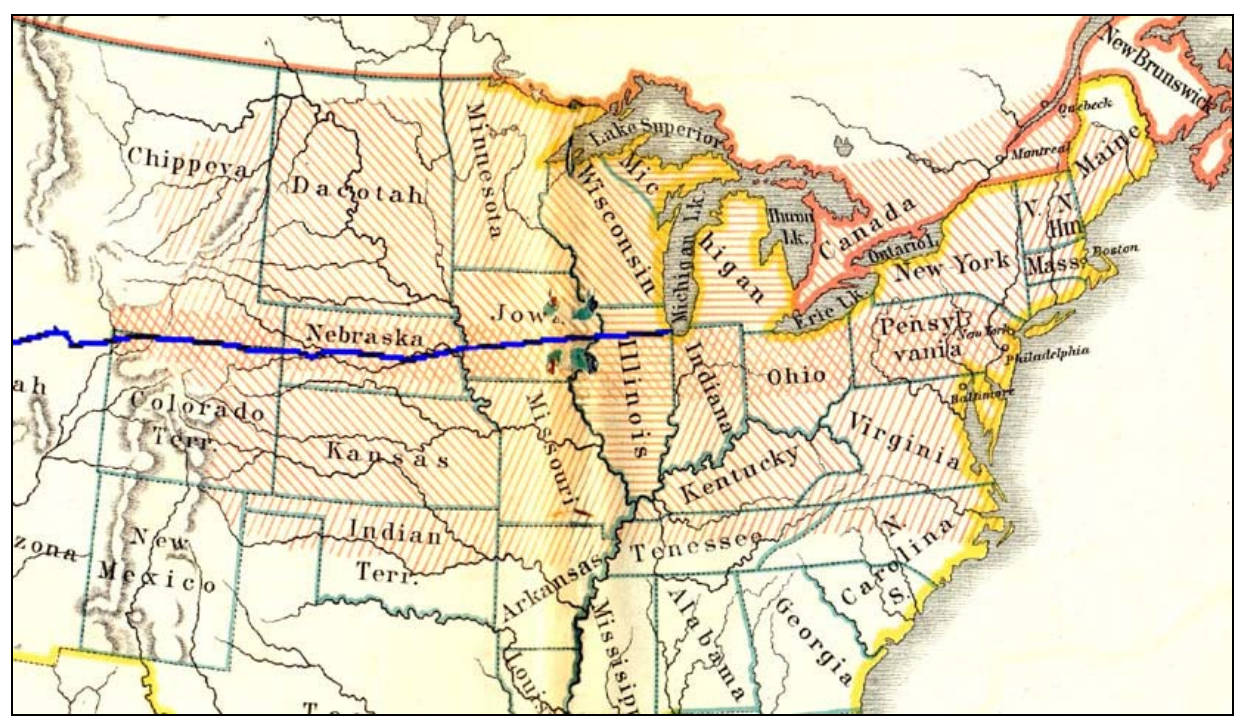

Abb. 7. Verbreitung des Colorado-Käfers 1877. Einfach schraffiert: Verbreitung des Käfers im Jahre 1877; gekreuzt schraffiert: Zone seines vorausgegangenen schnellsten Vorrückens (Kartenausriss aus Gerstaecker 1877). Blaue Linie: Trassenverlauf Pacific Railroad westwärts ab Chicago

Die natürliche Ausbreitung des Käfers gründete sich am häufigsten auf Schwärme, deren Wanderung durch den Wind Dauer und Beschleunigung erfährt. Es ist wiederholt beobachtet worden, dass Käferschwärme mit Windunterstützung den Erieund Michigan-See überwanden. ${ }^{560}$ Auffallend ist die Übereinstimmung zwischen dem Korridor der schnellsten Käferausbreitung von West nach Ost (Abb. 7) und der ältesten Trasse des Ost-West-Eisenbahnverkehrs seit der Mitte des 19.Jh.. ${ }^{561}$

559 Ibid.

560 Gerstaecker 1877, S. 13

561 Die Trasse der Union Pacific Railroad, der ersten transkontinentalen Eisenbahnlinie (Baubeginn 1862 in Omaha, Fertigstellung 1869 mit der durchgehenden Verbindung zwischen Pazifik- und Atlantikküste durch Verbindung der „westlichen“ und „östlichen“ Eisenbahngesellschaften im Knoten 
Gerstaecker (1877), der das Auftreten des Kartoffelkäfers auf deutschem Boden in ministeriellem Auftrag untersuchte, kam zu dem überzeugenden Schluss, dass die Reise als „blinde Passagiere“ auf Verkehrsmitteln (Land- und Wasserfahrzeuge) den damals wahrscheinlichsten Ausbreitungsweg des Käfers darstellte, sowohl trans- als auch interkontinental. 562

Biologisch bemerkenswert ist, dass der Colorado-Käfer ehemals mit einer für einen Edemiten notwendig sehr geringen Fruchtbarkeit auf seiner ursprünglichen Futterpflanze lebte. Die Adoption der Kartoffelpflanze als neuer Futterquelle setzte nicht nur die Verbringung von Kartoffeln in den Lebensraum des Käfers voraus, für Nordamerika war die Kartoffel eine Neophyte, sondern auch ihre offensichtlich physiologische Eignung als Futterquelle. ${ }^{563}$ Mit dem Übertritt auf die Kartoffel muss für den Käfer ein Fruchtbarkeitsanstieg unerhörten Ausmaßes verbunden gewesen sein. Nur die Kombination aus enorm angestiegener Fruchtbarkeit und der gleichzeitig umfänglichen Etablierung der Kartoffel ermöglichte ihm eine Ausbreitung nach Westen mit einer Geschwindigkeit von ca. $170 \mathrm{~km}$ pro Jahr.

\subsection{Erstes Auftreten in Deutschland 1876/77}

Besonders große Mengen von Kartoffelkäfern „überschwemmten“ im Sommer 1875 die Bucht von New York, die darin liegenden Inseln sowie die Delaware Bay mit ihren Schiffspiers, ${ }^{564}$ so dass sich Käfer in großer Zahl an Bord aller Schiffe befanden. ${ }^{565}$ Jedes der von hier abgehenden Transatlantikschiffe war in der Lage, Käfer lebend nach Europa einzuschleppen. ${ }^{566}$ Dies ist offensichtlich geschehen: 1876 wurden die ersten lebenden Käfer in mitteleuropäischen Häfen, darunter Bremen, ${ }^{567}$ gesichtet. Die ersten Infektionsherde mit Kartoffelkäfern auf deut-

Chicago), verlief zwischen Chicago und den Rocky Mountains innerhalb dieses Korridors (Ab. 7). Östlich von Chicago löst sich diese Überlagerung von Käferkorridor und Eisenbahntrassen auf, weil die Trassen aus geomorphologischen Gründen um den Erie See herum geführt wurden und östlich des Sees nördlich von jenem Korridor verlaufen, den Gerstaecker gekreuzt schraffiert darstellte.

562 Gerstaecker 1877, S. $20 \mathrm{ff}$

563 Ein grundsätzlicher Aspekt dieser Feststellung zielt auf eine bestimmte ideologische Position in der Biologie, wonach evolutive Prozesse angeblich immer zu „optimalen“ Resultaten führten. Aus der Sicht des Kartoffelkäfers war er keineswegs das optimale Ergebnis eines Anpassungsprozesses, sondern seine große Stunde kam erst nach Jahrhunderttausende langem Dämmerschlaf in den entlegenen Tälern der Bergwelt durch die opportunistische Nutzungsmöglichkeit der Kartoffel. Erst diese ermöglichte ihm eine Ausbreitung über weite Teile der Erde. Hätte der Käfer nicht die Kartoffel gefunden, wäre für alle Zeit unerkannt geblieben, welches evolutive Potential in diesem Tier schlummerte. Worauf also bezieht sich die Annahme „optimaler“ Ergebnisse im Prozess der Evolution?

564 Gerstaecker, ibid

565 Bericht des Senats der Stadt Bremen an das Reichskanzler-Amt vom 18.9.1876. [zit. nach Gerstaecker 1877, S. 80]

566 Gerstaecker (1877, S. 22) berichtet, dass der Käfer 48 Stunden in süßem, 24 Stunden in Salzwasser und in einem Behältnis ohne Nahrung sechs Wochen überleben könne. Die schnellsten Transatlantikdampfer waren um 1870 nur noch 8 Tage unterwegs. - Gegenwärtiger Wissensstand ist eine Überlebensfähigkeit in Seewasser von mindestens 6 Tagen (Langenbruch, S. 29).

${ }^{567}$ Langenbruch, S. 9 
schem Boden wurden 1877 bei Köln-Mühlheim und Schildau (bei Torgau/Elbe in Sachsen) registriert, ${ }^{668}$ es wird vermutet, dass sie mit Lastkähnen aus Amsterdam bzw. Hamburg in die Nähe der Infektionsherde kamen.

Längst war die Dimension der Bedrohung durch den Kartoffelkäfer erkannt. Bereits im Frühjahr 1875 erließ das Deutsche Reich ein „Verbot der Einfuhr von Kartoffeln aus Amerika, so wie von Abfällen und Verpackungsmaterial solcher Kartoffeln", in der Annahme, das Einschleppen des Kartoffelkäfers so verhindern zu können. Das Preußische Landwirtschaftsministerium veröffentlichte umgehend eine 15seitige Aufklärungsbroschüre mit einer Farbtafel der Käferlarven und Imagines und einer Verbreitungskarte des Käfers in den USA mit dem Stand von 1875.569 Gleichlautende Verbote wie das Deutsche Reich erließen, ebenfalls im Frühjahr 1875, Belgien, Spanien, Frankreich, Russland, Italien, Ungarn und Österreich, Portugal und Schweden 1876, England hingegen erst unter dem Eindruck des Infektionsherdes Mühlheim im Juli 1877. 570

Beide Infektionsherde konnten noch im selben Jahr ihres Auftretens (1877) erfolgreich bekämpft werden. ${ }^{571}$ Am effektivsten erwies sich das Absicheln des Kartoffelkrautes, seine Einbringung in eineinhalb Meter tiefe Gruben und das anschließende Übergießen mit Rohbenzol.572 Eine erfolgreiche Bekämpfung war unbedingt erforderlich, denn , die Verbreitung des Käfers würde aber, da bis jetə̧t alle Mittel, welche man gegen den Käfer und seine Larven versucht hat, wie das Ablesen und Vergiften der Felder, ziemlich erfolglos geblieben, gleichbedeutend sein mit der Verwüstung des deutschen Kartoffelbaus, auf welchem doch die Ernährung eines großen Theils der Bevölkerung vorzugsweise berubt." 573 Ein späteres Auftreten des Käfers 1887, bei der Ortschaft Mahlitzsch etwas nördlich von Torgau und in Lohe bei Meppen, konnte ebenfalls erfolgreich bekämpft werden. Erst 1914 und 1934 wurden wieder Kartoffelkäfer in Deutsch-

\footnotetext{
568 Die Angabe bei Langenbruch, S. 9, der Infektionsherd habe in Schildau/Schlesien gelegen, ist unzutreffend. Auch der bei Langenbruch genannte „dritte“ Infektionsherd des Jahres 1877 in Probsthain/Sachsen gibt den Verlauf irreführend wieder: Vom Infektionsherd Schildau kam es zum Befall der angrenzenden Feldmarken von Probsthain und Langenreichenbach. Es handelt sich hierbei um eine Ausdehnung des Infektionsherdes, nicht um einen eigenständigen (vgl. Gerstaecker 1877, S. 74ff).

569 Die Broschüre (hier als „Gerstaecker 1875“ bezeichnet) erschien ohne Autorenname, aber am Ende mit der Initiale „,(G.)“. Die Autorenschaft Gerstaeckers, der 1877 eine erweiterte Aufklärungsschrift veröffentlichte, ist zweifelsfrei.

570 Gerstaecker, 1877 , S. 78

571 Gerstaecker, 1875 und 1877

572 Die Methode erscheint ziemlich rabiat, es stehen aber zu dieser Zeit noch keine eigentlichen chemischen Pestizide zur Verfügung.

573 Textauszug aus Handzettel „Achtet auf den Kartoffelkäfer“, Verlag von Wiegandt, Hempel \& Parey, Berlin. 1877 (Handzettel in Akte BHLA Potsdam, Rep 2A, Abt.1 LW, Nr. 315) - Die Bedeutung des Kartoffelbaus für das Deutsche Reich ergibt sich aus Angaben des Statistischen Jahrbuches für 1880 (S. 23): Die Kartoffel wurde als Feldfrucht auf der absolut größten Hektarfläche aller Feldfrüchte angebaut (2,7 Mio. ha), die Erntemenge 1880 betrug 23,6 Mio. t und lag damit um fast das Fünffache über der zweitwichtigsten Feldfrucht, dem Hafer (Pferdefutter!). In der Bundesrepublik werden heute auf einem Zehntel dieser Fläche jährlich rund 110 Mio. Tonnen Kartoffeln produziert.
} 
land beobachtet, beide Fälle in Stade, 1939 ein Fall bei Lüneburg und 1944 einer bei West-Sternberg in der Neumark. In allen Fällen war die Bekämpfung erfolgreich, aber eigentlich waren es nur Scharmützel vor dem großen „Abwehrkampf“ (1936 - 1948), den schließlich der Colorado-Käfer gewann.

Der Erfolg der frühen Abwehrmaßnahmen war nicht zuletzt einem verhältnismäßig hohen informationellen Aufwand zu verdanken, mit dem die Verwaltung wie auch eine engagierte Öffentlichkeit auf die Käferbedrohung 1877 reagierte. Vorteilhaft war dabei auch, dass es praktisch keine einheimischen Europäischen Schädlinge gab, die den oberirdischen Teilen der Kartoffel bedrohlich werden konnten. Damit waren die Abwehrkräfte auf nur eine Tierart zu konzentrieren. ${ }^{574}$

Das Preußische Landwirtschaftsministerium ließ 1877 den erwähnten Handzettel drucken, der nicht nur eine Farb-Abbildung des Entwicklungszyklus der Käfers enthielt, sondern auch Teile der Schädlingsgeschichte des Kartoffelkäfers. ${ }^{575}$

Didaktisch völlig neue Wege beschritt die Kaiserliche Hof-Chocoladen-Fabrik Gebr. Stollwerck in Köln: „Die Dampf-Chocoladen-Fabrik der Gebrüder Stollwerk hat auf Anlaß des Bürgermeisters Steinkopf in Mülheim am Rhein, zu Nutz. und Frommen der Landwirtschaft, den bösen amerikanischen Gast, den Coloradokäfer, samt Puppen, Larven und Eiern, alles in natürlicher Größe und Zeichnung und in möglichst treuen Farben nachgebildet. Die kleinen Gebilde sind von täuschender Äbnlichkeit, so dass man dieselben, wie sie in niedlichen, mit Glasdecken versehenen Kästchen auf ebenfalls nachgebildetem Kartoffelkraut dasitzen, beim ersten Blick für wirkliche Eier, Larven, Puppen und Kartoffelkäfer zu halten versucht ist. Ein solches Kästchen enthält auf der unteren Seite eines Blattes 14 Eier, ferner eine Larve von 5-6 Tagen, eine zweite von ca.14 Tagen und eine dritte ausgewachsene und daneben eine Puppe und einen Käfer. Das Ganze kostet eine Mark. Wir möchten Landleute und Lebrer besonders auf diese schöne und wabrheitsgetreue Darstellung des Coloradokäfers aufmerksam machen, da dieselbe dazu angethan ist, Jeden mit dem verderblichen Insect in allen Stadien seiner Entwicklung bekannt zu machen. " 576 Die Repliken wurden aus Puderzucker und Tragant, ${ }^{577}$ gefertigt und waren offenbar handwerklich wie didaktisch von beispielhafter Qualität. ${ }^{578}$

\subsection{Ein Schädling etabliert sich}

Die schädlichen Folgen für die Agrarwirtschaft durch eine Verschleppung des Käfers nach Europa konnten durch dessen Beseitigung 1877 und in einzelnen späteren Fällen abgewendet werden. Ein Transfer des Käfers nach Bordeaux führ-

\footnotetext{
${ }^{574}$ Nach dem Zweiten Weltkrieg werden die Raupen des Totenkopfschwärmers Acherontia atropos häufiger auf Kartoffelpflanzen angetroffen. Dieser Schwärmer ist ein afrikanischer Wanderfalter Seine Raupen sollen der Kartoffelpflanze noch stärker zusetzen als die des Koloradokäfres. Insgesamt ist er jedoch selten und entsprechend auch als Kartoffelschädling zu vernachlässigen.

575 Es handelt sich um Übernahmen aus den Broschüren Gerstaeckers $(1875,1877)$.

576 Kölner Zeitung, Nr. 187 für 1877

577 Einem Rohstoff der Zuckerbäcker mit hervorragenden Eigenschaften zur Oberflächenabformung

578 Die Kästchen hatten eine Größe von 9x6x2 cm. Es befinden sich zwei Exemplare im Kölner Schokoladen Museum.
} 
te jedoch 1922 in der dortigen Region zu seiner dauerhaften Etablierung. Von hier breitete er sich über die Kartoffelanbaugebiete der alten Welt aus. ${ }^{579}$

Wie im Vorfelde der 1877er Infektion wurde nach dem ersten Auftreten des Colorado-Käfers bei Bordeaux in Deutschland 1923 ein Einfuhrverbot für Kartoffeln aus dem betroffenen Land (Frankreich) erlassen, ab 1932 wurde das Verbot inhaltlich erweitert. ${ }^{580}$ Der Schädling hatte in Frankreich 2-3 Generationen im Jahr und konnte sein Verbreitungsgebiet bis zu $150 \mathrm{~km}$ im Jahr nach Osten ausdehnen - Befunde, die sich mit den früheren Beobachtungen in den USA deckten. Ebenso wie dort wurden auch in Frankreich ungerichtete Massenflüge der Käfer von Mai bis in den Herbst beobachtet. Bereits 1924 waren in Deutschland Vorsorgepläne für die Abwehr der Käfer erstellt worden und die Zuständigkeit hierfür der Biologischen Reichsanstalt übertragen worden. Mit Aufrufen zu höchster Alarmbereitschaft und verstärkter Aufklärung wurde 1935 darauf reagiert, dass der Käfer nun fast an der deutschen Westgrenze stand. Der „Reichsnährstand“ richtete auf Vorschlag der Biologischen Reichsanstalt einen „Kartoffelkäfer-Abwehrdienst“ ein, in jeder Ortschaft diente ein „Vertrauensmann“ als Verbindung zwischen Abwehrdienst und Bevölkerung. Mittlerweile waren auch die größeren Schülerinnen und Schüler zu den Überwachungsmaßnahmen hinzugezogen. Aufklärungsmaterial wurde weit verbreitet, Kartoffelkäfer-Schaukästen nach der Idee der Gebr. Stollwerck klärten die Bevölkerung auf und Anreize spornten an. Jeder, der auf einem Feld den ersten Kartoffelkäfer (bzw. Eigelege oder Larve) fand, erhielt eine „Kartoffelkäfer-Ehrennadel“, für weitere Funde auf gleicher Fläche gab es eine „einfache Kartoffelkäfer-Anstecknadel"،.

\subsection{Die Erfolglosigkeit der Abwehr}

Der Kartoffelkäfer-Abwehrdienst hat mit großem Aufklärungsaufwand und der Einbindung weiter Bevölkerungsteile für einen hohen und anhaltenden Bekanntheitsgrad des Schädlings und eines Bewusstseins seiner wirtschaftlich nachteiligen Folgen gesorgt. Aufkleber, Plakate, Stundenplanformulare mit Kartoffelkäfern und Ehrennadeln gehörten in diese Kampagnen ebenso, wie eine „KartoffelkäferFibel“. Diese informierte mit Farbzeichnungen und einfachen Reimen über den Schädling, seine wirtschaftliche Bedeutung und seine Bekämpfung.

Dem hohen Bekanntheitsgrad des Schädlings, der straffen Organisationsform des Abwehrdienstes und seiner Helfer war zu verdanken, dass der Käfer bis 1939 nur den deutschen Südwesten besiedeln konnte. Schließlich gelang es 1943 sogar, ihn hinter die Linie seiner östlichen Ausbreitung von 1939 zurückzudrängen (Abb. 8).

579 Zur Neozoen-Thematik, auch des Kartoffelkäfers, siehe Geiter et al.

580 Die folgenden Ausführungen profitieren, teilweise bis in die Formulierungen hinein, von der Darstellung Langenbruchs. 


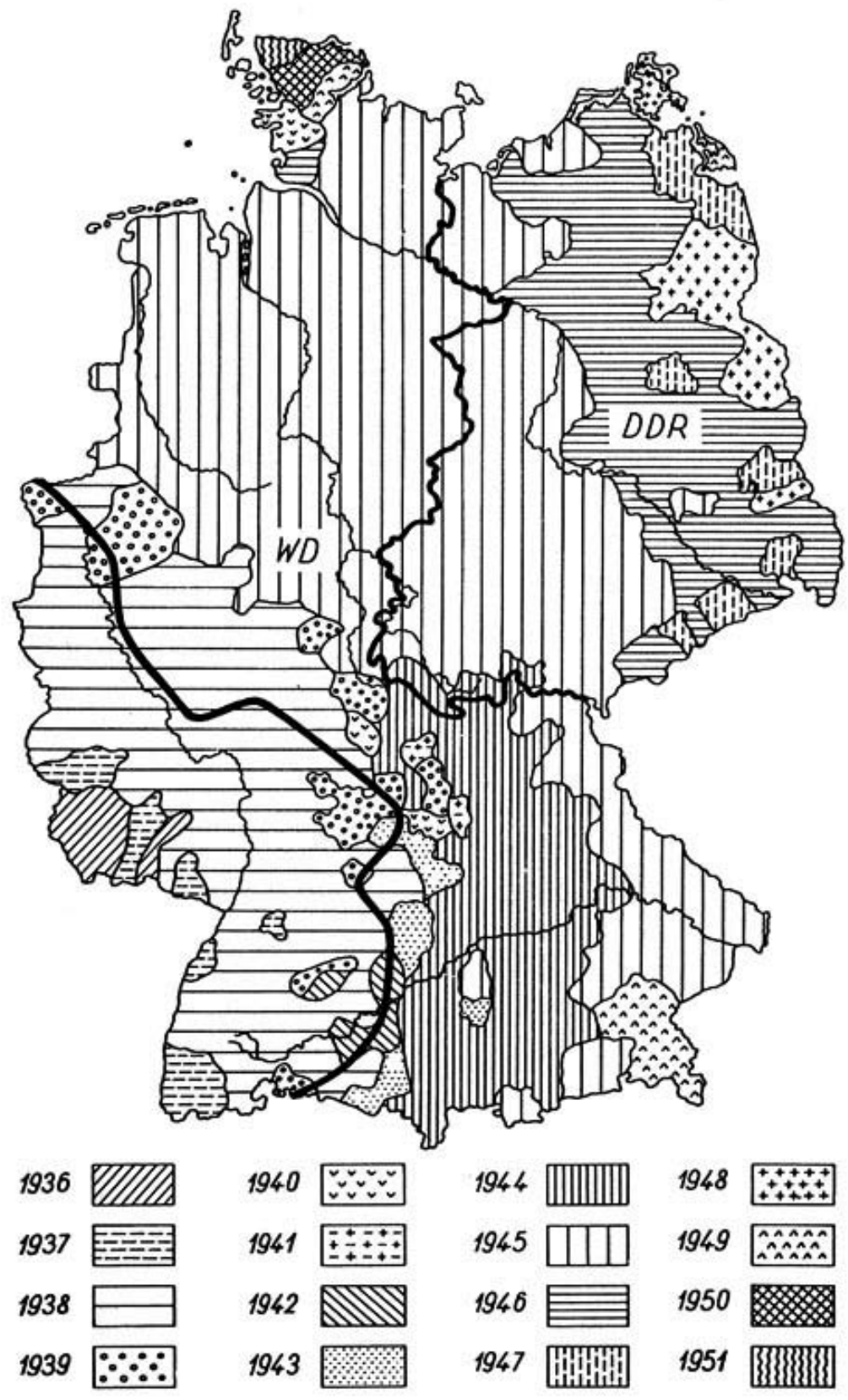

Abb. 8. Die Besiedlung Deutschlands durch den Kartoffelkäfer (WD = Westdeutschland; Karte nach Buhr, aus Langenbruch). Die durchgezogene schwarze Linie links zeigt die Grenze, auf die der Käfer durch den Kartoffelkäfer-Abwehrdienst bis Ende 1943 zurückgedrängt werden konnte. 
In den Kriegsjahren fehlten dann zunehmend einsatzfähige Menschen, Transportmittel und Pflanzenschutzprodukte. Der Kartoffelkäfer hatte 1944 ein besonders günstiges Jahr und erreichte 1945 die Elbe. Begünstigt durch die militärischpolitische Situation in Mitteleuropa, gelang es dem Schädling schließlich, sich hier dauerhaft zu etablieren.

Der Abwehrdienst wurde zwar nach dem Krieg in Ostdeutschland wieder aufgebaut, bis aber ausreichend Mittel und Geräte zur Verfügung standen, hatte das Insekt 1948 Deutschland bis zur Oder besiedelt. 581

Gegenwärtig ist der Kartoffelkäfer in den gemäßigten Zonen Nordamerikas verbreitet. Gesamt-Europa (immer noch mit Ausnahme der Britischen Inseln ${ }^{582}$ und der nördlichen Teile Skandinaviens) ist Verbreitungsgebiet, ebenso Nordafrika und Vorderasien wie große Teile Russisch-Asiens. Der Käfer ist in Korea, Japan, weiten Teilen Chinas, kleineren in Indien und in den gemäßigten Breiten der südlichen Hemisphäre verbreitet.

Natürliche Fressfeinde des Käfers oder Pathogene scheint es in den NeuHabitaten nicht zu geben, die Larven werden von einigen anderen Insekten, u.a. auch Marienkäfern, gejagt, ohne jedoch die Käferpopulationen auf für Menschen tolerable Dichten zu reduzieren.

Eine absolute Erfolgsgeschichte für den Käfer, die sich völlig der Verbreitung der Kartoffel verdankt ${ }^{583}$ und wobei der Käfer von einem biologischen Prinzip profitiert, das weltweit verstanden wird: Schwarz-gelbe Zeichnung ist eine äußerst ernst zu nehmend Warntracht. Nur, dass der Käfer mögliche Fressfeinde mit seiner Mimikry täuscht, denn er ist weder ungenießbar noch verfügt er über giftige Abwehrmechanismen.

\subsection{Schadensausmaße}

In nur 250 Jahren hat die Kartoffel die landwirtschaftliche Welt verändert, in nicht einmal 100 Jahren ist ihr Hauptfraßschädling, der Kartoffelkäfer, über die Anbaugebiete der Erde verteilt.

Fraß, vor allem der Larven, kann zum völligen Verlust der Assimilationsflächen der Kartoffelstauden führen. Die Pflanze setzt weder Knollen an, noch überlebt sie. Kartoffeln rangieren auf Position vier der weltweit bedeutendsten Nahrungspflanzen. Es ist offensichtlich, dass kartoffelbasierte Nahrungskulturen konsequent gegen den Kartoffelkäfer vorgehen müssen. Effiziente Bekämpfungsstrategien stehen seit langem und Pestizide seit mehr als 50 Jahren zur Verfügung und werden ständig verbessert.

\footnotetext{
581 Mit Ausnahme Schleswig-Holsteins, das erst um 1950/51 infiziert wurde. Zusammengefasst nach Langenbruch, S. 16-17

582 Telef. Auskunft des UK Dept. for Environment, Food and Rural Affairs (DEFRA) am 13.5.09: Es finden sich zwar einzelne Kartoffelkäfer, aber die Inseln gelten als "nicht infiziert". Hierfür scheint es klimatische Gründe zu geben.

583 Der Käfer kann andere Pflanzenmaterialien essen, vorwiegend von Nachtschattengewächsen (Solanaceaen), tritt aber an ihnen kaum oder gar nicht als Schädling auf.
} 
Insofern sind heutige Schäden durch Kartoffelkäfer weltweit eigentlich den Fehlern bei der Schädlingsbekämpfung zuzurechnen. Eine offizielle Statistik über jährliche Schadensausmaße durch Käferfraß ist nicht zu finden, ebenso keine über die jährlich weltweit gegen den Käfer eingesetzten Pestizide. ${ }^{584}$ Gemessen an der Bedeutung von Kartoffeln für die Welternährung und Weltwirtschaft ist die Beherrschung der Kartoffelkäferbekämpfung ein unabweisbares und prioritäres Erfordernis.

\subsection{Kartoffelkäfer, Biologische Kriegführung und politische Propaganda}

Überraschend früh hat der Kartoffelkäfer Anregung zu kriminellen und verbrecherischen Gedanken und Handlungen gegeben. Beispielsweise wurden Mitte 1931 mehrere Erpresser verurteilt, die landwirtschaftliche Großbetriebe in der Magdeburger Gegend mit der Infektion der Felder mit Kartoffelkäfern bedroht hatten. ${ }^{585}$

Von gänzlich anderer Dimension ist ein Szenarium mit Kartoffelkäfer, in dem dieser für Kriegs- und Propagandazwecke verwendet wurde:

Der Anzeiger für Schädlingskunde ${ }^{586}$ [Bd.22 (1949):96] berichtet in einer Kurzmitteilung ,An zablreichen Plätz̧en in Nordrbein-Westfalen und in Niedersachsen wurden im vergangenen Jahre587 auf Kartoffelfeldern Beutel mit Kartoffelkäfern festgestellt, die von Flugzengen unbekannter Nationalität abgeworfen waren.[Fußnote: Anm. der Schriftleitung: Beim Landwirtschaftsministerium des Landes Nordrhein-Westfalen eingeholte Information ergab Richtigkeit dieser Angabe, wenn auch die ganze Angelegenheit als reichlich mysteriös bezeichnet wird.] Diese Meldung wird in der schwedischen Tagespresse lebhaft kommentiert. So schrieb die in Stockholm erscheinende „Aftenposten", die Nachricht scheine Unheil an₹ukündigen und könne dabin ausgedeutet werden, dass der bisher "kalte Krieg" nunmehr in ein Stadium „direkter Methoden" übergegangen sei, den man „Insektenkrieg“ nennen könne. In einer künftigen Kriegfübrung seien sämtliche Sachverständigen sich darin einig, dass neue Kampfmittel benutzt werden würden. Der Oberbefehlshaber der schwedischen Wehrmacht, General Jung, äußerte bierüber, dass auch bakteriologische Kampfmittel in Betracht kommen könnten. Es handle sich nicht nur um die Verbreitung von Krankheiten verursachenden Bakterien, sondern auch um Beeinträchtigung von Kulturpflanzen. E.B. “

Der Wahrheitsgehalt dieser Mitteilung lässt sich heute nicht ohne weiteres bestätigen. ${ }^{588}$ Die Literatur ist wenig präzise und verweist am Ende immer auf eine Kampag-

\footnotetext{
584 Was zu der Anschlussfrage führt, inwieweit mögliche Folgeschäden durch Insektizide der Kartoffelkäfer-Bekämpfung zuzurechnen ist.

585 Anzeiger für Schädlingskunde 7 (1931): 105

586 Heute ,JJournal of Pest Control“", Springer, Heidelberg; bis heute (2009) erschienen 82 Jahrgänge

587 Also 1948

588 Die Anfrage des Verf., beim zuständigen Ministerium in Nordrhein-Westfalen wurde zur Beantwortung an den Pflanzenschutzdienst der Landwirtschaftskammer Rheinland in Bonn weitergeleitet, Von dort erging Auskunft „Bedauerlicherweise ergaben sich keinerlei Hinweise auf solche Vorgänge im Rheinland. Es ist demnach zu vermuten, dass eine damals erfolgte Bestätigung ggf. nur in mündlicher Form erfolgte, wobei sicherlich auch Gerüchte oder "scherzhafte" nachbarschaftliche Aktionen bei entsprechenden Funden eine Rolle gespielt haben dürften. Belegbar scheinen diese Aussagen jedoch nicht zu sein.“ ( 2.3.2009 an Verf.). Eine Anfrage ans Nieders. Landwirtschaftsministerium im
} 
ne der DDR, mit der diese innenpolitische Ablenkung betrieben hätte. Bis heute ist der Wahrheitsgehalt der Meldung nicht wirklich geklärt, in Internet-Blogs unterhalten sich Verschwörungstheoretiker mit Freunden Urbaner Legenden ${ }^{589}$ über dieses Thema.
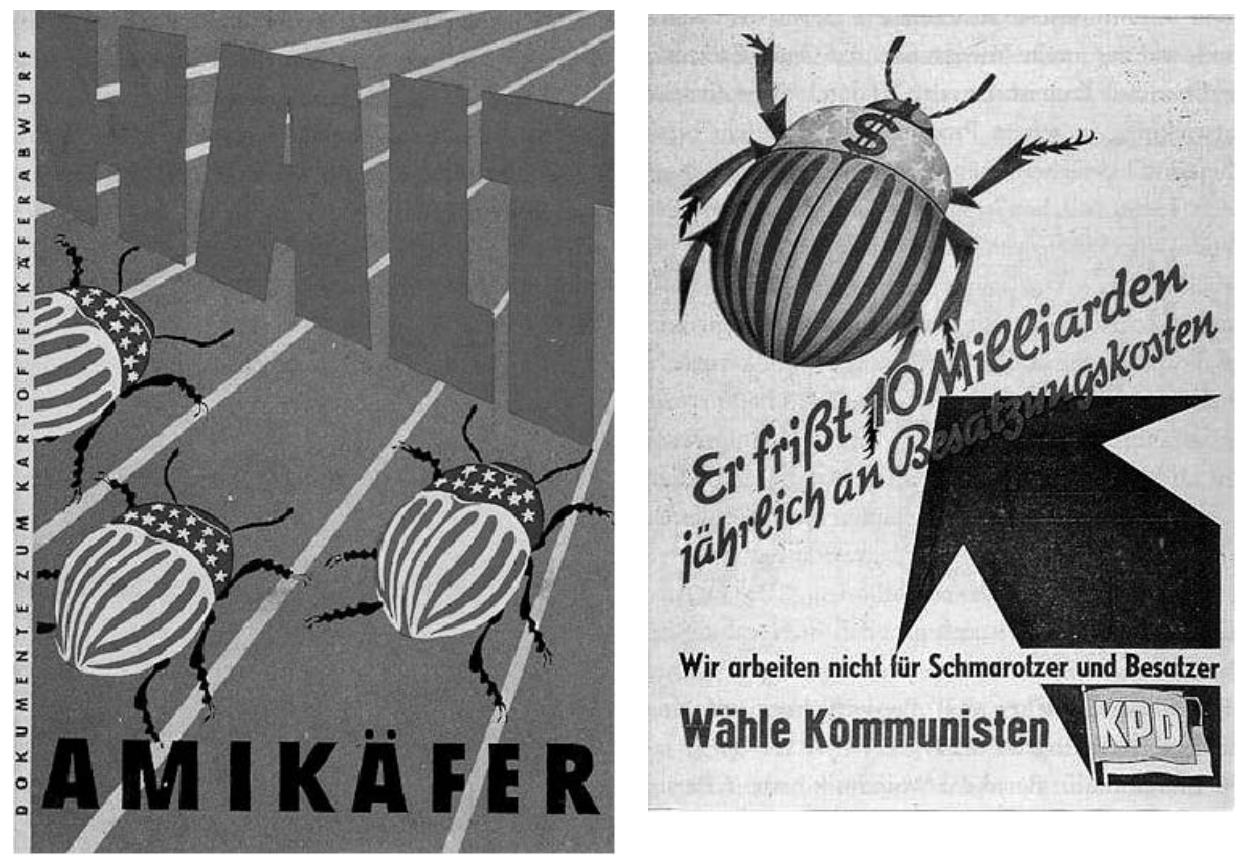

Abb. 9. Links: Die DDR beschuldigt die USA, die sozialistische Kartoffelernte vernichten zu wollen. Broschüre des Amtes für Information der DDR 1950 (Deutsches Historisches Museum). Rechts: Das Käfermotiv wird auch in Westdeutschland in der politischen Propaganda verwendet, wobei der politische Gegner als Schädling disqualifiziert wird; Wahlplakat der KPD aus 1953 (Bundesarchiv Koblenz). Das Datum ist ein Hinweis auf die anhaltende Wirkung der Kartoffelkäfer-Metapher.

Unbestreitbar ist, dass die DDR-Führung im Mai 1950 eine 24seitige Broschüre über den angeblichen Flugzeug-Abwurf von Kartoffelkäfern (Abb. 9). Wirtschaftlich hatte die Kartoffel in der DDR größere Bedeutung als in der BRD. 1949 trat der Kartoffelkäfer in Mecklenburg und Sachsen-Anhalt stark auf. 1950 waren 90\% der DDR befallen, der Käfer stand an der Oder. Die Nahrungsversorgung in der DDR war prekär. Als Ursache für das nun massenhafte Auftreten von Kartoffelkäfern wurden im Ministerium für Land- und Forstwirtschaft der DDR in internen Papieren der ,Zusammenbruch der Organisation des Abwehrdienstes, Mangel an geeigneten chemischen Mit-

März 2009 erbrachte ebenfalls keine Bestätigung, außer der, dass man „dieses Gerücht“ seit Jahren kenne.

589 Urbane Legenden, synonym für „Moderne Wandersagen“ und „Großstadtmythen“ nach dem Muster von „Krokodile in der New Yorker Kanalisation“; siehe Klintberg 
teln, Desinteressiertheit usw. an Pflanzenschutzarbeiten“ sowie begünstigende Witterung genannt. ${ }^{590}$ Öffentlich begann das Zentralorgan der SED, das Neue Deutschland, am 16.Juni 1950 mit der Propaganda, wonach USA-Flugzeuge große Mengen von Kartoffelkäfern über der DDR abgeworfen hätten. ${ }^{591}$

Die Propaganda verfehlte ihre Wirkung nicht, jedenfalls gemessen am noch heute nachweisbaren Bekanntheitsgrad des „Amikäfers“, wie der Colorado-Käfer umgetauft wurde. ${ }^{592}$ Selbst kritische Charaktere blieben nicht unberührt, wie das Beispiel Berthold Brechts zeigt. In seinen Kinderliedern, die er 1950 schrieb, findet sich folgendes:

\section{Die Amikäfer}

1. Schwesterchen, so komm doch

Und lass Dein Püppchen stehn

Lauf, lauf, am Himmel

Da ist was Schön's zu sehn.

2. Wolln auf dem Rücken liegen

Und sehn ins Himmelszelt

Die Amiflieger fliegen

Hoch übers Feld
3. Mutter, ich bin hungrig.

Wie lang ists zur Jause hin?

Mutter, ich weiß nicht

Warum ich so hungrig bin

4. Die Amiflieger fliegen

Silbrig im Himmelszelt

Kartoffelkäfer liegen

Im deutschen Feld.

Geißler (1998), der amerikanisches Geheimdienstmaterial und Archivmaterial der DDR einsehen konnte, kommt zu dem Ergebnis, dass es keinen Anhalt für Käferabwürfe durch die USA gebe, dass es sich vielmehr um einen Propagandatrick der DDR zur Zeit des Kalten Krieges gehandelt habe. Man möchte zunächst überhaupt glauben, dass es sich bei dem Propagandalärm um ein reines Phantasieprodukt von Abwehrspezialisten handelt, doch weit gefehlt.

Englische wie französische Militärs überlegten bereits z. Zt. des Ersten Weltkrieges, Colorado-Käfer und andere Kartoffelschädlinge gegen Deutschland einzusetzen, ${ }^{593}$ nahmen jedoch aus praktischen Erwägungen davon Abstand. ${ }^{594}$ Im Zuge des

\footnotetext{
590 Geißler, 2001, S. 25

591 Immerhin wäre dazu vermutlich im Rahmen der im Mai 1949 beendeten Berliner Luftbrücke vergleichsweise unauffällig Gelegenheit gewesen, die zudem in einem biologisch sinnvollen zeitlichen Verhältnis zum Massenauftreten von Kartoffelkäfern in 1950 stattfand. Auch die angeblichen 1948er Abwürfe liegen bereits in der Zeit der Luftbrücke. Indes ist die Durchseuchung Ostdeutschlands 1948 - 1950 auch ohne Annahme biologischer Kriegführung bzw. Sabotage allein aus der Populations- und Ausbreitungsdynamik des Käfers erklärbar.

${ }^{592}$ Der Bekanntheit des „Amikäfers“ in Deutschland entsprach eine Bekanntheit von „Doryphore“ in Frankreich zur Zeit der deutschen Besatzung. Der alte wissenschaftliche Name des Kartoffelkäfers wurde früh zu einem Synonym für die deutschen Besatzer, weil diese, dem Käfer ähnlich, die Kartoffeln ,stahlen“. Die Bekämpfung des „Doryphore“ entwickelte sich in der Resistance daher zu einer Chiffre des Kampfes gegen die deutschen Besatzer. Dabei war kaum Gefahr zu laufen, durch die Verwendung des Begriffes entdeckt zu werden, da ja die Bekämpfung des wirklichen Kartoffelkäfers in Frankreich eine absolute Notwendigkeit darstellte.

593 Geißler 1998,S. 452

${ }^{594}$ Hauptsächlich wegen der Befürchtung, die biologischen Kampfmittel könnten auch die eigene Landwirtschaft schädigen.
} 
deutschen Überfalls auf Frankreich wurden Unterlagen über französische Biowaffen erbeutet, in denen Flugzeugabwürfe von Käfern auf deutsche Kartoffelfelder erwogen wurden. Diese Unterlagen veranlassten Wehrmachtsführer, die Biowaffentauglichkeit des Colorado-Käfers durch eigene Forschungen zu prüfen. In diese Arbeiten wurde die Außenstelle der Biologischen Reichsanstalt in Kruft in der Eifel, eine Kartoffelkäfer-Forschungsstätte, einbezogen. Obwohl eine biologische Kriegführung von Hitler eigentlich untersagt war, wurden jedoch einschlägige Forschungen weitergeführt. Im Oktober 1943 gab es einen feldmäßigen Abwurfversuch mit Käfern bei Speyer. Insgesamt wurden 14.000 Käfer aus $8.000 \mathrm{~m}$ Höhe abgeworfen, bei der nachfolgenden Suchaktion wurden 57 Käfer wieder gefunden. 595 Die Arbeiten am Projekt kamen im Juni 1944 zum Erliegen, nicht wegen erwiesener Erfolglosigkeit, sondern wegen der militärisch-politischen Lage, in deren Folge die Kartoffelkäfer-Forschungsstelle der Biologischen Reichsanstalt nach Mühlhausen/Thüringen übersiedelte. Der Leiter des Kartoffelkäfer-Abwehr-dienstes der Reichsanstalt, Schwartz, hoffte noch im März 1945 die Biowaffenforschung mit Kartoffelkäfern im April 1945 in Thüringen wieder aufnehmen zu können. ${ }^{596}$ Dazu kam es aus bekannten Gründen nicht mehr. Stattdessen wurde Schwartz 1946 beauftragt, „die Arbeitsstätte (auch mit Unterstützung der sowjetischen Militäradministration) erneut zu einem leistungsfähigen Institut auszubauen. [...] Schwartz leitete diese Einrichtung und war gleichzeitig Generalbevollmächtigter für den Kartoffelkäfer-Abwehrdienst - der im Osten ab 1946 wieder aufgebaut wurde - bis zu seinem Tode im April 1947.“"597

Für Geißler (1998, 2001) ist die Kartoffelkäfergeschichte mit Abwürfen aus USamerikanischen Flugzeugen reine Propaganda der DDR. Bemerkenswert ist allerdings, dass eine solche Propaganda-Meldung überhaupt entwickelt wurde und Wirkung erzielen konnte. Einerseits erschien vermutlich zur Zeit der Luftbrücke bzw. kurz danach ein Abwurf-Szenarium für DDR-Bürger nicht unplausibel. Andererseits erscheint auch die Ausnutzung von Expertenwissen über B-Waffen-forschung für die Konstruktion dieser Propaganda wahrscheinlich, denn mit dem B-Waffenforscher und KZ-Arzt Kurt Blome wurde in den Nürnberger Prozessen ein intimer Kenner der einschlägigen Aktivitäten vernommen. ${ }^{598}$ Die Vernehmungsinhalte dürften allen Alliierten bekannt gewesen sein und vermutlich auch die Öffentlichkeit, vielleicht nicht immer im Detail, erreicht haben.

Geißler und Deichmann (die sich thematisch nicht mit dem „Amikäfers“ und der DDR-Propaganda auseinander setzte) haben beide nur Akten aus dem militärischadminsitrativen und wissenschaftlichen Bereich ausgewertet. Angeblichen Kartoffelkäfer-Abwürfen müsste aber in zeitgenössischen Presseberichten (West) und Akten der Landwirtschaftsministerien nachgegangen werden, bis sich die kursierenden Gerüchte wirklich zur Gewissheit verdichten ließen, wonach es sich lediglich um Propaganda handele, die bis heute als urban legends überlebt. Bis zu dieser Klärung sollte das Un-

\footnotetext{
595 Geißler, 1998, S: 465. - Vor Geißler war bereits Deichmann (S. 236) diesen Hinweisen aus anderer Motivation nachgegangen. Nach Geißler ist die Zahlenangabe bei Deichmann (1.400) falsch, richtig müsse es 14.000 Käfer heißen.

596 Geißler, 1998, S. 459

${ }^{597}$ Langenbruch, S. 28

598 Blome wurde 1947 erstaunlicher Weise freigesprochen.
} 
wahrscheinliche noch nicht völlig ausgeschlossen sein. ${ }^{599}$ Denn zahlreiche Ungereimtheiten lassen die Skepsis nicht verstummen. ${ }^{600}$

\section{Zusammenführung}

$\mathrm{Zu}$ den vielfältig und leicht erreichbaren Darstellungen über die Nützlichkeit der Kartoffel für die nationalen Ökonomien wie auch die Weltwirtschaft muss keine weitere geschrieben werden. Fraglos war und ist die Entdeckung der Kartoffel und die wirtschaftliche Nutzung ihrer einzigartigen Eigenschaften ein Glücksfall für die späteren Kartoffelesser in der Weltgeschichte.

Die hier erzählte Geschichte handelt von drei vom Menschen oder durch seine Wirkung verpflanzten Organismen und davon, dass autonome Prozesse der Natur sich

${ }^{599}$ Nachweisbar sind Abwürfe von Kartoffelkäferattrappen: „Nachdem im Juli 1950 die DDR ihre Kartoffelkäferpropaganda gestartet hatte, trafen sich Anfang August Mitarbeiter einer schwarzen Abteilung des Pressereferats des Gesamtdeutschen Ministeriums mit amerikanischen Geheimdienstleuten. Man kam überein, als Scherzartikel Kartoffelkäfernachbildungen aus Pappe mit aufklärerischen Politsprüchen und dem "F" für "Freiheit" auf der Rückseite zu versenden. Etwa 50 Kartoffelkäfer ließen sich auf einen postkartengroßen Pappbogen drucken und stanzen. Ein Teil der Bogen wurde mit der Post an sämtliche Räte der Gemeinden der DDR geschickt. Der Rest wurde ausgestanzt und dann mit Ballons über der DDR abgeworfen. "Die Schulkinder sollten beim Kartoffelkäfersammeln ja auch etwas geistige Nahrung finden", erläutert ein Teilnehmer das Unternehmen. Später konstituierte sich das Kartoffelkäfer-Team zur F-Aktion, "Freiheit", Aktion der Jugend.“ (Körner o.J., S .4)

${ }^{600}$ Eigene Einsicht in Unterlagen der Bundesbeauftragten für die Unterlagen des Staatssicherheitsdienstes der ehemaligen Deutschen Demokratischen Republik (BStU) förderten keine Belege für Kartoffelkäferabwürfe zutage. [Findbuch siehe unter http://www.bstu.bund.de/ im Literaturverzeichnis, dort Seite 86]. Während die Kampagne für die DDR-Bevölkerung nach Geißler am 16.6.1950 mit einem Leitartikel im „Neues Deutschland“ in Gang gesetzt wurde, findet sich bereits ein IM-,Stimmungsbericht“ vom 8.6. über die Situation am Schweriner Staatstheater, wonach „das Abwerfen von Kartoffelkäfern über dem Gebiet der DDR allgemein Empörung und Protest hervorrief.“ Als Datum erster, angeblicher Kartoffelkäferabwürfe gibt Geißler 22.- 24. Mai für Sachsen an. Bis 10.6. wären Mecklenburg, Sachsen-Anhalt und Thüringen hinzugekommen. - Die Akte „Allg. S 67/54“ enthält unbewiesene und unbeweisbare Zusammenhänge zwischen einzelnen Flugzeugbeobachtungen und Kartoffelkäfern, aber keine Meldungshäufung. Die Idee des Kartoffelkäferabwurfs müsste also bereits deutlich vor dem 16.6.1950 in der Bevölkerung lanziert worden sein, wenn sich die Schauspieler am Theater in Schwerin schon vor dem 8.6. ereifert haben. Möglich, dass die Mehrzahl der Beobachtungen auch Zusammenhänge aus hysterischer Stimmungslage konstruiert. Die Frage bleibt allerdings offen, wie und woher die Idee Breitenwirkung erzielen konnte. Einzelne Beobachtungen (aus 1951) wollen sogar spezielle Behälter an sehr tieffliegenden Flugzeugen gesehen haben. Anschließend habe man Kartoffelkäferansammlungen gefunden. Es sind auch Berichte enthalten, die auf landgestützte Anschläge bzw. Sabotageakte schließen lassen würden, wenn ihnen Wirklichkeitscharakter zukäme. - Merkwürdigerweise finden sich in der Akte keine Einträge, die auf eine zentralistische Lenkung, auf eine gesteuerte Kampagne hinwiesen. Dagegen wird in einem Bericht der Stasi aus Dresden (19.4.1951) die Übereifrigkeit der Volkspolizei in Flöha vom 18.4. kritisiert (,warum eine derart unsinnige Spitzenmeldung abgegeben wurde“). Die VP hatte eine Mutmaßung aus Kindermund am 18.4., die eine Verbindung zwischen sehr hoch fliegenden Flugzeugen und einem Käferschwarm herstellte, der einen nahen Kirschbaum umflog, eiligst weitergegeben. Abgesehen davon, dass es sich bei den Käfern um „gewöhnliche Mistkäfer" gehandelt haben solle, wird endlich einmal rational argumentiert: Abwürfe aus 10.000 m Höhe würden etwa 10 Minuten Fallzeit beanspruchen. - Insgesamt offenbaren die Berichte eher Einsicht in Techniken, wie man staatstreue Aufmerksamkeit demonstrieren konnte, ohne bestimmten Personen Schaden zuzufügen, als dass sie irgendeinen sachlichen Beitrag zum Wahrheitsgehalt des Kartoffelkäferabwurfs liefern. 
mit normativer oder praxeologischer Handlung von Menschen zu derartigen Konfliktlagen verbinden können, dass sie als Katastrophe erlebt werden. Nicht die autonomen Prozesse sind deren eigentliche Ursache, sondern ihre Nichtkenntnis und ggfl. ihre Nichtbeherrschbarkeit, aus denen die für Menschen nachteiligen Wirkungen resultieren. ${ }^{601}$ Letztlich ist die Geschichte dieser neuen europäischen Trias, der Neophyte Kartoffel, des Neomyceten Phytophthora und des Neozoons Kartoffelkäfer, eine Geschichte, die sich dem historisch größten Freisetzungsexperiment aller Zeiten, das mit dem Jahre 1492 begann, verdankt.

Die drei thematischen Stränge bündeln in ihrer Verbindung Grundprobleme einer globalisierten Naturnutzung. Was als nützlich für Menschen und zur Mitwirkung an der Deckung des Glückseligkeitsversprechens der Aufklärung geeignet erschien, kann - in veränderten Tableaus - die positiven Vorstellungen der Menschen durch negative Folgen und Nebenfolgen auf Umwege zwingen oder gar scheitern lassen.

„Umwelt“ sei, neben „Herrschaft, Wirtschaft und Kultur“, die vierte Grundkategorie der Geschichtswissenschaft, so das Diktum von Siemann \& Freitag (2003). Tatsächlich wird man das hier vorgestellten Beispiel nur im Zusammenspiel aller vier Kategorien angemessen erörtern können (Tab. 4, nachstehend):

$\begin{array}{cc}\begin{array}{c}\text { Geschichtswissenschaftliche } \\ \text { Kategorie }\end{array} & \begin{array}{c}\text { Zugehöriges Stichwort } \\ \text { (Auswahl) }\end{array} \\ \text { Umwelt } & \begin{array}{c}\text { Habitat Amerika; Neozoen-Neophyten; Stoffströme; } \\ \text { Energieabschöpfung; Reproduktion; }\end{array} \\ & \text { Kolonialreich Spanien; Siedlungsexpansion Nord- } \\ \text { Amerika; Monopolisierung von Nahrung; Versteti- } \\ \text { gung der Nahrung; Bevölkerungspolitik; Landnut- } \\ \text { zerschaft }\end{array}$

\footnotetext{
601 Die Öffentlichkeit und selbst die gehobene Literatur reden in solchen Fällen unsinnigerweise vom „Zurückschlagen der Natur“. Nichts dergleichen passiert, denn „die Natur“ ist kein Akteur. Tatsächlich verschleiert diese Formulierung, dass sich Extremereignisse, die Menschen als „Katastrophen“ zu bezeichnen pflegen, allermeist der mangelhaften Moderierung bzw. der ingenieurtechnisch mangelhaften Beherrschung naturaler Prozesse verdankt. In aller Regel wird stillschweigend fehlerhaftes menschliches Handeln als (mögliche) Ursache des „Zurückschlagens“ akzeptiert Extremereignisse, die jenseits jeden menschlichen Zutuns angesiedelt sind, wie ein Vulkanausbruch oder Erdbeben, werden entsprechend auch nicht als „zurückschlagende Natur“ eingeordnet.
} 
Selbstverständlich sind die Stichwörter den Kategorien nicht in einem ausschließlichen Sinne zugeordnet.

Die Rekonstruktion der Umweltbedingungen, die Rekonstruktion der Wahrnehmung durch die im jeweiligen Zeithorizont beteiligten Menschen und die Analyse beider ist der zentrale Zusammenhang in der Umweltgeschichte. ${ }^{602}$ Trotz der vielfältigen Verschränkungen, die sich aus den drei thematischen Wegen zu dem hier behandelten Thema ergeben, lassen sich diese Beziehungsgeflechte auf umwelthistorische Grundthemen zurückführen, im wesentlichen auf:

die energetische Bilanz der Kartoffel in agrarproduktiver Hinsicht und im Verhältnis zu konkurrierenden Grundnahrungsmitteln; Globalisierung durch Verbreitung und Menge; Umweltverträglichkeit der Pflanze; die fehlenden biologischen Antagonisten der Kartoffelschädlinge in den Neo-Habitaten; Akzeptanz gegenüber dem Nahrungsmittel; bevölkerungsbiologische Folgen; Änderungen im Ernährungsverhalten; materielle Grundlage der Volkswirtschaft; Verfügungsmacht über Nahrungsmittel; Verhalten der Betroffenen in der Nahrungsknappheit; Ausgestaltung normativer Bereiche.

Diese Aspekte werden in dieser Zusammenführung noch einmal hervorgehoben. Hingegen wurde bisher und wird im weitern Verlauf des Aufsatzes der mentalitätengeschichtlichen Rezeption der drei Organismen nicht in besonderer Weise nachgegangen. Die Anfangsprobleme, die sich einer Nutzung der Kartoffel in den Weg stellten, sind hinlänglich bekannt und in der aufgeführten Literatur leicht erreichbar, bis hin zu den Anekdoten, wonach die anfängliche Unkenntnis zum Verzehr der Beerenfrüchte führte. Deren geringe Zahl und vor allem ihre Ungenießbarkeit erschwerten die Akzeptanz der Kartoffel. Außerdem sprach sich bald herum, dass die nachgesagte aphrodisierende oder nymphomanische Wirkung der Kartoffeknollen - aus dem anfänglichen Missverständnis, es handele sich um etwas Ähnliches wie eine Trüffel - überwiegend auf sich warten ließ oder bestenfalls auf Placeboeffekten beruhte.

Der Kartoffelkäfer traf auf eine vorbereitete Administration. Einmal gab es bereits einen intensiven Erfahrungsaustausch mit den Vereinigten Staaten. Die Nachrichten von dort waren etwas, wonach man sich richtete. Zum anderen war durch das Einschleppen der Reblaus in den 60er Jahren des 19. Jh.s ein Bewußtsein für die Möglichkeit eines Schädlingstransfers und seiner wirtschaftsschädlichen Dimension entstanden. Für die Reblausbekämpfung wurde erstmals übernational eine gleichsinnige Gesetzgebung betroffener europäischer Länder betrieben. Dieses erfolgreiche Muster wurde auf den Kartoffelkäfer übertragen. Als dieser dann 1876 in Europa erschien, waren nicht nur die staatlichen Verwaltungen vorbereitet. Stimmen, den Käfer auf eine andere als natürliche Ursache zurückzuführen, finden

${ }^{602}$ Herrmann 2009, S 26 
sich nicht. Mit dem Aufdecken seines ehedem endemischen Vorkommens wurde auch ganz offensichtlich, dass sich seine Massenvermehrung Gründen verdankte, die man heute als „ökologisch“ und als „fehlerhafte Nebenfolge“ der Landwirtschaft bezeichnen würde. Der Käfer wird auch nicht in metatheoretische geopolitische oder straftheologische Konzepte eingebunden. Seit seinem Auftreten in Europa hat sich an der Bewertung des Käfers nichts geändert, geändert haben sich Techniken seiner Bekämpfung.

Dass die Bewertung der Kartoffelfäule vor allem in dem Teil der Irischen Bevölkerung eine straftheologische Konnotation erhielt, der sich nach religiösen, vorzugsweise katholischen Moralvorstellungen zu richten hatte, versteht sich von selbst. ${ }^{603}$ Die Rezeptionsgeschichte der Krautfäule in Deutschland scheint bislang praktisch ohne Niederschlag in der einschlägigen historischen Literatur zu sein. Krus hat in seiner Lokalstudie für Ostwestfalen-Lippe, die vor allem obrigkeitliche Reaktionen thematisiert, auch einige Stimmen gesammelt, ${ }^{604}$ die sich an zeitgenössisch übliche, vortheoretische Erklärungsmuster halten, wobei allerdings keine Letztursachen genannt sind. ${ }^{605}$ Ursache ist entweder eine Art Tau, ein mit der Luft transportierter Schadstoff, es ist ein Schwamm oder Schimmel, ${ }^{606}$ es sind Witterungsbedingungen oder es sind kleine Tiere, vorzugsweise Insekten, die den Pflanzen so zusetzen. Krus führt ein Zeitzeugnis des später und bis heute bekannten Anatomen H.W. von Waldeyer-Hartz (1836-1921) über das Auftreten der Kartoffelfäule auf dem vom Vater verwalteten Gut an, das aufschlussreich ist: „Kartoffeln wurden reichlich angebaut, deren Haupternte in den Monat Oktober fiel. Lebhaft ist mir in Erinnerung geblieben das Jahr, in welchem die sogenannte Kartoffelkrankheit zuerst auftrat. Es war ein trauriger

\footnotetext{
${ }^{603}$ Bourke

${ }^{604}$ Krus S. 104ff. Ich profitiere mit dieser wie der nächstgenannten Literaturstelle Schaier von einem Vortrag meines Kollegen Arnd Reitemeier vor dem Göttinger Arbeitskreis Umweltgeschichte am 8.7.09. Die Arbeit von Schaier wendet sich ausschließlich dem Verwaltungshandeln im badischen Odenwald während der Hungersnot 1846/47 zu. Obwohl der Hunger ganz wesentlich durch Ausfälle der örtlichen wie überregionalen Kartoffelernte verursacht wurde, kümmert sich Schaier allerdings nicht weiter um deren organische Ursache. In einer kurzen Fußnote über die Natur der Infektion (Nr. 15, S. 72)offenbart er gravierende Verständnisprobleme. Er behauptet, es gäbe die virusbedingte „Kartoffelkrankheit“ und die pilzbedingte „Kraut- und Knollenfäule“. Tatsachlich gibt es nicht eine, sondern mehrere virusbedingte Kartoffelkrankheiten. Schaier benutzt dann die Formulierung „Kartoffelkrankheit" praktisch durchgängig im Text, und zwar irritierender Weise offenbar auch als Synonym für die Krautsfäule. Da seine Abgrenzungsleistung unzulänglich ist, bleibt unklar, ob und wann er über die Kraut- und Braunfäule spricht, die hier interessiert. Schaiers Arbeit, so verdienstvolle Einblicke sie in administratives Handeln bieten mag, ist daher für die konkrete Erörterung der Folgen der Kraut- und Braunfäule unbrauchbar. - Man kann sich allerdings auch auf den Standpunkt stellen, dass sich administratives Handeln nicht weiter um die organischen Ursachen kümmern müsse. Eine solche Bewertung wäre nicht nur ein administrativer Fehler mit fatalen Folgen (weil ein Seuchengeschehen immer die Ursache berücksichtigen muß), es wäre auch ein Fehler bei der historischen Bewertung des Ereignisses.

${ }^{605}$ Weitergehende Ursachen als die nachfolgend genannten materiellen führt Krus nicht auf, insbesondere werden straftheologische Letztursachen nicht erwähnt.

${ }^{606}$ Die zeitgenössische wissenschaftliche Literatur beschreibt Schimmelpilzrasen als „Schwammgespinste"
} 
Anblick, die großen Kartoffelfelder der Güter mit schwärzlichen, faulenden, niedergesunkenen Krautmassen bedeckt zu sehen, die einen üblen Geruch verbreiteten. Allgemein wurde damals im Landvolk der Rauch der die Fluren durcheilenden Lokomotiven - kurz zuvor war eine Eisenbahn durch den Kreis gelegt worden - als Ursache der Erkrankung angesehen; auch mein Vater ließ sich lange Zeit von dieser Meinung nicht abbringen. Man hatte ja damals von der außerordentlich großen Bedeutung der Pilze als Krankheitserreger noch keine rechte Vorstellung. Selbst als die Pilze gefunden wurden, sagte man: Ja, die Pilze sind da, aber sie sind in den faulenden Massen entstanden oder haben sich dort angesiedelt, die Erreger sind sie nicht, wie sollen auch so unsichtbar kleine Wesen so ungeheure Verwüstungen anrichten?’ '607

Dabei war die Ad-hoc-Erklärung des Landvolkes nicht weiter von der eigentlichen Krankheitsursache entfernt als die Annahme vieler, auch gelehrter Köpfe, und in ihrer Schließweise sogar rational-logisch stärker, als es vorderhand scheinen will. 608 Die Krautfäule imponiert nämlich an Stengeln und Blättern mit schwarzen, trocken fallenden Nekrosen des Gewebes, und die Stengel brechen infolge der Austrocknung sehr leicht, geradezu ,gläsern“, sofern nicht die feuchte Witterung alles als faulen Matsch auf den Boden zusammen drängt. Angesichts solcher äußeren Übereinstimmung des Krankheitsbildes an der Pflanze mit der Farbe, den Inhaltsstoffen und der Trockenheit des Lokomotivenrauchs war die von Waldeyer-Hartz angeführte Meinung der ungebildeten Landbevölkerung eigentlich eine präzise, spätaufklärerische Ursachenannahme. ${ }^{609}$

${ }^{607}$ Das Zitat findet sich bei Krus nicht in seiner vollen Länge. - Waldeyer-Hartz, S. 26. Weder im Text noch in der ergänzenden Endnote (S. 405) erwähnt Waldeyer-Hartz eine begleitende Nahrungsverknappung oder gar Hungerkrise. Die Kalamität wird als Besonderheit, aber nicht einmal als betriebswirtschaftliche Belastung erwähnt. Sie ist es offenbar 1845 auf Gut Abbenburg, Kr. Höxter, nicht gewesen, obwohl „Kartoffeln reichlich angebaut“ wurden und damit ein beträchtlicher Schade eingetreten sein müsste.

608 Auf der Ebene des Entdeckungszusammenhanges konkurriert eben auch das einfache Landvolk mit dem gebildeten Akademiker. In den modernen Naturwissenschaften entscheidet der Begründungszusammenhang über die Gültigkeit einer Hypothese. Nicht das Zustandekommen entscheidet über ihre Gültigkeit, sondern rationale Kriterien wie Verifikation oder Falsifizierbarkeit.

${ }^{609}$ Die Enzyklopädie von Krünitz unterscheidet „Schimmel“ und „Mehltau“, sieht aber eine sehr große Nähe der Phänomene zueinander. Es ,schimmeln“ Nahrungsmittel, während aus dem Bereich der Landwirtschaft nur der Hopfen für Schimmel anfällig zu sein scheint und ansonsten Pflanzen vom „Mehlthau“ befallen werden. Die Unbestimmtheit des Begriffes „Mehlthau“ [Bd. 87, 1802], führe zu einer alltagspraktischen Einheitskategorie, deren Verursachung, einem Tau gleich, aus der Luft auf die Pflanzen falle: „Die Alten, welche das, was in der Natur vorging, nicht mit einem gehörigen Beobachtungsgeiste wahrnahmen, glaubten, daß gewisse scharfe und giftige Dünste vom Himmel fielen, welche den Pflanzen schädlich wären, und wodurch ihre Blätter verschrumpften und verdorreten." [S. 600] Der Autor des Krünitz weist eine solche Ursache zurück und positioniert sich bei denjenigen Theoretikern, die eine organische Entstehung, wie mikroskopisch kleine Würmer bzw. blattlausverwandte Insekten, als ursächlich annehmen. Weil die Phänomene der Mehltaukategorie sehr ähnlich wie die der Schimmel-Kategorie imponieren, versucht der Autor des Lemmas Schimmel [Bd.144, 1826] zwar eine naturwissenschaftlich-differentialdiagnostische Abgrenzung, die aber noch ohne mikrobiologische Kenntnisse auskommen muss und daher nur in die Nähe uns heute geläufiger Erklärungen kommen kann. „Schimmel“ und „Mehltau“ sind bis auf den heutigen Tag Sammelbegriffe für verschiedene Pilzarten bzw. Pflanzenkrankheiten, wobei „Schimmel“ allgemein der Nahrungsverderber war und geblieben ist und „Mehltau“ der Pflanzenverderber. Straftheologische Ursachen werden bei Krünitz zwar noch in Zusammenhang mit Heuschreckenkalamitäten (2. Auflage, 


\section{1}

Vergleichsweise rasch brach sich in Europa die Einsicht Bahn, dass die Kartoffel zu einem Grundnahrungsmittel werden könnte, das endlich nicht nur ein elastisches Ausweichen bei Nahrungsengpässen ermöglichte, sondern die Engpässe sogar in die Geschichte abschieben würde. Es ist sicher, dass die Urbanisierung in Europa durch die Verfügbarkeit der Kartoffel einen ganz erheblichen Schub erhielt, weil sie in Verarbeitung und Nährstoffeigenschaften in besonderer Weise den Erfordernissen städtischer Lebensweise entsprach. Verständlich ist, dass die Kartoffel als eine jener Pflanzen benannt wird, die „die Welt veränderten.“610 Verändert wurden u.a. Speisezettel und damit Geschmacksempfindungen, verändert wurden Pflanzen-611 und Tierproduktion, verändert wurden Bodennutzungen und marktbezogene bäuerliche Produktionsweise und schließlich menschliche Reproduktion, sei es durch gesteigerte Fruchtbarkeit, sei es durch die Arbeitsrhythmik, welche die Kartoffel und fast gleichzeitig die Zuckerrübe als neue Hackfrüchte der bäuerlichen Bevölkerung aufzwang. ${ }^{612}$

Zweifellos war es in manchen Regionen ein Fehler, das Portfolio teilweise so einseitig zugunsten der Kartoffel zu ändern. Aber, gab es Alternativen und hätte man welche erkennen können?

Es lassen sich gute Gründe für die Annahme beibringen, dass der europäische Bevölkerungsanstieg durch die Kartoffel positiv beeinflusst wurde. Ob man mit dem Wegfall fertilitätssenkender Nahrungsbegleitstoffe argumentiert oder mit dem Kalorien- und Vitamingehalt, das Argument stimmt letztlich auch ohne Kartoffel, wonach eine ausreichende und relativ belastungsarme Ernährung immer zu Bevölkerungsanstieg führt, ${ }^{613}$ weil bei guter Ernährungslage die Fertilität steigt und die Morbidität sinkt. Die Bevölkerungsvermehrung, die sich teilweise und regional unterschiedlich per saldo der Kartoffel verdankte, verstärkte aber die nachteiligen Folgen des kartoffelbedingten Ernteausfalls. Agraregimes, die im Grundsatz immer

1790) diskutiert, mit erkennbarer Bezweiflung ihres Zutreffens. Das Lemma „Mehltau“ (1802) kennt bereits nur noch diesseitige, materielle Ursachen.

${ }^{610}$ Hobhouse

611 Solche Begriffschiffren enthalten am Ende sehr diffizile Einzelmomente. So vermehrt die Kartoffel als Hackfrucht die Aufgaben von Frauen auf dem Feld; die Kartoffelernte beeinflusst das generative Verhalten, denn große Kartoffelmengen sind mit einem hochschwangeren Bauch nicht zu sammeln, usw.

${ }^{612}$ Die Kartoffel wird seit dem Ende des 18. Jh.s für den Eigenbedarf und lokale Märkte, spätestens seit Mitte des 19. Jh.s für überregionale Märkte produziert. Die Zuckerrübenproduktion ,,explodierte" förmlich zwischen den 1830er und 1860er Jahren: von 25.000 Tonnen auf 147.000. Bereits 1890 ist die Eine-Million-Tonnen Marke überschritten. (Zur Zuckerrübe und ihrer Auswirkung auf das bäuerliche Leben vgl. Imhof) Kartoffel- und Zuckerrüben-Produktion laufen in Deutschland parallel zum Ausbau des Schienenverkehrs.

${ }^{613}$ Es trifft z.B. auch auf das generative Verhalten bei ausreichender Maisdiät zu, wie von Gundlach belegen konnte. 
energetische Risikounternehmungen sind, ${ }^{614}$ waren gegen solche Extremschwankungen nicht zu schützen.

Mit Platz vier auf der Liste der weltweit meisterzeugten Agrarprodukte hat die Kartoffel eine absolut wichtige Rolle in der Welternährung eingenommen, ohne sie wäre die Weltbevölkerung nicht zu ernähren. Die Getreidearten, die heute Weltbedeutung haben, sind etwa 9.000 Jahre in Kultur ${ }^{615}$ und schon früh geographisch weit verbreitet. Es ist erstaunlich, dass ihre Produktivität nennenswert erst nach 1800 CE gesteigert werden konnte, und zwar seit derselben Zeit, seit der die Kartoffel mit dem Getreide zu konkurrieren begann. ${ }^{616}$

Die große Stunde der Kartoffel dürfte indes erst noch kommen, wenn nämlich die bevorstehende Verknappung der Ressource Wasser zum weltweiten Überdenken der landwirtschaftlichen Produktion zwingt. Die FAO schätzt den Gehalt an „virtuellem Wasser“ in der Kartoffel mit 250 l/kg. ${ }^{617}$ Die Bilanz der verlagerten Wassernutzung sieht für die meisten anderen Grundnahrungsmittel nachteiliger aus: Mais 900 l/kg, Weizen 1350 l/kg, Reis 3000 l/kg. ${ }^{618}$ Für die Erzeugung von Bioenergie hat die Kartoffel ebenfalls eine der günstigsten Wasserbilanzen. ${ }^{619}$ Vergleichende Bilanzen für erforderlichen Dünger- und Pestizideinsatz bei der Produktion scheinen zwar noch nicht verfügbar, aber vermutlich schneidet die Kartoffel auch in solchen Bilanzen günstig ab.

\section{2}

Es grenzt fast an ein Wunder, dass die Kartoffelfäule erst nach 250 Jahren die mittlerweile auch in der Alten Welt heimisch gewordene Kartoffel einholte. Das ist

\footnotetext{
${ }^{614}$ Weil Menschen ohne Einfluss auf das Klima/Wetter waren und die Problematik der Schadorganismen erst seit dem 20. Jh. annähernd beherrschbar wurde. - Die Flächen-Produktivität hängt an der einsetzbaren Energie, mit der Agrarprodukte hervorgebracht werden. Wegen des Fehlens u.a. von fossil-energetischer Substitution (Maschinenkraft und Kunst-Dünger), war die Gesamterzeugung gering. Ein anderer Grund war die Unkenntnis genetischer Grundlagen und das entsprechende Fehlen von Hochleistungssorten und -rassen. - An die Vernichtung der Ernten bei Kriegführung ist ebenfalls zu erinnern.

${ }^{615}$ Eingeschlossen ist hierin der Reis. Hingegen ist Mais mit etwa 4.500 Jahren Kultivierung jünger und erreichte erst wenige Jh.e vor Kolumbus Nordamerika. Die Kartoffel hat in Südamerika wahrscheinlich 7.500 Jahre der Kultivierung hinter sich und kommt erst um 1500 CE über ihr ursprüngliches Verbreitungsgebiet hinaus.

${ }^{616}$ Damit ist das Feld der genetisch bedingten Steigerungen in der Agrarproduktion angesprochen. Sie lässt sich bis heute für den vortheoretischen Zeitraum (d.i. vor der Verbreitung der Vererbungsregeln nach 1900) nur schwer rekonstruieren.

617 Der Begriff bezeichnet jene Menge Wasser, die nach einer Gesamtbilanz zur Herstellung eines Produktes benötigt wird, einschließlich auch der verdeckten Wassermengen. Werden z.B. europäische Rinder mit südamerikanischem Sojaschrot gefüttert, geht in die Wasserbilanz der in Europa produzierten Milch auch die Wasserbilanz der südamerikanischen Soja ein, weshalb auch der Begriff der „verlagerten Wassernutzung“" gebräuchlich ist.

${ }^{618}$ UNESCO-IHE- water footprint; Manning

${ }^{619}$ Gerbens-Leenes et al.
} 
leicht verständlich, denn die Kartoffeln, die den Pilz in sich tragen, verderben durch die Braunfäule und werden vor der Saat aussortiert, wenn sie denn überhaupt die Lagerphase während des Transportes von Übersee überstanden haben. Es konnten im Laufe der Zeit nur wenige infizierte Kartoffelknollen als Infektionsquellen für den europäischen Boden gewirkt haben. Nach DNA-Analysen erscheint ziemlich sicher, dass es sich um Pilze direkter südamerikanischer Provenienz handelte, die 1845 die Katastrophe europäischen Ausmaßes anrichteten. Unwahrscheinlich ist, dass die europäischen Pilz-Varietäten Ableger der 1843-1845 in Nordamerika herrschenden Kartoffelfäule waren. Damit ergibt sich das Bild einer sehr langsamen, sich allmählich in Europa unterhalb der Besorgnisgrenze etablierenden Infektion, die unter den Witterungsbedingungen von 1845 zu einer annähernd den gesamten Kontinent erfassenden, plötzlichen Epidemie werden konnte. Welche Faktoren dabei im Sinne wechselseitiger Verstärkung und Selbstverstärkung wirken mussten, von der Pilzbiologie über das Klima bis zur Agrarproduktion, ist nicht geklärt. Ständige Beobachtung und wirksame Fungizide verhindern heute ein erneutes verheerendes Auftreten der Kartoffelfäule.

Die Kartoffelfäule hatte nirgends solche dramatischen Auswirkungen wie in Irland, wo ihre Folgen nicht nur die Bevölkerungsgeschichte des irischen Mutterlandes grundlegend veränderte. Die hohen Auswanderungszahlen zwischen 1845 und 1851 legten den Grundstein dafür, dass Irisch-stämmige Menschen in den USA heute den relativ höchsten Bevölkerungsanteil stellen, gemessen an der Größe ihrer Ursprungsbevölkerung. ${ }^{220}$

Das Bevölkerungswachstum in Irland zwischen 1780 und 1845 ist in der Europäischen Bevölkerungsgeschichte ohne bekannt gewordene Parallele. "In the late eighteenth and early nineteenth century it is clear that the Irish were insistently urged and tempted to marry early: the wretchedness and hopelessness of their living conditions, their improvident temperament, the unattractiveness of remaining single, perhaps the persuasion of the spiritual leaders, all acted in this direction." 221 Das überraschend zurückhaltende Urteil Connells bezüglich des Anteils der katholischen Kirche verdankt sich wahrscheinlich der zum Veröffentlichungszeitpunkt seiner klassisch gewordenen Arbeit noch sehr einflussreichen katholischen Interessenslage. ${ }^{622}$

Ende des 18.Jahrunderts verabschiedete das Irische Parlament - auf Druck des mit Frankreich kriegführenden England - Reformen, mit denen auch die Überführung von Weidegründen und bisherigem Unland (Sumpfland und Berghänge) in Acker-

\footnotetext{
${ }^{620}$ Der Irisch-stämmige Anteil an der Bevölkerung der heutigen USA beträgt 10,8 \% (2000). Siehe http://www.census.gov/prod/2004pubs/c2kbr-35.pdf, S. 3 (16.6.2009)

${ }^{621}$ Connell, S. 81-82

${ }^{622}$ Dass sich an den reproduktiven Verhältnissen in Irland, einschließlich der begleitenden geistlichen Betreuung in den 150 Jahren nach 1800 offenbar wenig geändert hatte, kann man auch der Autobiographie von Frank McCourt, Die Asche meiner Mutter, entnehmen, in der bedrückende Einflussnahmen des Klerus noch für die 30er Jahre des 20. Jahrhunderts beschrieben werden.
} 
land herbeigeführt wurden. Damit entfiel der hauptsächliche Begrenzungsfaktor für Eheschließungen, weil jetzt Farmstellen in gewünschter Zahl verfügbar wurden. Anders als in den meisten Bevölkerungen Europas ließ sich die arme irische Landbevölkerung durch fehlendes Kapital und Lebensstandard nicht von einer Heirat abhalten. Die mit der Eheschließung verbundenen Kosten waren gering, eine Hütte wurde mit Hilfe von Freunden in wenigen Tagen errichtet, Hausrat war offenbar nur in sehr begrenztem Unfang vorhanden. ${ }^{623}$ Dass die Kartoffel auch auf solchen Böden auskömmliche Erträge liefert, die keine lang anhaltende Bewirtschaftungskultur aufweisen, erklärt ihre unmittelbare Vorteilhaftigkeit und Verbreitung schon vor dem großen Bevölkerungsboom, zumal Irland aus klimatischen Gründen kein Gunstraum für Getreidebau ist. Die Kartoffelerträge begünstigten nicht nur den Bevölkerungszuwachs. In einer sich selbst beschleunigenden Spirale unterstützen sie sogar die Aufsplitterung der Landparzellen für immer weitere Familien, bis ,land which formerly had been adequate for only one family's subsistence could be parcelled among sons or other sub-tenants" ${ }^{\prime \prime 24}$, schließlich unterhielt ein Acre ${ }^{625}$ mit Kartoffeln eine sechsköpfige Bauernfamilie einschließlich ihres Viehbestandes.

Mit dem Ausfall der gesamten oder teilweisen Kartoffelernten des Jahres 1845 beginnen in den unterschiedlich betroffenen Regionen Jahre unterschiedlichen Nahrungsmangels. Hungerkrisen sind ihrer Natur nach regionale Krisen, sie sind in geschichtstheoretischer Hinsicht zugleich „Ereignis“ und „Struktur“. Eine Fehlernte tritt als Ereignis unvorhersehbar auf (notwendige Bedingung). Nur wenn zu dem Ereignis strukturelle Defizite treten (hinreichende Bedingung), wie mangelnde Bevorratung, fehlende Verteilungssysteme oder Monopolisierung von Nahrung, kommt es zur Hungerkrise. Preußen wie Irland 1845 leiden an struktureller Armut, ${ }^{626}$ vor deren Hintergrund die Katastrophe zu sehen ist. Was für Irland und Preußen 1845 galt, dass ganzen Bevölkerungsteilen die Deckung des täglichen Bedarfs unmöglich war, ist heute überwunden. Es ist mit dem allgemeinen technischen Fortschritt nicht nur zu einer Verbesserung von Lager-, Transport- und Verteilungssystemen gekommen, sondern es hat sich durch den allgemeinen Reichtum Europas seit 1845 hier auch die Armutsgrenze innerhalb des Kontinents selbst und gegenüber anderen Teilen der Welt in einem Maße verschoben, dass Versorgungs- und Hungerkrisen selbst bei europaweiten Missernten ganz unwahrscheinlich sind. Versorgungsprobleme aus ,natürlicher Ursache" sind in Europa heute eher durch globale Ernteausfälle zu erwarten, die etwa nach Vulkanausbrüchen auftreten können. ${ }^{627}$

\footnotetext{
${ }^{623}$ Connell, S. 89ff

624 ibid. - Der Forschungsfortschritt gegenüber der Arbeit Connells, dessen grundsätzliche Aussagen nach wie vor zutreffen, ist am besten dokumentiert in O'Grada $(1993,1994)$ und O'Grada et al.

625 entspricht ca. $4.000 \mathrm{~m}^{2}$

626 Bass, S. 208; weitere Erläuterung bei Vanhaute

${ }^{627}$ Durch Vulkanstäube in den Stratosphäre kann es zur globalen Abdunkelung und Temperatursenkung kommen, wie zuletzt nach dem Ausbruch des Pinatubo 1991. - Europa hatte 1816-17 mit
} 
Im klinischen Sinne ist „Hunger“ keine Todesursache. Akute Todesursachen sind opportunistische Infektionserkrankungen oder Organversagen, die sich bei chronischer Unterernährung schnell infolge von Dystrophie und Schwächung des Immunsystems einstellen. Das typische Bild des Verhungernden ist geprägt von Auszehrung (Kachexie), von Untergewicht, verminderte Leistungsfähigkeit, Stoffwechselstörungen, Hautveränderungen, Infektanfälligkeit; Hungerödemen, mentaler Retardierung, extremer Lethargie. Als das Leben begrenzender Faktor gilt bei akuten Hungerzuständen ein Gewichtsverlust von 40\%, bei chronischem Hunger sollen größere Gewichtsverluste möglich sein. ${ }^{628}$

In den meisten Europäischen Ländern hatte der Hunger 1845 und Folgejahre bei weitem nicht jene Konsequenzen, die in Irland auftraten. Dennoch waren die Folgen auch auf dem Kontinent spürbar. Die Auswanderungsbewegung von Europa in die Neue Welt hat sicher von den Innovationen in der Transporttechnik und den politischen Verhältnissen profitiert, aber die ökonomischen standen gewiss mit in der ersten Reihe. Ökonomisch heißt hier, der Armut und auch damit verbundener Nahrungsknappheit zu entgegen.

Die irische Katastrophe hatte aber im Kern soziale Gründe. Irland hätte trotz der Missernte zu essen gehabt, wie die jährlichen Schlachtviehexporte selbst während der Hungerkrise belegen (Tab. 5). ${ }^{629}$ Aber Großbritannien, das Irland wie eine Kolonie ausplünderte, führte neben Tierprodukten auch weiter Getreide aus Irland aus und verbot Hilfslieferungen. Steuern wurden angehoben, Obdachlosigkeit nahm zu und örtlichen Hilfsaktionen setzten zu spät und in zu geringem Umfang ein.

Die anschließende Hungerepidemie, der etwa eine Million von insgesamt acht Millionen Iren zum Opfer fiel und in deren Folge eine annähernd weitere Million nach Amerika auswanderte, beruht letztlich auf dem politischen Versagen der Britischen Regierung und der irischen Landlords. Die Irische Hungerkrise, die hinsichtlich politischer Ursachen und im Ausmaß nach heutigen Standards als zumindest genozidnah einzustufen ist, sollte jedoch nicht die letzte ihrer Art in Europa bleiben, bei der Menschen entweder durch Export, Raub oder Vorenthalten der von ihnen produzierten Nahrung zu Tode kamen. ${ }^{630}$

\footnotetext{
schweren Ernteausfällen nach dem Ausbruch des Tambora 1815 und ab 1830 mit der neuen Infektionskrankheit Cholera zu kämpfen. Bis 1845 endeten also alle drei Jugendgenerationen des Jh.s mit Naturkatastrophen. - Gleichzeitig ist Europa nach den Napoleonischen Kriegen für 50 Jahre kriegsfrei.

${ }^{628}$ Madea \& Banaschek, S. 909

${ }^{629}$ Dass auch anderswo als in Irland zu dieser Zeit Hunger und soziale Probleme zusammenfielen, ist von Virchow eindrücklich geschildert.

${ }^{630}$ Beispiele aus dem 20.Jahrhundert: Der Holodomor hat 1932 - 1933 in der Ukraine rund 3,5 Millionen Menschenleben gefordert, die deutsche Besetzung Griechenlands verursachte allein 1941-1942 über 300.000 Hungertote; die Zahl der Hungertoten durch ethnische Säuberungen während des Balkankrieges 1991- 1995 ist nicht geschätzt.
} 
Tab. 5 Jährliche Schlachtviehexporte aus Irland nach England 1801 - $1849^{631}$

$\begin{array}{crc} & \text { Schweine } & \text { Rinder } \\ 1801-05 & 7.560 & 27.794 \\ 1806-10 & 15.364 & 26.351 \\ 1811-15 & 55.940 & 49.492 \\ 1816-20 & 58.642 & 45.299 \\ 1821-25 & 78.255 & 46.724 \\ 1835 & 376.191 & * \\ 1846 & 480.827 & * \\ 1847 & 106.407 & 201.892 * \\ 1848 & 110.787 & * \\ 1849 & 68.053 & * \\ * \text { gibt das } \text { jäbrliche } & \text { Mittel der Jahre 1835 - 1849 wieder }\end{array}$

Globalgeschichtlich bemerkenswert ist, dass es für die Insel Irland keine Überlegungen bezüglich einer Bevölkerungsbegrenzung gegeben hat, wenigstens keine, die bekannt geworden wäre. ${ }^{632}$ Vermutlich hängt das mit dem objektiv geringen Bevölkerungsanstieg zusammen, der für eine Verdoppelung fast 70 Jahre benötigte und daher der zeitgenössischen Alltagsbeobachtung leicht entgangen sein könnte. Die Ökonomen diskutierten die Bevölkerungsfrage, seit Malthus (1798), allerdings im Hinblick auf die limitierten Ressourcen der Welt. Es sind Überlegungen, die auch auf den Kontinent übergreifen. ${ }^{633}$ Aber sie bewegen sich doch auf einer recht akademisch-theoretischen Position.

Im Vergleich mit Irland ist die Bevölkerungsgeschichte Japans völlig anders verlaufen - und doch auch nicht unähnlich. Auch in Japan beginnt durch das Aufbrechen alter Sozial- und Familienstrukturen, durch neu verfügbares Ackerland und durch neue landwirtschaftliche Produktionsweisen im Übergang des 17. zum 18. Jh. ein erhebliches Bevölkerungswachstum. Die Bevölkerung stieg innerhalb des Jahrhunderts vor 1720 von 10 auf 30 (plus/minus 5) Millionen, bei einer jährlichen Wachstumsrate von 0,8 bis $1 \%$. Aber, als ob es eine Berücksichtigung der Inselnatur Japans gegeben hätte, verlangsamt sich der Bevölkerungsanstieg im folgenden Jahrhundert und erreicht nach einem weiteren um 1870 nur ca. 35 Mio.

${ }^{631}$ Nach O’Donovan aus Ross. Für eine neuere Irische Wirtschaftsgeschichte siehe O' Grada (1994). 632 Die Satire von Jonathan Swift (1729) A modest proposal. For preventing the children of poor people in Ireland from being a burden to their parents or country, and for making them beneficial to the public, ist als sozialkritische Schrift, nicht als Warnung vor einer sich abzeichnenden Irischen Bevölkerungsexplosion zu lessen.

633 Z.B. Hoffmann 
Die Bevölkerungszahl wurde an die begrenzte Agrarproduktivität nicht so sehr durch verzögerte Eheschließungen, sondern vor allem durch Abtreibungen und Infanticid ,angepasst“. ${ }^{\circ 34}$

Irland reagierte auf die Hungerkrise von 1845 mit deutlich ansteigendem Heiratsalter und einer zahlenmäßig großen Zunahme Unverheirateter. In Japan kam es zu keinen vergleichbaren plötzlichen und sichtbaren Einschnitten. Aber den zu diesen Zeiten anhaltenden sozialen Druck auf japanische Eltern bzw. Mütter, Abtreibungen bzw. Kindstötung zu praktizieren, als „less painful adjustment“ zu klassifizieren und als ,not the result of traumatic events“ mistisch. Es gab keine der Irischen vergleichbare sichtbare Hungerkrise in Japan, aber die täglichen Versorgungskrisen im familiären Maßstab und ihre Folgen waren bestimmt auch schmerzhaft und traumatisch, wenn eine Gesellschaft auf sie mit der Institutionalisierung von Abtreibung und Kindstötung antwortete.

Beide Beispiele sind keine Vorbilder für die Lösung des bevorstehenden Dilemmas der Übervölkerung, auf das die Weltbevölkerung aktuell zusteuert. Aber beide Beispiele sind geeignet, die Dringlichkeit einer Lösung in Erinnerung zu rufen und vor Lösungen zu warnen, die den Eigeninteressen moralischer Meinungsführer und Institutionen Raum gewähren.

\section{3}

An dieser Stelle ist auch eines Aspektes zu gedenken, der einen thematischen Bezug des umwelthistorischen Raisonnements zu aktuellen Problemen der Politischen Ökologie herstellt.

Am 14.4.2009 hat die Bundes-Landwirtschaftsministerin die Aussaat von gentechnisch verändertem Mais (Linie Mon 810 der Fa. Monsanto) verboten. ${ }^{636}$ Bei dieser transgenen Maissorte ist durch Einbau eines bakteriellen Gens die Pflanze in der Lage, ein tödliches Gift gegen einen ihrer Hauptschädlinge (den Schmetterling „Maiszünsler" und seine Larven) zu produzieren. Als Verbotsgrund wurden unbekannte Folgen für höhere Organismen und Ökosysteme bei Einbringen des Mais in die freie Natur und in das Nahrungsnetz angegeben. ${ }^{637}$ Vordergründig entsteht der Eindruck, als würde hier fortschrittsfeindlich gegen das ultimative Instrument

\footnotetext{
634 Livi-Bacci, S. 67

635 Livi-Bacci, ibid.

636Presseerklärung des BMELV vom 14.4.2009

637 Die Kommentatoren dieser Entscheidung in den Printmedien wie des öffentlich-rechtlichen Rundfunks und Fernsehens waren sich am 15.4.2009 darin einig, dass neben der Sorge der Verbraucherschutzministerin auch die des parteipolitischen Kalküls ausschlaggebend gewesen wäre. Die Ministerin (Aigner, CSU) hätte die landwirtschaftliche Klientel Bayerns, die gentechnisch veränderten Pflanzen gegenüber erhöhte Skepsis zeigt, mit dieser Entscheidung als Wähler für die Europawahl im Juni 2009 gewinnen wollen. Diese Wahl gilt als Vortest für die im Herbst 2009 anstehende Bundestagswahl, durch die man sich das Ende der derzeit im Bund regierenden Großen Koalition erhoffe. Die Entscheidung der Ministerin sei aus bayerischer Sicht deshalb einfach, da der Maiszünsler in Bayern nur ein kleines lokales Vorkommen in Unterfranken aufweise.
} 
zur Schadorganismen-Bekämpfung vorgegangen. Die komplexen Folgen und Nebenfolgen von Einbringungen transgener Pflanzen in die natürlichen Kreisläufe scheinen aus Sicht der politisch verantwortlichen Ministerin nicht hinreichend abschätzbar bzw. bekannt. ${ }^{338}$ Auf der Europäischen Ebene scheinen dagegen für eine Neuzulassung von Mon-810 durch die EU-Kommission keine solchen Bedenken zu bestehen. ${ }^{639}$

Für die wirtschaftlich ebenfalls bedeutende Kartoffel scheint sich im Hinblick auf die Kraut- und Knollenfäule eine gentechnische Veränderung geradezu anzubieten. Tatsächlich wird z.Zt. auch an transgenen Kartoffeln gearbeitet, wobei nicht die Schädlingsresistenz im Vordergrund steht, sondern Variationen von Inhaltsstoffen. ${ }^{640}$ Als Nebenfolge werden allerdings auch Resistenzeigenschaften gegenüber der Kraut- und Knollenfäule bzw. dem Kartoffelkäfer geprüft. Da die Kartoffelsaat aus vegetativen Vermehrungskörpern besteht, ihre Blüten und Blätter für die Nahrungsnetze von höheren Tieren, mit Ausnahme der Schadorganismen, keinen Attraktionswert besitzen, wird einer unbeabsichtigten Verbreitung transgener Kartoffeln allerdings keine erhebliche Bedeutung beigemessen. ${ }^{641}$ Andererseits sind Kartoffelsorten mit (annähernder) Resistenz gegen Phytophthora infestans bekannt und wurden z. T. bereits im Deutschen Kaiserreich angebaut. Aus Gründen geschmacklicher Präferenz sind sie jedoch heute vom deutschen Markt verschwunden (und werden z. B. in Afrika angebaut). ${ }^{642}$

Was wie ein Filz aus Wirtschaftsinteressen, Monopolisierungsbestrebungen und Erzeugung von Abhängigkeiten anmutet, als deren strukturbedingte Opfer von vornherein die Kleinbauern festzustehen scheinen, geht in Wahrheit noch viel weiter: tatsächlich geht es um die grundsätzliche gesellschaftliche Entscheidung, was und wie viel von der „Natur“ patentiert und monopolisiert werden kann! Es geht darum, wem der natürliche Reichtum der Biodiversität gehört, ${ }^{643}$ ob es akzep-

${ }^{638} \mathrm{Zu}$ den systemischen Risiken bei Freisetzung von GMO aktuell Schmidt et al. - Die Bekämpfung des Maiszünslers ließe sich auch in konventioneller Landwirtschaft ohne großen Pestizidaufwand durch Unterpflügen der Stoppeln erreichen. - Man darf indes nicht übersehen, dass der MonsantoKonzern, der ehedem Agent Orange herstellte, eine sehr aggressive Patentpolitik verfolgt. Zurzeit betreibt Monsanto (das Unternehmen steht hierbei möglicherweise stellvertretend auch für andere Agro- oder auch Pharma-Konzerne) die Patentierung von Sequenzen des Schweinegenoms. Sollte Monsanto dies erreichen, bestünde Gefahr, dass die Weltschweineproduktion (vermutlich einschließlich aller Landrassen) durch Monsanto monopolisiert würde. Über Praktiken des Saatgutherstellers Monsanto berichtet R. Lindner ausführlicher in der Frankfurter Allg. Ztg. am 13.6.2009 (Nr. 134; S. 3) und in pointierter Formulierung: „Monsanto verändert nicht nur die Gene des Saatguts. Es verändert das Erbgut der Landwirtschaft."

${ }^{639}$ „Genmais vor Neuzulassung?“" Frankfurter Allg. Zeitung Nr 155, 8.7.2009, Seite N1

${ }^{640} \mathrm{http}: / /$ www.biosicherheit.de/de/schule/96.doku.html (21.5.2009)

${ }^{641}$ Goeser \& Büntig

${ }^{642}$ Es ist nicht immer eine Verschiebung der Geschmackskultur beim Verbraucher, die eine Sorte vom Markt verschwinden lässt. Wie das Problembeispiel der Kartoffelsorte „Linda“ zeigt, kann eine bei Landwirten und Verbrauchern beliebt Sorte durch den Willen des Rechte-Inhabers zurückgezogen werden.

${ }^{643}$ Hierzu Ausführungen bei Herrmann 2008 
tierte Wege zu ihrer Aneignung durch gesellschaftliche Eliten oder Unternehmer geben kann, ob sie grundsätzlich als Gemeingut dem Zugang und der Verfügung Aller offen steht oder die Gesellschaft zur Sicherung ihrer eigenen Lebensgrundlagen und in Anerkennung der Lebensgrundlagen auch anderer Organismen strikte Regeln im Umgang mit dem biologischen Naturvermögen formuliert. Dass dies letztlich „gesellschaftliche Großalternativen“ (Niklas Luhmann) gegenüber der gegenwärtig herrschenden sind, die auf einem Naturverständnis mit ausschließlichen Verfügungsoptionen allein zum wirtschaftlichen Vorteil gründet, liegt auf der Hand.

\section{4}

Nicht die Eisenbahn brachte den Kartoffelkäfer an den Atlantik und damit letztlich nach Europa. Sucht man nach dem alles in Gang setzenden Erstereignis, dann sind es die Siedler, die nach Amerika mit den Pflanzen aus der Heimat zugleich ein Stück dieser Heimat verpflanzen. Hätte jemand voraussehen können, dass der Coloradokäfer auf die Kartoffel umsteigen und dabei eine Gesamtfruchtbarkeit erreichen würde, die die Kartoffel nicht annährend bei den Menschen bewirkte? Vielleicht würde man heute solche Möglichkeiten in Erwägung ziehen. ${ }^{644}$ Doch sie würden nicht weiter verfolgt, denn die allgegenwärtige chemische Keule enthält das Versprechen, Fehlentwicklungen sofort und wirksam entgegentreten zu können. Die Eisenbahn beschleunigte nur zeitlich, was durch den Futterpflanzenwechsel des Käfers unvermeidlich wurde. Und er würde noch heute ausschließlich in den Rocky Mountains leben, hätten die Europäer 1492 nicht entdeckt, dass es hinter dem Rand der Ökumene doch noch weiterging.

Weiterhin konnte niemand voraussehen, dass sich die Temperaturabhängigkeit des reproduktiven Verhaltens des Käfers mit der Temperaturabhängigkeit der wirtschaftlichen Nutzungsmöglichkeit der Kartoffel deckt: Der Käfer kann bei Temperaturen oberhalb von $30^{\circ} \mathrm{C}$ keine Metamorphose mehr durchführen und die Kartoffel bildet keine Knollen mehr aus. Eine Schicksalsgemeinschaft, deren biologisches Potential unbeabsichtigt durch den Mensch verknüpft wurde. Seitdem gilt: keine Kartoffel ohne Käfer. Der Schädling ist Kosmopolit geworden, ${ }^{645}$ wenn auch als Kulturfolger völlig abhängig von agrarpolitischen Entscheidungen, die den

\footnotetext{
${ }^{644}$ Man denke an die Vorsichtsmaßnahmen der Einwanderungsbehörden, mit denen das unkontrollierte Einschleppen von Fremdorganismen z.B. nach Australien verhindert werden soll. Dem gingen allerdings einige Desaster voraus, aus denen Australien nur langsam lernte. - Im Laufe der Zeit sind an den großen Umschlagplätzen für den Warenverkehr (Häfen, Flughäfen) Überwachungsmechanismen etabliert worden, mit deren Hilfe die unkontrollierte, passive Verbringung von Fremdorganismen - vorzugsweise mit Schadwirkung - unterbunden werden soll. Internationale Abkommen regeln darüber hinaus für bestimmte Arten die Einfuhr in Zielländer, nationale Gesetzgebungen verbieten das Freisetzen von (bestimmten) exotischen Arten.

${ }^{645}$ Als Fachbegriff für etablierte Neozoen schlagen Geiter at al. „Agriozoen“ vor, wobei sie auf den in der Botanik gebräuchlichen Begriff der „Agriophyten“ zurückgreifen. Auf beide Begriffe wird in diesem Aufsatz verzichtet, weil sie als reine Spezialistenbegriffe der Biologie nicht zum vorausgesetzten Bildungsumfang gehören (müssen).
} 
Anbau von Kartoffeln regeln, denn eine andere Futterpflanze steht ihm jenseits der Rocky Mountains nicht zur Verfügung.

Selbstverständlich hinterließ der Käfer auch im normativen Bereich seine Spuren, was angesichts der wirtschaftlichen Bedeutung der Kartoffel in vielen Europäischen Ländern nahe lag. Die Schädlingsgesetzgebung des ausgehenden 19. Jh.s gehört zu den ersten transnationalen Gesetzgebungen der Neuzeit und erkennt früh die Bedrohung auch durch den Colorado-Käfer. Aber mit der Einsicht in die Notwendigkeit der Schädlingsbekämpfung, den sich hierzu eröffnenden technischen Möglichkeiten durch Innovationen der chemischen Industrie entsteht auch eine Verschiebung im Blick auf den Schadorganismus. Im Hintergrund bildet der Darwinismus mit seiner vulgärkapitalistisch-liberalistischen Variante des Sozialdarwinismus eine Folie, vor der auch die Betrachtung von Menschen als Schadorganismen, als letztlich mit den Mitteln der Insektenbekämpfung zu vernichtenden Schädlingen, möglich wurde. ${ }^{646}$

Im Bereich der Schädlingsbekämpfung haben die Anstrengungen dann in den 1940er Jahren zu wirksamen synthetischen Insektiziden auch gegen den Kartoffelkäfer geführt. Doch die vereinten Anstrengungen betroffener bäuerlicher Gemeinschaften, die ihren Ausdruck im koordinierten Absammeln der Eier, Raupen und Imagines fanden, waren durchaus keine hilflosen Strategien. Immerhin war es mit derart einfachen Mitteln möglich, die Ausbreitung des Käfers lange aufzuhalten. Selbst seine erneute Eindämmung schien noch 1943 möglich. Die militärischpolitische Lage entschied allerdings zugunsten des Schädlings.

Schädlingsbekämpfung gilt vordergründig als eine selbstverständliche und ausgemachte Sache in Agrargesellschaften und ist es selbstverständlich auch. Obwohl einerseits reflexhafte Handlung, ist sie andererseits institutionalisiert. Ihr unterliegt ein Grundproblem, das sich aus dem Umgang des Menschen mit der Natur, mit den Mitlebewesen ergibt und vor allem die Denker beschäftigte, die sich mit dem Zustand der Welt befasst haben. Wenn die Welt, wie wir sie kennen, nach den Gottesbeweisen der Neuzeit die beste aller denkbaren Welten ist, wie kommen dann die Schädlinge in die Welt? Gibt es ein Recht, das Werk des Schöpfers durch Schädlingsbekämpfung zu korrigieren? Welche Handlungsgrenzen setzt sich der Mensch selbst gegenüber nichtmenschlichen Arten?647

Überraschend taucht der Kartoffelkäfer im Arsenal der Biologischen Kriegführung auf. Das ist bei Schadorganismen nicht ganz verwunderlich, bei einem nichtpathogenen höheren Lebewesen aber schon. Nur die Impraktikabilität der Anwendung

\footnotetext{
${ }^{646}$ Hierzu detailliert Jansen - Die Schädlingsmetapher ist indes viel älter, auch als Jansen suggeriert (siehe Herrmann 2006)

${ }^{647}$ Hierzu ausführlicher in Herrmann 2008
} 
hielt am Ende hüben wie drüben Militärs davon ab, den Kartoffelkäfer wirklich einzusetzen. Statt mit unhandlichen Metazoen sind die Bio-Waffen-Arsenale heute mit einzelligen Mikroorganismen und viralen Partikeln gefüllt - soweit man weiß. Wie harmlos und langwierig nehmen sich mögliche Sabotage-Akte mit Kartoffelkäfern aus neben den heute realen und mit sofortigen Wirkungen verbundenen Möglichkeiten zur Kontamination bzw. Infektion ganzer Bevölkerungen oder biologischer Ressourcen. Aber für die Entwicklung eines solchen Denkens in den Kategorien Biologischer Kriegführung bzw. der Entwicklung von Biowaffen steht der Kartoffelkäfer zusammen mit den Pesttoten, die 1347 über die Mauern nach Kaffa hinein geschossen wurden, am Beginn einer schlimmen Reihe von heute apokalyptischer Dimension.

Wurde die biologische Waffe auch nicht bis zu ihrem Einsatz entwickelt, so wurde sie erfolgreich in der Propaganda des Kalten Krieges eingesetzt. Heute noch wirken die Propagandabehauptungen nach, nach denen die Amerikaner Ende der 1940er Jahre Colorado-Käfer über der DDR abgeworfen hätten. ${ }^{648}$

Kartoffel, Kartoffelfäule und Kartoffelkäfer verbinden sich im hier behandelten Beispiel zu einem Beziehungs- und Wirkungsgeflecht. Es macht deutlich, wie sehr die autonomen Prozesse, denen die natürlichen, vom Menschen genutzten Ressourcen unterliegen, menschliche Handlungen beeinflussen. Am Ende bewegen sich zahlreiche, vom Menschen für genuin gesellschaftlich gehaltene Entscheidungen lediglich an der langen Leine unhintergehbarer biologischer Prinzipien. Die immer vollendetere Unterwerfung der Natur unter die Bedürfnisse des Menschen $^{649}$ verleitet zur Annahme, dass die Komplexität des Miteinanders menschlicher Entscheidungen und autonomer naturaler Prozesse durch verkürzte ingenieurtechnischer Leistungen zu moderieren sei. Tatsächlich lehrt die Kartoffelgeschichte, dass Folgen und Nebenfolgen menschlicher Handlungen in allen Berei-

\footnotetext{
${ }^{648}$ Ein glaubwürdiger Gesprächspartner, Geburtsjahrgang 1935, hat mir gegenüber geäußert, dass ihn seine Kriegserlebnisse in der Heimatstadt Augsburg dazu geführt hätten, der Propaganda als vermeintlich wahrer Geschichte zu glauben. Denn: In den Kriegsjahren wären von alliierten Flugzeugen kleine, damals kostbare Gegenstände wie Füllfederhalter abgeworfen worden, die beim Aufnehmen in der Hand explodierten. Deshalb habe er angenommen, wer zu solchen Taten (allererst gegen Kinder) fähig sei, der werfe auch Kartoffelkäfer ab. An dessen Bekämpfung hatte er als Schüler noch im Rahmen des Kartoffelkäfer-Abwehrdienstes teilgenommen.

${ }^{649}$ Eine der Speerspitzen der Aufklärung formuliert es in seinem Schlüsseltext so: „Die Einteilung der menschlichen Historie wollen wir nach dem Zustand und der Beschaffenheit der Natur selbst unternehmen, als die in dreifachen Zustand gesetzt erfunden wird und gleichsam eine dreifache Regierung eingeht. Denn entweder ist die Natur frei und erklärt sich durch ihren gewöhnlichen Lauf, wie an den himmlischen Körpern, den Tieren, den Pflanzen und dem ganzen Vorrat der Natur; oder sie wird durch bösartige Ungewöhnlichkeiten eines unbändigen Stoffes und durch die Gewalt der Hindernisse außer ihren Zustand gestoßen, wie in Missgeburten; oder sie wird endlich von der menschlichen Kunst und Arbeit gebunden, gestaltet und gleichsam erneuert, wie an den Kunstsachen zu sehen. Also teilt sich die natürliche Historie in die Historie der Zeugungen, der Miss-Zeugungen und der Künste, welche letztere man auch Mechanik und die Erfahrende Naturlehre zu nennen gewohnt ist. Die erste behandelt die Freiheit der Natur, die zweite die Fehler, die dritte die Bande." Bacon, S. 173
} 
chen menschlicher Tätigkeit nach ökologischen Prinzipien auszurichten sind, wenn sie der Nachhaltigkeit des menschlichen Zugriffs nicht entgleiten sollen. Und das Beispiel lehrt die Bedeutung umwelthistorischen Raisonnements nicht nur für die ökologische Grundbildung sondern auch als Voraussetzung für das praktische Handeln.

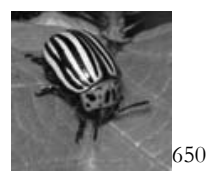

650 http://www.insektenwelt.ch/MeineBilder/Blatt/C22056b.JPG 
Derjenige, der schließlich den Spuren der Kartoffel und Kartoffelfäule in der Europäischen Kunst nachgehen möchte, wird bei Jeremias Gotthelf (Kati die Großmutter) über Liam O’Flaherty (Hungersnot) bis hin zu James Joyce fündig werden. Dem Kartoffelsujet ist verschiedentlich in der Malerei, vor allem im Stillleben, nachgegangen worden; der im 19. Jh. namhafteste einschlägige Maler war wohl van Gogh. Der Käfer hat es vor allem in die Plakatkunst des Agitprop geschafft. Sein historisch und biologisch falsches Erscheinen im CEvre von Günter Grass (Unkenrufe; Butt) ist dichterische Freiheit. Der Ostexpansion des Käfers ist im ungarischen Hedervar ein Denkmal (ungar.: krumplibogár szobor) gewidmet, das seines ersten Auftretens in Ungarn 1947 gedenkt, um den Betrachter an den allgemeinen Schutz der Biota zu erinnern.

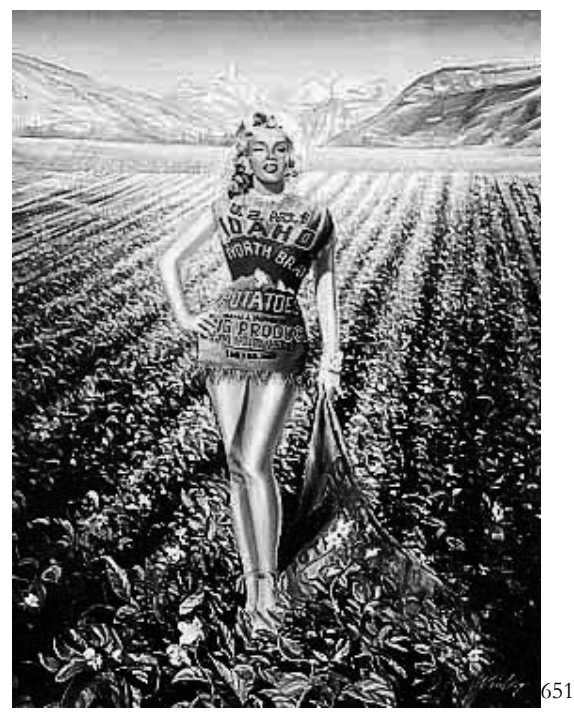

651 Bildvorlage hierzu unter http://marilynmonroepages.com/artwork.html - Ohne nachahmende Wirkung in der Modebranche wie beim Publikum blieb ein Werbefoto der 20th Century Fox, das Marilyn Monroe ca. 1952 in einem Kartoffelsack zeigt, weil sie in jeder Kleidung eine gute Figur machen würde. Das Foto wurde (um 1960?) Vorlage einer Werbe-Zeichnung, die vorgibt, für IdohaKartoffeln zu werben. Das Bild war jedoch niemals Teil einer offiziellen Kampagne [Auskunft des Idaho State Departments of Agriculture, 20.7.2009]. Aber MM war 1947 „Artischocken-Königin“. Dies könnte zu einer anderen umwelthistorischen Erörterung führen, weil Artischocken sich als aus Europa importierte Neophyten in Südamerika der bäuerlichen Kontrolle entzogen und im 18./19.Jh. ganze Landstriche in Wildnis verwandelten (Mann). - Auf die ebenso eigentümliche wie offensichtliche Bildsprache sei ausdrücklich hingewiesen. Unklar bleibt, ob die Kartoffel oder die aus ihr geborene Venus die Verheißung bildet. Sicher scheint soviel, dass die Kartoffel der Menschheit einen Weg zwischen den gewaltigen Herausforderungen der Zukunft hindurch (am Horizont) bahnt. 


\section{Danksagungen}

Frau PD Dr. Tatiana Czeschlik, Heidelberg, für sprachliche Unterstützung (Ungarisch)

Frau Andrea Durry, Kustodin des Schokoladen-Museums in Köln, für Angaben zu den Kartoffelkäfer-Schaukästen der Fa. Gebr. Stollwerck.

Frau Sybille Hourticolon, Göttingen, für Umsetzungen einzelner Abbildungsvorlagen in Druckversionen.

Frau Patricia Kolsteeg, Museum Plantin-Moretus/Prentenkabinet, Antwerpen - UNESCO World Heritage, für Vorlage und Veröffentlichungserlaubnis von Abb.1.

Frau Dr. Bärbel Schöber-Butin, Wolfenbüttel, für Auskünfte und Hinweise zu Phytophthora.

Frau Dipl.-Biol. Jana Sprenger, Göttingen, für Exzerpte aus der Akte über Kartoffelkäfer im Brandenburgischen Landeshauptarchiv.

Der Bundesbeauftragten für die Unterlagen des Staatssicherheitsdienstes der ehemaligen Deutschen Demokratischen Republik, vertreten durch Frau Gerlinde Schade, für die Unterstützung bei der Aktenbeschaffung und Einsicht.

Herrn Prof. Dr.Dr.h.c.mult. Wolfgang Frühwald für ein Zeitzeugnis.

\section{Literatur}

Ames M, Spooner DM (2008) DNA from herbarium specimens settles a controversy about origin of the European potato. American Journal of Botany 95: 252-257

Barth G (2008) Pilgramsreuth. Ursprünge des deutschen Kartoffelbaus. In: Herrmann B, Dahlke C (Hrsg.) Schauplätze der Umweltgeschichte. Universitätsdrucke Göttingen, S. 65-74

Bacon F (1783) Über die Würde und den Fortgang der Wissenschaften. Weingand \& Köpf, Pest

Bass H (2007) The crisis in Prussia. In: Ó Gráda C, Paping R, Vanhaute E (eds.) When the potato failed. Causes and effects of the last European subsistence crisis, 1845-1850. S. 185-212. (Corn Publication Series, Comparative Rural History of the North Sea Area Vol. 9). Brepols, Turnhout

Bittles A (1988a) Famine and man: lessons from the Irish past. A guide to the future? Biology and Society 5: 109-118

Bittles A (1988b) Famine and man: demographic and genetic effects of the Irish famine, $1846-1851$. Actes des 3eme Journées Anthropologiques, Notes et Monographies techniques No. 24, Edition du CNRS Paris, S. 159-175

Bourke A (1993) “The visitation of God?” The potato and the great Irish famine. Lilliput Press, Dublin

Butzer K (Hrsg.) (1992) The Americas before and after 1492: Current geographical research. Annals of the Association of American Geographers 82(3) 
Connell KH (1950) The Population of Ireland (1750-1845). Clarendon Press, Oxford

Crosby A (1986) Ecological Imperialism: the biological expansion of Europe 900-1900. Cambridge University Press, Cambridge

Deichmann U (1991) Biologen unter Hitler: die Vertreibung der jüdischen Biologen und biologische Forschung in Deutschland 1933 - 1945. Dissertation, Universität Köln

Denecke D (1976) Innovation and diffusion of the potato in Central Europe in the seventeenth and eighteenth centuries. In: Buchanan RH, Butlin RA (eds.) Fields, farms and settlement in Europe. Institute of Irish Studies, Belfast. S. 60-96

Elsholtz JS (1663) Flora Marchica, sive Catalogus plantarum quae partim in hortis electoralibus Marchiae Brandenburgicae primariis, Berolinensi, Aurangiburgico, Potstamensi excoluntur: parte sua sponte passim proveniunt. Rungiana - Reichel, Berlin

Fraser J (1757) Plain directions for raising potatoes on the lazy bed. Edinburgh

Geißler E (1998) Biologische Waffen - nicht in Hitlers Arsenalen. (Studien zur Friedensforschung 13). LIT, Münster

Geißler E (2001) Schwarzer Tod und Amikäfer. Biologische Waffen und ihre Geschichte. Anmerkungen zu einer Ausstellung. 2. Auflage. o.Oa.

Geiter O, Homma S, Kinzelbach R (2002) Bestandsaufnahme und Bewertung von Neozoen in Deutschland. Umweltbundesamt Berlin, Umweltforschungsplan des Bundesministeriums für Umwelt, Naturschutz und Reaktorsicherheit Forschungsbericht 29689 901/01 UBA-FB 000215

Gerbens-Leenes W, Hoekstra A, van der Meer T (2009) The water footprint of bioenergy. Proceedings of the National Academy of Sciences [publ. 3.Juni 2009; doi:10.1073/pnas.0812619106]

[Gerstaecker A] (1875) Der Kartoffelkäfer, Chrysomela (Doryphora) decemlineata. Im Auftrage des kgl. preußischen Ministeriums für die landwirthschaftlichen Angelegenheiten herausgegeben. Schotte \& Voigt, Berlin

Gerstaecker A (1877) Der Colorado-Käfer (Doryphora decemlineata) und sein Auftreten in Deutschland. Im Auftrage des Königl. Preußischen Ministeriums für die landwirthschaftlichen Angelegenheiten dargestellt. Fischer, Kassel

Glaser R (2001) Klimageschichte Mitteleuropas. Primus, Darmstadt

Goeser H, Büntig S (2006) Verbreitung transgener Kartoffeln durch Vögel. Deutscher Bundestag Wissenschaftliche Dienste. WD 5-161/06

Gundlach C von (1986) Agrarinnovation und Bevölkerungsdynamik - aufgezeigt am Wandel der Dreifelderwirtschaft zur Fruchtwechselwirtschaft unter dem Einfluß der Kartoffeleinführung im 18. Jh. Eine Fallstudie im südwestdeutschen Raum. Geowissenschaftliche Dissertation, Universität Freiburg

Hawkes JG (1990) The potato. Evolution, biodiversity and genetic resources. Smithsonian Institution Press. Washington D.C. 
Hawkes JG, Francisco-Ortega J (1993) The early history of the potato in Europe. Euphytica 70: 1-7

Herrmann B (2006) Zur Historisierung der Schädlingsbekämpfung. In: Meyer T, Popplow M (Hg.) Technik, Arbeit und Umwelt in der Geschichte. Günter Bayerl zum 60.

Geburtstag. Waxmann, Münster u.a. S. 317 - 338

Herrmann B.(2008) Empirische Zugänge zu historischen Biodiversitätsverdrängungen und Biodiversitätslenkungen: Die Beispiele Melioration und Schädlingsbekämpfung. In: Knopf T (Hrsg.) Umweltverhalten in Geschichte und Gegenwart. Vergleichende Ansätze. Attempo Verlag, Tübingen. S. 174-192

Herrmann, B (2009) Umweltgeschichte Wozu? Zur gesellschaftlichen Relevanz einer jungen Disziplin. In: Masius P, Sparenberg O, Sprenger J (Hrsg.) Umweltgeschichte und Umweltzukunft. Zur gesellschaftlichen Relevanz einer jungen Disziplin. Universitätsverlag Göttingen, Göttingen. S. 13-50

Hobhouse H (2000) Fünf Pflanzen verändern die Welt. Chinarinde, Zucker, Tee, Baumwolle, Kartoffel. Klett-Cotta/dtv, München (6.Auflage)

Hoffmann (1837) Über die Besorgnisse, welche die Zunahme der Bevölkerung erregt. Historisch Philosophische Abhandlungen der Königlichen Akademie der Wissenschaften zu Berlin aus dem Jahre 1835: 121-152

Imhof AE (1983) Leib und Leben unserer Vorfahren: Eine rhythmisierte Welt. In: Imhof AE (Hrsg.) Leib und Leben in der Geschichte der Neuzeit. (Berliner Historische Studien Bd. 9, Einzelstudien II). Duncker \& Humblot, Berlin. S. 21-38

Klintberg B af (1992) Der Elefant auf dem VW und andere moderne Sagen und Großstadtmythen. Serie Piper 1653. Piper, München/Zürich

Kruse H-D (1998) Hungersnot und Elend durch den Ausbruch der Kartoffelkrankheit im Vorfeld der Revolution von 1848. In: Vogelsang R, Westheider R (Hrsg.) Eine Region im Aufbruch. Die Revolution von 1848/49 in Ostwestfalen-Lippe. Verlag für Regionalgeschichte, Bielefeld. S. 99-130

Krünitz J G (ab 1773 ) Oekonomische Encyklopaedie, oder allgemeines System der Staats-, Stadt-, Haus- und Landwirthschaft. Pauli, Berlin.

[Hier zitiert aus der Online-Version: http://www.kruenitz1.uni-trier.de/home.htm]

Langenbruch G-A (1998) 100 Jahre Pflanzenschutzforschung. Der Kartoffelkäfer in Deutschland. Mitteilungen aus der Biologischen Bundesanstalt für Land- und Forstwirtschaft. Heft 341. Parey, Berlin

Laufer B (1938) The American plant migration. Part I: The potato. Anthropological Series Field Museum Natural History 28(1)

Livi-Bacci M (1992) A concise history of world population. Blackwell, Cambridge u. Oxford

Jager M (2005) Der Berliner Lustgarten. Gartenkunst und Stadtgestalt in Preußens Mitte. Deutscher Kunstverlag, München-Berlin 
Jansen S (2003) „Schädlinge“. Geschichte eines wissenschaftlichen und politischen Konstrukts 1840-1920. Campus, Frankfurt/New York

Jacques RL, Fasulo TR (2007) Colorado potato beetle. http://entomology.ifas.ufl.edu/creatures/veg/leaf/potato_beetles.htm (8.5.2009)

Körner K (o.J.) Politische Broschüren im Kalten Krieg. Materialien zur LeMO-Ausstellung „Deutschland im Kalten Krieg 1945 bis 1963“ nach der Ausstellung „Deutschland im Kalten Krieg“ (28.8. - 24.11.1992) Deutsches Historisches Museum, Lebendiges virtuelles Museum Online (20.5.2009): http://www.dhm.de/ausstellungen/kalter_krieg/brosch_04.htm

Kowarik I (2003) Biologische Invasionen: Neophyten und Neozoen in Mitteleuropa. Ulmer, Stuttgart

Madea B, Banaschek, S (2004) Verhungern. In: Brinkmann B, Madea B (Hrsg.) Handbuch der Gerichtlichen Medizin. Bd.1. Springer, Berlin usw., S. 907-919

Mann, C (2005) 1491: New revelations of the Americas before Columbus. Knopf, New York

Manning L (2009) Managing our water footprint. RuSource Briefing 775 [http://www.arthurrankcentre.org.uk/publications_and_resources/rusource_briefings/]

Matossian MK (1989) Poisons of the past. Molds, epidemics and history. Yale Univ Press, New Haven, London.

Messer E (2000) Lemma: Potato (White). In: Kiple K, Ornelas KC (eds) The Cambridge World History of Food. Chapter II.B.3. Cambridge University Press, Cambridge

Obermann K (1975) Die deutsche Auswanderung nach den Vereinigten Staaten von Amerika, ihre Ursachen und Auswirkungen. Jahrbuch für Wirtschaftsgeschichte 1975, Teil 2, S. 33-55

O'Grada C (1993) Ireland before and after the famine: explorations in economic history 1800 - 1925. (2 $2^{\text {nd }}$, rev. ed.) Manchester Univ. Press, Manchester

O’Grada C (1994) Ireland. A new economic History. Clarendon Press, Oxford

O'Grada C, Eirikson A, Guinnane T, Mokyr J, O’Rourke K (2006) Ireland's great famine. Interdisciplinary persepectives. University College Dublin Press, Dublin

Richerson PJ, Boyd R (1997) Homage to Malthus, Ricardo, and Boserup: Toward a general theory of population, economic growth, environmental deterioration, wealth, and poverty. Human Ecology Review 4: 85-90

Ross EB (1986) Potatoes, population, and the Irish Famine: The political economy of demographic change. In: Handwerker WP (ed.) Culture and Reproduction. An anthropological critique of Demographic Transition Theory. Westview, Boulder/London. 196-220

Saalfeld D (1982) Die Sorge um das tägliche Brot. In: Blum J (Hrsg.) Die bäuerliche Welt. Geschichte und Kultur in sieben Jh.en. Beck, München, S. 109-124 (Original title: 
Blum J (ed) Our forgotten past, chapter 5: The struggle to survive. Thames \& Hudson, London. 1982: 109-132)

Saalfeld D (1983) Bevölkerungswachstum und Hungerkatastrophen im vorindustriellen Europa. In: Ehlers E (Hrsg.) Ernährung und Gesellschaft. Bevölkerungswachstum Agrare Tragfähigkeit der Erde. Wiss. Verlagsgesellschaft, Stuttgart. S. 55-71

Saalfeld D (1991) Agrarproduktion in Fridericianischer Zeit und die Nahrungsversorgung der preußischen Bevölkerung im 18. Jh.. In: Ziechmann J (Hrsg.) Fridericianische Miniaturen 2, S. 9-35. [Forschungen und Studien zur Fridericianischen Zeit Bd. 3]

Salaman R (1949) The history and the social influence of the potato. University Press, Cambridge [new edition edited by J.G.Hawkes, 1985]

Schmidt G, Kleppin L, Schröder W, Breckling B, Reuter H, Eschenbach C, Windhorst W, Höltl K, Wurbs A, Barkmann J, Marggraf R, Thiel M (2009) System risks of genetically modified organisms in crop production: interdisciplinary perspective.

Gaia 18/2: 119 - 126

Schmitz N (2006) Bioethanol als Kraftstoff - Stand und Perspektiven.

Technikfolgenabschätzung 15: 16-26

Schaier J (1991) Verwaltungshandeln in einer Hungerkrise. Die Hungersnot 1846/47 im badischen Odenwald. Deutscher Universitäts-Verlag, Wiesbaden

Schöber-Butin B (2001) Die Kraut- und Braunfäule der Kartoffel und ihr Erreger Phytophthora infestans (MONT.) DEBARY. Mitteilungen aus der Biologischen Bundesanstalt für Land- und Forstwirtschaft 384. Parey, Berlin

Scott G, Rosegrant M, Ringler C (2000) Roots and tubers for the 21 ${ }^{\text {st }}$ century. Food, Agriculture and the Environment Discussion Paper 31. International Food Policy Research Institute, Washington und Centro Internacional de la Papa, Lima

Siemann W, Freytag N (2003) Umwelt - geschichtswissenschaftliche Grundkategorie. In: Siemann W, Freytag N (Hrsg.) Umweltgeschichte. Themen und Perspektiven. Beck, München. S. 7-20

Solar P (1989) The Great Famine was no ordinary subsistence crisis. In: Crawford EM (Hrsg.) Famine: The Irish experience 900-1900. Subsitence Crises and Famines in Ireland. John Doinald Publ., Edinburgh. S. 112- 133

Unesco Instutute for Water Education $\rightarrow$ Internetzugänge IHE

Vanhaute E (2007) "So worthy an example to Ireland". The subsistence and industrial crisis of 1845-1850 in Flanders. In: Ó Gráda C, Paping R, Vanhaute E (eds.) When the potato failed. Causes and effects of the last European subsistence crisis, 1845-1850. S. 123-148. (Corn Publication Series, Comparative Rural History of the North Sea Area Vol. 9). Brepols, Turnhout

Vanhaute E, Paping R, Ó Gráda C (2007) The European subsistence crisis of 1845-1850: a comparative perspective. In: Ó Gráda C, Paping R, Vanhaute E (eds.) When the potato failed. Causes and effects of the last European subsistence crisis, 1845-1850. 
S. 15-40. (Corn Publication Series, Comparative Rural History of the North Sea Area Vol. 9). Brepols, Turnhout

Virchow R (1849) Mittheilungen über die in Oberschlesien herrschende Typhus-Epidemie In: Virchow R, Sämtliche Werke, hrsg. v. Christian Andree, Bd. 4, Abteilung I, Medizin. Peter Lang, Bern usw. 1992. S. 357 - 492

Zuckermann L (1999) The Potato. From the Ands in the sixteenth century to fish and chips, the story of how a vegetable changed history. Mcmillan, London (Nachdruck der Ausgabe Faber \& Faber, Boston 1998)

http://research.cip.cgiar.org/confluence/display/wpa/Home

http://resistance.potatobeetle.org/index.html

http://www.ars.usda.gov/is/pr/2005/050318.htm

http://www.arthurrankcentre.org.uk/publications_and_resources/rusource_briefings/

http://www.biosicherheit.de/de/schule/96.doku.html

http://www.broad.mit.edu/annotation/genome/phytophthora_infestans/Info.html\#t5

http://www.bstu.bund.de/cln_029/nn_714824/DE/Archiv/Findhilfsmittel/Findbuch/sa chablage_download,templateId=raw,property=publicationFile.pdf/sachablage_downl oad.pdf

http://www.census.gov/prod/2004pubs/c2kbr-35.pdf

http://www.cipotato.org/

http://www.dhm.de/ausstellungen/kalter_krieg/imp.htm

http://www.ihe.nl

http://www.kartoffel-geschichte.de/index.html

http://www.potato2008.org/en/index.html

http://www.siwi.org/documents/Resources/Policy_Briefs/CSD_More_nutrition_per_dro p_2004.pdf\#page $=5$ 



\title{
Das landesverderbliche Übel der Sprengsel in den brandenburgischen Gemarkungen - Heuschreckenkalamitäten im 18. Jahrhundert ${ }^{652}$
}

\author{
Bernd Herrmann \& Jana Sprenger
}

\section{Einleitung}

Zuletzt wurde über ein massenhaftes Auftreten von Wanderheuschrecken in Deutschland für die Jahre 1873 - 75 berichtet. ${ }^{653} \mathrm{Im}$ darauffolgenden Jahr 1876 gab es offenbar noch vereinzelte sekundäre Brut, u. a. auf mecklenburgischen Gebieten, die Besorgnis erregte. ${ }^{54}$ Danach kam es augenscheinlich zu keinem Masseneinfall bzw. zu keiner Massenvermehrung mehr auf deutschem Territorium, denen betriebs- oder volkswirtschaftliche Relevanz zukam. Die Literatur der Biologen und Schädlingsbekämpfer ist sich einig über die Ursache, der sich der Rückgang dieses ehedem gefürchteten Schädlings verdankt: „Die fortschreitende Kultur machte immer weitere Strecken für die Zwecke der Heuschrecken-Massenentwicklung ungeeignet. Zuerst hörten sie in Ostelbien, später in Polen und Ungarn auf. Mit der zunehmenden Flußregulierung und Urbarmachung dürften sie in

\footnotetext{
${ }^{652}$ Zuerst erschienen in: Masius P, Sprenger J, Mackowiak E (Hrsg.) Katastrophen machen Geschichte. Umweltgeschichtliche Prozesse im Spannungsfeld von Ressourcennutzung und Extremereignis. Universitätsverlag Göttingen, S. 79-118

${ }^{653}$ Weidner, H. (1953): Die Wanderheuschrecken. Die Neue Brehm-Bücherei 96: Leipzig: S. 44, mit Ortsangabe „Brandenburg“; die Brockhaus Enzyklopädie 1884 bezieht konkreter auf den Bezirk Potsdam.

${ }^{654}$ Konow, F. (1876): Die sog. Wanderheuschrecke. In: Wöchentliche Anzeigen für das Fürstenthum Ratzeburg 1876, Nr. 66:2: S. 2.
} 
absehbarer Zeit dann auch aus Südrußland endgültig als Massen-Invasionen verschwinden und damit hätte dann die Menschheit in harter jahrhundertelanger Arbeit einen ihrer gefährlichsten Feinde aus Europa vertrieben." 655 Gleichlautend äußerte sich Schimitschek, der in erster Linie auf die Flussregulierungen des 19. Jh.s in Ungarn (u. a. der Theiß ab 1845), Rumänien und Südrussland und auf die Intensivierung der landwirtschaftlichen Kultur, vor allem in Mitteleuropa, abstellte. „Es ist dies einer der Fälle, wo Insektenmassenvermehrungen durch die Schaffung der Kulturlandschaft zurückgedrängt wurden. "656 Die Flussregulierungen entzogen im primären Brutgebiet der Heuschrecken dem Boden die höhere Feuchtigkeit, die für eine Larvenentwicklung der Insekten erforderlich ist. In Mitteleuropa entfielen im Wesentlichen mit dem Ende der Brachlandwirtschaft auch die begünstigenden Entwicklungsbedingungen in den sekundären Brutgebieten.

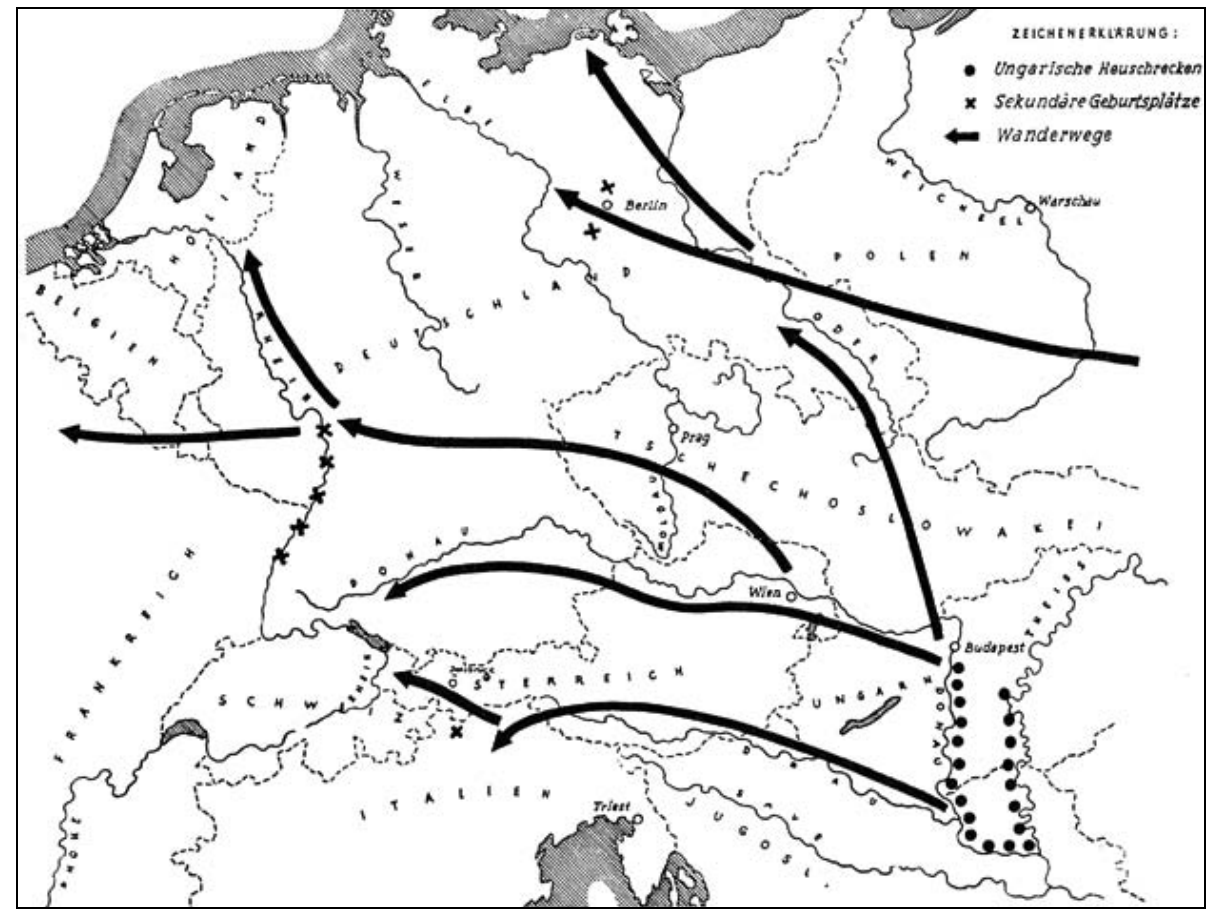

Abb.1: Wanderwege der Europäischen Wanderheuschrecke (aus Schimitschek, 1973). Dargestellt sind die Hauptwanderrouten sowie sekundäre Brutgebiete. Die Karte blendet die rumänischen und schwarzmeernahen primären Brutgebiete Südrusslands aus. Die sekundären Brutgebiete erklären sich aus naturräumlichen Ausstattungen und markieren zugleich die westlichsten Arealränder des Verbreitungsgebietes der Europäischen Wander-

${ }^{655}$ Bodenheimer, F. S. (1929): Geschichte der Entomologie bis Linné. Bd. 2, Junk: Berlin: S. 27.

${ }^{656}$ Schimitschek, E. (1973): Pflanzen-, Material- und Vorratsschädlinge. In: Helmcke, J.-G. / Starck, D. / Wermuth, H. (Hg.) Handbuch der Zoologie 4 (2) 1/8, S. 1-200, De Gruyter: Berlin: S. 9. 
heuschrecke. Die Pfeile sind großzügige, prinzipielle Richtungsanzeiger, die bei höheren Ortsauflösungen, wie sie die historischen Quellen zuweilen gestatten, zumindest für den deutschen Raum eher vagen Bestand haben.

Nach 1876 spielten Wanderheuschrecken als Schadinsekten in Deutschland definitiv keine Rolle mehr. Aussagen über „Heuschrecken in Mitteleuropa“ lösen heute eher ungläubiges Erstaunen aus. Tatsächlich waren Heuschrecken im Brandenburg des 18. Jh.s ein häufiger und gefürchteter Fraßschädling. Sein Beispiel ist geeignet, den Wandel einer einst in Mitteleuropa als schicksalhaft erfahrenen Existenzbedrohung hin zu einem Gegenstand völliger Bedeutungslosigkeit zu verfolgen; einer Existenzbedrohung, die der Vergessenheit anheim fallen konnte, heute in biblische und antike Zeiten projiziert und nur noch den Problemzonen der Schwellen- und Entwicklungsländer zugeordnet wird.

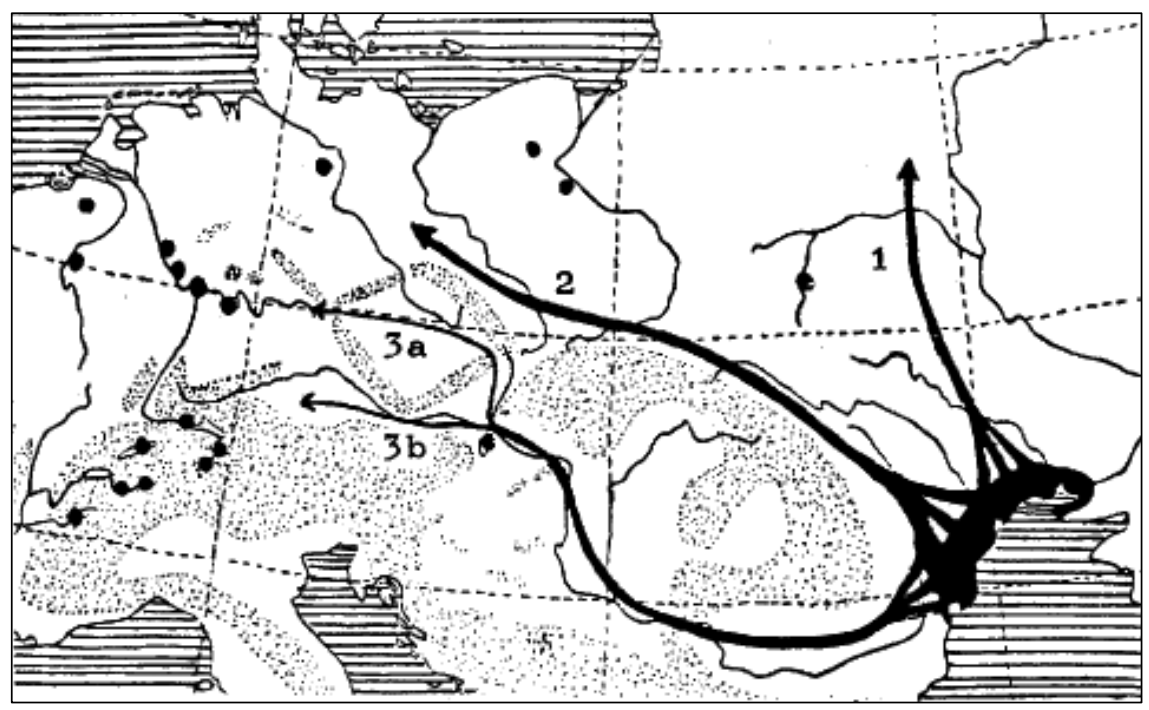

Abb. 2: Karte der „Wanderstraßen“ von Locusta migratoria migratoria in Europa. (aus Weidner 1986). Schwarz: Westpontisches Schwarmbildungszentrum, 1 - 3b Wanderstraßen. Schwarze Punkte: endemische Brutstätten. Fein punktiert: Gebirge. Ergänzung zu Abb. 1.

Die auffällige zeitliche Konzentration der Heuschreckenkalamitäten ${ }^{657}$ findet ihre einfache Erklärung in der klimatischen Veränderung nach der Kleinen Eiszeit, die mit dem Maunder-Minimum gegen 1715 endet. Die Heuschreckenzüge erreichten vorher nur sehr sporadisch den Ostrand Brandenburgs. Die Insekten blieben seit den 1720er Jahren eine Bedrohung für die Landwirtschaft fast über das gesamte

657 In der Ökologie wird unter „Kalamität“ die wirtschaftlich schädliche Phase bei der Massenvermehrung eines Schädlings verstanden. 
Jahrhundert. Erst gegen Ende des 18. Jh.s begann sich das für Heuschreckenzüge günstige Zeitfenster wegen der Landschaftsveränderung wieder zu schließen.

\section{Grundlagen}

\subsection{Biologische Orientierung}

Seit dem mittelalterlichen Landesausbau und der damit verbundenen Öffnung der Landschaft durch den Wegfall natürlicher Waldbarrieren boten sich Zugwege für Heuschreckenschwärme vom europäischen Südosten (Ungarn, Rumänien, Südrussland) auch in den europäischen Nordwesten (Abb. 1, 2). Die historischen Wanderrouten umgingen zumeist die gebirgigen Gegenden. Erste Erwähnungen solcher Heuschreckenzüge stammen aus dem 9. Jh. Sie tauchen seitdem in den Quellen sporadisch auf. Wegen des Klimapessimums der Kleinen Eiszeit waren solche Züge aus dem europäischen Südosten in dieser Zeit selten. Die Wanderungen und damit verbundene Sekundärbrut erreichten vom Ende des 17. bis zum Ende des 18. Jh.s in Mittel- und Ostdeutschland ihre historisch größte Intensität, um im 19. Jh. zum Erliegen zu kommen. ${ }^{658}$

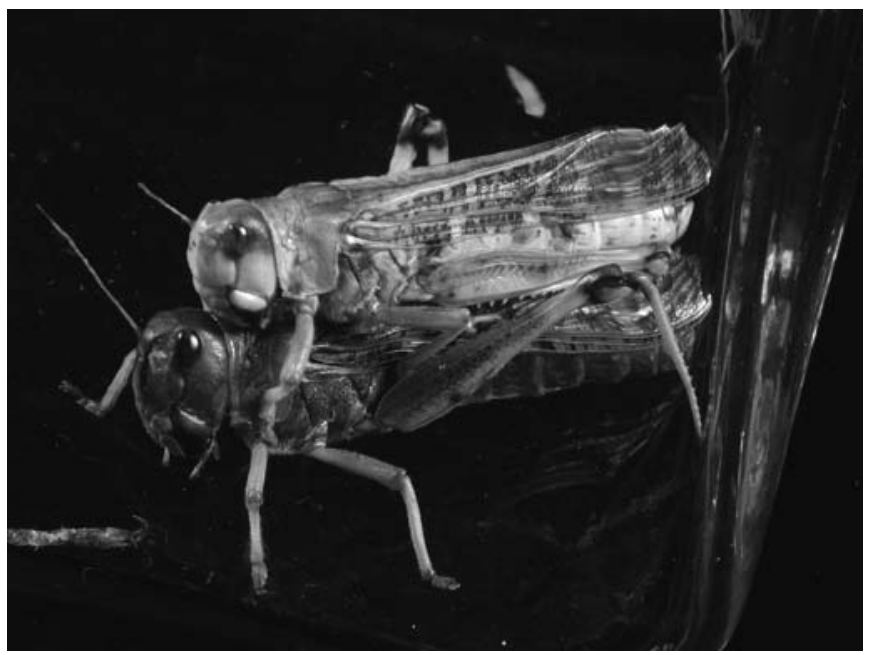

Abb. 3: Europäische Wanderheuschrecke Locusta migratoria im Beobachtungsglas. Expl. aus der Zucht des Johann-Friedrich-Blumenbach-Instituts für Zoologie und Anthropologie Göttingen, Februar 2006. Die Wanderheuschrecke kommt in verschiedenen Farben vor. Abgebildet sind eine gelbgrüne (oben) und eine braune Variante. Die gezeigten Exemplare

${ }^{658}$ Eine monographische Aufarbeitung der Heuschreckenzüge und damit verbundener Fragen steht aus. Hilfreiche, aber unvollständige Zusammenstellungen $u$. a. bei Schimitschek und Weidner. Z. Zt. immer noch am ergiebigsten Bodenheimer. 
stellen mit ca. $6 \mathrm{~cm}$ das obere Ende des Größenspektrums, das bei $3 \mathrm{~cm}$ beginnt. Abgebildet ist die sogen. Solitäre Phase, die nicht identisch mit der wandernden Form ist. (Foto: S. Hourticolon)

Die Wanderheuschrecken (Abb. 3) sind Fraßschädlinge, die vor allem krautige oberirdische Pflanzenteile und Blätter verzehren. In großer Zahl sind sie als Flugform wie als flugunfähige Larve in der Lage, Kulturflächen innerhalb von Stunden vollständig zu vernichten. Wandernde Heuschreckenschwärme verdanken sich im Prinzip dem Zusammentreffen ökologischer Determinanten im primären Brutgebiet. Wenn eine Periode von Jahren, die für die Massenvermehrung der solitären Heuschrecken günstig waren, von einer längeren Trockenheit gefolgt wird, ist der noch verfügbare Lebensraum für die Bevölkerungsdichte der Heuschrecken zu klein, sie wandeln sich durch hormonelle Umstellung in Wanderformen und beginnen zu schwärmen.

Solche Heuschreckenschwärme ereichten auch Brandenburg, wo sie sich als Schädlinge zeitweilig etablieren konnten. Die Heuschreckenkalamitäten hatten ihren Hintergrund auch darin, dass Wanderheuschrecken in Brandenburg und angrenzenden Gebieten sekundäre Brutplätze fanden. Weil Brandenburg noch zum natürlichen Verbreitungsrand der Wanderheuschrecke (Locusta migratoria) gehörte, konnten sich deren Populationsbestände daher ggfl. auch aus sich heraus und ohne beständigen ergänzenden Einfall aus dem europäischen Südosten erhalten und höhere Dichten erreichen. Sofern die Witterungsbedingungen es zulieBen, ${ }^{659}$ lag es in der Logik solcher Populationsdynamiken, dass auf ein Heuschreckenjahr häufig ein zweites folgte.

In diesen sekundären Brutgebieten waren es dann vor allem die bis zur letzten Häutung noch flugunfähigen Larvenstadien, die den Kulturflächen ab Mai als Fraßschädlinge zusetzten. Wegen ihrer Flugunfähigkeit bewegten sie sich hüpfend, springend. Hieraus erklären sich die alten Bezeichnungen „Sprengsel“ und „Sprenkel“, die vor allem für die Larvenstadien und selten für die voll entwickelten Imagines verwendet wurden, die ganz überwiegend als „Heuschrecken“ bezeichnet wurden. Die Fortpflanzung der Heuschrecken ist an das Imaginalstadium gebunden. Die Eiablage begann in Brandenburg um das Monatsende im August.

Begünstigt wurden sekundäre Bruten auch durch das Bewirtschaftungssystem: „Nach der gewöhnlichen Bestellung der Äcker in der Kurmark werden dieselben zwei Jahr zum Fruchttragen genutzt und bleiben das dritte Jahr brach. Denjenigen Acker, welchen man nicht dergestalt nutzt, sondern nur nach Verlauf mehrerer Jahre bestellt, nennt man drei-, sechs-, neunjährigen Acker, je nach dem diese Be-

659 Aus der Entwicklungsbiologie der Heuschrecke ist bekannt, dass Feuchtigkeit des Bodens und Wärme zusammentreffen müssen, um die Larvenentwicklung aus dem Ei zu befördern. Für die Sandböden Brandenburgs ergibt sich entweder ein Entwicklungsschwerpunkt in den Oder-Auen bzw. benachbarter Flusssysteme und /oder auf den glazialen Sandflächen vor allem des Barnim nach ausreichenden Niederschlägen. Über die Witterung in den Heuschreckenjahren sind uns keine Zusammenstellungen oder Untersuchungen bekannt. 
stellung alle drei, sechs oder neun Jahre wiederholt wird.“660 Ein „fünfjähriger Acker" wurde entsprechend jedes fünfte Jahr mit Roggen bestellt, lag dann ungedüngt vier Jahre brach bis zur nächsten Roggenbestellung. Die hohen Brachenintervalle entsprachen geringer Bodengüte. Die annähernden relativen Anteile dieser besonders lang brachliegenden Bewirtschaftungsflächen betrugen (umgerechnet aus Angaben von Borgstede):

\begin{tabular}{|l|l|l|l|l|l|}
\hline & 3-jährige & 5-jährige & 6-jährige & 9-jährige & 12-jährige \\
\hline $\begin{array}{l}\text { Gesamte } \\
\text { Kurmark }\end{array}$ & $61 \%$ & $1 \%$ & $19 \%$ & $9 \%$ & $8,5 \%$ \\
\hline
\end{tabular}

(Cave: die Tabelle bezieht sich auf die Brachen, nicht auf das Gesamt der Ackerflächen!)

Im Landesmittel der Kurmark lag ein Anteil von 29 Quadratmeilen der Ackerfläche (= ca. $1650 \mathrm{~km}^{2}$, das entspricht der doppelten Fläche des heutigen Berlin) für drei und mehr Jahre brach, eine ideale Voraussetzung ungestörter Heuschreckenentwicklung auf solchen Parzellen und für die weiter unten behandelte Frage der Heuschreckenjahre von Relevanz. Eine Aufstellung der ein- und zweijährigen Ackerfluren, die zur Abschätzung der Proportionen hilfreich wäre, war noch 1803 nicht verfügbar. ${ }^{661}$

Schließlich wird die Situation noch durch biologische Variabilität verkompliziert. Unter dem 30.7.1782 wurde über „4 Sorten“ von Sprengseln berichtet, die im Lebusischen Kreis aufgetaucht wären. Je ein Exemplar wurde nach Berlin geschickt, aber offensichtlich nicht aufbewahrt. Im Einzelnen waren es:

„1. eine gantz grüne Art

2. eine gantz graue Art

3. eine graue Art mit Flecken auf dem Rücken

4. eine schwartze Art mit gelben und rothen Bäuchen.

Wegen der drei Sorten wird sich wohl nun nichts mehr tun lassen, da solche, wie der v.Beerfelde bemerkt, bereits flugbar und im Getreide sind...dem letzten [aber] nicht schädlich, dann sie fressen bloß die Acheln von den Ähren... Die 4. Art wird für wirkliche Heuschrecken gehalten, welche die Ähren vom Getreide herunternagen ..." ${ }^{\text {6662 }}$

Es wird nicht das erste Mal gewesen sein, dass sich Massenvermehrungen unterschiedlicher Heuschreckenarten synchron ereigneten. Eine exakte biologische Dif-

\footnotetext{
${ }^{660}$ Borgstede, H. von (1788): Statistisch-Topographische Beschreibung der Kurmark Brandenburg... Teil 1, Unger: Berlin: S. 107; ähnlich Bratring, F. W. A. (1804-09): Statistisch-topographische Beschreibung der gesammten Mark Brandenburg. 3 Bände, Maurer: Berlin: Bd. 1, S. 12.

${ }^{661}$ Bratring: Beschreibung, S. 12.

${ }^{662}$ Geheimes Staatsarchiv Preußischer Kulturbesitz, II. HA, Kurmark Materien, Tit. CCLXVIII, Nr. 2, Vol. III.
} 
ferenzierung der an den Kalamitäten beteiligten Arten ist für die folgende Betrachtung jedoch nicht erforderlich.

\subsection{Historische Orientierung}

Die Literatur berichtet für die Zeit vor dem 18. Jh. nur gelegentlich über Heuschreckenzüge nach Mitteleuropa, sie waren augenscheinlich selten und erfolgten auch nicht regelhaft. Dieser Befund befindet sich in Übereinstimmung mit den Kenntnissen über historische Klimaverhältnisse. ${ }^{663}$

Da die Heuschrecken zum alttestamentarischen Plagenrepertoir gehören, waren sie selbstverständlich den Landeskindern vertraut, selbst, wenn eigene Anschauung fehlen sollte. Die vorauseilende straftheologische Bewertung eines Heuschreckenauftretens ist daher immer auch mit zu denken. Dieses Vorverständnis beeinflusste vermutlich auch die Bewertung eines möglichen tatsächlichen Schadens, der vor dem religiösen Hintergrund dann subjektiv höher ausfallen könnte als ökonomisch gerechtfertigt, weil in dieser Bewertung der immaterielle Schaden des Betroffenen als subtextliche Hypothek nicht ausgeschlossen werden kann: Der Geschädigte sah sich als vom Schicksal ungerechtfertigt behandelt an.

Mit Bezug zu Brandenburg setzten Mitteilungen spät ein. Coler (1566 - 1639), der mit den Verhältnissen in der Mark Brandenburg gut vertraut war und der sich in seiner Darstellung ohnehin hauptsächlich auf den deutschen Raum bezog, berichtete lediglich über einen Heuschreckenzug größeren Ausmaßes von 1542, „da ein grosser trefflicher Hauffe der großen Heuschrecken im Anfang deß Herbsts auß Lieffland herauß flogen, durch Polen und Schlesien, und kamen biß in Meissen, welche alles Graß, Kraut und Gesäme auff dem Feld abfrassen, und den Leuten grossen Schaden thaten." ${ }^{664}$ Man wird mit gewisser Berechtigung annehmen müssen, dass Coler größere Heuschreckenkalamitäten zumindest seiner Lebzeiten für den Brandenburger Raum erwähnt hätte. ${ }^{665}$ Er erweist sich zudem als unsicherer Zeuge, denn das von ihm angeführte Ursprungsgebiet ist wenig wahrscheinlich, hingegen ist die Erwähnung des Posener Raumes plausibel, sie findet sich für die Folgezeit häufiger. Aber Colers Heuschrecken fielen offenbar nicht in Brandenburg ein. Uns dient er hier als Hinweis, dass zumindest bis zur Mitte des 17. Jh.s

663 Glaser, R. (2001): Klimageschichte Mitteleuropas. Primus: Darmstadt; Pfister, C. (2008): Von der Hexenjagd zur Risikoprävention. Reaktionen auf Klimaveränderungen seit 1500. In: Lutz, P. / Macho, T. (Hg.): Das Wetter, der Mensch und sein Klima. Eine Ausstellung des Deutschen HygieneMuseums Dresden, Wallstein, Göttingen, S. 56-61.

664 Coler, J. (1680): Oeconomia ruralis et domestica, Darin das gantz Ampt..., Schönwetter: Frankfurt, Kap. 23, S. 168.

665 Coler war u. a. Professor der Philosophie an der Viadrina in Frankfurt a.d.O. [NDB]. - Nach Lindner ist die Bibliographie zu Coler schwierig und damit das Entstehungsdatum der Textbeiträge einzelner seiner Ausgaben ungewiß. Im Grundsatz ändert sich dadurch an der hier getroffenen Aussage nichts, die sich auf das Göttinger Exemplar von 1680 bezieht, das nach Lindner mit den früheren Ausgaben von 1668 identisch ist. 
die Heuschrecken in Brandenburg wie anderswo eine wegen ihrer Seltenheit untergeordnete Bedrohung darstellten.

Für die Erstlinge der Schädlingsbekämpfung und der entomologischen Literatur in Deutschland ${ }^{666}$ waren Heuschrecken ein selbstverständliches Thema.

Kraft ${ }^{667}$ berichtete ausführlich, aber eher allgemein über Heuschrecken und stellte nur kursorisch regionale Bezüge her. Dies liegt nahe, weil er eine Anweisung zur Schädlingsbekämpfung schrieb, für deren Marktinteresse regionale Bindungen eher nachteilig gewesen wären. Die Heuschrecken des Jahres 1682, die im Sommer bei Frankfurt und in der Neumark bei Crossen/Züllich im Juli gesehen wurden, erwähnte er hingegen ausdrücklich. Sie hätten „den Himmel bei heiterem Sonnenschein bedeckt." Weitere Angaben zu historischen Heuschreckeneinfällen in Brandenburg machte er jedoch nicht.

Frisch, der in Berlin am Grauen Kloster arbeitete und Klassen-Vorsitzender in der Preußischen Akademie war, verfasste seinen Heuschrecken-Aufsatz 1730, also erst im 9. Teil seiner 1720 begonnenen Insektenkunde. Auch er sprach die Brandenburger Verhältnisse nur einmal an: 1730 erschienen die Heuschrecken, auf die er sich in seiner später im selben Jahr erfolgten Veröffentlichung bezog. Als einem der Gründerväter der deutschen Entomologie war ihm das Zoologische gewiss wichtiger als die Bekämpfungsstrategie, der er zwar einen Kupferstich widmete, ohne jedoch näher auf diesen einzugehen. ${ }^{668}$ Gegenüber der sehr mäßigen Qualität des Bekämpfungs-Kupfers war seine Darstellung der Heuschrecken von deutlich besserer Handwerklichkeit (Abb. 4). Als Zeitzeuge für Daten von Heuschreckenkalamitäten entfällt Frisch, aber die nachdrückliche Ernsthaftigkeit, mit der er Maßnahmen zur Heuschreckenbekämpfung skizzierte, unterstrich sein Urteil: Heuschreckenbekämpfungen seien ungleich wichtiger als Wolfsjagden. Die Wölfe würden zwar das Fleisch wegnehmen, die Heuschrecken jedoch das Brot ${ }^{669}$. Es ging also, daran ließ Frisch keinen Zweifel, in existentieller Weise um das elementarste Nahrungsmittel. An dieser Stelle ist der Hinweis vorweggenommen, dass in Brandenburg-Preußen 1731 das erste Edikt zur Heuschreckenbekämpfung erlassen wurde.

Zedlers Universallexikon, das zwischen 1731 und 1754 erschien, erwähnte als einzigen Heuschreckenschwarm auf deutschem Territorium den von $1693^{670}$, der

666 Krafft, A. F. (1712-1713): Der sowohl Menschen und Viehe grausamen Thiere/schädlichen Ungeziefers und verderblicher Gewürmer gäntzliche Ausrottung..., Buggel: Nürnberg 1712 (anderer Theil), 1713 (erster Theil); Frisch, J. L. (1720-1730): Beschreibung von allerley Insecten in TeutschLand: Nebst nützlichen Anmerckungen und nöthigen Abbildungen von diesem kriechenden und fliegenden inländischen Gewürme...13 Teile, Nicolai: Berlin [auch Sekundärausgaben ab 1730]

${ }^{667}$ Krafft: Menschen: Teil 1, Cap. 26, ab S. 403; Teil 2, Cap.V, ab S. 55.

668 Wiedergabe bei Herrmann, B. (2007): Ein Beitrag zur Kenntnis von Schädlingsbekämpfungen und ihren Konzepten im 18. und frühen 19. Jahrhundert an Beispielen aus Brandenburg-Preußen. In: Engelken, K. / Hünniger, D. / Windelen, S. (Hg.): Beten, Impfen, Sammeln. Zur Viehseuchen- und Schädlingsbekämpfung in der frühen Neuzeit, Universitätsverlag Göttingen, S. 168.

${ }^{669}$ Frisch: Beschreibung: Teil 9, S. 9.

${ }^{670}$ Zedler, J. H. (1731 - 1754): Großes vollständiges Universal Lexikon aller Wissenschaften und Künste: Bd. 12, S. 1008 ff. - Zu diesem Schwarm siehe Weidner 1986. 
keinen Bezug zu Brandenburg hatte. Es erwähnte zwar die von den Tieren verursachten Agrarschäden, berichtete aber ausgedehnter über die Kulturkuriosa, die sich aus mitteleuropäischer Perspektive in ferneren Ländern um das Insekt rankten. Diese kurze Übersicht über ganz unterschiedliche Autorenperspektiven legt nahe, dass Heuschrecken in der Zeit vor 1700 keine ernstliche Bedrohung für die brandenburgischen Ackerkulturen darstellten.

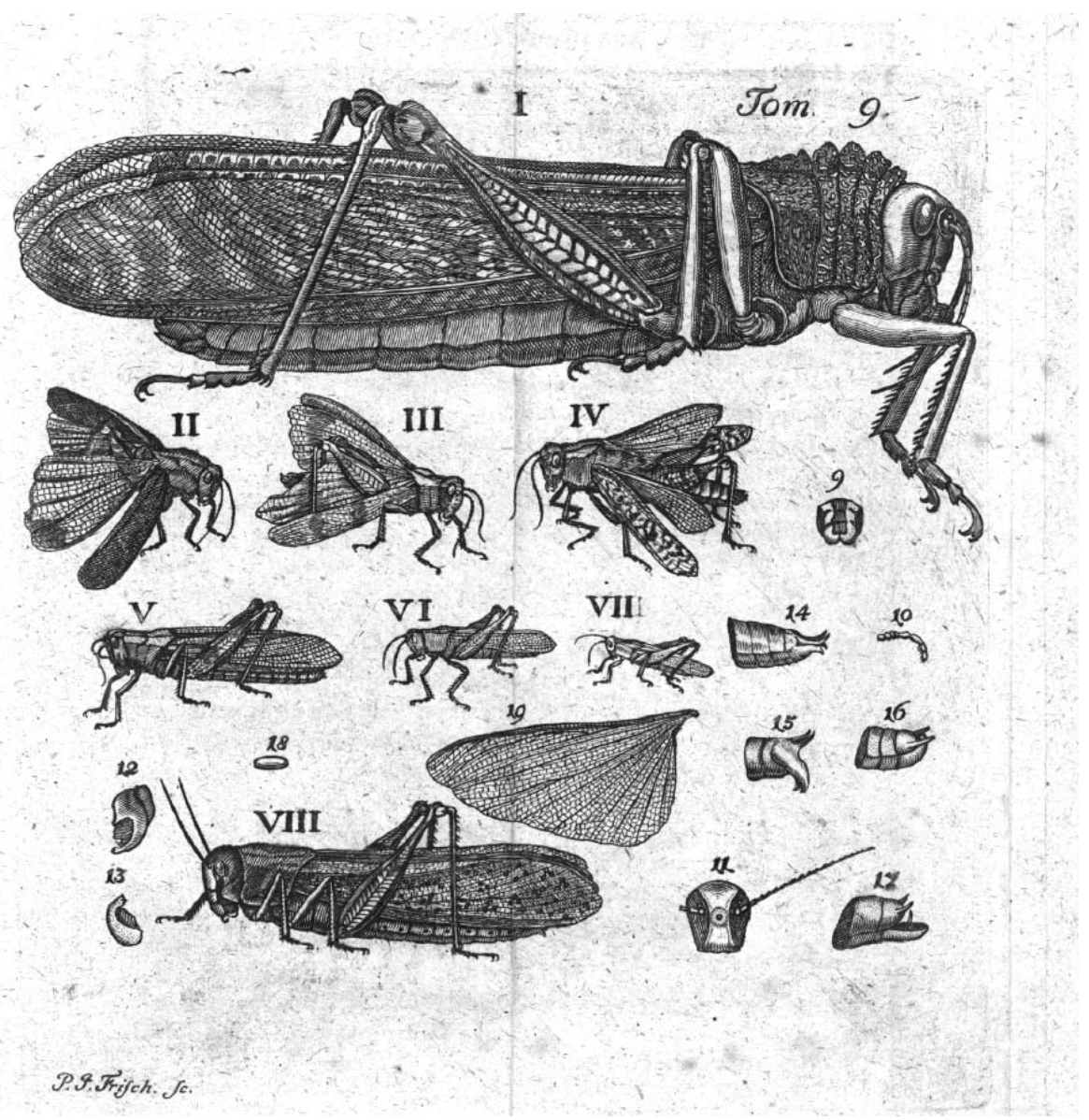

Abb. 4: Von Johann Leonhard Frisch (1730) abgebildete Heuschrecken. Pos. VIII: Europäische Wanderheuschrecke, Frisch nennt sie „Strich-Heuschrecke“; Pos. I: Große Orientalische (Wander)Heuschrecke. (Abbildung aus dem Exemplar der Göttinger Universitätsbibliothek). 
Anders als bei den bisher erwähnten Autoren, die trotz ihres teilweise unmittelbaren persönlichen Bezuges zu Brandenburg ein dortiges Heuschreckenauftreten nur sehr vereinzelt als Kalamität einordneten, wurde der Heuschrecken in der Darstellung Bekmanns gedacht. ${ }^{671}$ Er begann mit sehr frühen Heuschreckenjahren ,in der Mark": 1338, 1542, 1581, 1584. Einhundert Jahre später (1680) waren sie wieder da, besonders um Züllichau, 1681 mit dem Schwerpunkt Frankfurt und Umgebung, wo er für den 15./22. Juli einen fliegenden Schwarm erwähnte, 1682 waren sie in der Neumark und dem Herzogtum Crossen. Hier wären die Larven im Mai geschlüpft und durch Kälteeinbruch am 21./22. Juni getötet worden. Ab 1726 waren sie dann regelmäßig in Brandenburg:

\begin{tabular}{|c|c|c|}
\hline Jahr & $\begin{array}{l}\text { Besondere Häu- } \\
\text { fung um }\end{array}$ & Daten, sonstige Angaben \\
\hline 1726 & $\begin{array}{l}\text { Beeskow, } \\
\text { Crossen, } \\
\text { Lagow } \\
\text { Storkow }\end{array}$ & $\begin{array}{l}\text { „,in dem sie bald diese, bald jene Gegend überfal- } \\
\text { len und ausgeplündert“ } \\
\text { „seitdem die Mark fast nicht mehr verlassen“ } \\
\text { Fliegender Schwarm aus Polen und Schlesien }\end{array}$ \\
\hline $1727-1729$ & Lagow & \\
\hline $1726-1731$ & $\begin{array}{l}\text { Spiegelberg, } \\
\text { Sonnenberg }\end{array}$ & \\
\hline $1728-1730$ & Königswalde & \\
\hline $1727-1733$ & Zielenzig & \\
\hline $1729-1732$ & $\begin{array}{l}\text { Ziebingen, } \\
\text { Sonnenberg }\end{array}$ & \\
\hline 1729 & Göritz & \\
\hline $\begin{array}{l}1729 \\
1730-1731 \\
\end{array}$ & Drossen & $\begin{array}{l}1729 \text { Zuflug aus Polen } \\
1730-1731 \text { sekundäre Brut }\end{array}$ \\
\hline $1728-1730$ & $\begin{array}{l}\text { Schwiebus, } \\
\text { Züllichau } \\
\text { Beeskow/Frankfurt }\end{array}$ & \\
\hline $1730-1732$ & $\begin{array}{l}\text { Gr. Kienitz/ } \\
\text { Wusterhausen }\end{array}$ & \\
\hline $1727-1732$ & $\begin{array}{l}\text { Schalach, Brakwitz } \\
\text { Treuenbrietzen }\end{array}$ & \\
\hline $1729-1731$ & Müncheberg & \\
\hline $1730-1732$ & $\begin{array}{l}\text { Straußberg } \\
\text { Gütergotz }\end{array}$ & \\
\hline 1735 & Neuentempel & \\
\hline 1739 & Neuentempel & \\
\hline
\end{tabular}

${ }^{671}$ Bekmann, J. C. (1751): Historische Beschreibung der Chur und Mark Brandenburg, Voß: Berlin: Sp. $835 \mathrm{ff}$. 
Bekmanns Angaben, die in der vorstehenden Tabelle zusammen gefasst sind, enden um 1740 mit folgender Bewertung „Haben also das Sternbergische, Züllichowische und Krossensche Land und den größten Teil der Mittelmark bis an die Havel überzogen, über welche sie mit vollem Haufen nicht gekommen.[...] Ist also das Havelland bis 1740 damit verschonet, auch die Uckermark, Priegnitz und Altmark davon befreit geblieben."

Schwerpunkte des Auftretens waren die Gebiete südlich der Warthe und rechts der Oder (Sternberg, Züllichau), nach Süden hin durch den OW-Verlauf des Oderbogens begrenzt, sowie links der Oder mit der nördlichen Niederlausitz und in einem Gürtel vom Amt Lebus bis zum Teltow. Betroffen waren vor allem Regionen Brandenburgs, die an Flußauen grenzten oder sie beherbergten, erklärbar aus den entwicklungsbiologischen Ansprüchen der Insekten. Dass die Heuschrecken sich westlich der Havel nicht niederlassen konnten, obwohl die Oberhavel wegen ihrer geringen Breite kaum ein Hindernis darstellen konnte, wird eher mit der erfolgreichen Trockenlegung des Havelländischen Luchs $(1718$ - 1724) zusammenhängen. ${ }^{672}$ Das Muster ist erkennbar und konsistent mit den allgemeinen biologischen Grundlagen: entweder sorgte ein Heuschreckenschwarm aus dem europäischen Südosten für den initialen Anstoß zur nachfolgenden Heuschreckenvermehrung oder infolge günstiger Witterungsverhältnisse entwickelten sich länger im Boden ruhende Eier zu Heuschreckenlarven und flug- und fortpflanzungsfähigen Imagines, deren Eiablage das nächstjährige Auftreten sicherte. Es folgten zum Teil mehrere heuschreckengünstige Jahre aufeinander, bis ungünstige Populationsdynamiken oder Witterungsverhältnisse das jährlich konstante Auftreten aussetzen ließen.

Nach 1739 sind, ebenfalls vorzugsweise für den brandenburgischen Osten, weitere Heuschreckenjahre bekannt: 1748, 1750, 1752, 1753, 1754, 1760, 1761, 1763, 1777, 1782, 1783, 1784, 1785.673 Darunter waren nur vier Jahre, denen nicht mindestens ein weiteres Heuschreckenjahr folgte. Die längste HeuschreckenSequenz betrug vier Jahre (1782 - 1785), die Schadensausmaße waren 1752 - 1754 vermutlich am größten. Innerhalb dieses Tripletts wurde 1753 das bedeutsame Heuschrecken-Edikt erlassen (s.u.).

Angaben über Heuschreckenjahre variierten, vermutlich wegen genutzter unterschiedlicher Quellen und damit verbundenen Differenzen in den Angaben der Zeitzeugen und deren Bewertung durch spätere Quellennutzer. So gab Bodenheimer 674 für Brandenburg Heuschreckenjahre wie folgt an: „1730, 1733/39, 1748/50, 1752/54“ und für das 19. Jh. „1826/27, 1844, 1874/76, 1883.“ Bodenheimer ori-

\footnotetext{
672 Weitere größere Meliorationsmaßnahmen in Brandenburg-Preußen im 18. Jahrhundert: Oderburch 1747-1756; Silge 1747-1750; Rhinluch 1773-1777; Warthebruch 1765-1786; Drömling 1786.

${ }^{673}$ Herrmann, B. (2003): Die Entvölkerung der Landschaft. Der Kampf gegen „culthurschädliche Thiere" in Brandenburg im 18. Jh. In: Bayerl, G. / Meyer, T. (Hg.): Die Veränderung der Kulturlandschaft (= Cottbuser Studien zur Geschichte von Technik, Arbeit und Umwelt 22), Waxmann: Münster u. a., S. 33-59.

${ }^{674}$ Bodenheimer: Geschichte, S. 39.
} 
entierte sich u. a. an der kleinen Schrift von Körte. ${ }^{675}$ Darin hieß es: „Die Jahre, in welchen bald diese, bald jene Provinz Deutschlands von den Heuschrecken verheerend heimgesucht worden, sind, soviel mir auszumitteln möglich war, 1475, 1527, 1636, 1686, 1693, 1696, 1712, 1714, 1715, 1719, 1727, 1728, 1729, 1730, $1731,1734,1746,1747,1748,1749,1750,1752,1753,1754,1759,1763,1803 .{ }^{\text {“676 }}$ Körte selbst sah sich durch das Heuschreckenauftreten im Jahr $1827 \mathrm{zu}$ seiner Schrift veranlasst, so dass er die Reihe hätte fortsetzen können.

Offenbar unterschied Bodenheimer zwischen leichterem, lokalen und schwerem, überregionalen Heuschreckenbefall, denn in der Gesamtübersicht ${ }^{677}$ über Heuschreckenjahre für den Zeitraum 1701 - 1750 lautete seine Angabe über Heuschreckenjahre „Deutschland: 21 (42).“ Bodenheimer hat aus den bekannten Heuschreckenjahren zwischen 1301 und 1750 auf der Basis der ihm bekannten Heuschreckenjahre zwischen 1701 - 1750 hochgerechnet, dass für Deutschland nur $28 \%$ aller Heuschreckenjahre historisch überliefert wären. Da Bodenheimer in seine Erwägungen noch keine klimatischen Schwankungen als determinierenden Faktor einbeziehen konnte, müssen seine Schätzungen des Überlieferungsdefizits als zu hoch gelten.

Innerhalb dieser Arbeit orientieren wir uns für das 18. Jh. an der Zusammenstellung von Herrmann, ${ }^{678}$ die sich für Brandenburg auf die Aktenlage im Geheimen Staatsarchiv Berlin stützt. ${ }^{679}$ Weder die Quellenlage noch eine ihr angemessene Hermeneutik gestatten jedoch, nach „schweren“ oder „leichten“ Heuschreckenjahren zu differenzieren.

Ausführlich ist die Behandlung des Lemmas „Heuschrecke“ in der Enzyklopädie von Krünitz, ${ }^{680}$ der auch spätere Dekaden als Bekmann überblickte. Seine Darstellung ist aus zwei Gründen besonders interessant. Einmal war Krünitz durch seine Lebensmittelpunkte Frankfurt/Oder und Berlin mit den brandenburgischen Verhältnissen bestens vertraut, was sein Text auch entsprechend widerspiegelt. Der zweite Grund ist in der Ausrichtung der Enzyklopädie selbst zu sehen. ${ }^{681}$ Die Er-

${ }^{675}$ Körte war Professor an der königl. Akademie für Landbau zu Möglin, am Rande des Oderbruchs, jener landwirtschaftlichen Station, die auf A.v.Thaer zurückgeht. Körte schreibt durchaus aus der brandenburgischen Perspektive, ohne diese allerdings zu sehr zu betonen.

${ }^{676}$ Körte, F. (1828): Die Strich-, Zug- oder Wanderheuschrecke, ihre Beschreibung, Verheerung in jetzigen und frühern Zeiten, und die Mittel zu ihrer Vertilgung, Rücker: Berlin: S. 4.

677 Bodenheimer: Geschichte, S. 45.

${ }^{678}$ Herrmann (2003): Entvölkerung.

${ }^{679}$ Geheimes Staatsarchiv Preußischer Kulturbesitz, II. HA, Kurmark Materien, Tit. CCLXVIII, Nr. 2, Vol. I-III.

${ }^{680}$ Johann Georg Krünitz wurde 1728 in Berlin geboren, lebte von 1749 bis 1759 als Arzt in Frankfurt/Oder, kehrte dann nach Berlin zurück und begann 1773 mit der Herausgabe der Enzyklopädie, deren erste 72 Bände er bis zu seinem Tode 1796 selbst erarbeitet hat. Das Lemma Heuschrecke ist in Bd. 23 abgedruckt, der in erster Auflage 1781, in zweiter 1790 erschien.

${ }^{681}$ Der vollständige Titel der Enzyklopädie lautet: „Oekonomische Encyklopädie oder Allgemeines System der Staats- Stadt- Haus- und Landwirthschaft in alphabetischer Ordnung“ 
wähnung von Schadenspotentialen bzw. von Schäden erhält dadurch ein besonderes thematisches Gewicht.

Nach einer kurzen Einführung in die Heuschreckensystematik widmete Krünitz den größten Teil seines Artikels der mitteleuropäischen Bedeutung der Wanderheuschrecke.682 Einen frühen Einfall dieser „schädlichsten Art der Heuschrecken“ im Nachbarland Polen und in Schlesien nannte er für 1475. Zur Anwesenheit von Schwärmen in der Mark Brandenburg schrieb er: „Und wegen der Beschaffenheit des Bodens und der Nachbarschaft mit Polen, haben auch einige Provinzen der Mark Brandenburg, nebsteinem Theile von Pommern, Schlesien und der Niederlausitz, seit undenklichen Jahren, das Unglück gehabt, daß ihre Felder, Gärten, Weinberge und andere Fruchtländer, durch die Zugheuschrecken abwechselnd verwüstet worden sind." Im Laufe des Artikels hob er für die Mark besonders die Jahre 1731, 1749, 1750, 1752 und 1753 als Heuschreckenjahre hervor.

Es folgte eine Beschreibung von Morphologie, Verhalten und Lebenszyklus der Kerfe, denn „,man muß aber seinen Feind völlig kennen, wenn man sich in eine gehörige Verfassung gegen ihn setzen soll." Krünitz erläuterte unter anderem bereits, wie sich eine mitteleuropäische Landplage aus einer steigenden Populationsdichte in den südosteuropäisch-vorderasiatischen Verbreitungsgebieten der Insekten entwickeln konnte; wie die Tiere Kräfte sparend „wie eine Wolke“ „mit dem Winde streichen" und warum die Landschaftsstruktur und der sandige Boden Brandenburgs ihnen ideale Bedingungen boten, solange die Klimafaktoren in einem tolerierbaren Maß blieben.

Fast alle Feldfrüchte im Winter- sowie im Sommerfeld seien dem Fraß der Heuschrecken ausgesetzt. Eine der wenigen Ausnahmen bildete nach Krünitz der Buchweizen.

Die von ihm genannten Bekämpfungsmaßnahmen gegen die Heuschrecken gaben im Wesentlichen den Inhalt der preußischen Edikte wieder, ${ }^{683}$ welche er auch zitierte, beginnend mit dem Edikt vom 13. April 1731. Besonders wichtig erschienen ihm das Pflügen der Äcker zur vorgesehenen Feldbauzeit und das Aufsammeln der Eier auf Feldern, Brachen und Säumen im Herbst und Frühjahr. Gegen die jungen, noch nicht flugfähigen Heuschrecken empfahl er das Eintreiben von Schweinen und das Zusammentreiben der Sprengsel in Gräben. Die 1752er/53er Edikte gab er sehr ausführlich, wenn auch in eigener Formulierung wieder (hierzu s.u.).

Zeitlich später als Krünitz veröffentlichte Borgstede eine Statistische Topographie Brandenburgs.684 Borgstede erstellte sehr sorgfältige und umfassende Artenlisten von Tieren und Pflanzen der Kurmark, erwähnte aber die Heuschrecken überraschender Weise nicht. Die Insekten zählte er - ausdrücklich ihrer Artenvielfalt

\footnotetext{
${ }^{682}$ Krünitz, Lemma „Heuschrecke“, S. 385 ff.

683 Ebd.: S. 424 ff.

${ }^{684}$ Borgstede (1788): Beschreibung.
} 
wegen - nicht auf, sondern beschränkte sich auf zwei wirtschaftlich nützliche: Das damals in einheimischer Zucht genutzte Neozoon Seidenspinner und die Honigbiene. Ein Hinweis auf die wirtschaftlich - im negativen Sinne - ebenfalls bedeutsamen Schädlingskerfe, wie etwa Nonnen, Kiefernspinner oder eben Heuschrecken erfolgte nicht. Vielleicht wären sie dem nie erschienenen zweiten Theil seiner Topographie vorbehalten gewesen.

Bratring, der 15 Jahre nach der zweiten Auflage von Band 23 der Enzyklopädie von Krünitz mit der Veröffentlichung seiner Statistische Topographie Brandenburgs (1804-09) begann, sah offensichtlich ebenfalls keine Veranlassung, auf die Agrarschädlinge und damit auch die Heuschrecken einzugehen. Das Thema stand also schon 1804 nicht mehr im Vordergrund. Da Bratring aber - im Gegensatz zu Borgstede - keine allgemeinen Ausführungen zur Tier- und Pflanzenwelt machte, scheint die Lücke auch aus anderen Gründen erklärbar.

Alle erreichbaren Angaben zusammengefasst, bestätigt sich die Vermutung, dass bis ins frühe 18. Jh. die Heuschrecken in Brandenburg selten waren, dass sie im fortschreitenden 18. Jh. häufig wurden und im 19. Jh. nicht nur wieder seltener wurden, sondern ihr Auftreten auch erlosch.

\section{Die Perspektive der Betroffenen}

\subsection{Die Edikte}

Begreift man Gesetzgebung (bzw. deren Äquivalente) als eine Handlungsanweisung infolge akuten Regelbedarfs, dann sind Verordnungen usw. Reaktionen auf vorausgegangene Entwicklungen und Ereignisse, für die sich das Bewusstsein einer Regelungsnotwendigkeit durch staatliche Institutionen einstellt. Diese Notwendigkeit kann sich auf das spezifische Handlungsmonopol staatlicher Stellen beziehen und/oder auf das Ausmaß des Ereignisses, dessen Potential mit der Fürsorgeverpflichtung des Staates gegenüber seinen Einwohnern kollidiert und/oder eine koordinierte Handlungsweise zahlreicher Personen erforderlich machen.

Wenn es, wie 1731 und 1752/53, zu Heuschreckenedikten kam, dann offenbar deshalb, weil das Zutreffen aller dreier Randbedingungen gegeben war (für notwendig erachtete Verwaltungsmaßnahme; Bedrohung des Schutzversprechens für die Bevölkerung; koordiniertes Vorgehen).

Die insgesamt vier Edikte zur Heuschreckenbekämpfung im 18. Jh. spiegelten die wachsende Erfahrung im Umgang mit den Insekten wider. Das erste Gesetz wurde am 13. April 1731 publiziert. Um eine umfassende Verbreitung zu gewährleisten, sollte sein Inhalt an öffentlichen Orten angeschlagen, in den Kirchen von den Kanzeln gelesen und durch die Obrigkeiten verbreitet werden. Diese waren zu 
monatlichen Berichten über die Entwicklung der Situation und die Umsetzung der Weisungen verpflichtet. Das Edikt enthielt sechs Handlungsanweisungen:

1. Das Sammeln und Töten der jungen Heuschreckenlarven im Frühjahr direkt nach dem Schlüpfen, wobei für $1 / 2$ Scheffel (27,48 Liter) Jungtiere oder eine Metze Eier jeweils zwei Groschen Prämie gezahlt werden sollten.

2. Das Anlegen von Gräben gegen die noch nicht flugfähigen Jungtiere, wobei innerhalb der Gräben im Abstand von 15-16 Schritt Fanglöcher angelegt werden sollten. Die Tiere sollten von Arbeitern in die Gräben getrieben werden, sammelten sich dort in den Fanglöchern, um dort zu Tode gestampft zu werden. Anschließend mussten sie herausgenommen und vergraben werden. Die hierfür bestellten Helfer sollten für die Zeit der Arbeit 2-3 Reichsthaler bekommen.

3. Die Maßnahmen sollten so lange durchgeführt werden, bis die Felder und Wiesen vom Ungeziefer befreit waren.

4. In den Heiden und Wäldern sollte die Vertilgung durch die Hirten und Buschläufer geschehen und gegebenenfalls durch die umliegenden Dörfer.

5. Auf den Feldern sollten große Laken ausgebreitet werden, auf die die Heuschrecken getrieben und dort beispielsweise mit siedendem Wasser übergossen werden sollten.

6. Im Juni sollten die flugfähigen Jungtiere oder ankommende Zugsprengsel morgens, wenn sie an den Kornähren saßen und mit Tau überzogen waren, mit Käschern abgesammelt werden.

Schon am 24. Oktober desselben Jahres wurde das zweite Edikt als Ergänzung des vorhergehenden erlassen, da ,,wofern diesem höchstschädlichem Unfgeziefer nicht durch fernere möglichste Veranstaltungen entgegen gegangen wird, dasselbe doch wiederum überhand nehmen möchte." Nun wurde unter Androhung von Geldstrafen (für den Einzelnen mitunter 3-5 Thaler, für die ganze Gemeinde mindestens 20 Thaler) zusätzlich befohlen, die Brut bereits im Herbst einzusammeln und die Felder sowie die nicht zur Weide benötigten Brachen noch vor dem Winter flach umzupflügen, damit die Eier während des Winters erfroren. Jeder Bauer und Halbspänner wurde verpflichtet, im Herbst zwei Metzen und jeder Coßäthe eine Metze (3,4 Liter) Heuschreckenbrut unentgeltlich zu sammeln und gegen ein Attest bei der Obrigkeit abzuliefern. Für jede weitere Metze erhielten die Sammler zwei Groschen Belohnung (24 Groschen = 1 Taler.). Die im Frühjahr zu ziehenden Gräben wurden nun auf mindestens eine Elle $(\mathrm{ca} .65 \mathrm{~cm})$ in Breite und Tiefe festgelegt, jede Ortschaft wurde verpflichtet, ihre Nachbarn bei einer dortigen Kalamität mit Arbeitern zu unterstützen und die Forstbedienten wurden für die regelmäßige Untersuchung der Wälder verantwortlich.

Zu einer weiteren Ergänzung der Vorgehensweise schien es die nächsten 21 Jahre keine Notwendigkeit oder keine neuen Erkenntnisse gegeben zu haben. Das „,renovirte und erneuerte Edict wegen Vertilgung der Heuschrecken und Sprengsel“ wurde am 24. November 1752 erlassen, weil ,sich die Sprengsel oder Heu- 
schrecken im vergangenen Sommer in großer Menge eingefunden und an verschiedenen Orten großen Schaden angerichtet haben und die Brut hinterlassen haben, weshalb zu befürchten ist, daß sie im kommenden Frühjahr in noch größerer Menge erscheinen werden und das Unglück des Sprengsel=Fraßes allgemein werden dürfte.“ Ein Jahr später, am 30. November 1753 kam es dann schließlich zum vierten Heuschreckenedikt.

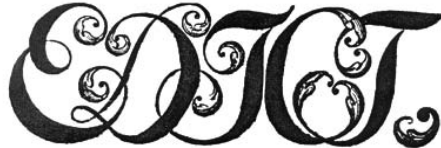

grisenen

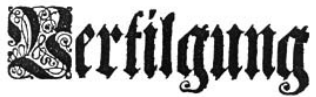

Dit

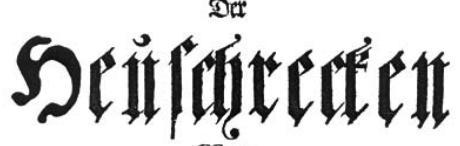

2014

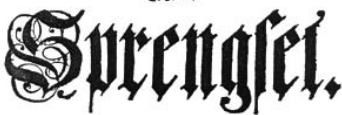

De Dato Betlin/ ben I3ten April. 1731.

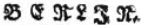

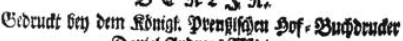

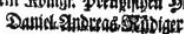

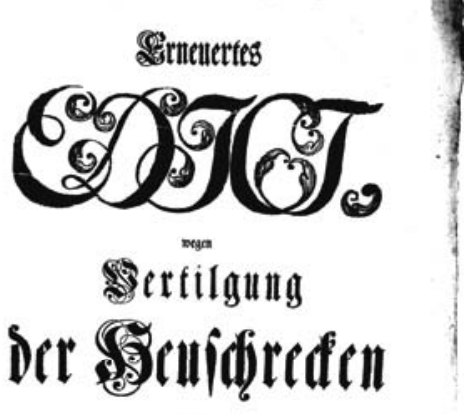

unb

Wrengiel.

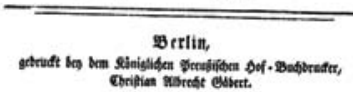

Cbrifian sistedt etbet.

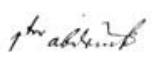

Abb. 5: Facsimiles der Titelseiten der Heuschreckenedikte;

Links: 1731, rechts: Andruck des Edikts $1753^{685}$

Die auffälligsten Fortschritte in den neuen Edikten waren die Aufnahme biologischer Schädlingsbekämpfungsmaßnahmen und die Berücksichtigung des natürlichen Verhaltens der Heuschrecken. Die Untertanen wurden verpflichtet, zur Vertilgung der Heuschreckenbrut die befallenen Felder und Brachen im Herbst mit ihren Schweinen zu betreiben. Schweine und Puten wurden ebenfalls als wirksames Mittel gegen bereits flugfähige Sprengsel empfohlen. Das Edikt wies auf die Notwendigkeit hin, sich beim Treiben der Heuschrecken an deren Verhalten anzupassen. So würden sie stets lieber von Ost nach West sowie mit dem Wind wandern. Die Ausdehnung der Gräben wurde 1752 auf die jeweilige Größe der Tiere abgestimmt. Bei den bereits flugfähigen Tieren sollten sie mindestens $1 \frac{1 / 4}{4}$ Elle breit

685 aus: Geheimes Staatsarchiv Preußischer Kulturbesitz, Berlin-Dahlem, II. HA, Kurmark Materien, Tit. CCLXVIII, Nr. 2, Vol. I und Vol. II. 
und tief sein, während das 1753er Edikt für die eben erst geschlüpften Sprengsel nur $2 \frac{1}{2}$ Fuß Breite und $1 \frac{1}{2}$ Fuß Tiefe (ca. $30 \mathrm{~cm}=1 \mathrm{Fu}$ ) vorschrieb.

Dieses letzte Edikt spezifizierte das System der im Herbst unentgeltlich zu sammelnden Heuschreckenbrut, indem es Regelungen über die Sammelverpflichtung weiterer Personengruppen wie Forstbediente mit Landbesitz, Ackerbürger in den Städten, Grundbesitzer ohne Ackerland und Prediger enthielt. Da frühere Edikte zu den Sammelpflichten dieser Personengruppen keine Angaben machten, wurden sie vermutlich erst mit dem 1753er Edikt verpflichtet. Diese Annahme könnte dann auch die auf den ersten Blick wie dysfunktional erscheinende reduzierte Abgabenpflicht für Landbesitzer gegenüber dem 1731er Edikt erklären. Bauern mussten jetzt nur noch eine Metze (24.10.1731: 2 Metzen), Halbbauern zweidrittel Metzen (1731: 2 Metzen) und Coßäthen 1/2 Metze (1731: 1 Metze) abliefern.

Durch das 1753er Edikt wurden auch die Durchführungsvorschriften beim Eintreiben der Heuschrecken im Frühjahr genauestens vorgegeben. Es wurde beispielsweise bestimmt, welche Obrigkeiten auf den Stadtfeldern bzw. auf den Dörfern für die Einteilung der Personen zuständig waren, wie viele Personen von welchen Untertanen gestellt werden mussten, in welchen Fällen auch Frauen und Kinder Teil der Mannschaften sein sollten und wer für die Aufsicht der Arbeiten zuständig war.

Im Prinzip galt bis 1752 das, was auch schon biblisches und antikes Wissen über Heuschreckenbekämpfung war. ${ }^{686}$ Die Edikte verordneten zwar das Sammeln, lobten aber auch Löhne und Prämien aus. Damit wurde bei der Heuschreckenbekämpfung zumindest teilweise grundsätzlich anders verfahren als bei der Sperlingsbekämpfung, die von vornherein als reine „Kopfsteuer“ angelegt wurde.

In Zusammenhang mit der Heuschreckenbekämpfung ist erstaunlich, dass die Entlohnungen der Sammlungen in Frühjahr und Herbst unterschiedlich erfolgte.

\subsection{Die Aktenlage}

Unsere Kenntnis gründet sich auf die Akten des Staatsarchivs in Berlin aus dem 18. Jh. ${ }^{687}$ Die ersten Einträge stammen aus 1731, die letzten aus 1785.

Im Brandenburgischen Landeshauptarchiv in Potsdam finden sich weitere Akten aus dem 18. Jh., welche teilweise dieselben Sachverhalte behandeln. Beispielsweise lagern hier Berichte einzelner Landräte, die der Kurmärkischen Kammer über den Zustand der Heuschrecken in ihren jeweiligen Kreisen berichteten. Die Kammer

\footnotetext{
686 Eine sehr umfassende Zusammenstellung der antiken Verhältnisse bei Graßl 1996, die bei Huber 2005 vorgestellte antike Heuschreckenabwehr ist ohne neue Einsichten. -- Den spätmittelalter- und frühneuzeitlichen Heuschreckenplagen im Alpenraum hat sich unlängst Rohr 2009 gewidmet. (Bibliographische Angaben hierzu siehe Literaturverzeichnis)

687 Geheimes Staatsarchiv Preußischer Kulturbesitz, Berlin-Dahlem, II. HA, Kurmark Materien, Tit. CCLXVIII, Nr. 2, Vol. I-III.
} 
sammelte die Berichte und leitete den wesentlichen Inhalt an das Generaldirektorium $^{688}$ weiter. Zusätzlich finden sich hier einige Akten der Ämterebene.

Klagen bzw. Eingaben von Betroffenen sind, bis auf ganz wenige Ausnahmen, in den Akten nicht enthalten. In der Hauptsache liegen Sachstandsberichte von Bekämpfungsmaßnahmen vor gemäß der gültigen Edikte von 1731 (April und Oktober), 1752 und 1753. Repräsentativ für den Inhalt der Einträge, wenn auch nicht hinsichtlich seines Adressaten, ist folgender Bericht aus Vol. II des Aktenkonvoluts:

Berlin den 20. Juli 1753

Die Churmärkische Kammer berichtet, daß die bisherigen Anstalten zum Heuschreckentreiben im Ober-Barnimschen-Kreise an jetzo cessiren:

Eure Königlichen Majestät müssen wir hierdurch untertänigst anzeigen, wie der Landrat von Forestier unterm 16. huius wegen der zu Tilgung der landverderblichen Heuschrecken im Ober-Barnimschen-Kreise vorgekehrten Anstalten berichtet, daß

1. die Stadt Neustadt.Eberswalde auf eine unterm 29. m.p. geschehene ander weite Requisition und Vorstellung, daß wegen Situation derer inficirten Örter die Höfe auf der Nähe nicht employret werden könnte, sich unterm 30. ejusd. zu Stellung 120 Manns und zum Graben tüchtige Weibs-Personen erkläret, auch solche nach der von ihm gemachten sub A beiliegenden Repartition und denen benannten Orten sich eingefunden und zwei volle Tage unter Aufsicht derer dazu commandirten Feldjäger denen notleidenden Dörfern mit Graben und Eintreiben die versprochene Hilfe wirklich geleistet. Außerdem

2. derer inficirten Orte Gemeinden täglich mit so viel Personen, als im Dorfe aufzubringen gewesen, solche Arbeit continuiret und eine fast unglaubliche Menge dieses schädlichen Ungeziefers vertilget, so daß die wenigste Quantität zu nennen, gewiß über tausend Wispel im ganzen Kreise gerechnet, eingegraben und getötet worden: wie dann

3. die in denen inficirten Dörfern wohnhaften Tagelöhner und Hausleute ohnentgeltlich hierzu, wenigstens um den dritten Tag mitgeholfen und da

4. also selbige für Geld zu mieten nicht nötig gewesen, hingegen in den einen Dörfern, so meist über vier Meilen entlegen, keine Hausleute auch für das im Kreise gewöhnlichen Tagelohn a Mannsperson vier Groschen aufzubringen gewesen, auch aus gleiche Ursach der Entlegenheit die in denen Städten Wrietzen, Neustadt und Freyenwalde befindliche Tagelöhner, so ohne dem bei denen verschiedenen Bauern mit Allaunwerk ihren guten und beständigen Verdienst finden, sich dazu nicht verstehen wollen, die in Straußberg Wohnhaften aber von der Bürgerschaft selbst zur Heuschreckenarbeit gebracht worden über dem die inficirten Dörfer keine auswärtige Hilfe weiter verlanget,

688 d.i. die Preußische Generalverwaltung. 
noch nützlich zu gebrauchen gewest; so sei hieraus abzusehen, warum in diesem Kreise nicht so, wie in dem Nieder-Barnim und Lebusischen Tagelöhnern vor Geld angenommenen worden zu geschweigen, daß eine allzu große Anzahl Menschen zu gänzlich Durchsicht und Reinigung derer weitläufigen Dorf- und Heide-Länder sonderlich im Amte Rüdersdorf erforderlich gewesen sein würden, ja

5. da aus denen benachbarten Kreisen auf die einmal gereinigte Feldmarken immer aufs neue sich wieder eine Menge Heuschrecken eingefunden, und weil sie schon großgewachsen, den Roggen mit einmal eingenommen, worin man ihnen nicht beikommen könne. Nunmehro auch

6. die Ernte überall anginge, und zumalen denen Heuschrecken, da sie schon fliegen, durch Eintreiben ferner kein Abbruch geschehen könnte, welches auch die beiden comandirten Feld-Jäger, Waldknecht und Schrader selbst vorgestellet, und um ihre Demission angehalten, so hätte er ihnen solche auch nach Bezahlung der ausgemachten douceurs den 10. hujus ohne Bedenken erteilet, weil ihre längere Gegenwart ohne allen Nutzen gewesen. Ob also gleich dieser Kreis durch Heuschreckenfraß immer großen Schaden litte, und teils Orten, wo sämtliche Feldfrüchte ruinieret wären, in dem größten Elende augenscheinlich sich befände. So sei solches je dennoch nicht denen unterlassenen Anstalten und Fleiß zu Tilgung des Ungeziefers beizumessen, weil solche in erstaunender Menge in solchen Gegenden von andern Orten sich eingefunden, und dahero ganz unmöglich sei, dieses Ungeziefer gänzlich auszurotten. Wir haben hierauf dem Landrat von Forestier aufgegeben, eine Liquidation von sämtlichen Kosten, so bei der Vertilgung der Heuschrecken verwandt worden, einzusenden, und sobald solche einläuft, werden wir selbige alleruntertänigst überreichen.

Es ist zwar einzuräumen, dass die 1753er Kalamität offenbar von besonderem Ausmaß war. Die Aktivitäten der Administration waren jedoch auch in ,,schwächeren“ Heuschreckenjahren nicht grundsätzlich andere.

Das im konkreten Beispiel beschriebene Ausmaß, die getroffenen Vorkehrungen und Bekämpfungen können keinen Zweifel aufkommen lassen, dass die Bedrohung auch ernsthafte Dimensionen erreichen konnte, dass man sich dann aber auch realistisch (schicksalergeben?) aus der aktuellen Bekämpfung der Imagines mangels geeigneter Mittel zurückzog.

Eine nächste wirksame Bekämpfungskampagne hätte sich erst auf die abgelegten Eier ab September beziehen können. Sie wurde im Vortrag der Kammer nicht aufgeführt.

Der Registrierungsaufwand durch die Administration, der sich in den Akten in Form von Ortsangaben, Daten und Quantitäten niederschlug, hatte zweierlei Hintergründe. Eine Folge der Edikte wie der Aktenführung war die zentrale Sammlung von Kenntnissen, die dem künftigen vorbeugenden Verhalten zugute kom- 
men konnte. Wenn nicht Vorbeugen, dann war mindestens akute koordinierte Abwehr unter obrigkeitlicher Aufsicht eine logische Folge des staatlichen Selbstverständnisses, das sich nach Meyer ${ }^{689}$ einem Glückseligkeitsversprechen für die Untertanen verpflichtete. Staatliches Handeln war daher sowohl von der Bedrohungslage wie vom Selbstverständnis bestimmt.

Insgesamt bestätigen die Akten, dass sich in der gesamten Kurmark und Neumark Sprengsel-Kalamitäten seit 1730 fast lückenlos bis ans Ende des Jahrhunderts nachweisen lassen. Betroffen waren selbstverständlich nicht alle Kreise in jedem Jahr, auch nicht alle Ämter in den Kreisen. Bringt man aber die diatopischen Berichte in eine Zeitreihe, dann litt Brandenburg im 18. Jh. praktisch durchgängig unter Heuschreckenbefall.

\subsection{Der Schaden wird in volkswirtschaftliche Perspektive gerückt, bleibt aber Angelegenheit der Betriebswirtschaft und des Privatrechts}

Mindestens die drei Jahre 1752, 1753 und 1754 müssen den meisten Oder-nahen Arealen Brandenburgs ein außergewöhnlich überdurchschnittliches SprengselAuftreten beschert haben. Das aus aktuellem Anlass „Renovirte und erneuerte Edict, wegen Vertilgung der Heuschrecken oder Sprengsel“" vom 24. Nov. 1752, konnte frühestens im Frühjahr 1753 greifen, wenn sich die Möglichkeit des Eiersammelns vor der Frühjahrsbestellung bot.

In den Akten befindet sich eine Denkschrift des Geheimen Justizrats von Oskiercka, der im Lebusischen das Gut Lichtenberg seit 1746 bewirtschaftete. Diese Denkschrift wird im Folgenden im Wortlaut wiedergegeben. ${ }^{690}$ Selbstverständlich ist sie allererst der Text eines durch die Kalamität wirtschaftlich Betroffenen. Sie ist ein Text, der, in eher literarischer und ins Allgemeine gesteigerter Form, einen Augenzeugenbericht gibt. Sie ist auch eine Schrift, die von einem Rechtskundigen und einem mit der Regelung praktischer Abläufe eines Gemeinwesens Vertrauten verfasst wurde. ${ }^{691}$

Als Quelle steht diese Denkschrift zwischen einer auf Entlastung zielenden Eingabe eines Supplikanten und einer Perspektive, die vorgibt, auf das Allgemeinwohl zu zielen. Oskierckas Vorschläge zur praktischen Organisation der Bekämpfungsmaßnahmen waren nun allerdings nicht innovativer als die Edikte 1752/1753,

${ }^{689}$ Meyer, T. (1999): Natur, Technik und Wirtschaftswachstum im 18. Jh.: Risikoperzeptionen und Sicherheitsversprechen. Wirtschaftswachstum, Rohstoffe und Technik im staatswissenschaftlichen Diskurs des ausgehenden 18. Jh.s (= Cottbuser Studien zur Geschichte von Technik, Arbeit und Umwelt 12), Waxmann: Münster u. a.

${ }_{690}$ An dieser Stelle ist der Leser um Lektüre der im Anhang im Wortlaut wiedergegebenen Denkschrift gebeten (Geheimes Staatsarchiv Preußischer Kulturbesitz, II. HA, Kurmark Materien, Tit. CCLXVIII, Nr. 2, Vol. II).

${ }^{691}$ Ein wegen seiner subjektiven Perspektive unmittelbarer wirkender Bericht von K. F. von Benekendorf (1775) findet sich in Auszügen bei Körte (S. 5 ff.) wiedergegeben. Körte zitiert einen weiteren Zeitzeugenbericht aus dem Kirchenbuch des Gutes Reichenow aus 1752 (S. 7 ff.). Beide Zeitzeugenberichte stehen hinsichtlich des von ihnen skizzierten Schadensausmaßes in einiger Differenz zur eher dilatorischen Haltung, die Krünitz bezüglich der Heuschreckenschäden insgesamt einnimmt. 
die gleichen Vorstellungen folgten. Wenn hier ein Betroffener dasjenige forderte, was das Edikt des Vorjahrs 1752 substantiell längst vorgab, obwohl er selbst zu den Besserinformierten des Landes gehörte, ${ }^{692}$ wirft dies ein bezeichnendes Licht auf die Schwierigkeit praktischer Staatsführung. Interessant an der Denkschrift ist allerdings auch und besonders, dass sie keinen Vorschlag zur Deckung auftretender Schäden durch den Staat oder zur besonderen Entlastung der Betroffenen enthält.

Anders als bei anderen Schädlingen vermeintlicher oder tatsächlicher gesamtstaatlicher Dimension, etwa den Sperlingen, regulierte der Staat im Falle der Heuschrecken nicht mit direkten Steuern. ${ }^{693}$ Er verpflichtete die Untertanen zur Bekämpfungstätigkeit, ${ }^{694}$ auch durch ein Anreizsystem, indem Sammelgelder ausgegeben wurden. Von einer Beteiligung „staatlicher Kräfte“ "zu sprechen, ist gewiss euphemistisch, denn es handelte sich ja in der Regel nur um einen Anordnungen treffenden Landrat, der die Aufsicht wenigen Funktionsträgern, wie z.B. Feldjägern, übertrug. Die Bekämpfungsarbeit selbst wurde unseres Wissens nur ganz selten durch staatliches Personal, etwa Soldaten, vorgenommen oder unterstützt, ${ }^{695}$ sondern durchgängig von bedarfsabhängig angeworbenem Personal. An keiner Stelle schien die Idee einer Staatshaftung im praktischen Handeln der Administration auf. 696

Der etwas zynischen Deutungsalternative, wonach ein im Grundsatz hilfloser Staat seinen Untertanen das psychologische Ventil angesichts objektiver Hilflosigkeit bot, wie in Zusammenhang mit der Sperlingsbekämpfung diskutiert wurde, ${ }^{697}$ können wir keinen substantiellen Wirklichkeitswert zubilligen. ${ }^{698}$ Die bei der Regelung eines Heuschreckenschadens anzuwendenden Rechtsprinzipien waren nämlich vergleichsweise übersichtlich. Krünitz ${ }^{699}$ fasste sie mit dem Blick auf Pachtverhältnisse zusammen, also betriebswirtschaftlich besonders herausfordernde Unternehmungen. Die entscheidende Frage sei, ob ein Heuschreckenschaden im Verpachtungsfall zu den remissionsfähigen Unglücksfällen zu rechnen sei. Hier sei zu unterscheiden zwischen einem Heu-

\footnotetext{
${ }^{692}$ Es ist davon auszugehen, dass zumindest einem Teil der Gutsbesitzer die einschlägigen Edikte als Ausdruck verfügbar waren. Hierzu Fußnote bei Sander, L. (1902): Die Wanderheuschrecken und ihre Bekämpfung in unseren afrikanischen Kolonien, Reimer: Berlin: S. 533.

${ }^{693}$ Herrmann (2007): Beitrag.

${ }^{694}$ Die von den Edikten vorgeschriebene Verpflichtung zur Bekämpfungstätigkeit trifft theoretisch die gesamte Bevölkerung in den betroffenen Gebieten, könnte also als eine in Arbeit zu entrichtende Steuer aufgefasst werden.

695 z.B. wurden 1763 zur Sprengselbekämpfung 4 Feldjäger und 20 Fußjäger nach Lebus und Beeskow kommandiert. Grundsätzlich, wenn auch auf den äußersten Notfall beschränkt, konnte auch Militärpersonal zur Bekämpfung herangezogen werden (Rescript an die Churmärkische Kriegs-und Domainen-Kammer, die Vertilgung der Heuschrecken betreffend, vom 13. Juni 1753; Mylius, Sp. 485-486).

${ }^{696}$ Gemeint ist hier der Anspruch eines Betroffenen aus staatlich fehlerhaftem Handeln, also z.B. der unterlassenen Heuschreckenbekämpfung.

${ }^{697}$ Engler, B. / Bauer, H.-G. (2002): Dokumentation eines starken Bestandsrückgangs beim Haussperling (Passer domesticus) in Deutschland auf Basis von Literaturangaben von 1850-2000. In: Die Vogelwarte 41, S. 196-210.

${ }^{698}$ Das Argument haben Herrmann \& Woods (im Druck) für die Sperlingsbekämpfungen geprüft und abgelehnt.

${ }^{699}$ Krünitz, Lemma „Heuschrecke“, S. 479 ff.
} 
schreckenschaden, der durch eine örtliche Brut verursacht ist und jenem, der sich einem aus der Fremde herbei gewehten Zugschwarm verdankt.

Zur Abwendung der auswärtigen Zugheuschrecken ,,ist alle menschliche Vorsicht vergeblich, und es ist daher dieser Schade, so wie der Hagelschlag, zu denjenigen Unglücksfällen zu rechnen, bei welchen eine Vis divina zum Grunde liegt; und es kann daher einem Pächter, den solches Unglück trifft, deshalb keine Schuld beigemessen werden." Anders verhalte es sich hingegen bei Schäden, die infolge einheimischer Heuschrecken auftreten: „Die einheimischen Heuschrecken, welche an den Orten selbst erzeuget werden, sind nicht allein weniger schädlich, sondern der Schade kann auch durch vernünftige Vorsicht, wodurch man sie in ihrer Brut tilget, und durch Anwendung der im Vorhergehenden, besonders auch in den königl. preuß. Edikten, v. 13 Apr. und 24 Oct. 1731, vorgeschriebenen Mittel, verhütet werden. In so fern also ein Pächter auf einem gepachteten Gute eine Brut von Heuschrecken hat, und er zu deren Tilgung nicht die vorgeschriebenen Mittel anwendet: so hat er sich den in der Folge davon entstehenden Schaden selbst beizumessen, und kann von seinem Verpächter keine Vergütung dafür verlangen. Von selbst versteht es sich aber, dass, wenn die Heuschrecken, die ihm Schaden getan haben, auf dem Grund und Boden eines Nachbarn durch dessen Schuld ausgekommen sind, dem Pächter hierunter nicht zur Last gelegt, noch ihm die nach den Rechten zuständige Vergütung verschränkt ${ }^{700}$ werden könne.“

Der Heuschreckenschaden verblieb im Privatrechtlichen und wurde gedanklich den betriebswirtschaftlichen Verlusten zugerechnet. Darin, dass die Staatskasse die Lohnkosten für die angeheuerten Schädlingsbekämpfer übernahm, wäre ein gewisses Anerkenntnis zu sehen, wonach die Schädlingsbekämpfung eben auch einen volkswirtschaftlichen Aspekt haben konnte.

\section{Objektive Schadensabschätzungen}

Es ist erstaunlich, dass Supplikanten Schäden beklagten, Wissenschaftler vor der Bedrohung warnten und zum präventiven Handeln aufforderten, ${ }^{701}$ Denkschriften formuliert und Edikte erlassen wurden, aber die Bezifferung eines heuschreckenbedingten Schadens nirgends zu finden ist.

Schadensabschätzungen bedürfen nachvollziehbarer Grundannahmen. Für Brandenburg lassen sich gegebenenfalls zwar Einsaatmengen angeben, die Parzellengrößen sind jedoch nicht einfach zu erreichen und unseres Wissens auch nicht für die Ämter tabellarisch zugänglich. Über Abgabenregister würden sich gegebenenfalls Erntemengen ermitteln lassen. Man müsste weiterhin wetterbedingte Ernteschwankungen möglichen heuschreckenbedingten Ernteausfällen gegen rechnen. All diese Approximationsverfahren würden sich jedoch mit erheblichen Unschärfen zufrieden geben müssen, so

\footnotetext{
$700=$ versagt

701 Gleditsch, J. G. (1754): Abhandlung von Vertilgung der Zug-Heuschrecken und den eigentlichen Hülfs-Mitteln, die sich auf eine richtige und Naturmäßige Erkäntniß dieses Ungeziefers gründen, Voß: Berlin /Potsdam.
} 
dass es uns nicht verhältnismäßig erschien, uns um weitere Konkretisierungen zu bemühen. Richtig ist, dass sich aus den Akten Klagen über die von Heuschreckenbefall verursachten Schäden finden. Diese Schäden wurde jedoch nicht (nach unserer Kenntnis ist eine Schadensbilanz nur einmal in den Akten erhalten, s.u.) ins Verhältnis zu längerfristigen Ernteerträgen gestellt oder in sonst einer geeigneten Weise in seiner Größenordnung skizziert. ${ }^{702}$ Die Supplikanten und Beamten berichteten über gefüblten Schaden, nicht über zahlenmäßig abgeschätzte, objektive Ernteeinbußen. Diese Argumentationsweise entspricht dem Muster des 18. Jh.s. Anstelle heute geläufiger Belege in Zahlenform traten damals Überzeugungsargumente, deren Wirksamkeit von der Autorität des Vortragenden abhing. Entsprechend sind zeitgenössische Schätzungen, wenn sie denn überhaupt mit Zahlen unterfüttert wurden, oft Zeugnisse von Phantasiebegabungen unter den argumentierenden Parteien. ${ }^{703}$

Ebenfalls nicht für die Abschätzung des Schadensausmaßes geeignet sind Angaben zu Befallsdichten, weil es für solche Befallsdichten keine Bezugsgrößen zu einer aus ihnen abzuleitenden Schätzung des potentiellen Ernteausfalls gibt. ${ }^{704}$ Angaben über Befallsdichten selbst fehlen zudem. Für das Amt Lebus sind jedoch Berichte über Sprengsel-Sammlungen im Juni 1753 und Juli 1754 erhalten. Zu dieser Zeit sind Fraßschäden am Getreide ganz sicher bereits mit erheblichen Ernteausfällen verbunden. Im Juni 1753 wurden im Kreis Lebus rund $573 \mathrm{~m}^{3}$ Sprengsel eingesammelt (siehe hierzu Abb. 6), im Juli 1754 waren es auf annähernd der gleichen Fläche $366 \mathrm{~m}^{3} .{ }^{705}$ Beide Zahlen sprengen bereits die Vorstellungskraft. Doch der weitere oben aufgeführte Akteneintrag von 1753 berichtete dem König, dass im Ober-Barnimschen Kreis (schließt nach Norden an den Kreis Lebus an) „um die wenigste Quantität zu nennen, gewiß über tausend Wispel im ganzen Kreise gerechnet, eingegraben und getötet worden“ wären. Diese Zahl entspräche 1300 $\mathrm{m}^{3} .{ }^{706}$

\footnotetext{
702 Einen Anhalt für unsere Vorstellung könnten z.B. heuschreckenbedingte Ernteausfälle liefern, die von der FAO für das Heuschreckenjahr 1997 in Madagaskar angegeben werden. Dort kam es zu folgenden Ernteausfällen: bei Mais $60 \%$, bei Reis $30 \%$, bei Maniok $12 \%$ und bei Kartoffeln $30 \%$.

Wenn man nun von der zeitgenössischen Durchschnittsernte bei Getreide in Brandenburg („,das 5. bis 6. Korn") die Größenordnung 30\% als heuschreckenbedingten Ernteausfall annehmen wollte, wären nur 4 Körner als Ertrag übrig. Davon geht eines zur Saat weg und ein weiteres als Lagerverlust. Es verbleiben zwei Körner. Damit wird das Bedrohungsausmaß plötzlich vorstellbar und gewinnt ernsthafte Dimensionen, zumal noch kein weiteres Grundnahrungsmittel zur Verfügung steht, auf das elastisch ausgewichen werden konnte. Dieser Vergleich ist indes nur begrenzt zulässig, weil es keine heuschreckenbedingten linearen Ausfälle über die gesamte Ernte gegeben haben kann.

703 Beispiele hierzu bei Herrmann (2007): Beitrag.

${ }^{704}$ Krünitz berichtet darüber, dass bei einem Einfall der Heuschrecken in den Hafer während der frühen Wuchsphase des Getreides überraschender Weise keine nennenswerten Enteausfälle zu erwarten wären.

705 umgerechnet aus Rohdaten in Geheimes Staatsarchiv Preußischer Kulturbesitz, Berlin-Dahlem, II. HA, Kurmark Materien, Tit. CCLXVIII Nr. 2, Vol. II. Die Sammelliste für 1753 ist wiedergegeben in Herrmann (2007): Beitrag.

706 nach Bericht der Kurmärkischen Kammer zur Vorlage beim König am 20.7.1753. Unpaginierte Akte wie vorstehend.
} 


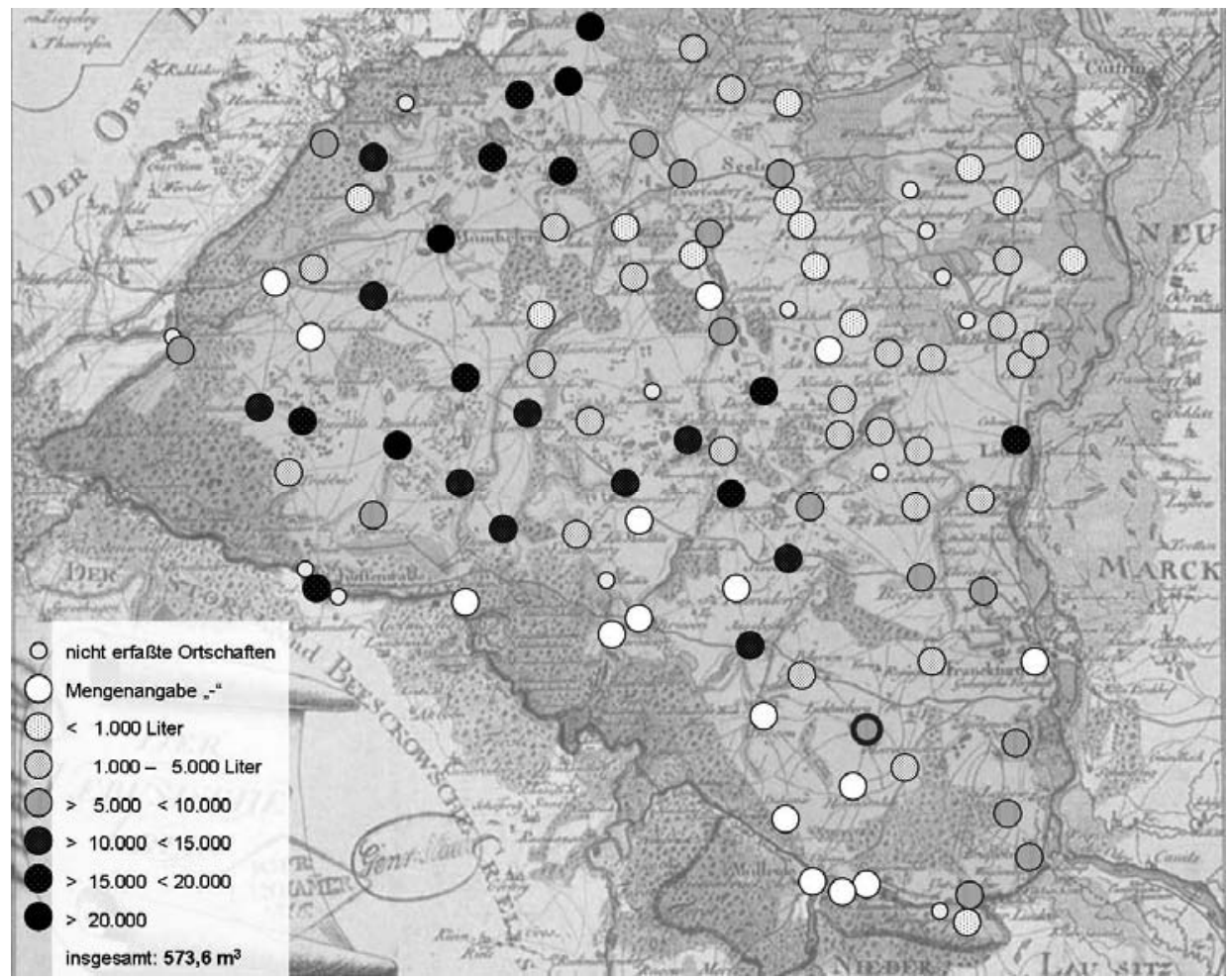

Abb. 6: Eine Bestandsaufnahme vom 29.Juni $1753^{707}$ gibt für die einzelnen Ortschaften die Menge der bis zu diesem Zeitpunkt des Jahres gesammelten und getöteten Heuschreckenlarven (Sprengsel) wieder. (Kreise mit Rasterung, deren Intensität proportional der gesammelten Sprengsel-Menge ist, siehe Kartenlegende) Das Volumen der gesammelten Heuschreckenlarven belief sich zum angegebenen Datum auf $573 \mathrm{~m}^{3}$, allein für das hier abgebildete Areal, wobei die Aufstellung unvollständig ist (Wiedergabe der Sammlungsliste bei Herrmann 2007). Der Pfeil weist auf den Herrensitz Lichtenberg, dessen Eigentümer von Oskiercka die weiter unten aufgeführte Denkschrift verfasste. Mit rund 5,4 $\mathrm{m}^{3}$ Sammlungsertrag gehörte Lichtenberg dabei lediglich zu den mittelschwer betroffenen Feldfluren.

Eine funktionale Interpretation des Verteilungsbildes ist praktisch ausgeschlossen, weil Angaben über die aktuelle und vorjährige Ackernutzung fehlen (Winterung, Sömmerung, Zwischenfrucht, Brache). [Grundlage ist eine Karte des Lebusischen Creises 1787. Staatsbibliothek Berlin, 4"@Kart. N 5447-7. Dunkle Zonen der Karte repräsentieren Waldgebiete, von denen eine gewisse Barrierewirkung gegen die Heuschreckenausbreitung ausgegangen sein könnte.]

707 Geheimes Staatsarchiv Preußischer Kulturbesitz, Berlin-Dahlem, II. HA, Kurmark Materien, Tit. CCLXVIII, Nr. 2, Vol. I. 
Ob und wie aus solchen Zahlen Schadensausmaße geschätzt werden könnten, ist mangels geeigneter Algorithmen unbekannt. Nach Plausibilitätserwägungen wird der Schaden ,erheblich“ gewesen sein. Die unten abgedruckte Denkschrift Oskierckas kann zur Stützung dieser Behauptung herangezogen werden; die Zeitzeugen, die Körte ${ }^{708}$ für das 18. Jh. aufbietet, äußerten sich gleichlautend. Ausdrücklich bezog sich Körte auf Krünitz, dem er viele Beobachtungen und Sicherheitsmaßregeln aus früheren Zeiten verdankte. Auffällig ist allerdings, dass Körte - und zwar dezidiert anders als Krünitz - die Schadensausmaße durch Heuschrecken mit Begriffen entgrenzender Qualität belegte, wie „unglaublich“, „ungeheuerlich“, „schrecklich“, ,,verheerend“ etc.

Von einigem Gewicht ist nun eine beiläufige und an versteckter Stelle abgegebene Einschätzung von Krünitz: „Mehrentheils empfindet ein Land bey uns von dieser Plage wenig oder nichts; in den Morgen=Ländern, wo sie eigentlich zu Hause gehören, mag es darin anders seyn. Es erfolgt bloß hieraus eben so wenig eine Theurung, als vom Hagel und Ungewitter; es betrifft der Schaden bloß die es trifft. Einige einzelne Gemeinden, und höchstens einige einzelne Provinzen, leiden darunter; ja, öfters leiden an ein und anderm Orte nur einzelne Personen hauptsächlich, und die übrigen kommen ganz gelinde davon. “ 709

Die einzige nach unseren bisherigen Erkenntnissen vorliegende Abschätzung eines durch Sprengsel verursachten Schadens findet sich in einer Akte über das Dorf Kagel im Amt Rüdersdorf. ${ }^{710}$ In Folge einer Sprengsel Kalamität im Jahr 1786, wodurch die Roggenfelder beschädigt wurden, reichten drei Untertanen, vertreten durch den Schultzen ihres Dorfes, ein Gesuch um Remissionszahlungen beim Ober-Barnimschen Kreis ein. Dabei handelte es sich um betriebswirtschaftliche Verluste, denen keinerlei volkswirtschaftliche Bedeutung zukam:

Da Die unter tahnen aus Kagel. Epfram Schönebeke. Christophel Alberecht u. Martin Krieger. Von Die Brach Sprengsel ihre Korne Auf gepfrässen, und Sie da Von wehnig zu Erntte

1. Epfram Schenebeck hatt Auß gesäth 7 Scheffel Da Von hat Er kennen gewinnen $3 \mathrm{u}$ 1/2 Korn Gewint 1 Korn Vor lust 2 u 1/2 Korn

2. Christopel Alberecht 2 Scheffel AußSatt hatt Er kennen gewinnen $3 \mathrm{u} 1 / 2$ Korn gewinnt nichts noch Von $2 \mathrm{u} 1 / 2$ Scheffel AußSat hat Er kennen gewinnen $3 \mathrm{u} 1 / 2$ Korn gewint 1 Korn. Vor lust 2 u 1/2 Korn

3. Martin Kriger hat AußSat 5 Scheffel Da Von kan Er gewinnen 3 u $1 / 2$ Korn. Gewinnt $1 \mathrm{u} 1 / 2$ Korn Vor lust 2 Korn

\footnotetext{
708 Körte veröffentlichte seine kleine Schrift 1828.

${ }^{709}$ Krünitz, Lemma „Heuschrecke“, S. 482.

710 Brandenburgisches Landeshauptarchiv, Potsdam-Bornim, Rep. 2, Domänenregistratur, Nr. 16171.
} 
Solches ist Von Mich den Schultze u gerichte Pflicht mässig Auf genommen

Kagel d 23 ten July 1786

\author{
Johan-Fr. Hentze \\ lehn Schultze \\ Christian Hahne gerichte
}

Die Kurmärkische Kriegs- und Domänen-Kammer beauftragte den zuständigen Landrat mit einer Untersuchung. Dieser bestätigte den Schaden und bemerkte am 6. Oktober 1786: ,und so geringfügig der Schaden an sich auch ist; so ist solcher doch für die Coßäthen zu Kagel von Wichtigkeit, indem deren gantze Aussaat an Roggen nur in 5 bis 6 Scheffel bestehet, und also fast gäntzlich verlohren gegangen." In der von ihm eingereichten Remissionstabelle (Tab. 1) errechnete er den tatsächlichen Schaden und die den drei Untertanen zustehende Entschädigung aus der Kreiskasse. Nach dem Cataster sollten die drei Coßäthen zwischen 10 3/4 und 13 Scheffel Roggen aussäen.. ${ }^{711}$ Die möglichen Gewinne aus der tatsächlichen Aussaat wurden vom Landrat nach dem vorliegenden Cataster unter der Annahme eines durchschnittlich vierfachen Ertrages berechnet. Aus der Remissionstabelle ergab sich daher für diese drei Bauern ein Verlust zwischen 60 und $97 \%$ der Roggenernte. Entschädigt wurden die Untertanen durch die Kreisremission nur für den Verlust an der Aussaat, also für $1 / 4$ des Gesamtverlustes mit 3 Reichsthalern pro verlorenem Wispel Aussaat. Dies war nur ein Bruchteil der an den Kreis zu bezahlenden Abgaben, welche 5 Reichsthaler pro Wispel catastermäßiger Aussaat betrugen.

Um diese sehr geringe Entschädigung, durch die die Bauern anscheinend noch nicht einmal in der Lage waren, ihre Felder weiter zu bestellen, zu erhöhen, schätzte das Amt Rüdersdorf die benötigte Höhe einer möglichen zusätzlichen Amtsremission ab, für die die Kurmärkische Kammer am 28. Dezember 1786 das Generaldirektorium um Bewilligung bat. „Nach der anliegenden Remissions Tabelle beträgt solche [die Kreisremission] nur eine so geringe Summe, daß durch deren Bewilligung diesen Leuten nicht geholfen werde, besonders da sie an und für sich sehr schlecht situiert sind. Wir haben daher von dem Amt eine ihnen außerdem noch zu bewilligende Unterstützung in Vorschlag bringen lassen, welche dasselbe, da sie durch den erlittenen Schaden, so wohl in Ansehung der Abgaben, als auch der Aus Saat zurückgeblieben, und keine Winterung aussäen können, für einen jeden auf $8 \mathrm{rth}$, und also für alle drey auf $24 \mathrm{rth}$ bestimmt, um sie in den Stand zu setzen, die nöthige Sommer Saat anschaffen zu können.“ Am 3. Januar 1787 wurden die Gelder schließlich bewilligt.

\footnotetext{
711 Abel, S. 212, gibt als Durchschnittswert 30 preußische Scheffel Aussaat auf eine Hufe Ackerland (etwa 7,5 ha, ebd. S. 77) an. Wird dies als Richtwert genommen, verfügten die drei Bauern jeweils über nur etwa 3 ha Saatland. (Abel, W. (1962): Geschichte der deutschen Landwirtschaft vom frühen Mittelalter bis zum 19. Jahrhundert. 3. Auflage, Verlag Eugen Ulmer: Stuttgart)
} 
Aus der Korrespondenz scheint hervorzugehen, dass die drei betroffenen CoBäthen aufgrund des Sprengsel Fraßes nicht in der Lage waren, die aktuelle Wintersaat auszubringen und auch das nächste Sommerfeld nur mit staatlicher Unterstützung bestellen konnten. So gering der ihnen zugefügte Verlust von insgesamt 2 Wispel und 3 Scheffel auch gewesen sein mag, bedeutete er für diese drei Bauern doch eine ernsthafte Existenzbedrohung.

Tab. 1: Remissionstabelle des Sprengsel-Schadens der Coßäthen Ephraim Schönebeck, Christian Albrecht und Martin Krüger aus Kagel, Amt Rüdersdorff, Anno 1786

[Angaben aus: Brandenburgisches Landeshauptarchiv, Potsdam-Bornim. Rep. 2. Domänenregistratur Nr. 16171]

\begin{tabular}{|l|l|l|l|l|l|l|l|l|l|l|l|l|l|}
\hline $\begin{array}{l}\text { Namen der } \\
\text { Untertha- } \\
\text { nen. }\end{array}$ & \multicolumn{2}{|l|}{$\begin{array}{l}\text { Sollen nach } \\
\text { dem Cataster } \\
\text { aussäen }\end{array}$} & \multicolumn{2}{|l|}{$\begin{array}{l}\text { Haben wirk- } \\
\text { lich ausgesäet }\end{array}$} & \multicolumn{2}{l|}{$\begin{array}{l}\text { Von der wirkli- } \\
\text { chen Aussaat } \\
\text { hätte nach dem } \\
\text { Catastro können } \\
\text { gewonnen werden } \\
\text { zum 4ten Korn. }\end{array}$} & \multicolumn{2}{l|}{$\begin{array}{l}\text { Ist aber nach der } \\
\text { Taxe nur ge- } \\
\text { wonnen. }\end{array}$} \\
& W & S & M & W & S & M & W & S & M & W & S & M \\
\hline Schönebeck & & 12 & 4 & & 7 & & 1 & 4 & & & 7 & \\
\hline Albrecht & & 10 & 12 & & 4 & 8 & & 18 & & & & 8 \\
\hline Krüger & & 13 & & & 5 & & & 20 & & & 7 & 8 \\
\hline Summa & 1 & 12 & & & 16 & 8 & 2 & 18 & & & 15 & \\
\hline
\end{tabular}

\begin{tabular}{|l|l|l|l|l|l|l|l|l|l|l|l|l|l|}
\hline $\begin{array}{l}\text { Namen der } \\
\text { Unter- } \\
\text { thanen. }\end{array}$ & $\begin{array}{l}\text { Mithin am } \\
\text { gehoften Ge- } \\
\text { winnst verloh- } \\
\text { ren }\end{array}$ & $\begin{array}{l}\text { Dieser Verlust } \\
\text { thut an Aus- } \\
\text { saat nach dem } \\
\text { Catastro zum } \\
\text { 4ten Korn }\end{array}$ & $\begin{array}{l}\text { Und beträgt an } \\
\text { Gelde, so wie sie } \\
\text { dem Creise nach } \\
\text { dem Catastro } \\
\text { jährlich versteu- } \\
\text { ert wird a Schefl } \\
5 \text { gs }\end{array}$ & $\begin{array}{l}\text { Summa des } \\
\text { Remittendi } \\
\text { (pro Wispel } \\
\text { verlohrener } \\
\text { Aussaat 3 rth) }\end{array}$ \\
\hline & W & $\mathrm{S}$ & $\mathrm{M}$ & $\mathrm{W}$ & $\mathrm{S}$ & $\mathrm{M}$ & $\mathrm{rth}$ & $\mathrm{gs}$ & $\mathrm{d}$ & rth & gs & $\mathrm{d}$ \\
\hline Schönebeck & & 21 & & & 5 & 4 & 1 & 2 & 3 & & 15 & 9 \\
\hline Albrecht & & 17 & 8 & & 4 & 6 & & 21 & $10 \frac{1 / 2}{2}$ & & 13 & $1 \frac{1}{2} 2$ \\
\hline Krüger & & 12 & 8 & & 3 & 2 & & 15 & $71 / 2$ & & 9 & $4 \frac{1}{2} 2$ \\
\hline Summa & 2 & 3 & & & 12 & 12 & 2 & 15 & 9 & 1 & 14 & 3 \\
\hline
\end{tabular}

$\mathrm{W}=$ Wispel (1319 Liter), $\mathrm{S}=$ Scheffel (55), $\mathrm{M}=$ Metze $(3,4)$;

1 Wispel $=24$ Scheffel, 1 Scheffel $=16$ Metzen

$\mathrm{rth}=$ Reichsthaler, $\mathrm{gs}=$ Groschen, $\mathrm{d}=$ Pfennige; $1 \mathrm{rth}=24 \mathrm{gs}, 1 \mathrm{gs}=12 \mathrm{~d}$ 


\section{Das Ende des Schädlings}

Die zeitlich auffällige Häufung der Heuschreckenkalamitäten in Brandenburg im 18. Jh. findet eine einfache Erklärung im klimatischen Wandel. Mit dem Auslaufen der Kleinen Eiszeit am Ende des 17. und vor allem im 18. Jh. wurden die klimatischen Bedingungen (Wärme und Feuchtigkeitszunahme in den primären und sekundären Brutgebieten) für Heuschreckenzüge günstig. Aufgabe der Brache in Mitteleuropa und Landschaftsumgestaltung hier wie im Südosten Europas entzogen den Heuschrecken in Mitteleuropa im 19. Jh. den Lebensraum. Nicht „Ausrottung“ im Sinne der effizienten Entfernung von der konkreten Fläche durch Töten der Tiere befreite Mitteleuropa von der Plage. Vielmehr waren es die fortschreitende Agrarkultur und der Landschaftswandel, also eine Verdrängung.

Der naturwissenschaftlich rationale und ökonomisch kritische Krünitz hatte, gegen Ende des 18. Jh.s, schon darauf verwiesen, dass die Heuschreckenschäden lediglich den betriebswirtschaftlichen Belastungen zuzurechnen wären. Hinsichtlich der von ihnen verursachten Notstände wollte Krünitz nicht einmal so recht eine überlokale Bedeutung anerkennen. Das Urteil des distanzierten zeitgenössischen Analytikers hilft, den wirtschaftlichen Stellenwert der Kalamitäten einzuordnen, wo die Aktenlage mit den besorgniserregenden Berichten über die Bedrohungslage, durch Betroffene wie berichtende Beamte, ein anderes Bild vermuten lassen würde. Es waren sozusagen nur kleine Katastrophen. ${ }^{712}$ Wen sie als Agrarproduzenten trafen, der mochte seine Einbuße haben. Auf die Ebene des Staates bezogen hätten sie sich - so sagt Krünitz - nicht bemerkbar gemacht. ${ }^{713}$ Dieses Urteil kollidiert zwar mit der geringen Getreideproduktivität in Brandenburg, ${ }^{714}$ die Mehrheit der Getreide produzierenden Flächen Brandenburgs war aber, soweit bekannt, nicht permanent heuschreckengefährdet. Selbst die vermeintlich auf hohe Schadwirkung hinweisende Schrift von Körte kann die Position von Krünitz nur sehr bedingt erschüttern. Körte hat Krünitz gelesen und dessen Bewertung nicht widersprochen, wozu sich seine Fußnote 1 (S. 3) angeboten hätte. Körte schreibt zudem aus einem aktuellen Anlass (Heuschrecken in Brandenburg 1826/27), um mit seiner kleinen Fibel eine Handreichung gegen den Schädling bereit zu stellen. Dass eine solche Zielsetzung sich verbaler Nachdrücklichkeit bedient, wird nicht verwundern.

Im Gegensatz zu anderen Naturkatastrophen sind Insekten in Brandenburg bzw. allgemein in Mitteleuropa heute kaum noch bewusst erfahrene Bedrohungen. Letzte große Schadensfälle von volkswirtschaftlicher Bedeutung erreichte der Kar-

\footnotetext{
712 Das Urteil findet eine Parallele in der Feststellung über Hungerkrisen, denen Heuschreckenkalamitäten letztlich zugeordnt werden müssen: "Famines are regional crises. One might go further and claim that famines are regional crises that can only be understood by the ,local story'" (Vanhaute et al., S. 34)

713 Krünitz, Lemma „Heuschrecke“, S. 482.

${ }^{714}$ Borgstede (1788): Beschreibung; Bratring (1803): Beschreibung.
} 
toffelkäfer (Leptinotarsa decimlineata) in den 30er bis 50er Jahren des 20. Jh.s in Mitteleuropa. Durch die weltweite Bedeutung der Kartoffelkultur lägen die unbekämpften Fraßschäden des Kartoffelkäfers weltweit vermutlich weit über denen heutiger Heuschreckenzüge.

Andere Insekten (Maikäfer, Borkenkäfer) haben ebenfalls durch effiziente Bekämpfungsmaßnahmen, vor allem seit Entwicklung chemischer Bekämpfungsmittel, in Mitteleuropa bestenfalls regionale, überwiegend nur noch lokale Bedeutung.

Für Heuschrecken wurde zuletzt um 1875 ein Massenauftreten in Deutschland registriert. Metahemerobe Bedingungen schließen seitdem aus, dass sie auf absehbare Zeit wiederkommen könnten. So war es möglich, sie als Bedrohung aus dem kollektiven Gedächtnis zu entlassen, in dem sie aber bereits vorher nicht sonderlich sicher vertreten war. Der „Grosse Brockhaus“ besprach 1935 die Europäische Wanderheuschrecke nur noch in enzyklopädischer Aufzählung, ohne Hinweis auf historische Schadensereignisse. Die Ausgabe 1884 erwähnte immerhin, dass 1875 Heuschrecken in den Bezirk Potsdam gekommen wären. In der Ausgabe von 1845 wurde nur der Heuschrecken ,in Deutschland“ von 1750 gedacht. In der „Allgemeinen deutschen Realenzyklopädie für die gebildeten Stände“ von 1824 wurde sogar behauptet, „Deutschland“ sei seit 1750 ,gäntzlich von dieser großen Plage verschont geblieben." Diese Aussage deckt sich zwar mit der Quellenstudie von Schönwälder, ${ }^{715}$ trifft aber in ihrem Urteilsanspruch nicht zu; nicht nur, weil die Bewertungsmaßstäbe für die Registrierung relevanter Fälle offen blieben, sondern auch, weil von Schönwälder nachweisliche jüngere Schwärme übersehen wurden.

In „Unsere Zeit. Deutsche Revue der Gegenwart“, einer Monatsschrift zum Konversationslexikon von Brockhaus, knüpfte Dürigen ${ }^{716}$ an das damals aktuelle Geschehen des Vorjahres an. Auch er bezifferte keine allgemeinen Schäden, sondern bezog sich nur auf die allseits und seit altersher bekannte Gefährdung und Zerstörungsleistung durch die Schadorganismen. ${ }^{717}$

Die Administration reagierte bereits 1731 vergleichsweise schnell und nach dem damaligen Wissensstand durchaus angemessen auf die seit den 1720er Jahren einsetzende Bedrohung der Landwirtschaft mit zwei Edikten. Nicht die Art der Bedrohung, nicht ihr Potential wurde falsch eingeschätzt, doch scheinen die Schadensfälle letztlich geringer als erwartet ausgefallen zu sein, sonst hätte man die regelmäßige und präventive Bekämpfung wohl kaum so nachlässig gehandhabt. So schickte denn auch der damals schon bekannte Gelehrte Gleditsch im Oktober 1776 sein ,allerletztes Exemplar“ seiner 1754 erschienenen „Abhandlung von der Vertilgung der Zug-Heuschrecken“ an die Verwaltung, mit dem resignierten Hin-

\footnotetext{
715 Schönwälder, H. (1959): Quellenstudien über Heuschreckeneinfälle in Mitteleuropa. In: Zeitschrift für angewandte Entomologie 46 (4), S. 401-419.

716 Dürigen, B. (1876): Die Wanderheuschrecke. In: Unsere Zeit. Deutsche Revue der Gegenwart. N.F. 12, 1.Hälfte: $170-186$.

717 Die Angabe Dürigens (S. 175), wonach ein Inspektor der Domäne Löwenbruch (Teltower Kreis) den Heuschreckenschaden für 1875 (?) oder 1876 (?) auf 800 Taler beziffert hätte, ist weder nachprüfbar noch geeignete Referenz für das 18. Jahrhundert.
} 
weis, dass er schon vor über 20 Jahren einen auf Dauer wirksamen Bekämpfungsvorschlag gemacht habe, den man seitdem nicht recht beherzigt hätte. Die Schrift hatte, vor ihrer endlichen Veröffentlichung, bereits 1750 der Königl. Akademie vorgelegen. Herr Gleditsch würde sich vermutlich wundern, dass Expertenrat bis auf den heutigen Tag nur langsam umgesetzt wird.

Die Frage, um wie viel höher seinerzeit die Schäden ausgefallen wären, wenn man nicht einmal in dem tatsächlichen Umfange gehandelt hätte, erübrigt sich als kontrafaktisch. Gleichwohl wäre ihre Beantwortung die Nagelprobe.

$\mathrm{Ob}$ dies nun insgesamt eine Fortschritts- oder Verlustgeschichte ist, entscheiden Bewertungsmaßstäbe in den jeweiligen Diskursen:

Kein aufgeklärter Mitteleuropäer wird heute diese Frage in straftheologischer Hinsicht diskutieren wollen. Krünitz war aufgeklärter Autor genug, dennoch „,gedenkt er des Themas auch als Christ" und kam dabei zu der Einsicht, dass die Heuschrecken in dieser Logik durchaus eine pädagogische Mission erfüllt hätten. ${ }^{718}$ Wer auf dieser Ebene weiterdenken möchte, landet angesichts fehlender Heuschrecken notwendig bei der Einsicht, dass es heute weniger zu Ermahnen, weniger zu Strafen gäbe. Hier lässt sich die Gewinn-Verlust-Rechnung nicht weiterführen, ohne den Raum der rational-logisch begründbaren Empirie zu verlassen (abgesehen davon, dass man eigentlich ein von Heuschrecken überquellendes Europa erwarten würde). Erreicht ist vielmehr die Ebene der Gottesbeweise, ${ }^{719}$ die Ebene des Glaubens, nicht diejenige der Wissenschaft.

Nachweise der Europäischen Wanderheuschrecke in Deutschland sind aus den letzten Jahrzehnten kaum noch bekannt, ${ }^{720}$ wohl vor allem auch deshalb, weil ein kontinuierlicher Brutbestand letztlich auf permanenten Zuzug aus den primären Brutgebieten angewiesen wäre. Brandenburg hat Locusta migratoria in seiner Roten Liste der Heuschrecken zur Zeit nicht eingeordnet, in Berlin gilt sie als ,,nicht etabliert bzw. nicht im Freiland etabliert", in Mecklenburg-Vorpommern gab es in den vergangenen Jahrzehnten nur Einzelnachweise, in Sachsen-Anhalt wurde sie in die Rote Liste nicht aufgenommen, weil sie nicht (mehr) als Brutbestand gilt, in Baden-Württemberg (ehem. sekundäres Brutgebiet) existiert keine für die Einordnung brauchbare Datenlage, Bayern führt sie als „,verschollen bzw. ausgestorben“. Dieselbe Bewertung vertritt zur Zeit auch der NABU, offenbar für Gesamtdeutschland.

Wer hingegen anstelle der Biodiversitätsaspekte seine Betrachtung auf die ökonomische Inwertsetzung der Natur, die Steigerung und die Sicherung der Agrarproduktion legt, wird die Wanderheuschrecke nicht vermissen: „damit hätte dann die Menschheit in harter jahrhundertelanger Arbeit einen ihrer gefährlichsten Fein-

\footnotetext{
718 Krünitz, Lemma „Heuschrecke“, S. 482 ff.

719 mit Blick auf den Katastrophendiskurs ergiebig ist Schmidt 1999, S. 43 ff. („Wolken krachen, Berge zittern, und die ganze Erde weint..." Zur kulturellen Vermittlung von Naturkatastrophen in Deutschland 1755 bis 1855 , Waxmann: Münster u. a.).

720 http://www.dgfo-articulata.de/de/Arten/Locusta_migratoria.php (26.5.2009)
} 
de aus Europa vertrieben.“721. Die Ausrottung, die sowohl im naiven Verständnis als auch in der euphemistischen Wortverkleidung „eine wirksame Entfernung von einer Fläche“ bedeutet, ist eine Kulturleistung, in positiver wie in negativer Bedeutung des Begriffs.

Dass die Wanderheuschrecke aber auch dem kollektiven Gedächtnis entfallen ist, muss als Hinweis darauf gelten, dass es keinen Grund gibt, sich ihrer zu erinnern. Darin unterscheidet sie sich vom Wolf oder Bären, die sich wenigstens im Erinnerungsprozess vom verfolgten Schädling zu musealisierten Sympathieträgern wandeln durften. Es wird wohl auch an der grundsätzlichen Fremdartigkeit der Organisationsform des Insekts selbst liegen, denn für die landläufige Alltagserfahrung müssen „Tiere“ allermeist vier Beine (nicht sechs), zwei Linsen-Augen (kein zusammengesetztes Facettenauge) und ein Fell oder wenigstens Federn (keine harte Außenschale) haben, abgesehen von einer „vernünftigen“ Größe (hamstergroß und aufwärts). Der Rest war „Gewürm“ und „Geschmeiß“, also „,minderwertig“", zumal, wenn es als Heuschrecke der zarten Lieblichkeit und leuchtendtransparenten Buntheit der Schmetterlinge entbehrte, der poetisch so apostrophierten „Sommervögel“. So kann das Verständnis der Voraufklärung heimlich weiter wirken.

Das Problem ist aber noch komplexer und erzeugt hinsichtlich der ,gerechten“ Bewertung der Lebensansprüche der beteiligten Arten gewisse Ratlosigkeit, wenn man sich der prozessualen Abläufe erinnert: Es war der klimatische Wandel, der von biogeographisch unbedeutenden Einzelereignissen historischer Heuschreckenzüge abgesehen - der Europäischen Wanderheuschrecke eine Erweiterung ihres westlichen Ausbreitungsgebietes ermöglichte. Die Arealerweiterung wurde letztlich durch die Konkurrenz menschlichen Nahrungsverhaltens gestoppt und wirksam rückgängig gemacht, nicht allein durch „Bekämpfung“, sondern wirksamer auf indirekte Weise durch den landschaftlichen Transformationsprozess. Ein klassischer Fall eines Verdrängungswettbewerbes. Die Heuschreckenzüge waren vor dem 18. Jh. so selten wie Kometen. In der hiesigen Alltagskultur haben die Heuschrecken ihr kurzes historisches Hoch nicht überlebt, präsenter sind sie durch die biblischen Plagen und die Naturgeschichten aus der Antike, der sich auch die geläufige metaphorische Phrase verdankt. Heuschreckenschwärme sind heute eher wieder die Naturkuriosa in weit entfernten Teilen der Welt geworden, ${ }^{722}$ die sie schon einmal zu Beginn des 18. Jh.s waren.

\footnotetext{
721 Bodenheimer: Geschichte, S. 27.

722 Wenn sie der aktuellen journalistischen Berichterstattung nicht als Chiffren für gesellschaftliche Umordnungsprozesse, für aus den Fugen geratene Gesellschaftsordnungen dienen. Diesem altbekannten Muster der Erklärung von Schädlingsaufkommen folgte nämlich die Berichterstattung z.B. in deutschen Nachrichtenmagazinen über eine Massenvermehrung von Heuschrecken mit Flugschwarmbildungen in Russland im Jahre 1999 [Der Spiegel 30(1999): 200; Focus 30(1999): 70-75]. Selbst die wirtschaftsskeptischen Urteile in der heutigen bundesrepublikanischen Politik, die Hedgefonds mit Heuschrecken verglichen haben, bedienen sich der biblischen Plagemetaphorik.
} 


\section{Anhang}

\subsection{Project, nach welchem die meisten, wo nicht alle einheimische Heuschrecken noch in diesem Jahre zu tilgen wären.723}

Ein jeder unter uns Menschen, auch der allerbeste ist leider! allso geartet, daß keiner von uns dies oder jenes unserem Nächsten zugestoßenes Unglück ernstlich beherziget, wenn man zuvor nicht ein gleiches selbst erlitten hat. Das landverderbliche Übel der Heuschrecken, wodurch schon drey Jahr nacheinander der hiesige Theil der Mittelmark und die angrenzende Neu:Märkischen Kreise erbärmlich mitgenommen sind, wird denen meisten hierzulande, gleich denen Auswärtigen, welche davon keinen Schaden gehabt, höchstens ein kaltsinniges Bedauern unseres Unglücks abgerungen haben. Allein, wie innigst würde sie alle diese Noth nicht gerühret haben, wenn sie auf ihrem eigenen Ackern vor einer Stunde den Waitzen dem dicksten Rohr gleich stehen gesehen, und vielleicht schon in ihren Gedanken ausgerechnet gehabt hätten, wie viel sie davon lösen wollten, eine Stunde danach aber darauf nichts, als pure Stoppeln erblicken können. Wie würden sie nicht die Achseln gezucket haben, da sie hätten wahrnehmen müssen, $[2]^{724}$ daß diese ohngedungene Schnitter nicht den schlechten, sondern ihren besten und stärksten Rocken zugesprochen hätten. Und wenn sie gleich noch standhaft genug gewesen wären, der darüber aufsteigenden Betrübniß Einhalt zu thun, so würden sie solche doch gewiß desto heftiger haben herausbrechen lassen, wenn sie ganze mit Hafer und Gerste besäete Felder der Brache gleich kahl gemacht gesehen; so daß sie nicht unterscheiden könnten, auf welchen von beiden Feldern die abgefreßene Sommerung ${ }^{725}$ gestanden.

Dies ist nur eine schwache Abbildung eines durch die Sprenkel verheerten Feldes, davon jedoch das Uhrbild einen gewaltigen Eindruck bei uns Verunglückten hinterlaBen, und noch unterhält; da allem Menschlichen Vermuthen nach wir ein gleiches Schicksal übers Jahr zu befürchten haben, weil die etliche Wochen lang angehaltene naße Witterung verhindert hat, daß dieses Ungeziefer sich weggeben können. Es ist eine so unbeschreibliche Menge der Heuschrecken nur auf meiner Lichtenbengischen ${ }^{726}$

\footnotetext{
723 aus: Geheimes Staatsarchiv Preußischer Kulturbesitz, II. HA, Kurmark Materien, Tit. CCLXVIII, Nr. 2, Vol. II.

Die Übertragung folgt in Duktus und Orthographie der Handschrift. Die Denkschrift ist in einer Kurrent-Schrift abgefasst. Für die Doppelbuchstaben „sz“ und „ss“ kennt die Kurrentschrift zwei unterschiedliche, aber recht ähnliche Buchstaben. Der Schreiber der Denkschrift verwendet mehrheitlich ,ß“.

724 Seitenumbruch in der Handschrift

725 Nach dem Kontext bezeichnet der Begriff „Sommerung“ hier das Sommergetreide, das im Frühjahr eingesät wird; entsprechend im Folgenden: Winterung für Wintergetreide. Nicht gemeint, aber nicht auszuschließen, sind hier offensichtlich die ebenfalls damals unter dem Begriff subsumierten anderen Sommerfrüchte der Dreifelderwirtschaft.

726 Sind Wörter bzw. Wortelemente in lateinischen Buchstaben verwendet, wird dies hier durch Kursiv-Druck gekennzeichnet.
} 
Feld:Mark zurück [3] geblieben, deren Bruth, wenn solche alle künftiges Frühjahr aus käme, allein imstande wäre, den ganzen Lebusischen Kreiß zu überschwemmen, und alle künftige Winterung und Sommerung zu verderben. Denn nach Proportion der jetzt zu Lichtenberg nur zurückgebliebenen Heuschrecken sind im vorigen Jahr kaum 1/8 derselben allhier geblieben, und hatten dennoch so viel Brut gelassen, daß ich dieses Frühjahr vor mein Teil an die 25 Winspel ${ }^{727}$ derselben getötet und einer von meinen Nachbarn, der Herr Major von Burgsdorff auf Marckendorff, deßen Rocken:Feld an meine Brache dieses Mal gestoßen, um zu verhüten, damit dieses Ungeziefer nicht in seinen Rocken eindringen möchte, hat gleichfalls auf meiner Feld:Mark an die 15 Winspel vergraben lassen, so daß alleine auf dem Lichtenbergischen an die 40 Winspel von diesem Ungeziefer im letzt verflossenen Frühjahr sind vertilget worden, und dem ohngeachtet so reine nicht ausgerottet werden können, daß die übriggebliebene mir und meinen Unterthanen nicht einen entsetzlichen Schaden an allerhand Getreyde angerichtet hätten. Es ist [4] also fürwahr Zeit an Vertilgung dieses so schädlichen Ungeziefers mit allem Ernst zu gedenken. Die in königl. Edicten solcherhalben verordnete Mittel sind zwar gut, nur die Anwendung derselben wird von denen meisten nicht recht veranstaltet, und bis auf die letzte Stunde, wann die Bruth lebendig geworden, und recht gar schon überhand genommen, verschoben; da dann die Ausrottung nicht nur mühsamer ist, sondern auch ohnmöglich ohne merkliche Beschädigung der im Halm bereits stehenden Winterung vorgenommen werden kann: zu dem so geschehet als dann meistenteils, daß man mehr Getreyde zertrit, als die aus eben dem Getreyde herausgetriebene Sprenkel davon verzehret hätten, wenn man selbige darin gelaßen hätte. Und dieses inconvenienz ist eigentlich daran Schuld, daß der Landmann so träge ist, die Sprenkel zu tilgen, indem der allermeiste Haufe, sonderlich von gemeinen Ackers:Leuten, ohne die gemeine Wohlfahrt in Erwägung zu ziehen, sich damit tröstet, daß die Sprenkel doch das meiste laßen und zum Teil weiter fortfliegen werden, dahingegen bei Heraustreibung derselben aus dem Getreide mehr Getreide zertreten würde, als vielleicht die Sprenkel aufgezehret hätten, wenn sie auch gar nicht wegflöhen.

Es ist demnach [5] das allerbequemste Mittel von diesem Ungeziefer sich los zu machen, derselben Eyer aufzusuchen. Diese Aufsuchung aber geschiehet jetzt, da sie solche eben legen, am füglichsten, weil die Stellen wo sie selbige verscharren, noch frisch und kennbar sind, die aber nachmals durch Wind und Wetter verwehet und gleichgemachet, auf denen Brach:Feldern aber umgepflüget und glat geegget worden, endlich aber den Winter durch hart und fest frieren; sodaß im Frühjahr, ehe die Eyer nicht aus kommen, die Stellen, wo selbige liegen, schwer zu finden sind; einfolglich die meisten davon beim Aufsuchen verfehlet werden, und ungestöhrt liegenbleiben. Bei Aufsuchung dieser Eyer müßen nicht so wohl die durch die Sprenkel im voraus gemachten noch offenen Löcher nachgegraben werden, weil man darin, so lange selbige offen sind, selten Eyer findet; anerwogen die Sprenkel diejenigen Löcher, welche sie

${ }^{727}$ Winspel $=$ Wispel. Hohlmaß. 1 Wispel $=24$ Scheffel $=1319$ Liter. 1 Scheffel $=16$ Metzen $=$ 54,96 Liter. 
wol geleget, gleich selbst gewissermaßen verscharren, sondern es müßten gantze Felder, worauf man Sprenkel noch herum hüpfen, oder todt liegen siehet durch gesuchet, und mit kleinen Späden, womit man Rüben ausgrabet, erwähnte Eyer gleich denen trockenen Rüben ausgescharrt werden; [6] da dann sonderlich auf sandigen Örtern innerhalb kleiner Distanz, zum Exempel, von einem quadrat von vier Ruthen ${ }^{728}$ zwo und mehr Metzen aufgefunden worden, weil die Eyer:Stöcke länglich und in der Erde hinunter geleget stecken, ein folglich auf einem kleinen Raum unzählige derselben Platz haben. Ein jeder von denen Eyer:Stöcken enthält an die 90 und mehr Eyer, welche vor jetzo noch weich sind, gegen das Frühjahr aber härtlich werden, und dem Rocken so ähnlich sehen, daß man ohne genaue Betrachtung nicht leicht einen Unterschied zwischen Rocken und Sprenkel:Eyern wahrnehmen würde. Diese Eyer wachsen den Winter durch im Stocke in dem sie jetzo klein sind, gegen das Frühjahr aber noch wohl einmal so groß werden, und wenn die Zeit des Auskommens kommt, so werden sie gleich dem dünnhülsigen Waitzen klar und fast durchsichtig, wenn man sie alsdann entzwei drückt, so komt eine sehr gelbe Materie, die einem Dotter gleich sieht, heraus, welche vorjetzo noch gantz flüßig, und einen ins Gelbe fallendem Waßer ähnlich ist. Die Schweine vertilgen aber solche viel; allein, weil die Schweine bekanntermaßen das Land nur [7] hin und her bewühlen, so bleiben demohngeachtet die meisten im Lande ungerührt liegen; so daß daher das allersicherste ist, besagte Eyer durch Menschen aufzusuchen zu lassen, und diese Aufsuchung jetzo schon vorzunehmen, weil die Sprenkel wirklich schon seit 14 Tagen und länger Eyer legen, zum Beweise deßen eine Schachtel vol von gedachten Eyern beilege, davon meines Verwalters Ehefrau vor 8 Tagen schon binnen Zeit von zwei Tagen 4 volle Metzen aufgefunden und abgeliefert hat, weil ich allein jeden aus meinem Dorfe so viel Rocken zu schenken versprochen, als man mir Sprenkel:Eyer liefern würde: wodurch jedoch nur die bemeldete Verwaltersfrau bewogen worden, die Sprenkel:Eyer aufzusuchen, alle übrige Einwohner aber sind mittelst eben dieser Vergütigung ihrer Bemühung noch nicht dahin zu bringen gewesen, daß sie ein gleiches thäten, ob sie gleich dadurch mehr, als ihr ordentliches Tagelohn verdienen könnten. Auch die Unterthanen haben mir insgesamt nur erst eine Metze geliefert. Vorjetzo noch [8] kann das Brachfeld gleichfalls durchgesuchet werden, weil man es erst anfängt mit Winterung zu besäen, wodurch denn verhindert werden würde, daß die Sprenkel im künftigen Jahr nicht mitten im Rocken auskämen, worin man deroselben nicht eher gewahr werden mag, ehe sie nicht Schaden angerichtet haben. Es würden aber die Bauers:Leute zu Aufsuchung der Spenkel:Eyer mit mehrern Nachdruck, und geschärfftem Ernste angehalten werden müssen, weil die Erfahrung lehrt, daß sie dazu so schwer zu bringen sind, und glaube ich gewiß, daß keine Dorfschaften von allen denen, wo Sprenkel die drei Jahr durch gewesen, nur die in denen königl. Edicten festgesetzte Metzen der Sprenkel:Eyer abgeliefert haben werden; geschweige, daß solche gegen die darin zugleich versprochene gratification mehrer hätten

728 Ruthe $=$ Rute, Längenmaß. 1 Quadrat-Rute $=14,19 \mathrm{~m}^{2}:$ „Ein Quadrat von vier Ruten“ = $56,76 \mathrm{~m}^{2}, 1$ Metze $=3,4$ Liter 
aufsuchen sollen. Meine Untertanen selbsten, ob ich sie gleich bei Strafe zu Ablieferung besagter Eyer im letzt verfloßenen Frühjahr angehalten habe, haben doch nicht die volle Maaße derselben eingebracht, weil, als sie solche aufzusuchen anfingen, die Sprenkel gleichfals anfingen auszukommen, da denn verschiedene von ihnen die aufgefundenen Eyer in ihren Häusern, weil sie noch einhitzeten, lebendig wurden. Überdem aber, so würde die Ablieferung der im königl. Edicten festgesetzten wenigen Metzen nicht hinlänglich seyn, die Heuschrecken:Bruth gäntzlich zu vertilgen; wannenhero ein höheres Maaße denen Unterthanen aufgeleget werden müßte, von besagten Eyern aufzusuchen, weil keine Gerichts:Obrigkeit vorjetzo [9] von ihnen mehres davon fordern darf, als was sie Einhalts (?) Edicten zu liefern schuldig sind, sie aber weder auf Geheiß, noch auch von selbsten gewiß nicht mehr liefern würden, wenn man gleich ihnen wie ich obbemeldetermaßen, doch fruchtlos gethan, dafür eine Vergütung verspräche, und ihnen zugleich aufs deutlichste vorstellte, daß dadurch, wenn sie vor jetzo 8 Tage nur zubrächten, um die Sprenkel:Eyer fleißig aufzusuchen, sie sich dadurch von der Last befreyen würden, im Frühjahr etliche Wochen lang täglich denen Sprenkeln nachzujagen, des noch größeren Vortheils zu geschweigen, daß an denen Örtern, wo Sprenkel:Eyer aufgesuchet seyn würden, wenigstens die Winterung von Sprenkeln nichts zu besorgen hätte, und also kein anderer Schade, als der von denen Flug:Sprenkeln bei der Sommerung zu befürchten wäre, welche Furcht aber auch verschwinden würde, wenn aller Orten denen Sprenkel:Eyer zu rechter Zeit, nämlich im Monath September nachgespüret würde; da dann keine einheimische Flug:Sprenkel geben würde, die aber von weitem aus fremden Ländern kommende würden wenigstens nicht so ofte, auch nicht an so vielen Örtern zugleich einen so entsetzlichen Schaden, alsden wir bisher erlitten, ausrichten können.

Es wäre also höchst nöthig, daß durch ein geschärftes königl. Edict interimistice aber durch ein Rescript und ein darauf sich gründendes Kreiß:Ausschreiben denen Unterthanen derer Örter, wo Sprenkel gewesen anbefohlen werden möchte, die Sprenkel:Eyer, so gleich mit Nachsetzung aller anderen Arbeit auf zu suchen und insbesondere, daß ein jeder Bauer 3 Scheffel, ein Einführer 2 Scheffel, ein bloßer Kossäte 1 Scheffel, ein Einliegener $1 / 2$ Scheffel aufsuchen und dem Land:Rath des Kreises selbst binnen 4 Wochen einliefern solle. Wobei auch nöthig wäre aufzugeben, daß sie vernehmlich vorerst das jenige Feld, welches vorjetzo mit Winterung besäet wird, durchsuchen sollten, damit keine Heuschrecken künftig im Rocken auskommen möchten. Wie aber die Einwohner derjenigen Dörfer, auf deren Felder dieses Jahr Sprenkel geblieben, nicht hinlänglich [10] wären, alle auf ihren Feldern liegende Sprenkel:Eyer aufzufinden; es wäre höchst nöthig, daß andere von der Heuschrecken:Plage verschont gebliebene Dorfschaften denen erstern in Aufsuchung gedachter Eyer hilfliche Hand zu leisten beordert werden möchten

$\mathrm{Da}$ auch Se. Königl. Majestät allergnädigst sich erkläret haben, daß allerhöchst dieselbe nicht nur dero Amts, sondern auch deren adeligen Unterthanen, welche durch Heuschrecken:Fraß vieles gelitten, gewisses Saat- und Brodt-Getreyde allergnädigst reichen lassen wollen; so würde nicht undienlich seyn um die Bauers:Leute zu desto fleißiger 
Aufsuchung der Sprenkel:Eyer zu animieren, diesen allen Dorfschaften mittelst oben besagtem Circularis deuten zu lassen, daß welche von ihnen nicht respective von dem Land:Rath des Kreyses, auch denen Beamten und ihren ordentlichen Gerichts:Obrigkeiten beglaubte Attestate beibringen würden, wie sie nemlich respective nicht nur die gesagte Scheffel:Zahl von besagten Eyern dem Land:Rath abgeliefert, sondern auch zu Aufsuchung mehrerer besagter Eyer allen nur möglichen Fleiß angewendet hätten, keine Vergütigung zu genießen haben sollten: Hingegen, wenn sie eine der gleichen Sorgfalt angewandt hätten, daß sie sogar über die gesetzte Scheffel:Zahl, welche sie bei $10 \mathrm{rf}^{729}$ Strafe vor jeden Scheffel durchaus liefern, und wenn sie solche auch nicht auf ihren eigenen Feldern finden dürften, auf den benachbarten Feldern aufsuchen sollten, $\mid$ : Wodurch denn der Einwendung als wären keine Eyer zu finden, vorgebeuget und der Haupt:Endzweck zugleich mit befördert werden würde :| mehrere Eyer liefern würden, so solte einem jeden von ihnen vor eine jede Metze Sprenkel:Eyer, so er über die gesetzte Maaße geliefert haben würde, ein Scheffel Rocken gereichet werden. Diese gratification wegen des Übermaaßes dürfte wenig austragen, hingegen der Vorteil daraus würde in Vergleich derselben unendlich größer sein, weil aus einer Metze Eyer ein Winspel und darüber Sprenkel werden. [11]

Diese aber viele Winspel Getreyde verzehren können, daher dann die ohnmasgeblich in Vorschlag gebrachte gratification nicht zu groß wäre, wenn solche auch nicht 100 Winspel |: so hoch sie doch nicht steigen wird :| belaufen solte. Und eine gleiche gratification würde auch denen fremden Dorfschaften, so zu Suchung der Sprenkel:Eyer aufgebothen werden dürfften, versprochen und gereichet werden müßen, damit sie bei Suchung Fleiß anwenden, weil, wer die Eyer nicht recht suchen wil, der findet sie auch nicht; wann er auch den ganzen Tag in der Erde buddelte. Um also der Bosheit der fremden Leute, welche vielleicht mit Fleiß nicht recht suchen würden, vorzubeugen, wäre beßer sie durch die vorgeschlagene Vergütigung, als durch Zwangsmittel zu bewegen, bei der Aufsuchung der Sprenkel:Eyer allen möglichen Fleiß anzuwenden. Wenn man nun überdem die noch übriggebliebene Bruth künftiges Frühjahr gleichfalls fleißig aufsuchen und vertilgen würde; so wäre zu hoffen, daß wir einmal diese Plage loswerden, oder doch wenigstens künftigen Jahr keinen so merklichen Schaden mehr davon haben würden. Nach paar Jahren aber, wenn man diesem Ungeziefer auf gleiche Weise auch künftighin nachgestellet haben würde, würden sie allem menschlichen Ansehen nach gewiß endlich gäntzlich vertilget worden, wozu der allmächtige Gott seinen Beistand verleihen wolle.

von Oskiercka

Lichtenberg, 3. September 1753

${ }^{729} \mathrm{rf}=$ Wärungssymbol für Groschen. 24 Groschen $=1$ Taler 


\section{Danksagung}

Wir danken Frau Sybille Hourticolon für die Unterstützung bei der Herstellung von Abbildungen.

\section{Ungedruckte Quellen}

Geheimes Staatsarchiv Preußischer Kulturbesitz, Berlin-Dahlem, II. HA, Kurmark Materien, Tit. CCLXVIII, Nr. 2, Vol. I (ab 1731)

Geheimes Staatsarchiv Preußischer Kulturbesitz, Berlin-Dahlem, II. HA, Kurmark Materien, Tit. CCLXVIII, Nr. 2, Vol. II (1752 - 1758)

Geheimes Staatsarchiv Preußischer Kulturbesitz, Berlin-Dahlem, II. HA, Kurmark Materien, Tit. CCLXVIII, Nr. 2, Vol. III (1758, 1763, 1776 - 1785)

Brandenburgisches Landeshauptarchiv, Potsdam-Bornim, Rep. 2, Domänenregistratur Nr. 16171 (1786-1787)

\section{Literatur bis 1850}

Bekmann, J. C. (1751): Historische Beschreibung der Chur und Mark Brandenburg, Voß: Berlin.

Benekendorf, K. F. von (1775): Beiträge zur Landwirthschaftswissenschaft. Bd. II. Berlin 1775, S. 341 (zit. nach Körte).

Borgstede, H. von (1788): Statistisch-Topographische Beschreibung der Kurmark Brandenburg... Teil 1, Unger: Berlin.

Bratring, F. W. A. (1804-09): Statistisch-topographische Beschreibung der gesammten Mark Brandenburg. Für Statistiker, Geschäftsmänner, besonders für Kameralisten, 3 Bände, Maurer: Berlin.

Coler, J. (1680): Oeconomia ruralis et domestica, Darin das gantz Ampt..., Schönwetter: Frankfurt.

Frisch, J. L. (1720-1730): Beschreibung von allerley Insecten in Teutsch-Land: Nebst nützlichen Anmerckungen und nöthigen Abbildungen von diesem kriechenden und fliegenden inländischen Gewürme...13 Teile, Nicolai: Berlin [auch Sekundärausgaben ab 1730]

Gleditsch, J. G. (1754): Abhandlung von Vertilgung der Zug-Heuschrecken und den eigentlichen Hülfs-Mitteln, die sich auf eine richtige und Naturmäßige Erkäntniß dieses Ungeziefers gründen, Voß: Berlin / Potsdam. 
Körte, F. (1828): Die Strich-, Zug- oder Wanderheuschrecke, ihre Beschreibung, Verheerung in jetzigen und frühern Zeiten, und die Mittel zu ihrer Vertilgung, Rücker: Berlin.

Krafft, A. F. (1712-1713): Der sowohl Menschen und Viehe grausamen Thiere/schädlichen Ungeziefers und verderblicher Gewürmer gäntzliche Ausrottung..., Buggel: Nürnberg 1712 (anderer Theil), 1713 (erster Theil).

Krünitz, J. G. (ab 1773): Oekonomische Encyklopaedie, oder allgemeines System der Staats-, Stadt-, Haus- und Landwirthschaft, Berlin. Bd. 23, Lemma Heuschrecke $(11781,21790)$ [Hier zitiert aus der Online-Version: http://www.kruenitz1.uni-trier.de/home.htm]

Mylius, C. O. (für das Jahr 1753): Novum Corpus Constitutionum PrussicoBrandenburgensis praecipue Marchicarum..., Berlin; elektronisch erreichbar: http://altedrucke.staatsbibliothek-berlin.de/Rechtsquellen /NCCT11753 /start.html (26.5.2009)

Zedler, J. H. (1731 - 1754): Großes vollständiges Universal Lexikon aller Wissenschaften und Künste. Lemma: Heuschrecken. [zitiert aus: http://www.zedlerlexikon.de]

\section{Jüngere Literatur}

Abel, W. (1962): Geschichte der deutschen Landwirtschaft vom frühen Mittelalter bis zum 19. Jahrhundert. 3. Auflage, Verlag Eugen Ulmer: Stuttgart.

Bodenheimer, F. S. (1929): Geschichte der Entomologie bis Linné. Bd. 2, Junk: Berlin.

Dürigen, B. (1876): Die Wanderheuschrecke. In: Unsere Zeit. Deutsche Revue der Gegenwart. N.F. 12, 1.Hälfte: 170-186.

Engler, B. / Bauer, H.-G. (2002): Dokumentation eines starken Bestandsrückgangs beim Haussperling (Passer domesticus) in Deutschland auf Basis von Literaturangaben von 1850-2000. In: Die Vogelwarte 41: 196-210.

Gerstäcker, A. (1876): Die Wanderheuschrecke (Oedipoda migratoria L.). Gemeinverständliche Darstellung ihrer Naturgeschichte, Schädlichkeit und der Mittel zu ihrer Vertilgung, Wiegandt / Hempel / Parey: Berlin.

Glaser, R. (2001): Klimageschichte Mitteleuropas, Primus: Darmstadt.

Graßl, H. (1996): Heuschreckenplagen in der Antike. In: Olshausen, E. / Sonnabend, H. (Hrsg.) Stuttgarter Kolloquium zur Historischen Geographie des Altertums Bd. 6. Steiner: Stuttgart, S. 439-447. 
Herrmann, B. (2003): Die Entvölkerung der Landschaft. Der Kampf gegen „,culthurschädliche Thiere“ in Brandenburg im 18. Jh. In: Bayerl, G. / Meyer, T. (Hg.): Die Veränderung der Kulturlandschaft (= Cottbuser Studien zur Geschichte von Technik, Arbeit und Umwelt 22), Waxmann: Münster u.a 2003, S. $33-59$.

Herrmann, B. (2007): Ein Beitrag zur Kenntnis von Schädlingsbekämpfungen und ihren Konzepten im 18. und frühen 19. Jahrhundert an Beispielen aus Brandenburg-Preußen. In: Engelken, K. / Hünniger, D. / Windelen, S. (Hg.): Beten, Impfen, Sammeln. Zur Viehseuchen- und Schädlingsbekämpfung in der frühen Neuzeit. Universitätsverlag Göttingen, S. 135-189.

Herrmann, B. / Woods, W. (im Druck): Neither biblical plague nor pristine myth. A lesson from central European sparrows. In: Geographical Review (to appear in early 2010)

Huber, I. (2005): Rituale der Seuchen- und Schadensabwehr im Vorderen Orient und Griechenland (Oriens et Occidens Bd. 10), Steiner: Stuttgart.

Konow, F. (1876): Die sog. Wanderheuschrecke. In: Wöchentliche Anzeigen für das Fürstenthum Ratzeburg 1876, Nr. 66:2.

Lindner, K. (1973): Das Hausbuch des Johann Coler. In: Festschrift für Claus Nissen, Pressler: Wiesbaden, S. 503-574.

Meyer, T. (1999): Natur, Technik und Wirtschaftswachstum im 18. Jh.:

Risikoperzeptionen und Sicherheitsversprechen. Wirtschaftswachstum, Rohstoffe und Technik im staatswissenschaftlichen Diskurs des ausgehenden 18. Jh.s (= Cottbuser Studien zur Geschichte von Technik, Arbeit und Umwelt 12), Waxmann, Münster u. a.

Pfister, C. (2008): Von der Hexenjagd zur Risikoprävention. Reaktionen auf Klimaveränderungen seit 1500. In: Lutz P. / Macho T. (Hg.): Das Wetter, der Mensch und sein Klima. Eine Ausstellung des Deutschen Hygiene-Museums Dresden. Wallstein: Göttingen, S. 56-61.

Rohr, C. (2009): „Sie seind krochen wie ain kriegsordnung.“ Heuschreckenplagen im Land Tirol im Spätmittelalter und in der frühen Neuzeit. In: Tiroler Heimatblätter 84, S. 20-25.

Sander, L. (1902): Die Wanderheuschrecken und ihre Bekämpfung in unseren afrikanischen Kolonien, Reimer: Berlin.

Schimitschek, E. (1973): Pflanzen-, Material- und Vorratsschädlinge. In: Helmcke, J.-G. / Starck, D. / Wermuth, H. (Hg.): Handbuch der Zoologie 4 (2) 1/8, S.1200, De Gruyter: Berlin. 
Schmidt, A. (1999): „Wolken krachen, Berge zittern, und die ganze Erde weint...“ Zufr kulturellen Vermittlung von Naturkatastrophen in Deutschland 1755 bis 1855, Waxmann: Münster u. a.

Schönwälder, H. (1959): Quellenstudien über Heuschreckeneinfälle in Mitteleuropa. In: Zeitschrift für angewandte Entomologie 46(4), S. 401-419.

Vanhaute, E. / Paping, R.. / Ó Gráda, C. (2007): The European subsistence crisis of 1845-1850: a comparative perspective. In: Ó Gráda, C. / Paping, R.. / Vanhaute, E. (eds.): When the potato failed. Causes and effects of the ,last' European subsistence crisis, 1845-1850 (CORN Publication Series, Comparative Rural History of the North Sea Area Vol. 9), Berpols: Turnhout, S. $15-40$.

Weidner, H. (1953): Die Wanderheuschrecken. Die Neue Brehm-Bücherei 96: Leipzig.

Weidner, H. (1986): Die Wanderwege der Europäischen Wanderheuschrecke Locusta mogratoria migratoria Linnaeus, 1758 in Europa im Jahre 1693 (Saltatoria, Acridiidae, Oedipodinae). In: Anzeiger für Schädlingskunde, Pflanzenschutz, Umweltschutz 59(3), S. 41-51. 


\title{
Comments on contributions to "Health versus Wealth - the biological and economic standards of living" - Fondatione Istituto Internazionale die Storia Economica "F. Datini", Prato (I), 26-30 April 2010
}

\author{
Bernd Herrmann ${ }^{730}$
}

\section{Thursday April 30th \\ Session: Health versus Wealth -The Biological and Economic Strandards of Living. Comment (pp 587-590)}

The session opened with two most impressive papers which demonstrated how biological basics are interweaved with complex human standards of living. In fact, it is the biological aspect or the biological part of these features that opens insight into societal conditions. Meat consumption and human body height become convincing proxydata for standards of living.

Following earlier ideas by Fernand Braudel, Soens \& Thoen stressed that gross meat consumption in medieval Europe seems rather unique in terms of global history. Meat consumption was a social marker in their region and time of focus.

\footnotetext{
730 Zuerst erschienen in: Le interazioni fra economia e ambiente biologico dell'Europa preidustriale secc.XIII-XVIII. - Economic and biological interactions in pre-indsutrial Europe from the 13th to the 18th centuries. Atti della «Quarantunesima Setimana di Studi», 26-30 aprile 2009 a cura di Simonetta Cavaciocchi. Fondazione Istituto Internazionale di Storia Economica «F.Datini», Prato. Serie II, 41. Firenze University Pres. S. 587-590, 594-596, 611-612. - I wish to thank the organizers of the conference and the Fondazione Datini for inviting me and making my participation possible. The provident help and support by staff from the Fondazione was highly appreciated.
} 
But meat means an energetic pitfall in terms of ecological balancing of the ancient agrarian regime. If plots are used for the production of meat, these plots can not be used for grain production, thus humans compete for space with their livestock in general, while they do not compete for fodder with their cattle. However, some of the domesticated animals as horses, which probably were not eaten, also competed with humans for grain consumption. Grosso modo, eating meat means to waive $90 \%$ of the "virtual energy" 731 content of the nutriment compared with the consumption of grain. ${ }^{732}$ Therefore, a growing population or a densely populated area will extend distances of energy flow by the exploitation of far distant areas. Exactly this happened during the Inner-European cattle trade, where Flanders imported cattle from Denmark or Poland. There might be a relaxation by harvesting meat from locally bred small ruminants as sheep and goat. Sheep can cope with salty meadows which are shunned by cattle, while goats eat almost anything but suffer from the wet ground. But both need additional energetic input in the shape of a stockman and his dogs. Thus the contribution by Soens \& Toen demonstrated meat consumption as a proxydatum for early and prime urban "wealth" in Flanders.

The title of the session "Health versus Wealth" suggests an opposition between the two issues, where in fact both went and still go hand in hand. Not focussing Flanders, but by browsing the available data of Early Modern Europe, Komlos presented a striking paper on cycles of human body height. Economic cycles are directly pictured in body height, as any food shortage instantly lead to suspended growth. "Hunger" means emaciation and opportunistic infections and both keep people short. The unbelievable difference in body height of lower class and upper class boys in England perfectly covers the theme of the session, since this difference is basically caused by an opposition: if you are wealthy, it is rather likely that your food supply prevents you from any disease that goes with exhaustion and cachexia. Even the course of diseases contracted by infectious pathogens would be milder on average in well nourished people. And all this is exactly told by Komlos' mass statistics. But it seems that there is slightly more in these data. While body height reflects nutritional uptake in humans and/or social classes respectively and thus standards of living, at the it reflects same time mean gross yields of harvest, which is nothing but a reflection of climatic oscillations. Hence body height is also a proxy for climatic conditions. However, the picture might be complicated, perhaps even camouflaged by genetic limitations, since European populations differ in body height not only because of differential access to nutriments but also

\footnotetext{
731 I use this term as a derivation according to the term "virtual water".

732 There is a biological thumb rule that $90 \%$ of the energy or matter is lost from one step of the food web to the next: $100 \mathrm{~kg}$ cereals make $10 \mathrm{~kg}$ pig meat, which is good for $1 \mathrm{~kg}$ human meat. Instead of using the pig as a bioconverter, consumption of $100 \mathrm{~kg}$ cereals would lead directly to $10 \mathrm{~kg}$ human tissue. This is why meat consumption is expensive, let alone the costs for breeding the animals. However, some animals grow at almost no costs for humans, except at harvest costs, as fish, poultry almost, game prey, if accessible, songbirds.
} 
for genetic reasons. For example, the difference in height between Scandinavians and South Italians is mainly caused by genetic factors.

The following communications to the sessions were case studies on topics from Italy and France. Cavalli et al. demonstrated the value of skeletons in terms of "histoire quantitative". Evidence of a rare case of endemic syphilis (non veneric syphilis, Bejel) suggests a very specific socioeconomic environment and pathways of infection, but also indicating extended traffic of merchandise and people.

In his contribution Andreozzi surveyed the1630 plague event and a subsequent epizootic that devastated Cremona and its district. The consequences for humans and the environment were dramatic: persistent emigration from the city and the hinterland, the expansion of abandoned land, increased breeding of sheep as counterstrategy, the weakening of land ownership, the interruption of flow to the investments in the improvement and in the maintenance of the complex system of rivers, canals and hydraulic works developed across the province and the deterioration of the rural landscape are the most significant evidence of this stagnation. The struggle for the individual GDP started severe competition within and between classes and lead to far reaching redistributions.

It is not really a surprise that occupational health and safety were considerably low for $18^{\text {th }}$ century hatters in France (Le Roux), but the example is a nice piece of work and the message is convincing: Wealth (of the retailer) is always at the cost of somebody's (the hatters) health.

In my opinion the topic "health vs. wealth" also needs to talk about a basic dilemma of the medieval European population but I assume it being also a basic dilemma for almost any agrarian society that grows.

Though reliable data are scarce, we know about a growing European population since $500 \mathrm{CE}$. Numbers are not available, but the character of the population curve is pretty well known: slightly increasing until $1000 \mathrm{CE}$, considerably increasing between 1000 and $1200 \mathrm{CE}$, accelerated increasing from 1200 to $1300 \mathrm{CE}$. At 1300 all of a sudden growth stopped and remained on a constant level until the Black Death took away so many European people. The character of the population curve thus resembles a sigmoid, a classic logistic form. Ecologists would tend to talk about the arrival of a population round about the "carrying capacity". Maybe, and not even unlikely, if the Black Death had not taken away one third to half of the European population, the European population would have collapsed during the last decades of the $14^{\text {th }}$ century. This is neither novel reasoning nor is it a surprise, as populations living at the edge of their habitat capacities are very endangered in their maintenance and numbers by determinants beyond their control (climate, vermin, disease).

Interestingly enough, there is one feature that has never been discussed so far in terms of the conference subject. Since it is my task to launch a specific consideration as credible to the community, it is not necessary to refer to specific literature, since my argumentation relies on easily accessible textbook knowledge. It relates to 
the decrease of life expectancy of people in Europe between 500 and 1350 CE. Data were employed from calculations of life expectancies from skeletal series coming from France to Poland and from Scandinavia to Switzerland (no Mediterranean series included). Within these 800 years, life expectancy at birth was reduced from an average of 33 years to an average of 22 years. ${ }^{733}$ Of course there are methodological obstacles in calculating these values, furthermore the data may have less reliability with respect to the unknown number of children in burying places and graveyards etc. However, not the exact number of years for life expectancy at birth is decisive, it is the order of magnitude that is important. Whatever the basis of calculation is: life expectancy is reduced by a considerable number of years.

Obviously this is in accordance to textbook knowledge in ecology about the negative correlation of life expectancy and population density for many mammals and other animal species, sometimes even plants, suggesting this negative correlation being a basic biological principle. Human life expectancy became positively correlated with population density (in Western societies) with the start of the demographic transition in the $18^{\text {th }}$ century, supported by inventions of health care, sanitation and hygiene and a perpetuation of food supply from the $19^{\text {th }}$ century on. But all this will happen only 500 years after the Black Death, and thus it seems as if pure biology explains the decrease for pre-Black Death times satisfactorily.

But "density" is not a sound parameter. Taking $1800 \mathrm{CE}$ as a reference before the population transition really became established, population density in central 18th century Europe is likely threefold of that of 1300. But life expectancy at birth in 1800 was approximately of the same dimension as it was in 500 CE: about $30-$ 35 years. The question is: what added to decreasing life expectancy at birth during the High Middle Ages prior to the Black Death, bringing it down to some 20 years?

Now is the time to remember the famous agrarian historian Ester Boserup. She coined the term "agricultural intensification": Changes often induce agricultural innovation but increased labour cost (Grenzertragsnutzen). The higher the population density the more hours the farmer must work for the amount of produce. Therefore workloads tend to rise while efficiency drops: Raising production at the cost of more work at lower efficiency.

Surely, the period of 500 to $1350 \mathrm{CE}$ was a period of changes, changes in power, in climate and in agrarian technology, thus bringing all prerequisites together and unravel the situation. Basically it was and remained a rural society, depending on its yields. The population grew by an increased total of yield (only). Feeding a population at the edge of the carrying capacity would necessarily mean increased labour costs for the peasants. This would mean exhaustion, since productivity could only be raised by intensified labour and extension of arable plots.

733 A table of life expectancies at birth for Central European skeletal series can be found in B.Herrmann (1987) Anthropologische Zugänge zu Bevölkerung und Bevölkerungsentwicklung im Mittelalter. In: Herrmann B, Sprandel R (eds.) Determinanten der Bevölkerungsentwicklung im Mittelalter. Acta Humaniora VCH; Weinheim. p. 55-72 
By 1300, outmost extension of arable land in Central European was already passed when the forerunners of the Little Ice Age stopped the climatic optimum. The firstly modest, then accelerated population increase between 1000 and 1300 also accelerated the decline of life expectancy by necessarily increased physical exhaustion of these people, which was put on top of the biological hazards of increased population density. In my opinion this effect has not been considered so far.

The absurd situation is that the Black Death stopped this development by reducing the actual life expectancy to zero for one third or one half of the European population.

\section{Thursday April 30th \\ Comment to concluding round table (pp 594-596)}

The title of the conference was "Economic and Biological Interactions in Preindustrial Europe from the 13th to the 18th Centuries". - As a biologist, I found this conference fascinating because bringing together different traditions of epistemological approaches always benefits both sides. This is why I appreciated very much what Bruce Campbell undertook in his introductory statement, to demonstrate that asking questions which can be answered only through efforts of different disciplines, is the most stimulating and promoting tool that can be applied on complex scientific questions. Further, as demonstrated by various contributors, how from their point of view these approaches might work. Some of them had done dedicated work on small scales in terms of epistemological approaches, and some had chosen a broader scale, with necessarily very general conclusions. This mixture was very stimulating.

"Health and wealth" was the part I had to comment on. It was amazing to me what these two different approaches have in common in terms of materialistic overlaps. It was soon visible that both biology and economics share a common currency. And this is rather surprising, since economists are usually talking about currencies in terms of pounds or florins or guilders. But economic currencies are nothing but an energy equivalent. Any energy equivalent can be changed into the currencies of biology, into health and/or offspring. I think this point was underestimated both in the presentations and in the discussions.

I was very happy also to listen to Richard Hoffman's and Bruce Campbell's contributions and I pick these two not only because I am most familiar with their subjects, but because they opened up the view of the audience towards the necessity of epistemological exchange and improvement. As the scientific community we do not have yet a strong tradition in communicating in a common language and in working pari passu on complex questions like that of this conference. This is why the conference was both necessary and important. There are huge epistemo- 
logical areas that have to be cultivated and developed and the conference stimulated future agendas in this sense.

Personally, I appreciated the discovery or adoption of human skeletons as a source for serial history by my colleagues from history at the conference, if you forgive me this professional bias. However, skeletons are just one cipher for the importance of biological materials in economics. But the importance is not always in the market values of biomaterials, as cereals, meat, oil, or herring. It is also in the biological rules, dependencies and determinants that govern the exploited plants or animals themselves.

First: We have heard about seeds and harvests, but isn't that surprising that since the thirteenth century up to 1800, the overall harvest in Europe, with the exception of (I'm entering a private conversation with Bruce Campbell) some areas in Spain, the overall harvest was of a ratio, say, of one to four, maybe fivefold or at the most sixfold? You lose one fourth by rodents; you use one fourth or one third for seed and you end up with one point something grains per harvest as a gain. This is not very promising and this is how one immediately realizes that agriculture was a high risk enterprise and why these regimes were so much endangered. Taking this into account, why is it that there is no genetic improvement over these 500 years and how did they overcome this situation in the eighteenth and nineteenth century, although no formal genetics had been discovered by that time? (And how would one at those times manage to control wind-pollination of grains?). This aspect needs to be extended also on livestock. The basic question is: what are the issues of productivity in terms of economy in classical genetics? Or: was there an impact of genetic improvement or impairment on the economy?

Second: Vermin. I really was surprised that you were talking extensively about weather conditions, but forgot about the vermin. Next to weather, vermin is the most endangering agent in an agrarian society. There were hardly any remarks on vermin here, they are also missing in economic history. Richard Hoffman made some and I was very thankful for that. Of course we have to admit that almost nobody has really looked up so far meticulously the archives for vermin. There is no history of vermin in the medieval, only scarce and scattered knowledge for Early Modern times. Why? Economic historians should know that in agrarian regimes the economy totally depends on harvests. Anything that endangers the harvest endangers economy.

Third, and this is my last point, I would like to look at cities in terms of ecology. Cities are the key invention to understand human ecology, since there is no other invention dominating the face of the earth as cities are. By 2015 , more than $75 \%$ of the world population of humans will live in cities and this percentage will increase further. If there is a story of success in the evolution of human ecology, it is this: the city is the mother of inventions. In my opinion, economic historians are only 
looking at cities in terms of markets. They should rather look at cities in terms of a biological entity that creates and supports the market. This point was definitely missed within the contributions and discussions.

Cities bring together people at close distances, enabling diseases to spread easily. Some pathogens already adopted so well to urban conditions that they are found only in these crowded, overpopulated spots with bad sanitary conditions. The average life expectancy of urban people was remarkably lower than for rural people until the 20ies century. Knowing about the health risks and reduced life expectance people kept on to move into towns though. The ecological reason for that counterintuitive behaviour is a basic and simple one: people go for information. First they have easier access to a mate, which means an exchange of genetic information. Second they go for material goods, for wealth, which is gained by access to cultural information. Thus its all about access to information. The compensation for the disadvantage of living in a city with the risks of illness and untimely death is the benefit from access to information, be it genetic or cultural.

Another main feature of city ecosystems is that they bring up the requirements to fulfil the demands they are producing. This is the only feature they have in common with "natural" ecosystems. Cities provide the prerequisites for "the market" as an institution (since "the market" as such is not a physical thing). In terms of biology the given economy equals the ecological demands of the society and is simply one way to monopolise and distribute items, goods and nutriments. Thus "the market" is an institution that regulates access to matters of desire according to a given societal background. I wonder if economists or economic historians are aware of how much of their theoretical background has in common with that of biology. However, this should not be a real surprise, since postdarwinian biology is based on an economic theory.

\section{Thursday April 30th \\ Round table, Dibattito}

Bernd Herrmann: Thank you. I do not need to add much to what Paul Slack said, because I am totally with him. But I feel to make two remarks.

The first is just to remind our friends who are so enthusiastic about malaria not to forget that (European non-tropical) malaria is firstly not a disease that affects men but is an issue between the Anopheles mosquito and cattle. The wrong thing was - to put a long story short - that humans went under one roof together with cattle, making themselves available to the mosquito. If one separates cattle and people, and if one drains carefully his/her country, malaria will be wiped out. It is that simple. It becomes more complicated as the plasmodium, the causative agent of malaria, obviously lost at least some of its virulence during the last two centuries. 
The second remark refers to a contribution from the floor with the warning, at least as I understood it, that theory-building should not be too far above the ground and should be aware of scales, and so on. Surely this is correct, as well as to a certain extent self understood. If you allow, I may rely on personal experience. As a trained biologist, I am part of a scientific community where you are educated in favour of permanent theory/hypothesis building. You get up in the morning, create one hundred hypotheses and by the end of the day they all went into dustbin. And nobody is disappointed about that. Because we believe, that the production of heuristic approaches is important because any scientific progress only results from the errors and does not arise from the obvious right. Giving errors a chance you will improve science and scientific progress. By admitting this I hope to encourage people who probably felt reluctant in continuing their work because of warnings as the one from the floor. I want to encourage you: Just formulate hypotheses in the morning, build alternative ones at noon and don't be afraid of dismissing them in the evening. Some may call this speculation, but it is more than that.

As we have seen, it is exactly what Bruce Campbell did in his introduction to the conference. By doing so, he created a most impressive scenario and a most credible narrative on the "plague" event in 1348 in terms of environmental history. As I mentioned earlier, the linkage between disasters, mentalities, and pathogens is something that is hard to prove, and perhaps never will be in the sense of strict scientific laws. The linkages are not "confirmed", but they are reliable and we all believe that he is absolutely right in creating this scenario and asking his key questions about "coincidence". Definitely I subscribe to what he has presented, though it is distant from being really confirmed. But it is credible. His scenario is the hypothesis. And if one has a different opinion, it would be too cheap to simply say "No", he/she would have to prove were Campbell's assumed linkage is wrong.

This is the type of knowledge producing narrative that I favour as a common enterprise. One of you just said "Well, we have to work on a common epistemological basis." - Yes, but its already visible, we simply got to work on it further. 


\section{Meisterwerke umwelthistorischer Bilder Ein Plädoyer für eine Galerie von Bildern mit umwelthistorischen Objekten, Vorbildern, Metaphern, Deutungsebenen und Dokumentationen}

\section{Bernd Herrmann ${ }^{734}$}

Über das Konzept der „Schauplätze der Umweltgeschichte“ ist in den Vorworten der bisherigen „Schauplatz“-Bände und auch noch im Vorwort zu diesem Band eigentlich alles schon gesagt. Einerseits wird mit der Belehrung am jeweiligen Beispiel die allgemeine Dimension umwelthistorischer Texte für eine ökologische Grundbildung greifbar. Andererseits liegt ihre Didaxe nicht nur beim Leser, sie ergibt sich ebenso als gewollte Folge beim Prozess des Schreibens für den Autor, in diesem Falle für einen Teilnehmer ${ }^{735}$ eines universitären Seminars. Damit ist die Doppelfunktion der Texte benannt, ihre Ausrichtung erkennbar und ihre Lektüre vor diesem Hintergrund zu bewerten.

Ein Aspekt ist jedoch bisher im „Schauplatz“-Konzept praktisch nicht umgesetzt worden, wenngleich alles, über das berichtet wurde, seinen Ort oder Gegenstand zu haben scheint. Was bisher fehlt, ist die Abbildung des thematisch Einschlägigen um seiner Selbst willen, um seiner Beispielhaftigkeit Willen oder um seiner historischen Einmaligkeit willen. Das Bild in des Wortes unmittelbarer Bedeutung soll zur umwelt-

\footnotetext{
${ }^{734}$ Zuerst erschienen in: Herrmann B, Kruse U (Hrsg.)(2010) Schauplätze und Themen der Umweltgeschichte. Umwelthistorische Miszellen aus dem Graduiertenkolleg. Werkstattbericht. Universitätsdrucke Göttingen. S. 107-154

735 In diesem Text bezeichnet die männliche Form immer auch die weibliche mit. - Wie alle „Schauplätze“-Beiträge, wurde auch dieser Beitrag im Seminar diskutiert. Ich danke für die dort gegebenen Anregungen.
} 
historischen Quelle werden. Aber selten wird es seine Zeugnishaftigkeit als Abbildung sein können, die einem Bild umwelthistorische Qualität verleiht. Wie die Leser eines Textes diesen erst durch das Lesen hervorbringen und je dessen Bedeutung freilegen, so sind Bilder ohne ihren Betrachter bedeutungslos. Der Betrachter erst verleiht dem Bild Bedeutung, erkennt in ihm den für ihn gültigen metaphorischen Gehalt, erliegt den durch Farbe und Gegenstand ausgelösten subjektiven emotionalen Zuständen und domestiziert seine Eindrücke durch die Einbringung kultureller, gegebenenfalls rational-logischer kulturhistorischer Deutungsmuster. Immerhin gilt „die Form der Abbildung [als] die Möglichkeit, dass sich die Dinge so zueinander verhalten, wie die Elemente des Bildes. "736 Das Bild ist zugleich unmittelbare und distanzierte, vielfach gebrochene Realität. Es ist kein historisches Dokument, aber es belegt ein Geschehen, es verknüpft das bislang Unverknüpfte, es suggeriert oder nimmt ontologische Gewissheit. In einer Bildbetrachtung tritt Ernst Cassirers Diagnose vom Menschen als dem animal symbolicum besonders deutlich zutage, wie er sie in jenem Kapitel gefasst hat, das sich direkt auf Jakob von Uexküll, dem Entdecker der biologischen „Umwelt“", bezieht: „Der Mensch kann der Wirklichkeit nicht mehr unmittelbar gegenübertreten; er kann sie nicht mehr als direktes Gegenüber betrachten. Die physische Realität scheint in dem Maße zurückzutreten, wie die Symboltätigkeit des Menschen an Raum gewinnt. Statt mit den Dingen hat es der Mensch nun gleichsam ständig mit sich selbst zu tun. So sehr hat er sich mit sprachlichen Formen, künstlerischen Bildern, mythischen Symbolen oder religiösen Riten umgeben, daß er nichts sehen oder erkennen kann, ohne daß sich dieses artifizielle Medium zwischen ibn und die Wirklichkeit schöbe." "737 Deshalb ist ein Bild noch weit vielschichtiger als die Wirklichkeit, die sie abbildet oder abzubilden vorgibt. Und genau deswegen sind Bilder erkenntnisproduzierende Objekte, sie sind Metaquellen. Und sie folgen absolut den umwelthistorischen Leitbegriffen, die für das Göttinger Verständnis stehen: Rezeption und Rekonstruktion. Das Bild reflektiert als künstlerisches Produkt seiner Zeit und seines Meisters die Rezeption des Dargestellten. Die Rekonstruktion wird sich bemühen, den Gehalt des Dargestellten zu prüfen. In der Beobachtung des Künstlers findet sich die „Beobachtung zweiter Ordnung“, 738 die ein Kernelement auch des Umwelthistorischen ist.

Der nachfolgende Essay ist ein Plädoyer für die Nutzung von Bildern zur Freilegung und Gewinnung umwelthistorischer Einsichten. Es könnte den Grundstein liefern für eine umwelthistorische Bildersammlung, einen umwelthistorischen Bilderkanon, an dem beispielhaft das Grundsätzliche wie auch das jeweils Neue aus den sich mehrenden Einsichten und dem Verständnis der umwelthistorischen Zusammenhänge gesehen und vermittelt werden können. Die Gelehrten könnten sich über das erste halbe Hundert Bilder streiten und verständigen, und jeder Leser würde den Kanon um

\footnotetext{
736 Wittgenstein, Satz 2.151 (Seite 15) - Wittgenstein hat eine Reihe von Setzungen über Bilder (d. i. mehrheitlich über unsere Vorstellungen von Bildern) formuliert, die thematisch sehr ergiebig sind. Verwiesen sei auf die Satzfolge 2.1 bis 2.225

${ }_{737}$ Cassirer, S. 50

738 Die „Beobachtung zweiter Ordnung“ stammt aus dem kybernetisch orientierten Konstruktivismus (Heinz von Foerster) und ist sehr schnell in soziologische Generaltheorien einbezogen worden. So hat auch Niklas Luhmann sie in seine Systemtheorie integriert, weshalb er häufig als „Entdecker“" oder Begriffsschöpfer der „Beobachtungen höherer Ordnungen“ missverstanden wird. - Eine kennenswerte Einführung in den philosophischen Konstruktivismus Heinz von Foersters bei L. Segal.
} 
die ihm wichtigen Bilder für sich selbst erweitern können. Eine offene Enzyklopädie also, aber nur begrenzt eine des gesicherten Wissens, vielmehr eine des Wissenswandels. Denn die Bewertung eines Bildes ist, trotz aller Stabilität eines Motivs, dem Urteil wechselnder Betrachter in wechselnden Zeitläuften unterworfen.

\section{Der Vorschlag ist weder neu noch originell}

Bereits der Titel des Beitrags rekurriert ungeniert auf eine erfolgreiche Sendereihe des Westdeutschen Rundfunks, die von 1980 bis 1994 in den Fernsehsendern der ARD ausgestrahlt wurde und sich ihrerseits an das Vorbild einer BBC-Sendung anlehnte. Auch deswegen kann auf die Idee unmöglich ein Originalitätsanspruch erhoben werden, weil sie ein unmittelbares und sogar thematisch einschlägiges Vorbild zu haben scheint. Sehr früh haben Henry Makowski \& Bernhard Buderath mit ihrem Bilderbuch „Die Natur dem Menschen untertan. Ökologie im Spiegel der Landschaftsmalerei“ (1983) einer Sammlung von Gemälden jeweils zwei Texte beigegeben, die im Buch zweispaltig parallel gesetzt sind. Der erste Text erklärt das Bild aus der kunst- bzw. kulturhistorischen Perspektive (Buderath), der zweite Text macht auf ökologische Gesichtspunkte aufmerksam, die in der jeweiligen Bildkomposition enthalten sind (Makowski). Das musste beileibe nicht immer ein prominentes Bilddetail sein, wie etwa die eher versteckte Wanderdüne im „Verlorenen Sohn“ von Jheronimus Bosch (ca. 1505), die als metaphores Bildelement zugleich Anspielung auf die kritisierte Lebensweise des Protagonisten wie auf die zeitgenössische Devastierung der Landschaft ist. Dass sich Landschaftsbilder von Hobbema über Friedrich und Renoir bis Nolde finden, überraschte angesichts des Untertitels des Buches nicht. Aber es gab manches auf den ersten Blick überraschende Bildmotiv, wie etwa „Mr. and Mrs. Andrews“ von Thomas Gainsborough aus dem Jahre 1749/50. Was hatte diese Darstellung englischer Landadliger mit „ökologischen Fragen“ und „Landschaft“ zu tun? Die rechte Bildhälfte, die vom Ehepaar nicht verstellt ist, weil es sich dem Maler gegenüber unter dem Baum auf der linken Bildseite leicht blasiert in Positur gebracht hatte, gibt den Blick frei auf mehrere in die Bildtiefe gestaffelte landwirtschaftlich bewirtschaftete Parzellen des Herrensitzes The Auberies nahe Sudbury, Essex. Diese Parzellen sind der Schlüssel zur Einbeziehung des Bildes in das Werk von Makowski \& Buderath. Denn es verweist auf die im 18. Jh. in England adaptierten neuen Methoden der Landwirtschaft. Es könnte auch zugleich auf die eminenten physiokratischen Wirtschaftstheoretiker Englands verweisen, wäre dies nicht eine anachronistische Interpretation, weil jene Autoren ihre einflussreichen Schriften erst deutlich nach dem Entstehungszeitpunkt des Bildes verfasst haben.

Die kurzen Hinweise mögen genügen, die kluge Auswahl der Bilder, ihre Potentiale, ihre Erläuterungen einschließlich dazugehöriger Kommentaren und ihrer Anschlussfähigkeit für den umwelthistorischen Diskurs mit Respekt hervorzuheben. Das Werk von Makowski \& Buderath stellt Bilder in Gruppierungen zusammen: „Garten und Park“, „Landwirtschaft, Felder und Flur“, „Wald“, „Wasser und Fluss“, „, Heide und Sand“, „Moor“, „Meer“, „Gebirge“. Die Themenfelder sind erkennbar solche, die sich zwanglos in einen umwelthistorischen Pflicht-Katalog einfügten. Qualitätvoll 
verbinden die Erläuterungen kulturgeschichtliches und ökologisches Wissen in einer Weise, die man auch zur Zeit der Veröffentlichung des Buches gewiss „umwelthistorisch" genannt hätte, wäre der Begriff schon allgemein verfügbar gewesen. Nach wie vor ist dieses Buch ein hervorragendes Musterbeispiel für umwelthistorische Wissensbildung und -vermittlung. Im akademischen Kontext wird erstaunlich selten auf es verwiesen. Zum einen mag dies daran liegen, dass verwendete Literatur nur als Auswahl-Liste im Anhang beigegeben und nicht in Form von Hinweisen, Bezügen und referenzierten Zitaten in den Textverlauf eingebettet ist. Das begrenzt den Nutzen des Buches auf unglückliche Weise. Es steht allerdings zu befürchten, dass dies zum anderen auch mit einem beobachtbaren Anerkennungsgeiz zusammenhängen könnte, den mancher professioneller Historiker den Leistungen entgegenbringt, die von Nichthistorikern auf Feldern erbracht werden, für die jene Historiker Besitzstand annehmen. Das Werk von Makowski \& Buderath kann heute zwar als umwelthistorische Fibel verstanden und gelesen werden, ${ }^{739}$ seine Entstehung verdankte es indes einem Impuls, den die Autoren selbst gleich mit den ersten Textzeilen des Buches benennen: „Die Anklage liegt vor. Die Verhandlungen sind öffentlich. Die Anklage lautet auf, Raubbau an der Natur in Tateinheit mit Nötigung und Gewaltanwendung'. Beklagter ist der Mensch, richtiger: der Mensch unserer Breiten und unserer Zeit. Der Hauptankläger ist ebenfalls der Mensch, unterstütət von einer Reihe von Nebenklägern. Die Verteidigung plädiert auf den Befehlsnotstand, der niedergelegt ist in dem Auftrag, sich die Erde Untertan ₹u machen. "(S. 7). Es ist die missionierende Aufforderung zu ökologischer Umkehr und naturkonservatorischer Buße, die Ende der 70er-, Anfang der 80er Jahre des 20. Jhs. in Deutschland den öffentlichen Diskurs als progressives politisches Programmelement durchzog. ${ }^{740}$ Erst kurz vor der Veröffentlichung des Buches waren „Die Grünen“ als politische Partei gegründet worden (1980). Der pädagogische Zeigefinger zeigte, soweit ist in der Zwischenzeit von der Umweltgeschichtsforschung Klarheit geschaffen worden, zu Unrecht allein auf das vermeintlich christlich-abendländische Ausbeutungserbe, denn bis heute sucht die Forschung vergeblich nach einer menschlichen Kultur, die sich außerhalb dieser Vorwürfe befindet, denen voreilig eine Spezifität christlicher Weltsicht unterstellt wurde. ${ }^{741}$

739 Die Deutsche Nationalbibliothek hat die beiden Druckversionen, die von diesem Werk existieren, folgenden Sachgruppen zugerechnet: „61 Geographie, Heimat- und Länderkunde, Reisen; 44 Umweltschutz, Raumordnung, Landschaftsgestaltung; 46 Bildende Kunst". Einen Zusammenhang mit der Sachgruppe „63 Geschichte und Historische Hilfswissenschaften” sahen die Bibliothekare bei Aufnahme des Titels nicht (letzte Katalogabfrage 7.2.2010). Das ist nicht weiter zu kritisieren, schließlich fehlt „Umweltgeschichte“ sogar in den Rezensionsrubriken von H-Soz-u-Kult bis auf den heutigen Tag (7.2.2010), sie wird auch im weit verbreiteten „Bücherverzeichnis zur deutschen Geschichte" (Baumgart, letzte Auflage 2006) vergeblich gesucht.

740 Mindestens ein Teil des Buches ist in Schneverdingen, Niedersachsen, geschrieben worden (u.a. das Vorwort). Schneverdingen ist seit 1981 Sitz der heute so genannten „Alfred Töpfer Akademie für Naturschutz (NNA)“

741 Abgestellt wird auf Genesis 1, 28: „Und Gott segnete sie [Mann und Frau] und sprach zu ihnen: Seid fruchtbar und mehret euch und füllet die Erde und machet sie euch untertan und herrschet über die Fische im Meer und über die Vögel unter dem Himmel und über das Vieh und über alles Getier, das auf Erden kriecht." Das Gebot fundierte theologisch den Umgang mit Natur im dominium terrae. ( Einschub und Hervorhebung B.H.) - Der Vorwurf, die Ausbeutung der Natur sei ein spezifisch christliches Erbe, wurde von dem Princeton-Historiker Lynn White (1967) in einem seinerzeit einflussreichen Aufsatz erhoben. Der Vorwurf schien damals, ohne hinreichende vergleichend umwelthistorische Kenntnisse, überzeugend. Heute ist er überholt (hierzu z. B. Diamond; Kaiser). [Dia- 


\section{$2 \quad$ Der Vorschlag hat weitere Vor-Bilder}

Eine im thematischen Zusammenhang andere wichtige Anregung geht auf Arthur E. Imhof zurück. ${ }^{72}$ Nicht, dass nicht schon vor Imhof Bilder als Instrumente, als Vehikel, als Beförderer historischer Wissensbildung verwendet worden wären. Jakob Burckhardt $^{743}$ und andere seien als Zeugen benannt. (Und wo wären die antiken Stätten Roms heute ohne Piranesis Veduten und deren Wirkung?) Die durch Bilder angeregte bzw. an ihnen entwickelte Ausführungen Imhofs über Alltagsleben in früheren Zeiten (1991) und CD-ROMs über meteorologische Bildmotive (Wolken, 1997) und die Bilderserie über Joos de Mompers „Vier Jahreszeiten“ (1998), die beide mit seiner Beteiligung realisiert wurden, haben Blick und Aufmerksamkeit auf Bildelemente gelenkt, aus denen umwelthistorisches Nachdenken entwickelt werden kann. Sein Anliegen war das des Sozialhistorikers und des Historischen Demographen, ${ }^{744}$ heute würde wohl wenigstens ein Teil seiner Arbeiten als „umwelthistorisch“ eingeordnet werden.

Praktische Erprobungen der umwelthistorischen Bildanalyse konnten sich auch in gemeinsamen Lehrveranstaltungen mit dem Kunsthistoriker Gerd Unverfehrt, ${ }^{745}$ realisieren und trugen sehr konkret zu Vorstellungen über das Machbare und das Unmögliche bei. Immer wieder wurde dabei deutlich, dass Bilder-Serien nach dem Muster der „Vier Jahreszeiten“ oder der „Monatsbilder“ sehr zuverlässige Einstiege in umwelthistorische Bildbetrachtungen ermöglichen. ${ }^{746}$

Eine den „100 Meisterwerken“ ähnlich gelagerte Idee verfolgt seit einigen Jahren die Zeitschrift Environmental History. Seit April 2003 druckt sie unter der Rubrik "Gallery" Fotografien, Cartoons, Plakate, Pflanzenabbildungen und Karten von umwelthistorischem Belang, und beschreibt auf der Homepage der Zeitschrift deren Zielsetzung: „Es sollen Anregungen gegeben werden sollen, visuelles Material für die Umweltgeschichte nutz̧bar qu machen. Dabei unterscheiden sich die einzelnen Beiträge sehr. Einige erklären, wie das Bild qustande kam, andere forschen nach seiner historischen Wirkung. Einige sehen im Bild eine bistorische Quelle. Oft kann aus der Bildquelle etwas gelernt werden, dass sich so oder überhaupt nicht in Schriftquellen finden lässt. Wieder andere „Gallery"-Beiträge interessieren sich für visuelles Lehrmaterial, um in Erfabrung zu bringen, welche Art von Diskussionen von ibm im Seminar angeregt werden. " $747 \mathrm{Da}$ -

monds Monographie wird hier lediglich wegen der Beispielauswahl angeführt. Es bedeutet keine Zustimmung zu seinen Schlussfolgerungen.]

${ }^{742}$ Arthur E. Imhof, Historiker-Kollege aus gemeinsamen Tagen an der FU in Berlin, sei an dieser Stelle für seine Anregungen bedankt.

743 „Die Kultur der Renaissance in Italien“, zuerst erschienen 1860

${ }^{744} \mathrm{Zu}$ den Sonderbarkeiten des sich herausbildenden Wissenszusammenhangs „Umweltgeschichte“ gehört es, dass bestimmte Themen endlos und sich ständig wiederholend ausgebreitet werden (z. B. das „Katastrophen“-Thema), andere Themen von ganz erheblicher Wichtigkeit überhaupt nicht beachtet werden, etwa die Demographie. Die Historische Demographie ist meiner Auffassung nach ein wichtiger Bereich der Umweltgeschichte, weil Bevölkerungsänderungen Umweltänderungen i.w.S. reflektieren.

${ }^{745}$ Des 2009 zu früh verstorbenen Göttinger Kollegen Gerd Unverfehrt sei an dieser Stelle mit dankbarer Erinnerung gedacht.

${ }^{746}$ Thematische Bilderserien sind indes selten. Einschlägige Zusammenstellungen verdanken sich der Bemühung engagierter Kuratoren, wenn etwa eine Bilderausstellung über „Die Kleine Eiszeit“ (Gemäldegalerie) veranstaltet wird.

747 http://www.environmentalhistory.net/index.htm (12.2.2010), Übersetzung des Verf. 
mit liegt Environmental History mit ihrer Rubrik nahe bei den Intentionen des hier vorgetragenen Vorschlags. Die bisher veröffentlichten „Gallery“-Bilder wiederholen meistens Bilder, die bereits von Makowski \& Buderath in den thematischen Zusammenhang gestellt wurden. Neu in der „Gallery“ ist die Idee, auch Reklamebilder, Cartoons und andere Bilder zu besprechen und sich damit den Ausdrucksmitteln der Gegenwart bzw. der Alltagskultur zuzuwenden.

Die Bildbetrachtungen Imhofs waren gewiss von vorausgegangenen Entwicklungen der Museumspädagogik, wie sie auch an den Berliner Gemäldegalerien (SMPK Nationalgalerie) gepflegt wurden, beeinflusst. Den Besuchern stellte die Gemäldegalerie in Dahlem bereits seit den frühen 1970er Jahren Führungsblätter mit ausführlichen Erklärungen zu einzelnen Gemälden von Weltgeltung zur Verfügung, was sich zu einem ungeheuren Erfolg entwickelte. Mit Beginn der 80er Jahre wurden international Bemühungen verstärkt praktiziert, bei Kunstwerken mit naturalistischen Darstellungen nicht mehr nur nach der Symbolik einzelner Pflanzen oder Tiere zu fragen, sondern möglichst alle abgebildeten Pflanzen und Tiere zu identifizieren. Beispielgebend und Maßstab setzend waren in neuerer Zeit vor allem die Arbeiten von Mirella Levi D’Ancona (z. B. 1977 und 1983) sowie die Ausstellungskataloge des niederländischen Botanikers und Kunsthistorikers Sam Segal (z. B. 1988 und 1990). ${ }^{748}$ Dass die Arbeit von Lottlisa Behling (1957) so wenig Resonanz außerhalb der Kunstgeschichte erfahren hat, lag sicherlich einerseits an der sehr auf die Symbolik bezogenen Interpretationsarbeit, obwohl die Autorin in sehr engem Kontakt mit dem bekannten Botaniker Troll stand. ${ }^{749}$ Andererseits aber gewiss auch daran, dass Ableitungen aus den Pflanzen selbst und aus ihren Standortbedürfnissen sich damals nicht gegen einen „Essentialismus"-Vorwurf hätten behaupten können. Aber alle diese Werke führen direkt und vertiefend auch in unwelthistorische Zusammenhänge. Die Berliner Museen erarbeiteten 1983 ein Führungsblatt zu „Der Blumenstrauß“ von Jan Brueghel d. Ä., in dem das Blumenbouquet zu einem enzyklopädischen Katalog mit vegetations- und kulturgeschichtlichen Einträgen über die Einführungsgeschichte der gemalten Blütenpflanzen geworden ist. Auf die Vorbildhaftigkeit dieses Führungsblattes wird weiter unten zurückzukommen sein.

In zeitgenössischer Fortsetzung dieser Idee bieten heute große Museen der Welt ${ }^{750}$ längst rechnergestützt nutzerorientierte Abfragemöglichkeiten über ihren Bestand an. So lässt sich in der Londoner National Gallery eine Bestands-Recherche z. B. über „Landschaften“ sehr schnell durchführen, beispielsweise über „Landschaften mit Tieren“, „Naturalistische Landschaften“ und „Topographische Landschaften“ (d. i.: das Umland konkreter Orte). ${ }^{751}$ Das Beispiel Landschaft drängt sich in diesem Zusammenhang geradezu auf. Sie ist nicht nur für die Kunstgeschichte ein unerschöpfliches Thema. Immerhin verdankt sogar die Wortfügung „Landschaft“ ihre Entstehung dem künstlerischen Bereich. „Landschaft“ ist, wenn man sie als Aufenthaltsort von Men-

\footnotetext{
748 Homepage von Sam Segal unter http://www.still-lifestudies.net/introduction.html (16.2.2010).

749 Behling hat beide Bände ihrer Arbeiten über Pflanzen (zur mittelalterlichen Tafelmalerei und zur plastischen Ornamentik in ma Kathedralen, 1964) dem Botaniker Troll gewidmet.

750 M.E. beispielhaft die National Gallery in London [http://www.nationalgallery.org.uk/].

751 Leider gilt für London, wie für fast alle große Museen, dass die im Hause selbst angebotenen rechnergestützten Dienstleistungen nicht in gleicher Weise on-line zugänglich sind.
} 
schen begreift und durch deren Aktivitäten geprägt versteht, sicher das komplexeste Archiv der menschlichen Kulturgeschichte an einem gegebenen Ort. In dieses kulturgeschichtliche Archiv sind die unabhängigen und doch durch ihre Einbindung in die menschlichen Angelegenheiten zugleich abhängigen Archive der belebten und unbelebten Natur integriert. Damit ist „Landschaft“ einer der zentralen Begriffe und Zugänge zur Umweltgeschichte. Mit den Namen von Humboldt, Hardt $(1970,2002)$ und Warnke sind Eckpunkte sehr bedeutender Theorieentwürfe der Landschaft benannt, wobei alle drei auf die Rezeption von Landschaft im Sinne von Bildern eingehen. ${ }^{752}$ Das ästhetische Moment ist auch Leitmotiv der im deutschsprachigen Raum einflussreichsten Landschaftsdefinition der letzten Jahrzehnte, die Joachim Ritter formulierte. ${ }^{753}$

Levi D’Ancona und Segal haben den floralen Bildelementen große Aufmerksamkeit gewidmet. Deren Verwendung als selbstständige Einheiten der Bildkomposition in der Malerei ist Ergebnis der Beobachtung durch den Künstler und seiner Beschreibung der Formenmannigfaltigkeit, der Fülle, der Diversität. Mit Beginn der frühen Neuzeit wird das Spiel der Künstler mit der Formenfülle selbstverständlich und gleichsam „natürlich“ in das Naturbeobachtungskonzept der Voraufklärung integriert, das in der „Grossen Kette der Wesen“ seine synthetische Theorie gefunden hatte. ${ }^{754}$ Daher sind diese Bildanalysen so bedeutungsvoll und auch im Hinblick auf die weniger häufig dargestellten Tiere umwelthistorisch ergiebiger.

\section{Der Vorschlag ist einfach und doch zugleich komplex}

Selbstverständlich sind Bilder, gemalte zudem, keine historische Quelle im Sinne einer authentischen Wiedergabe. Dass künstlerische Bilder die Aufgabe der authentischen Unterrichtung über objektive Abläufe oder Sachverhalten hätten, wird ohnehin niemand ernsthaft behaupten wollen. Selbst die so genannt authentischen Pressefotos sind subjektive Blickwinkel des Fotoreporters und sind Instrumente jener Berichterstattung, die sich ihrer bedient, also Ergebnis eines Auswahlprozesses.

\footnotetext{
752 Von Humboldt verwendet im Kosmos als Bezeichnung seines Kapitels „Allgemeine Übersicht der Erscheinungen“ in dem er u.a. Berichte außereuropäischer Völker über seltene Naturphänomene wiedergibt, das Wort „Naturbilder“. Das Kapitel stellt u.a. Sichtweisen vor, Rezeptionshaltungen, die zur Beobachtung des Phänomens eine spezifisch kulturell geprägte Erklärung hinzufügen, in der das Bildhaft-Plastische vorherrscht. Die Sprache von Humboldts weist darauf hin, dass ein Naturkonzept (und tatsächlich handelt das Kapitel von solchen) sich des Bildhaften mindestens dann als Ausdrucksmittel bedient, wenn und solange es schlüssiger positivistischer Erklärungen ermangelt.

${ }^{753}$ Selbstverständlich spielen auch andere Theoretiker eine wichtige Rolle. Ihrer sei jedoch, um nicht in ein Nebenthema zu geraten, mit dem Hinweis auf Apel hier abschließend gedacht.

${ }^{754}$ Lovejoy - Der Begriff „Synthetische Theorie“ spielt auf den Begriff „Synthetische Theorie (der Evolution)“ an, wie er in den zeitgenössischen Biowissenschaften geläufiger Weise für die „Zusammenfassung der Erkenntnisse aller biologischen Teilwissenschaften über die organismische Evolution" verwendet wird. In der voraufklärerischen Ausdeutung der Natur als einer Offenbarungsweise Gottes sowie in den Abbildungen von „Natur“ in der Malerei als „gemalte Predigten“, erkenne ich eine äquivalente „synthetische Theorie“, deren Fundierung u.a. in den physikotheologischen Schriften bereitgestellt wird (z. B. Michel).
} 
Weil Menschen Augenwesen sind, erreicht sie ein Bild unmittelbarer als das gesprochene oder gelesene Wort. Die Verwendung des Bildes zielt darauf, im Betrachter Assoziationen freizulegen, Gedanken und die daraus resultierende Wissensproduktion in Gang zu setzen. Bildergebrauch ist in der Alltagskultur und in der Wissenschaft selbstverständlich. Dort, wo er zur Sinnerzeugung dient, ist das Handwerkszeug der Ikonologie gefragt.

Wollte jemand ernsthaft im Angesicht eines Bildes bestreiten, welches die Freisetzung historischen Wissens katalysieren soll, dass „die Vergangenheit nicht das Erinnerte [ist], sondern der sich Erinnernde“ (Franz Baermann Steiner)? Für die Kunstgeschichte wie für die Geschichtswissenschaft sind kontextuell verwendete Bilder als Quelle daher immer ein zur Vorsicht gemahnendes Terrain gewesen, ${ }^{755}$ und ihrer umwelthistorischen Verwendung wird eine sehr penible Prüfung vorausgehen müssen.

Unzweifelhaft erscheinen Bilder wegen des Impulses, den sie beim Betrachter hervorrufen, viel subjektiver als ein Text. Während sich die Position des Autors während des Lesens im Leser aufbauen kann, hat das Bild wegen seiner Totalität und sofortigen Präsenz keine solche Chance der allmählich fortschreitenden emphatischen Rezeption. Das Bild bindet sofort emotional und gibt dem rationalen Korrektiv lediglich die nachgeordnete, die zweite Chance.

Die Verwendung von Bildern ist wirkungsvoll, weit reichend und vor allem didaktisch produktiv. Für Makowski \& Buderath waren diejenigen Bildelemente, an die sie ihre Erläuterungen knüpften, immer Abbildungen des Realen, waren immer Belege für das Vorkommen von Folgezuständen innerhalb ökologischer Prozesse, eine vielleicht etwas zu engagierte Position dieser Autoren und eine gewisse Schwäche ihrer Argumentation. Bilder enthalten mehr als positivistische ontologische Zuweisungen, manchmal aber nicht einmal das. Der Historiker lernt, die Bewertung eines Textes nicht auf die bloßen Buchstabenfolgen abzustellen, sondern Texte auch als Produkte ihrer Leser zu begreifen, er lernt, dass Texte also nicht nur einen Sender, sondern viele Empfänger haben. Genau dasselbe gilt für Bilder. Niemand kennt die wirkliche, die wahre, die immergültige Bedeutung. Denn ein Kunstwerk enthält immer auch Dinge, von denen selbst der Künstler nichts weiß. Deshalb ist die Herausforderung für den Verfasser einer umwelthistorischen Bildanalyse einerseits ungleich größer als beim Verfassen eines üblichen „Schauplätze“-Textes. Das unglaublich Reizvollste an umwelthistorischen Bildbeschreibungen ist aber, das es weniger Irrtümer gibt, weil der Betrachter über seinen Eindruck berichtet. Wer sagt denn, dass dieser von anderen geteilt werden müsse? Damit sie aber nicht ins Beliebige abgleitet, gilt es, eine umwelthistorische Ikonologie zu entwickeln. Hierzu sei aufgefordert.

\footnotetext{
${ }^{755}$ Für die Kunstgeschichte genügt der Hinweis auf den Klassiker Panofsky (1975, 1980). - Der Historischen Bildkunde wird seit einiger Zeit in den Geschichtsdisziplinen theoretisch wie praktisch zunehmende Aufmerksamkeit zuteil. Auch hierfür sei ein früher Wegbereiter (Keyser) und als Stellvertreter für die gegenwärtige Breite Burke benannt.
} 


\section{Der Vorschlag wird durch eine Bilderserie ergänzt und mit zwei Beispielen veranschaulicht}

Eine kurze Liste geeigneter Bilder lässt das Prinzip einer möglichen Serie erkennen:

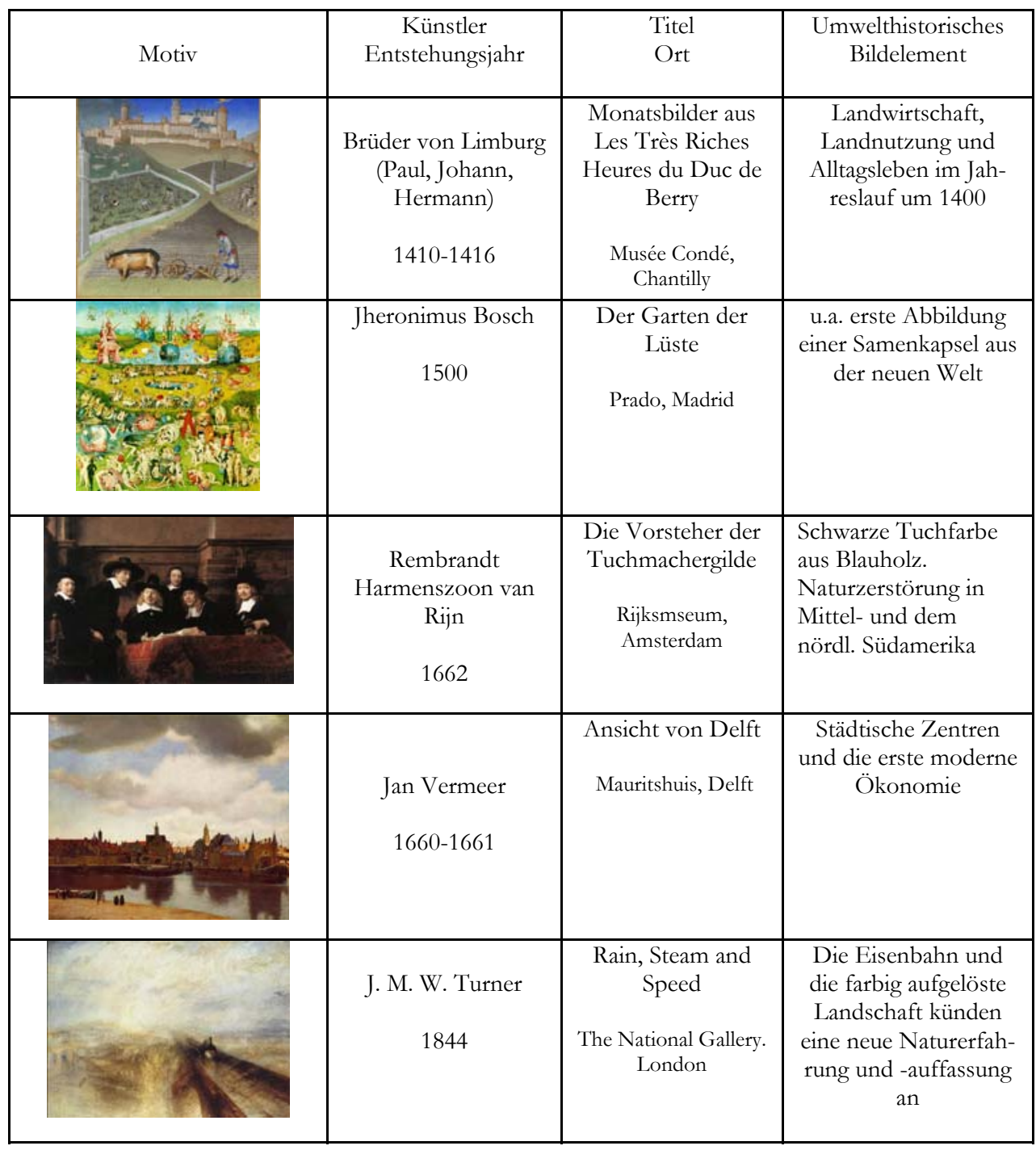




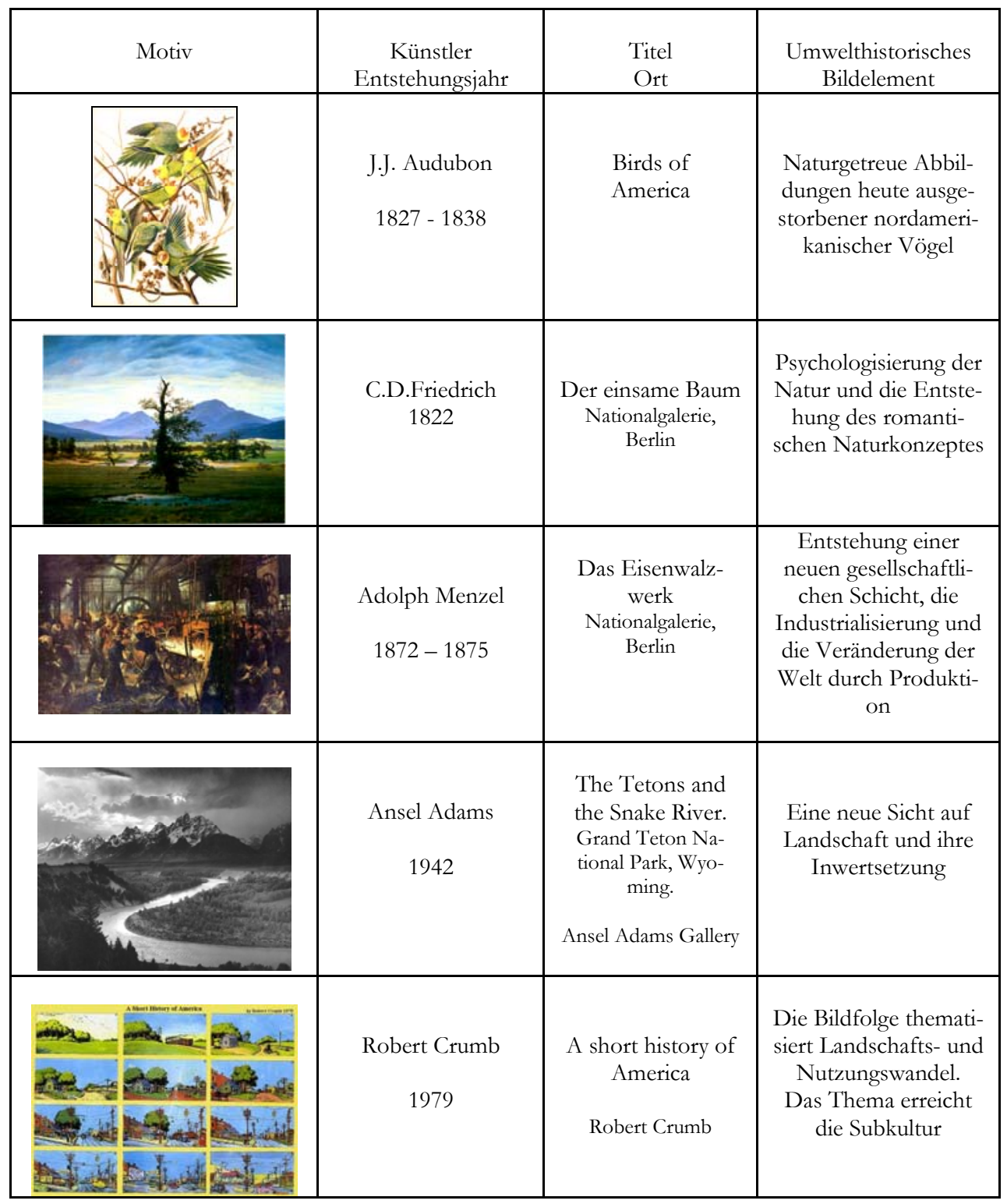




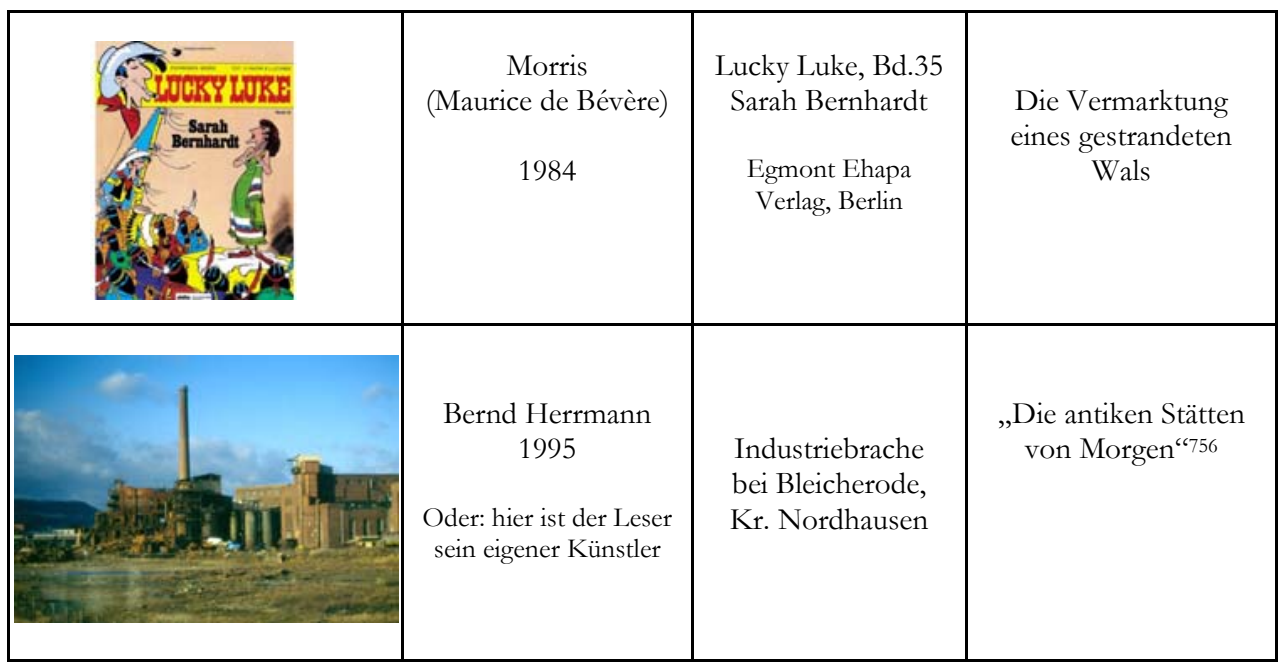

Wie man sich eine umwelthistorische Analyse von Bildern vorstellen kann, wird an den nachfolgenden zwei Beispielen gezeigt.

756 Anspielung auf: Hamm M, Sieferle R-P (2003) Die antiken Stätten von morgen. Nicolaische Verlagsbuchhandlung, Berlin. 
Das erste Beispiel ${ }^{757}$

Jan Brueghel d.Ä., (1568 - 1625), Blumenstrauß

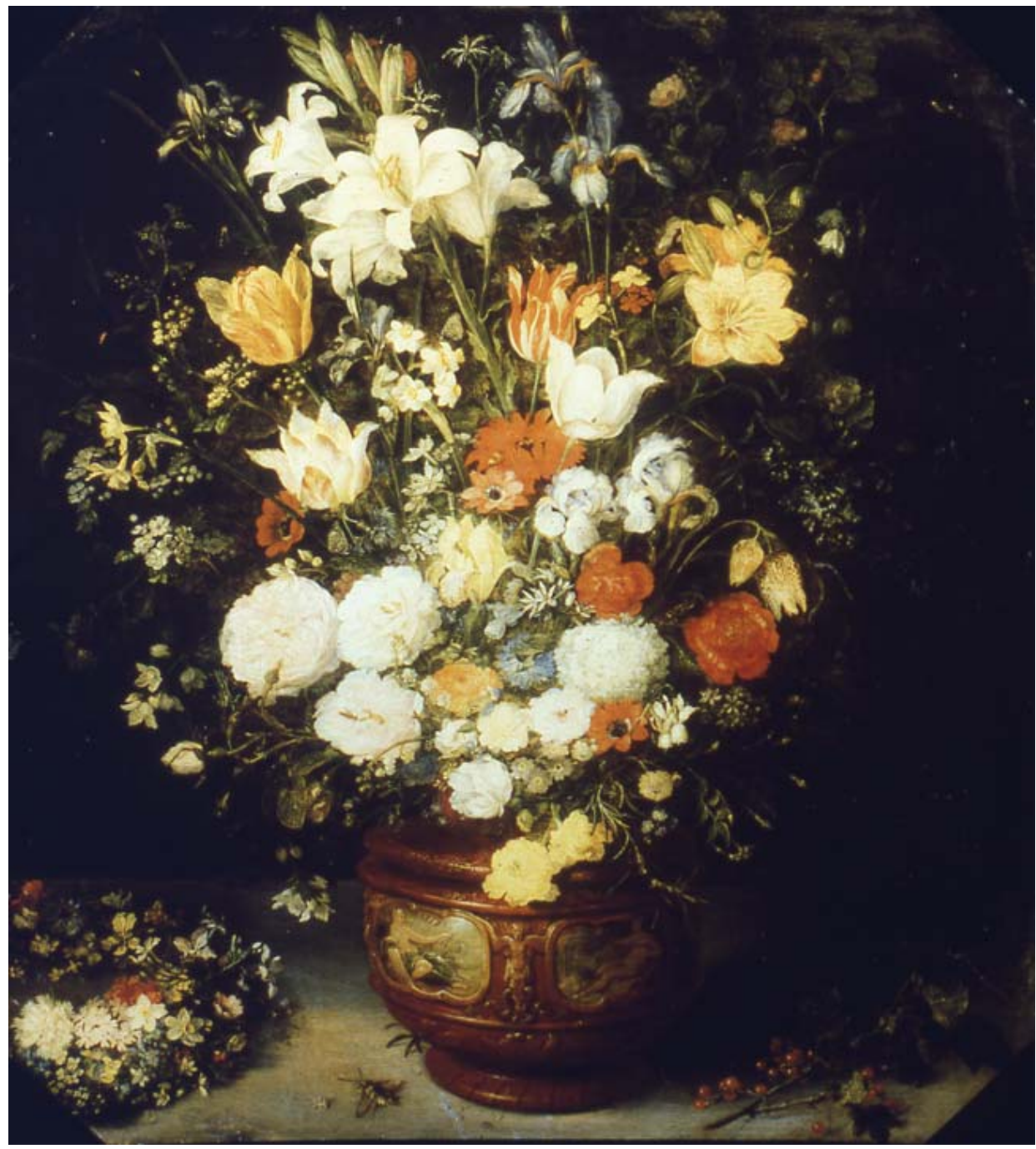

Abb. 1: 1619/1620, Ö1 auf Eichenholz, 64 x $59 \mathrm{~cm}$. Nationalgalerie, Berlin.

${ }^{757}$ Ich verwende hier einen Anteil eines früheren „Schauplätze“-Textes in abgewandelter Form mit. 
Brueghel hat das Motiv wiederholt gemalt. In mehreren großen Museen Europas ist es ähnlich zu finden. Es ist hier ausgewählt, weil sich die in realistischer Manier ausgeführten Bilder der alten Meister eher als die Klassiker der Modernen Kunst für umwelthistorische Überlegungen anbieten. Impressionistische, expressionistische, abstrakte oder surrealistische Kunstwerke lassen von vornherein keinen Zweifel an der Differenz zwischen Darstellung und Abbildung aufkommen. Die naturalistische Darstellungsweise der alten Meister erlaubt, die Rezeptionsgeschichte von Naturdingen zu verfolgen. Zudem sind die Bilder der alten Meister in die kollektive Sichtweise einer „europäische Sehschule“ eingegangen, welche die Herausbildung von Mensch-Natur-Verhältnissen in sehr weiten Teilen Europas beeinflussten.

Das bekannteste und langzeitwirksamste Beispiel für die Herausbildung kollektiver Sichtweisen ist sicherlich die Entwicklung eines in weiten Teilen Europas verbindlich gewordenen Landschaftsverständnisses. Dürer gilt als der Begründer des eigenständigen Landschaftsbildes. Pflanzen und Felsformationen, Landschaftsräume und Stadtansichten sind durch ihn Themen der künstlerischen Umsetzung geworden. Albrecht Dürer (1471-1528) hat aus Landschaften, die vorher nur sumarisch den Ort von Handlung andeuten, völlig neue Einblicke in die Natur geformt. ${ }^{758}$ Er steht auch am Beginn der detailfreudigen Beobachtung, die später im flämischen Stillleben einen Höhepunkt erleben und damit zu einer der Wurzeln der moderen Naturwissenschaft werden wird. ${ }^{759}$ Das Landschaftsbild findet dann nachfolgende Meister in Claude Lorrain (1600-1682), Nicolas Poussin (1594-1665) und Salvator Rosa (1615-1673). Insbesondere die arkadischen Landschaftsbilder Lorrains und Poussains treffen den Publikumsgeschmack und liefern die Blaupause für den englischen Landschaftsgarten (z. B. Stourhead, Wiltshire). An diesen Modellen lernt Europa, Landschaft zu sehen.

„Die Landschaft trägt [...] nicht nur eine, von Menschen gestaltete Physiognomie’, wir sehen sie auch ,mit durch die Kunst erzogenen Augen.' Malerei und Literatur haben die Landschaft für uns so eingerichtet, dass wir sie nach deren Bildern wahrnehmen. Das ging bereits dem jungen Friedrich Hebbel so: 'Ich glaube oft, schon etwas gesehen zu haben, was ich erweislich zum erstenmal sehe, namentlich Landschaften.' - Man kann dieselbe Beobachtung erstmals in der Breite im 18. Jahrhundert, dem großen Jahrbundert der Reisen, in England und auf dem Kontinent machen. Wobin die Reise auch ging, stets sprang den Landschaftsenthusiasten das Bild eines Meisters aus der Natur entgegen - eine ,schöne', ,reizende', ,malerische', ,erhabene', ,pittoreske' oder ,romantische' Landschaft, wie sie ein Lorrain, Poussin oder Salvator Rosa gemalt hatten. Die Namen dieses Dreigestirns waren Chiffren für drei Landschaftstypen und die durch sie erzeugten Stimmungen. Claude Lorrain stand für, zarte Schönheit' und das ,Heiter-Ideale', Nicolas Poussin für ,erhabene Größe' und das ,Klassisch-Heroische', Salvator Rosa für gebannten Schrecken' und das, Wild-Romantische'. "760

758 Siehe Schröder \& Sternath

${ }^{759}$ Hierzu ausführlich Alpers

${ }^{760}$ Fischer, S. 88 


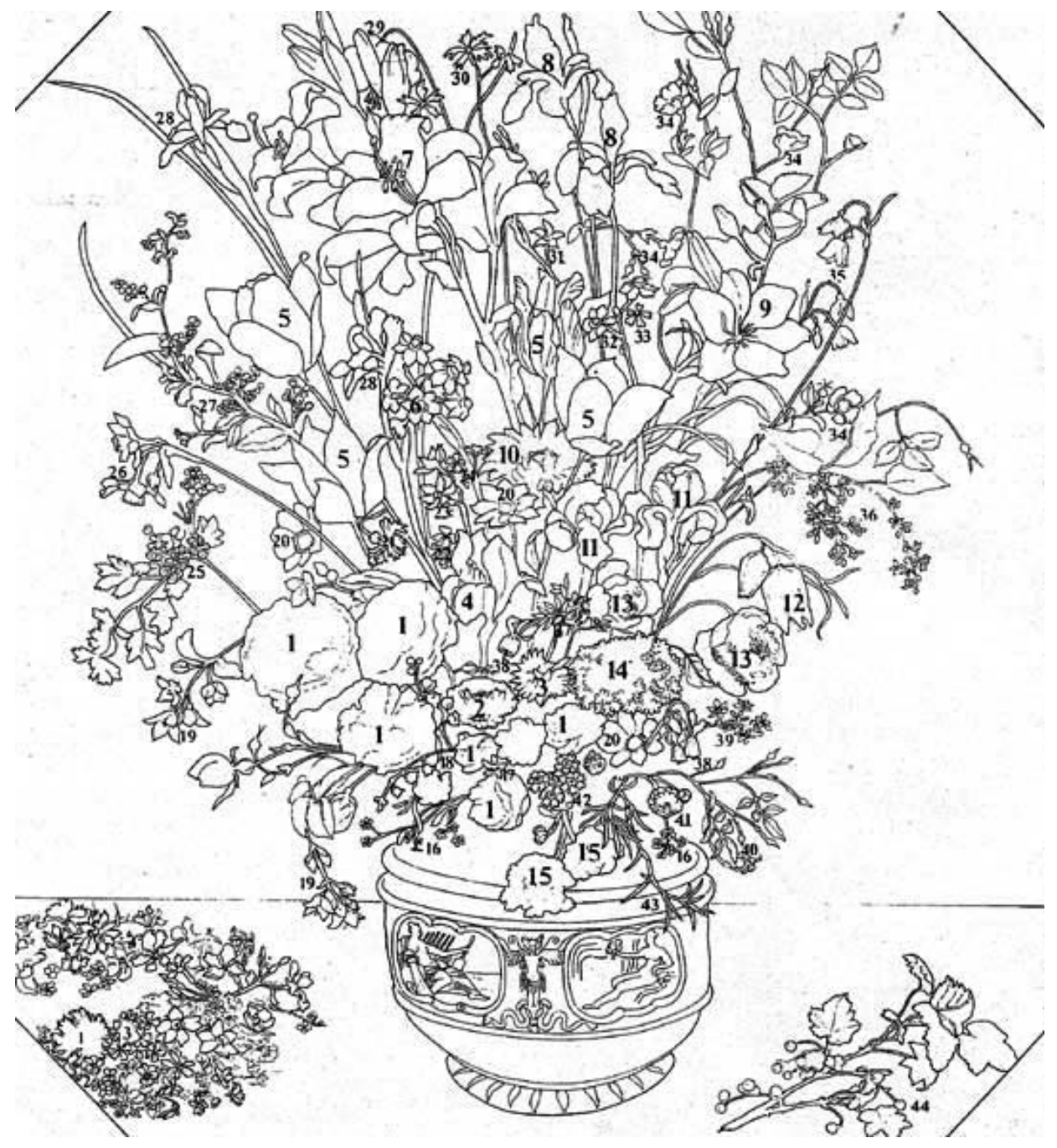

Abb. 2: Umzeichnung. Museumspädagogischer Dienst der Gemäldegalerie, Führungsblatt 752. Umzeichnung: Marina Heilmeyer. Botanische Bestimmungen: M. Heilmeyer und B. Zepernick, 1983. 
Abgebildet sind (Klammerangaben beziehen sich auf Einführungsdaten nach Mitteleuropa):

1. Damaszener Rose (1573), 2. Ringelblume (gefüllte Form seit Ende des 16.Jh), 3. Jungfer im Grünen (1596), 4. Wasser-Schwertlilie (einheimisch), 5. Tulpe (Mitte des 16.Jh), 6. Tazett Narzisse (1557), 7. Madonnenlilie (eine der ältesten Zierpflanzen), 8. Iris (1568), 9. Feuerlilie (1596), 10. Pfauenanemone (Ende des 16. Jh), 11. Schwertlilie (einheimisch), 12. Schachbrettblume (1572), 13. Pfingstrose (vor 1500), 14. Schneeball (einheimisch), 15. Sumpfdotterblume gefüllt (einheimisch), 16. Vergißmeinnicht (einheimisch), 17. Hundsveilchen (einheimisch), 18. Maiglöckchen (einheimisch), 19. Falscher Jasmin (einheimisch), 20. Kronenanemone (1596), 21. Kornblume (einheimisch), 22. Levkoje (seit dem 16. Jh.), 23. Weiße Narzisse (etwa 1600); 24. Bartnelke (1554), 25. Elsbeere (einheimisch), 26. Trompeten-Narzisse (um 1600), 27. Traubenkirsche (einheimisch), 28. Sibirische Schwertlilie (einheimisch), 29. Türkenbundlilie (einheimisch), 30. PrachtFedernelke (1583), 31. Pyramiden-Glockenblume (1569), 32. Narzisse (1565), 33. Brennende Liebe (1561), 34. Hundsrose (einheimisch), 35. Märzenbecher (1420), 36. Flieder (Mitte des 16.Jh), 37. Bärenlauch (1561), 38. Narzisse (1579), 39. Zweiblättriger Blaustern (1568), 40. Echter Jasmin (1548), 41. Strohblume (einheimisch), 42. Aurikel (einheimisch), 43. Rosmarin (alte Heilpflanze), 44. Johannisbeere (einheimisch).

Die Blumen des Kranzes: 1. Nelke (Mitte des 16.Jh), 2. Boretsch (sehr alte Kulturpflanze), 3. Primel (1583), 4. Kapuzinerkresse (1573), 5. Alpenveilchen (1600) 


\section{Umwelthistorische Einordnung}

Obwohl alle Blumen in dieser Vase so realistisch dargestellt sind, dass sie botanisch bestimmbar sind, ist das Unrealistische des Bildes offenbar. Es besteht in der Gleichzeitigkeit des Ungleichzeitigen. Alle Blumen blühen, obwohl jede ihre Vorzugszeit im Jahr hat (Abb. 3). Das Beispiel macht auf simple Weise deutlich, welche Probleme in „Bilddokumenten“ stecken, wenn sie ihrer Gegenständlichkeit wegen als Zeugnisse herhalten sollen. Sicher ist richtig, dass Brueghel dieses Bild erst um 1600 hätte malen können, sofern man eigene Anschauung in flämischer Heimat als Voraussetzung annehmen will. Allerdings übernehmen die Maler der Zeit auch Motive anderer Künstler, so daß eigene Anschauung nicht bestanden haben muß. Ebenso kann das künstlerische Motiv in der Verbreitung zeitlich seinem natürlichen Vorbild im Garten vorausgeeilt sein.

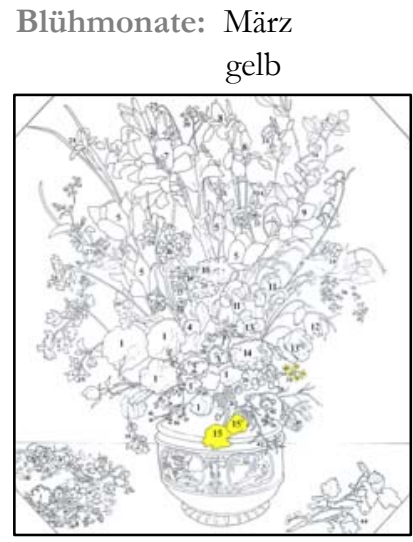

März - Juni gelb, rot, blau, lila

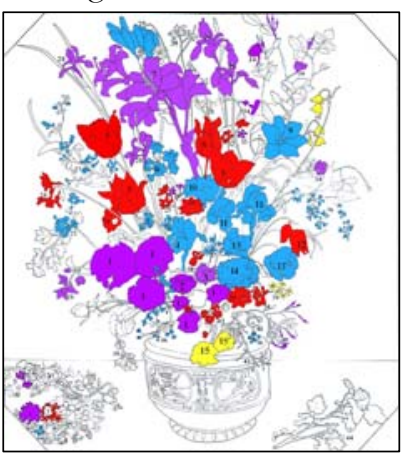

März - April

gelb, rot

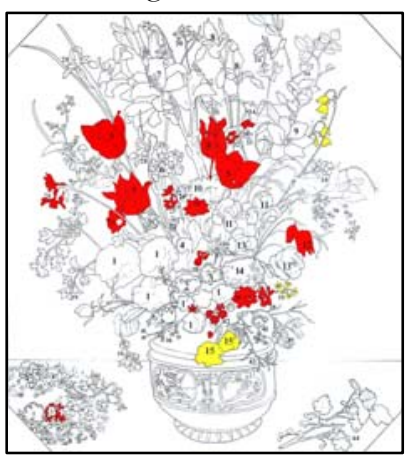

März - Juli

gelb, rot, blau, lila, grün

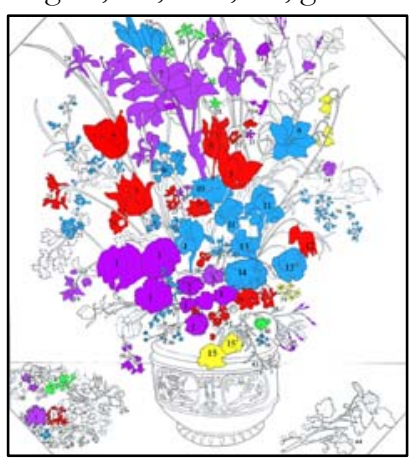

März - Mai

gelb, rot, blau

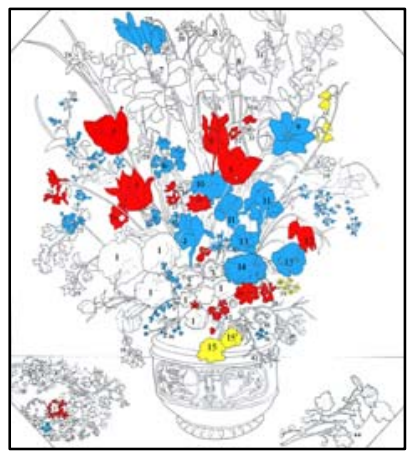

Abb. 3: Die

Blühmonate.

Angegeben ist der jewei-

lige Blütemonat der ein-

zelnen Pflanzenart.

Realisation:

S. Hourticolon. 
Das Berliner Bild vereint 49 identifizierbare Pflanzenarten, von denen nur etwa 20 zum mitteleuropäischen Bestand vor 1500 gehören. Die Mehrzahl der abgebildeten farbenprächtigen Kulturpflanzen wurde im 16. Jh. eingeführt. Umwelthistorisch stellt sich vor allem die Frage nach den Pflanzenarten und ihrer Nutzung. Das Dekorativ-Schmückende steht bei einem Blumenstrauß sicher im Vordergrund, und die Freude am Blumenbunten ist als Nutzungsvariante von naturalen Ressourcen bis auf den heutigen Tag der Motor eines umsatzstarken Wirtschaftszweiges. ${ }^{761}$ Die Herkunft der Blumen vermittelt einen Eindruck von der Erweiterung des europäischen Einflußbereiches insbesondere nach 1500 und der opportunistischen Nutzungsstrategie, mit der Europa auf das erweiterte florale Angebot reagiert. Brueghels Bild enthält vier Tulpen und ist knapp zwanzig Jahre vor der ersten Spekulationsblase der neuzeitlichen westlichen Wirtschaft enstanden. Auslöser dieser Spekulationsgeschäfte war die ursprünglich harmlose Freude am Naturbunten und der menschlichen Findigkeit, der Natur durch Züchtung immer neue Varianten zu entlocken.

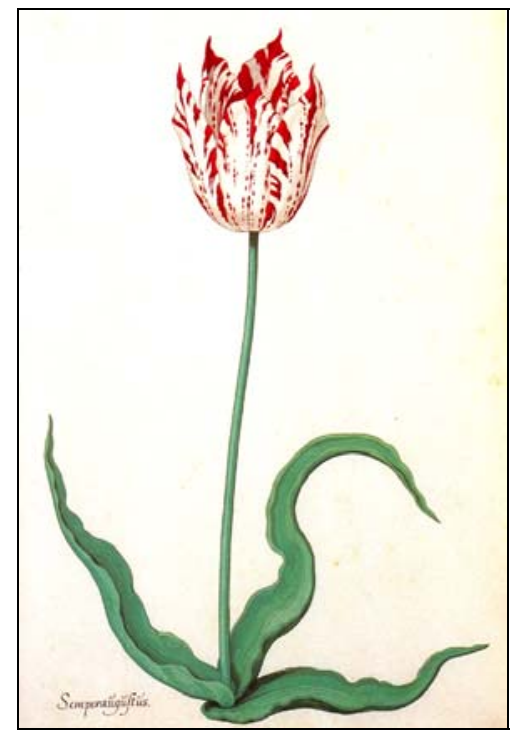

Abb. 4: Pieter Holsteyn der Jüngere (1612-1673) malte diese Gouache einer „Semper Augustus“ für einen Händlerkatalog. 1624 waren von dieser Sorte zwölf Zwiebeln bekannt, der Preis einer Zwiebel betrug 1200 Gulden. 1637 stieg der Preis einer Zwiebel auf 10.000 Gulden. ${ }^{762}$

761 Auf die metaphorische Ebene des Blumenstraußes auch als Vanitas-Symbol, also in der Tradition der ,gemalten Predigt“, ist bereits hingewiesen worden. Nichtsdestoweniger gehört wirtschaftlicher Erfolg, und sei es der mit dem Blumenhandel, zur niederländischen Variante des Calvininsmus.

762 Aus Pavord, S. 162 
Besonders begehrt waren Sorten mit „Buntstreifigkeit.“ Sie beruhten damals auf Viruserkrankungen der Pflanze. Die Erreger dieser Krankheit (Tulip Breaking Virus u. a.) werden durch Blattläuse übertragen. Die „Buntstreifigkeit“ erwähnte man in den Niederlanden bereits 1576. Es fiel in dieser Zeit auch bereits auf, dass die Zahl buntstreifiger Tulpen mit hohem Blattlausbefall des Tulpenfeldes einherging. Die virale Ursache der Blütenfarbbrechung bei Tulpen wurde jedoch erst 1928 nachgewiesen. Für die Züchter des 17. Jhs. war das Auftreten der Buntstreifigkeit nicht $\mathrm{zu}$ steuern, immerhin zeigten auch die Blüten der Tochterzwiebeln ein gleiches Muster, weil die Vermehrungszwiebeln von der Mutterpflanze her infiziert waren. Es konnte bei den damals bekannten Vererbungsregeln also von einer Sortenstabilität ausgegangen werden (die sich in Wahrheit der Weitergabe einer Krankheit verdankte). Da erkrankte Pflanzen eine reduzierte Vermehrungsneigung zeigen, war die Zwiebelproduktion dieser begehrten Sorten von vornherein begrenzt.

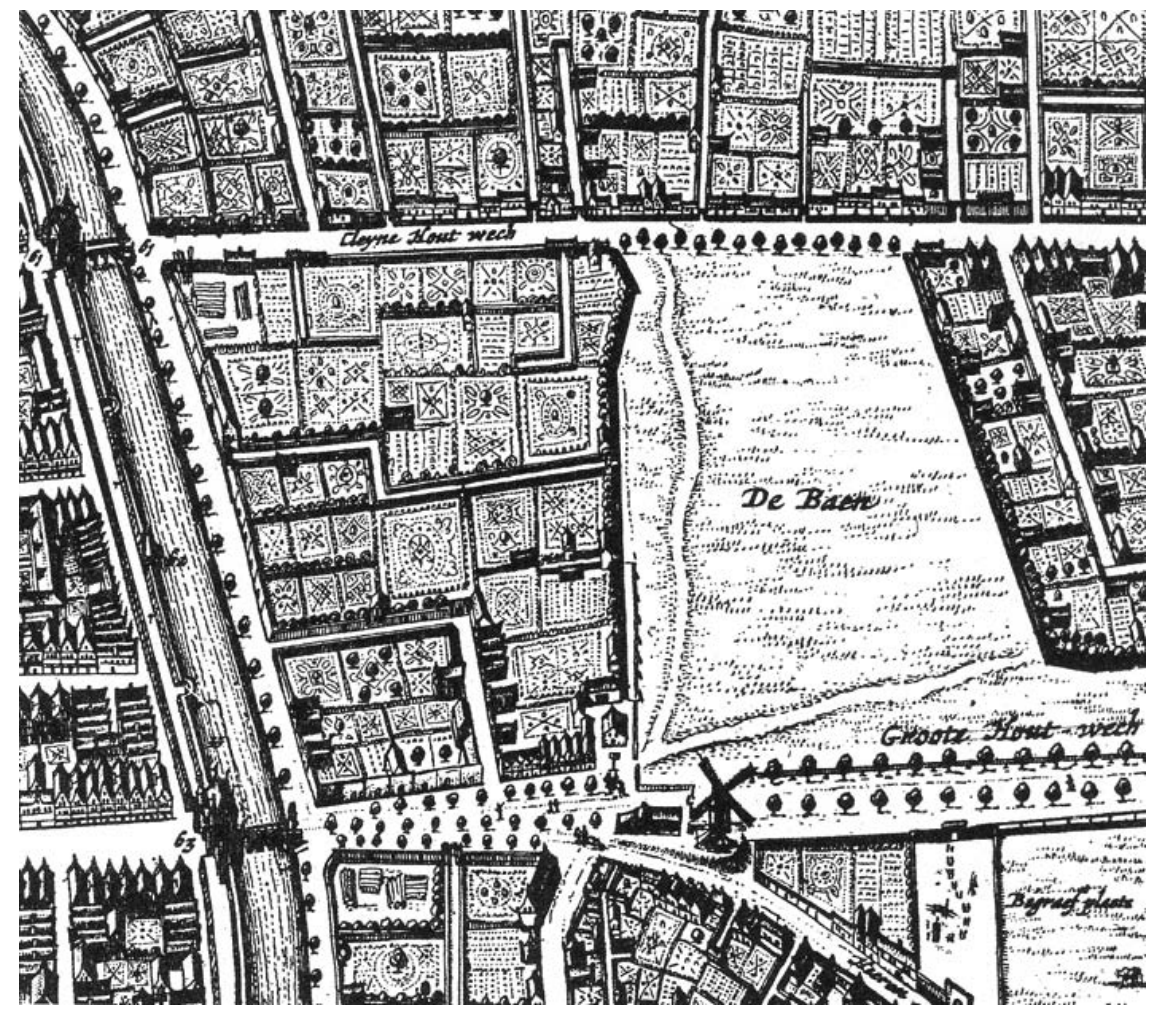

Abb. 5: Stadtplan von Haarlem 1628 mit den Tulpenfeldern (aus van Damme). Die meisten der hier abgebildten Wirtschaftsflächen liegen unter $500 \mathrm{~m}^{2}$, nach heutigen Begriffen in der Größenordnung von Kleingärten. 
Die Begeisterung für Blumen allgemein und Tulpen im Besonderen führte dazu, dass beinahe jedes Fleckchen Erde für die Blumenzucht genutzt wurde. Selbst Parzellengrößen von wenigen hundert Quadratmetern waren für die Tulpenzucht lukrativ, wenn man auf den Spekulationszug aufspringen wollte, wie man an der Parzellennutzung nach dem Kataster etwa der Stadt Haarlem erkennen kann (Abb. 5). Die heutige Nutzung der Niederlande als Blumengarten Europas nimmt von hier ihren Ausgang bzw. wird historisch verständlich. Die Niederlande verfügten früh über eines der größten Städteensembles in Europa, das nicht nur eine Nachfrage nach Blumenschmuck hervorbrachte, sondern auch einen großen Bedarf an Gemüsen, für deren Erzeugung sich eine besondere Gartenkultur entwickeln musste. ${ }^{763}$ Zudem bietet Gemüse die Möglichkeit der saisonalen Nachnutzung einer Parzelle, wenn die Zwiebel üblicher Weise etwa einen Monat nach der Tulpenblüte (März-April) aus der Erde geholt wird.764

Seit Beginn der 1630er Jahren wurden in den Niederlanden Warentermingeschäfte mit Tulpenzwiebeln im großen Stil geschlosssen. Die Tulpenenthusiasten waren bereit, für ausgefallene und begehrte Sorten horrende Preise zu zahlen. ${ }^{765}$ Innerhalb von nur drei Jahren stiegen die Preise für Tulpenzwiebeln, die in größeren Partien zumeist nur noch virtuell gehandelt wurden, ins Astronomische. Auf dem Höhepunkt der „Tulipomanie“ betrug der höchste je für eine Zwiebel der begehrten und seltenen Sorte „Semper Augustus“ geforderte Preis 13.000 Gulden. ${ }^{766}$ Im Frühjahr 1637 brach der Tulpenmarkt zusammen. In der Folgezeit wurden die Kaufverträge zum Teil rückwirkend für ungültig erklärt, wodurch viele Spekulanten auf ihrem Schaden sitzen blieben. Damit platzte die erste wirtschaftliche Spekulationsblase der Neuzeit. Vermutlich wäre sie ohnehin bald in sich zusammengefallen, denn später im Jahr 1637, dem Jahr des Wirtschaftscrashs, wurde die Übertragbarkeit der Blütenfarbbrechung durch Pfropfung entdeckt. ${ }^{767}$ Damit waren gestreiftfarbige Blüten in Grenzen gezielt zu erzeugen.

\footnotetext{
${ }^{763}$ Neben Blumenstillleben erfreuten sich in den Niederlanden auch Marktszenen großer Beliebtheit, auf denen die Vielfalt der Meeresfrüchte und vor allem der Gartengemüse ausgebreitet wurde. Sie sind ebenso gemalte Predigten wie sie Kataloge der Biodiversität sind, im Falle der Gartengemüse jener Diversität, die sich menschlicher Kunst verdankt (vgl. Fußnote 46).

${ }^{764}$ Das Thema Gemüse ist absolut unterforscht, es gibt für die frühe Neuzeit kaum gesichertes Wissen, das über Punktuelles und Anekdotisches hinausgeht. Nutzpflanzenkultivare auf niederländischen Tafelbildern des 16. bis 19. Jhs. hat u.a. Zeven identifiziert. Für das hier interessierende Zeitfenster und die Region hat Leo Wuyts den derzeitigen Forschungsstand skizziert. Vgl. auch Schaier.

${ }^{765}$ Eine großartige Quelle über Tulpensorten und die für eine Zwiebel im Jahr 1637 geforderten Preise stellt das Musterbuch von P. Coos dar, das die Universität in Wageningen ins Internet gestellt hat:

http://library.wur.nl/desktop/tulp/cos/origineel/images/index.html

${ }_{766}$ Pavord, S.143. - Zeitgleiche Durchschnittslöhne für Handwerker lagen zwischen 250 und 300 Gulden p.a.

767 Jaskolla - Die Viren können von vielen Blattlausarten übertragen werden, in denen sie keine Vermehrungsphasen durchlaufen. Übertragung ist auch durch die infizierte Menschenhand möglich. - Heute ist Buntstreifigkeit Ergebnis von Züchtungsbemühungen, virusbefallene Bestände werden dagegen heute vernichtet.
} 
Der Handel mit Blumenzwiebeln war, bevor sich im Verlauf des 17. Jhs. die Züchter auch um die Vermarktung ihrer Erzeugnisse zu kümmern begannen, zunächst im Kuriositätenhandel angesiedelt, der sich um eine beherrschende Stellung im Tulpengeschäft bemühte. So belieferte der Amsterdamer Kuriositätenhändler Emmanuel Sweert (1552-1612) nicht nur die Höfe in Prag und Wien und niederländische Blumenliebhaber, er handelte auch mit ausgestopften Vögeln, Muscheln und Schnecken, vor allem aus den Kolonien. Ähnlich den Tulpen avancierten aber auch diese Naturkuriosa zu Spekulationsobjekten. Ein Stillleben wie das von Jaques Linard (Abb. 6), einem fanzösichen Maler, zeigt die Sammelschachtel als Hinweis auf eine größere Kollektion und Exemplare aus dem Pazific, dem Indischen Ozean, dem Indo-Pazifischen Raum, von den Philippinen und der Westküste Mittel-und Südamerikas. ${ }^{768}$

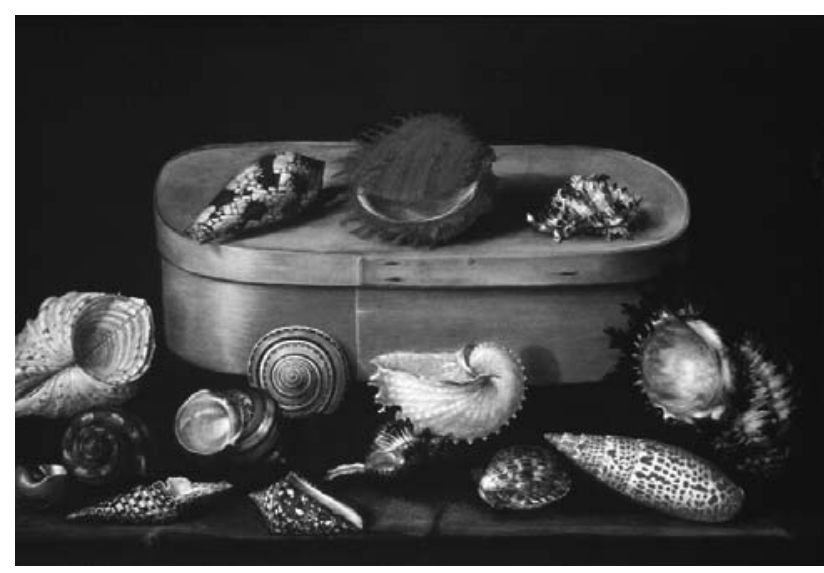

Abb. 6: Jaques Linard (1600-1645)

Exotische Conchilien

(1621 oder $1624,38 \times 52 \mathrm{~cm})$

(mit freundl. Genehmigung der Edward Speelman Ltd., London)

Noch nicht vertreten sind auf dem Bild Conchilien ${ }^{769}$ der Australis, da sie zu dieser Zeit noch nicht entdeckt ist. ${ }^{770}$ Wieder erkennt die Kunsttheorie eine gemalte Predigt, nicht nur nach dem Vanitas-Prizip (denn die Schalen sind Reste toter Tiere und ihre Farbigkeit symbolisiert die Eitelkeit der irdischen Welt) sondern auch als Gotteslob über die Vielfalt, Pracht und Vollendetheit seiner Schöpfung. Doch eine

\footnotetext{
768 Segal 1988, S. 85

${ }^{769}$ Begriff, mit dem die Biologen alle Gruppen schalentragender Weichtiere, bzw. vereinfachend deren Schalen selbst bezeichnen.

${ }^{770}$ Die zeitgenössisch eindrucksvollste Darstellung von Conchilien mit weiterführenden Erläuterungen liegt mit dem postum veröffentlichten zweibändigen Werk Dézalier d'Argenvilles (1680-1765) vor. Eine unlängst herausgegeben faksimilierte Fassung der Tafeln relativen (Carpita et al.) mit kurzen Hinweisen erleichtert immerhin den Zugang.
} 
Subebene der Bildbedeutung ist eben auch jene, in der hier ein wohlhabender Gehäusebesitzer seine Schätze, seine Spekulationsobjekte auslegt, denn diese Naturkuriosa wurden teuer gehandelt. Heute würde ein calvinistischer Protestant andere Statussymbole abbilden, heiraten oder vor die Villa stellen, aber heute wie damals erfolgte dies im Stolz über seinen wirtschaftlichen Erfolg, der zumindest damals in der niederländischen Variante des Protestantismus als Ausdruck des göttlichen Wohlgefallens galt. ${ }^{771}$

Die meisten der im Blumenarrangement Brueghels enthaltenen Neophyten stammen noch aus der Alten Welt, überwiegend dem mediterranen Raum bis nach Kleinasien. Das wird sich mit den Darstellungen des 17. Jhs. stark zugunsten der amerikanischen und pazifischen Komponenten verschieben. Doch bereits um 1500 verarbeitet Jheronymus Bosch im „Garten der Lüste“ erste exotische Früchte aus den eben entdeckten Amerikas. ${ }^{772}$

Das Blumenstillleben verdeutlicht auch, was in vielfacher Hinsicht durch Dahlien und andere prachtvolle Blumen noch verstärkt werden sollte. Europa war vor 1500 viel weniger farbig, weil zahlreiche uns heute geläufige Zierpflanzen in Wahrheit Neophyten sind. Den Europäern vor 1500 konnte das nicht bewußt sein, und uns ist die Vorstellung unmöglich, wie es sich mit diesem relativen Farbdefizit wohl lebte. Freude am Naturbunten hatte man sicher auch vor 1500. Detailgetreu hatten z. B. die Brüder Limburg im Stundenbuch des Duc du Berry die roten und blauen Tupfer der Ackerunkräuter im Getreide festgehalten, und Walther von der Vogelweide freute sich lange davor an den Wiesenblumen, die das mit der besungenen Dame gemeinsame Lager bildeten und schmückten.

Einige der bei Brueghel abgebildeten Gartenblumen werden sich in der Nachfolgezeit als „Gartenflüchter“ allmählich auch in Arealen etablieren, in denen sie, obwohl die Pflanze selbst ein mitteleuropäisches Vorkommen zeigte, zuvor wahrscheinlich nicht vertreten waren, wie z. B. heutige Wildvorkommen von Päonien (Pfingstrosen) in Franken oder Bartnelken in Schleswig-Holstein. Andere Blumen des Brueghelschen Gemäldes, wie z. B. Narzissen, Schachbrettblumen, Türkenbundlilien, Märzenbecher (Knotenblume), Primeln, repräsentieren heute oftmals als Ensemble-Elemente die Reste verwilderter Zierpflanzenbestände aufgelassener Herrschaftsgärten und Friedhöfe. Sie sind, als sogenannte „Stinzenpflanzen“, oftmals die letzte Nachweismöglichkeit alter Gartenanlagen und bei den Landschaftspflegern entsprechend gesuchte Hinweisgeber.

Die Zahl der indigenen europäischen Pflanzenarten in Deutschland wird auf ca. 2800 geschätzt. Seit der Neolithisierung kamen 165 etablierte Arten bis 1500 hinzu, während sich 315 Neophyten nach 1500 erfolgreich etablieren konnten. Die Zahl der nicht etablierten Neophyten (also ohne menschliche Pflege nicht

\footnotetext{
${ }^{771}$ Es ist übrigens darauf hingewiesen worden, dass die Tulipomanie der Niederlande nicht recht denkbar gewesen wäre ohne die allgemeinen politischen Entwicklungen und die endgültige Sicherung des Protestantismus durch schwedische Kriegserfolge und diplomatische Verhandlungen zwischen 1631 und 1635.

772 Z. B. die Frucht der Martyniaceae Ibicella lutea, der Teufelskralle.
} 
dauerhaft existenzfähig) stieg nach 1500 um rund 9000 weitere Arten in Deutschland. ${ }^{773}$ Die Artenverpflanzungen liefen aber nicht nur einseitig nach Europa, sondern auch von hier in die Neue Welt, nach Afrika und Asien. Über dieses größte denkbare Freisetzungsexperiment globalen Ausmaßes in der Geschichte wird unter Biodiversitätsforschern erstaunlich wenig diskutiert, die Umwelthistoriker thematisieren es unter dem Stichwort des „ökologischen Imperialismus."

Die Kunsttheorie weist immer wieder auf den theologischen Gehalt solcher Bilder hin. ${ }^{774}$ Die blumengleiche Vergänglichkeit des menschlichen Lebens ist der theologische Gehalt auch des Brueghelschen Blumenstraußes. Die niederländische Kunsttheorie der Brueghelzeit verlangte von einem soliden Bild aber vierfache Bedeutung: eine theologische, eine ,vaterländische“, eine militärische und eine ästhetische. ${ }^{775}$ Zweifellos repräsentiert Brueghels Blumenstrauß eine gemalte Predigt in der Art einer wenig raffiniert daherkommenden Vanitas-Metaphorik, das Bild konzentriert sich hingegen viel stärker auf das Lob des Schöpfers am Beispiel seiner Wunderwerke. Es ist derselbe physikotheologische Impuls, der exemplarisch im 1653 entstandenen Gedicht des protestantischen Kirchenmannes Paul Gerhardt (1607-1676) enthalten ist, das als Kirchenlied mit Volksliedcharakter, zumindest in seinen Anfangsstrophen, allgemein bekannt ist:

\section{Geh aus mein Herz und suche Freud}

Geh aus mein Herz und suche Freud

In dieser lieben Sommerszeit

An deines Gottes Gaben;

Schau an der schönen Gärtenzier

Und siehe, wie sie mir und dir

Sich ausgeschmücket haben.

Die Bäume stehen voller Laub,

Das Erdreich decket seinen Staub

Mit einem grünem Kleide;

Narzissen und die Tulipan,

Die ziehen sich viel schöner an

Als Salomonis Seide.

Die Lärche schwingt sich in die Luft,

Das Täublein fleugt aus seiner Kluft

\footnotetext{
773 WBGU (Wissenschaftlicher Beirat der Bundesregierung Globale Umweltveränderungen) Jahresgutachten 1999. Springer, Berlin usw., S. 10.

${ }_{774}$ Behling zitiert auf dem Titelblatt ihrer Monographie den Spruch von einem spätgotischen Grabstein: „O mensch zart, bedenck der blumen art.“

775 Hier beziehe ich mich auf meinen 2009 verstorbenen Göttinger Kollegen Gerd Unverfehrt, der mir gesprächsweise auch den zeitgenössischen Verfasser dieser These nannte. Einen Beleg muss ich hier schuldig bleiben.
} 
Und macht sich in die Wälder;

Die hochbegabte Nachtigall

Ergötzt und füllt mit ihrem Schall

Berg, Hügel, Tal und Felder.

Die Glucke führt ihr Völklein aus,

Der Storch baut und bewohnt sein Haus,

Das Schwälblein speist die Jungen;

Der schnelle Hirsch, das leichte Reh

Ist froh und kommt aus seiner Höh

ins tiefe Gras gesprungen.

Die Bächlein rauschen in dem Sand Und malen sich an ihren Rand

Mit schattenreichen Myrten;

Die Wiesen liegen hart dabei

Und klingen ganz vom Lustgeschrei

Der Schaf und ihrer Hirten.

Die unverdrossne Bienenschar

Fliegt hin und her, sucht hier und da

Ihr edle Honigspeise

Des süßen Weinstocks starker Saft

Bringt täglich neue Stärk' und Kraft

In seinem schwachen Reise.

Der Weizen wächset mit Gewalt

Darüber jauchzet jung und alt

Und rühmt die große Güte

Des, der so überflüssig labt

Und mit so manchem Gut begabt

Das menschliche Gemüte.

Ich selber kann und mag nicht ruhn

Des großen Gottes großes Tun

Erweckt mir alle Sinnen

Ich singe mit, wenn alles singt

Und lasse was dem Höchsten klingt

Aus meinem Herzen rinnen.

Ach denk ich bist Du hier so schön Und lässt Du's uns so lieblich gehn

Auf dieser armen Erde

Was will doch wohl nach dieser Welt

Dort in dem reichen Himmelszelt

Und güldnen Schlosse werden? 
Welch hohe Lust, welch heller Schein

Wird wohl in Christi Garten sein!

Wie wird es da wohl klingen?

Da so viel tausend Seraphim

Mit unverdrossnem Mund und Stimm

Ihr Halleluja singen.

Oh wär ich da, o stünd ich schon

Ach süßer Gott vor Deinem Thron

Und trüge meine Palmen!

So wollt ich nach der Engel Weis'

Erhöhen Deines Namens Preis,

Mit tausend schönen Psalmen.

Doch gleichwohl will ich weil ich noch

Hier trage dieses Leibes Joch

Auch gar nicht stille schweigen.

Mein Herze soll sich fort und fort

An diesem und an allem Ort

$\mathrm{Zu}$ Deinem Lobe neigen.

Hilf mir und segne meinen Geist

Mit Segen, der vom Himmel fleußt,

Dass ich Dir stetig blühe;

Gib, dass der Sommer Deiner Gnad

In meiner Seele früh und spat

Viel Glaubensfrücht erziehe.

Mach in mir Deinem Geiste Raum,

Dass ich Dir werd ein guter Baum,

Und lass mich Wurzeln treiben;

Verleihe, dass zu Deinem Ruhm,

Ich Deines Gartens schöne Blum

Und Pflanze möge bleiben.

Erwähle mich zum Paradeis,

Und lass mich bis zur letzten Reis

An Leib und Seele grünen;

So will ich Dir und Deiner Ehr

Allein und sonsten Keinem mehr

Hier und dort ewig dienen.

In der Gesamtlänge des Liedes wird sein religionspädagogischer Gehalt deutlich. Es nimmt die Vorbildhaftigkeit der Natur zum Anlass, das Wunder des sich saisonal neu entfaltenden und des mit seiner beschwingten Leichtigkeit sehnsuchtsvoll erwarteten sommerlichen Lebens als Metapher auf das christliche Jenseitsversprechen zu werten. Dass dem Dichter die phänologischen Elemente des Frühlings 
(April-Mai) mit denen des wirklichen Sommers (ab Mitte Juni) durcheinander geraten, ließe sich unschwer durch dichterische Freiheit oder eine grundsätzliche Jahresteilung in „Sommer“ und „Winter“ erklären.

Die drei anderen Deutungsebenen niederländischer Tafelmalerei treten im Brueghelschen Beispiel gegenüber der religiösen Ebene in den Hintergrund. Neben der Vanitas ist aber auch die Schöpfungsfülle eine religiöse Kategorie. Insbeson-dere die Gemälde der Niederländer des 16. und 17. Jhs. spielen mit dem Schöpfungsreichtum, in dem sie nicht nur einheimische Arten sondern auch die zunehmend bekannt werdenden Exoten abbilden.

Tatsächlich wird man diese Darstellungen nicht gelöst sehen können von der aufkommenden Idee der besten aller Welten und der großen Kette der Wesen. ${ }^{776}$ Es ist auch ein früher Höhepunkt einer (physikotheologisch) detailbesessenen natura-listischen Abbildungkunst, die zugleich ein Weg in die moderne Wissenschaft ist.777 Die Bestimmung von Pflanzen und Tieren auf Stillebenbildern, ${ }^{778}$ auf Jagd-, Markt- und Gartenszenen, ist aber auch eine Möglichkeit, das Auftreten und die Diffusionsgeschwindigkeit von Arten und die Variabilität alter Landrassen (Kultivare) zu rekonstruieren.

Die Idee der Fülle ist zugleich mit ihrer enzyklopädischen Erfassung, ihrer Auflistung, ihrer seriellen Darstellung verbunden. Überrascht wird der Interessierte u.a. registrieren, dass solche enzyklopädischen Bemühungen nicht nur das Repertoire der göttlichen Schöpfung erfasst und abgebildet haben. Roger Bacon hatte die Natur durch eine Dreiteilung segmental geordnet, nämlich ,in die Historie der Zeugungen, der Miss-Zeugungen und der Künste“. ${ }^{779}$ Was zunächst als reiner Systematisierungsansatz erscheinen könnte, verpackt zugleich selbstbewusst die Einsicht, dass auch die menschlichen Künste Dinge eigener Qualität hervor bringen. Zwar auf der Grundlage der „freien Natur“, aber aus den Vorgaben und Ansprüchen des Menschen, der der Natur „Bande“ auferlegt, ihr also vorschreibt, wie und wohin sie sich zu entwickeln hätte. Weithin sichtbar und erkennbar ist ein solches

\footnotetext{
776 Lovejoy

777 Alpers

778 „Das Flämische Stilleben“ mit weiterführender Literatur

779 „Die Einteilung der menschlichen Historie wollen wir nach dem Zustand und der Beschaffenheit der Natur selbst unternehmen, als die in dreifachen Zustand gesetzt erfunden wird und gleichsam eine dreifache Regierung eingeht. Denn entweder ist die Natur frei und erklärt sich durch ihren gewöhnlichen Lauf, wie an den himmlischen Körpern, den Tieren, den Pflanzen und dem ganzen Vorrat der Natur; oder sie wird durch bösartige Ungewöhnlichkeiten eines unbändigen Stoffes und durch die Gewalt der Hindernisse außer ihren Zustand gestoßen, wie in Missgeburten; oder sie wird endlich von der menschlichen Kunst und Arbeit gebunden, gestaltet und gleichsam erneuert, wie an den Kunstsachen zu sehen. Also teilt sich die natürliche Historie in die Historie der Zeugungen, der Miss-Zeugungen und der Künste, welche letztere man auch Mechanik und die Erfahrende Naturlehre zu nennen gewohnt ist. Die erste behandelt die Freiheit der Natur, die zweite die Fehler, die dritte die Bande." Bacon, S. 173
} 


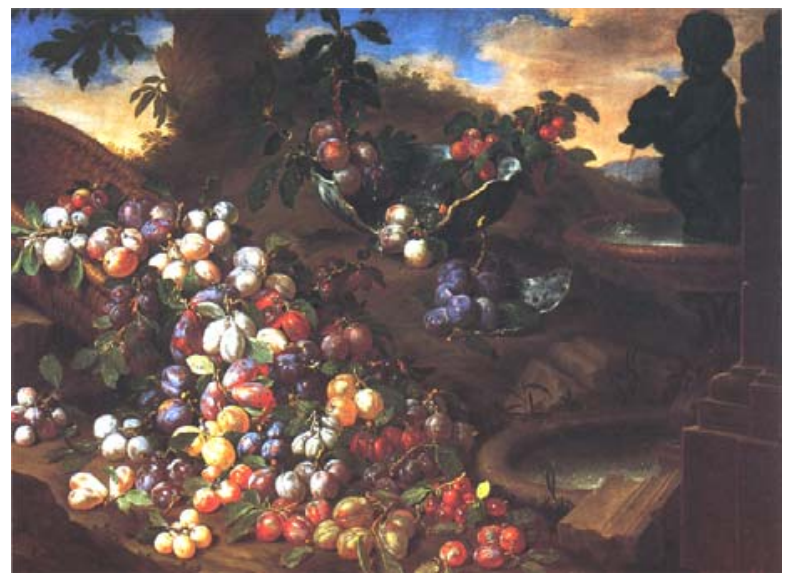

Abb. 7: Bartolomeo Bimbi, Susine, 1699

Pflaumen-Kultivare

Öl auf Leinwand, 176 x 184 cm. Poggio a Caiano

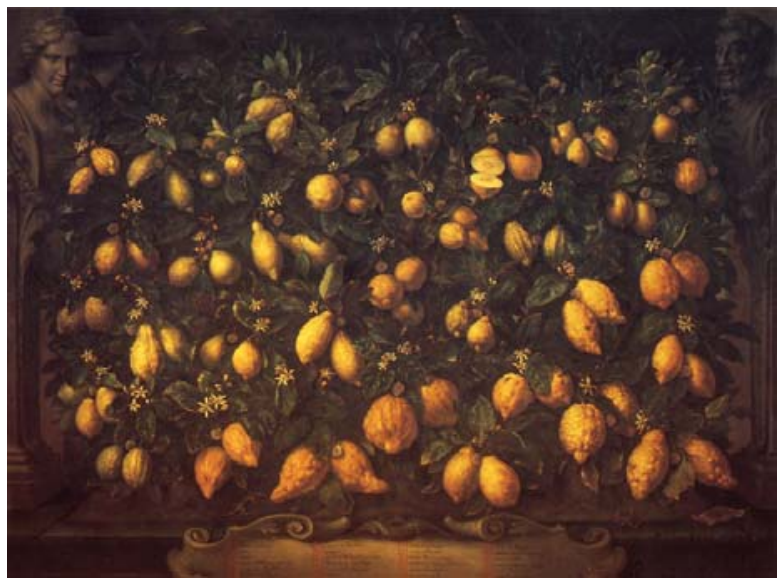

Abb. 8: Bartolomeo Bimbi, Natura morte con cedri e limoni. 34 Zitronen-Kultivare.

Öl auf Leinwand, 175 x $232 \mathrm{~cm}$. Poggio a Caiano 
Naturverständnis, wenn die Vielfalt züchterischer Bemühungen enzyklopädisch zusammengefasst wird. So hatte etwa Bartolomeo Bimbi (1648-1725) um 1700 italienische Landsitze mit Stillleben von Früchten ausgeschmückt, welche die damalige Palette der erreichbaren Kultivare 780 für Baumobst abbildeten: Kirschen, Pflaumen, Trauben, Äpfel, Zitronen usw. ${ }^{781}$ Solche Bilder sind selbstverständlich Kompositionen, aber sie sind neben ihrer Qualität als Kunstwerke eben auch frühe Archive der Biodiversität, und zwar derjenigen, die menschliche Kreativität hervorgebracht hat.

Bisher ist das Stillleben eher einseitig im Hinblick auf Schöpfungsreichtum und auf Vanitas-Metaphorik, eben auf theologische Sinngehalte, betrachtet worden. Die Betrachtung sollte künftig um den Aspekt eines naturalen Füllhorns aus menschlicher Befähigung und Fähigkeit ergänzt werden.

\footnotetext{
780 Kultivar: Terminus der Biologie für Kulturpflanzen-Sorte

${ }^{781}$ Soprintendenza per Beni Ambientali e Architettonici di Firenze, Pistoia e Prato. Bimbis bekanntesten Darstellungen befinden sich in der Medici-Villa in Poggio a Caiano, nahe Florenz.
} 


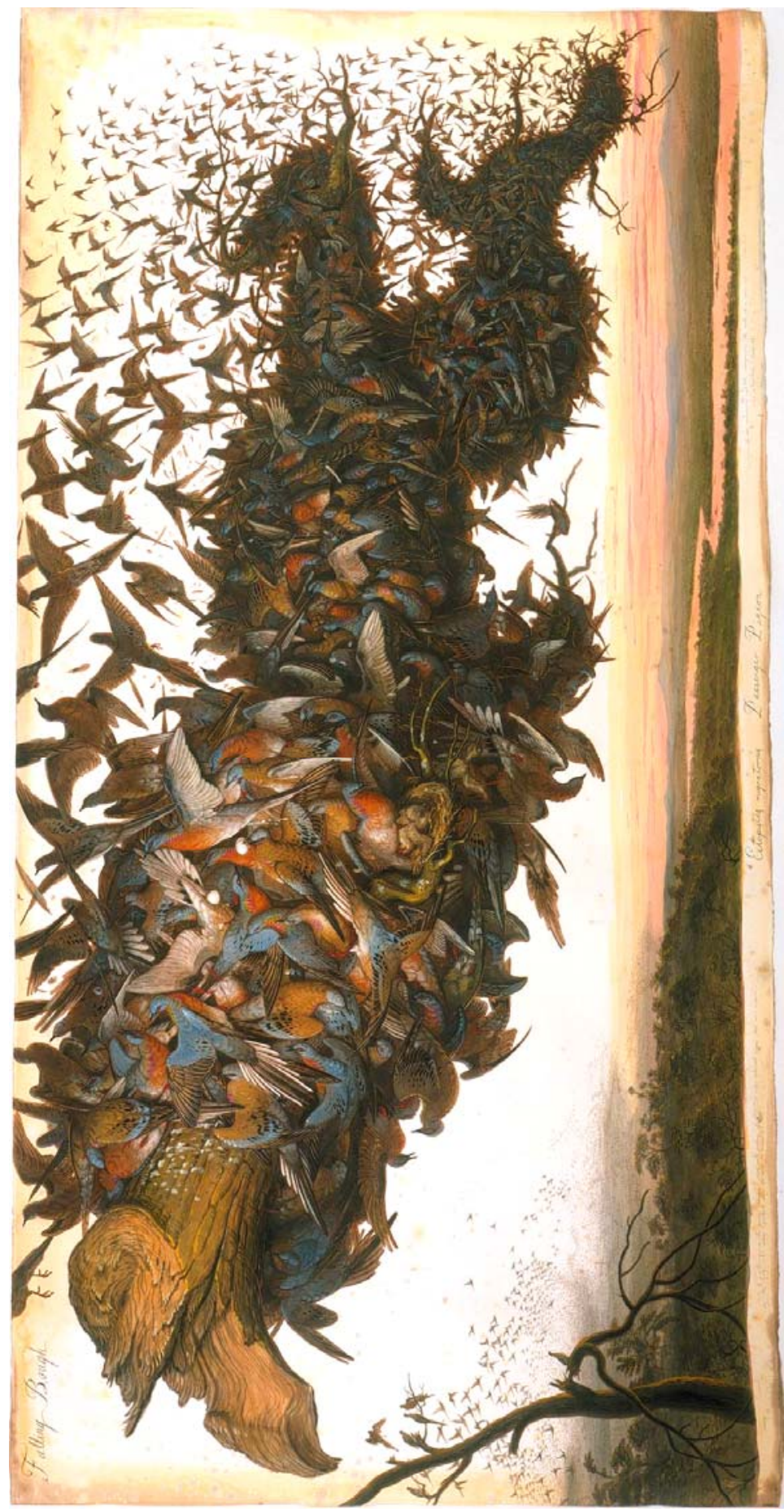




\section{Das zweite Beispiel \\ Walton Ford $(* 1960)$ \\ Falling Bough (Abb. 9)}

Beschriftung am unteren Bildrand in der Bildmitte: „Ectopistes migratorius Passenger Pigeon." Text links davon: Obere Zeile: "They repair to some undiscovered satellite accompanying the earth at a near distance. Cotton Mather".

Untere Zeile: "What it portends I know not. Tomas Dudley 1631"

Text rechts von der Bildmitte: "Millions of Turtledoves on the green boughes, which sate pecking of the full ripe pleasant grapes that were supported by the lovely tree whose fruitfull loade did cause the arms to bend. T. Morton 1637' 782

2002. Wasserfarbe, Gouache, Bleistift und Tinte auf Papier. 153,7 x 303,5 cm. [Ford, S.169-170; (C) Walton Ford und Paul Kasmin Gallery, New York]

Walton Ford ist ein zeitgenössischer US-amerikanischer Maler, der sich selbst auf den großen US-amerikanischen Ornithologen und Zeichner der „Vögel Amerikas", John James La Forest Audubon (1785-1851), bezieht und in dessen Tradition er zu sehen ist. Während Audubon erstmals vitale Situationen aus dem Vogelleben in präzise, wissenschaftlich ernst zu nehmende Darstellungen einbrachte, bereichert Ford seine lebensechten und minutiösen Darstellungen um Akzessoirs, um animalische Akteure und um Szenarien nahe am Katastrophenrande, scheinbar und anscheinend jenseits jeder Glaubwürdigkeit.

Das Bild zeigt einen über und über mit Wandertauben besetzten Ast im Augenblick seines Herabstürzens. Es findet sich in der Sammlung von Bildern Walton Fords, die erstmals 2007 unter dem Titel „Pancha Tantra“ zusammengestellt und veröffentlicht wurde. Der Buchtitel „Pancha Tantra“ nimmt den Namen einer Erzählungssammlung aus dem Sanskrit auf, deren heute bekannte Form auf das 3. bis 6. Jh. unserer Zeitrechnung zurückgeht und die moralische Geschichten in Form von Tierfabeln und -gleichnissen enthält. Die Sammlung „Pancha Tantra“ selbst ist vergleichbar mit europäischen Tierfabeldichtungen von Aesop bis La Fontaine und darüber hinaus.

In Tierfabeln werden anthropomorphisierten Tiergestalten (z. B. „Meister Bockert" $^{\prime \prime}$ der Biber) menschliche Grundeigenschaften (Biber = arbeitswütig) zugeschrieben. Längst nicht alle fabelwürdigen Tiere sind in der europäischen Erzähltradition mit Eigennamen versehen worden. Der Taube fehlt ein Eigenname, aber ihr werden Eigenschaften nachgesagt, wie: dumm, friedensbringend, heilsbringend, treu. Die Emblematik knüpft an Ovids „Ars amatoria“, Vergils „Ekologe 1“, an

\footnotetext{
782 Ich danke Nina Wiener, Taschen Verlag, New York, dass sie mir Abbildungsvorlagen zugänglich machte, denen ich die Texte entnehmen konnte. Die Texte sind am Original lesbar, wenn auch wegen des Formates - in Fußbodennähe nicht leicht zugänglich (Walton Ford „Bestiarium“, Hamburger Bahnhof Berlin, 23.4.2010).
} 
antike Bilder, auf denen Tauben den Wagen der Venus ziehen und an biblische Texte und Symbolik an (Henkel \& Schöne, S. 854ff). Das Taubenbild von Walton Ford wäre mit solchen Rückgriffen allerdings in einen falschen Kontext gestellt, denn die Nordamerikanische Wandertaube war schwerlich Vorbildvogel europäischer Fabeltexte. Selbstverständlich aber nehmen die nach Nordamerika auswandernden Europäer den Vogel wahr und werden ihn auch in ihre europäische Überlieferung integriert haben, denn die ersten Bezeichnungen der Europäer für die Wandertauben lauten auf „Turteltauben“. Der Vogel wird im 17. Jh. zu einem Sinnbild des paradiesischen Überflusses und später im Zusammenhang mit den Trails nach Westen als eingepökelter Proviant eine der wichtigsten Nahrungsressourcen während der langen Reisen. ${ }^{783}$ Ganz in diesen Sinn scheint sich ja auch das Zitat von Thomas Morton am rechten unteren Bildrand zu fügen, das seiner Schrift mit dem bezeichnenden Titel „The New English Canaan“ entnommen ist. Kanaan war biblisch das gelobte Land der Verheißung, jenes Land, in dem „Milch und Honig fließen“. ${ }^{784}$ Es mutet an wie ein Rückgriff auf ein angebliches Überflussbild, das als „paradiesischer Mythos“ topische Qualität erlangt hat. ${ }^{785}$ Das „Neue Englische Kanaan“ ist als Lockschrift zu verstehen, mit der Auswanderungswilligen ein Land des Überflusses und der religiösen Freiheit vorgestellt wird. Erst in letzter Zeit ist aber das biblische Bild vom „Überfluss von Milch und Honig“ als ein jahrhunderte anhaltendes Missverständnis entlarvt worden, indem eine Grenzertragslandschaft, die sich am Rande jeder Produktivität befand, fälschlich für eine Überflussregion gehalten wurde. In Wahrheit ist die Rede von einer devastierten Kulturlandschaft. ${ }^{786}$ Aber diese umwelthistorische Facette ist Walton Ford sehr wahrscheinlich unbekannt.

\section{I}

Walton Fords Thema ist scheinbar die unglaubliche Zahl der Wandertauben, die seit dem frühen 17. Jh. die europäischen Besucher und Siedler in Nordamerika beeindruckte. Die Marginalien sind Textzitate aus Briefen und Berichten zeitgenössischer Beobachter. Sie sind dem klassischen Werk von Arlie Schorger über die Wandertaube (Einleitungskapitel, S. 5-7) entnommen, wobei die Zitate von Mather und Morten gleichsam Anweisungen zur bildlichen Umsetzung sein könnten. Ma-

\footnotetext{
783 Schroger, ab S. 129

784 Exodus, Kap. 3

785 Da die puritanischen Pilgerväter den Begriff „Kanaan“ für Neuengland als Tropus verwenden, ist zur Entstehungszeit des Zitats unsicher, ob der Begriff für religiöse Freiheit oder für materiellen Wohlstand, womöglich auch für beides, steht. Der Begriff gibt sich hier für jede der Lesarten her.

${ }^{786}$ Hüttermann hat darauf verwiesen, dass „Honig“ für die Bienenweide und „Milch“ für die Haltung der kleinen Wiederkäuer (Schaf, Ziege) steht. Beides bezieht sich seiner gut begründeten Einsicht zufolge auf eine Macchien-Landschaft. Entstanden durch lange darniederliegende Pflege hatten die Bewohner das einstige Kulturland, die Heimat Josefs, zu einem üblen Verhau verkommen lassen. „Milch und Honig“" waren zunächst das einzige, was dem Land abgerungen werden konnte. Erst generationenübergreifende Rekultivierungsmaßnahmen erlaubten nach der Ůbersiedlung aus Ägypten ein auskömmliches Leben.
} 
thers Feststellung ${ }^{787}$ bezieht sich auf die damals nicht ganz verstandene Tatsache, dass Vögel saisonale An- und Abwesenheiten zeigen können. Dass es ein Zugvogelverhalten gibt, wurde erst sehr spät, nämlich erst im frühen 19. Jh., wissenschaftlich bewiesen. ${ }^{788}$ Davor war unbekannt, wohin die Vögel im Herbst verschwinden. Einer antiken Überlieferung zufolge überwinterten Schwalben auf dem Grunde von Seen, eine frühneuzeitliche deutsche Vermutung behauptete, die kleinen Singvögel würden des Winters als Mäuse in den Scheunen leben. Statt den noch wenig erkundeten Teil Nordamerikas außerhalb Neuenglands als Winterquartier oder Streifgebiet anzunehmen, ist es für Mather in der Tradition der magischen Wissenschaft näherliegend, den Tauben einen unirdischen Ort zuzuweisen. Unklar bleibt zunächst die Bedeutung des Zitates von Dudley auf dem Bild von Ford, das hier deshalb zu einem Rätsel eigener Art wird, weil es seines Kontextes beraubt wurde. Hierauf wird weiter unten zurückzukommen sein.

Walton Ford scheint unmittelbar an sein Vorbild Audubon anzuknüpfen, der ebenfalls ein Blatt mit der Nordamerikanischen Wandertaube gezeichnet hatte, in dem im Pancha Tantra (S. 306) eine Textpassage aus Audubons „Ornithological Biography“ (1831) zu den „Birds of America“ wiedergegeben wird:

„Im Herbst 1813 verließ ich mein Haus in Henderson an den Ufern des Obio und machte mich auf nach Louisville. Als ich ein paar Meilen hinter Hardensburgh das Ödland durchquerte, konnte ich verfolgen, wie die Tauben in Massen, die ich so noch nie zuvor gesehen hatte, von Nordosten nach Südwesten flogen. (...) Der Himmel war buchstäblich voller Tauben. Das Mittagslicht verdunkelte sich wie bei einer Finsternis und Kot tropfte wie schmelzende Schneeflocken herab. Das unaufhörliche Surren der Flügel wirkte auf meine Sinne regelrecht einschläfernd. (...) Der Kot, der den Rastplatz in seiner gesamten Ausdebnung bedeckte, war schon auf einige Zoll angewachsen. Ich sah, wie zahlreiche Bäume von zwei Fuß Durchmesser knapp über dem Erdboden wegbrachen, sah, wie die Zweige vieler der mächtigsten und größten Bäume nachgegeben hatten, als sei ein Tornado durch den Wald gefegt. Alles wies darauf hin, dass die Zahl der $V$ ögel in diesem Teil des Waldes jegliche Vorstellungskraft weit überstieg. (...) Als der Zeitpunkt ihres Eintreffens nabte, hatten ibre Feinde den Empfang schon unrubig vorbereitet. Einige schleppten Eisentöpfe heran, die mit Schwefel gefüllt waren, andere hatten sich mit Fackeln aus Kieferngeäst bewaffnet, viele mit Stangen und der Rest mit Gewehren. Die Sonne lag nicht mehr in unserem Blickfeld, doch noch war keine Taube zu sehen. Alles war bereit und aller Augen waren auf den klaren Himmel gerichtet. Der zwischen den hohen Bäumen aufblitzte. Plötzlich riefen alle aufgeregt, Da kommen sie!' Der Lärm, den sie verursachten, obgleich sie noch entfernt waren, erinnerte mich an einen heftigen Sturm auf See, er durch die festgereffte Takelage eines Schiffes fährt. Als die Vögel eintrafen und über mich flogen, verspürte ich einen Windzug, der mich überraschte. Tausende wurden sogleich von den Männern mit Stangen niedergeknüppelt. Immer mehr Vögel schwärmten an. Feuer wurden entzündet, und ein grandioser Anblick, wundervoll und erschreckend zugleich, bot sich dar. Zu Tausenden kamen die Tauben an, landeten

\footnotetext{
${ }_{787}$ Cotton Mather (1663 - 1728), puritanischer Geistlicher und Gelehrter in Boston, schrieb dies 1712 oder 1716 (Schorger 1938).

788 Kinzelbach 2005
} 
überall, eine auf der anderen, bis die Äste weit und breit schwer beladen waren. Hier und da brachen sie krachend unter dem Gewicht ein, rissen im Fall die dichten Trauben von Vögeln, die auf jedem Zweig lasteten, zu Boden und begruben Hunderte der Tiere unter sich. Die ganze Szenerie war von Tumult und Durcheinander geprägt. Es war sinnlos, mit jenen Personen, die sich in meiner Nähe aufhielten, zu sprechen oder ibnen etwas zuzurufen. Selbst das Knallen der Gewebrschüsse war nur vereinzelt zu bören. Nur weil ich die Schützen immer wieder laden sah, wusste ich, dass sie auch feuerten."
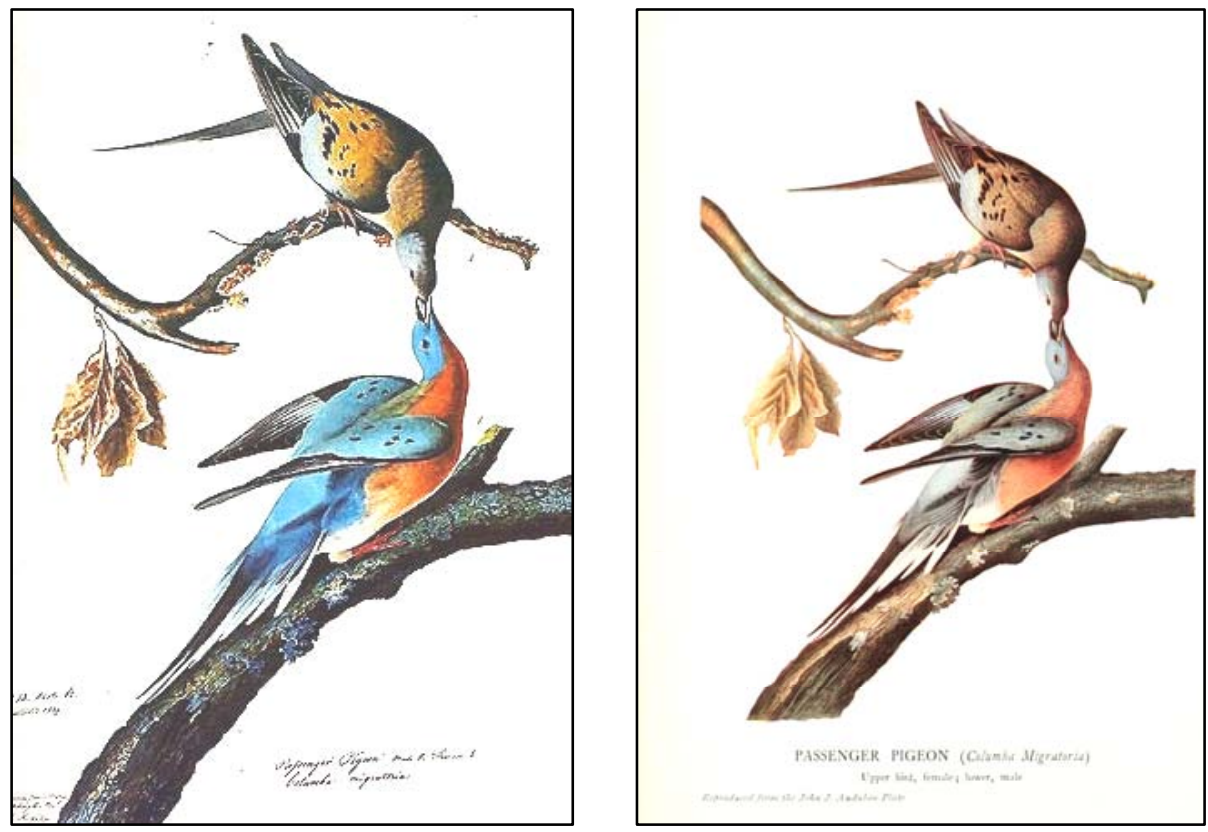

Abb. 10: Die Nordamerikanische Wandertaube, wie sie Audubon skizzierte (links). Die Vorlage wurde von Robert Havell gestochen und erstmals 1829 koloriert veröffentlicht. Rechts: Nachdruck von der Originalplatte aus 1907, deren Farben den heutigen musealen Exponaten eher entsprechen (s.u.). Unübersehbar ist die symbolbeladene Paarbeziehung, in der das männliche (untere) und das weibliche Exemplar im Motiv miteinander verbunden werden (s.u. im Text). Die Taube ist in den europäischen Symbolkanon eingeordnet. Ihr erster Trivialname ist bezeichnenderweise „Turteltaube“.

Fords Bild mutet wie die bildhafte Umsetzung eines Teils dieser Schilderung an. Es stellt den Betrachter auf eine Anhöhe, die eine weitläufige Talaue begrenzt. Es könnte eben jene Talaue des Ohio kurz vor Louisville, KY, gewesen sein, westlich des von Audubon erwähnten Hardensburgh, ${ }^{789}$ wie sie typisch vor allem für die großen nordamerikanischen Plains- und Prärieflüsse war, noch heute z. B. ide-

789 Vermutlich das heutige Hardinsburg, KY 
altypisch in Parzellen des American Bottom erhalten, ${ }^{790}$ bevor die europäische Besiedlung die Landschaft veränderte.

Walton Fords Bild schließt also suggestiv, so scheint es, an dieses Vorbild, an Vorstellungen vom Überfluss, an.

II

Tatsächlich ist dieser Anschluss ein scheinbarer. Sein Bild ist vielmehr in eine andere Deutungstradition zu stellen, in der die Taube als Opfervogel zu sehen ist, als Seelenvogel, als Todes- und Unglücksvogel. ${ }^{791}$

Auf dem Bild fällt vor dem Auge des Beobachters ein starker, viele Meter langer Ast unter dem Gewicht der Tiere zu Boden. Der Baum steht links außerhalb des Bildes und ist augenscheinlich schon länger abgestorben. Jedenfalls gibt es keinen Hinweis auf Laubgrün oder die für Grünholz typischen Auffaserungen der Bruchfläche, obwohl die Talaue die Farben und Formen der Vegetationsperiode zeigt. Ohnehin hätten die Tauben in der laubfreien Jahreszeit keine Nestlinge. Die zahllosen Vögel haben offenbar den Ast über seine Tragfähigkeit hinaus belastet. Die Tiere sitzen auf ihm, und zwar entgegen ihrer Natur und sogar entgegen der Schwerkraft auf seiner Unterseite. Sie zeigen soziales Verhalten, vitale Verdauungsreaktionen, sie paaren sich, sie legen Eier, brüten, füttern ihre Nestlinge, kurz, sie tun all das, was die als sozialen Brüter bekannten Wandertauben in ihren Nistquartieren und zu ihren Lebzeiten getan haben müssen. Dass sie nicht essen, ist verständlich, weil Schlaf- und Nistplätze nicht mit den Nahrungsplätzen zusammenfallen. Es ist bekannt, dass bei sozialen Brütern die hohe Individuenkonzentration in den Nistkolonien zu solchen Kotmengen führt, dass die Nistbäume in kurzer Zeit unter den Verdauungssekreten absterben. Insofern könnte der Ast innerhalb eines sich immer wiederholenden Szenariums zu Boden fallen.

Ungewöhnlich überhöht erscheint indes die Besatzdichte, mit der Walton Ford aber ganz direkt auf die ehedem legendäre Individuenabundanz der Wandertaube hinweist. Selbst in Sozialverbänden schwärmende Vögel achten üblicher Weise auf die Einhaltung einer Individualdistanz. Die Wandertaube scheint auf die Wahrung solcher Abstände keinen Wert gelegt zu haben, wenn denn die Augenzeugenberichte nicht maßlos übertrieben. Auf dem Ast wimmelt, flattert, lebt, kreischt und riecht es, und zwar weit über das Fassungsvermögen des Systems und über die Vorstellungskraft des Betrachters hinaus. Der Ast, eigentlich verlässliche Heimstatt der Vögel, auf dem sie einem Teil ihrer biologischen Bestimmung gemäß lebten, bricht unter der Masse, eine Metapher für die unerhörte Fülle, die grenzenlose Zahl der Tauben. Am vom Betrachter abgewandten Astende fliegen die Vögel auf,

790 Der “American Bottom” bezeichnet die Flußaue des Mississippi südlich seines Zusammenflusses mit dem Missouri zwischen dem Städtchen Alton und St. Louis. Die Region bildete in ihrem südlichen Abschnitt im 14. Jh. mit der Siedlung Cahokia, in der etwa 30.000 Menschen lebten, das größte Zentrum der nordamerikanischen Bevölkerung.

${ }^{791}$ Biedermann, S. $436 \mathrm{ff}$ 
ihre Menge verdünnt sich gegen den Himmel, in dem sie sich aufzulösen scheinen, auf ihrem Weg zum erdnahen Satelliten oder vor ihrer Auflösung ins Nichts? Wer nur hinsieht, erkennt, dass die Eier zerbrechen und die Nestlinge sterben werden, dass alles vergebens war für die Vögel dieses Astes, der Sinnbild für den irdischen Ort der Tauben wird. Die letzte stirbt 1914 im Zoo von Cincinnati, OH. Seitdem ist die Nordamerikanische Wandertaube ausgestorben. Das Bild symbolisiert den Untergang einer Art, und alle Welt kennt die traurige Geschichte, weil sie vor kaum 100 Jahren spielte und seitdem Sinnbild für die Bedenkenlosigkeit menschlicher Handlungsweise geworden ist, die sich blind gegenüber ihren Folgen und Nebenfolgen zeigt.

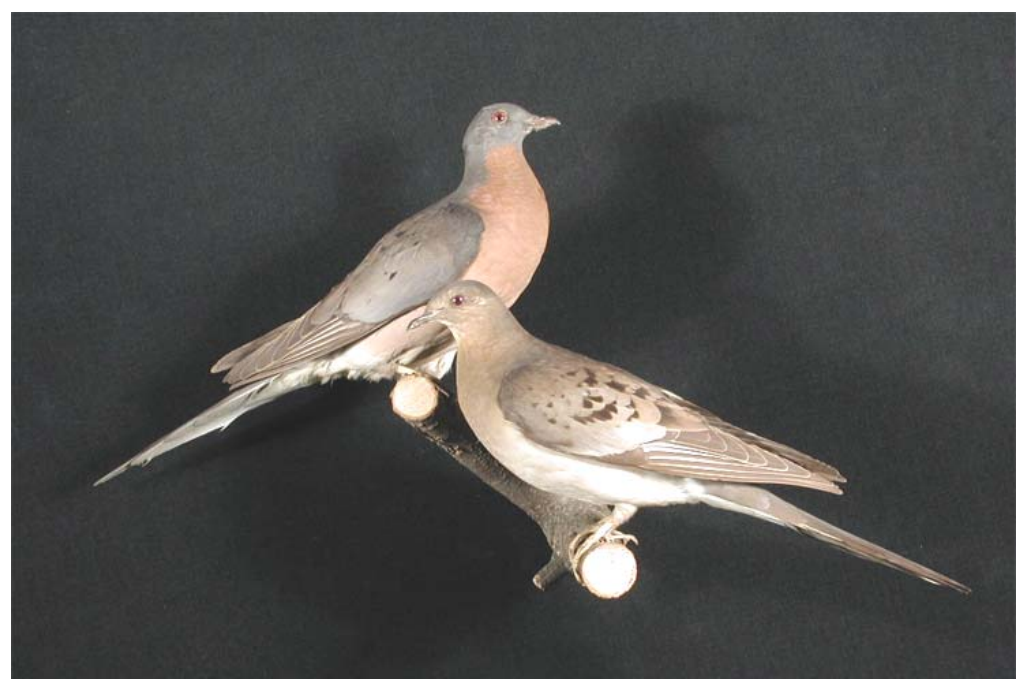

Abb. 11: Die Nordamerikanische Wandertaube Ectopistes migratoria Swainson 1827, + im Vordergrund.

Exemplare des Zoologischen Museums der Universität Göttingen. Foto: S. Hourticolon.

Walton Ford setzt die Nordamerikanische Wandertaube vor dem Hintergrund ihres historisch überlieferten Schicksals als Symbol ein für eine Natur, die der Mensch bedenkenlos seinem Fortschrittsstreben geopfert zu haben scheint. Er setzt die Taube ein als Vogel, der seinen eigenen Artentod repräsentiert. Er setzt sie ein als Menetekel, das dem Menschen sein eigenes Unglück vor Augen führt, welches unumkehrbar eintreten wird, wenn der Ast, auf dem alle sitzen, nachgibt. Wer auf diesem fallenden Ast sitzt, wird sterben, wird dem Artentod preisgegeben. Und es scheint so, als wäre den meisten Tauben, die wir auf dem Bild sehen, nicht einmal bewusst, dass der Ast bereits fällt. So sehr sind sie noch mit ihren unmittel- 
baren Dingen beschäftigt, dass ihnen entgeht, was der Betrachter bereits weiß, dass der Aufschlag des Astes unmittelbar bevorsteht.

Das Bild ist, sofern man sich auf diese Betrachtungsweise einließe, eine Metapher für das bevorstehende Ende der aus menschlichem Eigennutz und unstillbarem Ausbeutungshunger ruinierten Welt.

Damit ist das Terrain der missionierenden Belehrungen über den ökologischen Zustand der Welt erreicht, die heute zunehmend quasi-religiöse Bedürfnisse bedienen. Sie kommen einem Erleuchtungs- und Erweckungsbedürfnis nach, das an die Stelle der verloren gegangenen religiösen Verheißung treten soll. Geradezu idealtypisch lässt sich diese Entwicklung an der Entstehung und Verbreitung des Biodiversitäts-Begriffs und seiner politischen Implikationen veranschaulichen. ${ }^{792}$ Hatte sich nach Darwin noch die Einsicht Bahn gebrochen, dass der Prozess der Evolution selbstregulierend sei und in niemandes Verantwortung stünde, ${ }^{793}$ wurde mit der Konferenz von Rio de Janeiro ${ }^{794}$ allgemein akzeptiert, dass doch jemand ganz konkret für den Zustand der Welt verantwortlich wäre. Menschen würden nämlich Verantwortung, und zwar die Verantwortung, für den Zustand der Naturräume der Welt tragen. Damit war endgültige bestätigt, dass der „biophile“ Lebensstil, ${ }^{795}$ d.h. die Sorge um und das Eintreten für die Biodiversität, auch quasi-religiöse Bedürfnisse bedient bzw. bedienen kann. Die Almosenspende wird in eine Spende an den WWF gewandelt. An die Stelle der Sorge um das Seelenheil tritt die Sorge um die Jahresdurchschnittstemperatur. Die Postulatenethik der Zehn Gebote wird durch eine Globalisierungsethik nach Art des „Ökologischen Imperativs“ ersetzt. ${ }^{796}$ Nächstenliebe wird durch eine Fernstenliebe erweitert. Der aufgeklärten nachdarwinschen Einsicht, wonach ,in der Natur" nichts so bleiben wird, wie es im Moment ist, entgegnen Menschen mit einem Beharren auf realitätsüberfordernden Konservativismus, welcher in einer musealisierten Natur gleichsam einen anzustrebenden Idealzustand zu erkennen scheint. Von hier ist der Weg dann nur noch kurz zu Rückvergoldungen und Verlustklagen über den vermeintlich verlorenen paradiesischen Grundzustand.

Deshalb ist der Hinweis darauf, dass der Bildtitel „Falling Bough“ dem Titel des religionsgeschichtlichen Klassikers „The Golden Bough“"797 sehr nahe kommt,

\footnotetext{
792 Herrmann 2006, 2009

${ }^{793}$ Herrmann 2006, S. 187

${ }^{794}$ Konferenz der UN über Umwelt und Entwicklung, 1992

795 Wilson 1984

${ }^{796}$ Jonas 1984 „Handle so, dass die Wirkungen deiner Handlung verträglich sind mit der Permanenz echten menschlichen Lebens auf Erden.“ Dieser als „ökologischer Imperativ“ apostrophierte, seinerzeit sehr populäre Satz, ist erkennbar eine zeitgebundene Variante des Kategorischen Imperativs und zielt, anders als die bekante Vorgabe von Immanuel Kant, stärker auf die Folgen der Handlung im technisierten Zeitalter.

797 James George Frazer (1854-1941), Anthropologe in Cambridge, veröffentlichte “The Golden Bough. A study in magic and religion" in einer zweibändigen Erstausgabe 1890. Die dritte Ausgabe erschien zwischen von 1907 und 1915 und umfasste 15 Bände.
} 
keine absurd konstruierte Facette, sondern ziemlich handfest. ${ }^{798} \mathrm{Ob}$ nun kulturtheoretisch, psychoanalytisch oder evolutionsbiologisch gewendet, niemand wird heute mehr der Generalthese Frazers widersprechen, wonach die Entstehung von Religion und ihr Hauptzweck darauf gerichtet sind, sich Selbststabilisierung durch Rückgriff auf transzendente Mächte zu verschaffen, und dadurch das profane wie das spirituelle Überleben zu sichern oder als gesichert anzunehmen. Damit ergibt sich ein weiterer Anschluss an heilsgeschichtliche Facetten, die in der Auforderung zur ökologischen Wende zum „Richtigen“ hin besteht, auf die das Bild Walton Fords hinweist. Diese metatheoretische Ebene ergibt sich insbesondere aus jener Erzählung, die Frazers Werk den Titel geliehen hat: der Goldene Zweig aus der Äneis, ${ }^{799}$ mit dessen Hilfe Äneas in den Hades gelangt. Dort offenbart ihm sein Vater, dass Äneas der Stammvater der Römer und damit Begründer eines Weltreiches werden wird.

Fords Zweig taugt indes nicht dazu, einen Charon zu besänftigen. Aber gleich dem Goldenen Zweig in der Äneis, eröffnet der Zweig Fords einen Zugang. ${ }^{800}$ Dieser besteht darin, ein Raisonnement über die Zukunft zu eröffnen, nämlich die ökologische Zukunft, die nur dann zu einem Weltreich führen kann, wenn es gelingt, der Falle des „desire for gain“ (David Hume) zu entkommen, jenem Drange nach Über-Fülle, der in Gestalt des nicht enden wollenden materiellen Besitzes zwangsläufig zu einem fatalen Ende für alle und alles führen wird. Das Bild der Überfülle in Gestalt der Tauben ist am Ende ein gewendetes Plädoyer für die MäBigung menschlicher Habgier.

\section{III}

Die Erzählungen des Bildes können und müssen jedoch, kommt man von den Fakten her, noch in eine andere Richtung geführt werden. Es ist ein unbestreitbares Faktum, dass die Naturgeschichte der Wandertaube mit dem Tod des letzten Exemplars in Gefangenschaft am 1. September 1914 im Zoo von Cincinnati, in einem Alter von 29 Jahren, endete. Und ihre Geschichte beginnt eigentlich erst mit den Berichten über unvorstellbare Mengen an Tauben ab der Mitte des 17. Jhs. Diese Berichte reichen bis ins 19. Jh., gegen dessen Ende die Tauben sehr selten werden. Der beste Kenner der historischen Berichte, der zurückhaltende Arlie

\footnotetext{
798 Walton Ford studierte an der Rhode Island School of Design und hatte intensive Kontakte zu den Studierenden der Literaturwissenschaften der benachbarten Brown University, unter denen ganz bestimmt Auseinandersetzungen mit Frazers Werk stattfand, wie Quertests im Hinblick auf das Werk und die Lehrtätigkeit von Walton Fords Freund seit den Tagen in Providence, Jeffrey Eugenides, zeigen.

${ }^{799}$ Vergil Aeneis, Buch 6

${ }^{800}$ Es würden sich weitere Anschlüsse an den „Goldenen Zweig“ Frazers ergeben, z. B. wenn man den Artentod der Taube gleichsetzte mit dem Tod des alten Priesters oder Königs, der bei Frazer die Voraussetzung für Erneuerung liefert. Eine mögliche Erneuerung könnte darin bestehen, dass die gegenwärtige Wissenschaft sich ernsthaft bemüht, mit Forschungskonzepten zu ,alter DNA“ (ideengeschichtlich nach wie vor gültig, wenn auch technisch vom Forschungsfortschritt teilweise überholt: Herrmann \& Hummel) ausgestorbene Tierarten genetisch teilweise oder gesamtgenomisch zu rekonstruieren.
} 
Schorger, schätzte, dass die Gesamtpopulation der Tauben 3 Milliarden Individuen betragen haben könnte, und dass zeitweilig 25-40\% der gesamten Avifauna der Vereinigten Staaten aus Wandertauben bestanden. Schorger hat auch die Berichte über Schwärme zusammengestellt, aus deren Dauer, Fluggeschwindigkeit und Dichte auf die Individuenzahl geschätzt wurde. Seine Nachberechnungen lassen Zweifel an den astronomischen Zahlen früherer Autoren aufkommen, führen aber immer noch zu unglaublich hohen Zahlen, in einem Fall etwa zu einer Schwarmgröße von 1.000.000.000 Individuen. ${ }^{801}$ Es verwundert daher nicht, dass angesichts solcher Mengen die Taubenjagd in jedem Fall erfolgreich war. Man hielt z. B. die Schrotflinte ohne besonderes Zielen in Richtung des Schwarms und der ,Jagderfolg“" war auch dem Ungeschicktesten gesichert. Die Tauben wurden auf alle erdenkliche Weise erlegt, es gab sie so reichlich, das sie mit Knüppeln von den Bäumen geschlagen werden konnten. Sie entwickelten sich zu einem besonders im 19. Jahrhundert im Osten der USA verbreiteten und beliebten Nahrungsmittel. ${ }^{802}$

Über alle möglichen Ursachen ist wegen des Aussterbens der Wandertaube spekuliert worden. Die herkömmlichste Erzählung spricht von einer Kombination aus Überjagung der Wandertaube, dem Verlust der Futterplätze und der Einschränkung ihres Lebensraumes infolge der europäischen Kolonisierung Nordamerikas. Immerhin handelt es sich um einen sozialen Brüter, der jährlich nur ein einziges Ei legte. Damit waren die sonst bei Vögeln gängigen Kompensationsmuster für Brutausfälle nicht so einfach zu realisieren, eine rasche Abnahme der Individuenzahlen vorausgesetzt. Eine solche Zahlenreduktion könnte den Zerfall der Gesamtpopulation in Subpopulationen zur Folge gehabt haben, wobei dysfunktional verstärkend die Ausbreitungskorridore unterbrochen gewesen sein könnten. Damit wäre die Taube in eine sich selbst beschleunigende Populationskrise geraten. Vermutlich trat verstärkend noch eine bis heute unbekannte Vogelseuche auf. ${ }^{803}$

Über die Ursachen des Endes der Taube herrscht kein Dissens. Es ist allgemein akzeptierter Wissensstand, dass die Ursachen im Wesentlichen anthropogen bedingt waren. Die Klage über das menschliche Handeln fällt dabei umso massiver aus, weil sie sich an der historisch belegten unvorstellbar hohen Individuenzahl der Tauben festmacht. Das Entsetzen drückt die Fassungslosigkeit über die Tatsache aus, wie ehedem Milliarden von Tieren so völlig verschwinden können.

\footnotetext{
801 Schorger 1955, S. 203

802 Schorger 1955, ab S. 129

803 Alle vorgebrachten Gründe für das Aussterben in Schorger (1955) Kap. 9., einschließlich der absurden, die von einem Massenertrinken im Golf von Mexiko oder einem „Auswandern“ nach Südamerika ausgehen. Diese Hypothesen schließen erkennbar an Vorstellungen an, wie sie dem Zitat von Mather aus dem frühen 18. Jh. Zugrunde liegen, das Walton Ford auf den unteren Bildrand geschrieben hat.
} 


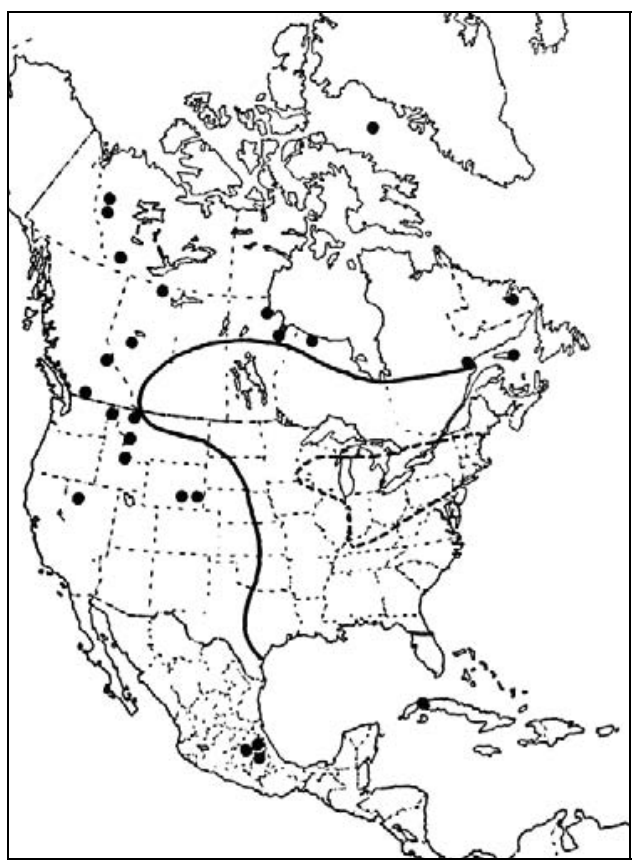

Abb. 12: Ehemaliges Verbreitungsgebiet der Nordamerikanischen Wandertaube. Die durchgezogene Linie schließt das normale Verbreitungsareal ein, die gestrichelte Linie die hauptsächlichen Brutgebiete. Die Punkte verweisen auf gelegentliches oder Irrgast - Vorkommen. ${ }^{804}$ Für Europa (Frankreich, England, Schottland) sind seit 1749 gelegentliche Freisetzungen belegt, sicher verbürgt ist ein Irrgast 1849 an der irischen Westküste. Kinzelbach (1988) vermutet für die Zeit um 1580 eine temporäre Wandertaubenkolonie in der Heidelberger Gegend. Die Vermutung wird von Kinzelbach \& Hölzinger (2000) nicht wiederholt.

Die Landwirtschaft der europäischen Siedler hatte ja nicht ernsthaft unter den Tauben als Saat- oder Ernteschädlingen zu leiden, ${ }^{805}$ so dass sich im Bewusstsein der Menschen die Bejagung als einziger direkter Einfluss auf die Zahl festsetzte. Das Abholzen der Futterbäume (und damit der Verlust der Hauptnahrungsmittel Eicheln und Nüsse) und die Veränderungen der Landschaft durch Landwirtschaft und Drainage (Fortfallen der Rast und Nistplätze in sumpfigen Talauen) waren als indirekte Verdrängungsmaßnahmen in ihrer unmittelbaren Wirksamkeit kaum wahrzunehmen. Die ohnmächtige Wut über den, wie immer man will, Verlust von

\footnotetext{
804 Aus Schorger 1955, S. 257

${ }^{805}$ Insofern stellt sich die Taubenproblematik noch einmal anders dar als bei Vogelarten, die in vergleichbarer Zahl wie die Wandertauben existieren, aber als Enteschädlinge auftreten, wie Quelea quelea, der Blutschnabelwebervogel, der im regenwaldfreien Afrika südlich der Sahara der am meisten gefürchtete Getreideschädling ist.
} 
„Schöpfungsreichtum“ oder „Artenfülle“ oder „Biodiversität“ muss sich jedoch an einer Stelle überraschend zügeln lassen. Die Vorstellung nämlich, hier wäre ein von Anbeginn bestehender paradiesischer Zustand abrupt beendet worden, bedarf einer differenzierten Betrachtung. Erst seit kurzem ist offensichtlich, dass sich die „Superabundanz“ der Wandertaube, die alle Berichterstatter des späten 17., des 18. und des 19. Jhs. so ungemein beeindruckte, ebenfalls einem völlig anthropogenen Ereignis verdankt.

Schon früher hatte Neumann (1985) darauf hingewiesen, dass in den archäologischen Archiven der präkolumbischen Ära ein merkwürdiger Mangel an Taubenknochen herrsche, der nur den Schluss zulasse, dass die Tauben vor der Ankunft der Europäer nicht in denselben Mengen existierten, wie im 18. und 19. Jh. Herrmann \& Woods (2010) fanden in einer Revision jüngerer archäologischer Fundplätze, besonders um die zentrale Siedlung Cahokia, ebenfalls nur einzelne Skelettknochen der Taube belegt. Mit ihren Schlussfolgerungen unterstützen sie die Thesen Neumanns und ziehen Parallelen zu den historischen Superabundanzen des Haussperlings in Mitteleuropa im 18. und z. T. im 19. Jh. Werden die historischen Abläufe und die Biologie der Taube kombiniert, ergibt sich folgende Skizze des Prozessgeschehens: In der vorkolumbischen Zeit besetzen die Indianer durch Siedlungsaktivitäten z. T. jene Talauenareale, die Vorzugsgebiete für Taubenrast und Brut sind. Der Druck auf die Taubenpopulation wird erhöht durch Nahrungskonkurrenz bei Nüssen und Eicheln und teilweise Entnahme von Nestlingen zum Verzehr. Nach Ankunft der europäischen Siedler stirbt ein erheblicher Teil der indianischen Bevölkerung an Infektionskrankheiten, die den Siedlern in der Ausbreitung vorauseilen. Der Druck auf die Nist- und Rastplätze der Tauben lässt infolge der Abnahme der indianischen Bevölkerung nach, auch, weil die Europäer ihre Siedlungstätigkeit nicht auf Parzellen beginnen, die als Brutreviere infrage kommen. Die Nahrungskonkurrenz entspannt sich, weil die Europäer nicht in gleicher Weise mit den Tauben um Nüsse und Eicheln konkurrieren. Und in dieser Situation explodieren die Individuenzahlen der Tauben in einem bis dahin nie gekannten Ausmaß. Thomas Dudley hatte in seinem Brief „To the Right Honourable, My very good Lady, The Lady Bridget, Countess of Lincoln. Boston, March 12 1631" 806 berichtet: "upon the eighth of March from after it was faire day light, until about eight of the clock in the forenoon, there flew over all towns in our plantations, so many flocks of doves each flock containing many thousands, and some so many, that they obscured the light, that it passeth credit, if but the truth should be written; and the thing was the more strange, because I scarce remember to have seen ten doves since I came into the country: they were all turtles, as appeared by divers of them we killed flying, somewhat bigger than those of Europe, and they flew from the north-east to the south-west; but what it portends I know not." [Hervorhebung B.H.]

Die Hervorhebung gibt jenes Zitat wieder, das Walton Ford auf den unteren Bildrand geschrieben hat. Dudleys Brief ist ein seltenes Dokument über das Leben in den Anfangsjahren der amerikanischen Kolonisierung. Er wurde neuneinhalb

806 Schorger 1955, S. 6 
Jahre nach dem Ersten Erntedankfest in der neuen Welt geschrieben, das im Herbst 1621 stattfand, nachdem die Pilgerväter ihre erste erfolgreiche Ernte in der Neuen Welt eingebracht hatten, die sie ohne die Hilfe der Wampanoag nicht hätten erleben können, weil diese ihnen über manchen Nahrungsengpass hinweggeholfen hatten. Nahm Dudley vor 1631 kaum Tauben wahr, erschienen sie nun in großen Schwärmen, worüber er sein offenbares Erstaunen ausdrückt. Doch ist seine Beobachtung, die ziemlich zeitgleich von Thomas Mather (1637) gestützt wird, ${ }^{807}$ völlig konsistent mit dem rekonstruierten Prozessgeschehen: die Taubenschwärme des 17., 18. und 19. Jhs. sind ein anthropogenes Produkt und vorher nicht in gleicher Weise existent. Sie sind anthropogen in ihrer unvorstellbaren Größe. Sie waren aber auch bereits anthropogen auf eine bestimmte, weitaus geringere Häufigkeit durch die Aktivitäten der präkolumbischen Indianer festgelegt. Es gibt keinen Weg, die ,natürliche“ Häufigkeit der Wandertaube vor dem Eintreffen des Menschen in Nordamerika abzuschätzen.

Sicher haben sie ihre historisch bekannten Brutgebiete erst nach der Eiszeit vom südlichen Nordamerika her besetzt und mussten sich von Beginn an mit einer Nahrungskonkurrenz mit den ebenfalls neu angekommenen Menschen auseinandersetzen. Das wäre populationsbiologisch ein besonders spannender Sachverhalt, weil Menschen dann seit Beginn der Nacheiszeit zu den populationsbegrenzenden Faktoren für die Tauben gezählt hätten, wie Klima, Nahrung, Krankheiten und Raubfeinde. Die Frage nach der theoretisch „,natürlichen Populationsgröße“ der Tauben wäre damit allerdings in doppelter Hinsicht unsinnig. In solchen Konstrukten steht „,natürlich“ regelhaft für „menschenfrei“. Sie ist einmal unsinnig, weil diese Frage so tut, als würden in einem menschenfreien System Populationsschwankungen nicht vorkommen. Sie ist ein weiteres Mal unsinnig, weil die Frage auf den ahemeroben Zustand zielt, der Begriff der Hemerobie aber nicht im Hinblick auf die Randbedingungen des sogenannten „Naturzustandes“ formuliert wurde. Menschen, deren Ökonomie das Sammeln, Fangen, Jagen und Aneignen ist, ernten ihre Schweifgebiete zunächst mit keiner anderen Intensität ab, mit der sonstige Top-Predatoren oder Nahrungsnetzknoten ihren Lebensraum nutzen. Der Begriff der Hemerobie ist sinnvoll nur an den Menschen der produzierenden Wirtschaftsweise zu binden. 808

\footnotetext{
807 Mather steuert ebenfalls ein Zitat am Bildrand bei Walton Ford bei. Ausführlicher als in Schorger 1955 wird Mather in Schorger 1938 zitiert.

808 Der „Hemerobie“-Begriff ist sinnvoll nur, wenn er den Grad der „Abweichung vom potentiell natürlichen Zustand“ durch menschliche Kulturwirkung beschreiben soll. Da der Mensch einerseits nicht kulturfrei gedacht werden kann, andererseits in seiner Stammesgeschichte aber auch Naturnutzungen aufwies, die von denjenigen nicht-menschlicher Prädatoren oder Sammler nicht abwich, ist auf diese Zustände der „Hemerobie“-Begriff nicht anwendbar. Hier offenbart sich ein weiterer Mangel biologischer Definitionsarbeit: Worin bestünde dann die Abweichung vom ,potentiell natürlichen Zustand" (offenbar im Gegensatz zum beobachteten Realzustand, dem signifikante menschliche Einflussnahme unterstellt wird), wenn beide Organismen (also Mensch und Taube) gleichzeitig in den postglazial menschen- wie taubenfreien Raum vorgedrungen sind und der Mensch keine produzierende Wirtschaft betrieben hätte? Mensch und Taube wären unter solchen Bedingungen ,gleichwertige" Konkurrenten. Ab wann ist dann der Zustand in Kategorien der Hemerobie beschreibbar?
} 
Es ist kein Trost, angesichts des Bildes von Walton Ford den Prozess in seinem realhistorischen Ablauf zu rekonstruieren, obwohl es schon eine gewisse Überraschung ist, die Taubenschwärme als anthropogen, als „künstlich“ zu erkennen. Es wäre auch ein Missverständnis, hinter dieser Rekonstruktion eine Entlastungsstrategie für das anthropogen verschuldete Aussterben der Wandertaube zu argwöhnen. Aber das Argument muss berichtigt werden. Der Vorwurf kann sich nicht auf den Verlust der Zahl richten. Ohnehin schwanken Populationsgrößen aus „natürlicher“ Ursache ständig. Der wirkliche Verlust besteht nicht in der Anzahl der Individuen, er besteht im Verlust des Genoms. Doch das ist nicht nur ein unanschauliches und theoretisches Gebilde, es ist auch eine unanschauliche Vorstellung, die zudem jedem Genom - kontraintuitiv - dieselbe Wertigkeit zumisst, zumessen muss. ${ }^{809}$ Mit der Gleichbewertung des Genoms, sei es einer Hefe, einer Kartoffel oder eines Braunbären wird ein erkenntnismäßiges Grundproblem berührt, das nicht gelöst ist. Denn die Gleich-Bewertung des Genoms knüpft an objektive Werttheorien der Natur an, wonach den Naturdingen ein unwandelbarer Wert innewohne. Selbstverständlich ist dieser Wert ein moralischer (religiöser). ${ }^{810}$ Biologen, die in den Kategorien des evolutiven Fortschritts denken, befinden sich bei ihrer Bewertung in einer Aporie, in der die Eigenständigkeit eines jeden organismischen Lebens abzuwägen ist gegenüber einem mechanistischen Komplexitätskriterium. Biologen nehmen an, dass ein Braunbär ein „komplexeres“, ein „höher entwickeltes" Lebewesen ist als eine Hefezelle. Aus dieser unterschiedlichen organismischen Komplexität ergeben sich Rangskalen von biologistischer Wertigkeit. Diese liegt nahe bei der Praxis des Alltagslebens, das im Allgemeinen den Wert eines Menschen höher als den eines Tieres oder gar einer Pflanze bemisst. Dabei geht es ausschließlich um subjektive Kategorien, denn die einzig objektive (das Genom) würde diese Bewertung untersagen und auf einen einheitlichen Wertbegriff zurückgreifen müssen. Doch dieser ist letztlich göttlich gesetzt. ${ }^{811}$

Und vor diesem Hintergrund erscheint die „Schuld“ des hochgerüsteten 19. Jhs., das der Taube den Garaus bereitete, in gewisser Weise „kleiner“, als diejenige der ersten, feuersteinbewaffneten Bevölkerung in Nordamerika, die als Jäger und Sammler möglicherweise lediglich mit bloßem Jagdeifer oder aber mit einem Pleistocene Overkill 12 einen gravierenden Beitrag dazu leisteten, dass ein erheblicher

809 Eine logische Konsequenz, die aus der Vermeidung des Naturalistischen Fehlschlusses folgt. Sofern der Gedanke hier noch nicht spontan akzeptiert wird, ergibt sich seine Begründung aus dem weiteren Text. Die Rede ist hier vereinfachend nur vom artlichen Genom. „Richtiger “wäre jedoch, jedes durch Rekombination und Mutation neu entstandene Genom als biologische Kategorie eigenständigen und gleichwertigen „Rechtes“ anzuerkennen, also jedes Individuum.

810 Vgl. etwa Werttheorie der Natur bei Albertus Magnus und Thomas von Aquin.

811 Damit wird das logische Problem besonders prekär: Wer solche Überlegungen anstellt oder zurückweist, behauptet die Ungleichwertigkeit von Genomen. Da „Wert“ keine wissenschaftliche Kategorie ist, würde am Ende jede Weise der Bewertung eines Genoms einen Naturalistischen Fehlschluss bedeuten. Dann aber erübrigte sich auch das Bedauern über den Verlust eines Genoms. Man ist also bei solchen Überlegungen von Anfang an in subjektiven Kategorien gefangen, die zu keiner objektiven Aussage führen können.

812 Martin \& Wright 
Teil des autochthonen Großwildbestandes in Nordamerika den Eintritt in die postglaziale Zeit nicht lange genießen konnte. Dies ereignete sich lange vor der Zeit und außerhalb des Entstehungsraums der biblischen Erzählungen und beseitigt zugleich auch den augenscheinlich unausrottbaren Mythos vom einstmals „,mit der Natur im Einklang lebenden Menschen“, der seinerseits dem angeblichen „Naturzustand“ (a la Rousseau) noch näher war. ${ }^{813}$ Der Mensch deckt aber, wie jedes Lebewesen, einfach nur seine Bedürfnisse. Wenn der für die Tauben gedeckte Tisch plötzlich größer ausfällt als früher, warum sollen sie ihre Zahl nicht opportunistisch vergrößern? Genauso, wie Menschen es tun, wenn ihnen der Tisch reicher gedeckt erscheint oder das Raumangebot es hergibt.

Schon im vorletzten Absatz hat die Argumentation das wissenschaftlich Begründbare zu verlassen begonnen. Da die Dinge in der Natur lediglich so sind, wie sie sind, nicht aber, weil sie so sein sollen, gibt es keine Entscheidungsmöglichkeit über eine richtige oder eine falsche Zahl von Tauben wie von Menschen, die aus der Biologie käme. Ökosysteme wandeln sich, und wenn infolge dessen eine Art gelegentlich ausstirbt, ist das aus der Struktur des Prozesses selbst begründet. „Nachhaltigkeit“ ist eine Wertefrage, keine Kategorie der Natur.

Es gibt allerdings Auffassungen darüber, wie viele Menschen es geben sollte oder dürfte und darüber, dass es ein Verlust ist, wenn die Tauben nicht mehr existieren. Und darüber, ob und wie Nachhaltigkeit zu praktizieren ist. Alles dieses sind absolut weltanschauliche Auffassungen, selbst wenn sie sich noch so pragmatisch oder einen von Sachzwängen diktierten Anschein geben. Selbstverständlich lohnt es sich, darum zu ringen und zu streiten. Aber dies mit dem Rückgriff auf ,richtige“ oder „falsche Natur“ zu tun, wäre ein schlimmer Fehler. Es sind und bleiben Fragen der Weltanschauung. Walton Fords Bild fordert auf, hierzu Stellung zu nehmen: „Ich für mein Teil wollte die Sprache der naturwissenschaftlichen Illustratoren des 19. Jhs. so benutzen, wie sie es sich selber nie erträumt bätten - um unser kollektives Bewusstsein in Bezug auf die Natur und die anderen Lebewesen, mit denen wir uns diesen Planeten teilen, auszuloten. "814

\footnotetext{
813 In dem es offenbar eine Natur zu geben scheint, die von der uns bekannten Natur grundverschieden sein muss: eine Natur ohne „Wettbewerb“, ohne „Konkurrenz“, ohne Nahrungskette, in der alle und mit allen und unbehelligt nebeneinander leben und an Altersschwäche sterben. Das ist, leicht erkennbar, nichts weiter als die Geschichte vom paradiesischen Mythos.

814 „In my case, I wanted to take the language of the nineteenth-century natural-history illustrators and use it in a way they would never have imagined - to plumb our own collective ways of thinking about the natural world and these beings we share the planet with." Walton Ford, zitiert aus Tomkins.
} 


\section{Literatur}

Alpers S (1998) Kunst als Beschreibung. DuMont, Köln

Apel F (2000) Deutscher Geist und deutsche Landschaft. Eine Topographie.

Goldmann, München

Bacon F (1783) Über die Würde und den Fortgang der Wissenschaften. Weingand \& Köpf, Pest

Behling L (1957) Die Pflanze in der mittelalterlichen Tafelmalerei. Hermann

Böhlaus Nachfolger, Weimar [zweite, fast unveränderte Auflage 1967, Böhlau, Köln/Graz]

Biedermann H (2002) Knaurs Lexikon der Symbole. Droemer/Knaur, München (1998), Lizenzausgabe Weltbild, Augsburg

Burke P (2003) Augenzeugenschaft. Bilder als historische Quellen. Wagenbach, Berlin

Carpita V, Willmann R, Willmann S (2009) Dezallier d'Argenville, ShellsMuscheln-Coquillages. Taschen, Hong Kong usw.

Cassirer E [1944] (1996) Versuch über den Menschen. Einführung in eine Philosophie der Kultur. Felix Meiner, Hamburg

van Damme A ([1899-1903]1976) Aanteekeningen betreffende de geschiedenis der bloemenbollen. Harlem. Nachdruck Boerhaave Press, Leiden

Das Flämische Stillleben: 1550 - 1680. Katalog der Ausstellung 2002.

Kulturstiftung Ruhr, Villa Hügel Essen. Luca Verl., Lingen

Dezallier d'Argenville AJ (1780) La conchyliologie ou histoire naturelle des coquilles de mer d'eau douce, terrestres et fossiles, avec un traité de la zoomorphose, ou représentation des animaun qui les habitent; ouvrage dans lequel on trouve une nouvelle méthode de les diviser. 2 Bände. de Bure, Paris

Diamond J (2005) Collapse. How societies choose to fail or succeed. Viking Penguin, New York

Fischer H (1997) „Nur wer den Garten bebaut, weiß, was Wildnis ist.“ Zum

Wandel der Naturwahrnehmung. In: Wilhelm-Busch-Gesellschaft und Grünflächenamt der Landeshauptstadt Hannover (Hrsg.) „Zurück zur Natur“

- Ideen und Geschichte des Georgengartens in Hannover-Herrenhausen.

Ausstellungskatalog. Wallstein, Göttingen, S. 83-94

Foerster Hv ([1982]1984) Observing systems. Intersystems Publ., Seaside, Cal. 
Ford W (2009) Pancha Tantra. Mit einer Einleitung von Bill Buford. Taschen, Köln [Originalausgabe Taschen, New York. 2007]

Gemäldegalerie, Staatliche Museen zu Berlin (Hrsg.) (2001) Die „Kleine Eiszeit““

Holländische Landschaftsmalerei im 17.Jh.. Ausstellungskatalog.

Gemäldegalerie Berlin

Hard G (1970) Die „Landschaft“ der Sprache und die „Landschaft“ der

Geographen: semantische und forschungslogische Studien zu einigen zentralen

Denkfiguren in der deutschen geographischen Literatur. Dümmler, Bonn

Hard G (2002) Landschaft und Raum. Rasch, Osnabrück

Henkel A, Schöne A (Hrsg.) ([1967]1996) Emblemata. Handbuch zur Sinnbildkunst des XVI. und XVII. Jh. Metzler, Stuttgart/Weimar

Herrmann B (2006) „Auf keinen Fall mehr als dreimal wöchentlich Krebse, Lachs oder Hasenbraten essen müssen!“ - Einige vernachlässigte Probleme der „historischen Biodiversität“، In: Baum H-P, Leng R, Schneider J(Hg.)

Wirtschaft - Gesellschaft - Mentalitäten im Mittelalter. Festschrift zum 75. Geburtstag von Rolf Sprandel. Stuttgart (Beiträge zur Wirtschafts- und Sozialgeschichte 107), S. 175 - 203

Herrmann B (2009) Umweltgeschichte Wozu? Zur gesellschaftlichen Relevanz einer jungen Disziplin. In: Masius P, Sparenberg O, Sprenger J(Hrsg.) Umweltgeschichte und Umweltzukunft . Zur gesellschaftlichen Relevanz einer jungen Disziplin. Universitätsverlag Göttingen, Göttingen. S. 13-50

Herrmann B, Hummel S (eds.) (1993) Ancient DNA. Recovery and Analysis of Genetic Material from Paleontological, Archaeological, Museum, Medical, and Forensic Specimens. Springer, New York, Berlin, Heidelberg. (2nd Edition August 1994)

Herrmann B, Woods W (2010) Neither biblical plague nor pristine myth. A lesson from European sparrows. Geographical Review 100: 176-187

Hüttermann A (1999) The ecological Message of the Thora. Knowledge, concepts, and laws which made survival in a land of "milk and honey" possible. South Florida Studies in the History of Judaism 199. Scholars Press, Atlanta

Humboldt Av ([1845] 2004) Kosmos. Entwurf einer physischen Weltbeschreibung. Eichborn, Frankfurt a.M.

Imhof AE (1991) Im Bildersaal der Geschichte oder ein Historiker schaut Bilder an. Beck, München

Imhof AE (1997) Votiv. Koautor in: Wolken - Malerei - Geschichte. CD-ROM. Hrsg.: Deutsche Meteorologische Gesellschaft [ISBN 3-928903-10-1] 
Imhof AE (1998) Koautor in: Die Vier Jahreszeiten nach einer Bildfolge von Joos de Momper. CD-ROM. Hrsg.: Deutsche Meteorologische Gesellschaft [ISBN 3-928903-16-0]

Jaskolla D (2006) Der Pflanzenschutz vom Altertum bis zur Gegenwart. Biologische Bundesanstalt, Informationszentrum Phytomedizin und Bibliothek, Berlin-Dahlem. $16 \mathrm{~S}$.

Kaiser R (1992) Die Erde ist uns heilig. Die Reden des Chief Seattle und anderer indianischer Häuptlinge. Herder Spektrum 4079, Freiburg

Keyser E (1935) Das Bild als Geschichtsquelle. Historische Bildkunde 2: 5-32

Kinzelbach R (1988) Ein historischer Hinweis auf die Wandertaube, Ectopistes migratorius, in Kontinental-Europa. Journal of Ornithology 129: 100-102

Kinzelbach R (2005) Das Buch vom Pfeilstorch. Basilisken-Presse, Marburg

Kinzelbach R, Hölzinger J (Hrsg.)(2000) Marcus zum Lamm, Die Vogelbücher aus dem Thesaurus pictuarum. Ulmer, Stuttgart

Levi D'Ancona M (1977) The Garden of the Renaissance. Botanical symbolism in Italian painting. Arte E Archeologia, Studie e Documenti 10. Olschki, Florenz

Levi D'Ancona M (1983) Botticelli's Primavera. A botanical interpretation including astrology, alchemy and the Medici. Arte E Archeologia, Studie e Documenti 20. Olschki, Florenz

Lovejoy AO ([1936] 1993) Die grosse Kette der Wesen. Geschichte eines Gedankens. stw 1104. Suhrkamp, Frankfurt a.M.

Makowski H, Buderath B (1983) Die Natur dem Menschen Untertan. Ökologie im Spiegel der Landschaftsmalerei. Kindler, München

Martin PS, Wright HE (eds)(1967) Pleistocene extinctions: the search for a cause.

Michel P (2008) Physikotheologie. Ursprünge, Leistung und Niedergang einer Denkform. Neujahrsblatt auf das Jahr 2008. Herausgegeben von der Gelehrten Gesellschaft in Zürich (Nachfolgerin der Gesellschaft der Gelehrten auf der Chorherrenstube am Großmünster) vormals zum Besten des Waisenhauses. 171. Stück. Als Fortsetzung der Neujahrsblätter der Chorherrenstube Nr. 229. Editions à la Carte, Zürich

Neumann TW (1985) Human-Wildlife Competition and the Passenger Pigeon: Population Growth from System Destabilization. Human Ecology 13: 389410.

Panofsky E ([1957]1975) Sinn und Deutung in der bildenden Kunst. DuMont Schauberg, Köln 
Panofsky E ([1939]1980) Studien zur Ikonologie. Humanistische Themen in der Kunst der Renaissance. DuMont, Köln

Ritter J (1963) Landschaft In: Ritter J (1989) Subjektivität. Sechs Aufsätze. Bibliothek Suhrkamp 379. Suhrkamp, Frankfurt a.M. S. 141-190

Schaier J (2006) Lemma Gemüse - Anbau und Verbreitung. In: Jaeger F (Hrsg.) Enzyklopädie der Neuzeit. Metzler, Stuttgart, Weimar. Bd.4 : 420-423

Schorger AW ([1955] 2004?) The Passenger Pigeon. Its natural history and extinction. Blackburn Press, Caldwell, N.J. [Reprint]

Schorger AW (1938) Unpublished manuscripts by Cotton Mather on the passenger pigeon. The Auk 55: 471-477

Schröder KA, Sternath ML (Hrsg.) (2003) Albrecht Dürer. Albertina, Wien

Segal L (1988) Das 18. Kamel oder Die Welt als Erfindung. Zum Konstruktivismus Heinz von Foersters. Piper, München/Zürich

Segal S (1988) A Prosperous Past. The sumptuous still life in the Netherlands 1600-1700. SDU Publishers, Den Hag

Segal S (1990) Flowers and Nature. Netherlandish flower painting of four centuries. SDU Publishers, Den Hag

Soprintendenza per Beni Ambientali e Architettonici die Firenze, Pistoia e Prato (Hrsg.) (1998) La natura morta in villa. Le collezioni a Poggio a Caiano e Topaia. Sillabe, Livorno

Tomkins C (2009) Man and Beast. The New Yorker, Vol. 84 (46) January 29: 50ff

Warnke M (1992) Politische Landschaft: zur Kunstgeschichte der Natur. Hanser, München

White LT (1967) The historical roots of our ecological crisis.

Science 155: 1203-1207

Wittgenstein L ([1922] 2003) Tractatus logico-philosophicus. Logischphilosophische Abhandlung. edition suhrkamp. Suhrkamp, Frankfurt/M.

Wuyts L (2000) Über den Anbau und den Bedarf an Gemüse und Obst in der Rubenszeit. In: Härting UA (Hrsg.) Gärten und Höfe der Rubenszeit im Spiegel der Malerfamilie Brueghel und der Künstler um Peter Paul Rubens [Ausstellungskatalog Gustav-Lübcke-Museum Hamm 15.10.2000-14.1.2001]. Hirmer, München. S. 155-161

Zeven A ([1991] 1995) Vegetables and vegetable garden in North-West Europe. Their history as shown by $15^{\text {th }}$ to $18^{\text {th }}$ century painting. PACT 42-15: 141- 149 
Zeven A, Brandenburg WA (1986) Use of paintings from the $16^{\text {th }}$ to $19^{\text {th }}$ centuries to study the history of domesticated plants. Economic Botany 40: 397-408 



\title{
Innerfachliches und Fächerübergreifendes aus einer anthropologischen Sicht und historische Mensch-Umwelt-Beziehungen ${ }^{815}$
}

\author{
Bernd Herrmann ${ }^{816}$
}

Zur Konferenz eingeladen war ich unter der Vorgabe, aus "Sicht der Anthropologie" einen Beitrag zu liefern, wobei die im Einladungsschreiben verwendeten Adjektive ,interdisziplinär“ und „transdisziplinär" bei mir zunächst eine gewisse Orientierungsschwäche zur Folge hatten. Soweit reichte meine Erinnerung dann doch noch, dass Jürgen Kocka einst behauptet hatte, ,interdisziplinäre Fragestellungen“ wären diese nur, weil sie ihr Fach noch nicht gefunden hätten (sie lägen also buchstäblich zwischen den Fächern). ${ }^{817}$ Wäre dieses Urteil richtig, müsste mein Auftritt

\footnotetext{
$815 \mathrm{Wg}$. der Mehrdeutigkeit des Anthropologie-Begriffs weise ich vorsorglich darauf hin, dass sich Missverständnisse beim Leser einstellen könnten. Leider sehe ich nicht, wie ich diese ausschließen oder in angemessener Kürze beseitigen könnte, zumal eine Begriffsbelehrung völlig außerhalb der Absicht meines Beitrags liegt. Ich bitte hierfür um Verständnis. Meine Darstellung ist formal wie inhaltlich als Essay zu lesen, der als ein Beitrag aus der Perspektive eines Anthropologen verfasst wurde, dessen Arbeitsgebiet ständige Berührung mit der Ur- und Frühgeschichte mit sich bringt, dem Arbeitsgebiet der Gastgeber. Ihnen und der VW-Stiftung sei für die Einladung und die Tagung gedankt.

${ }^{816}$ Zuerst erschienen in: In: Thomas Meier/Petra Tillessen (Hrsg.): Über die Grenzen und zwischen den Disziplinen. Fächerübergreifende Zusammenarbeit im Forschungsfeld historischer MenschUmwelt-Beziehungen. Budapest 2011. S. 449 - 463. Dem Aufsatz ist bewusst eine essayistische Form gegeben.
} 
als Vertreter einer Disziplin in doppelter Weise fehlgehen. Einmal, weil ich in dieser Funktion per definitionem eigentlich nichts zu den anzustrengenden Überlegungen beitragen könnte. Würde ich es aber doch können, wäre damit eingeräumt, dass innerhalb meines Faches „,interdisziplinäre“ bzw. „transdisziplinäre“ Fragen aufträten oder existierten, die mit den Mitteln des Fachs allein nicht zu lösen wären. Das wäre dann aber ein Indiz für einen entweder falschen Zuschnitt des Faches oder für falsche Kompetenzzuweisungen. Eines wie das andere könnte sich am Ende als Irrtum erweisen.

Irrtümer sind nun in der Regel, neben wissenschaftlichen Konjunkturen, die Hauptmotoren nicht nur für den wissenschaftlichen Fortschritt, sondern auch für Verlagerungen von Fächerinhalten. Wenn die Fächer diesem Veränderungsdruck nicht nachkommen wollen, werden die neuen Fragen bzw. deren Protagonisten marginalisiert. Ob sich diese, den wissenschaftlichen Fortschritt zu einem erheblichen Teil repräsentierenden, Fachvertreter als interdisziplinär oder transdisziplinär sehen sollten, entscheiden nicht sie selbst, sondern wird dadurch entschieden, ob ihnen die Heimatdisziplin schließlich doch noch folgt (die Bestätigung der Kockaschen These). Bleiben die Fächergrenzen rigide, dann bewegen sich die marginalisierten Fachvertreter entweder auf einem Erkenntnisniveau, das dem der Heimatdisziplin äquivalent ist. Das wäre dann in einem bestimmten Sinne ,interdisziplinär". Ob die so Verstoßenen dort ein neues Fach erfinden, wie zuletzt beispielsweise die Entwicklungsbiologen, setzt gewisse Randbedingungen voraus, die uns hier nicht mehr interessieren, hatte der Workshop auf Frauenchiemsee außerdem doch zur „Erkundung eines transdisziplinären Forschungsfeldes“ eingeladen. Die auf jenem Feld verorteten Dinge liegen meiner Einsicht nach nicht „dazwischen“, sondern entweder jenseits oder über den Fächergrenzen. Voraussetzung ist hierfür allerdings eine metatheoretischer Fundierung, die also dem Ziel zu einer voraussetzungsvollen Produktion von Wissen in neuen Zusammenhängen verpflichtet ist.

Nach meinem Verständnis träfe eine solche Zuschreibung auf das so genannt „interdisziplinäre Gespräch“ allermeist ohnehin nicht zu. In diesem, zumindest demjenigen mit der am weitesten verbreiteten Etikettierung, horcht allermeist ein Gesprächspartner sein Gegenüber zum Zwecke der eigenen Theoriebeförderung aus; er beseitigt eigene methodische, gedankliche oder originelle Defizite durch eine Art wissenschaftliches Mitessertum. Merkwürdigerweise erscheint dieses häufig kombiniert mit einem sonderbaren Mutualismus, denn beide Seiten dürfen sich nach einem solchen Gespräch üblicherweise in einer ritualisierten Außendarstellung sonnen: im Bewusstsein ihres scheinbaren Altruismus, der Modernität ihres Ansatzes und in nahezu sicherer Erwartung der Prämierung durch Drittmittelgeber. Ihnen gegenüber wird besonders häufig als synergetischer Fortschritt verkauft, was in der Zeit vor der Entdeckung der „Interdisziplinarität“ dem eigenen disziplinären Fleiß und eigener gedanklicher Anstrengung zugemutet worden wäre. Tatsächlich lenkt der alltägliche gedankenlose Gebrauch der Begrifflichkeit davon ab, dass „Interdisziplinarität“ häufig, bei Lichte besehen, als eine subtile und akzeptierte Form disziplinärer Ausbeutungen angelegt ist, die sich in ihrem mildesten 
Falle als Meinungsführerschaft äußert. Im deutschsprachigen Raum können beispielsweise die vermeintlichen Ancilla-Disziplinen vieler „Archäo...“-Fächer davon ein Lied der traurigen Sorte singen.

Dass wir dem Göttinger Graduiertenkolleg 818 dennoch den Namen „Interdisziplinäre Umweltgeschichte“ gegeben haben, hatte den Grund darin, dass wir zeigen wollten, dass die Umweltgeschichte nicht einer Disziplin allein gehört und dass sich Fächer tatsächlich selbstlos miteinander auf ein wissensproduzierendes Gespräch einlassen können. Außerdem wurde die Verwendung des Begriffs „Transdisziplinarität“ zum Antragszeitpunkt strategisch für kontraproduktiv gehalten.

Das transdisziplinäre Forschungsfeld gibt sich von vornherein für die disziplinäre Ausbeutung nicht her. Hier arrangieren sich die Akteure in neuer Weise; die disziplinär erworbenen Hierarchien bestimmen nicht über die Kompetenz eines Forschers auf dem transdiziplinären Feld, sondern sind hier bestenfalls die Zugangsberechtigung. Es kommt auf die Bereitschaft und Mitarbeit des Einzelnen an. Transdisziplinäre Forschungsfelder verbinden, um an das etymologische Bild anzuknüpfen, das Wissen unterer Erkenntnisebenen zu einem neuen, komplexeren Verständnis (Wissen, Einsicht), durchaus auch nach dem Vorbild der ,advanced studies“. Die hierbei involvierten Erkenntnisebenen beziehen sich hierarchisch aufeinander:

einmal, weil das transdisziplinäre Wissen auf der Voraussetzung des disziplinären Wissens beruht,

dann, weil das transdisziplinäre Wissen aus der disziplinären Ebene allein nicht entstehen kann.

Es ist ein emergentes Wissen. Zu ihm führen Fragestellungen, die in einer Ursprungsdisziplin ihrer Komplexität wegen nicht beantwortet werden können oder die als Frage entstehen, zu deren Beantwortung aber besonders voraussetzungsvolle Hypothesen entwickelt werden müssen. In beiden Fällen werden disziplinären Wissensmengen zu einem Konzept bzw. einer Hypothese eigenen Rechtes zusammengefügt werden müssen. Entscheidend ist, dass die transdisziplinären Hervorbringungen zwar deduktiv die vorausgesetzten disziplinären Hervorbringungen („Modelle“) erklären bzw. einschließen, dass sich aber die metatheoretische Ebene ihrerseits nicht einfach additiv aus dem Disziplinären ergibt. Die Ebene der transdisziplinären Metatheorie ist nach meinem Verständnis also eine autonome Ebene, die zwar der disziplinären Fundierung bedarf, aber in ihren Betrachtungsweisen und Schlussfolgerungen von neuer Qualität ist.

Ein Beispiel hierfür ist die Evolutionstheorie der Biologen. Sie ist ein autonomes Erklärungsmodell der organismischen Vielfalt, die als metatheoretische Synthese zu ihrer rationalen Fundierung der Voraussetzungen aus Geo- und Biowissenschaften bedarf. Brächte man die Einsichten der Geowissenschaften und der Biologie nicht zusammen, was z.B. durch Ausschalten des (geo-chronologischen)

${ }^{818}$ Gemeint ist das DFG-Graduiertenkolleg 1024. 
Zeitfaktors möglich wäre, entfiele das Argument der Verzeitlichung ${ }^{819}$ und damit das Verständnis für den Prozesscharakter des Geschehens. Es entstünde dann beispielsweise das bekannte Bild der ahistorischen Erschaffung der Welt aus einem kreationistischen Akt - mit all der bekannten Widersprüchlichkeit. Die Evolutionstheorie ist damit nach meinem Verständnis ein idelatypisch transdisziplinäres metatheoretisches Modell, das sich letztlich der Existenz von Querschnittsfragen verdankt, und das erst mit dem Hinzutun einer verzeitlichenden Betrachtung formuliert werden kann. Häufig wird jedoch übersehen, dass neben der Verzeitlichung erst eine weitere Anleihe aus der Wirtschaftstheorie der Evolutionstheorie ihre zentrale Erklärungsfigur liefert. Damit wird am Beispiel der Evolutionstheorie deutlich, welche Bedeutung in Wahrheit die Einführung kultur- und gesellschaftswissenschaftlicher Setzungen auf die Biologie haben und welche Bedeutung damit die wissensproduzierende Erzählung für die Hervorbringung des metatheoretischen Erklärungsmodells besitzt. ${ }^{820}$

\section{2}

Innerhalb der Anthropologie 821 läuft nach meiner Überzeugung die Produktion empirischer Daten zwingend auf eine solche nachgeordnete Ebene hinaus, eben die transdisziplinäre. Eine mögliche transdisziplinäre Ebene ist nach meiner Einschätzung die „umwelthistorische“, also jene Ebene der „historischen MenschUmwelt-Beziehungen“.

Ich bin zu der Einsicht gelangt, dass sich beim Betreten dieser Ebene eine disziplinäre Kompetenz zu einer transdisziplinären erweitern kann. Seinen konkreten Ausgang nahm meine persönliche Entwicklung ursprünglich von einer Untersuchung über Spurenelementgehalte von menschlichen Skeletten, um u.a. aus diesen Daten Ernährungsmuster zu rekonstruieren. Über die notwendig vorzuklärenden Fragen, wie denn Nahrungsproduktion im Mittelalter von statten ging, ob und wie die Nahrung sozial monopolisiert wurde usw., landet man schnell bei systemischen Betrachtungsansätzen, die das Einzelphänomen in seiner allein angemessen kontextualisierten Form behandeln. Nicht die Hervorbringung des SpurenelementDatums ist die Erkenntnis, sondern die durch und mit ihm gewonnene Information. Und warum sollte die nicht in der Hand desjenigen verbleiben, der über die Quellenkompetenz verfügt? Es macht keinen Sinn, die Produktion von Spurenelementdaten oder Messwerten von Stabilen Isotopen von der Ebene ihrer Bedeutungen zu trennen, weil sonst der Messwert ein nicht-kontextualisiertes Zeichen

\footnotetext{
819 Lepenies 1986

$820 \mathrm{Vgl}$. Mayr 2000, bes. Kapitel 4

821 Vgl. Herrmann et al. 1990, wo ich bereits ein kurzes Kapitel zur theoretischen Fundierung angefügt habe, in dem diese Überlegungen anklingen.
} 
bliebe. ${ }^{822}$ Wird die Bedeutungszuschreibung hingegen auf eine andere Disziplin verlagert, z.B. die Ur- und Frühgeschichte oder die Sozialgeschichte, bleibt der Datenproduzent der Messknecht und der Geschichtswissenschaftler wird zum Herren der Theorie, ${ }^{823}$ womit in der Tat ein erheblicher Teil des wissenschaftlichen Alltags treffend charakterisiert ist.

Das Quellenmaterial der Anthropologie, etwa ein Skelettfund, liefert in seiner biologischen Auswertung jedoch immer nur lediglich die Voraussetzung, nicht aber bereits die Antwort der eigentlichen Fragestellung. Insofern ist die häufig anzutreffende Rechtfertigungsrhetorik der Anthropologie, wonach sie aus dem Skelett „die Biologie“ bzw. „die Lebensbedingungen“ der Verstorbenen rekonstruiere, zunächst eine irreführende Wichtigtuerei. Verdeutlichen soll dies die Matrix der Erkenntnisproduktion aus den Daten eines Skeletts (Tabelle).

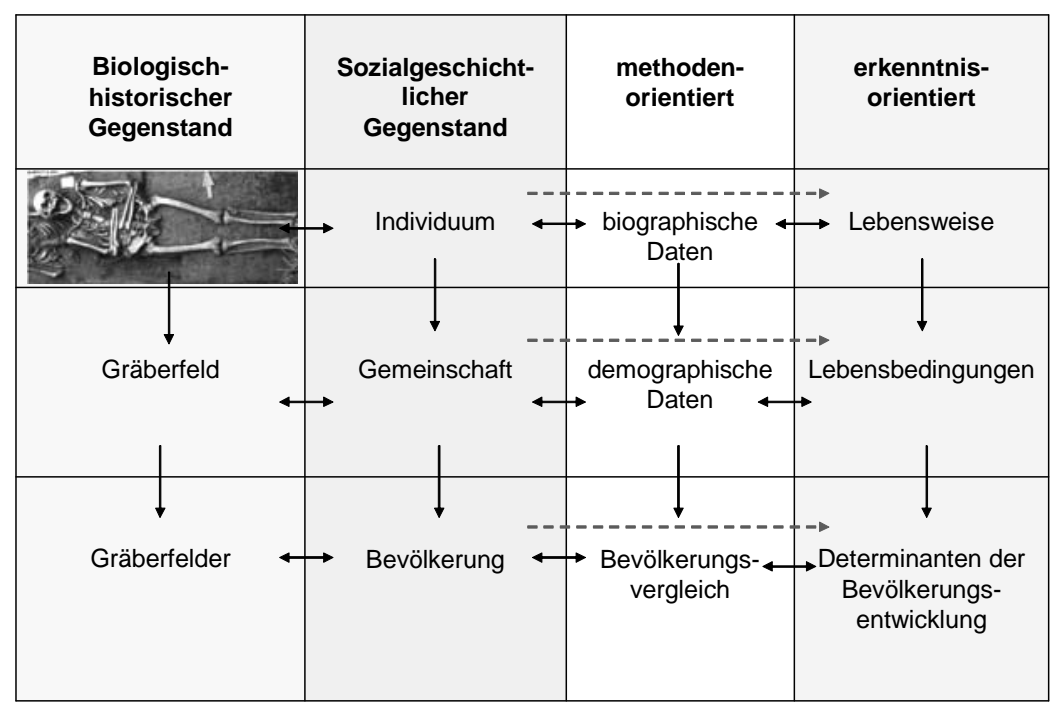

Tabelle zur schematischen Darstellung des Erkenntnisgewinns und der Erkenntnismittel bei der Bearbeitung von Skelettfunden. Die Pfeilrichtungen repräsentieren den Erkenntnisfluss; die horizontalen, spaltenübergreifenden gestrichelten Pfeile verbinden die disziplinär erarbeiteten Einsichten der Biologie und Sozialgeschichte auf einer Metaebene eigener Qualität (der Erkenntnisorientierung). Erst sie beinhaltet die in der Legitimationsrhetorik enthaltene Aussage über „die Menschen“ einer historischen Bevölkerung. Näheres zu den häufig beobachteten Diskrepanzen zwischen Aufklärungsanspruch und Aufklärungsleistung der physischen Anthropologie bezüglich der rechten Spalte im Text. Der Begriff „Le-

822 Zu Signifikanten und Signifikaten in der biologischen Erkenntnisproduktion: Herrmann 2007a 823 Mit immer noch großem Vergnügen danke ich Thomas Potthast für seinen Diskussionsbeitrag auf Frauenchiemsee, in dem er in Hegelscher Manier das Bild von den Theorie-Herren und unterprivilegierten Messknechten entwickelte, ein wunderbar pointiertes Bild. 
bensweise“ ist von „Lebensbedingungen“ durch die höheren Freiheitsgrade individueller Strategien unterschieden, während die Lebensbedingungen die Schnittmenge der individuell gleichartigen Strategien angibt. Sie sind zahlenmäßig geringer, aber normativ bzw. konstitutiv intensiver. Im gleichen Sinne erklärt sich die Differenz zwischen Lebensbedingungen und Determinanten der Bevölkerungsentwicklung.

Die Tabelle zeigt in ihrer ersten Spalte das einzelne Skelett als kleinste zu untersuchende Einheit in einem Bevölkerungsverband. Die biologischen Daten sind zugleich gesellschaftswissenschaftliche (zweite Spalte). Das eingesetzte methodische Instrumentar (dritte Spalte) muss sich der Erkenntnisorientierung der Fragestellung (vierte Spalte) unterordnen. Am Ende stehen Aussagen, die sich dem Zusammenwirken mindestens zweier Wissenszusammenhänge verdanken: der Biologie und der Kulturwissenschaft, wobei offenkundig ist, dass es eigentlich ebenso wenig eine Biologie gibt, wie es eine Kulturwissenschaft gibt. Das wäre beim Thema Mensch wohl auch kaum anders zu erwarten, und kann man bereits jetzt erahnen, dass die Pointe am Ende in einem Oxymoron liegen könnte, wonach die Anthropologie eine transdisziplinäre Disziplin ist.

Die Tabelle zeigt auch, dass die handwerkliche biologische Kompetenz auf die linke Spalte beschränkt ist. Das „Individuum“ und seine Äquivalenzbegriffe in der aufsteigenden Reihe der zweiten Spalte sind mit den bloßen Mitteln der Biologie nicht beschreibbar. Das Skelett einer Frau von 40 Jahren oder eines Mannes gleichen Alters sind in der historischen Perspektive nicht aus ihren biologischen Eigenschaften und Daten interessant, sondern wegen der gesellschaftlichen Rollen, die sich möglicherweise mit diesen Eigenschaften zu Lebzeiten der Individuen verknüpften. Auch das methodische Repertoire der demographischen Instrumente (dritte Spalte) ist vor allem auf sozialwissenschaftliche Episteme angewiesen. Die Begriffe der rechten Spalte, zunächst reine Begriffschiffren, übersetzen aber durch Kontextualisierungen die Zeichen (Skelette, Beigaben, usw.) in Bedeutungsträger, deren Bedeutungsinhalt ihre letztliche Ursache oder die Randbedingung ihrer Entstehung ist. Diese Transferleistung ist unausweichlich mit dem Entwurf einer Geschichte, einer Erzählung über ein Geschehen verbunden. ${ }^{824}$ Wird die rechte Spalte als Ziel derjenigen Analyse bestätigt, mit dem die Untersuchung des Skeletts begann, befindet man sich auf einer transdisziplinären Ebene. Es wäre m. E. unsinnig, die biologischen Anthropologen als zuständige Quellenkundler von der voraussetzungsvollen Produktion des Wissens, also vom Miterzählen, auszuschlieBen. Nach meiner Auffassung ist für die Gesamtheit der Matrixfelder ein Anthropologe zuständig, mindestens jedoch unter prominenter Beteiligung. Freilich einer, der nicht nur seine Biologie beherrschte, sondern der auch geübt im Erzählen wäre. Wenn es sie denn gibt, verdanken sich solche Anthropologen ihrer eigenen

\footnotetext{
824 Herrmann 2007a
} 
Initiative, denn die kontinentaleuropäische Anthropologie hat kein Interesse an dieser Art Qualifikation.

Konkret lässt sich die Setzung von der notwendigen erzählerischen Kompetenz der (biologischen) Anthropologen an einem einfachen Beispiel über genetische Informationen einer prähistorischen Bevölkerung illustrieren, mit dem die Anschlussfähigkeit biologischer Daten an eine höhere Abstraktionsebene erreicht wird. ${ }^{825}$ Für die bronzezeitliche Bevölkerung, die sich aus der Harzer Lichtensteinhöhle rekonstruieren lässt, ist genetisch Patrilokalität nachweisbar, weil die Variabilität bestimmter DNA-Abschnitte bei den Frauen größer als bei den Männern ist. Die genetische Analyse kann also der Aufdeckung eines institutionengeschichtlichen Sachverhalts dienen. Patrilokalität ist nun aber nur insoweit ein biologisches Datum, als es die formale genetische Variabilität und die aus ihr abgeleitete Schlussfolgerung betrifft. Doch ist diese Variabilität Voraussetzung wie Ergebnis gesellschaftlicher Prozesse, zu denen die Kulturwissenschaft nur dann Zugang findet, wenn sie von ihnen weiß. Dieses Wissen besorgt die Biologie. Weder Biologie noch Kulturwissenschaft erzählen adäquat die „Geschichte des Heiratssystems“ in dieser vorgeschichtlichen Bevölkerung. Diese Erzählung ist auf einer aus beiden „Disziplinen“ formulierten, metatheoretischen Plattform angesiedelt, die man „transdisziplinär“ nennen sollte, weil sie nur ihrer eigenen Meinungsführerschaft verpflichtet bleiben kann.

Am gleichen Kollektiv ist auch eine erstaunlich geringe Zahl laktosetoleranter Individuen nachgewiesen worden. Die Fähigkeit, Milchzucker aus der Rohmilch problemlos verdauen zu können, beruht auf einer bestimmten genetischen Eigenschaft. Die heutigen Europäer sind weltweit diejenige Gruppe mit dem höchsten Vorkommen dieser Eigenschaft (80 \% und mehr). Wenn die Lichtensteiner diesen Zahlen nicht nahe kommen, kann dies als Hinweis auf den seit der Bronzezeit stattgefundenen diachronen Wandel hin zu einer rohmilch-konsumierenden Gesellschaft in Europa begriffen werden. Auch hierbei verknüpfen sich wieder physiologische Faktoren und gesellschaftliche Entscheidungen im Verlauf der Geschichte in spezifischer Weise. Niemand muss Rohmilch konsumieren, denn das Problem des Milchzuckers ließe sich durch spezielle Milchaufbereitungsverfahren lösen, wie sie in vielen Teilen der Welt aus eben diesem physiologischen Grund verbreitet sind. Das Beispiel gehört, wie auch dasjenige über die grundsätzlich eingeschlagenen Subsistenzstrategien, in die komplexe Geschichte von Monopolisierung und sozialer Hierarchisierung der Nahrung. ${ }^{826}$ Die Koevolution biologischer und kultureller Sachverhalte und Systeme ${ }^{827}$ scheint mir als das Paradethema nicht nur der Transdisziplinarität, sondern auch der „historischen Mensch-UmweltBeziehungen“ überhaupt.

\footnotetext{
825 Herrmann et al. 2007

826 Z.B. Schutkowski et al. 1999

827 Durham 1991
} 
Wenn die Gastgeber mit der Einladungsschrift zum Workshop ihre Standortortbestimmung mit dem Hinweis auf Clyde P. Snow verbunden haben, sollte der differenzierenden Einwände gegen Snows Diagnose gedacht werden. Dessen ungeachtet bleibt es ein Faktum, dass ein wissenschaftssystematisch einheitlicher Überbau nur in Verabredungen auf bestimmte rational-logische Operationen gründen kann und im Alltag die Disziplinen nebeneinander her existieren. Und das ist in einem pragmatischen Sinne durchaus akzeptabel, denn vor den Gewinn abstrakter erkenntnistheoretischer Großentwürfe auf der metatheoretischen Plattform haben die Götter den Schweiß der alltäglichen disziplinären Kärrnerarbeit gesetzt.

Der transdisziplinäre Diskurs ordnet die einzelfachlichen Wissenselemente neu, indem er sie zu neuen Wissenszusammenhängen mit Anschlussfähigkeit arrangiert. Man kann dabei an Ernst Cassirers ${ }^{828}$ Aufforderung zur „Kontextualisierung des Wissens" anknüpfen, an die Aufforderung zur Interaktion des disziplinär erarbeiteten Wissens mit benachbarten, aber auch entfernten Formen und Feldern des Wissens und der Erfahrung. Für Wolfgang Frühwald gehört dies zu jener „Anthropologisierung des Wissens, die im 19. Jabrbundert abgebrochen ist, weil die zunebmende (und zunächst notwendige) Spaltung der Wissensfelder, die Entwicklung von experimentellen Naturwissenschaften auf der einen und emphatisch verstandenen Geisteswissenschaften auf der anderen Seite, die Institutionalisierung einer Gesamthumanwissenschaft Anthropologie scheinbar überflïssig machte. Odo Marquard hat...verdeutlich, dass und wie im 19. Jahrbundert statt der Anthropologie die Biologie erfolgreich institutionalisiert wurde. Aus ibr wurde das Thema der Besonderbeiten und Sonderbarkeiten des Menschen ausgeschlossen, seiner nabmen sich die Geisteswissenscbaften an; so [...] kam es gewissermaßen als Konsequenz der misslungenen Institutionalisierung der Anthropologie gegen Ende des 19. Jahrbunderts zur endgültigen theoretischen und institutionellen Durchsetzung der Geisteswissenschaften. "Frübwald ist der Auffassung, dass „die moderne Wissenschaftstheorie seit langem [versucht], auf der Basis hoch entwickelter Detailwissenscbaften zu jener Kontextualisierung und Anthropologisierung der in allen Wissenschaften gleichartig wirkenden Denkformen zu kommen, von denen aus neue Wege, begehbare Wege auch durch die immer undurchdringlicheren Datengebirge der experimentellen Fächer ibren Ausgang nebmen könnten."

Ich kenne mich mit der hier erwähnten „Anthropologisierung“ nur mäßig aus. Der Verdacht liegt nahe und lässt sich auch gut begründen, dass dabei der Weg zu einer umfassenden, holistischen Wissensproduktion beschritten wird, die transdisziplinär ist, weil sie alle Disziplinen hinter sich lässt, bzw. alle Disziplinen in ihr aufgehen. Unter der Generalhypothese von der Einheitlichkeit alles Humanen erscheint diese Entwicklung von gewisser Folgerichtigkeit. Welchen Erklärungswert die in diesem Zugang möglichen analytischen Arbeiten dann haben werden, scheint mir aller-

828 nach Frühwald 2006, bes. Seiten 19/20, von dort auch Übernahme des nachfolgenden Wortlautes bis zum Absatzende. Frühwald beruft sich dabei auf W. Lepenies und O. Marquard 
dings offen. Popper hatte ehedem über ähnliche holistische Erklärungsansätze der Biologie ein einleuchtendes, aber vernichtendes Urteil abgegeben. ${ }^{829}$

Meine Kompetenz bezieht sich ursprünglich formal auf eine spezialisierte Anthropologie, also eines disziplinär erarbeiteten Wissens, namentlich die Bereiche der „prähistorischen“ und „historischen Anthropologie“. Besonders letztere ist berüchtigt für ihre (disziplinäre) Konturlosigkeit. Sie ist auch bekannt dafür, dass sie sich einer Suche nach den archimedischen Punkten des Menschen und ausgerechnet in der Biologie verweigert, dabei aber unter kulturwissenschaftlicher Meinungsführerschaft gelegentlich vergisst, dass Menschen zunächst und auch biologische Wesen sind. Dennoch scheint mir der einzig gangbare Weg in eine Zukunft anthropologischer Wissenschaft die konsequente Verfolgung transdisziplinärer Fragestellungen. Es ist kein Geheimnis, weil ich dies bereits mehrfach geäußert habe, dass ich das Projekt „biologische Anthropologie“ als teilweise bis zur Unproduktivität abgegrast und weitgehend ohne künftige Anschlussfähigkeiten beurteile. ${ }^{830}$

Allein die Tatsache, welchen z. T. dramatischen Inhaltswechsel einerseits und welche thematischen Einengungen diese biologische (physische) Anthropologie in ihren deutschsprachigen Lehrbüchern nach einer Phase eklektizistischhypertropher inhaltlicher Ausuferung Mitte der $80 \mathrm{er}$ Jahre erfahren hat, ${ }^{831}$ ist ein Hinweis auf das fehlende sichere fachliche Selbstverständnis, auf die fehlende innerfachliche Kohärenz, und damit letztlich auch ein Hinweis auf die Beliebigkeit, mit der Fachvertreter die Inhalte ihres Faches bestimmen und den von ihnen verwendeten Stoff systematisieren. Diese Beschreibung verdichtet sich zu einer gerechtfertigten Diagnose durch den Umstand, dass das zuletzt veröffentlichte deutschsprachige Lehrbuch ${ }^{832}$ keine wissenschaftstheoretische Abgrenzung des

829 Popper 1989, S. 83. Popper geht für die Erläuterung der „Falsifizierbarkeit“ von einer verbreiteten verhaltensbiologischen Theorie aus, an der er vorführt, dass diese dem von ihm formulierten Anspruch an wissenschaftliche Eigenschaften nicht erfüllt: „..., Alle menschlichen Handlungen sind egoistisch, von Selbstinteresse gesteuert; und jene Handlungen, die es scheinbar nicht sind, werden im selbstischen Interesse unternommen, sich selbst, oder anderen als selbstlos zu erscheinen.' Diese Theorie ist weit verbreitet: sie hat behavioristische, psychoanalytische, utilitaristische, vulgärmarxistische, religiöse (,sich das Himmelreich verdienen') und wissenssoziologische (,Erkenntnis ist von Interesse gesteuert') Varianten. Es ist klar, dass die Theorie und alle ihre Varianten nicht falsifizierbar sind: Sie sind pseudowissenschaftliche Ideologien."

830 Herrmann 2001 - Eine ähnliche Diagnose bei Bittner 2004 - Die ältere Diagnose vom ,,Theoriedefizit der deutschen Anthropologie“ reflektiert durchaus damalige selbstkritische Einsicht eines Teils der deutschsprachigen Anthropologen. Sie geht zurück auf eine Diskussionsrunde bei der WernerReimers-Stiftung, Bad Homburg, am Beginn der 80er Jahre, in deren Verlauf diese Formulierung von Eike Winkler (Wien) aufgebracht wurde. Den anschließenden Versuch neuartige Standortbestimmungen fachlicher Ausrichtungen zu formulieren und umzusetzen, hat es meiner Wahrnehmung nach in der deutschsprachigen Anthropologie nur in Göttingen und - mit Anlehnung an politische Umfelder - in Wien gegeben.

831 Das gilt mutatis mutandis auch für ausländische Lehrbücher, obwohl sich das erkenntnistheoretische Defizit dort nicht in gleicher Schärfe zeigt. Global gesehen weist dies auf Auflösungserscheinungen eines Fachs hin und bestätigt meine oben geäußerte Endzeitdiagnose.

832 Grupe et al. 2005. - Um Missverständnissen vorzubeugen: Ich benutze das zitierte Lehrbuch als Beispiel, an dem ich meine Überlegung illustrieren kann. Meine andersartige Auffassung bedeutet nicht, dass es mir am Respekt vor der Arbeitsleistung der Fach-Kolleginnen mangele. 
Fachs und Begründung für die Stoffauswahl findet, sondern es über eine Eigenschaft („Brückenfach“) definiert. „Brückenfach“ ist aber weder eine identitätsoder kohärenz-, noch eine inhaltsstiftende Eigenschaft. Demgegenüber konnte z. B. das erste deutschsprachige Lehrbuch der Anthropologie nach dem Zweiten Weltkrieg noch in seinem ersten Satz programmatisch behaupten: „Anthropologie ist die Lehre von der Natur des denkenden Menschen." "833 So problematisch eine derartige Ontologie auch ist, ihr liegt immerhin ein inhaltliches Konzept, eine Generalhypothese, zugrunde. Was die im jüngst erschienen Lehrbuch präsentierten Sachverhalte zu elementaren Bestandteilen des Faches macht bzw. was die Nichtaufnahme anderer Themen begründet, wird dem Leser nicht vermittelt. Mit Verblüffung ist zu beobachten, dass dort, wo ein irgendwie interessantes Forschungsfeld vermutet oder thematisiert wird, allermeist ein fremdbestimmtes Verwertungsinteresse herangezogen bzw. unterstellt wird. Das könnte sich ja einem Fach auf dem Weg zur Transdisziplinarität verdanken. Aber die im Lehrbuch praktizierte Wissenschaftssystematik ordnet sich einem heimlichen Relevanzkriterium unter, was der Aufgabe selbst- und freibestimmter Forschungsthematik gleichkommt. Davon abgesehen gehört es mit zu den Eigenheiten des Lehrbuchs, dass es (funktional und thematisch durchaus vertretbare) Übertretungen des biologischen Erkenntnisrahmens vornimmt, ohne an dieser Stelle auf die Andersartigkeit der Argumentation durch diese neue Kontextualisierung hinzuweisen. ${ }^{834}$ Wiederum wird die eigentliche Perspektive des Ansatzes nicht in Produktivität grenzüberschreitender Wissensverknüpfung gewendet, weil die Grenzüberschreitung offenbar ohne Bewusstsein erfolgt, jedenfalls zu keiner wissenschaftstheoretisch erforderlichen neuen Positionsbestimmung führt. Das Lehrbuch legt also die Krise der biologischen Anthropologie offen und unterstützt meine Eingangsdiagnose vom Ende einer kohärenten biologischen Anthropologie.

In der Tat werden ganz allgemein biologisch-anthropologische Sachverhalte durchaus intensiv nachgefragt, aber mit dem ganz überwiegenden Zweck einer Nutzung in irgendwelchen andersfachlichen oder populären Zusammenhängen. Dort findet auch die Diskussion mit (und über) biologische Sachverhalte und ihre Bewertung statt. Wenn an diesen Diskussionen die biologischen Fachleute beteiligt werden, kommt der Dialog jedoch schnell zum Erliegen. Da ist zuerst der technische Grund: Zumeist geht es um Themen der Sozial- und Kulturwissenschaften, deren theoretische Fundierung den meisten biologischen Anthropologen weitgehend unbekannt ist. Hinzu kommt ein theoretischer Grund: Es existiert seit dem 19. Jahrhundert die Annahme von der Einheitlichkeit alles Humanen. Deshalb wird häufig auf „die Natur des Menschen“ abgestellt und damit die Biologie des Menschen als vermeintlich sicherer archimedischer Punkt bemüht. Ich kann keinen erkenntnistheoretischen Weg erkennen, mit dem es möglich wäre, beispielsweise

\footnotetext{
833 Scheidt 1953, S. 7

${ }^{834}$ Damit wird gewissermaßen der Küchenlieferant mit dem chef de cuisine verwechselt. - Vgl. weiter unten: Kategoriefehler nach Ryle
} 
Dantes Göttliche Komödie, Michelangelos Pieta, die Gotischen Kathedralen oder der Nord-Ostsee-Kanal, als Produkte einer genetischen Grundlage des Menschen aus einer evolutionsbiologisch fundierten adaptiven Verhaltensstrategie einzuordnen. Natürlich kann mein Körper sich nur in den von Genetik und Manifestationsform vorgegebenen Grenzen verhalten. Aber, ob eine romanische oder gotische Kathedrale gebaut wird, ist für mich keine Frage der genetischen Basis. Deswegen ist die Suche nach den archimedischen Punkten oft so sinnlos bzw. nur dort sinnvoll, wo es um das Durchschlagen der rein animalischen Existenz geht. Inwieweit aber eine Mitwirkung am vierhundertjährigen Bau einer Kathedrale die konkreten Fortpflanzungschancen verbessert oder den Zugang zu Nahrungsressourcen in Zeiten der Knappheit verbessert und ob diese letztlich die Motivationen für ihren Bau abgeben, halte ich für eine absurde Perspektive. Abgesehen davon ist die Rede von „der Natur des Menschen“ eine ontologische Zuweisung, ein kulturelles Konstrukt.

Wenn denn das Transdiziplinäre sich allerdings zuerst als kommunikationssoziologische und wissenschaftssoziologische Blüte begreifen sollte, wie man nach Lektüre von Bruno Latour vermuten könnte ${ }^{835}$ oder als eine Unternehmung, die „Wissenschaft und Gesellschaft wieder näher zusammenbringen, um dadurch unausgeschöpfte Problemlösepotentiale zu mobilisieren und innovative Lösungen zu ermöglichen" ${ }^{836}$ dann stimme ich in der Sache vermutlich ${ }^{837}$ zu. Ich hätte es allerdings, in der etwas hemdsärmeligen Diktion meiner Berliner Heimat, gern eine rhetorisch-deklamatorische Nummer kleiner.

Seit den 40er Jahren des letzten Jahrhunderts hat es in der internationalen Anthropologie eine fruchtbare Verbindung biologischer Fragestellungen hin zur Funktionalisierung kultureller Fragestellungen gegeben. Die international produktive biologiehaltige Anthropologie ist heute einem ökosystemaren Ansatz verpflichtet, ohne nur Biologie sein zu wollen oder es zu sein. Wie sich die internationale fachliche Entwicklung darstellte, ist in prägnanter Übersicht dem Einleitungskapitel bei Schutkowski zu entnehmen. 838

Nicht zu übersehen ist, dass sich international Begriffe mit überlappenden bzw. parallelen Inhalten herausbildeten, u.a. Cultural Ecology, Ecological Anthropology, Human Adaptability, Biocultural Anthropology, Cultural Materialism oder Human Ecology. Sie sind Ausdruck einer Partikularisierung, deren Pluralität keineswegs mit einem vergrößerten Theorieangebot gleichzusetzen ist. Es liegt nahe, nach einer Vermittlungs- und Synthesetheorie zwischen all diesen Begriffen zu suchen,

\footnotetext{
835 Soweit ich dies aus der mir ansonsten weitgehend verschlossenen analytischen Kraft der Latourschen Gedanken mit Hilfe von Michael Hagner begreifen durfte (Hagner 2006)

836 So der Wortlaut aus dem Editorial von Armin Grunwald zum Thematischen Schwerpunkt „Transdisziplinarität“" in Gaia 1/2007

837 Vorbehaltlich, dass mein Verständnis der zitierten Darstellungen mit den Intentionen der Verfasser zusammenfällt

${ }^{838}$ Schutkowski 2006
} 
die einerseits die Möglichkeiten zur diachronen Analyse und vergleichenden Betrachtung enthält, das einem systemischen Ordnungsprinzip verpflichtet ist und andererseits auf der Ebene von Individuen als auch von Populationen Anpassungen als biologisches und kulturelles Ziel erfassbar macht. Der Versuch der gleichzeitigen Berücksichtigung dieser ungleichzeitigen Faktoren führte, jedenfalls in meinem Falle, in die Umweltgeschichte (Environmental History).

Für mich ist dies ein Forschungsfeld, das die disziplinären Ergebnisse unter dem thematischen Dach kontextualisiert, methodisch opportunistisch (,anything goes “839) operiert und dabei gleichzeitig überzeitlichen Strukturen wie akuten Strategien im Umgang mit den naturalen Ressourcen nachgeht. Selbstverständlich geht es um Anpassung und Wandel, historische Fundamentalbegriffe. Aber Umweltgeschichte begreift die Geschichte nicht einseitig als eine Sache der menschlichen Angelegenheiten. Neben dem Menschen beeinflussen naturale Faktoren, die einer Eigengesetzlichkeit folgen, die Dinge der Natur ebenso, wie sie die Dinge der Menschen beeinflussen. Umweltgeschichte schließt damit nach meinem Verständnis selbstverständlich die Einsichten der historisch arbeitenden Naturwissenschaften ein. Es wäre ja wohl auch zu merkwürdig, nach historischem Hochwasserschutz zu fragen, ohne die naturalen Bedingungen, die zu ihm führen, zu kennen. Und: Wer regelmäßig Bäume fällen will, tut gut daran, die jährlich nachwachsende Holzmenge zu beobachten. Schließlich: Bevor das Getreide verteilt, verhandelt oder monopolisiert werden kann, muss es gesät und geerntet werden. Es gilt der Hinweis des Aristoteles, wonach das Getreide ohne Zutun des Bauern wächst, aber die Liege nicht ohne den Tischler entsteht. Man muss in Anlehnung an Schiller (Jungfrau von Orleans 1,3) jedoch ergänzen: Weder der politische, noch der gesellschaftliche oder der konstruktivistische Wille wird dazu führen, dass das „Kornfeld auf der flachen Hand" wächst. Das Naturale wird also zur unhintergehbaren Ausgangsbedingung.

Ich würde schließlich so weit gehen, künftige Berechtigungen meiner ursprünglich biologischen Heimat-Profession abhängig machen zu wollen von der Integrationsfähigkeit des in ihr erarbeiteten Wissens in transdisziplinäre Konzepte. Diese Anschlussfähigkeit ist meiner Auffassung nach mit dem Rückgriff auf z. B. ökosystemare Konzepte gegeben.

\section{4}

Was passiert in jenen vielgenannten Wissenszusammenhang über „historische Mensch-Umwelt-Beziehungen"? Mit der Aufdeckung von Vorstellungsstrukturen, die das Handeln der Akteure bestimmen und mit der Entwicklung eines analytischen Begriffssystems, das geeignet ist, die typischen Eigenschaften der Strukturen gegenüber anderen Determinanten menschlichen Verhaltens darzustellen, besteht

${ }^{839}$ Feyerabend 1986 
nach meinem Urteil eine gewisse Nähe zur „dichten Beschreibung“. Von dieser unterscheidet sich aber die umweltgeschichtliche Arbeit grundlegend durch ihre systemischen Anteile, ihren Focus sowie durch ihre Perspektive auf in der Regel kollektive (nicht individuelle) Handlungsmuster. ${ }^{840}$

Der Begriff der „dichten Beschreibung“ verdankt sich nicht etwa, wie oft angenommen, Clifford Geertz, sondern dem britischen Philosophen Gilbert Ryle, der vor allem aber wegen seines Hinweises auf die Gefahr des Kategorienfehlers bekannt geworden ist. ${ }^{841}$ Letztlich beruht sein Urteil auf der „metabasis eis allo genos“, mit der Aristoteles den Sprung von einem Bezugs- bzw. Wertesystem in ein anderes bezeichnet hatte. Es ist der häufigste Fehler z. B. der biologischen Systematisierungsbemühungen am ausgehenden 18. Jh., wodurch die mögliche Aufdeckung genealogisch-evolutionsbiologischer Zusammenhänge verzögert blieb. Wenn man, wie damals geschehen, z. B. die Vögel nach ihrem Verhalten gruppiert und dabei Gruppen bildet mit Vögeln, die im Wasser oder im Sande baden, gleichzeitig nach Vögeln, die am Morgen oder Abend singen usw., kann sich daraus keine sinnvolle Ordnung ergeben, weil die verwendeten Kategorien nicht äquivalent sind.

Ryle hat das populäre Beispiel für einen Kategorienfehler vorgestellt: Wenn eine Mannschaft in ein Stadion einläuft, bedeutet dies, dass die einzelnen Spieler dieser Mannschaft ins Stadion einlaufen. Es trifft nicht zu, dass zusätzlich zu den Spielern auch noch eine "Mannschaft" einläuft. Es wäre falsch (d.h. ein Kategoriefehler) den Begriff "Mannschaft" in dieselbe Kategorie einzuordnen wie den Begriff "Spieler". Wichtig wird Ryles Systematik, weil nach ihm die Begriffe „Geist“ und „Körper“ in demselben Verhältnis zueinander stünden wie die Begriffe „Spieler“ und „Mannschaft“. Aufgrund dieses Kategorienfehlers würden wir gewöhnlich auch versuchen, Geist und Körper gleichartig zu verstehen, was entsprechend unangemessen sei.

Die thematische Opposition „Mensch und Umwelt“ verleitet nach meiner Einsicht zu einem ebensolchen Kategorienfehler wie im Falle von „Körper und Geist“. „Mensch“ und „Umwelt“ gehören nicht derselben Kategorie an. Ohne uns hier weiter um die erkenntnisphilosophischen Implikationen zu kümmern, ${ }^{842}$ ist es aber nicht nur gerechtfertigt, sondern überhaupt notwendig, das damit bezeichnete Problem auf eine Ebene gleichwertiger analytischer Qualitäten zu beziehen, um die beiden unterschiedlichen Bereiche trotz der Kategorienunterschiede fruchtbar miteinander zu verknüpfen. Diese Ebene ist transdisziplinär und sie sei heuristisch mit „Mensch-Umwelt-Beziehungen“ bezeichnet.

\footnotetext{
${ }^{840}$ Die Brauchbarkeit mikrohistorischer Studien wird an der Verallgemeinerungsfähigkeit des Individuellen gemessen werden müssen

841 Ryle 1969

${ }^{842}$ Es ist hier weder Platz noch Ort zur Ausführung des Gedankens, daher muss dies einer anderen Darstellung vorbehalten bleiben.
} 
Wem könnte denn die Ebene dieser Bedeutungen gehören? Die Analyse historischer Mensch-Umwelt-Beziehungen ist methodisch zunächst den Geschichtswissenschaften zuzurechnen, gleichgültig, ob sie mit hermeneutischer oder naturwissenschaftlicher Methode arbeitet. Was sie m. E. von der Geschichtswissenschaft unterscheidet, ist die Kontextualisierung von Disziplinenwissen bezüglich Fragestellungen, die von der Geschichtswissenschaft nicht beantwortet werden können. Themen wie Verfassungsgeschichte, Institutionengeschichte, Herrschaftsgeschichte, Mentalitäten- und Sozialgeschichte können naturale Faktoren einbeziehen, kommen aber letztlich ohne den Rückgriff auf sie aus. Die umwelthistorische Ebene kommt hingegen nicht ohne diese naturalen Faktoren aus, sie sind sogar konstitutiv. Ich bin mir daher sicher, dass sie eine Ebene eigenen Rechts darstellt und dass die Umweltgeschichte daher niemandem in einem disziplinären Verständnis gehören kann.

Aber was ist mit ihr und durch sie gewonnen? Lassen sich im diachronen und interkulturellen Vergleich Strukturen erkennen, deren Kenntnis hilfreich wäre? Ich meine ja, denn man kann, ob mit Schiller oder ohne, die „Weltgeschichte als das Weltengericht" auffassen. Dann aber ist das Studium historischen Sachverhalte die Analyse von „Langzeitversuchen unter natürlichen Bedingungen“ (so wiederholt von mir bezeichnet), und man kann im Hinblick auf Umwelthandeln aus der Geschichte lernen. ${ }^{843}$ Zur Erinnerung: Es gäbe z. B. kein Bewusstsein einer anthropogenen Klimaveränderung ohne Kenntnisse aus der Vergangenheit.

Anders verhält es sich mit den theoretischen Grundlagen dieser transdisziplinären Plattform. Angenommen, man läge das biologische Konzept einer Verhaltensökologie zugrunde, landete man bei jener unhintergehbarer Grundaussage (vgl. Fußnote 17):

„Alle Handlungen biologischer Organismen sind egoistisch, von Selbstinteresse gesteuert; und jene Handlungen, die es scheinbar nicht sind, werden im selbstischen Interesse unternommen, sich selbst oder anderen als selbstlos zu erscheinen. "Abgesehen von Poppers weiter oben aufgeführtem Urteil erklärt ein solcher Ansatz gar nichts mehr, weil er alles erklärt. Strukturen menschlicher Geschichte wären dann lediglich zeitweilige Koalitionen individueller Strategien zur Erreichung des selbstischen Maximalergebnisses. Die Konsequenz aus dieser Einsicht wäre die Aufgabe jeder historischen Forschung, nicht nur um ihrer selbst Willen. Sie wäre bestenfalls interessant für die Aufdeckung einer Geschichte von Instrumentalisierungen für jeweils egoistisches Interesse. Damit wäre aber beispielsweise „die Geschichte der Hanse“ in korporationengeschichtlicher Hinsicht eine völlig verfehlte Erzählung. Richtig wäre, und zwar allein richtig, sie aus der Sicht des selbstischen Interesses einer jeden beteiligen

843 Der Gedanke, man könne aus der Geschichte lernen, stößt immer wieder auf Skepsis, wenn nicht gar (mitunter wütende) Ablehnung. Mir ist dieser Skrupel fremd, und es erscheint mir geradezu erforderlich, umwelthistorisches Wissen nutzbringend in gesellschaftliche Diskurse einzubringen. Warum sollte man auch angesichts der beklemmenden globalen Umweltaussichten auf einem Standpunkt bloßer Wissenschaftlichkeit beharren, der den Nutzen nur für und im Hinblick auf den Wissenschaftsbetrieb sieht? Jeder Beitrag zur Lösung der großen Probleme, sei er noch so klein, wird doch wohl willkommen sein. 
Person zu beschreiben. Der Versuch allein muss schon scheitern, es sei denn, man weist achselzuckend auf Schillers Formel (Weltengeschichte ist Weltengericht) hin und gibt sich damit zufrieden, dass die Dinge eben sind, wie sie sind und keiner weiteren Erklärung bedürfen. ${ }^{844}$

Überraschend ist für mich der Attraktionswert, mit dem in umwelthistorischen Kreisen der Globalansatz von Holling ${ }^{845}$ bewertet wird. Mit diesem Ansatz will er gleichermaßen biologische wie soziale Systeme fassen. Die analytische Qualität seines Ansatzes erscheint mir in der Einzelfallprüfung allerdings wenig überzeugend. ${ }^{846}$ Immerhin würde, wie bei Holling letztlich praktiziert, eine unterliegende, irgendwie geartete Ökosystemtheorie den Vorzug bieten, Strukturierungsprinzipien sowie Änderungen menschlicher Aktivitätsmuster als positive bzw. negative Koevolutionen des naturalen und des sozialen Systems erkennbar werden zu lassen. Das wäre schon ein Vorteil gegenüber historischen geschichtswissenschaftlichen Erklärungsmustern, die nach meiner Einsicht größere Probleme hätten, einen Interpretationsansatz ähnlich umfassender Art jenseits der vielbemühten „Kontingenz" zu formulieren. Kontingenz ist kein strukturierendes Prinzip. Aber als initiale Ursache eines anschließend mit innerer Notwendigkeit ablaufenden Prozesses ist Kontingenz in komplexe Problemstellungen integrierbar.

Historische Mensch-Umwelt-Beziehungen sind ein spezifisches kulturelles Muster, das Max Weber so definierte:

„'Kultur' ist ein vom Standpunkt des Menschen aus mit Sinn und Bedeutung bedachter endlicher Ausschnitt aus der sinnlosen Unendlichkeit des Weltgeschehens. Sie ist es für den Menschen auch dann, wenn er einer konkereten Kultur als Todfeind sich entgegenstellt und, Rückkehr zur Natur' verlangt. Denn auch zu dieser Stellungnabme kann er nur gelangen, indem er die konkrete Kultur auf seine Wertideen bezieht und, zu leicht' befindet. '847

Webers Einsicht führt nun unmittelbar zu einer Kernfrage: Zu welchem Sinn trägt das Konzept (oder: ein Konzept) des transdisziplinären Forschungsprogramms bei? Sucht es tatsächlich nach einem Sinn, wie die Formulierung der Tagung mir implizit nahe zu legen schien, oder liegt die Bedeutung des transdisziplinären Forschungsprogramms vielmehr in der Beförderung der disziplinären Fragestellungen, gewissermaßen durch Rückwirkung auf diese von einer höheren Warte aus? An die Stelle des Sinns träte eine andere Funktionalisierung, der Zweck. Das wäre zwar kein ganz großer Wurf, aber immerhin auch schon etwas. Es würde aber bedeuten, dass es keine einheitliche Theorie der historischen Mensch-UmweltBeziehungen gibt und nach ihr zu suchen auch nicht besonders sinnvoll wäre. Das deckte sich mit jener Einsicht Webers, ${ }^{848}$ nachdem Sinn „,niemals ein Produkt fort-

\footnotetext{
844 Das führt unmittelbar in die Sinn-Frage; siehe weiter unten.

845 Holling 2001

846 Herrmann 2007b

847 Weber 1988, S. 180

848 Weber 1988 , S. 154
} 
schreitenden Erfahrungswissens sein" kann, sondern wir müssten imstande sein, ihn selbst zu schaffen.

Die Dinge um ihrer selbst willen zu erörtern, wäre vielleicht interessant, aber dann letztlich kein hinreichender Grund, die „Mensch-Umwelt-Beziehung“ zu untersuchen, weil der Wert dieser Untersuchung nur in sich selbst läge. Ich wünschte mir, dass die Beschäftigung mit diesen Dingen die Einsichtsfähigkeit der Menschen im Sinne einer ökologischen Grundbildung steigern und Beiträge zu einem lebenswerten Leben aller liefern wird. Die meinungsführende Gegenwartskultur verwendet dafür im Moment die Wertidee „Nachhaltigkeit“.

\section{Literatur}

Bittner, Rüdiger 2004: Anthropologie - Das Projekt und seine Aussichten. In:

Wahrnehmen und Handeln. Perspektiven einer Literaturanthropologie. Hrsg. von Wolfgang Braungart, Klaus Ridder und Friedmar Apel. Bielefeld

(Bielefelder Schriften zu Linguistik und Literaturwissenschaft 20), S. 329-336

Durham, William H. 1991: Coevolution: genes, culture and human diversity. Stanford, California

Feyerabend, Paul 1986: Wider den Methodenzwang. Frankfurt

Frühwald, Wolfgang 2006: Wirkungen der Freiheit. In: Grimm, Dieter (Hrsg.): 25 Jahre Wissenschaftskolleg zu Berlin: 1981 - 2006. Berlin, S. 1-27

Grupe, Gisela; Christiansen, Kerrin; Schröder, Inge; Wittwer-Backofen, Ursula 2005: Anthropologie. Ein einführendes Lehrbuch. Berlin u.a.

Hagner, Michael 2006: Die Welt als Labor und Versammlungsort. Bruno Latours politische Ökologie aus dem Geiste der Wissenschaftsforschung. In: Gaia 2/2006, S. 127-134

Herrmann, Bernd 2001: Zwischen Molekularbiologie und Mikrohistorie. Vom Ort der Historischen Anthropologie. Jahrbuch 2000 der Deutschen Akademie der Naturforscher Leopoldina. In: Leopoldina (R.3) 46, S. 391-408

Herrmann, Bernd 2007a: Zur Einführung. In: Biologische Spurenkunde Bd.1, Kriminalbiologie. Hrsg. von Bernd Hermann und Klaus-Steffen Saternus. Berlin, S. 1-14

Herrmann, Bernd 2007b: Empirische Zugänge zu historischen Biodiversitätsverdrängungen und Biodiversitätslenkungen: Die Beispiele Melioration und Schädlingsbekämpfung. In: Umweltgeschichte in Geschichte und Gegenwart. Hrsg. von Thomas Knopf. (im Druck)

Herrmann, Bernd; Grupe, Gisela; Hummel, Susanne, Piepenrink, Hermann, Schutkowski, Holger 1990: Prähistorische Anthropologie. Berlin u. a. 
Herrmann, Bernd; Schilz, Felix; Fehren-Schmitz, Lars; Renneberg, Rebecca; Pollmann, Jutta; Hummel, Susanne 2007: Der Knochen als molekulares Archiv. In: Nova Acta Leopoldina NF 94, Nr. 384, S. 21-27

Holling, Crawford Stanley 2001: Understanding the Complexity of Economic, Ecological and Social Systems. In: Ecosystems 4 (2001), S. 390-405

Kocka, Jürgen (Hrsg.) 1987: Interdisziplinarität. Praxis - Herausforderung Ideologie. Frankfurt

Lepenies, Wolf 1986: Das Ende der Naturgeschichte. Wandel kultureller Selbstverständlichkeiten in den Wissenschaften des 18. und 19. Jahrhunderts. Frankfurt

Mayr, Ernst 2000: Das ist Biologie. Berlin

Popper, Karl 1989: Falsifizierbarkeit, zwei Bedeutungen von. In: Handlexikon zur Wissenschaftstheorie. Hrsg. von Helmut Seifert und Gerhard Radnitzky. München, S. 83

Ryle, Gilbert 1969: Der Begriff des Geistes. Stuttgart

Scheidt, Walter 1953: Lehrbuch der Anthropologie. Hamburg

Schutkowski, Holger 2006: Human Ecology. Biocultural Adaptions in Human Communities. Berlin u. a. (Ecological Studies 182)

Schutkowski, Holger; Herrmann, Bernd; Wiedemann, Felicitas; Bocherens, Herve; Grupe, Gisela 1999: Diet, status and decomposition at Weingarten: Trace element and isotope analyses on early medieval skeletal material. In: Journal of Archeological Sciences 26, S. 675-685

Weber, Max 1988: Die „Objektivität“" sozialwissenschaftlicher und sozialpolitischer Erkenntnis. In: Max Weber, Gesammelte Aufsätze zur Wissenschaftslehre. Hrsg. von Johannes Winckelmann. Tübingen 


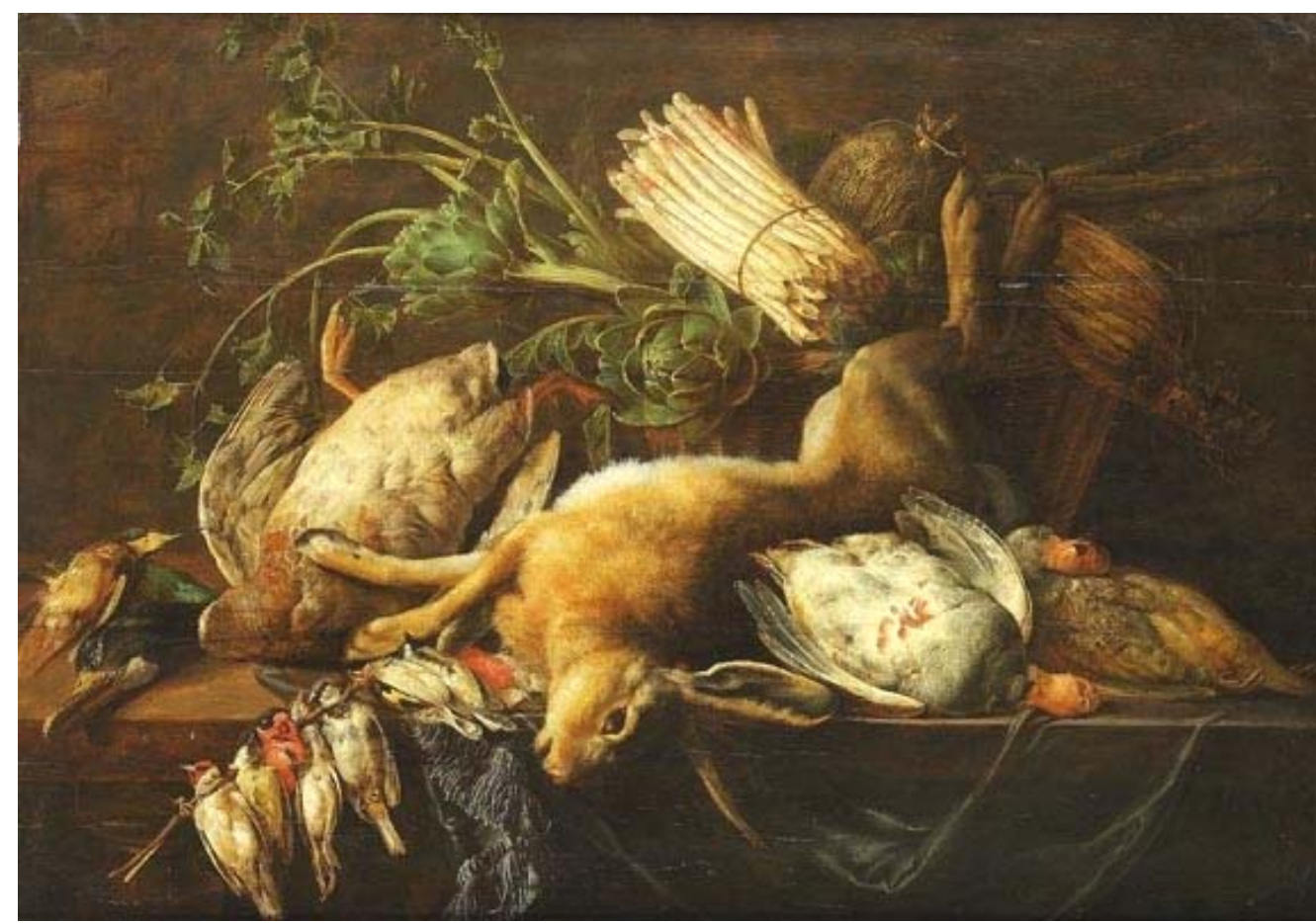

Abb. 1 Adriaen van Utrecht (1599 - 1652) Küchenstillleben mit erlegtem Wild und Gemüse. Zweite Hälfte 1640er Jahre. Öl auf Holz. Privatbesitz

Die Zutaten sind beisammen. Verbunden sind Vorfreude und Melancholie. Raffiniert spielt der Maler mit den Andeutungsebenen: dem Aristotelischen Diktum vom ,animal triste“, das vorher den „kleinen Tod“ gestorben ist, der in Wahrheit das Leben unterhält, wird hier mit den toten Tieren die Tristesse des großen Todes gegenübergestellt. Auch sie sind, als Nahrung, ein notwendiger Beitrag zum Leben.

Die Zusammenstellung der Objekte ist keine wirkliche Küchenszene, denn der unter den Singvögeln zweimal vertretene Stieglitz ist ein Zugvogel. Er ist zwar zur Spargelernte wieder in Mitteleuropa, dann ist hier aber die Artischocke nicht erntereif, und Hasen und Enten stünden, sofern geschützt, ebenfalls nicht zum Fang bzw. Abschuss. Weil es sich nicht um eine wirkliche Küchensituation handeln kann, ist nach einer anderen Bedeutung zu suchen. Die erwiesenen, vermuteten oder sympathetischen Eigenschaften der Nahrungsmittel liefern den weiterführenden Deutungsschlüssel: Artischocken und Spargel, damals absolute Luxusartikel, bilden zusammen mit Hase (oder Kaninchen) und Enten das Versprechen eines Mahls mit erotischer Konnotation an einer sozial gehobenen Tafel. Unter den einschlägig scheinbar unverdächtigen Singvögeln hängt, prominent unmittelbar vor der Tischkante, ein Sperlingshahn, das Symbol für Unkeuschheit und sexuelle Hyperaktivität schlechthin, schwerlich durch die Symbolik des Stieglitz (rechter Nachbar) gedämpft, der eben nur mit einer seiner Bedeutungen eine theologische Sinnzuschreibung erfährt, in der anderen aber für Beharrlichkeit und Fruchtbarkeit steht. Während der unmittelbare Nachbar links neben dem Sperling nicht zu identifizieren ist (? Sperlingshenne), sind die nächsten wieder bestimmbar: Dompfaffhahn, Sperlingshahn, Stieglitz. Der Dompfaff, auch Gimpel genannt, repräsentiert Tölpelhaftigkeit, Dummheit, Ungeschicklichkeit. Bringt er einen kritisch-ironischen Unterton in die Szene? Denn so leuchtend rot ist sein Federkleid nur während der Balz im Frühjahr, nicht aber in den übrigen Jahreszeiten. 


\title{
Natura morte im Delikatessenladen oder Wie viele Divisionen hat die Natur?
}

\author{
Bernd Herrmann
}

\begin{abstract}
Als die Frankfurter und die niederländischen Stilllebenmaler ihre enigmatisch codierten, artifiziellen Arrangements alltäglicher Gegenstände, raffinierter Leckereien, exotischer Delikatessen und wundersamer Naturdinge zu atemberaubender Kunstfertigkeit führten, war allen klar: hier betrachtete man calvinistisches Selbstbewusstsein und gekonnte Vanitasroutinen. Opulenter Naturgebrauch war nach dem göttlichen Verfügungsauftrag selbstverständlich und bedurfte keiner weiteren Rechtfertigung. ${ }^{849}$ Im Gegenteil, statt einer Rechtfertigung enthielt der Naturgebrauch, sofern er mit wirtschaftlichem Erfolg gepaart war oder sich diesem ver-
\end{abstract}

\footnotetext{
849 Zuerst erschienen in: Ermisch M; Kruse U, Stobbe U (Hrsg.) (2010) Ökologische Transformationen und literarische Repräsentationen. Göttingen, Univ.-Verlag. S. 96-129. - Abgestellt wurde auf Genesis 1,28: „Seid fruchtbar und mehrt euch und füllt die Erde und macht sie euch untertan und herrscht über die Fische im Meer und über die Vögel unter dem Himmel und über alles Getier, das auf Erden kriecht." Es ist der folgenschwere Imperativ, der als ,dominium terrae“ wirkungsgeschichtlich auf Naturkonzepte des Abendlandes Einfluss nahm. [Eigentlich müsste auffallen, dass aus diesem Auftrag alle Pflanzen ausgenommen sind. Der Begriff des „Getiers“ ist zudem eine ungeeignete Kategorie, weil er keine Differenzierung erlaubt und im Wortsinne nur die für menschliche Ohren lärmigen Tiere bezeichnet. In einem wörtlichen Sinne funktionierte der Auftrag auch deshalb nicht, weil die hier ausgenommene Kontrolle über Pflanzen als Primärproduzenten gleichzeitig die Kontrolle über die Lebensgrundlage aller Nahrungsketten darstellte. Kein Sophist der Nachaufklärung hätte je diesen Widerspruch aufgedeckt und damit z.B. Lynn Whites Argumente noch vor ihrer Formulierung (Science 155, 1967) ad absurdum geführt. Selbstverständlich geht es aber in dieser Passage um das vorweggenommene Faktum, dass Menschen - gleichgültig welchem Überzeugungssystem sie anhängen - in der Lage sind, der Erde ihren Willen aufzuzwingen. Von den kritischen Exegeten wird dabei vergessen, dass auch „die Gräser“, „die Saurier“ oder „, die Korallen“ zu ihrer Zeit planetare Wirkungen erzielten, ganz
} 




Abb. 2 Georg Flegel (1566 - 1638) Großes Schauessen mit Papagei (o.J., Öl auf Kupfer. Alte Pinakothek, München).

Köstliche exotische Früchte, exquisites Naschwerk und erlesene Genussmittel präsentieren sich in dieser Auslage, der als Blickfang eine südamerikanische Blaustirnamazone hinzugefügt wurde. Die Tulpenblüten seltener Färbung im Blumenstrauß unterstreichen die erlesene Kostbarkeit der einzelnen Gegenstände und den im Abgebildeten repräsentierten Wohlstand (vgl. Wettengl; bieræu weiter in einem Nachtrag am Ende des Aufsatzes)

zu schweigen von den Organismen, welche die Photosynthese erfanden und damit langfristig letztlich alle Lebewesen töteten, die in einer Sauerstoffatmosphäre nicht überleben konnten. Aber, das war noch zu den menschenfreien geologischen Zeiten der Erde, die so in der Bibel nicht vorkommen. Diese Gedankenführung ist erkennbar albern, weil sie Einsichten der Naturwissenschaft mit Postulatenethik verbindet und damit das Feld der naturalistischen Fehlschlüsse betritt. - Die Passage in Genesis 2,15 „Und Gott der Herr nahm den Menschen und setzte ihn in den Garten Eden, dass er ihn baute und bewahrte." [Hervorhebung $\mathrm{BH}]$ wird offenbar im Allgemeinen - wo nicht absichtlich übersehen - auf die Zeit vor der Vertreibung aus dem Paradies bezogen und damit offenbar als obsolet für den postparadiesischen Menschen angesehen. Will man nicht auf „,christliche“ Begründungsrhetoriken zurückgreifen, genügt allein schon der Hinweis auf die platonische Weltsicht, wonach die Welt so eingerichtet wäre, dass sie dem Menschen nützt. Skrupelloser Naturgebrauch hat also zumindest im Abendland eine lange geistige Tradition, da bei Lichte besehen die angeblichen Mahnungen selbst der griechischen Philosophen seit Platon keinen naturbewahrenden Gestus, sondern politische Gesellschaftskritik enthalten. 
dankte, die auf göttliches Wohlgefallen gegründete Selbstbestätigung. Es war zu derselben Zeit, in der sich noch die Bestimmung der Natur durch menschliche Nutzung vollendete, etwa als Vollendung der Bestimmung eines seltenen Fisches in einem herrschaftlichen Festbankett, wenn er nur rechtzeitig in der Küche von Françoise Vatel eintraf. ${ }^{850}$ Es ist die Zeit, in der sich die Frage des existentiellen Sinns vom Vertrauen auf die Heilserwartungen im Jenseits löst und auf das Diesseits und seine Ersatzbefriedigungen umzustellen beginnt.

Deswegen bereichern noch bizarre oder geschmackswidrige Gliederfüßer die abgebildete Tafel oder die Kredenz um ihre physikotheologischen Botschaften und gemahnen, den Genuss nicht zu sehr vom demütigen Gotteslob zu trennen, sofern sie denn ikonologisch dazu taugten und nicht einfach nur noch pflichtschuldig die ständige Bedrohung durch den altbösen Versucher abarbeiteten und im übrigen eine ästhetisch brauchbare Arabeske im Motiv darstellen. Im Beispiel (Abb. 2) besorgen diese Verbindungen das Tagpfauenauge links vorn als Symbol für die gefährdete menschliche Seele, und die Fliege am rechten mittleren Bildrand, die nicht nur vom Duft angezogen wird, sondern auch als Metapher unterweltlicher Macht auftritt. Einen ähnlich subtilen Hinweis gibt die Walnuss im Vordergrund, die gleichzeitig den Menschen und Christus repräsentiert. Alle drei Bildelemente sind auch kompositorisch als Farbtupfer und dekorative Struktur plaziert. ${ }^{851}$ Natur tritt in diesem Stillleben dem Betrachter vielgestaltig, köstlich und kostbar entgegen, versehen mit kleinen Warnungen. ${ }^{852}$

Der Naturgebrauch, wie ihn das Stillleben vorführt, steckt nicht allein deshalb voller Raffinesse, weil er sich auf den Genuss ihrer bloßen Voraussetzungen konzentriert, also etwa des mübsam Gesammelten, des von weit Hergeschafften, des Seltenen oder des sozial Monopolisierten konzentrierte, sondern weil er sich zusätzlich darauf konzentriert, was durch menschlichen Einfallsreichtum veredelt und raffiniert, was mit höchstem Einfallsreichtum und größter Kunstfertigkeit zubereitet wurde oder wird (deshalb steht das Naschwerk in Abb. 2 in der Mitte). Nicht das bloße Naturgut, sondern seine gesellschaftliche oder handwerkliche Veredelung macht die Delikatesse. Wenn Roger Bacon (1623) die Natur durch eine Dreiteilung ,in die Historie der Zeugungen, der Miss-Zeugungen und der Künste“ ordnet, ${ }^{853}$ dann steckt darin auch die selbstbewusste Einsicht, dass die menschli-

\footnotetext{
850 Meisterkoch am Hofe des Prinzen von Condé auf Schloss Chantilly, der sich wegen einer verspäteten Fischlieferung für ein Festbankett 1671 das Leben genommen haben soll.

851 Auf die Bedeutung der Stilllebenmalerei für die minutiöse Naturbeobachtung, die schließlich in die moderne Naturwissenschaft führt, wird hier nicht weiter eingegangen. Der Hinweis auf das Standardwerk von Alpers mag genügen.

852 So, wie es sich Flegels wohlhabende Auftraggeber wohl gewünscht haben werden.

853 „Die Einteilung der menschlichen Historie wollen wir nach dem Zustand und der Beschaffenheit der Natur selbst unternehmen, als die in dreifachen Zustand gesetzt erfunden wird und gleichsam eine dreifache Regierung eingeht. Denn entweder ist die Natur frei und erklärt sich durch ihren gewöhnlichen Lauf, wie an den himmlischen Körpern, den Tieren, den Pflanzen und dem ganzen Vorrat der Natur; oder sie wird durch bösartige Ungewöhnlichkeiten eines unbändigen Stoffes und durch die Gewalt der Hindernisse außer ihren Zustand gestoßen, wie in Missgeburten; oder sie wird endlich von der menschlichen Kunst und Arbeit gebunden, gestaltet und gleichsam erneuert, wie an
} 
chen Künste Dinge eigener Qualität hervor zu bringen vermögen. Zwar auf der Grundlage der „freien Natur“, aber nun gemäß den Vorgaben und Ansprüchen des Menschen, der der Natur „Bande“ auferlegt, ihr also vorschreibt, wie und wohin sie sich zu entwickeln oder was aus ihr zu entstehen hätte. Die Delikatesse repräsentiert den durch menschliche Kunstfertigkeit veredelten Gebrauch und Verbrauch von Natur auf der Stufe des höchsten sinnlichen Genusses, der dadurch noch verstärkt wird, dass die Sinnessensationen, die der so Privilegierte erlebt, von nur wenigen oder gar niemandem geteilt werden können.

In der Eitelkeit des weltlichen Genusses und im Vertrauen auf die göttliche Vor- und Fürsorge tauchte der Gedanke an eine endliche Welt im Sinne einer Endlichkeit der Ressourcen oder der sie hervorbringenden naturalen Prozesse noch nicht auf. Dass menschliche Nutzung Ressourcen erschöpfen könnte, widersprach absolut der Idee der besten aller Welten. Noch bedeutete „ausrotten“ wie bei Luther lediglich das vollständige Entfernen von einer konkreten Parzelle, ${ }^{854}$ nicht aber die Entfernung aus der Kette der Wesen. Noch fehlen Verlusterfahrungen aus mangelnder Verfügbarkeit; ${ }^{855}$ die Natur erscheint seit 1500, seit dem Beginn des globalisierten Handels und der Entstehung der ersten modernen Ökonomie, ${ }^{856}$ als Warenhaus, ${ }^{857}$ aus dem man sich grenzenlos bedienen kann. Erst das 18.Jh. wird beginnen, über die Endlichkeit von Ressourcen nachzudenken. Aber das sind Gedanken vereinzelter philosophischer Köpfe, Voltaire etwa, ${ }^{858}$ und für die betuchte Kundschaft sind jene Delikatessen, welche das Warenhaus der Natur nach wie vor bereithält, einladend ausgebreitet (Abb. 1 u. 2).

den Kunstsachen zu sehen. Also teilt sich die natürliche Historie in die Historie der Zeugungen, der Miss-Zeugungen und der Künste, welche letztere man auch Mechanik und die Erfahrende Naturlehre zu nennen gewohnt ist. Die erste behandelt die Freiheit der Natur, die zweite die Fehler, die dritte die Bande." Bacon, S. 173

854 DWB

855 Selbstverständlich ist hier nicht vom Mangel bei Armut die Rede, sondern davon, dass Wünsche selbst bei Reichtum unerfüllbar bleiben, wenn die Objekte der Begierde nicht mehr existieren. Ich übersehe nicht, dass sogen. Naturkatastrophen durchaus „Verlusterfahrungen“ bedeuten und dem Menschen um 1600 als Hochwasser, Ernteausfälle, Erdbeben, als Epidemien usw. durchaus bekannt waren. Die Rede ist hier vielmehr von Verlusten, die auf irreversiblen Naturverbrauch gegründet sind.

Die ersten anthropogenen Ausrottungen werden in Europa erst im 18.Jahrhundert „bekannt“. Sie werden bestenfalls unter Spezialisten (s.u.) diskutiert, obwohl sie historisch mindestens bereits in der Europäischen Antike eingesetzt haben und nicht allein in Europa, wenn nicht in Nord-Amerika sogar bereits am Ende der Eiszeit.

856 Gemeint sind die Niederlande und die Ostindien-Kompanie VOC (gegr. 1602) sowie die Westindien- Kompanie WIC (gegr. 1621); hierzu de Vries \& van de Woude.

${ }^{857}$ Eine Formulierung von Günter Bayerl, 2001, die sich ihm aus der Lektüre von Johann Beckmann, Anfangsgründe der Naturhistorie, Göttingen 1767, ergab. Ich danke Günter Bayerl, Cottbus, für seine Erläuterung.

858 In der Debatte über die Scala naturae hat Voltaire (1770), Questions sur l'éncyclopédie par des amateurs Vol 3, p. 284-287, auf die allgemeine Feststellung hin, dass es nach den Prinzipien der Scala naturae und dem der Fülle kein Aussterben von Arten geben könne, eingewandt, dass seit der Entstehung der Welt Tiere schon ausgestorben seien, bzw. der Mensch in der Lage wäre, Arten auszurotten (zit. nach Wagenitz, S. 187). 


\section{$1 \quad$ Im Delikatessenladen}

Ein Delikatessenladen ist ein verdinglichtes Stillleben. Er verspricht die Erreichbarkeit höchster Genussmittel, die Käuflichkeit des sublimsten Gaumenkitzels, dessen sich ein Jean Floressas Des Esseintes ${ }^{859}$ je hätte rühmen können, und zwar für denjenigen, der es sich leisten kann. Das Geheimnis der Delikatesse ist ihre für die meisten unerreichbare Exotik, ist ihre in Geld gegründete Exklusivität, ist der Nimbus, der sich allererst ihrer Seltenheit verdankt, ist die Distinktion, mit der sie ausschließt oder zurechnet.

Eine Frau betritt das Delikatessengeschäft von Ernst Jandl und trägt ihre Wünsche vor. ${ }^{860}$ Alles, was folgend geschlossen wird, bemisst sich an „Bedeutung und Interesse [von] Kunst einzig für den, der die kulturelle Kompetenz, d.h. den angemessenen Code besitzt"، 861

Mit dem beabsichtigten Einkauf bereitet sie nicht etwa ein exquisites Abendessen vor. Wie selbstverständlich verlangt sie nach ein, zwei ungewöhnlichen Dingen. Der Ort, die Situation, das Verlangte, es ist diese Kombination, die sofort unsere Vorstellungskraft übersteigt. Die Dame sucht nach den Ingredienzien für einen kulinarischen Höhepunkt eigener Art, bei dem das Gekaufte nicht mit dem Munde, sondern mit den Augen verschlungen werden soll: hier finden offenkundig Vorbereitungen für einen gehobenen Augenschmaus statt, oder vielleicht doch nicht?

Man hört den Gesprächspart der Käuferin, der sich nach anfänglich energischer Bestimmtheit nachdenklich verzögert, weil sie unerwartet umdisponieren muss und an die Stelle des ursprünglich geplanten genießenden Betrachtens dann offenbar doch das genießende Verzehren treten soll:

\footnotetext{
859 Protagonist in Joris-Karl Huysmans Roman „Gegen den Strich“ (1884).

${ }^{860}$ Meine nachstehende Deutung weicht, z.T. ganz erheblich, von derjenigen ab, die Ernst Jandl 1974 selbst gegeben hat (siehe Anhang). Fast fünfzig Jahre nach Entstehung des Gedichts, in denen u.a. der Naturverbrauch und die Konsequenzen menschlicher Handlung für das Weltklima als prekär erkannt wurden, sehe ich Jandls Gedicht in einem ganz anderen Kontext als er selbst.

${ }^{861}$ Die vorstehende Fußnote erklärt sich aus und findet ihre Berechtigung in der allgemeinen Position, die Pierre Bourdieu (2010) für die Bedeutung von abbildender Kunst formulierte, an die hier angeschlossen wird und die bereits an den eingangs gezeigten Stillleben demonstriert wurde: „Die Fähigkeit des Sehens bemisst sich am Wissen oder, wenn man möchte, an den Begriffen, an den Wörtern mithin, über die man zur Bezeichnung der sichtbaren Dinge verfügt und die gleichsam Wahrnehmungsprogramme erstellen. Von Bedeutung und Interesse ist Kunst einzig für den, der die kulturelle Kompetenz, d.h. den angemessenen Code besitzt" (S.19, Hervorhebung im Original). Die Essenz der Einsichten Bourdieus ist nicht neu und bereits mutatis mutandis in der 100 Jahre älteren und 600 Seiten kürzeren Abhandlung von Veblen zu lesen. Der Unterschied besteht lediglich darin, dass für Veblen das soziologische Phänomen der „feinen Leute“ rational in ökonomischen Ursachen gesehen wird, für Bourdieu hingegen scheint der Distinktionsgewinn einem narzistischen Selbstzweck zu folgen. Und selbstverständlich ist auch dem soziologischen Klassiker Simmel, der den Umwelthistorikern wegen seines Beitrags zur Landschaftsästhetik (vgl. Smuda) bekannt ist, vieles Grundsätzliche zur Distinktionsfrage zu entnehmen, z.B. dem Aufsatz über „Die Mode“"(1911), ein hier passender Hinweis.
} 


\section{Ernst Jandl (1962) \\ im delikatessenladen}

bitte geben sie mir eine maiwiesenkonserve etwas höher gelegen aber nicht zu abschüssig

so, daß man darauf noch sitzen kann.

nun, dann vielleicht eine schneehalde, tiefgekühlt ohne wintersportler. eine fichte schön beschneit kann dabeisein.

auch nicht. bliebe noch - hasen sehe ich haben sie da hängen. zwei drei werden genügen. und natürlich einen jäger. wo hängen denn die jäger?

Wird es nun, wo die Menüfolge offenkundig eine Änderung erfahren muss, doch bloß Gespickten Hasen und etwa Jägerschnitzel geben?

Jandls Schabernack bereitet vordergründiges Vergnügen. Der Leser begreift sofort, dass die Person, die den Einkauf besorgt, nur eine Frau sein kann. Kein Mann wäre in der Lage, sich so umstandslos flexibel dem kulinarischen Defizit

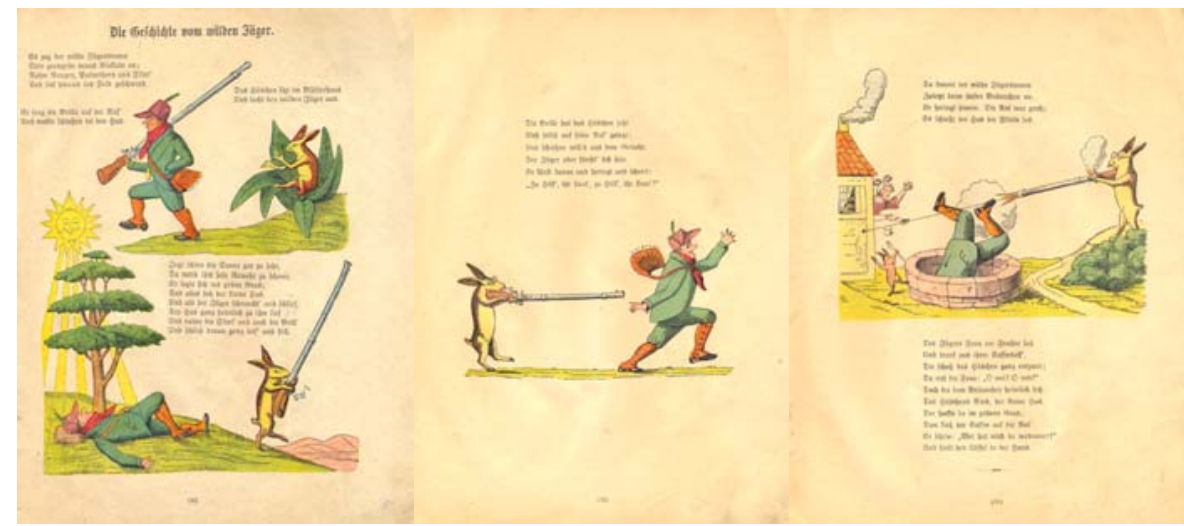

Abb. 3 Heinrich Hoffmann, Die Geschichte vom wilden Jäger

anzupassen und dabei noch so scheinbar arglos nach den Jägern zu fragen. UrRolle und Geschlechterkampf, gut abgehangen als amuse gueule. Der Spaß, eigentlich die Schadenfreude, die sich zum mitfühlenden Bedauern über die toten Hasen gesellt, denkt die Geschichte jenes Meister Lampe aus Dr. Hoffmanns lustigen 
Geschichten und drolligen Bildern endlich einmal bis zu ihrem angemessenen Ende (siehe Abb. 3). 862

Der Gott des Gemetzels entpuppt sich in dem Gedicht als Verwandter des Saturn, der nun selbst verschlungen wird von dem, was er verschlingt. Deshalb hängt der Täter neben seinem Opfer - freilich nur als Prinzip Hoffnung, denn dem Wunsch der Käuferin wird die Bedienung, obwohl das Gedicht hier abbricht, nicht entsprechen.

Jandls Beschreibung der Begebenheit im Delikatessenladen bürstet augenscheinlich allen Vorstellungswillen gegen den Strich. Aber, nur weil eine Maienwiese, vielleicht sogar die Szenerie um Heidis und Peters Maiensäß, nicht in eine Konservendose zu passen scheint, ist die Begebenheit keinesfalls völlig absurd, nicht nur, weil nach René Magritte eine Maienwiese eben nicht immer eine Maienwiese ist. ${ }^{863}$ Vielmehr werden im Gedicht zwei zutiefst problematische Dinge mit einem Mal auf den Punkt gebracht, den wir heute anders als zur Zeit Jandls dechiffrieren:

Es geht um Naturverbrauch, bei dem die Güter aus dem „Warenhaus der Natur" geholt werden, und es geht um Konservierung von Naturparzellen. Und noch ein Drittes gesellt sich dazu, angedeutet in der fragenden Suche nach den abhängenden Jägern.

\section{1 Die Naturkonserve}

Was scheinbar so fröhlich daher kommt, endet in einer bitteren Einsicht, allerdings erst in einem zweiten Anlauf. Vorderhand erscheint der Schmaus, zu dem hier die Zutaten eingekauft werden sollen, als einer, bei dem die Dinge nicht wirklich verzehrt werden und nicht verschwinden und der die Welt scheinbar um keinen Sekundenbruchteil ihrem Ende näher bringen wird. An der Tafel des Augenschmauses haben viele Gäste Platz, nichts wird tranchiert, nichts wird durch bloße Betrachtung verändert, es gibt keinen Verbrauch. Ob zwei Menschen oder Einhundert in „freier genießender Anschauung" 864 auf den Sonnenuntergang schauen, macht keinen Unterschied. Mit der Sprache der Ökonomen kommt es nicht zum „rivalisierenden Konsum“, wie etwa beim Tafelspitz-Essen, wo das Stück Rind, das ein Gast verzehrt, den anderen Gästen unumkehrbar vorenthalten bleiben wird.

Die bloße Betrachtung ist eine Seite, eine zweite aber der Naturverbrauch durch Besitz, der anderen den Zugang vorenthält oder späteren Anschlussnutzen für Dritte durch Störung wie Zerstörung des Ist-Zustandes erschwert oder gar ausschließt.

\footnotetext{
862 Hoffmann, ab 1858,

863 In der Folge von Magrittes’ La trahison des images (« Ceci n’est pas un pipe », 1929) kann eine Maienwiesenkonserve ebenso wenig ein Maienwiese sein, wie die Abbildung einer Pfeife eine Pfeife sein kann.

${ }^{864}$ Ritter, S. 151
} 
Wer eine Maienwiese schätzt, wird sich vermutlich gern auf ihr niederlassen. Dass man Maienwiesen (oder Schneehänge) kaufen kann, wird jeder Immobilienhändler gern bestätigen. Dass sie hier im Delikatessenladen gesucht werden, erscheint als untauglicher Versuch lediglich wegen des nur scheinbar irrigen Ortes, denn tatsächlich wird „Landschaft“, wo sie nicht wirtschaftlich genutzt oder ausgebeutet wird, längst so konsumiert, wie andere Genussmittel konsumiert werden.865 Landschaftliches Pathos ist ein Hauptmotor der Tourismusbranche und ein Imponierinstrument in der Konversation bestimmter Nachmittags- oder Abendgesellschaften.

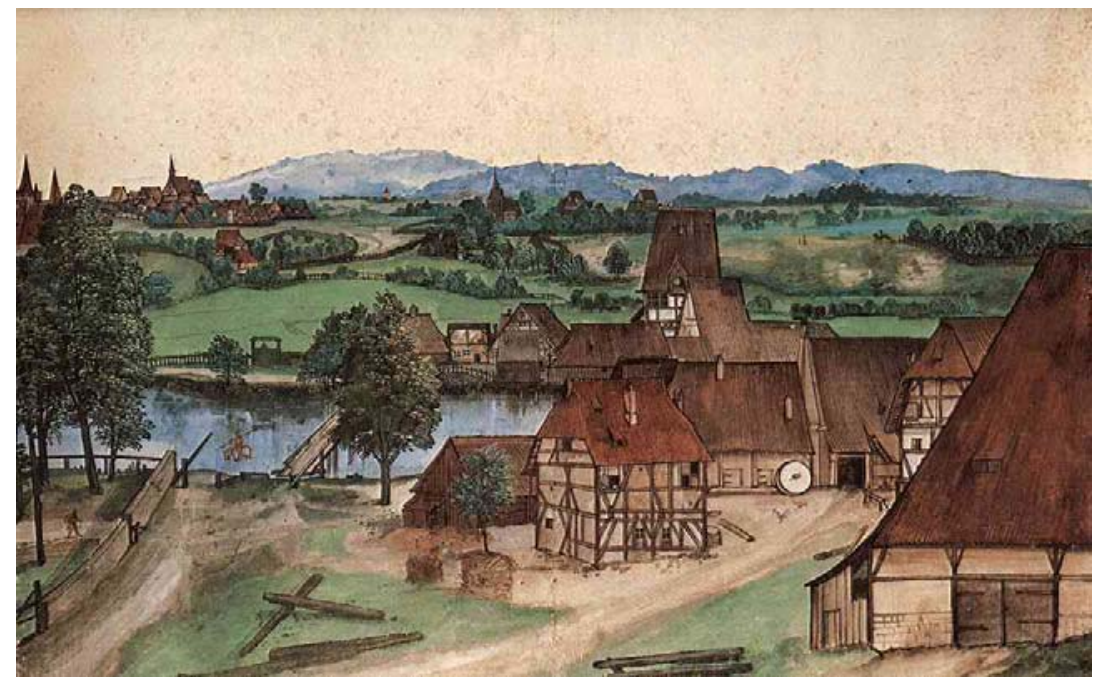

Abb. 4 Albrecht Dürer (1471-1528) Die Drahtziehmühle (an der Pegnitz) ( um 1494; Aquarell und Deckfarben) Kupferstichkabinett Berlin.

Eine der ersten mitteleuropäischen Landschaftskonserven. Es handelt sich um einen Kulturlandschaftstyp, der infolge fehlender Flurbereinigungen bis heute im benachbarten lieblichen Taubertal erhalten blieb.

Für den Unabkömmlichen oder den relativ Unbetuchten bietet der Delikatessenhandel Ausweichmöglichkeiten auf Surrogate für den anderweitig nicht erreichbaren Naturgenuss. Längst hat der technische Fortschritt Möglichkeiten bereitgestellt, Landschaften in Konserven zu füllen, nachdem die ersten Versuche von Albrecht Dürer, Claude Lorrain, Nicolas Poussin und Salvator Rosa ihren Weg auf das Papier, die Tafel und die Leinwand fanden. Nach der Malerei war die techni-

865 "Landschaft“ steht hier auch stellvertretend für „Natur“, und es müsste diese Subtextbedeutung mehr oder weniger durchgängig mitgelesen werden. Im konkreten Zusammenhang ist keine Diagnose wahrer als die Folgende: "Natur wird dadurch, dass der gesellschaftliche Herrschaftsmechanismus sie als heilsamen Gegensatz zur Gesellschaft erfasst, in die unheilbare gerade hineingezogen und verschachert." (Horkheimer/Adorno, S. 157) 
sche Konserve der Landschaft die Fotografie, ${ }^{866}$ heute ist es der Film, ist es die DVD. ${ }^{867}$ Der Genuss einer schönen Landschaft wird damit überall verfügbar. ${ }^{868}$

Selbstverständlich wird niemand von der Landschaftskonserve ähnlich beeindruckt wie es noch eine gute Kopie eines Kunstwerks vermag. Hierin weicht das konservierte „Naturschöne“ vom konservierten „Kunstschönen“ grundsätzlich ab. ${ }^{869}$ Der Konservenlandschaft fehlt die sinnliche Erfahrung, welche eine bewegte Luft auf der Haut hinterlässt, fehlt der Geruch der Pflanzen, die Geräusche der Tiere, womöglich das Gemurmel einer Quelle, die wechselnde Lichtintensität, fehlt der Nieselregen. Die Konserve vermittelt mir die Vorstellung der Wirklichkeit, vermittelt aber nicht die Wirklichkeit selbst. ${ }^{870}$ Ähnlich dem entscheidenden Unterschied, den Walter Benjamin für „Das Kunstwerk im Zeitalter seiner technischen Reproduzierbarkeit“ mit dem Mangel an „Aura“ benannte, die in Authentizität und Tradition verborgen wären, fehlt der Landschaftskonserve die aus der Erfahrung des in ihr anwesenden Menschen resultierende gesamtsinnliche Authentizität. Auch diese ist über die kollektive Schulung der Augen und anderer Sinne an den Naturdingen in einem Konstrukt der Konvention mit der Tradition verbunden. ${ }^{871}$

Anders als das vervielfältigte Kunstschöne, dem praktisch alle materiellen Eigenschaften des Originals zu eigen sind und bleiben, rangiert das konservierte $\mathrm{Na}$ turschöne von vornherein hoffnungslos hinter seiner Vorlage. Aber die Naturkonserve hat mit dem Datum ihres Entstehens der Vorlage gegenüber immer voraus, dass sie bewahrt, und am Tage ihrer „Öffnung“ im Vergleich mit dem heutigen Zustand des Originals das Ausmaß zwischenzeitlich unweigerlich eingetretener Veränderung dokumentiert. Die mediale Konserve ist, anders als das reproduzierte

866 In großartiger Meisterschaft ehedem vorgeführt von Georg Gerster. Neuerdings finden die Luftaufnahmen von Alex S. MacLean viel Beifall, ohne die älteren Aufnahmen Gersters oder die von Ansel Adams zu übertreffen, der allerdings keine Luftbildaufnahmen wie die beiden erstgenannten anfertigte.

867 Z.B. die Weltseller „Die Erde von oben“ oder „Home“ des Fotografen Yann Arthus-Bertrand.

868 Letztlich ist auch das Sonnenstudio (ugs. "Münzmalle“: als Mallorca-Ersatz) eine kleinstmögliche Variante des Landschaftssurrogats. Die Palette dieser inhaltlich und hinsichtlich der an sie gerichteten Ansprüche extrem reduzierten Ersatzlandschaften wird hier nicht weiter verfolgt.

${ }^{869}$ siehe weiter unten

870 „Das Bild bildet die Wirklichkeit ab, indem es eine Möglichkeit des Bestehens und Nichtbestehens von Sachverhalten darstellt“ (Satz 2.201) und „Aus dem Bild allein ist nicht zu erkennen, ob es wahr oder falsch ist." (Satz 2.224), Wittgenstein.

871 „Die Landschaft trägt [...] nicht nur eine ,von Menschen gestaltete Physiognomie’, wir sehen sie auch ,mit durch die Kunst erzogenen Augen.' Malerei und Literatur haben die Landschaft für uns so eingerichtet, dass wir sie nach deren Bildern wahrnehmen. Das ging bereits dem jungen Friedrich Hebbel so: 'Ich glaube oft, schon etwas gesehen zu haben, was ich erweislich zum erstenmal sehe, namentlich Landschaften.' - Man kann dieselbe Beobachtung erstmals in der Breite im 18. Jahrhundert, dem großen Jahrhundert der Reisen, in England und auf dem Kontinent machen. Wohin die Reise auch ging, stets sprang den Landschaftsenthusiasten das Bild eines Meisters aus der Natur entgegen - eine ,schöne', ,reizende', ,malerische', ,erhabene', ,pittoreske' oder ,romantische' Landschaft, wie sie ein Lorrain, Poussin oder Salvator Rosa gemalt hatten. Die Namen dieses Dreigestirns waren Chiffren für drei Landschaftstypen und die durch sie erzeugten Stimmungen. Claude Lorrain stand für ,zarte Schönheit' und das ,Heiter-Ideale', Nicolas Poussin für ,erhabene Größe' und das ,Klassisch-Heroische', Salvator Rosa für ,gebannten Schrecken' und das ,Wild-Romantische“" (Fischer, S. 88). 
Kunstwerk, das sich vom Original auch nach langer Zeit kaum unterscheiden wird, die einzige Möglichkeit einer wenigstens teilweise beobachtbaren und von mehreren Menschen teilbaren Erinnerung an einen ehemaligen Naturzustand.

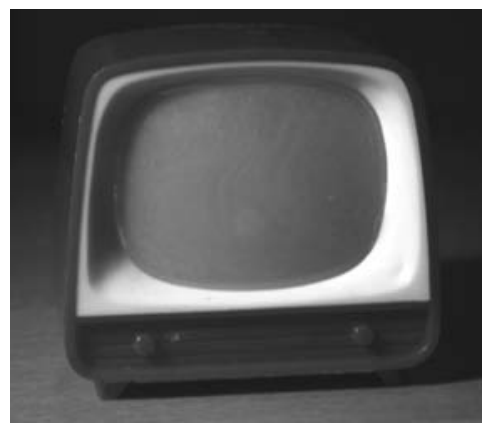

Abb. 5 Eine „Naturkonserve“ eigener Art bilden Guckkästen mit Landschaftsaufnahmen, die der Käufer so oder ähnlich anstelle von Postkarten wohl noch immer im Andenkenhandel erwerben kann. Im Innern befindet sich eine Scheibe mit 8 transparenten Landschaftsminiaturen. (Objektbasis: 5 $\mathrm{cm})$

Darin besteht ihr Wert, der sich auch unter dem wiederholten „Öffnen“ der Konserve in Form der wiederholten Vorführung ihres Inhalts nicht abnutzt. Der Augenschmaus wird zwar auf ein zweidimensionales Erlebnis reduziert, vielleicht ergänzt um eine Tonaufnahme, dem aber mindestens drei sinnliche, ${ }^{872}$ sowie eine räumliche und eine zeitliche Qualität fehlen. Aber selbst dieser folienhafte Abzug der Wirklichkeit ist wertvoller als die bloßen Erzählungen sich unsicher Erinnernder.

Vor jedem Landschaftsverbrauch aus menschlicher Ursache führt der ewige Wechsel der Jahreszeiten in ökologischer Zeit zum Verlust von Maienwiesen und Schneehalden. Es ist der ewige Kreislauf der Jahreszeiten, der aus Maienwiesen Schneehalden macht und aus Schneehalden manchmal Maienwiesen. Am Ende, wenn aus der ökologischen Zeit die geologische geworden ist, wird es keine Maienwiese mehr geben, vielleicht auch keine Schneehalde mehr. Das Beständige in der Natur ist der Wandel. Nicht nur, weil unsere Wahrnehmung nicht über unsere Lebensspanne hinausreicht, macht sich unsere Zukunftsvorstellung notwendig am Vergangenen fest. Die Wahrnehmung blendet in der Regel die Ungewissheit der Zukunft aus und beharrt auf der Konstanz des Gegenwärtigen. Auch „Natur“ solle sich als konstant erweisen, etwa unter der „Linde am Brunnen vor dem Tore,“ die ein deutsches Volkslied beschwört, ohne zur Kenntnis zu nehmen, dass Brunnen und Linde längst dem Parkplatz des Baumarktes im Weichgürtel der Zwischenstadt zum Opfer fielen. Das Beharren auf dem biedermeierlichen Topos bezieht sich letztlich auf eine spezifische Ästhetik, die in unserer Kultur aus der belehrten wie gelehrten Betrachtung von „Landschaft“ und den diversen physikotheologischen Zugängen $^{873}$ zum populären Konstrukt des „Naturschönen“ führte: „Schön ist an

${ }^{872}$ Es fehlen die geruchlichen, geschmacklichen und getasteten Eindrücke.

873 Michel 
der Natur, was als mehr erscheint, denn was es buchstäblich an Ort und Stelle ist.“ (Adorno, S. 111) Diese Bedeutung der Naturbetrachtung, ihre katalytische Rolle für die Ich-Erfahrung, für emotionale Selbststabilisierung und als Anknüpfungspunkt für Rückgriffe auf transzendente Mächte ist in unserer Kultur zutiefst verankert. Sie führt letztlich auch in die naive Vorstellung, dass der Besitz von Naturschönem, ${ }^{874}$ und sei es aus dem Delikatessenladen, existentielle Sicherung bedeutet.

\section{2. Die konservierte Natur}

Ob Maienwiese oder Schneehalde, beide sind ephemere, jährlich wiederkehrende Zustandsbilder naturaler Abläufe. Sie zu konservieren, kann ganz unterschiedliche Gründe haben. Wer sich biographisch immer weiter aus dem rhythmischen Wechsel saisonaler Erscheinungen in der Natur entfernt, weil die Kunstwelt der gerontologischen Aufbewahrungsanstalten einen klimatischen Dauerzustand in den Farben Beige und Graubraun erschafft, kann sich über die Betrachtung einer Winterlandschaft vielleicht noch daran erinnern, dass es „draußen“ Temperaturschwankungen gibt, dass die Maienwiese eben nur im Mai blühen und im Juni dort andere Blumen erscheinen, während sich die aus Seide gefertigten Mohnblüten im Aufenthaltsraum jahrelang und unverändert in ihrer immergleichen, verlogenen Vitalität präsentieren.

Im allgemeinen Bewußtsein kommt diese Konservennutzung nicht vor. Möglich, dass sie überhaupt nicht vorkommt. Die öffentliche Handlungsoption kreist vielmehr um die Idee einer Natur, die mit ihrer eigenen Konserve identisch ist und auf diese Weise zum Gegenstand der Verfügung wird. Die Bemühungen, „Natur“ zu erhalten, führen in vielfältiger Weise zu einem im wahrsten Sinne konservierenden, ja konservativen Naturverständnis. Da erhält die schutzwürdige Parzelle den Auftrag, sich nicht zu verändern, stille zu stehen, die Abläufe des NormalProzesshaften einzustellen. So, wie die Großmutter die Lüneburger Heide kannte, so kennen sie die Enkel. Kein Sandkorn darf sich um der Erhaltung von Natur

874 Die Verbindung von Naturschönen und seiner transzendenten Bedeutung für den Betrachter hat Adorno gleich eingangs seines „Verdiktes über das Naturschöne“ betont (S. 98): „Der Begriff des Naturschönen rührt an eine Wunde, und wenig fehlt, dass man sie mit der Gewalt zusammendenkt, die das Kunstwerk, reines Artefakt, dem Naturschönen schlägt. Ganz und gar vom Menschen gemacht, steht es seinem Anschein nach nicht Gemachtem, der Natur, gegenüber. Als pure Antithesen aber sind beide aufeinander verwiese: Natur auf die Erfahrung einer vermittelten, vergegenständlichten Welt, das Kunstwerk auf Natur, den vermittelten Statthalter von Unmittelbarkeit. Darum ist die Besinnung über das Naturschöne der Kunsttheorie unabdingbar. Während paradox genug Betrachtungen darüber, beinahe die Thematik an sich, zopfig, ledern, antiquiert wirken, versperrt große Kunst samt ihrer Auslegung, indem sie sich einverleibt, was die ältere Ästhetik der Natur zusprach, die Besinnung auf das, was jenseits der ästhetischen Immanenz seine Stätte hat und gleichwobl in diese als ibre Bedingung fällt." (Hervorhebung B.H.) Gemeint sind hier vermutlich Rezeptionsverständnisse nach physikotheologischen, nach panpsychistischen oder idolatrischen Grundmustern. Werden solche Rezeptionsweisen aus der Naturbetrachtung entfernt, wechselt diese aus der ästhetischen Sphäre in den Bereich der bloßen positivistischen Existenzerfahrung und - beschreibung. „Die Natur“" würde damit reduziert auf Dinge der Umgebung, die außer der Tatsache ihrer Existenz keine weitere Bedeutung haben. Damit würde auch der Erwerb einer Maienwiese ein sinnfreies Unterfangen. 
Willen bewegen. Alles hält den Atem an, wird auf dem status quo eingefroren. Und wenn der status quo nicht dem normativen Verständnis des konservativen Naturschutzes entspricht, wird zuerst der status quo ante hergestellt. Und dann wird eingefroren. Der Vorgang heißt dann z.B. „Landschaftspflege“.

Wer eine Maienwiesenkonserve oder eine Schneehaldenkonserve um ihrer selbst Willen kauft, offenbart eine konservative Vorliebe und Vorstellung von $\mathrm{Na}$ tur nach dem Muster der Vor-Darwin-Zeit. Einer Natur, in der die Dinge scheinbar von Anbeginn so waren, wie sie vor uns liegen. Einer Natur, in der auch die Kenntnis über das Ausmaß von „Gemachtem“, von anthropogenen Anteilen, völlig fehlt. Einer Natur, in welcher der paradiesische Mythos des ewigen Gleichstandes herrschen soll.

Dies ist eine Überforderung jeglicher realen Natur, die uns als Ökosystem oder eine ihrer Komponenten entgegen tritt, weil diese möglicherweise für den Zeitraum einer menschlichen Wahrnehmung „stabil“ bleiben können, aber darüber hinaus muss eine solche Stabilität durch investierte Arbeit erhalten werden. Da ist dann ständig die Schafherde über die Magerwiese zu treiben, der Wald auszulichten, die Lüneburger Heide mit Pestiziden, Maschineneinsatz und Tierproduktion auf Postkartenformat zu halten. Diese Vorstellung von konservierter Natur führt zwangsläufig in eine musealisierte Natur. Nirgends ist die Natur besser musealisiert als in der Konserve. Die heißt vielleicht „Naturschutzgebiet“ ${ }^{\text {“ }}$ " oder „Naturkundemuseum", oder hat einen anderen Namen, in dem alle möglichen Filiationen von „Natur“ auftauchen. Ein Delikatessenladen erscheint da nur als eine unwissenschaftliche, profanisierte, kulturell abgesunkene Variante für konservativen Naturgenuss, in der die Dinge zum Verkauf stehen und die damit ihr Eigeninteresse ungehindert zur Schau stellt. ${ }^{876}$ Ein „Natur“- Museum, das dagegen die Veränderung thematisierte, die doch das entscheidende Merkmal alles Lebendigen ist, würde in Widerspruch zu seinem eigenen Inhalt geraten müssen.

Jandl führt uns nach Art einer erlebten Verkennung vor Augen, dass der Delikatessenladen die konservative Bewahranstalt nicht nur jenes Keksduftes der Erinnerung ist, er ist es auch für die Erinnerung an Naturgenüsse, die wir aufsuchen, um uns dem Sog der natürlichen Veränderung zu entziehen, uns zu entschleunigen und zu erinnern. ${ }^{877}$ Wie in der antiken Tragödie entrinnt der Mensch in der Natur und als Teil dieser dem Schicksal der unaufhaltsamen Veränderung aber nicht. Die

875 Definitionsbestandteil des „Naturschutzgebietes“ im deutschsprachigen Raum ist „Schönheit“ und „Einzigartigkeit“, womit u.a. auch die Ensemblewirkung gemeint ist. Existieren etwa für die subjektiven Begriffe „Schönheit“ und „Einzigartigkeit“ normative Setzungen? Wandeln sich „Schönheit" und „Einzigartigkeit" etwa nicht in den Zeitläuften?

876 Es bieten sich hier kulturtheoretische Überlegungen an, ob, wann und wo Naturgenuss die Grenze überschreitet, die gewöhnlicher weise zwischen der Freiwilligkeit und der Prostitution gezogen wird. Was zunächst wegen des dieser Diagnose zugrunde liegenden naturalistischen Fehlschlusses nicht erörterungswürdig erscheint, wird es spätestens dann, wenn unsere Vorstellung der „Natur“ einen Metagehalt zuschreibt. Während dieser Gedanke, dem nachzugehen sicher lohnend wäre, hier nicht weiter verfolgt wird, erhält die Prostitutionsmetapher im zweiten Teil des Aufsatzes noch einmal Aufmerksamkeit.

877 Herrmann \& Schutkowski; Sebba 
Stunde verrinnt, das Leben geht weiter, es entgleitet und lässt zurück. Der Versuch sich „biophil“" zu gebärden, zu „,bewahren“, ist ein hilfloses Aufbäumen gegen die unabänderliche Tatsache der Veränderung in der irrigen Annahme, wonach das Bios beständig wäre. „Nachhaltigkeit“ erscheint da auch als Hoffnung, den gegenwärtigen Zustand durch Verstetigung dem Einfluss der unausweichlichen Veränderung zu entziehen. Dabei ist „Nachhaltigkeit“ als Konzept in der Natur unbekannt. Sie ist eine gesellschaftliche Vorstellung, wonach durch eine bestimmte Managementpraxis eine lang anhaltende Nutzung natürlicher Populationen oder anderer Ressourcen ohne deren Erschöpfung und ohne Einschränkungen auf der Nutzerseite möglich sei. Damit ist sie eine gesellschaftliche Utopie, die von unhintergehbaren Eigenschaften des betroffenen Naturgutes keine Kenntnis nimmt. ${ }^{878}$

Die Delikatessenabteilung im Warenhaus der Natur bedient in Wahrheit auch (oder ausschließlich?) Bedürfnisse des in seinem Verhältnis zur Natur mehrfach narzistisch gekränkten neuzeitlichen Menschen (Freud), in dem Delikatessen als Kompensationsangebote vorgehalten werden, die über die Kränkungen hinwegtrösten oder hinwegmogeln sollen:

o die erste Kränkung verdanke er Kopernikus, der nachwies, dass die Erde nicht der Mittelpunkt des Weltalls ist,

o die zweite Kränkung verdanke er Darwin, der nachwies, dass der Mensch nicht das Produkt einer kreationistischen Leistung ist,

o die dritte Kränkung verdanke er der Psychoanalyse, in deren Vermögen es liege, dem Bewußtsein erwachsener Menschen die unangenehme Einsicht vermitteln zu können, dass sein Anspruch auf Geborgenheit und Versorgung, auf Zuneigung durch einen anderen Menschen, auf Halt in Einrichtungen und Institutionen, infantil und illusorisch ist.

Alle drei Kränkungen lassen sich in umwelthistorische Erwägungen einbeziehen. ${ }^{879}$ $\mathrm{Zu}$ den Konsequenzen der dritten Kränkungen gehört ein allmähliches Erschre-

\footnotetext{
878 Die offenkundige Stabilität von Ökosystemen über sehr lange Zeiträume, z.B. die cyclische Sukzession in der afrikanische Gras-Baum-Steppe, ist als emergentes Phänomen des zufälligen Zusammenspiels vieler kleinskaliger Systemelemente zu begreifen, die auf der Skala des einzelnen Baums völlig vorhersagefrei abläuft (Gillson). Aus ihnen ist nicht abzuleiten, dass „Nachhaltigkeit“ ein natürliches Prinzip wäre. Nicht einmal „Stabilität“ kann einem Ökosystem als angestrebtem Zustand zugeschrieben werden, weil die naturalen Abläufe der „Natur“ (hier der organismischen Evolution) nicht zielsuchend sind (Mayr) und weder Ökosysteme noch „Natur“ als selbstständig handelnde Akteure anzusehen sind.

879 Diese Behauptung kann selbstverständlich nur für jene Menschen gelten, die von den kopernikanischen, darwinschen und freudschen Erklärungsmodellen betroffen sind, also den westlichen Kulturmenschen. Vier Jahrhunderte nach Kopernikus wird aber kaum noch jemand an dem von ihm entworfenen Weltbild verzweifeln. Hundertfünfzig Jahr nach Darwin waren dagegen zu einer allgemeinen Beruhigung nicht ganz ausreichend, wie u.a. der Blick auf den amerikanischen bible belt und dort tätige Kreationisten zeigt. In den fünfzig Jahren nach Freud selbst sind seine Hypothesen und Theorien noch nicht einmal allgemein rezipiert. In summa gilt auch den narzistischen Kränkungen gegenüber, die Freud ausgemacht hatte, die Gnade der späten Geburt. Dagegen ist die hier so bezeichnete vierte Kränkung (weiter unten) aktuell und bestimmend, bis hinein in Entscheidungen von weltpolitischer Bedeutung.
} 
cken darüber, dass Folgen und Nebenfolgen menschlichen Handelns den in „,prästabilierter Harmonie“" begriffenen Zustand der Welt zu destabilisieren in der Lage ist. Damit wird eine vierte Kränkung 880 unausweichlich:

\section{o das „W arenhaus Natur" wird sich künftig dem größeren Teil der Menschheit verweigern.}

Eine weltweite Konsumgesellschaft auf der Basis desjenigen Naturverbrauchs, wie er der euro-amerikanischen Zivilisation zugrunde liegt, wird es nicht geben können. Die narzistische Kränkung derjenigen, die von der Partizipation ausgeschlossen werden, weil sie ein entsprechendes Niveau noch nicht erreicht hatten, und derjenigen, denen der Abbau erreichter Konsumhöhe abverlangt wird, hat ein hohes Bedrohungspotential für gesellschaftliche Stabilität. Vladimir Majakowski konnte noch dichten:

Haselhühner schlemme, friss das Ananas, dein letzter Tag wird kommen, Bourgeois! 881

und unter der Chiffre der Delikatessen gesellschaftskritischen Agitprop betreiben, in der Hoffnung auf spätere Haselhühner und Ananas für alle. Anders aber als Majakowski dachte, wurde die Erreichbarkeit der Ananas bereits mit den Konserven des kapitalistischen Unternehmens Del Monte möglich. Freilich ist diese Erreichbarkeit nicht mit derjenigen Vergesellschaftung der Ressourcen und Produktionsmittel zu verwechseln, die nicht nur den Sowjetdichtern erstrebenswert schien. Denn es werden heute nur die Folgekosten der Ananasproduktion (o.̈.) vergesellschaftet, die Gewinne hingegen bekanntermaßen privatisiert. Erst wenn die heutigen Preise durch solche ersetzt sein werden, in denen die ökologischen Kosten nicht länger externalisiert sind und auf Allgemeinheit und Nachwelt abgewälzt werden, werden sie vor dem Konzept der „Nachhaltigkeit“, das in Wahrheit bisher immer nur Besitzstand und die Verstetigung des herrschenden kulturellen Niveaus meint, Bestand haben. Die potenzierte Ironie des Majakowskischen Kampfrufs besteht dann allerdings darin, dass tatsächlich die Bourgeoisie untergehen wird, wenn Haselhuhn und Ananas für Alle zur Verfügung stehen sollen. Neben dem Bourgois wird allerdings auch der Klassenkämpfer untergehen, weil eben Alle wegen der allgemeinen Ressourcenerschöpfung zugrunde gehen werden.

\footnotetext{
880 Da es weitere Anwartschaften auf die Position 4 unter den Kränkungen gibt (z.B. Braungart), ist meine Zählung lediglich als Fortsetzung der Reihe, nicht als Anspruch zu verstehen. Ich danke Ulrike Kruse für den Hinweis.

881 Ешь ананасы, рябчиков жуй, день твой последний приходит, буржуй (1917). Haselhühner und die im zaristischen Gewächshaus teuer erzeugte Ananas sind hier zunächst nur Chiffren einer Sozial- und Gesellschaftskritik, noch nicht des Naturverbrauchs.
} 


\section{Hase und Jäger}

Im Delikatessenladen von Ernst Jandl scheinen Jäger wie Hasen nebeneinander zu hängen. Während der Weg der Hasen in den Laden bekannt ist, kann Gleiches für die Jäger nicht behauptet werden. Ebenso, wie die Landschaftskonserven in Jandls Gedicht Metaphern für den Naturverbrauch und das Raisonnement über ihn sind, ebenso sind auch die abhängenden Jäger nur traurige Tropen. Sie sind gewendete Metaphern für den Akteur, der Unglück und Tod über die Hasen bringt. Der Jäger repräsentiert eine Ureigenschaft menschlicher Naturaneignung (sammeln, jagen) vor jeder produzierenden Ökonomie. ${ }^{882}$ Hier geht es also um ein urgrundsätzliches Verhältnis zwischen dem Menschen und dem Hasen, hinter dem der pars-pro-toto-Gedanke erkennbar ist: der Hase repräsentiert die Natur, die unter der Gewalt des Menschen leidet.

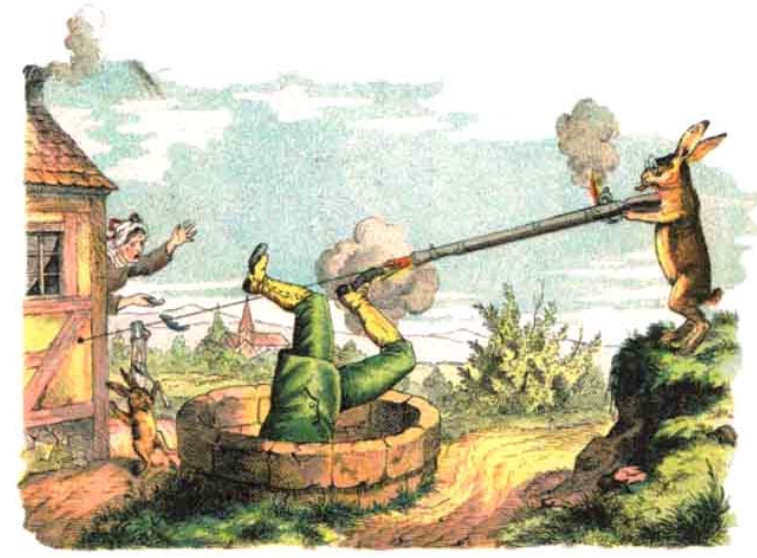

Abb. 6 Der Hase schießt auf den Jäger

Die „Geschichte von wilden Jäger“ im „Struwwelpeter“ kehrt die Verhältnisse drastisch um: hier wird der Jäger zum Gejagten, der Verfolgte zum Verfolger, der Starke wird schwach, der Schwache wird stark. In der Vorstellung einer verkehrten Welt wird die Wunschvorstellung der Ohnmächtigen nach Rache am Mächtigen, am Peiniger, am Ausbeuter für den Augenblick der bildlichen Vergegenwärtigung Realität. Das Opfer wendet sich gegen den Täter, wobei der Jäger im Struwwelpeter Glück hat: der Hase schießt sicher nicht aufihn, sondern nur in seine Richtung. Die Geschichte selbst hatte sich aus einem harmlosen Streich des übermütigen Hasen entwickelt (siehe die Eingangs-Abbildung, in welcher der Hase dem Jäger eine lange Nase dreht). Körperlichen Schaden erleidet am Ende sogar allein nur das Hasenkind, das als Nebenfolge des Geschehens eine Brandblase auf der Na-

${ }^{882}$ Die Ökonomie ist das Mittel zur Befriedigung der Lebensansprüche des Menschen. Damit ist die Ökonomie die spezifischste Seite der Humanökologie. 
senspitze beklagt. Der Vater wird den Kleinen ziemlich trösten müssen: Übermut (des Vaters) tut selten gut (dem Kinde).

Hoffentlich hat die Geschichte einen eher anderen moralischen Hintergrund oder auch mehrere. Eine Option wäre, dass die Handlung des Hasen den Jäger zum Nachdenken über sein Waidwerk bringt. Was aber, wenn der Hase keinen pädagogischen Zeigefinger am Abzug hätte, sondern einen alttestamentarischen?

\subsection{Der Hase ist Sinnbild der „zurückschlagenden Natur “6}

Die Geschichte vom Hasen und Jäger ist die Geschichte eines von vornherein und immer Unterlegenen, dem ein Augenblick der Überlegenheit geschenkt wird und der diesen Augenblick nutzt. Die im Hasen versinnbildlichte genutzte Natur beschreibt die gängige Naturwahrnehmung: sie ist Gegenstand des dominium terrae. Vermittels seiner technischen Überlegenheit, die er seinem Ingenium verdankt, kann der physisch schwache Mensch die Natur beherrschen, sie in die von ihm beabsichtigten Bahnen lenken. Der weiter oben zitierte Bacon entwarf, auf dieser Sicht aufbauend, sogar ein Bild der Natur, in dem dieser Vorwürfe gemacht werden. Statt in der ihr zugewiesenen ewigen Weise abzulaufen, würde sie zuweilen Fehler machen, wenn ,[die Natur] durch bösartige Ungewöhnlichkeiten eines unbändigen Stoffes und die Gewalt der Hindernisse außer ihren Zustand gestoßen“ werde. ${ }^{883}$

Übersetzt man die Vorstellung Bacons, die wohl auch unsere eigene ist, dann hat man sich einerseits mit bestimmten naturalen Abläufen abzufinden: mit Tag und Nacht, mit Ebbe und Flut, dem Regen womöglich, der Erosion der Alpen, dem Vogelzug, dem Planetenlauf, der Schwerkraft und ähnlichem mehr. Dem steht eine von menschlicher „Kunst und Arbeit gebundene, gestaltete und gleichsam erneuerte Natur gegenüber“. Das ist jede Form genutzter Natur, vom Pflasterstein über das Flugzeug, vom Schlachtvieh und Getreide bis hin zum Mittelmeerstrand: der Rohstoff wird verbessert im Interesse menschlicher Nutzungsmöglichkeit.

Zwischen diesen beiden Naturen stehen offenbar die Fehler. Dabei ist es mindestens absurd, der einen Natur ${ }^{884}$ vorzuhalten, sie würde die in sie gesetzten Erwartungen nicht erfüllen. Wer von Fehlern spricht, hat eine Vorstellung, wie es stattdessen, wie es „richtig“ sein müsste. Bacons Sicht beruht auf der Annahme einer absolut rational-logisch zu durchdringenden Natur. Bacon ahnte nicht, dass

883 Vgl. Fußnote 3 - Bacons Position ist bis auf den heutigen Tag ungebrochen zu finden: „... Denn viele öffentliche Krisen des vergangenen Jahrzehnts - Sars, Schweinegrippe, Aschewolke hängen damit zusammen, dass die Auswüchse der Natur, kombiniert mit dem weltumspannenden Flugverkehr, eine tödliche Gefahr bilden können..." (Aus dem Kommentar von Alfons Kaiser auf der ersten Seite der Frankfurter Allgemeinen Zeitung vom 23.April 2010. Hervorhebung BH). Nota bene: „Auswüchse der Natur“!

884 Unübersehbar teilt hier Bacon die Natur in zwei Reiche: in die unkultivierte Natur und die kultivierte, dazwischen befindet sich die dritte Natur, die der Fehler, wie in einem Limbus: Man weiß nicht recht, was von ihr zu halten ist. 
Erdbeben oder Vulkanausbrüche absolut keine Fehler der Natur waren, sondern lediglich aus mangelnder menschlicher Einsicht in die naturalen Abläufe so klassifiziert wurden. Naturerscheinungen sind feindselig dort, wo sie vom Menschen so belegt werden. Es wäre ein Fehler der Natur, ein Akt ihrer Feindseligkeit, wenn das Hochwasser eine Ernte vernichtete und nicht ein Fehler der Menschen, in dem sie die naturalen Abläufe in ihrem Interessengebiet falsch einschätzten? Bis auf den heutigen Tag ist die Verblüffung darüber groß, dass sich der Fluss bei Hochwasser nicht von der menschlichen Siedlung fernhält. Der Fehler liegt doch nicht wirklich auf Seiten der Natur, wie Bacon und seine Nachfolger meinen, sondern auf der Seite der Wahrnehmung.

Diese Wahrnehmung sieht das dominium terrae gefährdet und erträgt die Demütigung durch den „unbändigen Stoff“ zähneknirschend, wenn dem Ereignis straftheologische Botschaften abgewonnen werden, ${ }^{885}$ anderenfalls reagiert sie mit Entlastungsstrategien. Die Entlastung besteht in der Behauptung, dass Extremereignisse nicht zu kalkulieren wären. Dabei wäre es so einfach: wer nicht in der Flussaue lebt, brauchte das Hochwasser nicht zu kalkulieren, nicht zu fürchten. Er brauchte dann nicht einmal zu wissen, ob das Hochwasser alle 10, alle 100 oder alle 1000 Jahre so hoch ausfällt.

Manchmal scheint „der Mensch“ mit „der Natur“ „in Einklang“ zu leben, jedenfalls dort, wo es aus Sicht „des Menschen“ keine Probleme zu geben scheint bzw. Topoi einer Rückvergoldung bedient werden. ${ }^{886}$ Der tägliche Kampf gegen das

885 Z.B. wird man nach einem zerstörenden Hochwasser selten lesen können, dass die Menschen leichtfertiger Weise im Rückhaltesystem des Flusses gesiedelt hätten oder dort ihren Interessen mit einem Gefährdungsrisiko nachgingen. Es ist auch nichts zu lesen über ingenieurtechnische Fehler, sondern nur etwas über Jahrhundert- oder Jahrtausendhochwasser. Diese sind ja schließlich auch nicht vorauszusehen. Nun gilt als nicht vorhersehbar, was gängige Muster durchbricht, sich nicht an die Regeln hält, was Febler macht. Die „Schuld“ liegt selbstverständlich bei den Fehlern der Natur, ganz so, wie schon Bacon es wusste. - Könnte man Bacon befragen, der an den Folgen des einzigen eigenhändigen Experimentes, das von ihm überliefert ist, verstarb, nachdem er Hühner durch Ausstopfen mit Schnee länger genießbar machen wollte, könnte man also Bacon befragen, wo der Fehler lag, der zu seinem Tod durch Lungenentzündung führte, wen oder was würde er angeben? Läge der Fehler beim Schnee, bei der Kälte, bei der Lunge oder würde er akzeptieren, dass der „Fehler“ in einer von ihm selbst zu verantwortenden Entscheidung lag, sich dem Gefährdungsrisiko von Witterungsunbilden auszusetzen?

886 Der „Einklang mit der Natur“ ist immer ein Kampfbegriff des politischen Streites oder der Klientelpolitik gewesen, z.B.: „Biosphärenreservat - Mensch und Natur im Einklang. Im Nordosten Niedersachsens liegt eine Landschaft mit ganz eigenem Rhythmus. Im weiten Tal der Elbe bestimmt der breite Strom das Bild, prägt mit seinen wechselnden Wasserständen den Naturraum und das Leben der Menschen. Im Herbst und Frühjahr bieten zahlreiche Zugvögel, die dem Flusslauf folgen, ein beeindruckendes Naturschauspiel. [...] Nach der deutschen Wiedervereinigung nutzten die ElbeAnrainerländer die einmalige Chance, mit dem innerdeutschen Grenzfluss von einst ein verbindendes grünes Band zu knüpfen: Sachsen-Anhalt, Brandenburg, Niedersachsen, Mecklenburg-Vorpommern und Schleswig-Holstein beantragten bei der UNESCO die Anerkennung der Stromlandschaft der Mittelelbe als länderübergreifendes Biosphärenreservat.[...] [Der] niedersächsische Teil des Biosphärenreservats [ist] auf der seit 1998 geltenden rahmenrechtlichen Grundlage des $\ 25$ des Bundesnaturschutzgesetzes [seit November 2002] auch förmlich als Biosphärenreservat aus[gewiesen]. [...] Mit dem Biosphärenreservatsgesetz wurde der niedersächsischen Mittelelbe ein Schutz zuteil, der in dieser Weise in der Bundesrepublik Deutschland noch an keiner anderen Stelle verwirklicht worden war und 
Unkraut im Garten deutet es aber schon an: „die Natur“ scheint nur zu gern bereit, sich einiges „zurückzuholen“, mitunter wendet sie sich auch ganz offensichtlich „gegen den Menschen“.

In der Summe muss sich „die Natur“ offenbar vom Menschen eher einiges gefallen lassen. Jedenfalls wird gemeinhin verstanden, was die öffentlichen Rede meint, wenn von „,vergewaltigter“ Natur, von „Missbrauch“, „Ausbeutung“, „Zurückdrängung“ u.a.m. die Natur betreffend die Rede ist. Es stehen sich offenbar „der Mensch“ und „die Natur“ in einem Kampf gegenüber. ${ }^{887}$ Täglich scheint der Mensch erfolgreich „die Natur" nicht nur in Schach zu halten. Die eingesetzte Terminologie lässt kaum Zweifel daran, dass die dominium terrae-Metapher anspruchsbewusst und rabiat umgesetzt wird. ${ }^{888}$ Nur manchmal, so der Eindruck, gelingt es der Natur, sich Respekt zu verschaffen, wenn sie sich mit „Gewalt“ und kleinen Erfolgen dem menschlichen Würgegriff zeitweilig entziehen kann. Das ist gewöhnlich der Moment, in dem „die Natur zurückschlägt“. Dabei passiert eigentlich nichts weiter, als dass dem Menschen vorgeführt wird, bis zu welchem Grade er die naturalen Abläufe einzuschätzen, vielmehr nicht einzuschätzen, gelernt hat.

der das Fundament für ein neues Miteinander von Mensch und Natur im Elbetal gelegt hat.“(zitiert aus ttp://www.umwelt.niedersachsen.de/live/live.php?navigation_id=2431\&article_id=8077\&_ psmand $=10$, zuletzt besucht am 17.8.2010; Hervorhebung BH) Woraus das „Fundament für ein neues Miteinander von Mensch und Natur im Elbetal" besteht, erschließt sich weder hier noch an anderer Stelle des Textes. Vielmehr belegt dieser, dass „Mensch und Natur im Einklang“ lediglich eine rhetorische und inhaltsleere Floskel ist, die auf der unreflektierten Anschauung beruht, wonach geringe menschliche Eingriffstiefe einen „Einklang“ dar- oder herstelle bzw. Menschen auf eine eigentliche, auf eine technologie- und anspruchsreduzierte Weise lebten. Diese unsinnige Randbedingung erfüllen auch die Slums in Kalkutta.

887 Unübersehbar wird in solchen Reden der Natur Subjekthaftigkeit unterstellt, woraus archaisches Denken aufscheint. In der platonischen Philosophie (Platon, Timaios; vgl. Bredekamp) erhält die Erde die Seinsform eines lebendigen Wesens, was der älteren Idee der „Mutter Erde“ folgt und ihr Leibeigenschaft verleiht. Von hier leitet sich eine Vorstellung ab, die auch „der Natur“ wesenhafte, leibhafte, subjekthafte Züge zuschreibt. Diese Ideen bilden die Quelle jeder personalisierten Naturvorstellung. Die Vorstellung überlebt offensichtlich das Idolatrieverbot der christlichen Dogmatik. Zeitgenössisch werden solche Vorstellungen durch panpsychistische oder naturreligiös gefärbte Mythen wiederbelebt. - Vorstellungen von Gewalt, die „,der Natur“ angetan würde, bedienen sich bei der Leibmetapher einer analogen Bildhaftigkeit, die selbst vor den Gewaltperversionen des Sexuellen nicht zurückschrecken: Die Natur wird „,vergewaltigt“, „missbraucht“. „Mutter Erde“ muss sich ausbeuterisch ihren Leib „durchwühlen“ lassen und, mit dem was in ihm steckt, menschliche Gier befriedigen (Niavis). Wenn sie „zurückschlägt“, ist das die Verteidigung eines vergewaltigten, den Leib verkaufenden (sich prostituierenden) Wesens? Die Unangemessenheit der geübten Bildsprache ist offensichtlich. - Der Literaturwissenschaftler Dieter Hensing hat sich mit dieser Thematik am Beispiel eines Stückes von Heiner Müller befasst: „Gegen die anthropozentrische Wesensbestimmung der Geschichte bringt Sasportas [der Protagonist bei Müller, B.H.] mit der revolutionären Bestimmung der elementaren (unvernünftigen) Naturgewalt ein irrationales Modell der subjektlosen KörperRevolte zur Sprache: die sich gegen ihre Verdinglichungen, Versklavungen und Verstümmelungen „rächende“, die „zurückschlagende“ Natur-Landschaft als gedachtes Prinzip der Befreiung.“ (S. 312) Die Überlegung Hensings ist für den Naturdiskurs brauchbar und erhellend.

888 Während dominium terrae eine den christlichen Religionen verbundene Wortbildung ist und auch als spezifisch christlicher Umgang mit Natur angesehen wird, ist doch unübersehbar, dass alle Kulturen Naturnutzung im Rahmen ihrer technologischen Möglichkeiten praktizieren. Erreichen diese technologischen Möglichkeiten eine bestimmte Höhe, ist Naturverbrauch eine Universalie menschlicher Kultur. 
Und dass Folgen und Nebenfolgen menschlicher Handlungsweise für den Menschen selbst nachteilig sein können. 889

Der Begriff der zurückschlagenden Natur verlagert nach einem simplen Entlastungs-Prinzip die Verantwortung weg von der fehleinschätzenden prognostischen Kapazität menschlicher Planungsarbeit und Bedenkenlosigkeit gegenüber den Handlungsfolgen hin auf eine anonyme Naturmacht, auf ein Täterwesen, das sich der menschlichen Regieanweisung entzieht. Die kompensatorische Erhöhung der Deichkrone ist die Antwort auf das Hochwasser, mit der demonstrativ jede Bereitschaft zur friedlichen Koexistenz ausgeschlossen wird. „Die Natur“ soll „im Kampf bezwungen" werden, denn: Der Fluss hat gefälligst im menschengemachten Bett zu bleiben.

889 Hier genügt der Hinweis auf die anthropogenen Ursachen des globalen klimatischen Wandels. 


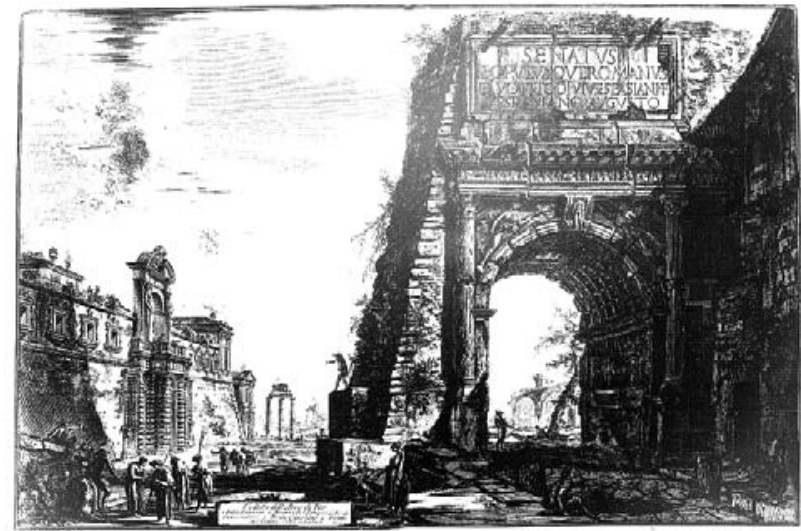

Abb. 7 oben: Piranesis Veduten der antiken römischen Bauwerke (Oben: Titusbogen, 1748) stellen mit ihrem sichtbaren Bewuchs ein frühes Beispiel für Szenerien dar, aus denen sich der Topos der angeblich ,zurückerobernde Natur“ entwickeln konnte. Eindrucksvollere Beispiele liefern mittlerweile alte, überwucherte Großbauten in Kambodscha oder Thailand oder Bauwerke mittelamerikanischer Indianerkulturen. Abb. 7 unten: zeigt eine von Würgefeigen überwucherte Tempelanlage in Koh Ker, Kambodscha (aus: National Geographic, April, 2008).

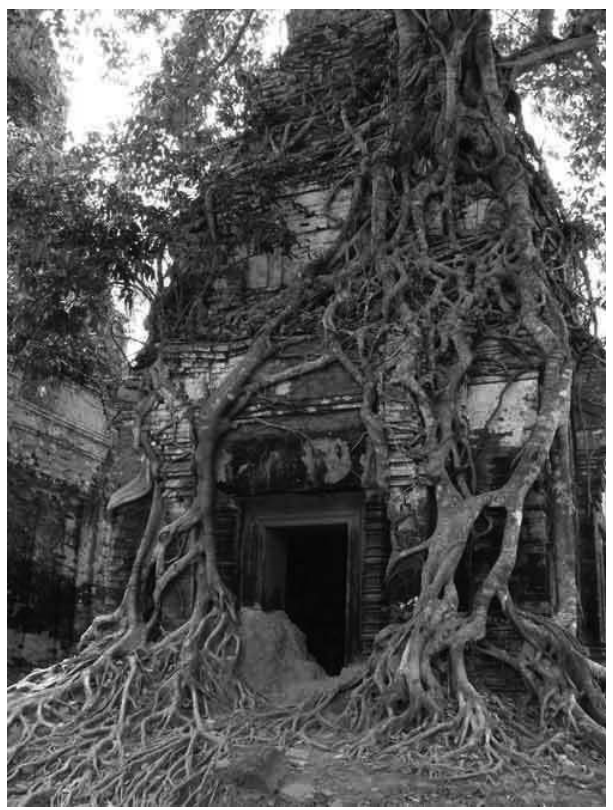


Die „zurückschlagende Natur“ wird gern dort bemüht, wo es um vermeintliche Unvorhersehbarkeit eines Elementarereignisses geht, meist um Hochwasser oder Flutereignisse. Die Printmedien haben die griffige Formel gern und schnell bei der Hand. So „zeigte“ in der Frankfurter Allgemeinen Zeitung am 3.8.2010 (Nr. 177) mal wieder „die Natur ihre Muskeln“ (in einem Bericht über das Elbe-Hochwasser 2002; Seite 31). An diese Vorstufe der Gewaltbereitschaft knüpft dann das brachiale „Zurückschlagen“ an.

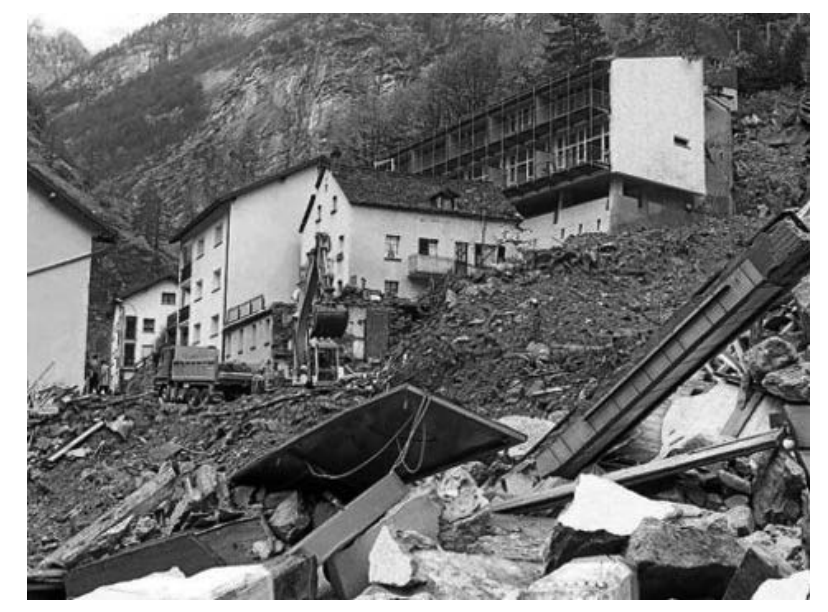

Abb. 8 ,Gräber aus Stein - die Natur schlägt zurück

14. Oktober 2000: Am Schweizer Simplonpass (an der Grenze zu Italien) geht eine Geröll-Lawine mit großer Geschwindigkeit ab. Die Folgen: elf Todesopfer im Dorf Gondo und zwei Verschollene. Die Mure hat ein Volumen von etlichen $10.000 \mathrm{Ku}-$ bikmetern. Genau vier Jahre später wurde das wieder aufgebaute Dorf eingeweiht. Vor der Katastrophe lebten 120 Menschen in Gondo, 2007 nur noch 80.“ (zitiert aus www.merkur-online.de, am 26.01.2010)

Warum in diesem Ereignis die „Natur zurückschlägt“, bleibt unklar. Worin hätte denn der „Angriff bestanden“, der „die Natur“ zum selbstverteidigenden oder rächendem „Zurückschlagen“ veranlasst haben könnte?

Tatsächlich ist auch dieses Beispiel in Wahrheit nichts als ein Beispiel der Fehleinschätzung naturaler Prozesse durch Menschen: der Fehleinschätzung von Erosionsprozessen und Stabilitäten im hängenden Gebirge und der Schwerkraft.

Die bis auf den heutigen Tag wirksame Vorstellung von einer personalisierten, autonom handelnden „Natur“ ist offenkundig. Sie beruht auch auf der alläglich vermeintlich in nämlicher Weise erfahrenen grundsätzlichen Differenz zwischen dem Bereich „der Natur“ und dem Bereich „der Kultur“, wobei diese erfahrene Differenz nicht Ergebnis eines analytischen Prozesses ist, sondern einer bloßen, alltagsentlastenden Spontanqualifizierung (vgl. auch die andere Lesart in Fußnote 41). 


\section{2 „Natur und Mensch“}

Eine Rede von Mensch und Natur, die einander gegenüberstünden, wäre nur möglich, wenn ihr zugleich die Annahme zugrunde gelegt wird, dass „Natur“ und „Mensch“ zwei gleichartige Kategorien bildeten oder in zwei gleichartigen Kategorien verortet wären. ${ }^{890}$ Diese Annahme ist erkennbar ein klassischer Kategorienfehler i.S. von Gilbert Ryle (1969), und zwar einer, der durchaus dem Kategorienproblem „Geist und Körper“ von Descartes äquivalent ist. Ohne weiter auf dieses für die Konzeption der Umweltgeschichte eminente Problem einzugehen, genügt hier, das Begriffspaar „Mensch“ und „Natur“ als Scheinopposition zu entlarven. Während „Mann und Frau“, „rechts und links“, „Tag und Nacht“ usw. zwar kulturelle Muster sind, die aber auf überkulturellen kategorialen Vorgaben beruhen, handelt es sich bei „Mensch und Natur“ um eine Bezugskonstruktion anderer Art. Selbstverständlich ist „Mensch“ enkaptisch in der Kategorie „Natur“ enthalten, und zwar in jeder nur denkbaren Weise. Selbst die Betonung der kulturellen Leistungen des Menschen kann weder die Naturbedingtheit dieser Leistungen selbst noch die Eigengesetzlichkeiten naturaler Prinzipien überwinden und damit eine logische Trennung von Natur und Mensch begründen. Den emergenten Phänomenen menschlicher Leistung, die sich scheinbar oder tatsächlich über alle Naturgesetzlichkeiten erheben können, sind mit den Möglichkeiten der materiellen Eigenschaften, denen sich jede Form menschlicher Existenz und Lebensäußerung verdankt, ihre absoluten Grenzen gesetzt. Dabei ist das logische Problem klein: „Natur“ wird

\footnotetext{
${ }^{890}$ Das alltagspraktisch konstruierte „Gegenüber“ von „Natur“ und „Kultur“ ist so wirkmächtig, dass ausgeschlossen erscheint, dass beide in einem anderen als oppositionellen Verhältnis zueinander stünden. Dieser Alltagsgebrauch verdeckt, dass „Natur“ und „Kultur“ derselben Kategoriengruppe angehören und als solche nicht gleichzeitig zueinander in Opposition gesetzt werden können. Siehe weiter im Text. - Gabriele Dürbeck hat in der Diskussion die berechtigte Frage aufgeworfen, ,warum man nicht davon sprechen können sollte, dass der Mensch (auch wenn er selbst eine physische Seite bat) sich in ganz verscbiedenen Weisen zu seiner Umwelt ins Verbältnis setzen kann; es ist dann i.E. ₹u bestimmen, was als, Umwelt und was davon als, Natur' bezeichnet wird. "- Fraglos ist dies möglich und unzweifelhaft auch alltagspraktische Realität. Ich plädiere ja in nämlicher Weise für relationale Umwelt-Umgebung-NaturBenennungen. Die Differenz ergibt sich gegebenenfalls aus der wissenschaftssystematischen bzw. epistemologischen Grundlage, auf die diese Relationen bezogen sind: auf die Konstruktion einer „Natur-Kultur-Opposition“ oder auf die erkenntnismäßige Ausdifferenzierung des menschlichen Erlebnisgehaltes unter einer Wahrnehmung und davon abgeleiteter Umwelt-Systematik. Das bloße Vertrauen auf posthumanistische Standpunkte würde hier nicht ausreichen, weil der Posthumanismus ja keine Aussage zu den Kategorien macht, sondern lediglich eine herausgehobene Stellung des Menschen bestreitet. Herausgehoben-Sein oder Eingeschlossen-Sein des Menschen berührt jedoch nicht die Frage der Natur-Kultur-Dichotomie sondern zunächst nur eine hierarchische Ebene.

Im Beitrag von Alexander Starre zu diesem Band wird dieselbe Frage ebenfalls behandelt, wobei der Ecocriticism, soweit ich verstanden habe, ebenfalls zu dem Ergebnis kommt, dass die Natur-KulturOpposition obsolet ist (vgl. das von Starre angeführte Zitate von Buell, S. 22-23). Alexander Starre verdanke ich darüber hinaus den Hinweis, dass Dana Phillips den zur Zeit ergiebigsten Überblick über Naturverständnisse liefert, die im Ecocriticism favorisiert werden. Gleichzeitig ist es verblüffend, dass im anderen Standwerk des Ecocriticism, dem von Greg Garrard, die Kapitelüberschriften geradezu wie einem Lehrbuch der Humanökologie oder einem der Umweltgeschichte entnommen erscheinen: pollution, wilderness, apocalypse, dwelling, animals, the earth.
} 
ausschließlich durch Wahrnehmung erfahren. Die Grundlage ihrer Wahrnehmung ist „Kultur“, und nicht unser bloßer sensorischer Apparat. „Kultur“ ist die hinreichende Bedingung der Wahrnehmung von Natur. Als ihre Bedingung kann sie der Natur nicht als gleichwertige Kategorie gegenüber gestellt werden. ${ }^{891}$

Wie immer auch: Die Rede von „Mensch und Natur“ tut so, als seien beide nach der derselben Art souverän handelnde Akteure, nach der Art, wie die Menschen sich erfahren, wenn sie sich unter dem Versuch objektivierender Betrachtung beobachten. Das Grundmissverständnis der Begriffsschöpfung „Mensch und Natur“ beruht darauf, dass der sich kultürlich definierende und erfahrende Mensch glaubt, in der Natur einem „objektiv“ verfassten Subjekt gegenüber zu stehen. ${ }^{892}$ Adorno (Fußnote 26) hatte bereits auf die Scheinbarkeit der Natur verwiesen, die nur ihrem Anschein nach nicht Gemachtes wäre. Tatsächlich ist „Natur“ in ihrer Totalität das kultürlichste aller Produkte, weil sie alle Projektionen, alles Verständnis des Menschen und alle seine Defizite aufnimmt, diese ständig zitiert, reflektiert und permanent zu Handlungen animiert. „Nicht die Dinge selbst beunruhigen die Menschen, sondern ihre Urteile und Meinungen über sie.“ (Epiktet, Handbuch der Moral 5).

Die Rede über die Natur wird gewöhnlich auf einen doppelten naturalistischen Fehlschluss gegründet. Zum einen wird nicht anerkannt, dass die Wahrnehmungen von und Aussagen über Natur den kulturell geprägten Mustern folgen. Aus diesem Fehlschluss folgt der nächste: Die Bewertungskategorien werden als vermeintlich natural vorgegeben angesehen, wo doch die Dinge in der Natur lediglich so sind, wie sie sind, nicht aber, weil sie so sein sollen. ${ }^{893}$ Jeder aus der Natur abgeleiteten Handlungsoption liegt eine menschliche Bewertung zugrunde. Niemals spräche z.B. die Natur, die ohnehin nicht spricht, über einen Hochwasserschutz. Selbstverständlich ist es die menschliche Bewertung, die naturale Gegebenheiten prospektiv und prophylaktisch in Deichbau übersetzt und von Sachzwängen spricht. Der Sachzwang ist menschliches Interesse, das an bestimmter Stelle umgesetzt werden soll.

Weiterhin wird in der Rede über Natur zumeist übersehen, dass im Falle von „Mensch und Natur“ vielfach und kontextabhängig der Begriff der „Natur“ syn-

${ }^{891}$ Diese Aussage benennt das logische Problem aller Kultur-Natur-Oppositionen und behauptet, dass „Natur" letztlich in „Kultur“ eingeschlossen ist, unabhängig davon, dass sie sowohl aus objektiver materieller Wirklichkeit wie aus konstruierter Wirklichkeit besteht. Dieser Erkenntnis-Fehler ist weit verbreitet und wird selbst in Lehrbüchern der Umweltgeschichte fortgeschrieben (z.B. Winiwarter/Knoll, S. 129). - Eine andere, wahrscheinlich die präziseste Lesart desselben hier vorgetragenen Gedankens ist: der "Natur“ kommt, als einer Universalie, die ontologische Existenz zu. Ihre Wahrnehmung allerdings ist kulturell vermittelt.

892 In den nachfolgenden Passagen wird belegt, dass diese Auffassung irrig ist. Allerdings: jede aufgeklärte Position wird ihrerseits ungültig, wenn Menschen aus einem wahrnehmungspsychologisch verständlichen Impuls in den voraufklärerischen Gestus zurückfallen und „die Natur" mit den Eigenschaften eines personalisierten, wenn auch irgendwie anonymen Täterwesens belegen. Es gilt das sozialpsychologisch grundlegende Thomas-Theorem: "If men define situations as real, they are real in their consequences." (Thomas \& Thomas, S. 572).

${ }^{893}$ David Hume „There is no Ought from an Is.” 
onym den Begriffen von „Umgebung“ und „Umwelt“ verwendet wird. In einem systematischen Verständnis ist „Natur“ zunächst alles, was in unserer und möglichen anderen Welten an belebten und unbelebten Dingen existiert. ${ }^{894}$ Selbstverständlich schließt dies den Menschen ein. Die Dinge der Natur, zwischen und mit denen wir uns in einem weitesten Sinne aufhalten, stellen dabei das Tableau, „die Umgebung“. Einer Entdeckung Jakob von Uexkülls zufolge bilden diejenigen Dinge der Umgebung, die Bedeutung für ein Lebewesen erhalten, seine „Umwelt". .895

„Umgebung“ ist eine relationale Form von „Natur“, die sich allein dem beschreibenden Bezug zu einem bestimmten Naturelement verdankt. Es gibt demnach die Umgebung eines Steines wie die einer Pflanze oder eines Tieres. Vereinfachend können diese „Umgebungen“ als gleich gedacht werden, wenn Stein, Enzian und Murmeltier auf derselben Maienwiese vorkommen. Aber allein jene Elemente der Maienwiese, die für die Murmeltierindividuen kollektive (artliche) Bedeutung haben, bilden die ,Murmeltier-Umwelt“ .896

Die Rede eines Menschen über „Natur“ ist entsprechend daraufhin zu prüfen, ob sie sich in einem abstrakten, philosophischen Verständnis bemüht, allgemein über die Dinge zu sprechen und sich dabei vielleicht sogar bemüht, sich von kulturellen Bewertungen frei zu halten, was ihr selbstverständlich (natürlich) nicht wirklich gelingt. Wenn die Rede konkret Bezug nimmt, kann sie dies nur auf Dinge der Umgebung bzw. der Umwelt tun. Einzig in den Wahrnehmungsperspektiven von „Umgebung“ und „Umwelt“ erscheint es möglich, sich den konkreten Dingen der

\footnotetext{
${ }^{894}$ Die „Totalität des Existierenden“ (Mutschler)

895 Auch der neuere Versuch Mutschlers zur Systematisierung der Naturzugänge kann die alte Dichotomie der Naturvorstellungen nicht hierarchisch überwinden, sondern stellt neben das szientifische Naturbild (die „objektive“ Natur) die Pluralität konkurrenzierender oder kontextuell anderer Naturbilder (Naturvorstellungen im kulturelle Kontext). Am Ende wird das Heil in einer Dreifaltigkeit der Natur gesucht: Natur als Korrelat des Theoretischen, Natur als Korrelat des Technisch-Praktischen und Natur als Korrelat des Ethisch-Praktischen. - Demgegenüber scheint mir das Skalentheorem, wie ich es nennen möchte, das sich aus Uexkülls Umwelt-Begriff ergibt, ein weniger kompliziertes und von vornherein auf Scheinobjektivität verzichtendes Naturkonzept zu sein. Diesem Theorem zufolge hätte man auf der kleinsten, der subjektivsten Ebene die „Umwelt“, dann die „Umgebung“ bei abnehmender Bedeutung für das Subjekt, und schließlich die abstrakte „Totalität des Existierenden“, zu der es keine subjektiven Bezüge mehr gibt. Mit diesem Theorem ist es gleichzeitig und ohne Wechsel eines theoretischen Bezugsrahmens möglich, sowohl über Amazonien als auch über meinen kleinen Kater zu sprechen, was mit keinem anderen Systematisierungsansatz über Natur möglich erscheint. Skalenspezifität würde, bei Anerkennung skalenabhängiger Emergenzen, auch mühelos Komplexitätszunahmen innerhalb des Gesamtsystems zulassen und anerkennen.

${ }^{896}$ Der „Umwelt“-Begriff ist bei Uexküll mindestens teilweise noch ein individualistischer Begriff. Da die Biologie aber bestrebt ist, sich der strengen Gesetzlichkeit der nomothetischen Naturwissenschaften zu nähern und an die Stelle des Zufalls die Notwendigkeit zu setzen und damit Ereignis und Struktur voneinander zu trennen, werden anstelle von Aussagen über Individuen solche über Kollektive angestrebt, z.B. über Arten, Gattungen, Familien usw. Entsprechend spricht die Biologie etwa seit den 1940er Jahren von ,der Umwelt der Fliege“ und meint damit, dass alle Fliegen-Umwelten im Grundsatz gleich wären. Entscheidend für den „Umwelt“- Begriff im Verständnis Uexkülls ist der über den jeweiligen Sinnesapparat einer biologischen Art vermittelte Eindruck, der zum „Weltbild“ einer Tierart führt. Entsprechend ist die Umwelt einer Fliege, eines Hundes und eines Menschen, die im selben Zimmer leben, je und spezifisch voneinander geschieden.
} 
Natur zu nähern. Über die Pinguine der Antarktis z.B. kann ich nur abstrakt als Elemente von Natur reden. Aus eigener Anschauung oder aus einer für mich bedeutsamen Beschäftigung werden sie zu Elementen von Umgebung oder von Umwelt.

Ernst Cassirer hatte dann die Uexküllsche Entdeckung von „Merknetz“ und „Wirknetz“ als Elemente desjenigen Funktionskreises im Tier, der die „Umwelt“ erfasst und auf sie reagiert, im Falle des Menschen um das „Symbolnetz“ bereichert. Alles, womit Menschen in ihrer Umgebung umgehen, wird von ihnen symbolisiert, wird mit Sinn und Bedeutung belegt, die Elemente der Umgebung sind nicht einfach mehr bloße Elemente der Umgebung. Sie werden zu den Elementen der „Umwelt“ und immer symbolisch belegt, so dass sie ,als mehr erscheinen gleichzeitig zu dem, was sie buchstäblich an Ort und Stelle sind“" (Adorno, a.a.O.). Und deshalb ist Umweltgeschichte von Naturgeschichte zu unterscheiden und geschieden. Am Ende aber können beide zusammen fallen. Man kann die die Naturgeschichte nämlich auch als eine nicht einmal besonders extreme Variante der Umweltgeschichte auffassen, wobei sich jene von dieser durch die Behauptung unterscheidet, dass man kulturfrei und zeitunabhängig über „Natur“ sprechen könne. ${ }^{897}$

\section{Wie viele Divisionen hat die Natur?}

Womit würden denn „die Natur“ tatsächlich „zurückschlagen“, wenn sie es denn täte? Die Formulierung greift die bekannt gewordene rhetorische Frage Josef Stalins auf. ${ }^{898}$ Abgesehen davon, ist die Frage sinnvoll nur zu stellen im Hinblick darauf, was den Menschen irgendwie angeht. ${ }^{899}$ Was den Menschen irgendwie angeht, ist eben nicht mehr „die Natur" in der „Totalität des Existierenden“, sondern es ist ein konkreter Ausschnitt aus ihr, es ist „Umwelt“. Und diese ist durch den Menschen mit Sinn und Bedeutung versehen. Menschen belegen das Geschehen in diesem Naturausschnitt, in Verkennung der Abläufe, mit den Handlungsqualitäten einer personalisiert gedachten Natur, obwohl es sich tatsächlich um zufällige, aber mit Notwendigkeit ablaufende Vorgänge handelt oder sogar um die reinen Folgen

\footnotetext{
897 Vgl. Fußnote 41

898 „Wie viele Divisionen hat der Papst?“, mit der Stalin auf der Konferenz von Jalta die Beteiligung des Vatikans an späteren Friedensverhandlungen mit Deutschland abgelehnt haben soll. Wer nicht mit schießt, kann sich hinterher nicht an der Verteilung des Bärenfells beteiligen.

${ }^{899}$ Die unter den (deutschsprachigen) Biologen des 20. Jh.s gängige Verständnisformel für „Umwelt“ ist nach meiner Kenntnis von Friedrichs (1943) herausgearbeitet worden: Er definierte Umwelt ,für den praktischen Gebrauch“ als „Komplex der direkten und der konkret greifbaren indirekten Beziehungen zur Außenwelt." Der Unterschied gegenüber der Definition von Uexkülls bestehe in der Aufnahme aller Beziehungen (Friedrichs 1943, S.157). Eine überdachte Begriffserläuterung durch Friedrichs (,dasjenige außerhalb des Subjekts, was dieses irgendwie angeht". 1950, S.70) kann als für die nachfolgenden Biologen leitend bezeichnet werden, ohne dass die Autoren sich jeweils explizit auf Friedrichs bezogen hätten. Friedrichs fasste die Leitlinien des biologischen Diskurses zusammen, wie er davor bestimmend war und es im Grunde bis heute ist.
} 
menschlicher Fehler. Wer also schlägt zurück, wenn es gar nicht die als Personalität verkannte Natur sein kann? Mit der Behauptung einer zurückschlagenden Natur fällt der Mensch tatsächlich auf sich selbst zurück.

Die Gewaltkataloge, mit denen sich Menschen seit historischen Zeiten auseinandersetzen müssen, sind anthropogen und anthropozentrisch. ${ }^{900}$ Deshalb wird die Rede über Elementarereignisse, deren Letztursache nicht menschliche Absicht ist, vom Menschen ebenfalls anthropomorph als „Gewalt“ bewertet. „Gewaltig“ sind Regenfälle, sind Stürme, Hagelschlag, Erdbeben, Hochwasser, Feuersbrünste, Heuschreckenschwärme. Diesen lautstarken Extremereignissen werden mit „Gewalt" in Verbindung gebracht, weil menschliches Interesse sie als zerstörerisch oder als die menschliche Vorstellung „sprengend“ (sic!) erfährt. Die Dimensionen solcher Extremereignisse übersteigen am Ort ihres Auftretens die technischen Möglichkeiten menschlicher Gegenmaßnahmen. Das Ohnmachtsgefühl angesichts dieser tosenden Freisetzung ungeheurer naturaler Kräfte entspricht dem gewaltigen Ausmaß, in dem diese erfahren werden.

Die dominium-terrae-Idee wird seit der Renaissance selbstbewusst verstärkt. Die philosophische Formel wandelt sich in ,faber mundi und beansprucht, die Welt zwar nicht in einem kreationistischen, aber einem erkenntnis- und wahrnehmungsmäßigen Prozess hervorzubringen. ${ }^{901}$ Deshalb fällt das Entsetzen über eine als gewaltbereit dargestellte „Natur“ auch jeweils groß aus (z.B. Erdbeben von Lissabon 1755), u.a. wohl auch, weil nach dem menschlichen Selbstverständnis der aufgeklärten Moderne (homo faber) das Monopol für „Gewalt“ ausschließlich beim Staat läge. ${ }^{902}$ Die Natur hält sich in solchen Fällen erkennbar nicht an die Regeln, die der rational-logisch funktionierende Mensch der Nachaufklärung als selbstverständlich und allen Abläufen in der Welt unterliegend annimmt.

Selbstverständlich hat die Natur keine Divisionen. Sie brauchte sie nicht einmal. Sofern man existentielle Bedrohung als eine Form von Gewalt begreift, steht der Umwelt des Menschen ein unerschöpfliches Gewaltreservoir zur Verfügung und ist auch ununterbrochen tätig. Leben in der uns bekannten Form ist ohne das Risiko der existenziellen Gefährdung weder denkbar, noch offenbar möglich. ${ }^{903}$ Alles kann zu Gewalt werden, aber nur, weil Menschen die Elemente der Umwelt entsprechend symbolisieren. „Der Natur“ sind wir und unsere Taten gleichgültig.

\footnotetext{
900 Der Tiger, der einen Menschen tötet, tötet ihn, weil der Mensch keine dem Tiger angemessene Weise der Koexistenz mit ihm oder ihm angemessene Verhaltensweise gefunden hat. Letztlich ist auch diese Form der Gewalt dadurch anthropogen.

${ }^{901}$ Es ist offensichtlich, dass in dem Ausdruck ,faber mundi" alle philosophischen Probleme zur Sortierung und Hierarchisierung der Natur angelegt sind.

902 Dass „Naturkatastrophen“ straftheologische Bedeutung haben, glaubt um 1800 eigentlich kaum noch ein gebildeter Mensch. - Hier müsste sich eine Gegenüberstellung der Konstrukte „Natur" und „Staat" anschließen, die vermutlich direkt aufeinander aufbauen oder sich einander in gewisser Weise sogar bedingen.

903 Biologen gehen davon aus, dass sich die Fortpflanzung, bei der Erbanlagen rekombinant neu arrangiert werden (also bei allen „,höheren“ Lebewesen), einer Strategie verdankt, mit der die Lebewesen existenziellen Bedrohungen durch Pathogene ausweichen.
} 
„Die Natur“ ist auch sich selbst gegenüber gleichgültig. Nicht nur, weil sie kein personalisiertes Wesen ist, sondern auch, weil alles bloß so ist wie es ist, und nicht weil es in irgendeiner Weise so sein soll. ${ }^{904}$

Es wird damit zu einer absolut kulturabhängigen Frage, ob wir überhaupt Mitleid haben und wenn ja, Mitleid mit dem Hasen oder mit dem Jäger oder mit beiden? Der Aporien, in die der Mensch in seinem Verhältnis zu „Natur“ gerät, sind viele. Sie lassen sich mit weltlichen oder religiösen Weltbildern zwar nicht reduzieren, sie lassen sich aber zum Teil verdrängen. Der Kompromiss, dem alle folgen können sollten, ist die Praktizierung von Konvivialität. Ganz gewiss leben Hasen länger auf dieser Erde als Menschen. Wer müsste also - wenn Seniorität, wenn „Erstgeburt“ zu einer historisch akzeptablen Größe erklärt wird - allererst Verständnis dafür haben, wenn der Hase den Gabentisch des Menschen entdeckt und für sich nutzt, so wie der Mensch vor Zeiten Hasenland zu seinem Nutzen in Ackerland und Gemüsegarten verwandelte, in dem er den Hasen verdrängte? Jedes Lebewesen verhält sich opportunistisch bezogen auf das Erreichen seines ultimaten Lebensziels, von dem Biologen behaupten, es sei nichts weiter als die Fortpflanzung. Nur der Mensch beginnt mit der Sortierarbeit, die seit Noahs Arche in der Welt ist: in Tiere (Organismen), die nützlich sind, in jene, die lästig sind und solche, die schädlich sind. ${ }^{905}$ Auf der Grundlage dieser Sortierarbeit übt er das dominium terrae aus.

Dass „die Natur zurückschlägt" ist manchmal auch einfach nur der Wunsch, dem dominium terrae möge dort ein Ende gesetzt werden, wo der angeblich vernunftbegabte und verantwortlich handelnde Mensch jene Verantwortung missen lässt, auf die er sich so viel einbildet. Deshalb ist es richtig, im Delikatessenladen (mitunter) auch nach den Jägern zu fragen.

\footnotetext{
904 Selbstverständlich ist dies nicht die Behauptung der Aufhebung von Kausalitäten.

905 Die christliche Meistererzählung über den Tierbestand, der die Sintflut überlebte, ist eine Erzählung auch über eine Umbewertung, die Gott selbst offenbar mit seiner Schöpfung vornahm. Er veranlasst nämlich die Benachteiligung eines Teiles der Tierwelt bei ihrer Verladung auf die Arche. Wenn doch alles so richtig war, wieso reduziert Gott die Anteile der „,nicht nützlichen“ (d.i. nicht zum Opfer geeigneten) Tiere? Die Archen-Erzählung sagt außerdem nichts über Pflanzen, die selbstverständlich außerhalb der Arche keine vierzigtägige Wasserbedeckung überlebt hätten. Zu den „nicht nützlichen Tieren“ gibt es mit den „Unkräutern“ ein analoges Problem für Pflanzen, über die uns die biblischen Texte jedoch nichts weiter mitteilen.
} 
Nachtrag zum Stillleben Abb. 2, Flegel, Schauessen.

Der Nachtrag ergibt sich aus Platzgründen, da im unmittelbaren Anschluss an das Bild kein hierfür ausreichender Druckraum zur Verfügung steht.

In der Diskussion warf Manfred Jakubowski-Tiessen die Frage auf, ob die Bewertung des Bildes als Beispiel eines Naturgebrauchs und -verbrauchs angemessen wäre, der einem beeindruckten oder neidischen Betrachter opulentes Luxusleben vorführt. Die Lebenszeit Flegels (1566-1638) wäre eine des allgemeinen wirtschaftlichen Mangels und der klimatischen Depression gewesen. Somit könnte das Stillleben in Wahrheit auch seine eigene Verkehrung darstellen: thematisiert wären Gegenstände, die aus Gründen des Mangels tatsächlich gar nicht zur Verfügung gestanden haben könnten.

Ich habe auf diese Vermutung zurückhaltend reagiert, nicht nur, weil mir dieses Argument trotz langjährigen Interesses am Stillleben bisher weder direkt noch indirekt begegnet ist, sondern auch und gerade, weil aus der Situation Georg Flegels eine solche Deutung sehr überraschend wäre. Gewöhnlich bedient sich das Interpretationsrepertoir von Stillleben bei physikotheologischen Lesarten, bei reiner Objektsymbolik oder einer bloß dekorativen Abbildungskunst. Ein Reflex des allgemeinen Zustands der Welt zur Zeit des Malers oder die Thematisierung der allgemeinen Lebenssituation bzw. gar ihre kritische Darstellung wäre eine neuartige Interpretationsebene des spezifischen Sujets, das in aller Regel einem sehr bestimmten und begrenzten Verwendungszweck diente. Eine solche, neue Bewertung lässt sich auch nach aller Kenntnis der Kunstgeschichte, zumindest für Flegels „Grosses Schauessen“, nicht unterstützen, das zudem auf einer Kupfertafel gemalt ist und nicht auf Leinwand oder Holz. Frankfurt am Main, die Wirkungsstätte Flegels ab 1593, war zu seiner Zeit eine sehr prosperierende Handelsstadt, war „eine Stadt des Luxus und der Eleganz“ und keine Stadt des Mangels, bis sie 1630 in den Strudel des Dreißigjährigen Krieges geriet. Alle abgebildeten Gegenstände, reine Luxuswaren, wurden nachweislich zu Flegels Zeiten in Frankfurt gehandelt. Die Bilder bedienen Geschmack und Nachfrage einer sehr wohlhabenden bürgerlichen Oberschicht der Stadt oder von wohlhabenden Messebesuchern, die mit dem Bild zugleich den eigenen Wohlstand zur Schau stellten. - Ich danke in diesem Zusammenhang Kurt Wettengl, Dortmund, für seine freundliche Auskunft. 


\section{Literatur}

Adorno T([1970] 2003) Ästhetische Theorie. Suhrkamp, Frankfurt/M.

Alpers S (1998) Kunst als Beschreibung. DuMont, Köln

Bacon F (1783) Über die Würde und den Fortgang der Wissenschaften. Weingand \& Köpf, Pest

Bayerl G (2001) Die Natur als Warenhaus. Der technisch-ökonomische Blick auf die Natur in der Frühen Neuzeit. In: Hahn S, Reith R (Hg.): UmweltGeschichte. Arbeitsfelder, Forschungsansätze, Perspektiven. Oldenbourg, Wien/München (= Querschnitte. Einführungstexte zur Sozial-, Wirtschaftsund Kulturgeschichte, Bd. 8), S. 33-52.

Beckmann J (1767) Anfangsgründe der Naturhistorie. Georg Ludewig Förster, Göttingen und Bremen

Benjamin W ([1936] 2006) Das Kunstwerk im Zeitalter seiner technischen Reproduzierbarkeit. Suhrkamp, Frankfurt/M.

Bourdieu P ([1982] 2010) Die feinen Unterschiede. Suhrkamp; Frankfurt/M.

Braungart G (2008) „Katastrophen kennt allein der Mensch“. Recherche - Zeitung für Wissenschaft 2/2008: 17-19

Bredekamp H (1984) Der Mensch als Mörder der Natur. Das ,Iudicium Iovis’ von Paulus Niavis und die Leibmetaphorik. In: Reinitzer H (1984) All Geschöpf ist Zung' und Mund. Vestigia Bibliae 6: 261-283

Buell L (2005) The Future of Environmental Criticism. Blackwell, Malden

DWB Das Deutsche Wörterbuch von Jacob und Wilhelm Grimm in der InternetOnlineversion: http://germazope.uni-trier.de/Projects/DWB

Fischer H (1997) „Nur wer den Garten bebaut, weiß, was Wildnis ist.“ Zum

Wandel der Naturwahrnehmung. In: Wilhelm-Busch-Gesellschaft und Grünflächenamt der Landeshauptstadt Hannover (Hrsg.) „Zurück zur Natur“ - Ideen und Geschichte des Georgengartens in Hannover-Herrenhausen. Ausstellungskatalog. Wallstein, Göttingen, S. 83-94

Friedrichs K (1943) Über den Begriff der „Umwelt“ in der Biologie. Acta Biotheoretica 7: 147-162

Friedrichs K (1950) Umwelt als Stufenbegriff und als Wirklichkeit. Studium Generale 3: 70-74 
Garrard G ( 2004) Ecocriticism. The new critical idiom. Routledge. London, New York

Gerster G (1985) Brot und Salz. 4. Auflage. Birkhäuser, Basel u.a.

Gerster G (1987) Der Mensch auf seiner Erde. 7. Auflage. Birkhäuser, Basel u.a.

Gillson L (2004) Evidence of hierarchical patch dynamics in an East African savanna? Landscape Ecology 19: 883-894

Hensing D (2002) Wenn der Stein der Geschichte zurückrollt. Über einen glücklichen und vor allem einen unglücklichen Sisyphos - über Albert Camus und Heiner Müller. In: Stillmark H-Ch, Lehker C (Hrsg.) Rückblicke auf die Literatur der DDR. Amsterdamer Beiträge zur neueren Germanistik Bd. 52, S. 253-305

Herrmann B, Schutkowski H (1998) Naturerfahrungsgebiete - Humanökologische Prolegomena zur Sicherung der Landschaft als Erlebnisraum und zur Förderung einer natur- und landschaftsverträglichen Erholung. In: Schemel HJ (Bearb.) Naturerfahrungsräume. Angewandte Landschaftsökologie Heft 19: 13-29. Bundesamt für Naturschutz. Bonn, Bad Godesberg

Hoffmann H [ab 1847] Die Geschichte vom wilden Jäger. In: Hoffmann H, Der Struwwelpeter. Verschiedene Ausgaben, Verlage und Verlagsorte

Horkheimer M, Adorno TW ([1969]2009) Kulturindustrie. In: Dialektik der Aufklärung. Philosophische Fragmente. S. 128-178. Fischer Taschenbuch Verlag, Frankfurt/Main

Huysmans J-K ([ 1884] 1981) Gegen den Strich. Diogenes Verlag, Zürich

MacLean AS (2008) OVER: The American landscape at the tipping point. Abrams, New York

MacLean AS (2010) zahlreiche seiner Abbildungen sind enthalten in: Valentien D (ed.) Wiederkehr der Landschaft. Return of landscape. Jovis Verlag und Akademie der Künste, Berlin

Mayr E (1979) Teleologisch und teleonomisch: eine neue Analyse. In: Mayr E, Evolution und die Vielfalt des Lebendigen. Springer, Berlin usw. S. 198-229

Michel P (2008) Physikotheologie. Ursprünge, Leistung und Niedergang einer Denkform. Neujahrsblatt auf das Jahr 2008. Herausgegeben von der Gelehrten Gesellschaft in Zürich (Nachfolgerin der Gesellschaft der Gelehrten auf der Chorherrenstube am Großmünster) vormals zum Besten des Waisenhauses. 171. Stück. Als Fortsetzung der Neujahrsblätter der Chorherrenstube Nr. 229. Editions à la Carte, Zürich

Mutschler H-D (2002) Naturphilosophie. Kohlhammer, Stuttgart 
Niavis P ([1492-1495] 1953) Iudicium Iovis oder Das Gericht der Götter über den Bergbau. Ein literarisches Dokument über den Bergbau. übers. u. hrsg. von Paul Krenkel. Freiberger Forschungshefte, Kultur und Technik D3, Akademie Verlag, Berlin

Phillips D (2003) The truth of ecology. Nature, culture, and literature in America. Oxford University Press, Oxford usw.

Ritter J ([1974] 1989) Landschaft. Zur Funktion des Ästhetischen in der Gesellschaft. In: Ritter J, Subjektivität. Suhrkamp, Frankfurt/M. S. 141-190

Ryle G (1969) Der Begriff des Geistes. Reclam, Stuttgart

Sebba R (1991) The landscapes of childhood. The reflection of childhood's environment in adult memories and children's attitudes. Environment and Behavior 23: 295-322

Simmel G (1911) Die Mode. In: Simmel G, Philosophische Kultur. Gesammelte Essays. Philosophisch-soziologische Bücherei Bd. 27. Klinkhardt, Leipzig. S. 29-64

Smuda M (1986) Natur als ästhetischer Gegenstand und als Gegenstand der Ästhetik. Zur Konstitution von Landschaft. In: Smuda M (Hrsg.), Landschaft Suhrkamp, Frankfurt. S. 44-69

Thomas WI, Thomas DS (1928) The Child in America. Behavior problems and programs. Knopf, New York

Veblen T([1899] 2007) Theorie der feinen Leute. Eine ökonomische Untersuchung der Institutionen. Fischer, Frankfurt

Vries J de, Woude A van de (1997) The first modern economy: success, failure, and perseverance of the Dutch economy : 1500 - 1815. Cambridge Univ. Press, Cambridge

Wagenitz G (1997) Die ,Scala naturae' in der Naturgeschichte des 18.Jahrhunderts und ihre Kritiker. Jahrbuch für Geschichte und Theorie der Biologie 4: 179195

Wettengl K (Hrsg.)(1993) Georg Flegel 1566 - 1638. Stilleben. Historisches Museum, Frankfurt/ Schirn Kunsthalle, Frankfurt/ Verlag Gerd Hatje, Stuttgart

White LT (1967) The historical roots of our ecological crisis.

Science 155: 1203-1207

Winiwarter V, Knoll M (2007) Umweltgeschichte. Böhlau, Köln

Wittgenstein L ([1922] 2003) Tractatus logico-philosophicus. Logischphilosophische Abhandlung. Suhrkamp, Frankfurt/M. 


\section{Anhang}

Jandls Gedicht entstand am 27.5.1962.906 Ernst Jandl hat sein Gedicht in einem Brief an eine Schülerin am 7. Mai 1974 erläutert. Dieser Brief wird hier im Wortlaut wiedergegeben. ${ }^{907}$ Das Verständnis des Dichters zwölf Jahre nach der Entstehung seines eigenen Werkes mutet vor dem Hintergrund der bis zum Jahre 2010 erfolgten Veränderungen in der Welt und dieser Welt selbst sonderbar unterkomplex. Es wird offensichtlich, wie sich Lesart oder Verständnis der Lyrik zeit- und leserabhängig verschieben, was ihr zugleich überzeitliche Bedeutung verleiht.

\section{"Im Delikatessenladen": \\ Ernst Jandl antwortet einer Schülerin \\ Wien, 7. Mai 1974}

Liebe Christine,

herzlichen Dank für Deinen Brief und das hübsche bunte Bildchen, über das ich mich sehr freue. Nun zum Gedicht "im delikatessenladen". Delikatessen sind bekanntlich besonders köstliche Dinge zum Essen. In diesem Gedicht betritt ein Mann einen Laden, wo solche besonders köstlichen Dinge, die man essen kann, verkauft werden. Er tut nun so, als erwarte er, dass er dort nicht bloß köstliche Dinge zum Essen kaufen könne, sondern auch köstliche Dinge anderer Art, diese Dinge übrigens in derselben Weise haltbar gemacht wie Speisen, die man in einem Delikatessenladen kaufen kann, also etwa tiefgekühlt oder als Konserve. Zu solchen köstlichen Dingen gehört zum Beispiel eine sonnige Landschaft im Frühling, eine blühende Wiese im Mai, irgendwo in den Bergen. Wenn die Sonne warm scheint, kann man sich dort niederlassen, die Natur genießen und alles andere vergessen. Warum tut er so, als erwarte er, dass er eine solche Wiese im Delikatessenladen kaufen kann? Nun, vielleicht gehört er zu den Leuten, die glauben, dass man im Leben alles kaufen kann; damit hat er natürlich unrecht, und schließlich bekommt er ja seine "Maiwiesenkonserve" auch nicht. Oder er weiß, dass es Leute gibt, die glauben, dass man im Leben alles kaufen kann, gehört aber selbst nicht zu diesen Leuten und verlangt im Delikatessenladen die Maiwiesenkonserve, um durch dieses unsinnige Verlangen deutlich zu machen, dass man nicht alles Schöne einfach kaufen kann.

Er bekommt sie nicht, doch er lässt nicht locker, sondern verlangt darauf eine schöne Winterlandschaft, also ebenfalls etwas Köstliches, das man nicht einfach kaufen kann. Wieder hat er keinen Erfolg, das heißt, es zeigt sich wiederum, dass man nicht alle schönen Dinge des Lebens einfach kaufen kann. Jetzt geschieht aber

\footnotetext{
906 Jandl, Poetische Werke, Bd. 5, Nr. 136

907 Wiedergabe nach F.A.Z.-Archiv: Frankfurter Allgemeine Zeitung, 1.8.2005, Nr.176, S. 33
} 
etwas Seltsames: er bemerkt etwas, das zu beiden Landschaften gepasst hätte, zur Frühlingswiese ebenso wie zur Winterlandschaft. Es sind Hasen, die in diesem Delikatessenladen verkauft werden. Es gibt große Delikatessenläden, wo neben tausend anderen Dingen auch Wildbret zum Verkauf angeboten wird. Die Hasen, tot, sind dann meist an den Hinterbeinen zusammengebunden und an einen Haken gehängt, also mit dem Kopf nach unten. Hier hat er in diesem Delikatessenladen nun tatsächlich etwas entdeckt, das zu der Landschaft gehört, die er ursprünglich haben wollte, ein Stück Natur. Wie zur Maiwiese die Sonne und die Blumen, und wie zur Schneehalde die schön beschneite Fichte (und auch die Wintersportler, die er nicht haben wollte), so gehört zu den Hasen in dem Zustand, in dem sie da hängen, also totgeschossen, auch der Jäger. Deshalb also die Frage: „Wo hängen denn die Jäger?"“ - eine unsinnige und zugleich grausame Frage, die aber in dem Augenblick einen Sinn bekommt, wenn man nicht mehr damit einverstanden ist, dass die einen immer die Gejagten sind, und die andern immer die Jäger, und dass sich daran niemals etwas ändern soll. Aus der Sicht des Jägers ist es ganz richtig, dass die Hasen immer die Gehetzten und Gejagten sind, die schließlich totgeschossen und verkauft werden. Aus der Sicht der Hasen allerdings müsste das gleiche Recht für alle gelten. Warum sollte es den Jägern dann nicht ebenso ergehen wie den Hasen?

Das Gedicht ist vielleicht eine Art Fabel, mit einer Lehre am Schluss. Von dort könnte man vielleicht weiterdenken, ob es hier wirklich nur um Jäger und Hasen geht, oder ob es nicht in unserer menschlichen Welt vorkommen kann, dass die einen immer die Mächtigen sind, und die andern immer die Machtlosen, und dass dieser Zustand als ein rechtmäßiger Zustand bezeichnet und verteidigt wird. Ich hoffe, dass es mir gelungen ist, Dir und den Mädchen und Jungen in Deiner Klasse das schwierige Gedicht etwas klarer zu machen.

Herzliche Grüße

Dein Ernst Jandl 
ie hier zusammengestellten Aufsätze verdanken sich letztlich sämtlich der langjährigen Bemühung des Autors, der Umweltgeschichte im Wissenschaftsbetrieb ihren Platz als fächerübergreifendes Gespräch zu sichern. Als Querschnitt durch seine umwelthistorischen Arbeiten der letzten Jahre dokumentieren sie einen Teil der Publikationstätigkeit des Autors. Sie hat naturgemäß ihren Schwerpunkt in biologischer Thematik, von hier aus thematisiert sie aber immer auch eine allgemein umwelthistorische Perspektive.

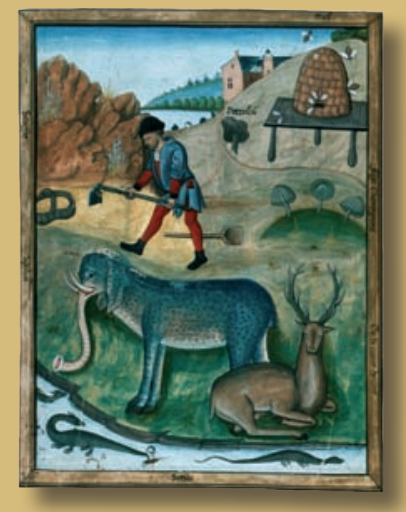

